


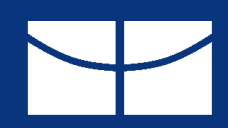

UNIVERSIDADE DE BRASÍLIA

FACULDADE DE ARQUITETURA E URBANISMO

PROGRAMA DE PESQUISA E PÓS-GRADUAÇÃO
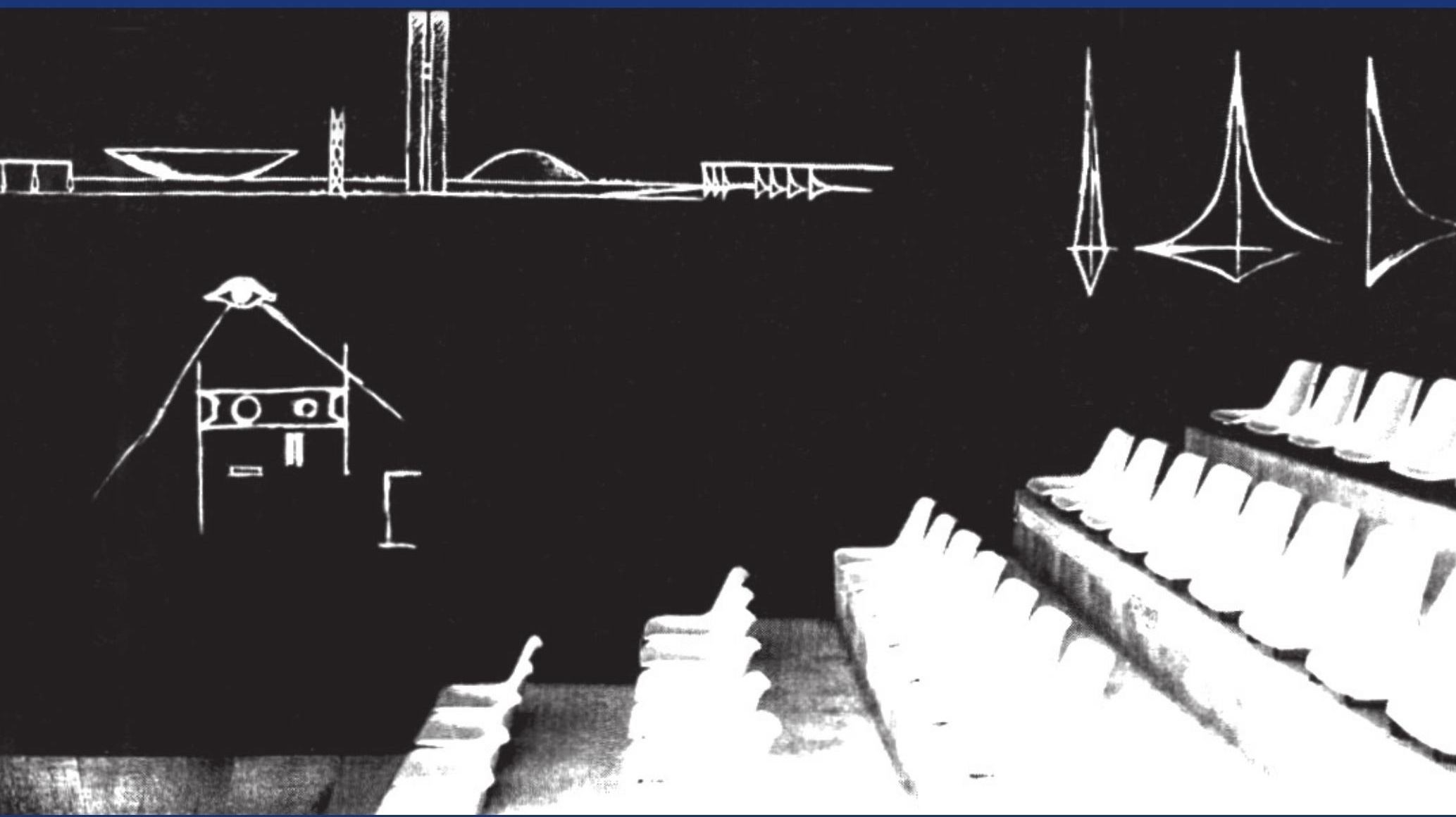

\title{
CEPLAN: 50 ANOS EM 5 TEMPOS
}

Neusa Cavalcante

\author{
Orientadora
}

Professora Doutora Elane Peixoto Ribeiro 


Ceplan: 50 anos em 5 tempos 



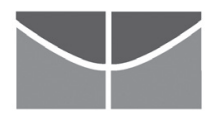

UNIVERSIDADE DE BRASÍLIA

FACULDADE DE ARQUITETURA E URBANISMO

PROGRAMA DE PESQUISA E PÓS-GRADUAÇÃO

\section{Ceplan: 50 anos em 5 tempos}

Neusa Cavalcante

Tese apresentada ao Curso de Doutorado em Arquitetura e Urbanismo, da Faculdade de Arquitetura e Urbanismo, da Universidade de Brasília, como requisito para a obtenção do título de Doutor em Arquitetura e Urbanismo

Orientadora

Professora Doutora Elane Peixoto Ribeiro 



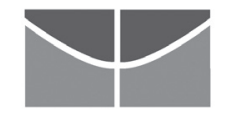

UNIVERSIDADE DE BRASÍLIA FACULDADE DE ARQUITETURA E URBANISMO PROGRAMA DE PESQUISA E PÓS-GRADUAÇÃO

\section{CEPLAN: 50 ANOS EM 5 TEMPOS}

TESE DE DOUTORADO EM ARQUITETURA E URBANISMO

Neusa Cavalcante

Banca Examinadora

Profa. Dra. Elane Peixoto Ribeiro - FAU/UnB - Orientadora

Profa. Dra. Raquel Naves Blumenschein - FAU/UnB

Profa. Draa. Ana Elizabete Medeiros - FAU/UnB

Profa. Dra. Márcia Metran de Melo - UFG

Profa. Draa. Adriana Mara Vaz de Oliveira - UFG

Prof. Dr. Márcio Buzar - FAU/UnB - Suplente 

Aos filhos Rodrigo, Luana e Gabriel e netos

Renato, Luca, Milena, Cecília, Diego e Bernardo, como um estímulo a mais. 



\section{AGRADECIMENTOS}

Tantos e tantos têm caminhando a meu lado nesta já longa jornada vida que qualquer tentativa de listar as importantes colaborações que me fizeram chegar até aqui seria um enorme desafio e, como a memória não é apenas o lembrar mas também o esquecer, muitos certamente ficariam de fora. Assim, preferi limitar os agradecimentos àquelas pessoas mais diretamente ligadas à realização deste trabalho, o qual teria sido impossível sem a força e a disposição para a luta herdada dos meus pais, Manuel e Elka (in memoriam), e a ajuda de Nanã. Ao Silvio, meu irmão, que, além de ter me lançado na trilha das escritas, contribuindo assim para tornar menos árdua a tarefa de redação, foi responsável por algumas das muitas fotos exibidas no trabalho. Aos arquitetos João da Gama Filgueiras Lima (Lelé), Glauco de Oliveira Campello, Jayme Zettel, Luiz Humberto Miranda Martins Pereira, José Galbinski, Paulo de Mello Zimbres, Érico Paulo Seigmar Weidle, Antônio Carlos Moraes de Castro, Frank Algot Svensson, Matheus Gorovitz, Cláudio José Pinheiro Villar de Queiroz e Alberto Alves de Faria sem cujos depoimentos esta tese não poderia ter sido escrita, em especial Luiz Henrique Pessina que além das esclarecedoras informações, cedeu boa parte das belas fotos mais antigas. À Vera Braun Galvão, parceira perfeita na lide de organizar e gravar a maior parte das entrevistas. À velha amiga Viviane Aronovicz, que percorreu acervos à cata de documentos e informações. Aos alunos Octávio Souza Silva e Maria Vitória Garcia, que vasculharam os arquivos do Cedoc/UnB e do Correio Braziliense em busca de imagens significativas. Ao Kristian Schiel, fiel companheiro de todas as horas, incansável no trabalho de escanear grande parte das imagens contidas nas páginas desta tese. Ao solidário amigo Eliel Américo Santana da Silva que, com seus desenhos sensíveis, contribuiu para tornar este trabalho mais bonito. À Irene Ernest Dias, amiga e revisora de mão cheia, que fez de tudo "pra eu não falar a palavra errada". À Maylena Clécia Gonçalves, que, com seu olhar crítico e aguçado, soube organizar textos e figuras para que tomassem um lugar graficamente correto; e a Max Nogueira que colaborou no tratamento e organização no material visual disponível. Ao saudoso amigo Ademaro Mollo Júnior, pela autoria da foto da capa. À amiga e guerreira Márcia Urbano Troncoso, que não me deixou desistir no meio do caminho; também a seu pai Andrês Troncoso pela ajuda na hora certa. À minha orientadora, professora Elane Ribeiro Peixoto, que, acreditando na importância do tema, me ajudou a concretizá-lo, adequando as ideias aos padrões acadêmicos. À colega e professora Raquel Naves Blumenschein, firme no seu propósito de contornar os obstáculos, sem nunca duvidar que esta trajetória chegaria a um bom termo. Ao colega e professor Márcio Buzar, pelo apoio durante minha estada na pós-graduação. E aos demais professores membros da banca, Ana Elisabete Medeiros e Adriana Mara Vaz de Oliveira, pelo tempo dedicado a apreciar e avaliar o meu trabalho, em especial à professora Márcia Metran, cuja veia poética pude testemunhar durante o período em que foi docente da Universidade de Brasília. Ao professor e amigo Jorge Fiori que, com sua presteza facilitou o processo de aproveitamento dos créditos obtidos junto a Architectural Assocation. Ao prestativo funcionário Diego Luna, por seu empenho na solução de entraves administrativos surgidos durante a realização do doutorado. À minha irmã Raquel, por sua contribuição com parte dos insumos neces- 
sários à materialização do produto final. E, finalmente, gostaria de agradecer aos muitos alunos do Curso de Arquitetura e Urbanismo da UnB que, com sua juventude, energia, alegria e sede de saber, foram responsáveis por minimizar em mim o peso da idade, tornando-me disposta a iniciar e capaz de concluir um doutorado tardio. 
Para tudo há uma ocasião, e há tempo para cada propósito debaixo do céu:

tempo de nascer e tempo de morrer, tempo de plantar e tempo de arrancar o que se plantou,

tempo de matar e tempo de curar, tempo de derrubar e tempo de construir,

tempo de chorar e tempo de rir, tempo de prantear e tempo de dançar,

tempo de espalhar pedras e tempo de ajuntá-las, tempo de abraçar e tempo de se conter,

tempo de procurar e tempo de desistir, tempo de guardar e tempo de lançar fora,

tempo de rasgar e tempo de costurar, tempo de calar e tempo de falar,

tempo de amar e tempo de odiar, tempo de lutar e tempo de viver em paz.

Eclesiastes 3 



\section{RESUMO}

O tema desta tese é a história do Centro de Planejamento Oscar Niemeyer (Ceplan), órgão de assessoria técnica da Universidade de Brasília, criado, em 1962, com a tripla missão institucional de planejar o campus e projetar seus edifícios; servir de suporte para a prática profissional de professores e alunos da Faculdade de Arquitetura e Urbanismo e, comprometendo-se com o projeto de desenvolvimento do país à época, contribuir com a produção de tecnologia no campo da arquitetura e da construção. Após atravessar distintos períodos, o Ceplan construiu uma trajetória que permanece restrita àqueles que a protagonizaram ou que dela são testemunhas. Afinada com a história cultural, a metodologia adotada contemplou tanto a pesquisa bibliográfica e documental como a história oral, a partir de depoimentos de arquitetos responsáveis pela produção do Ceplan ao longo de seus cinquenta anos de existência. Reconhecendo com as pesquisas teóricas a importância da memória para a historiografia contemporânea, as informações colhidas nos diversos depoimentos e a análise da produção arquitetônica de cada período vivenciado na atuação do Ceplan, pretendeu-se demonstrá-lo como um lugar de memória, e, mais que isso, como um patrimônio histórico e cultural da Universidade de Brasília, quiçá do Brasil, a ser preservado, vivo e atuante, para as futuras gerações.

\section{PALAVRAS-CHAVE:}

Ceplan, memória, lugar de memória, arquitetura brasileira, produção de tecnologia, patrimônio histórico e cultural. 



\section{ABSTRACT}

This thesis examines the history of the Centro de Planejamento Oscar Niemeyer (Ceplan), a technical advisory body of the Universidade de Brasília set up in 1962 with the threefold institutional mission of planning the university campus and designing its buildings, providing support to the professional practice of teachers and students of the School of Architecture and Urbanism, and committing to Brazil's development project of the time by producing technology in the fields of architecture and construction. After undergoing different periods, Ceplan constructed a trajectory which remains restricted to those who played a leading part in it or simply witnessed it. In tune with cultural history, the methodology employed in this study comprises bibliographic and documentary research as well as oral history, the latter based on the accounts of architects responsible for Ceplan's production over the past fifty years. By acknowledging the importance of memory in contemporary historiography, information extracted from the various testimonies, and the analysis of Ceplan's architectural production throughout its history, this thesis aimed to shed light on Ceplan as a place of memory and, above all, as a historical and cultural heritage of Universidade de Brasília and maybe of Brazil itself, which must be preserved, in its living and active form, for future generations.

\section{KEYWORDS:}

Ceplan, memory, place of memory, Brazilian architecture, historical and cultural heritage. 



\section{LISTA DE SIGLAS}

$A B I$

ADUnB

Andes

Aposfub

Asfub

AUR

BCE

BID

BNDE

$\mathrm{BNH}$

BSA NORTE (Baes)

BSA SUL

Cacon

Caep

Capes

CBPE

CDS

CDT

CEF

Ceftru

Cepal

Cepes

Cespe

CET

CEu

CFE

CGT

$\mathrm{CIC}$

Ciem

CIEP

CMBEU

CME

Comasa

Concretide

CPD

CPI

CPMF

Crad

CUB

DAE

Dacau
Associação Brasileira de Imprensa

Associação dos Docentes da Universidade de Brasília

Associação Nacional de Docentes do Ensino Superior

Associação dos Aposentados da FUB

Associação dos Servidores da Universidade de Brasília

Departamento de Arquitetura e Urbanismo

Biblioteca Central da Universidade de Brasília

Banco Interamericano de Desenvolvimento

Banco Nacional de Desenvolvimento Econômico

Banco Nacional de Habitação

Bloco de Salas de Aula Norte Eudoro de Sousa

Bloco de Salas de Aula Sul Luiz Fernando Gouvêa Labouriau

Centro de Alta Complexidade em Oncologia

Centro de Atendimento e Estudos Psicológicos

Coordenação de Aperfeiçoamento de Pessoal de Nível Superior (Capes)

Centro Brasileiro de Pesquisas Físicas

Centro de Desenvolvimento Sustentável

Centro de Apoio ao Desenvolvimento Tecnológico

Caixa Econômica Federal

Centro de Formação de Recursos Humanos em Transportes Urbanos

Comissão Econômica para a América Latina e Caribe

Comissão Especial para Execução do Plano de Melhoramento e Expansão do Ensino Superior

Centro de Seleção e Promoção de Eventos

Centro de Excelência em Turismo

Casa do Estudante Universitário

Conselho Federal de Educação

Central Geral dos Trabalhadores

Departamentos de Ciência da Computação

Centro Integrado de Ensino Médio

Centro Integrado de Educação Pública

Comissão Mista Brasil-Estados Unidos para o Desenvolvimento Econômico

Centro de Manutenção de Equipamentos Científicos

Construtora Martins Almeida S. A.

Comissão Permanente do Regime do Tempo Integral e Dedicação Exclusiva

Centro de Processamento de Dados

Comissão Parlamentar de Inquérito

Contribuição Provisória sobre a Movimentação ou Transmissão de Valores e de Créditos e Direitos de Natureza Financeira

Centro de Referência em Conservação da Natureza e Recuperação de

Áreas Degradadas

Cidade Universitária do Brasil

Diretoria de Acesso ao Ensino Superior

Diretório Acadêmico de Arquitetura 


\begin{tabular}{|c|c|}
\hline DAVC & Departamento de Artes Visuais e Cinema \\
\hline DM & Departamento de Música \\
\hline Dops & Departamento de Ordem Política e Social \\
\hline DpAU & Departamento de Arquitetura e Urbanismo \\
\hline Eapes & Equipe de Assessoria ao Planejamento do Ensino Superior \\
\hline EBA & Escola de Belas Artes \\
\hline $\mathrm{ECl}$ & Escola de Ciência da Informação \\
\hline EDU & Editora Universidade de Brasília \\
\hline EEB & Estação Experimental de Biologia \\
\hline ENC & Exame Nacional de Cursos \\
\hline Enem & Exame Nacional do Ensino Médio \\
\hline EST & Departamento de Estatística \\
\hline EV & Escola de Veterinária \\
\hline Ex-UnB & Associação dos Ex-Alunos da UnB \\
\hline FA & Faculdade de Estudos Sociais Aplicados \\
\hline Face & Faculdade Administração, Contabilidade e Economia \\
\hline Fafich & Faculdade de Filosofia e Ciências Humanas \\
\hline Fale & Faculdade de Letras \\
\hline FAU & Faculdade de Arquitetura e Urbanismo \\
\hline FAU-USP & Faculdade de Arquitetura e Urbanismo da Universidade de São Paulo \\
\hline FD & Faculdade de Direito \\
\hline FE & Faculdade de Educação \\
\hline Feub & Federação dos Estudantes da Universidade de Brasília \\
\hline Fies & Fundo de Financiamento ao Estudante do Ensino Superior \\
\hline Finatec & Fundação de Empreendimentos Científicos e Tecnológicos \\
\hline Finep & Financiadora de Estudos e Projetos \\
\hline Fiocruz & Fundação Oswaldo Cruz \\
\hline FM & Faculdade de Medicina \\
\hline FNDCT & Fundo Nacional de Desenvolvimento Científico e Tecnológico \\
\hline FS & Faculdade de Ciências da Saúde \\
\hline FT & Faculdade de Tecnologia \\
\hline FUB & Fundação Universidade de Brasília \\
\hline Funtec & Fundo de Desenvolvimento Técnico-Científico \\
\hline Geres & Grupo Executivo para a Reformulação da Educação Superior \\
\hline GTI & Grupo de Trabalho Interministerial \\
\hline GTRU & Grupo de Trabalho da Reforma Universitária \\
\hline HUB & Hospital Universitário de Brasília \\
\hline IA & Instituto de Arquitetura e Urbanismo \\
\hline IAA & Instituto de Artes e Arquitetura \\
\hline$I A B$ & Instituto de Arquitetos do Brasil \\
\hline IB & Instituto de Biologia (IB) \\
\hline ICA & Instituto Central de Artes \\
\hline ICB & Instituto de ciências Biológicas \\
\hline ICC & Instituto Central de Ciências \\
\hline ICEx & Instituto de Ciências Exatas \\
\hline ICS & Instituto de Ciências Sociais \\
\hline
\end{tabular}




\begin{tabular}{|c|c|}
\hline IdA & Instituto de Artes \\
\hline IE & Instituto de Ciências Exatas \\
\hline IES & Instituições de Ensino Superior \\
\hline Ifes & Instituições Federais de Ensino Superior \\
\hline Inep & Instituto Nacional de Ensino e Pesquisa \\
\hline Ipês & Instituto de Pesquisas e Estudos Sociais \\
\hline IPM & Inquérito Policial Militar \\
\hline Ipol/Irel & nstituto de Ciência Política e Relações Internacionais \\
\hline IQ & Instituto de Química \\
\hline LDB & Lei de Diretrizes e Bases para a Educação \\
\hline LDBEN & Lei de Diretrizes e Bases da Educação Nacional \\
\hline Leau & Laboratório Experimental de Arquitetura e Urbanismo \\
\hline Lega & Laboratório de Estudos Geodinâmicos e Ambientais \\
\hline MAM/RJ & Museu de Arte Moderna no Rio de Janeiro \\
\hline Mare & Ministério da Administração e Reforma do Estado \\
\hline Masc & Módulo de Apoio e Serviços Comunitários \\
\hline MDB & Movimento Democrático Brasileiro \\
\hline MEC & Ministério da Educação e Cultura \\
\hline MRE & Ministério das Relações Exteriores \\
\hline NMT & Núcleo de Medicina Tropical \\
\hline Novacap & Companhia Urbanizadora da Nova Capital \\
\hline $\mathrm{OAB}$ & Ordem dos Advogados do Brasil \\
\hline PAC & Programa de Aceleração do Crescimento \\
\hline Paiub & Programa de Avaliação Institucional da Universidade Brasileira \\
\hline PCTec & Parque Científico e Tecnológico \\
\hline PDE & Plano de Desenvolvimento da Educação \\
\hline PIJ & Programa de Educação Infanto-Juvenil \\
\hline PM I & Pavilhão Multiuso I \\
\hline PM II & Pavilhão Multiuso II \\
\hline Premesu & Programa de Expansão e Melhoramento das Instalações do Ensino Superior \\
\hline Prouni & Programa Universidade para Todos \\
\hline $\mathrm{PUC} / \mathrm{RJ}$ & Pontifícia Universidade Católica do Rio de Janeiro \\
\hline Reuni & $\begin{array}{l}\text { Programa de Apoio a Planos de Reestruturação e Expansão das } \\
\text { Universidades Federais }\end{array}$ \\
\hline RU & Restaurante Universitário \\
\hline SBPC & Sociedade Brasileira para o Progresso da Ciência \\
\hline Sesu/MEC & Secretaria de Ensino Superior do Ministério da Educação e Desporto \\
\hline SG & Serviços Gerais \\
\hline Sinaes & Sistema Nacional de Avaliação da Educação Superior \\
\hline UFMG & Universidade Federal de Minas Gerais \\
\hline UNE & União Nacional dos Estudantes \\
\hline UISS & Unidade Integrada de Saúde de Sobradinho \\
\hline URSS & União das Repúblicas Soviéticas Socialistas \\
\hline Usaid & United States Agency for International Development \\
\hline
\end{tabular}




\section{LISTA DE FIGURAS}

\section{CAPÍTULO 1}

1. JK após a posse

2. JK durante as comemorações da inauguração de Brasília

3. LP Canção do amor demais, 1958

4. LP Chega de saudade, 1959

5. Filme de Nelson Pereira dos Santos

6. Filme de Marcel Camus

7. Manifesto do Grupo Ruptura (São Paulo)

8. Cartaz da $1^{\text {a }}$ Exposição de Arte Neoconcreta

9. Comemoração dos 50 anos do Manifesto Neoconcreto

10. A comemoração da vitória brasileira na Copa de 1958

11. Tenista Maria Esther Bueno, 1960

12. Pugilista Éder Jofre, 1960

13. Seleção brasileira de basquete, campeã em 1959

14. Brasília, Marcel Gautherot

15. Brasília, Marcel Gautherot

16. Véspera da inauguração de Brasília, 1960

17. Solenidade de inauguração de Brasília,1960

18. Vista aérea de Brasília.

19. Plano Piloto de Brasília, Lucio Costa, 1957

20a, 20b, 20c. Darcy Ribeiro, Anísio Teixeira e Israel Pinheiro

21. Frei Mateus Rocha

22. Posse do presidente Jânio Quadros

23. Renúncia do presidente Jânio Quadros

24. Posse de João Goulart

25. Assinatura da Lei 3.998, de 15 dezembro de 1961

26. Darcy Ribeiro, Hermes Lima, João Goulart; e Antônio Ferreira de Oliveira Brito.

27. Posse do primeiro Conselho Diretor da UnB

28. Inauguração da Universidade de Brasília

29. Discurso do reitor Darcy Ribeiro na inauguração da Universidade de Brasília

30a-30b. Início das aulas no campus da Universidade de Brasília

31. Capa do Plano Orientador da UnB, 1962

32. Oscar Niemeyer e Lucio Costa

33. Joaquim Cardoso

34. Localização da Fazenda Água Limpa no Distrito Federal

35a-35b. Plano Piloto da Universidade de Brasília, Lucio Costa

36. Casa pré-fabricada com o uso do sistema SR2

37a e 37b. Vistas do pavilhão construído com o sistema R2 no late Clube de Brasília

38. Mutirão para as instalações do campus da UnB

39. Mesa desenhada para o Ministério das Relações Exteriores

40. Cadeira com assento de couro trançado, Sérgio Rodrigues

41. Professores do ICA-FAU

42a-42d. Projetos de Oscar Niemeyer no exterior 
43. Professores do ICA-FAU

44. Instrutores da FAU

45. Casa do Frei Mateus, João Filgueiras Lima

46. Instituto de Teologia, Oscar Niemeyer

47. Habitação coletiva pré-fabricada, Oscar Niemeyer

48. Habitação Coletiva, Glauco Campello

49. Escola Primária, Oscar Niemeyer

50. Estudos para a Praça Maior, Oscar Niemeyer

51. Estudos para o Centro Esportivo da Juventude, Oscar Niemeyer

52a-52i. OCA I e OCA II

53a-53n. Faculdade de Educação: FE 1, FE 3 e FE 5

54a-54h. Protótipo

55a-55z. Serviços Gerais: SG 1, SG 2, SG 4, SG 8, SG 10

56a-56l. Serviços Gerais: SG 9, SG 11, SG 12

57a-57m.Colina: Blocos A, B , C e D.

58a-58e. SQN 107 - Conjunto São Miguel

59a-59d. Centro Integrado de Ensino Médio (Ciem)

60a-60u. Instituto Central de Ciências (ICC)

\section{CAPÍTULO 2}

61. Posse de Ranieri Mazzilli

62a-62c. Ocupação do campus por tropas da polícia

63. Marcha de 30 de março de 1964

64a-64b. Cartas dos professores demissionários

65. Demissão coletiva

66. Contratação de professores

67. Volta às aulas

68. Corpo do jovem Edson Luís

69. Igreja da Candelária cercada durante missa de sétimo dia de Edson Luís

70. Marcha dos Cem Mil

71. Invasão da UnB

72. Estudantes acampados no Congresso

73. Suspensão das aulas na UnB

74. Professores tentam libertar estudantes presos

75. Prisão de líder estudantil

76. Líderes estudantis presos em 30 de agosto de 1968

77a-77e. Invasão da UnB

78. A decretação do Ato Institucional n. 5

79a-79b. Manifestação de maio de 1968 na França

80a-80b. Protesto de estudantes em Praga

81. Martin Luther King durante discurso

82. Integrantes do Black Panther Party

83. Capa do LP Tropicália, 1968

84. Jorge Ben, Caetano Veloso, Gilberto Gil, Gal Costa e os Mutantes

85. Cynara e Cybele interpretaram "Sabiá"

86. Geraldo Vandré no Festival Internacional da Canção de 1968 


\section{CAPÍTULO 3}

87. Manifestação dos estudantes excedentes

88a-88c. Faculdade de Arquitetura da USP

89. Teatro de Arena

90a-90c. Plano UnB, 1969

91a-91c. Ginásio Coberto

91a-91c. Centro de Vivência

93. Plano urbanístico do campus, 1974

94a-94e. Aula Magna e Museu

95a-95f. Invasão militar, maio de 1976

96. Castelo d'água, Maurício Azeredo

97a-97d. Manifestações pelas Diretas

98. Morte de Tancredo Neves

99a-99q. Biblioteca Central (BCE)

100a-100m. Casa do Estudante Universitário (CEU)

101a-101l. Centro Olímpico (CO)

102a-102q. Restaurante Universitário (RU)

103a-103u. Reitoria

104a-104d. Núcleo de Medicina Tropical (NMT)

105a-105j. Faculdade de Tecnologia (FT)

106a-106e. Faculdade de Ciências da Saúde (FCS)

107a-107I. SQN 206

108a-108h. SQN 205

109a-109h. Faculdade de Estudos Sociais Aplicados (FA)

\section{CAPÍTULO 4}

110. Posse de Sarney

111. Relatório do Geres

112. Cristóvam Buarque

113. Sessão final dos trabalhos da Assembleia Constituinte

114. Ulysses Guimarães exibindo cópia da Constituição Federal de 1988

115. Posse de Collor

116. Repercussão das reformas de Collor

117. Movimento dos caras-pintadas

118. Os caras-pintadas

119. O impeachment de Collor

120. Posse de Itamar Franco

121. Posse de Fernando Henrique Cardoso

122. Plano Diretor Físico do Campus Darcy Ribeiro, 1998

123a-123e. Pavilhão Multiuso I (PM I)

124a-124c. Pavilhão Multiuso II (PM II)

125a-125f. Centro de Excelência em Turismo (CET)

126a-126e. Laboratório de Termobiologia (LT)

127a-127e. Colina: blocos E, F, G, H, I, J

128a-128c. Casa do Estudante Universitário - Pós-Graduação (CEU-PÓS)

129a-129d. Centro de Vivência 
130. Autotrac

131a-131c. Observatório Sismológico (SIS)

132a-132b. Centro de Formação de Recursos Humanos em Transportes Urbanos (Ceftru)

133a-133i. Pavilhão de Oficinas Especiais - Instituto de Artes (IdA)

134a-134g. Posto Ecológico e Empório Ambiental

135. Almoxarifado Central

136a-136e. Centro Comunitário Athos Bulcão

137a-137c. Centro de Desenvolvimento Tecnológico (CDT)

138a-138m. Pavilhão Anísio Teixeira e Pavilhão João Calmon

\section{CAPÍTULO 5}

139. Posse de Lula

140. Logomarca do Prouni

141. Logomarca do Enade

142a-142c. Projeto vencedor do Concurso para o Museu de Ciência e Tecnologia

143a-143d. Destaque no Concurso para o Museu de Ciência e Tecnologia

144a-144b. Estudos para o Setor Sul do campus

145. Logomarca do PDE

146. Logomarca do Reuni

147a-147c. Projeto vencedor do concurso para a Praça Maior

148. Capa do livro Estilo e época (1924)

149. Capa da tradução inglesa de Estilo e época (1983)

150a-150b. Clínica Odontológica / Farmácia Escola

151a-151f. Centro de Seleção e Promoção de Eventos (Cespe)

152a-152b. Associação dos Aposentados da Universidade de Brasília (Aposfub)

153a-153m. Casa do Professor. Sede da Adunb

154a-154g. Instituto de Biologia (IB)

155a-155o. Instituto de Química (IQ)

156a-156c. Laboratório de Estudos Geodinâmicos e Ambientais (Lega)

157a-157f. Faculdade de Economia, Administração e Contabilidade (Face)

158a-158d. Centro de Alta Complexidade em Oncologia (Cacon-HUB)

159a-159g. Programa Infanto-Juvenil (PIJ)

160a-160o. Fundação Oswaldo Cruz (Fiocruz)

161a-161c. Centro de Manutenção de Equipamentos Científicos (CME)

162a-162k. Bloco de Salas de Aula Norte Eudoro de Souza (BSA NORTE)

163a-163c. Bloco de Salas de Aula Sul Luiz Fernando Gouvêa Labouriau (BSA SUL)

164a-164f. Módulo de Atividades e Serviços Comunitários (Masc)

165a-165d. Centro de Informática (CPD) 

INTRODUÇÃO

De memórias e patrimônios.

1.1. A invenção de uma universidade . .53

1.2. A concepção do espaço pioneiro .69

1.3. Arquitetura como experimento e inovação .......................................................................................101

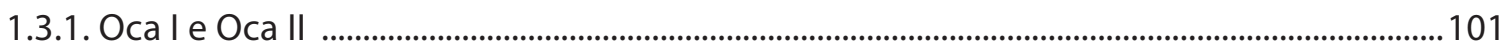

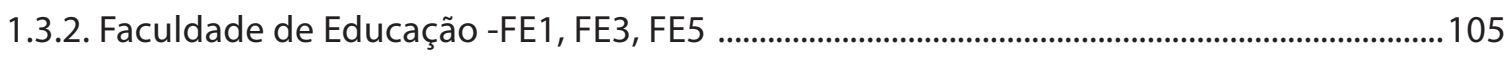

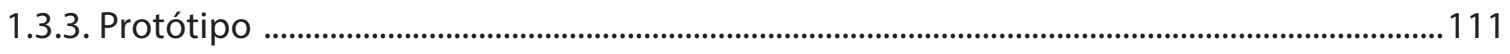

1.3.4. Serviços Gerais - SG1, SG2, SG4, , SG8, SG10 ...................................................................114

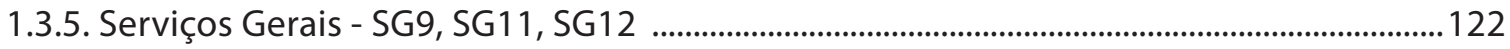

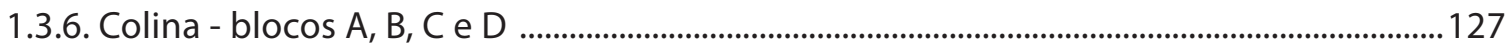

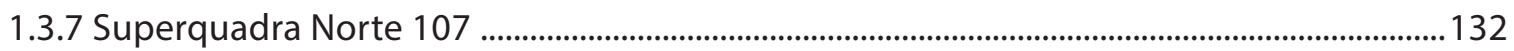

1.3.8. Centro Integrado de Ensino Médio (Ciem) .........................................................................135

1.3.9. Instituto Central de Ciências (ICC) .............................................................................................. 138

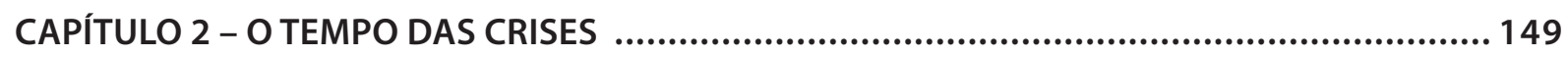

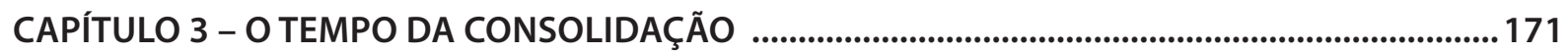

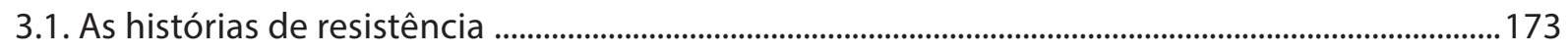

3.2. Arquitetura como valorização da linguagem.........................................................................................195

3.2.1. Biblioteca Central (BCE) .............................................................................................................. 195

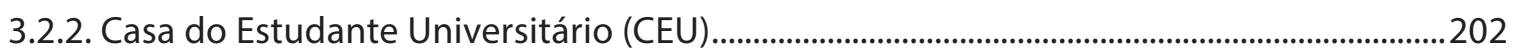

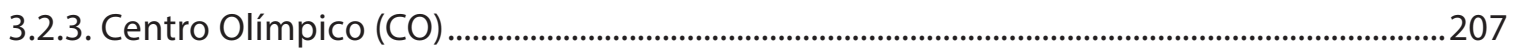

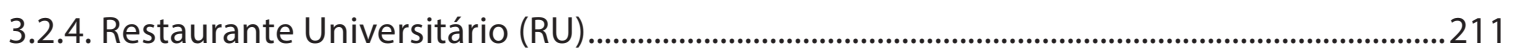

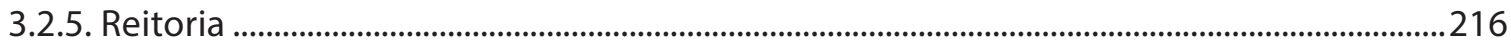

3.2.6. Núcleo de Medicina Tropical (NMT) ...........................................................................................222

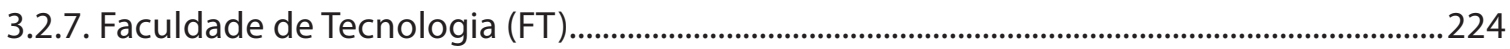

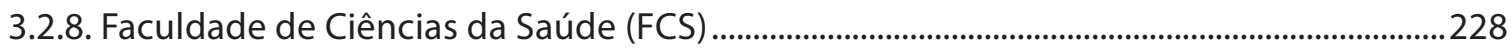

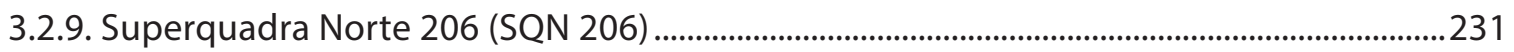

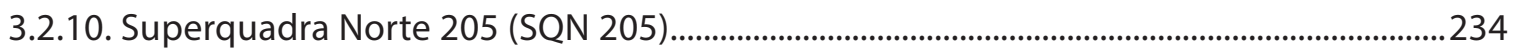

3.2.11. Faculdade de Ciências Sociais Aplicadas (FA) .....................................................................26 
4.2. Novas demandas e quebra da unidade arquitetônica ...................................................................254

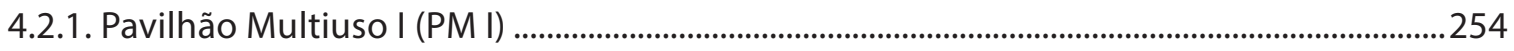

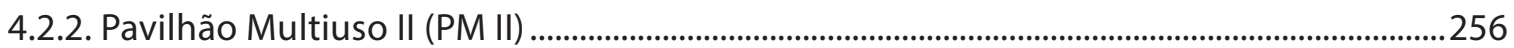

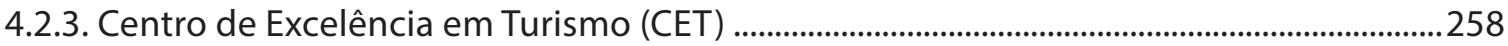

4.2.4. Laboratório de Termobiologia (LT) ................................................................................................260

4.2.5. Colina Nova - blocos E, F, G, H, I, J ...........................................................................................262

4.2.6. Casa do Estudante Universitário - Pós Graduação (CEU-PÓS)................................................264

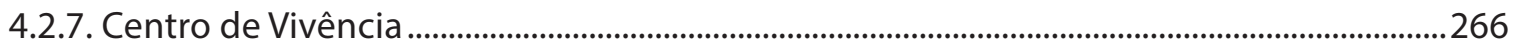

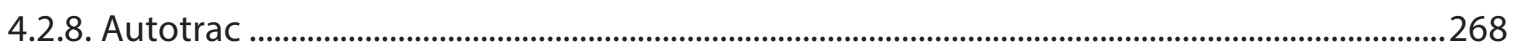

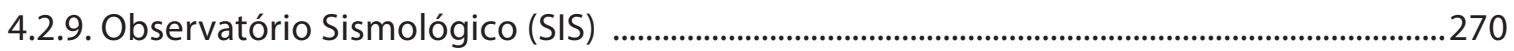

4.2.10. Centro de Formação de Recursos Humanos em Transportes Urbanos (Ceftru) ............272

4.2.11. Pavilhão de Oficinas Especiais - Instituto de Artes - (IdA).....................................................2

4.2.12. Posto Ecológico e Empório Ambiental .........................................................................................277

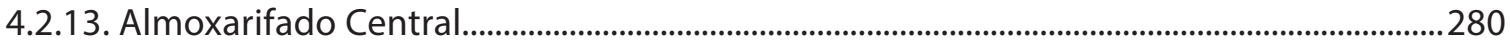

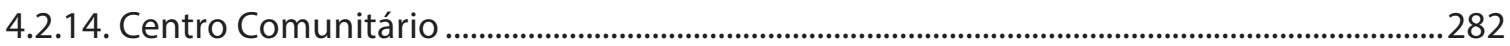

4.2.15. Centro de Apoio ao Desenvolvimento Tecnológico (CDT) .................................................284

4.2.16 Pavilhão Anísio Teixeira (PTA) e Pavilhão João Calmon (PJC) ...............................................286

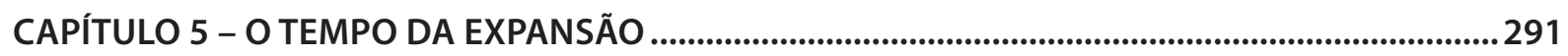

5.1. Correndo contra o tempo

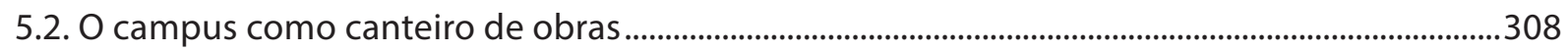

5.2.1 Clínica Odontológica / Farmácia Escola...........................................................................................308

5.2.2. Centro de Seleção e Produção de Eventos (Cespe) ......................................................................310

5.2.3. Associação dos Aposentados da UnB (Aposfub) …………………………………………….....312

5.2.4. Casa do Professor Associação Docente da UnB (ADUnB) ...........................................................314

5.2.5. Instituto de Ciências Biológicas (IB) ..............................................................................................

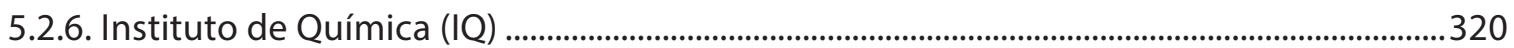

5.2.7. Laboratório de Estudos Geodinâmicos e Ambientais (Lega) ...................................................324

5.2.8. Faculdade de Economia, Administração e Contabilidade (Face) ..............................................326

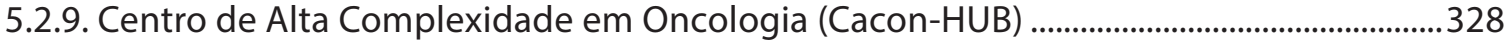

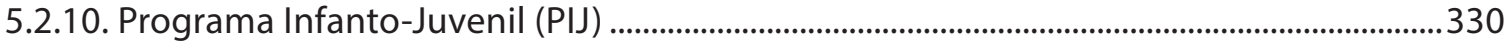

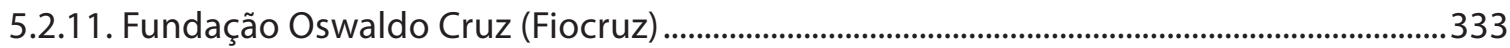

5.2.12. Centro de Manutenção de Equipamentos (CME) ......................................................................338 
5.2.13. Bloco de Salas de Aula Norte Luiz Fernando Gouvêa Labouriau (BSA NORTE) .....

5.2.14. Bloco de Salas de Aula Sul Eudoro de Souza (BSA SUL) ....................................................343

5.2.15. Módulo de Atividades e Seviços Comunitários (Masc) ........................................................345

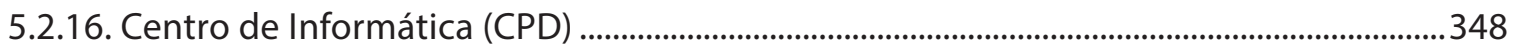

5.2.17. Instituto de Ciência Política / Instituto de Relações Internacionais (IPol/IRel)...............350

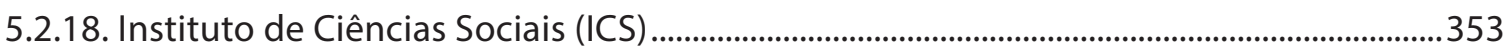

5.2.19. Centro de Atendimento e Estudos Psicológicos (Caep) .......................................................357

5.2.20. Centro de Referência em Conservação da Natureza e de Áreas Degradadas (Crad) .......359

5.2.21. Centro de Desenvolvimento Sustentável (CDS) .................................................................361

5.2.22. Memorial Darcy Ribeiro - Beijódromo.................................................................................363

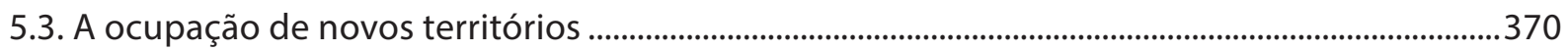

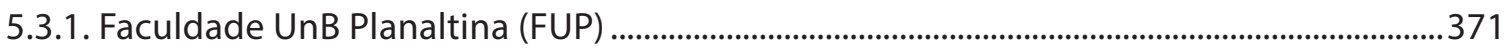

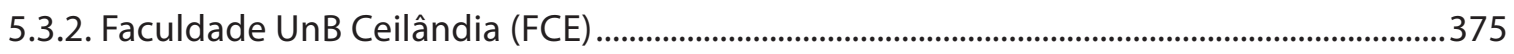

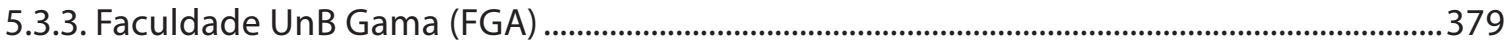

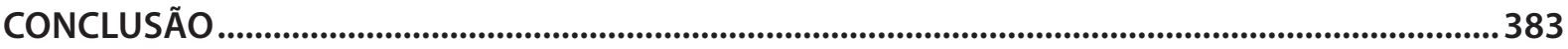

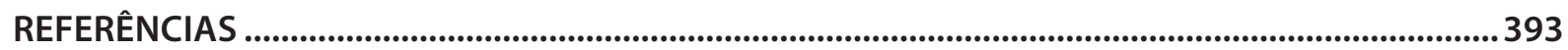

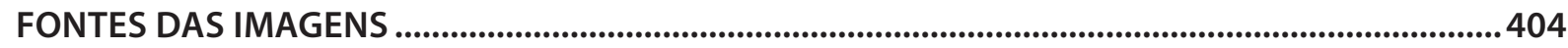

ANEXO I - Linha do Tempo ...................................................................................................415

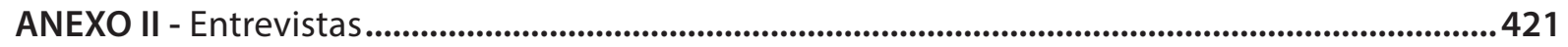

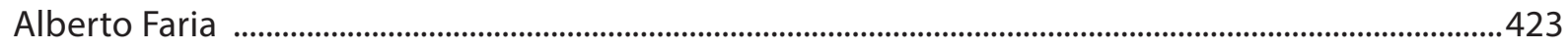

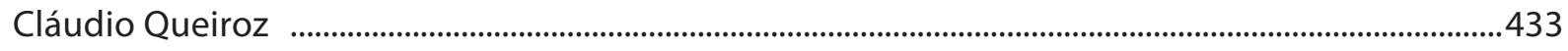

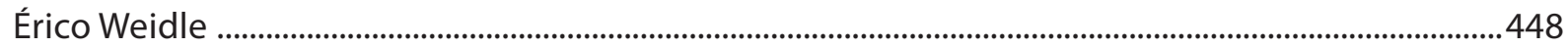

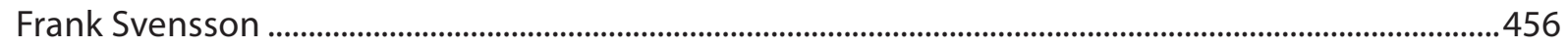

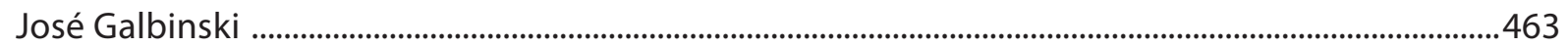

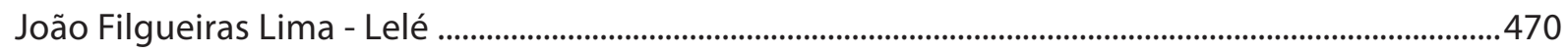

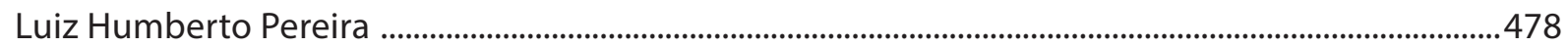

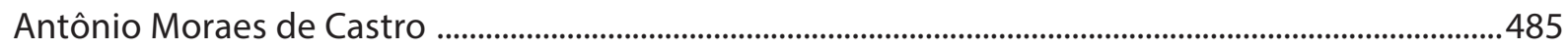

Luiz Henrique Pessina ............................................................................................................................................493

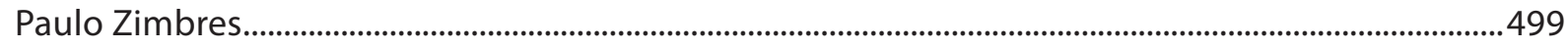



Ceplan: 50 anos em 5 tempos 



\section{INTRODUÇÃO}

[...] a história só pode ser uma ciência da mutação e da explicação da mudança. Jacques Le Goff, História e memória

A trajetória de uma instituição como o Centro Planejamento Oscar Niemeyer da Universidade de Brasília (Ceplan/UnB) e seu papel na vida universitária do país e nos rumos recentes da arquitetura brasileira se conformou como objeto de estudo desde a constatação, por uma professora desta universidade, de que ensinar passou a ser uma parte indissociável de si mesma. A esta aluna, parafraseando Gilberto Gil, a UnB "deu régua e compasso"; e à professora, a oportunidade de desenvolver um longo processo de reflexão... e, lado a lado com os alunos, a possibilidade de vivenciar experiências no campo da arquitetura e das artes das quais resultaram significativos frutos.

E por que escrever especificamente sobre o Ceplan, o nosso Centro de Planejamento Oscar Niemeyer? Pareceu instigante especular sobre um órgão que surgiu com o objetivo claro de fincar os pilares que iriam materializar o sonho de um Brasil novo e que, ao longo de sua trajetória de cinquenta anos, permaneceu engajado na construção do patrimônio físico da universidade que estava na origem desse sonho.

Criado em 1962 como órgão de assessoria técnica da jovem Universidade de Brasília, o Centro de Planejamento (Ceplan) tem como missão institucional, desde sua fundação, desenvolver o planejamento para o crescimento físico da UnB. Depois de atravessar várias fases e ter o seu funcionamento alterado pelas diferentes circunstâncias político-institucionais, o Ceplan tem percorrido uma significativa trajetória que, infelizmente, permanece ainda restrita àqueles que a protagonizaram ou que dela são testemunhas.

Revisitando a área do campus Darcy Ribeiro onde se localizam os cinquentenários pavilhões de Serviços Gerais - que outrora abrigavam o Instituto Central de Artes e a Faculdade de Arquitetura e Urbanismo (ICA-FAU) -, percebe-se que muita coisa está diferente: os cursos de arquitetura e design não estão mais lá; no Instituto de Artes (IDA) (antigo Instituto Central de Artes - ICA) não existem mais os antigos ateliês de xilogravura, gravura etc.; o curso de música ocupa hoje os espaços antes destinados aos ateliês de projeto... Ao mesmo tempo, embora tenha se mantido do mesmo tamanho e no mesmo cantinho de sempre, o Ceplan não é mais o mesmo...

O que mudou? Como mudou? Por que mudou? Foi dessa curiosidade que surgiu a ideia de um trabalho de pesquisa histórica e iconográfica que permitisse resgatar a memória institucional do Centro de Planejamento Oscar Niemeyer, que, criado junto com a Universidade de Brasília, tem sido o órgão responsável pela construção física de seus campi. De acordo com Pierre Nora, 


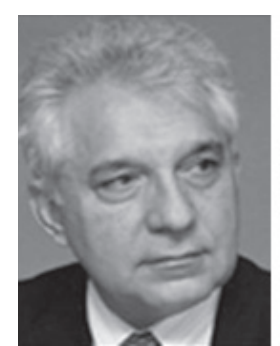

Glauco de Oliveira Campello

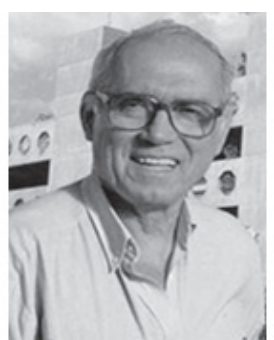

João da Gama Filgueiras Lima (Lelé)

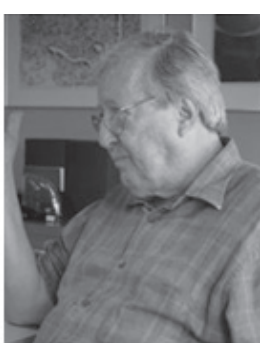

Luiz Henrique Pessina

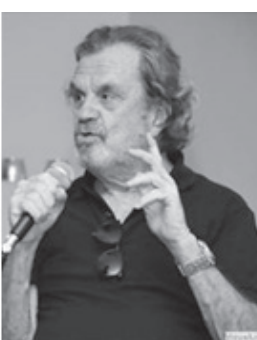

Jayme Zettel

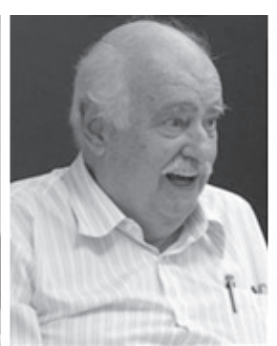

Érico Paulo Seigmar Weidle

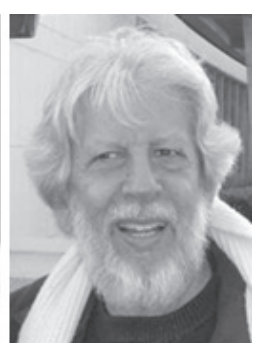

Antônio Carlos Moraes de Castro

A curiosidade pelos lugares onde a memória se cristaliza e se refugia está ligada a este momento particular da nossa história: momento de articulação onde a consciência da ruptura com o passado se confunde com o sentimento de uma memória esfacelada, mas onde o esfacelamento desperta ainda memória suficiente para que se possa colocar o problema de sua encarnação (1993, p. 7).

Buscou-se primeiramente compreender as causas e características das transformações que, ocorridas ao longo de cinquenta anos, acabaram por determinar a periodização histórica utilizada na organização dos capítulos do trabalho proposto. E com isso demonstrar a hipótese desta tese de que o Ceplan constitui um lugar de memória.

Parte da história do Ceplan a que expressa está devidamente registrada na minha memória ${ }^{1}$ e, considerando que esta faculdade é reconhecida pela historiografia contemporânea como um suporte legítimo de informações, buscou-se primeiramente ampliar esse registro mnemônico por meio da coleta de depoimentos de profissionais que participaram, em distintos momentos e em diversas funções administrativas, da construção e desenvolvimento desse centro de pesquisa e produção arquitetônica.

Além de apoiado na pesquisa bibliográfica e documental feita no Centro de Documentação da UnB (Cedoc), na Biblioteca Central, no Arquivo Público do Distrito Federal, na Fundação Oscar Niemeyer, no Correio Braziliense, no próprio Ceplan e em acervos particulares, este trabalho, que partiu de lembranças pessoais, desenvolveu-se sobretudo a partir dos depoimentos de arquitetos que fizeram parte da construção dessa memória institucional, na qualidade de protagonistas das atividades desenvolvidas tanto na Faculdade de Arquitetura e Urbanismo quanto no Centro de Planejamento, ao longo de sua existência.

[...] não se trata mais de lidar com os fatos sociais como coisas, mas de analisar como os fatos sociais se tornam coisas, como e por quem eles são solidificados e dotados de duração e estabilidade. Aplicada à memória coletiva, essa abordagem irá se interessar, portanto, pelos processos e atores que intervêm no trabalho de constituição e de formalização das memórias (POLLAK, 1989, p. 4).

Nas entrevistas, devidamente gravadas em áudio e transcritas entre outubro de 2011 e abril de 2012, esses profissionais forneceram informações significativas e inéditas, sem as quais seria impossível reconstituir o cinquentenário do Ceplan. Colaboraram com este trabalho, concedendo entrevistas e cedendo fotos e documentos de época, os arquitetos: Glauco de Oliveira Campello, João da Gama Filgueiras Lima, Luiz Henrique Pessina, Jayme Zettel, Érico Paulo Seigmar Weidle, Antônio Carlos Moraes de Castro, Frank Algot Svensson, Luis Humberto Martins Pereira, Cláudio José Pinheiro Villar de Queiroz, Paulo de Mello Zimbres, José Galbinski, Alberto Alves de Faria. 


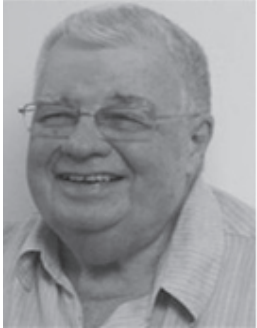

Frank Algot

Svensson

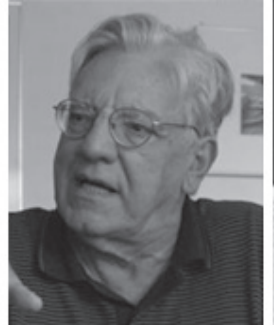

Luis Humberto Martins Pereira

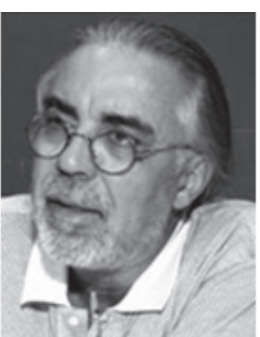

Cláudio José

Pinheiro Villar de

Queiroz

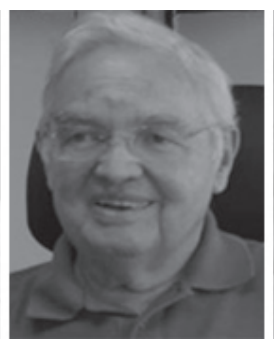

Paulo de Mello Zimbres

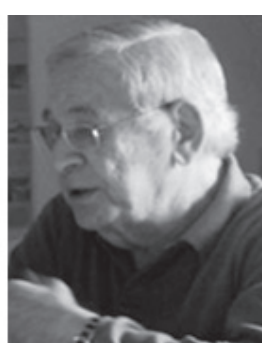

José Galbinski

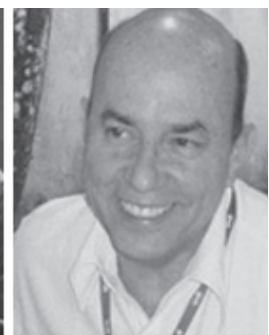

Alberto Alves de Faria

Os diversos testemunhos repousam na relevância atribuída à oralidade que, como estratégia de comunicação espontânea, permite uma experiência mais viva e polissêmica, mais adequada à exposição dos registros mnemônicos, naturalmente carregados de apelo sentimental. Thompson afirma que a história oral pode

[...] alterar o enfoque da própria história e revelar novos campos de investigação; derrubar barreiras que existam entre professores e alunos, entre gerações, entre instituições e o mundo exterior; e, na produção da história, pode devolver às pessoas que fizeram e vivenciaram a história um lugar fundamental, mediante suas próprias palavras (1992, p. 22).

Para dimensionar o valor dos registros mnemônicos e das histórias orais, foi preciso recorrer primeiramente aos conceitos referentes à importância da memória para a historiografia recente, que compreende a memória coletiva como aquela formada pela memória individual somada a fatos que, tendo sido escolhidos como importantes, podem ser convertidos em memória social.

Em seguida, avançou-se no sentido de tentar explicar o conceito de memória institucional que, com a velocidade das comunicações, a consequente mudança nas sensações em relação ao tempo e a necessidade de buscar a transparência das organizações, se torna, cada vez mais, um tema importante para a historiografia.

Buscou-se ainda compreender o valor dos registros iconográficos - fotografias e desenhos - para a reconstituição histórica, em geral, e para a compreensão da trajetória do Ceplan, em particular. Encerrando a pesquisa teórica, procedeu-se a uma breve revisão do conceito contemporâneo de patrimônio.

Com o intuito de enfrentar, sem muitos tropeços, a análise da produção do Ceplan, foram feitos estudos sobre períodos da história da arquitetura, buscando-se sempre que possível estabelecer paralelos entre as arquiteturas da UnB e as tendências a que estiveram filiadas. Um mergulho na história do Brasil contribui também para esclarecer de que forma as conjunturas política, social e cultural interferiram e mesmo determinaram essa produção.

Esse conjunto heterogêneo de informações foi organizado em relatos sobre os períodos estudados, em alguns casos seguidos de fichas ilustradas sobre cada uma das obras analisadas. Dessa forma, o trabalho ficou esboçado como se segue.

Concluída a introdução, em que os conceitos teóricos foram devidamente revisados com base em uma bibliografia específica, partiu-se para o relato sobre a trajetória dos 50 anos do Ceplan, que foi dividido em cinco capítulos, cada qual referente a um tempo histórico específico. 
O Capítulo 1 - O Tempo dos Pioneiros - foi dividido em três partes. Na primeira, por meio de uma descrição sucinta da origem da UnB e da interface entre esse feito e as circunstâncias políticas, sociais e culturais da época, pretendeu-se avaliar o significado do surgimento desta instituição pública no bojo da construção da nova capital no Planalto Central do país. A segunda foi dedicada à explicitação dos condicionantes que contribuíram para a criação do Ceplan e para a determinação de sua missão fundadora, tendo sido integrados a esse relato obras que, por um ou outro motivo, ficaram apenas no papel e também aquelas que, embora construídas, não fazem mais parte do patrimônio da UnB. Na terceira foi feita a descrição e análise ilustrada da produção desenvolvida pelo Ceplan no período, caracterizada fundamentalmente pela pesquisa e experimentação no campo da pré-fabricação em concreto armado, com a linguagem dos edifícios refletindo a preocupação com o desenvolvimento da tecnologia no campo da construção² .

O Capítulo 2 - O Tempo das Crises - foi dedicado aos conflitos políticos que atingiram a UnB e que resultaram na demissão dos professores, fazendo com que as atividades do Ceplan fossem totalmente paralisadas. Muitos projetos que constavam do plano urbanístico de Oscar Niemeyer, além da construção da fábrica de pré-fabricados, uma grande ambição da equipe, não foram executados em função de problemas políticos impostos pelo golpe militar de 1964.

O Capítulo 3 - O Tempo da Consolidação - foi suddividido em duas partes. Na primeira, tratou-se de relatar momento vivenciado pelos integrantes da Universidade que, além das lutas contra o autoritarismo e pelo retorno da democracia, tinham como responsabilidade a consolidação de um projeto de universidade interrompido e desestruturado pelo golpe militar. A segunda foi dedicada à descrição e análise ilustrada da produção desenvolvida pelo Ceplan no período, caracterizado sobretudo pela adoção e valorização de uma linguagem arquitetônica específica, identificada, na época, com o processo de industrialização em curso no país. Após uma sucinta revisão bibliográfica sobre o brutalismo, verificou-se a influência desse estilo, especialmente a vertente associada à chamada Escola Paulista, na produção do Ceplan à época, sobretudo a partir das especulações textuais e projetivas do Team Ten e de seus correligionários ${ }^{3}$.

O Capítulo 4 - O Tempo da Democratização - também foi subdividido em duas partes. Na primeira, enfocou-se tanto a ampliação do número de vagas como a nova vinculação institucional do Ceplan e sua repercussão na mudança da demanda por projetos no campus, incluindo-se a abertura para instalação de obras financiadas por empresas privadas. Na segunda, foi feita uma descrição e análise ilustrada da produção desenvolvida pelo Ceplan no período, caracterizado por maior liberdade individual compositiva, o que, sem o suporte de um projeto coletivo, acabou por resultar em um conjunto arquitetônico cujos exemplares não mantêm unidade entre si. Se nas décadas anteriores prevaleciam as obras em concreto armado, sobretudo aparente, nas décadas de 1960 e 1970 a haver uma diversificação no uso dos materiais, o que contribuiu para essa heterogeneidade da produção. Ao contrário do que aconteceu nas décadas anteriores, quando os arquitetos responsáveis pelas obras eram também professores da instituição, profissionais de fora começaram a ser contratados pelo Ceplan, tendo havido ainda uma sobreposição de funções, o que fez com que muitos

\footnotetext{
2 Foram objeto de estudos específicos as seguintes obras: OCA I e OCA II; FE 1, FE 3 e FE 5; Prtótipo; SG 1, SG 2, SG 4, SG 8 e SG 10; SG 9, SG 11 e SG 12; Colina, blocos A, B, C e D; Conjunto São Miguel (SQN 107), bolcos F, G, H e l; Centro Integrado de Ensino Médio (CIEM), atual ambulatório do HUB; Instituto Central de Ciências (ICC).

${ }^{3}$ Foram objeto de estudo as seguintes obras: Biblioteca Central (BCE); Casa do Estudante Universitário (CEU); Centro Olímpico (CO); Restaurante Universitário (RU); Reitoria; Núcleo de Medicina Tropical (NMT); Faculdade de Tecnologia (FT); Faculdade de Ciências da Saúde (FS); SQN 206, blocos A, B, C, D, E, F, G, H, I, J, K; SQN 205, blocos I, J; Faculdade de Estudos Sociais Aplicados (FA), atual Faculdade de Direito (FD).
} 
edifícios fossem projetados e construídos pela Prefeitura do Campus, sem a interferência do Ceplan ${ }^{4}$.

O Capítulo 5 - O Tempo da Expansão - foi subdividido em três partes. Na primeira, buscou-se contemplar as mudanças políticas, pautadas em maior democratização e especialização do ensino superior, e sua repercussão nas novas demandas a serem satisfeitas na universidade. Data do período um certo esvaziamento do Instituto Central de Ciências (ICC), devido à exigência de unidades mais autônomas; uma rápida e desordenada ocupação dos espaços livres; e a construção de novos campi nas cidades-satélite. Na segunda parte, foi feita a descrição e análise ilustrada das obras produzidas pelo Ceplan no período, que se caracterizou fundamentalmente pela adoção da pré-fabricação de ciclo aberto, em que a pesquisa e a experimentação de novas tecnologias, antes desenvolvidas no âmbito do Ceplan, foram susbtituídas pela aquisição de componentes no mercado para posterior montagem no canteiro ${ }^{5}$. A terceira parte é dedicada aos novos campi da Universidade de Brasília, localizados nas cidades-satélite de Planaltina, Ceilândia e Gama.

\section{De memórias e patrimônios}

Do grego mnemis e do latim memoria, a memória expressa tanto o fato da recordação, as lembranças, as reminiscências, como o ato de narrar, relatar. Ela é a memória e seu avesso, ou seja, é, a um só tempo, a lembrança como uma faculdade psíquica e seu relato. De acordo com Chauí, a "[...] memória é uma evocação do passado. É a capacidade humana de reter e guardar o tempo que se foi, salvando-o da perda total. A lembrança conserva aquilo que se foi e não retornará jamais" (2005, p. 138).

Com as mudanças ocorridas na construção do conhecimento, também presentes na história orientada por reflexões que compreendem uma longa démarche da chamada École des Annales ${ }^{6}$ à chamada história cultural, outros temas passam a despertar o interesse dos historiadores. Novos campos de pesquisas são abertos, não mais limitados às visitas aos registros oficiais, emanados dos governos e preservados em arquivos. Nasce uma outra historiografia que, abarcando as mentalidades das épocas passadas, a geografia, o clima, os costumes, a vida cotidiana, abre espaços para a compreensão das subjetividades, fazendo com que as experiências pessoais passem a ser portadoras de interesse. Como ressalta José Carlos Sebe Meihy,

[...] a história, como tal - disciplina decorrente de fatores ligados aos documentos escritos e, portanto, espaço de letrados -, não é alternativa única ou hegemônica [...] Há, no lugar, outros ataIhos, com destaque às referências mnemônicas feitas por meio da expressão oral (2010, p. 179).

Diante da constatação de que a história não pode reviver o passado, apenas narrá-lo, Paul Veyne afirma que "[...] a história é filha da memória". Partindo-se da seleção e organização de dados, produz-se uma síntese que, segundo esse autor, “[...] não é menos espontânea do que a da nossa memória, quando evocamos os dez últimos anos que vivemos" (1992, p. 15).

\footnotetext{
${ }^{4}$ Foram objeto de estudo específico as seguintes obras: Pavilhão Multiuso I (PM I); Pavilhão Multiuso II (PM II); Centro de Excelência em Turismo (CET); Laboratório de Termobiologia (LT); Colina, blocos E, F, G, H, I, J E K; Casa do Estudante Universitário (Pós- Graduaçâo); Centro de Vivência; Autotrac; Observatório Sismológico (SIS); Centro de Formação de Recursos Humanos em Transportes Urbanos (Ceftru); Pavilhão de Oficinas Especiais do Instituto de Artes (IdA); Posto Ecológico; Almoxarifado Central; Centro Comunitário Athos Bulcão; Centro de Apoio do Desenvolvimento Tecnológico (CDT); Pavilhão Anísio Teixeira (PAT) e Pavilhão João Calmon (PJC).

${ }^{5}$ Foram objeto de estudo específico as seguintes obras: Clínica Odontológica de Ensino e Farmácia Escola; Associação dos Servidores da Universidade de Brasília (Asfub); Centro de Seleção e Promoção de Eventos (Cespe); Laboratório de Estudos Geodinâmicos e Ambientais (Lega) / Laboratório de Geocronologia; Casa do Professor - Sede da Associação dos Docentes da Universidade de Brasília (Adunb); Instituto de Ciências Biológicas (IB); Instituto de Química (IQ); Associação dos Aposentados da Fub (Aposfub) e Associação dos Ex-Alunos da Unb (Ex-Unb); Faculdade de Economia, Administração e Contabilidade (Face); Centro de Alta Complexidade em Oncologia do Hospital Universitário de Brasília (Cacon-HUB); Programa de Educação Infanto-Juvenil (PIJ); Fundação Oswaldo Cruz (Fiocruz); Centro de Manutenção de Equipamentos Científicos (CME); Bloco de Salas de Aula Norte Eudoro De Sousa (Baes); Bloco de Salas de Aula Sul Luiz Fernando Gouvêa Labouriau (BSAS); Módulo de Atividades e Serviços Comunitários (MASC); Centro de Informática (CPD); Instituto de Ciências Exatas (IE); Instituto de Ciência Política (Ipol); Instituto de Relações Internacionais (Irel); Instituto de Ciências Sociais (ICS); Centro de Atendimento de Estudos Psicológicos (Caep); Centro de Referência em Conservação da Natureza e Recuperação de Áreas Degradadas (Crad); Centro de Desenvolvimento Sustentável (CDS); Memorial Darcy Ribeiro (MDR) - Beijódromo.
}

${ }^{6}$ Liderada por um grupo de historiadores reformistas, reunidos ao redor de Marc Bloch e Lucien Febvre, durante os anos 20 do século passado, a École des Annales tinha por objetivo afastar a historiografia da sua dependência para com a política, como queria a corrente positivista então ainda largamente hegemônica. 
Assim, não se trata mais de uma história única tida como verdade, mas sim de uma história problema, aberta às sensibilidades e à vida cotidiana. Com isso, a memória passa a ser caracterizada como um processo dinâmico de representação do passado, sendo seu registro aceito como importante fonte historiográfica. Nesse panorama, perde força a linearidade temporal calcada nas noções de progresso e evolução, o viés "positivo-evolucionista-linear-progressivo" dos historiadores, dando lugar ao viés não linear da memória.

Vista anteriormente com desconfiança devido à plausibilidade científica, a memória assume hoje um papel central e perfeitamente aceitável na historiografia contemporânea. A importância da memória para a história não é pequena, pois ela constitui significativa fonte para o trabalho dos historiadores; as lembranças e reminiscências da memória coletiva auxiliam o pesquisador, que, com rigor metodológico, as transforma em valiosas fontes para a produção do conhecimento científico. Para Peter Burke (1991), embora a história identifique, contextualize e analise as memórias como fonte, elas também podem ser o seu objeto de estudo.

Apesar de a história alimentar-se da memória tomada como objeto, matéria-prima ou ponto de partida, não se pode construir conhecimento exclusivamente a partir dela, pois se corre o risco de não avaliar corretamente o grau de parcialidade, subjetividade, superficialidade e deformação que pode conter. Alertando para esse fato, Lowenthal diz que a memória produz a revisão das próprias lembranças, fazendo uma espécie de depuração do que pode ser compreendido como inconveniente: "[...] a memória transforma o passado experimentado no que mais tarde pensamos que deveria ter sido, eliminando as cenas não desejadas e adequando as prediletas". Ao fazer uma espécie de depuração do que é considerado incorreto ou inadequado, "[...] a memória transforma o passado, prestando um grande serviço à história" (1998, p. 301).

Feitas essas considerações, pode-se afirmar que, não sendo esperado que a narrativa histórica se imponha como uma verdade única, mas como uma forma possível de reconstruir, pelo presente, um passado fadado ao esquecimento, o presente trabalho, apoiado na base documental disponível, empenha-se na construção de uma história singular, a partir de um sistema plural de histórias individuais, pois, como diz Myrian Santos, "[...] o passado deixa de ser resgatado a partir de uma estrutura pré-determinada e passa a ser compreendido a partir dos grupos sociais envolvidos em sua construção" (2003, p. 78).

Seria eu a melhor pessoa para intentar uma construção, ou uma reconstrução dessa monta, principalmente quando a memória figura como depositária de muitas situações que, costuradas umas às outras, pretendem constituir o suporte principal do presente trabalho? Afinal, uma vida de constantes mudanças de casa, cidade, escola e amigos não facilita a guarda de nomes, feições e circunstâncias. Assim como a de Dom Casmurro, minha trajetória não se compara "[...] a quem passe a vida na mesma casa de família [...] que se lhe grava tudo pela continuidade e repetição" (Assis, 1996, p. 79). Como afirma Ecléa Bosi, “[...] mudar é perder uma parte de si mesmo; é deixar para trás lembranças que precisam desse ambiente para sobreviver" (1994, p. 436).

Por outro lado, em que medida a própria incerteza do dia seguinte, a velocidade das transformações do cotidiano não contribui para uma "intuição", quase premonitória, que auxilia na seleção e retenção de algumas lembranças? Serviriam essas como pontos de apoio suficientes para esta narrativa a que ora me proponho realizar? Uma possível resposta pode ser encontrada em Nora, que chama a atenção para uma característica que marca as sociedades que experimentam mudanças rápidas: 
[...] o medo de que tudo está na iminência de desaparecer, acompanhado da ansiedade sobre o significado preciso do presente e a incerteza sobre o futuro, investe até a mais humilde testemunha, o mais modesto vestígio, com a dignidade de ser potencialmente memorável. Dessa forma, a resultante obrigação de lembrar faz de todo homem o seu próprio historiador (NORA, 1996, p. 8, tradução nossa).

Mas seria o fenômeno de selecionar e reter circunstâncias decorrente única e simplesmente das condições transitórias vivenciadas no passado? Ou dos registros que se mantêm vivos como uma sombra por toda a vida? Qual a força do presente na recuperação dessas lembranças? Para Henri Bergson,

Arrastamos atrás de nós, sem disso nos apercebermos, a totalidade de nosso passado; mas nossa memória só derrama no presente duas ou três lembranças que completarão, por algum aspecto, a situação atual [...] Chega um momento em que a lembrança reduzida se encaixa tão bem na percepção presente que não saberíamos dizer onde a percepção acaba e onde a lembrança começa (1999, p. 195).

Esse "derramar" quase ao acaso, a que o autor se refere, pressupõe uma acurada seleção que, ao determinar a lembrança que completa e esclarece a situação presente, contribui para preparar a ação. À memória, por sua vez, cabe evocar todas as percepções análogas a uma percepção presente para nos sugerir a decisão mais útil. Ainda nas palavras desse autor, [...] o papel do corpo não é armazenar as lembranças, mas simplesmente escolher, para trazê-la à consciência distinta graças à eficácia real que lhe confere a lembrança útil, aquela que completará e esclarecerá a situação presente em vista da ação final (1999, p. 209).

Bergson distingue ainda dois tipos de memória: a "memória-hábito", que, adquirida pelo esforço da atenção e pela repetição de gestos ou palavras, traz o passado para o presente, aniquilando-o como passado, e retendo, da criação, somente os entes criados; e a "memória pura", que retorna ao passado como tal, revivendo-o como processo de criação e efetivação. Essa distinção é importante porque abre caminho para se entender a socialização da memória: "No processo de socialização tem lugar a memória-hábito, repetição do mesmo esforço, adestramento cultural. No outro polo, a lembrança pura traz à tona da consciência um momento único, singular, irreversível, da vida" (BOSI, 2003, p. 52).

O presente funciona, então, como uma espécie de fenda, cujo acúmulo da vida passada determina continuamente nossa compreensão do passado. A memória é, portanto, a conservação e a acumulação do passado no presente. Na medida em que se conserva, o passado não se arquiva na forma de uma coleção de objetos esparsos, mas se mantém em incessante conexão com a vivência individual presente. Ou, como diz Bosi,

Antes de ser atualizada pela consciência, toda lembrança "vive" em estado latente, potencial. Esse estado, porque está abaixo da consciência atual ('abaixo' metaforicamente), é qualificado de 'inconsciente'. [...] A própria ação da consciência supõe o 'outro', ou seja, a ação de fenômenos e estados infraconscientes que costumam ficar à sombra. É precisamente nesse reino de sombras que se deposita o tesouro da memória (1994, p. 51-52).

Argumentando contra a acusação de a memória ser pouco confiável, e estabelecendo o testemunho como estrutura que liga a memória à história, Paul Ricoeur aponta para o fato de ser a memória o único recurso para significar o caráter passado daquilo que se declara ter lembrado. Paradoxalmente, ao aproximar a memória da imaginação, afirma que "[...] a escrita da história partilha das aventuras da composição em imagens da lembrança, sob a égide da função ostensiva da imaginação" (2007, p. 70). 
No entanto, ao cunhar o conceito de memória coletiva, Maurice Halbwachs interfere a favor da memória e, buscando neutralizar os possíveis efeitos negativos da imaginação para a construção histórica, conclui que as vivências do passado não se materializam em nossos corpos ou mentes, e sim na sociedade circundante. Para o autor, as memórias se perpetuam enquanto nos mantivermos ligados aos grupos sociais com os quais partilhamos experiências, vida, crenças, e a memória se esvai quando nos afastamos do grupo. Em suas palavras,

[...] o funcionamento da memória individual não é possível sem os instrumentos que são as palavras e as ideias, que o indivíduo não inventa, mas toma emprestado de seu ambiente [...] para evocar seu próprio passado, em geral a pessoa precisa recorrer às lembranças de outras (Halbwachs, 2006, p. 72).

Na tentativa de justificar sua hipótese, Halbwachs recorre aos sonhos e às memórias de infância. Os sonhos seriam momentos em que as recordações estão ausentes, uma vez que, muito embora apresentem fragmentos semelhantes a lembranças ou reminiscências, uma cena do passado nunca apareceria diante dos olhos em sua completude/totalidade/inteireza, porque durante os sonhos o espírito estaria mais afastado da sociedade. Segundo ele, sem o suporte social que confronta a nossa consciência com as memórias de outros, toda recordação se faz impossível. Por outro lado, não somos capazes de armazenar imagens e pensamentos da primeira infância porque as impressões só se ligam a uma base mais sólida quando os indivíduos se tornam seres sociais. $\mathrm{O}$ pensamento de Halbwachs é corroborado por Ricoeur, para quem "[...] não é senão a partir de uma análise sutil da experiência individual de pertencer a um grupo, e na base do ensino recebido dos outros, que a memória individual toma posse de si mesma" (2007, p. 130).

Apesar de em seus estudos privilegiar a memória coletiva, ao se referir à memória individual Halbwachs não deixa de observar a existência, na base de toda lembrança, de "[...] um estado de consciência puramente individual que, para distingui-lo das percepções onde entram elementos do pensamento social, admitiremos que se chame intuição sensível" (2006, p. 41).

Para Bosi, quando a percepção original obriga o sujeito a conter as distorções em certos limites, por ser ele a testemunha ocular do fenômeno, a memória individual é mais fiel que a social. No entanto, a autora alerta que, se a memória do coletivo for ameaçada, "[...] sempre é possível um confronto e uma correção dos relatos individuais, e a história se salva de espelhar apenas os interesses e distorções de cada um" (1994, p. 420).

Como a memória individual não é formada pela vivência simultânea de uma pessoa em diversos grupos, a soma não redutível dessas várias memórias coletivas que se alocam no ser representa sua parcela individual de experiência. Em outras palavras, a constituição da memória é, em cada indivíduo, uma combinação aleatória das memórias dos diferentes grupos aos quais ele pertenceu ou pertence, o que talvez possa explicar por que as pessoas guardam memórias diferenciadas.

A despeito dessa diferenciação, a hipótese de a memória ser um atributo meramente individual está hoje superada. Estudos, de diversos campos disciplinares, concordam que a memória constitui uma experiência compartida, ou seja, de natureza social. Mesmo como registros de experiências pessoais, as lembranças resultam da interação com outras pessoas.

Longe de se constituir em uma repetição exata de algo passado, a memória, como faculdade ativa e dinâmica, corresponde a uma reconstrução que cada um realiza dependendo da sua história, do momento e do lugar em que se encontra. Nesse processo, cada indivíduo constrói sua 
memória em ativa interação com os demais, ou seja, ligada às experiências e aos elos afetivos de pertencimento a um determinado coletivo social. Tais laços, por sua vez, ao produzirem e reforçarem lembranças comuns, geram uma memória social ou coletiva, que confere ao indivíduo o sentimento de identidade, calcado numa memória compartilhada não só no campo histórico, mas sobretudo no campo simbólico.

A memória se modifica e se rearticula conforme a posição ocupada pelo indivíduo e as relações que este estabelece nos diferentes grupos de que participa. Também está submetida a questões inconscientes, como o afeto, a censura, entre outros. Ao se alimentar da memória coletiva e histórica, a memória individual inclui elementos mais amplos do que a memória construída pelo indivíduo e seu grupo.

É preciso enfatizar que lembrar não é uma atitude meramente contemplativa, saudosista, passiva. Pelo contrário, exige o esforço de trazer para o presente, e com os recursos do presente, as vivências do passado. Ou, como diz Bosi, com muita propriedade e em linguagem poética,

\begin{abstract}
Na maior parte das vezes, lembrar não é reviver, mas refazer, reconstruir, repensar, com imagens e ideias de hoje, as experiências do passado. A memória não é sonho, é trabalho. Se assim é, deve-se duvidar da sobrevivência do passado, "tal como foi", e que se daria no inconsciente de cada sujeito. A lembrança é uma imagem construída pelos materiais que estão agora à nossa disposição, no conjunto de representações que povoam nossa consciência atual. Por mais nítida que nos pareça a lembrança de um fato antigo, ela não é a mesma imagem que experimentamos na infância, porque nós não somos os mesmos de então e porque nossa percepção alterou-se e, com ela, nossas ideias, nossos juízos de realidade e de valor (1994, p. 55).
\end{abstract}

O caráter social da memória é fortemente reafirmado pelo fato de que a troca de rememorações de experiências entre os membros de um grupo se realizam por meio da linguagem. Como afirma Bosi, a linguagem, como instrumento socializador da memória, reduz, unifica e aproxima, no mesmo espaço histórico e cultural, vivências tão diversas como o sonho, as lembranças e as experiências recentes.

Na pesquisa que deu origem ao presente trabalho, às recordações pessoais acrescentaram-se fragmentos da memória de vários dos participantes da história do Ceplan. Traçando-se os elos de pertencimento entre indivíduos que, de uma forma ou de outra, estiveram vinculados à construção dessa história, buscou-se conferir ao conjunto de lembranças individuais o status de memória coletiva ou social.

Estabelecidas as conecções entre as lembranças do passado e o presente, e a importância das lembranças individuais para a memória coletiva, coube investigar um pouco mais de que forma uma narrativa apoiada em registros de memória pode adquirir legitimidade. Para tanto, parece adequada a comparação que Nora estabelece entre a memória e a história:

Memória é vida. Seus portadores sempre são grupos de pessoas vivas e, por isso, a memória está sempre em permanente evolução [...] Porque é afetiva e mágica, a memória não se acomoda a detalhes que a confortam; se alimenta de lembranças vagas, telescópicas, globais ou flutuantes, particulares ou simbólicas, sensível a todas as transferências, cenas, censura ou projeções. A história, como operação intelectual e laicizante, demanda análise e discurso crítico. A memória instala a lembrança no sagrado, a história a liberta e a torna prosaica. A história é a sempre a incompleta e problemática reconstrução do que já não existe. A memória sempre pertence a nossa época e está intimamente ligada ao eterno presente: a história é uma representação do passado (1993, p. 9). 
No que diz respeito à relação entre memória e história, a diferença entre as postulações feitas por Halbwachs na década de 1920 e aquelas mais recentes de Nora está no fato de que para este último a categoria memória deixou de existir na medida em que passou a ser reivindicada pelo discurso histórico. Ao invés de se dedicar prioritariamente à história política oficial dos povos com base na cronologia como único meio de organização das informações, a história cultural se ocupa da pesquisa de determinada cultura em um dado período e lugar. Sobre a questão do tempo na historiografia contemporânea, assim se manifesta Jacques Le Goff:

\footnotetext{
À história estão intimamente conectados dois progressos essenciais: a definição de pontos de partida cronológicos [...] e a busca de uma periodização, a criação de unidades iguais, mensuráveis, de tempo [...] Hoje, a aplicação à história dos dados da filosofia, da ciência, da experiência individual e coletiva tende a introduzir, junto destes quadros mensuráveis do tempo histórico, a noção de duração, de tempo vivido, de tempos múltiplos e relativos, de tempos subjetivos ou simbólicos. O tempo histórico encontra, num nível muito sofisticado, o velho tempo da memória, que atravessa a história e a alimenta (1990, p. 9).
}

Privilegia-se hoje a história em seu sentido plural, ou seja, a história das representações que, em função das múltiplas realidades que engloba, assume formas diversas. Para Le Goff (1990), as concepções mais globais da sociedade podem ser enquadradas na história das ideologias; a história das estruturas mentais integra a história das mentalidades; a história da produção do espírito ligada à imagem corresponde à história do imaginário; e a história das condutas, ou história do simbólico, lidando no campo das práticas e dos rituais, pode ser vista como história do oculto.

Essa mudança de ótica recoloca o papel da iconografia como fonte historiográfica. Se até o início do século XX o documento escrito constitui o registro privilegiado de reconstrução do passado em detrimento de outros tipos de fontes, a partir 1929 Lucien Febvre e Marc Bloch, fundadores da revista Annales d'histoire économique et sociale, passam a insistir na necessidade de ampliação do escopo da noção de documento. Acreditando que a falta de registros escritos não significa a impossibilidade de construção da história, eles defendem a diversificação dos documentos de pesquisa, o que acaba por configurar, principalmente a partir de 1960, uma "revolução documental". A utilização de novas fontes, entre as quais as imagens, provoca uma renovação dos estudos históricos e da própria atuação do historiador, do antropólogo, do sociólogo etc.

Coforme afirma Boris Kossoy, "[...] com o alargamento do conceito que o termo 'documento' passou a ter, a fotografia começa a ser tratada de forma diferenciada" (2001, p. 31). Com isso, os atributos técnicos e formais da imagem fotográfica assumem papel relevante no entendimento das diferentes questões das quais a história se ocupa, não somente pelo fato de a fotografia dar ênfase aos temas que nela aparecem retratados, mas à forma como esses temas são constituídos.

Referindo-se ao papel da fotografia na divulgação da arquitetura moderna, Patrícia Méndez (2007) afirma que "Os edifícios, por suas condições tectônicas, estáticas e formais, constituíram o 'modelo' mais acabado e puderam se transformar em notícia graças às imagens fotográficas". Cabe acrescentar aqui a importância dos croquis e desenhos dos arquitetos na divulgação do feito arquitetural.

Assim a fotografia está indelevelmente relacionada ao tempo, à história, e ao ser humano que a propõe ou dela faz parte; está sempre no tempo passado, tentando uma permanência impossível. Para Susan Sontag, "[...] a fotografia transforma o passado em objeto de carinhoso respeito, confundindo diferenças morais e desarmando julgamentos históricos, através do patético generalizado que é olhar para o tempo passado" (1981:70). 
Para efeito do presente trabalho, os edifícios assumem a condição de documentos, pois se trata da reconstrução histórica de uma instituição criada com o objetivo explícito de produzir arquitetura, ofício para o qual a imagem, como suporte de informação, desempenha um papel privilegiado. Se em muitas instituições o registro de suas trajetórias está contido basicamente em documentos - atas, cartas, memorandos, relatórios etc. - nos "papéis envelhecidos" a que se refere Paulo Nassar, no caso do Ceplan, os testemunhos mais importantes de suas ações estão materializados em edifícios que, por refletirem as demandas de seus tempos, merecem a qualificação de históricos. $\mathrm{O}$ Ceplan, instância responsável pela produção do patrimônio material da Universidade de Brasília, terá aqui sua produção descrita histórica e iconograficamente. Pretende-se, com tal descrição, demonstrar que esse centro de planejamento - cuja produção é muito pouco conhecida e ainda não foi devidamente estudada - é um lugar de memória.

A análise desses edifícios pressupõe uma ampla consulta aos documentos iconográficos - desenhos e fotografias -, os quais ganham cada vez mais espaço no meio acadêmico como fonte de conhecimento histórico. Considerando que os edifícios contêm em si a "escrita" do passado, é para desvendá-la que a iconografia, cumprindo duas funções distintas, assume um papel relevante no contexto da reconstituição histórica aqui realizada: por um lado, complementando o texto, deve servir como instrumento de contextualização espaço-temporal dos fatos narrados; por outro, deve ser responsável pela explicitação das características formais e construtivas dos edifícios não facilmente transmissíveis por meio da linguagem verbal.

Para tratar das particularidades que envolvem a atuação do Ceplan, cabe alargar este quadro teórico referencial para tratar de um tipo particular de memória, que tem ocupado cada vez mais espaço na produção acadêmica, a memória institucional.

A complexa realidade atual com seus valores efêmeros, ao subverter os quadros de referência que ensejavam certa estabilidade no meio social, tem provocado um abalo da identidade individual e coletiva, levando os indivíduos, por um lado, a se empenharem na busca do sentido daquilo que fazem, e, por outro, a se dedicarem a novas formas de prática social. De acordo com Maria Ester de Freitas, "[...] os indivíduos se encontram numa situação de fragilidade de identidade, de enfraquecimento de vínculos sociais diversos, de busca de sentido, de desorientação quanto ao presente e ao futuro e de carência de referenciais" (2000, p. 57).

Essa assertiva encontra respaldo em Manuel Castells, para quem, "[...] diante da ampla desestruturação das organizações, deslegitimação das instituições, enfraquecimento de importantes movimentos sociais e expressões culturais efêmeras", a busca pela identidade tornouse "a fonte básica de significado social neste mundo de fluxos globais de riqueza, poder e imagens" (2000, p. 23).

Nesse sentido, todo o esforço de resgatar a memória social, na qual se inclui a memória institucional, apresenta-se, principalmente a partir da segunda metade do século XX, como uma possibilidade de estabelecer 'lugares' mais seguros para os sujeitos dispersos nos não lugares da complexidade social contemporânea.

Conforme observou Nassar,

Mais do que nunca, a questão do pertencimento, na sociedade atual, está posta como algo que diferencia e solidifica a relação dos públicos com a organização. Em um mundo que é rapidamente banalizado pela massificação, pela utilização cotidiana, pelo excesso de exposição, uma diferenciação que nasce pela história de uma organização, é um atributo que poucos têm (2007, p. 186). 
Para Halbwachs (2006), são os grupos sociais que determinam o que é memorável e os lugares nos quais essa memória será preservada. Esses espaços, chamados de "lugares de memória" por Nora (2008), são assim conceituados por Le Goff:

\footnotetext{
Lugares topográficos, como os arquivos, as bibliotecas e os museus; lugares monumentais como os cemitérios ou as arquiteturas; lugares simbólicos como as comemorações, as peregrinações, os aniversários ou os emblemas; lugares funcionais como os manuais, as autobiografias ou as associações: estes memoriais têm a sua história. Mas não podemos esquecer os verdadeiros lugares da história, aqueles onde se deve procurar não a sua elaboração, não a produção, mas os criadores e os denominadores da memória coletiva: Estados, meios sociais e políticos, comunidades de experiências históricas ou de gerações, levadas a constituir os seus arquivos em função dos usos diferentes que fazem da memória (1990, p. 473).
}

Esses lugares de memória admitem uma tríplice acepção: são lugares materiais onde a memória social se ancora e pode ser apreendida pelos sentidos; são lugares funcionais porque têm ou adquirem a função de alicerçar memórias coletivas, e são lugares simbólicos onde essa memória coletiva se expressa e se revela. Longe de ser um produto espontâneo e natural, os lugares de memória são uma construção histórica.

Considerando que a partir dos "verdadeiros lugares da história" é possível encontrar os criadores da memória coletiva e que é necessário, como afirma Halbwachs, "[...] colocar em ação todos os recursos da memória coletiva" (1990, p. 187), as instituições, como parte integrante dos meios sociais e políticos da sociedade e fontes produtoras de informações, têm papel importante na construção da memória social.

Como agentes coletivos planejados para realizar determinados objetivos, como, por exemplo, a produção de bens e serviços - as organizações podem, segundo Andréia Barbosa (2010), ser reconhecidas atualmente também como produtoras de significado e como espaços para o desenvolvimento de saberes e de valorização dos indivíduos. Antes, no entanto, de concordar com essa afirmativa, cabe recorrer ao antropólogo francês Marc Augé: "[...] se um lugar pode se definir como identitário, relacional e histórico, um espaço que não pode se definir nem como identitário, nem como relacional, nem como histórico definirá um não lugar". Para o autor, o não lugar constitui um espaço de passagem, do provisório, do efêmero e do transitório, e representa uma configuração social característica de uma época que se define pelo excesso de fatos, pela superabundância espacial e pela individualização das referências. Em contrapartida, o lugar compõe a identidade individual e marca as relações dos sujeitos com os outros. Em geral, os lugares são espaços utilizados para organizar atividades consideradas importantes para determinada sociedade ou comunidade; locais com os quais as pessoas se identificam e chamam de 'seu' (Augé, 1994, p. 73).

Ainda conforme Augé, o lugar torna-se fonte de referências e de identidade, um espaço onde os sujeitos podem (re)encontrar o seu valor e (re)adquirir o sentido de suas existências à medida que visualizam a ampla trajetória da organização disposta na linha do tempo e percebem que fazem parte dessa história de valores não transitórios.

Assim, dependendo das relações sociais que nelas se estabelecem e dos objetivos de sua existência, as organizações podem se constituir em lugares ou não lugares para os sujeitos que as integram. Um estudo que revele o funcionamento de determinada organização pode servir como parâmetro para a análise tanto das mudanças ocorridas ao longo de sua trajetória como dos diferentes papéis desempenhados por seus integrantes. 
Com o impacto das novas tecnologias e mídias na percepção e na sensibilidade humanas, a cultura em torno da memória busca ocupar um importante papel nas transformações atuais da experiência com o tempo. Ao propiciar um sentido de continuidade em um contexto caracterizado pelo efêmero, pode significar um contraponto aos não lugares. De acordo com João Carlos Tedesco, "Num contexto de mercantilização da cultura, percebe-se a necessidade de construir uma biografia, uma história da própria vida que tenha possibilidade de fornecer, ainda que limitadamente, um senso de continuidade do tempo num contexto de fragmentação" (2004, p. 75).

Estendendo essa necessidade de reconstituição da memória ao caso das organizações ou instituições, Adriano Maricato assinala que,

[...] ao compreender a vida de uma organização disposta na linha do tempo, podemos distinguir quão importantes foram e são os fatos históricos, as reações, as linhas de comando e o perfil que ela vai incorporando, traduzindo-se na própria maneira de ser da organização $(2006$, p.126).

Como ferramenta na comunicação entre as organizações e seus públicos, a memória institucional é, atualmente, um mecanismo ágil capaz demonstrar valores e princípios que acompanham a vida de uma organização, com o intuito de promover um sentimento de identificação com suas diretrizes e, por conseguinte, com a própria instituição. Além disso, mais que um repositório de informações, a memória institucional é tida hoje como um fator de responsabilidade social, que inclui a transparência das ações institucionais como um valor a ser perseguido.

De acordo com Peter Drucker (1999), no último século as inúmeras transformações pelas quais o mundo passou modificaram mais as suas configurações, processos e estruturas do que em qualquer outra época da história humana. No entanto, se por um lado o recente impulso no desenvolvimento das tecnologias da informação e da comunicação tem levado a uma ruptura das noções de tempo e espaço e a profundas mudanças nas relações sociais, nas formas de ver, ouvir, sentir e se relacionar, por outro essa tecnologias têm facilitado a construção de memórias institucionais.

Exercendo um papel preponderante na vida dos indivíduos, a informação adquire hoje papel estratégico, cujos reflexos são sentidos também no ambiente organizacional. Para Margarida Kunsch, "[...] é exatamente no âmbito dessa nova sociedade e de cenários mutantes e complexos que as organizações operam, lutam para se manter, para cumprir sua missão e para cultivar seus valores" (2006, p. 35).

As instituições e organizações em geral produzem, ao longo de sua trajetória, vasta quantidade de documentos fundamentais para a preservação da memória institucional que, além de retratarem as atividades realizadas, fornecem um precioso panorama do contexto em que estão inseridas, contemplando o tempo e o espaço que ocupam na sociedade. No entanto, mesmo tendo sido produzido em diferentes suportes, pouco valor têm essas informações se não estiverem reunidas, e devidamente guardadas, organizadas e classificadas para serem disponibilizadas para consultas. O armazenamento da documentação e das memórias ocorre em acervos com conteúdos e características diversas, incorporando vivências e experiências dos indivíduos, assim como outros elementos fundamentais para a imagem organizacional. A responsabilidade histórica nesse processo cabe ao profissional que recupera, organiza e comunica essa memória da organização para atender aos objetivos do presente e favorecer o seu futuro. 
A memória institucional figura como uma alternativa eficaz de legitimação dos valores, posturas éticas, princípios e responsabilidades de uma organização no meio social onde esta se insere. Karen Worcman vai além ao afirmar que a memória institucional não significa apenas uma reconstrução do passado da instituição, ela pode constituir "[...] um marco referencial a partir do qual as pessoas redescobrem valores e experiências, reforçam vínculos presentes, criam empatia com a trajetória da organização e podem refletir sobre as expectativas dos planos futuros" (2004, p. 23). O objeto do presente estudo, o Ceplan, é visto aqui como uma instituição viva, que tem o futuro como um espaço aberto a novos desafios.

Segundo Icléia Costa, "Se a instituição existe, a memória se plasma. É pregnante. Constitui marcas, rastros ou traços que contêm informação. Substâncias formadas. Em estado caótico ou virtual, a informação é sempre embrião: forma e contém informação" (1997, p. 3). E,

Ao contrário do que costumamos pensar, nós somos e fazemos nossas instituições. [...] cada indivíduo cria um elo na instituição da qual faz parte, e esta é uma relação criada ao longo do tempo, que não percebemos. E a memória institucional é o reflexo dessa trajetória, não como mimesis, mas como um cristal com suas múltiplas e infinitas facetas. É também uma memória histórica, efeito dos condicionamentos e das formações históricas. Ao invés de ficarmos no registro das causas, é preciso lançar as ideias no seio das indeterminações, onde é necessário escolher, afirmar a divergência produzida pelo próprio problema. A resolução do problema será a criação (COSTA, 1997, p. 146).

A afirmação sobre o papel da criação e da participação de cada um na construção das instituições, conforme observado pela autora, está vinculada à importância das subjetividades. Assim, sem fugir ao compromisso de buscar, a todo custo, a legitimidade das informações, pretende-se, aqui, manter um espaço aberto para que os sentimentos subjetivos daqueles que testemunharam a história do Ceplan nos últimos cinquenta anos possam aflorar sem censura. Trata-se de transformar cada um dos depoentes em partícipes diretos desta iniciativa de construir essa história, preservando-se inclusive a carga subjetiva e afetiva implícita na realização dessa tarefa, pois como diz Gabriel Garcia Márquez (2003) na epígrafe da primeira edição de sua autobiografia Viver para contar, "A vida não é a que a gente viveu, e sim a que a gente recorda, e como recorda para contá-la".

\section{Reportando-se a Prochasson, Manoel Luiz Salgado Guimarães reconhece que}

[...] estaríamos sob um novo regime de escrita, segundo o qual seria exigido cada vez mais uma
escrita submetida aos ditames dos afetos, sejam eles derivados de engajamentos políticos específi-
cos, de crenças particulares ou mesmo derivados de um convite à indivi-7dualidade do historiador
[...] Esse novo regime emocional supõe determinados constrangimentos às narrativas do passado
assim como fazem um apelo à dimensão cada vez mais autoral do texto historiográfico (2008, p. 18).

Oliveira vai buscar na mitologia grega uma explicação para a relação, indissociável e complexa, entre a memória e a imaginação.

A deusa Mnemosine, ou Mnêmesis, nasce dos amores do Céu, a eternidade (Cronos), e da Terra (Gea), sendo a rainha de Eleutera, a terra da liberdade completa. É a deusa protetora da justiça e da vingança, já que une o presente e o passado, realizando também a ligação entre o mundo do real de Gea e o mundo da representação de Cronos. Mnemosine ligou-se a Zeus, senhor do Olimpo, rei de todos os deuses gregos e administrador da justiça, nascendo daí Clio, a História, cujo berço está na representação do passado. Desta forma, a memória seria a mãe de todas as artes, tendo ligação direta com o sobrenatural. É a deusa que possibilita aos poetas a lembrança do passado e a sua transmissão oral aos mortais. Assim, a memória tem estreita ligação com 
a imaginação. Por isso, lembrar e inventar têm relações profundas. A ligação entre Mnemosine e Clio é muito próxima, mas nem sempre coincidente, nem sempre pacífica, sendo por vezes até conflituosa (2008, p. 41).

Ao advogar a importância das ações de preservação da memória institucional para o desenvolvimento de uma nação, Costa chama a atenção para os desdobramentos da mudança de paradigmas da historiografia contemporânea, que, contrariando o postulado da neutralidade da ciência, abre espaços para "a convivência de enfoques diferenciados na metodologia das Ciências Sociais e Humanas" e, consequentemente, para "a recuperação de aspectos do cotidiano nunca antes estudados". Segundo a autora,

A chamada Nova História nos conduz a repensar o fato histórico, os acontecimentos e as crises, alargando o campo do documento histórico para abrigar fotografias, filmes, documentos orais, ferramentas, ex-votos, ampliando os horizontes da crítica desses documentos, bem como da percepção do tempo e da mudança (COSTA, 1995, p. 45, 46).

O que ecoa a constatação de Le Goff, para quem

[...] ampliou-se a área dos documentos, que a história tradicional reduzia aos textos e aos produtos da arqueologia, de uma arqueologia muitas vezes separada da história. Hoje os documentos chegam a abranger a palavra, o gesto. Constituem-se arquivos orais; são coletados etnotextos (1990, p. 11).

No que diz respeito à construção da memória institucional, Nassar chama a atenção para o fato de que "[...] recuperar, organizar, dar a conhecer a memória não é juntar em álbuns velhas fotografias amareladas, papéis envelhecidos. É usá-la a favor do futuro da organização e de seus objetivos presentes. É tratar de um de seus maiores patrimônios" (2004, p. 22). A afirmativa de Nassar conduz à abordagem de mais um aspecto vinculado ao tema do presente trabalho: a possibilidade de os documentos 'de pedra e cal' se alçarem à condição de patrimônio histórico. Sem menosprezar as outras fontes de informação, o fato de ter como suportes para a reconstrução da memória institucional o acervo documental armazenado no Centro de Documentação da UnB (Cedoc) e no Ceplan e os edifícios produzidos, alguns dos quais cinquentenários, coloca em pauta a questão do patrimônio, o que sugere algumas considerações teóricas específicas.

No âmbito deste trabalho são reconhecidos dois suportes principais: os registros mnemônicos coletados, que, como história oral, correspondem a um patrimônio imaterial; e os documentos, entre os quais os próprios edifícios produzidos no âmbito do Ceplan, que integram o patrimônio material da Universidade de Brasília.

O conceito de patrimônio histórico vem adquirindo novas dimensões e significados. Françoise Choay (2006) identifica, especialmente a partir da década de 1960, uma intensificação da prática patrimonial, que, culminando com um alargamento da noção de patrimônio histórico, passa a atingir novas categorias de edifícios, além de conjuntos urbanos e do chamado patrimônio imaterial. Esse alargamento da noção de patrimônio observado por Choay, que resulta na preservação tanto de conjuntos edificados como de modos de vida, é observado também Nora, que chama a atenção para um patrimônio renovado,

[...] que desceu do céu das catedrais e dos castelos para refugiar-se nos costumes olvidados e em antigas maneiras de fazer, no bom vinho, nas canções e nos dialetos locais; saiu dos museus nacionais para invadir os espaços verdes ou afirmar-se nas pedras das velhas ruas (2008, p. 183).

Esse autor não vê os lugares de memória como repositórios, e sim como espécies de oficinas, elementos a partir dos quais a memória trabalha: “[...] os lugares de memória não são aquilo a partir 
do que se lembra, mas lá onde a memória trabalha; não a tradição mesma, mas seu laboratório" (NORA, 1993, p. 50). Ao analisar a memória nacional francesa, o autor propõe a seguinte caracterização tipológica: memória real, referente ao período feudal; memória-Estado, identificada com o período da monarquia absoluta; memória-nação, correspondente ao momento de consolidação da Revolução; e memória-cidadão, identificada com o período republicano. Segundo ele, esses quatro tipos só ganham sentido quando vinculados a uma quinta memória, a memória-patrimônio, que, resultante do crescimento da importância do patrimônio cultural, corresponde a uma forma privilegiada de expressão da memória nacional:

\begin{abstract}
Por memória-patrimônio não basta se contentar em entender o alargamento brutal da noção e sua dilatação recente e problemática a todos os objetos testemunhos do passado nacional, mas, muito mais profundamente, a transformação em bem comum e em herança coletiva das implicações da memória mesma (NORA, 2008, apud GONÇALVES, 2012, p. 40).
\end{abstract}

Ainda referindo-se ao contexto francês, Nora completa: "Havia antes uma história nacional e memórias particulares; hoje há uma memória nacional, cuja unidade é feita de uma reivindicação patrimonial dividida, em permanente multiplicação e busca de coesão" (2008: 193).

O patrimônio histórico é hoje subdividido em duas categorias: o patrimônio material, referente aos testemunhos físicos do passado; e o patrimônio imaterial, referente aos bens cuja importância não está na dimensão física, como os saberes, as tradições orais, os modos de fazer etc. Essa distinção não é simples, pois, quando registrados em determinadas mídias, muitos dos chamados patrimônios imateriais passam a se constituir em documentos que têm uma dimensão física, passando, portanto, a fazer parte do patrimônio material móvel ${ }^{7}$.

De acordo com a Declaração do México, assinada durante a Conferência Mundial sobre as Políticas Culturais, promovida em 1985 pelo Conselho Internacional de Monumentos e Sítios (Icomos), "O desenvolvimento global da sociedade exige políticas complementares nos campos da cultura, da educação, da ciência e da comunicação, a fim de estabelecer um equilíbrio harmonioso entre o progresso técnico e a elevação intelectual e moral da humanidade" (IPHAN, 1985).

Nesse sentido, a preservação do patrimônio histórico, em suas duas dimensões material e imaterial, pode ser vista como uma ação de resistência, ou seja, como uma forma de manter a salvo as características das culturas locais diante de um processo de descaracterização ensejado pela globalização econômica. O patrimônio imaterial torna-se, por sua vez, estratégico para a valorização das manifestações culturais de grupos sociais minoritários e para o reconhecimento da participação destes na formação da identidade cultural nacional. Dessa forma, a preservação pode representar um instrumento de mediação entre a velocidade das transformações promovidas pelo progresso tecnológico e o desejo de manter a cultura proveniente do passado.

Segundo Guimarães (2008, p. 18),

[...] a reflexão em torno do patrimônio pode ser compreendida em suas estreitas vinculações com o trabalho de produzir narrativas sobre o passado. Assim, o patrimônio é também uma escrita do passado, submetida evidentemente a uma gramática e uma sintaxe específicas.

Ao serem transcritos, os registros da história oral transformam-se em documentos escritos, passando a integrar o patrimônio material móvel, que inclui: coleções arqueológicas, acervos museológicos, documentais, bibliográficos, arquivísticos, videográficos, fotográficos e cinematográficos. 
Referindo-se ao caso brasileiro, mais especificamente ao Instituto do Patrimônio Histórico e Artístico Nacional (Iphan), esse autor afirma que "[...] os esforços empreendidos por esta agência do Estado brasileiro apontam na direção de uma aceleração do tempo e da consequente necessidade de tornar patrimônio objetos de um passado cada vez mais recente" (2008, p. 26).

O avanço das mídias eletrônicas, que possibilitam a comunicação em tempo real, faz com que a percepção acerca da velocidade do tempo seja potencializada, indicando a necessidade de maior proteção de determinados bens que parecem condenados ao desaparecimento. Os investimentos na área de preservação teriam, então, a função de garantir maior segurança às sociedades atemorizadas pela velocidade das transformações, que poderiam pôr em risco o sentido de estabilidade e continuidade. Ainda conforme Guimarães,

[...] o trabalho de rememoração deve ser compreendido não como um transbordamento da memória que fluiria do passado em direção ao presente, mas exatamente como uma captura, um ato de escolha de um determinado presente que organiza o conjunto de lembranças segundo uma gramática específica [...] uma reflexão sobre o patrimônio integra-se a esse ato criativo de um determinado presente interrogando certo conjunto de vestígios do passado e produzindo-os como patrimônio histórico (GUIMARÃES, 2008, p. 28).

O esforço das sociedades contemporâneas em narrar o passado leva à reflexão em torno de uma forma específica que tem a sociedade contemporânea de lidar com a experiên $\neg$ cia do transcurso do tempo, o que significa enfrentar a ausência e o sentimento que ela provoca com base nos traços, dos restos e dos indícios remanescentes. São esses registros que, segundo Guimarães, podem levar à "[...] resignificação das construções materiais fazendo com que seus objetos possam ser vistos como algo diferente daquilo que eram quando foram criados" (2008, p. 29).

A razão de objetos ou conjuntos de objetos serem reconhecidos como patrimônio nem sempre se deve à natureza do objeto em si. Em muitos casos, alçam a essa condição devido à operação que permite que sejam vistos como integrantes de um patrimônio histórico, com direito a uma nova visibilidade. Ou, dito de outra maneira: a produção de objetos como integrantes de um patrimônio coletivo possui uma historicidade, o que os leva à condição de legado e herança comum a ser preservada e transmitida de geração em geração, independentemente de sua natureza intrínseca.

As considerações acima remetem à noção de patrimônio cultural, da qual fazem parte as dimensões materiais e simbólicas. Na Declaração do México sobre Políticas Culturais, de 1982, a Organização das Nações Unidas para a Educação, Ciência e Cultura (Unesco) institui como patrimônio cultural “[...] as obras de seus artistas, arquitetos, músicos, escritores e sábios, assim como as criações anônimas, surgidas da alma popular, e o conjunto de valores que dão sentido à vida" (IPHAN, s.d., p. 4).

Esse alargamento da noção de patrimônio está contemplado pela Constituição Federal do Brasil de 1988, que em seu artigo 216 define como patrimônio

[...] as formas de expressão; os modos de criar; as criações científicas, artísticas e tecnológicas; as obras, objetos, documentos, edificações e demais espaços destinados às manifestações artístico-culturais; além de conjuntos urbanos e sítios de valor histórico, paisagístico, artístico, arqueológico, paleontológico, ecológico e científico. 
A Convenção para a Salvaguarda do Patrimônio Cultural Imaterial, realizada em Paris em 2003, entende por patrimônio cultural imaterial

[...] as práticas, representações, expressões, conhecimentos e técnicas - junto com os instrumentos, objetos, artefatos e lugares que lhes são associados - que as comunidades, os grupos e, em alguns casos os indivíduos reconhecem como parte integrante de seu patrimônio cultural. Esse patrimônio cultural imaterial, que se transmite de geração em geração, é constantemente recriado pelas comunidades e grupos em função de seu ambiente, de sua interação com a natureza e de sua história, gerando um sentimento de identidade e continuidade, contribuindo assim para promover o respeito à diversidade cultural e à criatividade humana (UNESCO, 2003, p. 2-3).

Essa Convenção estimula que a salvaguarda do patrimônio imaterial ou intangível ${ }^{8}$ seja integrada a outras intervenções estatais, como planos de desenvolvimento, pesquisas científicas, instituições e leis locais, além de cooperação internacional. Para a Convenção, que compreende o patrimônio não como produto mas como processo, reconhecendo-o como fonte de identidade, diversidade e transmissão de um conhecimento, não cabe à Unesco ou ao Estado determinar como proteger os bens intangíveis. A despeito da parceria com essas instituições, são os participantes/praticantes os principais responsáveis pela indicação de determinados bens culturais a serem preservados.

Quando ao valor histórico e artístico é acrescentado o cultural, entende-se que a identificação de um bem passou pelo reconhecimento dos seus usos locais. Como dizer que ele é um patrimônio cultural se não é assim visto na cultura onde foi elaborado/construído? [...] Identificado pela lógica dos seus realizadores, ele pode inclusive ser submetido aos instrumentos privilegiados por diferentes legislações e recomendações oficiais enquanto benéficos e complementares aos interesses locais (SOUZA \& CRIPPA, 2011, p. 248, 249).

Willian Souza e Giulia Crippa não pretendem com isso que as instituições ou os especialistas sejam substituídos pelos grupos sociais na nomeação de seu patrimônio cultural; defendem que a responsabilidade de atribuir um valor simbólico aos bens culturais seja, em primeira instância, dos indivíduos que o produziram. Somente depois disso, por meio de um processo de diálogo e mediação, deve haver o reconhecimento oficial, para garantir que quando um bem seja nomeado patrimônio cultural, pelas instituições responsáveis, possa beneficiar ou não prejudicar os propósitos dos sujeitos que o produziram ${ }^{9}$.

Conforme argumenta Regina Abreu (2003), essa mudança de perspectiva se deve, em primeiro lugar, à maior organização da sociedade civil, que hoje estaria mais presente nas decisões sobre o registro dos seus bens como patrimônio cultural; em segundo, a um avanço no conceito de cultura, que passou a privilegiar os processos sociais pelos quais os homens significam e interpretam o mundo e a si mesmos.

\footnotetext{
${ }^{8}$ Alguns autores têm preferido o termo patrimônio intangível para classificar: os bens culturais que, uma vez produzidos, passam a apresentar um relativo grau de autonomia em relação a seu processo de produção; as manifestações que precisam ser constantemente atualizadas por meio de suportes físicos (FONSECA, 2009).

${ }^{9} \mathrm{O}$ processo para o registro do Toque dos Sinos em Minas Gerais como patrimônio cultural imaterial brasileiro, por exemplo, foi iniciado, em 2009, com um abaixo-assinado dos moradores de São João Del Rei. Apoios e anuências de várias instituições civis e públicas foram incluídos no processo, o que garantiu, mesmo com a pesquisa tendo sida dirigida por especialistas, o reconhecimento dos valores e sentidos atribuídos pela população (BRASIL. Ministério da Cultura. Instituto do Patrimônio Histórico e Artístico Nacional. Parecer n. 27/GR/DPI/Iphan, de 30 de setembro de 2009, referente ao Registro d'O.
} 
Assim, a preservação de bens materiais e imateriais, tangíveis e intangíveis, não constitui por si só um patrimônio. De acordo com Mário Chagas, "[...] é preciso que tanto o remetente quanto o destinatário dessa prática social reconheçam e agreguem valores a esse mesmo aglomerado de bens, que poderá ser transmitido de uma geração para outra" (2003, p. 97).

Pretende-se com este trabalho contribuir para a recriação e resignificação da memória do Ceplan, reforçando não somente a importância da obra material ali concebida e produzida, mas também a participação dos diferentes coletivos na sua realização. Talvez a divulgação de um documento assim produzido possa servir de base para a posterior transformação do Ceplan em patrimônio cultural da Universidade de Brasília, que merece ser revitalizado e preservado para as futuras gerações. Para isso cabe o seu reconhecimento como lugar, mais especificamente como um lugar de memória, ou seja, um espaço determinado a partir do qual a memória se torna ação e trabalha não no sentido de trazer de volta o passado, mas de recriá-lo, de reconstituí-lo no presente. Todo o esforço aqui realizado resultou na percepção de que o Ceplan, ao alicerçar memórias coletivas, configura-se como um lugar simbólico, onde essa memória se expressa, se revela. Como um espaço revelador de processos sociais, conflitos, paixões e interesses que, conscientemente ou não, se revestem de uma função icônica (NORA, 1993). 



\section{O TEMPO DOS PIONEIROS}

Foi toda a floração de uma universidade que se inventava a si mesma à medida que crescia, dentro de um ambiente incomparável de criatividade e de convivência grata e solidária. DARCY RIBEIRO, 1978, p. 34

E todos os projetos do professor Darcy se faziam realidade na grande arrancada da Universidade de Brasília [...] O professor Darcy tinha certeza de que tudo ia dar certo. SEBASTIÃO VARELA, 1989, p. 21 e 22. 


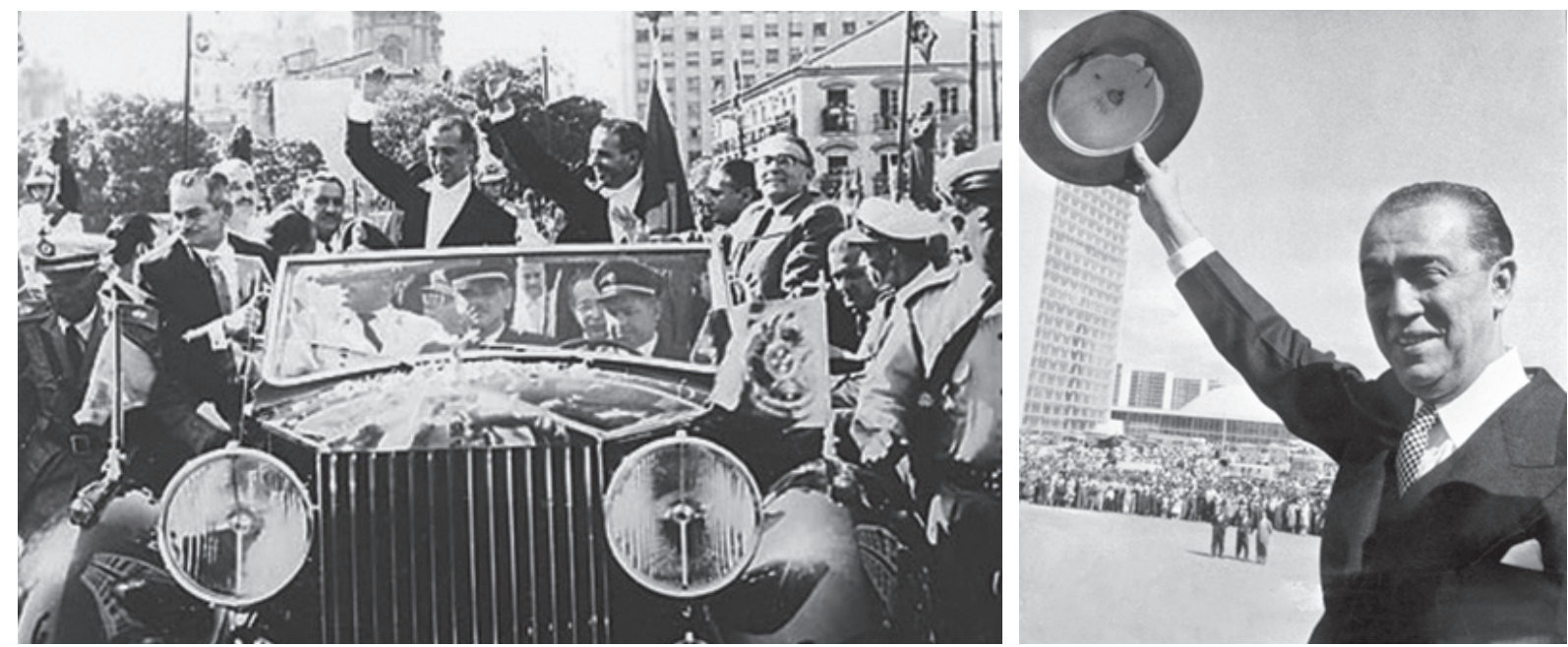

\subsection{A invenção de uma universidade}

A chegada de Juscelino Kubitschek de Oliveira (JK) à Presidência da República coincidiu com um Figura 1. clima de otimismo, respaldado pela política nacional-desenvolvimentista voltada para a possibilidade de um progresso decorrente de incentivos à indústria nacional e de mudanças socioeconômicas. Esse ideal foi consolidado no Plano de Metas, um conjunto de trinta objetivos a serem alcançados durante os cinco anos de governo. A décima primeira meta, conhecida como meta-síntese, previa a transferência da capital federal para o Planalto Central.

Tanto no nível do pensamento como no das práticas de governantes e grupos sociais mais podede Brasília rosos, observa-se impaciência, pressa, sofreguidão. Algumas realizações famosas dão uma ideia desse clima. A construção da cidade de Brasília pretende simbolizar o Brasil Moderno, representa o coroamento de uma larga história de intentos de tornar o Brasil contemporâneo do seu tempo. Uma capital nova, feita sob medida, lançada em traços audaciosos, nas proporções do século XXI - e povoada pela mesma humanidade que se pretendia esquecer ou exorcizar (IANNI, 1996, p. 36).

Com o slogan "50 anos de progresso em 5 anos de governo", cunhado por Augusto Frederico Schmidt, JK propunha-se a impulsionar o desenvolvimento do país mediante o incremento de cinco áreas - energia, transporte, alimentação, indústria de base e educação - e a construção de Brasília. Em mensagem enviada ao Congresso em 15 de março de 1956, o chefe da nação declarou: "A importância que passou a adquirir, no país, o transporte rodoviário, a curta e longa distância, vem criar a necessidade de ser instituída, entre nós a indústria automobilística, em bases amplas e definitivas" (apud GATTÁS, 1981, p. 189).

O Plano de Metas de JK teve como base uma série de estudos iniciados ainda no governo de Getulio Vargas. Os diagnósticos, feitos pela Comissão Mista Brasil-Estados Unidos para o Desenvolvimento Econômico' e pela Comissão Econômica para a América Latina e Caribe (Cepal) ${ }^{2}$, haviam indicado a necessidade de eliminar os pontos de estrangulamento da economia brasileira. Para os analistas da época, o Brasil vinha passando por um processo de substituição de importações não planejado, sendo esta a causa dos constantes desequilíbrios no balanço de pagamentos.

'Criada em 19 de julho de 1951 no âmbito do Ministério da Fazenda e integrada por técnicos brasileiros e norte-americanos, a Comissão Mista Brasil-Estados Unidos para o Desenvolvimento Econômico foi resultado das negociações iniciadas em 1950, durante o governo Dutra, visando ao financiamento de um programa de reaparelhamento dos setores de infraestrutura da economia brasileira. Fonte: Cpdoc/FGV.

${ }^{2}$ Como economista da Cepal, Celso Furtado coordenou, juntamente com técnicos do Banco Nacional de Desenvolvimento (BNDE), ações para elaboração do estudo, conhecido como "Esboço de um programa de desenvolvimento para a economia brasileira no período de 1955 a 1960 ", que serviu de base para elaboração do Plano de Metas (VERSIAN; BARROS, 1977). 
A despeito das adversidades políticas, JK conseguiria não somente "[...] implantar as empresas criadas por Vargas, mas também implementar um novo modelo de desenvolvimento sobre a base industrial estatal instalada" (Caldeira, 1997, p. 294). E, indiferente às críticas, o presidente Juscelino Kubitschek dava sequência às inúmeras realizações que contribuem para promover um crescimento econômico sem precedentes na história do país ${ }^{3}$.

Entre 1955 e 1961, a produção de aço cresceu 100\%; a das indústrias mecânicas, 125\%; a das elétricas e de comunicações, $380 \%$; e a das indústrias de equipamentos de transportes, $600 \%$. A produção industrial como um todo cresceu $100 \%$, a taxa de crescimento real foi de $7 \%$ ao ano, e a renda per capita aumentou $4 \%$ ao ano (CALDEIRA, 1997, p. 295).

Esse progresso mudou a imagem externa e a vida cotidiana do país. "Valorizavam-se as conquistas da vida urbana, os novos produtos da indústria, as diferenças da vida social, o maior acesso à educação" (CALDEIRA, 1997, p. 297). O exercício democrático e a abertura econômica para o mundo contribuíam também para a transformação da cultura nacional. O Brasil, impulsionado por mais uma revolução industrial, entrava na era da novidade...

O espírito do novo, a vontade de mudança transcenderam as esferas econômica e política e contaminaram o domínio das artes e da cultura. Importantes movimentos no campo artístico nasceram e/ou tomaram novo impulso na segunda metade da década de 1950. Surgiram novas formas de conceber o cinema, o teatro, a música, a poesia e as artes plásticas, em decorrência de uma reflexão crítica acerca da produção existente e das linguagens vigentes em cada um desses domínios: "[...] A efervescência do movimento cultural sintonizava-se tanto com o espírito nacionalista que crescia na época, quanto com a crença nas possibilidades de desenvolvimento e transformação do país" (FERREIRA; MESQUITA, 2001, p. 2).

Surgiram o Cinema Novo, a Bossa Nova e o Teatro do Oprimido, formas de expressão artística que pretendiam integrar a cultura ao novo momento que o país atravessava. $O$ samba tradicional passou a ser influenciado pelos acordes jazzísticos, e não tardou para que o país passasse a se orgulhar de seus grandes embaixadores culturais: canções de Tom Jobim, João Gilberto e de tantos outros tornaram-se produtos de exportação. Inspirado no Neorrealismo italiano e na Nouvelle Vague, o cinema ensaiava uma nova linguagem que, representada em Rio 40 graus, de Nelson Pereira dos Santos (1955), adequava-se à situação social da época. Com "uma ideia na cabeça e uma câmera na mão" ${ }^{4}$, diretores brasileiros mostravam a cara nos festivais internacionais. Em 1959, o filme Orfeu negro, dirigido por Marcel Camus, foi o primeiro filme em língua portuguesa a receber a Palma de Ouro em Cannes; e, em 1960, ganhou o Oscar de melhor filme estrangeiro.

Considerado como a origem da Bossa Nova, o long play (LP) Canção do amor demais foi gravado por Elizete Cardoso em 1958. Um ano depois, João Gilberto gravou Chega de saudade, que marcou definitivamente o gênero musical brasileiro.

No terreno da literatura, no quinquênio de Juscelino Kubitschek chegaram às livrarias importantes obras como Grande sertão: veredas e Corpo de baile, de Guimarães Rosa; Laços de família, de Clarice Lispector; O encontro marcado, de Fernando Sabino; Duas águas, de João Cabral de Melo Neto, entre tantas outras.

\footnotetext{
${ }^{3}$ Segundo estudos do Dieese, o maior salário mínimo pago no Brasil foi em 1959, durante o governo Juscelino Kubitschek, quando atingiu um valor que equivaleria hoje a $\mathrm{R} \$ 1.580,00$ - mais de três vezes o atual (www.diplomatique.org.br/artigo.php?id=684).

${ }^{4}$ Segundo Glauber Rocha, o verdadeiro autor da frase "Uma ideia na cabeça e uma câmera na mão" foi o roteirista, produtor e diretor cinematográfico Paulo 

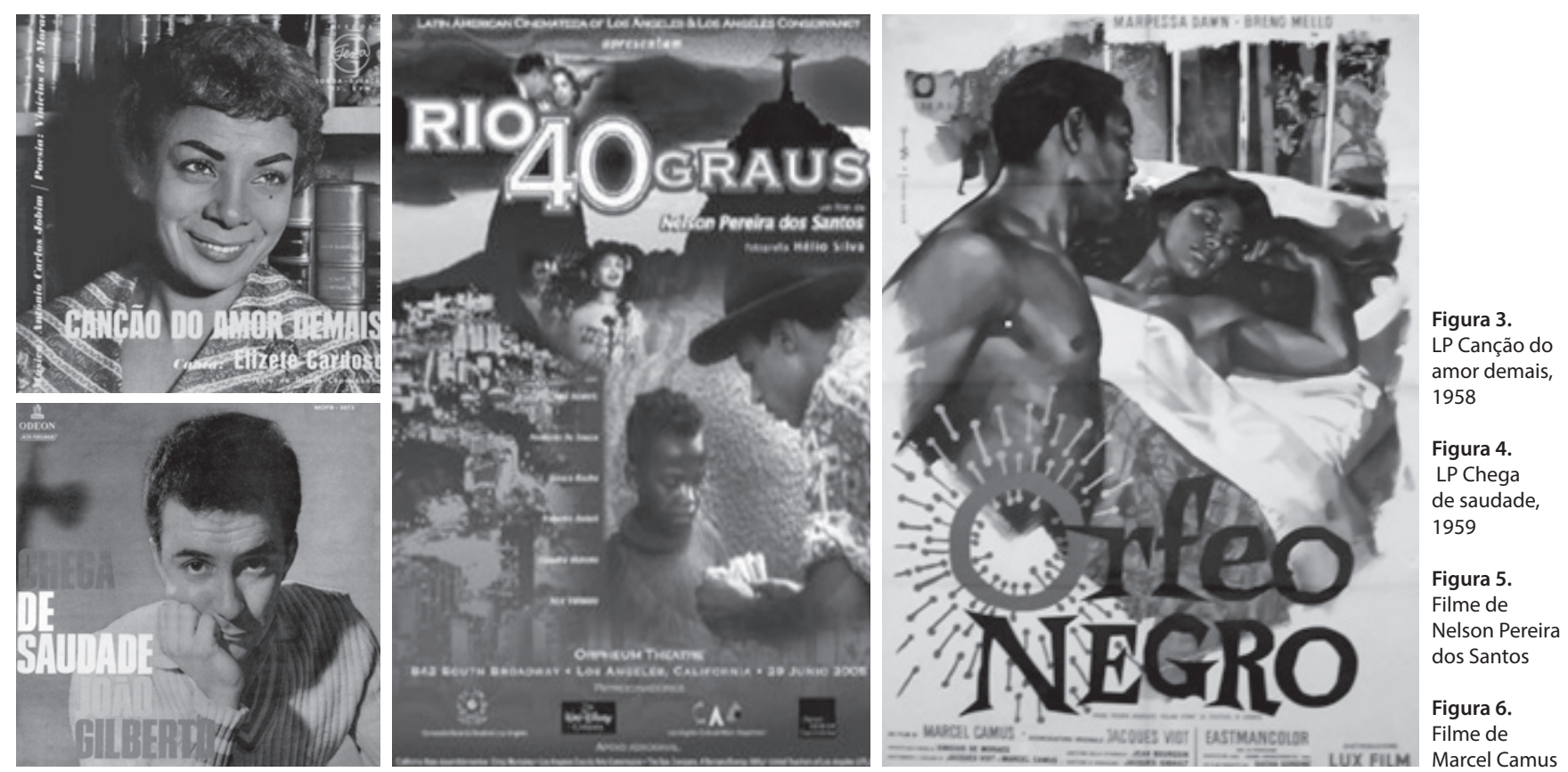

O panorama artístico enriqueceu-se ainda com o surgimento dos grupos Ruptura, em São Paulo, e Frente, no Rio de Janeiro, que deram origem respectivamente ao concretismo e ao neoconcretismo, movimentos que, animados pelos poetas Augusto e Haroldo de Campos, Décio Pignatari, Ferreira Gullar e Reinaldo Jardim, contaram com a adesão de muitos artistas plásticos, entre os quais Waldemar Cordeiro, Hélio Oiticica, Lygia Clark, Lígia Pape, Ivan Serpa, Abraham Palatinik, Franz Weissman, Luiz Sacilotto.
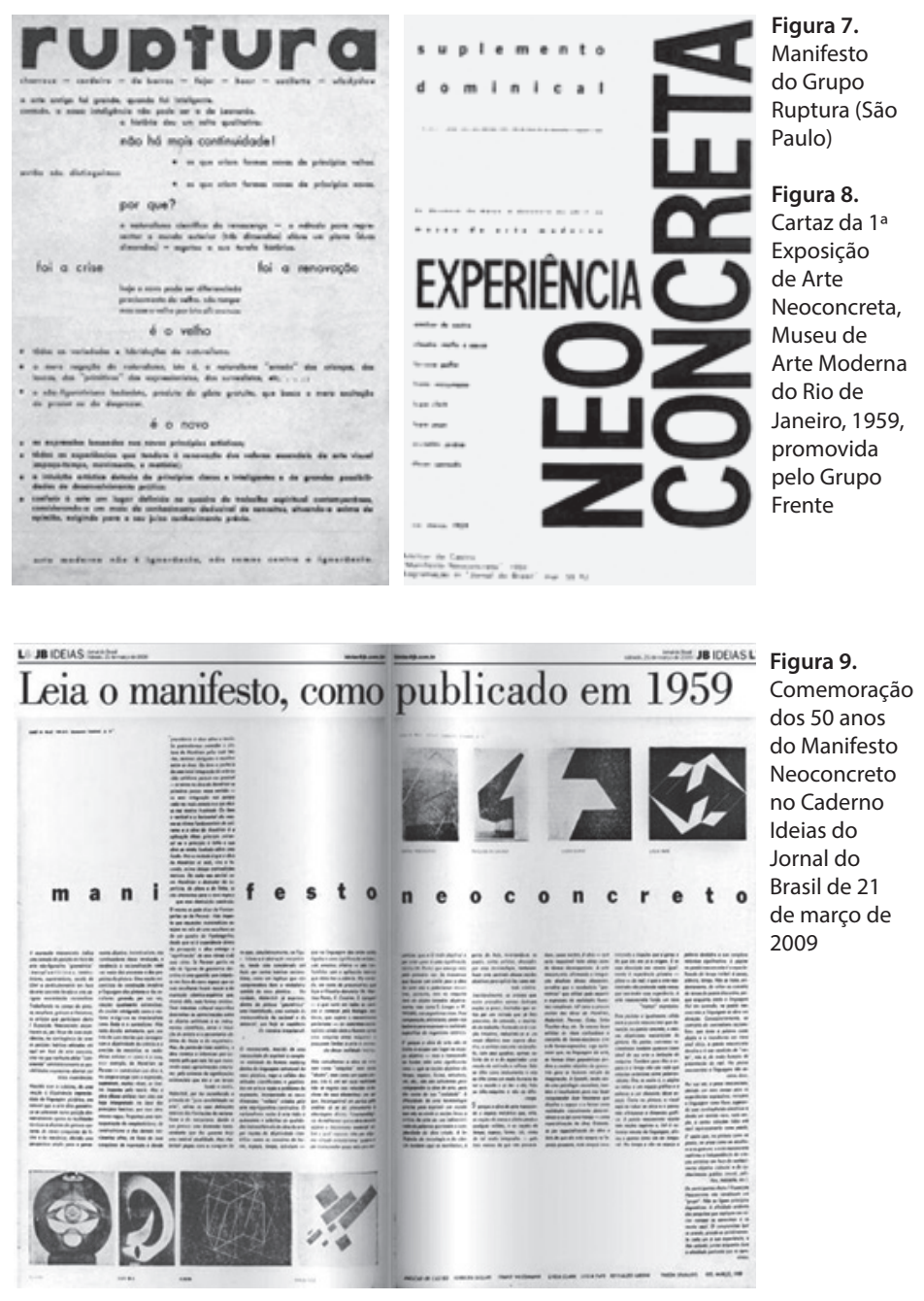

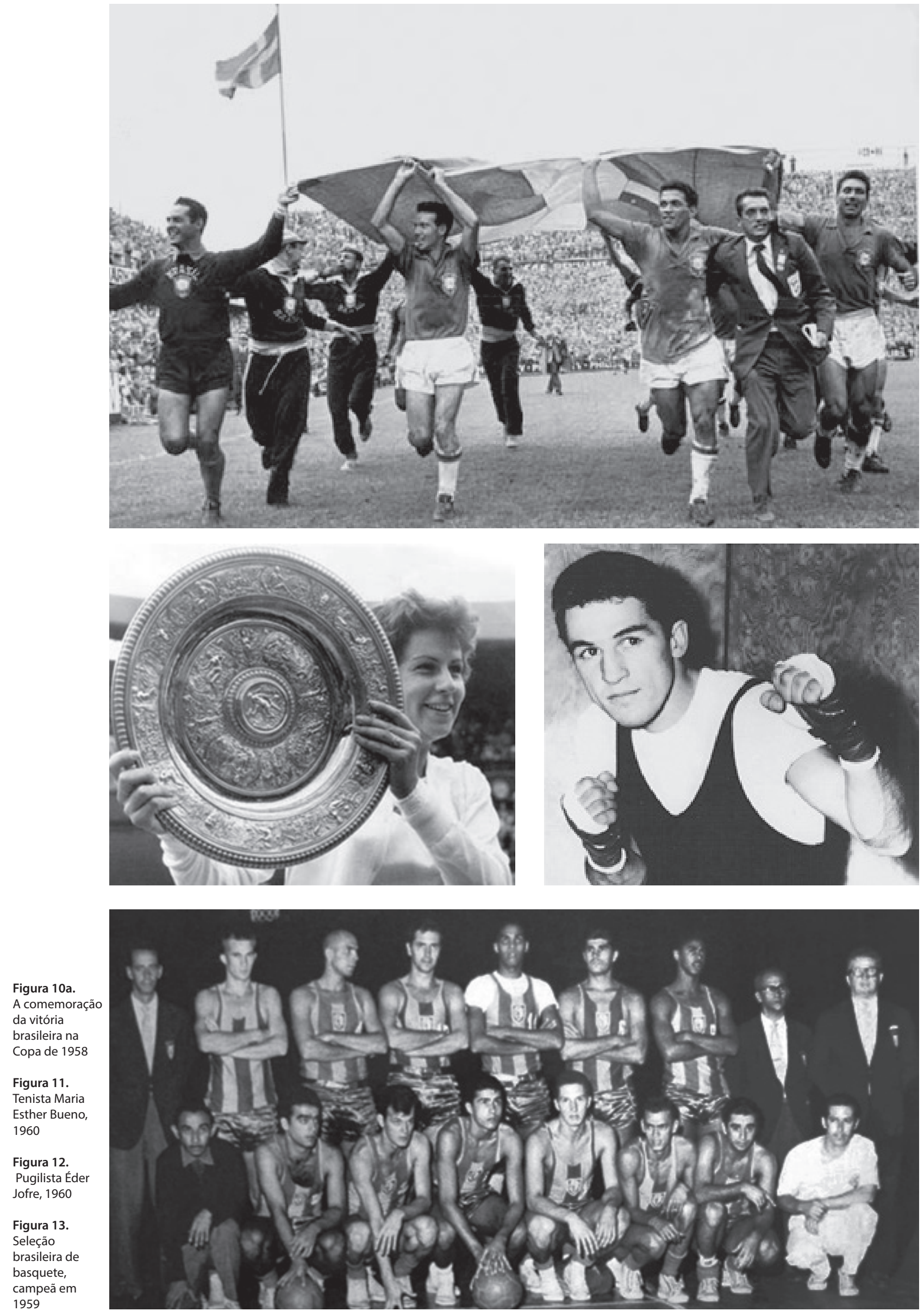
No esporte não foi diferente: o Brasil conquistou alhures a Copa do Mundo de 1958, mostrando a habilidade dos seus craques. A partir de então, Pelé, antecipando seus longos tempos de glória, tornou-se um cartão-postal do país. O futebol também se modernizou: pela primeira vez, o time brasileiro foi devidamente preparado por uma comissão técnica de reconhecido gabarito. O otimismo era contagiante: a nação passava a acreditar em si mesma e no seu futuro!

No mesmo ano, a tenista Maria Esther Bueno ganhou seu primeiro título no torneio de Wimbledon, na Inglaterra, em dupla com a americana Althea Gibson. Bicampeã em 1960, ela se tornou também a primeira mulher a vencer os torneios de duplas do Grand Slam. Em 1959, a seleção brasileira de basquete trouxe de Santiago, no Chile, seu primeiro título mundial. Também no boxe o Brasil ganhou seu primeiro título mundial, em 1960, quando Éder Jofre derrotou o mexicano Eloy Sánchez.

A capital moderna, que começara a ser construída em 1957, não apenas representava um modelo de civilização a ser seguido, mas dava suporte ao processo de interiorização previsto no modelo desenvolvimentista. Como observou Darcy Ribeiro, "[...] a criação da nova capital, articulando rodoviariamente as diversas regiões do país, ataria a sociedade brasileira de hoje tal como o ouro das Minas Gerais unificou a sociedade colonial" (1978, p. 15).

O país passava, então, a ser respeitado também pela epopeia da construção, em tempo recorde,
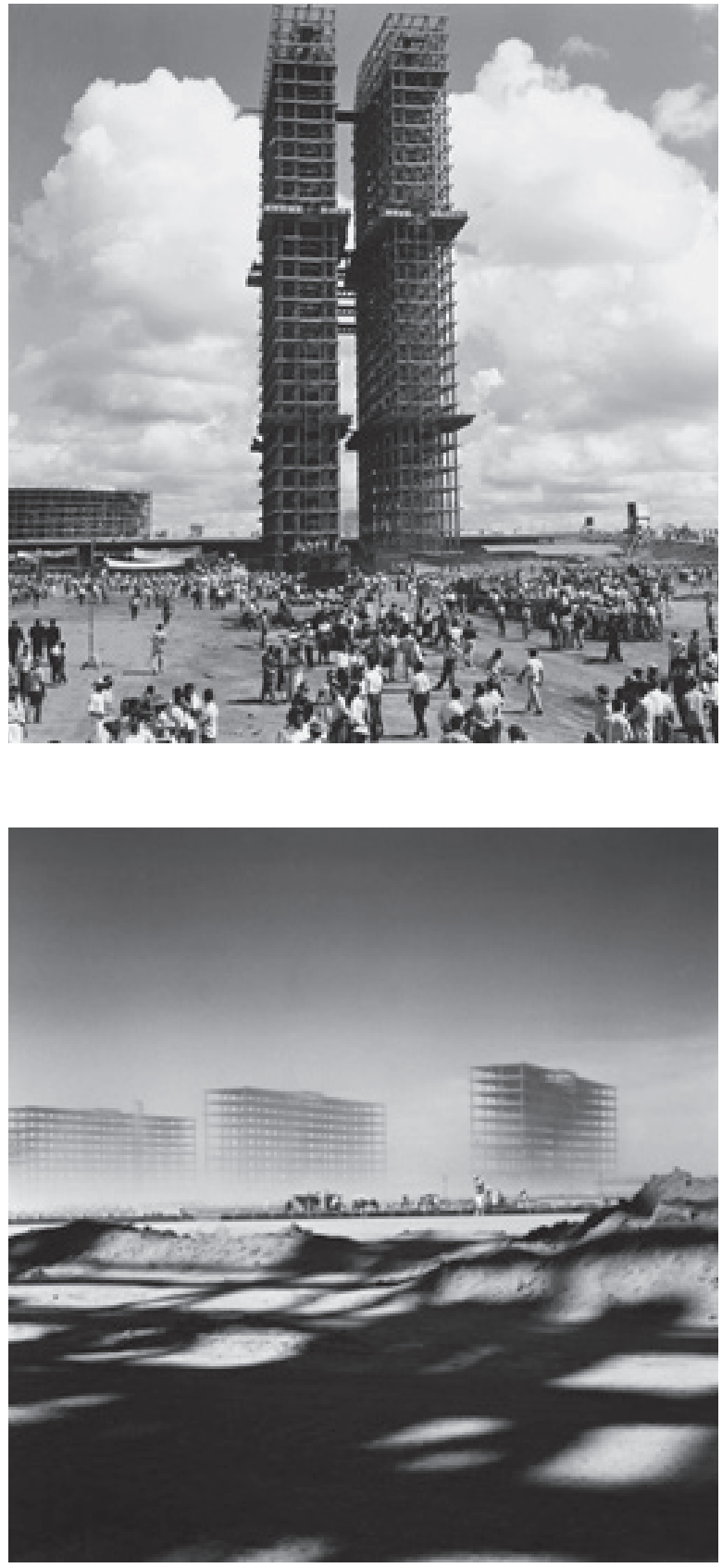

Figuras 14 e 15.

Brasília pela lente do

fotógrafo Marcel Gautherot da cidade que harmonizava uma arrojada arquitetura com um urbanismo inusitado. Quando da inauguração, no dia 21 de abril de 1960, André Malraux, ministro da Cultura da França, referiu-se à cidade como "capital da esperança", e comparou as colunas de Brasília com as colunas gregas (NIEMEYER, 1997). 

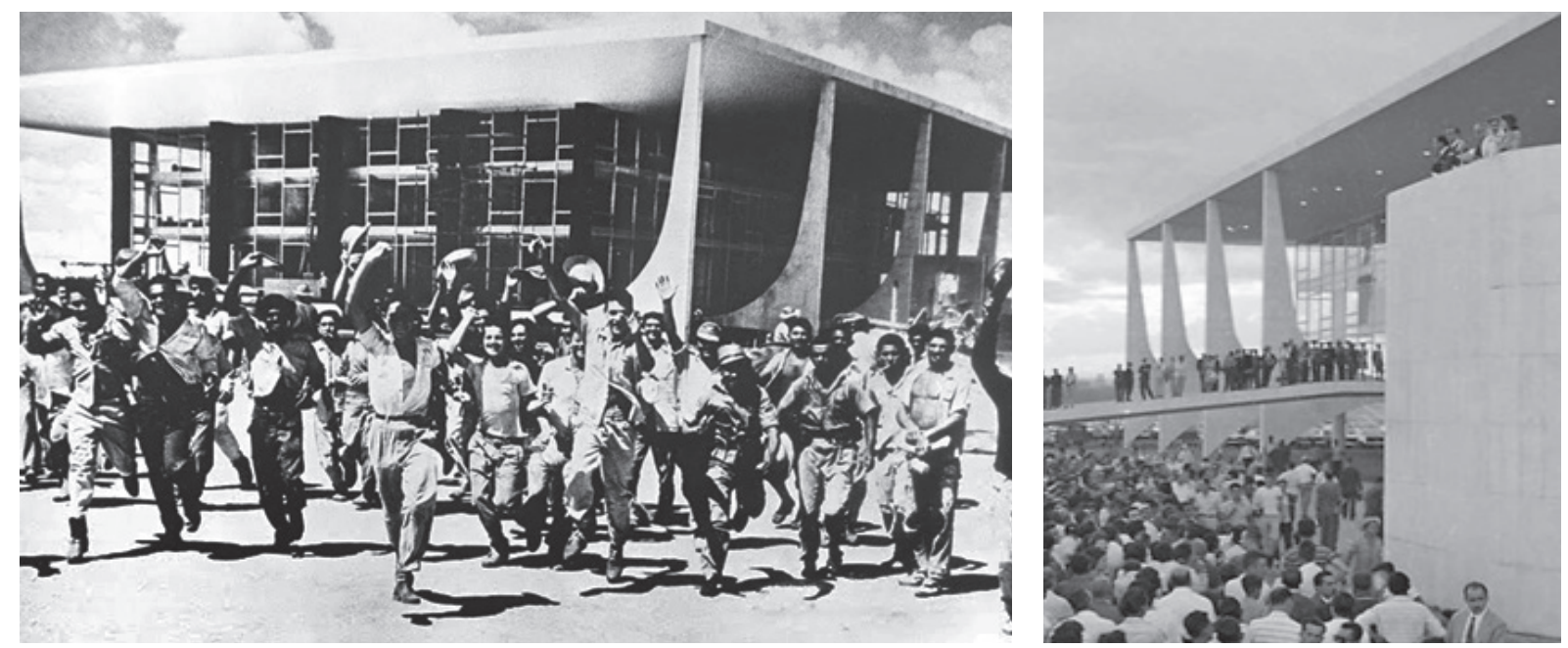

O grau de expectativa que cercava o empreendimento da nova Capital, podia, segundo Ana Luiza Nobre (2008), ser medido pela concentração de influentes críticos, arquitetos e urbanistas de várias partes do mundo no Congresso Internacional Extraordinário de Críticos de Arte $^{5}$ realizado entre Brasília, São Paulo e Rio de Janeiro, em setembro de 1959. Como participante desse congresso, o artista e professor argentino Tomás Maldonado, posteriormente diretor da Hochschule für Gestaltung Ulm (HfG-Ulm), assim se manifestou:

Brasília é uma tremenda oportunidade para o moderno planejamento de cidades. É uma grande possibilidade e ao mesmo tempo uma grande responsabilidade. O fracasso de Brasília seria um dos maiores traumas da cultura de nossos tempos. Devemos fazer tudo para evitar que venha a falhar (MALDONADO, 1959, p. 7).

Segundo Nobre (2008), a preocupação com os rumos tomados por um viés de modernização que de certo modo se cumpria em Brasília se justificava na medida em que Maldonado incluía a si próprio entre os agentes então responsáveis pela condução de tal processo.

\footnotetext{
Brasília é para nós, sul-americanos, uma possibilidade de importância e significação extraordinária. Às vezes, em momentos de desânimo, nós, os intelectuais sul-americanos, tendemos a acreditar que o destino de nosso continente é de frustração [...] Com a criação de Brasília, temos pela primeira vez a possibilidade de ir para a frente, de abrir novas perspectivas. Não quero dizer que a tentativa seja inteiramente convincente sob todos os pontos de vista. Mas Brasília não é somente a realização de um estadista; é quase que um gesto de desespero da inteligência sul-americana para abrir novas perspectivas à nossa realidade terrível e dolorosamente fechada (MALDONADO, 1959, p. 102 e 103).
}

Além da beleza, a cidade surpreendeu o país e o mundo pelo novo modus vivendi que ajudava a criar. O bucólico, o monumental, o gregário e o residencial misturavam-se para dar à cidade o caráter urbano e cívico que o programa exigia. Era também o espaço resultante da técnica rodoviária imposta pela nova e promissora indústria automobilística ou, no dizer de Lucio Costa, a "capital aérea e rodoviária; cidade parque. Sonho arqui-secular do Patriarca" (1991, p. 32).

${ }^{5}$ Entre os 47 participantes presentes no Congresso, estavam Giulio Carlo Argan, Meyer Schapiro, Carola Giedion-Welker, Bruno Zevi, Gillo Dorfles, André Chastel, Richard Neutra, CharlottePerriand, Jean Prouvé, Eero Saarinen e Frederick Kiesler, Tomás Maldonado, Otl Aicher e Giulio Pizzetti, além de Mário Pedrosa, Ferreira Gullar, Flávio de Aquino, Mário Barata e Carlos Flexa Ribeiro. 


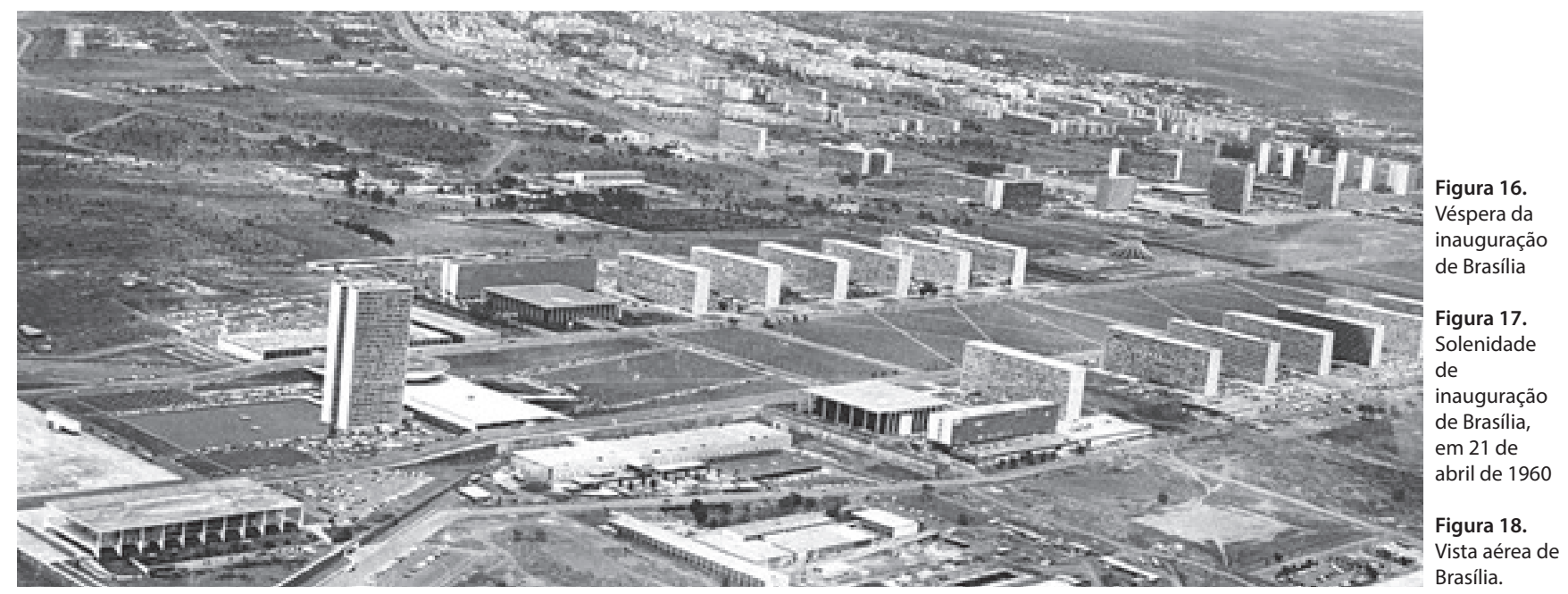

Idealizada na mesma época que a cidade, pode-se dizer que a Universidade de Brasília (UnB) surgiu, em parte, como resposta à vocação definida para a nova capital, a qual deveria se impor como um polo de irradiação cultural e intelectual do país. É interessante notar que, no Concurso Nacional para o Plano Piloto de Brasília (1957), dos 26 projetos apresentados, 11 contemplavam cidades universitárias, sendo que os sete premiados faziam parte deste grupo. Os diversos projetos exprimiam "[...] a certeza de que a universidade necessitaria de uma grande área física setorizada na cidade para melhor cumprir suas funções" (ALBERTO, 2007, p. 9).

A justificativa para a existência de uma universidade na nova capital já aparecia esboçada no Relatório de 1957: "Cidade planejada para o trabalho ordenado e eficiente, própria ao devaneio e à especulação intelectual, capaz de tornar-se, com o tempo, além de centro de governo e administração, num dos focos de cultura dos mais lúcidos do país" (COSTA, 1957, 1991, p. 20). Esse documento fundador indicava ainda a localização da futura Cidade Universitária.

Ao longo dessa esplanada - o Mall, dos ingleses - extenso gramado destinado a pedestres, a paradas e a desfiles, foram dispostos os ministérios e autarquias (...) sendo o último o da Educação, a fim de ficar vizinho do setor cultural (...) setor este também contíguo à Cidade Universitária com seu respectivo Hospital de Clínicas, e onde também se prevê a instalação do Observatório (COSTA, 1957, 1991, p. 22).

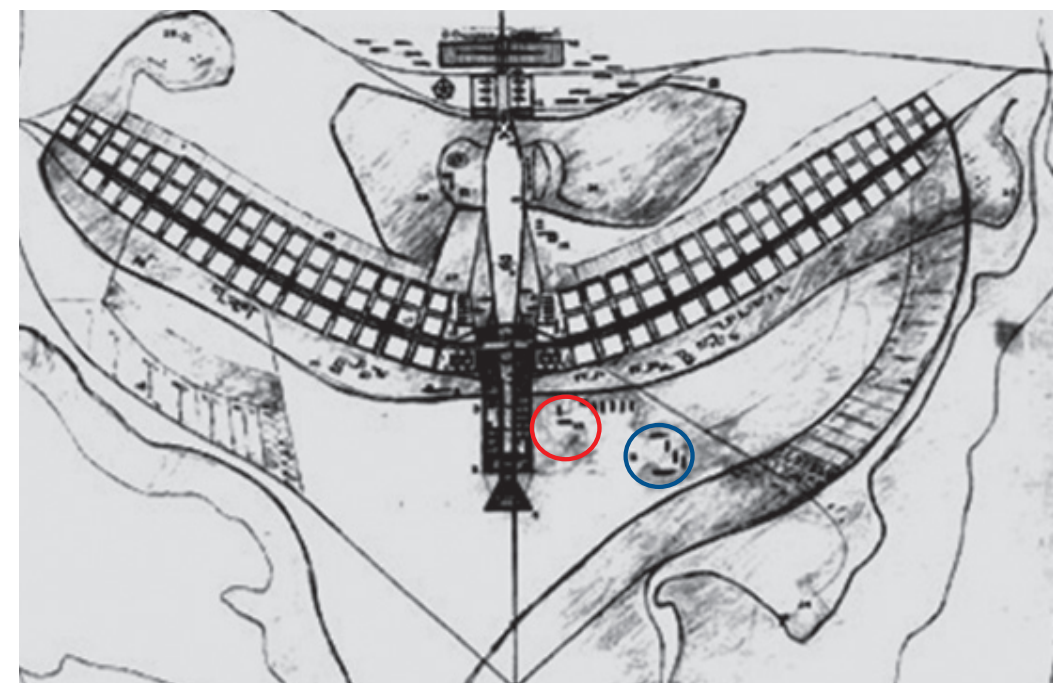

Figura 19.

Plano Piloto de Brasília,

Lucio Costa, 1957

Local designado por Lucio Costa para a Cidade Universitária

Localização do campus da Universidade de Brasília 

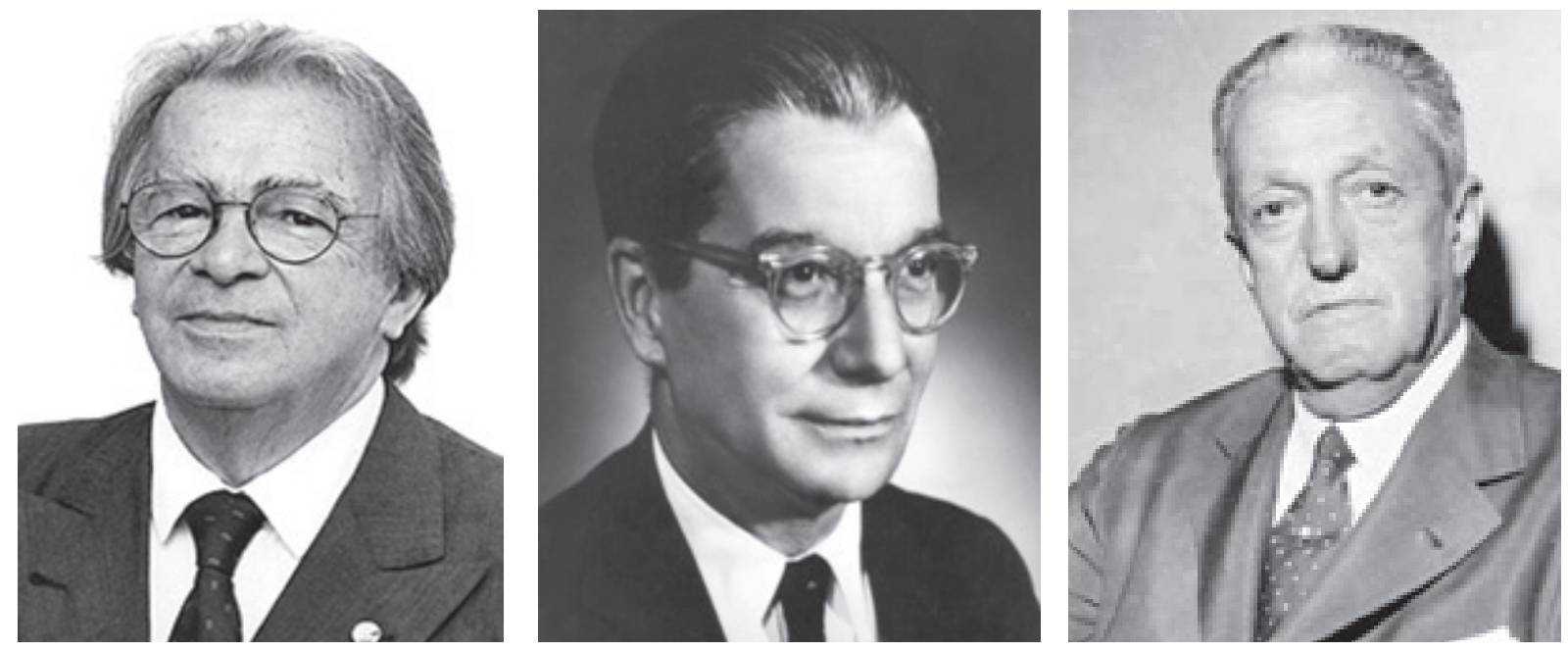

Figura 20a. Darcy Ribeiro

Figura 20b. Anísio Teixeira

Figura 20c. Israel Pinheiro

Capaz de imprimir um caráter renovador aos seus empreendimentos, a nova universidade teria que assegurar o requisito intelectual necessário a uma capital, contribuindo para que esta pudesse exercer o papel integrador que se propunha assumir. Deveria ainda garantir à nova capital a capacidade de interagir com os principais centros culturais do país, ensejando o pleno desenvolvimento das ciências, das letras e das artes, assim como oferecer à população da cidade uma perspectiva cultural apta a libertá-la do risco de se fazer medíocre e provinciana no cenário urbanístico e arquitetônico mais moderno do mundo (MEC, 1962).

Embora tivesse sido prevista uma área para a construção do campus, a institucionalização da nova cidade universitária parecia não fazer parte das prioridades do governo federal. Essa situação não agradava ao escritor, jornalista e professor Cyro dos Anjos, que, sobrevoando as obras de Brasília, teria lamentado a falta da universidade como instrumento de afirmação da nova capital: "Parece que estou vendo a bela Brasília engolida pelo vazio e pelo atraso que a circulam. Brasília, sem universidade, não se imporá como capital" (apud SALMERON, 2007, p. 41).

Além de servir à cidade-líder, a Universidade de Brasília, indo ao encontro da crescente insatisfação nos meios acadêmicos com o formato vigente no ensino superior brasileiro, tinha como meta a construção de um novo modelo a ser disseminado pelo país e pela América Latina, conforme explicou o professor José Leite Lopes, do Centro Brasileiro de Pesquisas Físicas (CBPE):

\footnotetext{
Se não é possível uma reforma radical da universidade pela própria universidade, então a solução será construir um exemplo novo e, nesse sentido, Brasília se apresenta como uma oportunidade única. Construa-se ali uma universidade nos moldes mais modernos, mais eficientes, mais adaptados à época da revolução científica que estamos vivendo hoje; e que as demais universidades, pelo exemplo do que se fizer em Brasília, procurem ver que não haverá outra saída senão modificarem sua estrutura atual (apud RIBEIRO, 1991, p. 105).
}

Tornava-se necessário que a universidade a ser implantada no Planalto Central não representasse a mera ampliação das oportunidades de educação oferecidas à juventude brasileira e latino-americana, mas significasse a diversificação das modalidades de formação científica e tecnológica, instituindo novas orientações técnico-profissionais que o incremento da produção, a expansão dos serviços e das atividades intelectuais passavam a exigir. E que ensejasse a formação de núcleos de pesquisas científicas de alto padrão, capazes inclusive de facilitar aos poderes públicos o assessoramento de que careciam em todos os ramos do saber. 


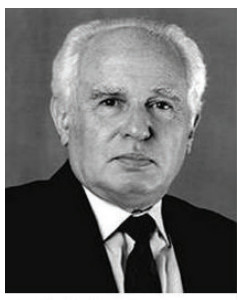

José Goldenberg

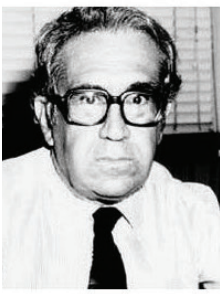

Jacques Danon

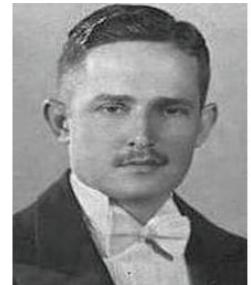

Leopoldo Nachbin

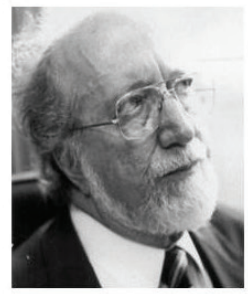

José Leite Lopes

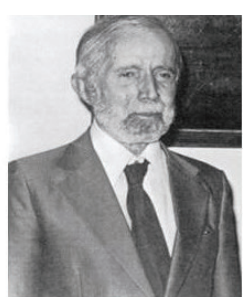

Alcides Rocha Miranda

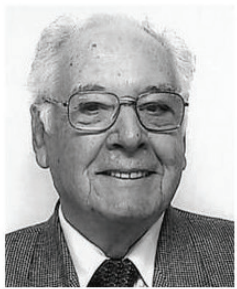

Antônio Cordeiro
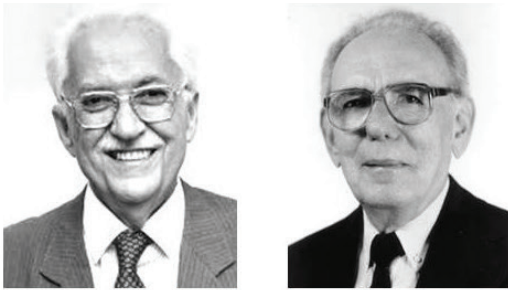

Roberto Pompeu de Souza Jayme Tiomno

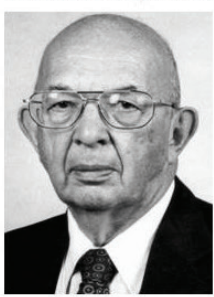

Isaías Raw

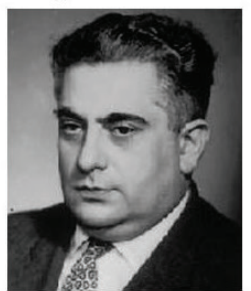

Mário Schenberg

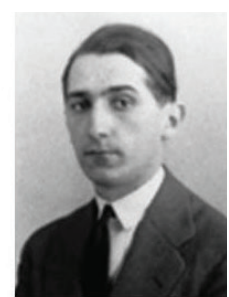

Mário Pedrosa

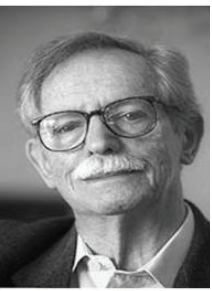

Roberto Salmeron

Embora inicialmente cético, o professor Anísio Teixeira - fundador da Universidade do Distrito Federal em 1935, fechada por motivos políticos quatro anos mais tarde - passou a ser um dos principais mentores do projeto pedagógico e institucional da Universidade de Brasília:

Não fui, de início, entusiasta de uma universidade em Brasília. Fundamentalmente contrário à ideia de Metrópole, nunca achei que a Capital de uma República devesse necessariamente possuir uma Universidade. Brasília deveria ser apenas a sede do governo. Vi, porém, transformada em lei, durante o último ano, o projeto de criação de nada menos de onze universidades! ${ }^{6}$ Diante disto, logo percebi que, mais dia menos dia, Brasília teria a sua Universidade e, a tê-la, que a tivesse certa: aderi então, à ideia de Darcy Ribeiro, e não só à ideia, ao plano de Darcy Ribeiro (apud RIBEIRO, 1991, p. 96-97).

E nessa condição, Anísio Teixeira assumiu a linha de frente dos debates junto com Darcy Ribeiro, que se ocupava também da formalização do projeto, ao mesmo tempo que buscava reunir, com o apoio da Sociedade Brasileira para o Progresso da Ciência (SBPC) ${ }^{7}$, a comunidade científica do país em torno da ideia. Colaboraram com a iniciativa, desde a primeira hora, Almir de Castro, Alcides da Rocha Miranda, Antônio Cordeiro, Jayme Tiomno, Eduardo Galvão, Jacques Danon, José Leite Lopes, José Goldenberg, Júlio Pudles, Leopoldo Nachbin, Mário Pedrosa, Mário Schemberg, Pompeu de Souza, Roberto Salmeron, entre outros ${ }^{8}$.

Devido à falta de tradição da cidade emergente, persistiam, nos meios acadêmico e político, dúvidas e críticas em relação à criação de uma universidade em Brasília. Israel Pinheiro, "o grande condutor da construção da nova Capital", considerava que era preciso manter longe de Brasília duas grandes ameaças: "[...] as manifestações estudantis e as greves operárias, que poriam a perder todo o esforço de interiorização da capital" (apud RIBEIRO, 1991, p. 126).

\footnotetext{
${ }^{6}$ Entre as universidades criadas no período estão: Universidade Federal de Santa Catarina (UFSC), Universidade Federal do Rio Grande do Norte (UFRN), Universidade Federal da Paraíba (UFPb), Universidade Federal do Ceará (UFC), Universidade Federal do Pará (UFPA), Universidade Federal Fluminense (UFF), Universidade Federal de Goiás (UFG), Universidade Federal de Juiz de Fora (UFJF), Universidade Federal de Santa Maria (UFSM) E Universidade Federal de Pelotas (UFPel).

${ }^{7}$ A Sociedade Brasileira para o Progresso da Ciência (SBPC), fundada em 1948, era então em um dos poucos fóruns de discussão e de crítica em relação ao regime político vigente. Nesse contexto, a instituição também preconizava a modernização e expansão dos sistemas universitários e de ciência e tecnologia.

${ }^{8}$ Entre várias iniciativas do mesmo gênero destinadas a debater o projeto de estruturação da Universidade de Brasília, a Sociedade Brasileira para o Progresso da Ciência convocou uma reunião especial realizada no Rio de Janeiro em outubro de 1960, da qual participaram: os físicos Gleb Watghin, José Leite Lopes, Mário Schemberg, José Goldenberg, Jayme Tiomno, Richard Walauschek, Oscar Sala, Guido Beck, Lauro Nepomuceno; os matemáticos Leopoldo Nachbin, M. L. Leite Lopes, A. Ferreira Gomes; os químicos J. Cristóvão Cardoso, Jacques Danon, Water B. Mors, Julio Puddles, Ricardo Ferreira, Lúcia Furtado; os geógrafos Orlando Valverde, Pinchas Geiger, Fábio M. S. Guimarães; o diplomata Wladimir Murtinho; o filósofo Euryalo Cannabrava; os biólogos Paulo Sawaya, Friedrich Gustav Brieger, Carlos Chagas Filho, Walter Oswaldo Cruz, Haiti Moussatché, M. Rocha e Silva, Clodowaldo Pavan, Newton Freire-Maia, Sebastião Baeta Henriques, Annie P. Dannon, Amadeu Cury, Herman Lent, Antonio Couceiro, Oswaldo Frotta-Pessoa, Segadas Vianna, Carlos Zilbertstchmidt; os médicos Arthur Moses, Paulo de Góes, M. de Freitas Amorim; os escritores Cyro dos Anjos, Paulo Duarte, Afrânio
} 
Para Darcy Ribeiro, que considerava inevitável a criação de uma universidade na nova capital, não havia muitas opções na luta pela transformação do Brasil em uma nação autônoma e independente dos países tecnologicamente desenvolvidos:

\begin{abstract}
[...] Trata-se de escolher entre deixar que surja em Brasília, espontaneamente, uma série de escolas superiores precárias, como as que vêm se multiplicando por todo o país, que em breve se aglutinariam em mais uma universidade inviável, ou aproveitar a oportunidade para, com os mesmos recursos, provavelmente até com maior economia, dotar o país de uma universidade moderna, estruturada nos moldes que vêm sendo recomendados pelos nossos mais capazes professores e pesquisadores [...] Só seremos realmente autônomos quando a renovação das fábricas aqui instaladas se fizer pela nossa técnica, segundo procedimentos surgidos do estudo de nossas matérias-primas e de nossas condições peculiares de produção e de consumo. Só por este caminho poderemos acelerar o ritmo de incremento de nossa produção, de modo a reduzir e, um dia, anular a distância que nos separa dos países tecnologicamente desenvolvidos e que se apartam cada vez mais de nós pelos feitos de seus cientistas e técnicos (RIBEIRO, 1961, p. 170).
\end{abstract}

Figura 21. Frei Mateus

A despeito da consistente argumentação, surgiu, em meio à polêmica decorrente da radicalização entre partidários e adversários da ideia, um novo enfrentamento, dessa vez com a Companhia de Jesus, cuja intenção era fundar uma universidade católica e manter um controle hegemônico sobre o ensino superior na nova capital. Sabedor de divergências entre jesuítas e dominicanos, Darcy Ribeiro tratou de propor ao geral da Ordem Dominicana, Frei Mateus Rocha, um acordo. Nos termos dessa negociação, a Igreja daria apoio à UnB em troca da criação do Instituto de Teologia, destinado a promover cursos de doutoramento, além da formação ordinária de profissionais. Depois de obter o apoio do Papa João XXIII para tal realização, Frei Mateus foi posteriormente nomeado reitor da UnB.

O próprio presidente da República, Juscelino Kubitschek, inicialmente reticente diante da ideia de criação da universidade, só ficou convencido quando o então chefe da Casa Civil, o jurista Vitor Nunes Leal, lembrou-lhe que Thomas Jefferson pediu que consignasse em seu túmulo apenas que ele fora o criador da Universidade de Virgínia (RIBEIRO, 1991, p.126.).

E a despeito das muitas batalhas, a UnB, antes mesmo de existir, tornava-se "[...] o principal tema dos debates dos universitários brasileiros". Como consequência, o seu projeto difundia-se nacionalmente "[...] convertendo-a no que ela foi e no que ela é: a cristalização, como utopia concreta, das aspirações mais profundas da intelectualidade brasileira" (RIBEIRO, 1991, p. 127).

No dia 16 de abril de 1960, o ministro da Educação, Clóvis Salgado, submeteu ao presidente da República, por meio da Exposição de Motivos n. 492, o projeto de criação da Fundação Universidade de Brasília, que enfatizava a existência, no plano urbanístico da cidade, de área reservada à cidade universitária. Com base nesse documento, o presidente encaminhou para o Congresso Nacional, no dia 21 de abril de 1960 - data da inauguração da nova capital - a Mensagem Presidencial n. 128, autorizando o Poder Executivo a instituir a Fundação Universidade de Brasília (FUB) e a praticar atos para consolidação de seu patrimônio inicial. Em julho do mesmo ano, por meio do Decreto n. 48.599, o presidente designou uma comissão especial encarregada de realizar estudos complementares sobre a criação da Universidade de Brasília, da qual faziam parte Darcy Ribeiro, como presidente, Cyro dos Anjos e Oscar Niemeyer. 


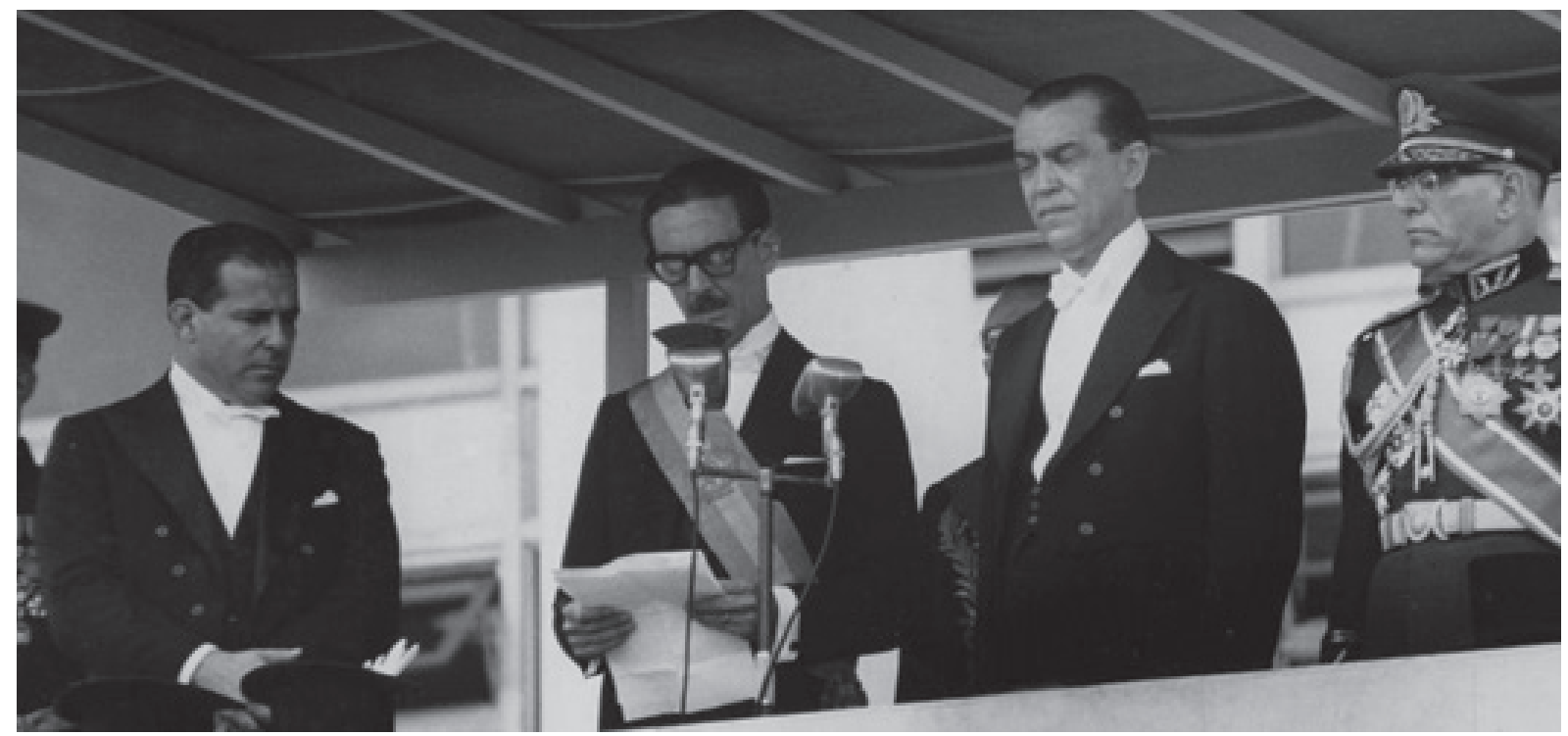

Figura 22. Posse do presidente Jânio Quadros, 31 de janeiro de 1961

Lamentavelmente, JK chegaria ao fim do seu mandato sem que o projeto de criação da universidade tivesse obtido a sanção do Congresso Nacional. Apesar de aprovado em todas as comissões da Câmara dos Deputados sem alterações substanciais, a matéria não foi levada a plenário devido à resistência por parte da oposição udenista.

Em meados de 1960, o plano desenvolvimentista começava a dar sinais de esgotamento, com o crescimento da dívida pública que se traduzia em elevada inflação. $O$ aumento das denúncias contra os gastos governamentais abria espaço para as lutas pela reforma agrária e pelos direitos trabalhistas. A legitimidade das instituições era questionada, enquanto os sindicatos mobilizavam-se em repetidas greves. Em pouco tempo, o otimismo e o clima de democracia reinante davam lugar à instabilidade política.

Em outubro de 1960, com grande número de votos, foi eleito o paulista Jânio da Silva Quadros. No seu discurso de posse, o presidente chegou a tecer elogios ao governo anterior. Porém, na noite desse mesmo dia, Jânio atacou violentamente o governo Kubitschek em cadeia nacional de rádio, atribuindo ao ex-presidente ineficiência administrativa e a responsabilidade pelos altos índices de inflação e pela dívida externa.

Na capital federal, onde a crise econômica e o desemprego eram especialmente sentidos, temiamse depredações e tumultos. E as críticas de Jânio da Silva Quadros a Brasília ameaçavam pôr em risco o ritmo de construção da cidade, deixando incerto o destino do Departamento de Urbanismo e Arquitetura (DUA), vinculado à Companhia Urbanizadora da Nova Capital (Novacap).

Na verdade, em 1961, teve toda uma perspectiva terrível de que o Jânio, por ter falado muito mal de Brasília, iria fechar o DUA, não haveria mais escritório. O Oscar tinha me convidado, naquela época, para assumir o DUA, porque o Nauro Esteves estava indo para o Rio de Janeiro [...] Nisso surgiu o Darcy Ribeiro com aquela esfuziante necessidade de criar uma porção de coisas. E ele tanto pressionou o Oscar que, em vez de remontar o DUA conforme estava se pretendendo, ele montou o Ceplan [...] e o Darcy falou para o Oscar: o escritório que você está querendo montar no DUA, você monta na Universidade e faz lá todos os projetos de Brasília (LELÉ, entrevista em 29 fev. 2012). 
Em meio a um governo marcado por um estilo dramático e contraditório, o novo presidente da República constituiu, por meio do Decreto n. 50.732 de 06 de junho de 1961, uma Comissão de Planejamento da Universidade de Brasília, coordenada por Darcy Ribeiro e integrada pelos professores Anísio Spínola Teixeira, Paulo Novai, Almir Godofredo de Almeida e Castro, Celso Furtado e Roberto Herbster Gusmão, com o objetivo de desenvolver estudos complementares ao plano anterior. Essa comissão manteve contatos constantes com vários cientistas e pensadores, entre os quais Afrânio Coutinho, Almir de Castro, Antônio Cordeiro, Antônio Houaiss, Celso Cunha, Florestan Fernandes, Gilberto Freyre, Haiti Moussatché, Jayme Tiomno, José Sérgio Leite Lopes, Mário Pedrosa, Mário Schemberg, Roberto Pompeu de Souza, Roberto Salmeron, considerados coautores na grande aventura de reflexão sobre o modelo universitário brasileiro. O médico Heron de Alencar, amigo e conterrâneo de Anísio Teixeira, também prestou colaboração ao projeto de criação da nova universidade por ter sido, segundo o professor Frank Svensson, "[...] quem mais havia se aproximado de leituras e reflexões do que seria uma universidade" (Entrevista em 23 fev. 2012).

Logo foram tomadas providências para a instalação do Centro de Documentação, que seria o núcleo inicial da Biblioteca Central da Universidade de Brasília (BCE).

No entanto, os momentos conturbados entre a posse e a repentina renúncia do presidente Jânio Quadros ${ }^{9}$ fizeram com que o Projeto n. 1.861, de 16 de maio de 1960, transformado no Projeto de Lei n. 122, passasse mais de um ano na Câmara dos Deputados, sendo encaminhado para o Senado Federal somente em agosto de 1961, durante o mandato interino do presidente da Câmara dos Deputados, Ranieri Mazzilli.

Nesse meio-tempo, o arquiteto carioca Alcides da Rocha Miranda, que vinha trabalhar no núcleo do Serviço do Patrimônio Histórico e Artístico Nacional (Sphan) ${ }^{10}$ em Brasília, teve um papel fundamental. Segundo o arquiteto e professor da Universidade de Brasília Luís Humberto Martins, "[...] Alcides ajudou muito o Darcy, na conversa com os deputados, para a promulgação da lei de criação da universidade" (Entrevista em 26 jan. 2012). Homem sensível e de espírito poético, Alcides ficou encantado com Brasília desde a primeira hora, como se pode depreender de suas palavras, que, ditas na volta de uma viagem que fez à cidade, como arquiteto convidado do Banco Nacional de Desenvolvimento Econômico (BNDE) para projetar sua sede, foram rememoradas por seu filho Luiz Áquila:

É uma beleza! As nuvens são soltas. Não são como no Rio, que tem sempre um fundo de umidade e as nuvens são como se estivessem presas numa abóbada. Lá, não, elas são tridimensionais e soltas no espaço e o sol projeta a sombra dessas nuvens no platô, e é uma coisa tão bonita! Vamos morar lá, não é? (MIRANDA, 16 de março de 2010, p. 13)

Em seu depoimento, Frank Svensson também destacou o papel do Dr. Alcides, como era chamado:

[...] se queria a UnB como uma espécie de MIT (Massachusetts Institute of Technology) brasileiro, que se dedicasse às ciências exatas, humanas e naturais. O Dr. Alcides é que se bateu para que houvesse também uma formação em arte e arquitetura [...] foi o que mais se empenhou" (SVENSSON, entrevista em 23 fev. 2012).

\footnotetext{
${ }^{9}$ Enquanto desenvolvia uma política econômica considerada conservadora, Jânio afirmava no plano externo os princípios de uma política independente e aberta a relações com todos os países do mundo, inclusive com as nações socialistas - URSS, China e Cuba -, decisão que provocou protestos dos setores e grupos que o apoiavam. A um descontentamento da população somou-se o rompimento da base aliada com o governo. A situação comprometeu a governabilidade de Jânio, que, depois de denunciar um possível golpe que estaria sendo articulado contra ele, anunciou, em 25 de agosto de 1961 , sua renúncia.

${ }^{10}$ Alcides Rocha Miranda foi o primeiro diretor do núcleo de Brasília do Serviço do Patrimônio Histórico e Artístico Nacional (Sphan), aqui instalado no final da década de 1960. Esse núcleo mais tarde se transformou em Superintendência Regional do Instituto do Patrimônio Histórico e Artístico nacional (Iphan), englobando todo o Centro-Oeste do Brasil.
} 

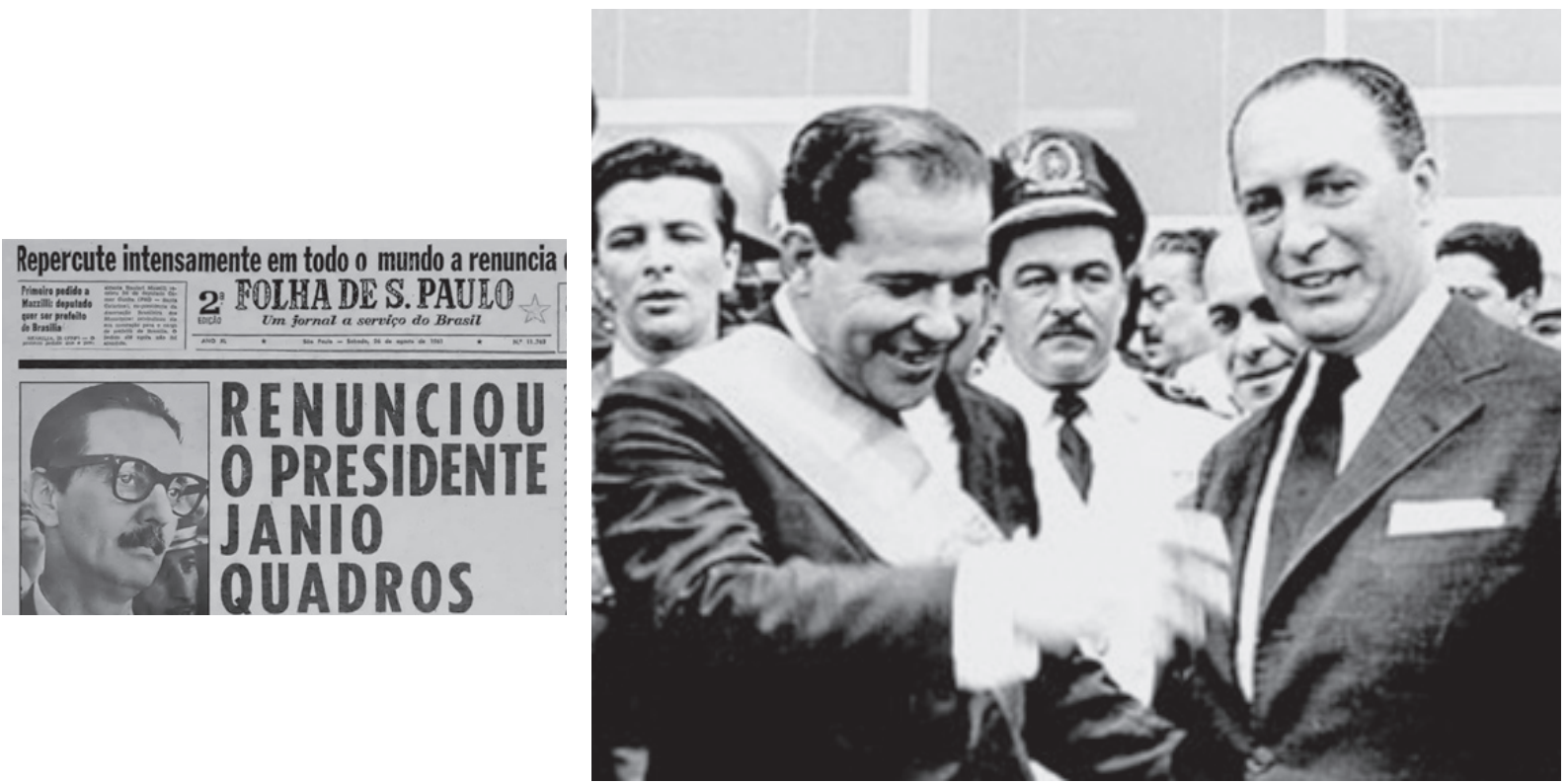

Figura 23. Renúncia do presidente

Jânio

Quadros,

25 de agosto de 1961

Assim é que, na proposta para a Universidade de Brasília, a arquitetura e o urbanismo não foram vistos apenas como mais um curso em meio a tantos outros, e sim como importante campo de pesquisa e experimentação integrante de sua base conceitual.

Após a renúncia de Jânio Quadros, os ministros militares manifestaram-se contra a posse do vice-presidente devido a suas posições políticas, consideradas de esquerda. Com o apoio de vários oficiais-generais, que serviam em vários pontos do país, o governador do Rio Grande do Sul, Leonel Brizola, formou o que ficou conhecido por Cadeia da Legalidade para lutar pela posse de João Belchior Marques Goulart, o Jango. O impasse político foi superado com a adoção provisória do sistema parlamentarista, que reduziu os poderes de João Goulart, Jango, cuja posse ocorreu em 7 de setembro de 1961.

Em 15 de dezembro do mesmo ano, foi sancionada a Lei n. 3.998, que autorizava o Poder Executivo a instituir a Fundação Universidade de Brasília (FUB), mantenedora da futura instituição federal de ensino superior. Alguns dias depois, o então ministro da Educação e Cultura, Antônio Ferreira de Oliveira Brito, empossou os membros do primeiro Conselho Diretor da FUB: Anísio Teixeira Spínola 11, Abgar Renault, Alcides da Rocha Miranda, Darcy Ribeiro, Hermes Lima, João Moojen de Oliveira, Oswaldo Trigueiro e o Frei Mateus Rocha. No dia 15 de janeiro de 1962, o presidente do Conselho de Ministros, Tancredo Neves, assinou o Decreto n. 500, pelo qual foram aprovados o Estatuto da FUB e a estrutura da Universidade de Brasília (UnB). Darcy Ribeiro, talvez o mais ferrenho de seus defensores, foi eleito reitor da nova universidade que, segundo ele,

[...] nasceu sem molde anterior em que se inspirar, e até mesmo sem precedente vivo e bem sucedido com que se emparelhar, tão pobre fora a nossa experiência universitária anterior e tão infaustas as tentativas de revitalizá-la e de dar-lhes autenticidade. Só nos consola dessa estreiteza pensar que a própria carência teria, talvez, dado à UnB uma liberdade de se inventar que, provavelmente, seria tolhida em um país melhor servido por universidades que realizassem satisfatoriamente suas próprias ambições (RIBEIRO,1991, p. 133).

11 Anísio Teixeira assumiu a presidência do Conselho Diretor da Fundação Universidade de Brasília e foi o quarto reitor da UnB, cargo que ocuparia até 13 de abril de 1964, quando todos os membros do Conselho Diretor foram exonerados pelo governo militar. 

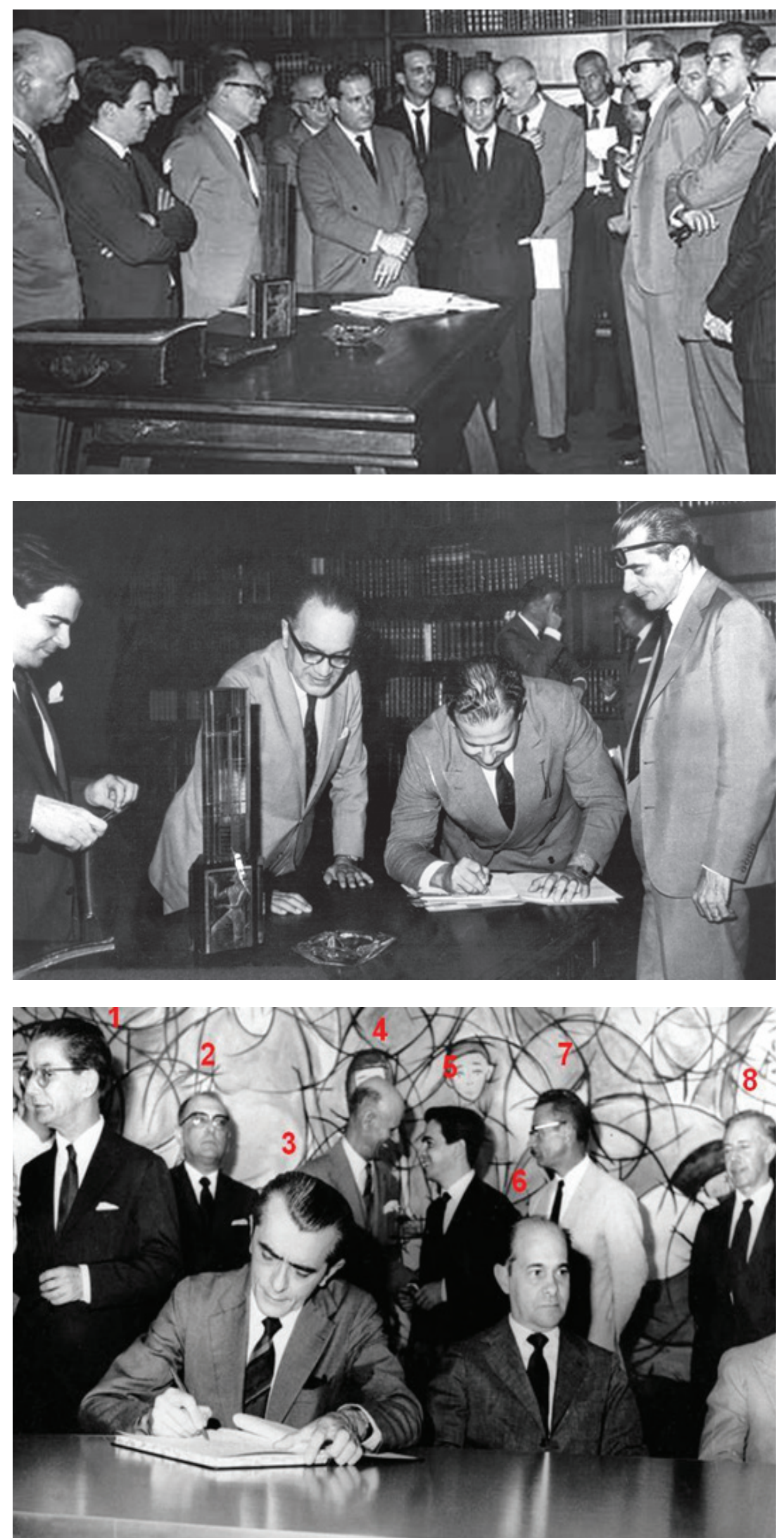

Figura 25

Assinatura da Lei 3.998, de 15 dezembro de 1961 , que instituiu a Fundação Universidade de Brasília

Figura 26.

Da esquerda para a direita: Darcy Ribeiro, reitor; Hermes Lima, primeiro-ministro; João Goulart, presidente; e Antônio Ferreira de Oliveira Brito, ministro da Educação e Cultura

1. Anísio Teixeira 2. Oswaldo Trigueiro 3. Antônio Ferreira de Oliveira Brito

4. Abgar Renault 5. Darcy Ribeiro 6. Tancredo Neves 7. João Moojen de Oliveira 8. Alcides Áquila da Rocha Miranda

Figura 27.

Posse do primeiro

Conselho Diretor da UnB: 


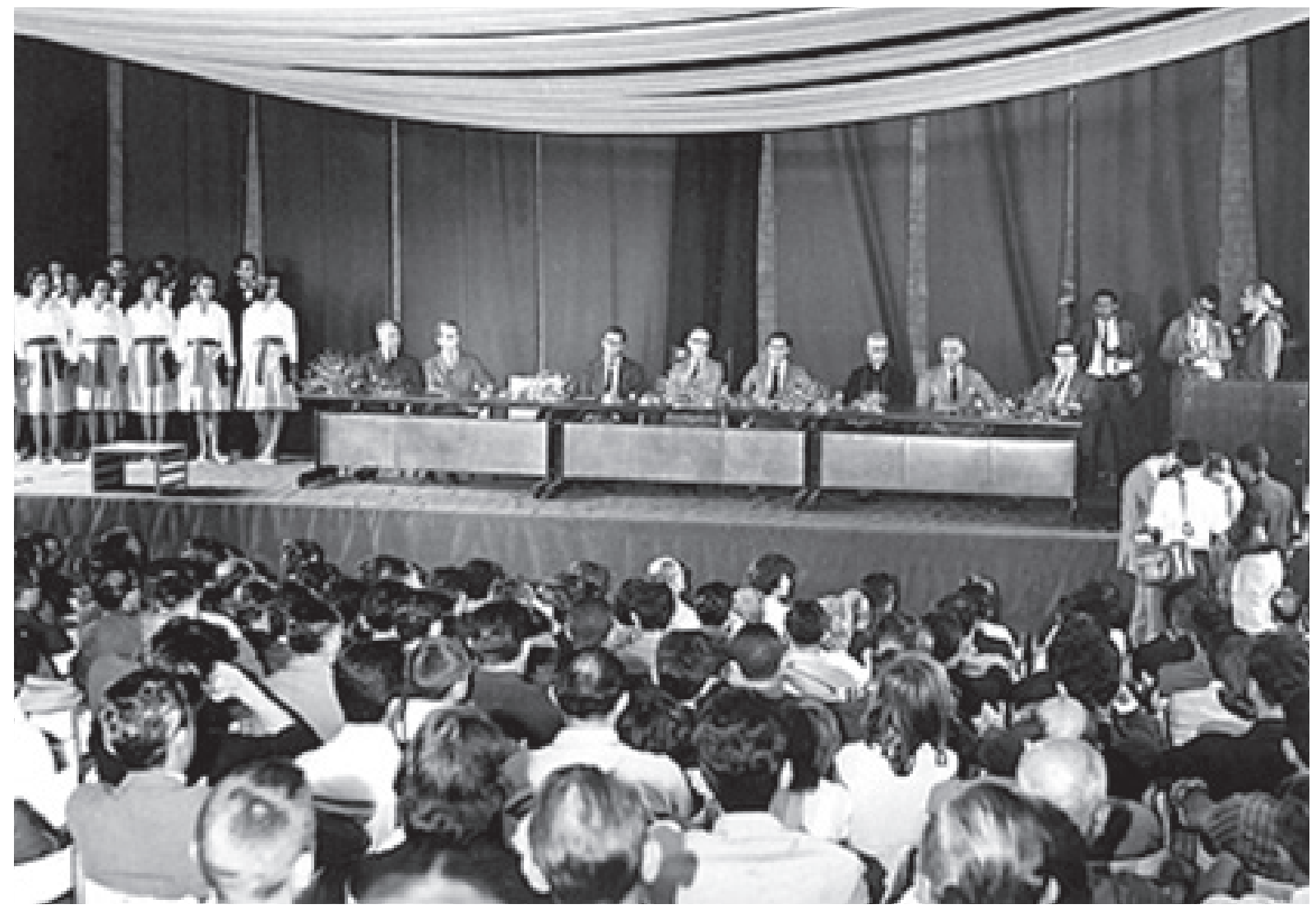

Figura 28. Inauguração da

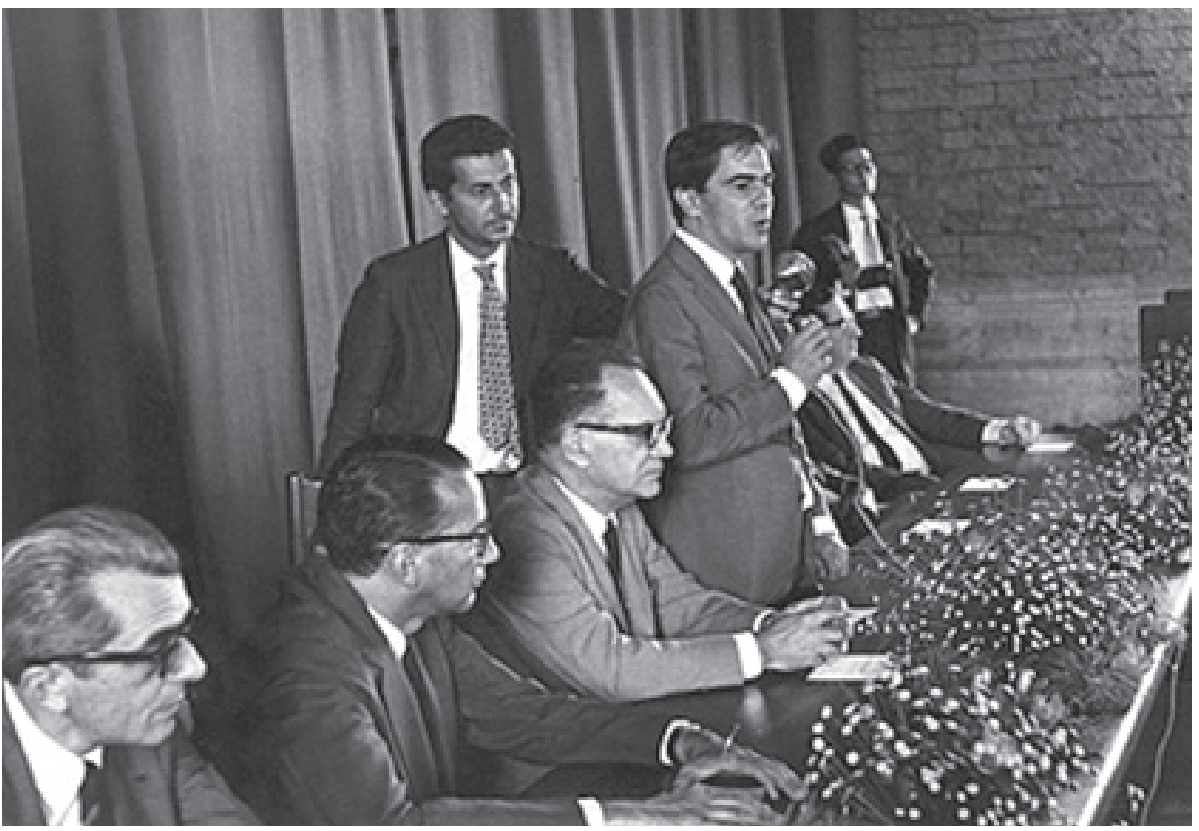

Universidade

de Brasília,

21 de abril de

1962

\section{Figura 29}

Discurso do reitor Darcy Ribeiro

na inauguração da

Universidade de Brasília,

21 de abril de 1962.

À sua direita estão Hermes Lima,

Anísio Teixeira e Antônio Ferreira

de Oliveira Brito

A Universidade de Brasília foi inaugurada no dia 21 de abril de 1962, em meio às comemorações do segundo aniversário da nova capital. A cerimônia foi realizada no Auditório Dois Candangos, às 10 horas, momentos depois do término das obras. 


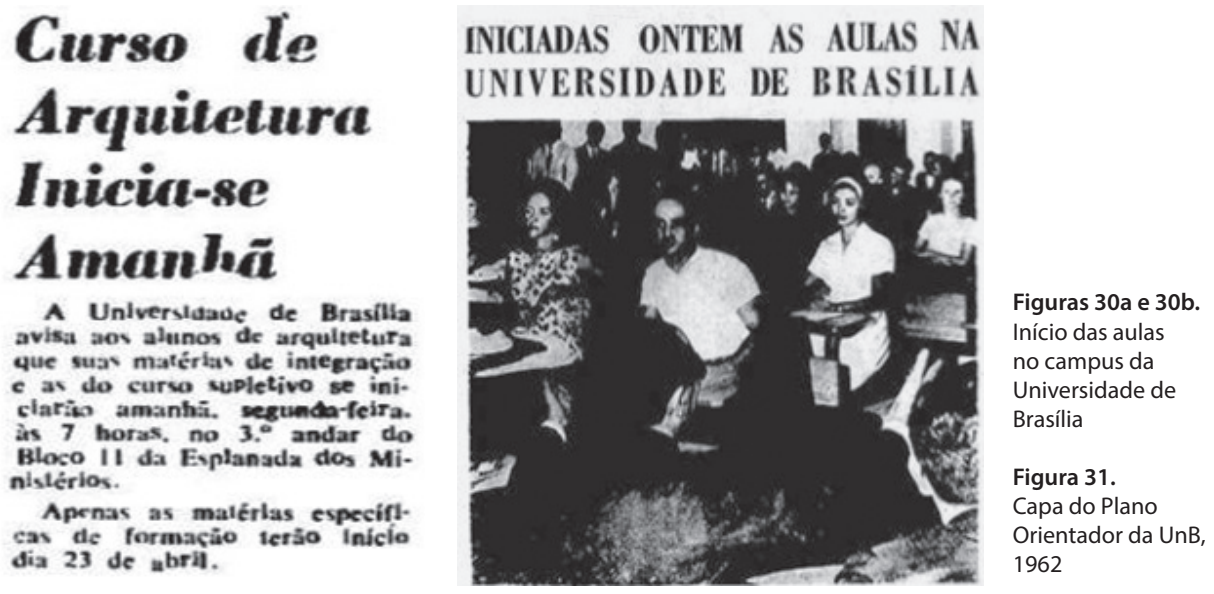

Na verdade, as aulas da Universidade de Brasília já haviam sido iniciadas no dia 9 de abril de 1962, conforme comprovam as matérias publicadas no Correio Braziliense.

Com autonomia financeira, administrativa e didática, a Universidade deveria, conforme o artigo 10 da Lei n. 3998, de 15 de dezembro de 1961, “[...] empenhar-se nos estudos dos problemas relacionados com o desenvolvimento econômico, social e cultural do país". Para Ribeiro, que considerava a Universidade de Brasília "[...] o projeto mais ambicioso da intelectualidade brasileira", tratava-se de "produzir na cidade inovadora uma gente nova de mentalidade renovada, sem nenhum complexo de inferioridade colonial e sem nenhuma subserviência classista" (1978, p. 73).

Como primeira publicação da Editora da UnB, o Plano Orientador da Universidade de Brasília, datado de 1962, além da estrutura acadêmica e da concepção administrativa, afirmava o espírito da instituição: "Só uma universidade nova, inteiramente planificada, estruturada em bases mais flexíveis, poderá abrir perspectivas de pronta renovação do nosso ensino superior". Do ponto de vista educacional, o grande distintivo do projeto original da UnB concentrava-se em sua

\footnotetext{
[...] macroestrutura tripartida de Institutos Centrais de Ciências, Letras e Artes, dedicados ao cultivo e ao ensino do saber fundamental; de Faculdades Profissionais, dedicadas à pesquisa e ao ensino nas áreas das ciências aplicadas e das técnicas; e dos Órgãos Complementares que prestariam serviços à comunidade universitária e à cidade (RIBEIRO, 1991, p. 154).
}

Nos institutos centrais, os estudantes fariam cursos introdutórios de dois anos a fim de obter uma capacitação intelectual e científica básica. Além de um preparativo para a faculdade, os institutos ofereceriam cursos de bacharelado de três anos para os alunos que desejassem seguir a carreira do magistério. Inicialmente foram programados oito institutos: Matemática, Física, Química, Biologia, Geociências, Ciências Humanas, Letras e Artes, que seriam compostos por vários departamentos. As faculdades receberiam os alunos que, após os estudos nos institutos, optassem por fazer uma formação profissional. E os órgãos complementares, além de servirem de extensão para a cidade e para o país, deveriam criar as condições para a existência de uma vida universitária, voltada para os professores, estudantes e funcionários que ali permaneceriam em tempo integral.

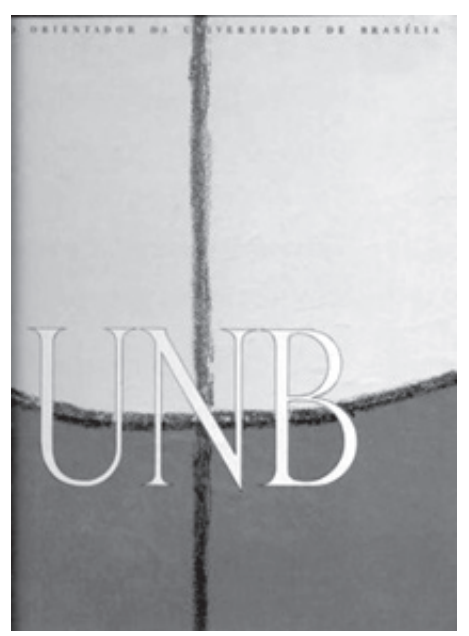


Entre os principais órgãos complementares estavam a Aula Magna; a Biblioteca Central; a Rádio e TV Universitária; a Editora; o Museu da Civilização Brasileira e as Casas de Cultura, voltadas para o ensino de línguas e de tradição cultural de diversos países. Faziam parte ainda desse segmento estrutural: o Centro Integrado de Ensino Médio (Ciem), escola de aplicação do ensino secundário vinculada à Faculdade de Educação; o Centro Recreativo e Cultural; o Estádio Universitário; o Centro de Assistência Médica e Dentária; a Casa Internacional, destinada a abrigar estudantes estrangeiros; e o setor de habitações para estudantes e professores.

Apesar de previstos no Plano Orientador oito institutos centrais, a serem posteriormente desdobrados em departamentos e faculdades, o Conselho Diretor autorizou, em 1962, a implantação imediata de três cursos transitórios, que passaram a constituir o embrião da nova universidade. Os professores nomeados para a coordenação desses cursos-tronco foram: Vitor Nunes Leal, para o curso de Direito, Economia e Administração; Cyro Versiani dos Anjos, para Letras Brasileiras; e Alcides da Rocha Miranda, para Arquitetura e Urbanismo.

\begin{abstract}
O Plano Orientador de 1962 refere-se às faculdades e institutos com seus respectivos dirigentes, e menciona os coordenadores de curso da FAU, Lucio Costa e Oscar Niemeyer. No mesmo ano, sob o título 'O ritmo de trabalho na Universidade de Brasília', Antônio de Oliveira Britto, ministro da Educação e da Cultura no último parágrafo, informa que grupo de arquitetos, tendo à frente Oscar Niemeyer e Alcides da Rocha Miranda, já iniciou estudos e começou a projetar os edifícios que se encontram na Praça Maior da Universidade de Brasília [...], passando a enumerá-los. (Cláudio QUEIROZ, entrevista em 15 abr. 2012).
\end{abstract}

Institucionalmente, a UnB também nasceu diferente. Rompendo com a lógica da legislação que determinava o ordenamento e funcionamento das demais universidades, sua lei de criação estabelecia que as definições de seus rumos seriam todas tomadas no âmbito de sua comunidade acadêmica:

\footnotetext{
A definição de seu regime jurídico como fundação de caráter especial deveria assegurar a autonomia na sua organização, manutenção e direção [...] No campo da gestão acadêmica, o primeiro estatuto, aprovado em 1962 previa várias instâncias de decisão coletiva, com uma representação ampliada de estudantes e professores, em relação à existente em outras universidades (RIBEIRO, 1991, p. 42).
}

Embora os grandes projetos para cidades universitárias no Brasil tivessem passado pelas mãos de arquitetos adeptos do Movimento Moderno, em Brasília essa participação ocorreu de forma diferente: por fazer parte da Comissão Especial responsável pela concepção institucional, o arquiteto Oscar Niemeyer tomou parte também das discussões para a elaboração do programa de necessidades da UnB.

\title{
1.2. A concepção do espaço pioneiro
}

Apesar das mudanças políticas advindas com a renúncia de Jânio e a posse do vice-presidente João Goulart, o Jango, prevalecia a ideia de Darcy de criar na UnB um órgão responsável pelos projetos e obras dos prédios do campus. E, em maio de 1962, o Conselho Diretor da UnB instituiu, como órgão de Assessoria Técnica da Reitoria, o Centro de Planejamento (Ceplan), sob a coordenação de 

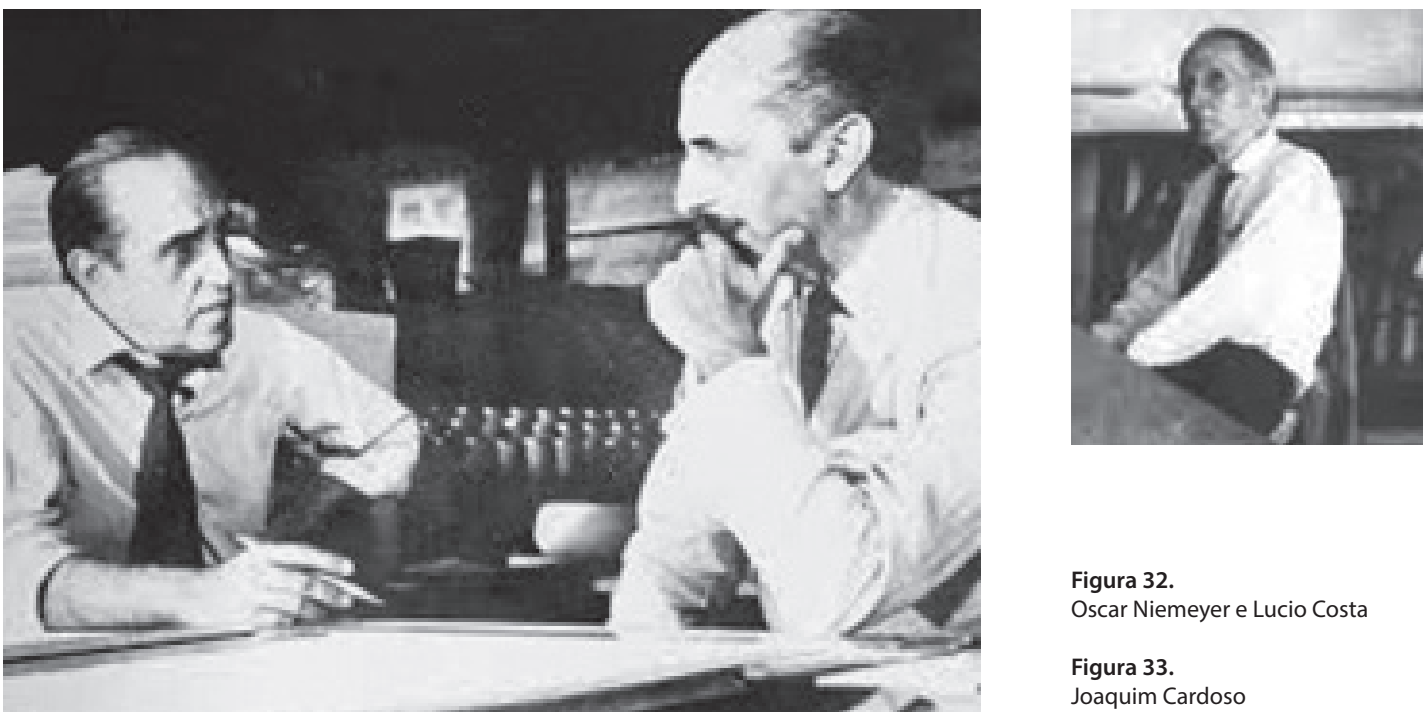

Figura 32

Oscar Niemeyer e Lucio Costa

Figura 33.

Joaquim Cardoso

Oscar Niemeyer, tendo como consultores Lucio Costa e o engenheiro e poeta Joaquim Cardoso. $\mathrm{O}$ órgão tinha como objetivo "[...] elaborar os projetos de todos os edifícios da Universidade, dentro das normas urbanísticas do plano de Lucio Costa. Fixar a arquitetura da Universidade e, também, orientar e conduzir os cursos da Faculdade de Arquitetura" (MÓDULO, 1963, p. 26).

O terreno, cedido pela Novacap à Universidade de Brasília em dezembro de 1960, corresponde a uma gleba na Vargem Bonita, de aproximadamente 4.500 hectares, onde passou a funcionar a Fazenda Água Limpa. Com a interferência de Darcy Ribeiro, que apresentou seu plano para o uso dessa zona rural, são doadas para a instituição uma faixa de 257 hectares, próxima à margem norte do Lago Paranoá, destinada à construção do campus; e as projeções correspondentes a 12 superquadras situadas na Asa Norte ${ }^{12}$.

O primeiro plano urbanístico para a UnB foi feito, em 1960, por Lucio Costa. Embora tenha sido apresentada em forma de esboço, a proposta, constituída por edificações dispersas, contemplava a setorização para os institutos centrais, as faculdades e os órgãos complementares. E, diferentemente do plano elaborado pelo arquiteto para a Universidade do Brasil (1936), as interligações entre os edifícios da UnB ocorreriam em função das afinidades de programa: o Instituto Central de Artes, por exemplo, deveria se situar próximo ao Museu de Artes e às faculdades afins.

Na proposta original de Lucio Costa, o acesso principal se dava pela via L4, a partir da Praça Maior, e o campus era estruturado em parcelas, como quadras internas, sendo que

[...] as morfologias insinuadas constituíam edificações dispersas em subsetores organizados por áreas universitárias. Era evidente a importância dada à ocupação da área central da grande gleba, pelo conjunto de quadras universitárias, ao longo dos eixos que definiam a Praça Maior (FARIA et al., 2003, p. 7).

Apesar de Lucio Costa ter imaginado a cidade universitária como um grande parque, conforme consta do Plano Orientador (1962) - "[...] toda a área cortada por estradas, predominantemente curvas, que pela suavidade contrastam predominante com as linhas hieráticas do conjunto da cidade"

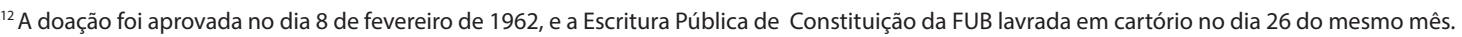




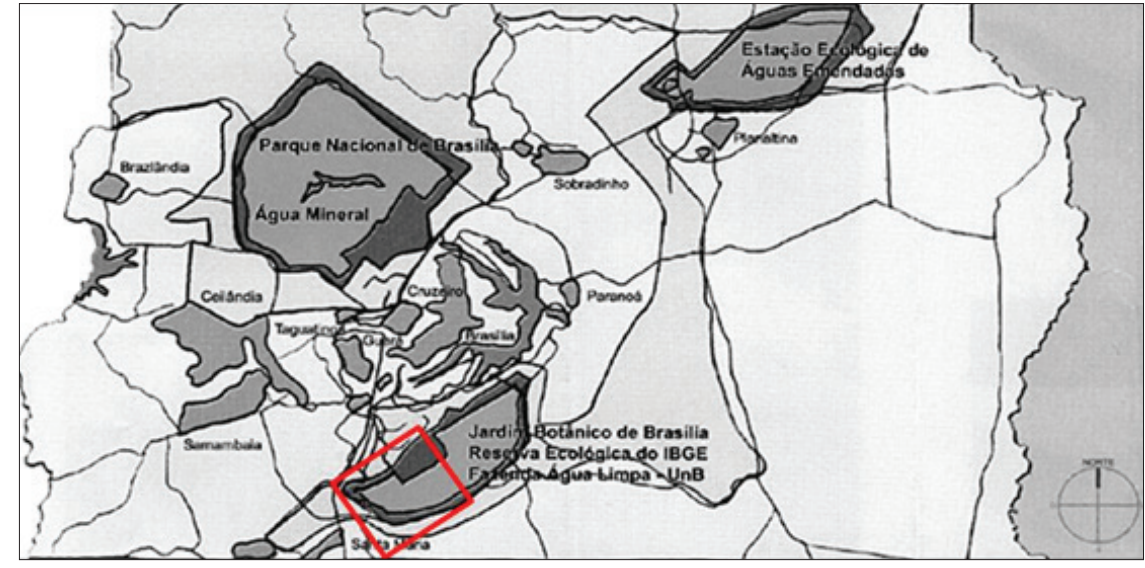

Figura 34.

Localização da Fazenda Água Limpa no Distrito Federal

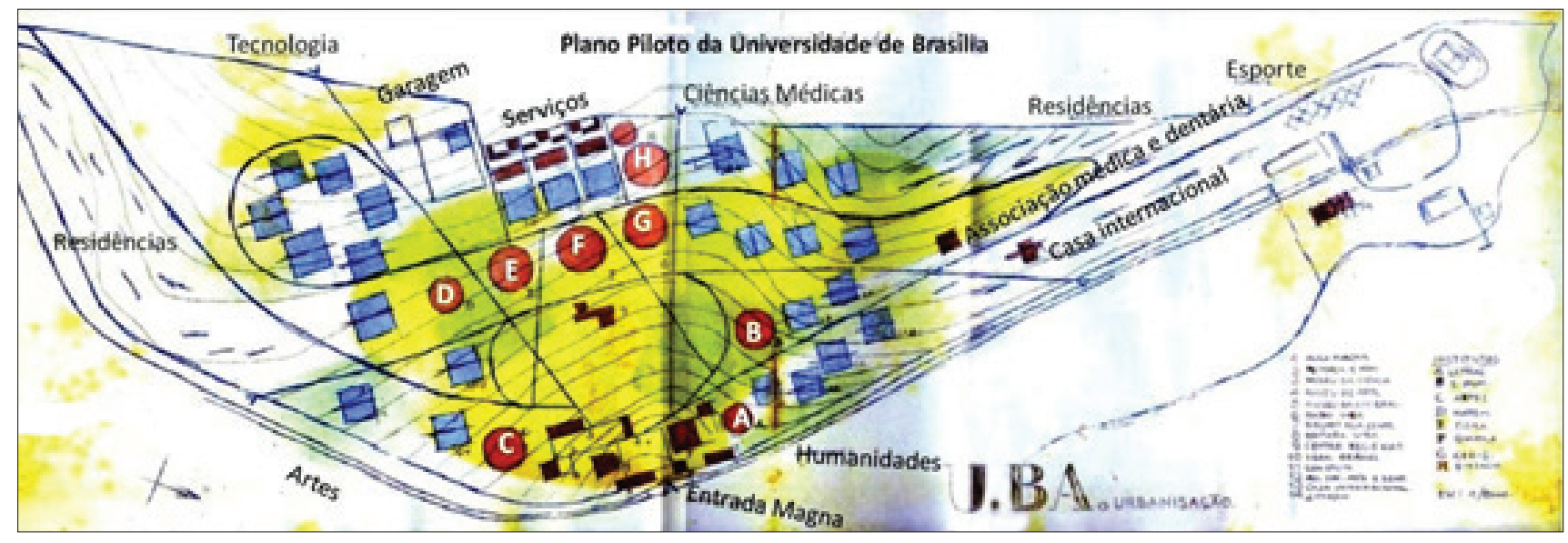

Figura 35a.

Plano Piloto da

Universidade de Brasília
A - Letras

B - Ciências HumanaS

C - Artes

D - Instituto de Matemática

E - Instituto de Física

F - Instituto de Química

$\mathrm{G}$ - Instituto de Geociências

$\mathrm{H}$ - Instituto de Biologia

Plano Orientador da

Universidade de Brasília,1962

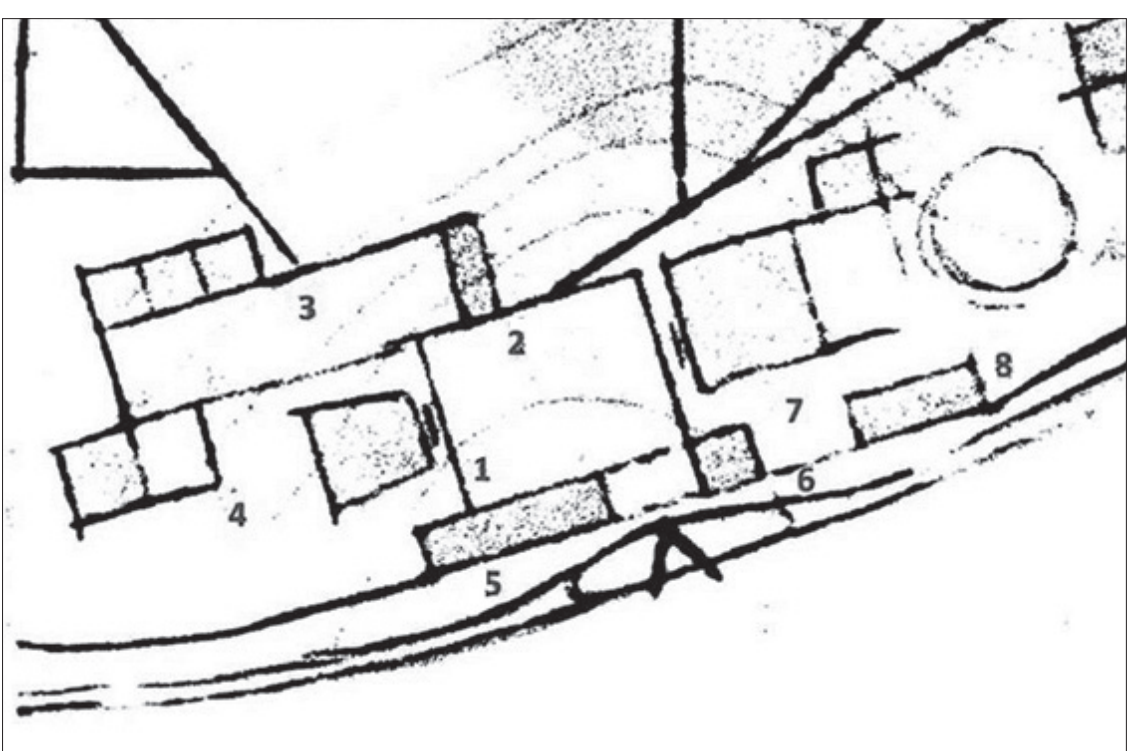

Figura 35b.

Plano Piloto da Universidade de Brasília (detalhe da Praça Maior)

1. Aula Magna

2. Reitoria e Administração

3. Museu da Ciência

4. Museu de Arte

5. Museu da Civilização Brasileira

6. Rádio da UnB

7. Biblioteca Central

8. Editora da UnB 
-, existe uma relação entre a Praça Maior da Universidade de Brasília e a da Cidade Universitária do Brasil (CUB), projetada em 1936 por Lucio Costa no Rio de Janeiro.

[...] não há como negar o parentesco existente entre a Praça Maior da UnB com a Praça Maior da Cidade Universitária do Brasil [...] (que) também pode ser descrita como uma praça "quadrangular, delimitada por edifícios funcionalmente significativos que a tangenciam", só que pavimentada. São eles: o pórtico, a reitoria, a aula magna e a biblioteca (SCHLEE, 2011, p. 4).

Juntamente com os estudos de urbanização avançaram, na Comissão Especial, constituída em 1960, as discussões em torno da estrutura pedagógico-institucional e, consequentemente, das necessidades físicas capazes de abrigar as atividades acadêmicas no campus. Com isso,

[...] nos trabalhos do Ceplan para a UnB encontram-se edifícios que inicialmente não foram pensados por Lucio Costa para a universidade. Isso ocorreu porque o próprio programa da UnB estava ainda em elaboração e deveria atender não apenas às questões acadêmicas, mas também às sociais e políticas (ALBERTO, 2009, p. 83).

Apesar de a Petrobras e o Ministério da Educação terem cedido espaços para a administração da UnB e mesmo apartamentos de sua cota, um dos problemas que a nova universidade teve que enfrentar, logo de início, foi a construção de dependências para abrigar as primeiras atividades no campus, bem como os docentes que chegavam todos os dias.

Assim, antes mesmo de ter sido promulgada a lei de criação, já começava o processo de edificação da Universidade de Brasília. A urgente demanda por espaços físicos fez com que fosse aproveitada, em construções do campus, a experiência de Sérgio Rodrigues, que desde 1959 vinha desenvolvendo estudos para o SR2 $2^{13}$ - nome dado a um sistema composto de elementos de madeira préfabricados para a arquitetura habitacional.

Em 1960, um protótipo desse tipo de construção foi exposto no Museu de Arte Moderna no Rio de Janeiro (MAM/RJ). Composto de estrutura de peroba maciça e cobertura plana, o sistema foi modulado em função das dimensões das chapas de compensado disponíveis no mercado. Placas de feltro asfáltico revestidas de alumínio foram fixadas ao forro de réguas de madeira. Embora fosse bastante flexível e permitisse diferentes usos e arranjos, foram apresentadas versões de plantas para unidades de um, dois e três quartos, que mediam, respectivamente, 25, 47 e 65 metros quadrados, além da área livre resultante da elevação dos pisos das casas.

Segundo Nobre (2008, p. 161),

[...] a simultaneidade da exposição no MAM com a inauguração de Brasília tinha sua razão de ser: acreditava-se numa convergência entre o sistema pré-fabricado de Sergio Rodrigues e a construção da nova capital, visto que ambos projetos podiam ser enquadrados, afinal, dentro da mesma perspectiva de industrialização do país.

${ }_{13}$ O SR2 surgiu de uma brincadeira com o nome Sérgio Roberto Santos Rodrigues, que tem 2 Ss e 2 Rs. 


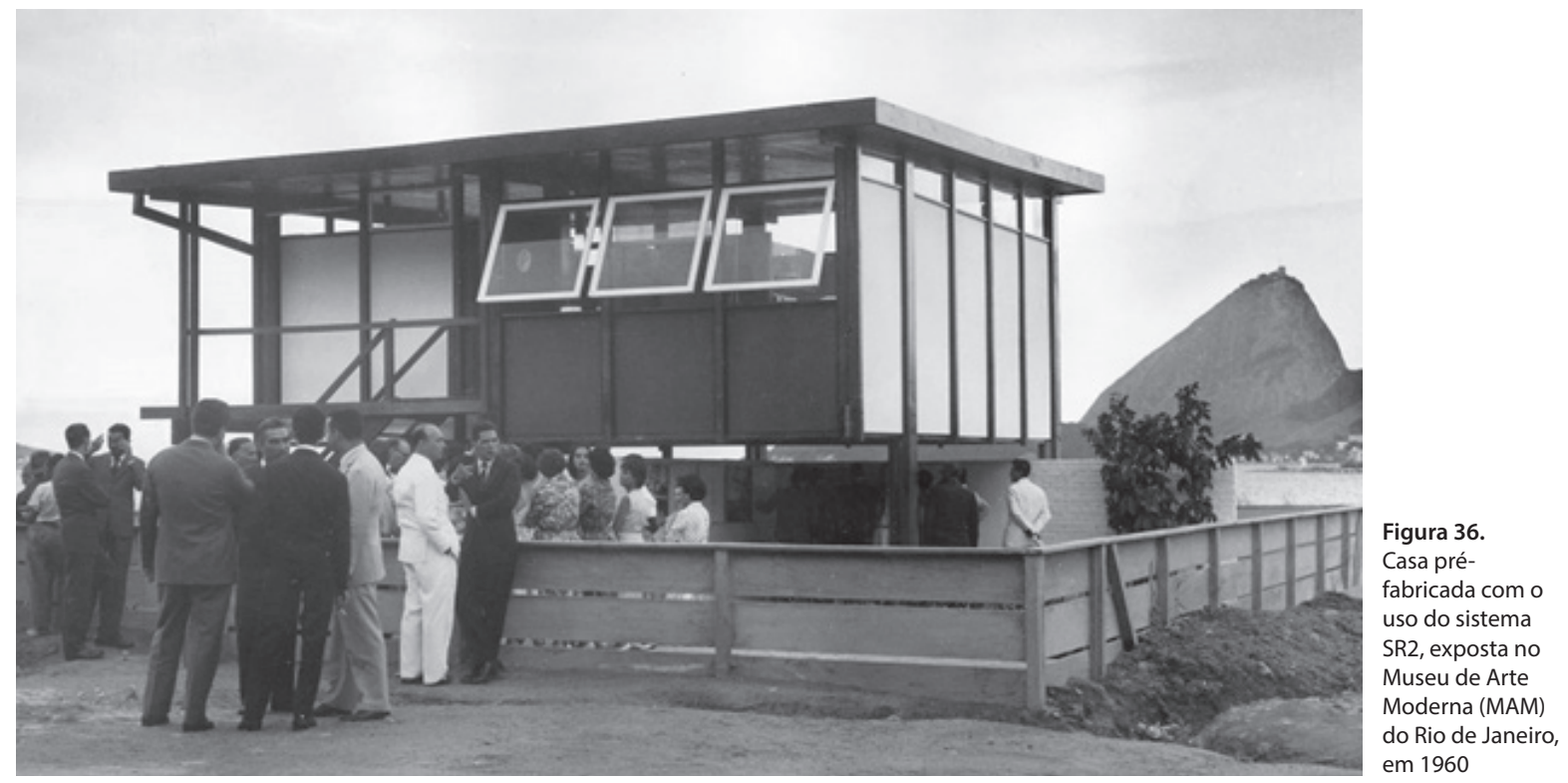

Com o sistema SR2, em apenas dois meses foram erguidos na UnB: dois pavilhões de alojamento - OCA I e OCA II, com térreo e sobreloja - e um restaurante, todos em estrutura de madeira de lei, e ainda um prédio de alvenaria onde passaram a funcionar provisoriamente a biblioteca e a sala dos professores. O nome dado a esses alojamentos foi uma alusão à indústria Oca, que havia sido criada pelo autor do projeto em 1955:

Eu cheguei em $1^{\circ}$ de julho de 1962. Nessa época, o que havia no campus eram barracos. Além desses, existiam alojamentos para professores, instrutores, alunos de pós-graduação [...] produzidos pela Oca, uma firma do Rio de Janeiro que fez construções muito boas em madeira. Era ali que nós morávamos, e o restaurante onde almoçávamos, jantávamos e tomávamos o café da manhã, enfim (PESSINA, entrevista em 1 dez. 2011).

Usado também na construção da primeira sede do late Clube de Brasília em 1960, o sistema foi reproduzido, posteriormente, em mais de 270 unidades - casas, conjuntos habitacionais, pousadas, clubes e restaurantes -, muitas das quais na floresta amazônica.

A pesquisa para casas industrializadas começou nos anos 50. Imaginava fazer uma casa com estrutura metálica, mas depois pensei em utilizar a madeira nas bitolas disponíveis no mercado, sem usinagem. Eu apenas cortava, furava, transportava e montava na casa do cliente, como um brinquedo de armar. Em 1960 expus uma dessas casas no MAM do Rio de Janeiro, a convite de Niomar Muniz Sodré Bittencourt ${ }^{14}$. O professor Lucio Costa viu essa exposição e ficou tão entusiasmado que escreveu uma carta para o Israel Pinheiro, diretor da Novacap em Brasília, dizendo que seria a única casa de madeira que poderia ser construída no Plano Piloto. A partir daí, mais de 200 unidades foram montadas em Brasília e pelo Brasil afora, inclusive 70 casas para o Instituto Humboldt, no interior do Amazonas. (RODRIGUES, agosto e setembro de 2001, p. 87)

\footnotetext{
${ }^{14}$ Niomar Muniz Sodré Bittencourt (1916-2003) era filha do advogado, jornalista e político baiano Antônio Muniz Sodré de Aragão e casada com Paulo Bittencourt, filho de Edmundo Bittencourt, fundador do jornal Correio da Manhã. Sob a liderança de Raymundo Ottoni, integrou o grupo de empresários responsáveis pela fundação,em 1948, do Museu de Arte Moderna do Rio de Janeiro (MAM), do qual foi diretora por dez anos.
} 
Figuras 37a e $37 b$.

Vistas do pavilhão construído com o sistema R2 no late Clube de Brasília,
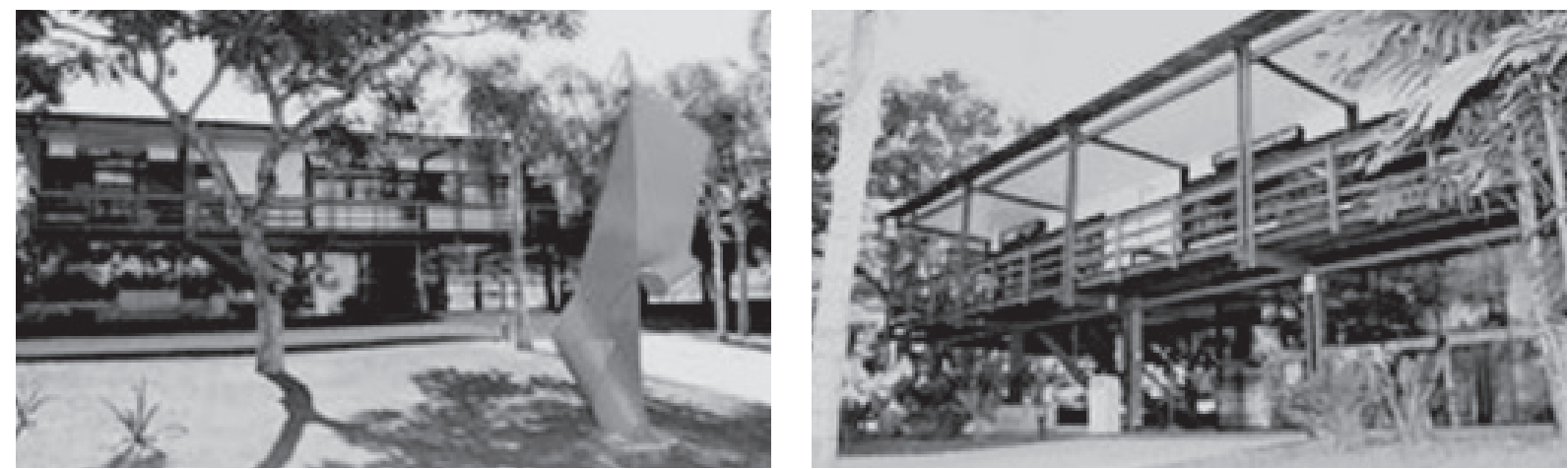

De acordo com Nobre, apesar de Lucio Costa ter aberto as portas de Brasília para a arquitetura residencial de Sergio Rodrigues e de ter reconhecido o padrão de acabamento, a simplicidade e a rapidez de montagem de seus pré-fabricados de madeira, no entendimento do criador de Brasília essas habitações deveriam ser pavilhões de morar provisórios, até que fossem construídas as casas definitivas (2008, p. 161).

A despeito da qualidade arquitetônica dos pré-fabricados de madeira que produziu, a atuação de Sérgio Rodrigues como arquiteto ficou relativamente ofuscada por sua notoriedade como designer de móveis. Para a UnB, por encomenda de Darcy Ribeiro, Sérgio Rodrigues projetou, entre outros móveis, a mesa e os assentos do Auditório Dois Candangos ${ }^{15}$.

Darcy Ribeiro me levou para ver o Auditório Dois Candangos, porque queria instalar ali 250 poltronas dentro de três semanas. Gesticulou no terreno livre, como se houvesse alguma construção no lugar, e disse que não queria nada pronto, de linha, não era o caso de fazer compras em São Paulo. Eu deveria desenhar e mandar produzir as cadeiras do auditório da universidade, uma das obras-primas de Alcides da Rocha Miranda. Fiquei apavorado, mas ele me tranquilizou: 'Isso aqui é Brasília. Quando você voltar a construção estará pronta'. Voltei numa Semana Santa, faltando três dias para a inauguração. Foi emocionante: precisei mandar um caminhão com a faixa 'A UnB precisa de você' para trazer os estudantes para a obra. Era feriado, eles vieram. (RODRIGUES, 30 de junho de 2010, p. 66)

Cabe aqui um parêntese para lembrar o espírito de solidariedade dos estudantes da época, atestado por matéria publicada no Correio Braziliense de 19 de abril de 1962. Por iniciativa de um grupo de estudantes interessados em apressar a inauguração da UnB, a Reitoria convidou os demais alunos para participarem de um mutirão de limpeza das instalações do campus, disponibilizando, para tanto, um ônibus para o seu transporte.

A originalidade e a simplicidade das cadeiras instaladas no Dois Candangos contribuíram para que estas fossem replicadas em vários outros locais: "Desenhei essas cadeiras, que também foram utilizadas em uns 20 ou 30 auditórios no Brasil, inclusive no Anhembi, em São Paulo" (RODRIGUES, 2003). Juntamente com Oscar Niemeyer, autor da famosa poltrona

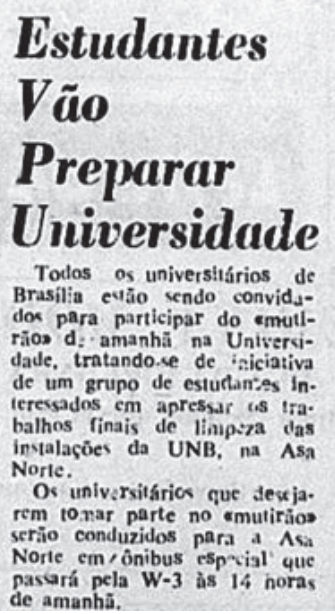

Estudantes

Vão Preparar Universidade Todos os universitários de
Brasilia evão sendo convidaBrasilia ettão cendo convidarãos d.-amanhä na Universide um grupo de esturtantes in cresos cm apressar us tra. instalaçóes da UNB, na Asa Nerte conduzidos para d As: pascrá pela W-3 às 14 horas 
Easy Chair - encontrada no Palácio do Itamaraty e no Congresso Nacional -, Sérgio Rodrigues foi responsável pela concepção do mobiliário dos palácios da Alvorada, do Congresso, do Planalto e do Jaburu. Entre as peças de sua autoria que compõem esses edifícios estão as poltronas Beto, Vronka e Kiko e o sofá Navona.

Merece destaque ainda sua contribuição para a ambientação do Palácio do Itamaraty. O embaixador Wladimir Murtinho, responsável pelo andamento das obras, e o arquiteto Olavo Redig de Campos, chefe do Serviço de Conservação e Patrimônio do Ministério das Relações Exteriores, encomendaram ao arquiteto a produção de mesas de trabalho, "com design representativo do espírito brasileiro", para os gabinetes dos diplomatas na nova capital, conforme pode ser comprovado pelas palavras do próprio designer: "Em meados de 1960, Wladimir Murtinho e Olavo Redig de Campos, funcionários do Itamarati, me procuraram porque precisavam de mesas para ministros, para a inauguração de Brasília. A mesa do ministro Horácio Lafer foi um sucesso" (RODRIGUES, 2003).
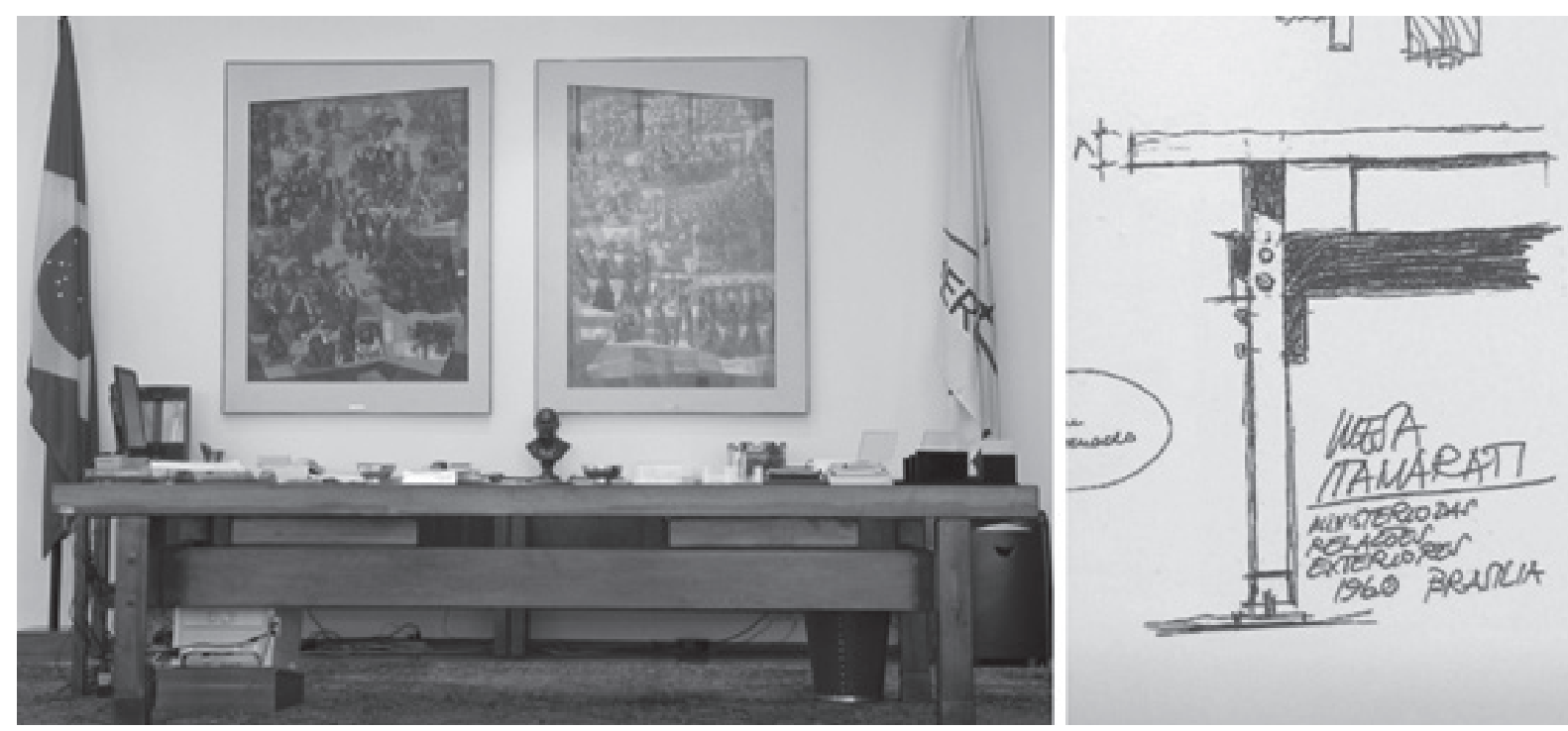

Figura 39

Com base no desenho dessas mesas, conhecidas pelo nome de Itamaraty - logo aprovadas, executadas e levadas para Brasília -, viriam outros trabalhos para a mesma repartição, tais como as mesas Redig e Alex, as poltronas Oscar e Tião e os conjuntos de sofás Pajé e Millôr.

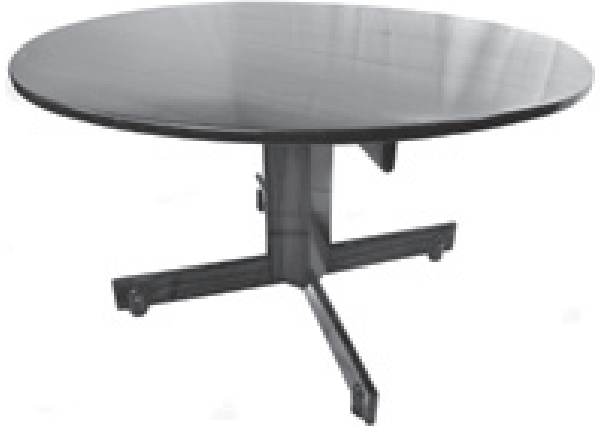

Mesa Alex

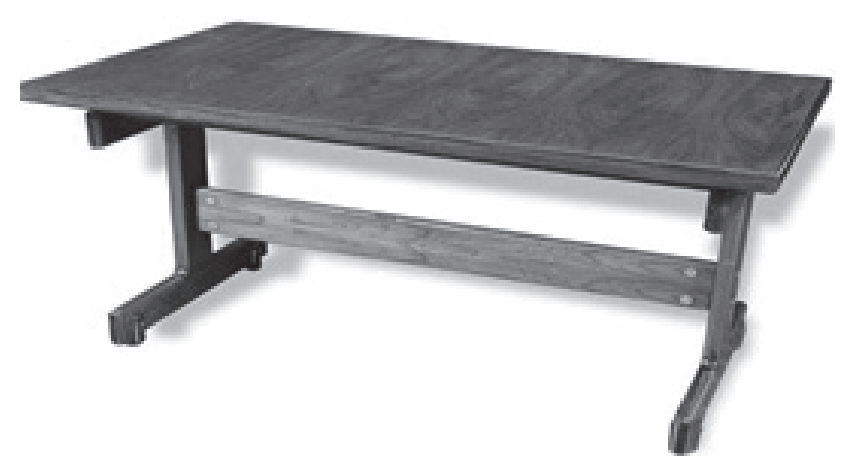

Mesa Redig 


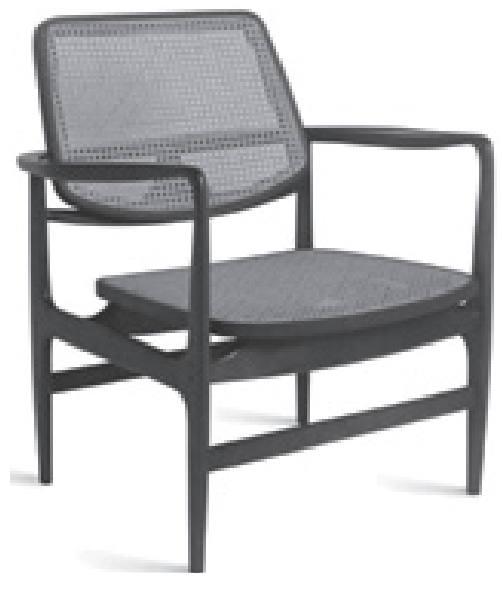

Poltrona Oscar

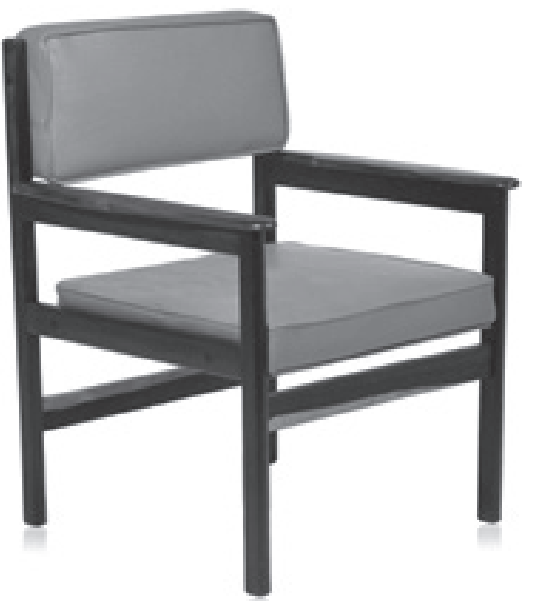

Poltrona Tião

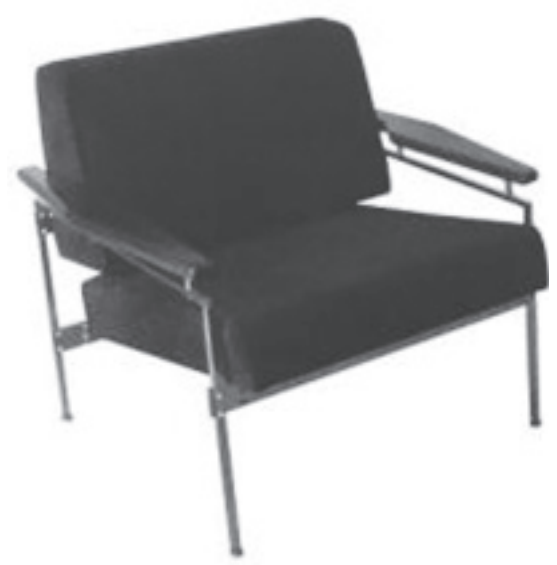

Poltrona Beto

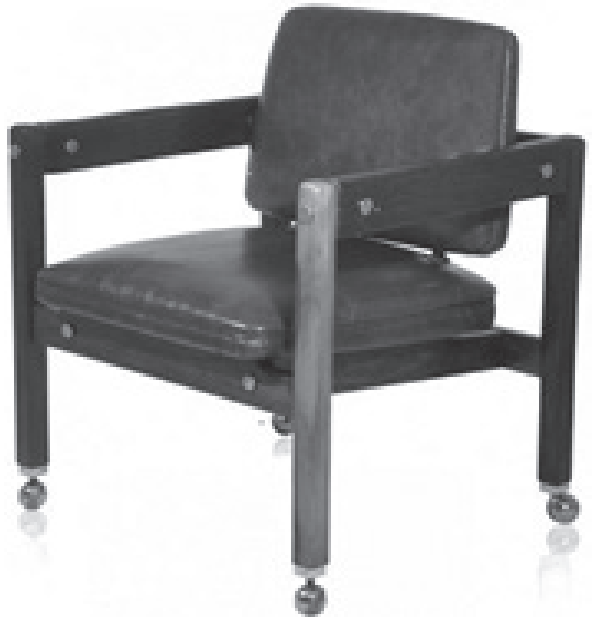

Poltrona Kiko

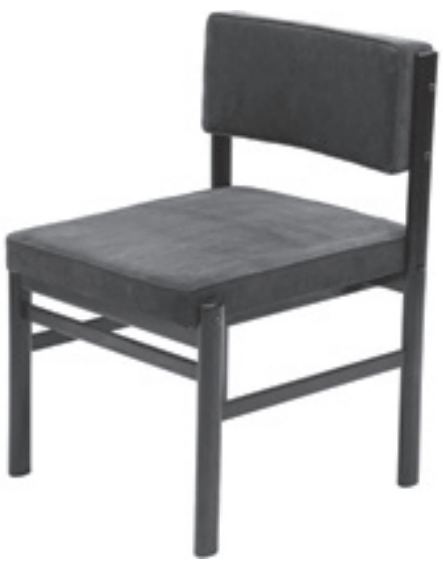

Cadeira Tião

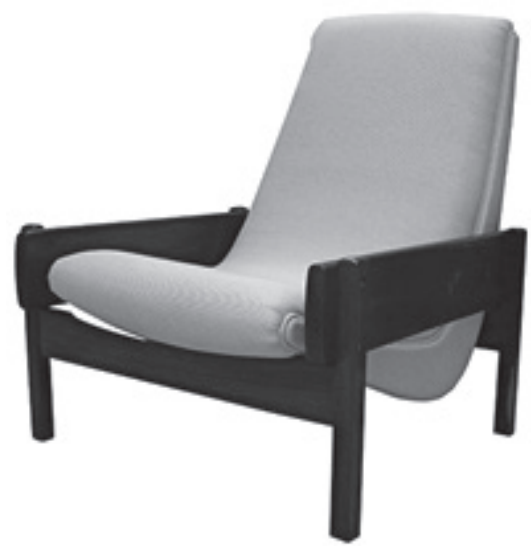

Poltrona Vronka 


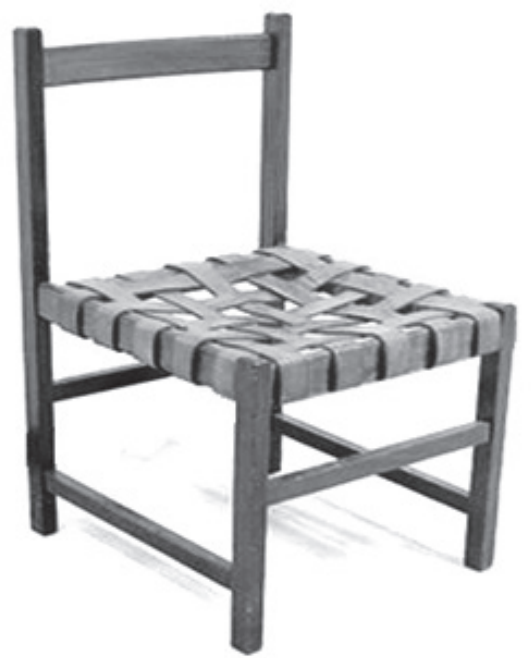

Figura 40.

Cadeira com

assento de couro

trançado

Cadeira com assento de couro trançado

Muitas peças do mobiliário da UnB foram desenhadas no Ceplan, entre as quais a cadeira com assento de couro inteiriço e costura para fora, e a de couro trançado, de autoria do arquiteto carioca Elvin Mackay Dubugras. Sobre essas cadeiras, assim se manifestou Luis Humberto:

[...] o Elvin se dedicava ao desenho de dos móveis da UnB. O Elvin desenhava uma cadeira, então tinha os vários biotipos, o Klaus que era gordo, o Leo, que era pequeno e gordinho, eu que era grande, a gente ia sentando para ele fazer os ajustes das cadeiras, e ele ficava medindo (Entrevista em 26 jan. 2012).

Deixando o mobiliário e voltando para a arquitetura, em dezembro de 1961 a construtora carioca Martins Almeida S. A. (Comasa) deu início às obras da FE1, um dos blocos pertencentes ao conjunto destinado à Faculdade de Educação, cujo projeto foi doado à UnB pelo arquiteto carioca Alcides da Rocha Miranda. O desenvolvimento dos projetos contou com a colaboração de Luís Humberto Miranda Martins Pereira, à época arquiteto da Divisão de Obras do Ministério da Educação e Cultura (MEC), e posteriormente passaram a colaborar com a equipe o arquiteto português José Manuel Kluft Lopes da Silva, o designer Alex Ivan Peirano Chacon, professor auxiliar do Instituto Central de Artes da UnB, e o desenhista português Manuel Curto Lopes da Silva. Responsável também pelo mural de azulejos que integra o FE1, o arquiteto Luís Humberto recordou:

Aí o Alcides ficou pensando no azulejo... Athos não estava aqui, e eu desenhei o azulejo. Originalmente era amarelo e branco, mas ficava muito apagado, o velho disse assim, 'tenta em azul'. Aquele azulejo é meu, e todo mundo pensa que é do Athos. Eu fico honrado... (Entrevista em 26 jan. 2012).

Em seguida vieram as obras do FE5, com suas salas de aula, seus espaços multiuso, e ainda um auditório para 250 pessoas; e as do FE3, onde deveria funcionar a administração da faculdade ${ }^{16}$. Na construção do FE5, morreram soterrados dois operários paraibanos - Expedito Xavier e Gedelmar Marques, em cuja homenagem foi dado ao edifício o nome Dois Candangos. 
Assim que os edifícios da Faculdade de Educação foram concluídos, os barracões de obra foram imediatamente ocupados pelas sedes da Federação dos Estudantes da Universidade de Brasília (Feub), da Associação Atlética da UnB, da Federação dos Estudantes Secundaristas, por alguns diretórios acadêmicos e por uma agência dos Correios.

Trocando mais tarde a prancheta pela câmera, Luís Humberto fez um dos mais belos e inusitados retratos de Brasília e de seu cotidiano, em uma época em que ser fotógrafo não era muito bem visto pela sociedade, como ele mesmo observou:

Quando fiz a opção pela fotografia, nos anos 60, foi uma atitude muito mal aceita. Como se a profissão estivesse num nível inferior às outras. Afinal, eu deixava de ser arquiteto, ou 'doutor' para ser fotógrafo. Tinha dificuldade em fazer com que as pessoas aceitassem. Teve gente que me virou a cara, outros que achavam que eu estava passando necessidades. Ninguém entendeu que a minha opção foi absolutamente passional (PEREIRA, 2008, p. 220).

Ainda segundo Luis Humberto, "[...] para cá ele (o Dr. Alcides) trouxe Glênio Bianchetti, Hugo Mund Júnior, Alfredo Ceschiatti, Athos Bulcão, Amélia Toledo e Marília Rodrigues, e com essas pessoas nós formamos um grupo" (Entrevista em 26 jan. 2012).

Logo depois vieram também integrar o corpo docente da UnB os arquitetos Edgar Albuquerque Graeff e Elvin Donald Mackay Dubugras; o designer gráfico Claus Peter Bergner; os artistas plásticos Léo Barcellos Dexheimer, Maria José Costa Sousa, a Zezé; e, a convite de Darcy Ribeiro, o professor de maquete José Zanine Caldas.

Sobre Zanine, Luis Humberto comentou:

[...] ele estava fazendo o mestrado, ele não tinha graduação, na UnB tinha várias pessoas que não tinham graduação, como nas universidades de fora, aproveitava-se quem era um talento comprovado. O Zanine provou isso, encheu a Barra da Tijuca de belas casas. Então, o seu trabalho de mestrado era um trabalho concreto de valorização do cerrado, a proposta era limpar, tirar o que não interessava e deixava as espécies mais interessantes, (ele era meio multimídia, fazia tudo, pois era um cara muito inteligente). O Dr. Alcides o conhecia desde o tempo em que ele fazia maquetes no Rio. Algumas pessoas tentavam desmerecê-lo chamando o de maqueteiro (Entrevista em 26 jan. 2012). 


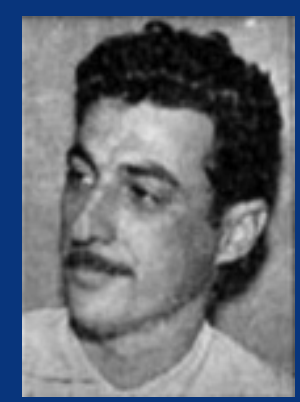

Glênio Bianchetti (1928-2014) iniciou seus estudos artísticos, em 1946, com o pintor e escultor José Moraes. Frequentou o Instituto de Belas Artes de Porto Alegre (hoje Instituto de Artes da UFRGS), onde foi aluno de Iberê Camargo. Integrou o corpo docente do Curso de Arquitetura da UnB e foi o primeiro responsável pelo ateliê de artes plásticas e do setor gráfico da universidade. Após 1964, foi preso e afastado da UnB, à qual seria reintegrado somente em 1988. Mesmo sem vínculo com a universidade, decidiu se radicar em Brasília, dedicando-se sobretudo à pintura e à tapeçaria.

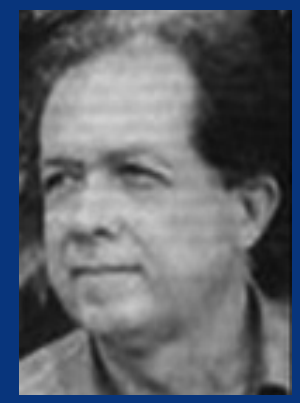

Hugo Mundo Júnior cursou a Escola Nacional de Belas Artes. Filho de pais italianos, foi à Itália em 1957, beneficiado por iniciativa do governo italiano de promover viagens de filhos de imigrantes ao país. De volta ao país, fixou-se na cidade do Rio de Janeiro onde estudou na Escola Nacional de Belas Artes. Conheceu Oscar Niemeyer, que Ihe encomendou uma escultura para o Conjunto da Pampulha, em Belo Horizonte. Em 1960 esculpiu As três forças armadas, um dos temas no Monumento aos Mortos da Segunda Guerra, no Rio de Janeiro. Lecionou no Instituto Central de Arte da UnB de 1962 a 1965.

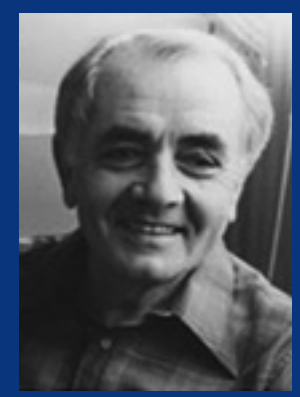

Athos Bulcão (1918-2008) desistiu do curso de medicina em 1939 para se dedicar às artes visuais. Trabalhou como assistente de Cândido Portinari no painel de São Francisco de Assis da Igreja da Pampulha, em Belo Horizonte. Em seguida mudou-se para Paris, onde viveu até 1949. Colaborou com Oscar Niemeyer em 1955 e integrou o esforço de construção de Brasília, para onde se mudou em 1958. Nos anos 1960, fez vários trabaIhos artísticos para os edifícios projetados por João Filgueiras Lima.

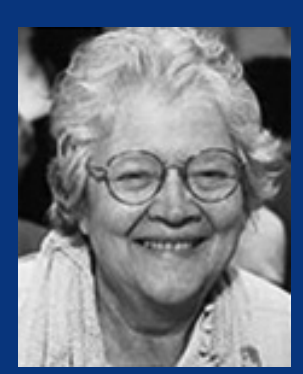

Amélia Toledo (1926) trabalhou, na década de 1940, com desenho de projetos no escritório de Vilanova Artigas. Estudou pintura com Waldemar Costa e Yoshiya Takaoka e gravura em metal com João Luís Chaves. Cursou a London Country Council Central School of Arts and Crafts. Foi professora na UnB entre 1962 e 1965, na FAAP e na Universidade Mackenzie, em São Paulo, na Escola Superior de Desenho Industrial, no Rio de Janeiro, e na Sociedade Nacional de Belas Artes, em Lisboa.

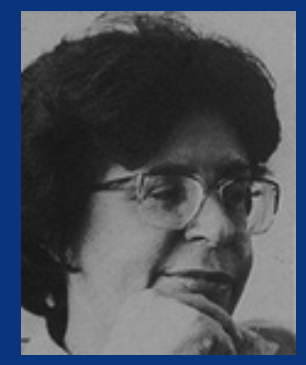

Marília Rodrigues (1937-2009) estudou desenho com Haroldo Mattos na Escola de Belas Artes, em Belo Horizonte, na qual, mais tarde, trabalhou com xilogravura. Conseguiu bolsa para estudar gravura em metal no Ateliê de Gravura do Museu de Arte Moderna do Rio de Janeiro, com Edith Behring, Anna Letycia e Rossini Perez. Estudou também com Oswaldo Goeldi, na Escola Nacional de Belas Artes. Em 1963, lecionou gravura em metal na Escolinha de Arte do Brasil, no Rio de Janeiro e na UnB. Deu aulas na Escola Guignard,em Belo Horizonte, e na Oficina de Gravura Sesc Tijuca, no Rio de Janeiro. 
Figura $41 \mathrm{~b}$. Professores do ICA-FAU

Edgar Albuquerque Graeff (1921-1990), arquiteto formado na Universidade do Brasil, Rio de Janeiro, com pós-graduação em Urbanismo pela Universidade Federal do Rio Grande do Sul, de onde foi professor catedrático. Fundador do Curso de Arquitetura e Urbanismo da UnB, onde lecionou entre 1962 e 1964. Professor da Pontifícia Universidade Católica de Goiás. Em 1980 assumiu o cargo de Assessor da Coordenação de Ciências Humanas e Sociais da Secretaria de Ensino Superior do Ministério da Educação.

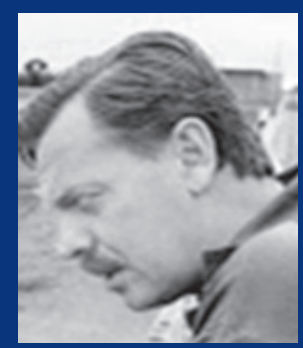

Elvin Donald Mackay Dubugras ( - 2000) fez carreira em Brasília, onde desenvolveu diversos projetos. Foi um dos fundadores do Curso de Arquitetura e Urbanismo da UnB, onde trabalhou como professor entre 1962 e 1965. Com a anistia, voltou a dar aula de Projeto de Arquitetura até se aposentar em 1993.

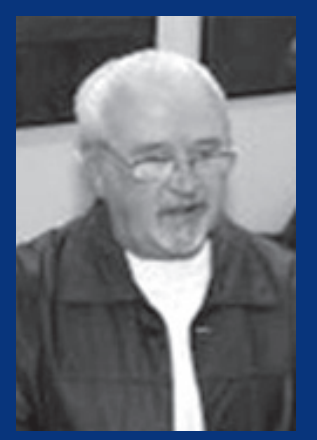

Léo Barcellos Dexheimer (1935) fez cursos de litografia com Marcelo Grassmann e gravura em metal com Iberê Camargo, em Porto Alegre. Em 1960, concluiu o curso de pintura na Escola de Belas Artes da Universidade Federal do Rio Grande do Sul. Com colegas da Escola de Belas Artes, fundou o grupo Bode Preto, que se opõe à rigidez acadêmica da instituição. Trabalhou em diagramação em jornais de Porto Alegre, lecionou pintura, desenho e gravura nas Escolas de Arte de Novo Hamburgo e de Cachoeira do Sul. Entre 1963 e 1965, lecionou desenho e artes gráficas na UnB. De 1988 a 1991, retornou para a UnB.

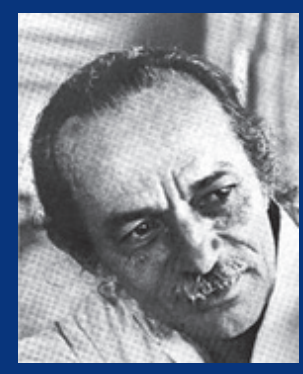

José Zanine Caldas (1919-2001) integrou o corpo docente da UnB como professor de maquete. Em 1965 perdeu o cargo, tendo sido reintegrado apenas em 1987, sem voltar a dar aulas. No final dos anos 60 estabeleceu-se no Rio de Janeiro, onde construiu dezenas de casas no bairro de Joatinga. Na década de 1980, fundou o Centro de Desenvolvimento das Aplicações da Madeira (DAM), no Rio de Janeiro. Seu trabalho foi exposto no Museu do Louvre, em Paris, o que lhe trouxe o reconhecimento internacional. No mesmo período, deu aulas na escola de arquitetura de Grenoble.

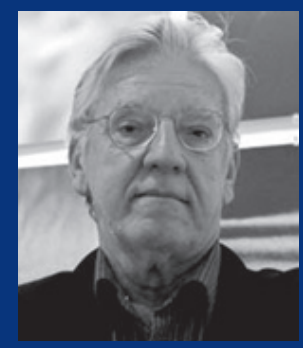

Luiz Humberto Miranda Martins Pereira nasceu no Rio de janeiro, em 1934. Veio para Brasília para trabalhar no MEC, mas, a convite do arquiteto Alcides da Rocha Miranda, passou a colaborar na implantação do curso tronco de Arquitetura e Urbanismo, onde lecionou desenho e plástica. Depois da demissão coletiva, Luis Humberto resolveu permanecer na cidade onde o trabalho em uma revista semanal abriu caminho para que o então arquiteto virasse um renomado fotógrafo. 
Com a criação do Ceplan, em maio de 1962, Niemeyer, na qualidade de coordenador, passou a permanecer mais tempo em Brasília do que no Rio de Janeiro, embora estivesse, na época, comprometido também com projetos no exterior, entre os quais a Feira Internacional Permanente Rashid Karami, em Trípoli; a Sede do Partido Comunista Francês, em Paris; a casa Strick, na Califórnia, e a Universidade de Haifa.
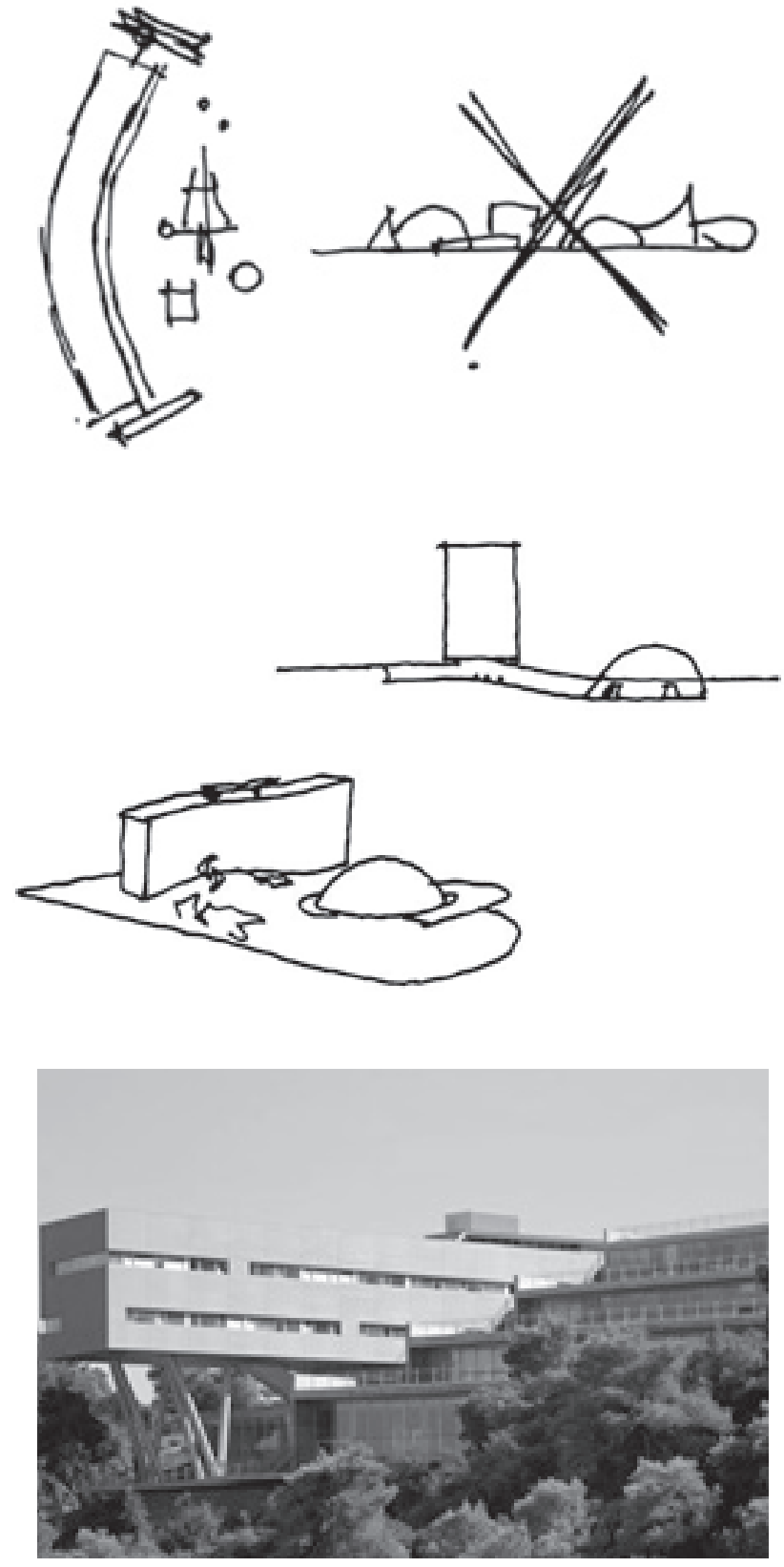
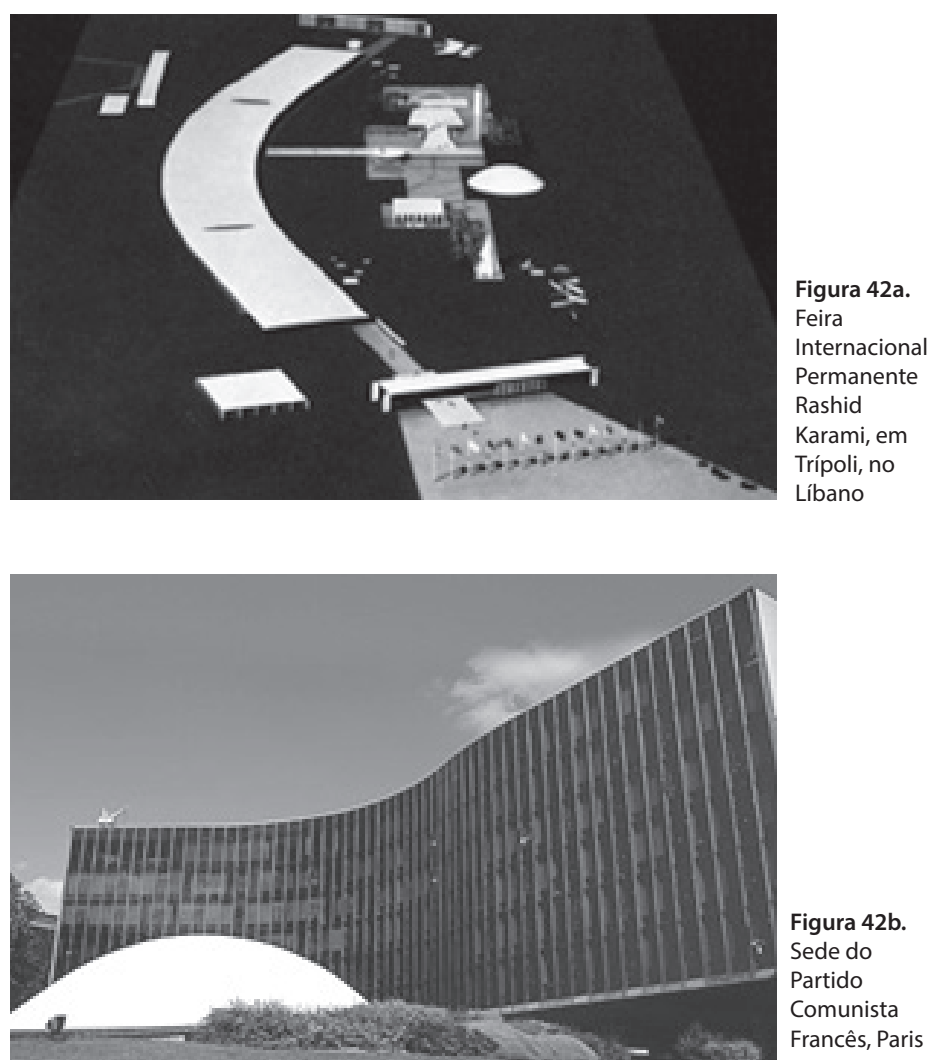

Figura 42b.

Sede do

Partido

Comunista

Francês, Paris

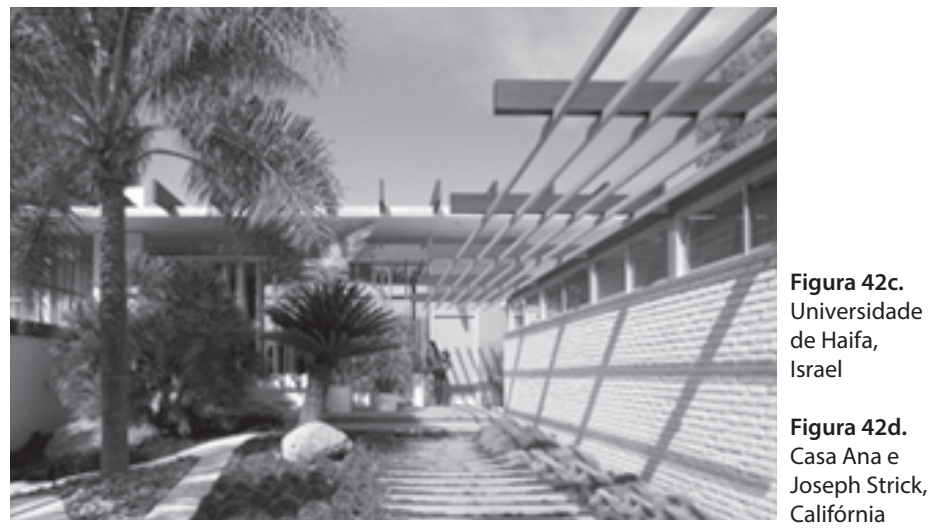



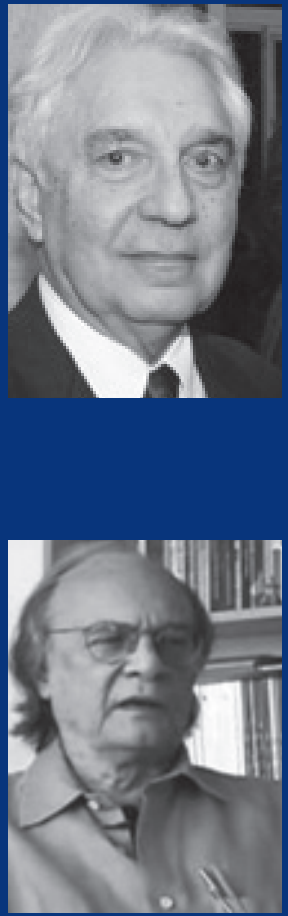

Ítalo Campofiorito (1933), arquiteto formado na Universidade do Brasil, Rio de Janeiro. Realizou estudos de Estética, História da Arte e Sociologia da Arte na Sorbonne, entre 1957 e 1958. Trabalhou como arquiteto do DUA entre 1958 e 1961. Foi professor da FAU-UnB entre 1962 e 1965. Em 1978, assumiu o cargo de Diretor do Patrimônio Histórico e Artístico do Inepac/RJ. Participou do International Council on Monuments and Sites (Icomos) e do Instituto do Patrimônio Histórico e Artístico Nacional (Iphan), onde assinou o tombamento de Brasília. É professor titular aposentado da UnB e foi diretor executivo do Museu de Arte Contemporânea (MAC) de Niterói entre 1996 e 2004.

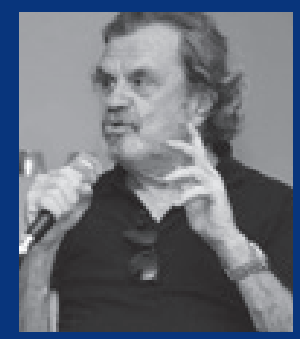

Jayme Zettel - Trabalhou como desenhista no escritório MMM Roberto, tendo ajudado a desenhar o projeto dos três irmãos para o concurso do Plano Piloto. Foi trabalhar no escritório de Lucio Costa para desenvolver o desenho da nova capital do Brasil. Em 1959, foi fazer um estágio de seis meses no London British Council (Inglaterra). Foi presidente do Instituto de Patrimônio Histórico e Artístico Nacional (Iphan) entre 1992 e1993. No cargo, assinou a Portaria n. 314/92, que regulamentou o tombamento de Brasília.

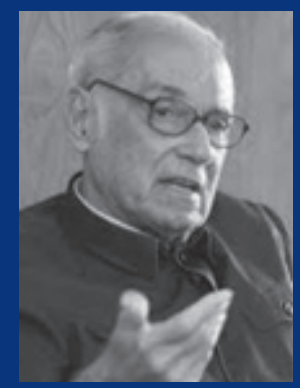

João da Gama Filgueiras Lima (1932-2014) formou-se arquiteto pela Universidade do Brasil e, sob influência de Oscar Niemeyer e Nauro Esteves, mudou-se para Brasília em 1957, ano em que foi iniciada a implantação do Plano Piloto. Construiu, projetou e colaborou com Oscar Niemeyer na construção da cidade. Trabalhou na UnB de 1962 a 1965, quando pediu demissão. A necessidade de racionalização na construção de Brasília despertou em Lelé o interesse na tecnologia de racionalização do uso do concreto armado, da argamassa armada e do aço.

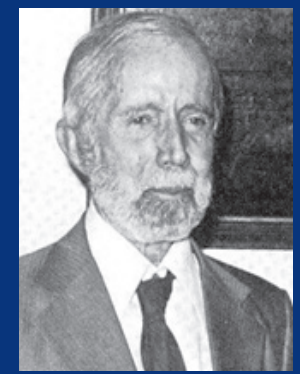

Alcides Rocha Miranda (1934-1997). Nasceu no Rio de Janeiro Foi professor da Faculdade Arquitetura da USP, idealizador e professor do Instituto Central de Artes da UnB e funcionário do Iphan por 40 anos. Sua atividade autônoma como arquiteto e artista plástico resultou em 58 projetos, construídos e não construídos, sendo muitos deles intervenções em sítios ou em edificações de interesse histórico e cultural. 
Durante essas ausências, a equipe formada pelos arquitetos Evandro Pinto Silva, Glauco de Oliveira Campello, Hilton Gerson Costa, Ítalo Campofiorito, Jayme Zettel, João da Gama Filgueiras Lima (Lelé) e Virgílio Ernesto Sosa e pelo o desenhista Abel Carnaúba Accioly encarregava-se de dar continuidade aos trabalhos do Ceplan ${ }^{17}$. Conforme explicou Lelé,

[...] na véspera do Oscar ir embora ele delineou aquele projetinho, o espaço do Ceplan. Ele viajou e disse: seja o que Deus quiser. Nesse ínterim o Darcy pressionou e o Oscar, que já tinha estudado aquela questão, disse 'vamos fazer em pré-moldado'. As primeiras peças do Ceplan foram desenhadas, ele viajou e o Darcy, na mesma hora, disse:'nós temos que fazer não é só o Ceplan, temos que fazer o prédio para a Música, o ICA e mais um auditório'. E aí surgiu aquele conjunto [...] quando o Oscar viajou só tinha designado para o Ceplan eu, como secretário executivo; o Glauco Campelo; o Abel Carnaúba; o Ítalo (Campofiorito); o Virgilio Ernesto Souza, um arquiteto panamenho que já estava atuando conosco no DUA; e o Jaime Zettel, ligado ao Dr. Lucio Costa, que faria a parte de urbanismo. Então, houve um deslocamento do DUA, do Bloco 1 do Ministério da Educação, mas nós só fomos para a Universidade quando o Oscar voltou (Entrevista em 29 fev. 2012)

Colaboraram também com os trabalhos do Ceplan, à época, os instrutores Armando de Holanda, Cydno Ribeiro da Silveira, Fernando Burmeister, Geraldo Sá Nogueira Batista, Geraldo Santana, Luiz Henrique Gomes Pessina, Luiz Marçal Neto, Márcia Nogueira Batista, Mayumi Watanabe Souza Lima, Sérgio Souza Lima e William Ramos Abdala ${ }^{18}$. Conforme informações prestadas por Pessina e confirmadas por Zettel (Entrevistas em 9 dez. 2014), os arquitetos Sabino Machado Barroso ${ }^{19} \mathrm{e}$ Carlos Bittencourt, vinculados diretamente ao Departamento de Urbanismo e Arquitetura (DUA) da Novacap, deram contribuições esporádicas à Universidade de Brasília, devendo-se ao primeiro o projeto do antigo Centro Integrado de Ensino Médio (Ciem), edifício que hoje integra o Hospital Universitário de Brasília (HUB).

Como a pesquisa fazia parte do fundamento da instituição, havia uma categoria do corpo discente, a dos instrutores, que era integrada por estudantes de pós-graduação, conforme explicou o professor e ex-reitor da UnB João Cláudio Todorov, instrutor da psicologia à época:

Éramos instrutores, ao mesmo tempo alunos de pós-graduação e professores, e exercíamos a docência sob a direção dos pesquisadores mais qualificados. Muitos deles eram nossos orientadores de tese. Estipulou-se que ao final de dois anos, o instrutor deveria apresentar sua tese e, com título de Mestre, poderia candidatar-se ao concurso de ingresso na carreira docente, como assistente (1991, p. 57).

\footnotetext{
${ }^{17}$ Evandro Pinto Silva (1937) e Hilton Gerson Costa (1932) vieram da Bahia; Glauco de Oliveira Campello e Abel Carnaúba Accioly, de Pernambuco; Ítalo Campofiorito, Jayme Zettel e João Filgueiras Lima (Lelé), do Rio de Janeiro; e Virgilio Ernesto Souza, do Panamá. Posteriormente Glauco Campello, Jayme Zettel e Ítalo Campofiorito estiveram vinculados ao Instituto do Patrimônio Histórico e Artístico Nacional (Iphan) e João Filgueiras Lima continuou atuando no campo da pré-fabricação, tendo feito inúmeros projetos com o emprego da argamassa armada e do aço.

${ }^{18}$ Fernando Burmeister - Arquiteto formado na Universidade Federal do Rio Grande do Sul, cursou Mestrado na UnB em 1963. Foi professor desta instituição de 1962 a 1965, tendo ficado em Brasília até 1972, quando embarcou para a Argélia na equipe de Oscar Niemeyer. De volta em em 1977, trabalhou na empresa Estudos Técnicos e Projetos S.A. Com a anistia, voltou a ser professor da UnB até se aposentar. Cydno Ribeiro da Silveira, Luiz Henrique Gomes Pessina e Luiz Marçal vieram do Rio de Janeiro; Mayumi Watanabe Souza Lima (1934-1994) e Sérgio Souza Lima, de São Paulo; Fernando Burmeister (1937-1989), do Rio Grande do Sul, e William Abdala, de Minas Gerais.

${ }^{19}$ Sabino Machado Barroso - Como funcionário da Novacap projetou, em 1961, os primeiros pontos de ônibus construídos em Brasília. Foi chefe do Departamento de Urbanismo e Arquitetura até 1965, quando passou a ser vinculado ao Iphan, onde permaneceu até 1968 . Em 1980 reingressou no Iphan para trabalhar na 6a Coordenação Regional, tendo sido seu coordenador até 1993, quando passou a diretor do Departamento de Proteção. Em 1999, por discordar do presidente do Iphan, Francisco Weffort, pediu demissão do cargo.
} 
Figura 44. Instrutores da FAU

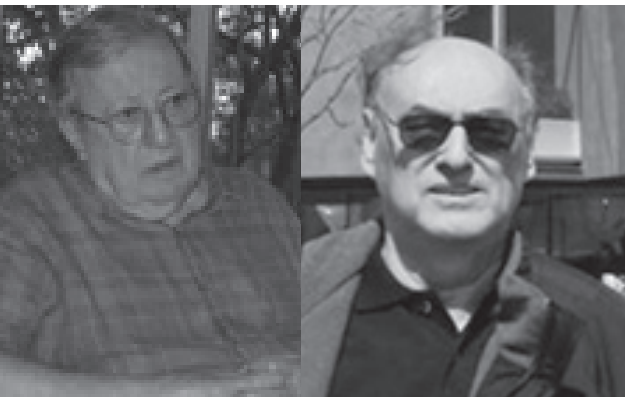

Luís Henrique Pessina

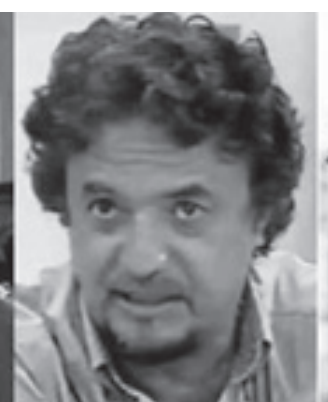

Cydno Silveira

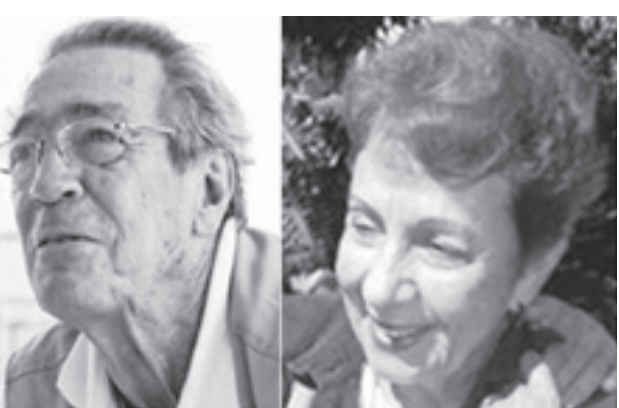

Márcia Nogueira Batista

No caso específico da Faculdade de Arquitetura, esses instrutores, além das atividades de ensino e pesquisa, desenvolviam atividades de projeto no Ceplan.

Niemeyer passou também a dirigir a Faculdade de Arquitetura e Urbanismo (FAU), juntamente com o professor Edgar Albuquerque Graeff, a cuja interferência deve-se a vinda para a UnB dos arquitetos gaúchos Fernando Lopes Burmeister e Oscar Borges Kneipp.

[...] nesse período já havia o Instituto Central de Artes, e até o curso de Arquitetura já estava se iniciando, com o Alcides da Rocha Miranda, o Luis Humberto e o (José Eduardo Maia de) Mendonça, arquitetos do grupo do Alcides que já tinham iniciado aqueles prédios do FE 1. Então, convencionou-se que o curso de formação, o curso básico, continuava sendo ministrado pela equipe do Alcides, e nós montaríamos então o curso de formação de arquitetura já no Ceplan. Usando o Ceplan como um espaço de convívio também, para a formação profissional e para a pós- graduação [...] à qual foram integrados o (Luís Henrique) Pessina, o Fernando Burmeister, a Márcia (Aguiar Nogueira Batista), a Mayume Watanabe e o Sérgio Souza Lima. (LELÉ, entrevista em 23 fev. 2012)

Além de planejar as edificações do campus e contribuir para o desenvolvimento da Faculdade de Arquitetura, o grupo, integrado por professores e pós-graduandos, deveria intervir em todas as questões, construtivas ou acadêmicas relacionadas à arquitetura da UnB.

[...] a graduação era assistida pela pós-graduação, tendo no Ceplan uma estrutura peculiar de apoio que, além de responder pelos projetos do campus, viabilizava na prática a ação dos pósgraduandos. Estamos novamente em face do ensino e sua aplicação; isto é, em face do viés bauhauseano: o corpo teórico que se preocupa com as leis da forma, o conhecimento da natureza e domínio dos materiais, das técnicas e dos processos produtivos, todos voltados para sua utilização conforme os preceitos éticos do comprometimento social comum. (CASTELO, 2010)

Se a existência dos dois grupos - do Alcides e do Oscar - suscitava algumas intrigas, servia também de mote para algumas paródias. Lelé lembrou-se de uma que fez para o Athos Bulcão, o Monsenhor, a qual fazia menção ao Lombrigão, nome dado por Darcy ao prédio do ICA, em alusão ao Minhocão (ICC):

Professor Monsenhor chegou,

Professor Monsenhor chegou,

Ele agora é o dono do Lombrigão.

Mas deixa só, deixa só, o Oscar chegar,

Para mostrar que ele não é de lá.

(Entrevista em 23 fev. 2012) 

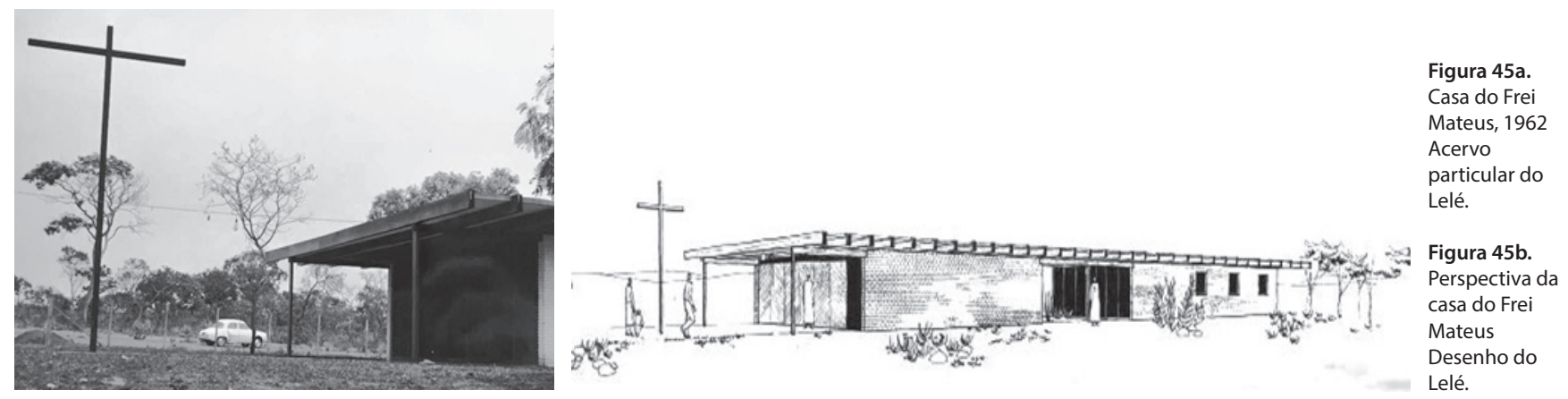

A fase de pré-fabricados de madeira foi encerrada na UnB com o projeto e construção da casa do Frei Mateus, que mais tarde seria totalmente destruída por um incêndio. O projeto, de autoria do Lelé, previa um sistema misto em que parte das vedações eram de alvenaria aparente.

Permaneceu, porém, a função destinada ao Ceplan desde o início de sua concepção, ou seja, o desenvolvimento da pré-fabricação, conforme explicou por Lelé sobre o convite que recebeu de Darcy Ribeiro:"Ele me estimulou a criar lá (na UnB) um grande centro de construção industrializada, um centro de tecnologia que seria usado pela universidade, e logo se tornou um entusiasta da ideia" (LIMA, 2004, p. 51).

Perguntado, em 1989, por que o momento da construção de Brasília - com suas superquadras e seus edifícios modulados, seus "pré-moldados" urbanos - não fora aproveitado para o desenvolvimento de um sistema de pré-fabricação em série, o professor Graeff respondeu de imediato que no Brasil não havia tecnologia para tal; e que muito dos elementos pré-fabricados usados na construção da cidade - como as estruturas de aço usadas nos ministérios - haviam sido importados. Assim, cabia ao Ceplan suprir essa lacuna tecnológica ${ }^{20}$.

Sobre esse assunto, o engenheiro e professor Ernesto Walter, ex-chefe do Departamento de Arquitetura da FAU-UnB, deu em 1985 um depoimento interessante: as empresas norte-americanas responsáveis pela produção das referidas estruturas de aço, ao invés de disporem as peças de forma ordenada, espalharam-nas, sem qualquer critério, sobre o grande canteiro central da Esplanada. Foi preciso, então, contratar uns motoqueiros, que na época usavam a Lambreta, para percorrer a imensa área identificando as peças de cada um dos edifícios ministeriais a serem montadas. Segundo o professor, teria havido uma espécie de sabotagem com o objetivo de atrasar as obras e, portanto, comprometer o governo JK.

A opção do Ceplan pela pesquisa de novos materiais deveu-se ao fato de a madeira ser considerada cara e pouco resistente às intempéries, o que fazia com que seu uso ficasse restrito às construções provisórias. Cabe lembrar que, na época, não havia as técnicas contemporâneas de proteção, imunização, prensagem e colagem das madeiras. Ao mesmo tempo, o concreto armado - "a pedra dos tempos modernos", como dizia a professora Christina Jucá ${ }^{21}$ - despontava como uma solução promissora para a industrialização, responsável, portanto, pelo atendimento das grandes demandas sociais no campo da construção, a médio e longo prazo.

Essa missão fundadora do Ceplan teve como origem, por um lado, a preocupação com a construção de grandes conjuntos residenciais para os trabalhadores, desde os primeiros anos da revolução bolchevique; por outro, os grandes planos de reconstrução das cidades europeias atingidas pela

\footnotetext{
${ }^{20}$ Essa entrevista ocorreu no apartamento do professor Edgar Albuquerque Graeff, na SQS 305. Infelizmente a fita K7, gravada na época, não resistiu ao tempo.

${ }^{21}$ Chistina Bezerra de Mello Jucá foi professora da FAU-UnB, da década de 1980 até se aposentar em 2008.
} 
Segunda Guerra. Na experiência soviética, principalmente na construção de edifícios institucionais, optou-se, de início, pela produção de grandes painéis de concreto armado, a serem montados in loco. Esse sistema demonstrou-se insatisfatório, em razão do "baixo nível de organização da maioria dos grupos de produção e montagem, além da dispersão dos meios existentes numa grande quantidade de programas" (BRUNA, 1976, p. 51). Em 1954, passou-se à fase de construção em massa de habitações, a partir de projetos-padrão produzidos integralmente em usinas.

No restante da Europa, duas estratégias diferentes foram adotadas: na Inglaterra, a opção foi por uma industrialização de ciclo aberto, ou seja, voltada para a "produção de componentes destinados à construção, aproveitando uma capacidade ociosa já instalada (em ramos industriais como o aeronáutico e o automobilístico) e altamente qualificada" (BRUNA, 1976, p. 50); na França, devido à carência de materiais e mão de obra devidamente habilitada, inicialmente foram utilizados "elementos pré-fabricados de dimensões médias [...] montados numa estrutura portante convencional"; no entanto, ao longo do tempo, houve o aumento do tamanho gradativo e a consequente redução do número de jutas, até se chegar ao abandono da estrutura portante e à adoção de grandes painéis de concreto com função estrutural, produzidos em usinas fixas ou em usinas móveis próximas aos canteiros.

No pós-guerra, generalizou-se na Europa a construção industrializada de ciclo fechado, que ocorre quando "[...] uma mesma empresa, ou grupos de empresas coligadas, executa inteiramente, com seus próprios meios e em suas usinas, o produto final, ou seja, o edifício completo" (BRUNA, 1976, p. 52).

Em meados da década de 1950, já era possível produzir habitações em vários pontos da Europa Inglaterra, Suécia, Dinamarca e nos países socialistas -, e nos Estados Unidos, a partir de sistemas totalmente industrializados, com soluções próprias e originais em cada caso, considerando as diferenças sociais, econômicas, técnicas e políticas nacionais. Na União Soviética, para a produção em massa de edificações foi utilizada a pré-fabricação pesada de células modulares completas; na Escandinávia, foi escolhido o sistema alveolar. Nos Estados Unidos deu-se ênfase à produção de componentes industrializados e novos materiais e à racionalização da construção de estruturas.

Além da questão tecnológica, o que caracterizava a produção arquitetônica soviética da época era, antes de tudo, sua importância para a construção de uma sociedade socialista. Como afirmou Kopp (1990, p. 74),

[...] é a correlação entre projeto arquitetônico e projeto social o principal interesse das pesquisas dessa época; é essa correlação que fez dessa arquitetura uma causa social e política e, ao mesmo tempo, um movimento de vanguarda [...] Em certo momento na URSS, acreditou-se que as coisas seriam diferentes, pois o partido no poder e o governo afirmavam o desejo de construir essa sociedade nova no país todo. Foi também nessa escola que foram concebidas as pesquisas arquitetônicas e urbanísticas dos que se proclamavam "Construtivistas", e para os quais o produto dessas pesquisas deveria contribuir para a edificação dessa nova sociedade, da qual a URSS seria o canteiro de obras e o campo de experiências.

O paralelo entre essas condições e o que ocorreu nos primórdios de em Brasília parece real. Por um lado, o feito da construção de uma nova capital, com uma concepção inovadora e progressista, dava a seus protagonistas a confiança para o enfrentamento de novos desafios. Por outro, muito embora o Brasil não fosse um país socialista, não é desconhecido o fato de que muitos dos fundadores da Universidade de Brasília eram militantes de esquerda ou pelo menos simpatizantes das ideias socializantes. 
Se havia sido possível erigir, em tempo recorde, uma cidade pautada por um plano que trazia em seu bojo explícitas determinações socializantes, por que não enveredar pelo campo das pesquisas de sistemas construtivos, capazes de transformar a realidade social do país? Era, então, real a possibilidade de o Ceplan, reunindo importantes nomes do urbanismo e da arquitetura da época, se tornar um centro de pesquisas avançadas para a produção de equipamentos públicos para atender às demandas sociais por habitação, educação, saúde, lazer etc.

Embora o audacioso empreendimento socialista não tenha obtido êxito na construção efetiva de uma sociedade fraternal, igualitária e libertadora, restavam lições a serem aprendidas, sobretudo no campo das realizações referentes à construção industrializada que, voltada para a produção em massa, era agenciada pelo Estado. Mesmo os erros técnicos cometidos nos países socialistas serviam como parâmetros para conduzir a pesquisa brasileira que se intentava.

Como alguns países do Leste Europeu haviam avançado nessa matéria e mantinham negócios com o Brasil, Lelé e Sabino Barroso foram para lá enviados com o objetivo de realizar pesquisas sobre a pré-fabricação em curso e sua possível adaptação para o Brasil. Sobre esse apoio institucional para o desenvolvimento da pré-fabricação, assim se manifestou Lelé:

\footnotetext{
O Darcy era muito esperto: o Brasil tinha fornecido à Polônia uma quantidade enorme de café, ele descobriu isso e queria readquirir o valor em matéria-prima e equipamentos do Leste Europeu. Fomos principalmente, à Tchecoslováquia, onde tinha um sistema de pré-fabricação com guindastes, e tudo já bem desenvolvido. A intenção era montar aqui, e chegamos a projetar, a nossa fábrica. Qual era a ideia? Era um espaço de convívio, que seria dirigido pelo Ceplan e pela Faculdade de Engenharia, até para desfazer essas diferenças entre engenheiro e arquiteto (Entrevista em 23 fev. 2012).
}

Com o retorno desses arquitetos três meses depois, o Ceplan passou a desenvolver edifícios em pré-moldados de concreto, sistema construtivo que, devidamente registrado em um documentário didático realizado pelo fotógrafo e cineasta Heinz Forthmann ${ }^{22}$ - Universidade de Brasília: primeira experiência em pré-moldado (1962-1970) -, transformou o Centro em referência nacional. Como afirmou Castelo em entrevista em 2010, “O Ceplan foi responsável à época pelo maior canteiro de pré-moldagem da América Latina. Era, portanto, um campo de experimentação exitosa que objetivava a pré-fabricação da construção no país" (in SCHLEE, 2014, p. 24).

Na verdade, a Universidade de Brasília passou a assumir a dianteira de um pesado investimento em pré-fabricação em concreto armado, capaz de viabilizar a produção de edificações dentro e fora do campus. Como observou Nobre, "Esse objetivo era compartilhado pela direção da Universidade, que o entendia como uma solução de esquerda para os problemas de construção do país" (2008, p. 164).

Segundo o arquiteto e professor Luís Henrique Gomes Pessina, "[...] chegou-se à conclusão que era mais barato fazer o Ceplan em concreto armado, com uma construção que seria definitiva, embora com um uso que poderia ser provisório [...] Começou aí a história dos pré-fabricados da UnB" (Entrevista em 1 dez. 2011).

\footnotetext{
22 O fotógrafo e cineasta Heinz Forthmann (1915-1978) trabalhou para o Serviço de Proteção ao Índio (SPI), onde atuou com o indigenista Cândido Mariano Rondon da Silva. Ao lado de Darcy Ribeiro e dos irmãos Orlando e Cláudio Villas-Boas, realizou vasta documentação etnográfica que resultou em importantes documentários, entre os quais Os Índios Urbus, 1950; Funeral Bororo, 1953; Txukahamãe, 1955; e Jawari, 1957. Foi professor de fotografia e cinema na UnB de 1963 a 1978.
} 
Embora não tivesse sido previsto nas primeiras discussões do plano da UnB, Niemeyer foi o autor do projeto do Instituto de Teologia ${ }^{23}$, em que se destaca um contraste entre a estrutura composta pela sequência contínua de módulos pré-moldados, no edifício principal, e o uso mais plástico do concreto, no espaço destinado à igreja.

O Instituto de Teologia terá característica arquitetônica diferente - barroca, se o desejarem - mas será também simples, sóbrio e recatado. Seus acabamentos respeitarão a austeridade necessária - quase tudo de tijolo e concreto aparentes - harmonizando-se assim com a filosofia da pobreza e humildade dos que o deverão habitar. Nele será mantido, embora num sentido mais amplo e flexível, o critério da pré-fabricação adotado na Universidade de Brasília, critério que o bloco principal caracteriza com suas colunas-parede ( $10 \times 5)$ recurvadas, sobre as quais se apoiarão as placas nervuradas dos pisos ( $16 \times 5)$ por meio de pinos de concreto armado. A cobertura, também pré-fabricada, representa um elemento independente do conjunto estrutural. Na Igreja Conventual prevalecerá, porém, o aspecto plástico com suas formas imprevistas, visando a iluminação interna e o ambiente de recolhimento e mistério procurado (NIEMEYER, 1963).

Apesar de se tratar de um edifício único, e portanto não replicável, empregou-se o sistema de pré-fabricação, de ciclo fechado, das peças estruturais do conjunto. De acordo com o projeto concebido por Niemeyer, o conjunto era composto pelo corpo principal, uma sequência contínua e ritmada de placas verticais pré-fabricadas e pela igreja, que, em contraste, exibe formas mais livres e um uso mais flexível do concreto armado.

A estrutura pré-moldada foi pensada para o corpo principal do edifício, criando uma sequência contínua, quase monótona, de módulos. No espaço destinado à igreja, à direita do conjunto, já acompanhamos um uso mais flexível do concreto [...] para Niemeyer, embora existisse o esforço para a utilização da pré-fabricação, ela teria circunstâncias mais e menos felizes para sua aplicação (ALBERTO, 2009, p. 83).

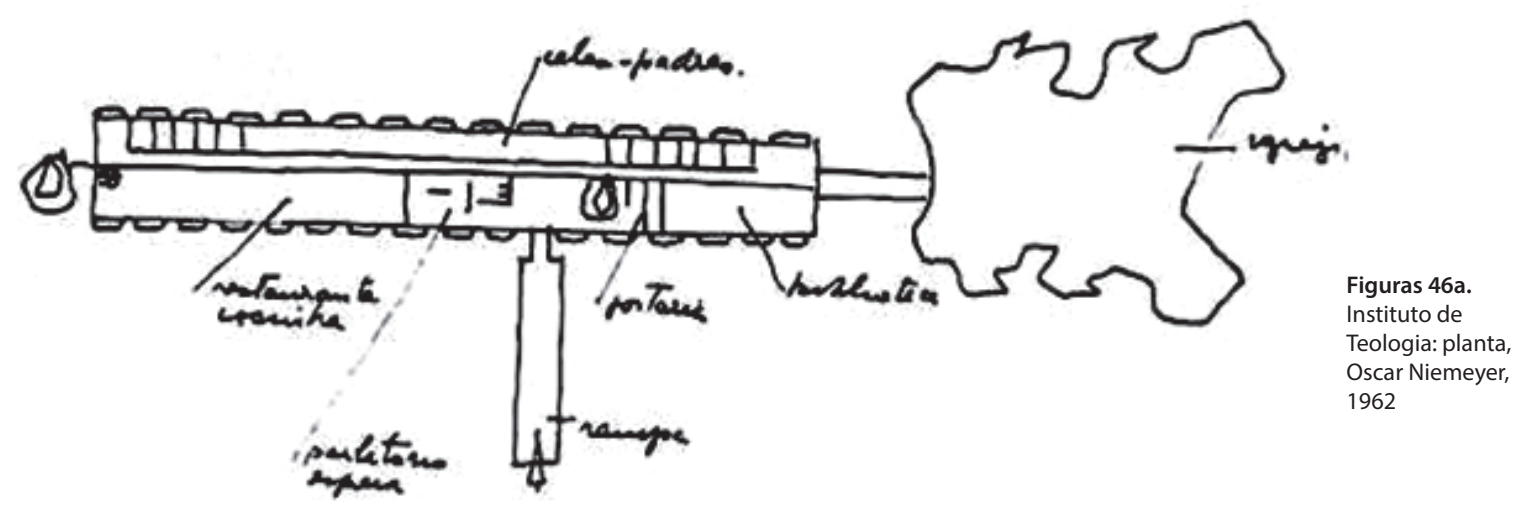

Em sua concepção estrutural, o projeto previu colunas-parede pré-fabricadas e placas nervuradas de piso, sendo que a cobertura, independente, seria formada por colunas e vigas também préfabricadas. Sobre a valorização da estrutura como elemento expressivo do projeto arquitetônico, assim se expressou o autor do projeto: 


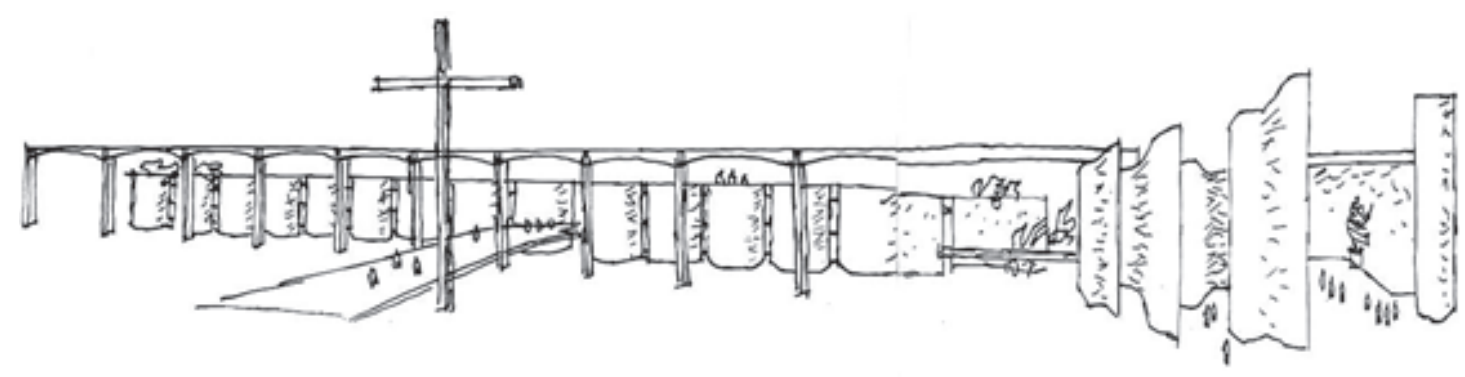

Figuras 46b.

Instituto de

Teologia:

perspectiva do

conjunto

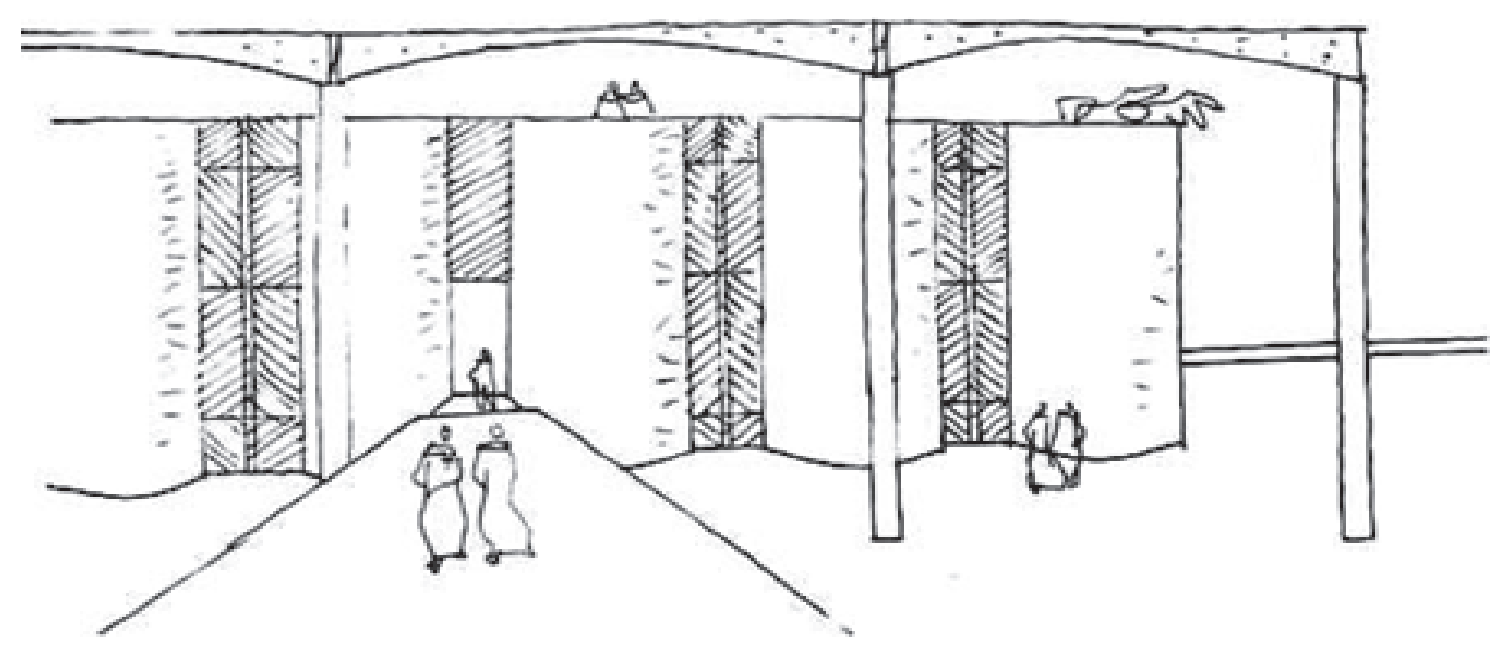

Figura $46 c$.

Corpo principal:

terraço
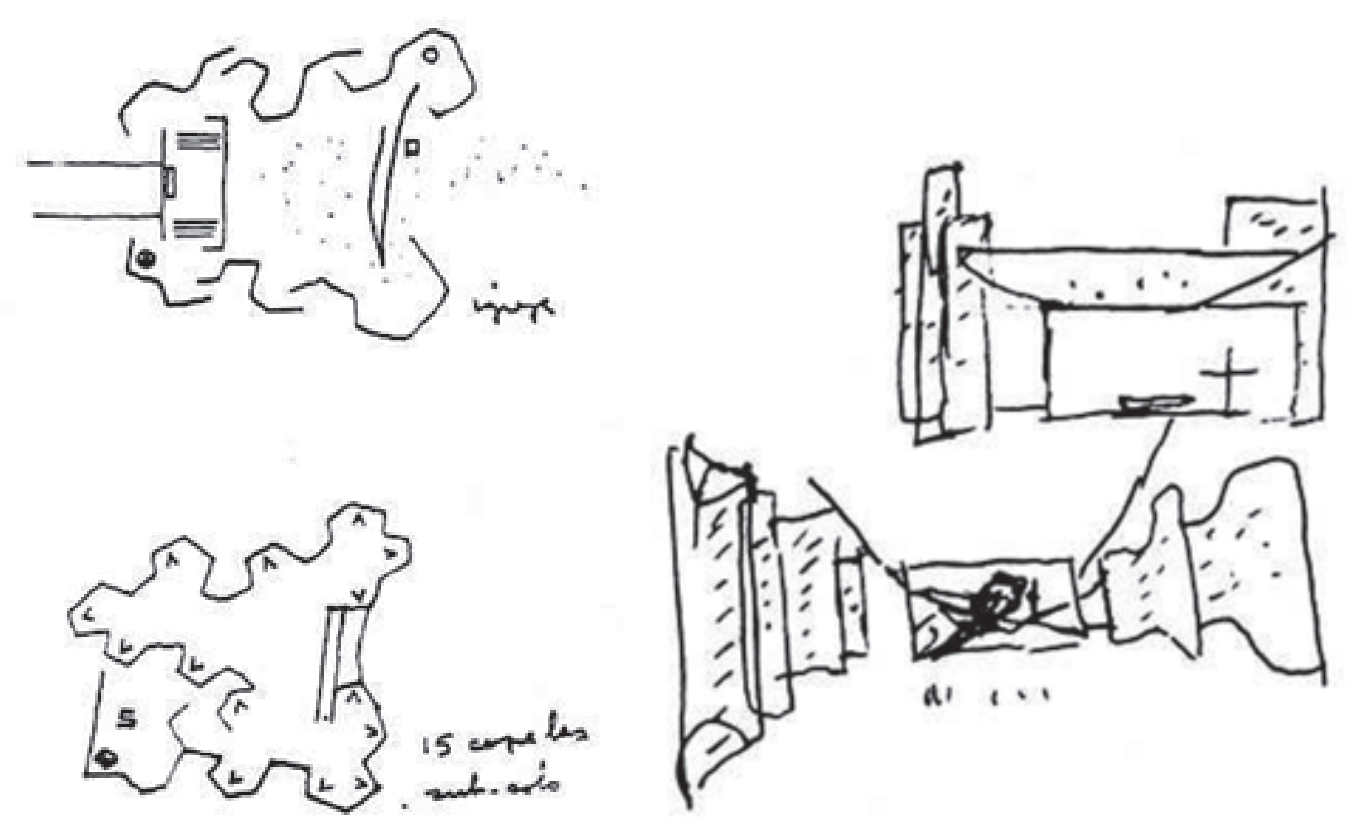

Figura 46d e 
[...] passaram a me interessar as soluções compactas, simples e geométricas; os problemas de hierarquia e de caráter arquitetônico; as conveniências de unidade e harmonia entre os edifícios e, ainda, que estes não mais se exprimam por seus elementos secundários, mas pela própria estrutura, devidamente integrada na concepção plástica original. Dentro do mesmo objetivo, passei a evitar as soluções recortadas ou compostas de muitos elementos, difíceis de se conterem numa forma pura e definida (NIEMEYER, 1986, p. 45).

O caráter experimental que norteou as ações do Ceplan nos seus primórdios levou seus integrantes a apostarem, quase que simultaneamente, em quatro tipologias distintas de construção préfabricada de concreto armado: os painéis-parede e vigas, como os que foram usados nos pavilhões de Serviços Gerais (SGs) de um pavimento; o esqueleto pré-fabricado composto de pilares e vigas, empregado nos SGs de dois pavimentos e no Instituto Central de Ciências; a unidade alveolar de $50 \mathrm{~m}^{2}$ a ser sobreposta a outras, formado habitações de até quatro pavimentos; e uma solução mista composta de elementos pré-fabricados e outros moldados in loco, como foi usado na área do campus conhecida como Colina.
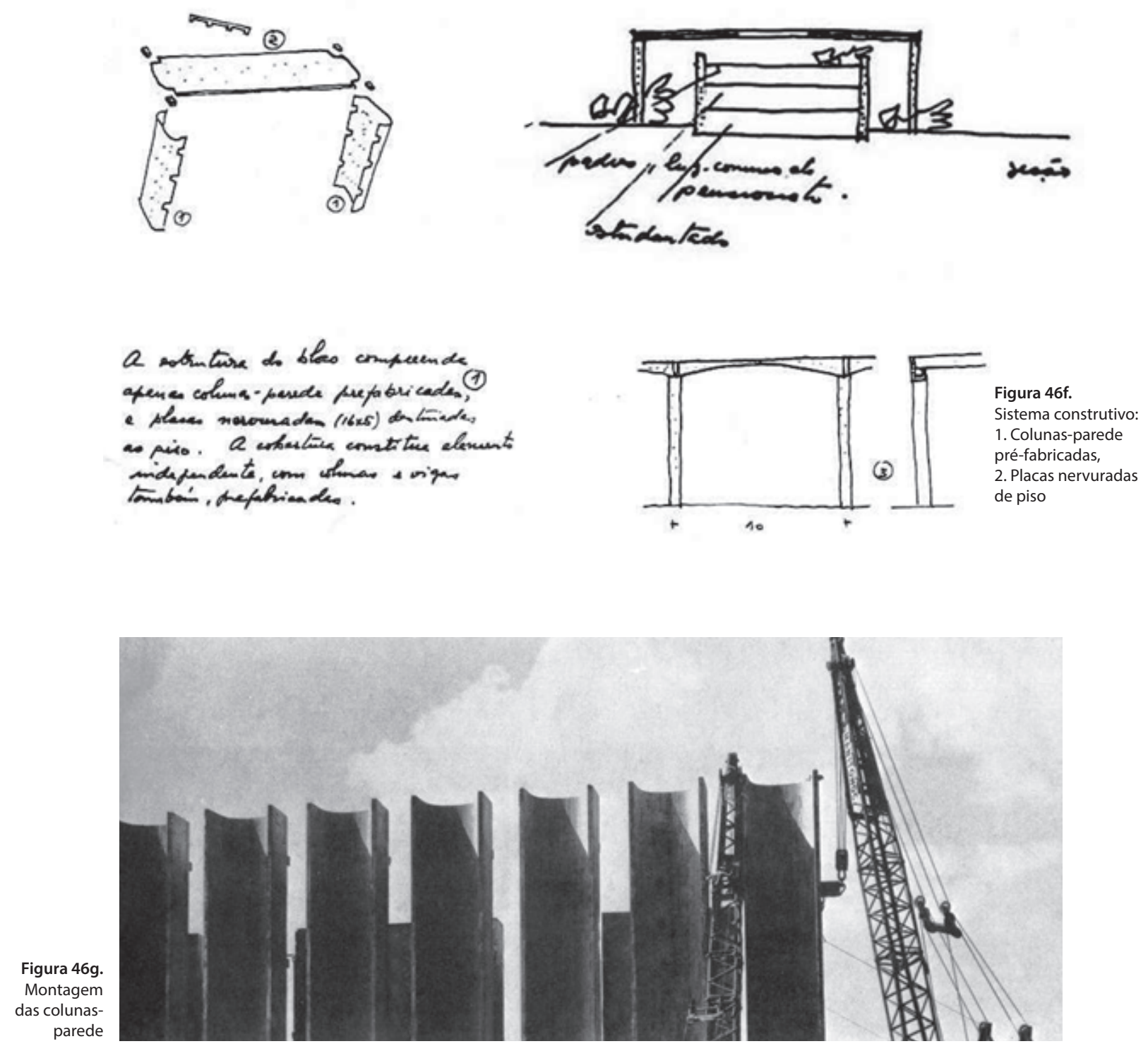
Antes mesmo do término das obras da Faculdade de Educação, a Construtora Rabello iniciou a construção dos blocos de um pavimento, de autoria de Oscar Niemeyer. Tão logo concluído, o SG-10 - primeiro edifício pré-fabricado do campus -, passou a sediar o Ceplan. O sucesso dessa experiência levou, em seguida, à construção dos pavilhões de Serviços Gerais SG1, SG2, SG4 e SG-8.

Depois vieram os blocos de dois pavimentos - o SG11 e o SG12, de autoria de Lelé, que passaram a abrigar, na época, o Departamento de Engenharia Elétrica e, provisoriamente, a Biblioteca Central.

[...] o prédio onde funcionou a Biblioteca da UnB era um projeto do Lélé, pré-fabricado em dois pavimentos; aliás, tem até subsolo. Então, é o térreo e uma sobreloja, pendurada nas vigas da cobertura. Detalhei uma escada pré-fabricada, que ia do térreo para a sobreloja. O prédio era concebido de tal maneira que ele podia ser modificado amanhã. A sobreloja podia diminuir ou aumentar. Então, a escada tinha que sair de um lugar e ir para outro [...] era muito versátil, a coisa toda (PESSINA, entrevista em 1 dez. 2011).

Além disso, foram desenvolvidos, a partir dos riscos de Oscar Niemeyer, o projeto e o protótipo, em escala 1:1, de um módulo residencial. Segundo o próprio autor, essas unidades pré-fabricadas “[...] seriam colocadas sobre o terreno nivelado, umas sobre as outras, e alternadas, para que o teto de uma servisse de terraço-jardim para outra" (1993, p. 43). Elas deveriam ser produzidas, em grande escala, em uma usina de pré-fabricação, que não chegou a ser construída.

Outra proposta de Oscar para habitação, que consistia em um edifício de sete pavimentos, não chegou sequer a ser desenvolvida.

Com a continuidade dos trabalhos em pré-fabricação, a técnica pôde ser aplicada em quatro edifícios residenciais, de autoria de Lelé, destinados à moradia de professores e alunos. Os prédios de três pavimentos sobre pilotis, construídos na Colina, em quatro edifícios constituíram a primeira experiência nacional de utilização de elementos pré-moldados na construção habitacional.

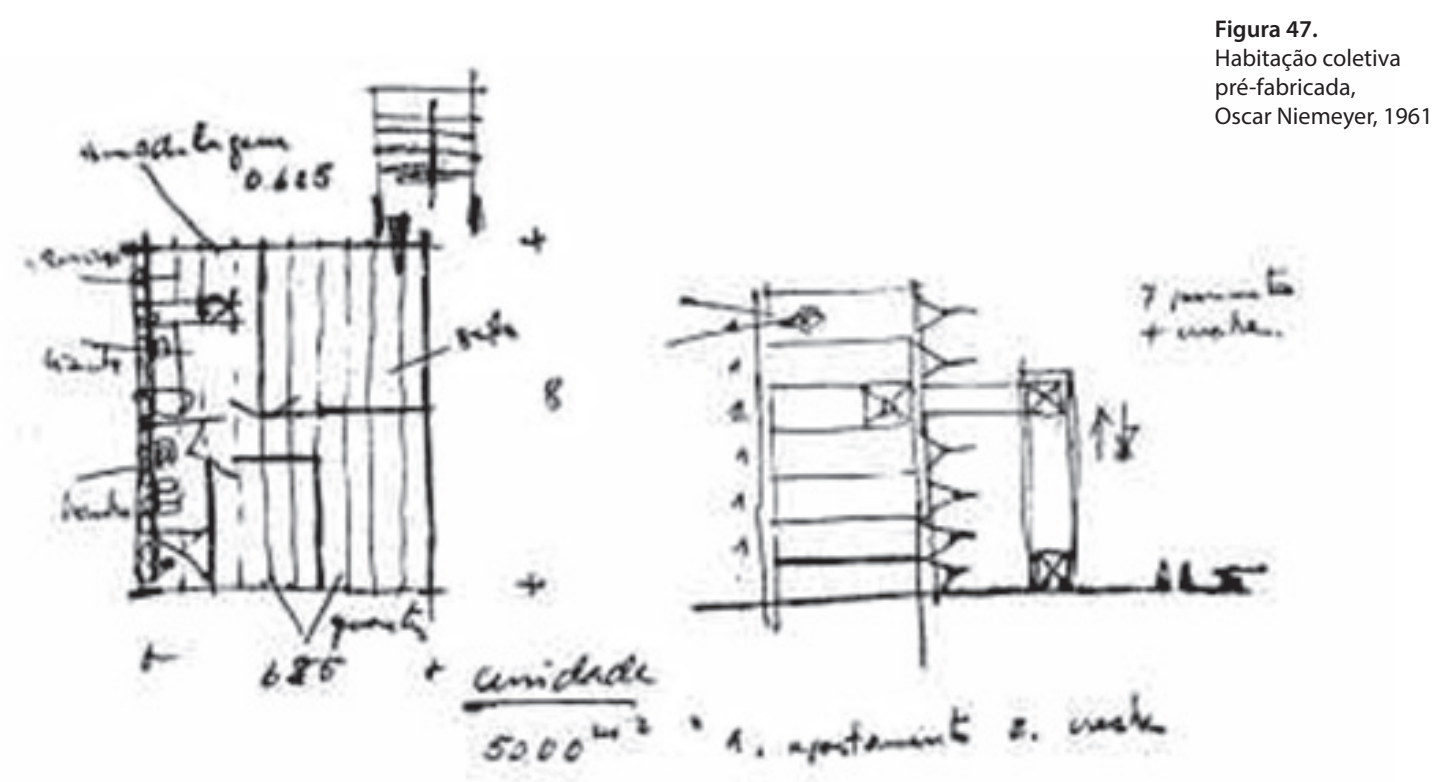


Ainda em 1962, foi apresentado o segundo plano urbanístico para a UnB, que tinha como característica principal a aglutinação dos institutos de Matemática, Química, Física e Biologia em um único edifício, o Instituto Central de Ciências (ICC). Apesar disso, o padrão de distribuição dos demais edifícios assemelhava-se à proposta de Lucio Costa. Como afirmou Faria, “Em um croqui posterior (ano de 1963), Niemeyer e sua equipe reestudam a volumetria das diversas áreas do campus, sempre tomando o ICC como o edifício que deveria reger as possíveis composições do plano de ocupação da cidade universitária" (2003, p. 10).

Niemeyer também aproximou a Praça Maior, por ele projetada, do ICC, reduzindo o número de edifícios a ela contíguos a quatro: Biblioteca Central, Museu da Civilização Brasileira, Aula Magna e Reitoria. A Praça Maior, configurada então como uma grande plataforma horizontal de articulação dos volumes propostos, foi invertida, abrindo-se para o Lago Paranoá. O Museu da Civilização Brasileira, elevado quatro metros acima do solo, passou a atuar como pórtico de entrada para a Universidade. As unidades, antes dispersas pelo campus, foram condensadas em quatro grandes áreas: Ciências Médicas, Artes e Arquitetura, Ciências Humanas e Tecnologia. Niemeyer produziu dois estudos para a Praça Maior.

Nessa mesma época foram incorporados ao campus da UnB 114 hectares destinados ao Centro Olímpico da Juventude. Essa seria uma compensação pela ocupação das margens do Lago Paranoá por clubes e agremiações inacessíveis à população de baixa renda.

Ao juntar todos os edifícios dedicados à ciência em um só, Niemeyer, inovando em relação a outros projetos de cidades universitárias, produziu uma significativa alteração no partido original de Lucio Costa. De acordo com Pessina, foram os arquitetos Ítalo Campofiorito e Jayme Zettel, ambos vinculados ao urbanismo da cidade de Brasília, que desenvolveram o projeto do urbanismo da universidade, seguindo o risco de Lucio Costa. Com essa unificação, segundo Lelé, "[...] conseguimos reduzir muito o programa, porque cada cientista pedia um feudo. Se fossemos reproduzir cada feudo, o ICC teria dez vezes o tamanho que tem" (Entrevista em 23 fev. 2012).

Na verdade, a solução significou um passo adiante no processo de integração da universidade brasileira, que, da disseminação, nos anos 1930, de escolas isoladas na malha urbana, evoluiu para a concentração das atividades acadêmicas em um único território - a chamada cidade universitária - durante a década de 1960. Sobre o ICC, assim se pronunciou, de modo espirituoso, Darcy Ribeiro:

\footnotetext{
Gosto de dizer, para divertir os amigos, que foi por preguiça que Oscar projetou o Minhocão tal qual ele é: 780 metros de comprimento por 80 de largura, em três níveis. A verdade que há nisso é só que Lucio Costa previa no plano urbanístico no campus da UnB oito áreas para os Institutos Centrais, cada uma delas contando com edifícios especializados para anfiteatros, salas de aula, laboratórios, departamentos, bibliotecas etc. No total, somariam mais de quarenta edificações que deveriam ser projetadas e construídas uma a uma. Oscar resumiu tudo isso num edifício só, composto por seis modalidades de construção, que permitiriam acomodar qualquer programa de utilização (RIBEIRO, 1991, p. 131).
}

No campo da pré-fabricação na UnB, o Instituto Central de Ciências (ICC) foi, sem dúvida, o edifício mais significativo projetado no Ceplan à época. Carinhosamente apelidado de Minhocão, respondia de forma enfática ao projeto pedagógico proposto para a Universidade de Brasília: "Torna-se difícil imaginar uma proposta que melhor simbolizasse o plano pedagógico de integração proposto pelos responsáveis da UnB" (ALBERTO, 2009, p. 84). 
A pré-fabricação impunha-se então como solução adequada às premissas de um edifício cujo programa complexo previa a integração entre os diferentes cursos, a livre circulação de pedestres e, sobretudo, a grande flexibilidade de espaços e instalações especiais.

[...] foi ponto básico do programa o de que a solução garantisse a maior flexibilidade, que os laboratórios pudessem crescer ou diminuir de tamanho, e que fossem previstas áreas especiais onde laboratórios futuros pudessem ser localizados sem limitações antecipadas de superfícies, forma e altura (NIEMEYER, 1963, p. 35).

Contrastando com as linhas sóbrias do grande edifício, foram propostas "[...] variações de formas e coberturas" que, segundo o autor do projeto, "[...] constituirão a principal característica da arquitetura: imprevista e dinâmica como a própria ciência" (NIEMEYER, 1963, p. 36).

Segundo depoimento de Pessina, foi adotado no ICC o sistema de radier, tendo sido utilizada, na escavação, a técnica rodoviária de pavimentação. De acordo com o projeto, os subsolos eram restritos às alas Oeste e Leste do edifício e, no primeiro caso, serviam para abrigar os auditórios; no segundo, para garantir o acesso às instalações dos laboratórios situados no térreo. Durante a obra, por proposição da construtora, esses dois subsolos acabaram sendo unidos (Entrevista em 1 dez. 2011).

O ICC foi um projeto muito trabalhoso que nós desenvolvemos no Ceplan. O professor Ramiro Muniz ${ }^{24}$ foi incumbido de ajustar comigo os programas de todos os institutos. Foi uma trabaIheira! O Ramiro estava no Rio e eu ia constantemente para lá até conseguirmos organizar o programa, em contato com todos os cientistas. Foi até engraçado como surgiu o projeto do ICC: tinha o plano de urbanismo da UnB do Dr. Lucio. No plano do Lucio tinha aquelas bolinhas que até faziam uma curva, e o Oscar disse: 'vamos fazer logo um prédio só, pegando todos estes institutos... E o ICC surgiu assim (LELÉ, entrevista em 23 fev. 2012).

Por volta de abril de 1962, com o término dos edifícios da Faculdade de Educação, a construtora Rabello transferiu grande parte de seus operários para outras obras fora do campus, ficando apenas as máquinas e seus operadores encarregados de abrir as valas para as fundações do Minhocão.

Além dos trabalhos específicos da Universidade, o Ceplan atendia a outras demandas decorrentes de convênios culturais, como o celebrado com a Embaixada da França. Assim, foi desenvolvido, pelo arquiteto pernambucano Glauco Campello, um bloco de apartamentos para os diplomatas franceses em Brasília:

Bloco simples, limitado em volume e altura pelos regulamentos urbanos, mas que apresenta características construtivas interessantes, como a solução adotada nas fachadas, onde os quadros pré-moldados de concreto armado substituem os caixilhos das esquadrias, servindo ainda como apoios estruturais. Essa solução evita colunas internas, tornando os apartamentos mais flexíveis às conveniências de seus moradores (MÓDULO, 1963, p. 42).

Em 1964, como resultado de um convênio entre a UnB, o Ministério das Relações Exteriores e a Novacap, a quadra 107 Norte - conhecida como Área de Vizinhança São Miguel - foi destinada a residências para integrantes do corpo diplomático e servidores da UnB. Nesse local foram erguidos, pela Serveng-Civilsan S.A., três blocos de apartamentos, de planta quadrada, cujo projeto é de autoria dos arquitetos paulistas Sérgio Souza Lima e Mayume Watanabe, integrantes da equipe do Ceplan e da Faculdade de Arquitetura.

\footnotetext{
${ }^{24}$ Ramiro de Porto Alegre Muniz foi um importante nome da ciência e um dos fundadores, em 1962, do Instituto de Física na UnB.
} 


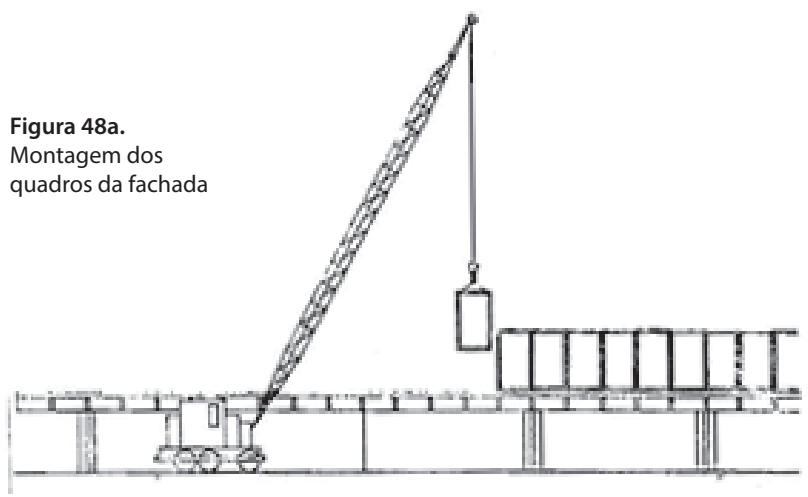

Montagem dos quadros da fachada

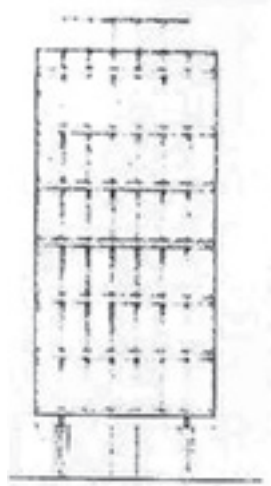

Fachada

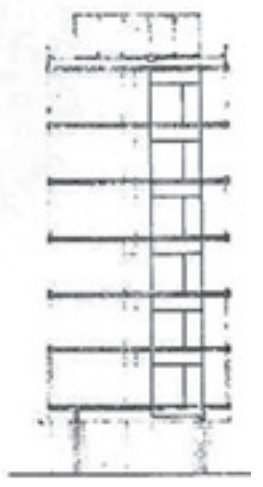

Corte transversal

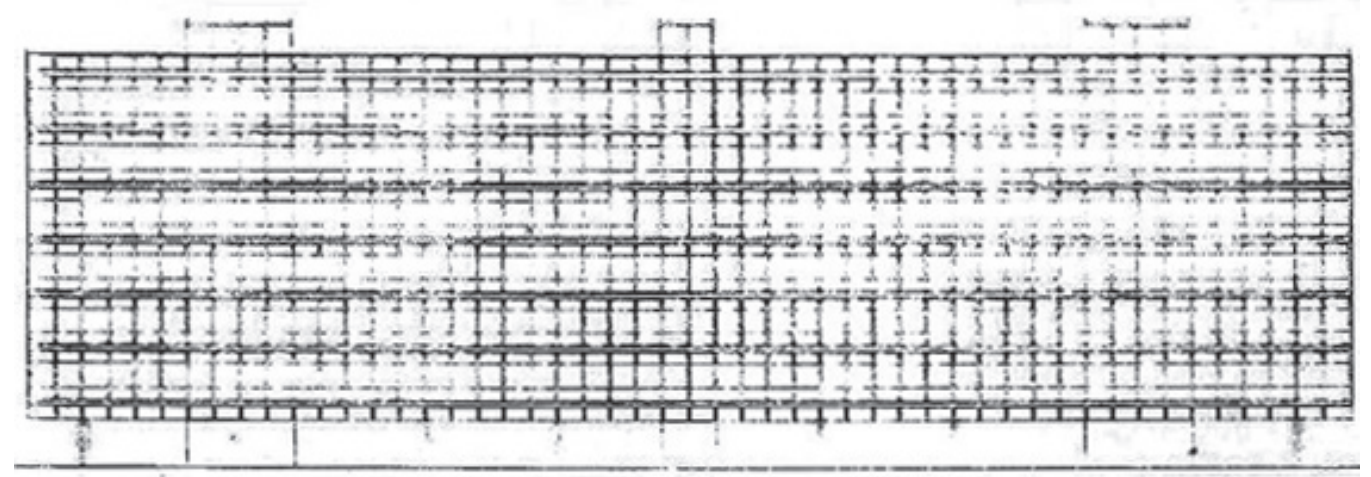

Figura 48b.

Fachada principal

Fachada principal

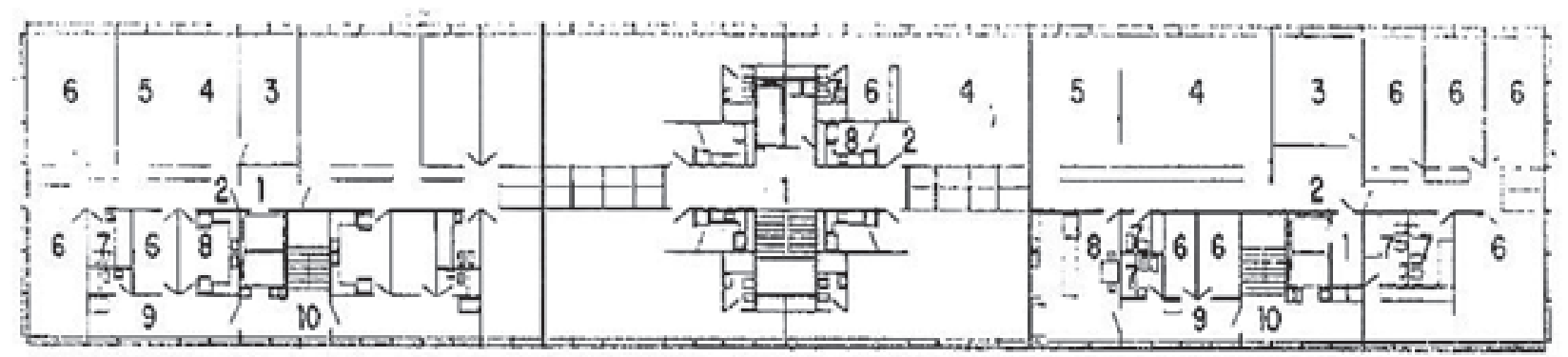

1. Elevadores; 2. Hall; 3. Biblioteca; 4; Sala de estar; 5. Sala de refeições; 6. Quart; 7. Banheiro; 8. Cozinha; 9. Serviço; 10. Hall de serviço

Pavimento-tipo

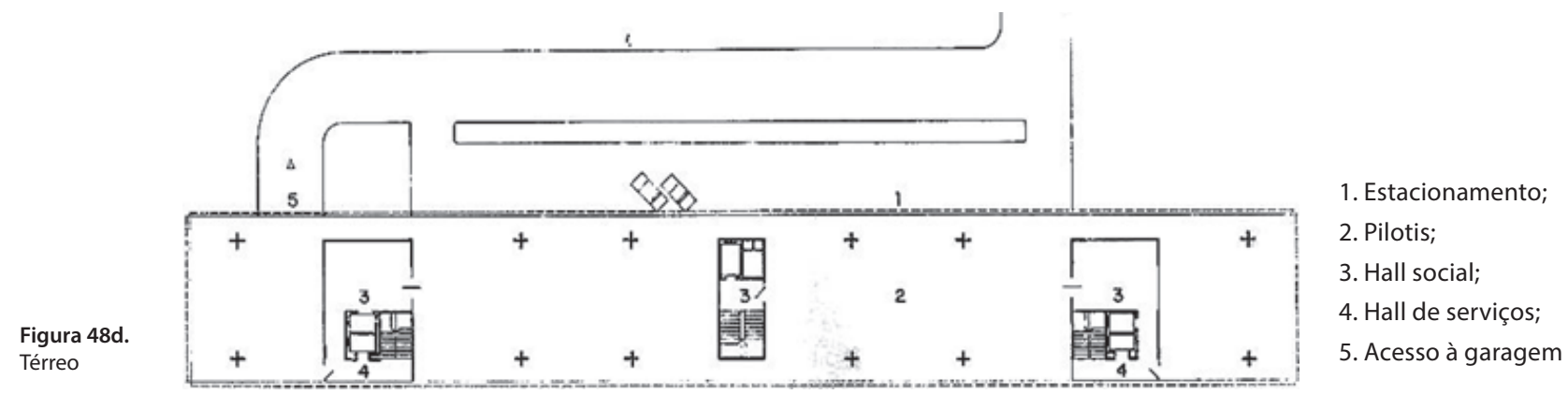

Térreo 
[...] o embaixador Wladimir Murtinho, que prestigiava muito o Ceplan, propôs que ali se projetassem as superquadras com a técnica da pré-fabricação (...) e o Ceplan decidiu que o projeto deveria ser feito pelos instrutores - arquitetos que eram professores da Escola de Arquitetura e trabalhavam eventualmente no Ceplan. E se fez um concurso, no qual o projeto da Mayumi e do Sérgio venceu. Mas a coisa foi muito tumultuada pelo golpe militar, e não sei dizer realmente como isso se deu. Sei que, por meio desse concurso e do que foi projetado, foram construídos só três prédios, quadradinhos, na 107 Norte [...] o longitudinal foi projetado depois, e tinha uma garagem comum interligada com os quadradinhos (PESSINA, 1 dez. 2011).

Na verdade, pretendia-se que o Ceplan pudesse prestar serviços à cidade, levando inclusive a técnica da pré-fabricação para as cidades-satélite, como observa Pessina:

[...] o Ceplan poderia ter colaborado com a cidade. Provavelmente ter ajudado no planejamento das cidades-satélite, para que tivessem um desenvolvimento mais de acordo com o padrão urbanístico de Brasília. Isso não foi adiante, mas havia a ideia disso tudo ser desenvolvido na escola e no Ceplan. Enfim, em 64 e 65 houve essa ruptura realmente (Entrevista em 1 dez. 2011).

Um dos exemplos de pesquisa em pré-fabricação voltada para o atendimento de demandas sociais fora do campus foi o projeto da escola primária concebido por Niemeyer, que não saiu do papel. Segundo ele, tratava-se de uma solução "de fácil aplicação por todo o país", devido aos "elementos pré-fabricados que se subordinam às condições de transporte (caminhão) e à possibilidade de ser montada em qualquer lugar em poucas horas" (MÓDULO, 1963, p. 46-47).

O campus enchia-se de prédios e gentes ocupadas com seus diversos afazeres. O clima da UnB à época pode ser depreendido das palavras de Sebastião Varela, o Tião Poeta, contratado pela UnB em 1962 como servente:

Trabalhava-se dia e noite [...] Oscar Niemeyer trabalhava fortemente no projeto arquitetônico do ICC. Às vezes até altas horas da noite, debaixo de um pequeno prédio pré-moldado, construído pela Rabello. E todos os projetos do professor Darcy se faziam realidade na grande

Figura 49.

Escola Primária, Oscar Niemeyer, 1962

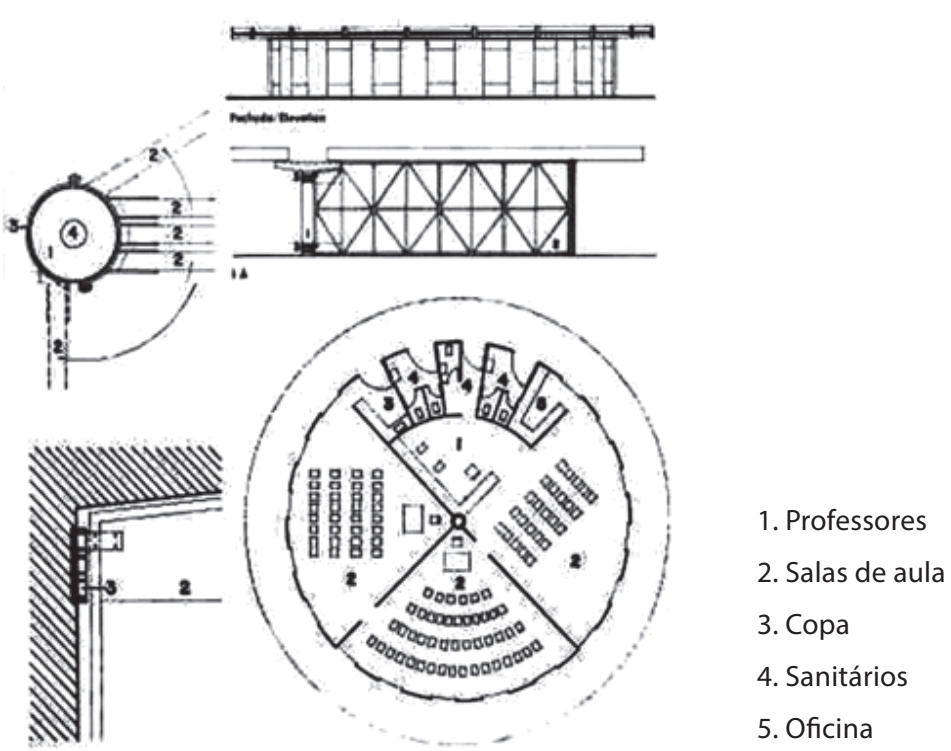

Escola Primária 
arrancada da Universidade de Brasília [...] O professor Darcy tinha certeza de que tudo ia dar certo (VARELA, 1989, p. 21 e 22).

No entanto, as crises que a UnB atravessaria nos anos seguintes mostraram que nem tudo deu certo. Assim, foi transformada em arquitetura de papel “[...] a maior parte do que Oscar projetou para a Universidade". Essa referência de Darcy Ribeiro diz respeito principalmente à Praça Maior, que, segundo ele, "[...] poderia estar atraindo tanta atenção quanto a Praça dos Três Poderes".

A Praça Maior, criada pelo poeta do traço, seria a essência da UnB. Com quatro grandes prédios, foi idealizada para preencher o vazio que se descortinava entre o principal bloco do espaço acadêmico, o Instituto Central de Ciências (ICC), e o Lago Paranoá [...] O arquiteto das curvas queria uma obra que representasse a magnitude da instituição pensada por seus companheiros Darcy Ribeiro e Anísio Teixeira. Buscava o traçado de um espaço amplo, que reunisse a ciência, a cultura, a memória e a administração da universidade de forma sutil e imponente (CAMPOS, 2009, p. 56).

São conhecidos dois estudos de Niemeyer para a Praça Maior da UnB, sendo que a principal diferença entre está no edifício da Reitoria: no primeiro, foi proposta uma lâmina vertical; no segundo, o edifício assumiu a forma de um prisma horizontal, mais de acordo com o gabarito previsto por Lucio Costa para edificações próximas ao Lago Paranoá25 .

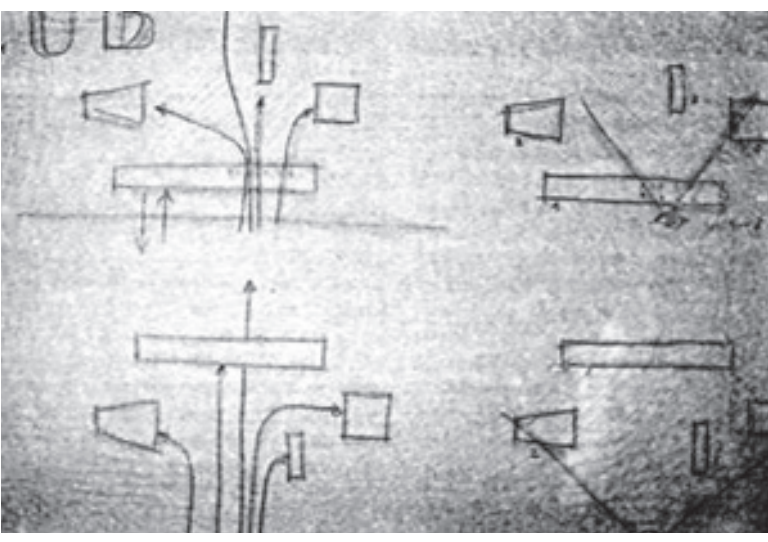

Figura 50a.

Estudos de fluxos para a

Praça Maior

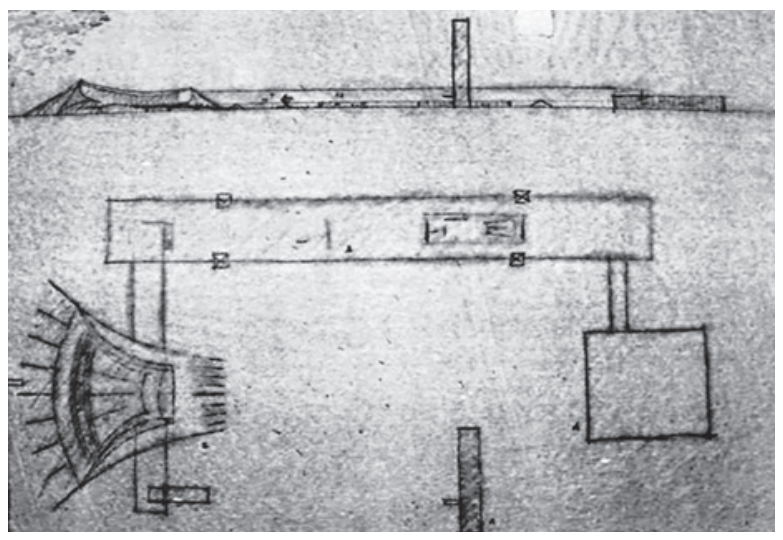

Figura 50b.

Planta e corte da primeira

versão para a Praça Maio

Outro projeto de Niemeyer que ficou no papel foi o Centro Esportivo da Juventude, cujos equipamentos foram previstos para serem compartilhados com a cidade como um todo, conforme explicou o próprio autor:

O Centro Esportivo da Juventude equilibrará, em parte, tanta injustiça, criando para a juventude operário-estudantil uma grande praça de esporte e recreio, onde poderão, afinal, usufruir o que até hoje lhes foi negado. A praça de esporte contará com cine-teatro (2.000 pessoas), um teatro ao ar livre (5.000 pessoas), um estádio (3.000 pessoas), campos de esporte etc. Uma sede social, um restaurante, bar e piscina de recreio, com cerca de 150 metros de extensão, também estão previstos. Um play-ground com piscina infantil completa o conjunto (MÒDULO, 1963, p. 48).

${ }^{25} \mathrm{~A}$ coleção de desenhos da primeira versão de Oscar Niemeyer para a Praça Maior, guardada pelo arquiteto panamenho Virgílio Ernesto Sosa por longos 36 anos, só seria devolvida ao reitor da UnB, Lauro Morhy, em 2001, pela então presidente do Panamá, Mireya Moscoso. Esses desenhos foram publicados no 
Praça Maior
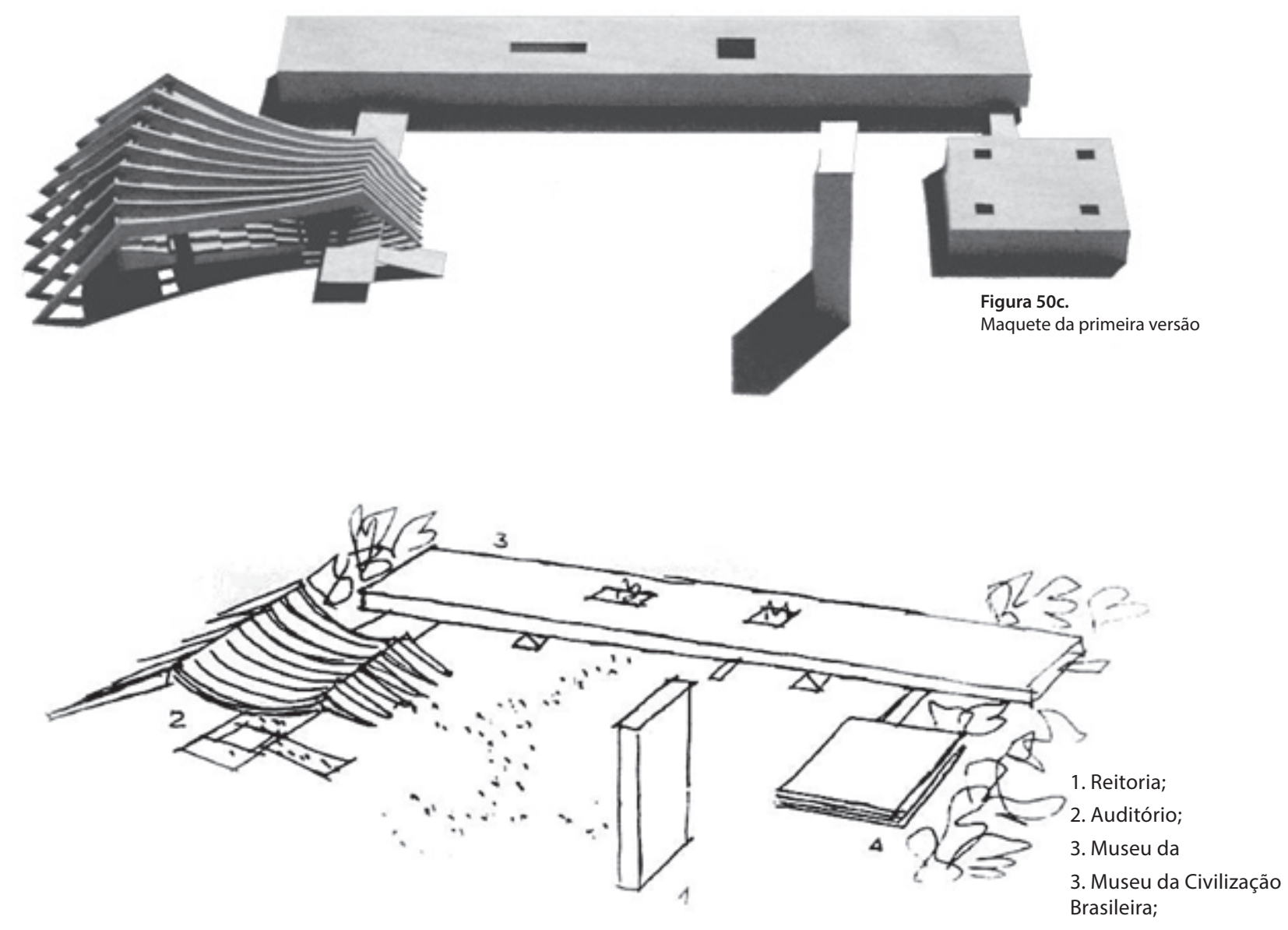

Figura 50d.

4. Biblioteca

Perspectiva da primeira versão para a Praça Maior
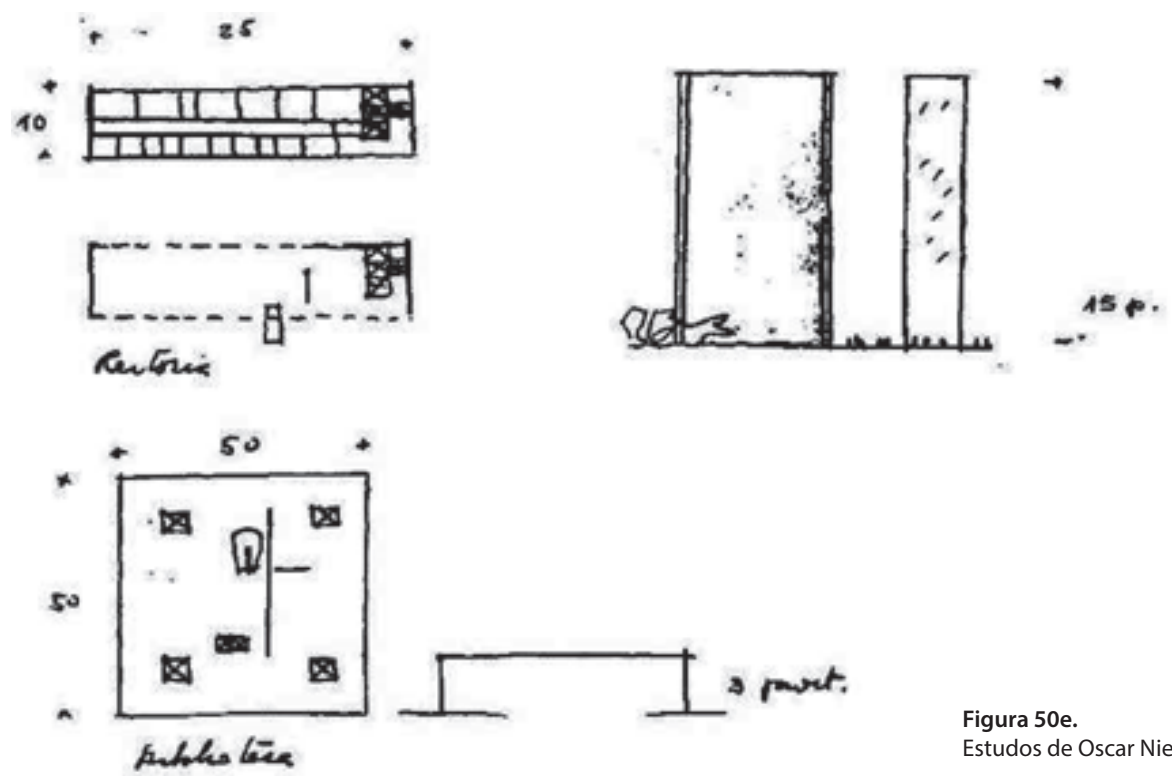

Figura 50e.

Estudos de Oscar Niemeyer 


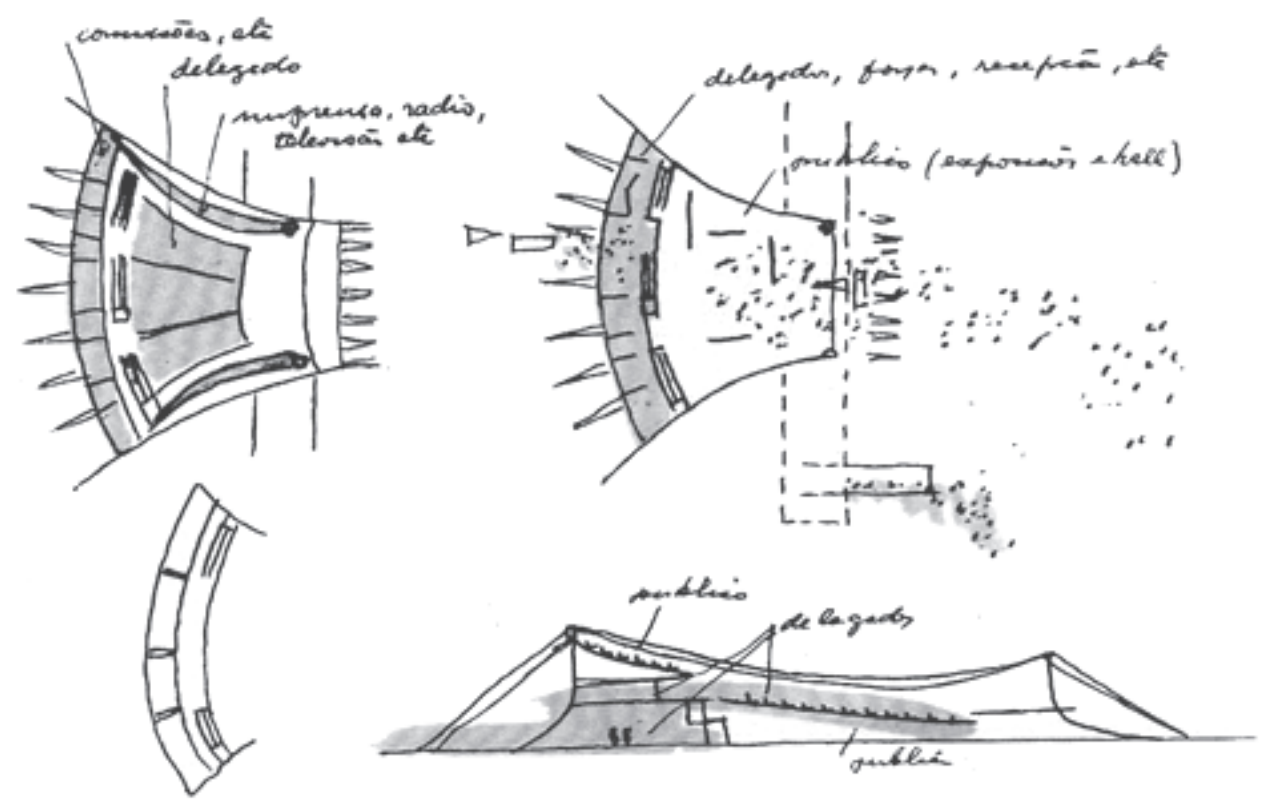

Figura 50f.

Planta da segunda versão.

Desenhos de Oscar Niemeyer

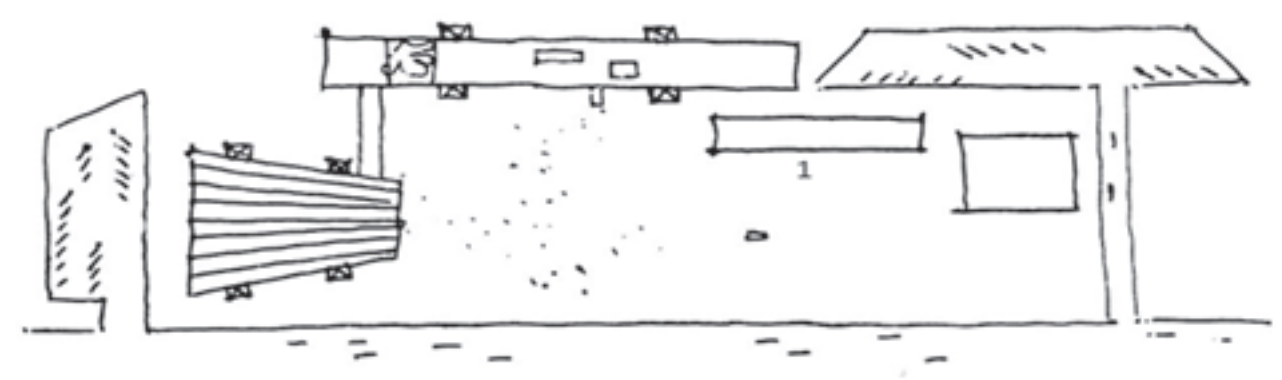

Figura 50g.

Maquete da segunda versão da Praça Maior

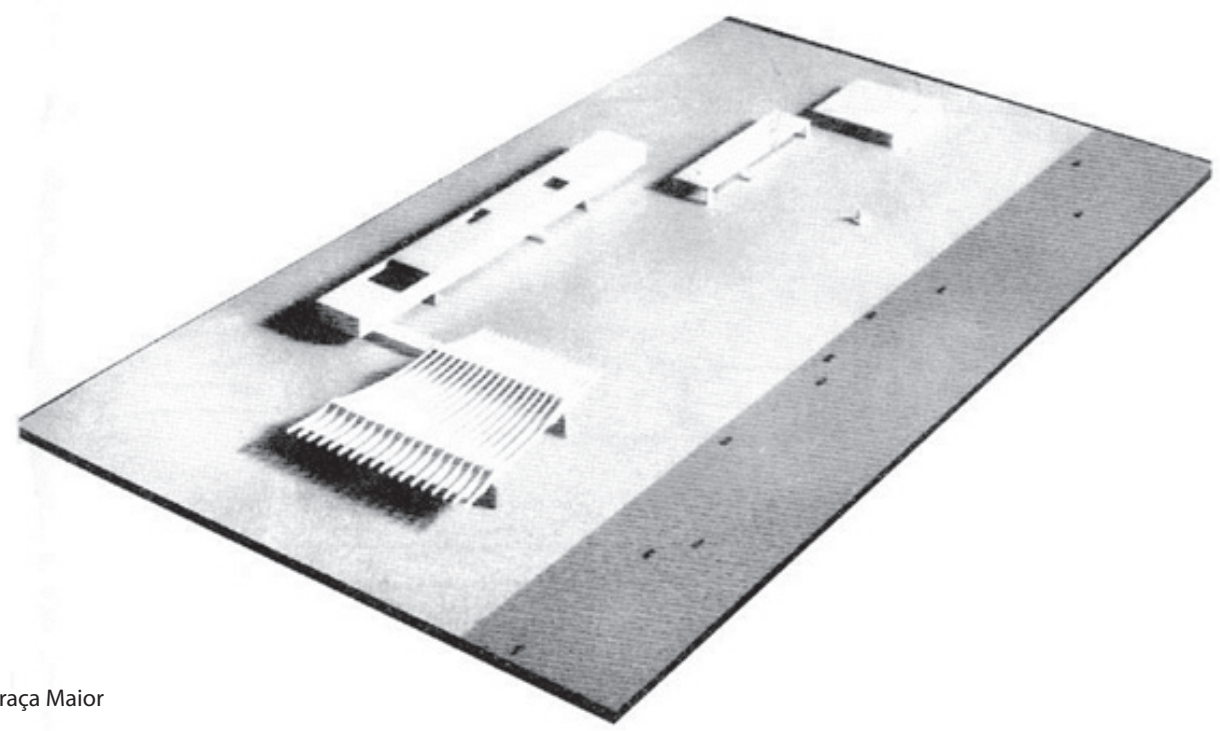



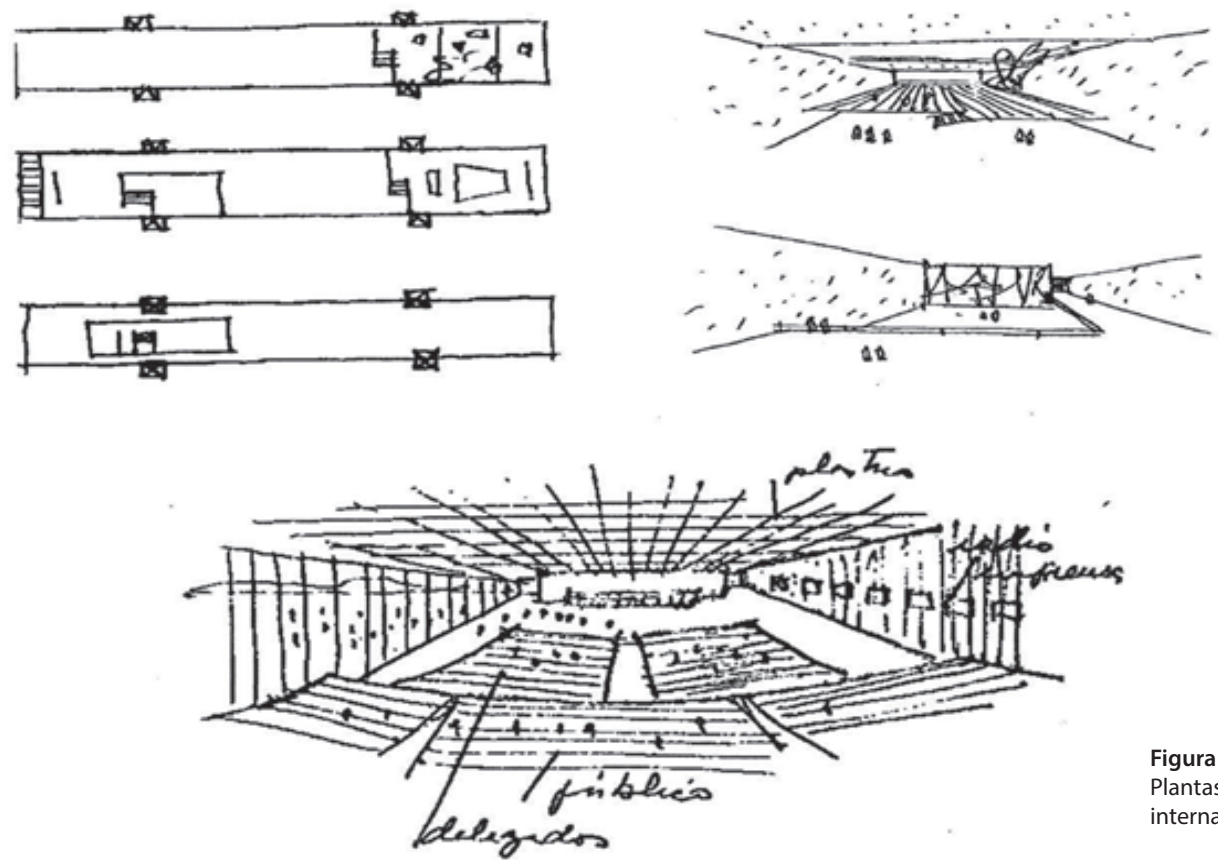

Figura 50h

Plantas do Museu e vista internas da Aula Magna

Em uma visita à UnB na década de 1990, Darcy Ribeiro também lamentou que a proposta paisagística para a UnB que tivesse sido implementada: "Onde o bosque de árvores regionais que se tinha previsto? Onde os renques de buritis? Onde tanta coisa apenas pensada, mas que eu procurava no chão do mundo, cobrando, querendo que se tivesse concretizado por milagre?" (1978, p. 131).

Se esse período pode ser caracterizado fundamentalmente pelo lançamento do "embrião da pré-fabricação", a principal perda que a UnB sofreu a partir de 1964 foi o desmantelamento de uma equipe fortemente comprometida com o desenvolvimento da construção no país. Como explicou Lelé,

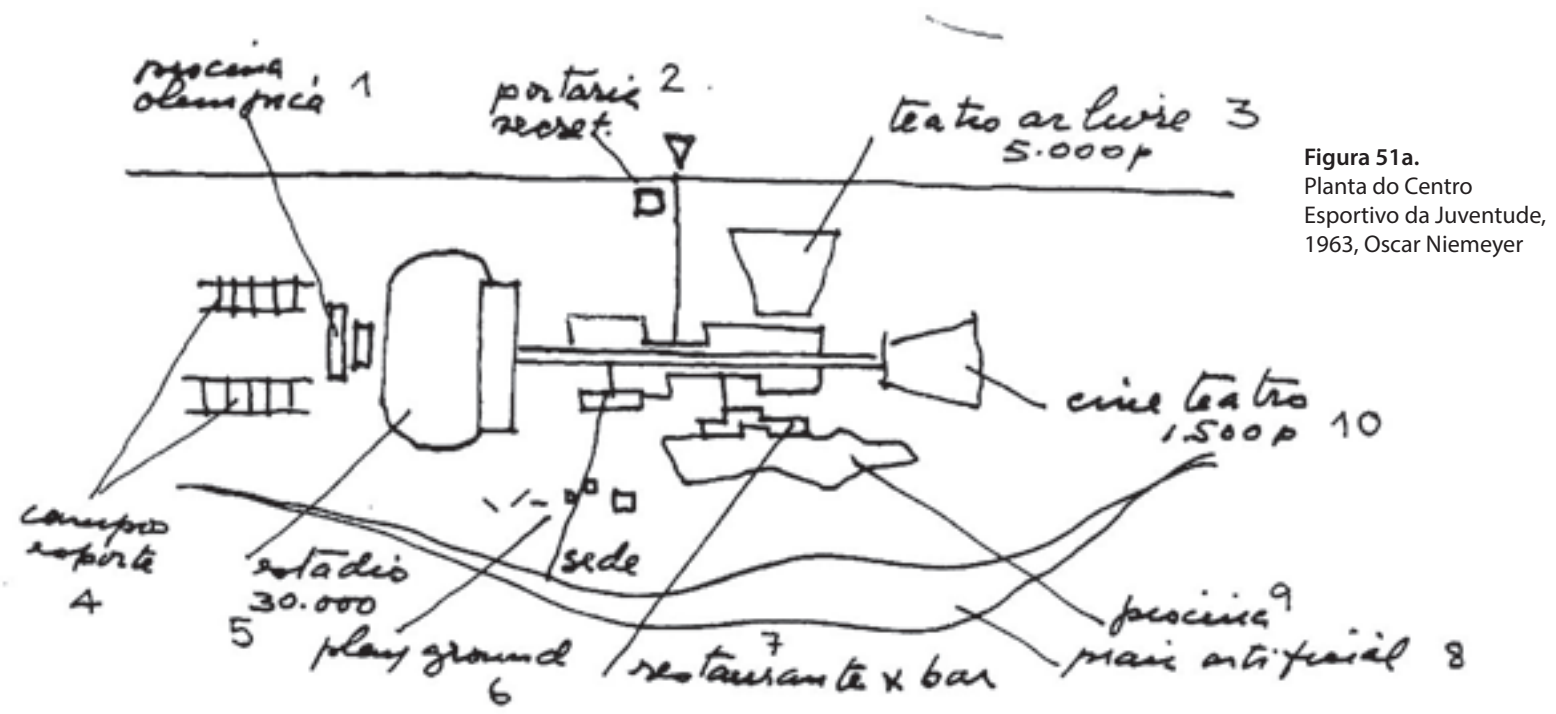




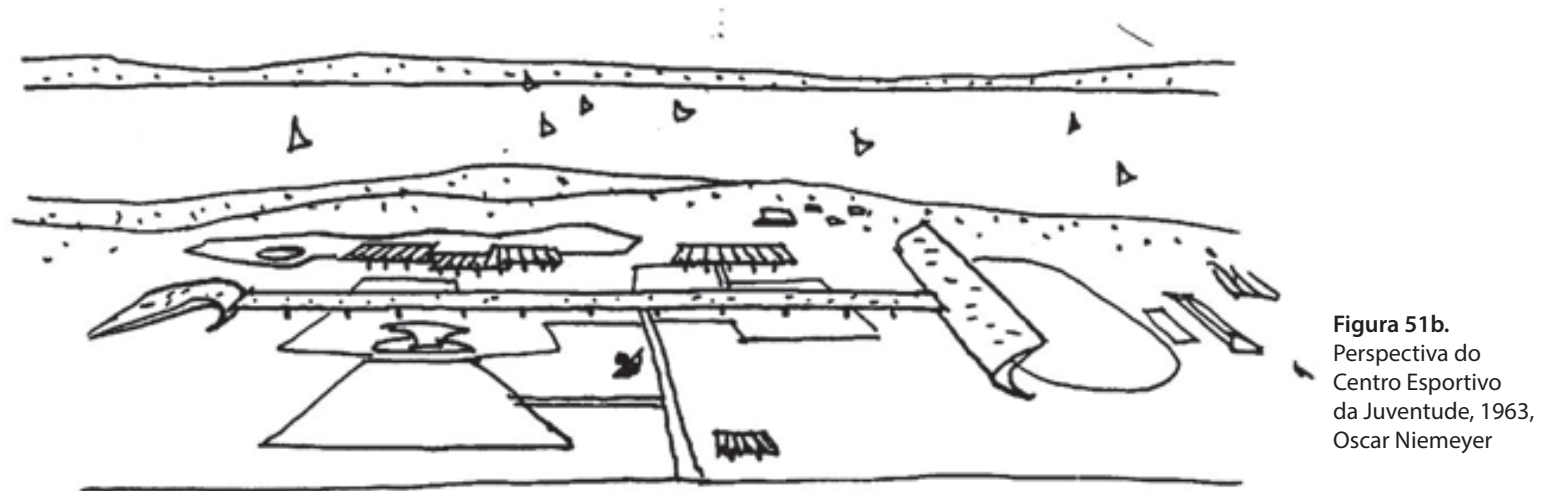

O projeto mais ousado, entre muitos outros que não foram realizados, foi o da construção de uma fábrica de pré-moldados, que constituiria um laboratório de pesquisas no campo da construção civil e um importante centro de vivência e de formação profissional para os estudantes de Arquitetura e Engenharia. Infelizmente essa experiência foi paralisada pelo Golpe Militar de 1964 (LIMA, 2014, p. 10).

Esse sentimento de perda foi partilhado pelos entrevistados, que vivenciaram a saga de construção e desconstrução na Universidade de Brasília. Todas as conversas foram permeadas por um misto de orgulho pela participação na construção desse patrimônio e, ao mesmo tempo, de tristeza e melancolia pela forma violenta com que esse esforço foi abortado. Assim, não é demais reproduzir mais algumas palavras emocionadas de Lelé:

Creio que todos aqueles que, como eu, participaram da implantação da Universidade de Brasília se emocionaram ao relembrar aquele episódio extraordinário e inusitado liderado pelo gênio de Darcy Ribeiro, e que certamente criou referências profundas na trajetória de cada um de nós (LIMA, 2014, p. 10). 
1.3. ARQUITETURA COMO EXPERIMENTO E INOVAÇÃO

Assim começou a UnB...

\section{OCA I e OCA II}

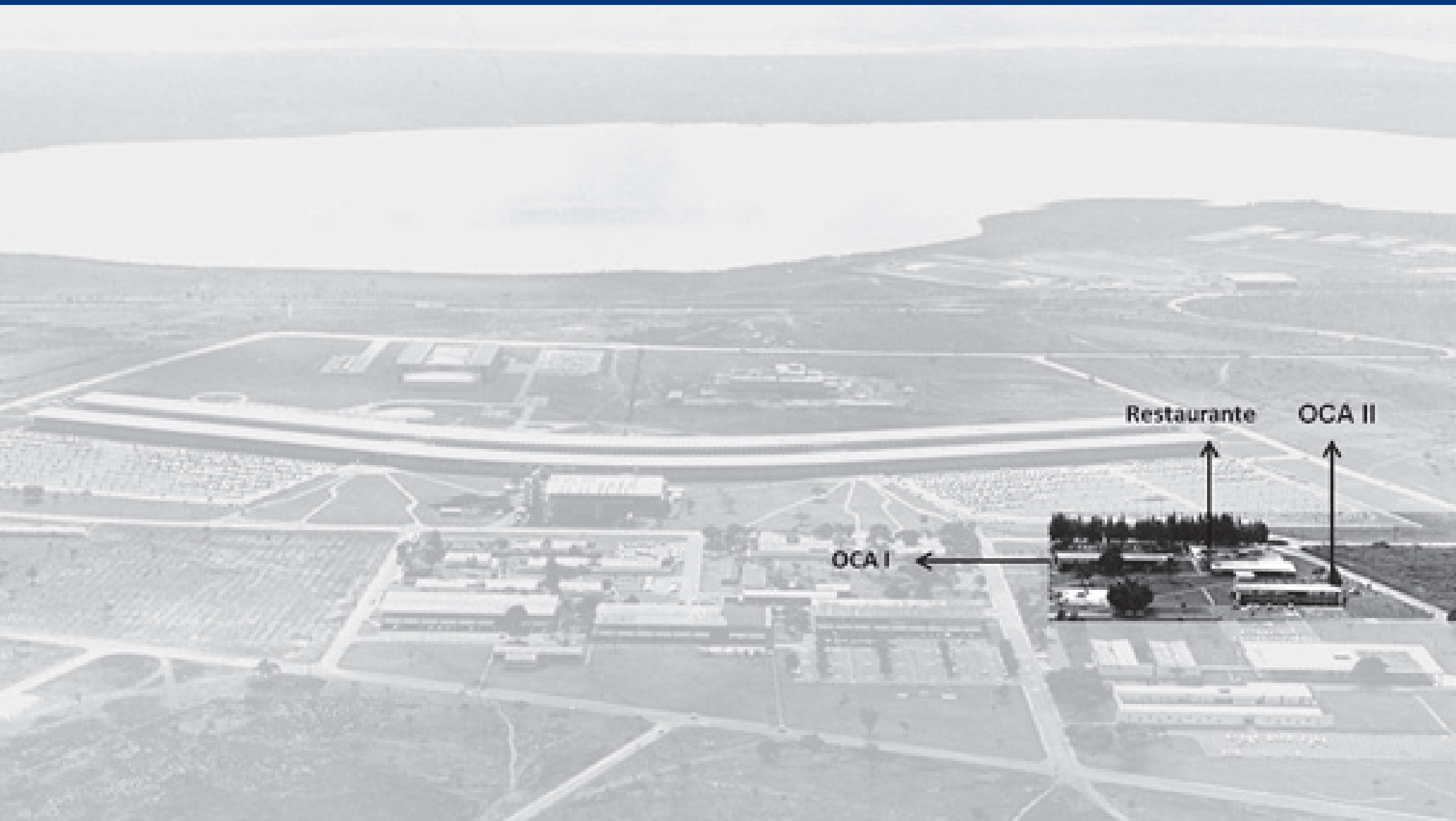

Autoria

Sérgio Rodrigues

Data

1961-1962

Área construída

OCA I = $944 \mathrm{~m}^{2} ;$ OCA II $=944 \mathrm{~m}^{2}$
Figura 52a.

Localização da

OCA I e da OCA II

no campus 
A OCA I e a OCA II' foram os primeiros edifícios do campus. Essas construções pré-moldadas de madeira (peroba), concluídas em 1962, serviram como alojamento de professores, funcionários e estudantes, e ainda para abrigar serviços comunitários e administrativos. A denominação OCA foi dada em alusão à empresa responsável pela construção. O restaurante provisório, construído, também em pré-fabricado de madeira, foi implantado na mesma área dos dois pavilhões de alojamento.

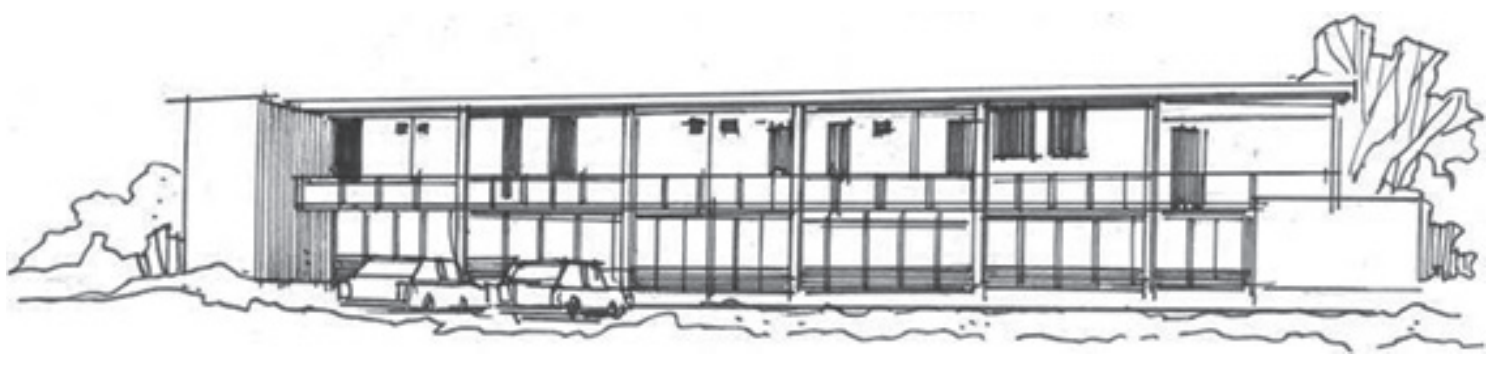

52 c.

OCA I e OCA II.

Desenho de

Eliel Américo

Santana da Silva

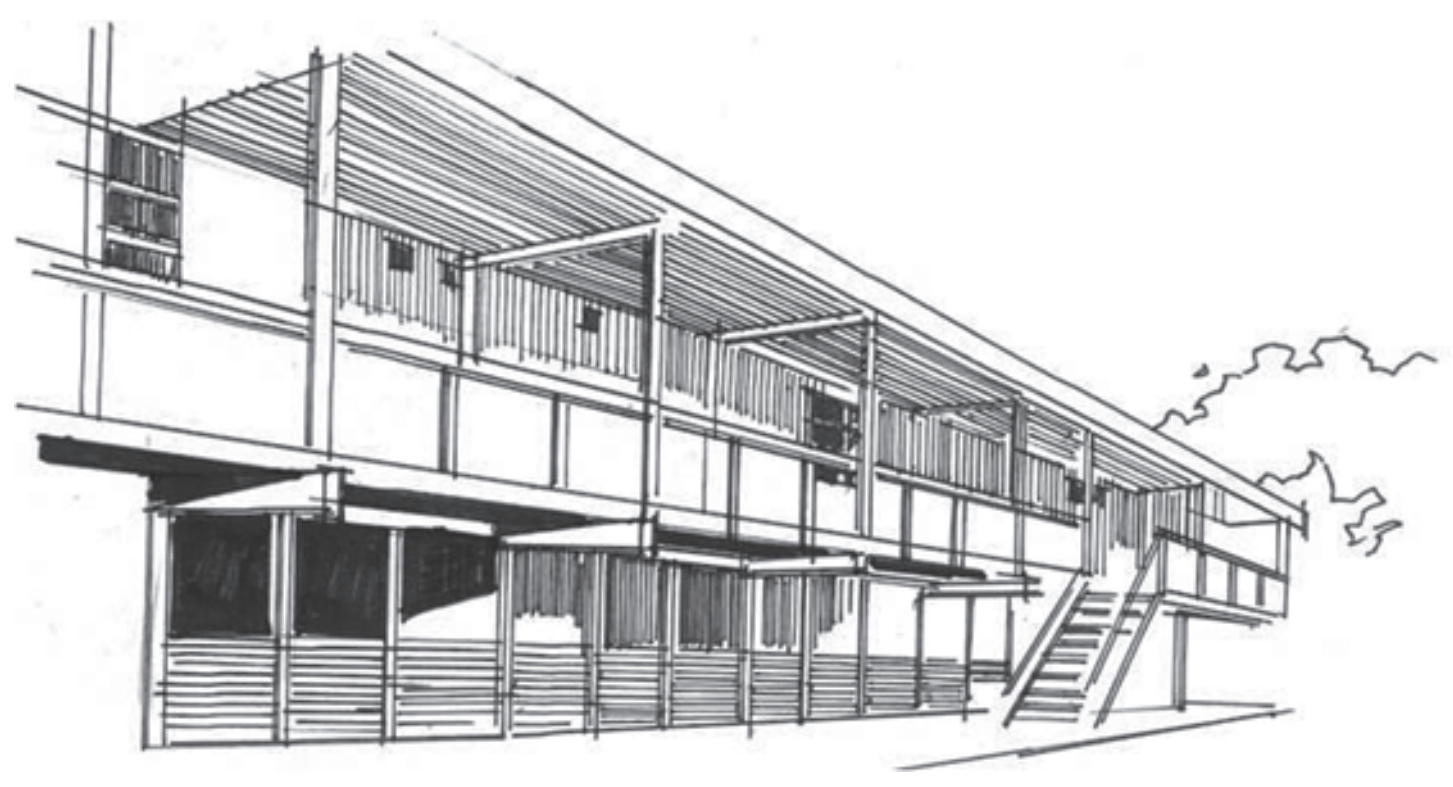

Figura 52d.

Darcy Ribeiro com autoridades

em visita ao

campus

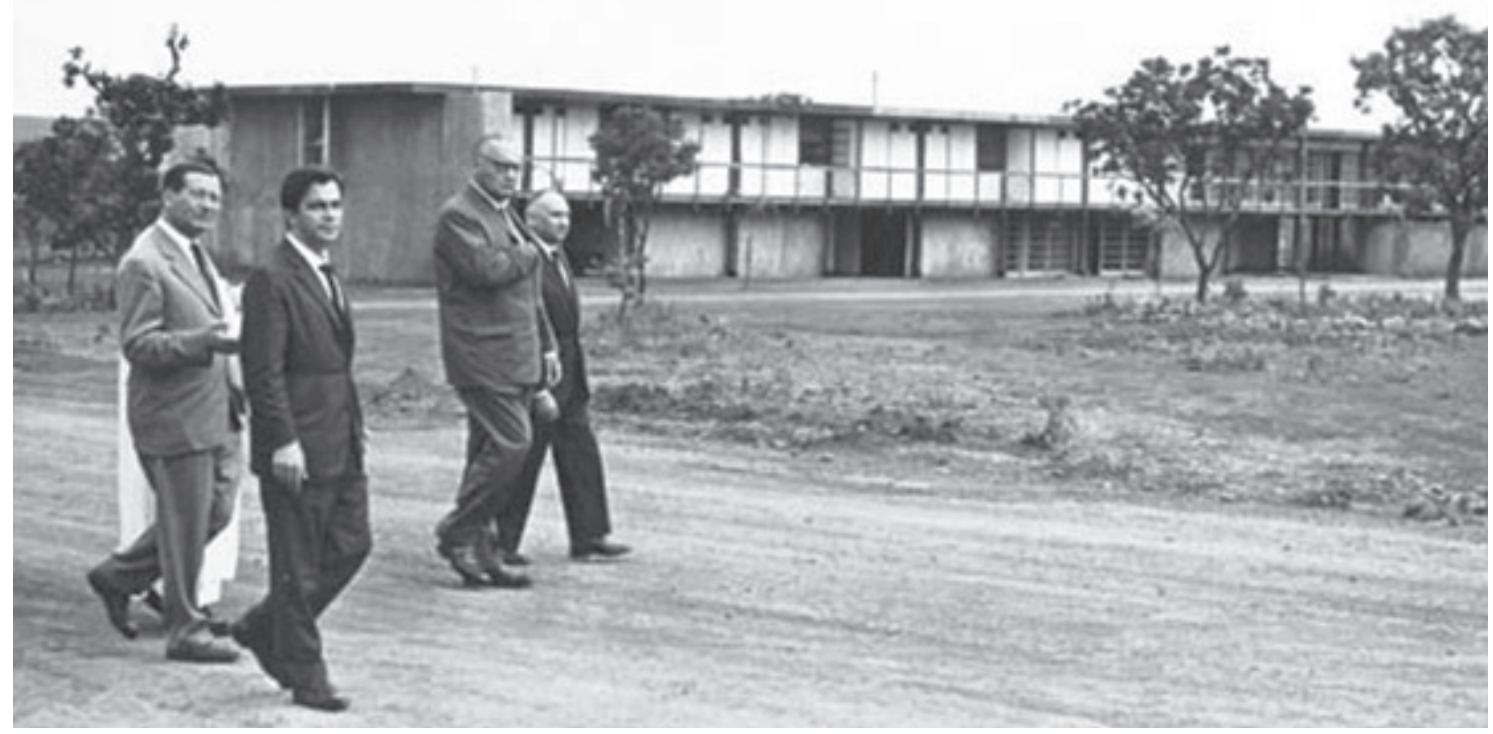

'As informações sobre datas e áreas construídas foram extraídas dos relatórios anuais de obras, contidos no documento "Arquivo sobre construções no cam- 


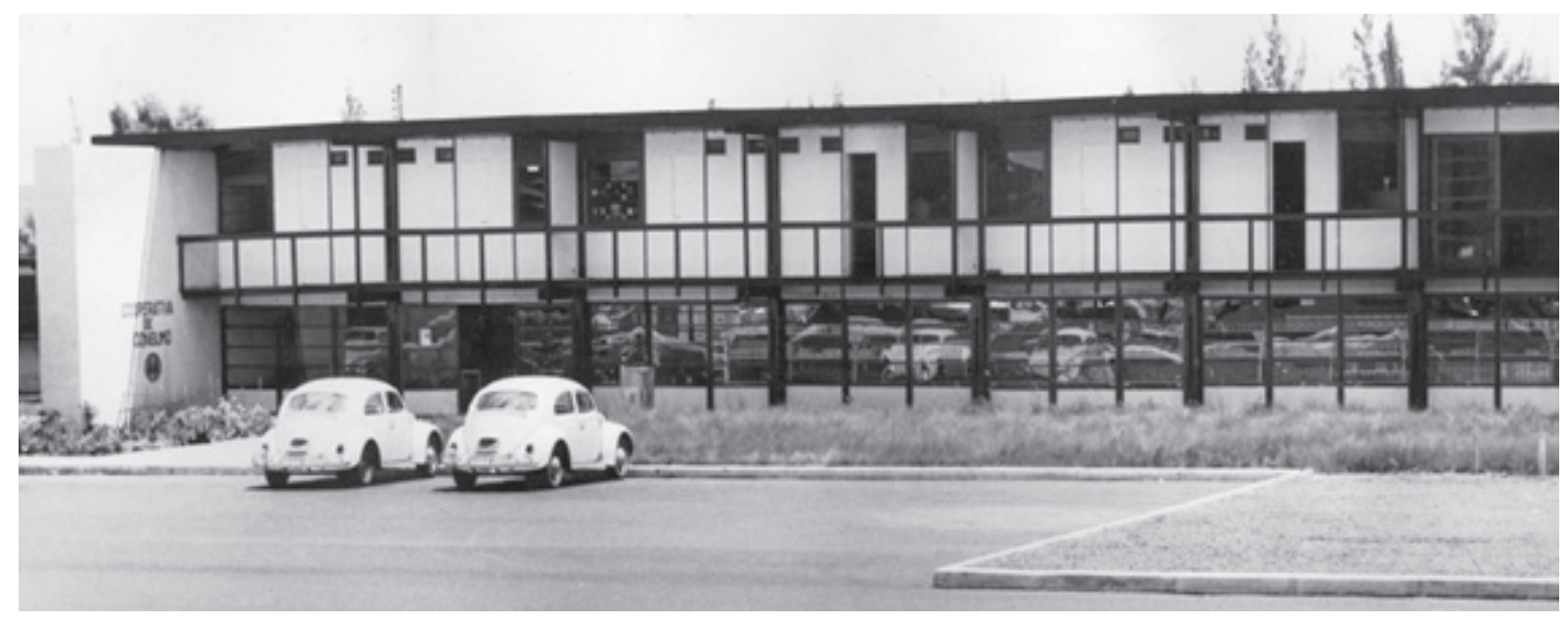

A escolha do sistema construtivo deveu-se à necessidade de abrigar rapidamente os professores que vinham construir a nova universidade.

Com empenas em alvenaria, os prédios apresentavam 12 módulos de 4,00 m; piso de tábua corrida; cobertura com telhas de zinco; e esquadrias com venezianas em chapa dobrada. As vedações consistiam em divisórias com duas foIhas de compensado de $4 \mathrm{~mm}$ ligadas por tarugos de madeira com enchimento. As vigas e os pilares, compostos por peças duplas e paralelas de $8 \times 21 \mathrm{~cm}$ de seção, formavam estruturas biapoiadas e parafusadas, semelhantes a pórticos travados entre si apenas pelo barroteamento que sustentava o piso do pavimento superior.
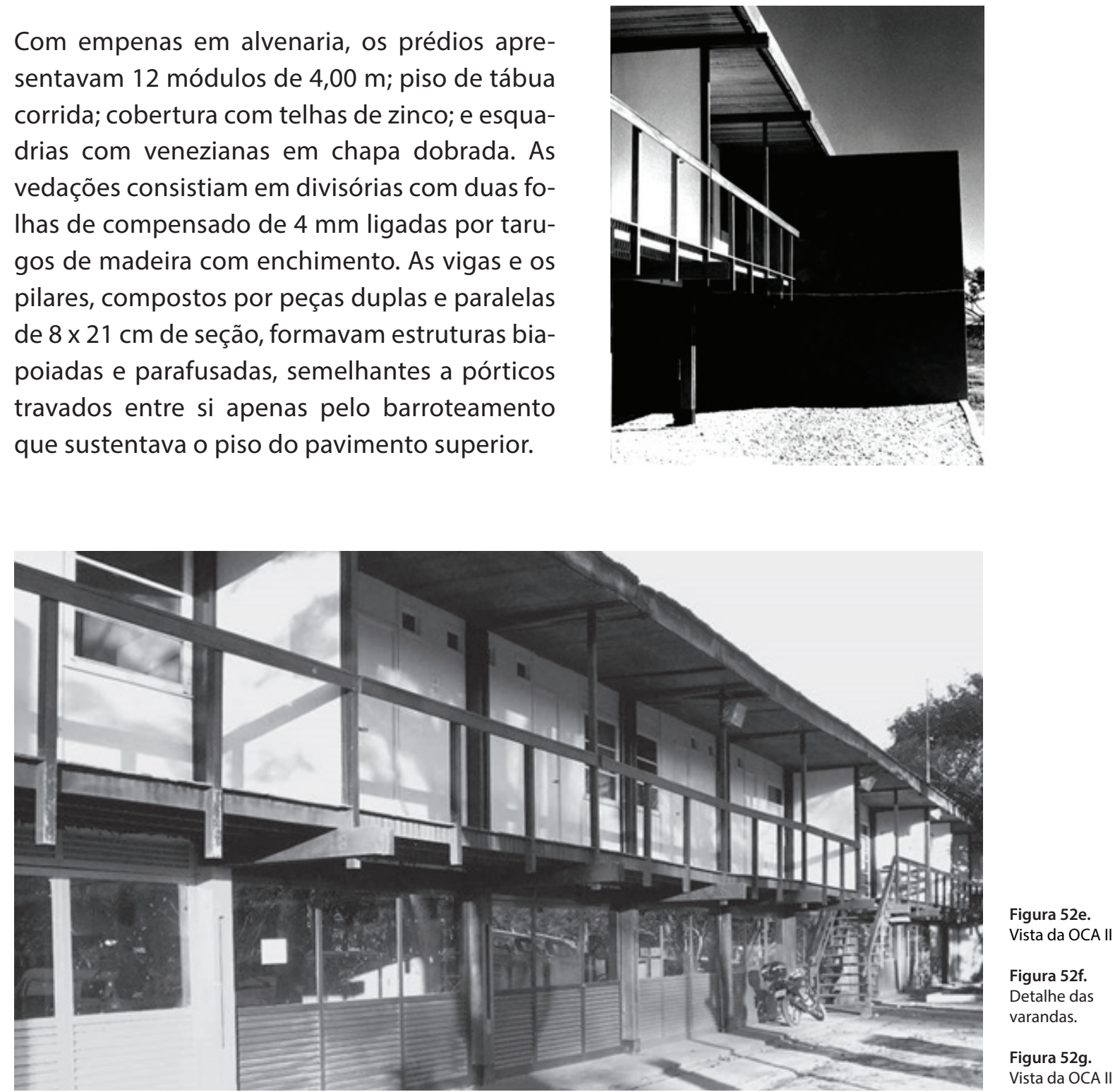


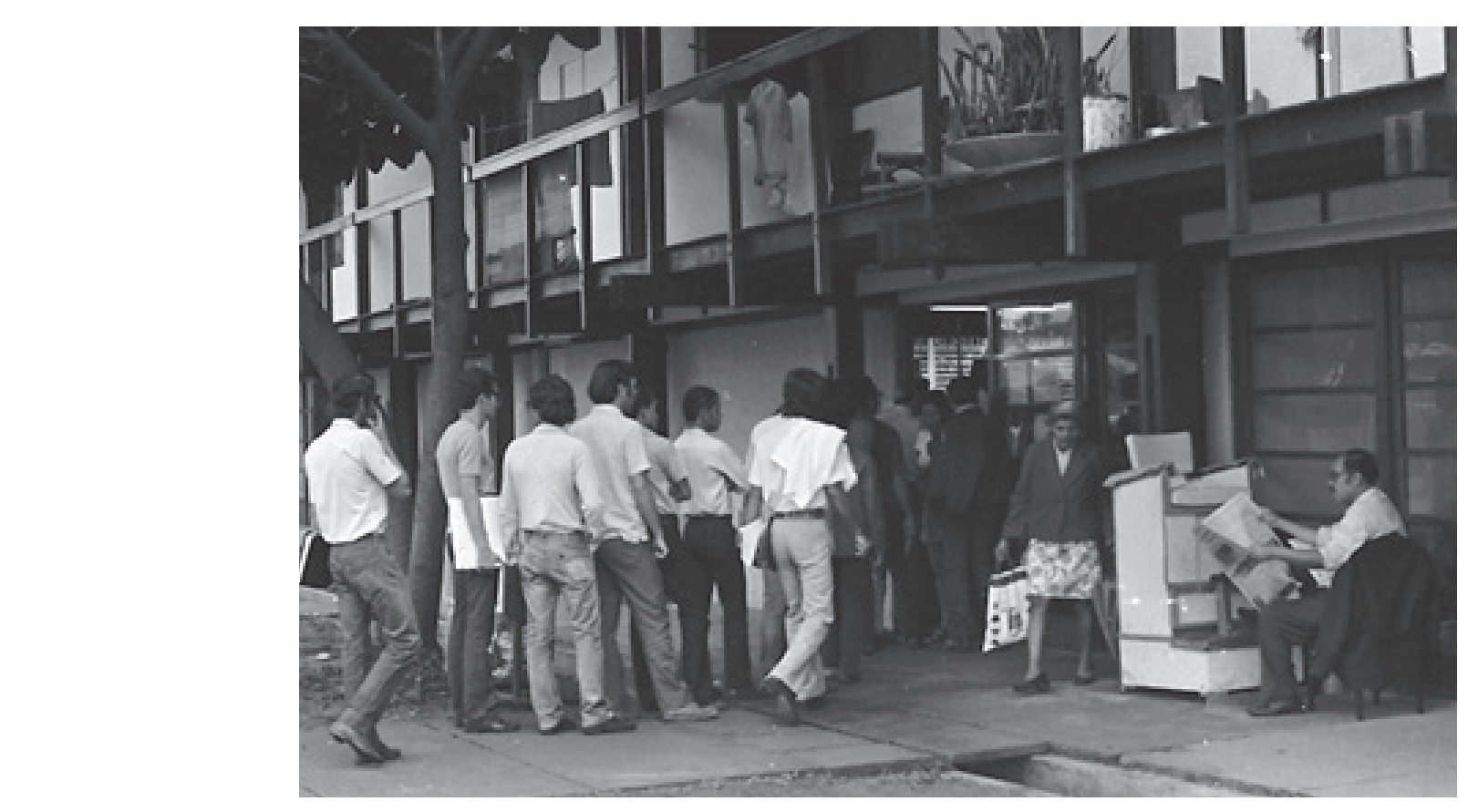

Figura 52h.

Fila para entrar no

restaurante (provisório).

Figura 52i.

Interior do restaurante.

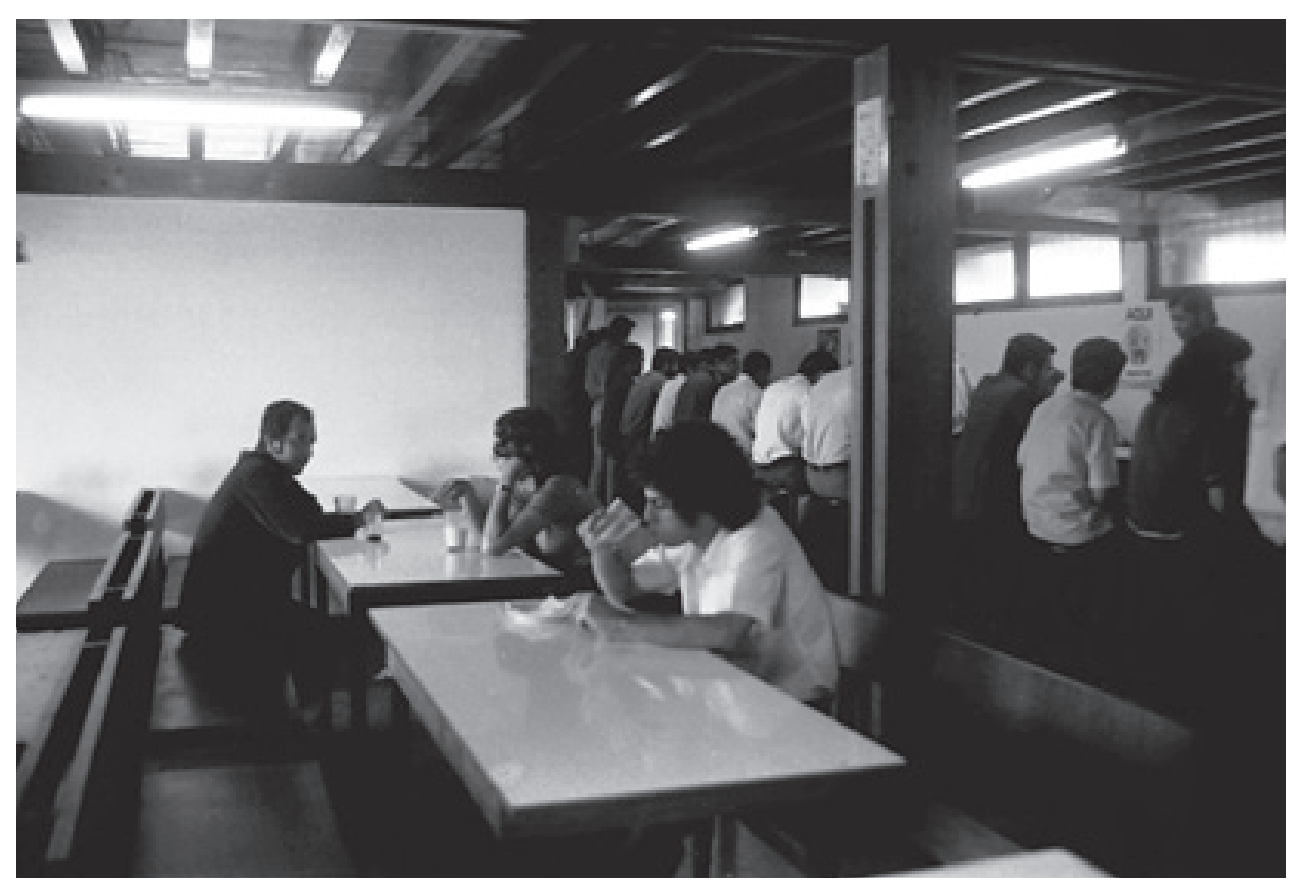

O restaurante, que funcionou provisoriamente na OCA, foi transferido para um edifício térreo, construído também com o sistema SR2. 
Pouco tempo depois, vieram os primeiros prédios definitivos...

FACULDADE DE EDUCAÇÃO (FE): FE 1, FE 3 E FE 5 
Figura 53b.

Vista aérea

das obras da Faculdade

de Educação, com a FE

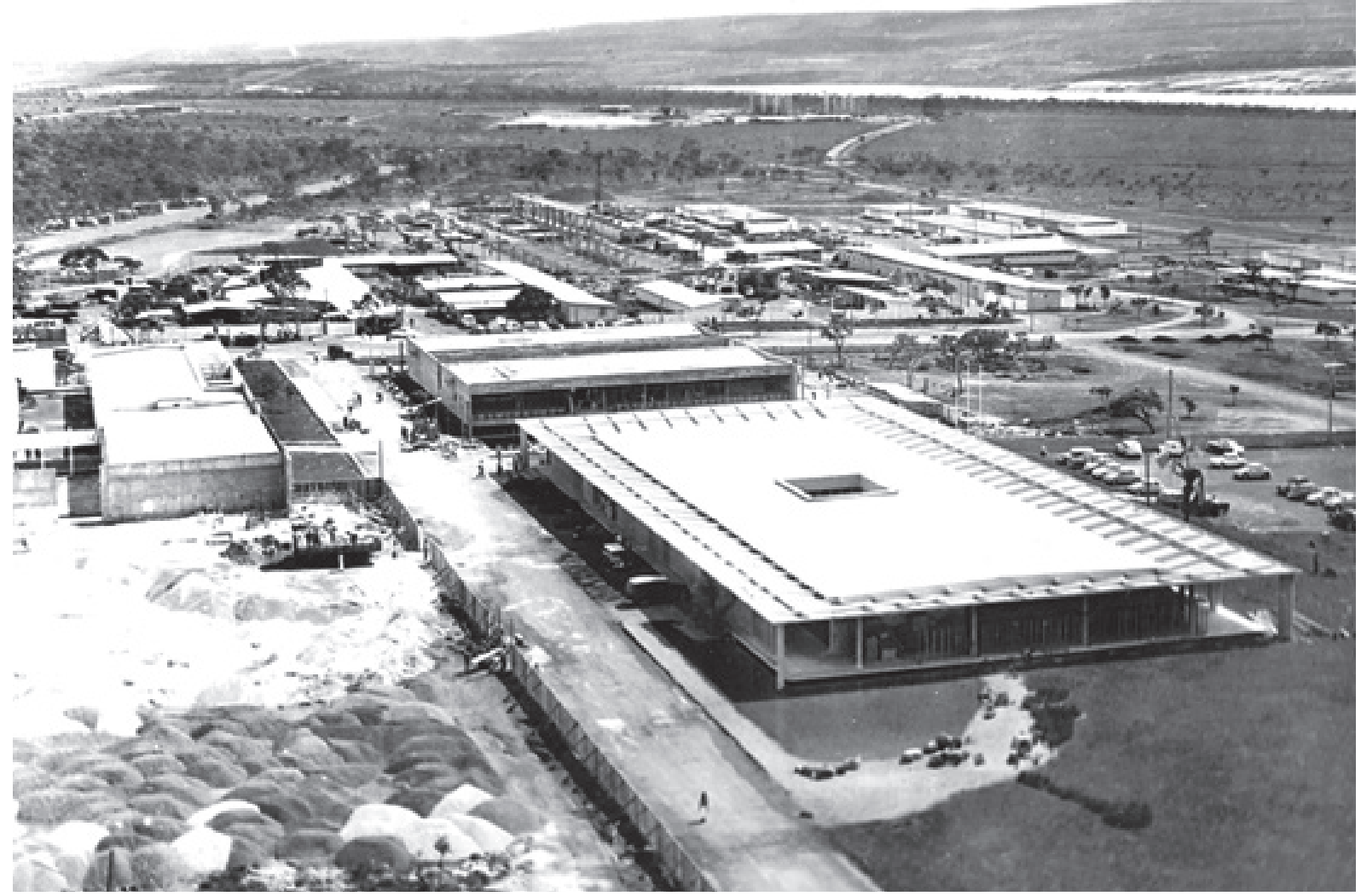

A Faculdade de Educação foi o primeiro conjunto de edificações definitivas construídas no Campus Darcy Ribeiro. E, até 1975, além das funções acadêmicas e administrativas da faculdade, abrigou a Reitoria da universidade. No bloco conhecido como FE 5 está instalado o Auditório Dois Candangos, que nos primeiros anos de vida da universidade funcionou como local dos eventos culturais e políticos. O nome foi uma homenagem os operários Expedito Xavier e Gedelmar, que faleceram durante um acidente na obra, ocorrido em 1962.

O conjunto é integrado por três blocos, sendo que o mais imponente - o FE 1 - caracteriza-se por um avarandado, que circunda todo o prédio e para o qual se voltam os espaços de salas de aulas, organizadas livremente por meio de divisórias removíveis. As demais salas de aulas e departamentos distribuem-se no interior do prédio, em torno de um pátio central. O volume é elevado em relação ao solo, o que lhe confere elegância e leveza. A estrutura é em concreto aparente, os brises

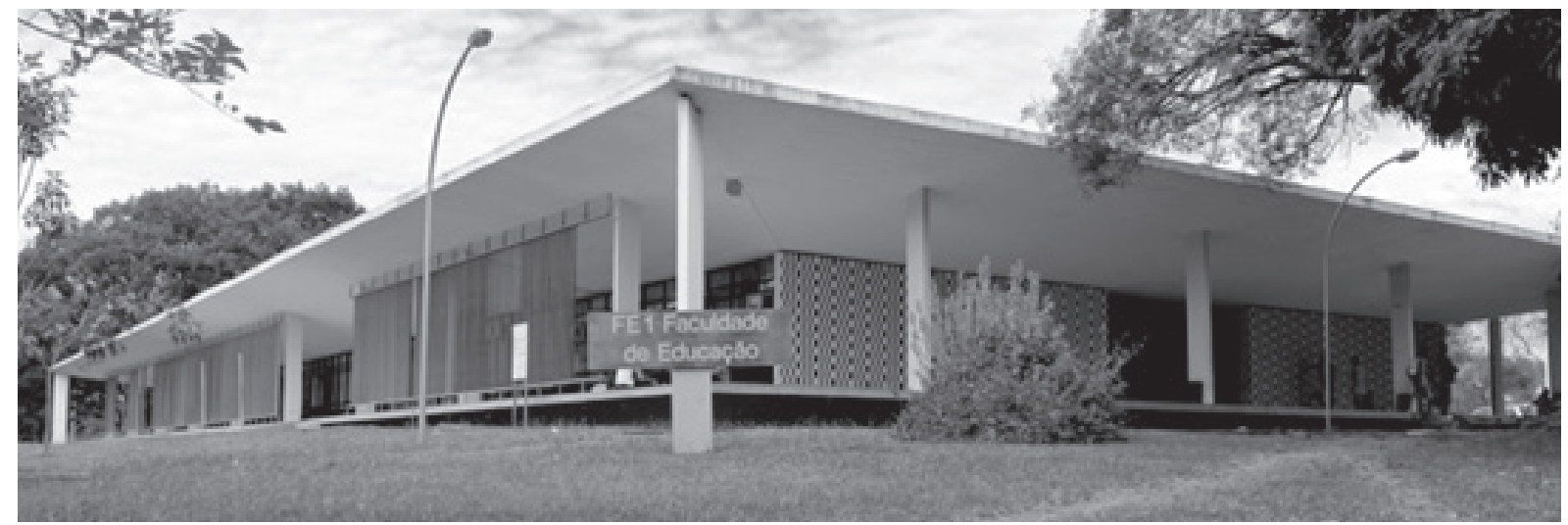



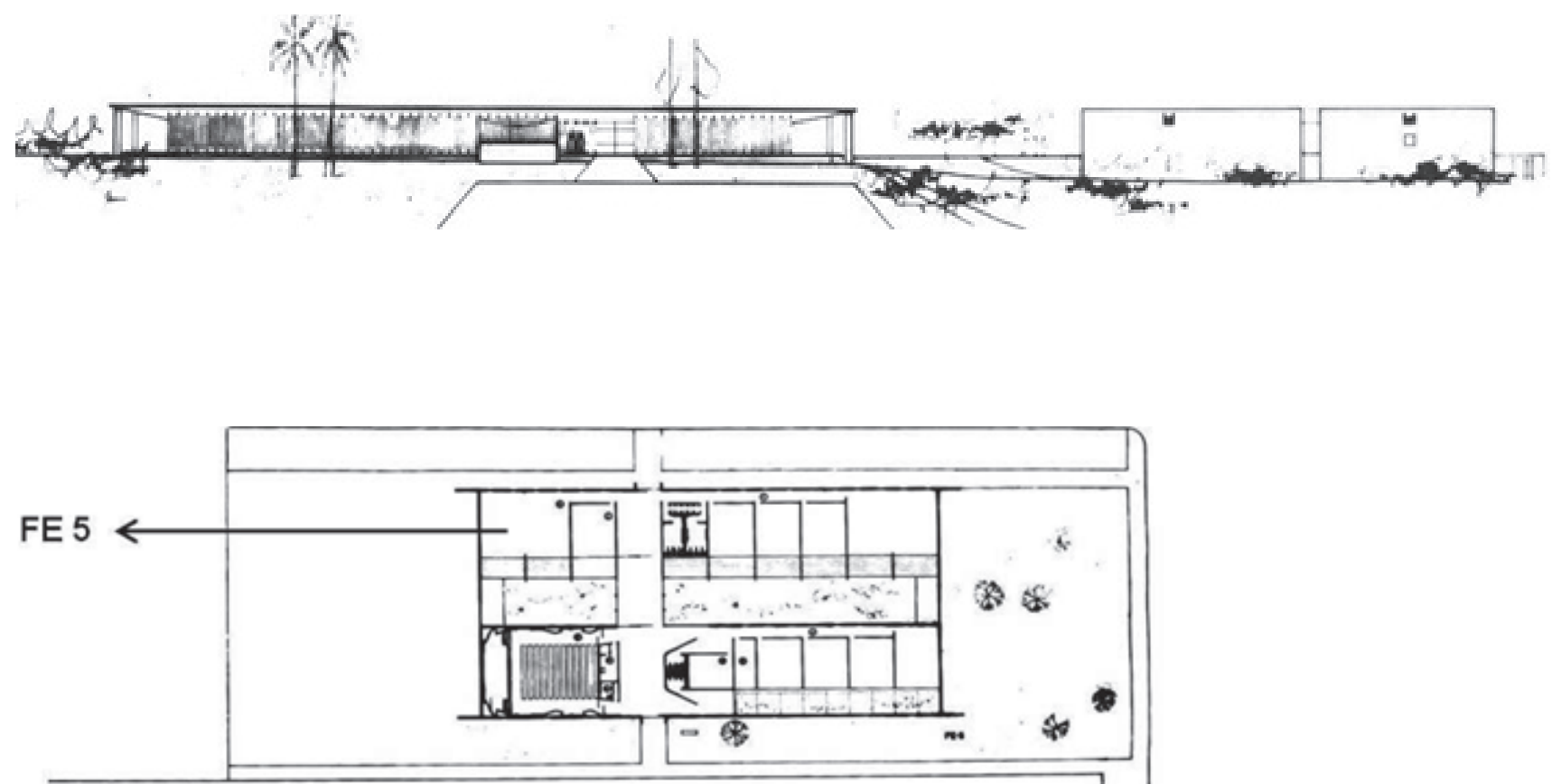

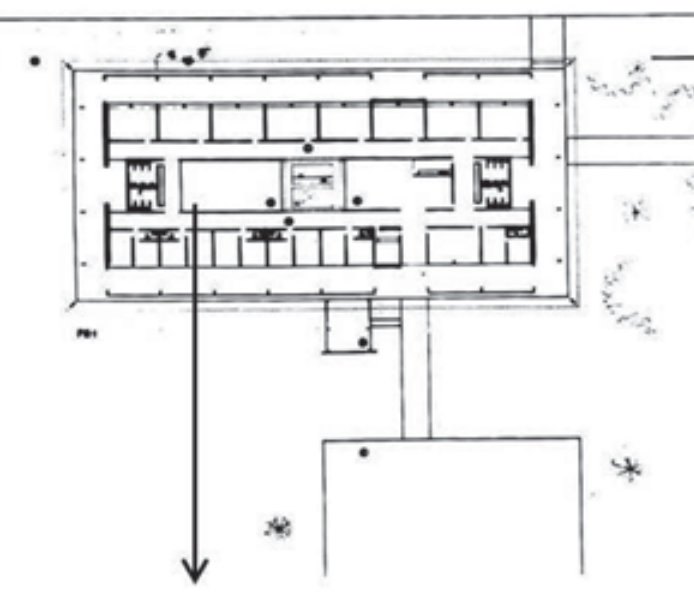

FE 1
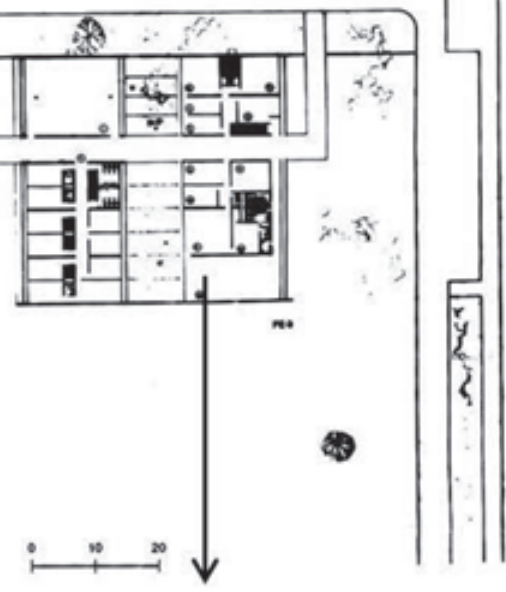

Figura 53d.

Fachada Norte - FE 1

e FE 5. Desenho de

Alcides Rocha Miranda.

Figura 53e.

Planta do conjunto

da FE.

Figura 53f.

Perspectiva da FE 1

Desenho de Eliel

Américo Santana da

FE 3

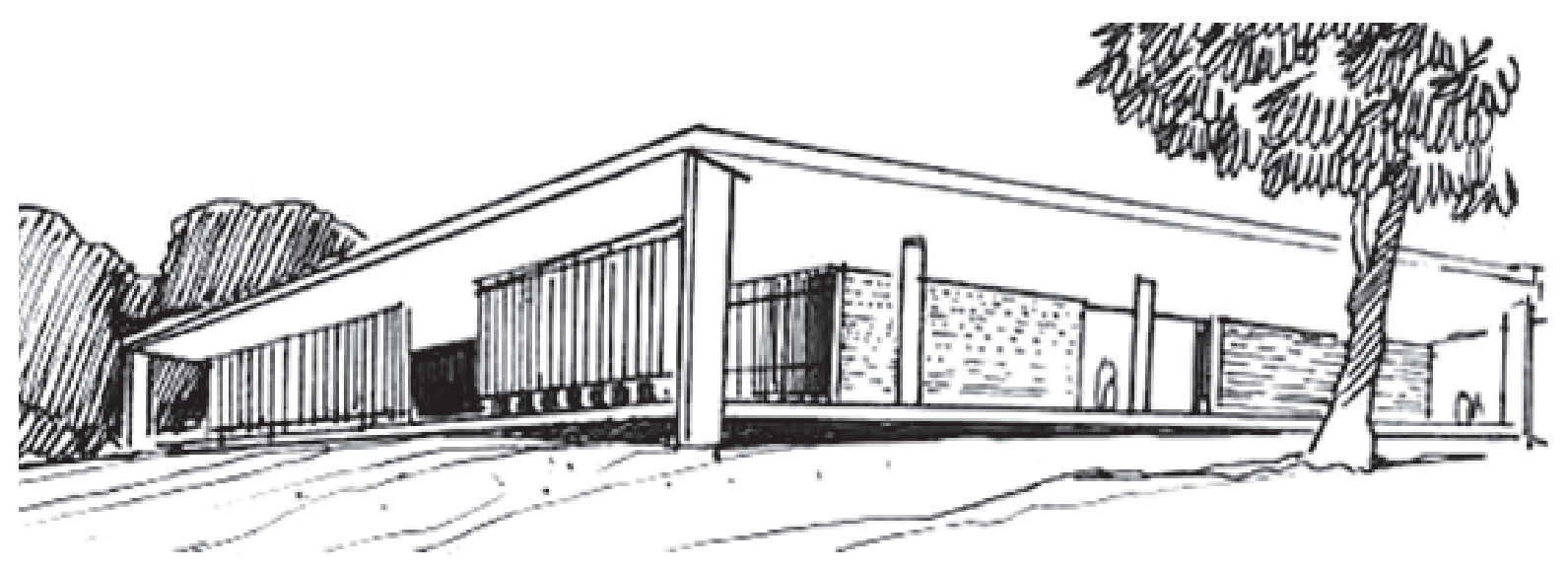



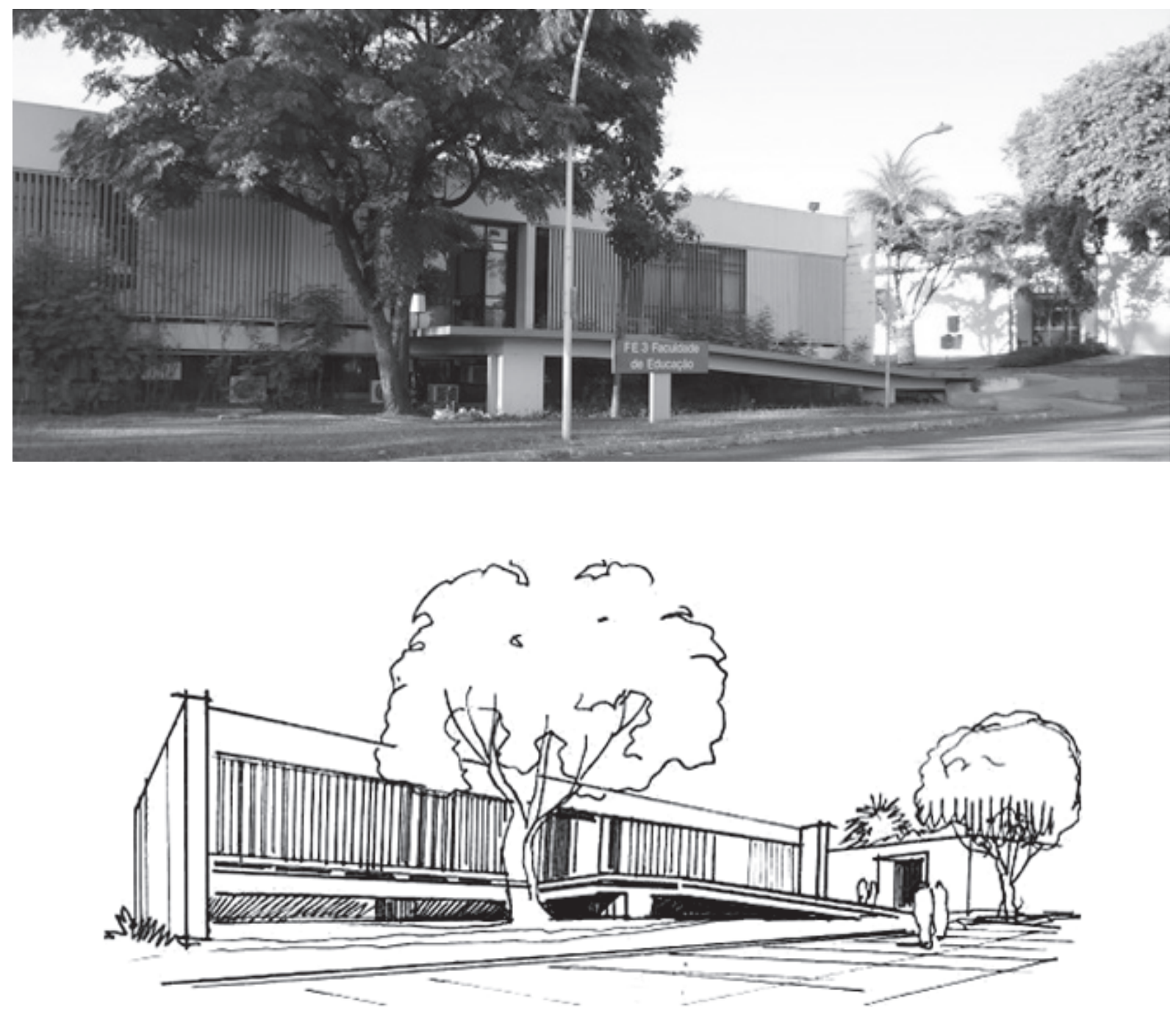

são de alumínio anodizado e as paredes cegas são protegidas por painéis murais de azulejos.

O da administração - FE 3 -, com dois pavimentos sendo um semienterrado, é fechado para o exterior e seu espaço interno é organizado em torno de um pátio coberto por um pergolado de concreto. $\mathrm{O}$ acesso ao edifício se dá através de uma rampa localizada na fachada principal, e sua

Figura 53g.

Fachada principal da FE 3

Figura 53h.

FE 3 - Desenho de Eliel Américo Santana da Silva

Figura 53i.

FE 5 - Desenho

de Eliel Américo

Santana da Silva

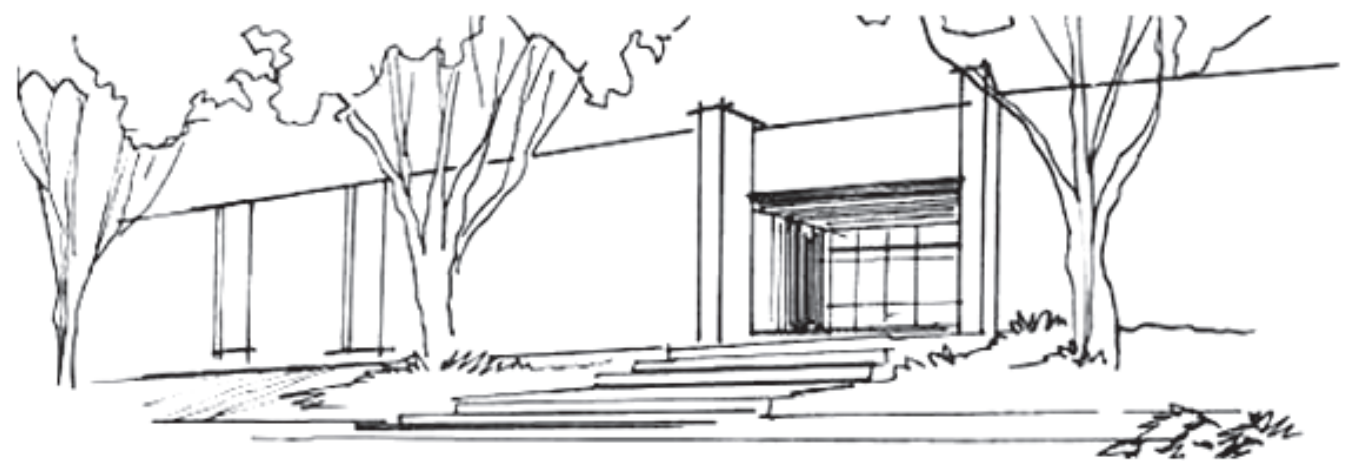



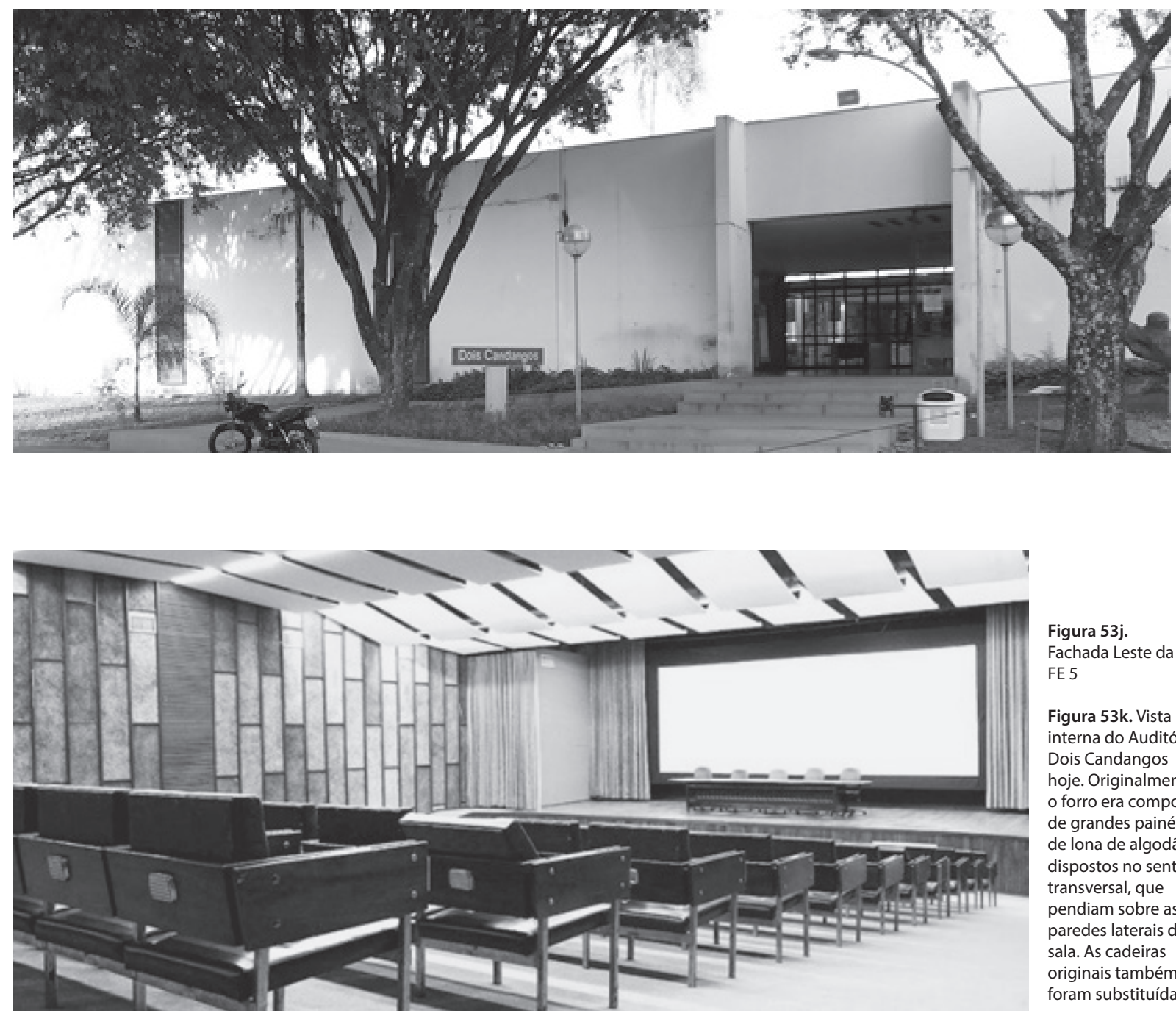

Figura 53j.

Fachada Leste da FE 5

Figura 53k. Vista interna do Auditório Dois Candangos hoje. Originalmente, o forro era composto de grandes painéis de lona de algodão, dispostos no sentido transversal, que pendiam sobre as paredes laterais da sala. As cadeiras originais também foram substituídas

ligação com o bloco FE 1 é feita por uma passarela .

O de salas multiuso e laboratórios - FE 5 -, que abriga o Auditório Dois Candangos, com capacidade para 250 pessoas, é formado por alas intercaladas por jardins cobertos por pergolados.

Sobre o Auditório Dois Candangos, assim se manifestou Luis Humberto: "Para resolver o forro, o Alcides colocou uns tecidos no teto. Hoje, já foi substituído. Estive lá outro dia, o que me incomoda muito, porque volta tudo na memória" (Entrevista em 26 jan. 2012). E Marcelo Mari (2014), do Departamento de História da Arte, reiterou: “Toda a UnB passou por um processo muito duro, principalmente nos anos de governo militar. Muita coisa foi descartada ou simplesmente substituída, como as poltronas do Auditório Dois Candangos. A UnB não cuidou do seu patrimônio".

Outra característica marcante dos edifícios construídos em Brasília nessa época foi a presença das artes - pinturas, esculturas, relevos etc. - integradas à arquitetura. $\mathrm{O}$ conjunto da Faculdade de Educação, que não fugiu a essa regra, tem duas esculturas em bronze: o "Monumento à cultura nacional" (1965), de Bruno Giorgi, na área externa do bloco de aulas, e a "Índia Bartira" (1952), de Victor Brecheret, na entrada do Auditório Dois Candangos, além dos murais de azulejo, nas cores azul e branca, de autoria de Luis Humberto Martins. 

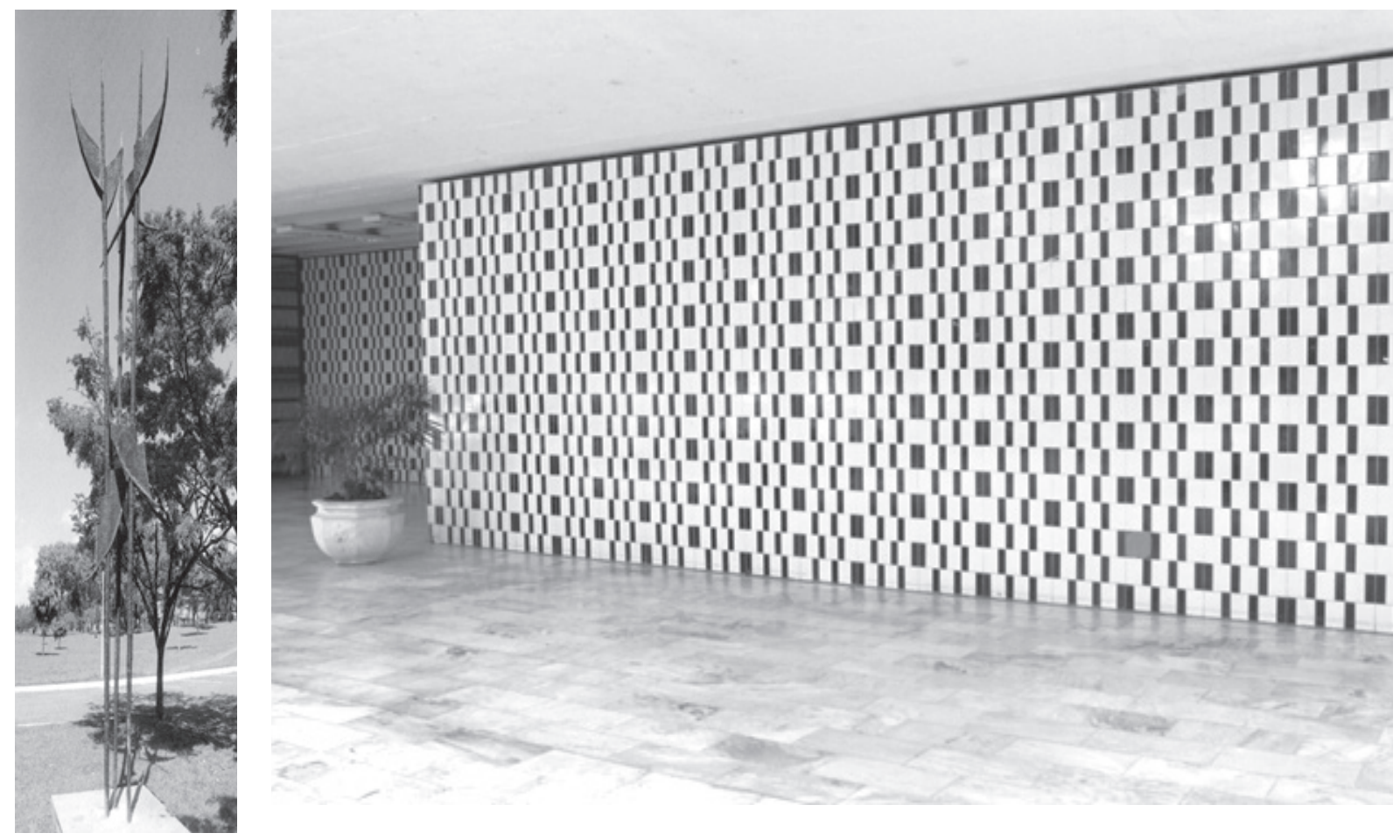

Figura 53l.

Monumento à Cultura

Nacional, Bruno Giorgi,

1965.

Figura $53 \mathrm{~m}$

Mural de azulejos

de autoria de Luiz

Humberto Martins,

1961.

Figura 53n.

Índia Bartira, Victor

Brecheret, 1952.

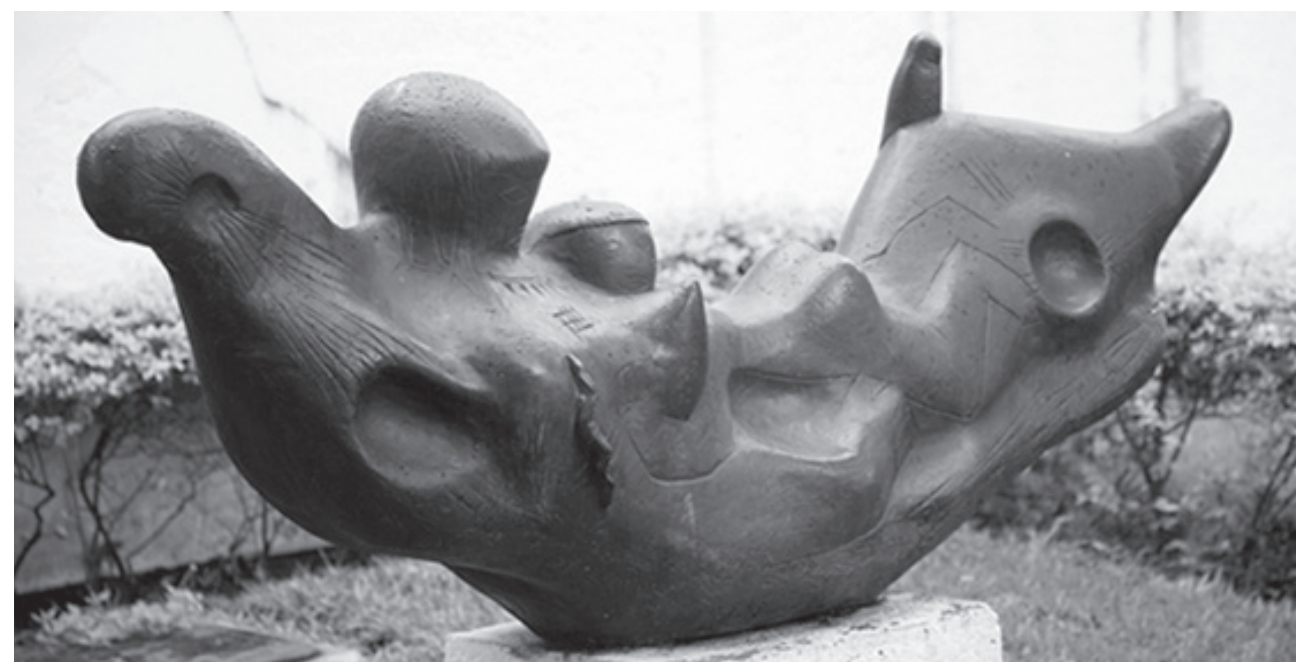


Depois, uma experiência em pré-fabricado que não foi levada adiante.

PROTÓTIPO
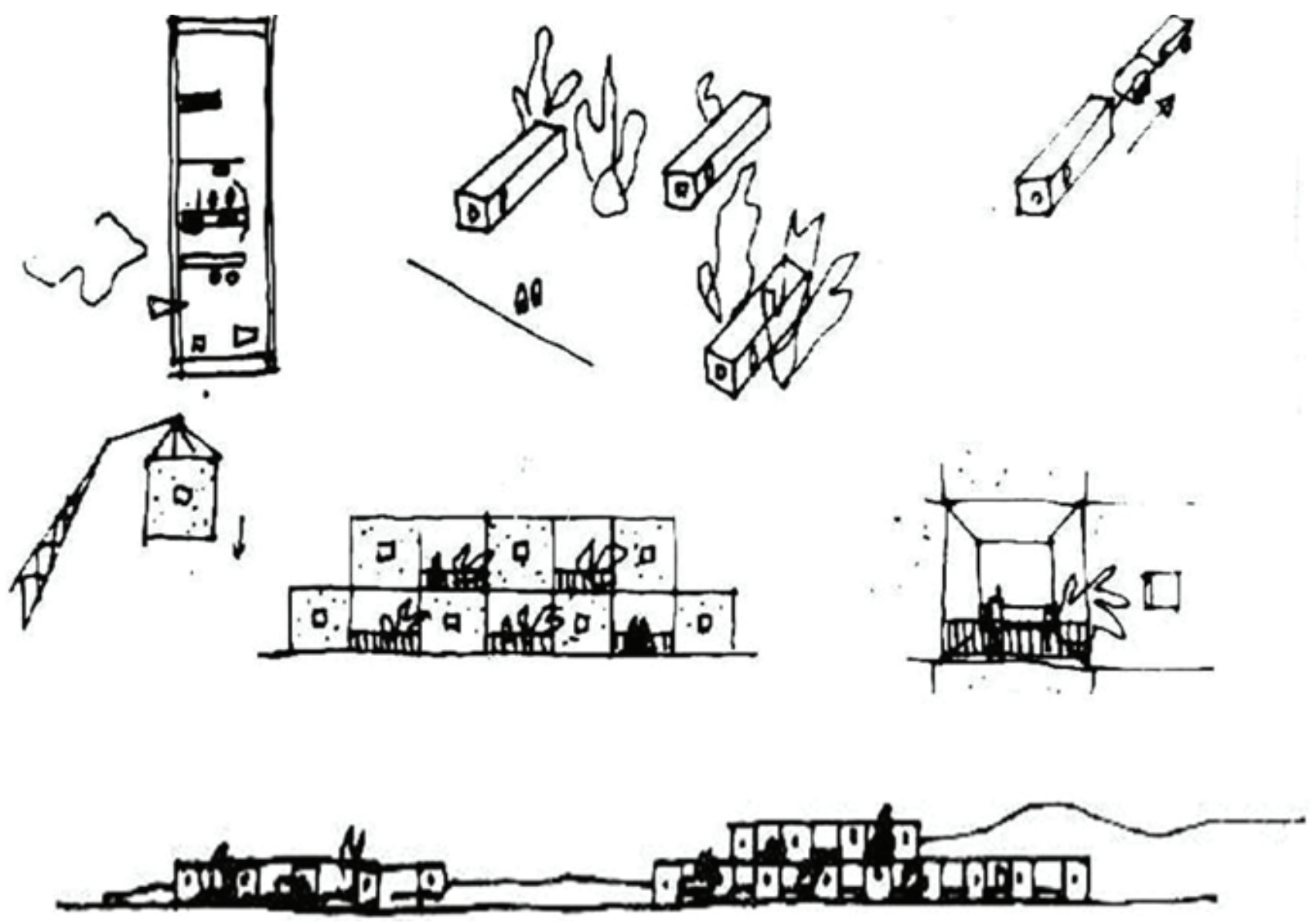

Autoria

Oscar Niemeyer

Data

1962

Área construída

$47 \mathrm{~m}^{2}$
Figura 54a.

Estudos para o

protótipo, 1962,

Oscar Niemeyer 

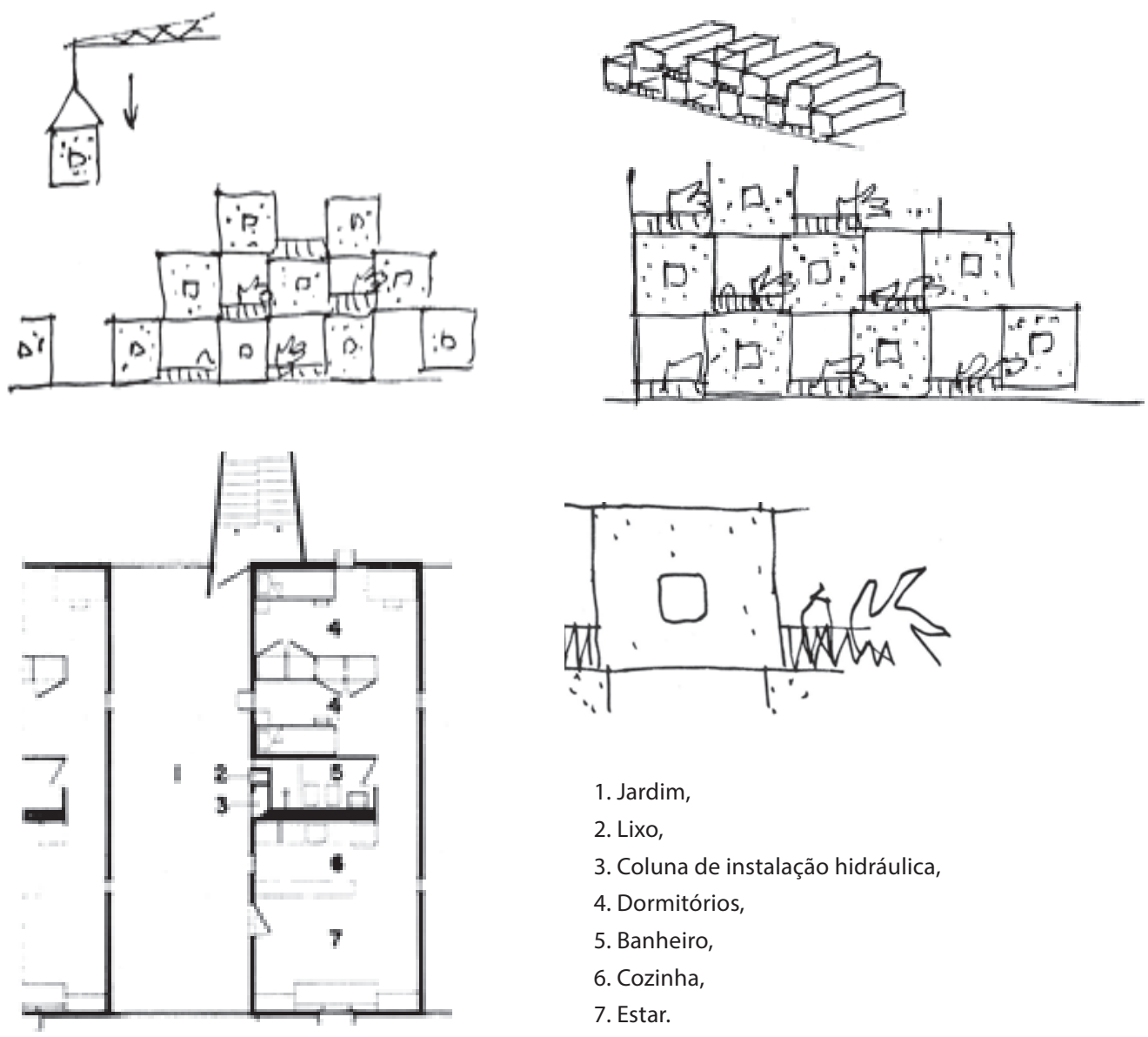

O protótipo, ou módulo, foi configurado como uma espécie de container de concreto, que poderia se tornar uma habitação individual, ou coletiva, por meio da sobreposição das unidades em 2, 3 ou 4 pavimentos. A alternância dos módulos permitiria inúmeras possibilidades de arranjo volumétrico, podendo existir entre eles um jardim para cada célula residencial.

A célula habitacional, com 42 toneladas, foi dividida em dois ambientes de 4,50 x 4,00 m2 cada, sendo um destinado à cozinha e ao estar, e o outro aos dormitórios. Entre esses ambientes, localizou-se o núcleo sanitário. As instalações hidráulicas foram concentradas na parede divisória entre o banheiro e a cozinha. Escadas moduladas, também pré-fabricadas, permitiriam o acesso aos pavimentos superiores.

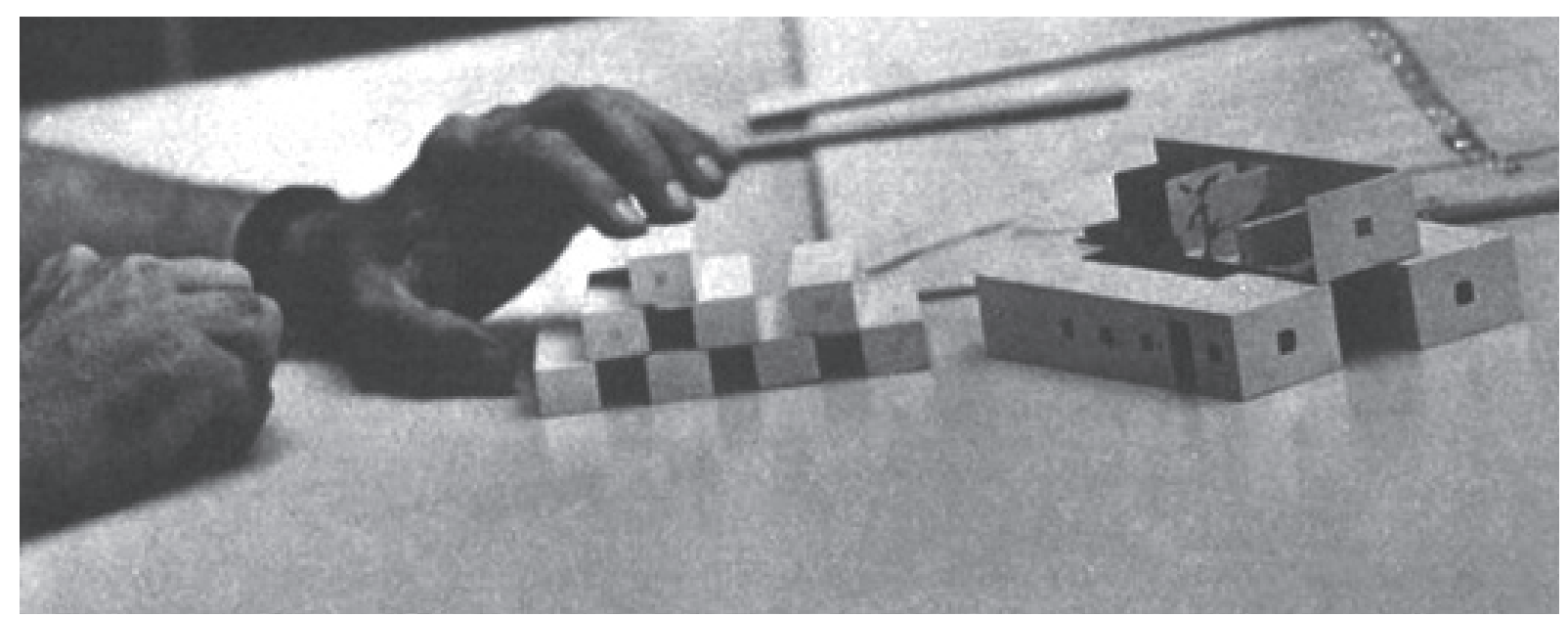



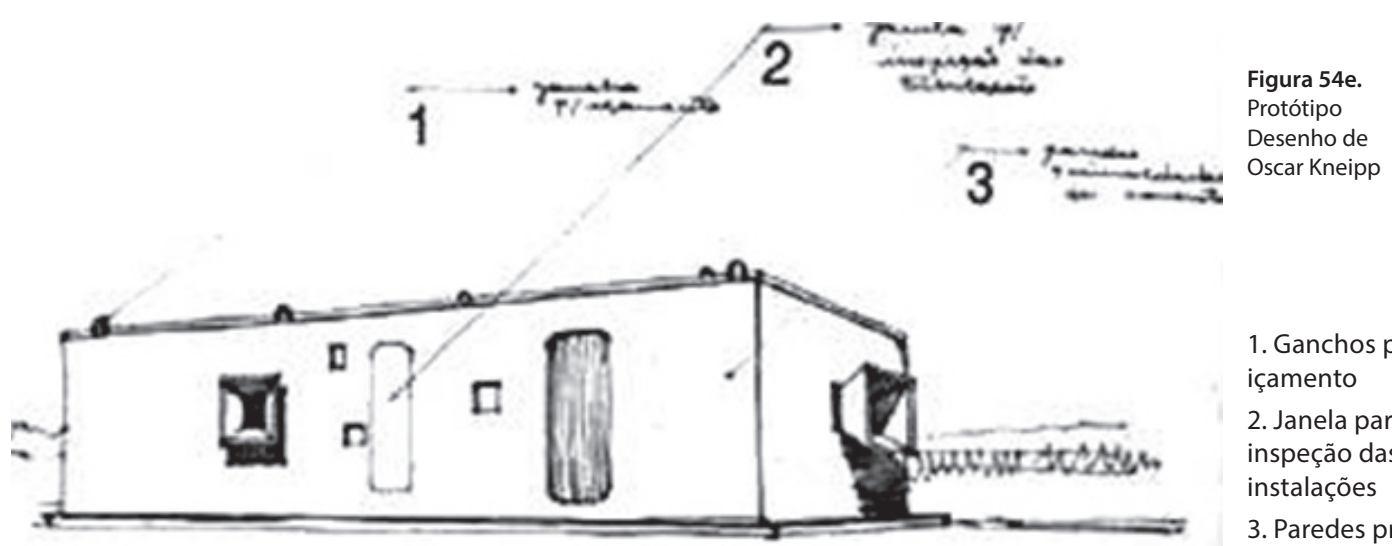

1. Ganchos para içamento

2. Janela para inspeção das instalações

3. Paredes prémoldadas de concreto.

Como resultado dessa proposta foi construído um único protótipo, já que a construção de mais unidades dependia de uma usina de pré-moldados que não chegou a ser implantada.

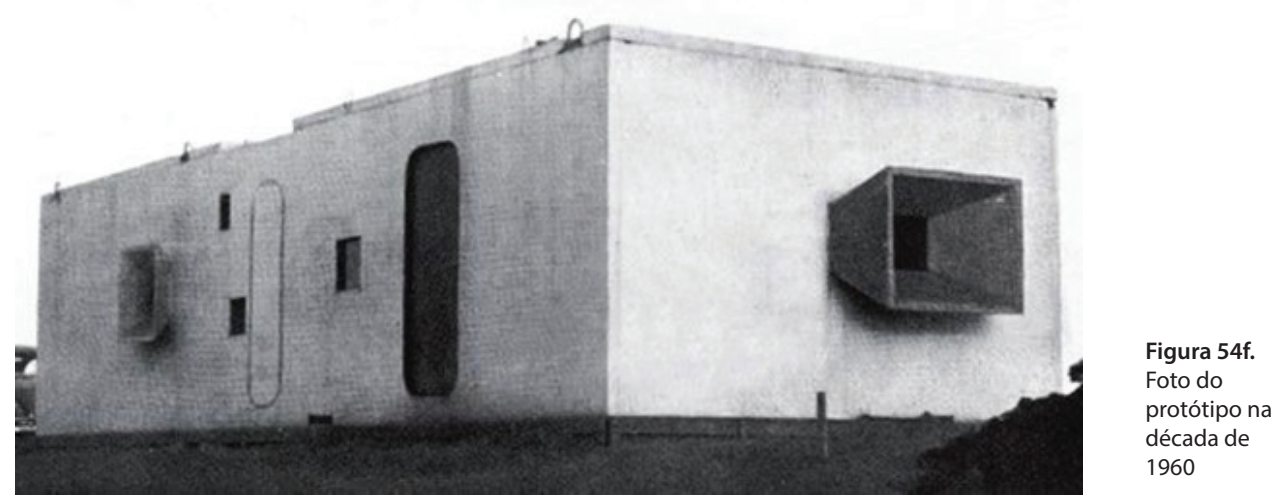

Localizado no atual estacionamento sul do Instituto Central de Ciências (ICC), o protótipo, ou casinha, como foi apelidado na década de 1960 por ter servido, durante um tempo, como moradia para estudantes, foi sapataria e barbearia, e hoje abriga a Barbearia do Chico e uma copiadora.
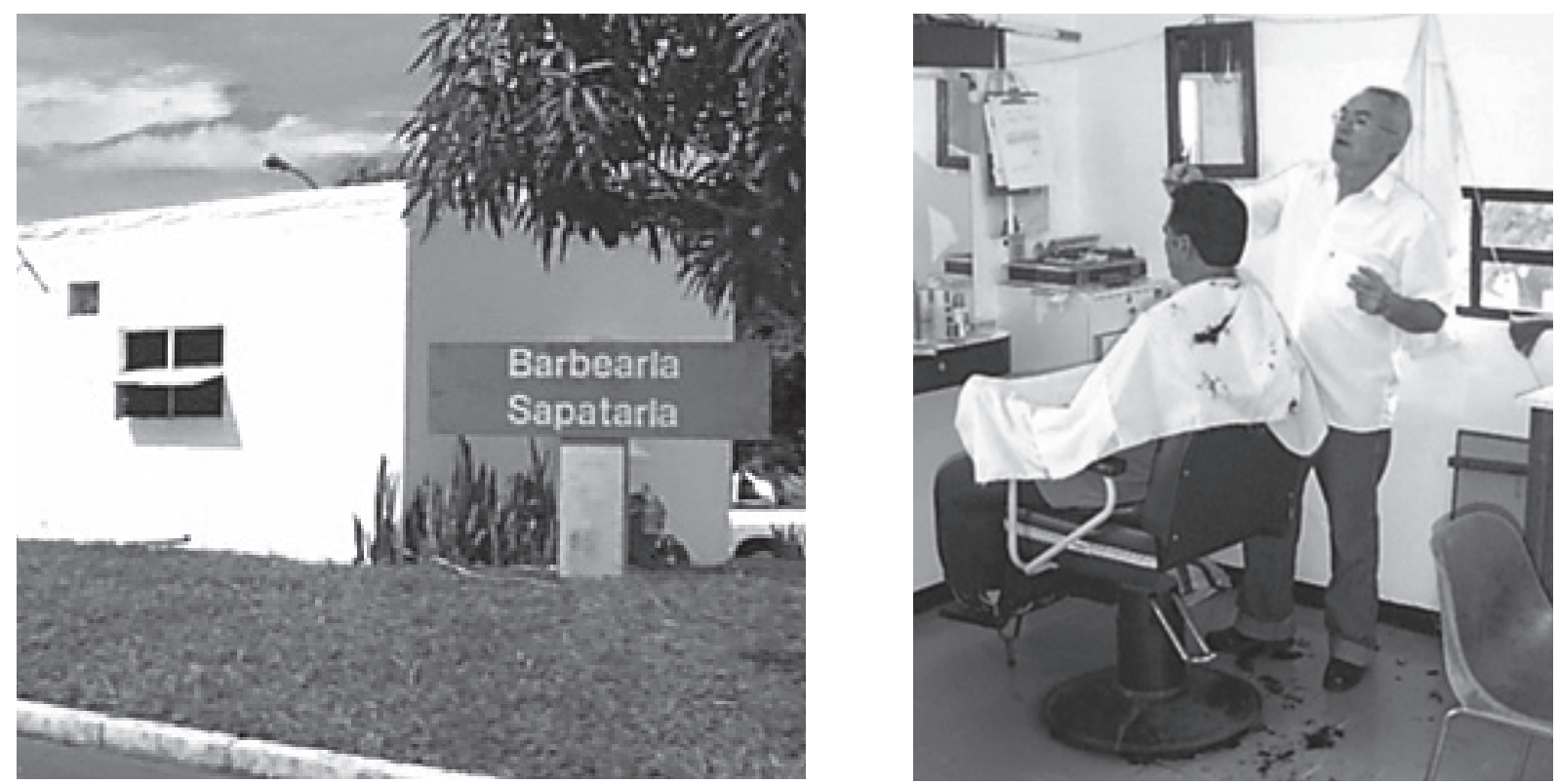

Figura 54g.

Sapataria em

funcionamento

Figura 54h.

Barbearia do

Chico 
Vieram, então, os primeiros edifícios feitos com a técnica da pré-fabricação em concreto armado.

SERVIÇOS GERAIS - SG1, SG2, SG4, SG8 e SG10

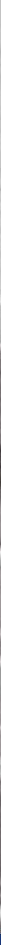

6010

Autoria

Oscar Niemeyer, com a colaboração de João da Gama Filgueiras Lima, responsável também pelo design das cadeiras do Auditório da Música. O paisagismo original do conjunto é de Alda Rabelo. Os móveis e as cadeiras originais do auditório do SG10 foram desenhados pelo arquiteto pernambucano Glauco de Oliveira Campello.

Data

1962-1963

Área construída

SG1 $-2.700 m^{2}$, SG2 $-1.010 m^{2}$, SG $4-960 m^{2}$, SG $8-960 m^{2}$, SG10 $-1.130^{2}$
Figura 55a.

Implantação

dos SGs de um

pavimento 
Inicialmente pensados para atividades de Serviços Gerais, esses galpões foram construídos logo após o conjunto da Faculdade de Educação (FE) e antes dos SGs de dois pavimentos.

O SG1 passou a abrigar o Instituto Central de Artes (ICA), hoje Instituto de Artes (IdA); o SG2, o Departamento de Música; o SG4, a Faculdade de Arquitetura e Urbanismo, e hoje ocupado também pelo Departamento de Música; o SG8, o Auditório da Música; e o SG10, o primeiro a ser concluído, parcialmente pelo Centro de Planejamento (Ceplan) e por outras atividades diversas. Atualmente parte do SG10 está ocupada pelo Centro de Dança da UnB.

Para que fosse concluído em tempo recorde, o sistema adotado é composto apenas de duas peças: painéis-parede em " $U$ " (1 $\mathrm{m} \times 3 \mathrm{~m})$ nas fachadas e vigas pré-moldadas protendidas (seção de 0,12 $\mathrm{m} \times 0,40 \mathrm{~m}$ ) na cobertura, sendo estas as primeiras peças em pré-moldado protendido feitas no Brasil. $O$ encontro das nervuras laterais dos painéis forma um volume que cumpre o papel de pilar. As vigas, moduladas pelos painéis-parede, apoiam-se nesses "pilares".

Os espaços internos são totalmente flexíveis, delimitados apenas por divisórias feitas com montantes de chapas de aço dobradas e painéis de compensado ou vidro. As faces que se abrem para os jardins internos são protegidas por esquadrias, fixas e móveis, de aço e vidro.

A estanqueidade da edificação é garantida por um recobrimento com uma chapa metálica fina, que preenche o espaço entre vigas, havendo, na face interna, um isolamento termoacústico.

Todos os galpões são pintados de branco, e as portas externas, venezianas de chapa de aço pintadas de vermelho colorado, são basculantes.

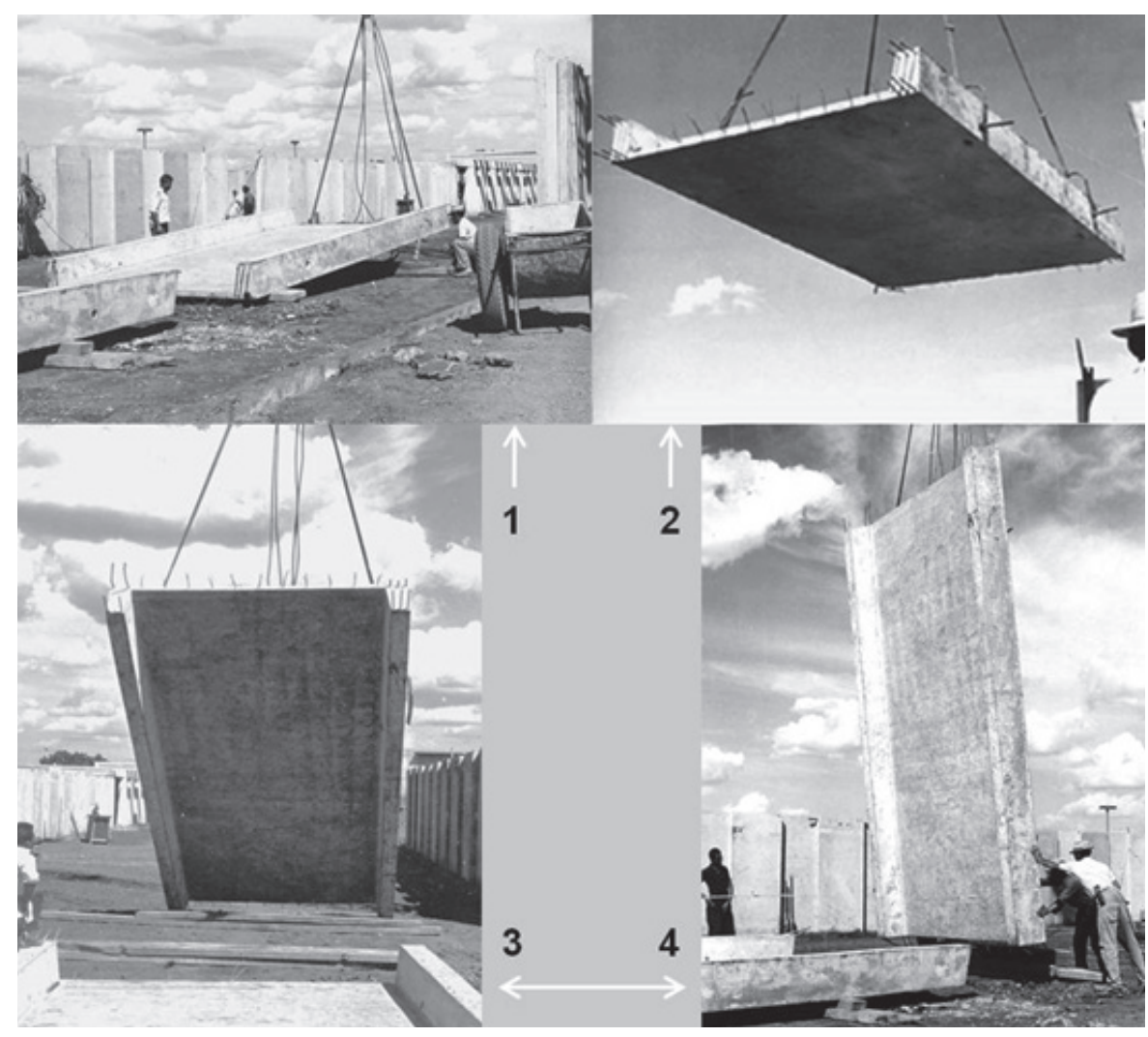

Figura 55b.

SG 1 - Sistema

de transporte do

painel-parede

Figura 55c.

Croquis do

princípio

construtivo
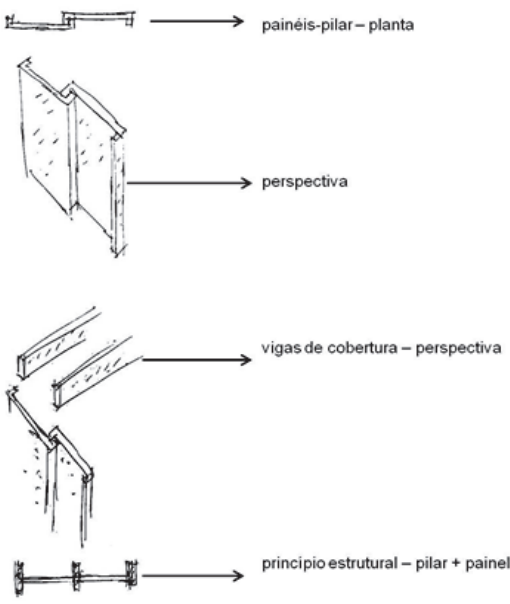

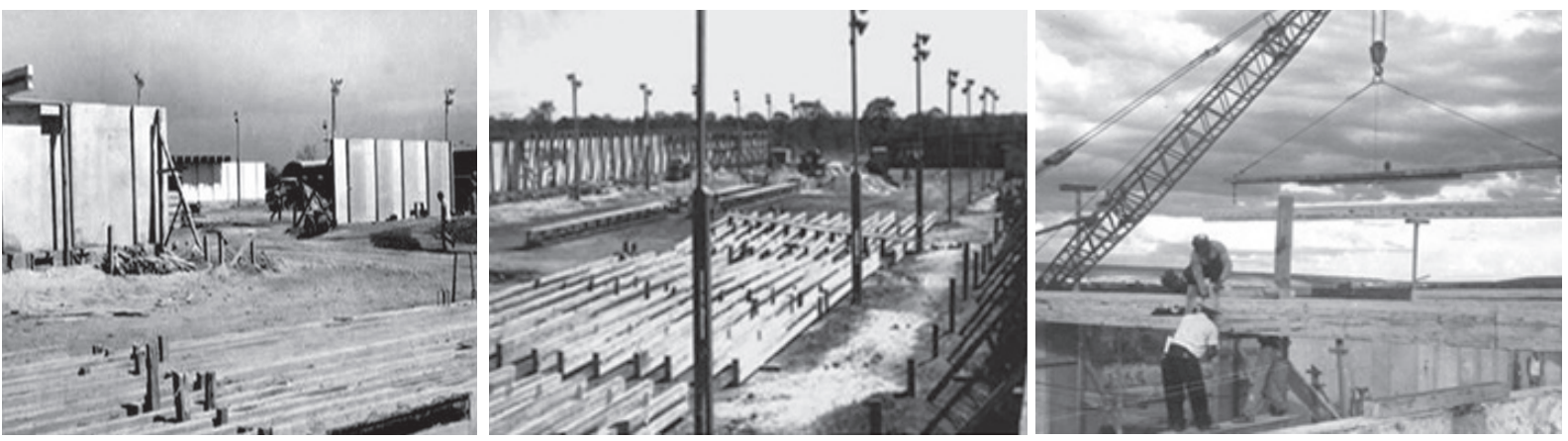

SG1 - edifício que se destaca do conjunto por ser duplo e unido por uma calha central, e pela ausência de janelas, sendo a ventilação e a iluminação asseguradas por quatro jardins internos: um em cada uma das extremidades (norte e sul) e dois a meia distância entre as extremidades e a marquise central de acesso. Disposta ao longo de todo o edifício, a calha central funciona também como elemento estrutural.

Figura 55d.

Escoramento dos painéis-parede

Figura 55e. Estoque de vigas no canteiro

Figura 55f. Montagem da cobertura

Figura 55g. Montagem da viga-calha (SG 1)

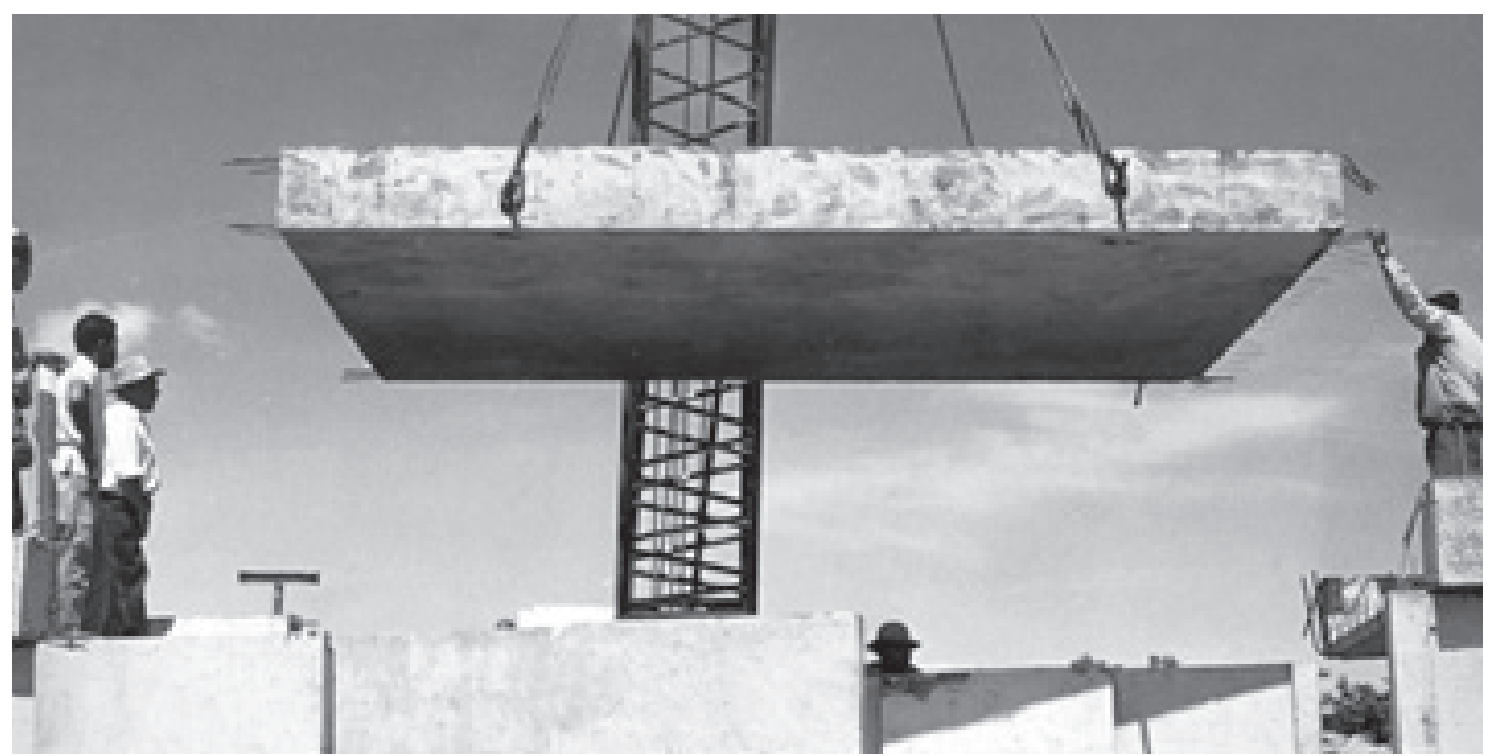

SG2 e SG4 - compostos de um único bloco cada, esses edifícios respeitam, respectivamente, uma modulação de $11 \mathrm{~m}$ X $83 \mathrm{~m}$ e $11 \mathrm{~m} \times 73 \mathrm{~m}$. Além dos jardins internos localizados nas extremidades norte e sul e na área central do edifício, apresentam janelas maxim-ar em suas fachadas.

SG8 (antigo SG6) - O edifício possui ventilação cruzada proporcionada por grandes venezianas metálicas. O foyer é aberto, porém delimitado por grandes painéis fixos de concreto.

SG10 - não possui janelas, sendo a ventilação e a iluminação asseguradas por quatro jardins internos: dois nas extremidades, um no centro da área ocupada pelo Ceplan, e outro que separa esta parte de outras atividades que ocupam o espaço ao longo do tempo. As portas são grandes venezianas de aço basculantes. Sobre esses edifícios, assim se manifestou o arquiteto e professor aposentado da FAU José Carlos Córdoba Coutinho: 
Pela natureza das atividades, que exigem um ambiente de tranquilidade e concentração, os edifícios são fechados para o exterior e abertos para amplos pátios internos ajardinados, que asseguram o controle do microclima. São obras-primas da arquitetura do período, exatamente por serem edifícios despretensiosos, inovadores (COUTINHO, 2012).
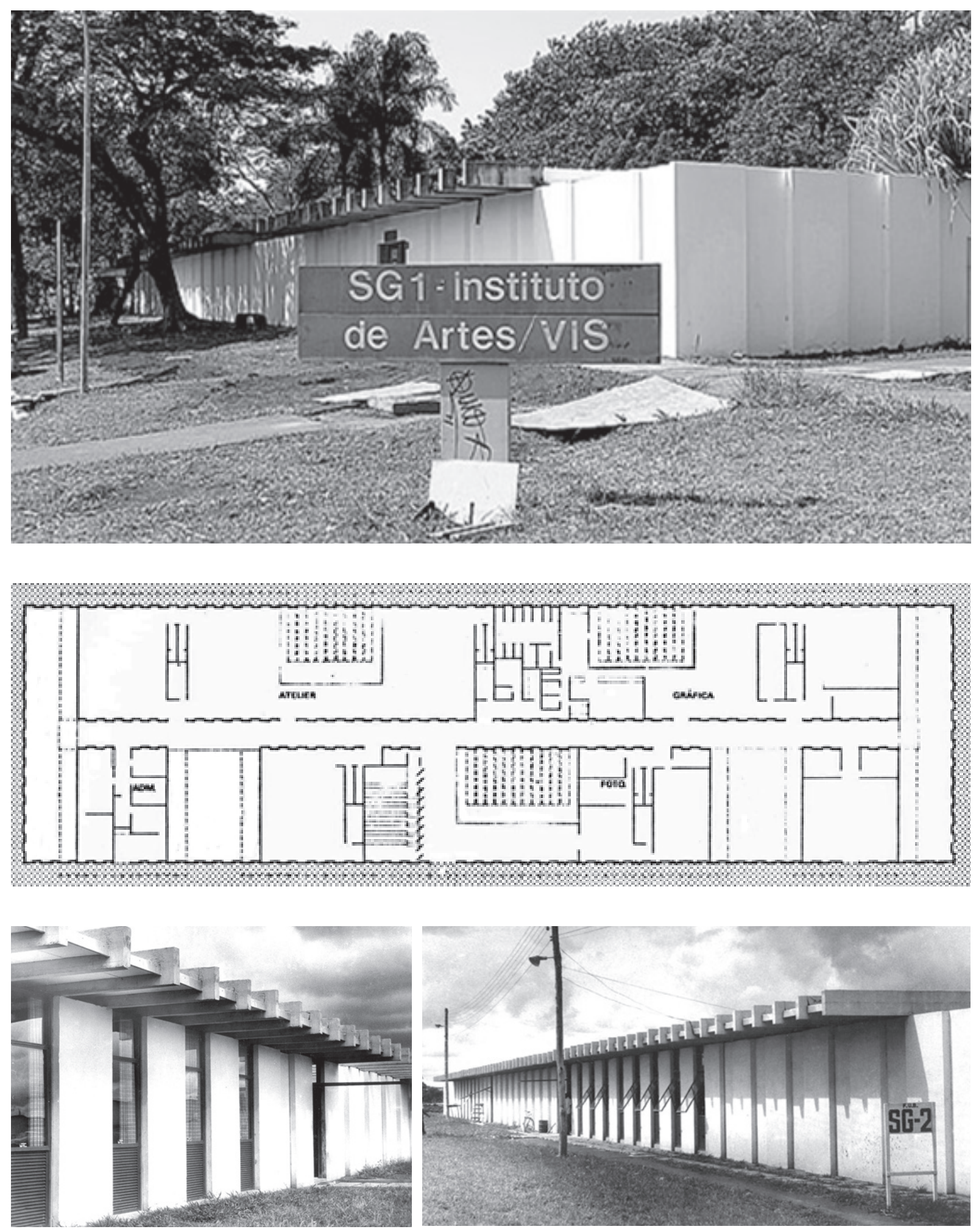

Figura $55 \mathrm{~h}$.

SG 1 - Vista

externa atual

Figura 55i.

Planta do SG 1

Figura 55j.

SG 4 - Vista

externa, década

de 1960

Figura 55k.

SG 2 - Vista

externa, década

de 1960 
Figura 55I.

SG 4 - Vista

atual do jardim

interno

Figura $55 \mathrm{~m}$.

SG 8 - Vista

externa atua

Figura 55n.

SG8 - Vista atual

do auditório
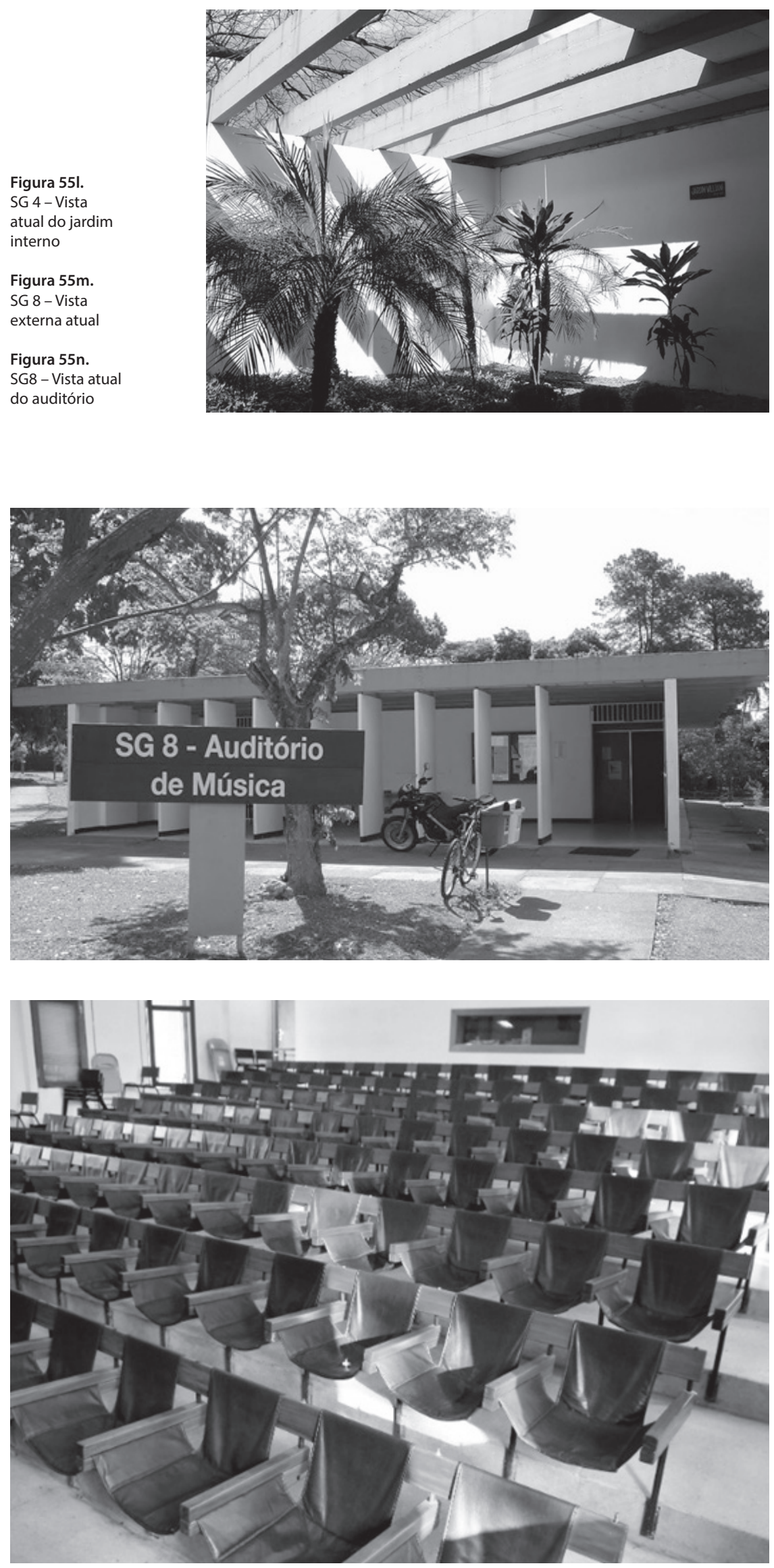


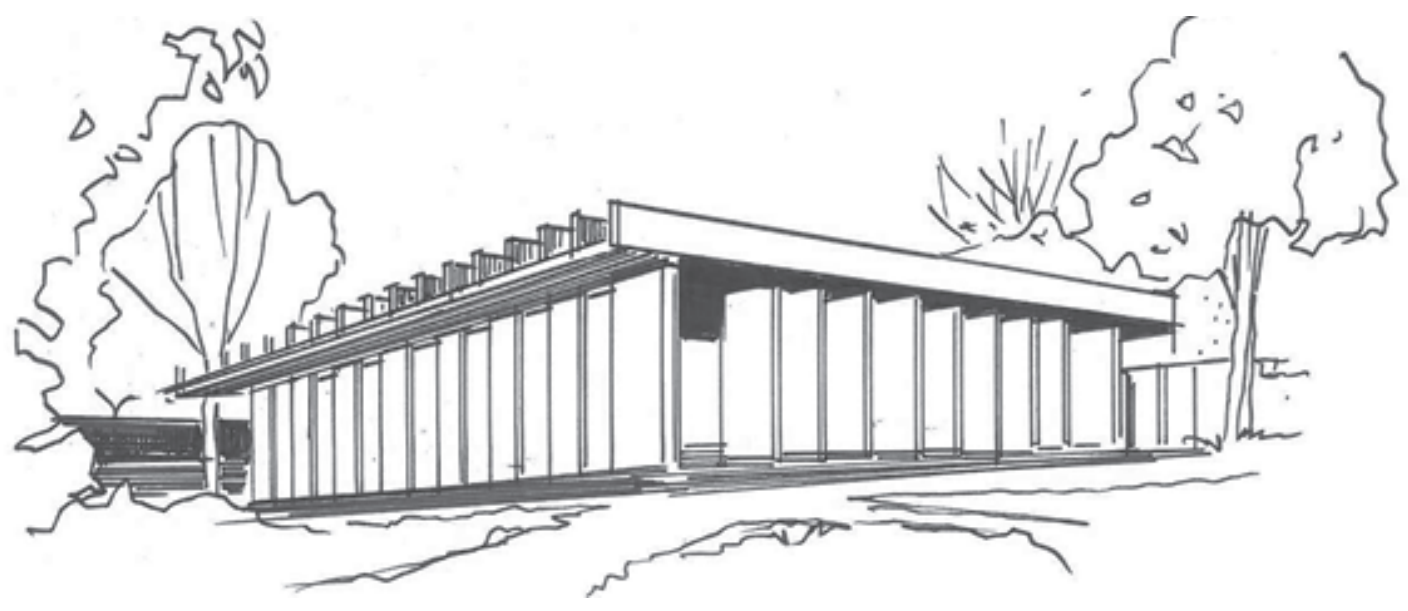

Figura 55o.

SG8 - Vista externa

do auditório de

música.

Figura 55p.

SG 8- Vista interna

do auditório de

música.

Figura 55q.

SG8 - Vista externa

do auditório de

música. Desenhos

de Eliel Américo

Santana da Silva
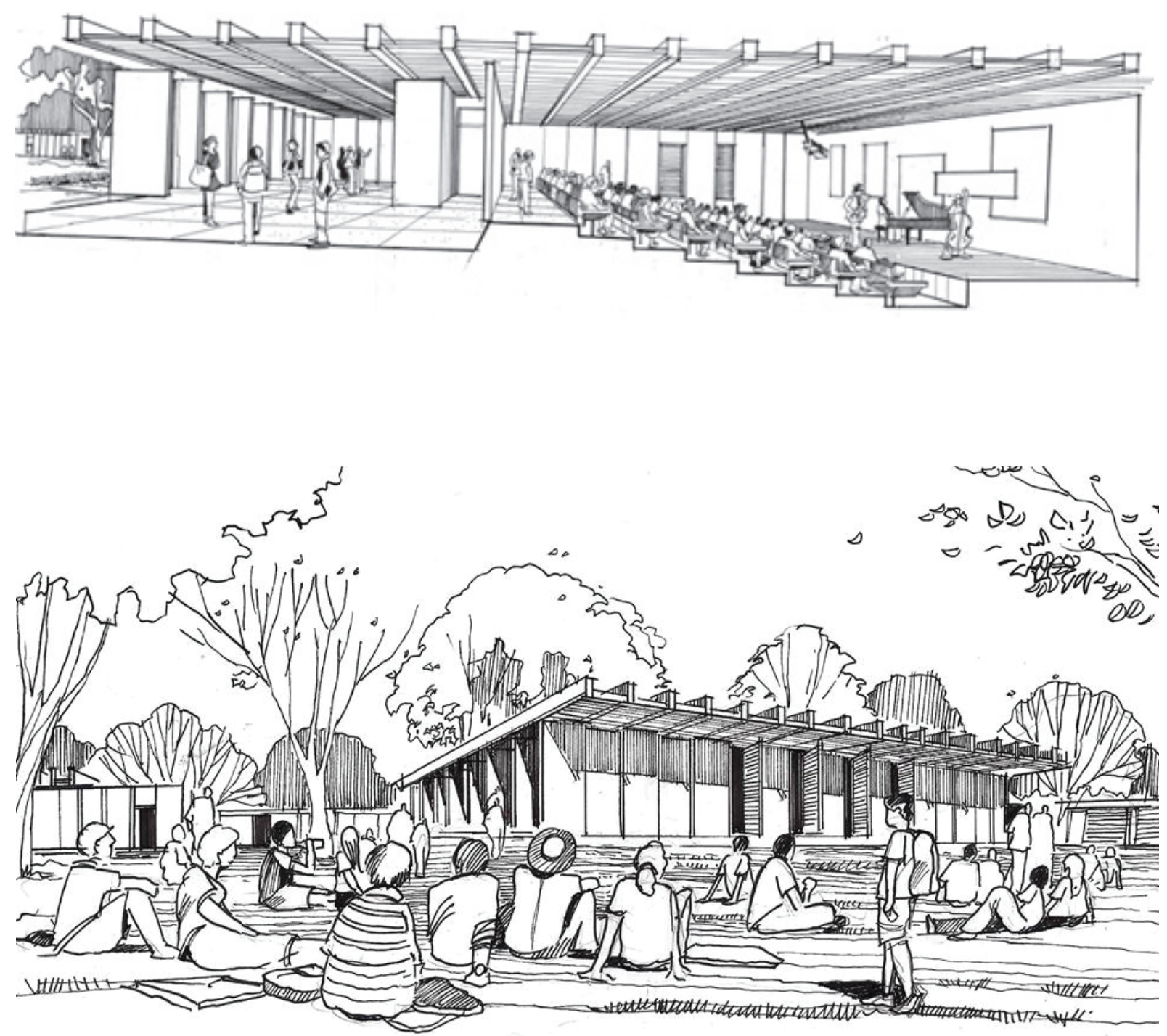

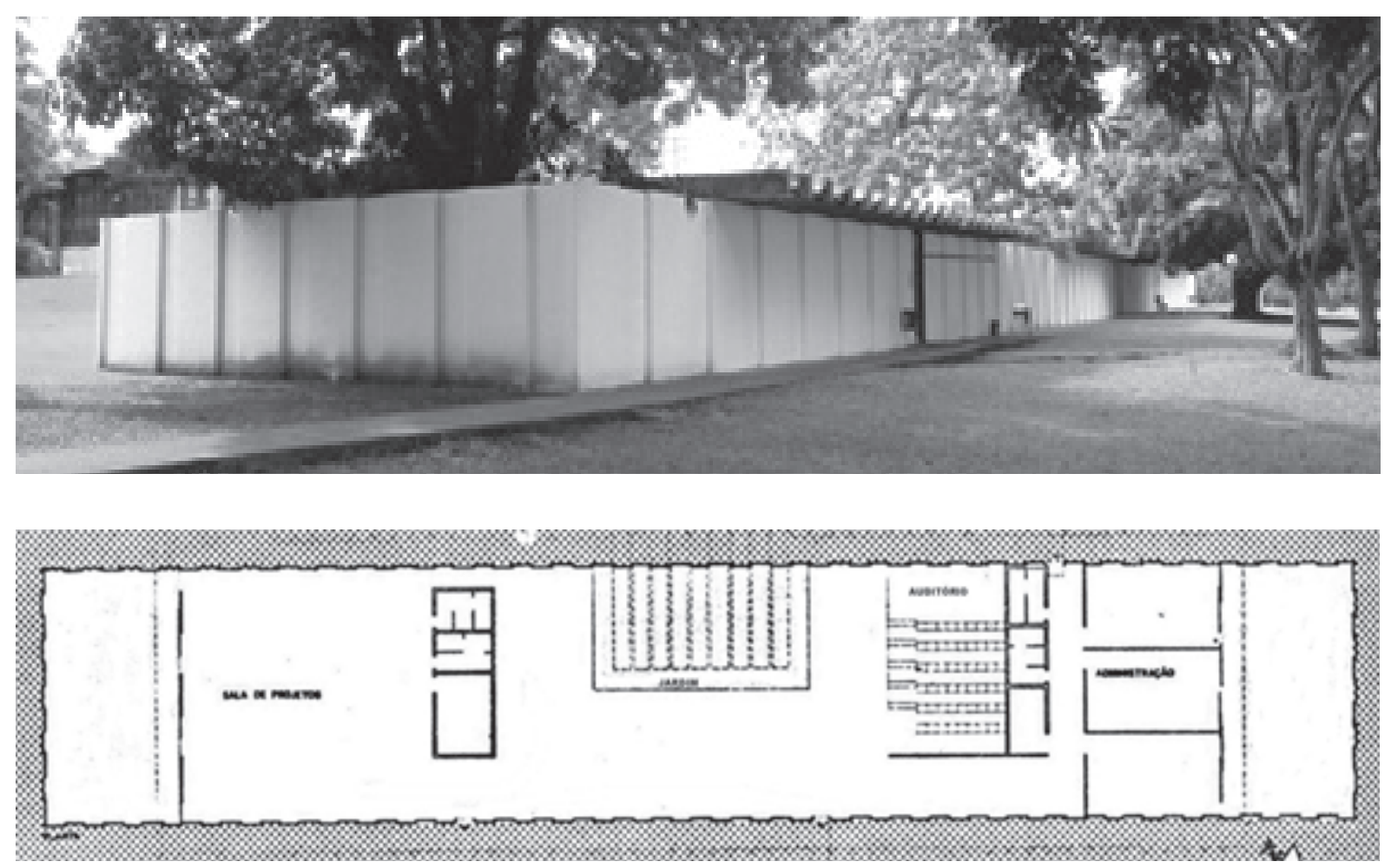

Figura 55r.

SG10 Foto: Walter

de Carvalho.

Figura 55s.

SG 10: Planta

Figura 55t.

SG10: Vista aérea.

Desenho de Eliel

Américo Santana

da Silva
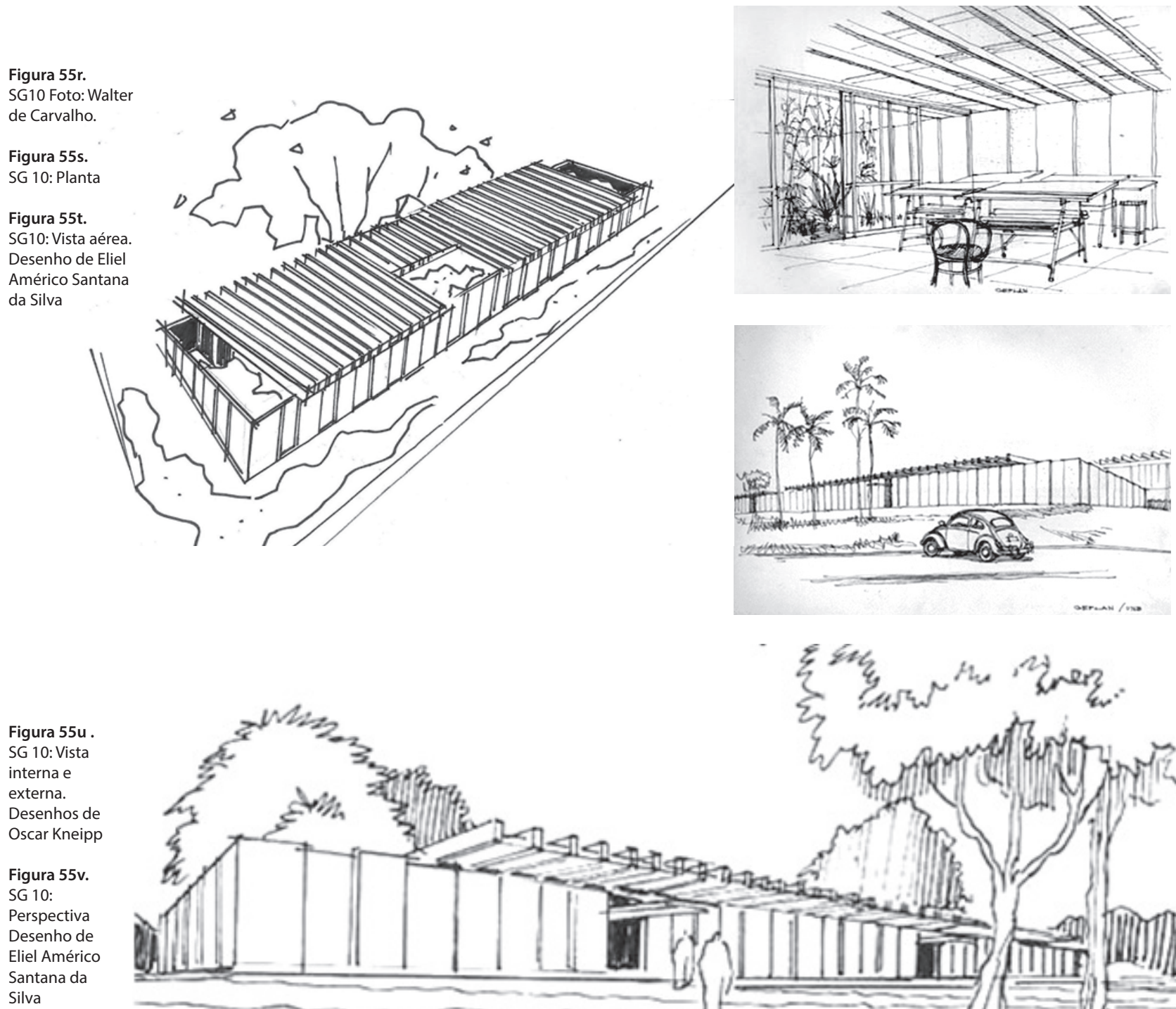

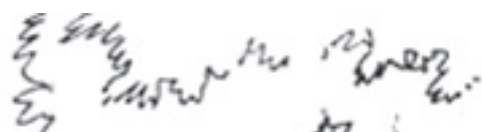

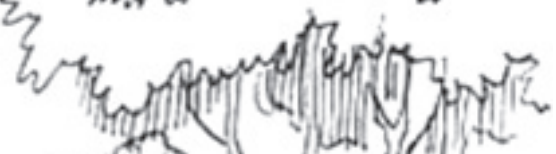
Thend S \{

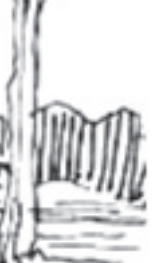


Uma curiosidade do edifício do Ceplan são os vários croquis de Oscar Niemeyer estampados nas paredes.
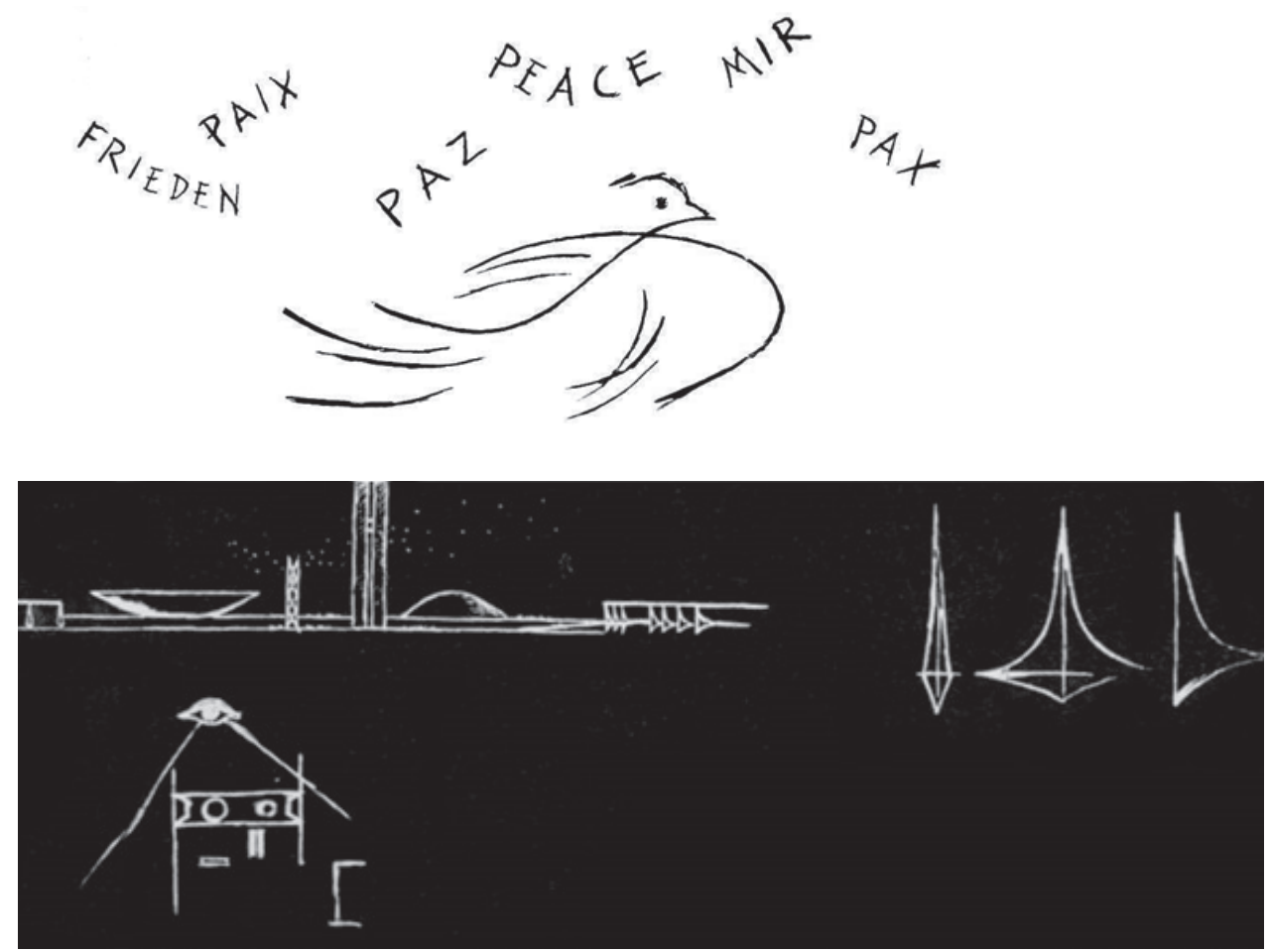

Figura 55w e 55x.

Desenhos na parede do Ceplan.
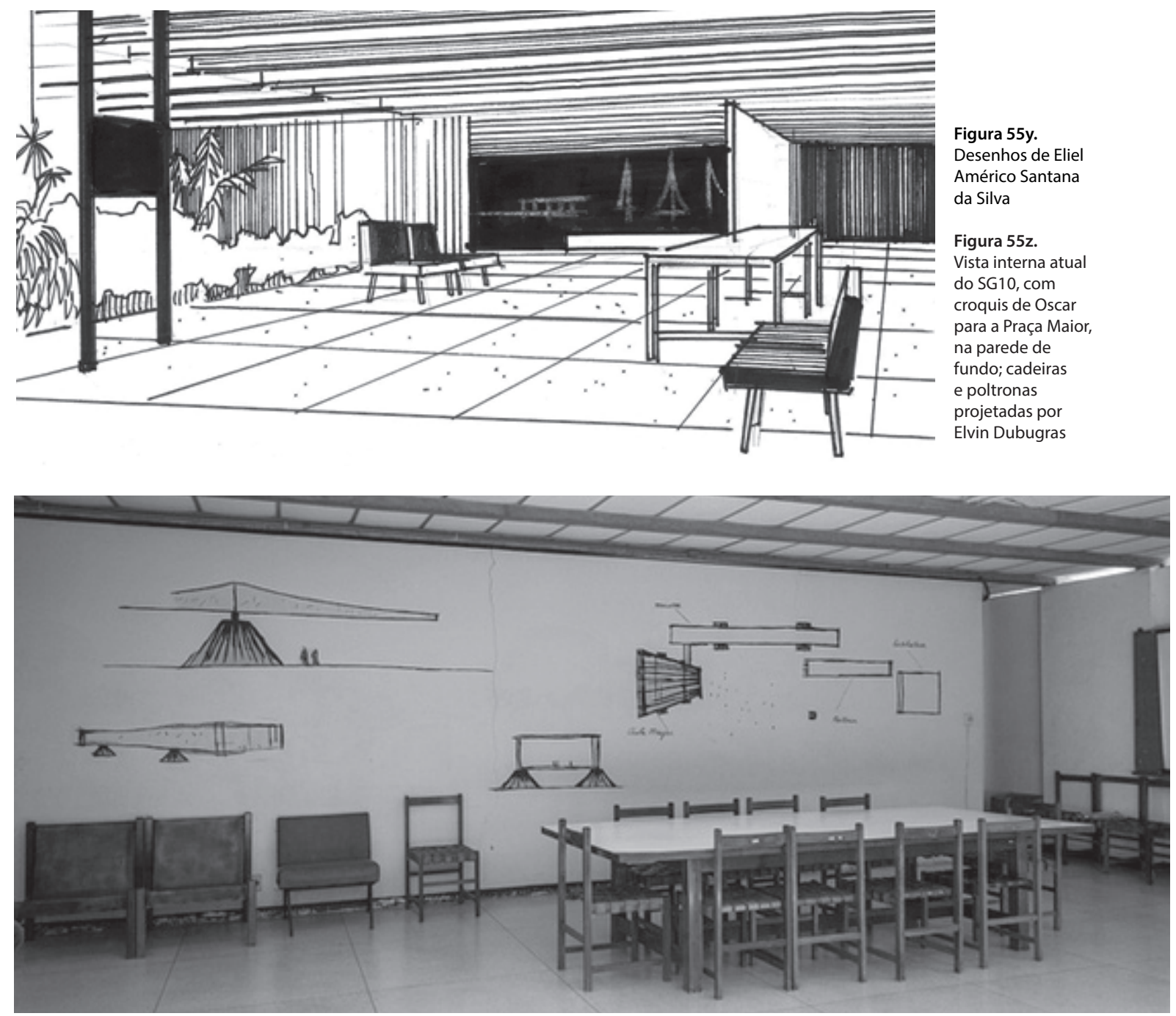
Com o sucesso das primeiras experiências em pré-fabricado, foram construídos novos edifícios que, além de subsolo, ganharam mais um pavimento.

SERVIÇOS GERAIS - SG9, SG11 E SG12

Autoria

João da Gama Filgueiras Lima

Datas

SG11 - 1964

SG12 - 1965

SG9 - 1969

Área Construída

SG11 - $3.600 \mathrm{~m}^{2}$, SG12 - $5.437 \mathrm{~m}^{2}$ e SG9 $-2.800 \mathrm{~m}^{2}$
Figura 56a.

Implantação dos

edifícios de Serviços

Gerais de dois

pavimentos 


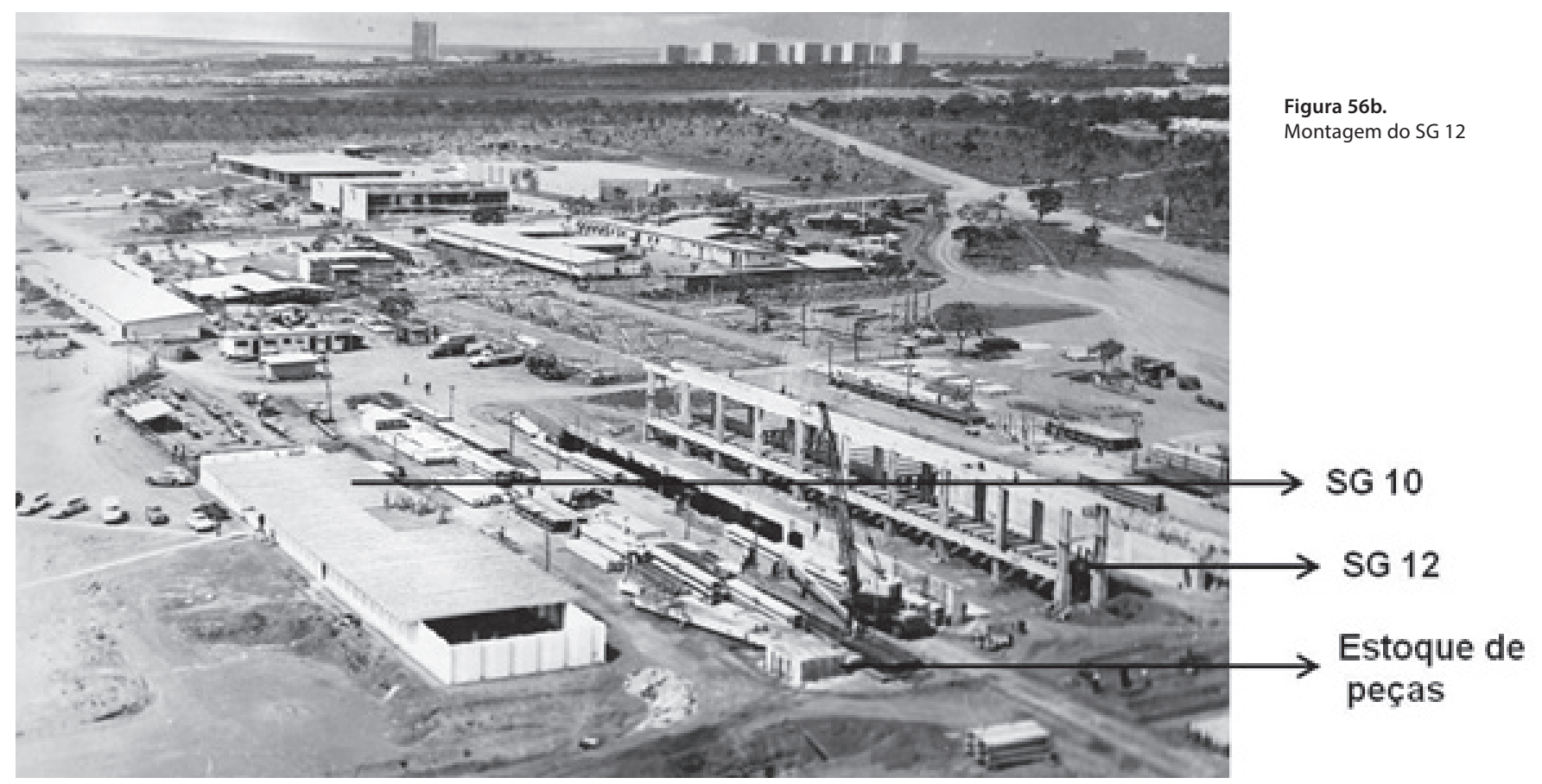

Estes galpões, que representam uma variante dos primeiros blocos pré-moldados de serviços gerais, térreos e mais simples, contam com subsolo, térreo e mezanino.

Um mesmo projeto foi repetido nos três edifícios - SG9, SG11 e SG12 - que, inicialmente destinados aos serviços gerais, passaram a abrigar outras funções, entre as quais a de laboratórios de engenharia. No SG12 funcionou a primeira biblioteca da UnB.

A estrutura pré-moldada, além de ter economizado tempo de construção, possibilitou grande flexibilidade interna, inclusive pelo fato de o mezanino poder ser desmontado. O princípio de vigas de cobertura paralelas com espaçamento reduzido, que é vedado com material leve, é o mesmo dos outros galpões de serviços gerais. Para permitir uma largura maior, existem dois vãos no sentido transversal, intercalados por uma viga-calha central fundida in loco. Uma trama de vigas longarinas, apoiadas em pilares espaçados modularmente, recebe essas vigas transversais paralelas na fachada.

Executado posteriormente para abrigar a Oficina de Mecânica da Faculdade de Tecnologia, o SG9 foi construído em alvenaria convencional, pois na época só havia uma empresa capaz de fornecer as peças, o que caracterizaria vício de licitação.

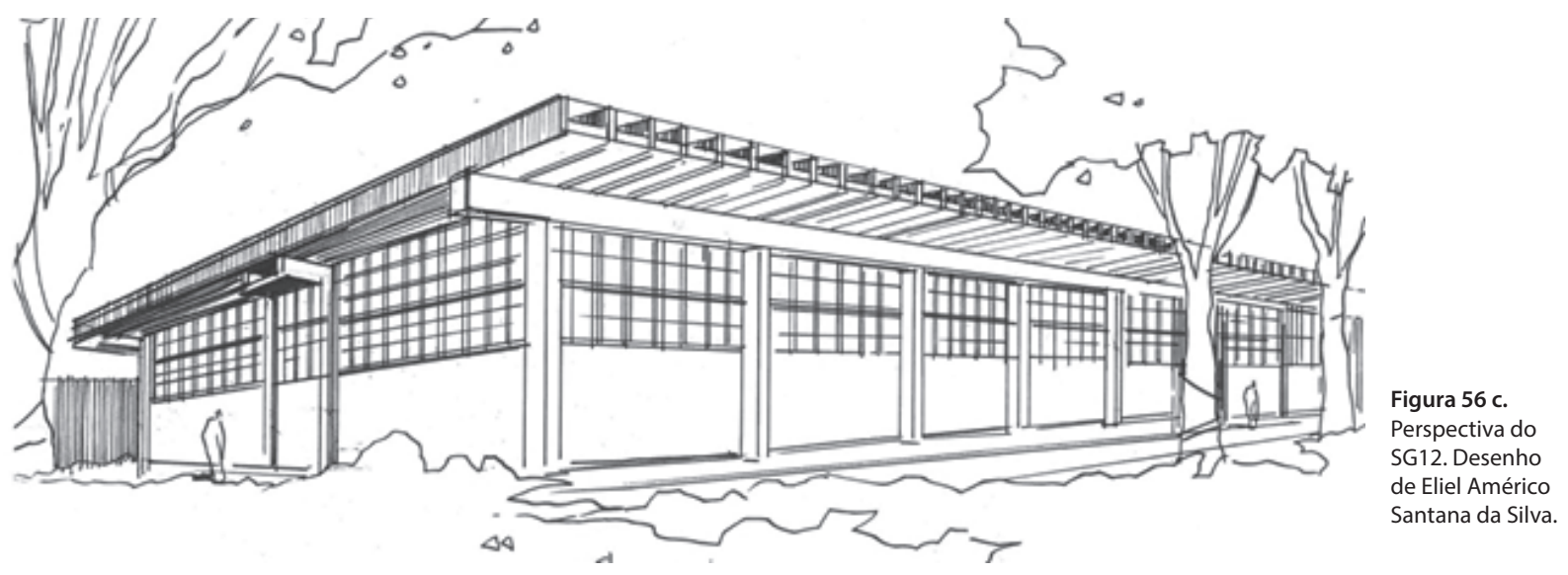



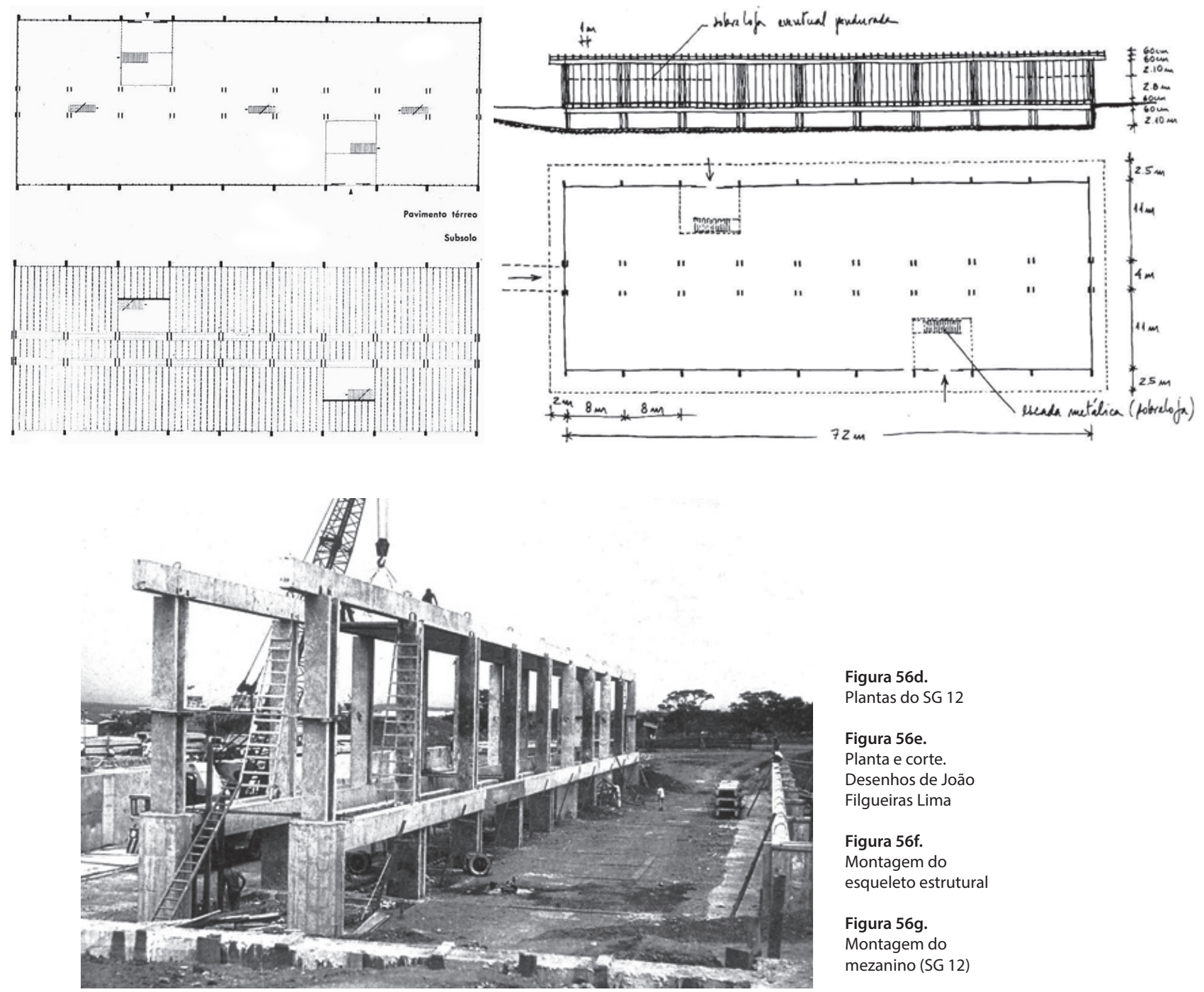

Figura 56d.

Plantas do SG 12

Figura 56e.

Planta e corte.

Desenhos de João

Filgueiras Lima

Figura 56f.

Montagem do

esqueleto estrutural

Figura 56g.

Montagem do

mezanino (SG 12)

Uma curiosidade desta construção: a laje do primeiro pavimento (mezanino) é atirantada nas vigas de cobertura, garantindo um espaço flexível também na vertical, ou seja, permitindo o uso de pédireito duplo onde se fizer necessário. As vedações externas entre pilares são obtidas por painéis não portantes e/ou esquadrias.

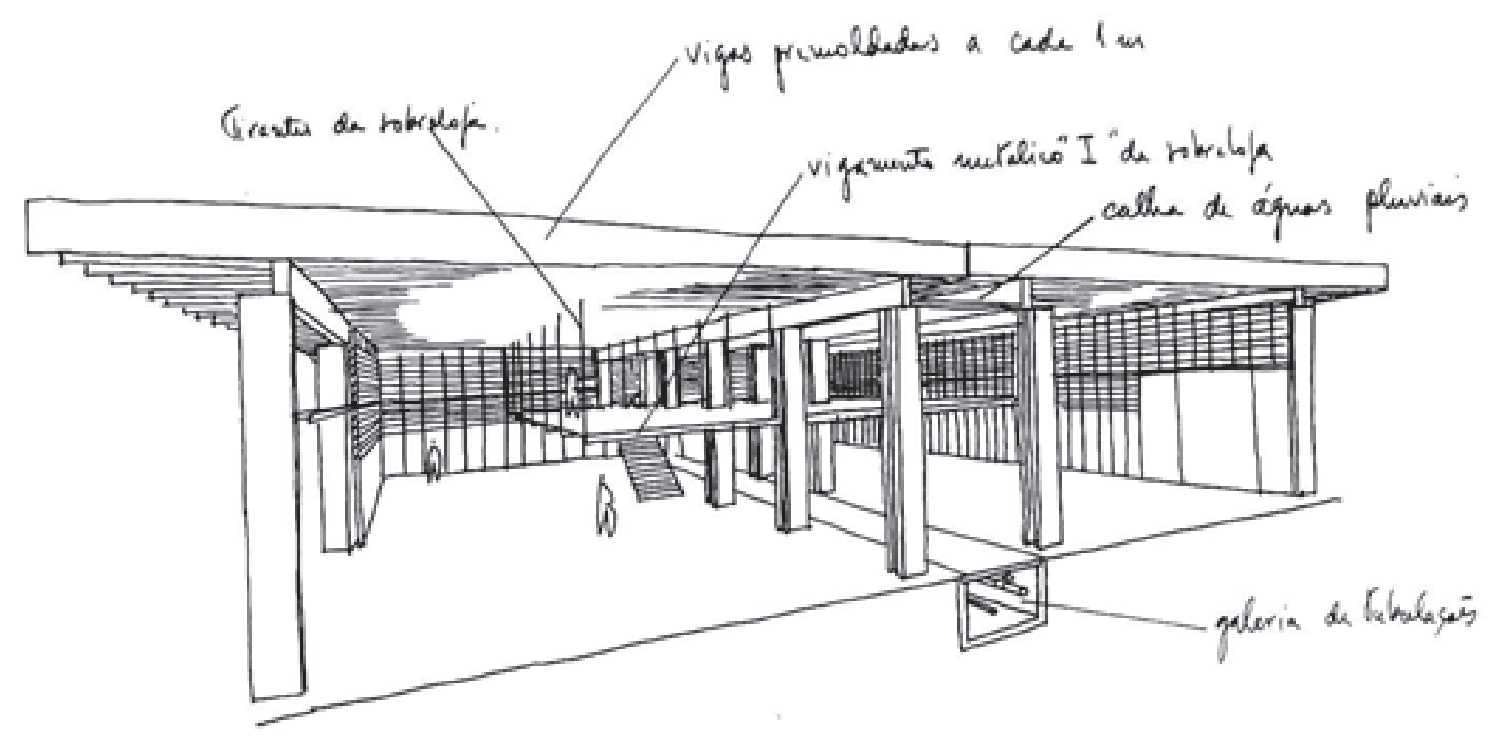




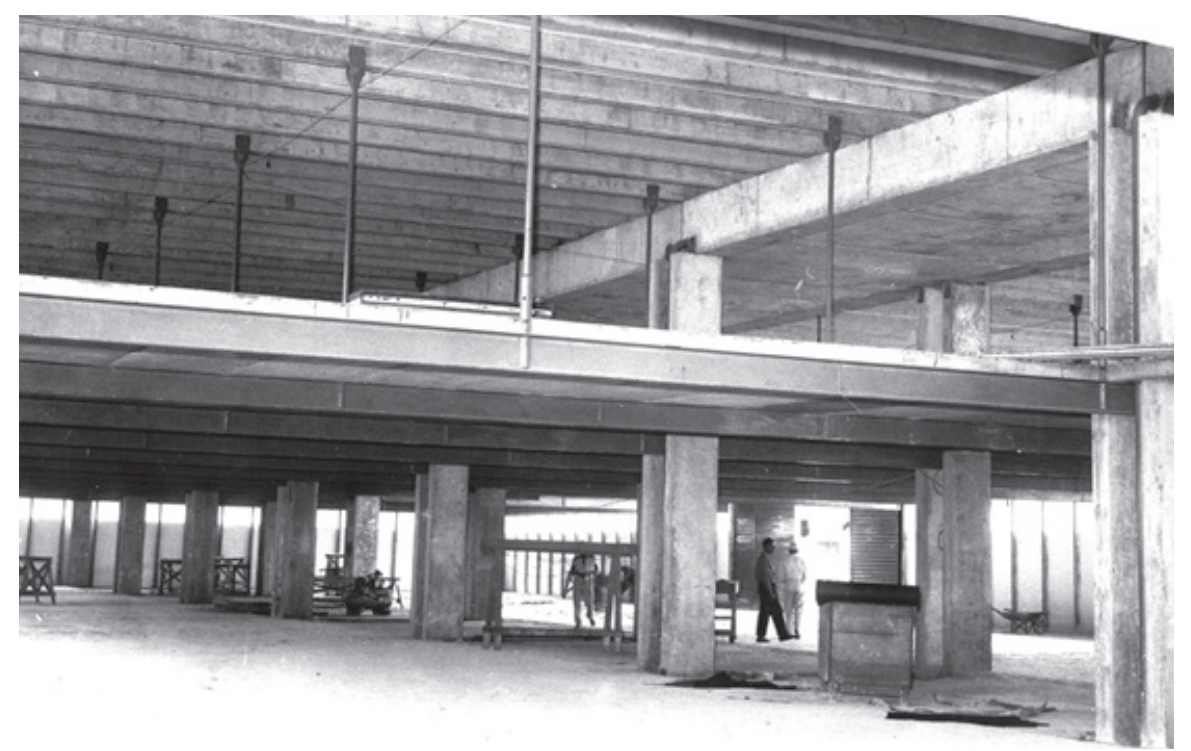

Figura 56h.

SG 12: Montagem

do mezanino

Figura 56i.

SG 12: Vista externa

Figura 56j.

SG 12: Vista externa
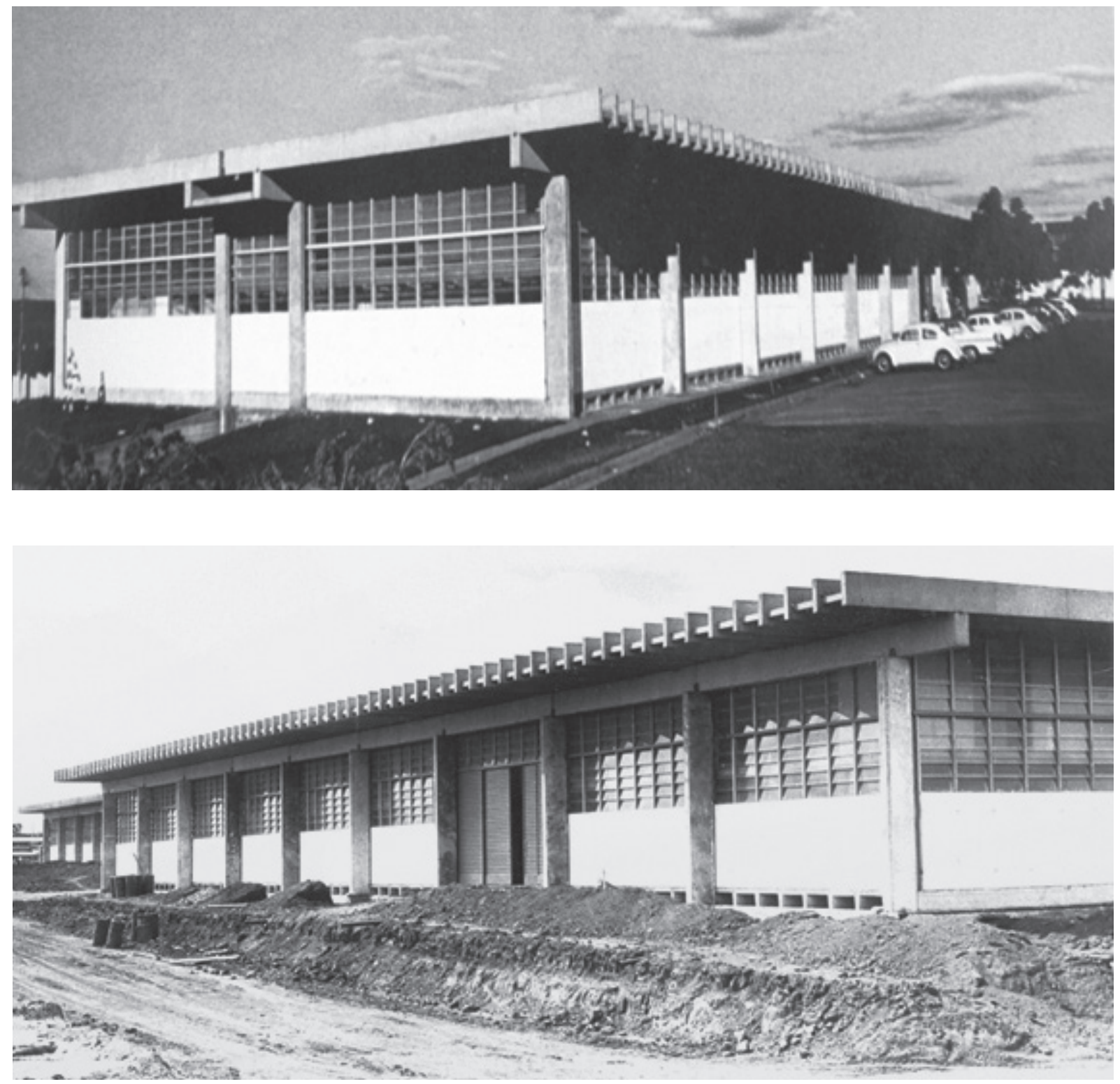

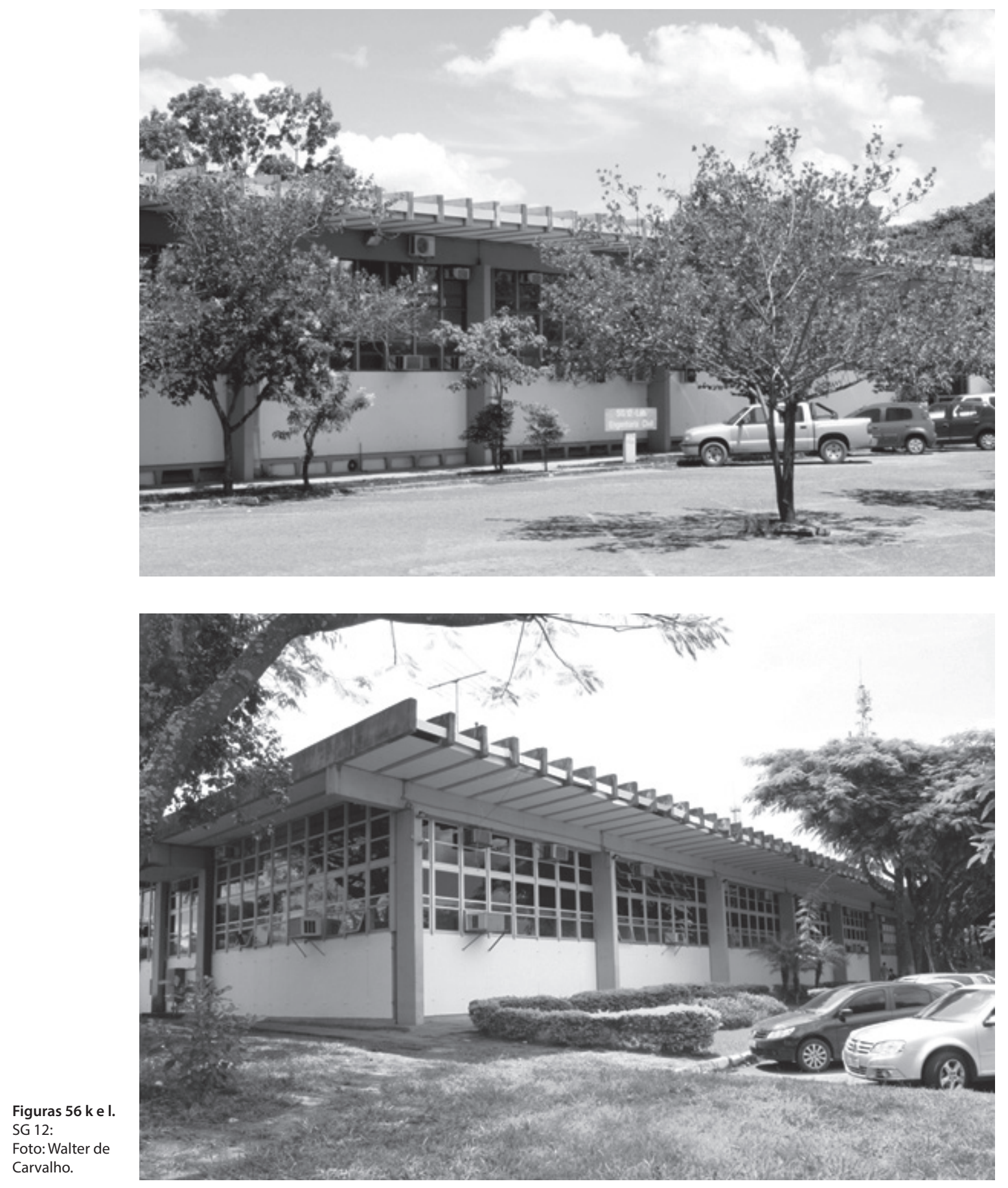
E a UnB tornou-se pioneira no Brasil na pré-fabricação de habitações.

\section{COLINA - BLOCOS A, B, C e D}

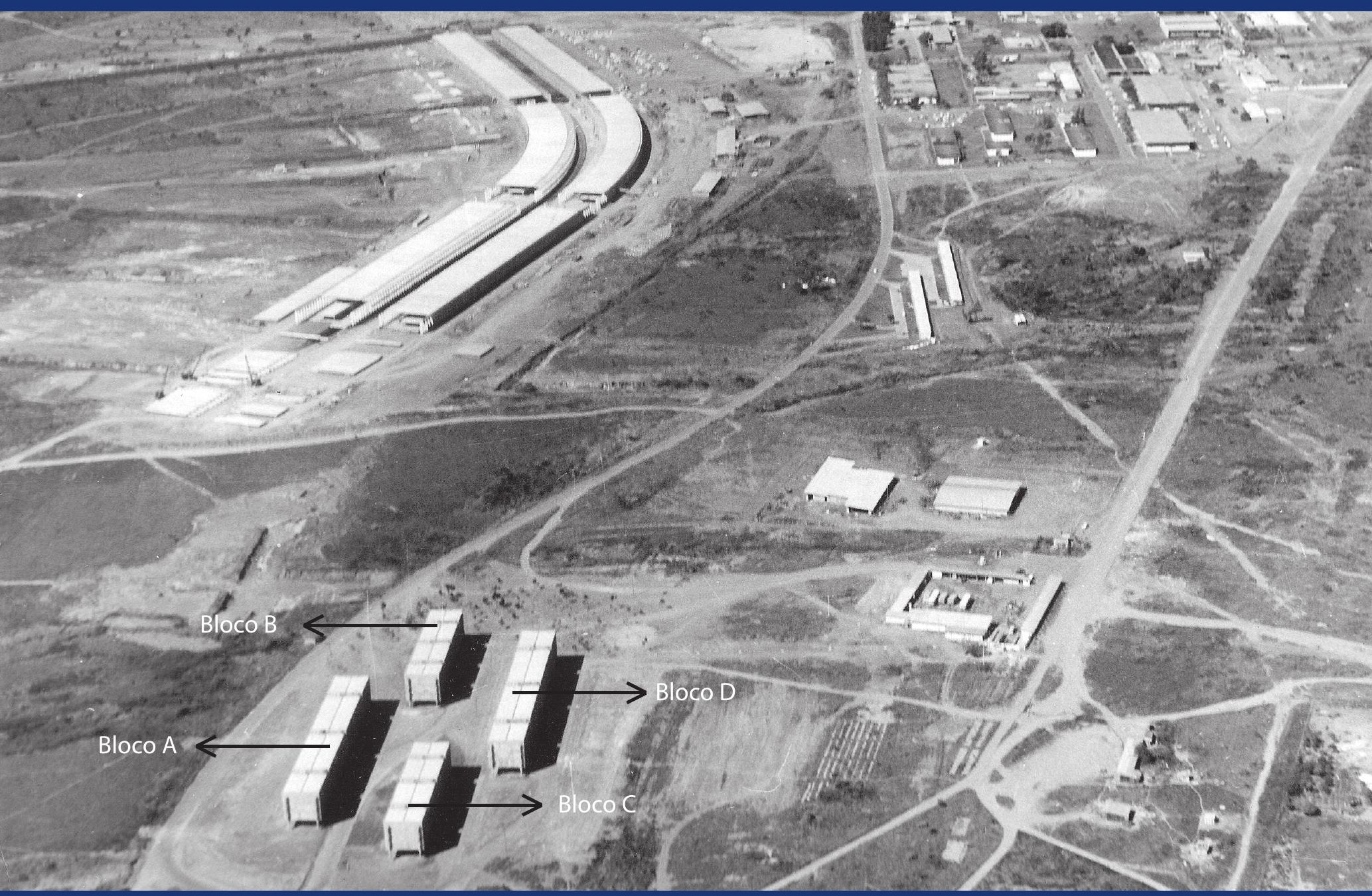

Autoria

João da Gama Filgueiras Lima

\section{Data}

1962

Área Construída

A e D - $3.250 \mathrm{~m}^{2}$; B e C $-2.050 \mathrm{~m}^{2}$
Figura 57a.

Implantação dos

primeiros blocos da

Colina 
Seguindo o plano urbanístico de Lucio Costa (1962), em 1963 foram construídos, em uma área próxima à L3 Norte, os blocos A, B, C e D da Colina, primeiras construções habitacionais pré-moldadas do Brasil. Esses edifícios, que serviram de alojamento para professores e alunos, constituem a primeira experiência no uso da pré-fabricação para uso habitacional com tecnologia totalmente brasileira.

Os quatro prédios, de três pavimentos sobre pilotis e sem elevadores, abrigam três tipos de apartamentos: I, com 144; II, com 108; e III, com $84 \mathrm{~m}^{2}$. As plantas flexíveis permitem o ajuste dos ambientes às necessidades de cada caso.

O projeto previu um sistema misto de pilares e vigas pré-moldados e conjuntos de circulação vertical fundidos in loco. Reproduzindo as técnicas do trato com a madeira, os elementos pré-fabricados de concreto armado foram unidos por parafusos,. As peças pré-moldadas incluíram: vigas protendidas em forma de " $U$ ", de 14 metros de comprimento; lajes nervuradas de piso; painéis parede; e cobogós.

As lajes nervuradas pré-moldadas dos pavimentos apoiam-se em vigas " $U$ " recuadas da fachada. Essas vigas, por sua vez, descarregam seu peso nas torres de circulação vertical, fundidas in loco para garantir um contraventamento eficaz ao conjunto da edificação. Nas empenas, onde não há torre de circulação vertical, as mesmas vigas duplas descarregam em pilares aparentes e sobrepostos a esta empena em toda a altura do edifício. Esse apoio é rotulado por intermédio de um pino metálico ligando as duas vigas e o pilar.

As instalações elétricas e hidráulicas alojam-se aparentes no seio das vigas "U" e ligam-se aos ramais principais localizados nos conjuntos de circulação vertical. As vedações nas fachadas posteriores são feitas por meio de painéis pré-moldados de cobogó; e as empenas são vedadas com painéis de concreto de piso a teto. Nas fachadas frontais, esquadrias em chapa dobrada, com vidro (parte superior) e um painel opaco (parte inferior), garantem a vedação.

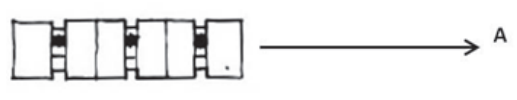

\section{torres de circulação vertical moldadas in loco}

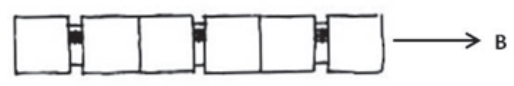

$\begin{array}{ll}\begin{array}{l}\text { Figura 57b. } \\ \text { Tipologias dos } \\ \text { apartamentos: }\end{array} & \text { 1. Circulação } \\ \text { A e B } & \text { 2. Estar } \\ \text { Figura 57c. } & \text { 3. Quarto } \\ \text { Plantas dos } & \text { 5. Banheiro empregada } \\ \text { apartamentos } & \text { 6. Banh. empregada } \\ \text { tipo A e B } & \text { 7. Cozinha } \\ & \text { 8. Área de serviço } \\ & \text { 9. Despensa } \\ & \text { 10. Depósito }\end{array}$

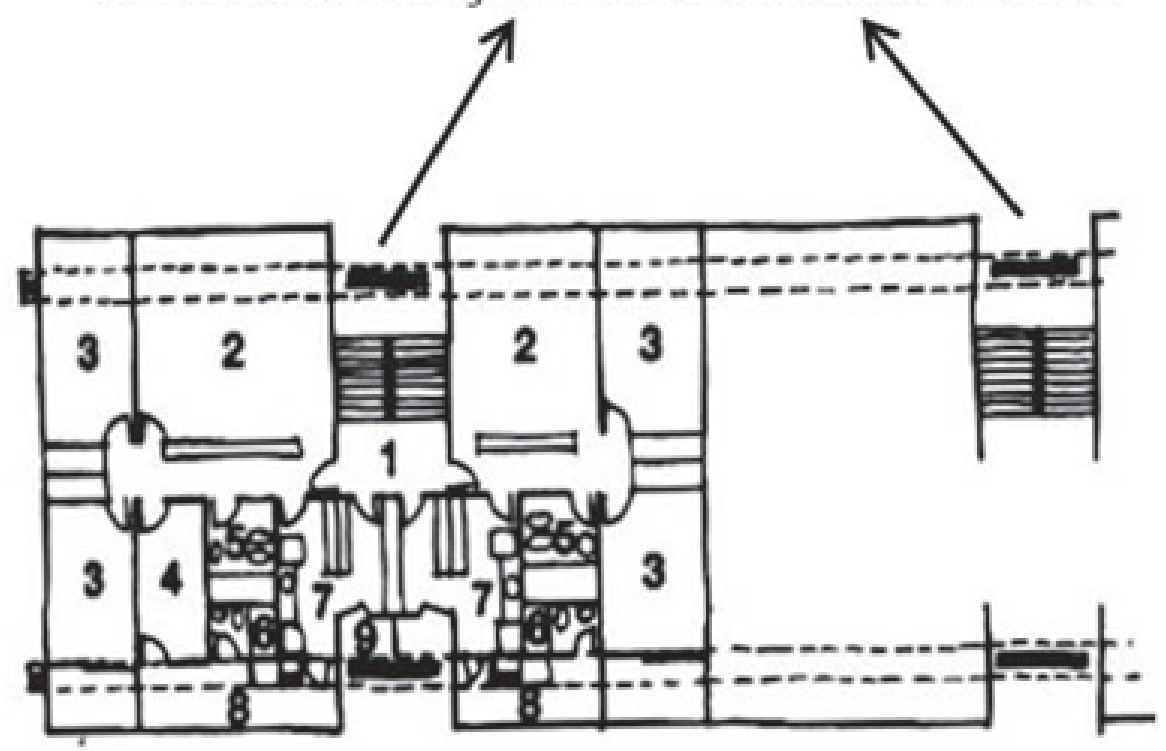



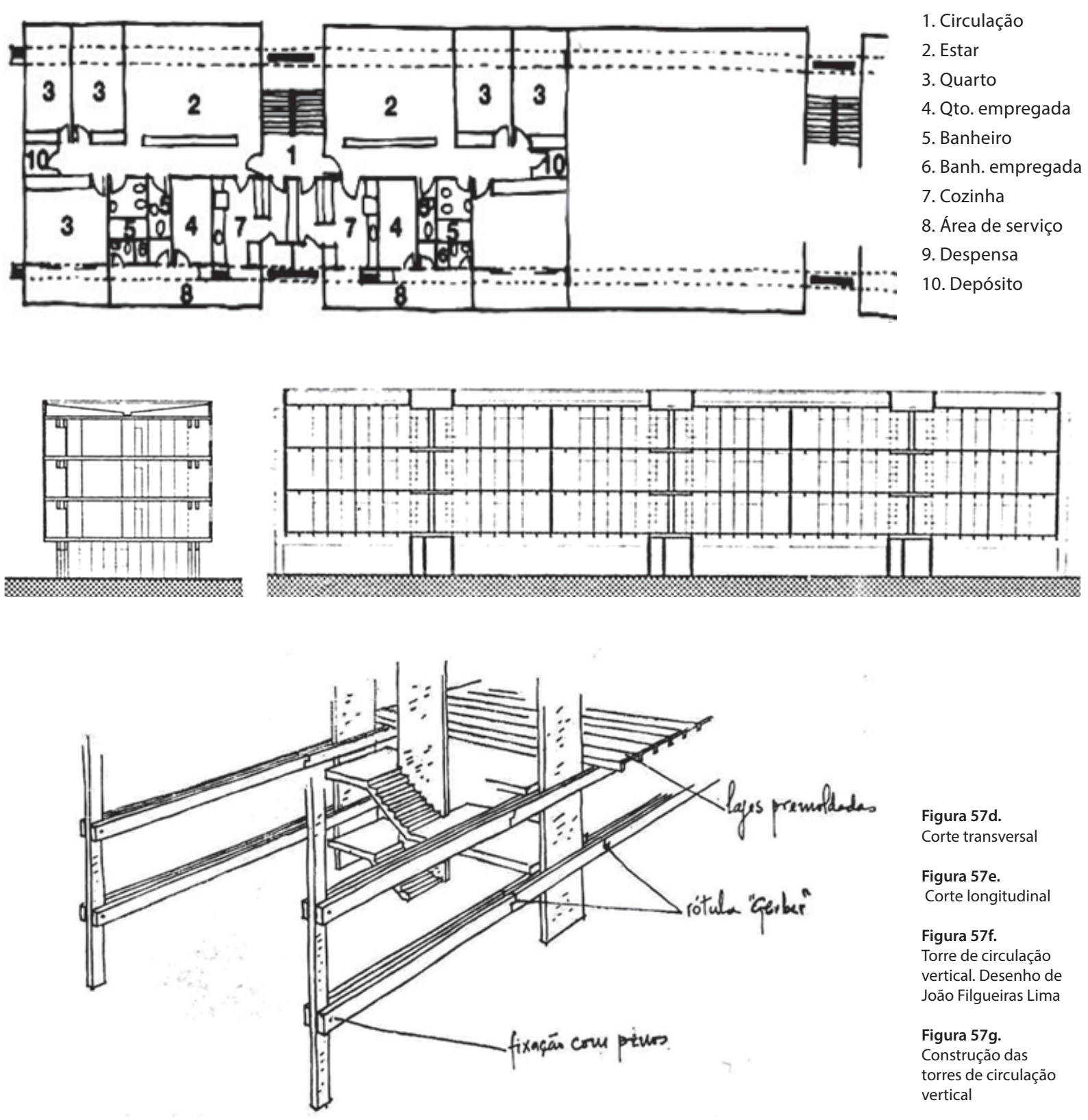

Figura 57d.

Corte transversal

Figura 57e.

Corte longitudinal

Figura $57 \mathrm{f}$

Torre de circulação

vertical. Desenho de João Filgueiras Lima

Figura 57g.

Construção das

torres de circulação

vertical

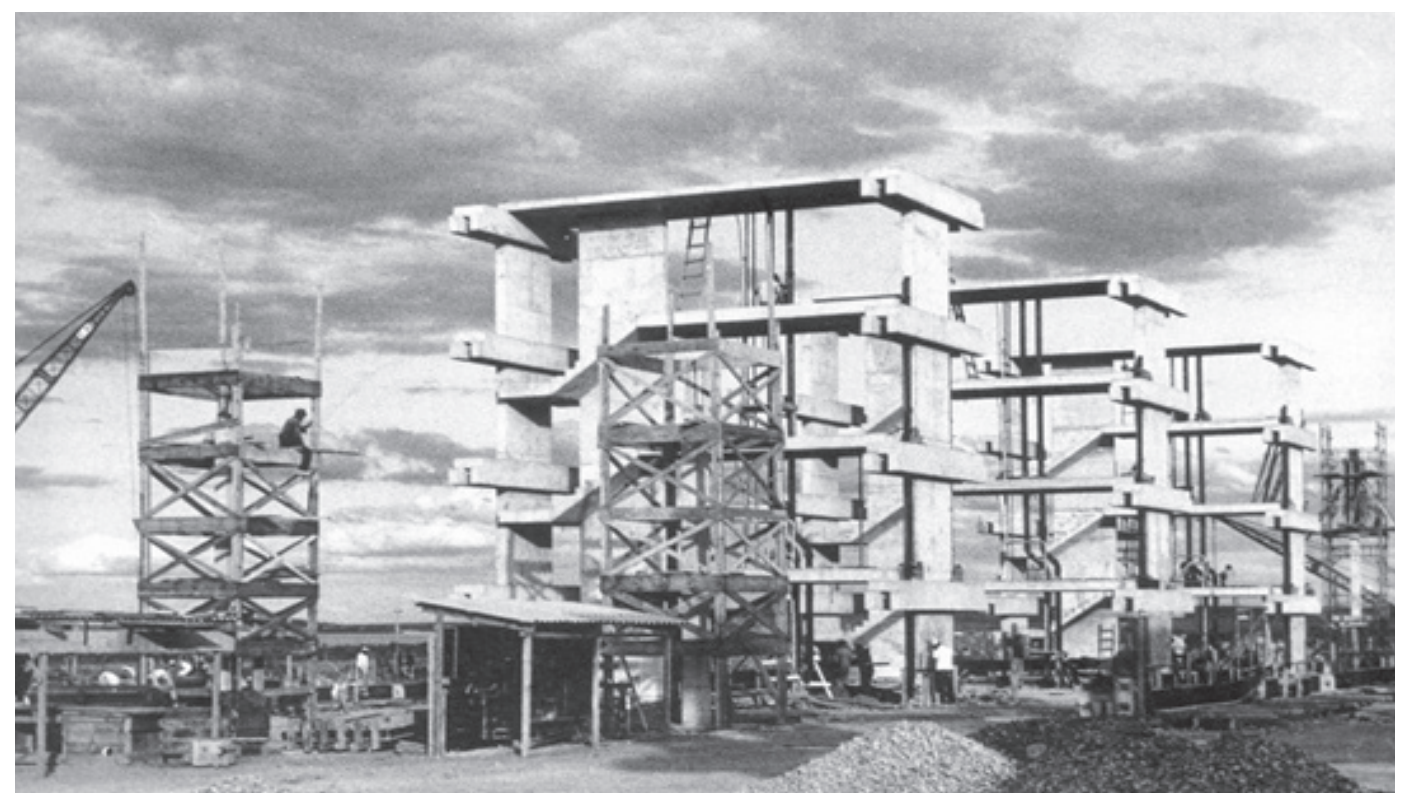



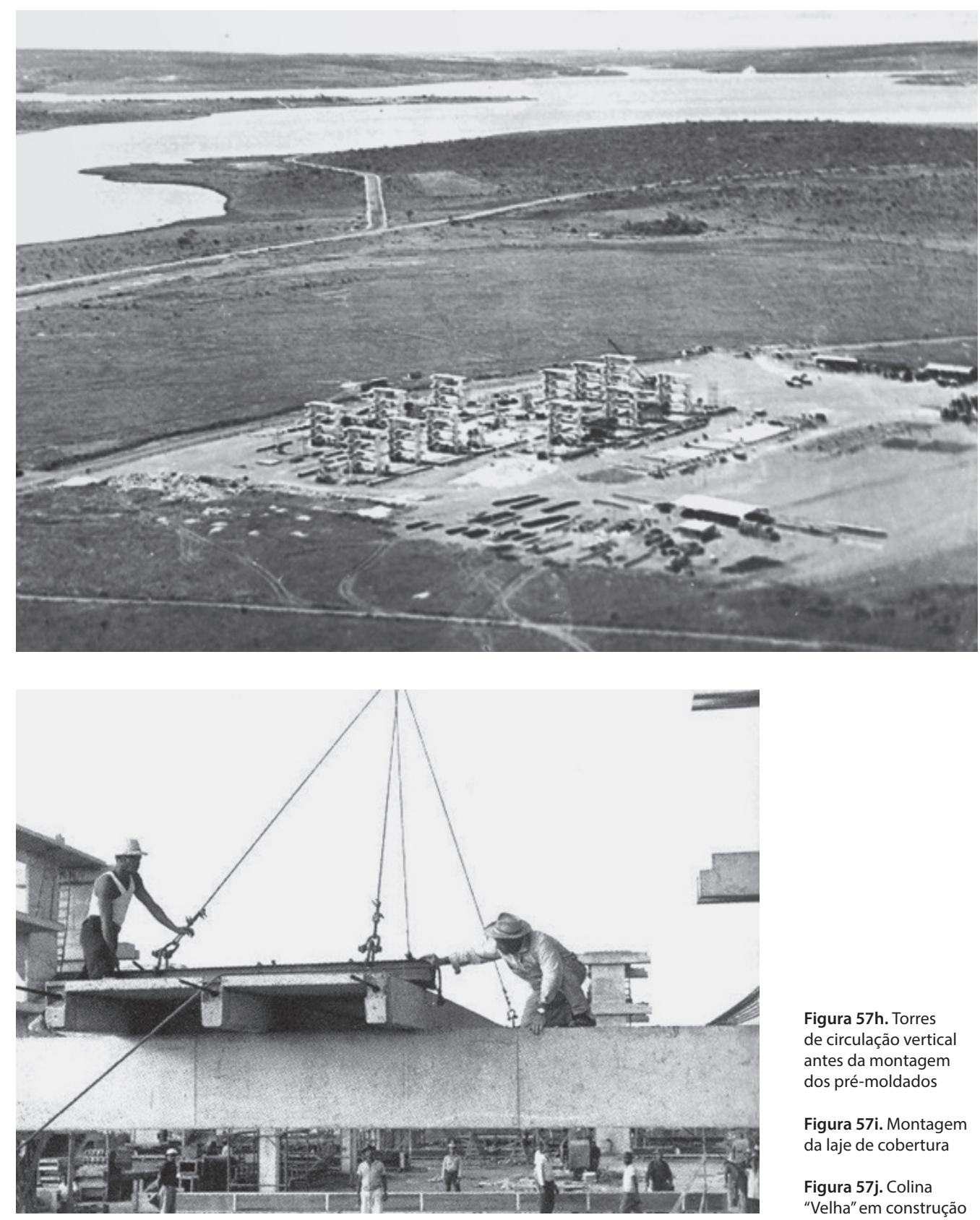

Figura 57h. Torres de circulação vertical antes da montagem dos pré-moldados

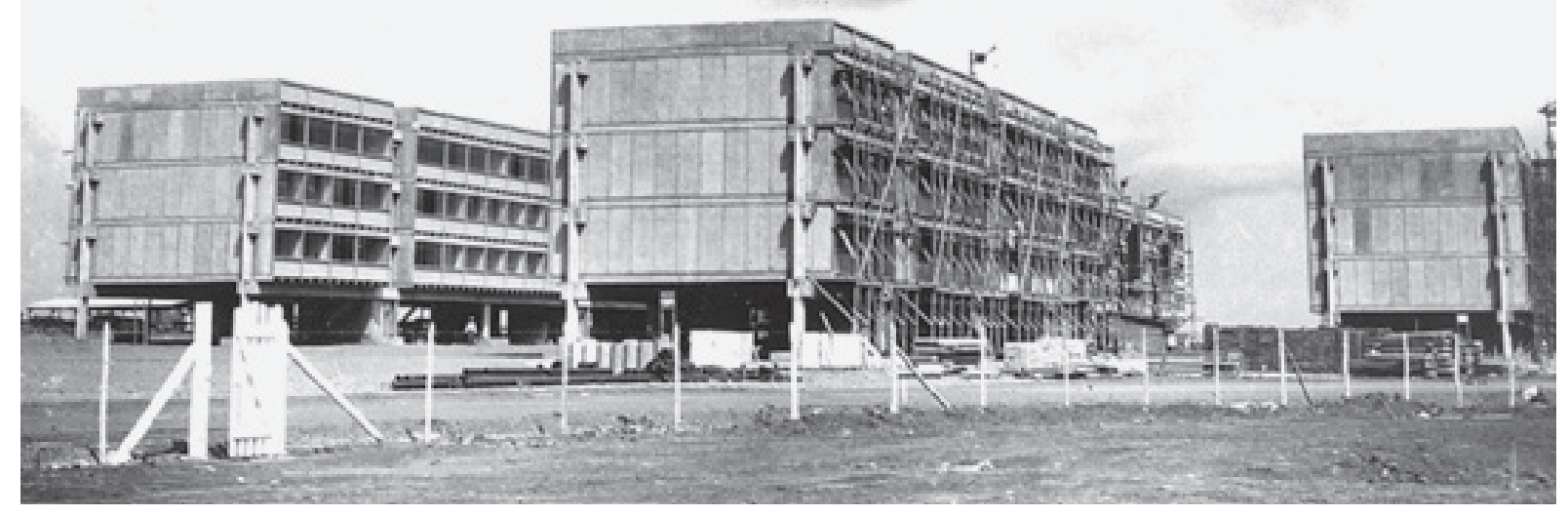



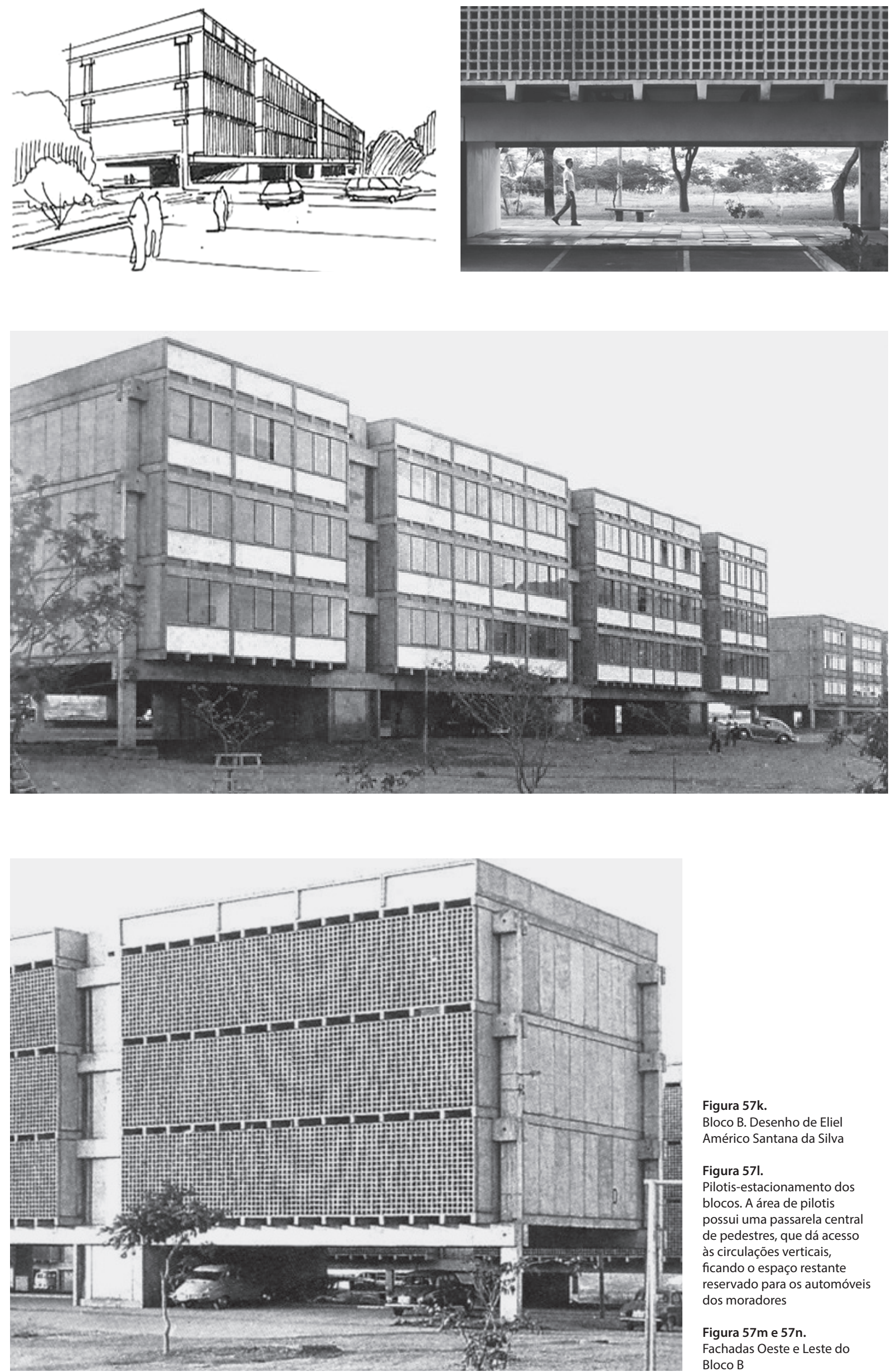

Figura 57k.

Bloco B. Desenho de Eliel

Américo Santana da Silva

Figura 571.

Pilotis-estacionamento dos

blocos. A área de pilotis

possui uma passarela central

de pedestres, que dá acesso

às circulações verticais,

ficando o espaço restante

reservado para os automóveis

dos moradores

Figura $57 \mathrm{~m}$ e $57 \mathrm{n}$

Fachadas Oeste e Leste do Bloco $B$ 


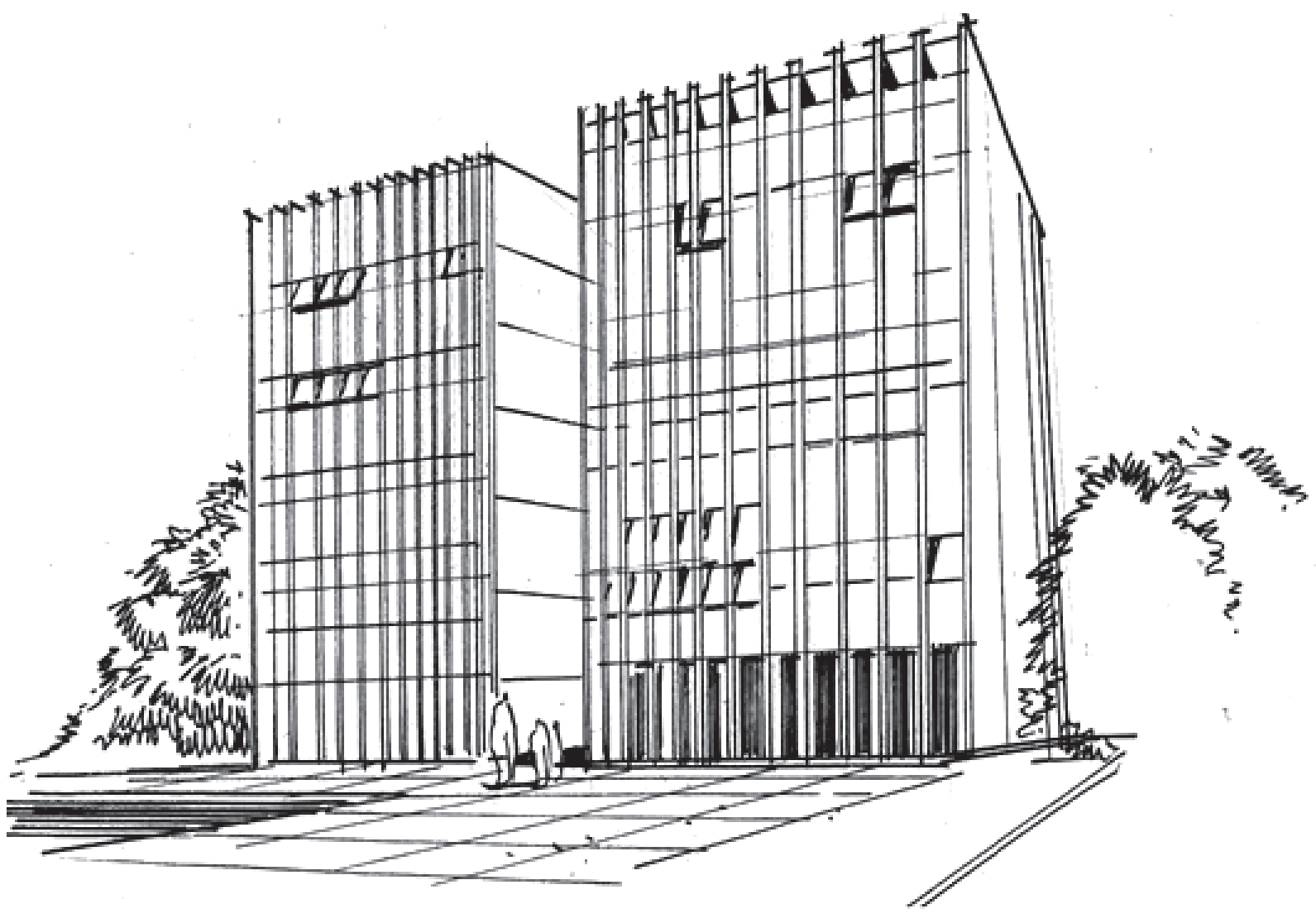

\section{Autoria}

Mayumi Watanabe de Souza Lima e Sérgio Souza Lima (torres), com a colaboração de Fernando Burmeister. O cálculo estrutural é de responsabilidade do engenheiro Ernesto Walter e o projeto original de paisagismo é do arquiteto colombiano Alfonso Leiva Galvis. ${ }^{2}$

\section{Datas}

1964/1965 (projeto)

1967-1972 (obra).
Figura 58a.

Vista da fachada Leste do bloco

F da SQN 107.

Desenho de

Eliel Américo

Santana da Silva 
A construção dos blocos de apartamentos do Conjunto São Miguel, destinados a abrigar funcionários do corpo diplomático e professores e funcionários da UnB, se deu em decorrência de um convênio assinado entre a Comissão Urbanizadora da Nova Capital (Novacap), os ministérios das Relações Exteriores (MRE) e da Educação e Cultura (MEC) e a Fundação Universidade de Brasília (FUB). Por esse acordo, todos os projetos e especificações dos edifícios deveriam ser feitos pelo Centro de Planejamento da Universidade de Brasília (Ceplan/UnB), pioneiro no trabalho com préfabricação: “[...] com as possibilidades que Brasília sempre ofereceu no campo da pré-fabricação, com as facilidades dos canteiros de construção amplos, tivemos oportunidade de fazer uma série de experiências" (LIMA, 1976, p. 219-220).

Com o golpe militar, a licitação para a construção foi impugnada, o sistema construtivo em prémoldados foi questionado e o convênio anulado. E, apesar de Mayumi e Sérgio Souza Lima terem assumido a empreitada de alterar o projeto para o sistema construtivo tradicional, o edifício do tipo lâmina acabou sendo modificado pelo arquiteto Hélio Ferreira Pinto, que gozava de boas relações com os militares. Apesar das mudanças no projeto original, voltado para a pré-fabricação total dos edifícios, a estrutura e seus elementos foram mantidos, em concreto aparente, os elementos protendidos e as lajes nervuradas em grelha, que garantem plantas flexíveis, condicionadas apenas pelos caminhamentos das instalações.

O conjunto é composto de três blocos do tipo torre, de planta quadrada, com 72 apartamentos de 2 quartos; e um bloco do tipo lâmina, com 36 apartamentos de 4 quartos. Subvertendo a lógica de ocupação da projeção na superquadra, o projeto enfatiza a verticalidade dos elementos que integram o conjunto.

De feição brutalista, o partido se expressa por meio de um conjunto de elementos verticais que, além da função estrutural (exoesqueletos), são responsáveis pela proteção solar das fachadas correspondentes às salas e aos quartos dos apartamentos. Esses elementos, que criam interessantes espaços internos, comparecem no térreo sob a forma de pilotis. Com exceção das áreas de serviço, há um equilíbrio entre cheios e vazios: todas as aberturas são protegidas pelos elementos verticais. No caso dos banheiros, houve a adição de planos diagonais com pequenas aberturas, que garantem a ventilação natural e uma iluminação difusa.

As paredes, que têm a função ora de fechamento da caixa, ora de paredes e divisórias, são em concreto fundido in loco, com a mesma espessura dos montantes. Nas superfícies externas são visíveis as marcas das fôrmas de concreto.

Para as torres, utilizam-se elementos semelhantes, com a diferença de que as cargas são diretamente transmitidas no solo, através dos montantes. No primeiro piso uma grelha de concreto armado, moldada no local, receberia também os esforços incidentes na linha das paredes divisórias (SOUZA LIMA, 1965, p. 53).

No caso da lâmina, as lajes perfuradas de faces lisas apoiam-se nos montantes externos e na linha longitudinal das paredes de serviço. Em um sentido, os montantes espaçados de 0,75 m transmitem os esforços às vigas transversais; no outro, as vigas longitudinais recebem as cargas transmitidas pelas transversais e descarregam nos pilares, que têm a forma de pirâmides truncadas. As vigas longitudinais são dispostas duas a duas, para permitir a descida das tubulações. 
Por meio de grandes áreas separadas por pequenos desníveis, o projeto paisagístico procurou integrar o piso térreo dos edifícios, proporcionado assim o efetivo uso dos pilotis pelos moradores.

É a única quadra de Brasília que, ao invés de número, ficou conhecida pelo nome de Conjunto São Miguel. Empenhado em promover a transferência do Itamaraty para Brasília, o embaixador Wladimir Murtinho, em visita às obras dos edifícios que seriam destinados aos diplomatas recémchegados, vendo-as em total estado de abandono, teria apelidado a quadra de São Miguel, o nome do santo das causas perdidas (MENDES, 1995, p. 79).
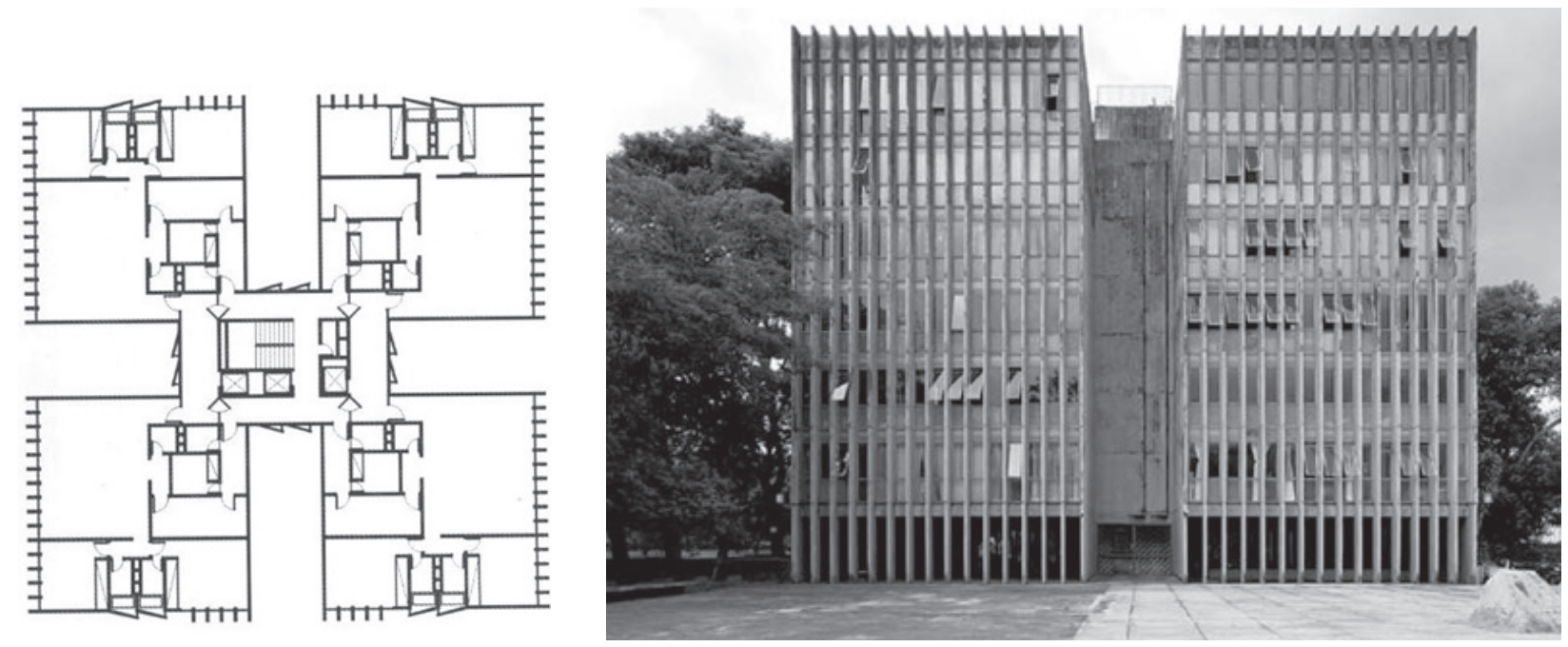

Figura 58b.

Planta do Pavimento

Tipo: 1. Quarto; 2. Copa/

Cozinha; 3. Sala; 4.

Dependência; 5 . Hall
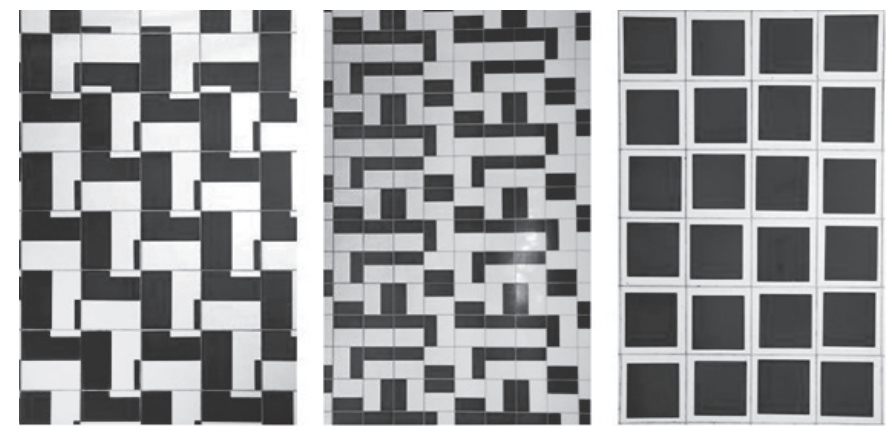

Figura 58c.

Vista da fachada Leste do bloco F da SON 107

Foto: Walter de

Carvalho.

Figura 58d.

Painéis de azulejos de Athos Bulcão (1965) respectivamente para os blocos F, G e I da SQN 107

Fotos de Patrick

Grosner.

Figura 58e

Vista das fachadas Leste e Norte do bloco I
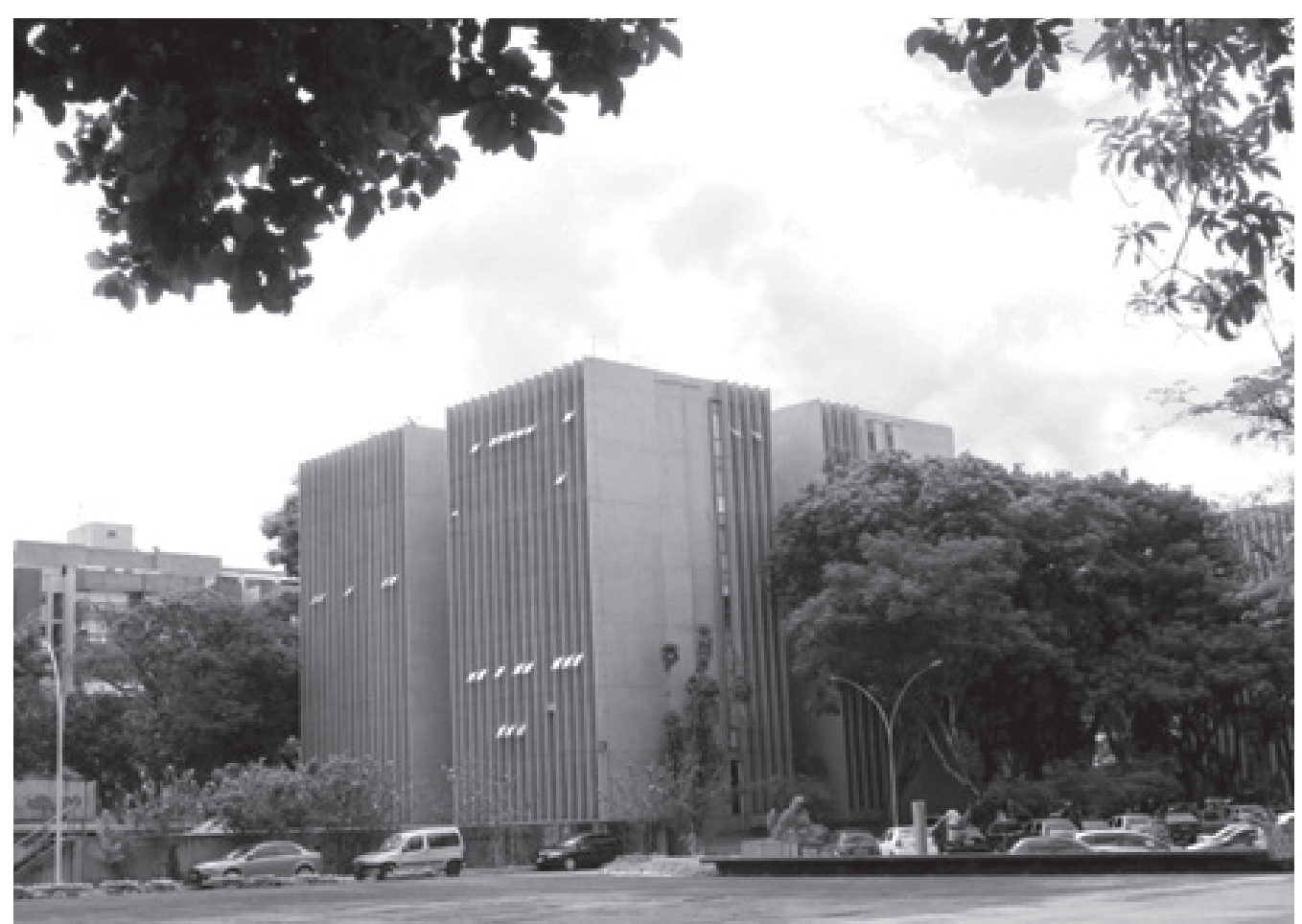


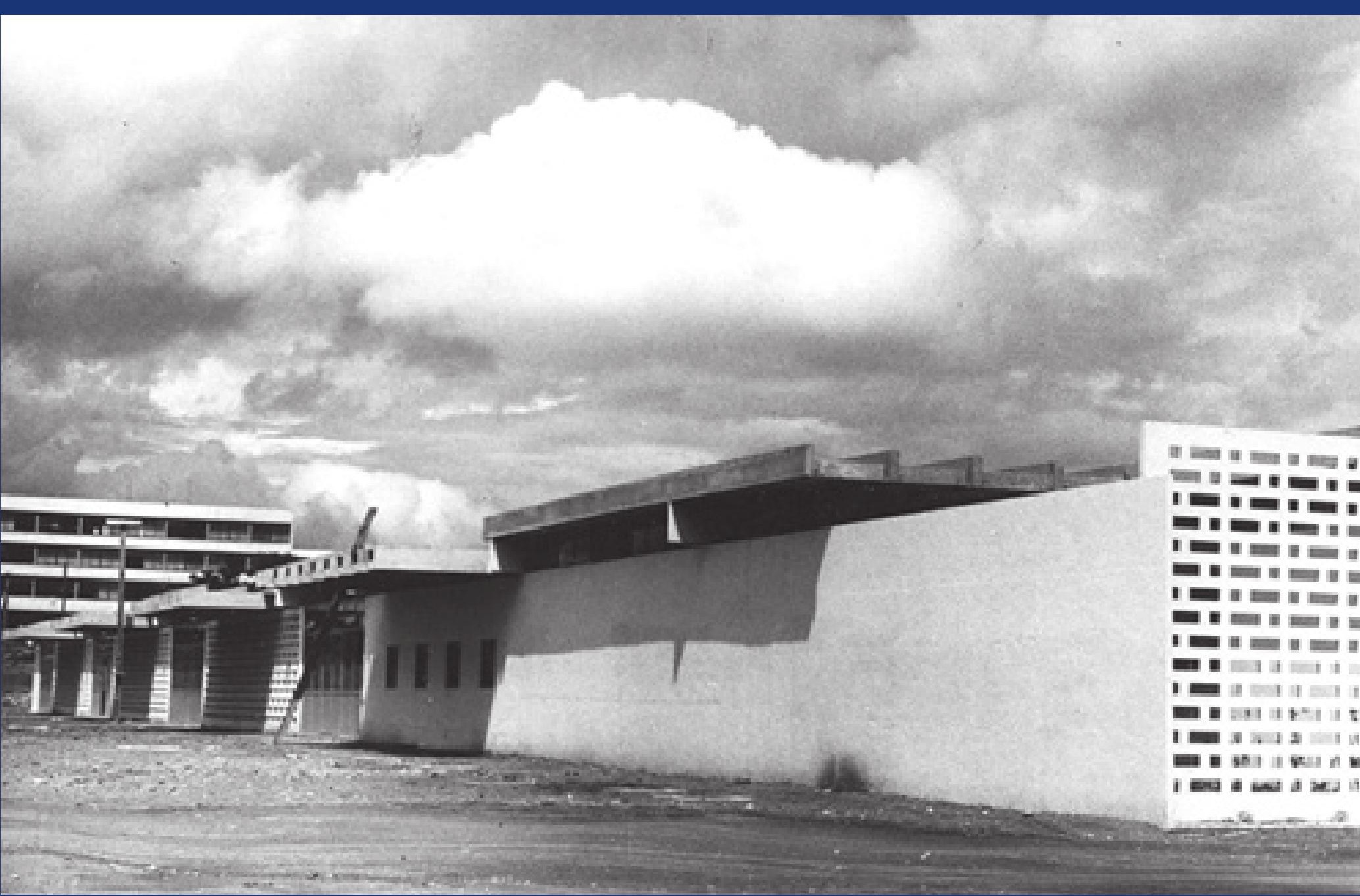

Autoria

Sabino Machado Barroso 3

Data

1963

Área Construída

$8.100 \mathrm{~m}^{2}$
Figura 59a

Vista da

fachada Sul 
O edifício foi construído para abrigar uma instituição similar aos colégios de aplicação ${ }^{4}$ existentes em alguns estados brasileiros. Assim, o Ciem deveria servir de local para a prática pedagógica dos alunos de licenciatura da Faculdade de Educação da Universidade de Brasília 5 .

O edifício, de um pavimento, foi composto por quatro alas de ensino, cada uma das quais se abria, ao mesmo tempo, para uma passarela de circulação e para um pátio ajardinado. Completando o conjunto havia mais duas alas separadas por uma circulação central. Uma dessas alas era voltada para um pátio aberto e a outra para o exterior, compondo a fachada leste. Nessas alas diferenciadas, dispunham-se, originalmente, pequenas moradias para os professores da instituição, sendo que as células habitacionais eram separadas entre si por jardins internos. A fachada principal, voltada para a L2-Norte, é protegida por painéis vazados pré-fabricados.

O sistema construtivo adotado foi composto de vigas, painéis-parede e painéis vazados (tipo cobogó) pré-fabricados de concreto armado.

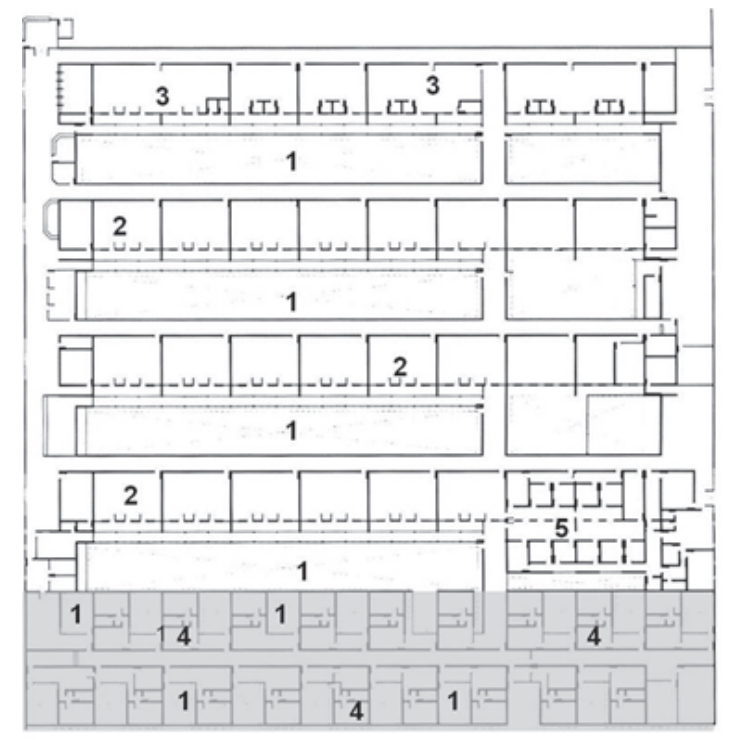

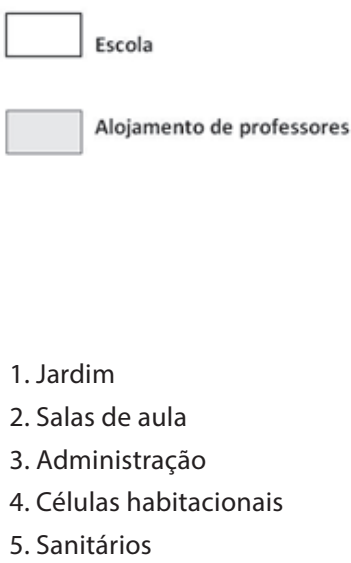

Figura 59b.

Planta do CIEM (ocupação original)

O Ciem funcionou de 1964 até 1971, quando foi fechado, pondo fim a uma promissora experiência pedagógica em Brasília. O edifício foi, então, reformado para abrigar o Ambulatório do Hospital Universitário de Brasília (HUB).

Encerrando o experimento em pré-fabriação da UnB, surgiu o grande edifício-rua que, destinado a abrigar os ambientes voltados para a pesquisa e produção científica, apresenta, segundo Coutinho, "[...] uma concepção muito inovadora: praticamente toda a Universidade é alojada ao longo de uma rua" (2012).

\footnotetext{
${ }^{4}$ Os Colégios de Aplicação foram criados pelo Decreto Federal n. 9.053, de 12 de março de 1943, com a função específica de ser um tipo de estabelecimento de ensino em que os próprios alunos dos cursos de Licenciatura fizessem a aplicação, numa situação real de ensino-aprendizagem, dos conhecimentos técnicos adquiridos no Curso de Graduação, servindo também de campo de experimentação pedagógica para renovação e melhoria do ensino fundamental e médio.

${ }^{5}$ De acordo com Teresinha Rosa Cruz, ligada ao Projeto Ciem-UnB desde seus primórdios, a experiência brasiliense repetia o que aconteceu no Colégio de Aplicação de São Paulo e de outros estados como Minas Gerais e Bahia (CRUZ, 2001).
} 


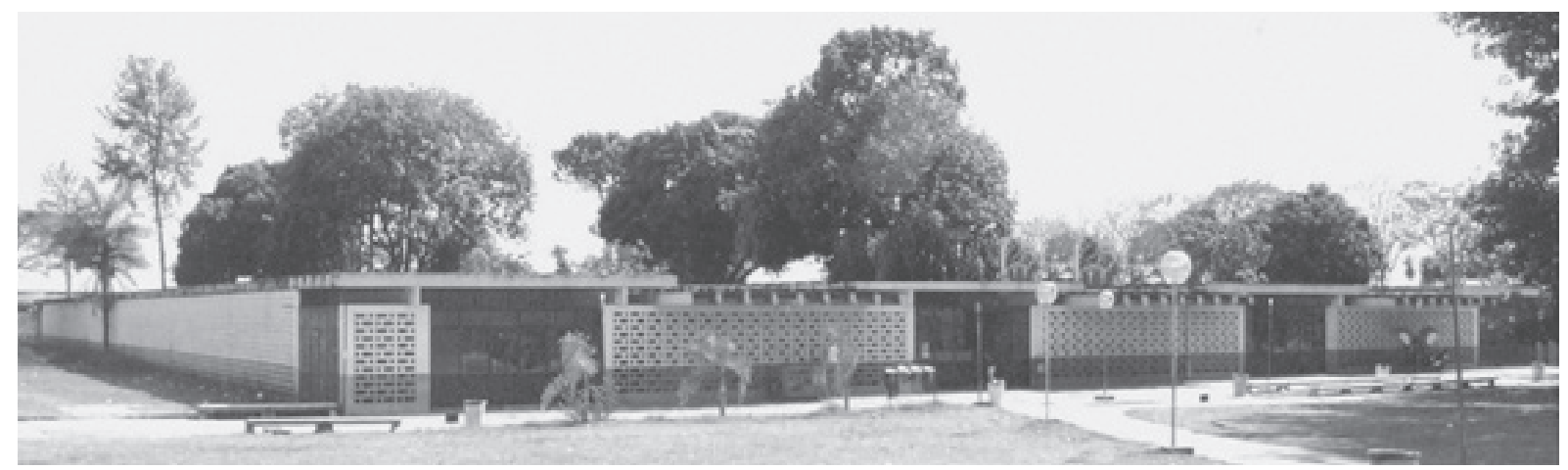

Figura 59c.

Planta do Ciem:

ocupação origina

Figura 59d. Vista

externa atual

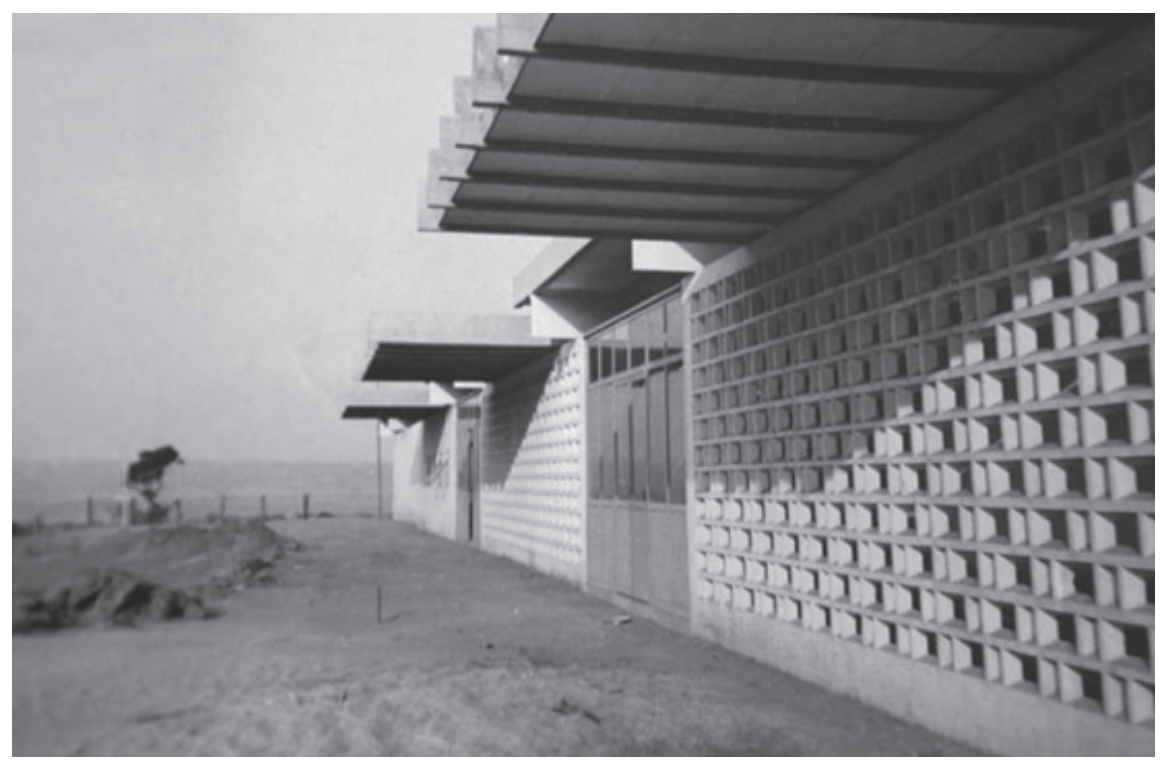


INSTITUTO CENTRAL DE CIÊNCIAS (ICC)

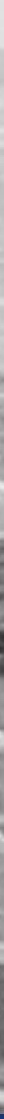

Autoria

Oscar Niemeyer, com a colaboração de João Filgueiras Lima

\section{Datas}

1963 (projeto)

1972 (conclusão parcial da obra) $^{6}$

Área Construída

$126.600 \mathrm{~m}^{2}$
Figura 60a.

Implantação do ICC

\footnotetext{
${ }^{6}$ O prédio começou a ser ocupado, em 1970, logo que a estrutura ficou pronta, pela Psicologia e pela Biologia. Apesar de ter sofrido várias
} alterações em relação ao projeto original, a obra não chegou a ser totalmente concluída. 
O ICC resultou da unificação dos cinco institutos de ciências - Matemática, Física, Química, Biologia e Geociências - previstos por Darcy Ribeiro e contemplados no primeiro plano urbanístico da UnB concebido por Lucio Costa.

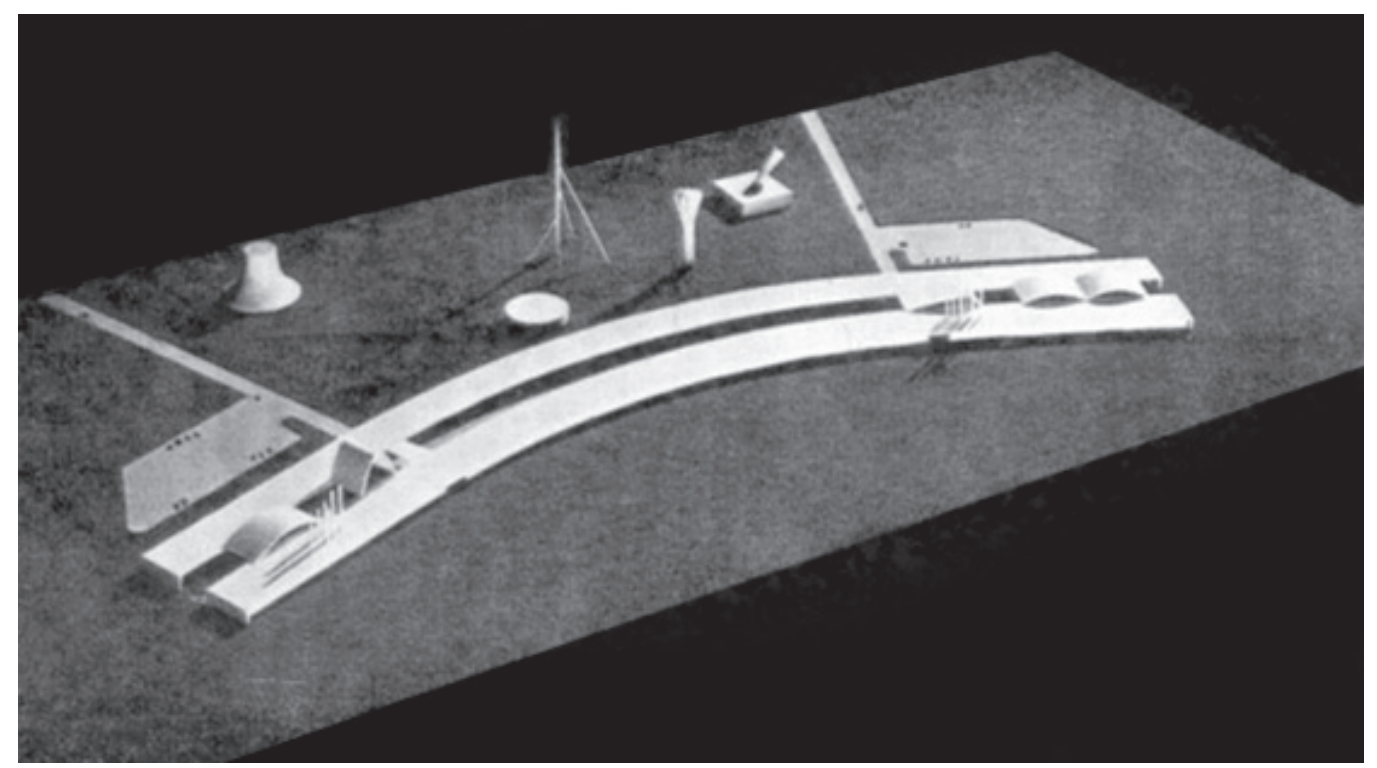

Figura $60 \mathrm{~b}$. Maquete do ICC

O partido adotado, uma edificação em escala urbana, lembra outras propostas feitas por Le Corbusier (Edifício Autoestrada, 1929) e Affonso Reidy (Conjunto Residencial de Pedregulho, 1948) para o Rio de Janeiro.

O edifício, que se propõe a ser uma arquitetura verdade, não esconde seus elementos componentes: as alvenarias em tijolos e todos os componentes do sistema estrutural são aparentes, o que o torna bastante didático.

Trata-se de um conjunto de dois pavimentos e um subsolo - $696 \mathrm{~m}$ de extensão, $60 \mathrm{~m}$ de largura e $120.000 \mathrm{~m} 2$ de área. Longitudinalmente é composto por dois grandes blocos retos, nas extremidades Norte e Sul, e um curvo no centro, intercalados por dois amplos halls de entrada, que chegam a ter 45 metros de vão livre. Desses halls, o acesso ao mezanino se dá por grandes rampas em forma de "U", conforme descrito por Schlee (2012):

[...] em cada praça do Instituto Central de Ciências (entradas Norte e Sul), Oscar Niemeyer colocou uma rampa em balanço, como que assinando sua obra [...] a força plástica de tais elementos, a curvatura do prédio, o ritmo proposto pelos pórticos estruturais aparentes e a variada vegetação do jardim interno garantem ao prédio uma surpreendente, diversificada e rica leitura. No ICC, ele obteve uma arquitetura imprevista e dinâmica, como a própria ciência.

Transversalmente, as faixas Leste (B) e Oeste (A) são separados, no nível térreo, por uma faixa de 15,00 metros de jardins e circulações (C); e, no nível do subsolo, por uma via interna de veículos, que atravessa todo o edifício no sentido Norte-Sul. Parte do arco externo, com 30 m de largura, apresenta pé-direito duplo; e o interno, que mede $25 \mathrm{~m}$ de largura, abriga, principalmente, os auditórios e as salas de aula. Os dois blocos, concebidos com propósitos diferentes, são constituídos de térreo, mezanino e subsolo. O mais estreito apresenta pé-direito duplo e foi destinado aos laboratórios de pesquisa; o mais largo foi reservado às atividades de ensino. 


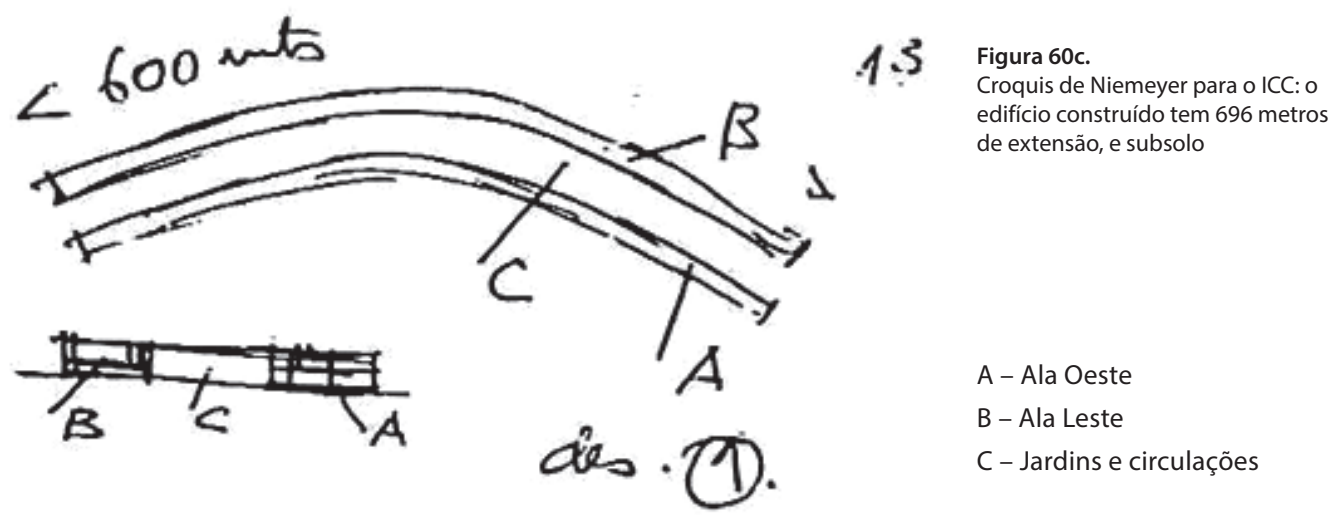

A opção, mais uma vez, recaiu sobre um sistema de pré-fabricação, que pode assim ser resumido: pilares a cada 3 metros definem o módulo estrutural de $3 \mathrm{~m} \times 30 \mathrm{~m}$. As lajes do térreo e do mezanino são compostas por vigas-calhas ocas, sendo os vazios destinados às instalações. Pilares duplos disponibilizam espaço para o caminhamento vertical dessas instalações, promovendo total flexibilidade dos leiautes internos. Para vencer o vão de 30 metros foi usado o sistema de protensão das vigas pré-moldadas em perfil " $T$ ".

Conhecido como "minhocão" por sua forma alongada, o edifício começou a ser construído nos primeiros anos da universidade, a partir da extremidade sul.

Conforme explicou Pessina, como o terreno era do tipo argiloso, ficava inviável o uso de estacas devido ao curto prazo. A solução foi a execução de um subsolo com uma camada de cascalho, que funcionava como um radier, transferindo as cargas da edificação diretamente para o solo.

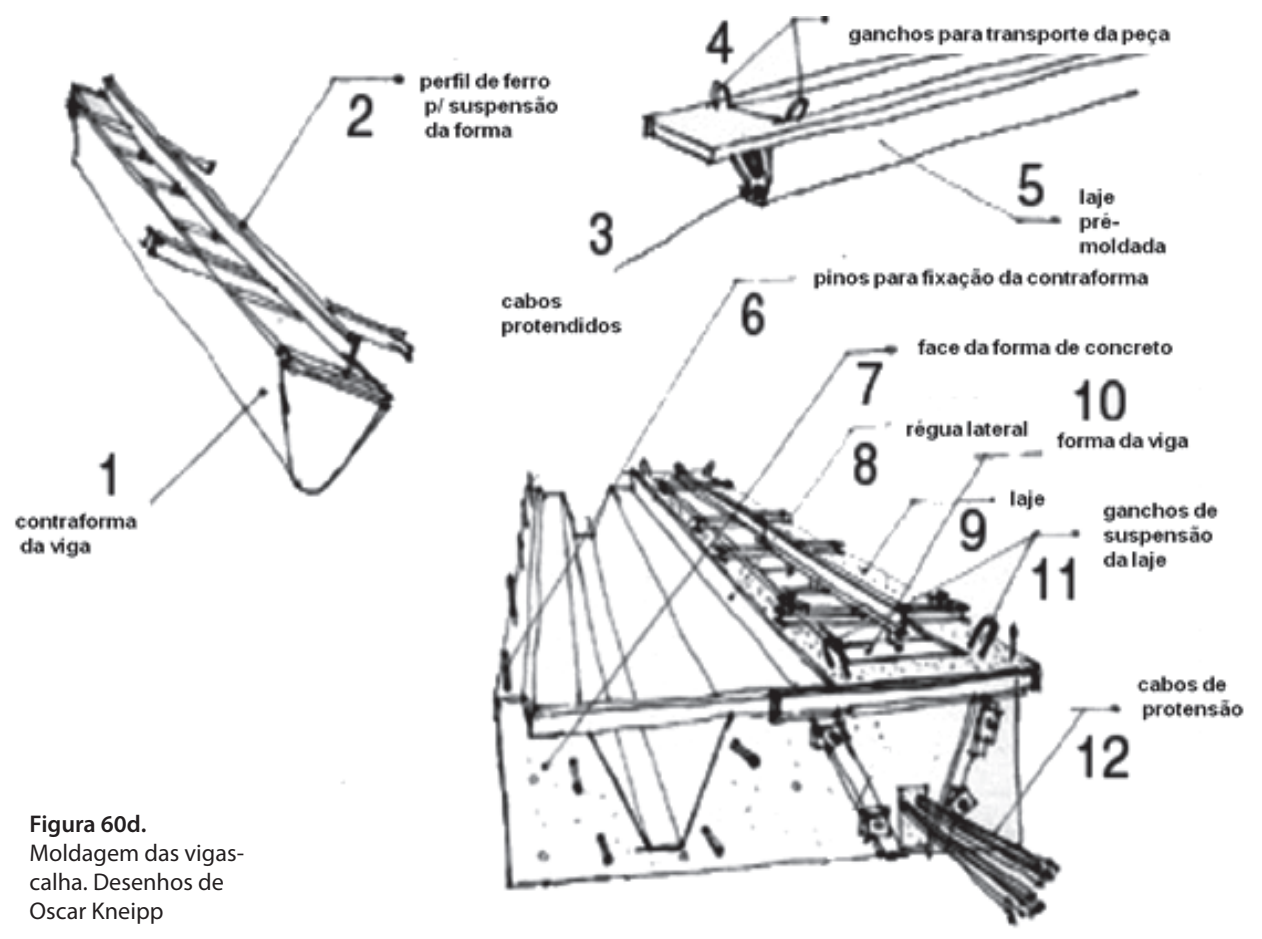



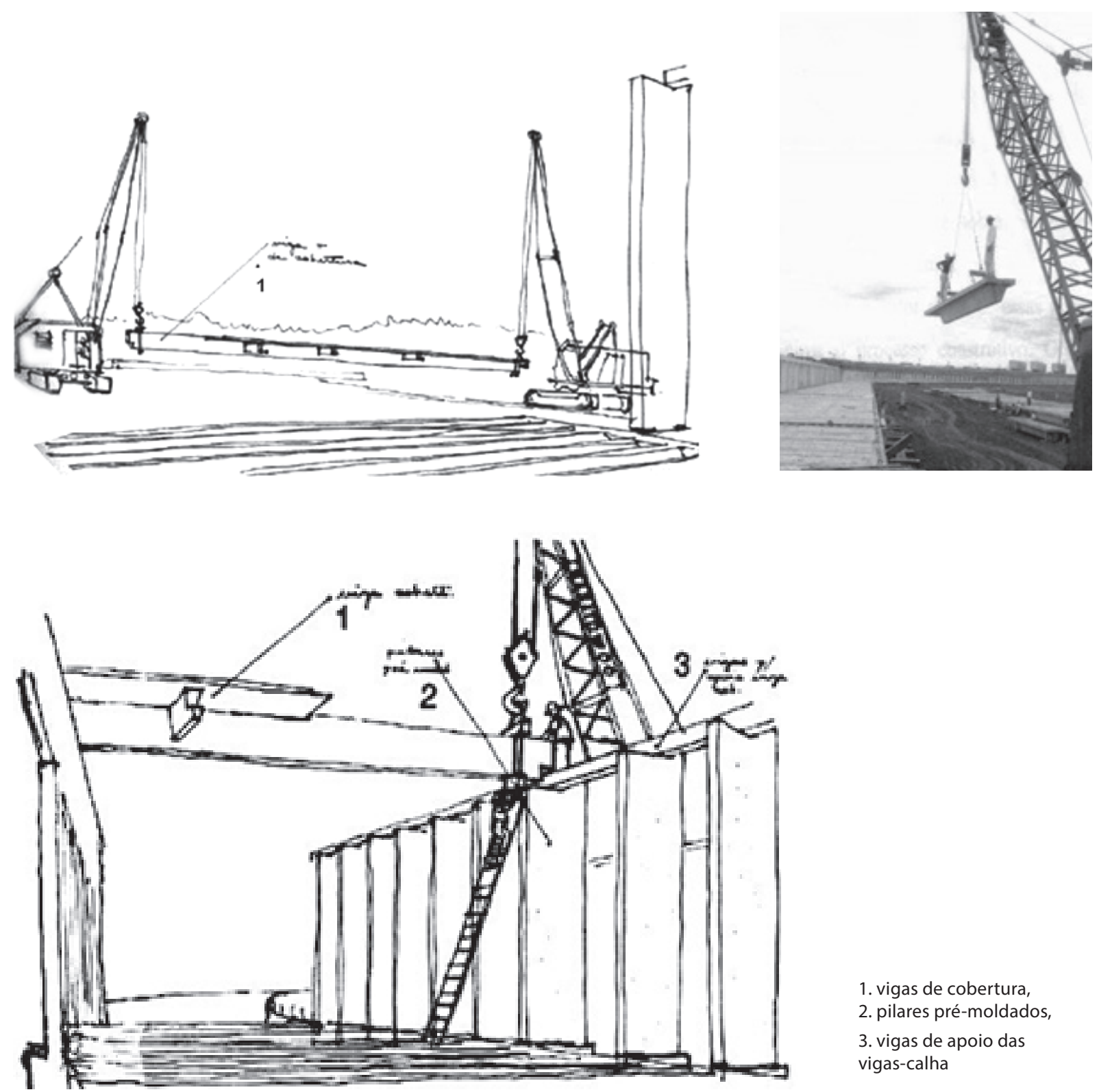

1. vigas de cobertura,

2. pilares pré-moldados,

3. vigas de apoio das vigas-calha

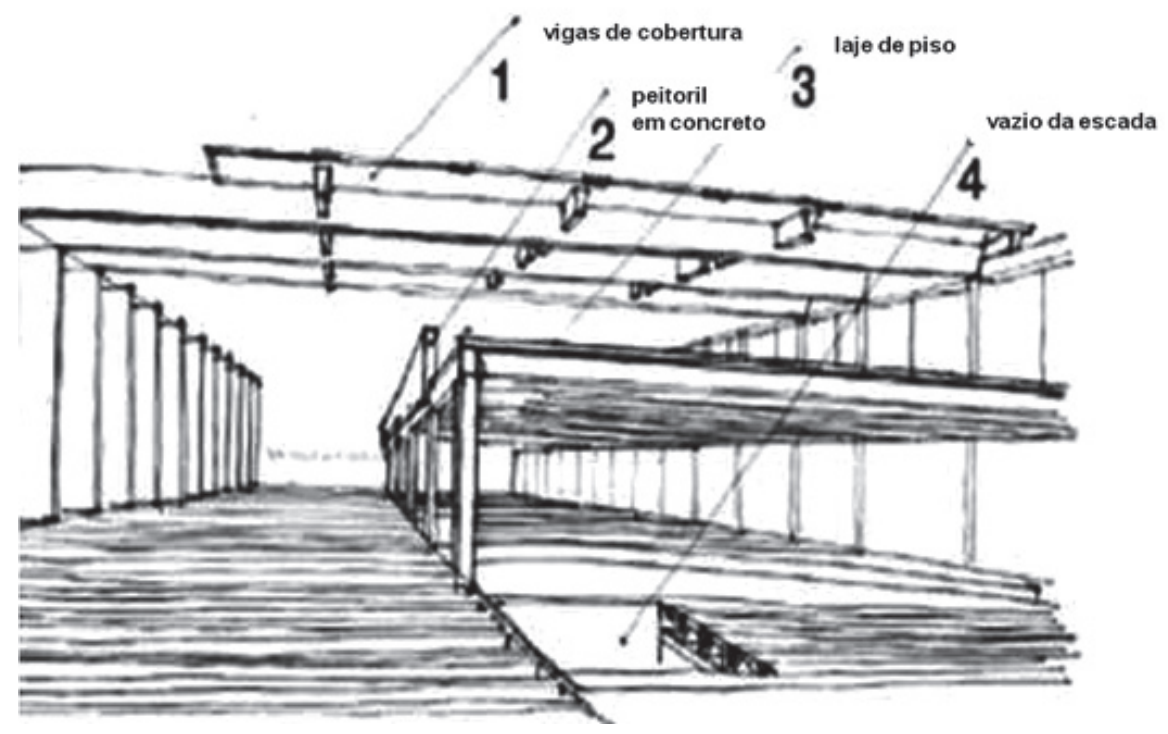

Figura 60e e $60 \mathrm{f}$.

Sistema de montagem:

1. Vigas de cobertura

Figura 60g.

Montagem da cobertura

Figura $60 \mathrm{~h}$.

Sistema de montagem:

1. Vigas de cobertura 

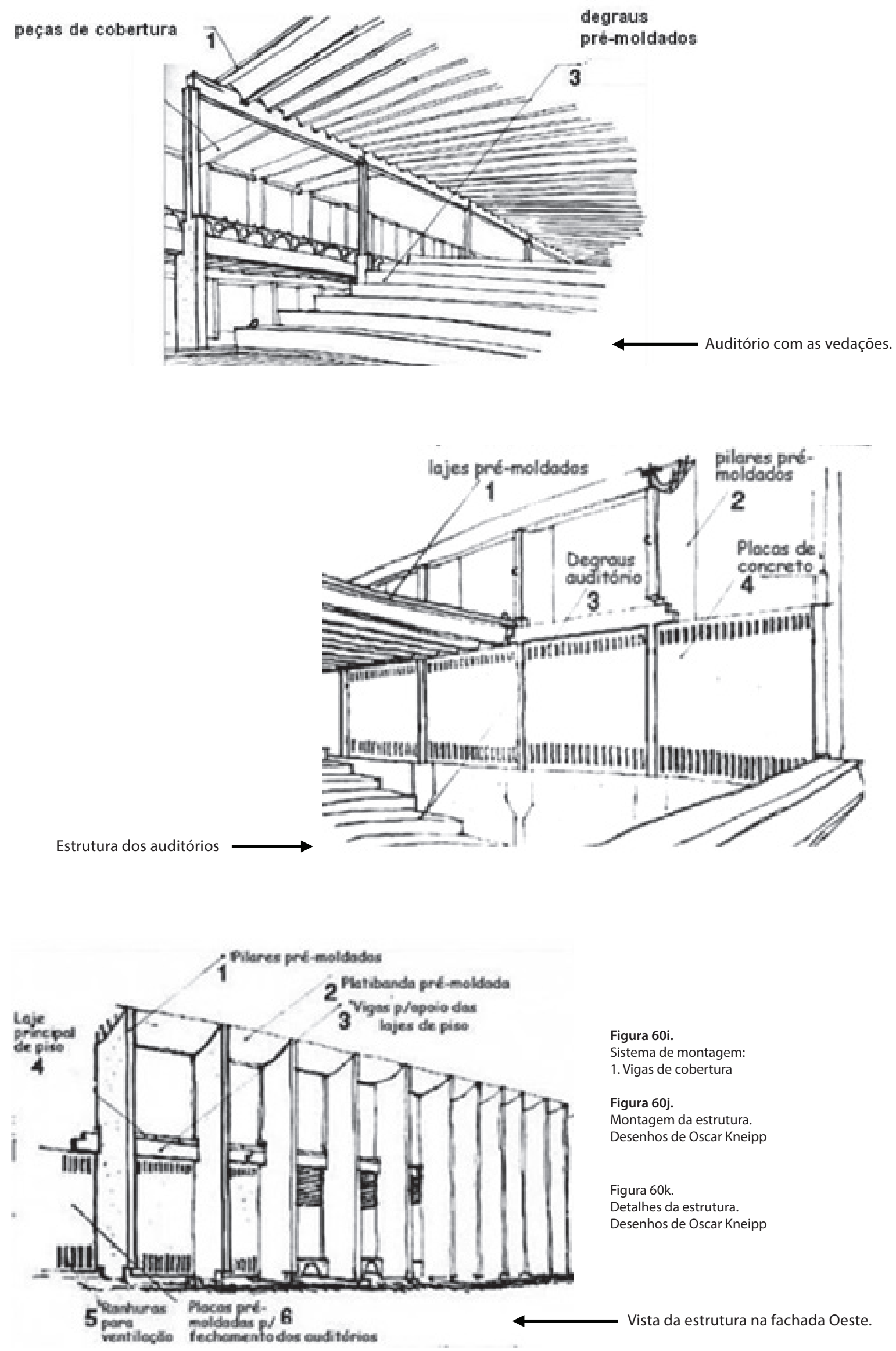

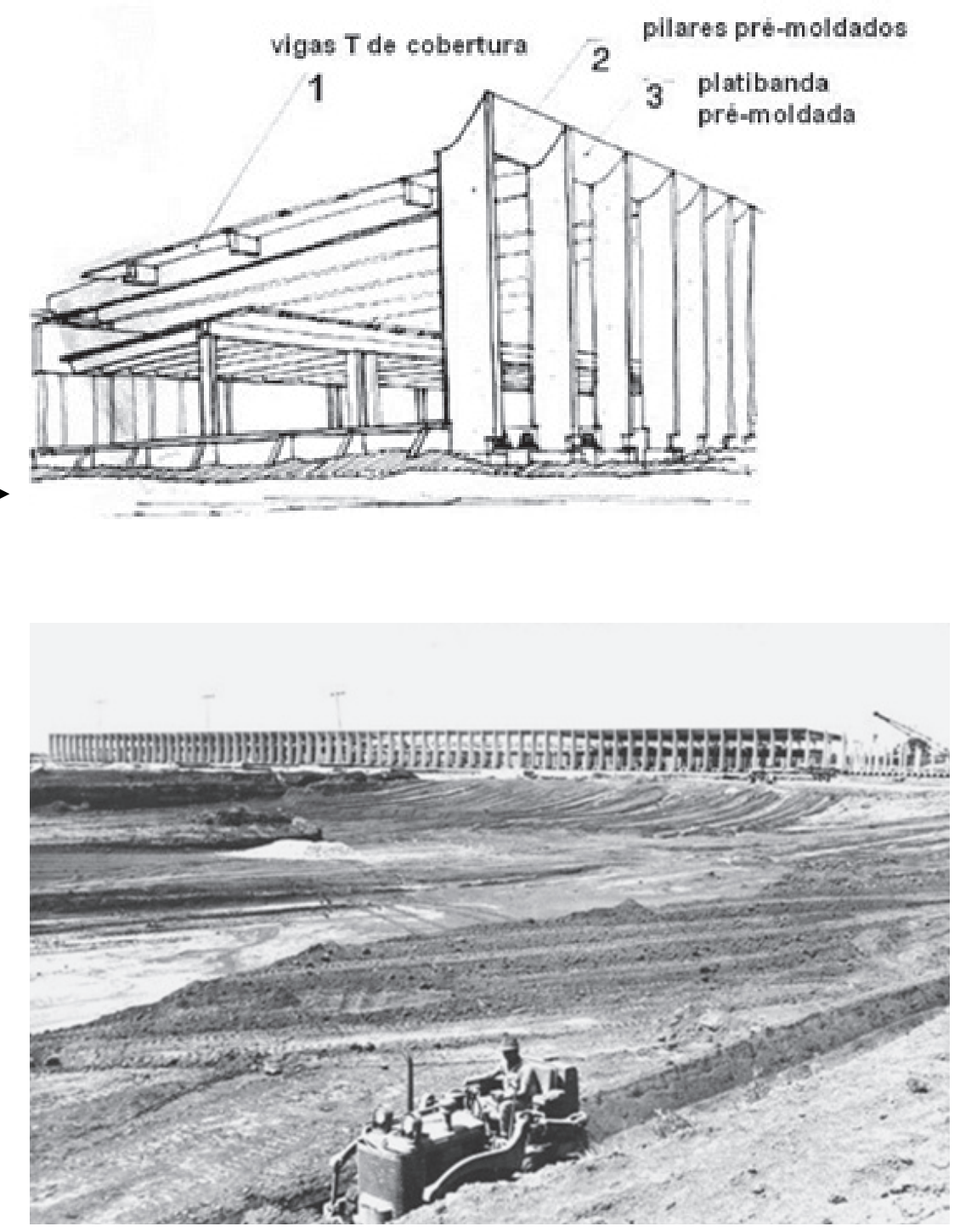

Figura 60l.

Detalhes da estrutura.

Desenhos de Oscar Kneipp

Figura $60 \mathrm{~m}$.

Movimento de terra

Figura 60n.

Montagem da estrutura do ICC

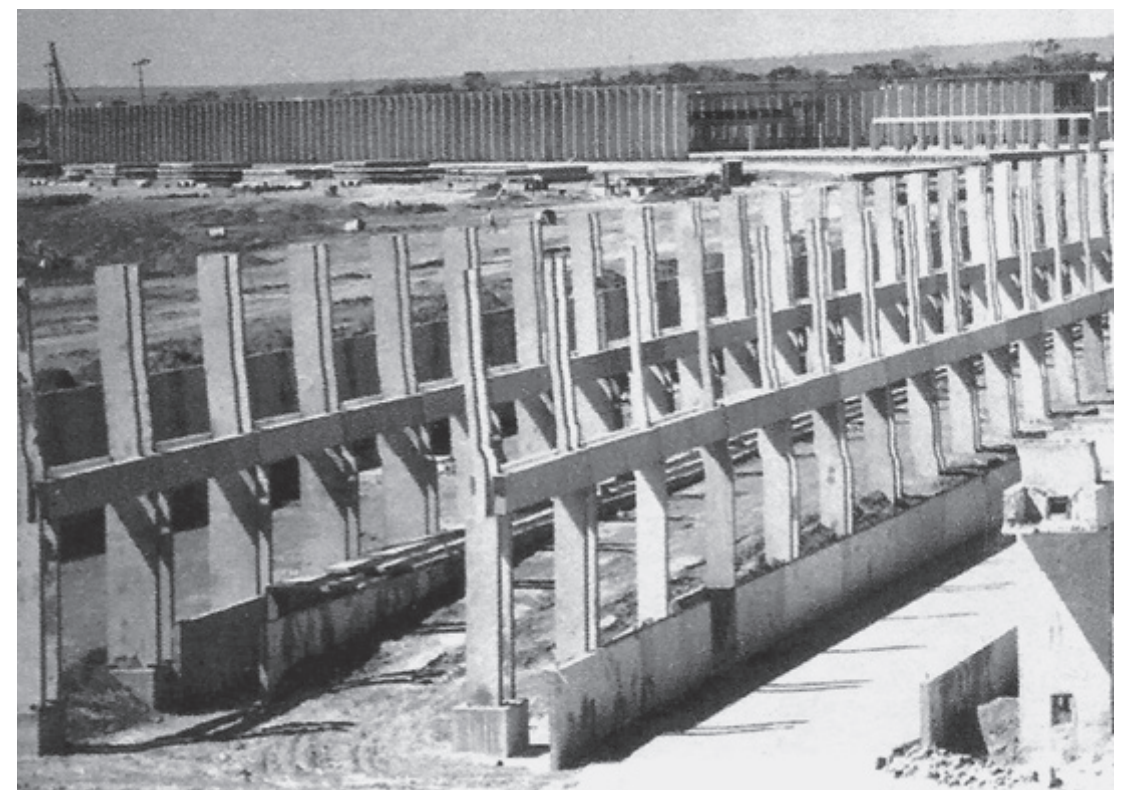




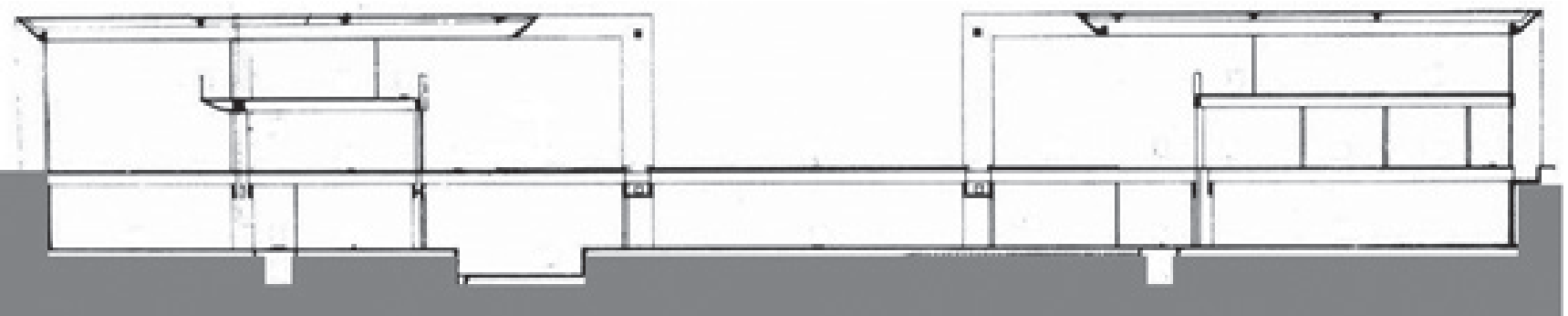

Figura 60o.

Desenho de Eliel

Américo Santana

da Silva

Figura 60p

Corte transversal

esquemático

Figura 60q

Vista da estrutura

na fachada Sul.

Desenho de

Oscar Kneipp

Figura 60r.

Vista da fachada Sul
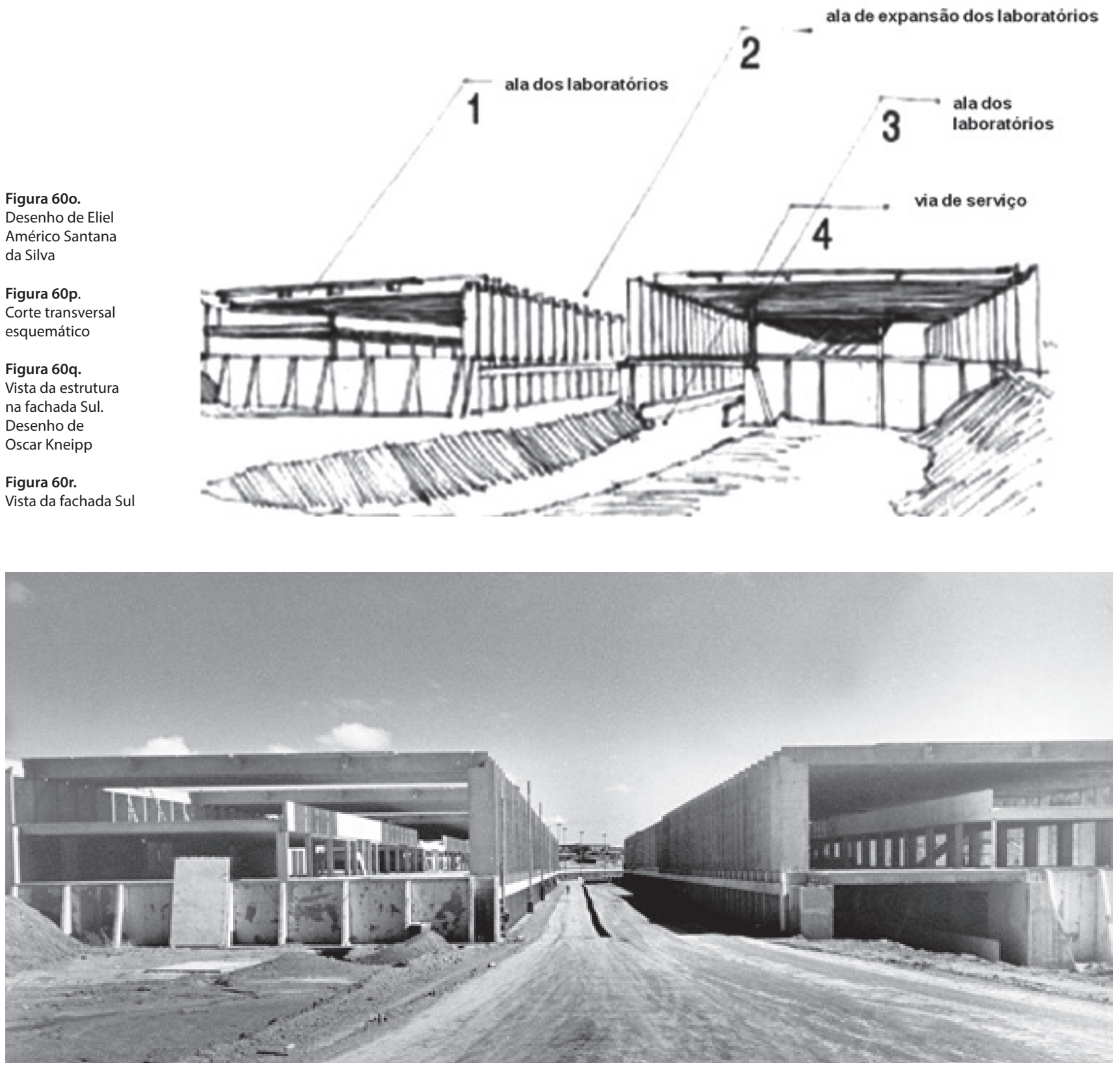


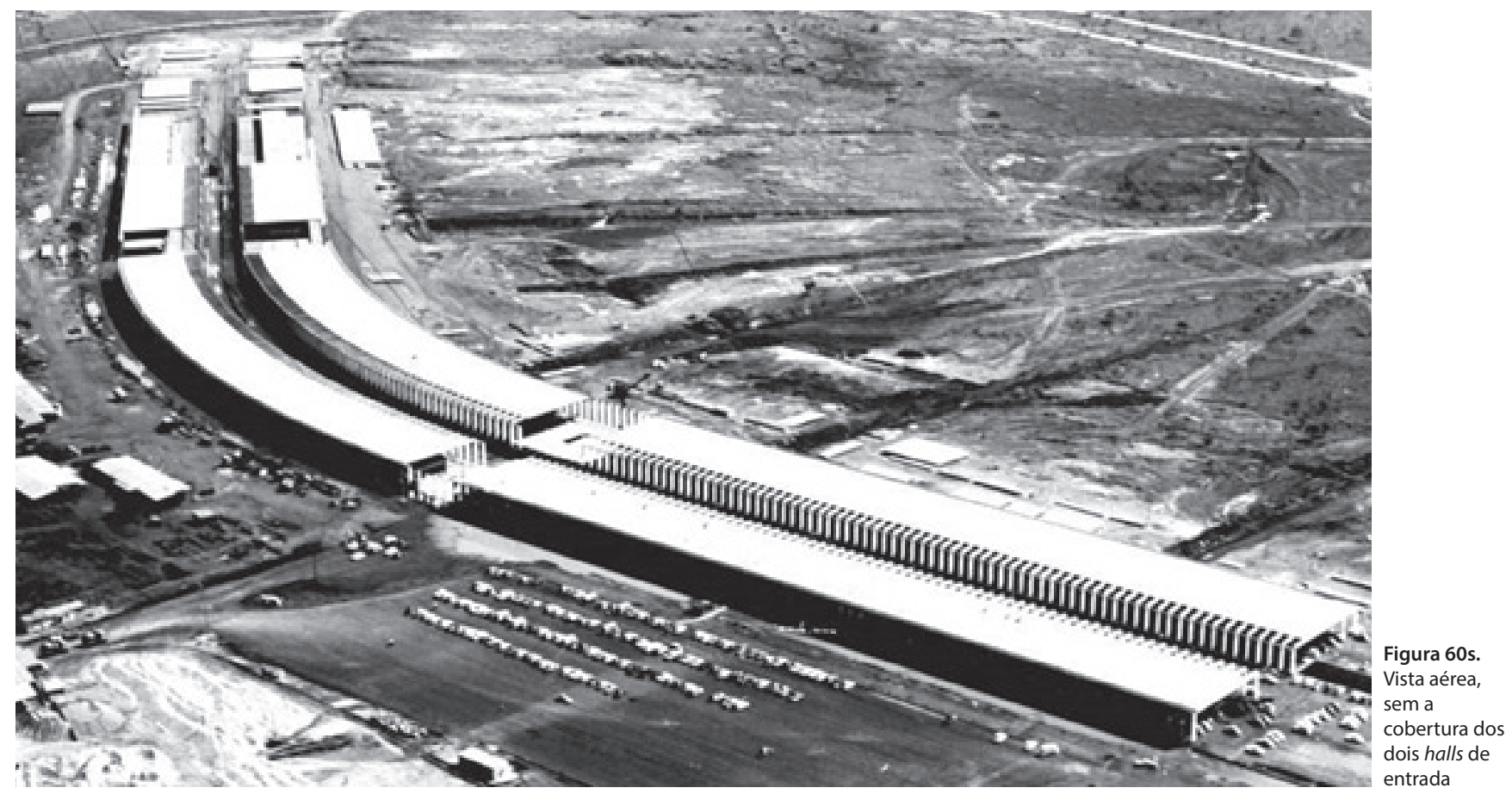

Logo após a escavação das fundações foram feitas algumas modificações no projeto do ICC; a principal delas foi o aumento da área de ocupação do subsolo. Conforme explicou Lelé,

No Minhocão houve um problema [...] A gente imaginava que a parte de baixo não existisse. Era só uma rua de serviços com uma ala de depósitos. Quando fizeram as fundações, escavaram tudo. Íamos recolocar a terra, aí o Darcy disse: "Não, a gente não pode perder esse espaço. A gente pode guardar coisas lá". O Oscar concordou. Então sobrou aquele espaço enorme. Foi a primeira distorção do projeto do ICC. Acabaram "enfiando" salas de aula lá embaixo. Em 1965, ainda no início da execução, nós fomos demitidos da Universidade. O ICC foi construído praticamente sem a nossa participação [...] O projeto do ICC deixa muito a desejar na questão do acabamento. A ideia era fazê-lo completamente pré-fabricado, com placas de pré-moldado. $O$ tijoloinho foi uma adaptação. Depois do Golpe, a obra foi paralisada completamente. Entrou um pessoal que questionava o ICC, dizendo que era uma coisa enorme, que não ia ficar pronta... Foi um projeto muito sacrificado (LIMA, 1999, p. 18).

Sobre a continuidade do trabalho de pré-fabricação na UnB, assim se manifestou Lelé:

A intenção era montar aqui a nossa fábrica [...] Eu cheguei a fazer uma perspectiva, mas o projeto sumiu. Na verdade, havia uma pressão da Rabello, que estava montando os pré-fabricados, para participar do projeto. O Oscar fez a proposta inicial e depois eu fiz a adaptação e desenvolvimento do projeto. A construtora Rabello iria construir a obra, mas isso aconteceu exatamente na época da demissão (Entrevista em 29 fev. 2012).

Assim, foi abortada a tentativa de desenvolvimento tecnológico da construção na Universidade de Brasília. No entanto, a ideia de um sistema de pré-fabricação no âmbito universitário seria implementada, a partir de 1969, pela Universidade Federal de Minas Gerais (UFMG). A experiência, que durou até a década de 1990, constituiu, por sua escala, suas estratégias e seus princípios projetuais, um importante exemplo de arquitetura produzida com base nos fundamentos consolidados pela arquitetura moderna. 


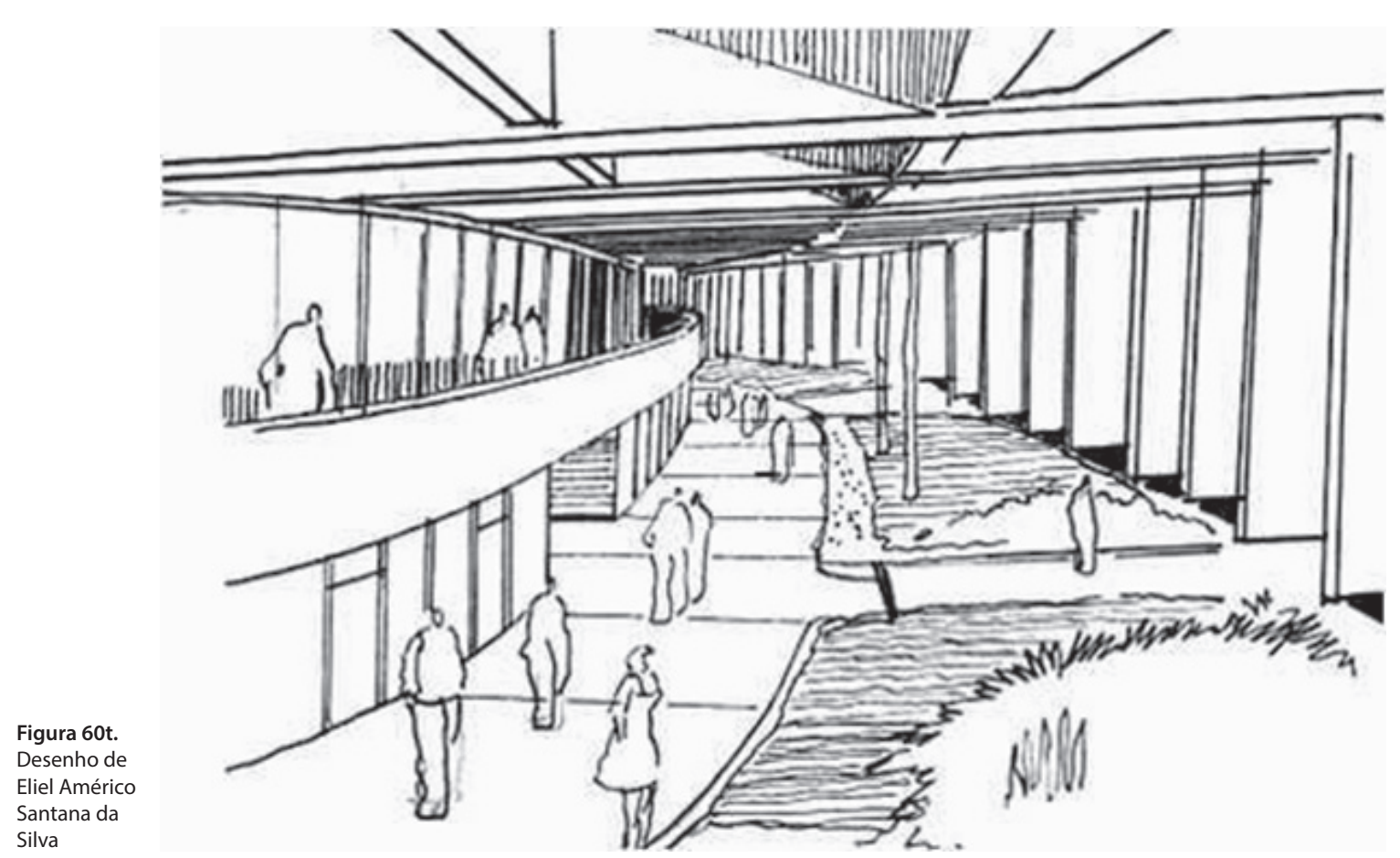

Concebido pelo Setor de Arquitetura do Conselho de Planejamento da UFMG, o chamado metaprograma partia de uma proposta conceitual que, resumindo as atividades da vida acadêmica, deveria ser aplicado para a construção de um metaprojeto, concebido como um sistema contínuo e de crescimento regular. Conhecido por Sistema Básico, o projeto, desenvolvido principalmente pelos arquitetos Alípio Pires Castello Branco, José Abílio Belo Pereira, Maria Lúcia Malard e Sebastião de Oliveira Lopes, partia de uma malha coordenada, que tratava de organizar os espaços internos, externos, os fluxos, os acessos e as travessias, definindo também as possibilidades de crescimento do campus.

O sistema foi responsável pela construção dos edifícios que abrigam atualmente: o Instituto de Ciências Biológicas (ICB), o Instituto de Ciências Exatas (ICEx), a Faculdade de Letras (Fale), a Faculdade de Filosofia e Ciências Humanas (Fafich), a Escola de Ciência da Informação (ECI), a Escola de Belas Artes (EBA), a Escola de Veterinária (EV), a Biblioteca Central e o Restaurante Setorial II.

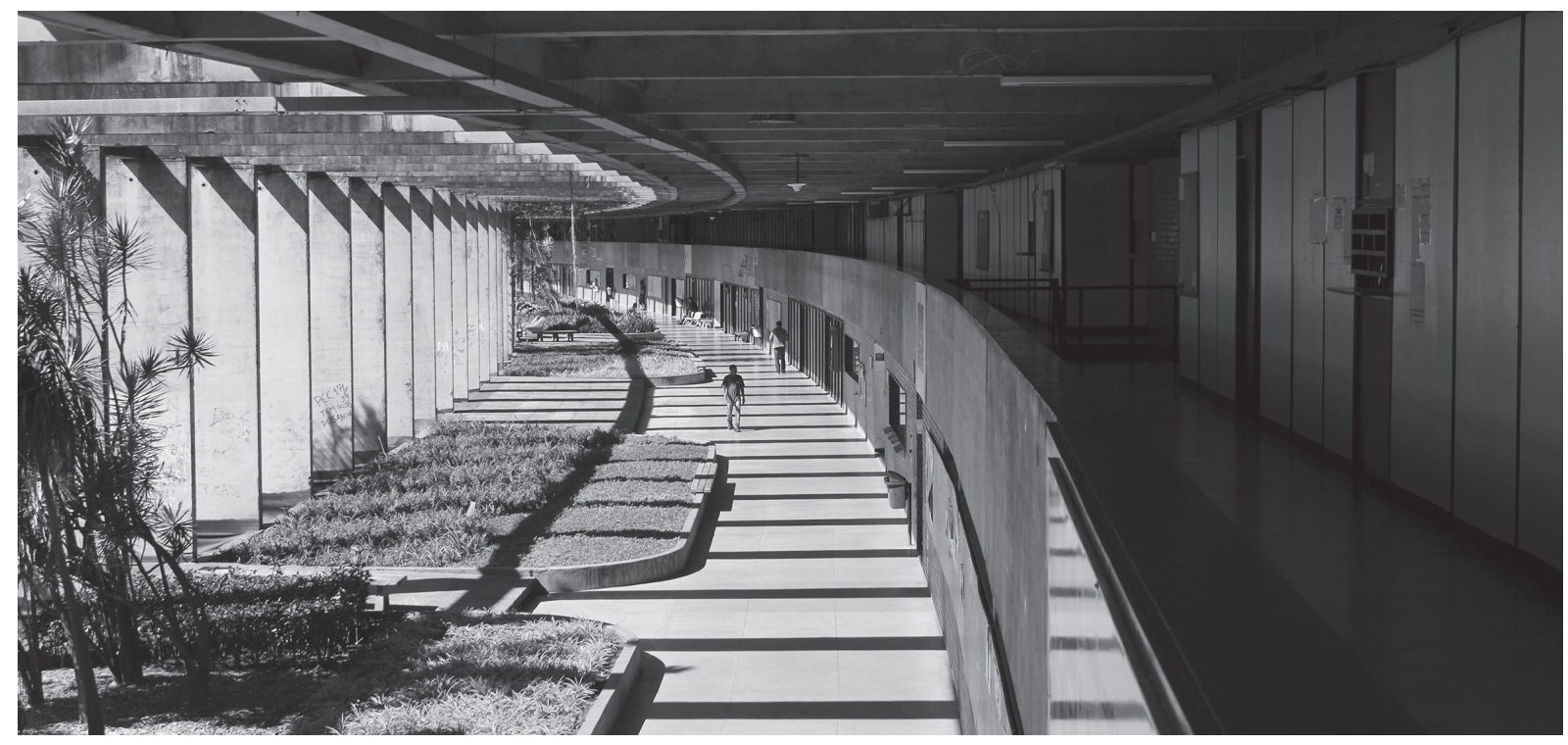




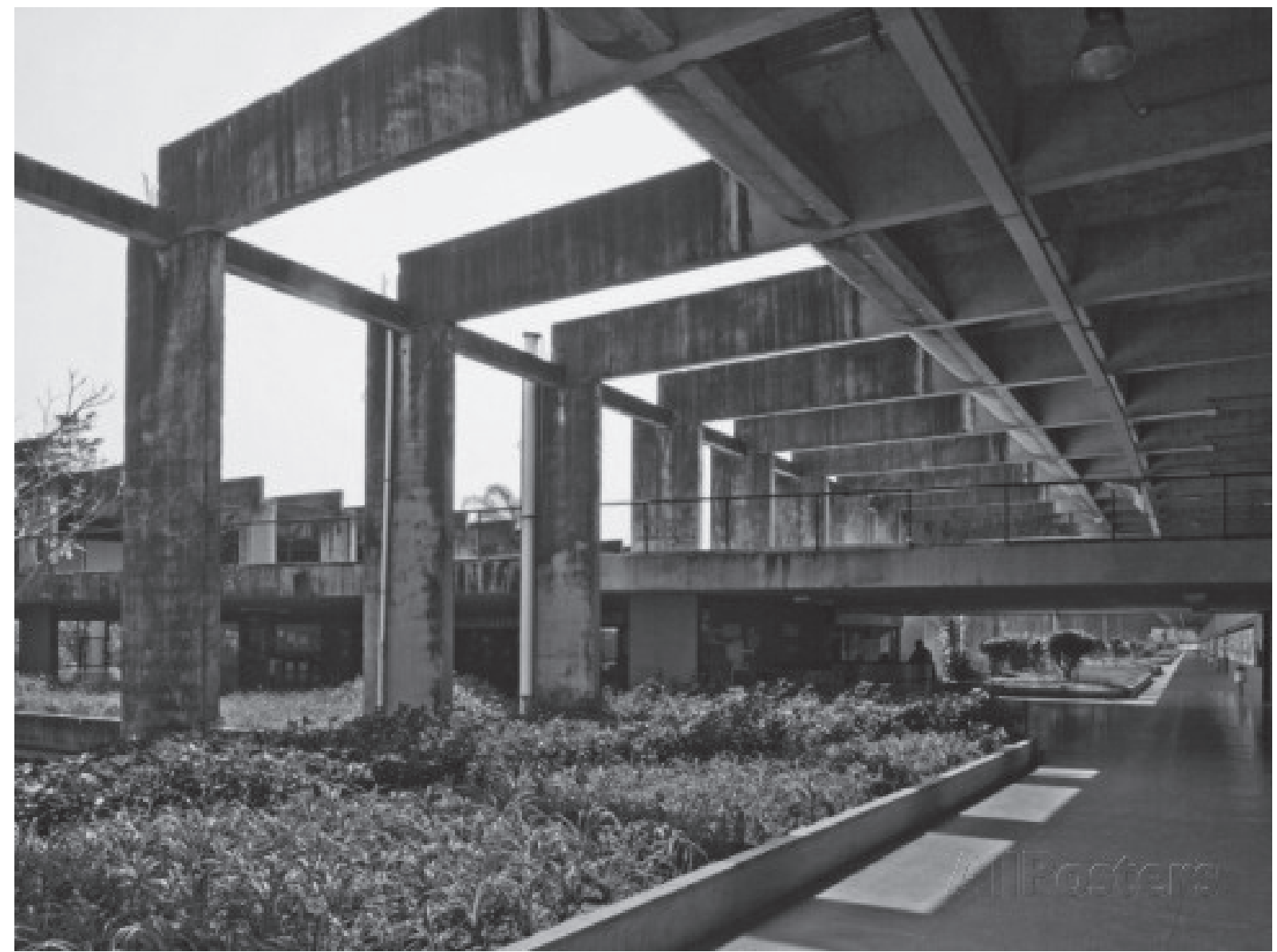



2. O TEMPO DAS CRISES 



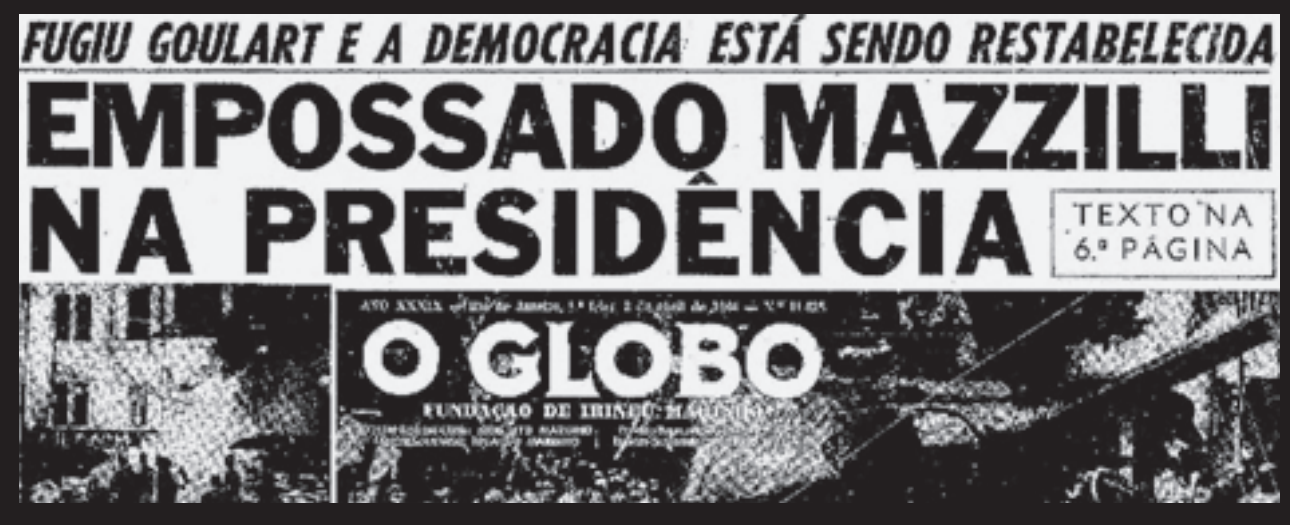

Com um discurso de preservação do Estado democrático, os militares entraram em cena em abril Figura 61. de 1964, deflagrando um golpe contra o governo democraticamente constituído de João Goulart. Não houve uma reação imediata dos grupos de apoio ao governo, fracassou a tentativa de greve convocada pela Central Geral dos Trabalhadores (CGT) e Jango, desistindo de um confronto com os militares, seguiu para o exílio no Uruguai. A falta de resistência só fez encorajar os golpistas, que prenderam cerca de cinco mil pessoas, exilaram os principais líderes do governo deposto, fecharam o Congresso Nacional, expurgaram oficiais das Forças Armadas, destituíram as diretorias de vários sindicatos e, entre outras ações, incendiaram a sede da União Nacional dos Estudantes (UNE).

Conforme relatou Perseu Abramo (2006), a situação em Brasília também ficou bastante tensa:

[...] durante todo o dia 10, circularam os mais desencontrados boatos, a Capital Federal estava praticamente isolada do resto do país e não havia como conferir as informações [...] Somente na manhã seguinte é que a Comissão bem como o restante da população universitária e dos habitantes da cidade tomaram conhecimento de que, durante a noite, o Governo havia sido deposto e assumira o poder o Sr. Ranieri Mazzili, presidente da Câmara dos Deputados.

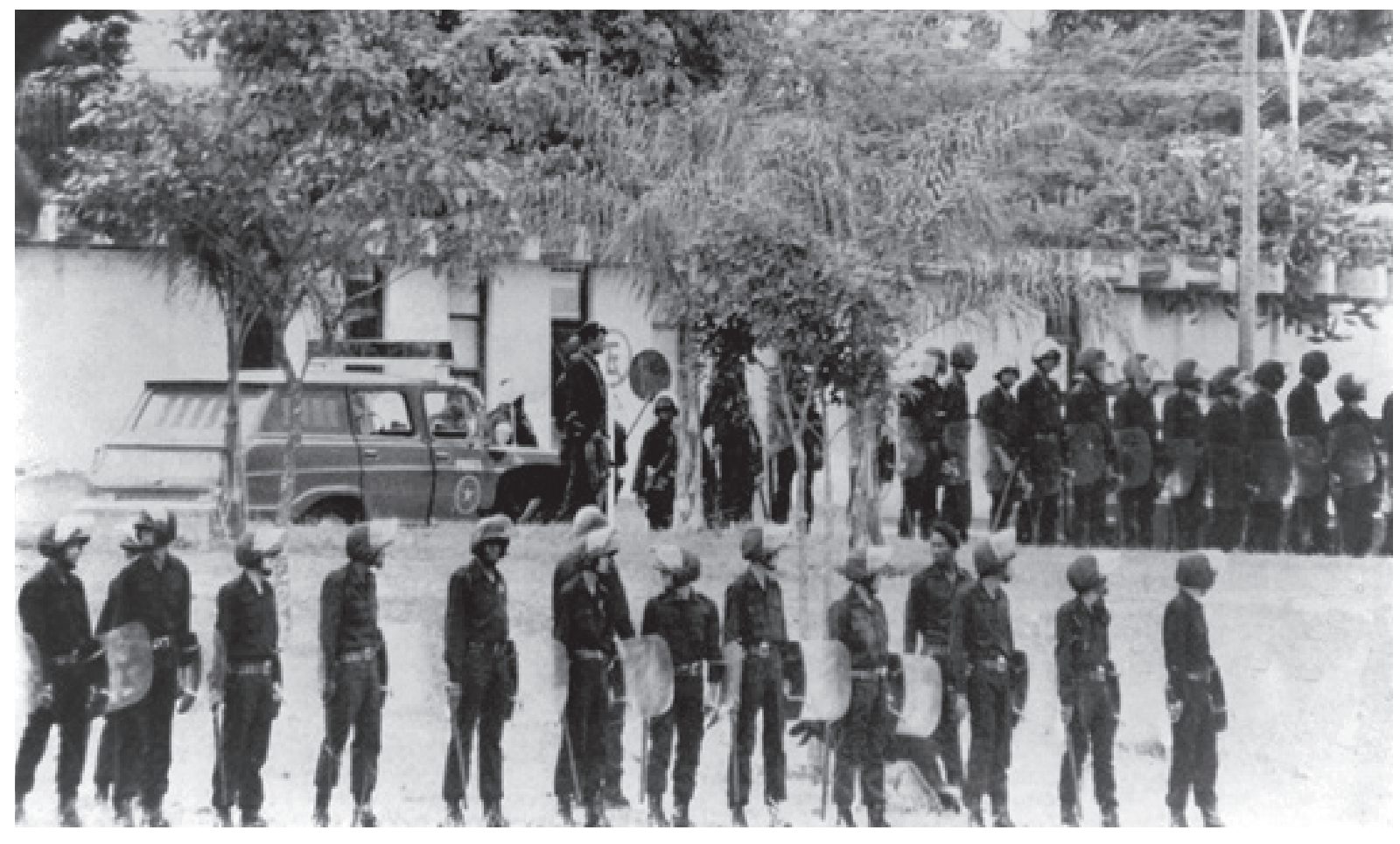


No dia 9 de abril de 1964, sob a alegação de investigar denúncias de subversão e indisciplina, tropas do Exército e da Polícia Militar de Minas Gerais invadiram a Universidade de Brasília (UnB). Acomodados em 14 ônibus, acompanhados por caminhões, ambulâncias e carros de rádio patrulha, os militares adentraram o campus preparados para possíveis confrontos. Como resultado dessa operação, 12 professores e quatro estudantes foram levados para o Teatro Nacional, e de lá para o quartel do Exército, para interrogatório. Além disso, depois de vasculhadas salas de aula e revistados estudantes, em busca de armas e material subversivo, o reitor e o vice, Anísio Teixeira e Almir de Castro, foram sumariamente demitidos no dia 13 de abril de 1964. O professor de medicina veterinária da Universidade de São Paulo (USP), Zeferino Vaz, foi nomeado reitor, cargo que ocupou até agosto de 1965.

Em 15 de abril de 1964, sob o governo do general Humberto Castelo Branco, foi decretado o Ato Institucional n. 1, que conferia ao presidente da República poderes para cassar mandatos eletivos e suspender direitos políticos. Com o objetivo de apurar atividades consideradas subversivas, ainda durante todo o mês de abril de 1964 foram abertas centenas de inquéritos policiais, que atingiram milhares de pessoas: mandatos parlamentares foram cassados, direitos políticos foram suspensos e funcionários públicos foram sumariamente aposentados ou demitidos. Essas ações eram justificadas como forma de restaurar a disciplina e a hierarquia das Forças Armadas, e de deter a ameaça comunista que, segundo os militares, pairava sobre o país.

Os militares contaram, pelo menos de início, com o apoio de importantes segmentos importantes da sociedade civil, entre os quais os grandes proprietários de terra, parte do empresariado e da classe média urbana e o setor conservador da Igreja católica, que promoveu a Marcha da Família com Deus pela Liberdade, nome dado a um conjunto de manifestações ocorridas entre março e junho de 1964 em diferentes pontos do país.

Em 21 de julho de 1964 os diretórios acadêmicos passaram a ser regulamentados por normas do governo.

Na UnB, no dia 28 de julho de 1964 a Instrução da Reitoria n. 9 determinou a extinção dos cursostronco, e em 1965 todos os cursos passaram a ser ministrados em regime integral isto é, integralmente nas faculdades profissionais, sem os cursos básicos. Essas transformações, implantadas de forma autoritária, causaram a indignação de membros do corpo docente, o que acabou levando à renúncia do reitor Zeferino Vaz. Em seu lugar, assumiu o professor de filosofia Laerte Ramos de Carvalho.

\footnotetext{
O Zeferino Vaz tentou não mexer demais na UnB. Mas o segundo reitor, Laerte Ramos de Carvalho, veio para acabar com a UnB. Praticamente todas as coisas pararam, os projetos pararam e você não tinha o que fazer lá. Você tinha só que aguardar, sem saber o que iria acontecer no dia seguinte (PESSINA, entrevista em 1 dez. 2011).
}

No mês seguinte, em resposta ao afastamento, "por conveniência da administração", de Ernani Maria Fiori, Roberto Décio de Las Casas e Edna Soter de Oliveira ${ }^{1}$, foi deflagrada uma greve de professores. O clima de apreensão no campus, devido ao temor de que outros docentes também fossem demitidos de forma arbitrária, e a adesão dos estudantes ao movimento culminaram com uma nova invasão do campus, em 11 de outubro. O então reitor, Laerte Ramos de Carvalho, solicitou a presença do Exército no campus, por considerar a greve uma falta grave e as pichações uma ameaça à integridade

'Ernani Maria Fiori (1914-1985) nasceu em Porto Alegre, onde se formou em direito e filosofia. Foi professor na Universidade Federal do Rio Grande do Sul e da UnB. Alvo da ditatura militar, foi cassado e expulso de ambas as universidades, condição que o levou ao exílio no Chile, onde foi vice-reitor da Universidade Católica. Também foi colaborador de Paulo Freire nas reflexões sobre educação popular.

Roberto Décio de Las Casas (1929-1993) nasceu em Belo Horizonte, onde se formou em ciências sociais. Com a saída da UnB em 1965, esteve exilado em Roma, no Chile e em Paris.

Edna Soter de Oliveira foi secretária de Darcy Ribeiro quando este foi reitor da UnB. 


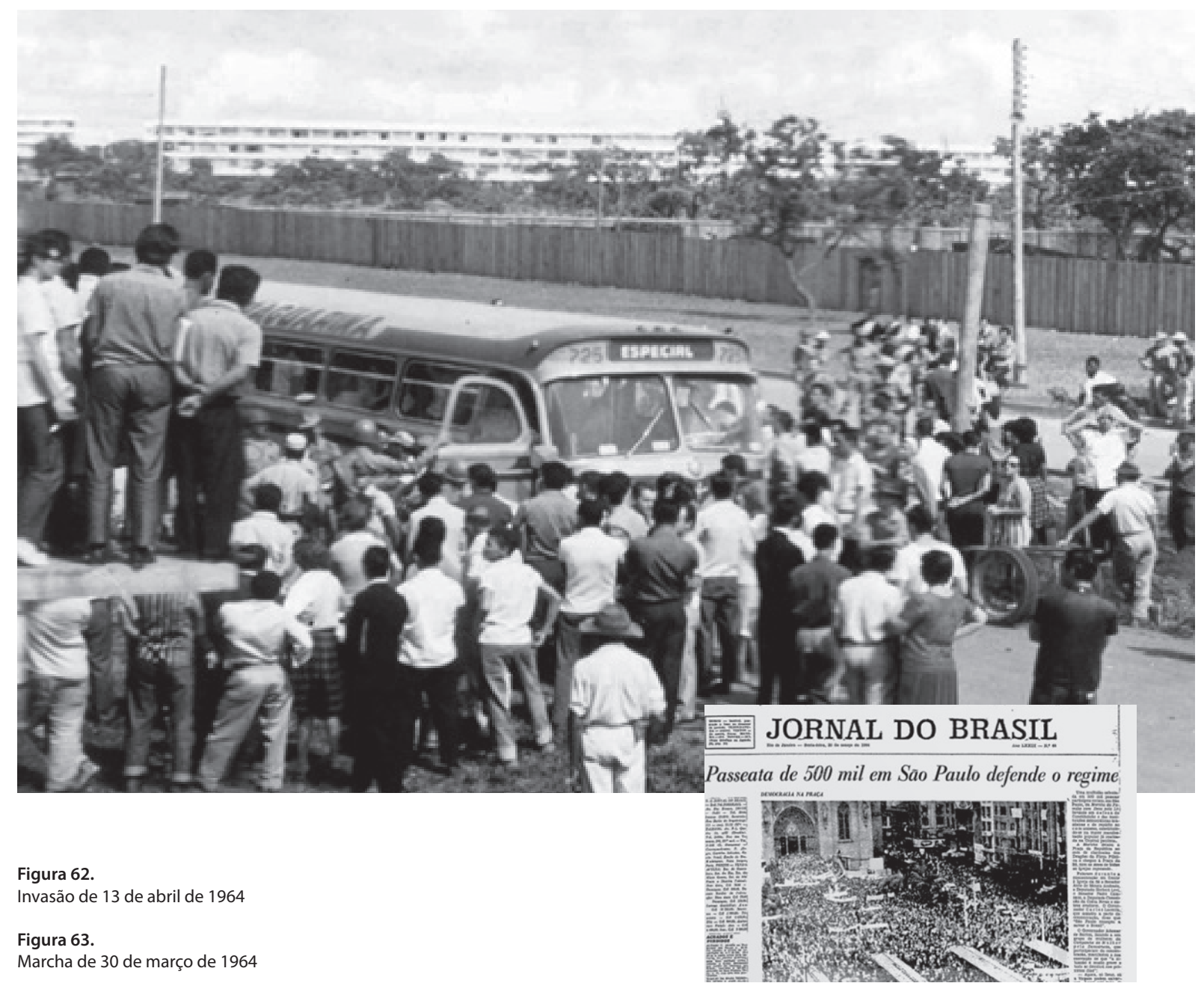

do patrimônio público. Alunos e professores foram impedidos de ter acesso aos prédios e ficaram proibidos os agrupamentos de pessoas, sob qualquer pretexto.

Diversos prédios foram interditados, notadamente o barracão onde funcionava o Serviço de Mecanografia e onde estavam os esquemas de aula e os textos de leitura; e o prédio SG-12, onde funcionavam a Biblioteca Central e as salas de trabalho dos professores de ciências humanas. Sobre as buscas na biblioteca, Abramo (2006) comentou:

\begin{abstract}
[...] resultou a apreensão de uma bandeira do Japão (utilizada no ano anterior durante uma exposição de gravuras de artistas japoneses), que foi anunciada como sendo da China Comunista; um facão de mato do professor de linguística, utilizado nas suas pesquisas de campo com populações indígenas; um revólver do século passado, encontrado por um professor de Arte numa antiquíssima cidade de Goiás [...] dos livros separados como subversivos na Biblioteca constavam: "Le Rouge et le Noir", de Stendhal; "O Círculo Vermelho", de Conan Doyle; "A Revolução Francesa", de Carlyle, e um álbum do arquiteto Le Corbusier, confundido com Roland Corbisier, e que, ao ser folheado, provocava as seguintes exclamações dos oficiais: "Olha como se tratam esses comunistas!".
\end{abstract}

No dia 18 de outubro de 1965, 15 professores foram demitidos, acusados de incompetência ou de subversão; destes, foram presos Edgar Albuquerque Graeff, Eustáquio Toledo Machado Filho, José Zanine Caldas, Ítalo Campofiorito, Nelson Rossi, José Paulo Sepúlveda Pertence, Lincoln Ribeiro, Perseu Abramo, José Albertino Rodrigues, Hélio Pontes, Ramiro de Porto Alegre Muniz, Glênio 
hetti e José Guilherme Vilela² . A ordem de prisão atingia ainda Oscar Niemeyer e o maestro Cláudio Santoro, ausentes de Brasília na ocasião. Mas a reação não se fez esperar: no dia seguinte, em solidariedade aos colegas e fartos do clima de instabilidade que havia se instalado na universidade, 223 dos 305 professores pediram demissão. Sobre esse fato, assim se pronunciou Lelé:

Acho que foi um pouco de falta de amadurecimento aquela demissão coletiva, mas aquilo estava eminente. Podíamos ter resistido mais, mas nesse ambiente começavam a surgir intrigas... A gente fazia aquelas reuniões, o Oscar estava fora, eu e o Ítalo o representávamos. O Oscar deixou um documento de demissão pronto, caso fosse preciso. Então, naquele contexto era impossível segurar [...] Nós sentíamos que tínhamos uma responsabilidade enorme permitindo que duzentos e tantos professores se demitissem, mas acho que havia duas posturas: uma, de se demitir, e outra de resistir e continuar brigando, mas certos professores, principalmente na área de ciências, não admitiam uma postura mais indisciplinada, como a greve - por exemplo, o (Roberto) Salmeron era uma figura ótima, mas extremamente disciplinada, e o (Jaime) Thyomno também. Era difícil chegar a um consenso, e uma solução daquelas só podia ser feita através de consenso (Entrevista em 23 fev. 2012).
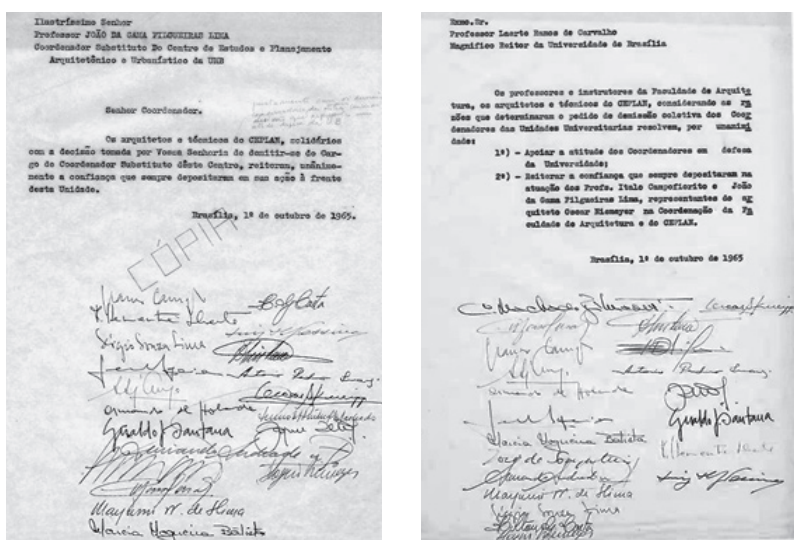

\section{Figura 64a e 64b.}

Cartas encaminhadas respectivamente ao coordenador substituto do Ceplan, João Filgueiras Lima, e ao reitor, Laerte Ramos de Carvalho, pelos arquitetos e técnicos do Ceplan, comunicando a demissão de suas funções na UnB

Figura 65.

Demissão coletiva

Figura 66.

Contratação de professores

Figura 67.

Volta às aulas

Assim, a universidade que acabara de nascer perdia a maior parte dos profissionais que haviam sido selecionados para construir a instituição de vanguarda idealizada por Darcy Ribeiro e Anísio Teixeira.

O modelo universitário cristalizado nos primeiros estatutos da UnB, aprovados em fins de 1962, se baseava na aplicação do princípio da autonomia universitária e na estreita articulação entre ensino e pesquisa. Porém, a demora na implantação efetiva do estatuto e a grande movimentação política gerada em torno do assunto criaram um clima de instabilidade institucional que teve como desfecho a invasão e a ocupação policial do campus em outubro de 1965, e a demissão de quase todos os professores, além da repressão aos estudantes. A UnB, pensada em ambiente democrático no governo JK, teria sua regulamentação implementada sob o regime autoritário pós-64 (BOMENY, 1993, p. 58).

\footnotetext{
2 Eustáquio Toledo Machado Filho (1919-1973), professor de tecnologia das construções e encarregado de organizar o instituto do mesmo nome. Foi casado com a artista plástica Amélia Toledo, professora do Instituto Central de Artes (ICA). Hélio Pontes (1929-2010), chefe do Departamento de Administração e vice-coordenador do Departamento de Ciências Humanas. José Albertino Rodrigues (1928-1992), professor responsável pela disciplina Sociologia Urbana e chefe do Departamento de Sociologia. José Guilherme Vilela (1926-2009), professor do Departamento de Direito da UnB e, posteriormente, ministro do Superior Tribunal Eleitoral, de 1980 a 1986, e ministro do Superior Tribunal de Justiça. José Paulo Sepúlveda Pertence (1937), formado em direito pela Universidade Federal de Minas Gerais, foi o primeiro vice-presidente da UNE, de 1959 a 1960. Fez mestrado na Universidade de Brasília, onde foi instrutor e professor, de 1962 a 1965, quando foi demitido. Reintegrado como professor adjunto por força da anistia em 1985, está licenciado. Foi procurador-geral da República e ministro do Supremo Tribunal Federal. Lincoln Ribeiro, coordenador do Curso de Ciência Política, vinculado ao Departamento de Ciências Humanas. Nelson Rossi, coordenador do Setor de Língua Portuguesa. Perseu Abramo (1929-1996), graduado em ciências sociais pela então Faculdade de Filosofia, Ciências e Letras da Universidade de São Paulo, participou ativamente da criação da UnB, onde lecionou sociologia no Departamento de Ciências Humanas, de 1962 a 1965, quando se demitiu por força do golpe militar. Ramiro de Porto Alegre Muniz (1926), começou seu curso de física na Faculdade Nacional de Filosofia, mas se transferiu para a Universidade da Califórnia, Berkeley, em 1952, contemplado com uma bolsa do CNPq, onde concluiu a graduação e o mestrado. Em 1949 ajudou a fundar o Centro Brasileiro de Pesquisas Físicas (CBPF), órgão do qual seria diretor, em 1982. Foi professor da antiga Faculdade de Filosofia da Bahia. A convite de Darcy Ribeiro veio estruturar o Curso de Física na UnB, do qual foi professor até 1965.
} 
Como se essa perda nada significasse para a qualidade do ensino e para o desenvolvimento da UnB, no dia seguinte à demissão coletiva dos professores, a Reitoria, considerando a decisão dos docentes um ato de indisciplina, já anunciava o recrutamento de novos docentes.

Três dias depois, o então ministro da Educação, professor Flávio Suplicy de Lacerda, anunciava a reabertura da UnB e a volta às aulas.

Em meio a invasões policiais, prisões, demissões e intervenções constantes, a política passava a preencher todos os espaços acadêmicos e de convivência da UnB, que não tardaria a se tornar um centro de resistência na capital federal. Sem sindicatos trabalhistas estruturados e com movimentos sociais embrionários, o movimento estudantil constituía então a principal força de mobilização contra a ditadura no Distrito Federal.
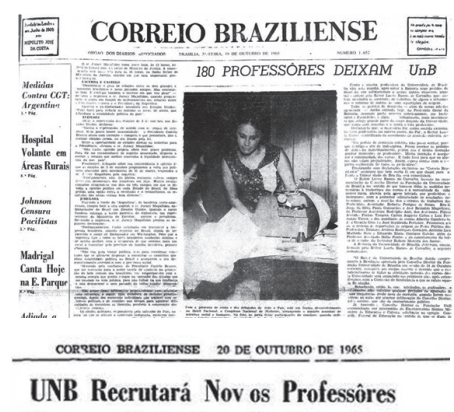

Para as Vagas Dos Demissionários

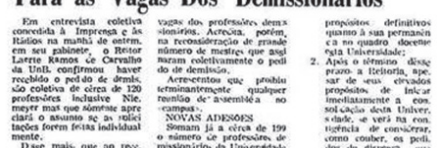

CORREIO BRAZILIENSE

SUPLICY: UNB SERÁ REABERTA 2."-FEIRA

Com a justificativa de combater as ideias comunistas supostamente difundidas entre os estudantes, na verdade o governo militar tinha outros planos para o ensino superior no Brasil. Como forma de contribuir para o desenvolvimento, a educação passava a ser vinculada ao planejamento econômico e político global. E, como tal, deveria ser submetida a mudanças consideradas importantes para fazer face ao novo modelo de desenvolvimento, baseado na maciça entrada de capitais estrangeiros no país e na configuração de um espaço internacionalizado que estabelecia novas exigências ao sistema produtivo.

Tanto entre os correligionários do governo como entre facções da oposição, era consenso que o Brasil precisava fazer uma reforma na estrutura educacional como forma de estimular a produção de ciência e tecnologia. Quanto ao ensino superior, a meta principal consistia na ampliação das oportunidades educacionais, traduzida na construção de novas instituições e na consolidação das já existentes.

Com base nessa demanda, o governo apelou para a cooperação financeira e a assistência técnica norte-americana, o que resultou na série de acordos MEC-Usaid (Ministério da Educação e Cultura e United States Agency for International Development) firmados entre 1964 e 1968.

Uma das primeiras iniciativas oficiais com relação à qualificação de quadros foi expressa no parecer do Conselho Federal de Educação n. 977, de 3 de dezembro de 1965, conhecida como Lei Sucupira $^{3}$, que implantou formalmente os cursos de pós-graduação no Brasil. Também a convite do Ministério da Educação e Cultura (MEC), o norte-americano Rudolph Atcon realizou, entre junho e setembro de 1965, estudos sobre a reformulação estrutural do ensino superior no país.

Em 18 de novembro de 1966, foi promulgado o Decreto-Lei n. 53, que dispunha sobre as mudanças na organização das universidades. Por esse instrumento, teve início a modernização do ensino superior, que estabeleceu as bases da departamentalização. Essa reformulação, baseada principalmente na proposta de Atcon, resultou no Acordo MEC-Usaid de 30 de dezembro de 1966.

${ }^{3}$ Em alusão ao relator Newton Sucupira. 
Se essas mudanças atendiam a reivindicações antigas, algumas já contempladas inclusive no projeto pioneiro da Universidade de Brasília $(1961)^{4}$, a reestruturação dos órgãos de representação estudantil e as sanções previstas em caso de desobediência às novas regras, impostas desde 1964, provocavam muitas manifestações estudantis por melhores condições de ensino e mais vagas na educação de nível superior.

Por um lado o governo induzia as universidades a aumentarem as vagas, por outro a legislação dos vestibulares dava margem a interpretar a aprovação como direito à matrícula, o que fazia com que juízes deferissem mandatos de segurança por candidatos aprovados e não matriculados por falta de vagas.

\begin{abstract}
A pressão pela ampliação de direitos de participação de segmentos excluídos da sociedade atingiu uma escala incomum nos anos 60 . Os ecos de rebeldia e de toda uma movimentação social ressoaram nas universidades. Foram elas alvo dessa pressão continuada. Um dos símbolos dessa luta que ficou na memória foi a bandeira empunhada pelos estudantes em prol dos 'excedentes' (BOMENY, 1993, p. 62).
\end{abstract}

Obrigadas a receber um grande número de alunos e sem recursos para arcar com os decorrentes dispêndios, a qualidade do ensino nas universidades decaía gradativamente. Os protestos dos estudantes eram seguidos pelos professores que, em face da superlotação e da falta de verbas, exigiam melhores condições de trabalho.

No caso específico da UnB, a recomposição emergencial do quadro docente, feita em 1966, não foi bem recebida pelos estudantes. Exigindo a demissão dos novos professores, os alunos do Instituto de Artes e da Faculdade de Arquitetura (ICA/FAU) suspenderam as aulas, fecharam literalmente os prédios que ocupavam e iniciaram uma greve que duraria vários meses.

O Conselho Diretor decidiu manter a suspensão das aulas do ICA/FAU no decorrer do segundo semestre de 1967, com a condição de que os dias letivos fossem compensados nos primeiros meses de 1968. Além disso, autorizou a constituição de uma comissão para estudar e propor uma solução para a crise. Numa tentativa de reiniciar as aulas, o reitor Laerte Ramos de Carvalho convidou Oscar Niemeyer para reestruturar o curso de Arquitetura. Em solidariedade aos demais professores, o arquiteto recusou o convite e indicou o Instituto de Arquitetos do Brasil (IAB) para assessorar a universidade na contratação de novos professores.

Com recursos da Fundação Ford, um especialista em arquitetura de bibliotecas, Frazer G. Poole, foi convidado a participar do planejamento da Biblioteca Central da UnB. Foi elaborado, então, um detalhado programa de especificações técnicas e firmado um convênio entre o MEC e o Banco Interamericano de Desenvolvimento (BID) para garantir o financiamento para a construção. Apesar disso, os cinco anteprojetos desenvolvidos pelo Ceplan à época não lograram a aprovação do BID por não corresponderem às especificações da assessoria especializada.

Paralelamente, o marechal Costa e Silva, que tomou posse em 15 de março de 1967, adotava medidas concretas para enfrentar os problemas ligados ao ensino superior no país. Assim, criou, pelo Decreto n. 60.461, de 13 de março de 1967, a Comissão Especial para Execução do Plano de Melho- 


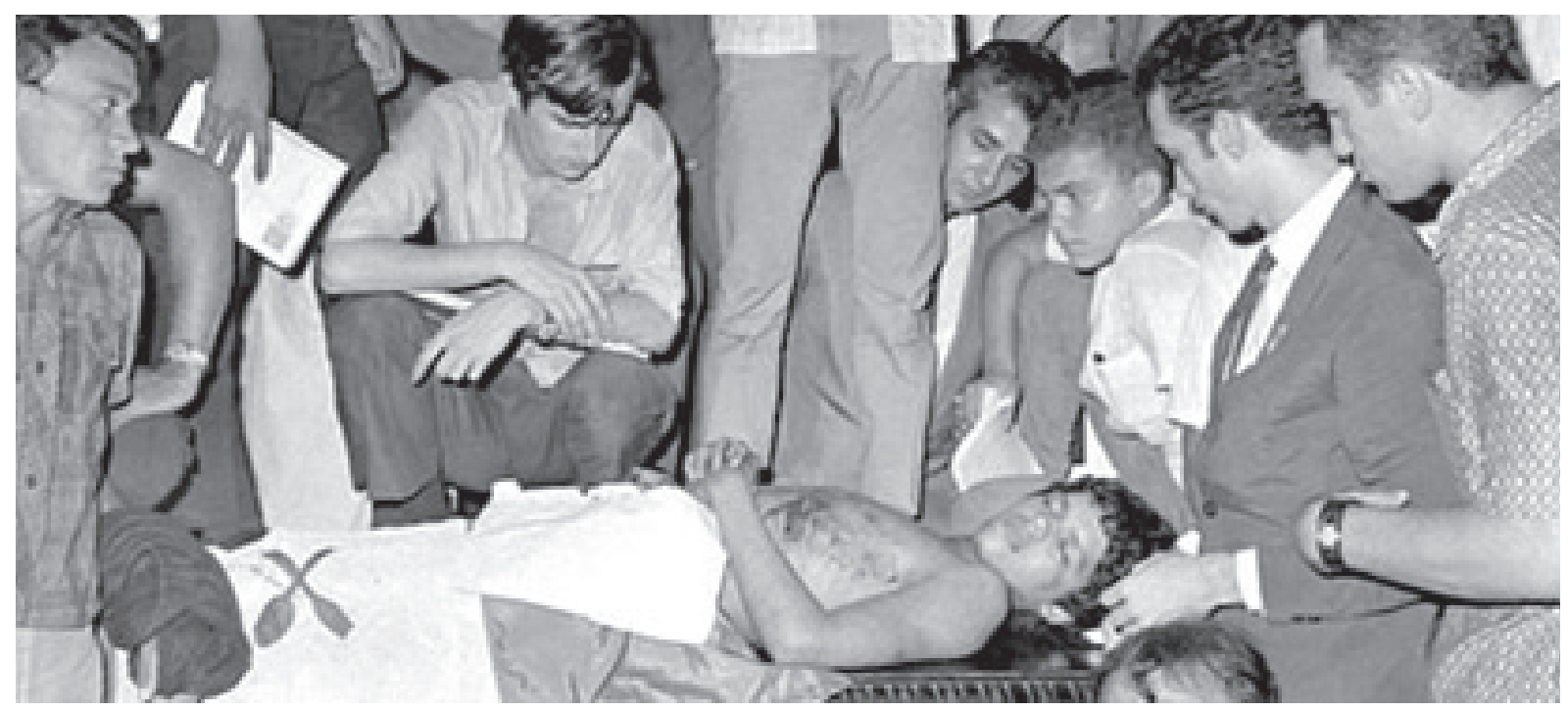

ramento e Expansão do Ensino Superior (Cepes) ${ }^{5}$, que deveria representar o MEC no contrato a ser firmado entre a União Federal e o BID, para melhoramento e expansão do ensino em universidades brasileiras, mediante obras, equipamentos e assistência técnica. Em dezembro do mesmo ano, o ministro interino da Educação Favorino Bastos Mércio instituiu uma comissão especial que, formada pelo general Carlos de Meira Mattos ${ }^{6}$, Hélio de Souza Gomes, diretor da Faculdade de Direito da Universidade Federal do Rio de Janeiro, Jorge Boaventura de Souza e Silva, diretor da Divisão de Educação Extraescolar do MEC, Waldir de Vasconcelos, secretário-geral do Conselho de Segurança Nacional, e o promotor Affonso Carlos Agapito da Veiga, deveria, em um prazo de três meses, emitir parecer sobre os pontos críticos do ensino superior brasileiro.

Mas não havia clima para que os esforços fossem levados adiante. O próprio conteúdo dessa mudança, a forma autoritária com que foi imposta, o fechamento da UNE e as prisões arbitrárias acirraram os protestos por todo o país.

No dia 20 de abril de 1967, o embaixador americano esteve na UnB para a cerimônia de doação de 3,5 mil livros. Os estudantes aproveitaram o evento para denunciar as arbitrariedades que vinham ocorrendo no país. Após a saída do diplomata, a polícia fechou as portas da biblioteca, bateu em uns estudantes e prendeu outros.

Em janeiro de 1968, a reitoria da UnB contratou um grupo de professores do Paraná, composto pelos arquitetos José Maria Gandolfi, Roberto Luiz Gandolfi, Jaime Lerner, Marcos Prado e Leo Bonguestap, o que desagradou os estudantes da FAU, que, além de fortemente influenciados pelas referências deixadas pelos fundadores, reivindicavam o direito de participar na escolha do quadro docente da escola. Assim, em assembleia geral, os alunos, confrontando a determinação da Reitoria, decidiram impedir o reinício das aulas. Por todos os lados eclodiam protestos de estudantes, acusando o reitor por sua fraqueza na direção e resolução dos problemas da UnB.

\footnotetext{
A Cepes foi criada pelo Decreto n. 60.461, de 13 de março de 1967. Pelo Decreto n. 61.778, de 24 de novembro de 1967, o MEC foi autorizado a contratar, em nome da União Federal, operações de crédito com o Banco Interamericano de Desenvolvimento (BID) destinadas ao financiamento parcial de um programa de expansão e melhoramento do ensino superior.

${ }^{6}$ Carlos de Meira Mattos (1913-2007) nasceu no interior de São Paulo. Obteve o grau de doutor na Universidade Mackenzie. Foi comandante da Academia Militar das Agulhas Negras e general de Divisão, especializado em geopolítica. Participou ativamente do golpe militar (1964) e foi amigo e colaborador do presidente Humberto de Alencar Castello Branco, atuando como subchefe do gabinete militar da Presidência da República.
} 


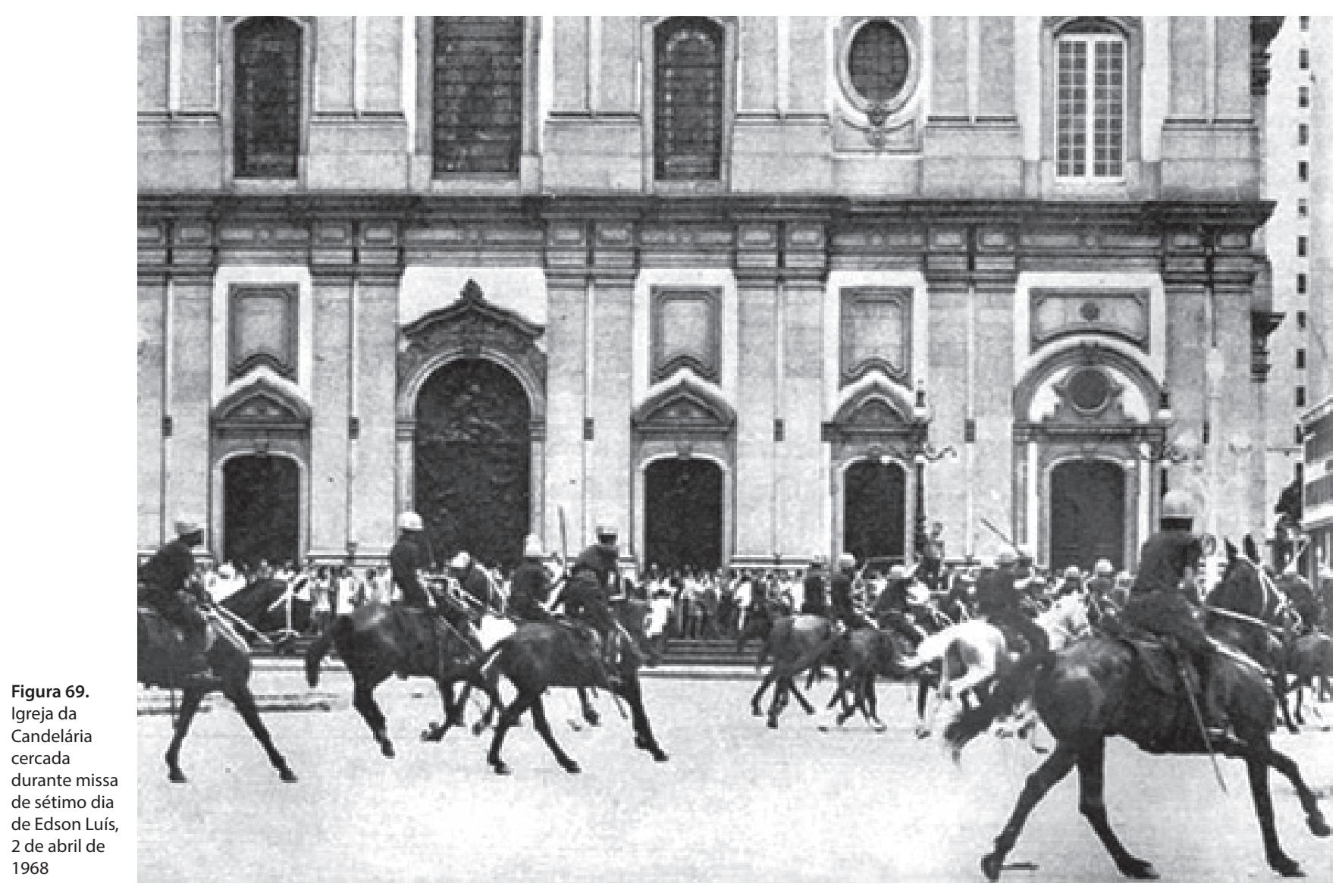

Ao mesmo tempo, uma grande agitação tomou as ruas do Rio de Janeiro em protesto contra a qualidade de serviços prestados aos estudantes. Durante a manifestação, o estudante Edson Luís de Lima Souto, de apenas 17 anos, foi baleado e morto após a invasão do restaurante universitário Calabouço ${ }^{7}$. O fato, que comoveu e revoltou todo o país, serviu para acirrar os ânimos e fortalecer a luta pelas liberdades. Durante o velório, o confronto com policiais ocorreu em várias partes do Rio de Janeiro, e o cortejo fúnebre foi acompanhado por 50 mil pessoas.

Nos dias seguintes, sucederam-se manifestações no centro da cidade do Rio de Janeiro, todas reprimidas com violência, até culminarem na missa de sétimo dia em homenagem ao estudante, na Igreja da Candelária, em 2 de abril de 1968, quando soldados a cavalo investiram contra estudantes, padres, repórteres e populares.

Em Brasília, apesar do clima de intranquilidade, no dia 27 de maio houve a primeira reunião do Grupo de Trabalho instituído para promover a reestruturação do ICA-FAU, composto pelos arquitetos Edgar Graeff, Neudson Braga, Miguel Alves Pereira, José Liberal de Castro, Maurício Nogueira Lima, Pasqualino Romano Magnavita, Paulo Mendes da Rocha, Paulo de Mello Bastos e Paulo Barbosa Magalhães.

Com o objetivo de concretizar a proposta apresentada no Relatório Final do Grupo de Trabalho, foi realizado o Seminário de Reestruturação ICA-FAU, que ficou conhecido como I Fórum ICA-FAU, organizado com a participação do Diretório Acadêmico de Arquitetura e Urbanismo (Dacau). Para coordenar as discussões preparatórias da reabertura do ICA-FAU, "[...] os estudantes queriam o

${ }_{7}^{7}$ Em homenagem ao estudante morto, os alunos da UnB decidiram dar o seu nome à praça situada próximo à quadra de basquete, em frente ao prédio da Faculdade de Educação. 


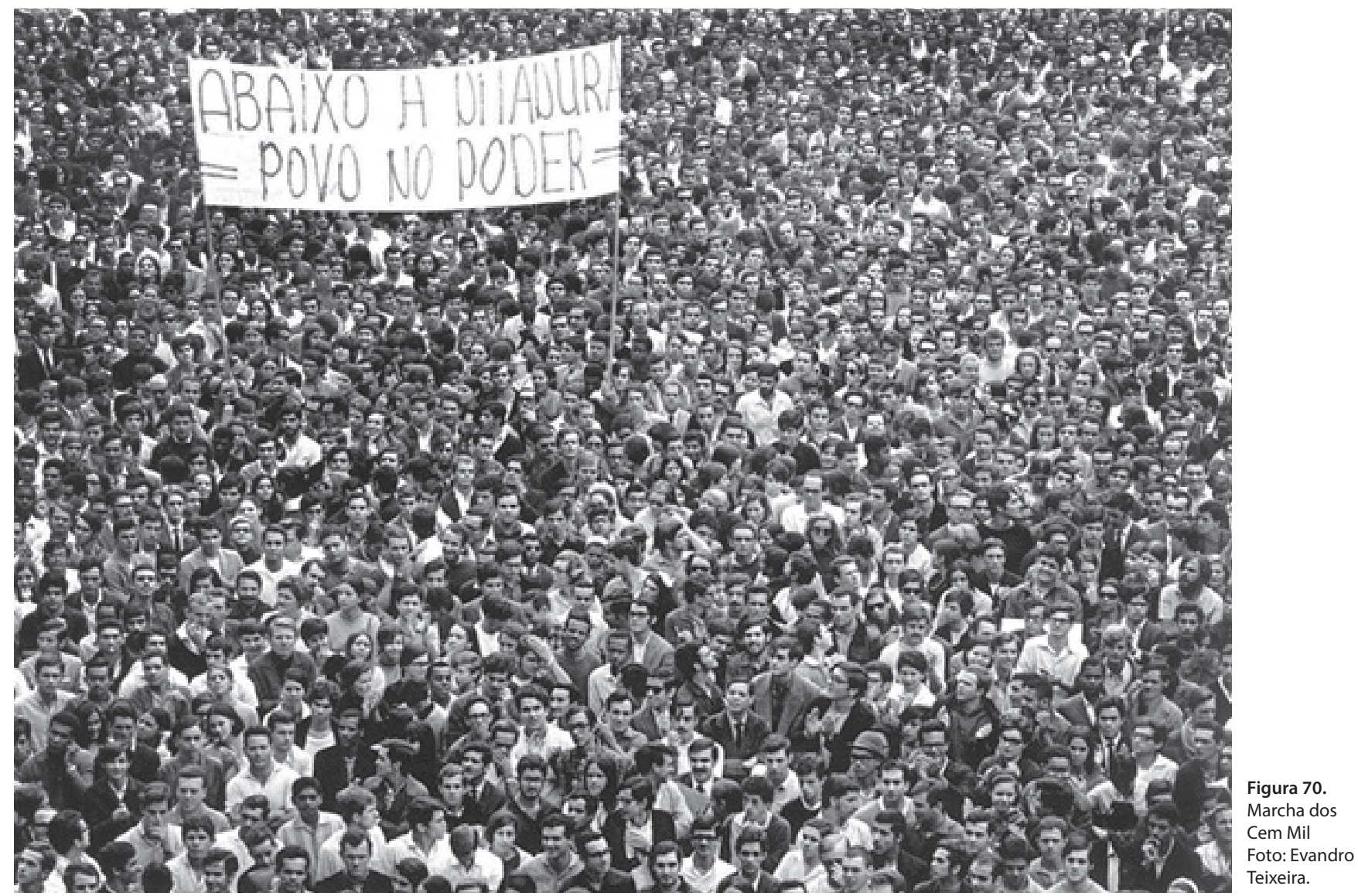

Paulo Magalhães, entretanto o Miguel foi indicado pelo Graeff como chefe da reabertura, da qual participaram Neudson Braga, do Ceará; Pasqualino, da Bahia, Maurício Nogueira e Paulo Bastos, de São Paulo" (SVENSSON, entrevista em 16 fev. 2012).

Em âmbito nacional, os estudantes da Universidade Federal do Rio de Janeiro se reuniram para organizar novos protestos e exigir a libertação de diversos alunos presos. Uma manifestação em frente à embaixada norte-americana terminou com mortos, feridos e presos, e viaturas policiais incendiadas. A repercussão do episódio fez com que o comando militar permitisse uma manifestação marcada para o dia 23 de junho. Contando com a adesão de outros segmentos da população, a manifestação ganhou as ruas, no evento que ficou conhecido como a Marcha dos Cem Mil.

Vigiada por mais de dez mil policiais e acompanhada por estudantes, artistas, intelectuais e religiosos, a manifestação foi um protesto contra a ditadura, mais especificamente contra a privatização do ensino, pois o governo abria caminhos para a instauração do ensino pago em todos os níveis, incluindo o superior, e para a criação de cursos pragmáticos com o único intuito de formar mão de obra para as empresas.

Na madrugada desse mesmo dia, 23 de junho, a UnB foi novamente invadida. Cerca de trezentos estudantes, expulsos do campus, refugiaram-se no Congresso Nacional, solicitando a proteção dos parlamentares e transformando as galerias da Câmara em um verdadeiro acampamento. Parlamentares tentaram negociar com a polícia a saída dos estudantes do recinto do Congresso e a garantia de sua liberdade. Para tentar abrandar a crise, as aulas foram suspensas na UnB. Quatro dias depois, alguns os professores tratavam de negociar a liberdade dos estudantes presos. 


\section{CORREIO BRAZILIENSE}

POLICIA OCUPA DE SURPRESA A UnB E O ELEFANTE BRANCO
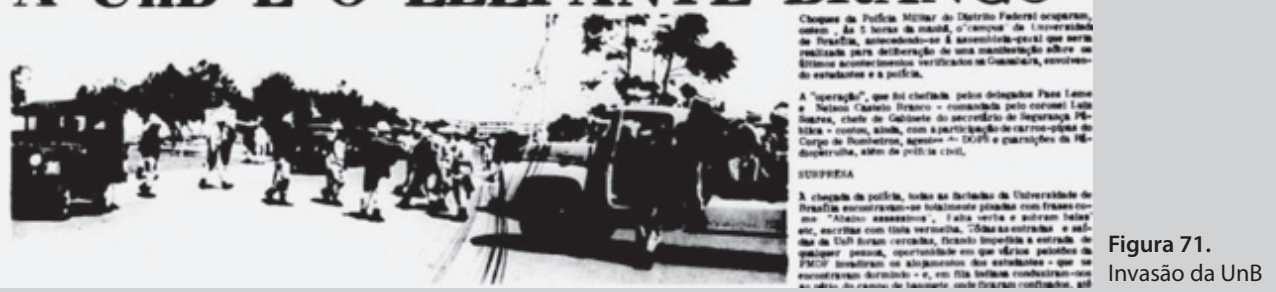

ESTUDANTES RECEIAM SAIR DO CONGRESSO Reitoria da UnB relata os fatos ali ocorridos
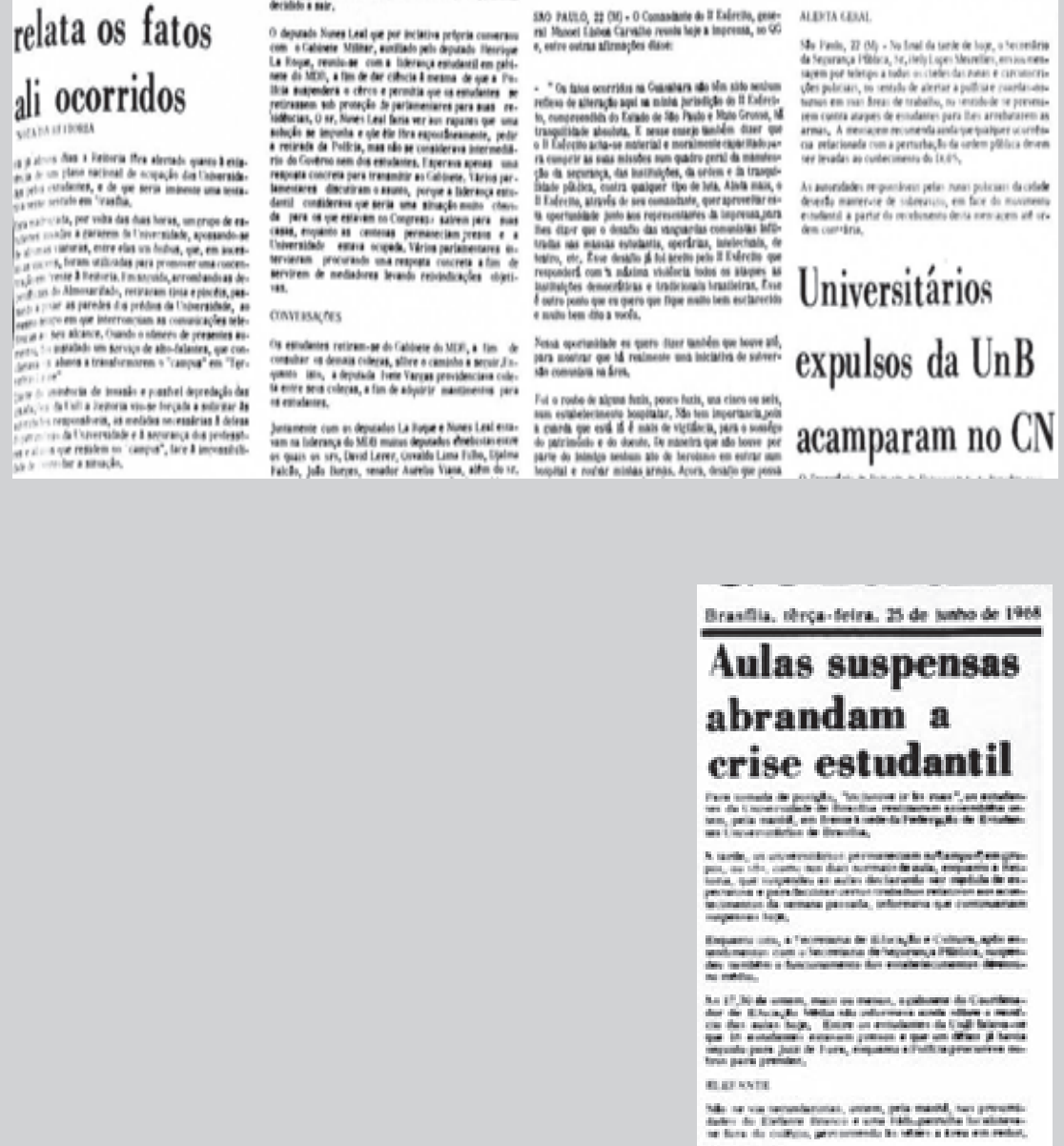

\section{PROFESSÓRES QUEREM} LIBERTAR ESTUDANTES

Terapêutica

Ocupacional tem

III Exposição

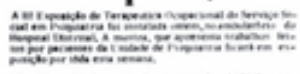
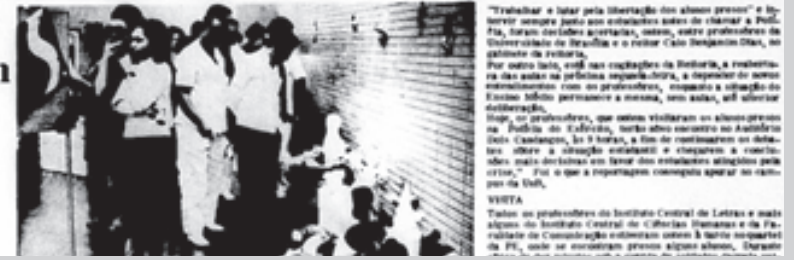
Sobre mais essa invasão, assim se manifestou Paulo Speller, estudante de psicologia da UnB e líder estudantil à época:

\begin{abstract}
As assembleias da Feub mobilizavam o conjunto dos estudantes. Todos queriam participar. $O$ auditório Dois Candangos era pequeno para a UnB de 1968. A morte do estudante Edson Luís, no Restaurante Calabouço, no Rio de Janeiro, foi o estopim da indignação de todos. A UnB foi novamente invadida; Honestino foi preso, e então o substituí como presidente da Feub, em julho de 1968. Levamos a voz livre e solta dos estudantes para a Esplanada dos Ministérios, para o Teatro Nacional, para o Congresso Nacional: “Abaixo a ditadura!". Ninguém discordava, o consenso era de todos (apud GROPPO, 2008, p. 38).
\end{abstract}

A forte repressão da mobilização dos estudantes no Rio de Janeiro levou os integrantes da Federação dos Estudantes da Universidade de Brasília (Feub) a organizarem um amplo protesto em Brasília. Uma campanha de pichações deu origem a dezenas de inscrições nos muros da capital federal, e as manifestações se estenderam até o dia seguinte.

A capital da República viveu desde as 18 horas de ontem, até a madrugada de hoje, cenas de violência, em virtude das manifestações de condenação do assassinato do estudante Edson Luís no Rio de Janeiro. As demonstrações reuniram centenas de universitários e estudantes secundaristas, além de populares na avenida W3. Aos gritos de "Assassinos", "Abaixo a ditadura" e outros, os manifestantes se dirigiam para a Praça 21 de abril, mas foram impedidos de ali se reunirem (Correio Braziliense, 30 jun. 1968).

No mesmo mês, estudantes da UnB invadiram a residência do professor do Departamento de História, Roman Blanco, que, acusado de delator, teve seus pertences e móveis colocados pelos invasores na área externa do prédio da Colina onde morava. Sobre esse professor, assim se manifestou a ex-deputada distrital, Maria José da Conceição, ou Maninha, como era conhecida a estudante de medicina na época do despejo:

Esse cara nos deixava com muita raiva, por que ele promovia uma ação violenta de desmoralização da esquerda dentro da universidade. Naquela época ele já alimentava o jornal O Globo com matérias que pretendiam mostrar que nós, da esquerda da universidade, vivíamos de festinhas, de drogas, de prostituição (Entrevista à revista Campus Impresso, jun. 2011) (https:// shalders.wordpress.com/2013/03/31/campus-impresso-arquivos-da-unb-na-ditadura/) ${ }^{8}$.

Além disso, uma marcha contra a ditadura reuniu centenas de estudantes e populares na avenida W3 Sul. Dando sequência aos protestos, houve mais uma manifestação organizada pela Feub: para evitar mais uma possível intervenção, foram erguidas barricadas no campus, declarado então território livre. Um agente policial, infiltrado no Restaurante Universitário, foi preso pelos estudantes e mantido em cárcere durante toda a noite. Essas demonstrações de organização e poder dos estudantes ameaçavam e provocavam temor nos militares. O movimento estudantil tinha seus próprios meios para lidar com o aparato de inteligência: uma de suas táticas era fazer determinada informação chegar a certa pessoa, a fim de provocar uma reação do regime. Se isso acontecesse, ficava provado que a pessoa era infiltrada.

Em 28 de junho de 1968 foi preso o líder estudantil Aurélio Wander Chaves Bastos, aluno do curso de Direito na UnB. 


\section{CORREIO BRAZILIENSE \\ Exército prende líder estudantil

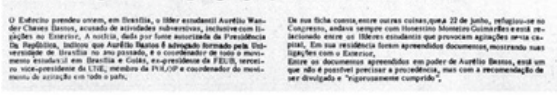

Figura 75

Prisão de líder estudantil

Figura 76.

Líderes estudantis presos

em 30 de agosto de 1968

Honestino Guimarães e

José Antonio Prates

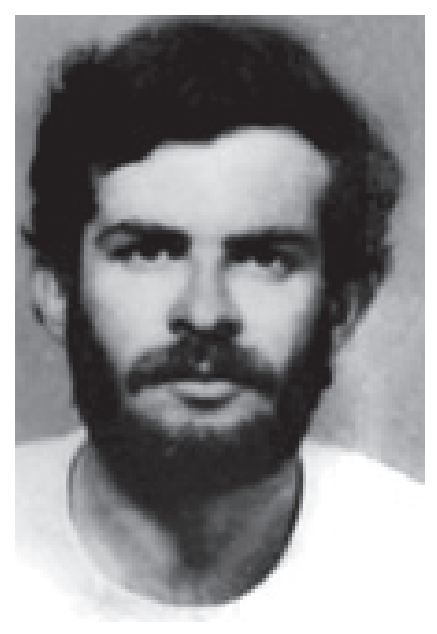

Honestino Guimarães

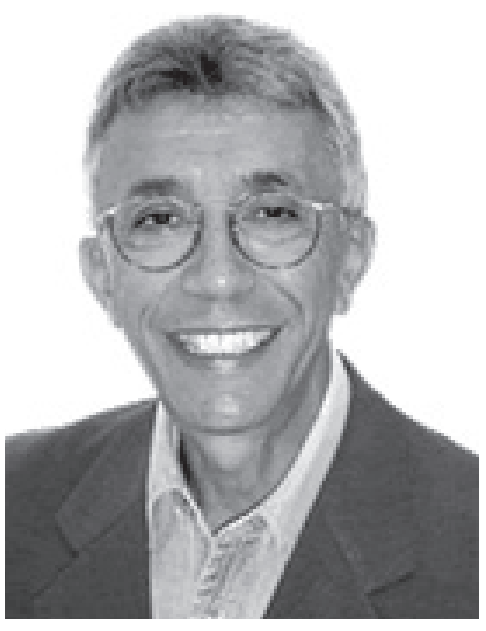

José Antonio Prates

No fim de julho, o reitor, sob o pretexto de não conseguir defender o patrimônio da universidade dos efeitos da rebeldia dos estudantes, solicitou, mais uma vez, a intervenção policial no campus. No fundo, essa rebeldia era uma forma de oposição à falta de diálogo com as autoridades estabelecidas. Conforme confirmado por José Antônio Prates, presidente do Diretório Acadêmico de Arquitetura (Dacau) à época, como os prefeitos de Brasília eram nomeados pelos militares, eles eram obrigados a atuar na paralisação do movimento estudantil, que eles chamavam de pacificação.

No dia 15 de agosto, o coronel Murilo Rodrigues de Souza, encarregado do Inquérito Policial Militar (IPM) do movimento estudantil, comunicou a decretação da prisão preventiva de sete estudantes, entre eles Honestino Monteiro Guimarães.

Sob a alegação do cumprimento do mandato de prisão de alunos, em 29 de agosto de 1968 a UnB foi novamente invadida, em uma operação conjunta entre as polícias Civil e Militar, a Polícia do Exército e o Departamento de Ordem Política e Social (Dops). Os estudantes reagiram, exigindo a saída da polícia do campus, e várias viaturas foram apedrejadas, viradas de cabeça para baixo e incendiadas. Enfrentando a resistência, a polícia adentrou os prédios da universidade, destruindo instalações e laboratórios. Mais de quinhentas pessoas foram acuadas na quadra de basquete, das quais sessenta acabaram presas, entre elas o presidente da Feub, Honestino Monteiro Guimarães, e o presidente do Diretório Acadêmico dos Estudantes de Arquitetura e Urbanismo, José Antônio Prates. $O$ estudante de engenharia mecânica Waldemar Alves da Silva Filho, atingido na cabeça, perdeu $60 \%$ da visão do olho esquerdo, além de outras sequelas.

Alguns estudantes faziam prova. Outros estavam nas aulas práticas de medicina. De repente, todo o campus e os edifícios foram envoltos em nuvens de gás e pólvora. Houve depredações, choques, lutas corporais, agressões, tiros, prisões. Mais uma vez a Universidade de Brasília era invadida pela polícia, agora incumbida da missão de prender cinco estudantes. Dos cinco, apenas dois chegaram a ser detidos (Correio Braziliense, 30 ago. 1968).

No dia 2 de setembro de 1968, o deputado federal Márcio Moreira Alves - filiado ao Movimento Democrático Brasileiro (MDB) do Rio de Janeiro - em discurso no plenário da Câmara dos Deputados contra a invasão policial da UnB, propôs que o povo boicotasse a comemoração do dia 7 de setembro e pediu ainda para que as moças não dançassem com os cadetes. Irritados, os generais passaram a pressionar a Câmara pela cassação do deputado. 

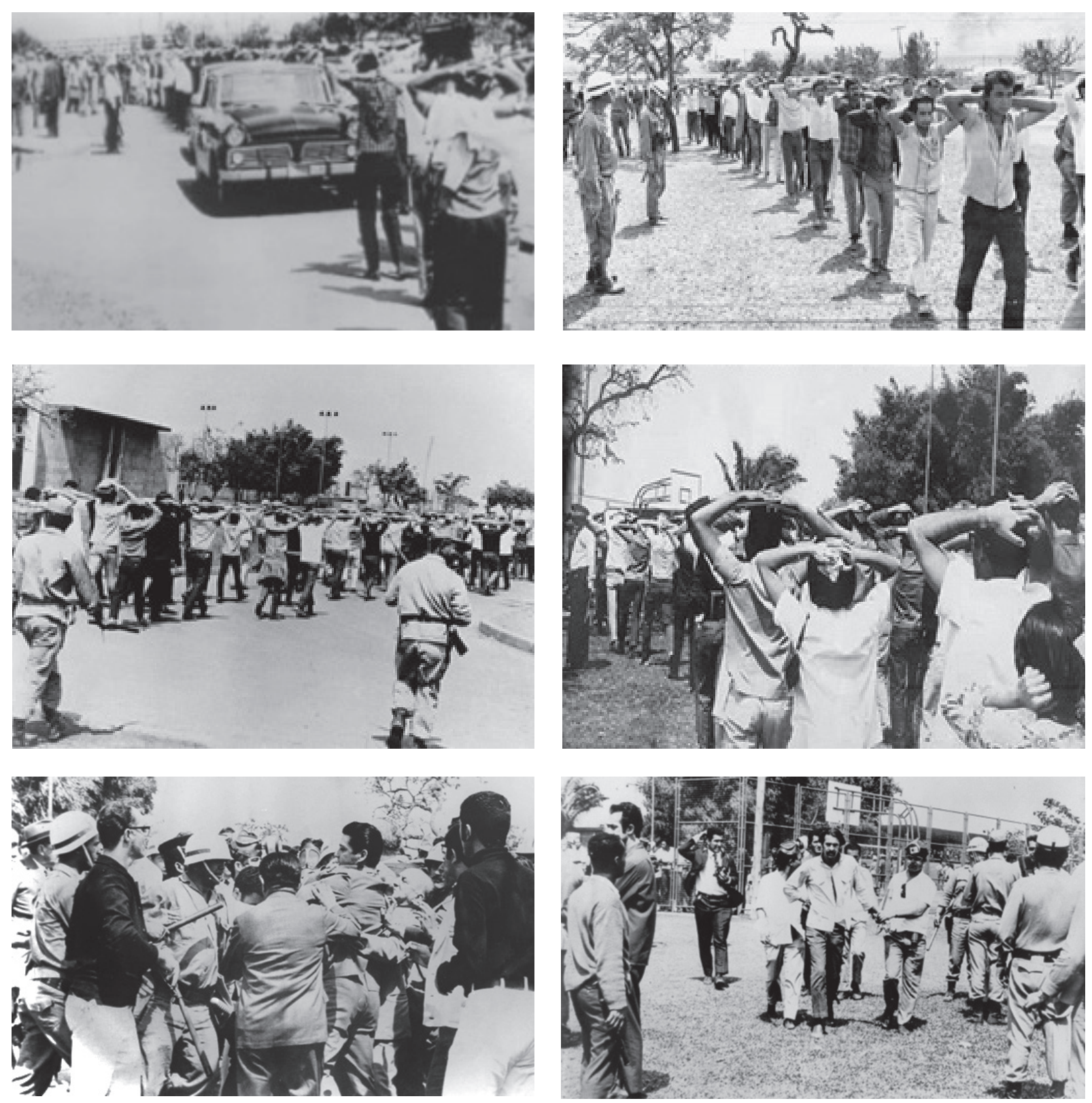

Figura 77a, 77b, 77ce 77d.

Intimidação e revista de estudantes próximo à quadra de
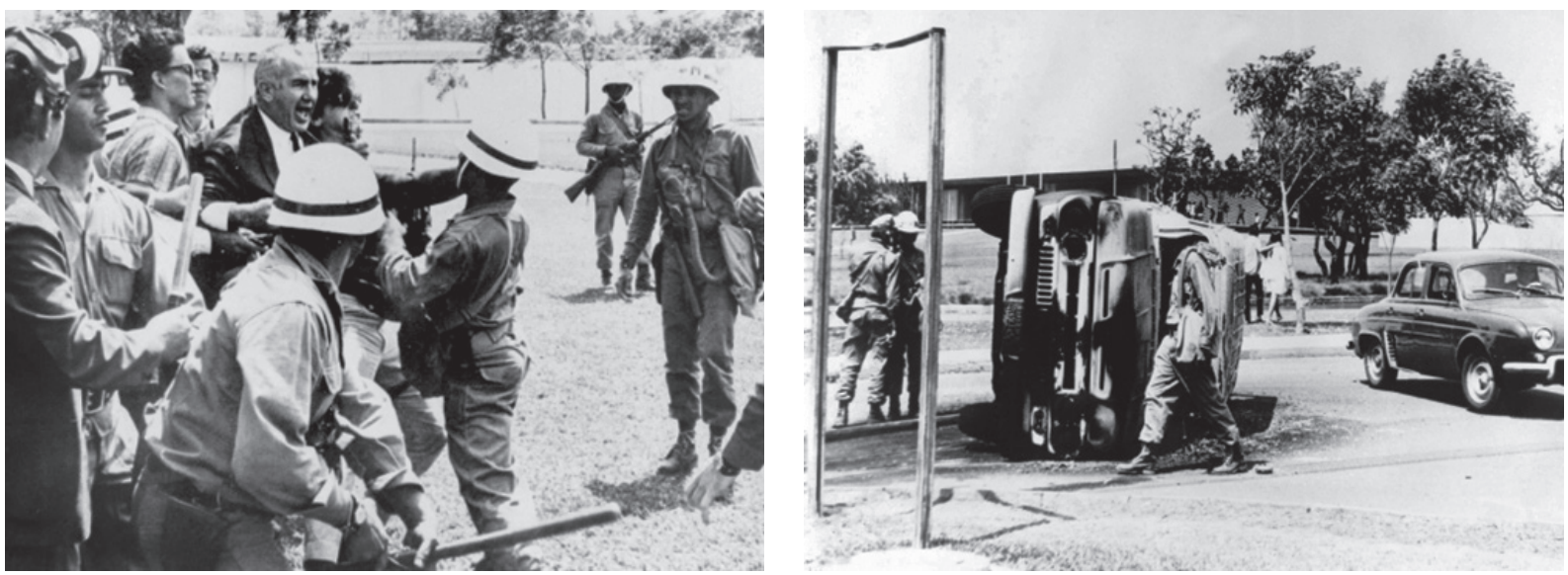
sportes em frente à OCA

Figura 77e Polícia prende estudantes na UnB Figura 77g. Autoridades tentaram impedir a
prisão de estudantes no campus 


\section{JORNAL DO BRASIL}

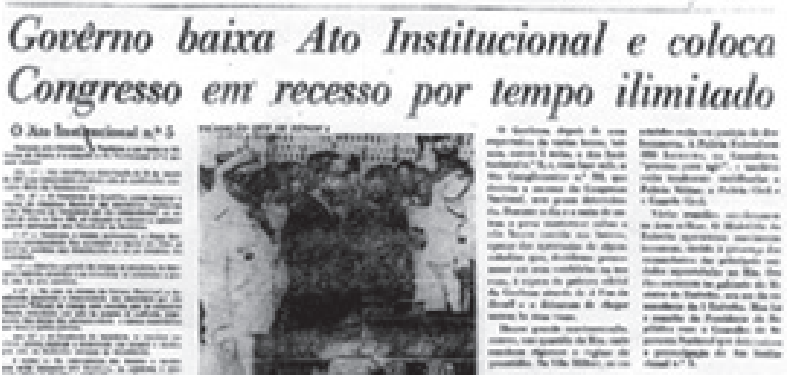

FOLHA DE S. PAULO

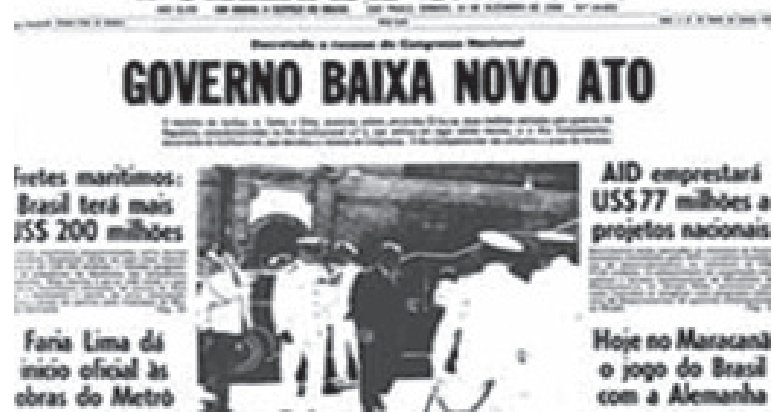

\section{EDITADO 0 ATO 5}

1) Coagresso em recesso

Figura 78.

A decretação

do Ato

Institucional

n0. 5 é

manchete

nos principais

jornais

brasileiros

do dia 14 de

dezembro de

\section{2) Confisco de bens}

3) Sorpensos thabeas" polticos

4) Restabelecilas as cassuctes

5) Liquidada a vitaliciedade

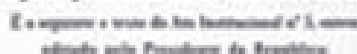
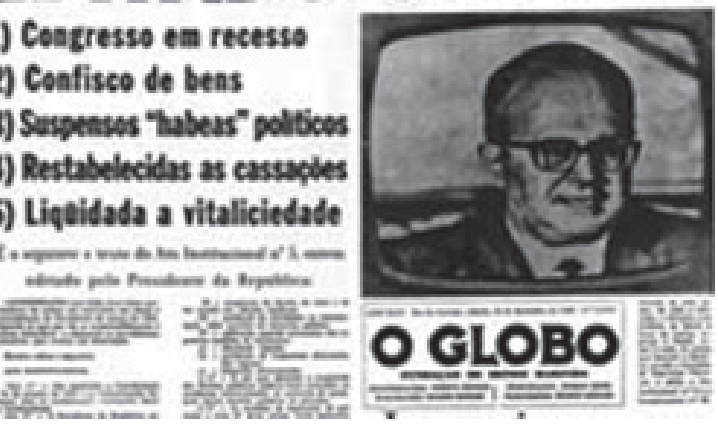

FER 0 ESTADO DE S. PAULO
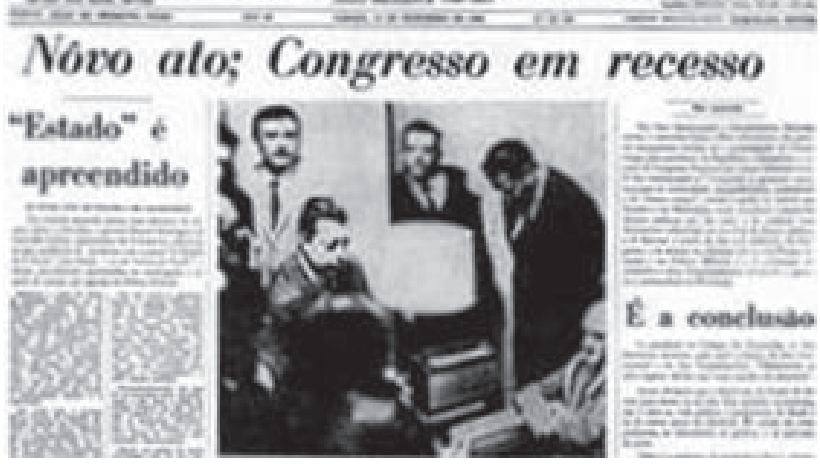

Indiferente aos graves incidentes envolvendo os estudantes, o governo insistia na reforma do ensino superior. O Relatório Meira Mattos, que resumiu o resultado dos trabalhos da comissão instituída durante o governo Costa e Silva, deixou claro que a melhoria do modelo universitário vigente dependia de uma nova legislação. Com o objetivo de dar encaminhamento a esse intento, o MEC instituiu o Grupo de Trabalho da Reforma Universitária (GTRU) ${ }^{9}$, que tinha trintas dias para apresentar um projeto conclusivo sobre a reforma da universidade brasileira.

Entre outubro e novembro do mesmo ano, empresários paulistas e cariocas, integrantes do Instituto de Pesquisas e Estudos Sociais (Ipês), de orientação católica e anticomunista ${ }^{10}$, se reuniram no fórum A Educação que nos Convém, realizado no Rio de Janeiro sob o patrocínio da Pontifícia Universidade Católica (PUC/RJ). Além de um diagnóstico da situação, a conferência-síntese do evento estabeleceu uma série de recomendações. Acreditava-se então que o universitário, “[...] um privilegiado na esfera social", deveria ser equipado para o trabalho, evitando-se, dessa forma, o "[...] fenômeno do letrado ou do universitário desocupado" (Mário Henrique Simonsen in IPÊS, 1969, p. 77).

Com base nessas discussões e nos relatórios de Rudolph Atcon (1966), da Comissão Meira Mattos (1968), da Equipe de Assessoria ao Planejamento do Ensino Superior (Eapes) e do GTRU, o Congresso Nacional aprovou a Lei n. 5.540, de 28 de novembro de 1968, a Lei da Reforma Universitária.

Embora os estudantes do ICA-FAU tivessem retomado as aulas no dia 4 de outubro de 1968, o movimento estudantil só seria controlado, em todo o território nacional, após a promulgação do Ato Institucional n. 5, de 13 de dezembro de 1968, que foi complementado pelo Decreto-Lei n. 477, de 26 de fevereiro de 1969. Depois de ter sido negada pela Câmara dos Deputados a licença para o governo

${ }^{9}$ Instituído pelo Decreto n. 62.937, de 2 de julho de 1968, o GTRU teve como integrantes o ministro Tarso Dutra, Antônio Moreira Coureiro, Fernando Bastos de Ávila, Fernando Ribeiro do Val, Haroldo Leon Perez, João Lyra Filho, João Paulo dos Reis Velloso, Newton Sucupira, Roque Spencer Maciel de Barros e Valnir Chagas.

${ }^{10}$ Entre os membros do Ipês estavam: Golbery do Couto e Silva, Mário Henrique Simonsen, José de Magalhães Pinto, Walter Moreira Salles, Augusto Trajano de Azevedo Antunes - ligado à Companhia Auxiliar de Empresa de Mineração (Caemi), voltada para a extração de manganês na Serra do Navio, no Amapá - e Antônio Gallotti - ligado à Light Serviços de Eletricidade S.A. 
processar o deputado Márcio Moreira Alves, o general Costa e Silva fechou o Congresso Nacional e decretou o Al 5, dando início ao período de maior centralização e violência da ditadura militar.

O presidente da República estava autorizado ainda a intervir nos municípios, cassar mandatos parlamentares, suspender direitos políticos, decretar o confisco de bens considerados ilícitos e suspender a garantia do habeas corpus, enquanto o Decreto-Lei 477 permitia ao reitor expulsar sumariamente estudantes, professores e servidores acusados de manter atividades subversivas.

Calava-se o movimento estudantil que, celebrizado como protesto dos jovens contra a política e o autoritarismo que se instalara no país, havia encontrado eco em diferentes países nos vários cantos do planeta. 1968 passaria para a história como o ano da juventude, ou como o ano em que os jovens quiseram mudar o mundo:

\begin{abstract}
Em um planeta iniciando um irreversível e acelerado processo de globalização, com as primeiras transmissões ao vivo pela televisão, via satélite, encurtando extraordinariamente as distâncias entre tempo e espaço, não era nada espantoso que jovens de tradição e história tão diferentes como franceses, alemães, italianos, americanos, escandinavos, brasileiros, tchecos, eslovacos, mexicanos, chineses e japoneses se rebelassem e encontrassem em seus protestos - que curiosamente tinham algo em comum com o autoritarismo - inspiração para criar novas formas de luta (ZAPPA \& SOTTO, 2008, p. 12).
\end{abstract}

Na França, o movimento estudantil manifestava-se contra as reformas do ensino superior propostas pelo governo do general Charles De Gaulle. Embora os protestos tenham começado na Universidade de Nanterre, foram a ocupação da Sorbonne e a violenta reação policial e governamental contra os estudantes que desencadearam o Maio de 1968 no país. Unindo-se aos operários, os universitários promoveram uma grande greve geral, que contou com a participação de cerca de nove milhões de pessoas. Mesmo derrotado, o movimento francês abriu caminho para

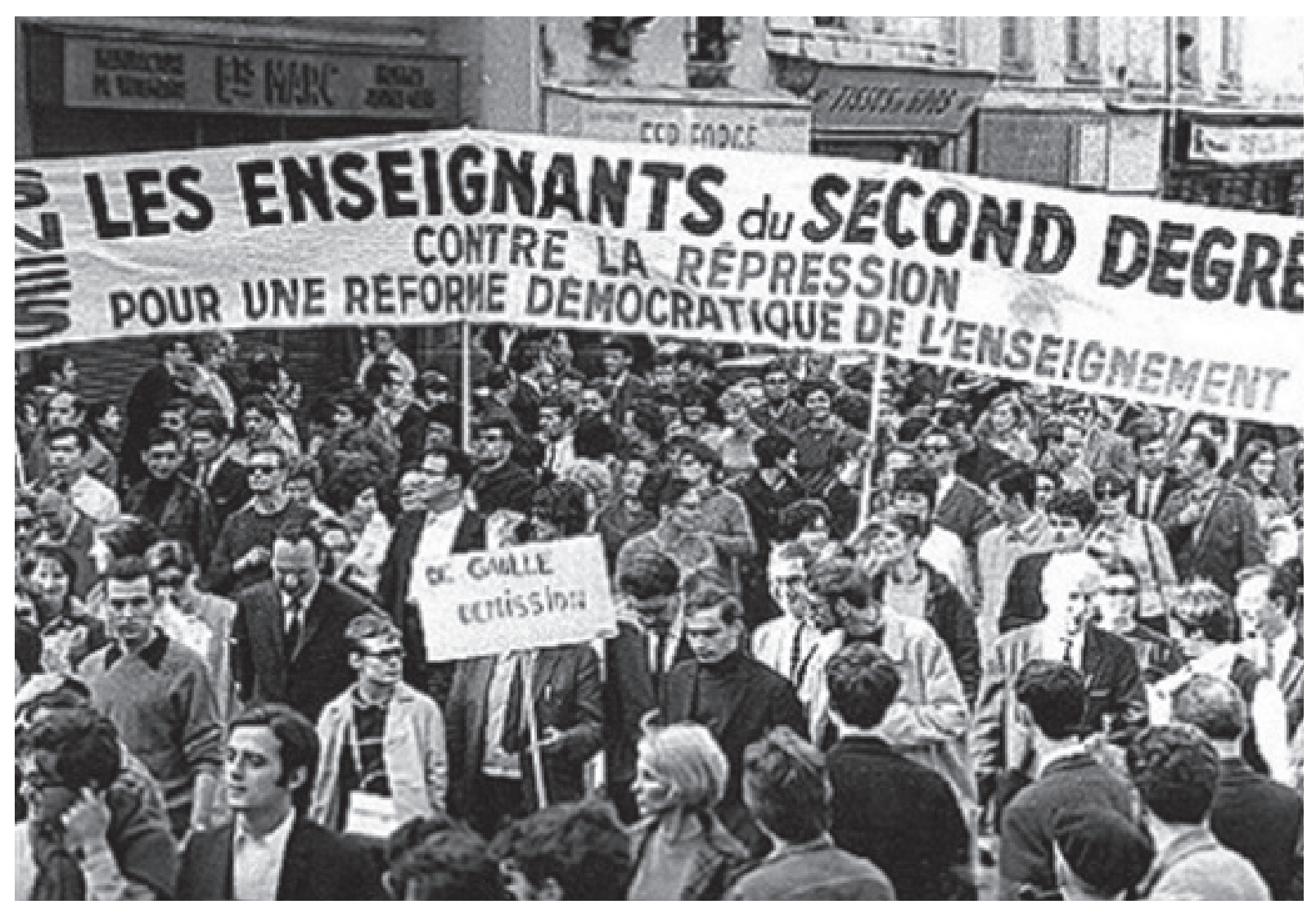



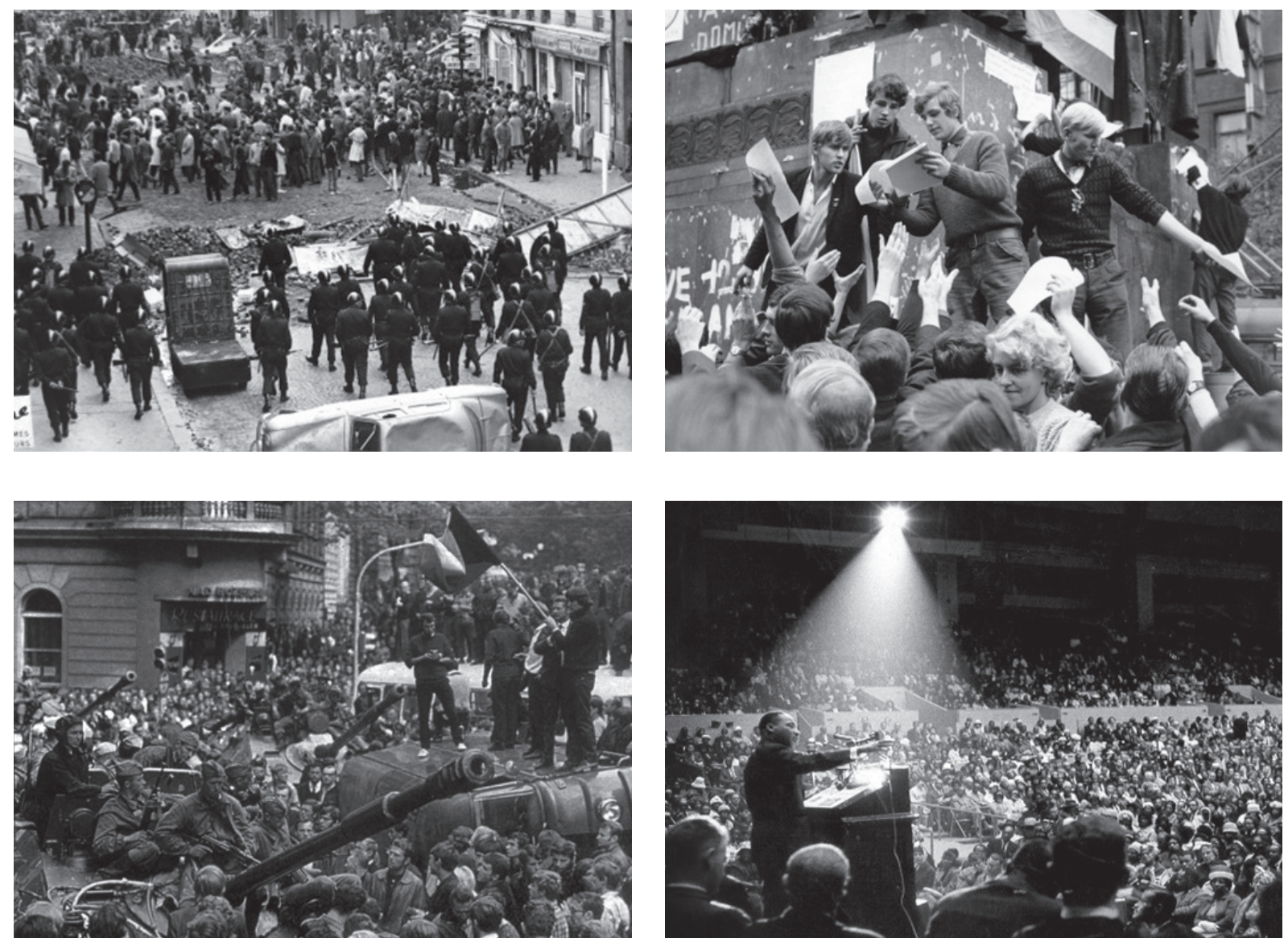

um conjunto de mudanças sociais e culturais e para a ampliação de direitos a grupos até então discriminados, como as mulheres e os jovens.

Na Tchecoslováquia, no início de 1968, o Partido Comunista substituiu os antigos dirigentes por uma nova geração que, liderada por Alexander Dubcek, propunha o desenvolvimento de um socialismo com liberdade, por meio de reformas na agricultura e na indústria, da diminuição da censura, da abertura de canais de TV e do direito à greve. Também foi permitida a liberdade religiosa e a formação de partidos políticos. Mas o aprofundamento da aliança entre estudantes e trabalhadores em torno do novo plano de ação desagradou os militares soviéticos: as fronteiras do país foram invadidas e tanques chegaram ao centro da capital, determinando o fim do movimento conhecido como Primavera de Praga.

O ano de 1968 foi marcante também nos Estados Unidos: o avanço do movimento negro em todo o país deu a tônica das tensões sociais internas. $\mathrm{O}$ assassinato do líder Martin Luther King, no dia seguinte a um pronunciamento no Tennessee, acirrou a crise e a radicalização da luta entre brancos e negros.

Divergindo do pacifismo vigente, o Black Panther Party passou a ocupar maior espaço na sociedade, na luta pelos direi-

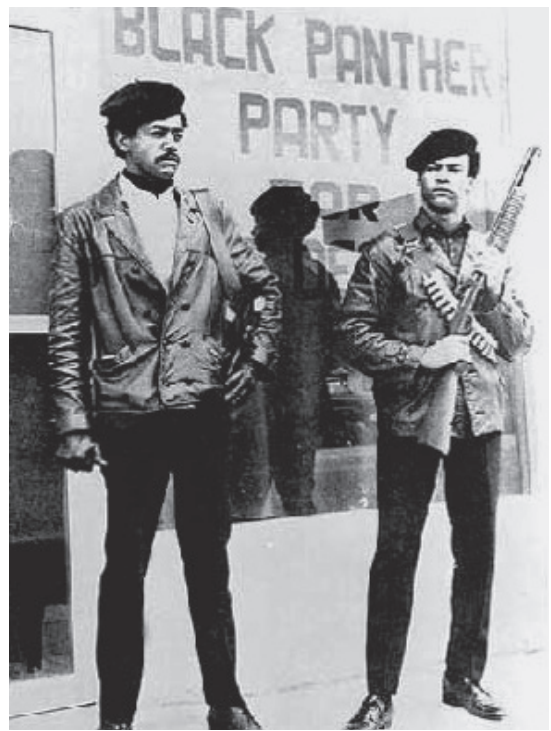

Figura $79 b$.

Protesto em Paris, maio de 1968

Figura 80a.

Protesto de estudantes em Praga, abril de 1968

Figura 80b.

Movimento de protesto na Tchecoslováquia, maio de 1968

Figura 81a. Martin Luther King durante seu famoso discurso "Eu estive no topo da montanha', no Tennessee (Memphis), em 3 de abril de 1968

Figura 82.

Integrantes do Black Panther Party 


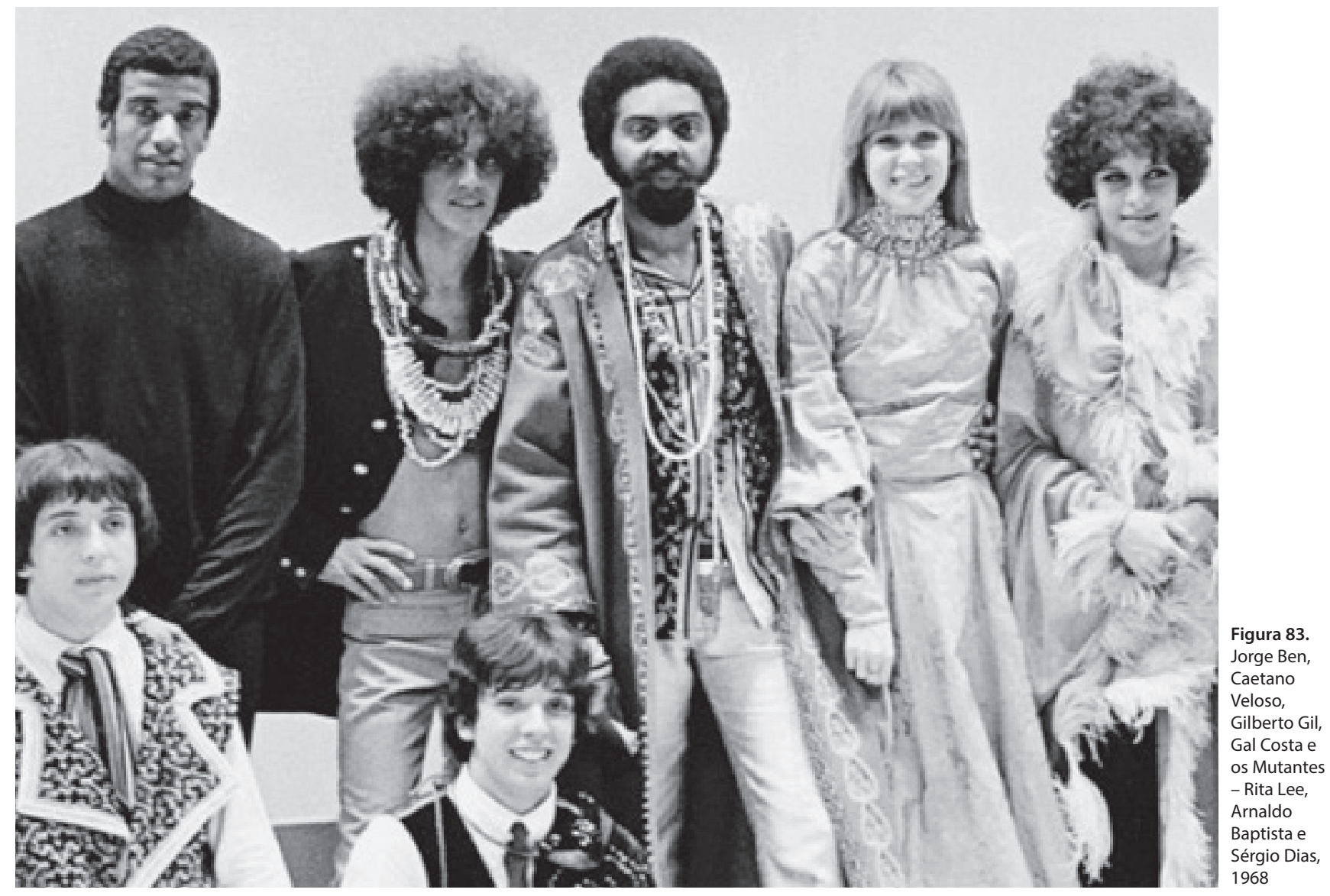

tos dos negros. Os mais moderados defendiam que escolas e universidades ensinassem a história dos negros americanos e de suas lutas políticas, enquanto os mais radicais propunham a tomada do poder pelos negros. Em meio a essa onda de radicalismo, os defensores do black power procuravam novas formas de manifestação artística e expressão própria na arte, na moda e até nos cortes de cabelo genuinamente africanos.

No ano de 1968, a música brasileira tomava rumos bastante peculiares. Embora não fosse engajado politicamente, o Tropicalismo, movimento que exprimia uma crítica ao conservadorismo e ao autoritarismo reinante, chamou a atenção do público no III Festival de Música da emissora Record. Ao cantar a canção "Alegria, alegria", Caetano Veloso inovou principalmente pelo acompanhamento de guitarras elétricas, instrumentos cujos sons destoavam dos sons da viola e do violão, de longa data associados à música popular brasileira.

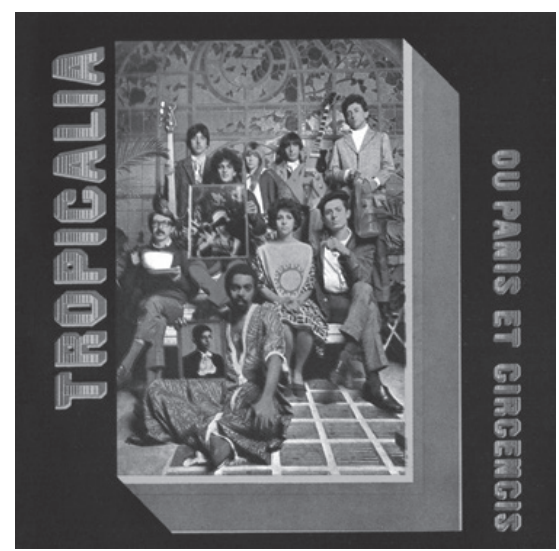

Em setembro do mesmo ano, o III Festival Internacional da Canção, promovido pela Rede Globo, entra- Figura 84. va para a história da MPB pelo tom de protesto contra o regime militar. $O$ anúncio da música vencedora Tropicália, - "Sabiá", de Tom Jobim e Chico Buarque -, foi recebido com vaias, pois o público presente preferia a canção "Pra não dizer que eu não falei de flores" (Caminhando), que, interpretada pelo próprio autor, Geraldo Vandré, acabou se tornando um símbolo da resistência e um hino dos estudantes na luta contra a ditadura. Na verdade, as vaias não foram dirigidas exatamente à música de Tom e Chico, e sim ao resultado e ao júri, que escolheu "Sabiá" para o primeiro lugar.

Eram tempos difíceis... Durante o conturbado período, que se estendeu de meados de 1965 até o final de 1968, a Universidade de Brasília foi duramente atingida. 
CAPÍTULO 2.

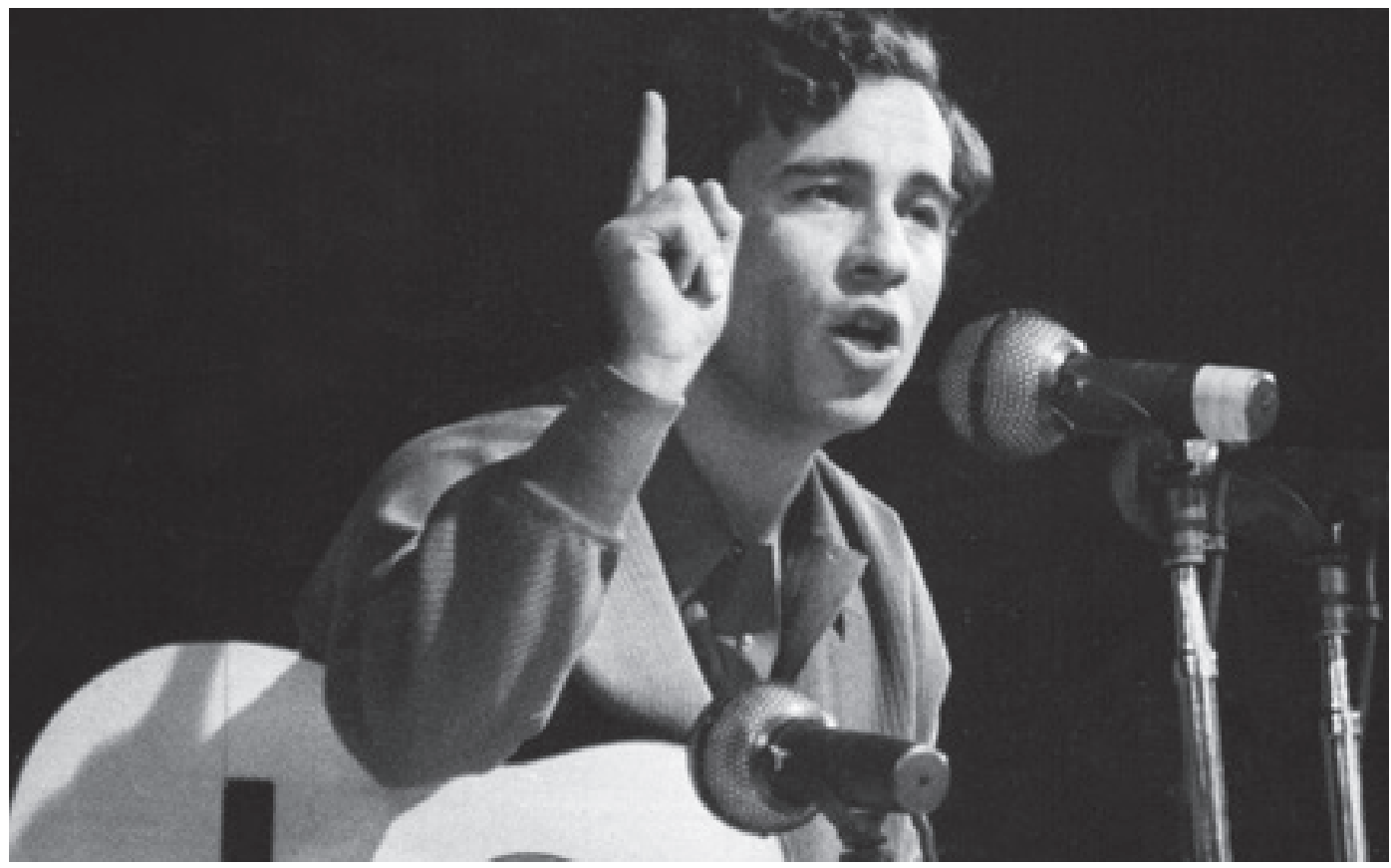

Figura 85.

Geraldo Vandré

defendeu os

vencedore

no Festival

Internacional da

Canção de 1968

Figura 86.

Cynara e Cybele

interpretaram

"Sabiá", de Tom

Jobim e Chico

Buarque, 30 set.

1968

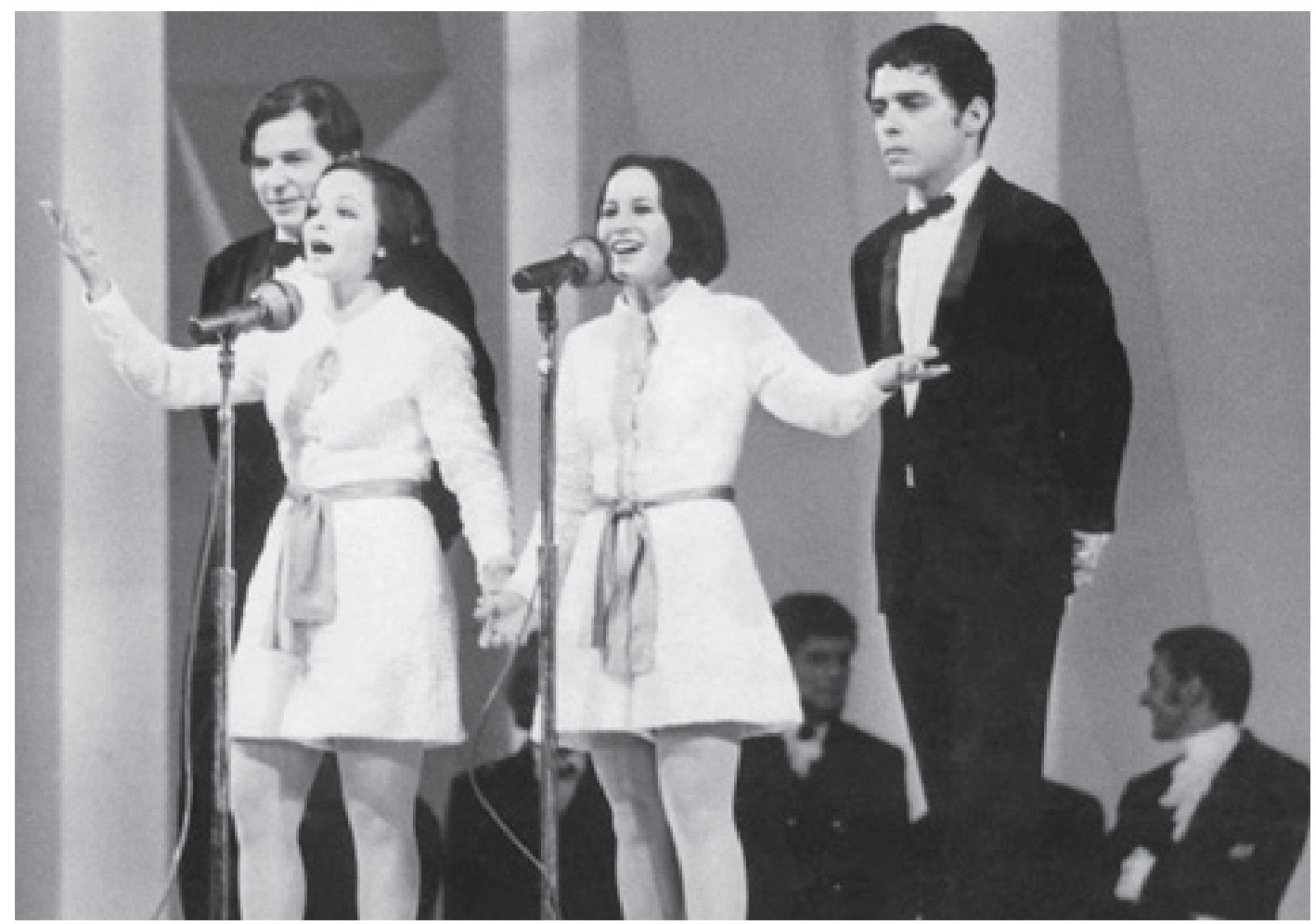


Em dezembro de 1968, Miguel Alves Pereira, coordenador recém- empossado do Instituto Central de Artes e da Faculdade de Arquitetura e Urbanismo, abriu o Seminário de Revisão e Consolidação dos Planos de Ensino e do Projeto Cultural do ICA-FAU, como parte de um processo crítico e avaliativo do ensino. Após a realização do II Fórum ICA-FAU, em março de 1969, foi encaminhada à administração central da UnB uma proposta contendo a descrição do material mínimo necessário ao cumprimento das novas propostas didáticas. Mas a reunião para tratar do assunto, agendada entre o vice-reitor professor José Carlos de Almeida Azevedo e a coordenação do ICAFAU, nunca se realizou.

Como consequência das discussões durante os dois referidos fóruns, o ICA-FAU daria lugar ao Instituto de Artes e Arquitetura (IAA), que seria constituído por três departamentos: Arquitetura e Urbanismo (DpAU), Artes Visuais e Cinema (DAVC) e Música (DM) ${ }^{11}$.

\begin{abstract}
Um fato significativo que precedeu a passagem daquele para este modelo foi o fechamento da FAU/UnB pelos estudantes em 1968. Os seminários para a organização do projeto cultural da escola, ocorridos após tal evento, apontavam para uma mudança de orientação no ensino. Advogava-se por uma arte participante do seu tempo e transformadora da realidade sociocultural (ALMEIDA, 1997, p. 45).
\end{abstract}

O IA apoiava-se, então, em quatro atividades pedagógicas: a pesquisa, o trabalho interdisciplinar, as áreas temáticas e o básico em geral. No entanto, se no âmbito do novo projeto acadêmico foi aberto um espaço para o estudo de problemas locais e regionais relacionados com as camadas mais pobres da população, "[...] não houve, em contrapartida, o desenvolvimento de uma estrutura organizacional de pesquisa. O Ceplan [...] não cobriu tal lacuna. Persistia nele a prática de escritório liberal de arquitetura" (ALMEIDA, 1997: 46).

Embora continuassem os trabalhos nos canteiros, pouco ou quase nada se produziu no Ceplan entre 1965 e 1968, conforme afirmou Pessina: “[...] os projetos todos pararam em 1965, sobretudo com o segundo reitor" (Entrevista em 1 dez. 2011).

Com o abandono de que foi vítima, pelo afastamento de seus idealizadores, muito da breve história do Ceplan ficou sem registro: parte do material foi retirada de suas dependências, devido à ameaça de possíveis depredações, e outra danificada pelo tempo e pelos maus-tratos. Conforme afirmou Pessina,

Pode ser que negativos tenham sumido quando houve a invasão da UnB, porque eles andaram levando muita coisa: boa parte do que eu tinha, do que eu consultava... Eu tinha os anais da União Internacional dos Arquitetos, do Congresso em Havana. Esse congresso foi sobre pré-fabricação, então interessava diretamente para a minha tese, que foi sobre pré-fabricados. Esses anais foram confiscados porque eram de Havana, e também as fichas do Congresso da UIA foram embora. Os caras também levaram fotografias! (Entrevista em 1 dez. 2011).

${ }^{11}$ O DAVC transformou-se no Departamento de Desenho, ainda vinculado ao IA. Mais tarde, esse departamento seria elevado à categoria de instituto, o Instituto de Artes (IdA), e o DpAU seria transformado na Faculdade de Arquitetura e Urbanismo (FAU), rompendo-se os vínculos acadêmicos entre eles. 



\section{O TEMPO DA CONSOLIDAÇÃO}

[...] era considerado por nós uma questão de honra que todos os projetos do campus fossem elaborados pelos professores da Arquitetura. Isso permitiria unir a prática com a proposta pedagógica do curso. José Galbinski, 2012 



\subsection{As histórias da resistência}

[...] era considerado por nós uma questão de honra que todos os projetos do campus fossem elaborados pelos professores da Arquitetura. Isso permitiria unir a prática com a proposta pedagógica do curso. José Galbinski, 2012

Durante o regime militar, as medidas de repressão ao movimento estudantil e a estrita vigilância dos docentes combinaram-se com propostas de modernização e expansão do ensino superior' .

De acordo com Carlos Benedito Martins (2009), a Lei 5.540, de 28 de novembro de 1968, que instituiu a Reforma Universitária, produziu efeitos paradoxais nas universidades federais e em determinadas instituições estaduais e privadas. Por um lado, o sistema de cátedras vitalícias foi substituído pelo regime departamental, que já havia sido introduzido na Universidade de Brasília por Darcy Ribeiro; a carreira acadêmica foi institucionalizada; e o ingresso e a progressão docente foram vinculados à titulação acadêmica. Por outro, a Reforma Universitária favoreceu o surgimento de instituições privadas de ensino, organizadas a partir de estabelecimentos isolados, voltados para a transmissão de conhecimentos de cunho marcadamente profissionalizante e distanciados da atividade de pesquisa.

O ensino superior privado que surgiu após a Reforma de 1968 tende a ser qualitativamente distinto, em termos de natureza e objetivos, do que existia no período precedente. Trata-se de outro sistema, estruturado nos moldes de empresas educacionais voltadas para a obtenção de lucro econômico e para o rápido atendimento de demandas do mercado educacional (MARTINS, 2009, p. 17)

[...] a expansão do ensino superior foi conduzida pelo setor privado, abrindo e expandindo cursos propiciadores da mais elevada taxa de lucro, pouco ou nada tendo a ver com a formação da força de trabalho para os setores dinâmicos da economia. Menos ainda com a preparação de agentes da propalada "consciência crítica e criadora" (CUNHA, 2007, p. 17, 291).

Para Otaíza de Oliveira Romanelli (1988), a educação passou a ser encarada como o caminho disponível para as classes médias conquistarem postos de trabalho e para as empresas preencherem os seus quadros. Assim, apesar da expansão do ensino, houve uma grande defasagem em relação à demanda de candidatos ao ensino superior que, embora aprovados, não conseguiam acesso à Universidade. Pode-se dizer que o aumento da demanda social por educação estaria vinculada, por um lado, à aceleração da industrialização e, por outro, à deterioração dos mecanismos tradicionais de ascensão da classe média.

O estímulo à privatização do ensino e os escândalos motivados pela existência dos "excedentes" ${ }^{2}$ em relação ao número de vagas oferecidas pelas instituições de ensino provocavam inúmeros protestos estudantis. À luta pela restauração da democracia somavam-se pressões sobre o regime militar para que este reestruturasse e expandisse o ensino superior.

1 Dispositivos repressivos: Decreto n. 4.464/64 - extinguiu a União Nacional dos Estudantes (UNE); Decreto n. 228/67 - limitou a existência de organizações estudantis ao âmbito estrito de cada universidade; Decreto n. 477/69 - impôs severas punições aos estudantes, professores ou funcionários que desenvolvessem atividades consideradas hostis ao regime militar; criação, no MEC, de uma divisão de segurança e informação para fiscalizar as atividades políticas de professores e estudantes nas instituições; aposentadorias compulsórias de professores considerados nocivos ao regime militar em várias universidades públicas. 


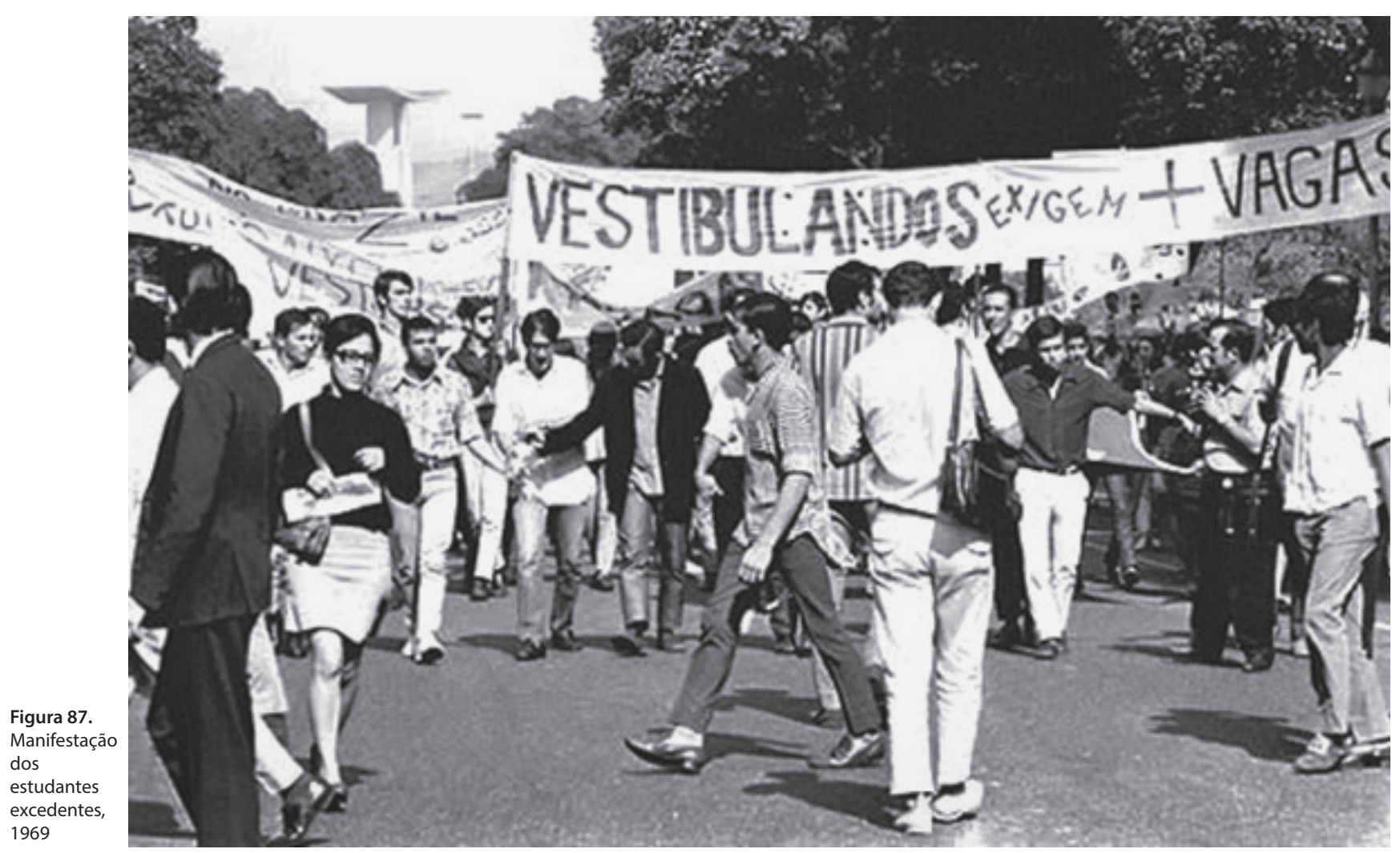

Estruturava-se, nesse momento, um modelo duplamente seletivo de universidade federal: no plano social, suas vagas passariam a ser ocupadas por um grupo restrito de estudantes dotados de razoável volume de capital econômico e/ou cultural; no plano acadêmico, procurava-se concretizar um elevado padrão de qualidade acadêmica, fundado na associação entre ensino e pesquisa, no interior do qual a pós-graduação exerceria um papel central (MARTINS, 2009, p. 21-22).

Além de criticar o caráter elitista da reforma, o movimento estudantil indicava a necessidade de realização de concursos públicos para a admissão de professores, além de lutar por currículos atualizados e pela ampliação da participação estudantil nos órgãos colegiados. Tratava-se de um difícil embate, pois, desde a edição do Decreto n. 477, de 26 de fevereiro de 1969, os corpos docente e técnico-administrativo estavam constantemente ameaçados de substituição e o corpo discente vinha sendo vítima de enquadramento por infração disciplinar.

À medida que os confrontos se acirravam, o governo militar promovia importantes mudanças na área da educação, que iam da implantação do Programa Comissão Permanente do Regime do Tempo Integral e Dedicação Exclusiva (Concretide), que possibilitou um crescimento de mais de $70 \%$ do número de horas-aula contratadas no sistema federal de ensino, à instituição do concurso vestibular. O setor privado, por sua vez, foi beneficiado com isenção de impostos e financiamentos por intermédio de bancos oficiais a juros subsidiados, o que provocou considerável aumento no número de instituições particulares de ensino.

Na tentativa de minorar o descontentamento da comunidade acadêmica, o Ministério da Educação assinou vários acordos com a United States Agency for Internacional Development (Usaid) e montou um eficiente sistema de fomento para sua política de desenvolvimento científico-tecnológico. Além dos recursos provenientes do convênio MEC-BID, o Fundo de Desenvolvimento TécnicoCientífico (Funtec), o Banco Nacional de Desenvolvimento Econômico (BNDE), e posteriormente o Fundo Nacional de Desenvolvimento Científico e Tecnológico (FNDCT) e a Financiadora de Estudos 
e Projetos (Finep), passaram a fornecer auxílios financeiros às instituições públicas, contribuindo para instalação da pós-graduação, edificação de novos campi universitários, construção de laboratórios, institucionalização da carreira docente etc.

A partir de 1969, a exemplo das demais universidades federais, a UnB, então sob a gestão de Caio Benjamin Dias, contou com significativo apoio financeiro, por meio de convênios entre o governo federal e várias instituições norte-americanas: "As universidades federais receberam recursos financeiros, que lhes possibilitaram a edificação de novos campi universitários, a construção de laboratórios, a institucionalização da carreira docente etc." (MARTINS, 2009, p. 21).

Essa nova condição pode ser atestada pelas palavras de Érico Weidle: "Todos foram pegos de surpresa: de repente o BID largou uma enorme verba para ampliação das universidades, e ninguém sabia o que fazer!" (Entrevista em 7 dez. 2011).

O grande montante de recursos impôs alterações na estrutura original do Ceplan, então sob a direção do arquiteto paulista e professor da FAU Pedro Paulo de Melo Saraiva, que permaneceu no cargo de abril a setembro de 1969. Deixando de lado as pesquisas e experimentos em torno da pré-fabricação e das inovações tecnológicas, os esforços do Centro concentravam-se na construção da infraestrutura necessária para garantir o funcionamento e o crescimento da universidade, embora continuasse envolvendo professores da Faculdade de Arquitetura e Urbanismo na elaboração dos projetos.

Isso permitia unir a prática com a proposta pedagógica do curso, que inclusive previa isto. Essa questão era fundamental. Exemplo disso foi quando fui fazer o projeto do Restaurante Universitário, o Bandejão. Naquele momento estavam sendo desenvolvidos, simultaneamente, os projetos da Reitoria, pelo Paulo Zimbre, e o do Museu, pelo Vasco de Mello. A pressão por tempo era tanta que a Reitoria nos propôs a liberação das atividades didáticas para'que vocês se dediquem $100 \%$ aos projetos para ganhar tempo'. Queria que parássemos de ministrar aulas! Isto foi rejeitado por nós, porque abriria um flanco capaz de separar o Ceplan da parte didática. Não aceitamos e continuamos com as aulas. As aulas concentravam-se no turno da manhã e tínhamos o período das tardes para trabalhar nos projetos (GALBINSKI, entrevista em 20 fev. 2012).

Além de Miguel Alves Pereira, integravam o quadro docente da Faculdade de Arquitetura e Urbanismo (FAU): Alberto Fernando Xavier, Érico Paulo Seigmar Weidle, José Carlos de Córdoba Coutinho, José Galbinski, Léo Bonfim Júnior, Lourival Machado Rezende, Luiz Fisberg, Mário dos Reis Villaverde, Marta Maria Soban Tanaka, Paulo de Mello Zimbres, Pedro Paulo de Melo Saraiva, Ricardo Libanez Farret, Telma Portugal Henrique, Tomio Tanaka e Vasco de Mello; e os instrutores Adalton Paes Manso, Jodete Rios Sócrates, Márcio Villas Boas, Sólon Leão Pereira de Souza e Viviane Ventura Dias.

O Ceplan ingressava então em um novo período de sua atuação, caracterizado fundamentalmente pela apropriação de uma linguagem arquitetônica associada à chamada Escola Paulista. Se o Centro deixava de lado a pré-fabricação, permanecia a questão de adotar uma linguagem identificada com uma sociedade voltada para a produção em massa, e o brutalismo poderia satisfazer a essa necessidade.

O Brutalismo tenta ser objetivo com a realidade, os objetivos culturais da sociedade, suas exigências, suas técnicas etc. O Brutalismo se defronta com uma sociedade de produção em massa e arranca uma rude poesia das confusas e poderosas forças com as quais trabalha (SMITHSON \& SMITHSON, 1957, p.66). 
Aqui talvez caiba um parêntese para revisitar algumas reflexões sobre o brutalismo.

Apesar de muito usado na literatura arquitetônica da segunda metade do século XX, como observou Ruth Verde Zein, o conceito de brutalismo não é unívoco, e por isso não é fácil defini-lo de maneira acurada e isenta. Em sua tese de doutoramento, a autora situou a origem do termo no

[...] do uso do béton brut, concreto aparente, de textura deliberadamente marcada pelas fôrmas, deixado exposto e sem acabamento, cujas possibilidades plásticas são potencializadas por meio do cuidadoso desenho de um conjunto característico de pequenos e macros detaIhes, a partir do exemplo dado por Le Corbusier em sua primeira grande obra do pós-ll guerra, a Unité d'Habitation de Marselha (1947) (ZEIN, 2005, p. 16).

Zein também propôs uma periodização para a trajetória dessa vertente da arquitetura: entre 1950 e 1956, o novo brutalismo, adotado por uma geração de arquitetos ingleses liderados por Alison e Peter Smithson, servia como bandeira de sua insatisfação contra o que consideravam uma acomodação indevida da arquitetura moderna; de 1955 a 1959, surgiram obras isoladas que, consideradas como "inaugurais do brutalismo", resultaram de uma frutificação do "modelo formal, estético e construtivo" concebido por Le Corbusier; de 1959 em diante, houve uma expansão do brutalismo, agora como um "estilo mais ou menos sistematizado"; em 1966, o brutalismo emergiu em uma versão sistematizada por Reyner Banham. Com base nesse autor, Zein resumiu o que seriam as características fundamentais do brutalismo:

Franca exposição dos materiais; vigas e detalhes como brises em concreto aparente, combinados com fechamentos em concreto aparente ou com fechamentos em tijolos deixados expostos; mesma exposição de materiais nos interiores; geralmente a seção do edifício dita sua aparência externa; em alguns casos, o uso de elementos pré-fabricados em concreto para os fechamentos/revestimentos; em outros, uso de lajes de concreto em forma de abóbada "cataIã". Brutalismo enquanto estilo provou ser uma questão de superfícies em associação com certos dispositivos-padrão tridimensionais retirados da mesma fonte (calhas, caixas de concreto sobressalentes, gárgulas), com certa crueza proposital no detalhamento e nos acabamentos. Essas características genéricas do canôn nominalmente brutalista aceitariam ser apropriadas por uma ampla variedade de expressões arquitetônicas, derivando sempre em algum grau de referência da linguagem de Le Corbusier, misturada em menor ou maior grau com outras variadas influências (ZEIN, 2005, p. 20 e 21).

Seriam essas características suficientes para delinear um estilo arquitetônico que, em determinado momento histórico, se manifestou em obras localizadas em várias partes do mundo? E que, segundo Banham (1966), não apresentavam nenhuma relação nítida de afinidade a não ser, primeiramente, com os ensinamentos presentes na obra de Le Corbusier, sem deixar de lado outras influências posteriores?

Para Zein, não há problema em dar o título de brutalista a resultados próximos, corretamente datados, que compartilham um conjunto mais ou menos definido de características formais ou superficiais, mesmo que cada obra, em uma cuidadosa análise, revele diferenças conceituais e de intenção ética, garantindo-se a variedade potencial das obras brutalistas, sem perda de sua inserção neste conjunto. Ou, em suas próprias palavras: 
[...] pode-se simplesmente afirmar que determinadas obras são brutalistas, apenas e suficientemente porque parecem ser; e o que determina sua aproximação e inserção na tendência não é sua essência, mas sua aparência, não é seu íntimo, mas sua superfície, não são suas características intrínsecas, mas suas manifestações extrínsecas (ZEIN, 2005, p. 24).

Mais além das aparências, surgiu uma discussão em torno do caráter ético ou estético do brutalismo. De acordo com Sanvitto, o movimento dividiu os arquitetos e os críticos:

[...] para alguns foi uma arquitetura com considerações principalmente éticas e para outros de cunho estéticas. Segundo Bruno Zevi, foi uma ética para os que pretendiam restaurar a integridade originária e agressiva do movimento moderno, e uma estética para quem buscasse um enriquecimento de superfícies e volumes (2013, p. 2).

Para Yves Bruand, existiu uma diferença entre o brutalismo de Le Corbusier e o brutalismo inglês. No primeiro caso, o termo se referia tão somente ao emprego do concreto bruto, ao passo que no segundo haveria uma ênfase em uma franqueza puritana quanto às estruturas e aos materiais. No entanto, o autor reconhece, em ambos os casos, a expressão de "[...] um desafio tingido de violência, uma revolta contra os usos estabelecidos e os regulamentos que entravam o progresso, uma segurança quanto ao caminho a seguir e uma vontade de impor esse caminho" (BRUAND, 1997, p. 295).

De exemplos isolados, o brutalismo passou a nomear uma tendência arquitetônica que, além de vários outros exemplos, passou a se identificar com importantes obras da arquitetura paulista, surgidas a partir da segunda metade do século XX:

As datas e os conteúdos conferem. Os discursos se aproximam. As aparências confirmam. Nada há que impeça, logicamente, de considerar como brutalistas um conjunto signficativo de obras realizadas na arquitetura paulista a partir de meados dos anos 1950 e por duas (ou três) décadas seguintes. (ZEIN, 2007)

Embora tivesse sugerido uma certa rivalidade entre a produção arquitetônica carioca e a paulista, liderada por Vilanova Artigas, Bruand reconheceu preocupações formais similares entre as duas escolas, caracterizando o brutalismo, em um caso e no outro, como uma volta ao funcionalismo estrito, pelo investimento técnico que aspirava à industrialização da construção e por uma estética que valorizava "a força, o choque, a massa, o peso e os contrastes violentos" (1997, p. 315).

Para Zein, tendo a produção carioca como "precedente notável", a Escola Paulista a esta se contrapôs. E, embora "[...] não havendo ruptura completa, mas inflexão de rumos", criou-se em São Paulo uma arquitetura que não significou mera continuidade e seguimento da Escola Carioca. O que, segundo a autora, permite identificar o brutalismo com a a arquitetura paulista de 1950 a 1970 é a grande quantidade de obras "[...] de peculiar organização formal, espacial, construtiva e plástica, num esforço potencial para a formação de um estilo" (ZEIN, 2005, p. 4 e 1)

Como contraponto entre a Escola Carioca e a Paulista, da década de 1960, pode-se afirmar que, enquanto a primeira valorizou a forma e levou em conta uma certa caracterização programática, a segunda privilegiou o espaço genérico, capaz de abrigar diferentes usos (ACAYABA, 1995). Além disso, a arquitetura paulista brutalista pode ser caracterizada por um conjunto de regras compo- 
sitivas, tais como univolumetria, presença de um núcleo ordenador, unidade espacial interna, permeabilidade interior-exterior e configuração de espaços por volumes fechados.

Em relação à arquitetura dos anos 60 em São Paulo, Sérgio Ferro, admitindo a influência europeia, chamou-a de "espécie cabocla de brutalismo (oposto ao brutalismo estetizante europeu)", em que prevalecia "a excessiva racionalização construtiva; o 'economismo' gerador de espaços ultradensos raramente justificados por imposições objetivas" (2006, p. 49).

Com poucos elementos, baixo custo e muita austeridade os arquitetos pretendiam resolver o problema habitacional do país. As preocupações sociais e políticas estavam acima das preocupações estéticas ou de conforto. O projeto arquitetônico era também um projeto social, e a austeridade fazia parte de sua ideologia (SANVITTO, 2002, p. 6).

Referindo-se a obras de Paulo Mendes da Rocha, João de Gennaro, Joaquim Guedes, Fábio Penteado, Pedro Paulo de Mello Saraiva e Miguel Juliano, assim se expressou Maria Alice Junqueira Bastos (2010) sobre a arquitetura paulista:

\footnotetext{
Esses arquitetos, nascidos entre o final dos anos 1920 e o começo dos 1930, foram responsáveis por uma radicalização da linguagem moderna. Expressavam-se com uma arquitetura inspirada pela engenharia, preocupada com a racionalização dos processos construtivos e o desenvolvimento de soluções modelares [...] Essa arquitetura perseguia uma expressão universal, tecnológica, a implantação genericamente correta. A premissa da industrialização da construção informava as soluções arquitetônicas que assim passaram a evitar os revestimentos, explorando as próprias soluções construtivas na expressão plástica da obra arquitetônica. As estruturas de concreto assumiram linhas retas, preterindo a linha curva, admitida apenas quando o programa expressamente a sugeria.
}

Apesar de ter admitido inicialmente que a produção do casal Alison e Peter Smithson, identificada como integrante do que chamou de novo brutalismo inglês, tinha motivações éticas e estéticas, Banham, na segunda metade do seu livro O novo brutalismo: ética ou estética?, afirmou:

O Brutalismo chegou, certamente, a ser "uma arquitetura", um idioma, um estilo vernáculo; estética bastante universal para expressar uma variedade de modalidades arquitetônicas, inclusive perdendo algo do fervor moral que iluminou suas primeiras pretensões de ser uma ética (1966, p. 89).

Maria Luiza Adams Sanvitto, por sua vez, defendeu a presença do binômio ética-estética no brutalismo paulista, sendo que o primeiro termo, referindo-se às motivações sociais e à verdade dos materiais, deveu-se ao contato com o novo brutalismo inglês, e o segundo, ou a influência formal, aos exemplos de Le Corbusier, com o uso do concreto bruto aplicado aos prismas puros, e sua univolumetria. Para a autora, o brutalismo paulista

[...] foi uma tendência que partia de um discurso defendendo uma postura ética para a sociedade. Foi messiânica e salvadora na medida em que propagou novas idéias em busca de um mundo melhor. Acreditava na verdade, na correção, na virtude e na igualdade dos homens. Esta ideologia conduzia soluções arquitetônicas nas quais nada havia a esconder. Sugeria a vida comunitária decorrente da utilização do espaço único. As segregações não eram bem aceitas, assim como as compartimentações evitadas (SANVITTO, 2002, p. 15). 


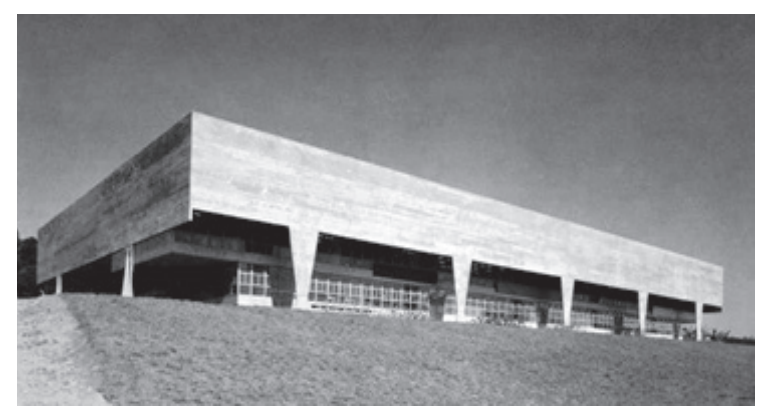

Figura 88a.

Vista externa da Faculdade

de Arquitetura da USP

(FAU-USP), de autoria do

arquiteto Vilanova Artigas,

1969

Figura $88 b$ e $88 c$.

Vista interna da FAU-USP
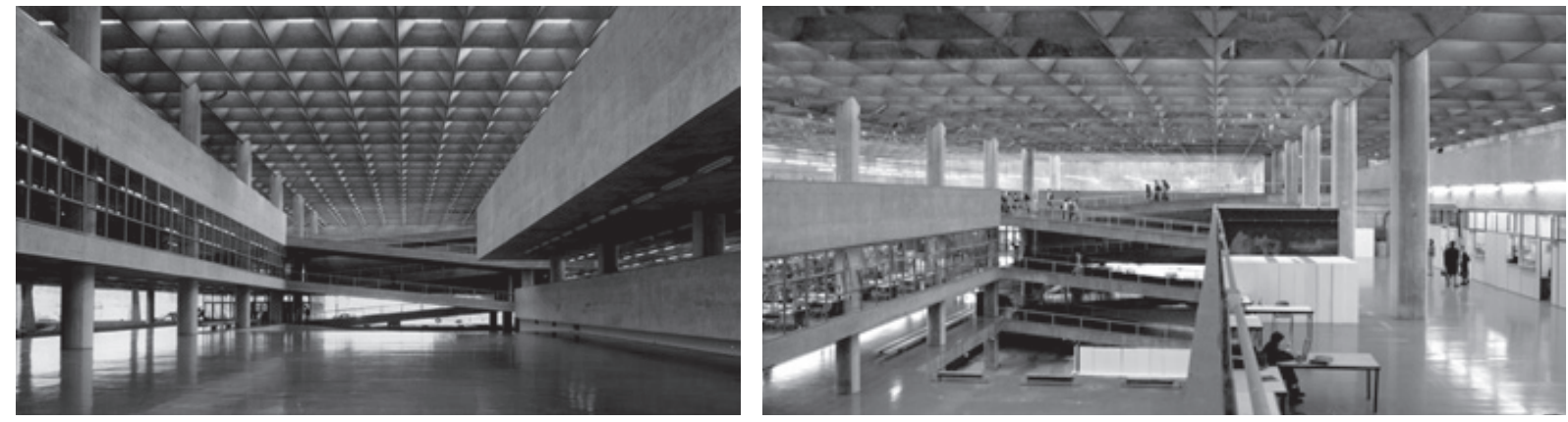

Refletindo sobre o caráter ideológico por trás do processo de projetação, assim se pronunciou o arquiteto Vilanova Artigas sobre o edifício da Faculdade de Arquitetura e Urbanismo da Universidade de São Paulo:

Pensei que este espaço fosse a expressão da democracia. Pensei que o homem na Faculdade de Arquitetura teria o viço e que nenhuma atividade aqui seria ilícita, que não teria de ser vista por ninguém, e que os espaços teriam uma dignidade de tal ordem que eu não podia pôr uma porta de entrada, porque era para mim um crime (1989, p. 22).

Tanto o discurso doutrinário como a prática fizeram com que Artigas se firmasse como um importante protagonista da Escola Paulista, sendo sua atuação política na arquitetura o eixo para a compreensão de sua trajetória. A arquitetura produzida por ele e por seus discípulos foi distinguida pelo uso de materiais brutos (em especial o concreto) e por um determinado vocabulário formal, decorrente da técnica e da intenção ética aliada ao projeto.

Para encerrar estas breves especulações em torno do brutalismo, cabem algumas considerações sobre o caráter ético das escolas paulista e carioca. Ao se referir à primeira, Sanvitto afirmou:

A obra do Brutalismo Paulista foi criada por arquitetos politizados, imbuídos de um ideal de melhoria social. Acreditavam na construção de um país novo, participando desta tarefa através de seu trabalho. Na primeira metade da década de 60, esta tendência foi doutrinária, propagando soluções arquitetônicas que pretendiam ser modelo para a construção de uma sociedade mais justa. Foi uma tendência austera (2013, p. 14).

Sobre a segunda, a mesma autora declarou:

Embora os representantes da Escola Carioca não fossem alheios aos problemas do país, o exercício de sua profissão não estava ligado à solução dos mesmos. Respondiam, através de sua produção, aos anseios de representatividade de uma clientela (2013, p. 15). 
A atuação do Ceplan, na sua fase pioneira, já mostrada neste trabalho, nos permite discordar da autora quando afirmou que a preocupação social dos arquitetos cariocas não estava ligada à solução dos problemas do país. Ao fundar um centro de pesquisa voltado para a pré-fabricação, Oscar Niemeyer e sua equipe pretendiam, de fato, desenvolver tecnologias capazes de se constituírem em alternativas para a produção de equipamentos a serem apropriados, posteriormente, pela população brasileira. Ao que tudo indica, eles acreditavam que somente por meio da produção em massa seria possível atender, qualitativa e quantitativamente, às demandas por bens e serviços públicos para o país.

Além disso, os arquitetos que chegaram à UnB na primeira hora eram também politizados e estavam, de uma forma ou de outra, engajados na luta política por melhores condições para o país. Militantes ou simpatizantes de partidos de esquerda, eles tinham como objeto privilegiado de estudo os sistemas de construção, que vinham sendo desenvolvidos nos países socialistas do Leste Europeu, baseados na pré-fabricação e na produção em série.

Entre 1980 e 1990, Oscar Niemeyer seria chamado a participar, no Rio de Janeiro, do Programa Especial de Educação, voltado para a construção dos Centros Integrados de Educação Pública (CIEPs), pelo sistema de pré-fabricação ${ }^{3}$. Herdeiro da fase pioneira da UnB, Lelé continuaria, até o fim de sua vida, a trabalhar no desenvolvimento de tecnologia e na produção de pré-fabricados - de concreto, argamassa armada e aço - para a construção de equipamentos públicos de qualidade, como os desenvolvidos na Rede Sarah de Hospitais, hoje uma referência mundial. Esse duplo compromisso com a tecnologia e a questão social pode ser depreendido do discurso de integrantes do Ceplan:

[...] Tinha um pedido para fazer um projeto de uma hotelaria de professores, mas não foi construída. Glauco também fez um projeto, eu também fiz uma porção de projetos que não foram construídos (LELÉ, entrevista em 29 fev.2012).

[...] o Ceplan poderia ter colaborado com a cidade. Provavelmente, ter ajudado no planejamento das cidades-satélite, para que tivessem um desenvolvimento mais de acordo com o padrão urbanístico de Brasília. Isso não foi adiante, mas era uma ideia também, disso tudo ser desenvolvido na escola e no Ceplan (PESSINA, entrevista em 1 dez. 2011).

Sem querer estender esse assunto, para não fugir ao propósito do presente trabalho, cabe resgatar alguns cânones do brutalismo paulista da segunda metade do século XX que foram, de certa forma, contemplados em obras construídas na UnB a partir de 1970:

A arquitetura brutalista demonstra os materiais utilizados e a técnica que permite sua execução. Interna e externamente, procura distinguir vedação ou estrutura, levando o uso de revestimentos a uma categoria de dissimulação. Não existe um critério seletivo do que deva ou não estar à vista e onde o rigor pode chegar à exposição das canalizações. O Brutalismo se caracteriza pela expressão dos materiais em detrimento de superfícies bem acabadas, onde a idéia de beleza é associada à verdade construtiva. A edificação deve ser honesta, demonstrando seus materiais assim como a técnica construtiva adotada (SANVITTO, 2013, p. 2).

${ }^{3}$ A despeito das críticas a esse importante projeto de educação integral, foram construídas centenas desses centros. A técnica da pré-fabricação adotada em sua construção teria permitido uma economia de 30\% em relação à construção convencional (https://pt.scribd.com/doc/36579672/A-Arquitetura-Do-Ciep). 
A ideia de construir uma usina para o desenvolvimento da pré-fabricação na UnB não foi levada adiante pelo Ceplan, por diferentes motivos. Em primeiro lugar, tratava-se então de produzir edifícios, em tempo recorde, para atender a uma demanda crescente. Em segundo, o fato de alguns projetos terem sido concebidos para edifícios únicos, não reproduzíveis, desestimulou o desenvolvimento das pesquisas em torno da pré-fabricação. Mesmo quando os projetos foram desenvolvidos com base nessa tecnologia, a construção acabou sendo convencional, em função de impedimentos burocráticos e financeiros, principalmente se for considerado que as planilhas de custo não contemplavam investimentos em pesquisa e experimentação tecnológica.

O que vou fazer com a biblioteca? Fiquei pensando, fiz o projeto, a concepção. E agora, onde entra a pré-moldagem? Cheguei à conclusão de que em obras isoladas a pré-moldagem seria um encarecimento muito grande da obra. E nós tínhamos o orçamento de um milhão e meio de dólares. O que você faz com esse valor? Não tinha condição (GALBINSKI, entrevista em 20 fev. 2012).

O terceiro motivo, e certamente o mais forte, era de ordem política, como explicou o arquiteto e professor Galbinski:

O BNH, que foi fundado nesta época, estava a todo vapor. O BNH não queria a pré-moldagem, era programático, porque a construção civil tradicional era absorvedora de mão de obra: se colocássemos a pré-moldagem aqui no Brasil, se criaria um problema social. A pré-moldagem era malvista pelas instituições federais, era coisa de esquerdista, de comunista (Entrevista em 20 fev. 2012).

O discurso de Rubens Vaz da Costa, presidente do Banco Nacional de Habitação (BNH) entre 1971 e 1974, atesta a veracidade da afirmação de Galbinski:

\begin{abstract}
No setor da construção civil, os meios tradicionais de produção devem ter preferência no momento atual, dada a necessidade de criar empregos para a mão de obra não qualificada. Os modernos métodos industriais de produção, no entanto, podem ser objeto de estudo, de experimentação, mas a sua utilização no país é ainda prematura, inclusive porque, de modo geral, são mais caros do que os meios tradicionais que empregam mão de obra não qualificada, de baixo salário. É, portanto, o setor da construção civil o que mais tem correspondido à necessidade de criação de empregos; e deverá continuar a ser ainda por muitos anos um baluarte do emprego em nosso país (COSTA, 1972, p. 11).
\end{abstract}

Pelas palavras acima, pode-se deduzir que os governos militares não tinham interesse algum de investir na qualificação da mão de obra, para que ela permanecesse barata, e nem de estimular os métodos industriais, vez que o setor da construção civil servia como garantia de emprego a grandes contingentes de população sem acesso à educação. Além disso, em seu livro Arquitetura, industrialização e desenvolvimento (1976), Paulo Bruna chamou a atenção para a necessidade de rebater falsas verdades sobre as vantagens dos métodos tradicionais de construção baseados no trabalho intensivo. $\mathrm{O}$ argumento repousa, sobretudo, na constatação da baixa produtividade dessa mão de obra e do aproveitamento pouco racional dos materiais. Segundo o autor, "[...] o critério básico para se julgar o papel da inovação tecnológica não é tanto o seu efeito imediato sobre o emprego, mas seu efeito sobre a acumulação de capital", pois "[...] se uma inovação tecnológica aniquila empregos no canteiro, sua contribuição para a acumulação de capital permite a criação de empregos em outras áreas, e nas indústrias de material de construção" (1976, p. 125 e 126). 
Sobre a questão da tecnologia, assim se manifestou Galbinski:

Essa questão da tecnologia era quase uma ideologia no Ceplan, tanto assim que nós vivíamos autopressionados [...] vivíamos sob a influência de fazer obras de alto nível. Todos nós tínhamos um viés social, alguns eram até engajados em partidos políticos de esquerda; todos tinham o viés social e consciência disso. Pois se manifestava ali, de uma forma geral, que devíamos usar as obras como um experimento, uma pesquisa, de pré-moldagem, ou no mínimo de racionalização da construção, com vistas ao problema da habitacional brasileiro, que era muito grave etc. E o exemplo estava na nossa frente, o ICC em construção; o Ceplan totalmente pré-moldado, montado, projeto muito bonito; a Colina; os SGS (Entrevista em 20 fev. 2012).

Nessa época, a UnB vivia não somente sob o peso da ditadura militar como também sob uma gestão bastante diferente daquela presidida por Darcy Ribeiro, um verdadeiro entusiasta das ideias progressistas e socializantes, conforme lembrou Lelé: "Ele me estimulou a criar lá (na UnB) um grande centro de construção industrializada, um centro de tecnologia que seria usado pela universidade" (2004, p. 51$)$.

Em um trecho do Plano Diretor Físico do Campus Universitário Darcy Ribeiro, de 1998, é possível depreender como o clima dos tempos da ditadura interferia no planejamento institucional e físico da UnB: Mesmo num momento de inegável criatividade e resistência - e de vivo debate sobre o espaço universitário -, não transparecia uma discussão mais ampla sobre a instituição e sua proposta acadêmica: eram de difícil superação as barreiras entre planejamento institucional e planejamento físico, entre administração e comunidade naquela Universidade de Brasília sob intervenção do governo militar (1988, p. 15).

Finalmente, tendo caído por terra o que poderia efetivamente ter significado um caminho para uma produção em massa, restou ao Ceplan manter um vínculo com uma linguagem, o brutalismo paulista, cujos projetos e detalhes estavam associados, pelo menos simbolicamente, à ideia de industrialização e produção em série, conforme explicitou Sanvitto (2013, p. 13):

Embora muitos elementos de arquitetura que apresentavam detalhes inovadores fossem executados artesanalmente, eram sempre projetados imaginando sua potencialidade de industrialização e produção em série. Os arquitetos do Brutalismo Paulista projetavam e detalhavam residências tendo em mente a expressão de uma sociedade melhor que contava com a indústria para atingir seus objetivos.

Devidamente reestruturado, o Ceplan, imprimindo um novo ritmo ao trabalho de planejamento, crescimento e consolidação do campus, procedeu à revisão da Praça Maior e deu início à elaboração dos projetos de seus edifícios.

\footnotetext{
A gente se organizava em equipes por interesse no tema e afinidades quanto à forma de ver e fazer arquitetura. Todos em dedicação exclusiva, pois essa era uma condição imposta para a nossa vinda: atuar em dedicação exclusiva, e a prática era assegurada no Ceplan. Só aceitei o convite para integrar o corpo docente da UnB com essa condição. A gente constituía equipes quando abertas as inscrições para os projetos. Quando o tema era muito atraente montavamse concursos internos (ZIMBRES, entrevista em 26 out. 2011)
}

Nessa época, foi aprovado o projeto para a Biblioteca Central, desenvolvido no Ceplan por uma equipe formada pelos arquitetos José Galbinski e Miguel Alves Pereira, com a colaboração de Jodete Rios Sócrates e Walmir Santos Aguiar, e pelos bibliotecários Rubens Borba de Moraes, Edson Nery da Fonseca, Antônio Agenor Briquet de Lemos e Elton Eugênio Volpini. Sobre os primeiros projetos desenvolvidos no Ceplan nesse período, vale destacar o comentário de Galbisnki: 
Os projetos iniciais que fizemos naquele período eram projetos que nos davam medo. Medo! De que não atingissem o nível das coisas que já estavam lá. Isso era obsessivo, ameaçador. $\mathrm{O}$ que estava lá, nós considerávamos o nível a ser atingido (Entrevista em 20 fev. 2012).

Às vésperas da Copa de Futebol de 1970, Zimbres, na qualidade de coordenador do Ceplan - cargo que exerceu de setembro de 1969 a setembro de $1973^{4}$-, foi ao Rio de Janeiro convidar Oscar Niemeyer para participar desse processo, oferecendo-lhe todas as condições de suporte para o desenvolvimento dos trabalhos. $\mathrm{O}$ arquiteto carioca

\begin{abstract}
[...] delicadamente declinando do convite, lembrou-me que não se sentiria confortável em voltar dessa maneira à Universidade, pois ainda não fora adequadamente superada a crise que culminou com a demissão coletiva dos professores em 1965. Reafirmou seu apoio à equipe que naquele momento trabalhava para revitalizar o ICA-FAU, reconhecendo que o Ceplan era o laboratório necessário para unir atividade docente, de pesquisa e prática do ofício, sugerindo que fizéssemos com liberdade as intervenções que julgássemos necessárias no campus (ZIMBRES, entrevista em 26 out. 2011).
\end{abstract}

Diante da negativa, foi dado início ao projeto da Reitoria, de autoria de Paulo Zimbres, com a participação de Josué de Carvalho Macedo e Vera Lúcia Braun Galvão5, e posteriormente também de Érico Weidle.

Ainda em 1970, foram iniciadas as obras do Centro Desportivo, projetado por Márcio Villas Boas, Ricardo Farret e Paulo Zimbres, e da Casa do Estudante Universitário (CEU), de autoria dos arquitetos Léo Bonfim e Alberto Xavier, com a colaboração de Solón Leão Pereira de Souza.

Com a aprovação do novo Estatuto da UnB, em 13 de março de 1970, pelo Conselho Federal de Educação (CFE), foi abandonado o compromisso com as concepções originais da universidade, que vinham sendo mantidas até então, em favor de critérios de eficiência e racionalidade. Com isso, a UnB seria reestruturada em novas bases: os institutos centrais perderiam gradativamente sua importância; as mudanças de curso tornar-se-iam mais rígidas; desapareceria o Centro Integrado de Ensino Médio (Ciem), que funcionava como escola de aplicação da Faculdade de Educação; o edifício do Instituto de Teologia seria transferido para a Fundação Educacional do Distrito Federal; e o Ceplan perderia seu caráter experimental, voltado principalmente para a pesquisa de novas tecnologias construtivas.

Nessa época, foi concluído o novo plano para o campus, que promoveu a transferência dos alojamentos estudantis para as proximidades dos locais destinados aos equipamentos esportivos e recreativos; e a consolidação da Praça Maior, cujo projeto paisagístico ficou a cargo do arquiteto carioca Fernando Chacel.

Em 1971, a administração superior da UnB decidiu iniciar os planos para a construção do Restaurante e da Reitoria, ensejando um debate sobre a viabilidade de locação de um equipamento na Praça Maior, que funcionasse como um centro de gravidade da vida do campus. As conclusões desse debate levaram os arquitetos do Ceplan a uma revisão do projeto urbanístico, visando inserir a proposta de uma Praça Central dentro de uma perspectiva de desenvolvimento global do campus. Assim, às quatro unidades previstas por Niemeyer - Reitoria, Biblioteca, Aula Magna e Museu da Civilização - foi acrescido o Centro de Vivência, então integrado por restaurante, supermercado, farmácia, agência dos Correios e associações em geral.

\footnotetext{
${ }^{4}$ Durante esse período, exerceram interinamente a coordenação do Ceplan os arquitetos e professores da FAU Ricardo Farret (janeiro de 1972), José Galbinski (março de 1973) e Adilson Costa Macedo (fevereiro de 1973).

${ }^{5}$ Josué de Carvalho Macedo e Vera Lúcia Braun Galvão, ex-alunos da FAU-UnB, não tinham vínculo com a docência, tendo sido contratados para o desenvolvimento de projetos, devido à urgência imposta pela Reitoria.
} 
[...] no início da década de 70, estudos mais ambiciosos propõem soluções de consolidação da Praça Maior. Reforçava essa nova leva de estudos o projeto de implantação do Centro de Vivência [...] Contudo, as grandes composições da época eram variações sobre o tema do centro da universidade, sobre seu espaço simbólico e de poder mais nitidamente identificado. Mesmo num momento de inegável criatividade e resistência [...] não transparecia uma discussão ampla sobre a instituição e sua proposta acadêmica: eram de difícil superação as barreiras entre planejamento institucional e planejamento físico, entre administração e comunidade naquela Universidade de Brasília, sob intervenção do governo militar (FARIA; ARANTES; BARRETO, 2003: 12).

Assim, os arquitetos incumbidos do projeto da Praça Maior tiveram que driblar as ordens superiores, como atestam as palavras de Zimbres: "Nós recebemos ordens expressas da Presidência da República dizendo que teatro não interessava na universidade, porque eram notórios os conflitos dos teatros com o poder constituído". Apesar disso, juntamente com o paisagismo foi projetado e construído, na Praça Maior, um Teatro de Arena: "Nós o colocamos, passando de contrabando, como quem não quer nada, e, por muito tempo, ele ficou sendo o espaço da resistência democrática" (ZIMBRES, entrevista em 26 out. 2011).

Figura 89.
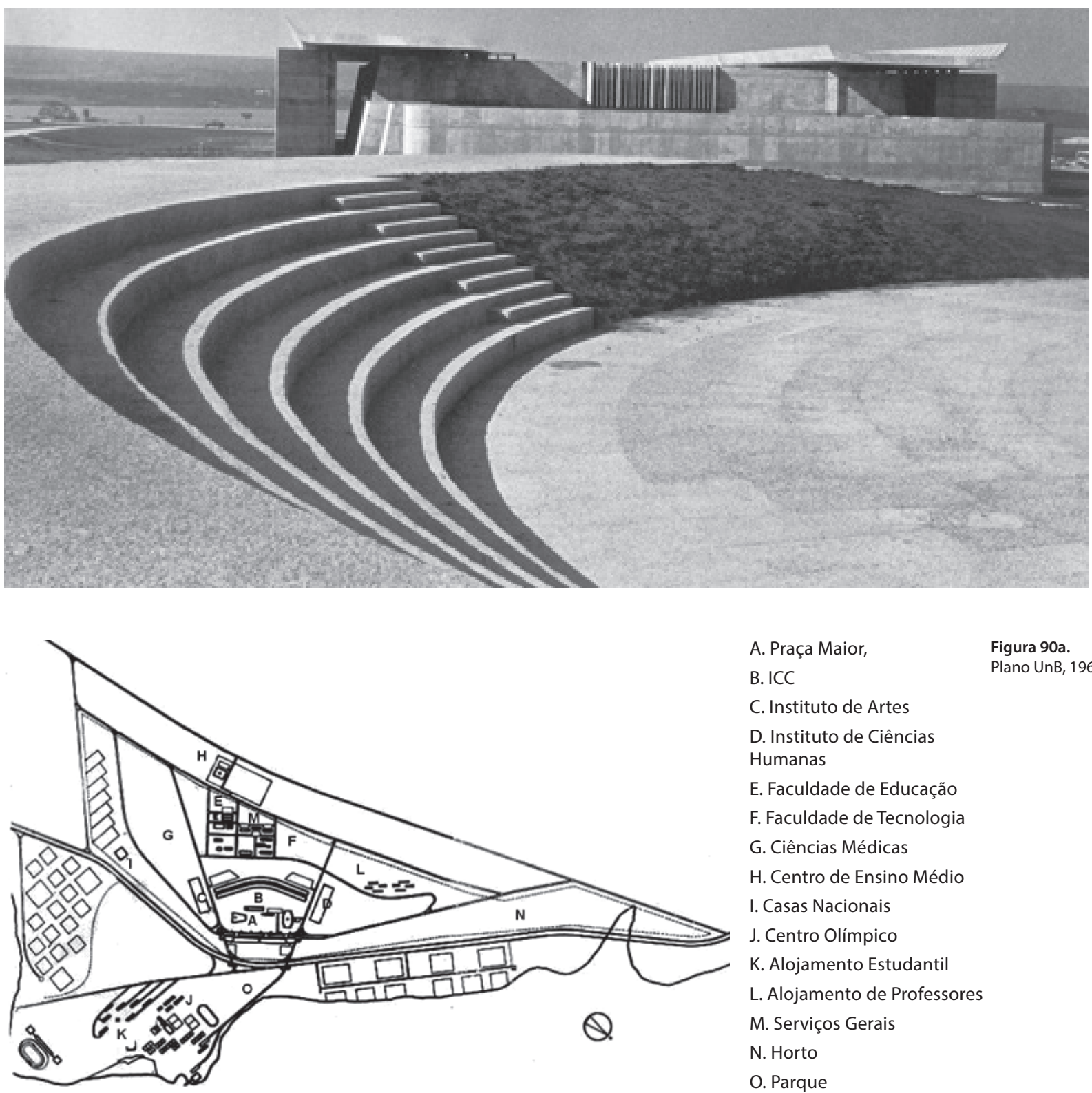

A. Praça Maior,

B. ICC

C. Instituto de Artes

D. Instituto de Ciências Humanas

E. Faculdade de Educação

F. Faculdade de Tecnologia

G. Ciências Médicas

H. Centro de Ensino Médio

I. Casas Nacionais

J. Centro Olímpico

K. Alojamento Estudantil

L. Alojamento de Professores

M. Serviços Gerais

N. Horto

O. Parque 

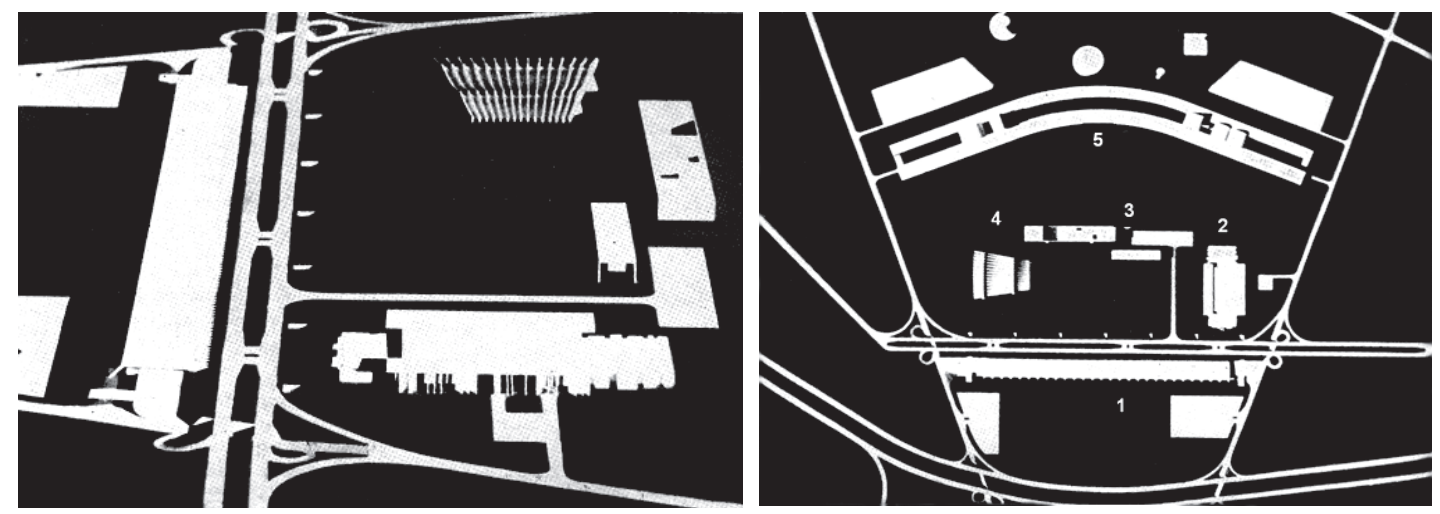

Figura 90b.

Praça Maior

Figura 90c.

Maquete da

Praça Maior

1. Centro de Vivência

2. Biblioteca

3. Reitoria

4. Aula Magna

5. ICC

No dia 25 de março de 1971, o professor Amadeu Cury assumiu a Reitoria com uma proposta de reestruturação da universidade, que pressupunha sua consolidação física e acadêmica. A postura menos confrontadora da nova administração rendeu apoio financeiro do governo federal para a instituição. $\mathrm{Na}$ década de 1970, foram criados 14 novos cursos de graduação, um aumento de 82\% em relação a 1962.

O Departamento de Arquitetura e Urbanismo foi beneficiado nessa época pelo ingresso de novos docentes, entre os quais Adilson Costa Macedo, Benamy Turkienicz, Frank Algot Eugen Svensson, Paulo Renato Silveira Bicca e, posteriormente, Frederico Rosa Borges de Holanda.

Durante essa gestão, prosseguiram as obras no Centro Desportivo, com a construção do pavilhão de administração, vestiários, alambrados, campo de futebol, quadras e serviços de urbanização. Foram feitas ainda as sondagens de reconhecimento e pesquisa do lençol freático na área do ginásio coberto, cujo projeto, de autoria de Paulo de Mello Zimbres, Márcio Villas Boas e Ricardo Farret ${ }^{6}$, ficou apenas no papel.
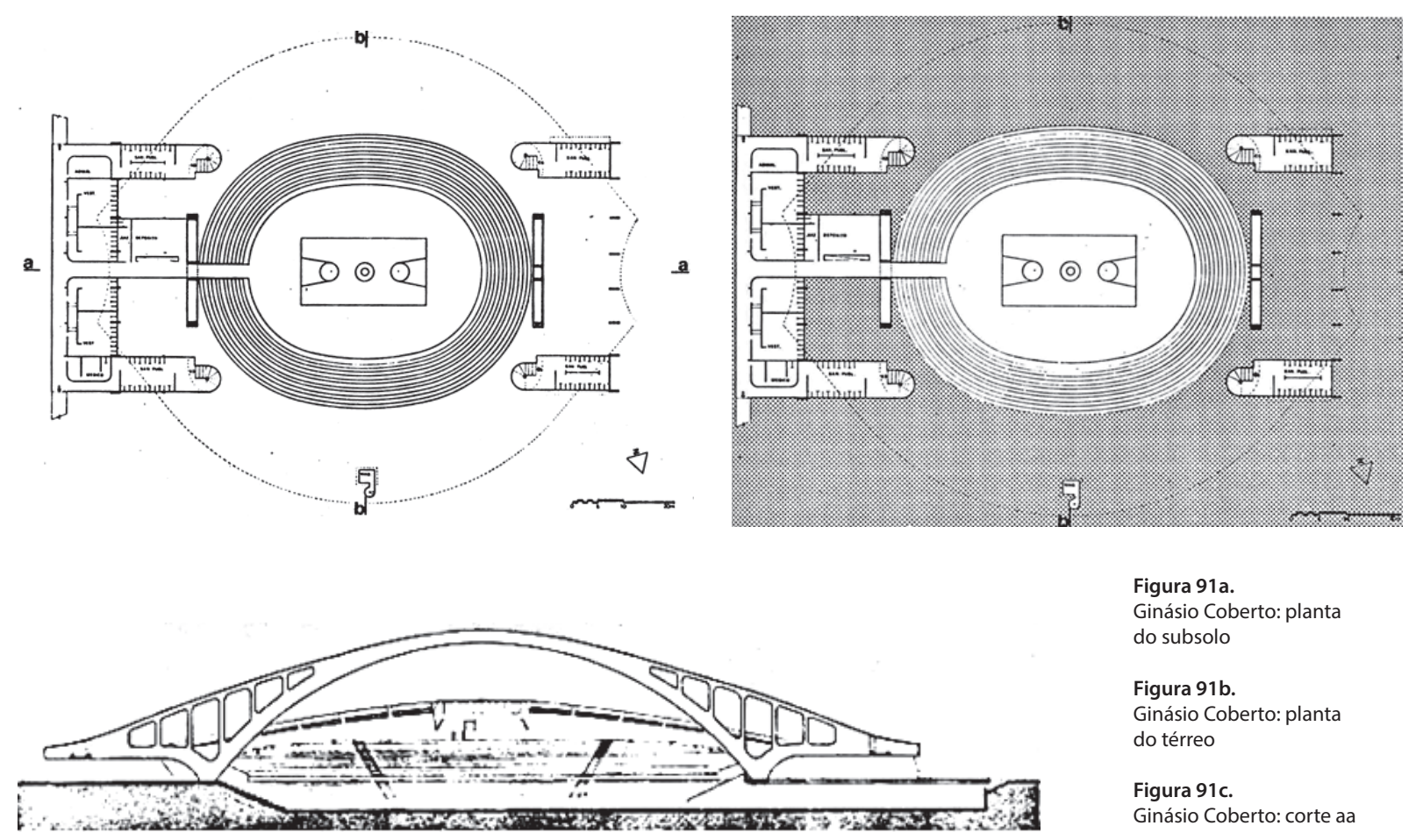

Figura 91a.

Ginásio Coberto: planta do subsolo

Figura 91b.

Ginásio Coberto: planta do térreo 
Foram iniciadas ainda as obras de estrutura do Restaurante Universitário, que teve sua localização modificada, já que a Administração da UnB não queria movimento de estudantes perto do novo prédio da Reitoria. Imposta de forma considerada autoritária, essa decisão superior contrariou o Plano Urbanístico de 1969, que previa a localização do Restaurante na Praça Maior. Com isso a praça, que passou a ser denominada de Praça Central, seria reservada apenas aos acontecimentos mais importantes da Universidade.

[...] a gente tinha um projeto do Pedro Paulo Saraiva que colocava o restaurante na Praça Maior. A Praça Maior não seria só um espaço de grandes eventos, de grandes momentos da universidade, excelência, das aulas magnas, mas seria também um espaço do cotidiano, e o restaurante foi proposto na Praça Maior para enfatizar esse destino. Isto causou uma grande dificuldade de entendimento dos quadros dirigentes, a maioria militares, que viam naquela posição, um foco, muito complicado de rebeldia, de geração de protestos e tudo mais. Sua preferência seria deslocar o restaurante para o Centro Olímpico, perto do Alojamento de Estudantes. Iniciou-se um debate acalorado que resultou em um acordo: 'Tudo bem, não sendo na Praça Maior, propomos localizá-lo em um local equidistante de todas as unidades de ensino então existentes, no eixo do Minhocão'. Foi então decidida a questão (ZIMBRES, entrevista em 26 out. 2011).

O projeto de Pedro Paulo de Mello Saraiva ${ }^{7}$ a que se refere o arquiteto e professor Paulo Zimbres é o de um Centro de Vivência, contíguo à Praça Maior, que não chegou a ser construído, por interferência da Reitoria. De acordo com Galbinski, não havia verba para construção de um centro de vivência, e sim para o restaurante. Mas o impasse maior se deu porque a Reitoria não concordou com a localização do restaurante, projetado pelo arquiteto como o coração desse centro. Como explicou Galbinski,

Na época em que foi formado o grupo para estudar o campus e os projetos do Centro de Vivência, do Restaurante Universitário, da Reitoria e do Museu, o chefe do Ceplan era o Pedro Paulo de Melo Saraiva. Ele disse: "tá resolvido, está aqui o projeto". Era o Centro de Vivência. Competia-me desenvolver o projeto do Restaurante naquele espaço generoso. O projeto foi rechaçado! Estávamos nessa época nos anos 70 e, em 68, os grandes movimentos estudantis da Europa começaram sempre nos restaurantes universitários, nenhum começou numa faculdade ou em outro local qualquer. A Reitoria tinha isso catalogado. Eles disseram o seguinte: "a Praça Maior, de Oscar Niemeyer, é o lugar da Biblioteca, da Reitoria e da Aula Magna. Nós não queremos colocar o restaurante aqui. Aqui, não!" (Entrevista em 20 fev. 2012).

Figura 92a. Corte BB

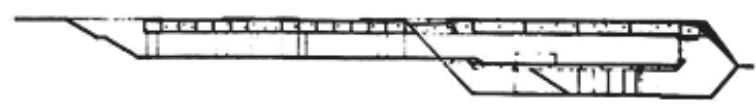

Figura 92b.

Planta do

Centro de

Vivência, de autoria do

arquiteto

Pedro Paulo

de Mello

Saraiva

Figura 92c.

Maquete do

Centro de

Vivência
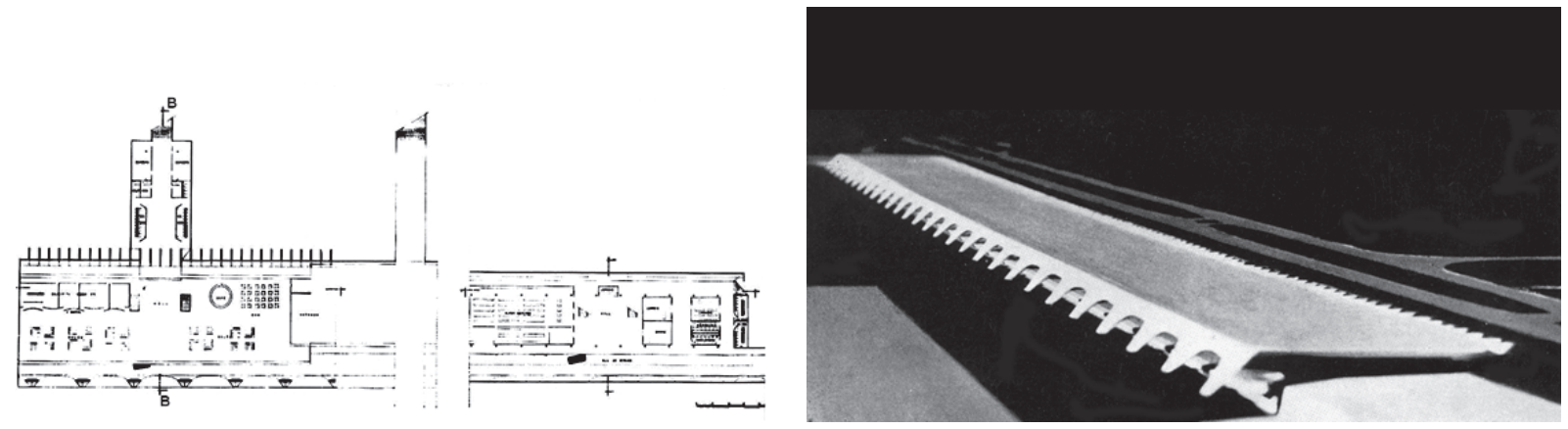
Segundo o professor Galbinski, a propósito desse tema, o coronel Lister Figueiredo, secretário executivo da Reitoria à época, teria dito:"[...] olha, vou lhe dizer uma coisa: se nós fossemos coerentes, faríamos esse restaurante lá na Península Norte, além do campus" (Entrevista em 20 fev. 2012).

No ano seguinte, teve início a construção do edifício sede do Departamento de Educação Física, localizado na área do Centro Desportivo, além das obras do Laboratório de Nutrição e Pesquisa de Doenças Tropicais, de autoria do arquiteto Adilson da Costa Macedo.

Em 1973, o diretor do Instituto de Artes e Arquitetura (IAA), Miguel Alves Pereira, solicitou ao então reitor Amadeu Cury providências para a transformação do Ceplan em um laboratório experimental, subordinado ao IA. Segundo ele, a estrutura desse órgão deveria

[...] constituir-se num verdadeiro laboratório experimental de arquitetura e urbanismo, situado na base do ensino, como fonte de instrumentação docente e de exercício profissional [...] sem qualquer característica de unidade administrativa. Trata-se de um setor (laboratório) do Departamento de Arquitetura e Urbanismo (AUR) ${ }^{8}$.

Embora a decisão não fosse consensual entre os professores, o Laboratório Experimental de Arquitetura e Urbanismo (LEAU) foi criado nesse mesmo ano, ficando a responsabilidade por sua produção a cargo da Direção do IAA. Se, por um lado, esse novo formato institucional tendia a enfatizar o caráter experimental dos trabalhos ali desenvolvidos, por outro criava problemas de ordem prática, como explica o professor Érico: "Esse vínculo foi muito salutar, mas não tinha sustentação econômica [...] a maioria dos nossos colegas não se interessava pelos projetos que não dessem mídia e visibilidade, como também em fazer desenvolvimento de projetos" (WEIDLE, entrevista em 7 dez. 2011).

Entre 1973 e 1974, ocorreram novas contratações para o Departamento de Arquitetura e Urbanismo, e para cá vieram Christina Bezerra de Mello Jucá, Günter Kohlsdorf, Maria Elaine Kohlsdorf, Matheus Gorovitz e Suely Franco Netto Gonzáles.

Nesse meio-tempo, prosseguiam as obras da Reitoria, do Restaurante e da Escola de Educação Física. E ainda começaram a sair do papel a quadra coberta do Centro Desportivo e também a Faculdade de Tecnologia (FT), projetada por Érico Weidle e Adilson Macedo, com a colaboração de Jayme Kerbel Golubov. Essa mesma equipe projetou os laboratórios de Hidráulica e Estruturas e o de Termociência e Metrologia Dinâmica, cujas coberturas são paraboloides hiperbólicos. A reflexão sobre essa experiência levou a uma reestruturação do ensino de estrutura nos cursos de Arquitetura e Urbanismo em geral, conforme explicou o professor Érico Weidle:

Um belo dia, participando de reuniões de reforma de ensino na faculdade, falei que tínhamos que pensar seriamente no ensino de estruturas e tecnologia da construção, já que os alunos de arquitetura não aprendiam nada sobre a concepção estrutural ao cursarem as disciplinas 'clássicas' oferecidas simultaneamente para os alunos de engenharia [...] E coincidiu que, naquele semestre, teve um grande encontro de professores de estrutura em São Paulo, e a FAU me mandou como representante da escola [...] Resultado: ali naquela reunião começou a germinar um monte de coisa. Fui parar na comissão de redação dos anais do encontro, junto com o Zanetini, o Mário Franco e mais um professor do Rio de Janeiro. Discutimos muito, e criamos um documento sobre o pensamento desse ensino nas escolas de arquitetura, a bíblia das mudanças que ocorreriam em vários lugares. Voltei com esse 'trem' dentro da mala e, chegando aqui, contei o que aconteceu [...] Daí criou-se um curso voltado para a concepção estrutural (Entrevista em 7 dez. 2011). 
Um novo plano urbanístico, realizado em 1974, determinou a localização da Faculdade de Tecnologia, da Faculdade de Estudos Sociais Aplicados (FA) e das áreas reservadas às Ciências da Saúde. Essas novas implantações, ao elegerem a via transversal Norte-Sul como eixo de expansão para as novas edificações, conduziram à mudança da filosofia calcada na fixação da Praça Maior e do ICC como elementos estruturadores do desenvolvimento do campus. De acordo com esse novo plano, foi criado um eixo de ensino e pesquisa, em torno da Praça Maior, e um eixo de vivência, entre o ICC e os edifícios de Serviços Gerais.

As críticas contra o Plano de 1974 eram contraditórias: tanto a criação da "rua" inautêntica do Restaurante quanto o isolamento dos edifícios eram crivados pelo olhar de desconfiança quanto ao tipo de controle que poderia ser desejado pelos interventores da UnB ou pela sistêmica repressão às liberdades civis (UNIVERSIDADE DE BRASíLIA, 1998, p. 16)

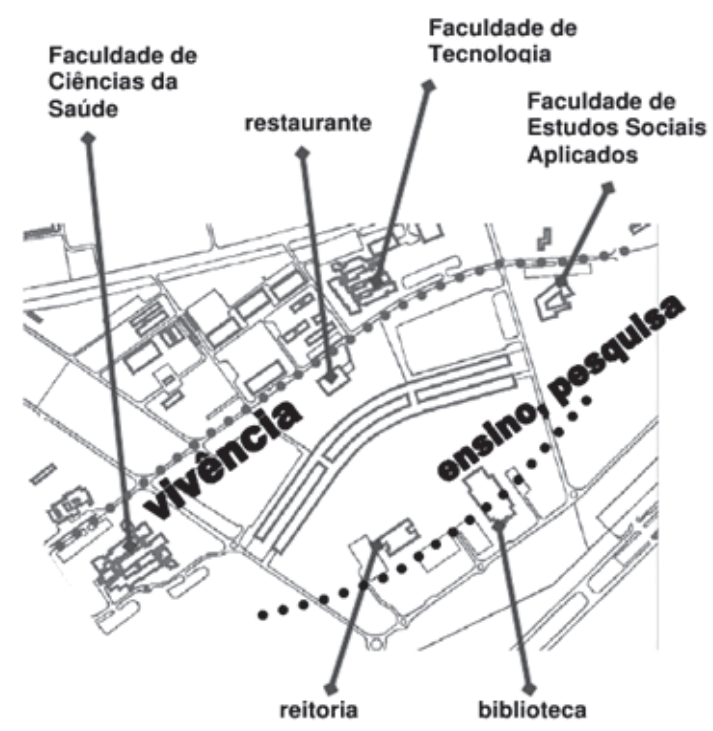

Figura 93.

Plano urbanístico

do campus, 1974

Nesse mesmo ano, o governo federal lançou, por meio do Decreto n. 73.857, de 14 de março, o Programa de Expansão e Melhoramento das Instalações do Ensino Superior (Premesu), que substituiu a Comissão Especial para Execução do Plano de Melhoramento e Expansão do Ensino Superior (Cepes). No ano seguinte foi celebrado o convênio FUB/MEC/BID/Premesu, que tinha como objetivo aprimorar os propósitos da Reforma Universitária de 1968, proporcionando à universidade os meios necessários à melhoria da qualidade e eficiência do ensino superior, à ampliação das funções docentes de pesquisa e de extensão universitária e ao gerenciamento dos projetos objeto de financiamento.

Esse reforço orçamentário permitiu a conclusão de várias obras na UnB, fazendo de 1975 um ano marcado por uma série de inaugurações: uma quadra coberta no Centro Desportivo, os edifícios do Restaurante Universitário e da Reitoria, e a urbanização da Praça Central. Nessa época foram demolidos o velho Restaurante e o antigo galpão da Oficina de Maquetes.

Ainda durante a gestão de Amadeu Cury, foram construídos, por meio de um convênio entre a UnB e a Caixa Econômica Federal (CEF), segundo projeto de Marcílio Mendes Ferreira e Takudo Takada, 11 blocos de apartamentos funcionais na SQN 206, destinados a professores e servidores da Fundação Universidade de Brasília (FUB). 
Data dessa época um novo projeto para a Aula Magna e o Museu, que visava integrar o ICC com a Biblioteca Central e a Reitoria. O conjunto de $20.000 \mathrm{~m}^{2}$ previa a construção de cinco auditórios para congressos, convenções, conferências, concertos, teatro, dança, cinema; áreas para exposições permanentes e temporárias, além de espaços para festas, bailes e banquetes.

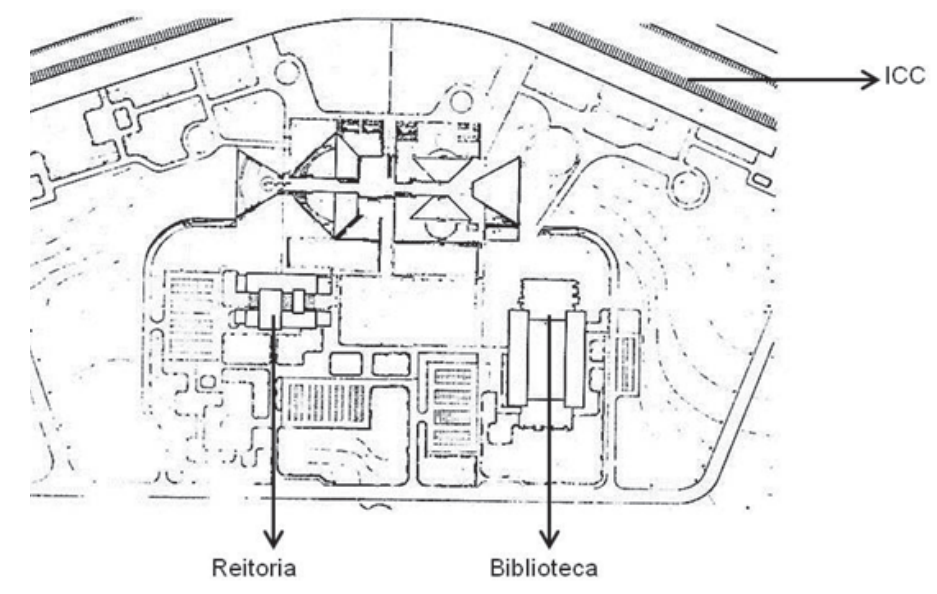

Figuras 94a e

94b.

Implantação do

conjunto Aula

Magna e Museu

Biblioteca
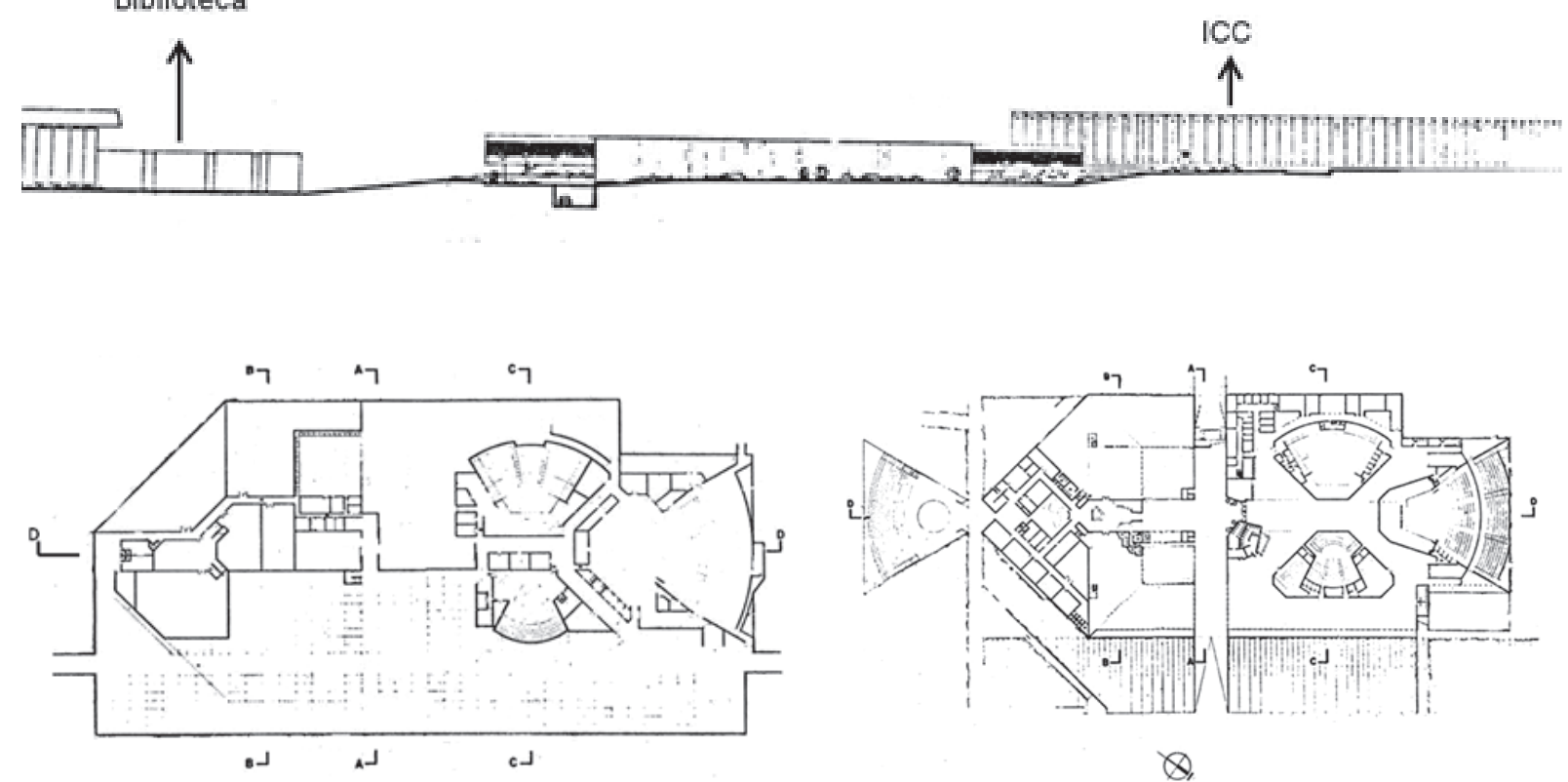

$\varnothing$
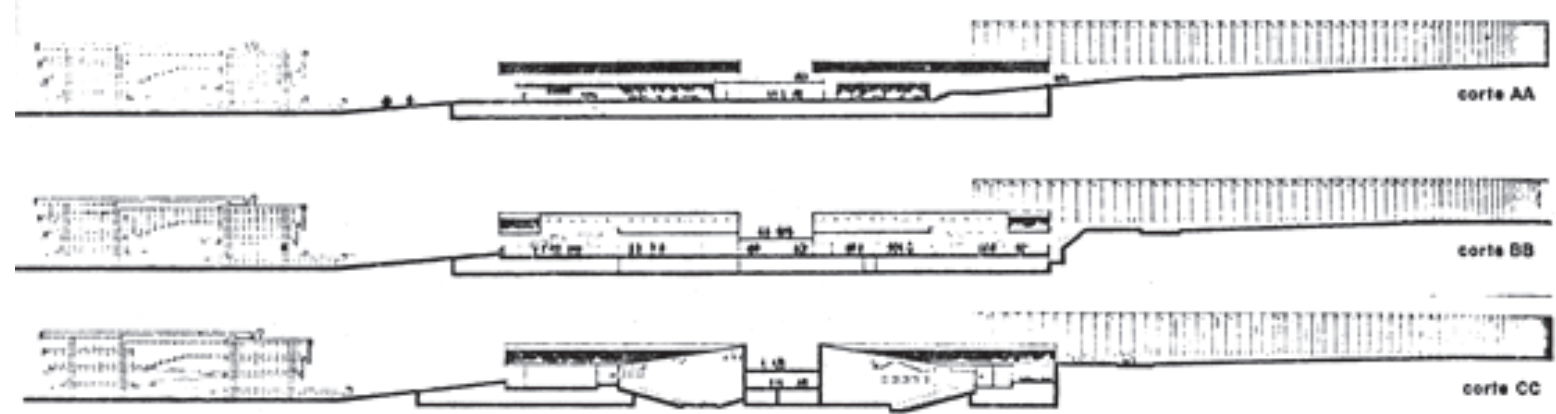

Figura 94c.

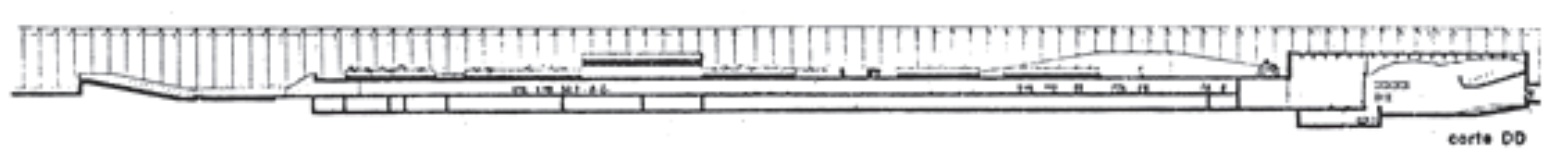


Mas o conjunto também não saiu do papel, pois o clima de construção e certa calmaria durou pouco. Com a posse do novo reitor, o professor, doutor em física e oficial da Marinha José Carlos de Almeida Azevedo, em maio de 1976, as manifestações recomeçaram. A decretação de uma greve de estudantes por tempo indeterminado fez com que o campus fosse, mais uma vez, ocupado pela polícia, chamada pelo próprio reitor para garantir a normalidade das aulas. A crise, que ultrapassou o limite do campus, obrigou o Senado Federal a criar uma comissão para interferir no conflito. Muito embora 150 professores tenham se colocado como mediadores entre a reitoria e os estudantes, em 6 de junho de 1977 tropas militares invadiram a UnB, intimando professores e funcionários. Reunido pela primeira vez desde sua criação, o Conselho Universitário aprovou as sanções impostas pelo reitor a 64 estudantes, os quais foram punidos com penas que iam da suspensão por poucos dias à expulsão.

Entre outubro e novembro desse mesmo ano, ocorreram duas outras invasões no campus da UnB: uma para reprimir uma assembleia, cuja proposta era discutir o indicativo de uma nova greve, e outra devida à encenação da peça teatral $O$ preço da liberdade é a eterna vigilância, considerada subversiva.

Como forma de fortalecer a ação dos professores, foi criada, em 24 de maio de 1978, a Associação dos Docentes da UnB (ADUnB), que teve como primeiro presidente o professor João Cláudio Todorov.

Mas as invasões da UnB só acabariam com a abertura política no Brasil, cujo início se deu de forma bastante curiosa. Por um lado, o presidente João Batista Figueiredo promulgou a Lei n. 6.683, de 28 de agosto de 1979, que concedia anistia a todos que cometeram crimes políticos desde 1961. Por outro, a Lei n. 6.733, de 4 de dezembro de 1979, determinava que os reitores e vice-reitores das universidades federais fossem escolhidos pelo presidente da República sem a exigência da lista sêxtupla, assim como os membros do Conselho Diretor. Devido a esse instrumento legal que ficou conhecido como Lei Azevedo, o então reitor da UnB teve seu mandato prorrogado até 16 de março de 1985.

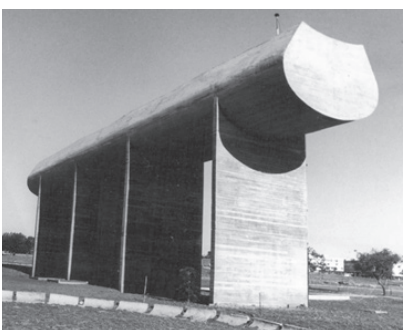

Data dessa época a construção do castelo d'água ${ }^{9}$ da UnB, com projeto de Maurício dos Santos zeredo.

Apenas quatro professores foram contratados pelo Departamento de Arquitetura e Urbanismo no período: Jaime Gonçalves de Almeida, Maurício dos Santos Azeredo, Paulo Marcos Paiva de Oliveira e Sylvia Fisher.

Além dos inúmeros conflitos políticos, durante esse período a UnB foi assolada por problemas de ordem financeira. As obras da Faculdade de Tecnologia, por exemplo, foram paralisadas por falta de verbas. Entre 1977 e 1978 foram construídos, por força de convênio, apenas dois blocos de apartamentos, na SQN 205, com projeto de autoria de Marcílio Mendes Ferreira, para abrigar professores e servidores da Fundação Universidade de Brasília (FUB). Essa situação de precariedade pode ser comprovada pelas palavras de Érico Weidle:

${ }^{9}$ A obra do castelo d'água foi concluída em 1978. Na época pensava-se em atender à demanda da universidade por meio de um castelo d'água. Mais tarde, os prédios passaram a ser projetados com reservatórios próprios. O reservatório superior tem capacidade de 235.000 litros, enquanto a do inferior é de 1.065 .000 litros. 

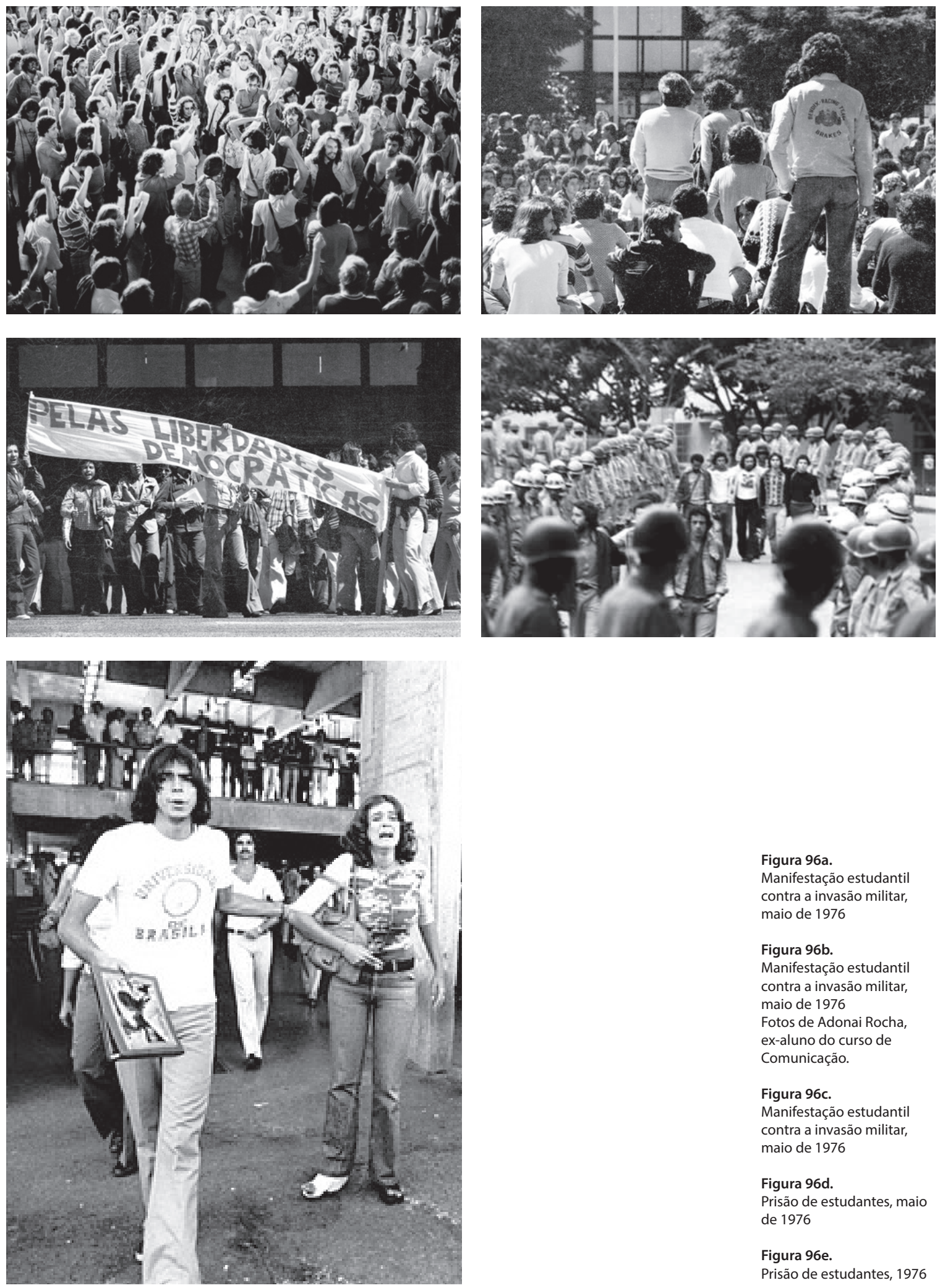

\author{
Figura 96a. \\ Manifestação estudantil \\ contra a invasão militar, \\ maio de 1976 \\ Figura 96b. \\ Manifestação estudantil \\ contra a invasão militar, \\ maio de 1976 \\ Fotos de Adonai Rocha, \\ ex-aluno do curso de \\ Comunicação. \\ Figura 96c. \\ Manifestação estudantil \\ contra a invasão militar \\ maio de 1976 \\ Figura 96d. \\ Prisão de estudantes, maio \\ de 1976 \\ Figura 96e. \\ Prisão de estudantes, 1976
}




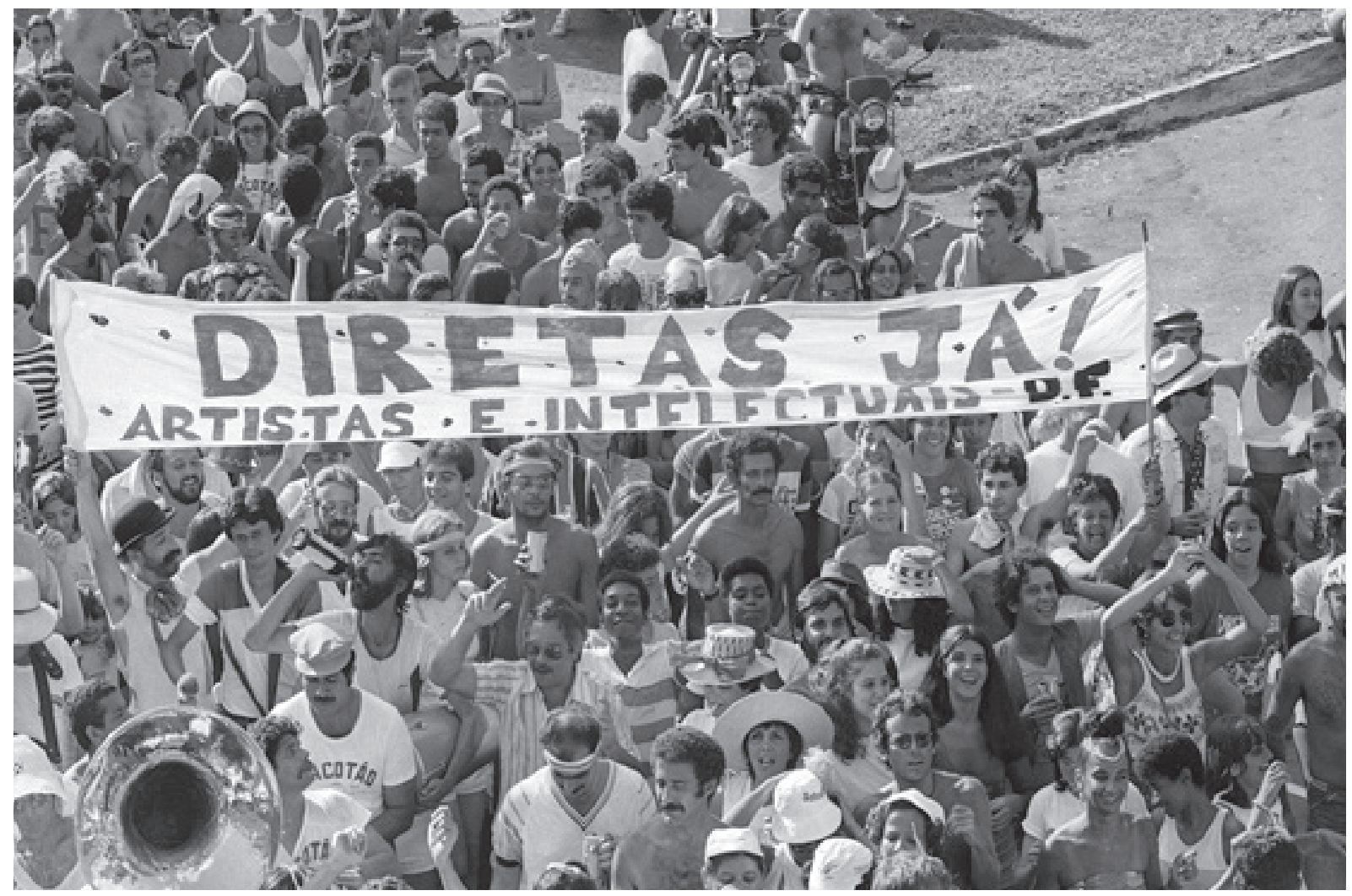

[...] cansado das dificuldades para conseguir os meios para conduzir os trabalhos, pedi entrevista ao coronel Lister, o todo-poderoso superintendente da universidade. Fui ter com ele vestido com um boné velho na cabeça. Tirei o roto chapéu da cabeça e, com ele na mão, estiquei-o em sua direção, como que pedindo uma esmola [...] Foi essa a forma que encontrei de sensibilizá-lo para dotar o Ceplan de desenhistas, material e equipamentos necessários ao desenvolvimento dos projetos. Funcionou [...] Os registros, a publicação, fotografia, maquetes e acompanhamentos de projetos em execução não entravam na composição dos custos da Administração Central. O entendimento do trabalho de arquitetura era limitado e bisonho. Assim, qualquer alteração no projeto ou uma exposição, por exemplo, já não contava com o pessoal e o material necessários, pois o projeto dado como concluído não contava com mais verba. Os próprios autores cumpriam tarefas de desenho, montagem e produção de material ilustrativo às próprias custas. Essa experiência de realizar projetos em bases precárias me esgotou (Entrevista em 7 dez. 2011).

O país, por sua vez, tornava-se palco de uma série de manifestações populares. Lançada pelo então senador Teotônio Vilela, a ideia de criar um movimento a favor de eleições diretas para presidente ganhou as ruas e diversos setores da sociedade brasileira, entre 1983 e 1984.

Muito embora a Emenda Constitucional Dante de Oliveira tivesse sido rejeitada pelo Congresso em abril de 1984, os adeptos do movimento pelas Diretas Já conquistaram, em janeiro do ano seguinte, uma vitória parcial com a eleição, pelo Colégio Eleitoral, de Tancredo Neves para presidente. Infelizmente, o primeiro presidente civil, eleito após duas décadas de ditadura no Brasil, acabou falecendo sem jamais assumir o cargo. 
O vice-presidente José Sarney foi empossado em 15 de março de 1985, marcando o início do processo de abertura política do país, que seria reforçado com a aprovação de uma nova Constituição Federal em 1988 e a realização de eleições diretas para presidente da República em 1989.

Todo esse movimento teve forte repercussão na UnB. A ADUnB assumiu um papel relevante no questionamento da gestão acadêmica e da estrutura formal e burocrática, passando a reivindicar maior participação da comunidade acadêmica no funcionamento da universidade.

Com os problemas políticos enfrentados pelo país, foram reduzidas em muito as obras no campus da UnB: grande maioria dos projetos desenvolvidos no período - Centro de Processamento de Dados (CPD), Capela, Estação de Gasolina e Serviços, Auditório da Faculdade de Educação - não se materializou. Até o final da gestão do reitor José Carlos Azevedo, em março de 1985, foram apenas iniciadas as obras da Faculdade de Ciências da Saúde, de autoria de Érico Weidle e Adilson Macedo, e da Faculdade de Estudos Sociais Aplicados (FA), de Matheus Gorovitz e Maurício Azeredo.

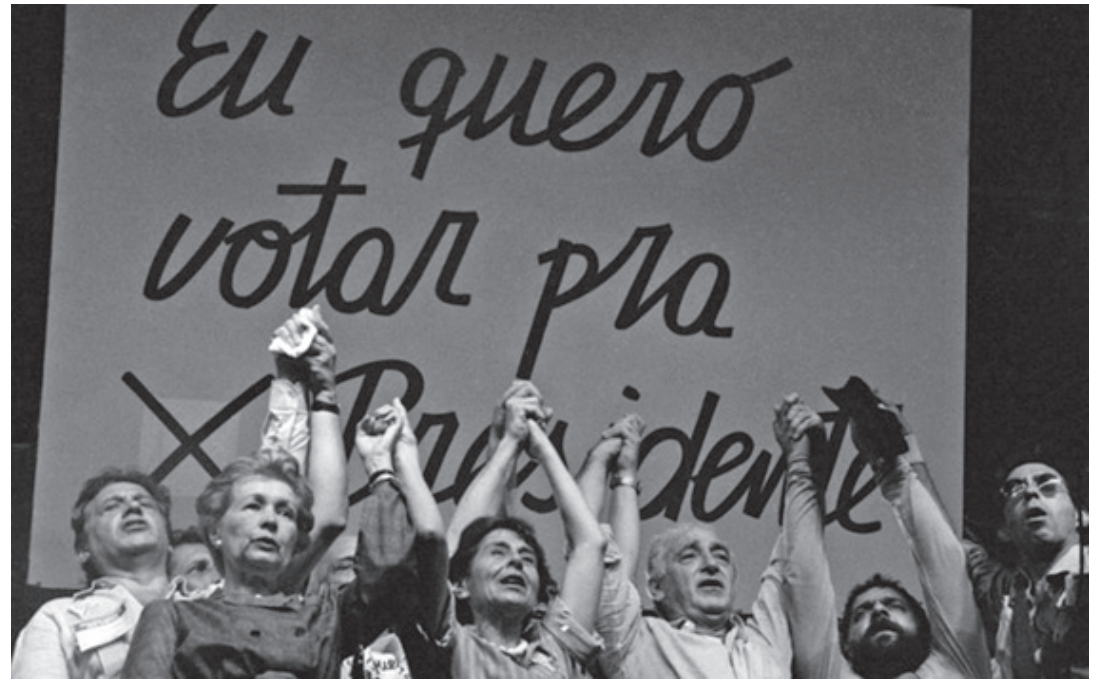

Manifestação de 15 mil exige a volta das diretas

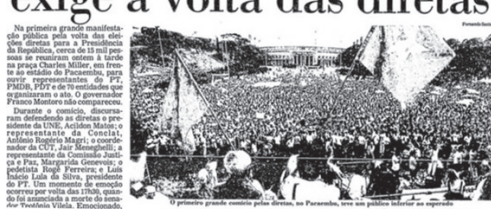

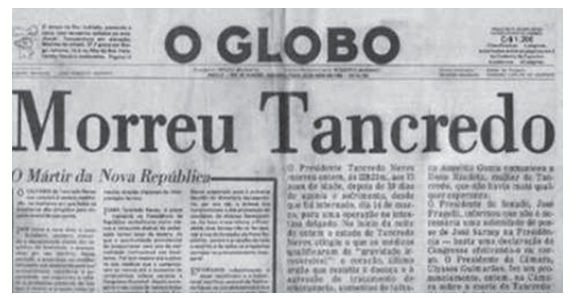

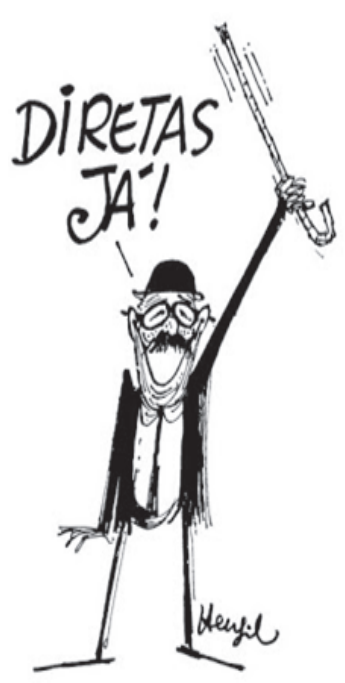

Figura 97a.

Manchete do Jornal do Brasil, 1984

Figura 97b.

Da esquerda para a direita,

Fernando Henrique Cardoso, Mora Guimarães (mulher de Ulisses Guimarães), Luci Montoro, Franco Montoro e Lula em um comício Pró-Diretas, na Praça da Sé, em São Paulo, 1984

Figura 97c.

Charge do senador Teotônio Vilela, de autoria de Henfil, que acabou batizando o movimento pela democratização de Diretas Já!

Figura 97d.

Manchete do Estado de S. Paulo

Figura 98a.

Manchete do jornal O Globo 
O acirramento dos conflitos e a diminuição da demanda por projetos e obras fizeram com que o Ceplan perdesse muito de sua razão de existir, como expresso nas palavras do professor Érico: "Eu tenho uma lembrança do Ceplan numa fase em que ele estava praticamente parado, invadido por outras pessoas que não tinham nada a ver com a arquitetura, não exatamente com a versão original de fazer projeto" (Entrevista em 7 dez. 2011). Essa paralisação das atividades regulares fez com que parte do espaço físico do Ceplan fosse temporariamente ocupada por cursos de pós-graduação, em nível de especialização e mestrado, da Faculdade de Arquitetura e Urbanismo. Além disso, havia forte interferência da Reitoria da UnB nas atividades do Ceplan, conforme esclareceu Zimbres:

A Administração Central interferia muito; percebia claramente a relação entre o arranjo físico do campus e o grau de interação social que se poderia proporcionar. O próprio projeto cultural do ICA-FAU foi afetado muito pelo governo autoritário. [...] Projetos foram sendo cortados. Aquela que poderia ter sido uma experiência rica, inspirada na Bauhaus, foi esvaziada. Ficou restrita a departamentos isolados, de Música, Artes Plásticas, Arquitetura e Urbanismo, que se transformou em um Instituto de Arquitetura e Urbanismo (IAU) hoje com 50 anos de vida, com certa história para ser contada. Tem uma tradição, mas foi originada de um processo de cisalhamento de uma ideia estimulante. Mas a FAU inspira respeito, tem a sua história. Teve momentos brilhantes na inovação; teve rupturas importantes em 65 com o fechamento; foi reaberta; depois se lutou muito face a uma situação de autoritarismo pleno; depois a reabertura, até os dias de hoje. Muitos contarão essa história de modo diverso... (Entrevista em 26 out. 2011). 
3.2. Arquitetura como valorização da linguagem

\section{BIBLIOTECA CENTRAL (BCE)}

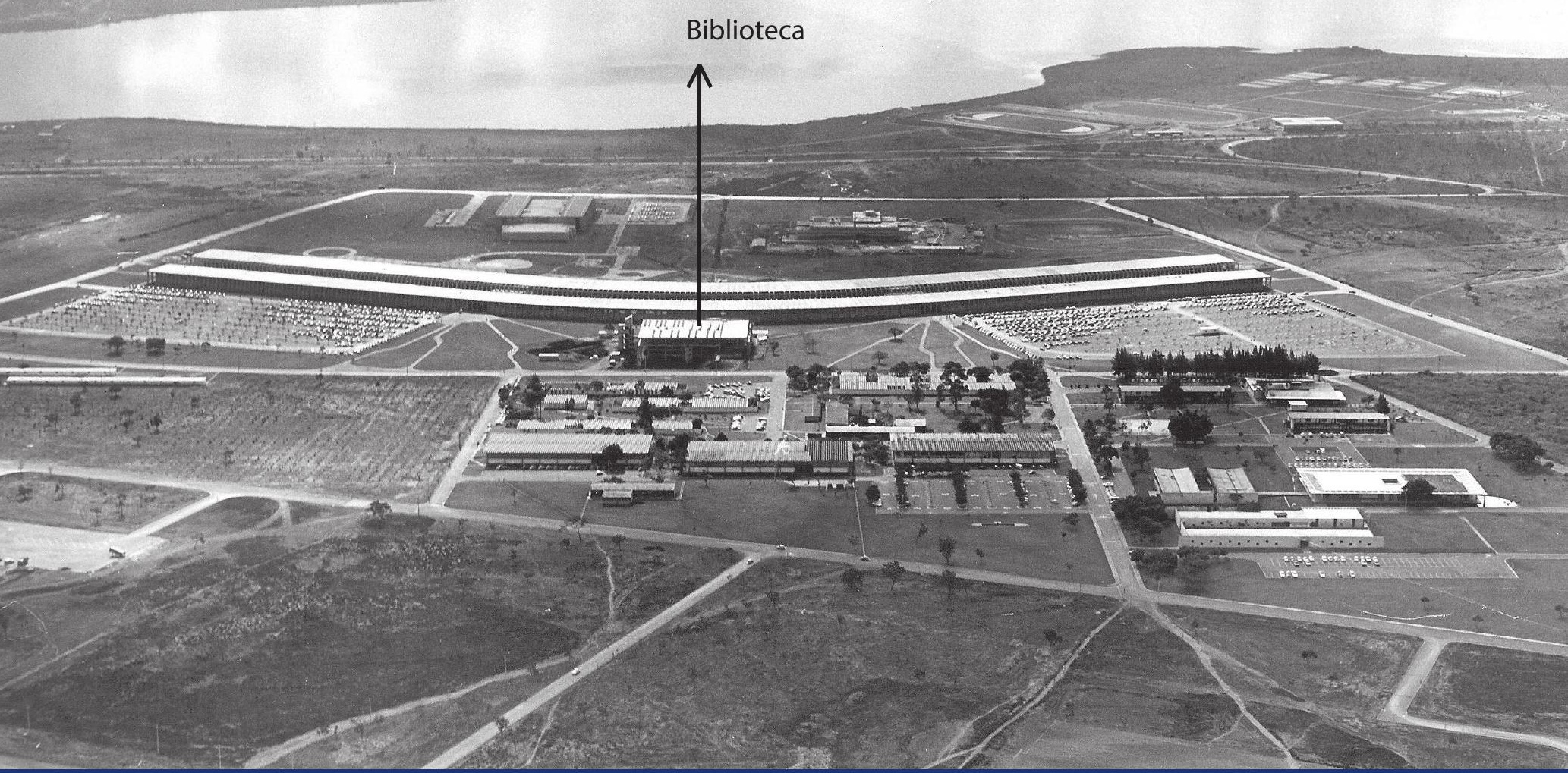

Autoria

José Galbinski e Miguel Pereira, com a colaboração de Jodete Rios Sócrates e Walmir Santos Aguiar. O projeto estrutural é de Ernesto Walter e a execução da obra de Milton Ramos.

Data

1969 (projeto) 1970-1972 (obra)

Área Construída

$15.200 \mathrm{~m}^{2}$
Figura 99a.

Implantação da

Biblioteca Central 


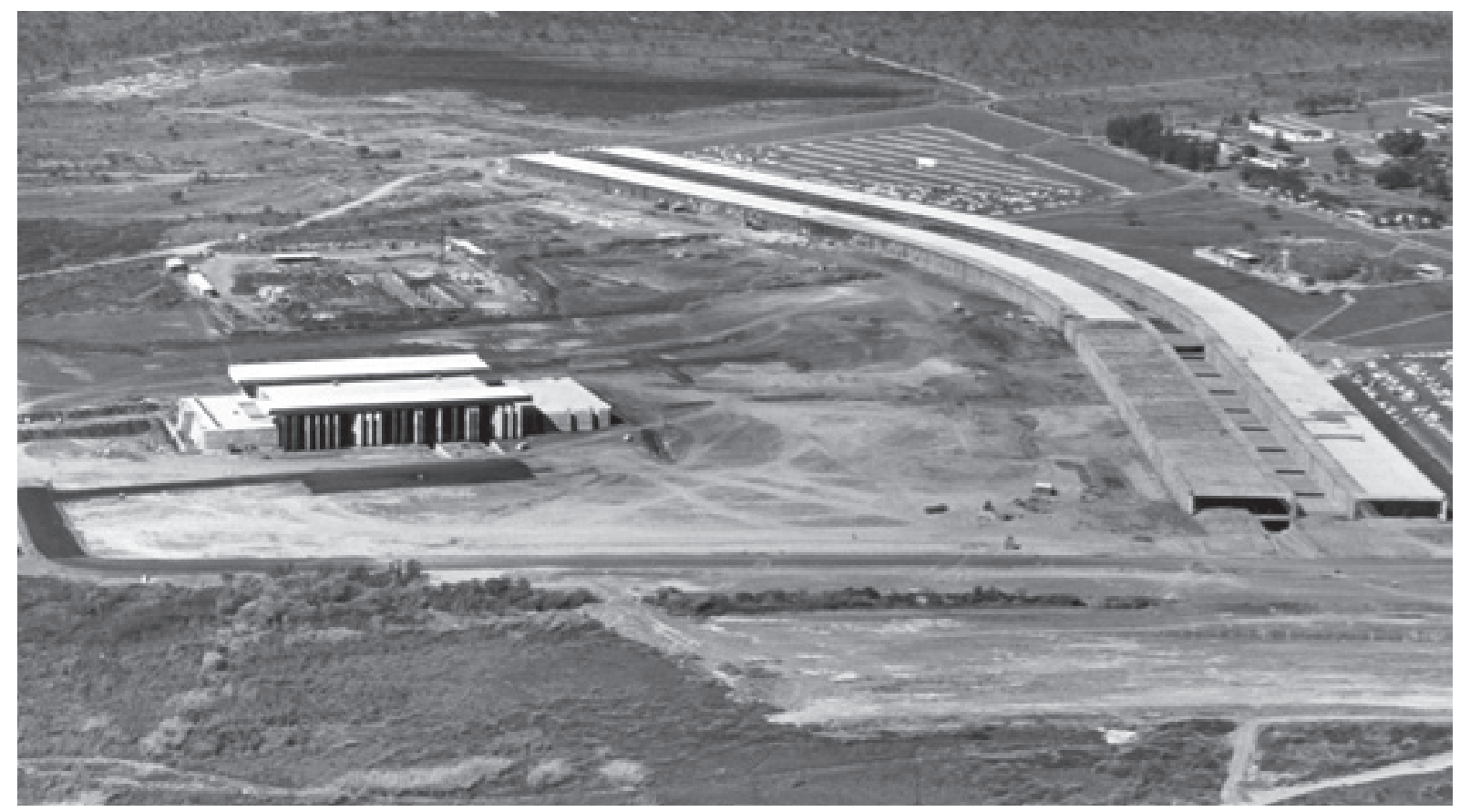

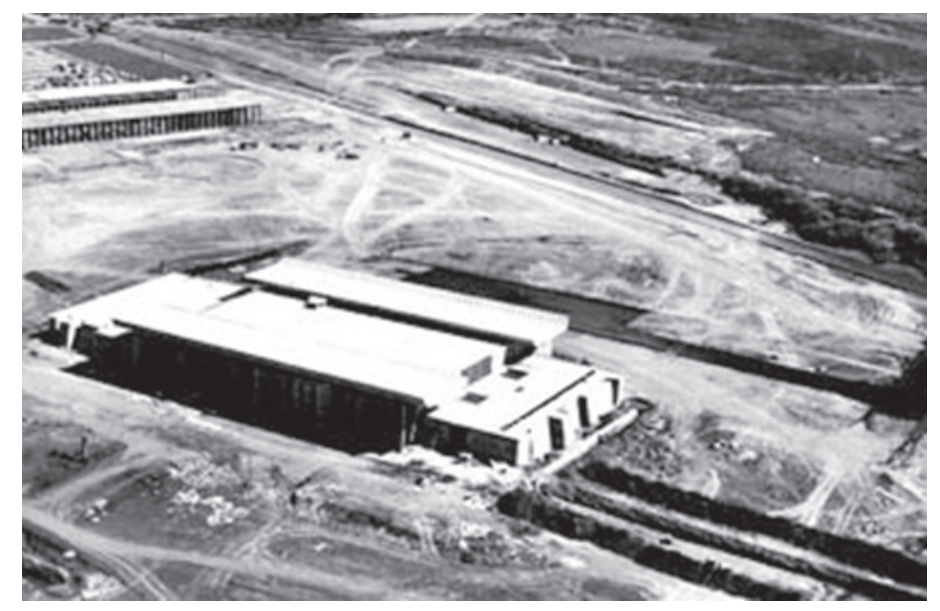

Figura 99b.

Vista aérea da Biblioteca

Central em obras

Figura 99c.

Biblioteca Central em obras

A primeira biblioteca da Universidade de Brasília foi instalada, em 1962, no edifício do Ministério da Educação e Cultura (MEC), na Esplanada dos Ministérios, onde funcionaram provisoriamente os cursos de Direito, Economia, Administração e Arquitetura e Urbanismo. Com a inauguração do campus, a biblioteca passou a ocupar, ainda em caráter provisório, o edifício SG-12, de onde somente em 1973 foi transferida para o prédio definitivo.

A BCE foi criada no contexto de implantação, no país, de um modelo que veio substituir o de bibliotecas dispersas pelas unidades de ensino. Além de dar apoio às atividades universitárias, reunindo material referente a todos os cursos, a BCE abriga o Departamento de Ciência da Informação e Documentação (CID).

Como primeiro edifício construído na Praça Maior, a implantação da Biblioteca resultou da modificação da concepção original de Oscar Niemeyer para a área. 


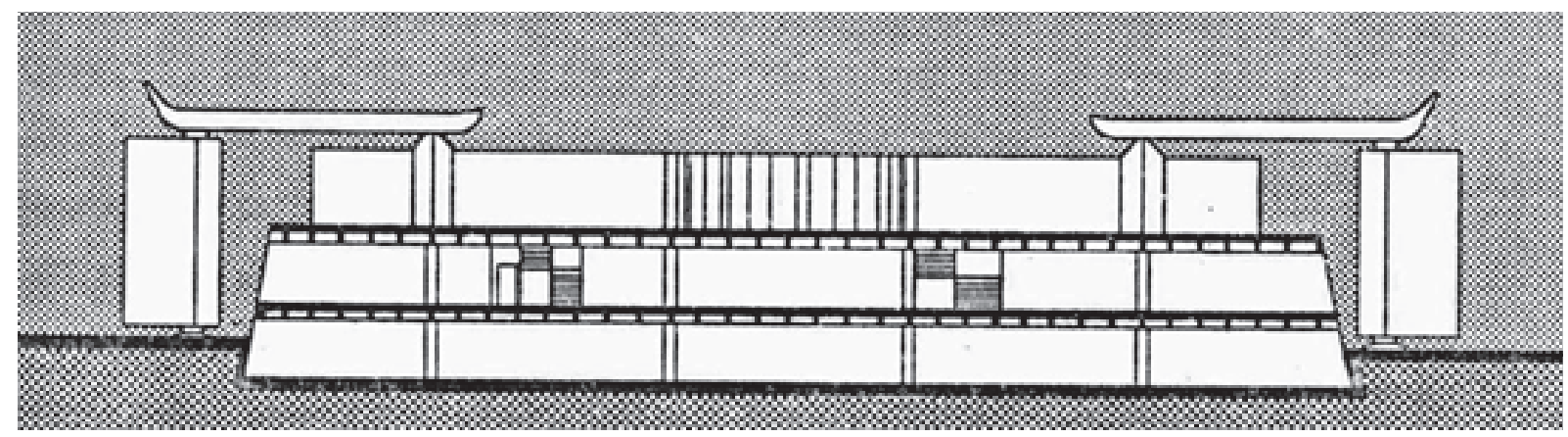

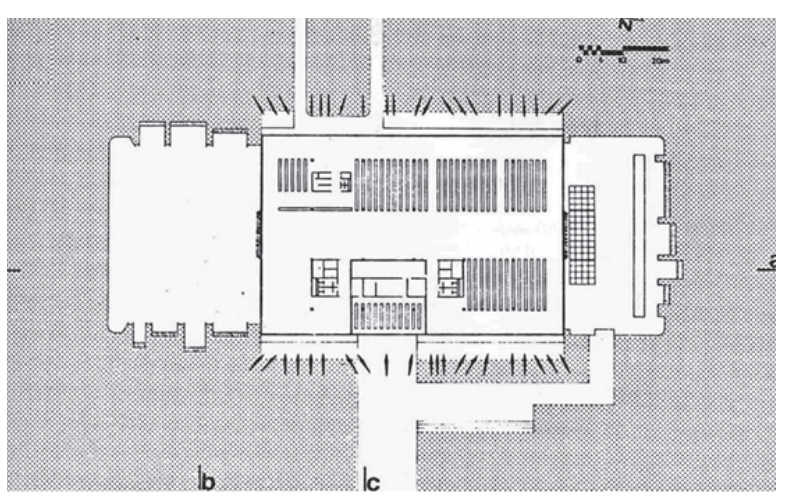
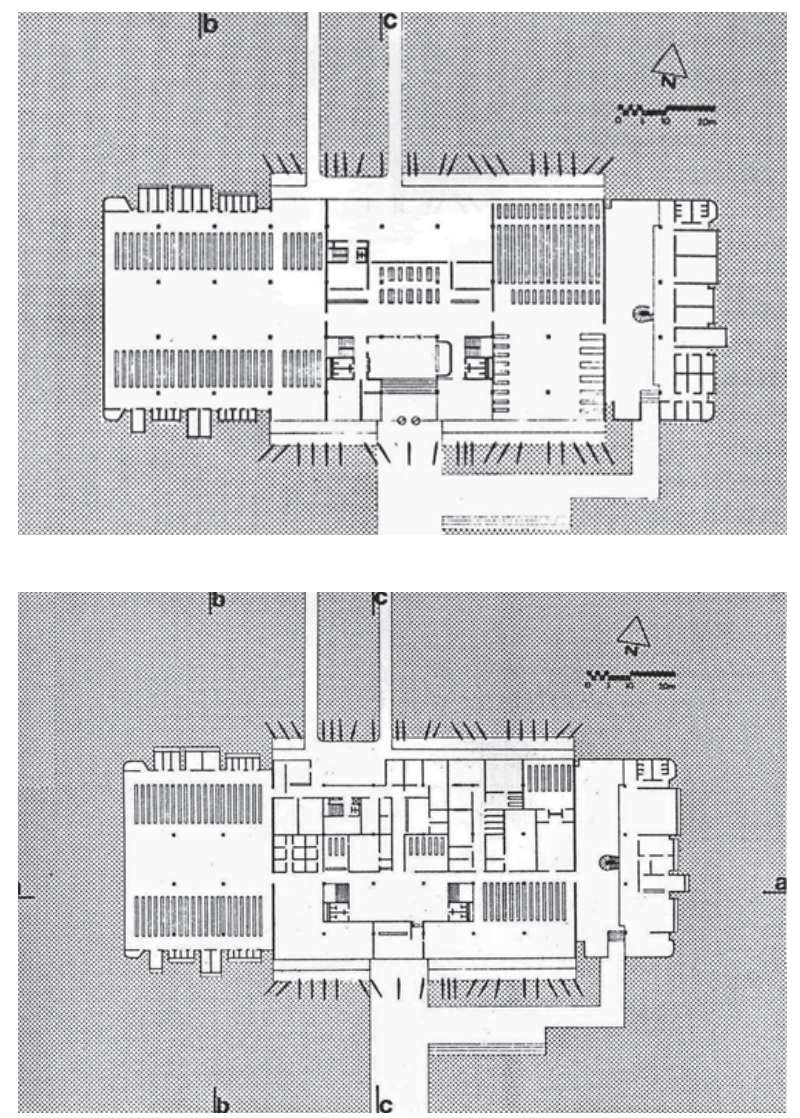

Trata-se de um grande bloco de concreto apa- Figura 99d. rente, de caráter telúrico, voltado para o interior. De feição brutalista, o partido adotado resulta em uma univolumetria, tripartida no sentido longitudinal, com as extremidades Leste e Oeste - mais baixas em relação à porção central, "[...] marcada e valorizada pelos pórticos de inspiração corbusiana, como os do Palácio da Assembleia de Chandigarh, 1962" (SCHLEE, 2013 , p. 7). Também denotam uma influência de Corbusier os extensos panos de concreto e as lajes curvas sobre as faces Norte e Sul.

O edifício tem três acessos: o principal, na fachada Sudeste; o de funcionários, na Noroeste; e um terceiro, também na face Noroeste, destinado aos serviços de descarga de material no subsolo. A estrutura, composta por peças de concreto aparente, está disciplinada por uma malha de $12 \mathrm{~m} \times 12 \mathrm{~m}$.

No bloco central, o programa foi distribuído em três pavimentos: subsolo, térreo e pavimento superior, enquanto nas extremidades foram ocupados apenas dois pavimentos. Os níveis são interligados por circulações verticais por meio de amplas escadas e um elevador de serviço. As áreas laterais, que correspondem às extremidades mais baixas, abrigam o acervo geral e grandes espaços de leitura. 

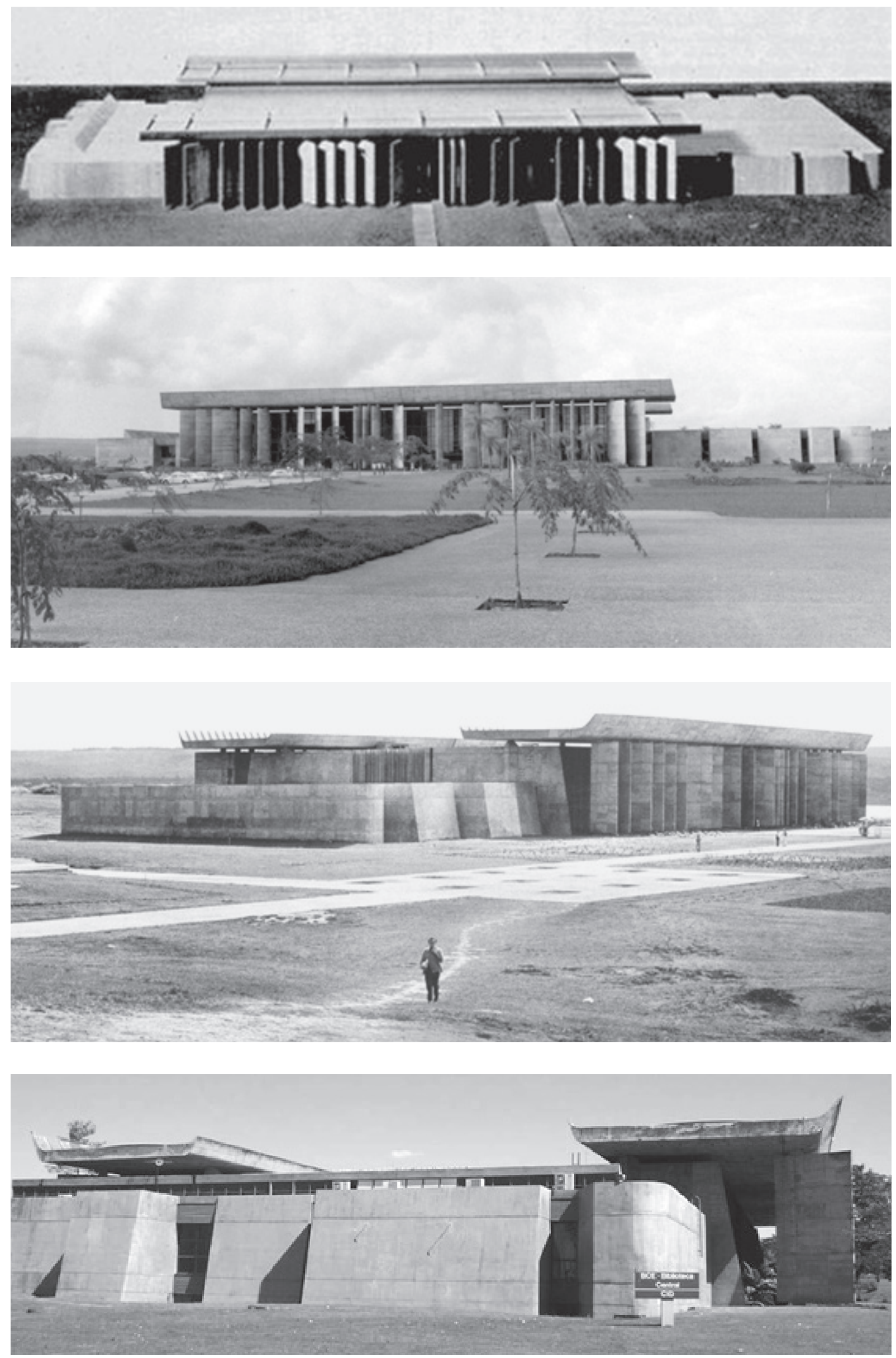
No pavimento térreo, a área central é ocupada pelas circulações vertical e horizontal, pela prumada sanitária (banheiros) e por salas de recepção/empréstimo e administração.

O subsolo apresenta duas áreas distintas: um espaço para acervo e o "fluxograma do livro" (GALBINSKI, 1993, p. 22), que corresponde ao circuito técnico do livro, da chegada à biblioteca até a colocação na prateleira para uso do leitor.

As grandes placas verticais de concreto armado, dispostas de modo variado em parte das faces Noroeste e Sudeste, produzem um ritmo não uniforme, funcionando como brises-soleil para o sombreamento dos espaços internos. A fachada principal, voltada para Sudeste, favorece a integração com os demais edifícios da Praça Maior.

As faces Leste e Oeste são inclinadas e cegas em quase toda sua extensão.

Tanto as grandes placas verticais parecem pousadas no solo, como as lajes de coroamento do módulo central parecem descansar suavemente sobre estas placas.
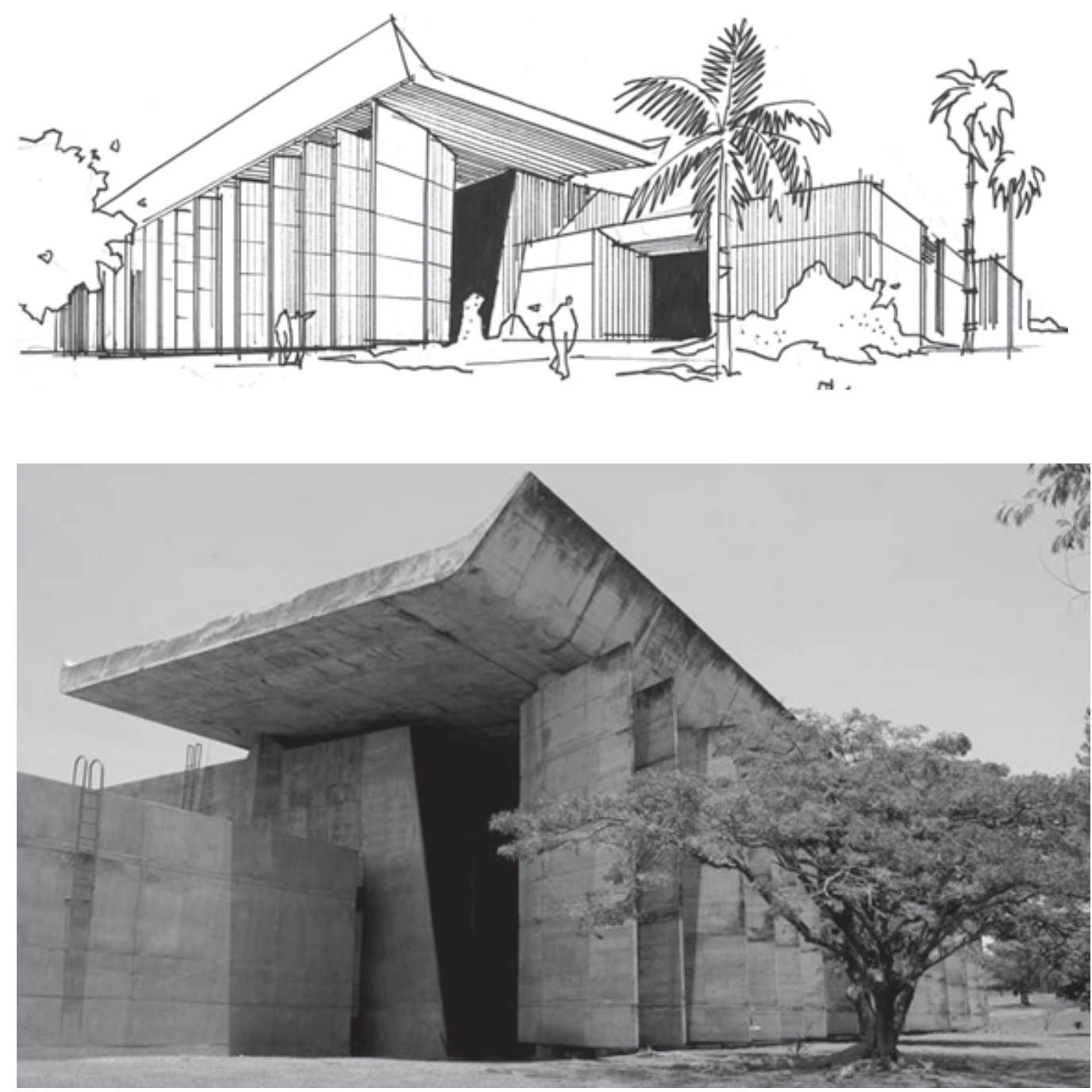

Figura 99h. Maquete da Biblioteca Central

Figura 99i. Vista da fachada principal

Figura 99j. Volumetria da Biblioteca Central

Figura 99k.

Vista da fachada Oeste

Figura 99l.

Vista das fachadas Sul e Leste. Desenho de Eliel Américo Santada da Silva

\section{Figura 99m.}

Detalhe das placas (brises) e da laje curva de coroamento em concreto aparente. 

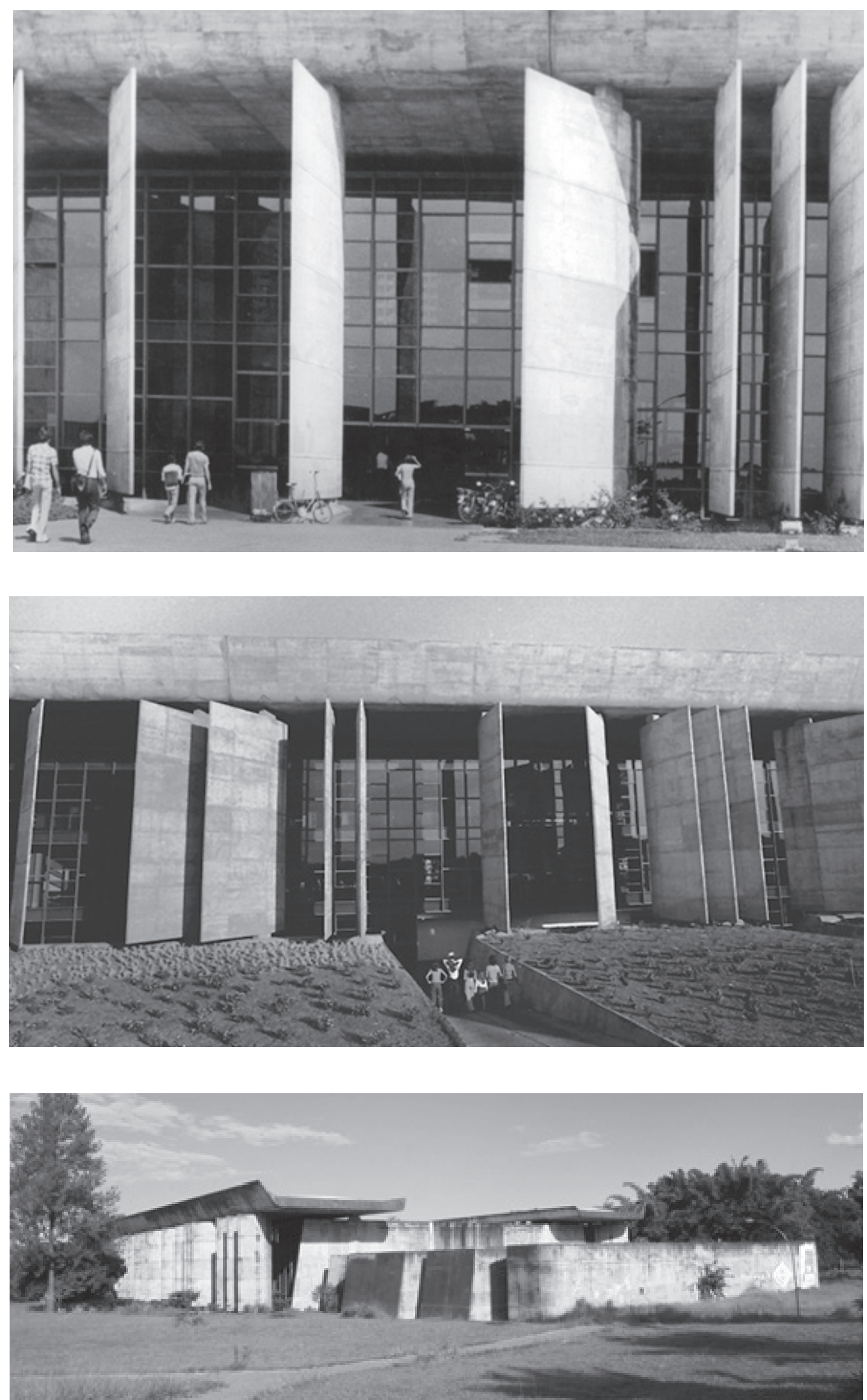

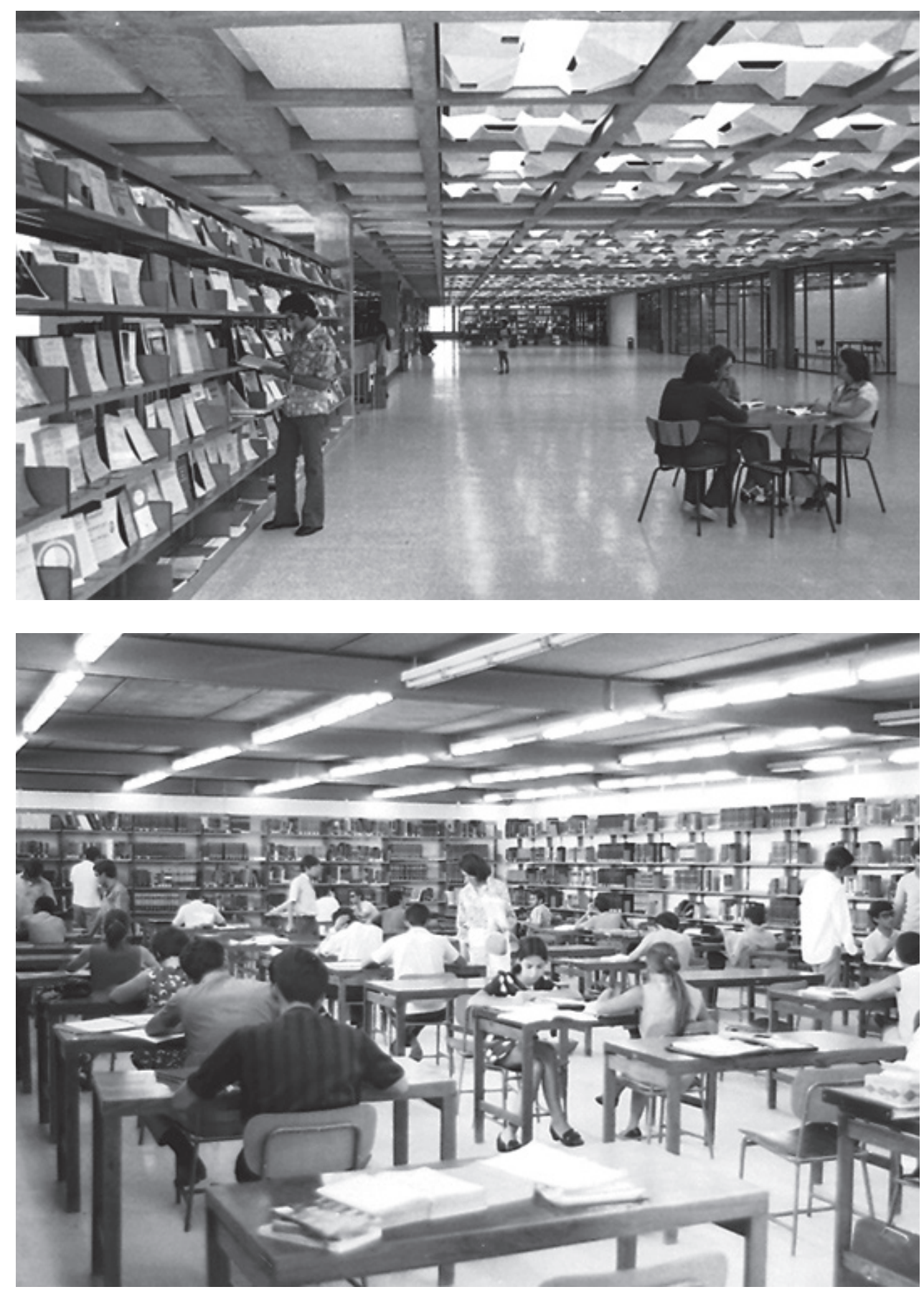

Figura 99n.

Entrada principal

Figura 99o.

Entrada de serviços

Figura 99p.

Foto atual

Walter de Carvalho

Figura 99q e 99r.

Vista interna 


\section{CASA DO ESTUDANTE UNIVERSITÁRIO (CEU)}

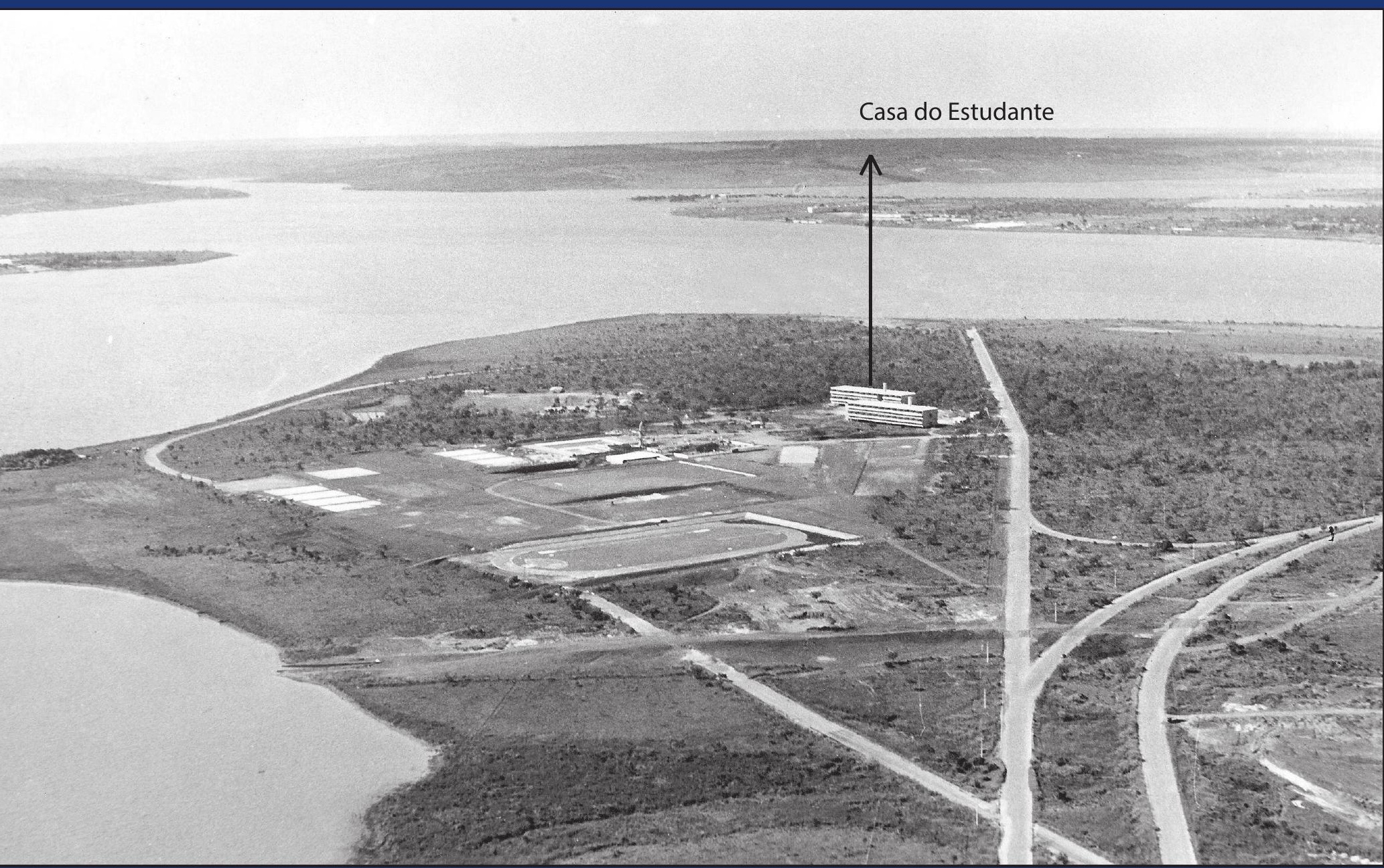

\section{Autoria}

Léo Bonfim Júnior, Alberto Fernando Xavier, com a colaboração de Solón Leão Pereira de Souza. O paisagismo original é do arquiteto José Paulo de Bem

\section{Data}

1969 (projeto) 1969-1971 (obra).

Área Construída

$4.700 \mathrm{~m}^{2}$ (cada bloco). Total: $9.400 \mathrm{~m}^{2}$
Foto $100 \mathrm{a}$.

Implantação

do Centro

Universitário 


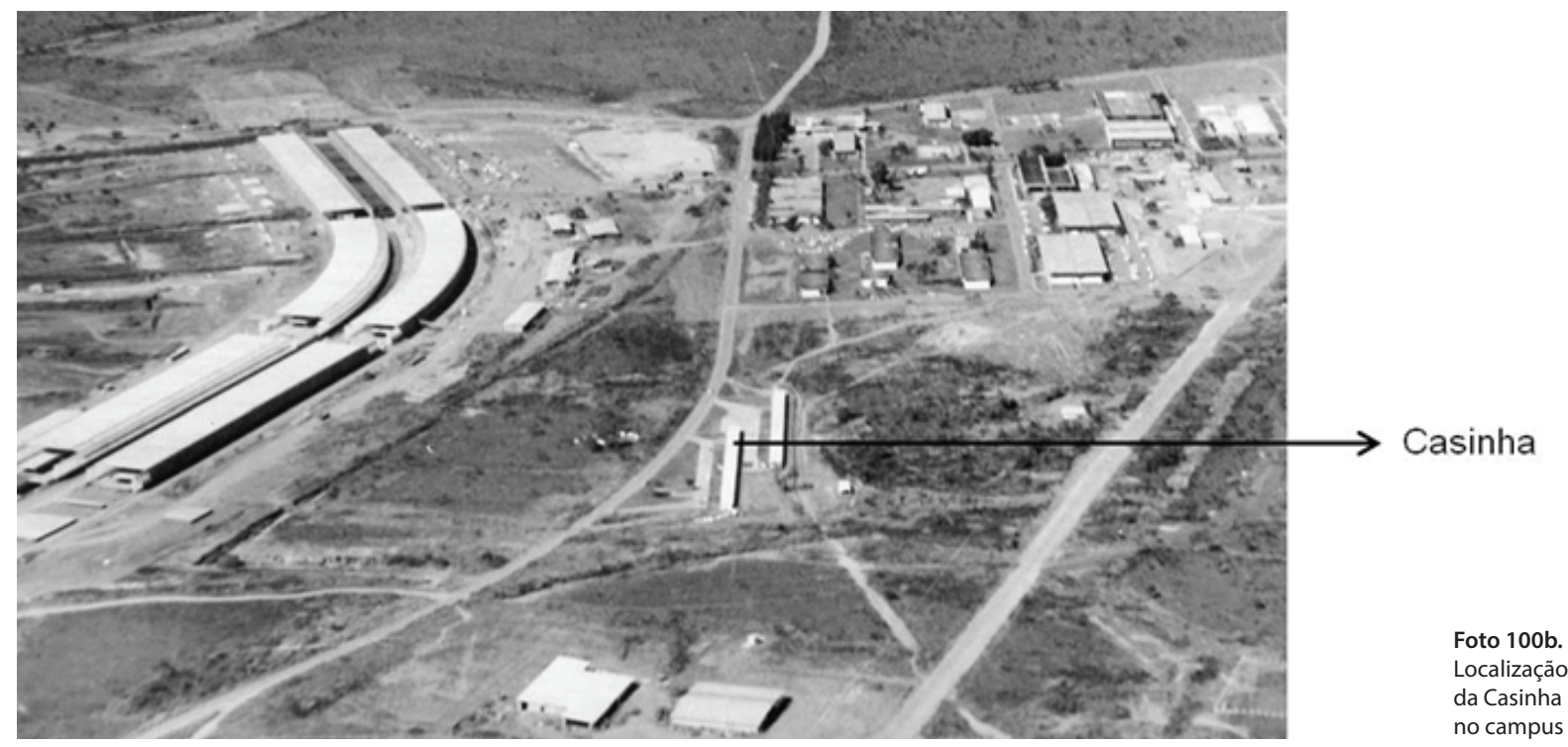

Em 1966 ocorreu a primeira experiência brasileira em solo-cimento, voltada para a construção de alojamentos estudantis provisórios em um terreno próximo de onde funciona atualmente a Faculdade de Tecnologia (FT). Logo chamado de "Casinha", o alojamento deixava a desejar no que diz respeito ao conforto de seus usuários.

A primeira proposta para o edifício definitivo para a Casa do Estudante da UnB foi elaborada pelos arquitetos Léo Bonfim Júnior, Alberto Fernando Xavier e Solón Leão Pereira de Souza (colaborador), em 1969. O projeto foi concebido para ser construído em pré-moldados de concreto. Mas a equipe de arquitetos do Ceplan foi pressionada a modificar seus planos para se adaptar às exigências da Reitoria, que exigiu, com a máxima urgência, um projeto diferente do anterior, para ser executado de forma convencional. Até o momento foram construídos apenas dois do conjunto de oito edifícios projetados.

[...] no prédio dos alojamentos, como eram dois ou três blocos, que tinham um módulo repetido, ele foi feito para ser pré-moldagem. Mas a firma que ganhou a licitação para a construção apresentou um orçamento que barrou todas as outras. Então, não foi construído em pré-moldagem (GALBINSKI, entrevista em 22 fev. 2012).

O alojamento de estudantes localiza-se na área do Centro Desportivo, tendo acesso independente ligado ao prolongamento da via L4 Norte. Os edifícios, que apresentam a forma de prismas retangulares sobre pilotis, foram implantados ao lado do parque aquático do Centro Olímpico, próximo ao lago Paranoá.

O conjunto é integrado por dois blocos com 92 apartamentos duplex. Cada bloco, de $76 \mathrm{~m} \times 15 \mathrm{~m}$, é dividido em 12 módulos, cada um dos quais abriga dois apartamentos - um com orientação Sul e outro voltado para o Norte. Cada apartamento dispõe de, no pavimento inferior, um ambiente de estar, sanitário e cozinha, e no superior dois dormitórios, acessíveis por uma escada helicoidal interna. As camas são separadas duas a duas por uma divisória de armários embutidos, atendendo a uma determinação da Reitoria, que estabelecia a necessidade de integração dos moradores. 

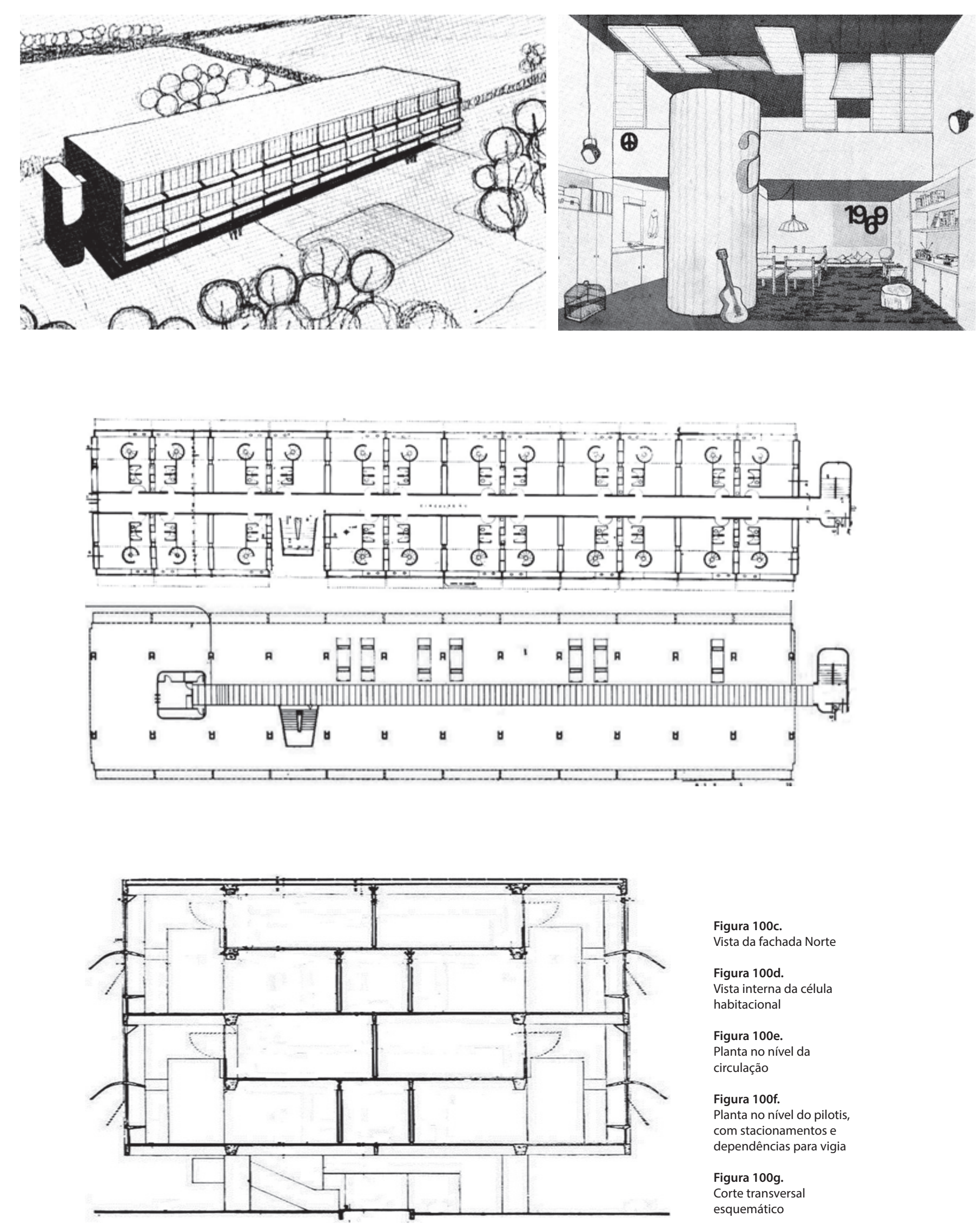

Figura 100c.

Vista da fachada Norte

Figura 100d.

Vista interna da célula

habitacional

Figura 100e.

Planta no nível da

circulação

Figura 100f.

Planta no nível do pilotis,

com stacionamentos e

dependências para vigia

Figura 100g.

Corte transversal

esquemático 
O acesso às células habitacionais é feito por meio de uma escada, localizada em um volume anexo junto à fachada Leste do edifício principal. A ligação entre a escada e o prédio se dá por meio de duas passarelas dispostas em alturas diferentes.

Cada bloco tem 46 unidades habitacionais, com $67 \mathrm{~m}^{2}$ e capacidade para 4 estudantes, o que permite alojar 368 alunos nos dois blocos. As células são dotadas de uma bancada fixa e um tanque em concreto armado. Brises-soleil, também em concreto, protegem esquadrias de chapa de aço e vidro das fachadas longitudinais.

A opção por apartamentos duplex, com mezanino, e a organização das células, com o recuo do nível inferior para locação da circulação horizontal geral, remete à Unidade de Habitação de Marselha (1947), de Le Corbusier.
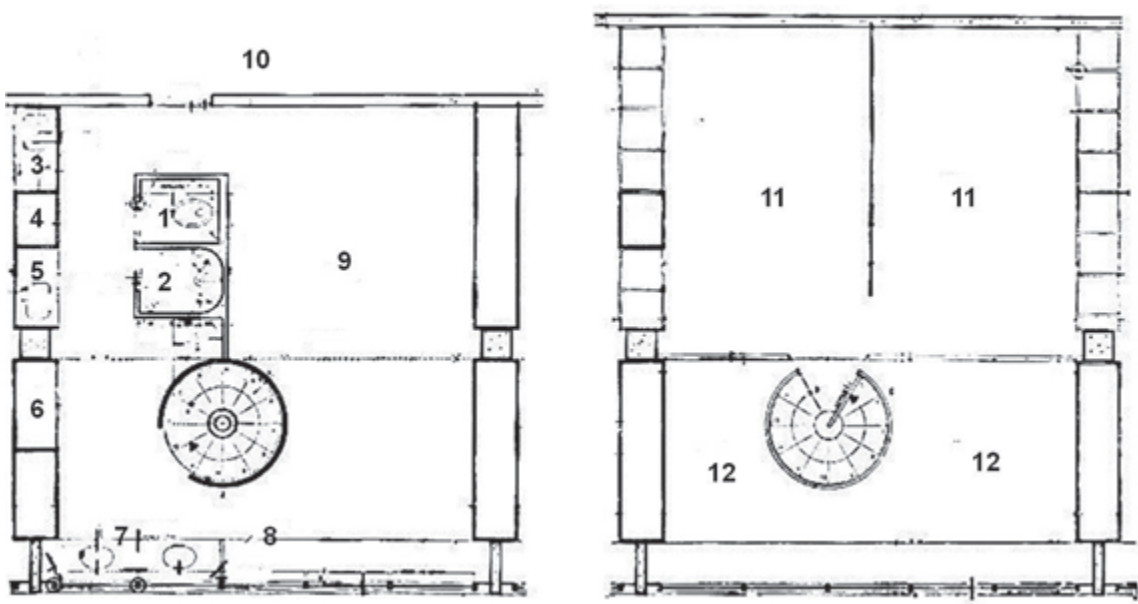
1.WC
2. Banho
3. Pia/fogão
4. Instalações
5. Área de serviço
6. Armários
7. Pias
8. Bancada
9. Estar
10. Circulação Figura
11. Dormitório
12. Vazio

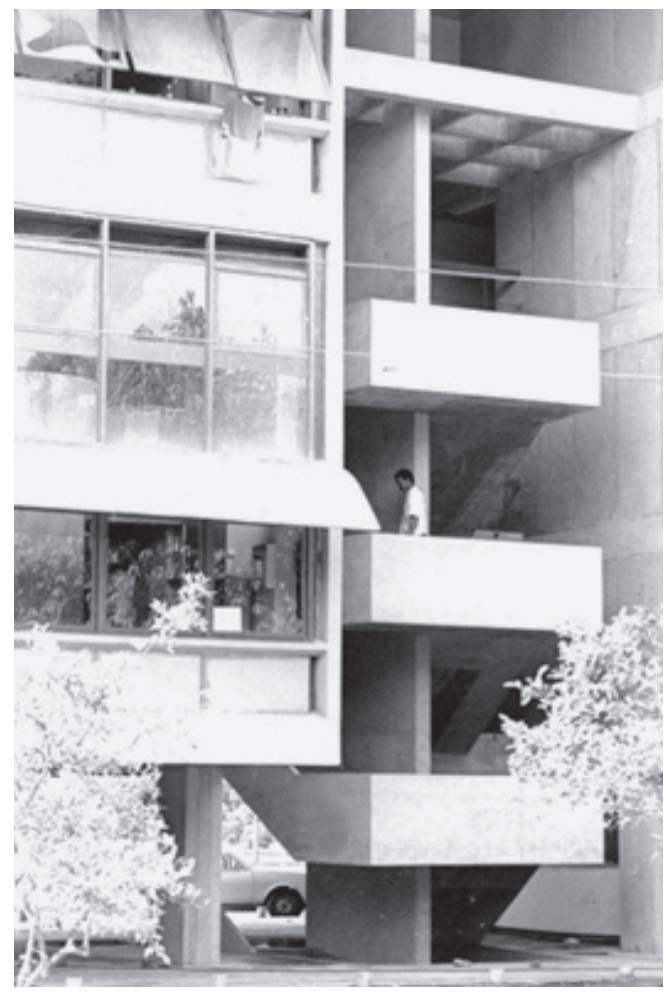

Figuras100h.

Planta da célula - nível

inferior

Figura 100i.

Planta da célula - nível

do mezanino

Figura 100j. Detalhe da circulação vertical 

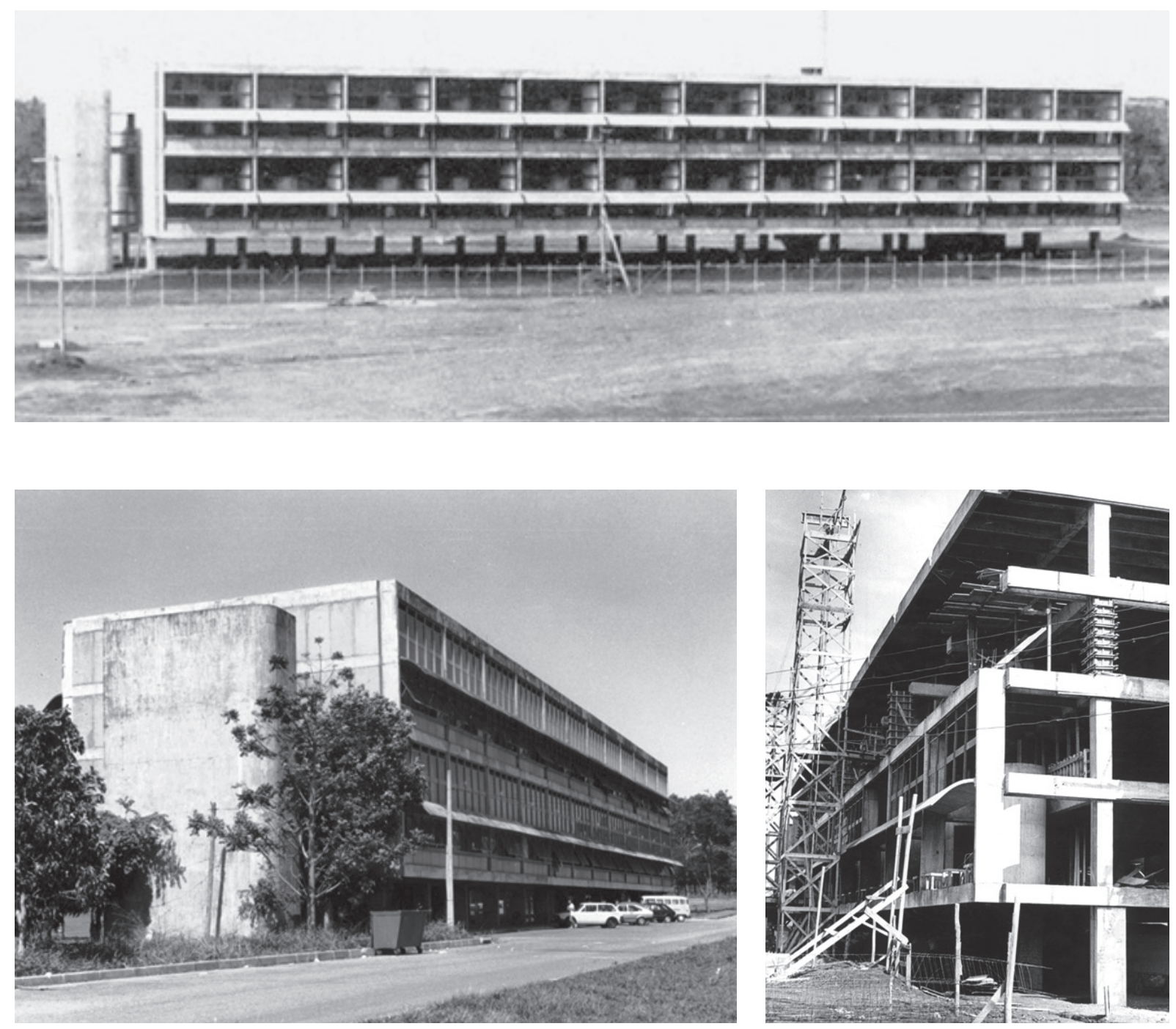

Figura 100k.

Alojamento em construção

Figura 1001.

Vista da fachada Norte

Figura 100m. Alojamento em

construção 


\section{CENTRO OLÍMPICO (CO)}

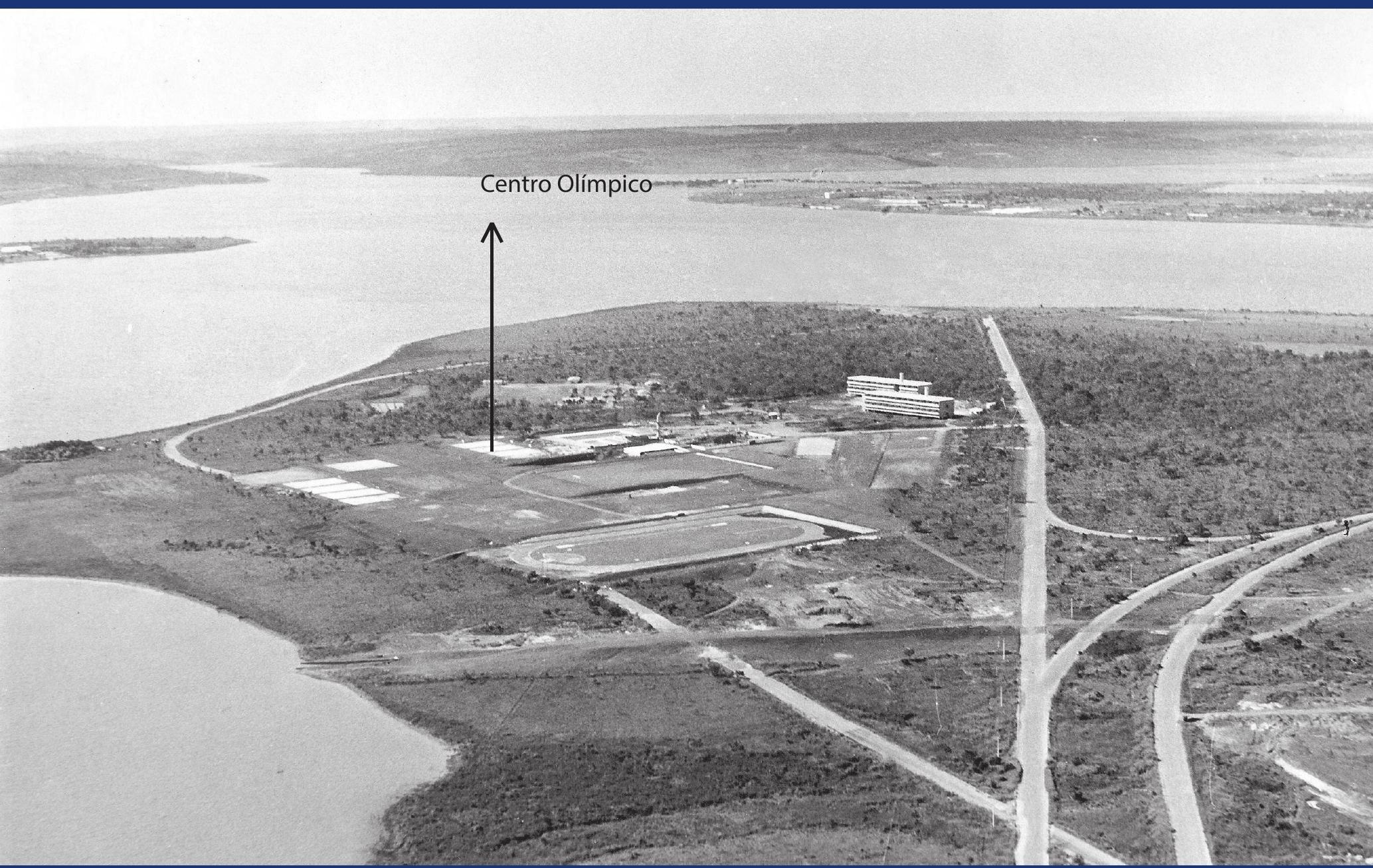

Autoria

Márcio Villas Boas, Ricardo Farret e Paulo de Mello Zimbres

\section{Data}

$1969 / 1970$ ( $1^{\text {a }}$ fase $)$

1976 ( $2^{\text {a }}$ fase)

\section{Área Construída}

Total: $78.700 \mathrm{~m}^{2}$. Faculdade de Educação Física $(F E F)=2.598 \mathrm{~m}^{2}+600 \mathrm{~m}^{2}$ (complementação); Quadra coberta $=2.800 \mathrm{~m}^{2}$
Figura 101a. Implantação

do Centro

Olímpico 

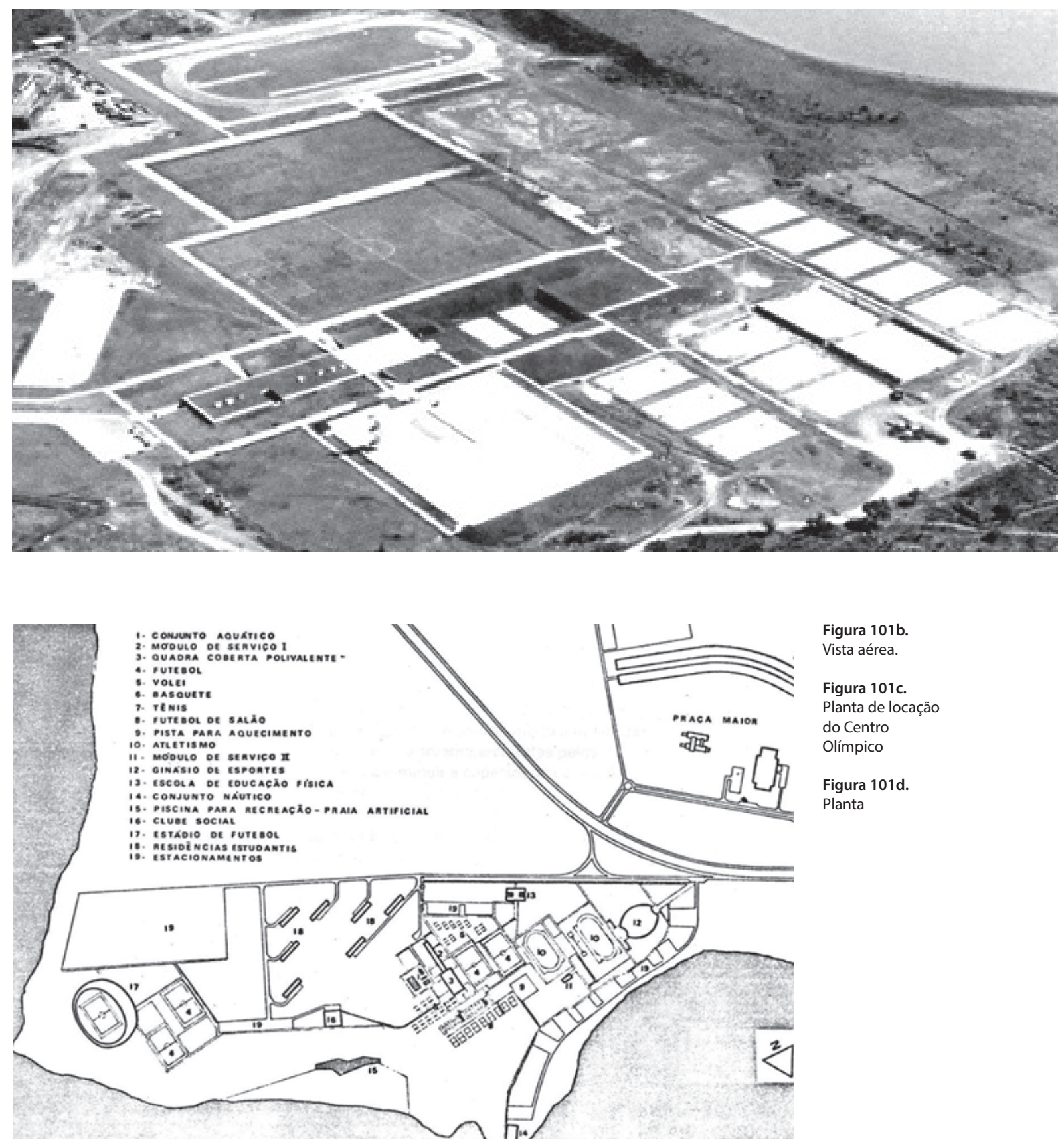

Figura 101b.

Vista aérea.

Figura 101c.

Planta de locação

do Centro

Figura 101d.

Planta

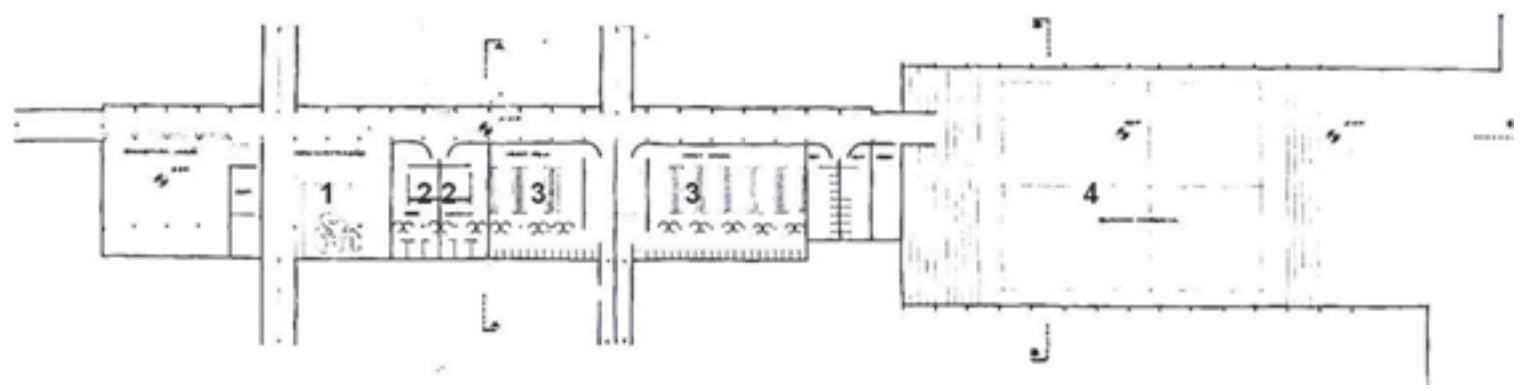

1. Administração

2. Sanitários

3. Vestiários

4. Quadra coberta 
O CO é o centro de esportes da universidade, local aberto para toda a comunidade acadêmica onde acontecem várias atividades de treinamento e integração social.

O Departamento de Educação Física foi criado, em 1972, ligado à Faculdade de Ciências da Saúde. Em 1997 foi instituída a Faculdade de Educação Física, que, além do curso regular de Educação Física, vem desenvolvendo programas de atendimento à comunidade de Brasília. Além da Faculdade de Educação Física, integram o conjunto do Centro Olímpico: o Ginásio, as Quadras Poliesportivas e o Parque Aquático.

O Ginásio, com duas quadras poliesportivas e uma arquibancada, abriga ainda a área administrativa do CO, os vestiários, a sala de musculação e fisioterapia, duas saunas, um auditório, salas de aula e o Laboratório de Aptidão Física.

As Quadras Poliesportivas estão assim divididas: seis de basquetebol; quatro de voleibol; quatro de futebol de salão ou handebol; quatro de tênis; dois campos de futebol, sendo um iluminado; um campo de futebol de areia e além de uma pista de cross-country com 2.500 m de extensão.

O Parque Aquático, usado para os treinos de atletas da região, possui três piscinas - uma olímpica, uma semiolímpica e outra destinada a saltos ornamentais.
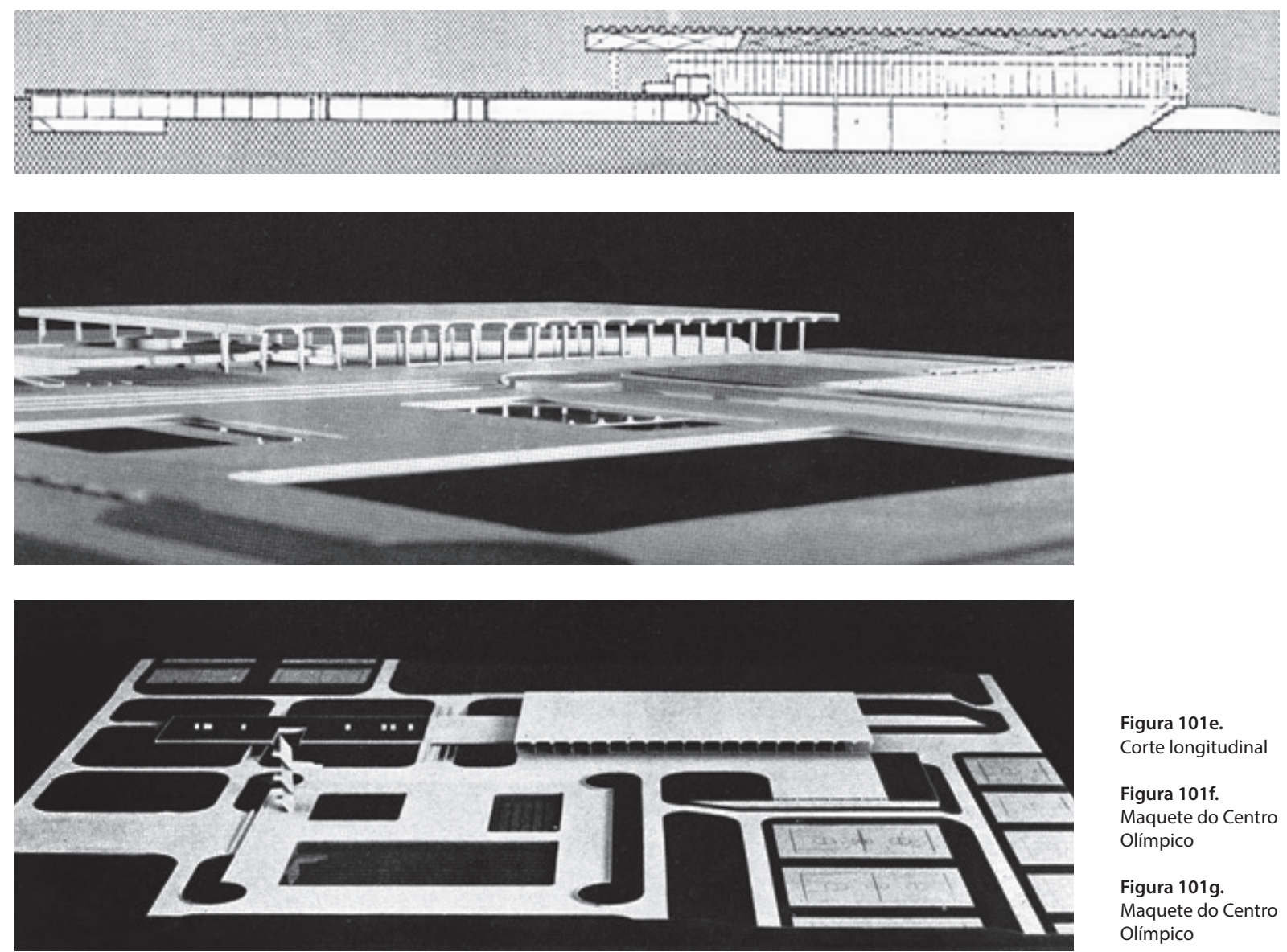
A Faculdade de Educação Física está instalada em uma edificação de planta retangular, voltada para o interior, que abriga três grupos funcionais: um didático-teórico, em uma ala com dois pavimentos; um didático-prático, em uma ala paralela à primeira mas com pé-direito duplo; e um de serviços médicos e sanitários, semienterrado. Entre as duas primeiras alas, a meio nível acima delas, situa-se um pátio com iluminação artificial, que faz a articulação dos três grupos funcionais. A construção apresenta estrutura independente de concreto armado aparente.
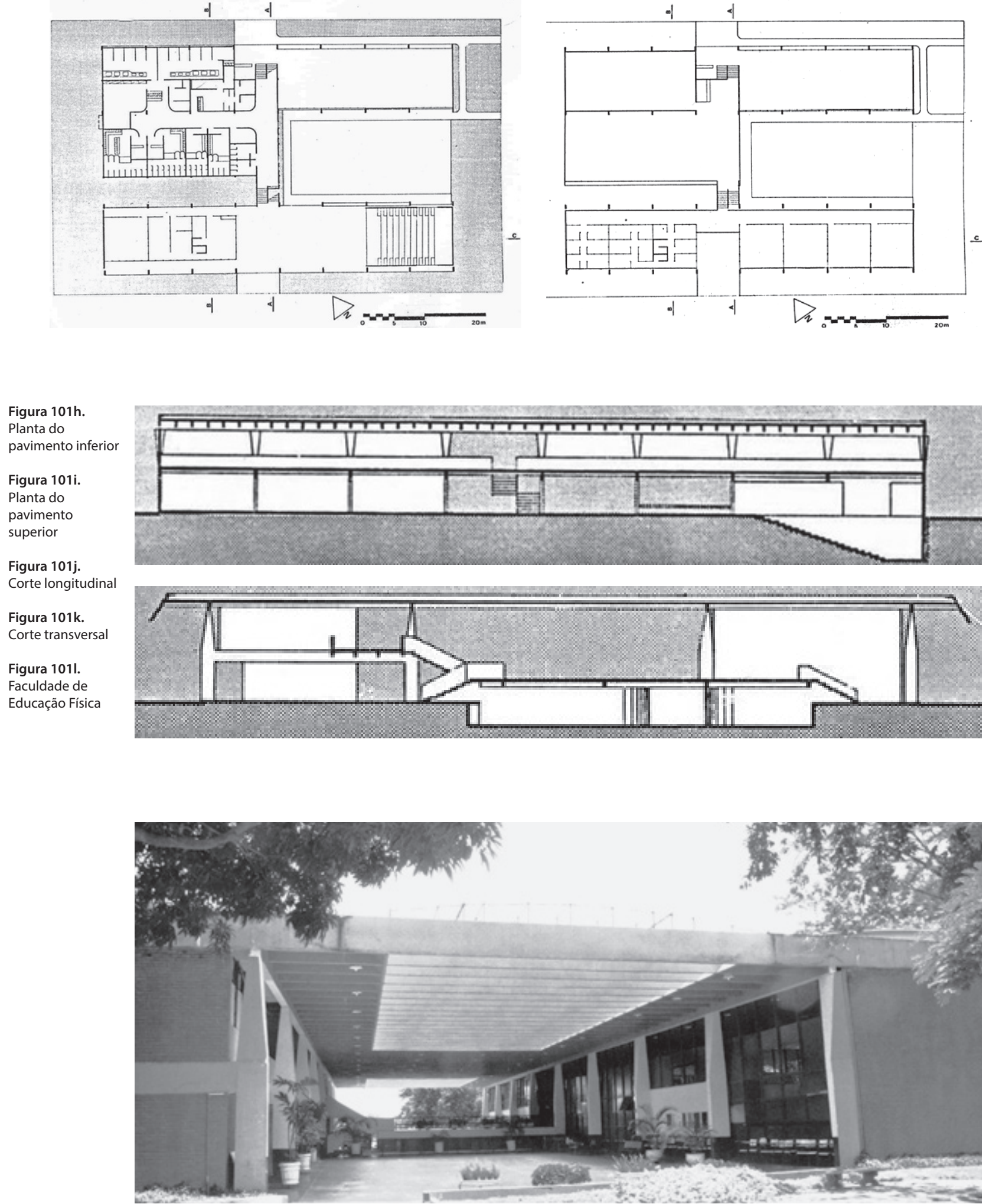


\section{RESTAURANTE UNIVERSITÁRIO (RU)}

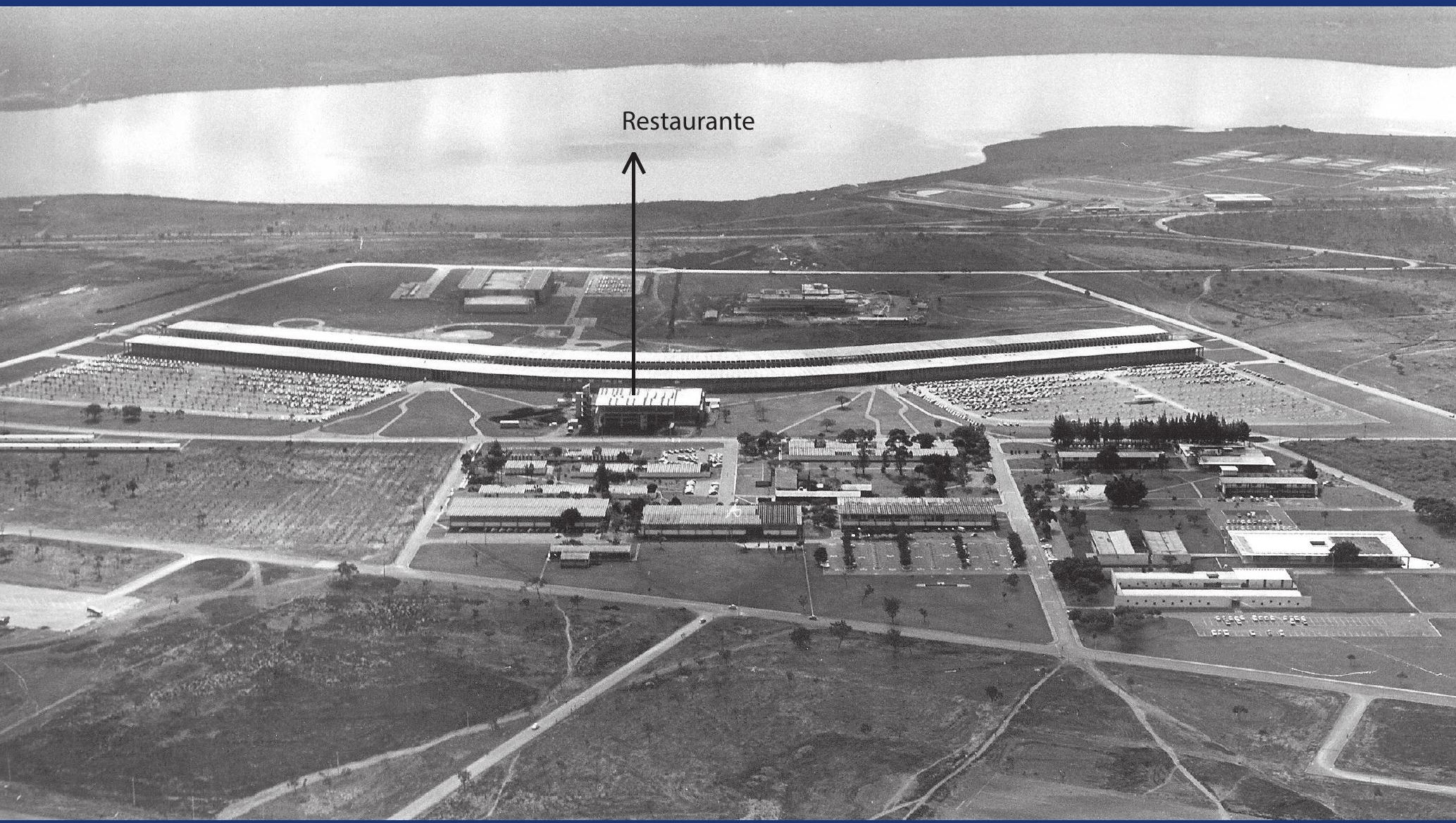

Autoria

José Galbinski, com a colaboração de Antônio Carlos Moraes de Castro. O projeto estrutural é de Ernesto Walter

Data

1971 (projeto)

1973/1975 (obra)

Área Construída

$6.700 \mathrm{~m}^{2}$
Figura 102a.

Implantação

do Restaurante

Universitário 
A localização da edificação obedeceu a uma determinação da Administração Central da UnB, que pretendia evitar a concentração de estudantes nas proximidades da Reitoria.
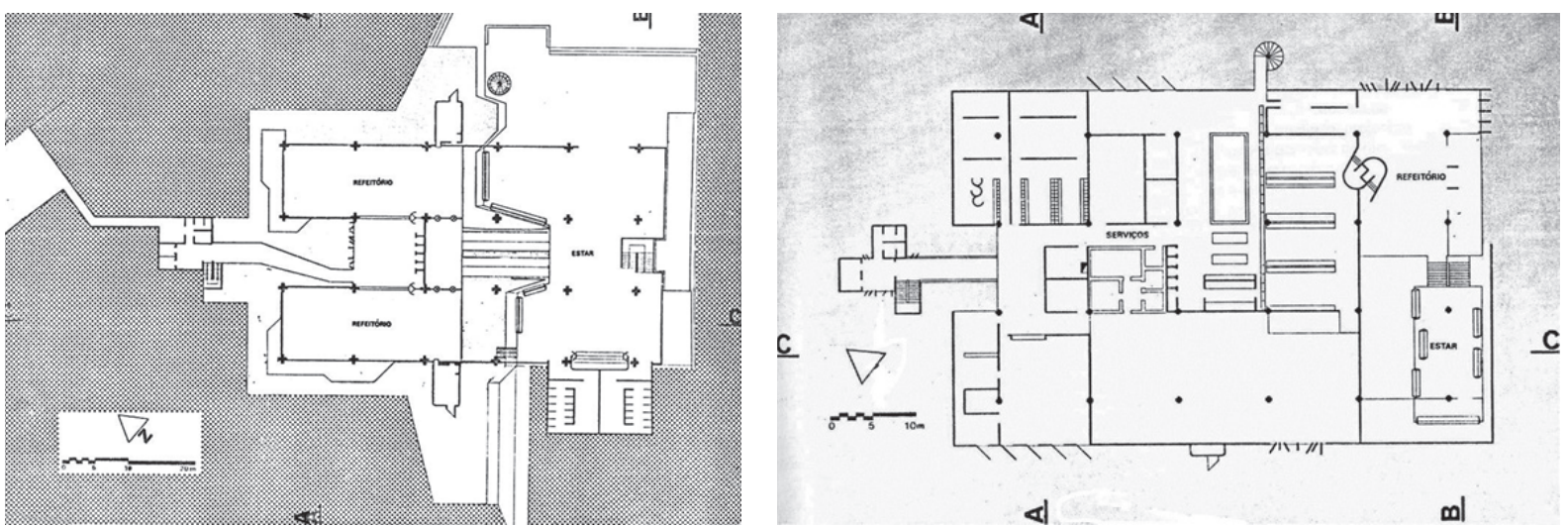

Figura 102b.

Planta do pavimento inferior

Figura 102c.

Planta do pavimento

superior

Figura 102d.

Corte AA

Figura 102e.

Corte BB

Figura $102 \mathrm{f}$

Corte CC
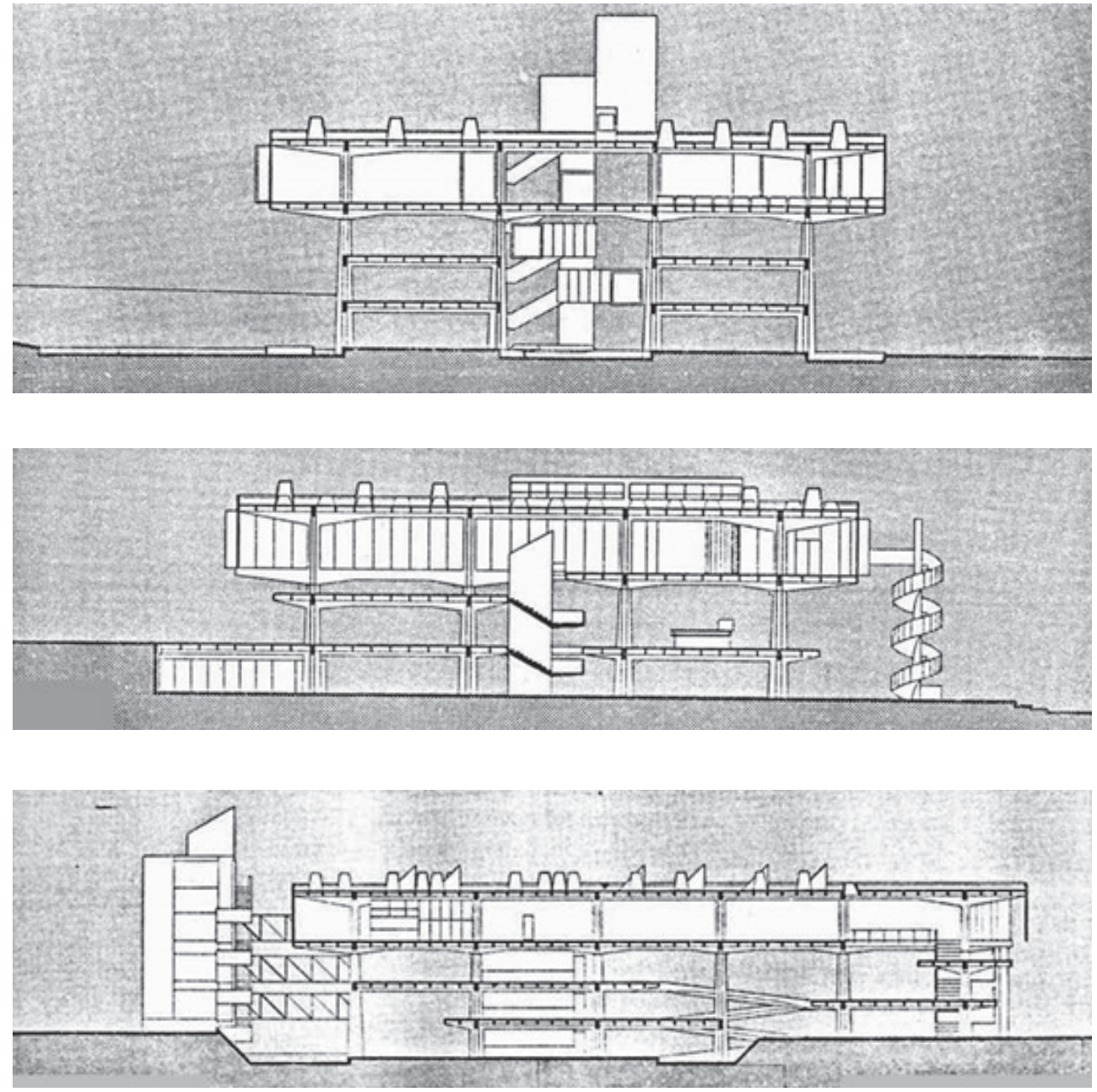

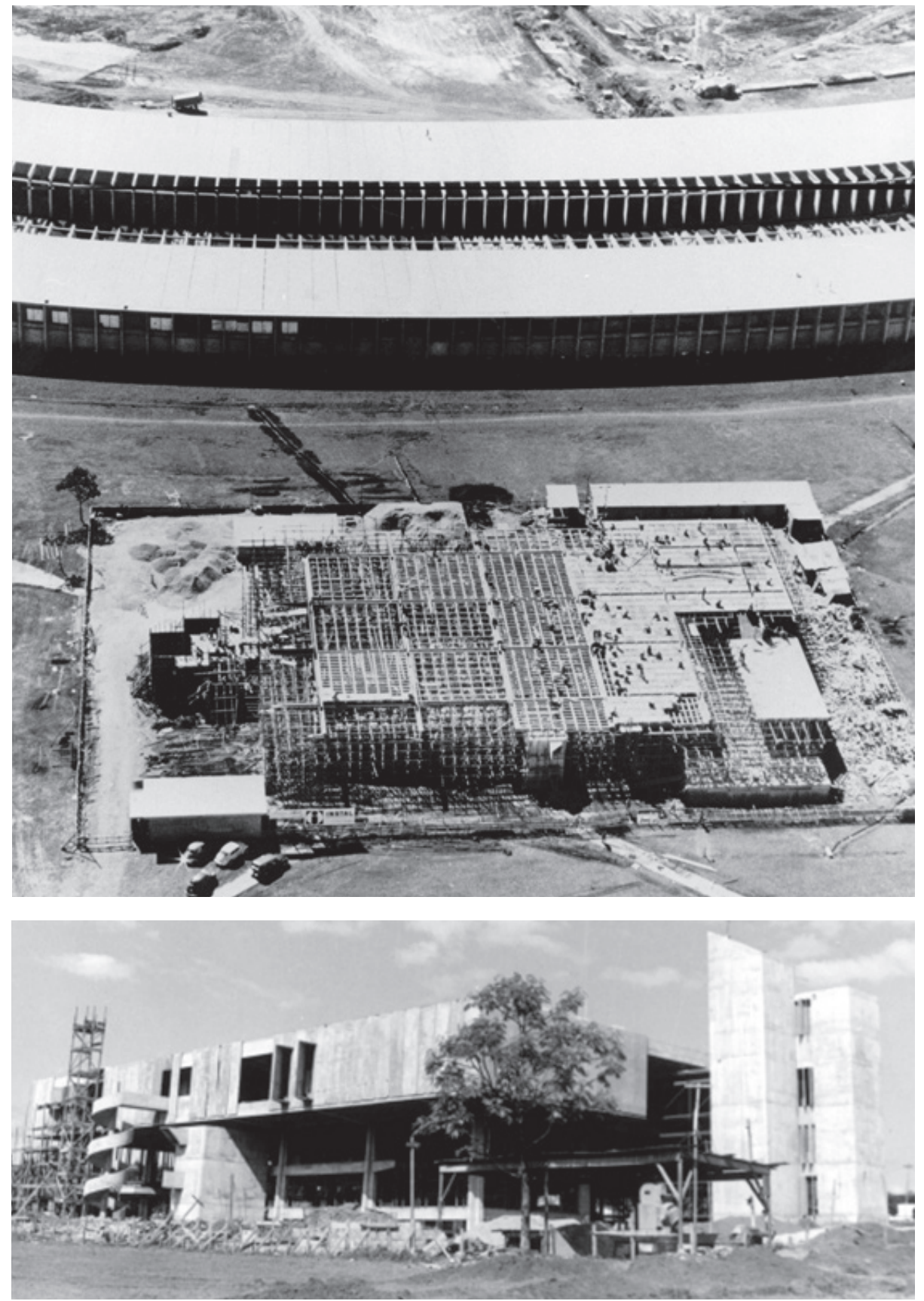

Figura 102g.

Vista aérea da

obra, com o ICC no

segundo plano

Figura 102h.

Restaurante em

construção

Figura 102i.

Fachada Oeste

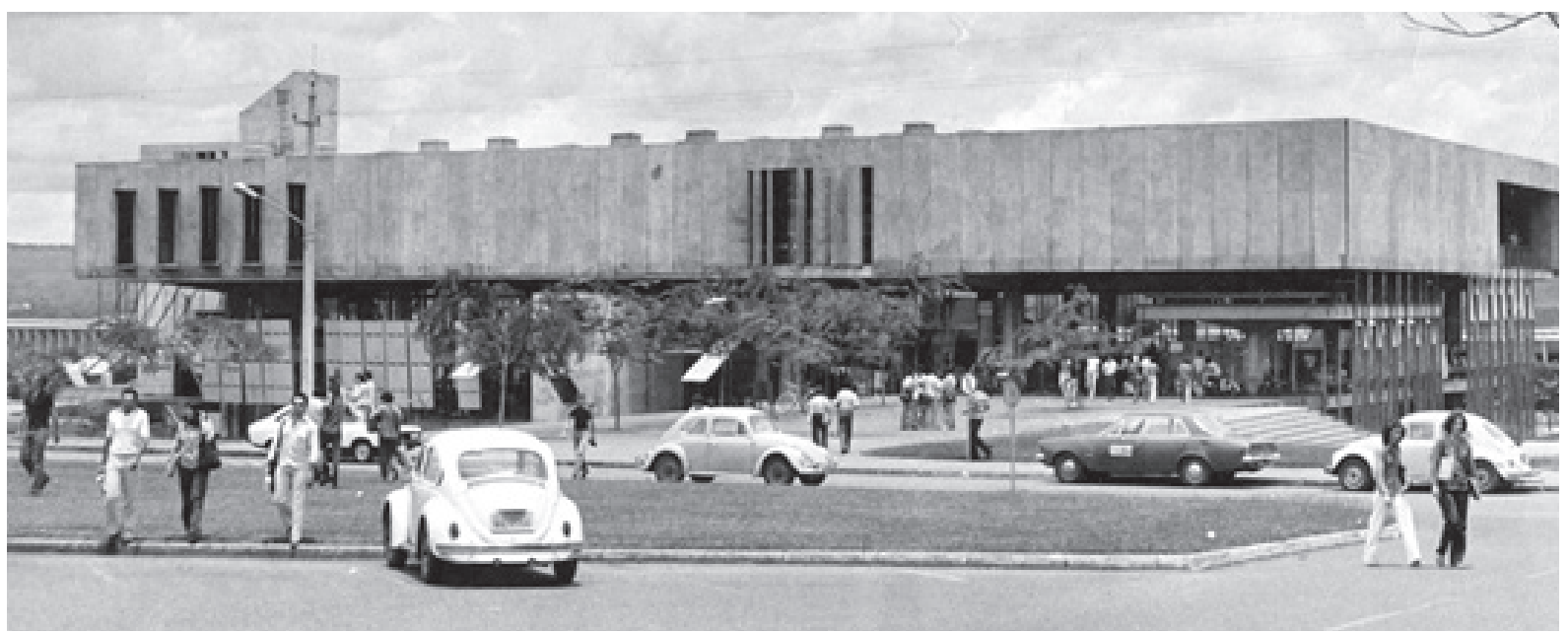


Ao situar a cozinha no nível mais elevado da construção, o partido inverteu a organização tradicional desse tipo de edificação. Tem-se, assim, uma caixa de concreto aparente, por vezes cega, apoiada em um sistema rígido de pilares cruciformes e elevada cerca de três níveis em relação ao solo. No interior dessa caixa ficam a cozinha e os demais espaços de apoio, ventilados e iluminados por um sistema zenital. Dessa caixa para baixo, tudo é envidraçado e protegido por beirais ou por grandes brises amarelos.

Além dos espelhos d'água e dos jardins, o prédio é marcado externamente por uma escada helicoidal que, localizada na fachada Leste, delimita o acesso Leste do restaurante, voltado para o ICC. $\mathrm{O}$ outro acesso, Oeste, dá diretamente para a via.

Os diferentes pavimentos do refeitório, distribuídos a cada meio nível, foram articulados por meio de rampas.

A estrutura, em concreto aparente, é composta de pilares cruciformes, vigas ligeiramente arqueadas e grelha reticulada.
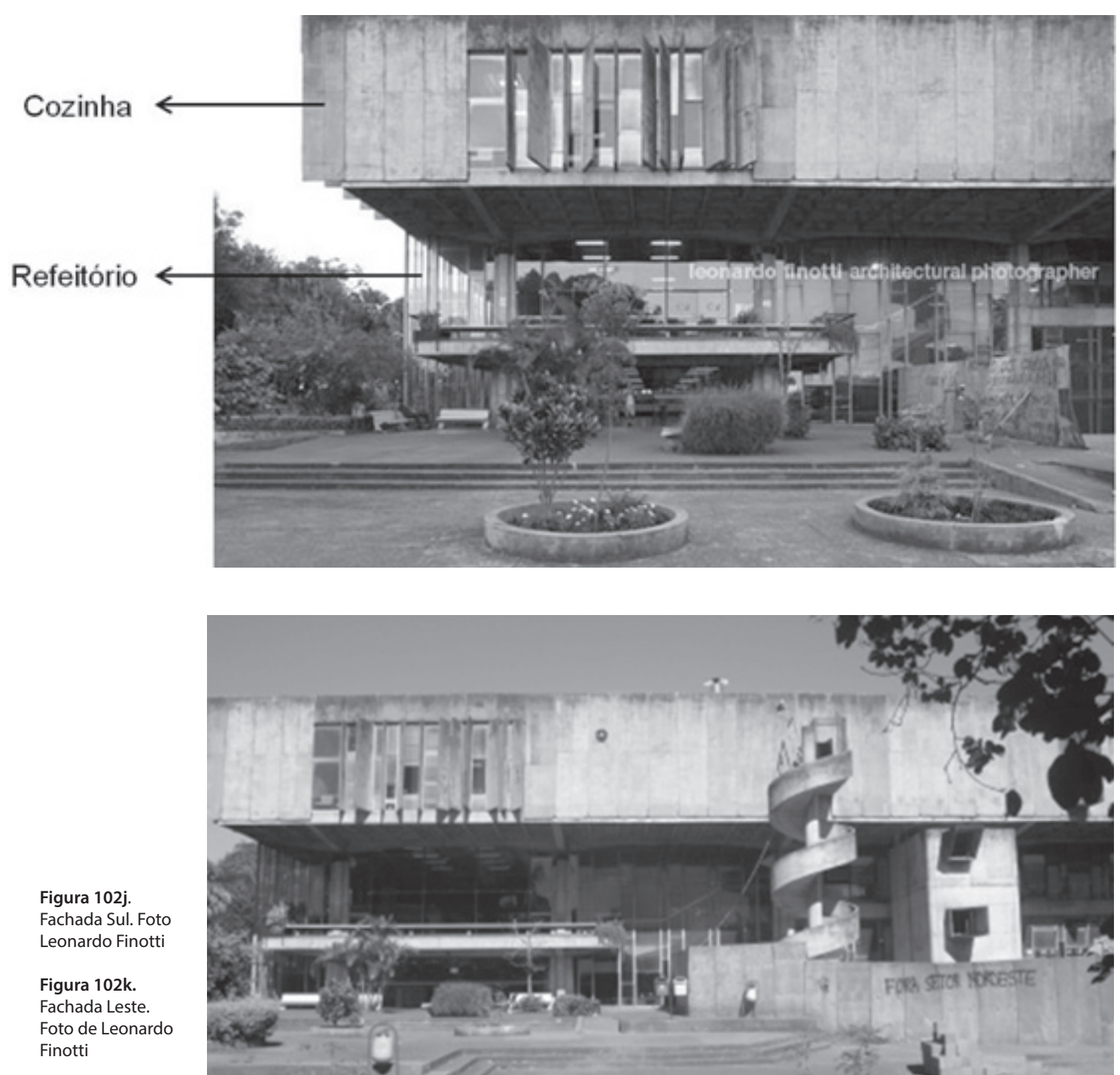

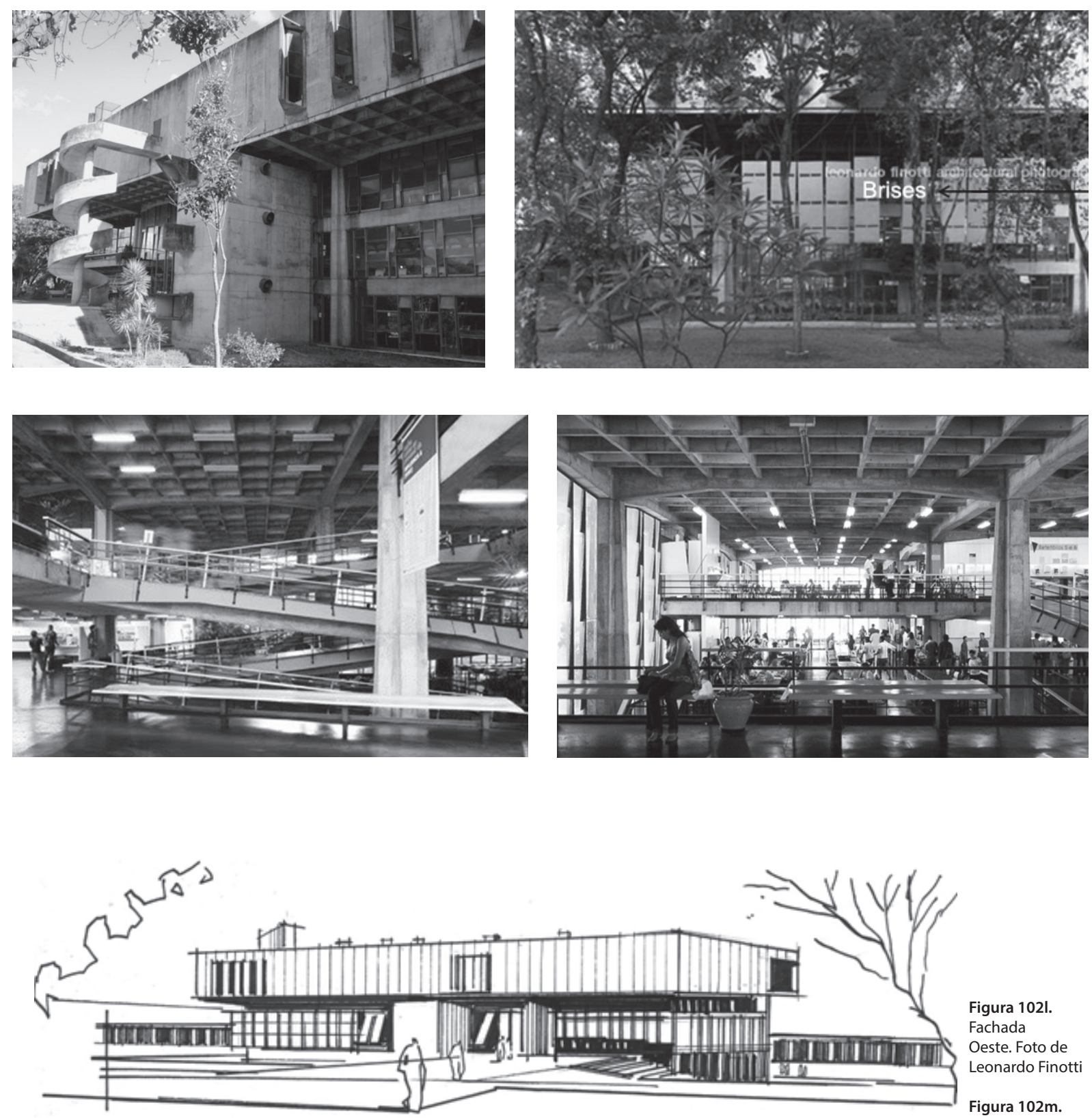

Figura 102I.

Fachada

Oeste. Foto de Leonardo Finotti

Figura $102 \mathrm{~m}$ Fachada Norte.

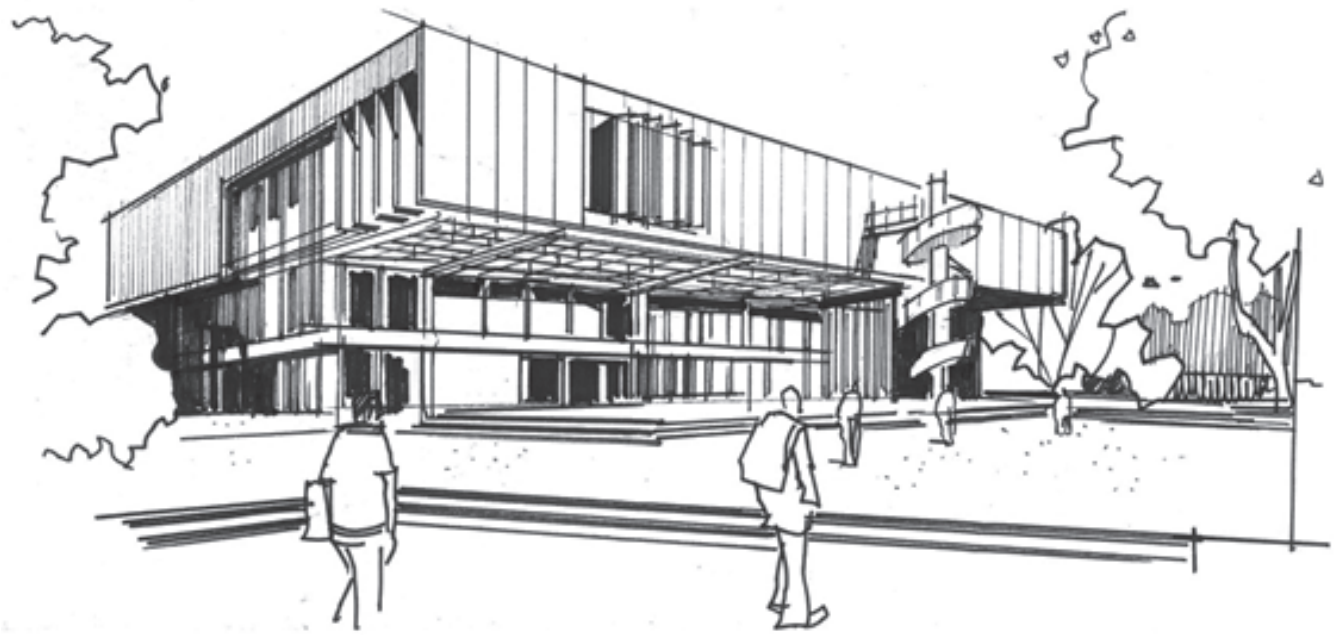

Foto Leonardo Finotti

Figura 102n.

Vista da rampa.

Foto Leonardo

Finotti

Figura 1020.

Vista interna.

Foto Leonardo

Finotti

Figura 102p. Entrada principal

Figura 102q Vista da escada de serviços.

Desenhos de Eliel Américo Santana da Silva 


\section{REITORIA}

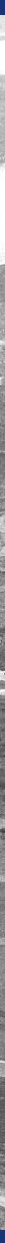

\section{Autoria}

Paulo de Mello Zimbres, com a colaboração de Érico Paulo Seigmar

Weidle, Josué de Carvalho Macedo e Vera Lúcia Braun Galvão
Figura 103a.

Implantação da

Reitoria

\section{Data}

1971 (projeto)

1973/1975 (obra)

Área Construída

$8.850 \mathrm{~m}^{2}$. 
Quando da fundação da UnB, a Reitoria passou a funcionar no prédio do então Ministério da Educação e Cultura (MEC), tendo sido posteriormente transferida para o bloco FE 3, então recém-inaugurado.

O atual edifício sede da Reitoria, de feição brutalista, permite estabelecer um paralelo com projetos contemporâneos de Alison e Peter Smithson, Shadrach Woods, Alexis Josic e Georges Candilis, que tiveram como motivação as discussões sobre as megaestruturas, que, por sua vez, não negam a influência da noção cobusiana de arquitetura como solução generalizada para a questão social.

O projeto de Shadrach Woods para o concurso da Universidade de Berlim, desenvolvido entre 1963 e 1973, foi o grande estimulador da discussão das megaestruturas. Retomando o conceito utilizado no Hospital de Veneza, do mesmo ano, o projeto da Universidade Livre de Berlim reunia as unidades de atividades através de uma imensa laje para circulação de pedestres. A laje era concebida a partir de uma grelha reticulada, onde alguns espaços eram ocupados pelos blocos, outros eram simples acessos e pontos de encontro e outros ainda eram deixados livres para iluminarem e ventilarem (BARONE, 2002, p. 94).

No entanto, o autor do projeto, apesar de não negar a filiação da Reitoria ao estilo brutalista, faz uma ressalva: "Mas fui contaminado pela beleza do Cerrado, do céu escancarado de Brasília. Concebemos o prédio olhando para a natureza, com rasgos que miram o horizonte" (Paulo ZIMBRES, 2012 in www.unb.br/noticias/unbagencia/unbagencia.php?id=6468).

b

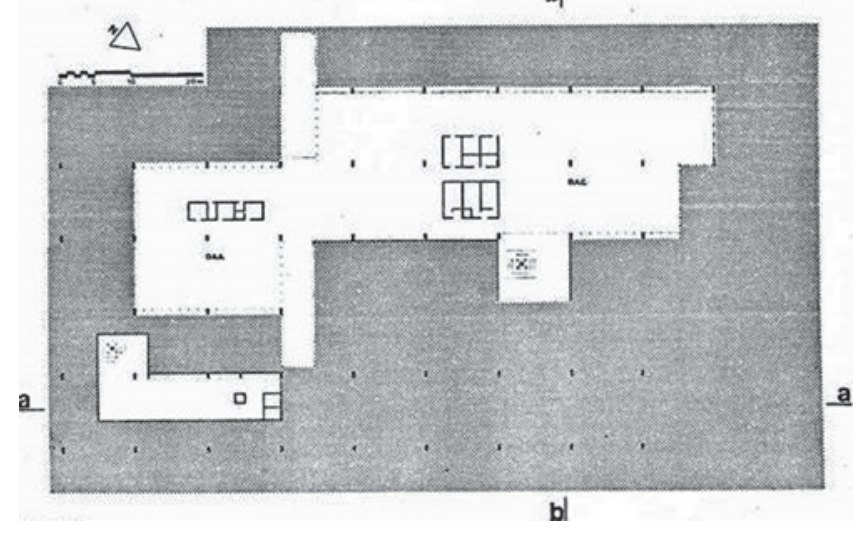

Q

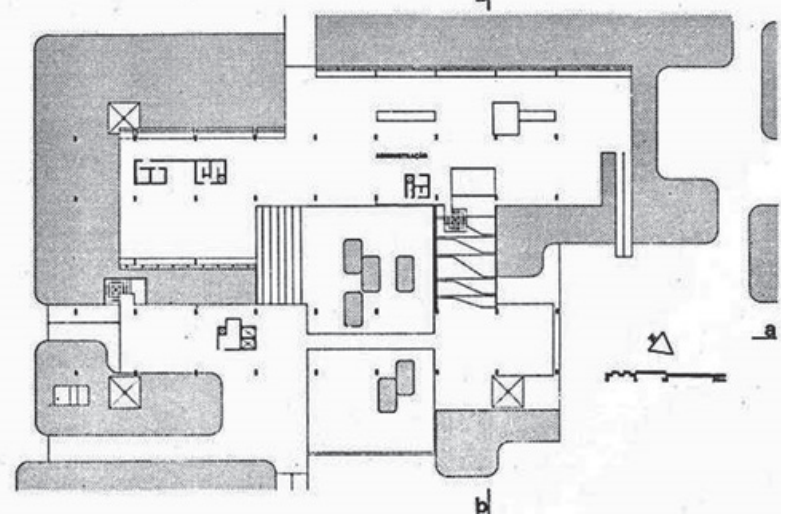

b

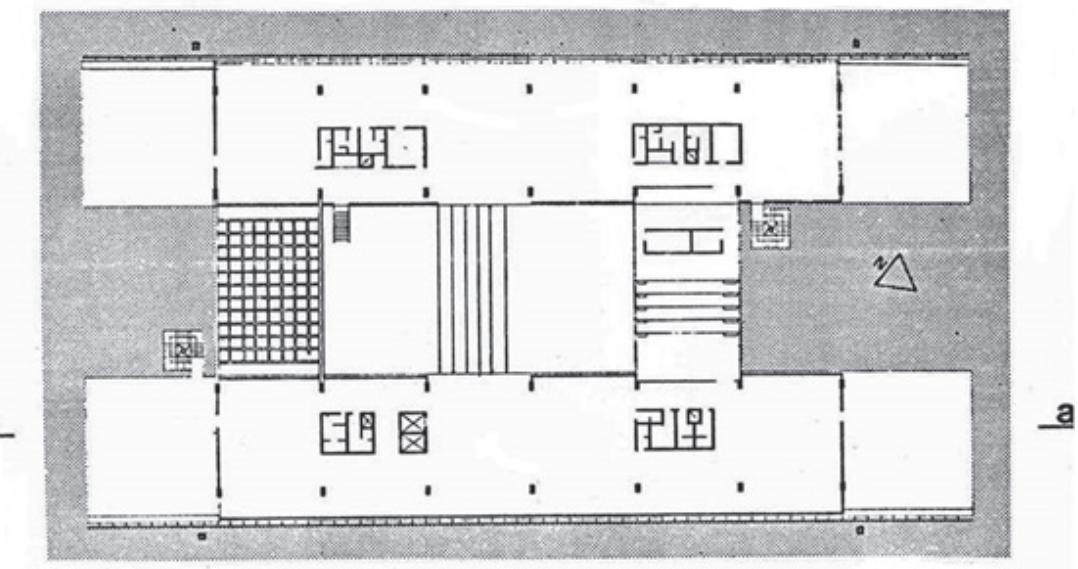

Figura 103b.

Planta do subsolo

Figura 103c.

Planta do pavimento inferior

Figura 103d.

Planta do pavimento superior 

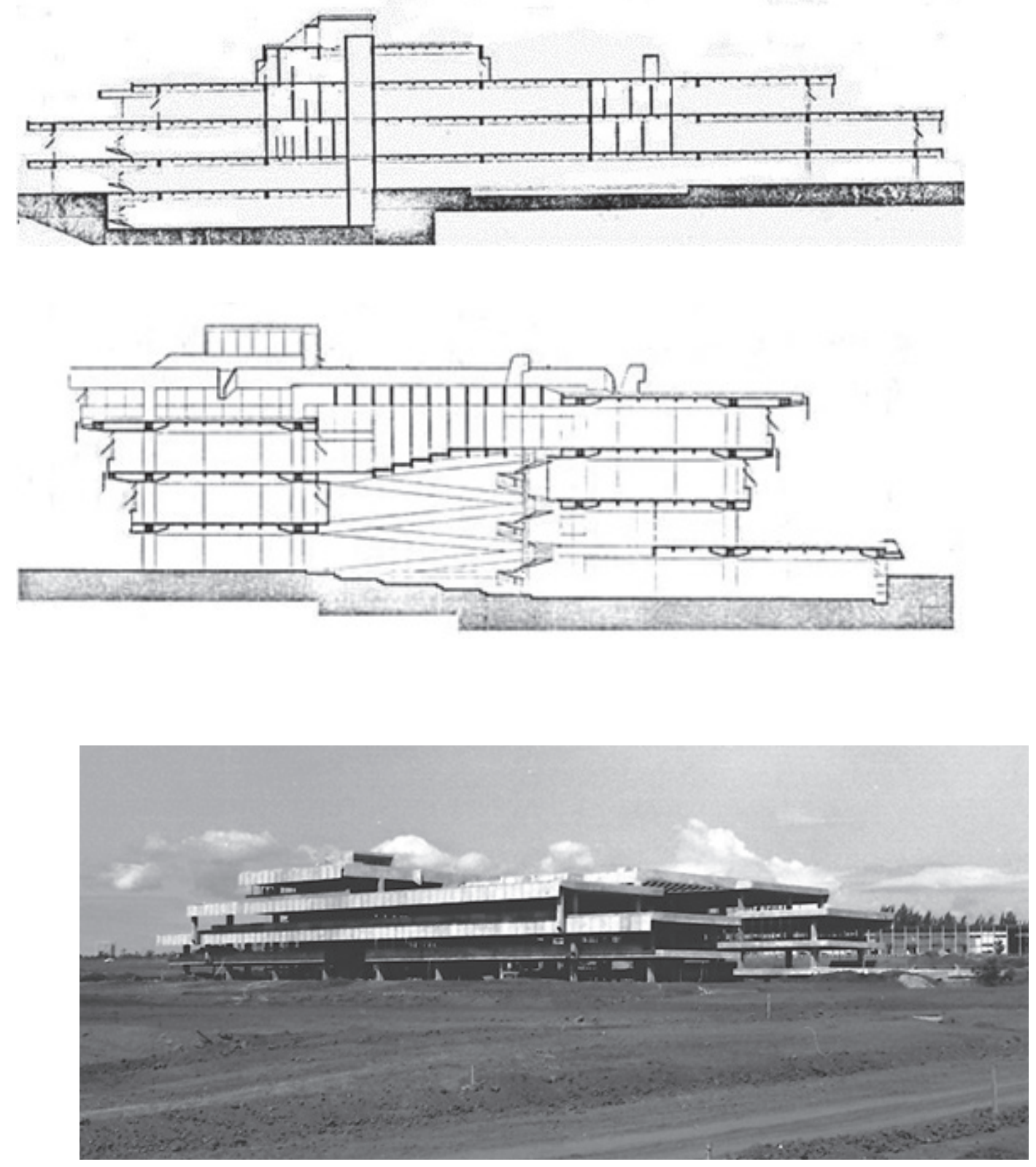

Figura 103e. Corte longitudinal

Figura $103 f$. Corte transversal

Figura 103g.

Reitoria em construção

Figura $103 \mathrm{~h}$.

Reitoria em construção

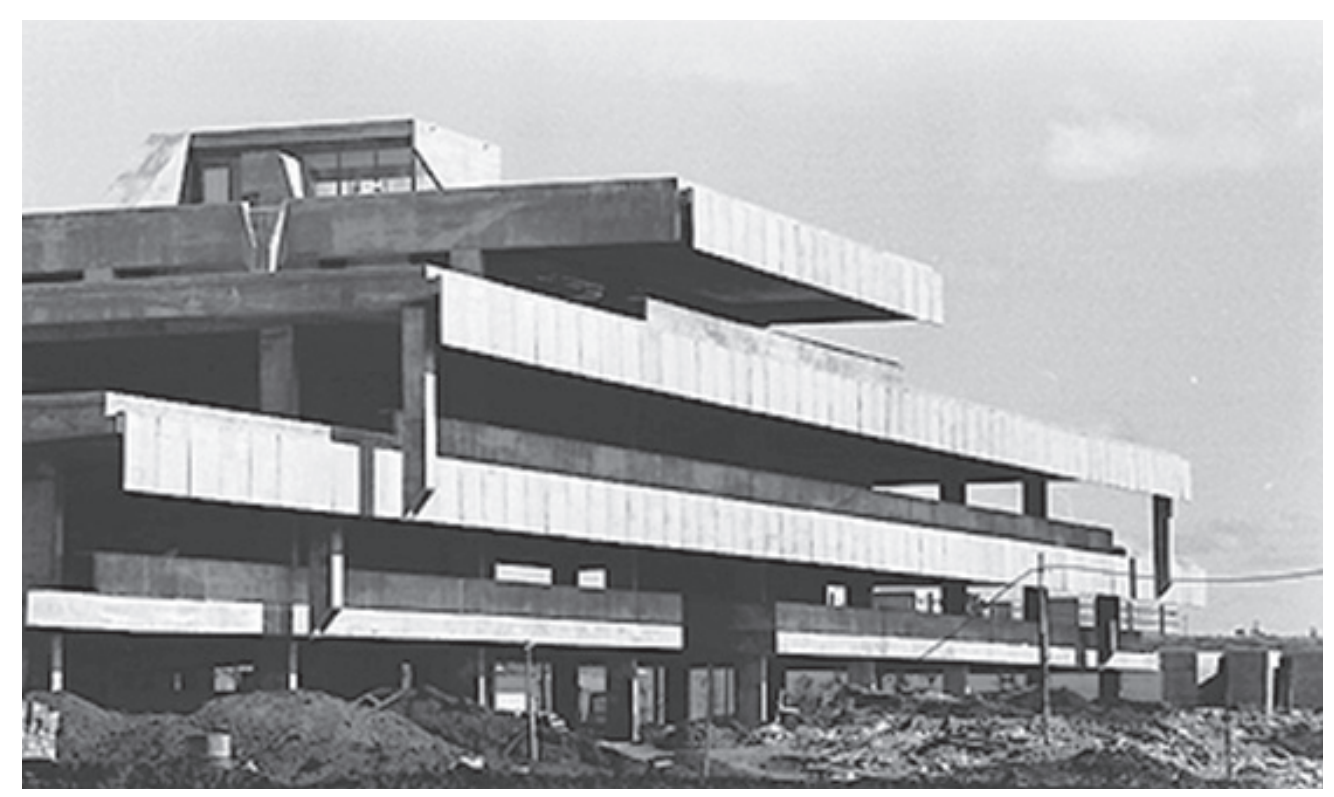


Trata-se de um edifício de planta retangular e estrutura em concreto aparente. São dois blocos ligados por uma ampla rampa transversal, sendo que cada pavimento do primeiro bloco guarda um desnível de meio pé-direito em relação ao pavimento correspondente do segundo. $O$ edifício, que pode ser acessado por todos os lados, não apresenta uma marcação das hierarquias que abriga.

No início o projeto da Reitoria não foi bem recebido por alguns colegas. Algumas críticas nossa equipe acolheu, ainda durante os debates no Ceplan. Depois da obra construída, ocupada e ajardinada, seus atributos ficaram mais evidentes e sua presença brutalista foi amenizada pelo arvoredo que a envolveu. Aracy Amaral, professora titular de História da Arte pela Faculdade de Arquitetura e Urbanismo da USP, escreveu sobre a reitoria uma resenha elogiosa. Dizendo ter encontrado no campus um projeto interessante, ela comenta: "trata-se de um prédio que exibe certa horizontalidade presente na arquitetura brasileira, que tem também um jeito paulista de ser... mas que se abriu no cerrado encontrando uma feliz relação interior/exterior. Apresenta-se como um oásis no cerrado a acolher a quem vem vindo do campus ensolarado e encontra ali um lago e áreas ajardinadas, que criam um clima ameno em seu interior" (ZIMBRES, entrevista em 26 out. 2011).
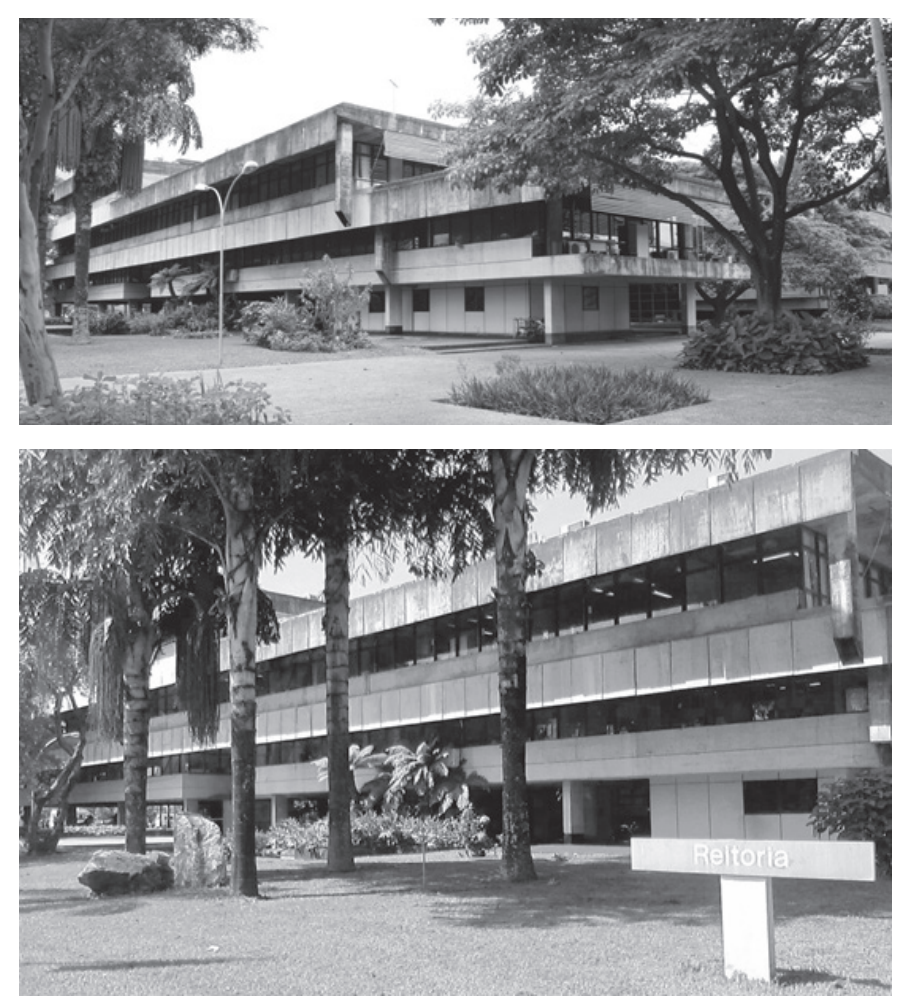

Figura 103i.

Vista das fachadas Leste/Norte

Figura 103j.

Vista da fachada Leste.

Figura 1031.

Fachada Norte

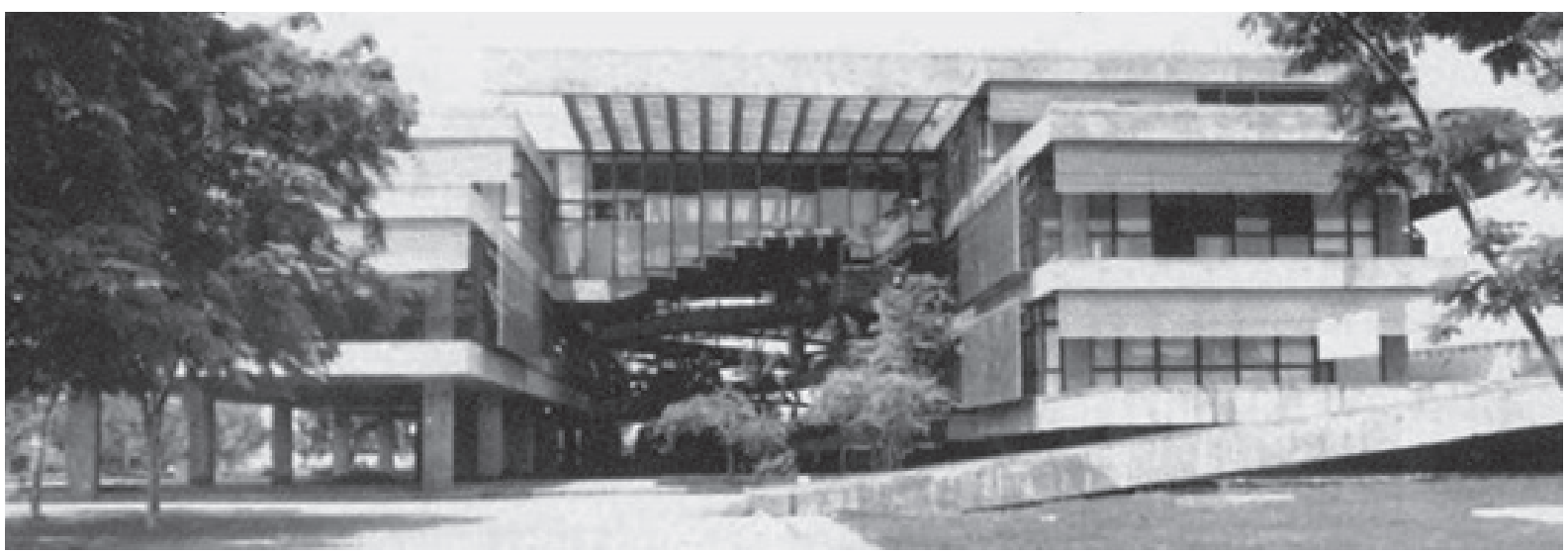


As rampas, como no Restaurante, ligam meios níveis, e o auditório consiste em um volume suspenso, suportado por tirantes fixados à cobertura.

A estrutura, em concreto aparente, é composta de pilares, vigas e uma grande grelha reticulada, que em certos momentos aparece vazada para permitir a entrada de luz e chuva para os jardins internos.

Seguindo a tradição brasiliense de arte integrada à arquitetura, o edifício exibe a escultura "Olho o verde, vejo o azul", do arquiteto e ex-professor da FAU Jayme Kerbel Golubov.
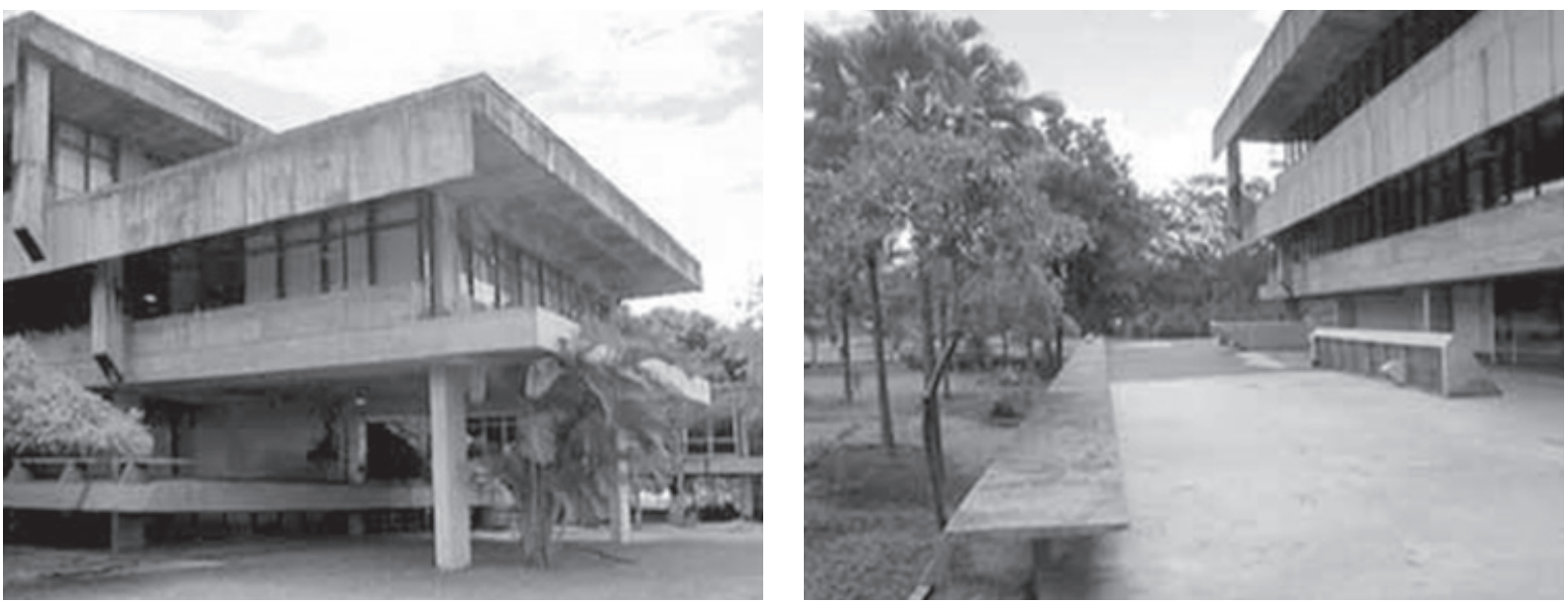

Figura $103 \mathrm{~m}$

Detalhe da

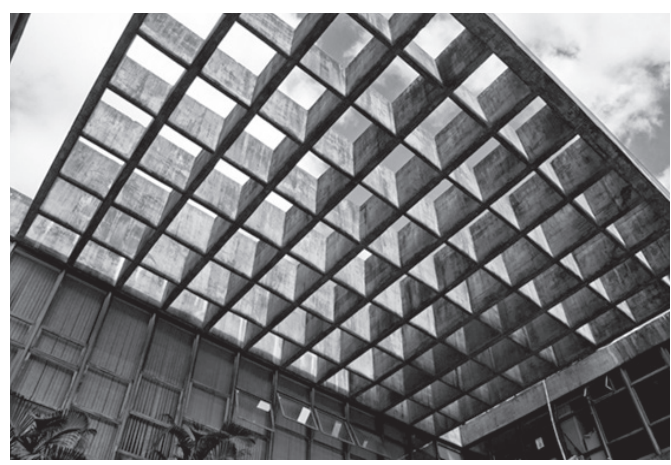

Figura 103n.

Espaços de

convivência

Figura 1030.

Grelha reticulada

Figura 103p.

Escada de serviço

Figura 103q.

Auditório

atirantado
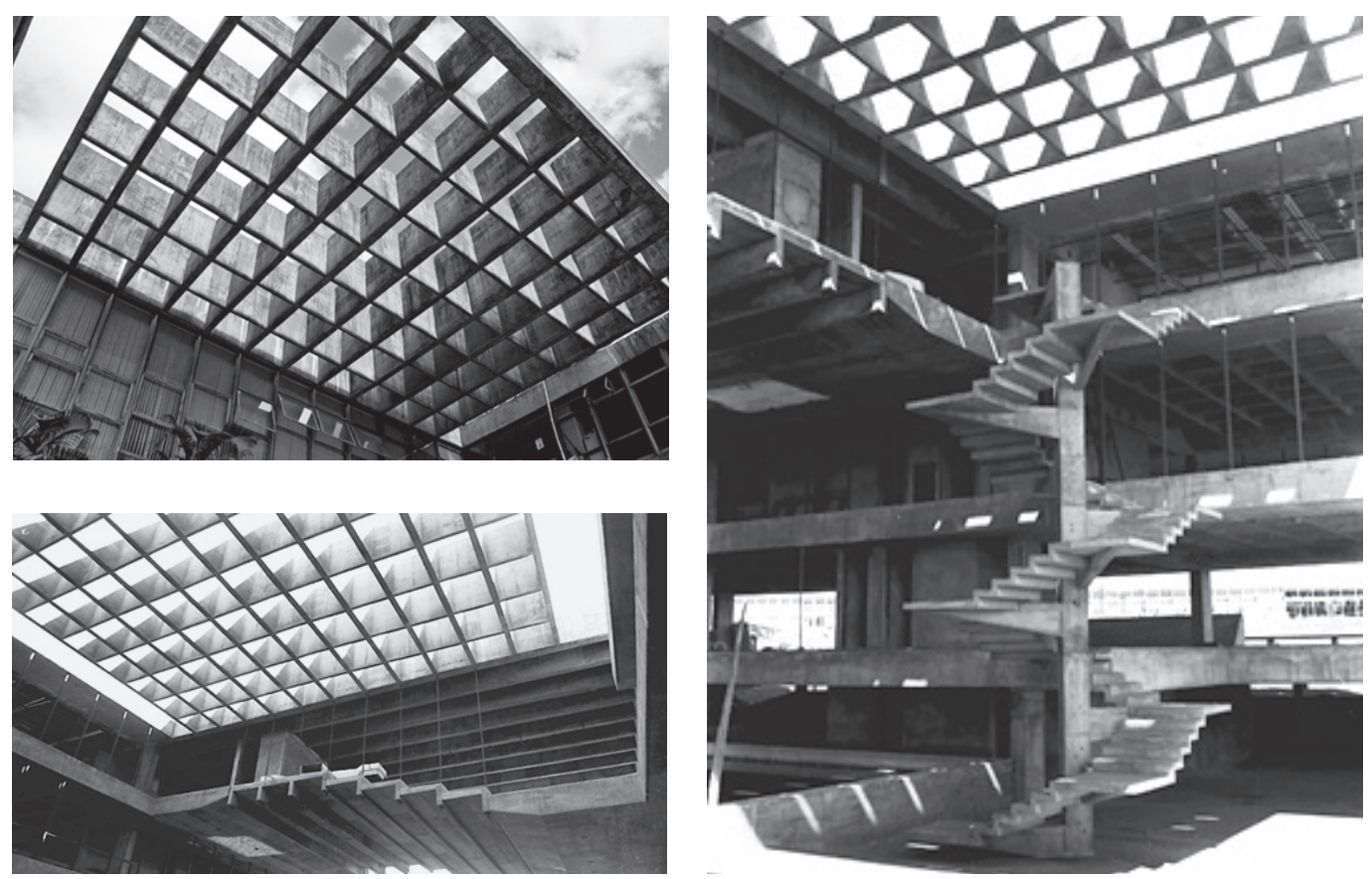

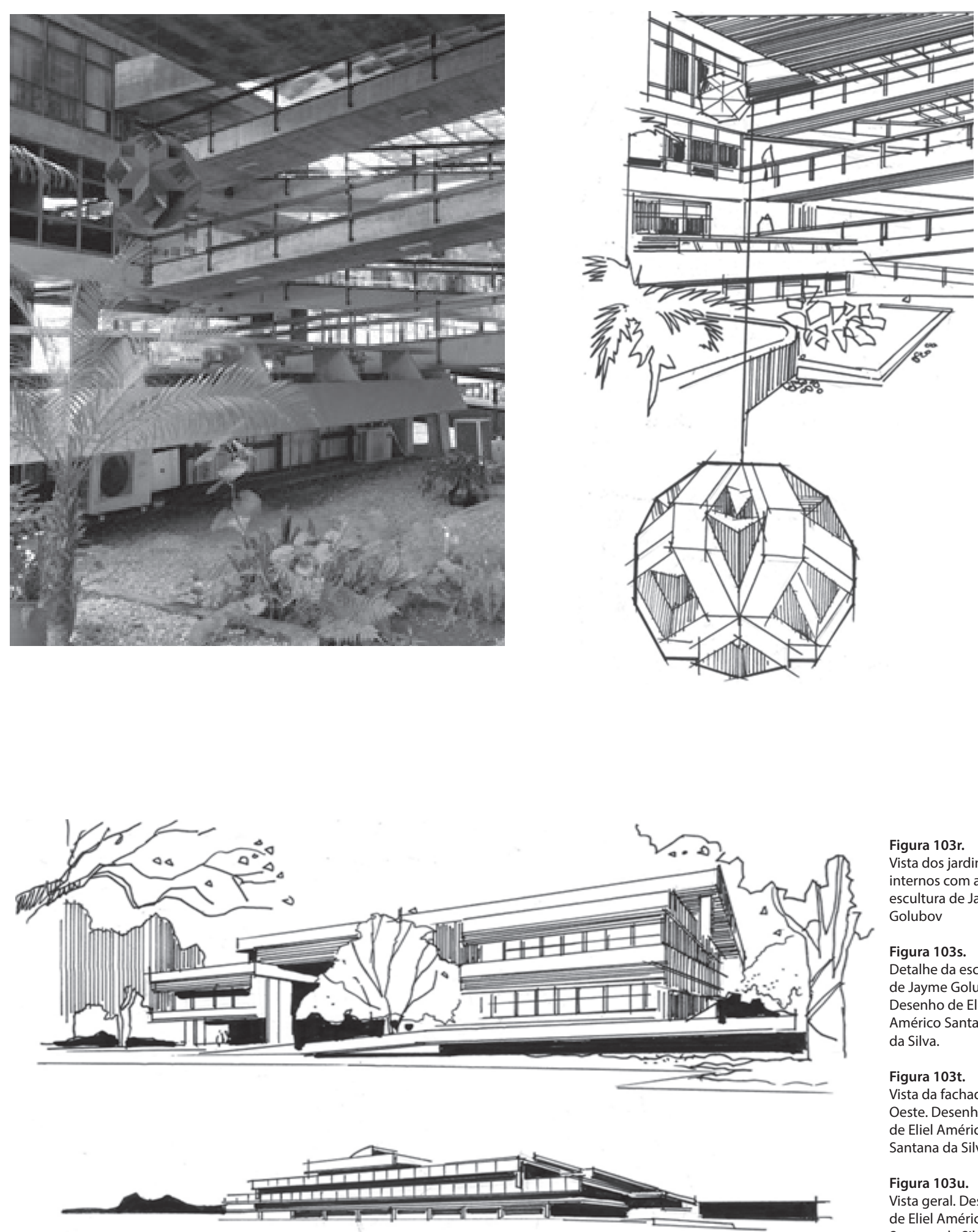

Vista da fachada

Oeste. Desenho

de Eliel Américo

Santana da Silva.

Figura 103u.

Vista geral. Desenho

de Eliel Américo

Santana da Silva. 
NÚCLEO DE MEDICINA TROPICAL (NMT)

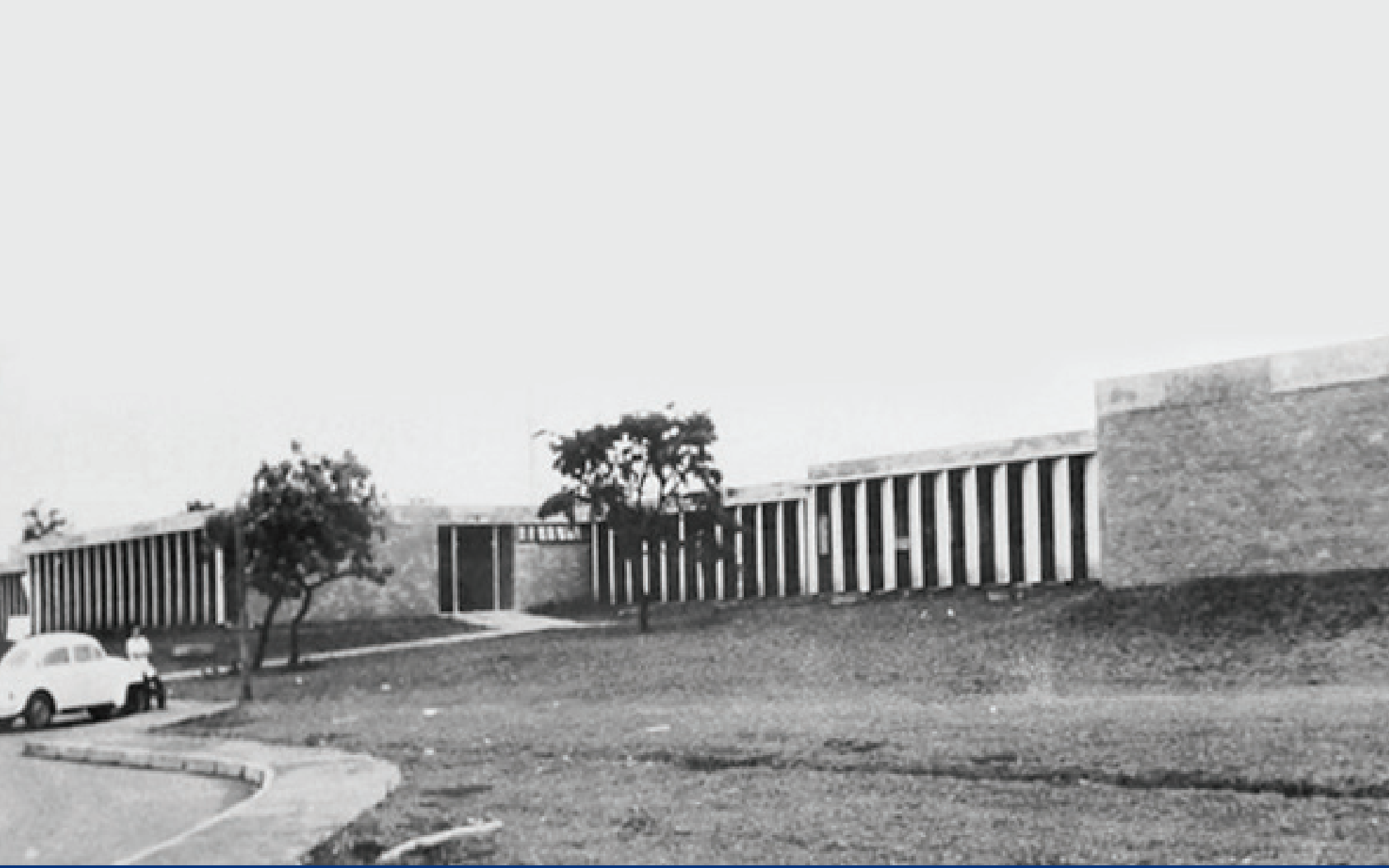

Autoria

Adilson Costa Macedo

\section{Data}

1972/1973 ( $1^{\text {a }}$ fase)

$1977 / 1978$ ( $2^{\mathrm{a}}$ fase)

Área Construída

$2.367 \mathrm{~m}^{2}$ (1 $\left.{ }^{\text {a fase }}\right)+502 \mathrm{~m}^{2}$ (2a fase)
Figura 104a.

Fachada Leste 
O NMT foi criado em 1973, com base nos trabalhos desenvolvidos pelo professor João Bosco Salomón, no Hospital de Sobradinho. Com o apoio de recursos provenientes da Financiadora de Estudos e Projetos (Finep), o NMT foi transferido para o campus, instalando-se em um edifício, próximo à Faculdade de Ciências da Saúde (FS), que passou a ser dividido com o curso de Nutrição.

O Núcleo conta com laboratórios de entomologia médica, imunologia da malária, diagnóstico de leishmaniose, exame parasitológico de fezes, biotério e insetários para criação de triatomídeos e anofelinos. Em 1978, devido às necessidades do curso de mestrado, e também para a guarda de periódicos, a ala Norte foi ampliada.

O conjunto edificado resultou da articulação de vários blocos de planta retangular, independentes entre si e interligados por áreas comuns de circulação, voltadas para pátios internos.

O sistema construtivo adotado baseou-se em estrutura independente em concreto armado, vedações externas em alvenaria de tijolo aparente e divisórias internas de madeira ou placas de cimen
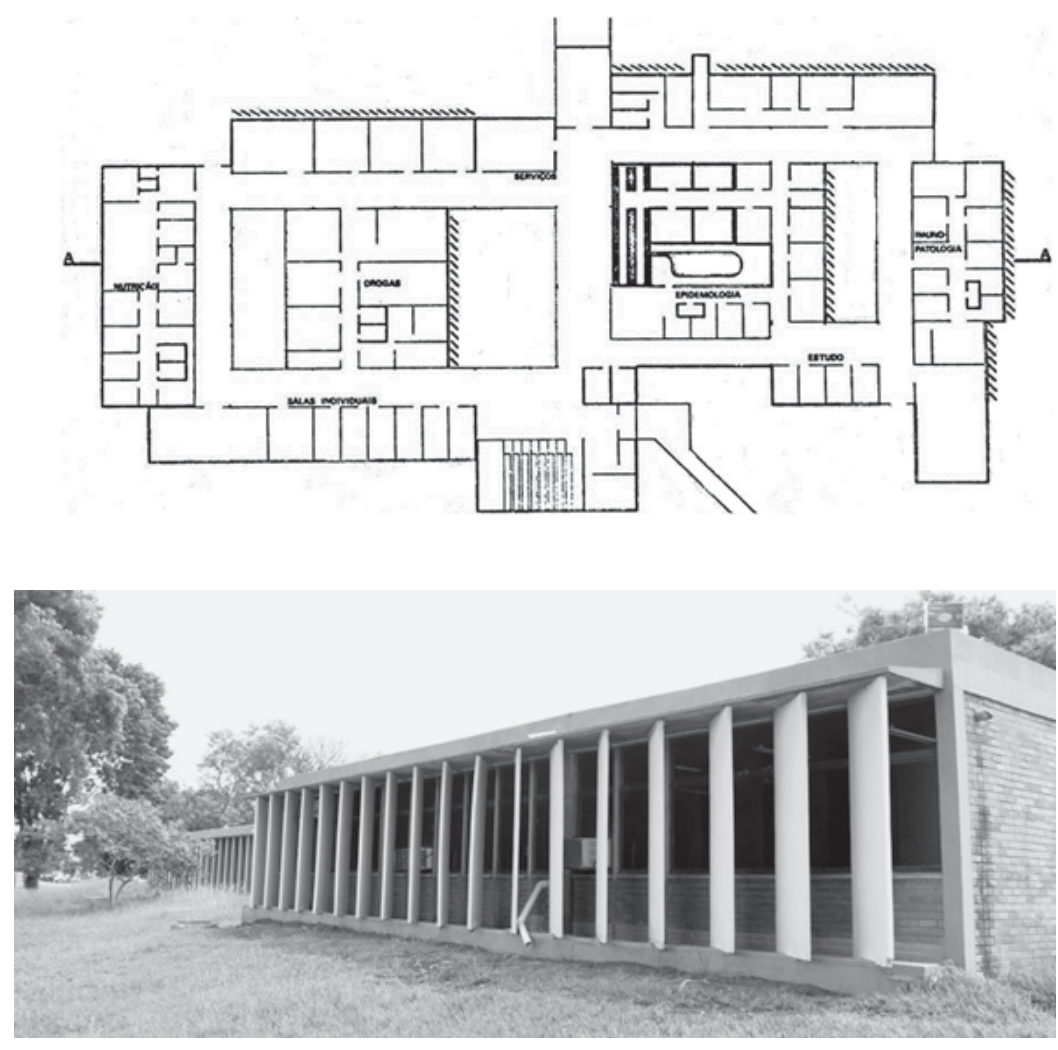

Figura 104b.

Planta esquemática

Figura 104c.

Fachada Leste

Figura 104d. Fachada Norte

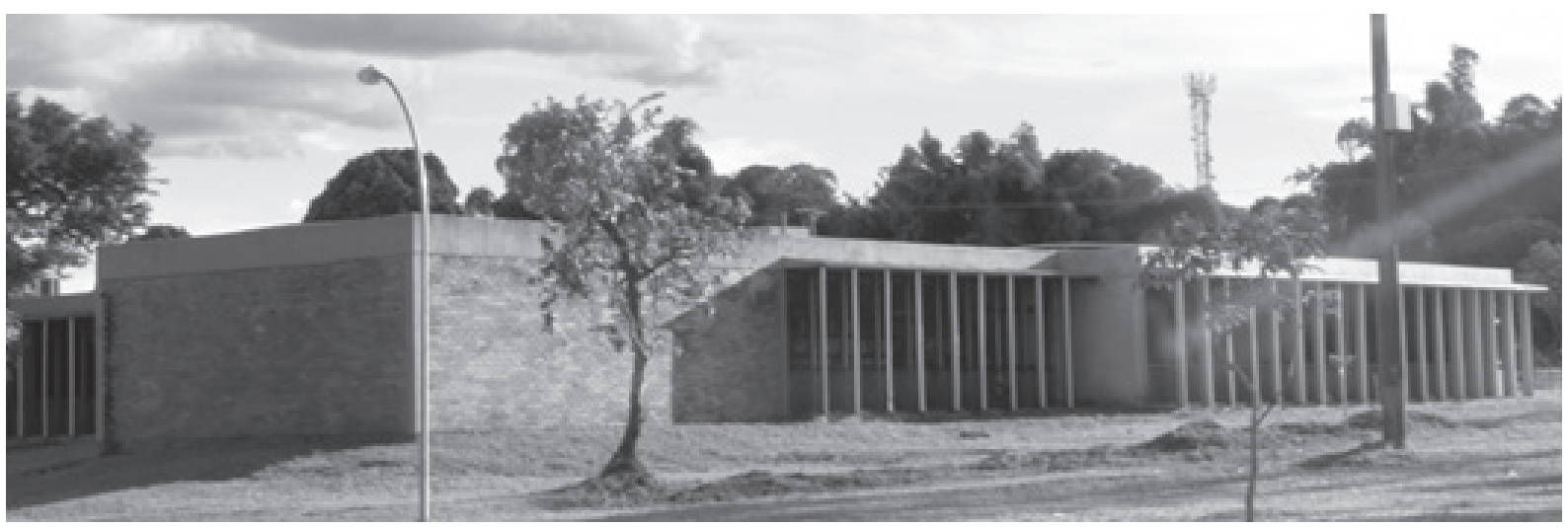


FACULDADE DE TECNOLOGIA (FT)

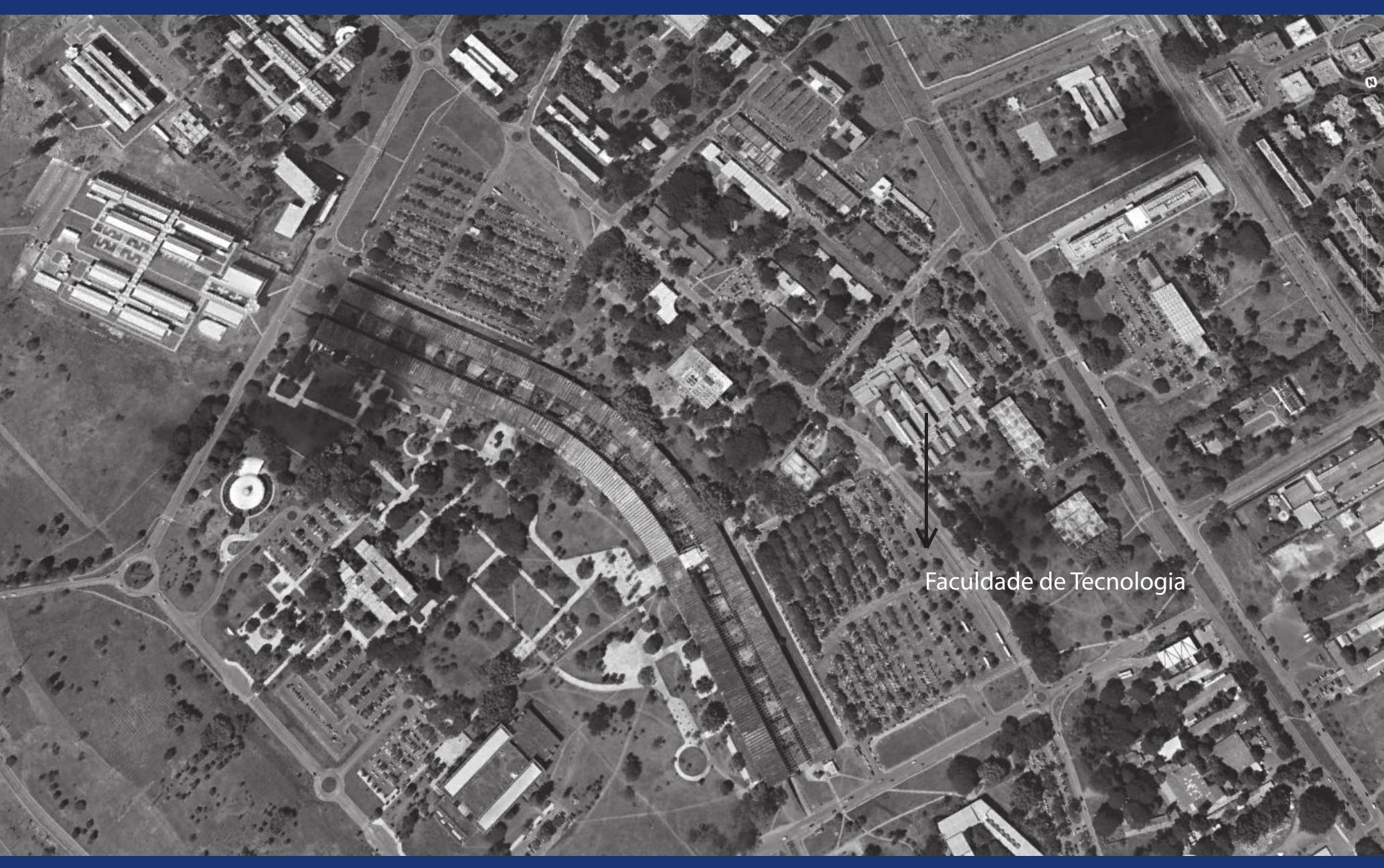

Autoria

Adilson Costa Macedo e Érico Paulo Siegmar Weidle, com a colaboração de Jayme Kerbel Golubov. O paisagismo original é de Eurico João Salviatti

Data

1973 (projeto)

1974/1977 (obra)

Área Construída

$15.095 \mathrm{~m}^{2} ; 2.281 \mathrm{~m}^{2}$ (LT); $1.994 \mathrm{~m}^{2}$ (LHE)
Figura 105a.

Implantação da

Faculdade de

Tecnologia 
Embora a FT tenha iniciado suas atividades em 1967, somente em 1974 o projeto de suas instalações definitivas começou a sair do papel. A obra', que ficou paralisada durante um ano devido a problemas financeiros, só foi retomada com a criação do Programa de Expansão e Melhoramento das Instalações do Ensino Superior (Premesu), que contou com recursos do Banco Interamericano de Desenvolvimento (BID).

Além do edifício principal e dos laboratórios adjacentes - Laboratório de Termociência e Metrologia Dinâmica e Laboratório de Hidráulica e Estruturas -, a FT ocupa três prédios de serviços gerais - SG 9, SG 11 e SG 12 - construídos na década de 1960.

O conjunto de ensino é composto de quatro blocos paralelos - um administrativo e três didáticos, cortados transversalmente por dois grandes eixos de circulação, gerando um esquema de dupla "espinha de peixe".

Os blocos, assentados em diferentes níveis respeitando a configuração do terreno, são separados entre si por pátios ajardinados. Todo o conjunto foi construído com estrutura de concreto armado e vedações externas em alvenaria de tijolo aparente.

A volumetria é marcada pelo emprego de sistemas de proteção solar e de iluminação zenital. Integram o complexo da Faculdade de Tecnologia duas outras edificações: o Laboratório de Termociência e Metrologia Dinâmica e o Laboratório de Hidráulica e Estruturas.

No prédio do Laboratório de Termociência, vinculado ao Departamento de Engenharia Mecânica, funcionam sete laboratórios ligados às áreas de escoamentos multifásicos, turbulência, motores de combustão interna, automação e controle de processos de fabricação e mecânicas dos sólidos. No Laboratório de Hidráulica e Estruturas, vinculado ao Departamento de Engenharia Civil, foi construído um sistema de reservatórios, canais e bombas responsável pelo provimento da água necessária ao funcionamento de diversos equipamentos.

Ambos os laboratórios apresentam uma base composta pela repetição de peças descontínuas de alvenaria de tijolo aparente, que formam uma espécie de meandros. Dessas bases, responsáveis pela vedação, contenção e delimitação das áreas funcionais, brotam conjuntos articulados de paraboloides hiperbólicos de concreto armado, que servem de cobertura para os laboratórios. $\mathrm{O}$ de Termociência, que possui planta retangular, é coberto por oito paraboloides; o de Hidráulica, de planta quadrada, é coberto por nove paraboloides.

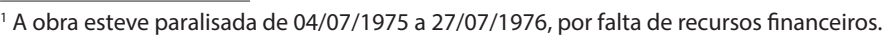



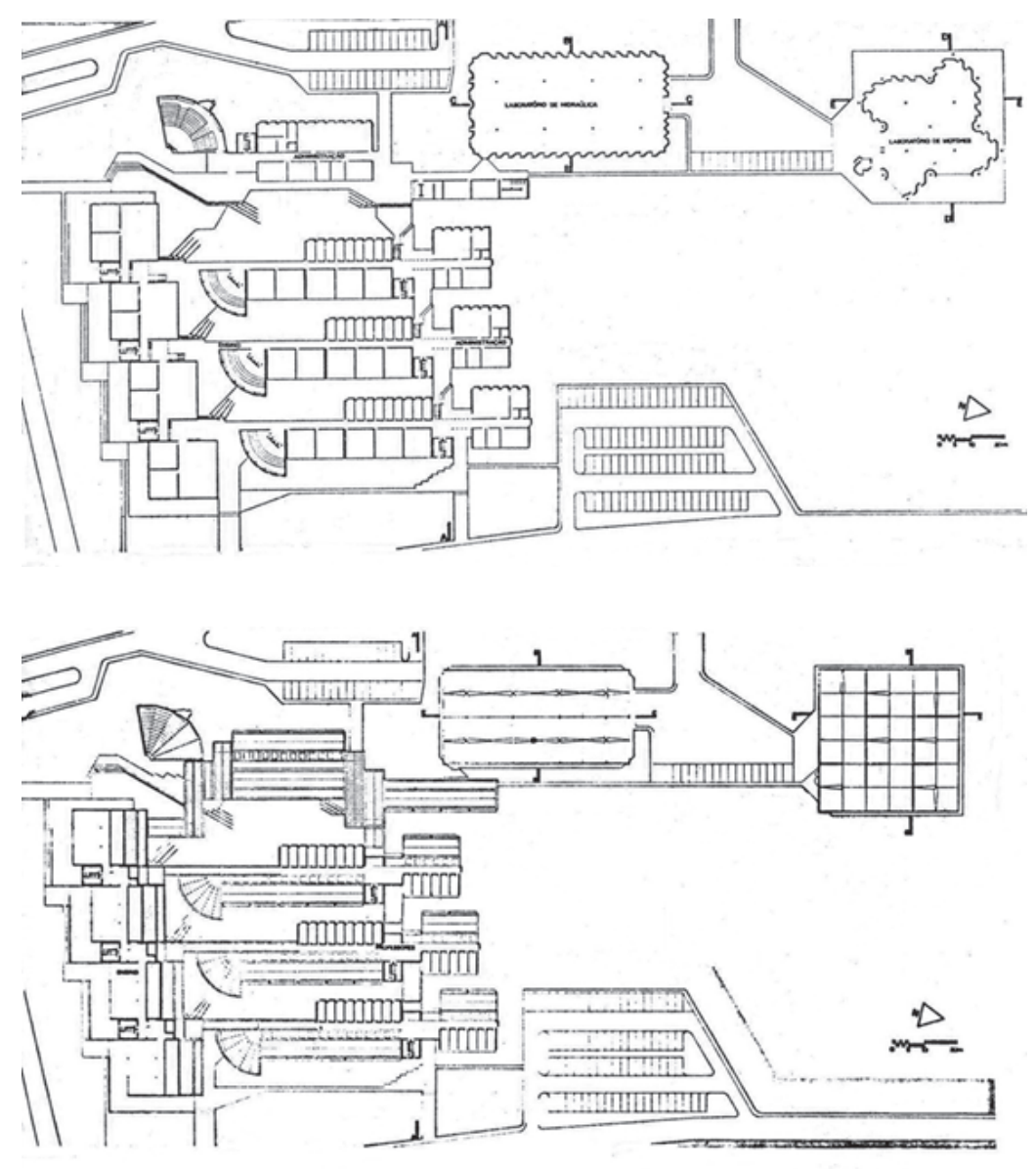

Figura 105b.

Corte transversal esquemático

Figura 105c.

Planta do pavimento inferior

Figura 105d.

Planta do pavimento superior

Figura 105e.

Acesso entre o auditório maior e as salas de projeção

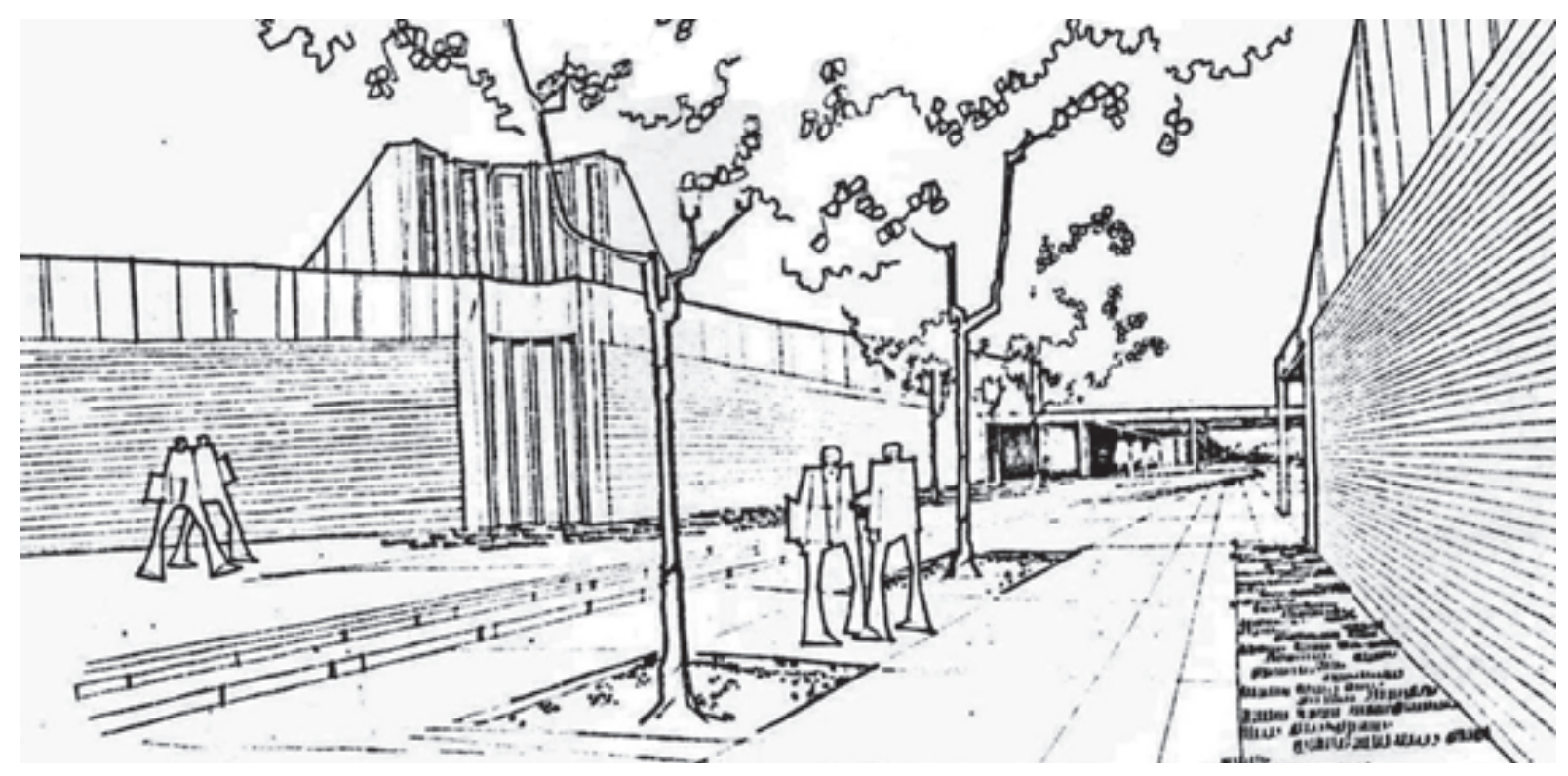



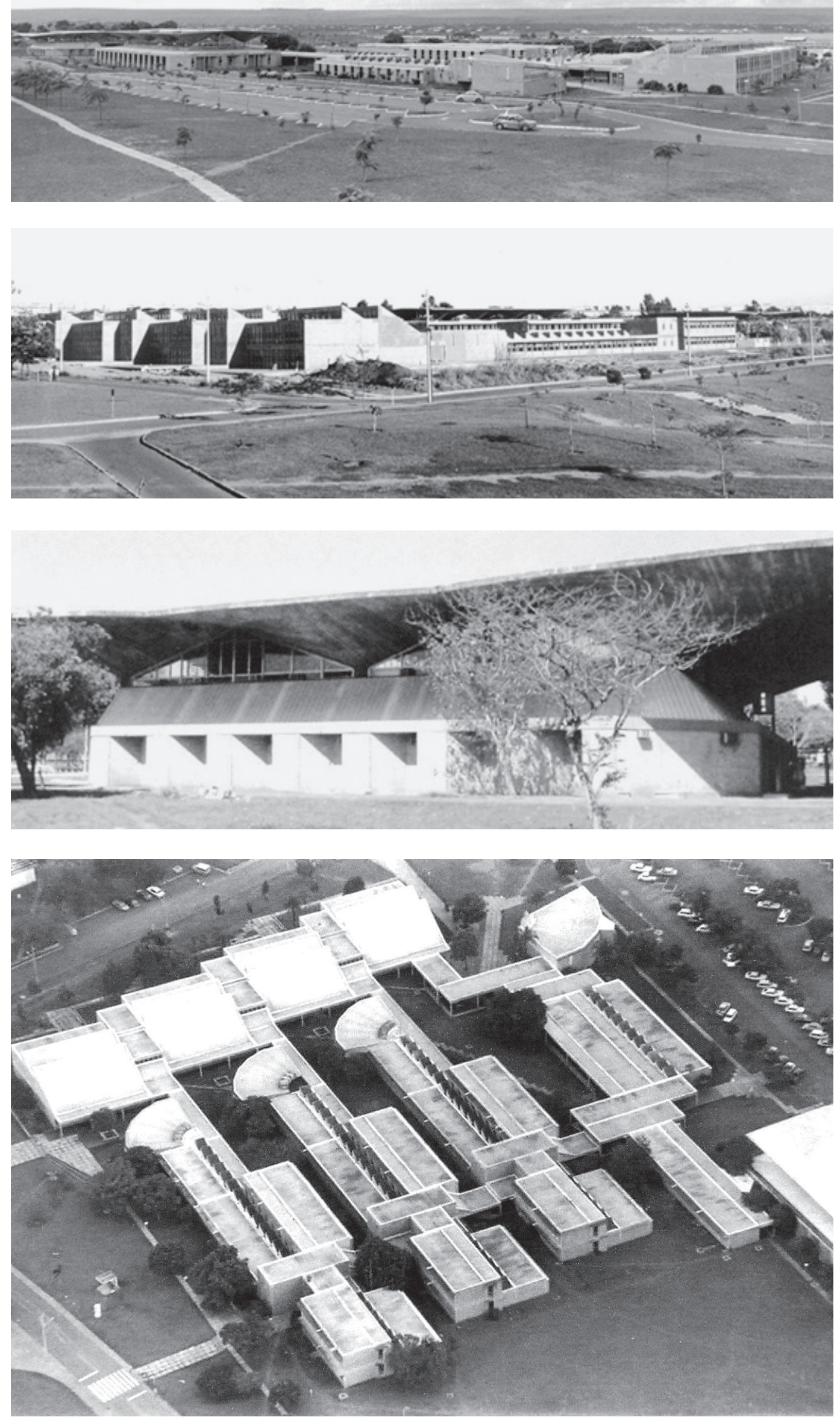

Figura $105 f$.

Vista geral do

conjunto recém-

edificado

Figura 105g

Vista geral do

conjunto

Figura $105 \mathrm{~h}$.

Laboratório de

Hidráulica e Estruturas

Figura 105i.

Vista aérea 


\section{FACULDADE DE CIÊNCIAS DA SAÚDE (FS)}

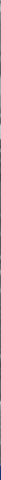

Autoria

Érico Paulo Siegmar Weidle e Adilson Costa Macedo. O cálculo estrutural é de responsabilidade de Ernesto Walter

\section{Data}

1973 (projeto)

1978/1981 (obra)

Área Construída

$18.018 \mathrm{~m}^{2}$
Figura 106a.

Implantação da

Faculdade de

Ciências da Saúde 
O curso de Medicina foi inaugurado em 1966. Depois de montados e equipados os laboratórios multidisciplinares, foi criada, em 1967, a Unidade Integrada de Saúde de Sobradinho (UISS), que passou a funcionar como hospital-escola. Em 1979, o treinamento do corpo discente foi transferido para o Hospital Presidente Médici, próximo ao Campus Darcy Ribeiro. As instalações definitivas da Faculdade de Ciências da Saúde (FS) foram inauguradas em 1980, com espaços já destinados ao curso de Odontologia, iniciado em 1981. Em 1999, foi criada a Faculdade de Medicina (FM), que continuou a funcionar no mesmo prédio.

O conjunto baseia-se em três blocos paralelos de edificações, articulados em torno de dois eixos principais de circulação, gerando um esquema de dupla "espinha de peixe".

Respeitando a configuração natural do terreno, cada um dos blocos funcionais apresenta uma solução distinta: a administração e os serviços, com dois pavimentos, ocupam um nível; os laboratórios de pesquisa outros dois; e os laboratórios multidisciplinares, um terceiro.

A planta, constituída de blocos separados entre si por pátios internos ajardinados, remete ao projeto para o Orfanato de Amsterdam (1955-1960), de Aldo Van Eyck.

Planta do pavimento inferior

Figura 106c.
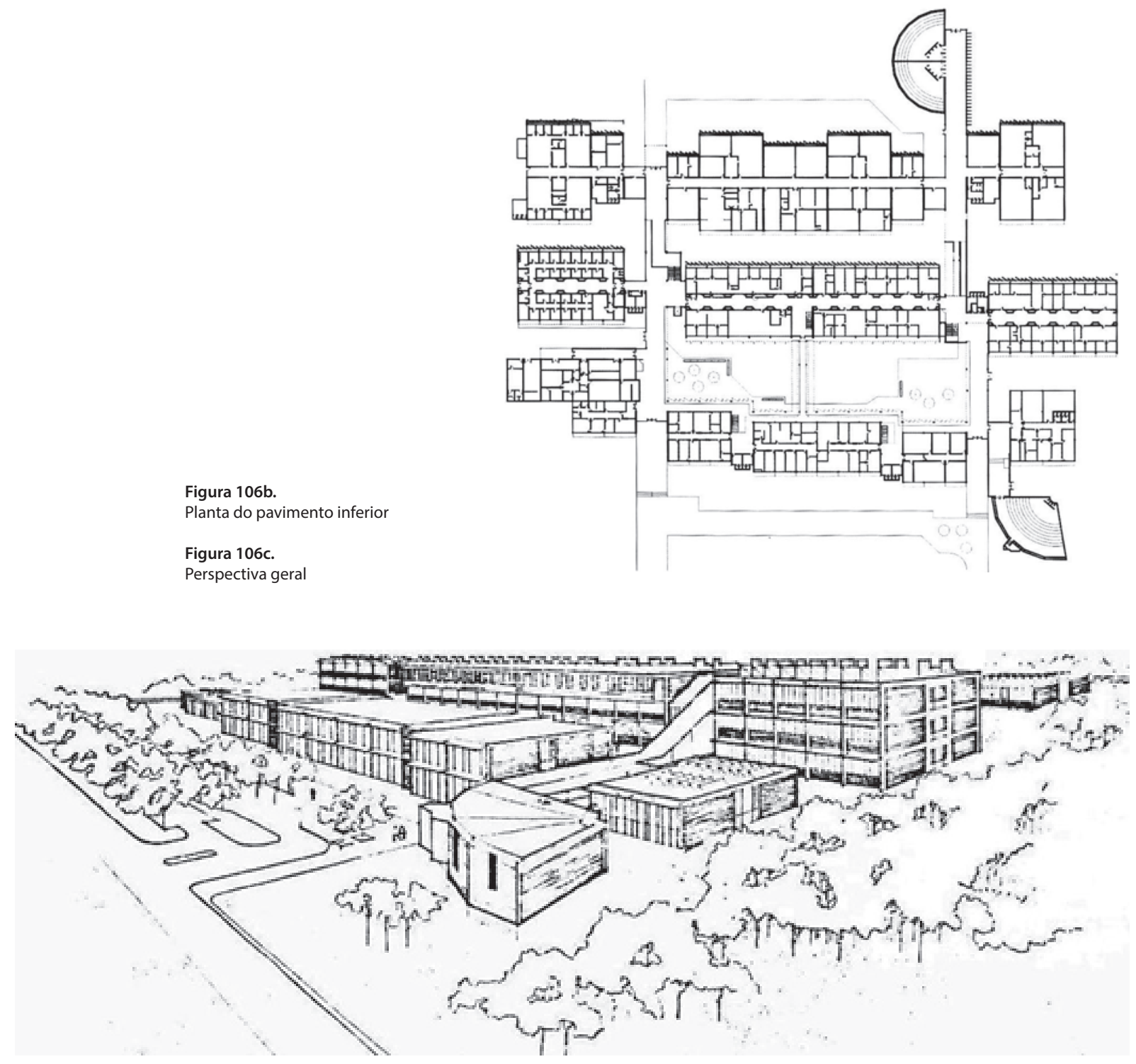


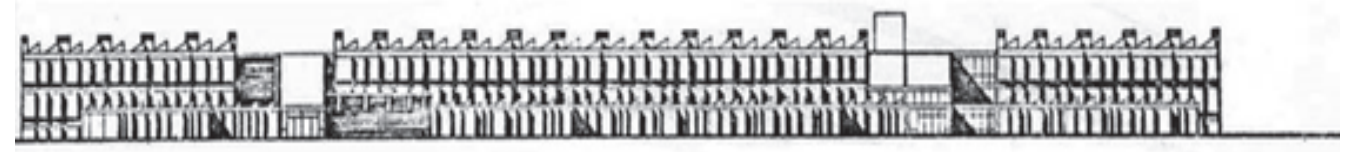

Fachada Sudoeste

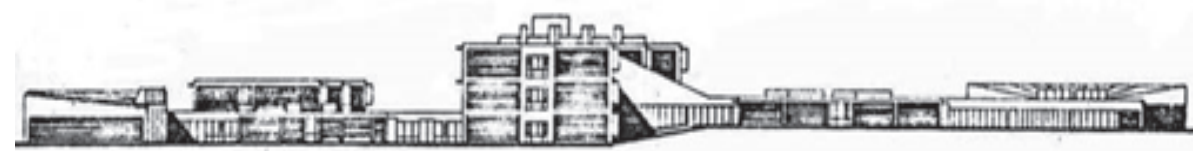

Fachada Noroeste

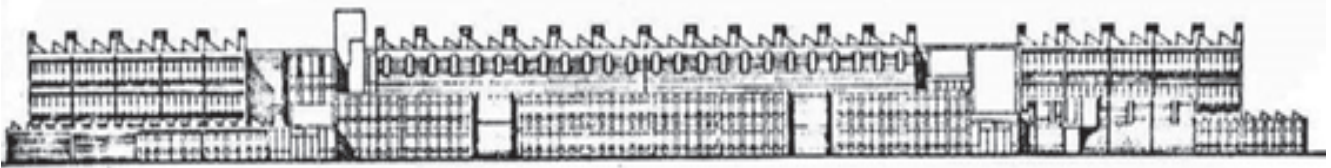

Fachada Nordeste

Figura 106d.

Fachadas.

Figura 106e.

Vista da fachada

Oeste
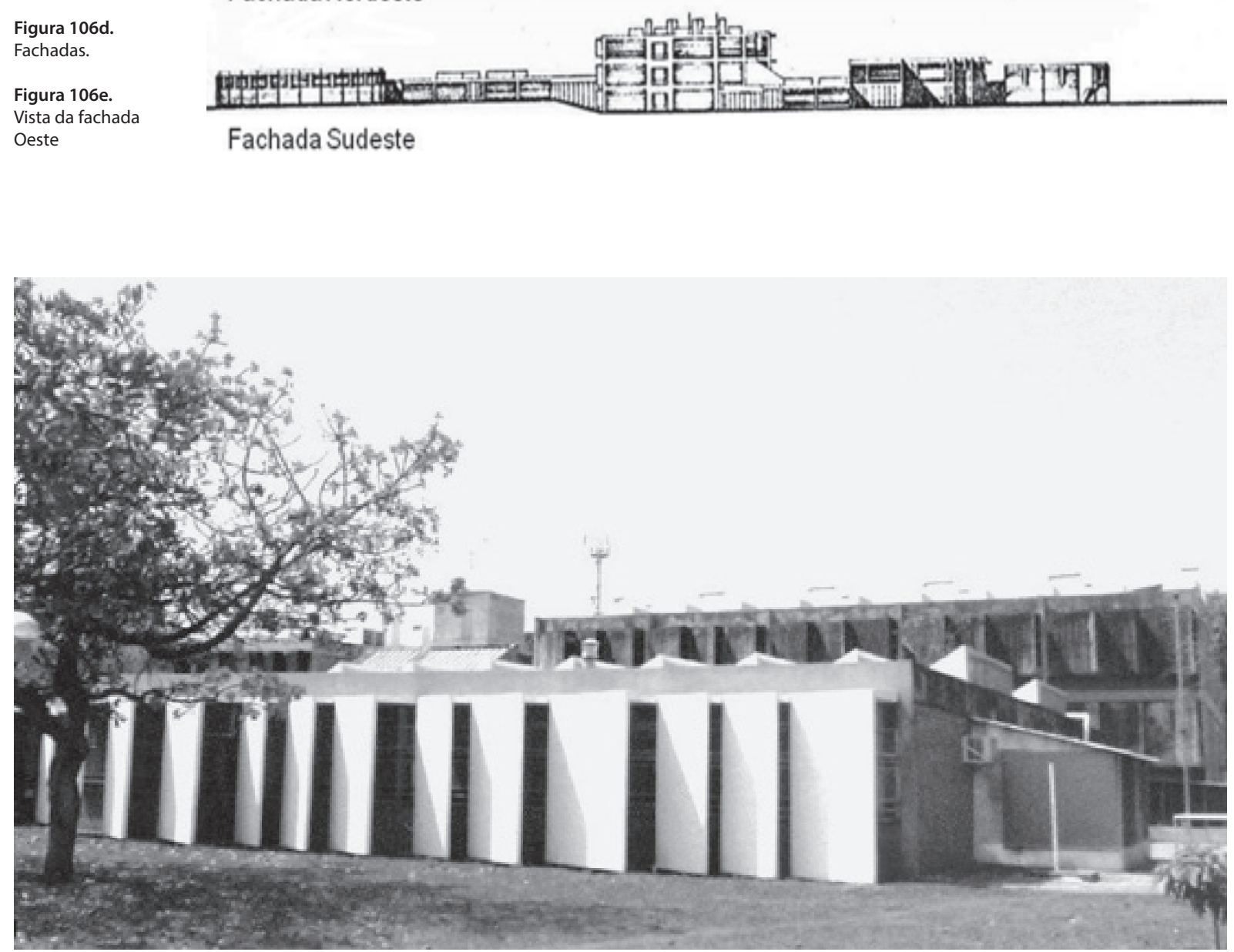

Todo o complexo foi erguido em estrutura de concreto armado com vedações externas em alvenaria de tijolo aparente. A volumetria é marcada ainda pelo emprego de sistemas de proteção solar e de iluminação zenital do tipo shed. 
SUPERQUADRA 206 NORTE - Blocos A, B, C, D, E, F, G, H, I, J, K

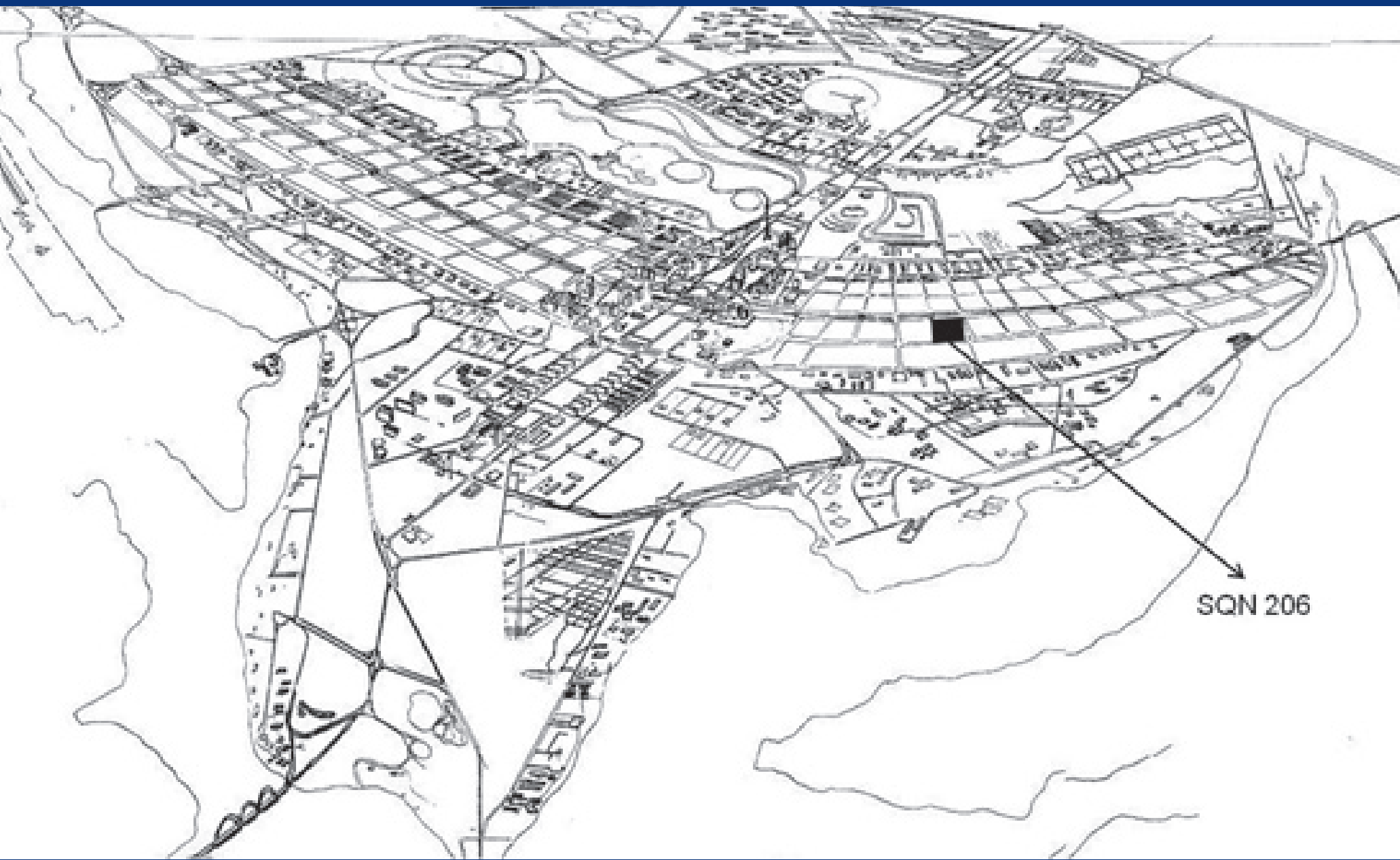

Autoria

Marcílio Mendes Ferreira e Takudoo Takada. O projeto estrutural é de Stênio Moreira de Deus.

Data

1974 (projeto)

1975/1977 (obra)

Área Construída

$6.990 \mathrm{~m}^{2}$ por bloco. Total $76.895 \mathrm{~m}^{2}$
Figura 107a.

Implantação da

SQN 206. Desenho

de Eliel Américo

Santana da Silva 
A superquadra ${ }^{2}$ foi construída para abrigar apartamentos funcionais destinados à moradia de servidores da Fundação Universidade de Brasília (FUB) e da Caixa Econômica Federal. Formada por 11 blocos residenciais, com seis pavimentos sobre pilotis e garagem subterrânea, a superquadra tem um total de 396 apartamentos.

Buscando manter as características dos blocos residenciais projetados no início de Brasília, os prédios apresentam linhas simples e o uso de brise-soleil, diferenciando-se, no entanto, no que diz respeito aos pilares do térreo, em forma de "V", e aos grandes painéis compostos por elementos pré-moldados que, funcionando como brises, recobrem as fachadas.
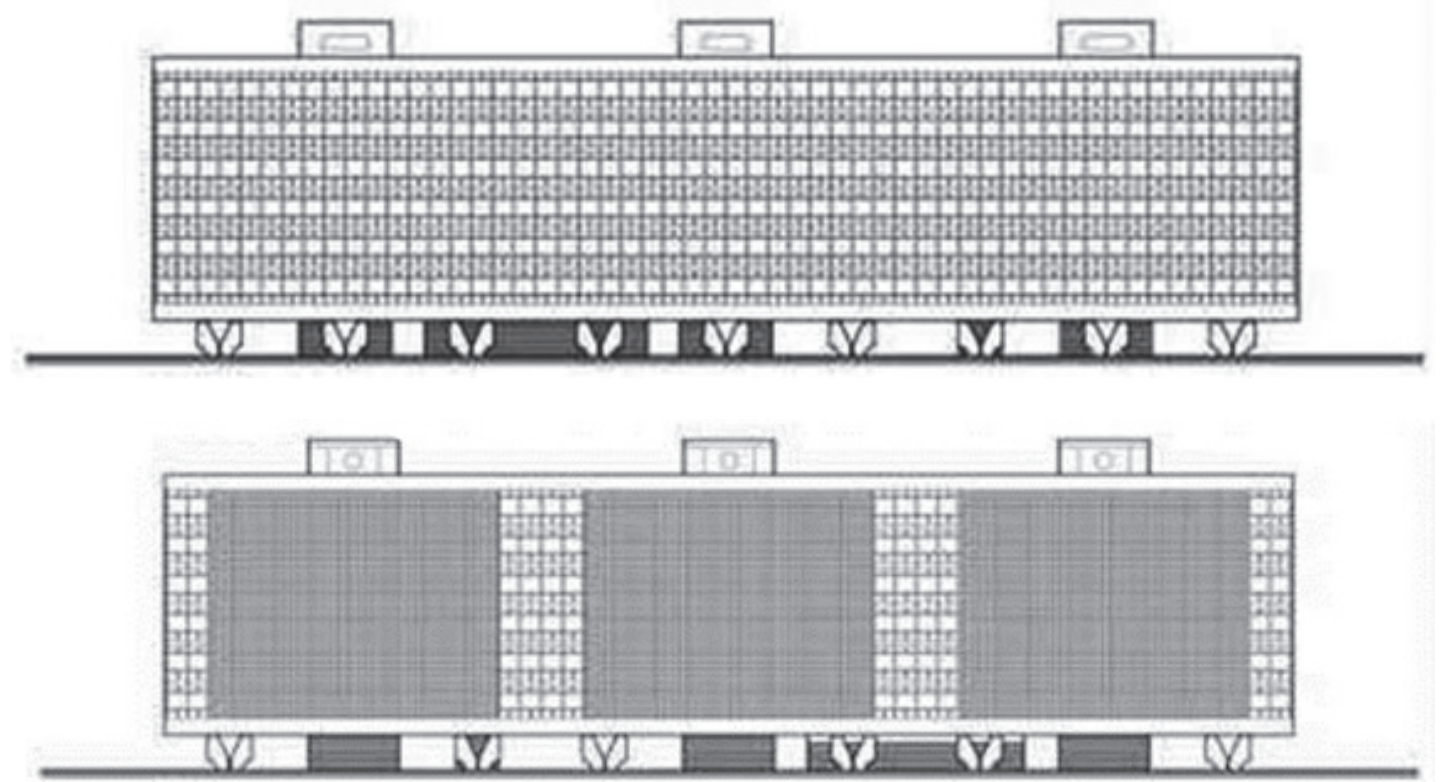

Figura 107b.

Fachada principal

Figura 107c.

Fachada posterior

Figura 107d.

Corte transversal

Figura 107e.

Fachada lateral

Figura 107f.

Planta do pavimento tipo

Figura 107g.

Planta do pilotis
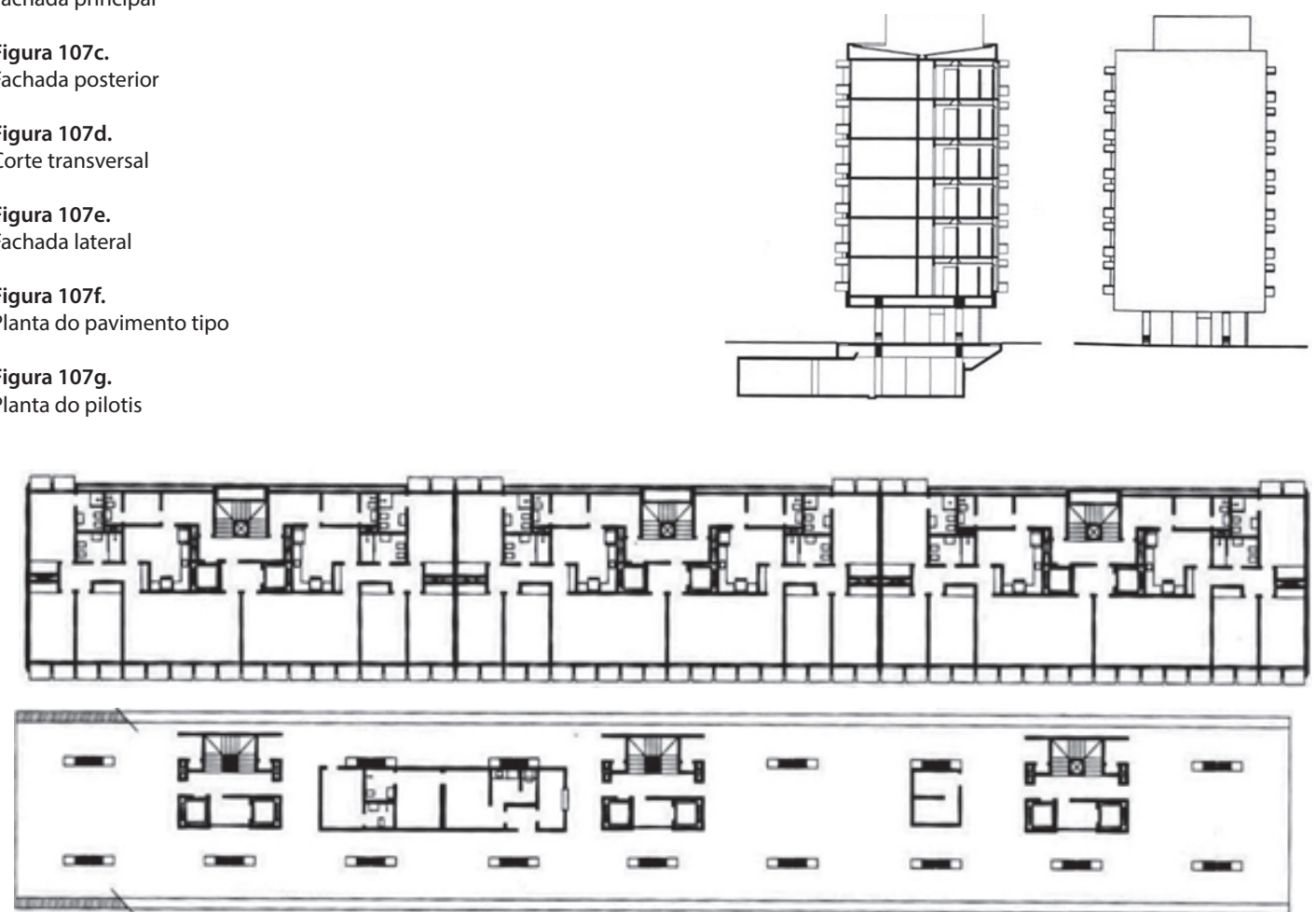

2 Embora o projeto não tenha sido feito oficialmente no âmbito do Ceplan, e sim da Caixa Econômica Federal, da qual o autor era funcionário, optou-se por 
A fachada principal é totalmente protegida por brises, ao passo que a outra fachada longitudinal recebe cobogós, nas áreas de cozinha e serviços, e brises na parte correspondente aos quartos. Os grandes panos de cobogós, de concreto aparente, apresentam, por sua vez, um desenho similar ao dos brises, também de concreto aparente, porém com peças bem menores.
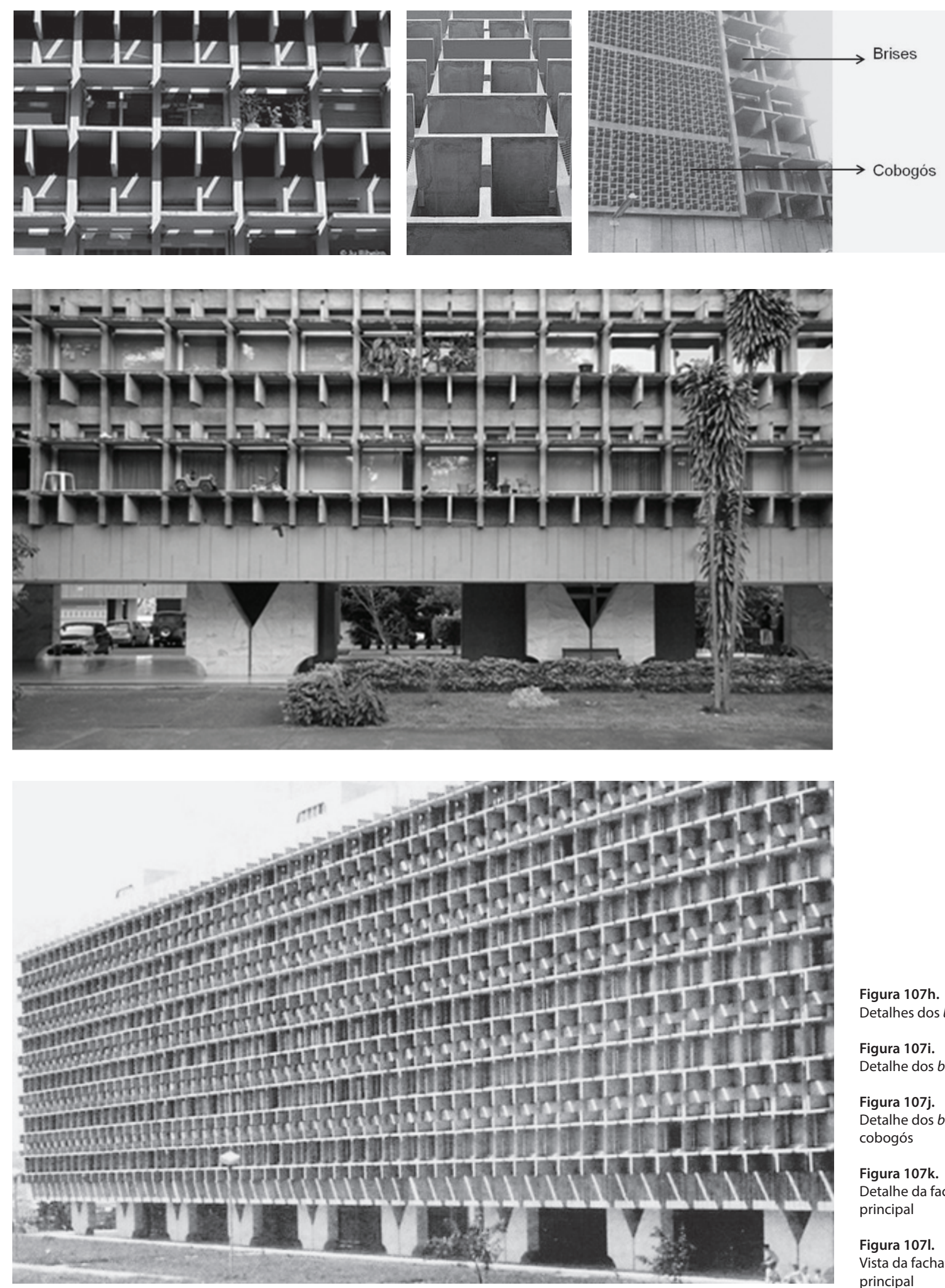

Figura 107h.

Detalhes dos brises

Figura 107i.

Detalhe dos brises

Figura 107j.

Detalhe dos brises e cobogós

Figura 107k. Detalhe da fachada principal 
SUPERQUADRA 205 NORTE - Blocos I, J

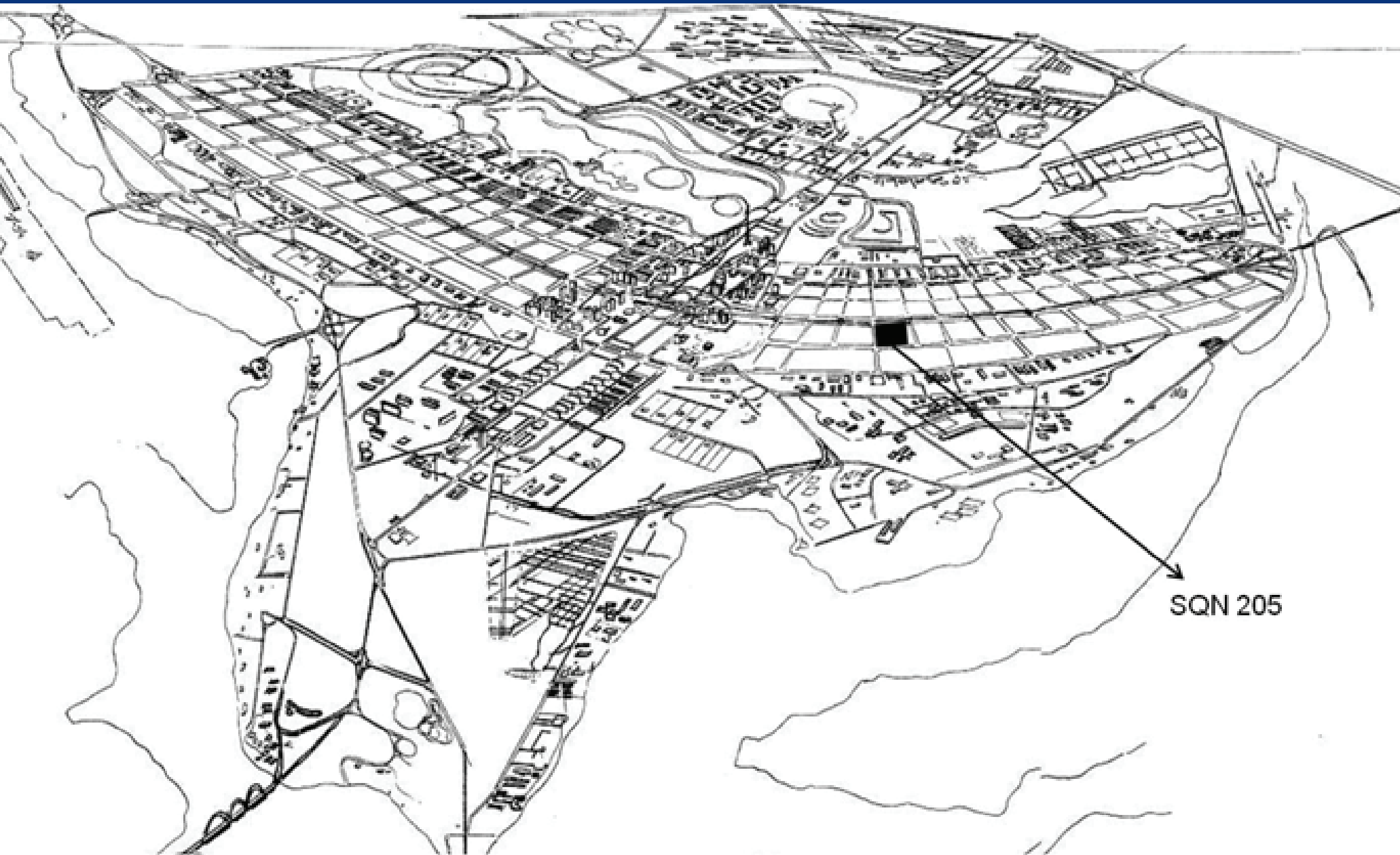

Autoria

Marcílio Mendes Ferreira

Data

1977/1978 (projeto)

1981 (obra)

Área construída

$7.354 \mathrm{~m}^{2}$ por bloco. Total $14.708 \mathrm{~m}^{2}$
Figura 108a.

Implantação da

SQN 205. Desenho

de Eliel Américo

Santana da Silva 
Os edifícios ${ }^{3}$, construídos com o apoio da Caixa Hipotecária do Clube Militar, abrigam apartamentos funcionais destinados à moradia de servidores da Fundação Universidade de Brasília (FUB).

Trata-se de blocos duplos de seis andares sobre pilotis, com garagem subterrânea. Cada apartamento, com 125,45 m², possui ampla varanda, três dormitórios, dois sanitários, lavabo, sala de estar, cozinha e dependências de serviço: lavanderia, quarto e sanitário.

$\mathrm{Na}$ área de pilotis, os pilares apresentam a forma de troncos de pirâmides. Cinco torres de circulação vertical, externas ao volume principal, estão localizadas na fachada Leste, ao passo que a Oeste é marcada pelo ritmo das placas de concreto aparente, à guisa de brises. Os cobogós da fachada Oeste, em concreto aparente, foram confeccionados no próprio canteiro de obra.
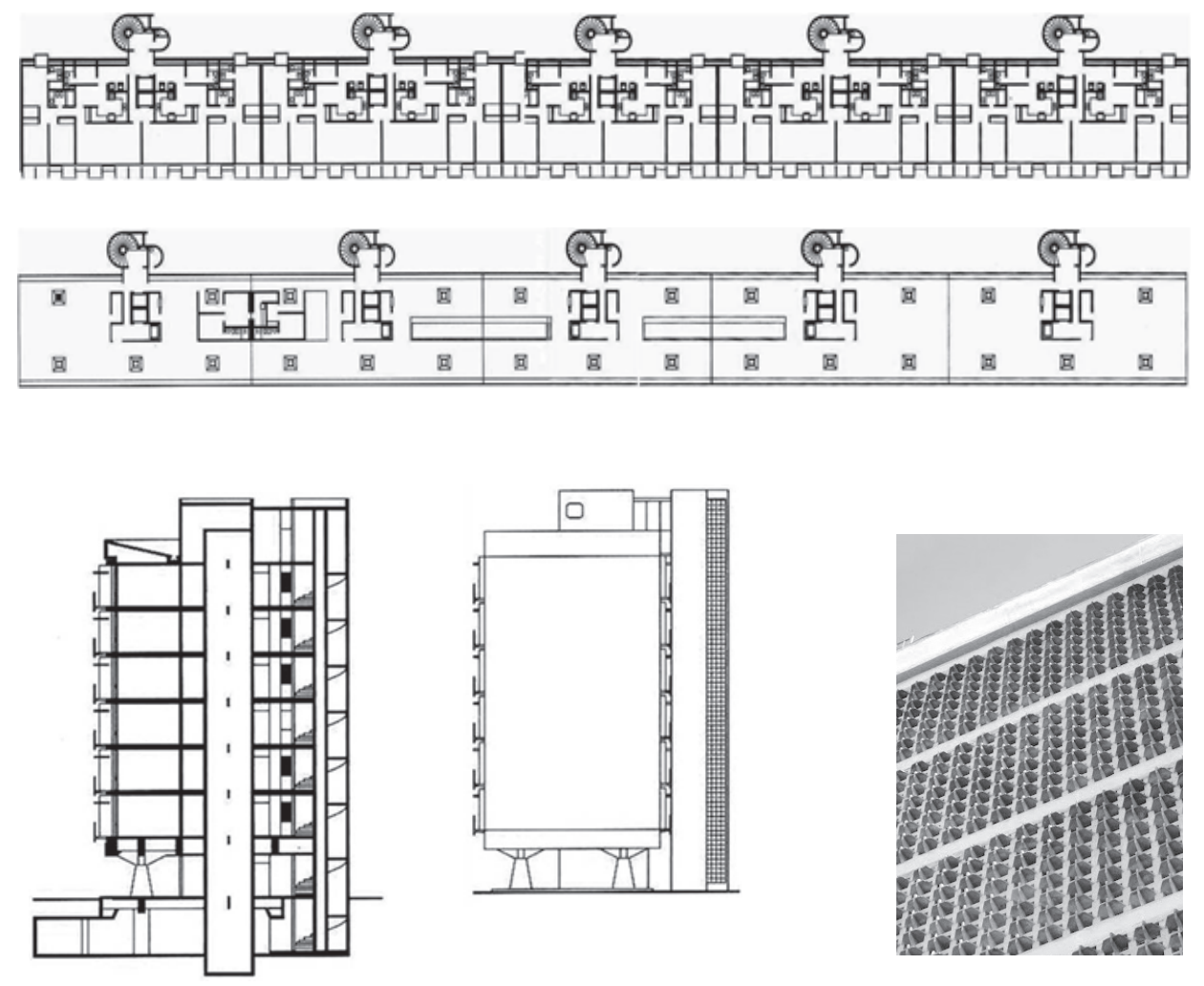

Figura 108b.

Planta do pavimento tipo

Figura 108c.

Planta do pilotis

Figura 108d.

Corte transversal

Figura 108e.

Fachada lateral

Figura $108 \mathrm{f}$.

Detalhe do cobogó da

fachada Oeste

Figura 108g.

Detalhe do pilotis

Figura 108h

Vista da fachada Oeste

do Bloco J
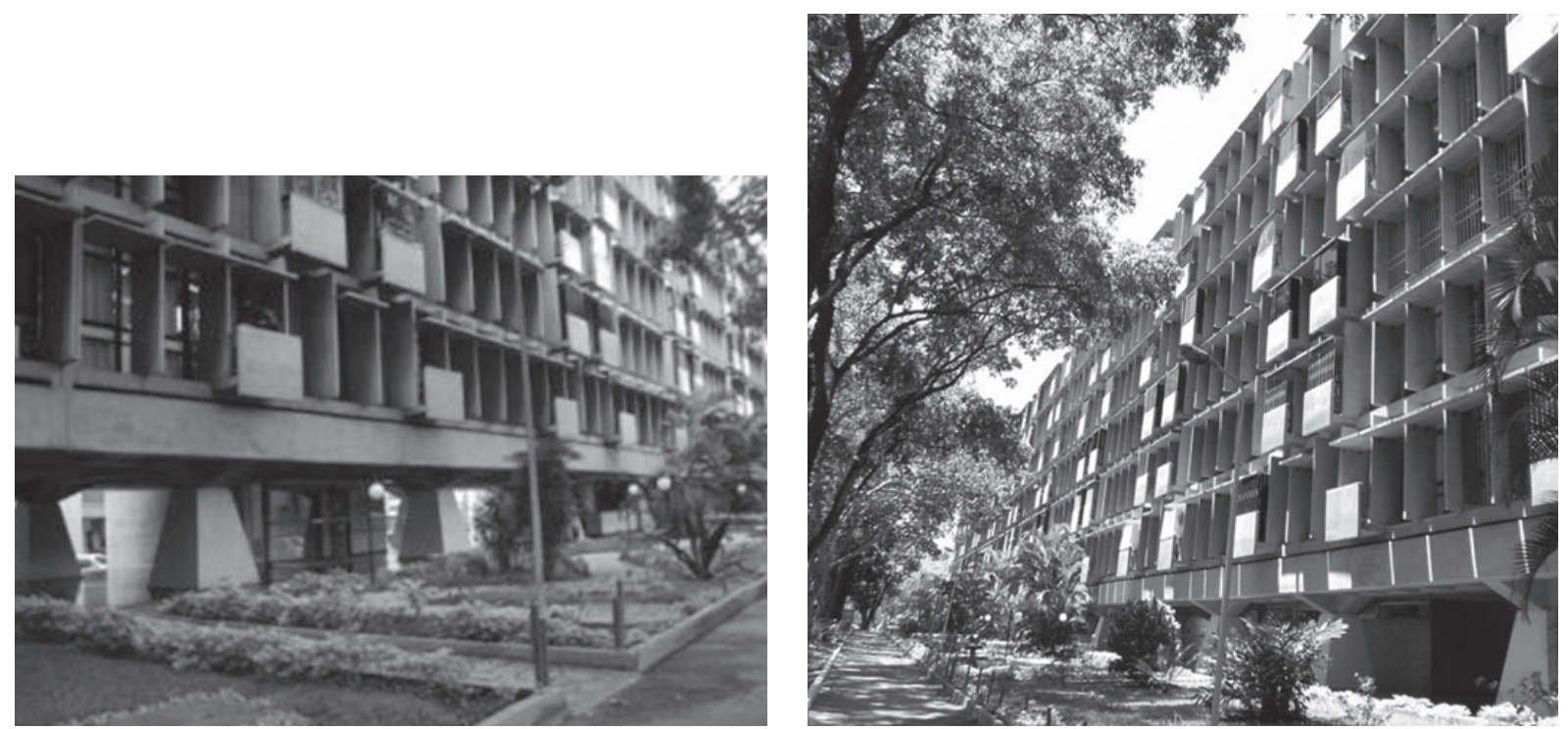

${ }^{3}$ Embora o projeto não tenha sido feito oficialmente no âmbito do Ceplan, e sim da Caixa Econômica Federal, da qual o autor era funcionário, optou-se por registrá-lo aqui tendo em vista que pertence à Fundação Universidade de Brasília (FUB) e abriga muitos dos seus servidores. 
FACULDADE DE ESTUDOS SOCIAIS APLICADOS (FA), ATUAL FACULDADE DE DIREITO (FD)

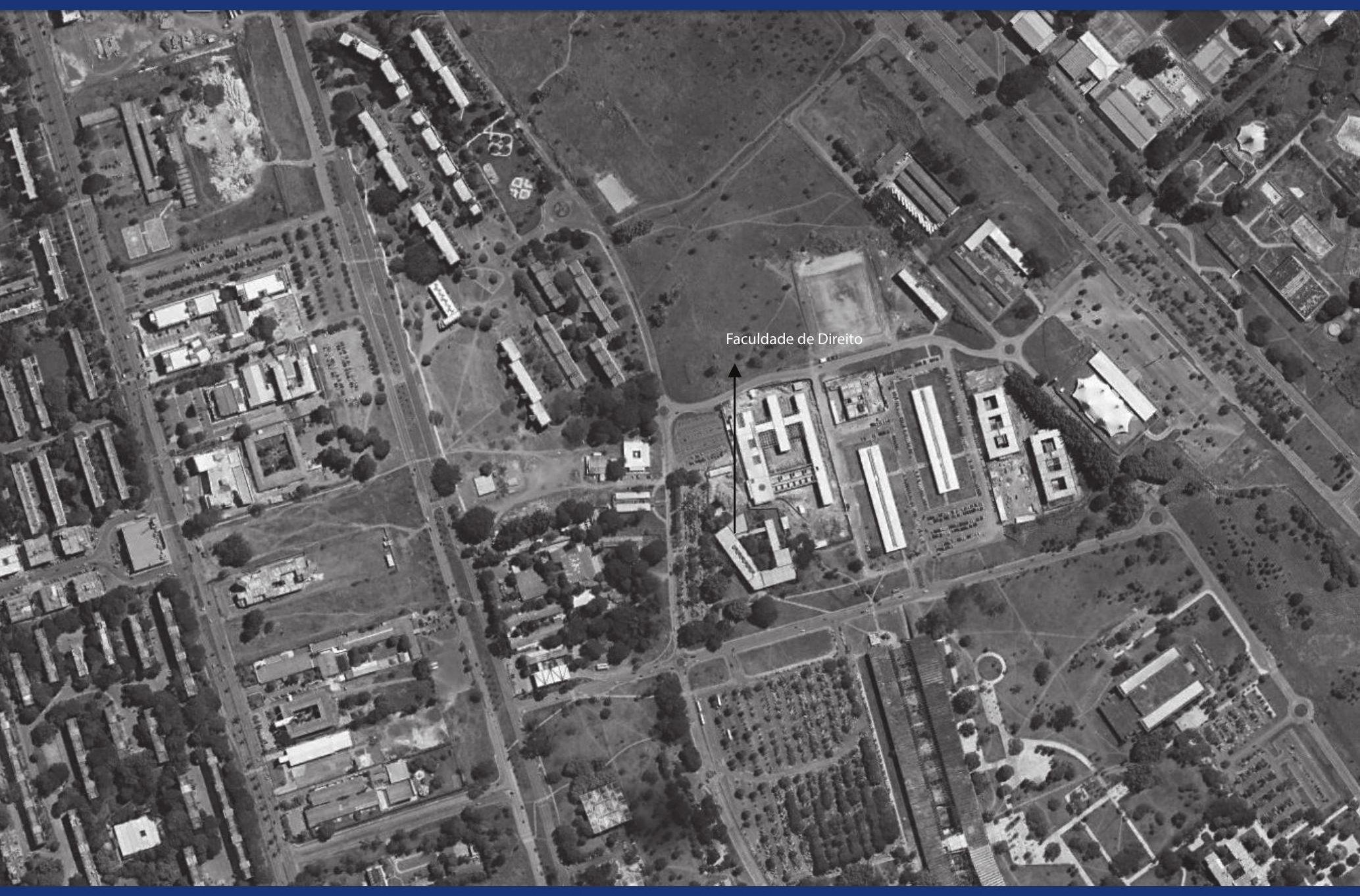

Autoria

Matheus Gorovitz, com a colaboração de Maurício Azeredo

Data

1978 (projeto)

Área Construída

$6.912 \mathrm{~m}^{2}$
Figura 109a.

Implantação da

Faculdade de

Estudos Sociais

Aplicados (FA),

de Direito (FD) 
Embora o curso-tronco de Direito-Administração-Economia tenha começado em 1962 e em 1970 tenha sido criada a Faculdade de Estudos Sociais Aplicados (FA), somente em 1982 foram construídas suas instalações específicas. Em 1994, foram criados a Faculdade de Direito (FD) e o Instituto de Ciência Política e Relações Internacionais (IPR), processo que culminou, em 2004, com a extinção da Faculdade de Estudos Sociais Aplicados e a criação da Faculdade de Economia, Administração, Contabilidade e Ciência da Informação e Documentação (Face). Em 2003, o IPR foi extinto, tendo sido criados o Instituto de Ciência Política (Ipol) e o Instituto de Relações Internacionais (Irel).

O conjunto edificado é composto de três blocos em concreto aparente, dois dos quais paralelos a vias internas do campus. O primeiro bloco, em forma de " $\mathrm{L}$ ", abriga a administração e as salas de professores; o segundo, de planta retangular, contém as salas de aula; e o terceiro, um polígono irregular em planta, contém o auditório. A circulação, contígua aos blocos, abre-se para o pátio central, que apresenta um piso rebaixado em relação ao nível do espaço edificado.

As fachadas externas são marcadas por placas de concreto aparente: painéis horizontais na fachada Leste e grandes abas na fachada Oeste.

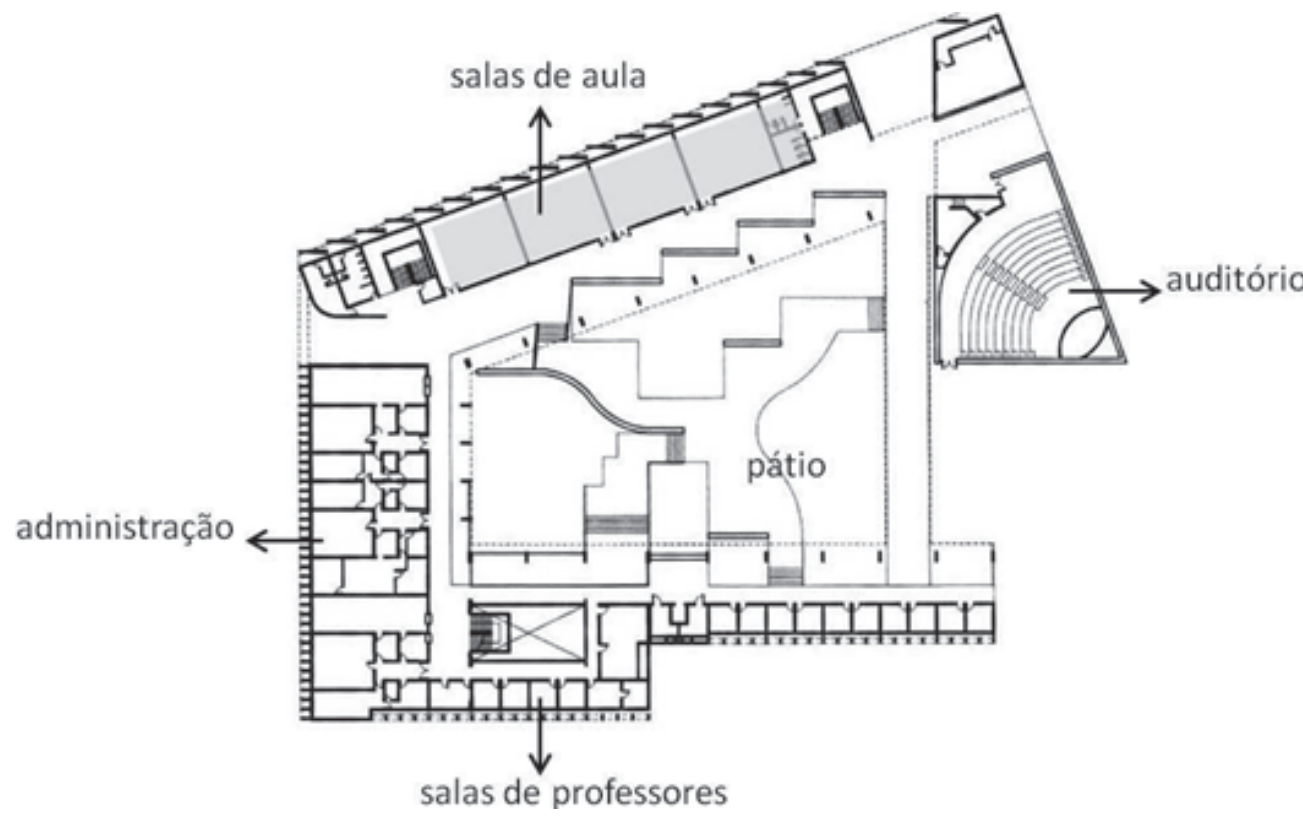

Figura 109b. Planta esquemática

Figura 109c. Detalhe dos brises

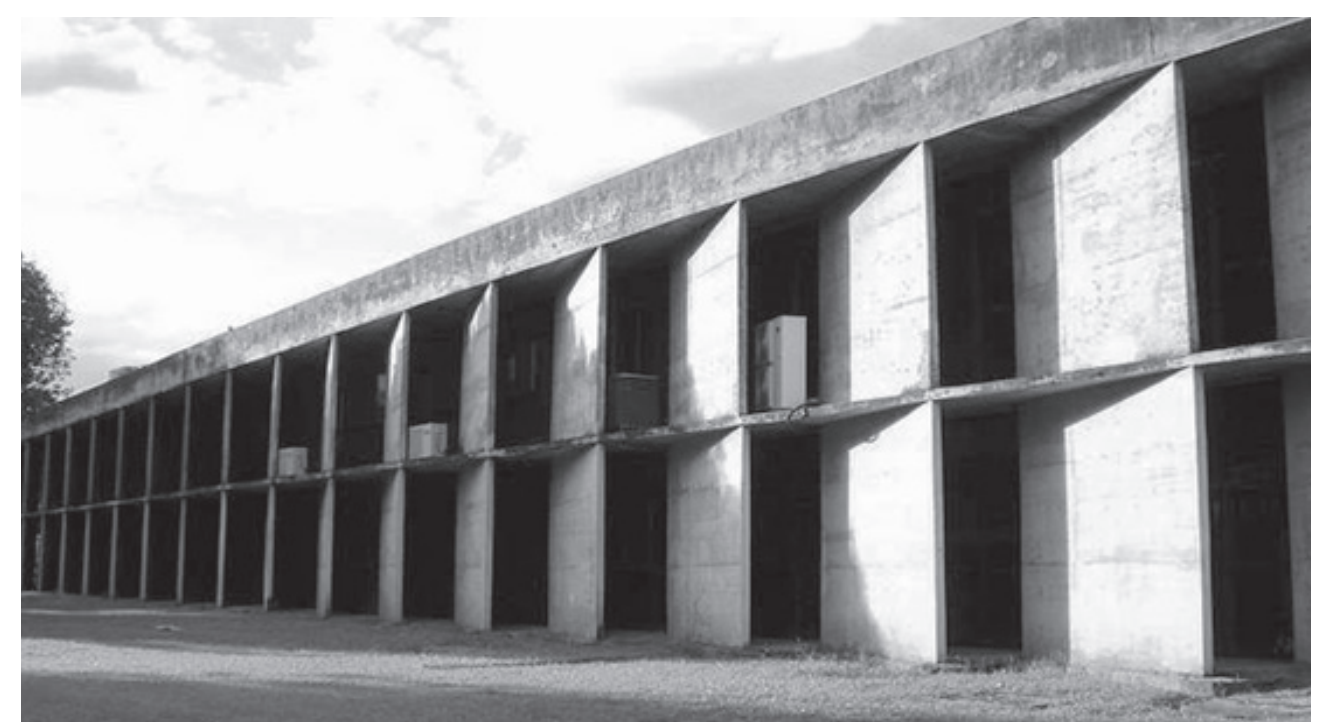


No segundo piso, uma passarela metálica faz a ligação entre o bloco de aulas e o de administração/ professores.
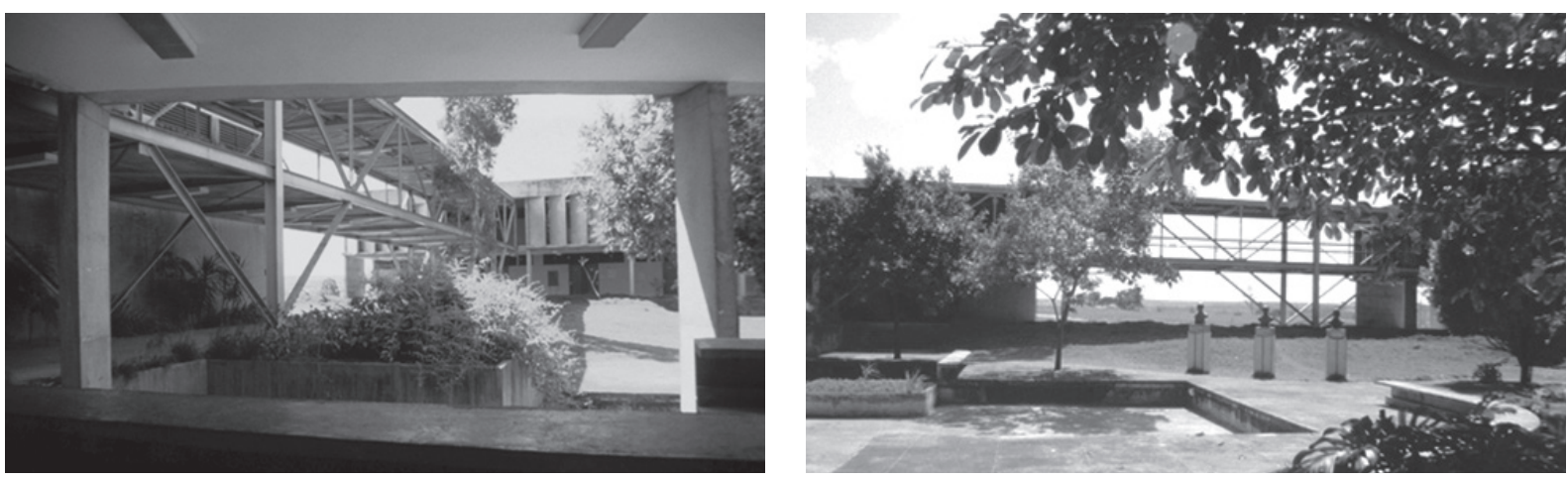

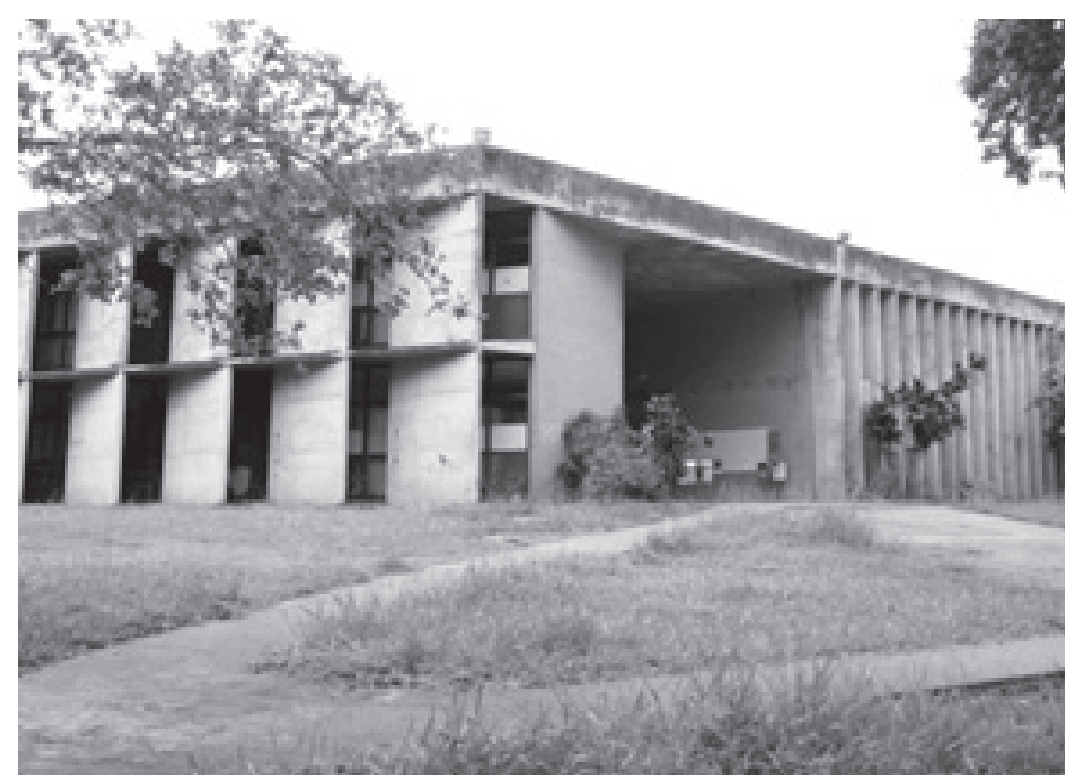

Figura 109d.

Vista do pátio interno

com a passarela

metálica

Figura 109e.

Vista do pátio interno

com a passarela

metálica ao fundo.

Fotos de Julio Katinsky, década de 1980

Foto $109 f$.

Vista das fachadas Oeste e Sul

Figura 109g

Vista do acesso Sul

Figura 109h.

Entrada principal,

fachada Sul. Fotos de

Julio Katinsky, década

de 1980 
FACULDADE DE ESTUDOS SOCIAIS APLICADOS

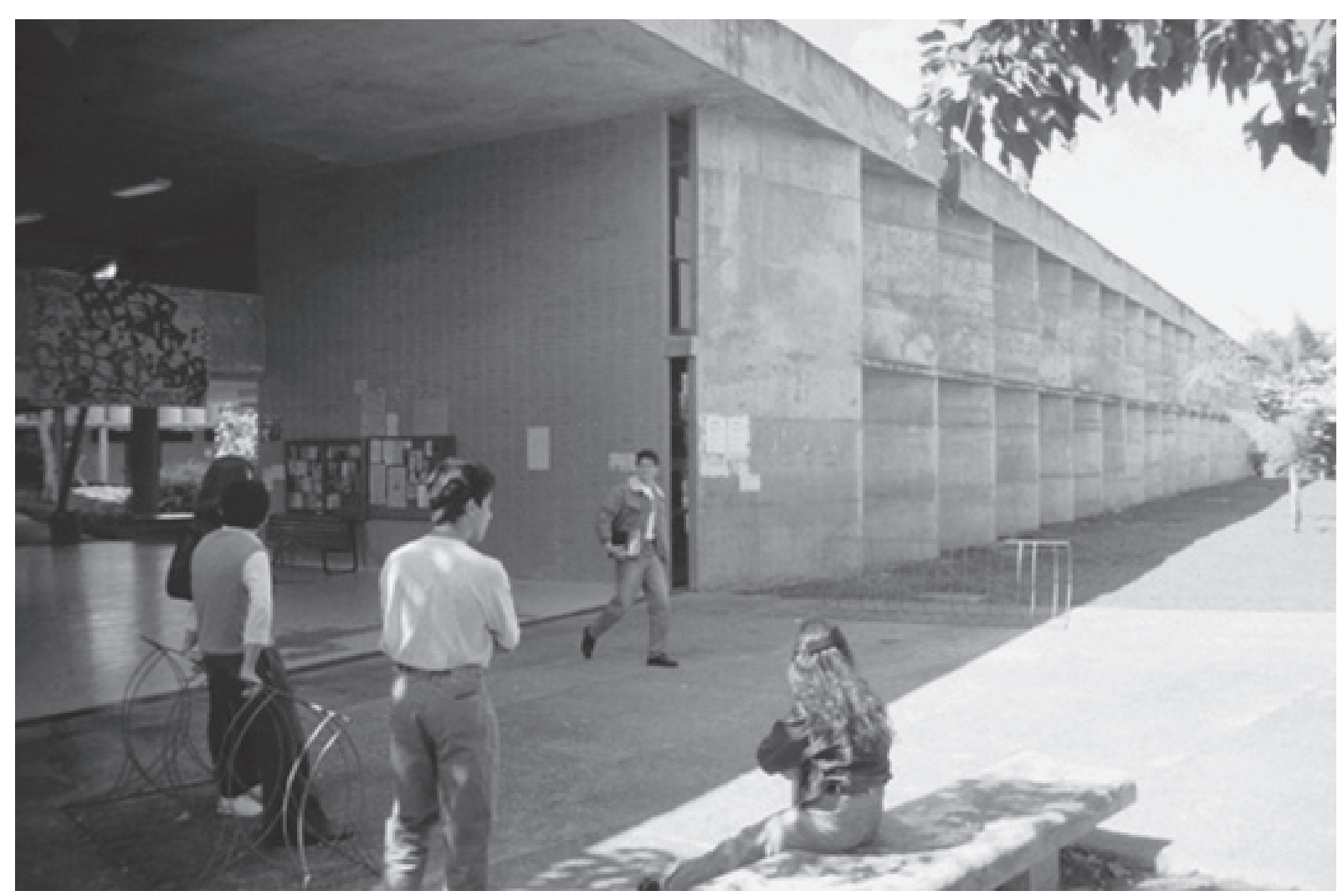





\section{O TEMPO DE REDEMOCRATIZAÇÃO}

A UnB é produto da vontade de revolucionar a sociedade brasileira, está na hora de retomarmos isso. Derrubar o muro do atraso, derrubar o muro da desigualdade, eram sonhos de Darcy. Longa vida à UnB!

Cristovam Buarque, discurso em homenagem aos 45 anos da UnB. Senado Federal, 25 abr. 2007 



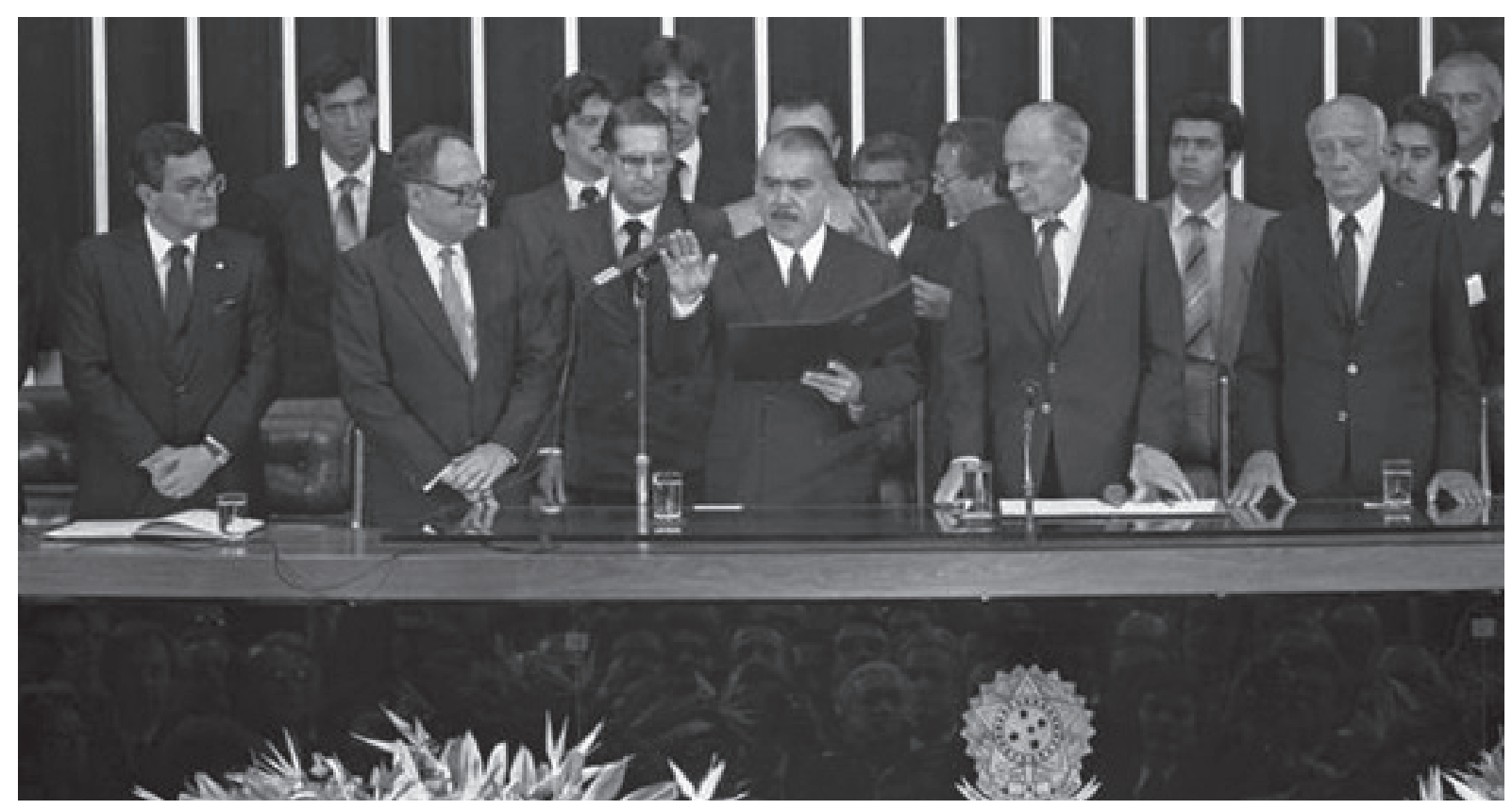

\subsection{Reconquistando as liberdades}

Ao tomar posse, José Ribamar Ferreira de Araújo Costa, ou José Sarney, como se fez conhecer, Figura 110. anunciou as mudanças a serem implementadas pelo seu governo no sentido de consolidar o pro- Passe de cesso de redemocratização. Já em maio de 1985 foi aprovada a emenda constitucional que es- Congresso tabeleceu eleições diretas para presidente, prefeitos e governadores. Além disso, os analfabetos passaram a ter direito a voto e os partidos comunistas foram legalizados.

Na área da educação, o presidente Sarney foi responsável pela constituição do Grupo Executivo para a Reformulação da Educação Superior (Geres) ${ }^{1}$, baseada na proposta da Comissão de Alto Nível criada pelo então ministro da Educação, Marco Maciel. O projeto foi marcado pelo princípio da racionalização nas universidades, presente na Reforma de 1968. Embora se pretendesse reformular aspectos da lei considerados superados pela conjuntura, não houve nenhuma transformação significativa no ensino em andamento no país.

O relatório Uma Nova Política para a Educação Superior, produzido pela referida comissão, destacou como um dos graves problemas do ensino superior brasileiro a falta de parâmetros para uma política racional de alocação de recursos públicos, capaz de fortalecer as melhores instituições e induzir as demais ao aperfeiçoamento.

Para o Geres, a avaliação de desempenho deveria cumprir um papel importante tanto no controle social da utilização de recursos como no processo de formulação de políticas e de estabelecimento de normas para o sistema educacional, ao passo que a alocação de recursos públicos deveria se dar em função do desempenho, priorizando-se os chamados centros de excelência, instituições com padrões internacionais de pesquisa e produção acadêmica.

Contrário à proposta do governo, o movimento docente chamou a si o processo de discussão sobre a reestruturação do ensino superior, com o

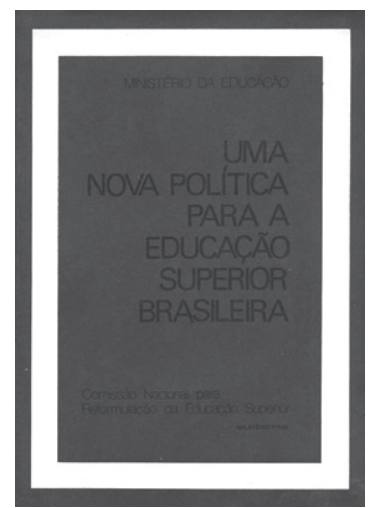


simpósio "O Público e o Privado, o Poder e o Saber: a universidade em debate", a categoria ganhou força. A pauta definida durante o Seminário de Olinda, em 1985, deu origem à Proposta das Associações Docentes e da Andes para a Universidade Brasileira, que previa um padrão unitário de qualidade para o ensino superior.

Buscando a ampliação e a legitimação do debate, a Associação Nacional de Docentes do Ensino Superior (Andes) a Ordem dos Advogados do Brasil (OAB), a Sociedade Brasileira para o Progresso da Ciência (SBPC) e a Associação Brasileira de Imprensa (ABI) celebraram um acordo para a reestruturação das universidades no Brasil baseado nos seguintes princípios:

\begin{abstract}
Manutenção e ampliação do ensino público e gratuito; autonomia e funcionamento democrático da universidade com base em colegiados e cargos de direção eletivos; estabelecimento de um padrão de qualidade para o ensino superior, estimulando a pesquisa e a criação intelectual nas universidades; dotação de recursos públicos orçamentários suficientes para o ensino e pesquisa nas universidades públicas; criação de condições para a adequação da universidade à realidade brasileira, garantia do direito à liberdade de pensamento nas contratações e nomeações para a universidade, bem como no exercício das funções e atividades acadêmicas (ANDES, 1986, p. 2).
\end{abstract}

No âmbito da UnB, o início da década de 1980 também foi marcado pelo processo de redemocratização. Em julho de 1984, o professor Cristovam Ricardo Cavalcanti Buarque tornou-se o primeiro reitor eleito pela comunidade universitária, a qual apostava na possibilidade de se libertar do conservadorismo e de reconquistar para a UnB o status de instituição de vanguarda. Para a nova administração da UnB, tratava-se de revitalizar o ensino, a pesquisa e a extensão. O semestre letivo foi ampliado, foram criadas matérias de módulo livre e foi adotado um sistema informatizado para a matrícula em disciplinas.

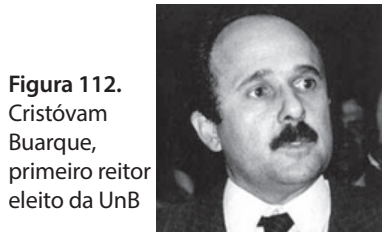

Além disso, Cristovam reincorporou os professores que participaram da demissão coletiva em 1965, e a capacitação docente passou a ser considerada prioridade: nos dois primeiros anos de sua gestão, o número de docentes em programas de treinamento e capacitação aumentou em 50\%. Em apenas cinco anos, o número de vagas de graduação aumentou de 210 para 1.035 , e o número de disciplinas ofertadas passou de 1.549 para 2.089. Com o programa de apoio à pesquisa, a produção científica da UnB cresceu 105\% entre 1985 e 1986, e 68\% entre 1986 e $1987^{2}$.

Nesse período, foram instituídos ainda na UnB os núcleos temáticos, em que as demandas brasileiras eram abordadas com olhar multidisciplinar. Essa estrutura previa o encontro de pesquisadores de diversas áreas em busca de soluções para os desafios do país.

Um reitor eleito, ou mais especificamente a forma de gestão em um regime democrático, passaria a interferir diretamente no funcionamento e na produção do Ceplan, conforme observou Érico:

Quando a UnB passa a eleger seus dirigentes, o relacionamento referido anteriormente muda. Inicialmente diria que os erros passam a ser compartilhados. Ou, seja "o cliente" não é mais sua majestade, nem o autor dos projetos é o detentor das certezas sobre o que é bom ou não para a Universidade. É fundamental essa responsabilidade compartilhada peculiar na atitude democrática (WEIDLE, entrevista em 7 dez. 2011).

${ }^{2}$ www.unb.br/sobre/principais_capitulos/redemocratizacao 

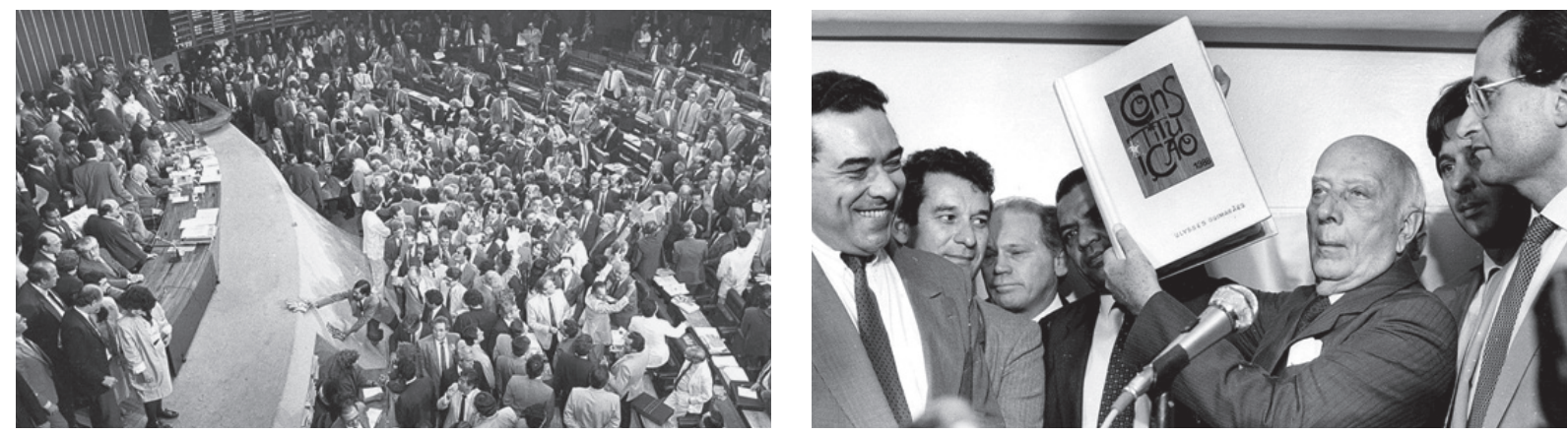

Em 1986, após um período de 12 anos sem investimentos significativos no planejamento físico Figura 113a. da UnB, foi criada a Prefeitura do Campus, que, tendo à frente o professor e arquiteto Érico Paulo Siegmar Weidle, deveria arcar com as funções de planejamento e manutenção de suas edificações, dentro e fora do campus.

os trabalhos da Assembleia set. 1988

Data dessa época a construção do Pavilhão Multiuso I (PM I), de autoria de Érico Weidle e Rogério Carvalho de Melo Franco, e do PM II, projetado por Paulo Renato Silveira Bicca, Alberto Alves de Faria e Luís Otávio Alves Rodrigues. Cabe chamar a atenção para o fato de que esses pavilhões foram as primeiras edificações Figura 114b. Ulysses

Guimarães exibindo cópia da em aço feitas no campus da UnB. A opção pode ser justificada pela queda do preço do aço no mercado Federal de nacional, possibilitada pelo acentuado avanço da produção siderúrgica no Brasil na década de $1980^{3}$.

Paralelamente, entre 1987 e 1988, equipe coordenada pelo professor e arquiteto Gunter Kohlsdorf, então à frente da Prefeitura do Campus, desenvolveu o trabalho intitulado Ideia de Desenvolvimento Físico Espacial do Campus da UnB, visando atualizar aspectos da realidade urbana da cidade.

Cabe lembrar que nessa época o Plano Piloto de Brasília era candidato a ser tombado pela Organização das Nações Unidas para a Educação, a Ciência e a Cultura (Unesco) como Patrimônio da Humanidade. Marco da arquitetura e do urbanismo modernos, Brasília, detentora da maior área tombada do mundo - 112,25 km² -, foi inscrita na lista do Patrimônio Mundial em 7 de dezembro de 1987. É o único bem contemporâneo a merecer essa distinção.

Em 1988 Paulo Zimbres, Alberto Faria e outros elaboraram o"Planejamento da extremidade sul do campus", que definiu um novo plano viário e elementos de ocupação do setor, que viriam a ser confirmados por estudos realizados nos anos seguintes.

Segundo consta do Plano Diretor Físico do Campus Universitário Darcy Ribeiro (1998), marca os primeiros anos da Prefeitura do Campus a construção de edifícios multifamiliares nas superquadras norte 109, 309 e 310, de propriedade da Fundação Universidade de Brasília.

Como parte do processo de redemocratização nacional, em $1^{\circ}$ de fevereiro de 1987 tomou posse a Assembleia Constituinte que, presidida por Ulysses Guimarães, estava encarregada de elaborar uma nova Constituição para o país. Controvérsias à parte, a Constituição Federal de 1988 contribuiu para dar maior efetividade aos direitos fundamentais. Reafirmando a mudança no sistema governamental brasileiro, a nova Carta Magna, que refletiu os interesses de diversos grupos da sociedade brasileira à época, qualificou como crimes inafiançáveis a tortura e as ações armadas contra o estado democrático e a ordem constitucional.

${ }^{3}$ O comportamento do mercado siderúrgico nacional na década de 1980 caracterizou-se por um consumo interno que alternava fases de crescimento e redução, pelo acentuado avanço da produção siderúrgica, pela drástica redução das importações e pelo grande aumento das exportações (www.metalica.com.br/o-setor-siderurgico). 
A despeito dos avanços na esfera política, o país sofria com a alta inflação deixada pela ditadura militar e agravada pela crise internacional, o que levou, nos quatro primeiros anos do governo Sarney, ao acionamento de diversos mecanismos de controle econômico que, embutidos nos planos Cruzado I (1985) e II (1986), Bresser (1987) e Verão (1988), iam do congelamento de salários e preços ao aumento dos tributos fiscais. Com o fracasso desses planos, Sarney terminaria o mandato, em 1990, em meio a uma grande recessão econômica.

No âmbito da UnB, de acordo com a Resolução do Conselho Universitário n. 17/1988, o Instituto de Artes e Arquitetura (IAA) foi substituído por duas unidades independentes: o Instituto de Arquitetura e Urbanismo (IA) e o Instituto de Artes (IdA), que reincorporou o Departamento de Música4.

Durante a gestão de Cristovam, que terminou em agosto de 1989, foram construídos ainda seis blocos residenciais na chamada Colina Nova, de autoria de Paulo Marcos de Paiva Oliveira; a Estação Experimental de Biologia (EEB), que passou a abrigar o herbário particular doado pelo ambientalista Ezechias Heringer; e o Centro de Excelência em Turismo (CET), de autoria de Zanine Caldas, inicialmente concebido para sediar o Instituto Nacional de Ensino e Pesquisa (Inep), vinculado ao Ministério da Educação (MEC).

Embora seja dessa época a construção do Laboratório de Termobiologia, o projeto não foi desenvolvido no Ceplan. Criado após a reintegração do professor Luiz Fernando Gouveia Laboriau à UnB, o referido laboratório passou a desenvolver pesquisas voltadas para os efeitos da temperatura em processos biológicos, com destaque para a germinação de sementes.

Novos professores também passaram a integrar a FAU, como Aleixo Anderson Furtado, Antônio Carlos Cabral Carpintero, Cláudia Estrela Porto, Cláudio José Pinheiro Villar de Queiroz, José Manoel Morales Sánchez, Jônio Cintra Oliveira, Marta Adriana Bustos Romero, Neusa Cavalcante e Otto Toledo Ribas.

No final de seu mandato à frente da UnB, Cristovam assinou o Ato da Reitoria n. 208, de 19 de junho de 1989, que aprovou a criação do Ceplan, como um centro de custo vinculado ao Instituto de Arquitetura e Urbanismo (IA), com "[...] a finalidade de promover o desenvolvimento de estudos, planos e projetos nas áreas de arquitetura e urbanismo" (www.ceplan.unb.br/). Essa vinculação institucional do Ceplan era, no entanto, polêmica. Segundo Érico Weidle, em 1989 a ligação institucional do Ceplan à FAU prejudicava o andamento das atividades do centro de planejamento, sobretudo devido aos entraves burocráticos para os repasses de verba, embora esse vínculo tenha sido importante em 1968, quando da reabertura da escola:

O Instituto de Arquitetos do Brasil, que mediou a reabertura, exigiu que a Escola reabrisse tendo um laboratório profissional, o Ceplan como escritório de prática permanente dos professores de arquitetura, que estavam em sua maioria na condição de dedicação exclusiva. Esse vínculo foi vital, como experiência e até como forma de atrair professores, na época oriundos exclusivamente da atividade profissional (WEIDLE, entrevista em 7 dez. 2011).

Fernando Collor de Mello chegou à Presidência da República, em 15 de março de 1990, com um discurso de combate à espiral inflacionária. Para combatê-la, lançou o ousado Plano Brasil Novo, popularmente conhecido como Plano Collor.

Além da substituição da moeda cruzado novo pelo cruzeiro e do confisco dos depósitos bancários superiores a Cr $\$ 50.000,00$ (cinquenta mil cruzeiros) por um prazo de 18 meses, visando reduzir a 

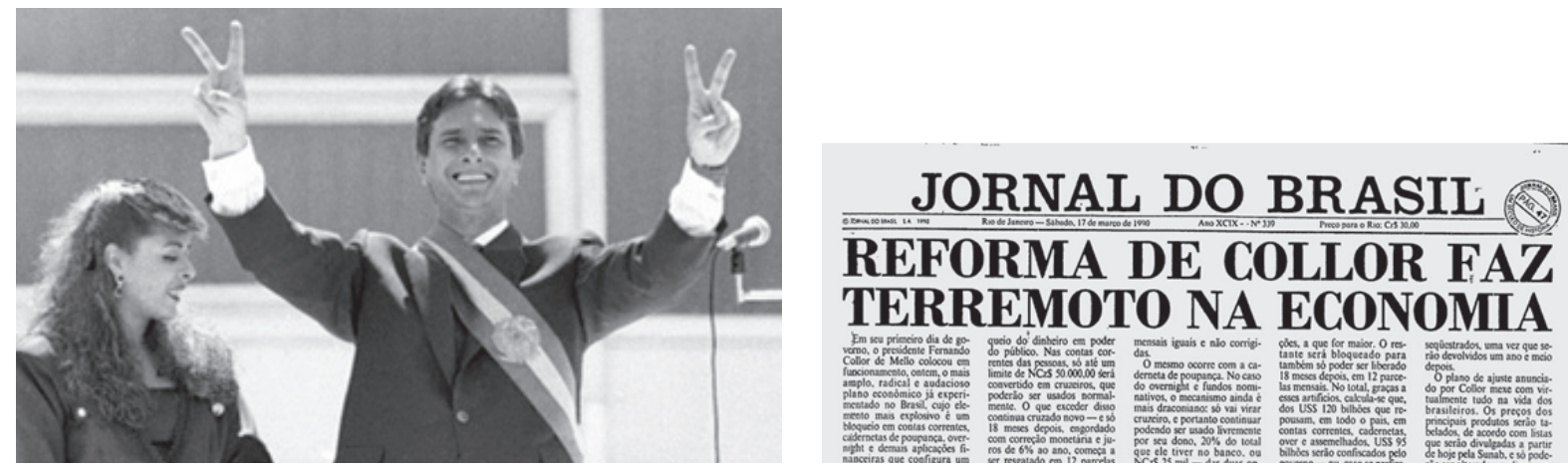

Figura 115.

Posse de

Collor, 15 mar.

1990

Figura 116.

Repercussão

das reformas

de Collor,

17 mar. 1990

quantidade de moeda em circulação, o novo governo promoveu alterações no cálculo da correção monetária e no funcionamento das aplicações financeiras; uma redução da máquina administrativa, com a extinção ou fusão de ministérios e órgãos públicos; a demissão de funcionários públicos; e o congelamento de preços e salários.

Verificou-se ainda um estímulo maior para a implantação do modelo neoliberal, paradigma com o qual o Brasil já vinha se habituando desde a década anterior. Essa nova concepção de mundo levou para dentro das instituições a lógica da produção empresarial, influenciando todos os níveis de educação, principalmente o ensino superior. Causou impacto, nessa época, a divulgação de um projeto de emenda constitucional, de autoria do ministro da Educação José Goldemberg, que pretendia transformar as universidades públicas em uma categoria específica de entidade, perdendo o seu pessoal a condição de funcionário público.

\footnotetext{
No governo Fernando Collor de Mello a concepção de avaliação da educação superior, articulada às demandas da reforma do Estado pauta-se em uma ação centralizadora, autoritária e controladora por parte do Estado em relação às instituições de educação superior. A intenção de incrementar a eficiência e a produtividade das instituições de educação superior preocupa o meio acadêmico. São instituídas as Comissões de Especialistas de Ensino com a incumbência de prestar assessoria à Secretaria de Ensino Superior (SESU) na instalação de um processo permanente de avaliação, acompanhamento e melhoria dos padrões de qualidade do ensino superior (ZAINKO, 2008, p. 829).
}

No entanto, todas as iniciativas governamentais seriam logo paralisadas porque, mais uma vez, o país foi atingido por grave crise política. Entre 1991 e 1992, as denúncias de irregularidades envolvendo pessoas do círculo próximo de Fernando Collor somaram-se às revelações feitas por seu irmão, Pedro Collor de Mello, o que levou à instalação de uma Comissão Parlamentar de Inquérito (CPI) para apurar as responsabilidades do governo sobre os fatos.
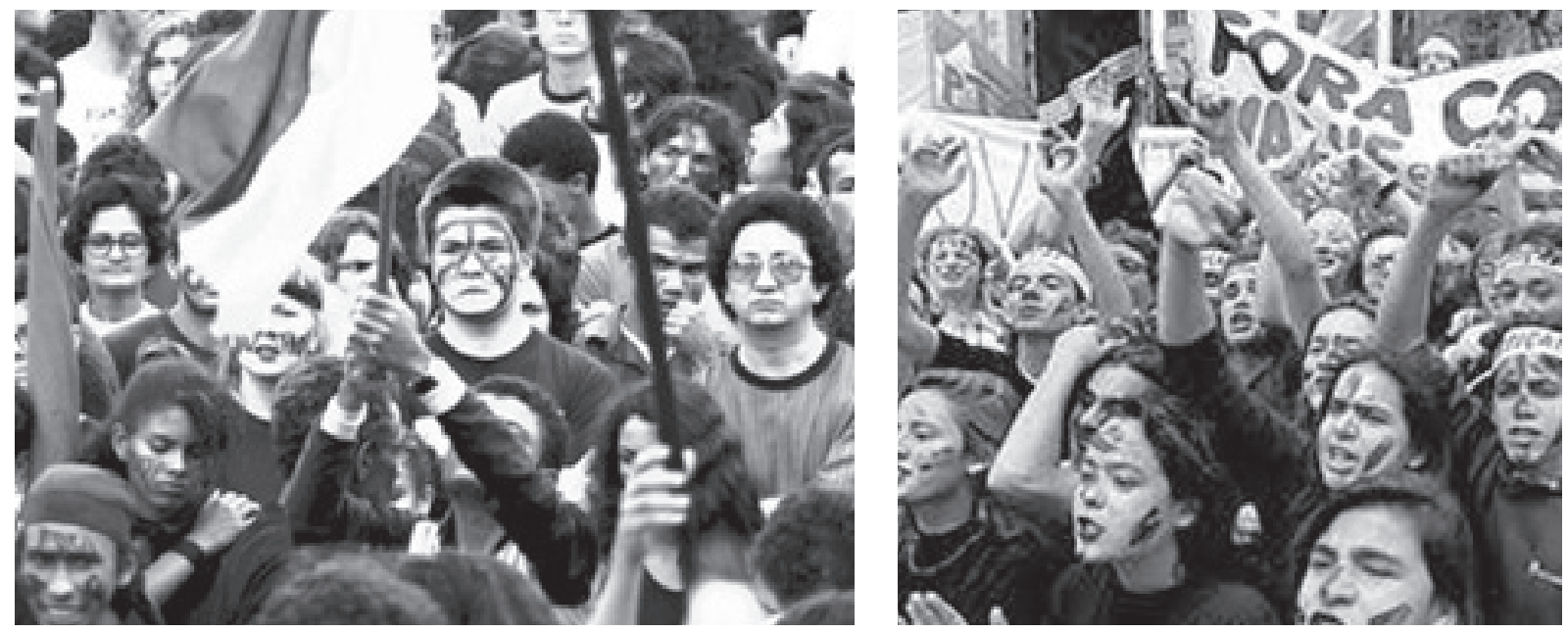

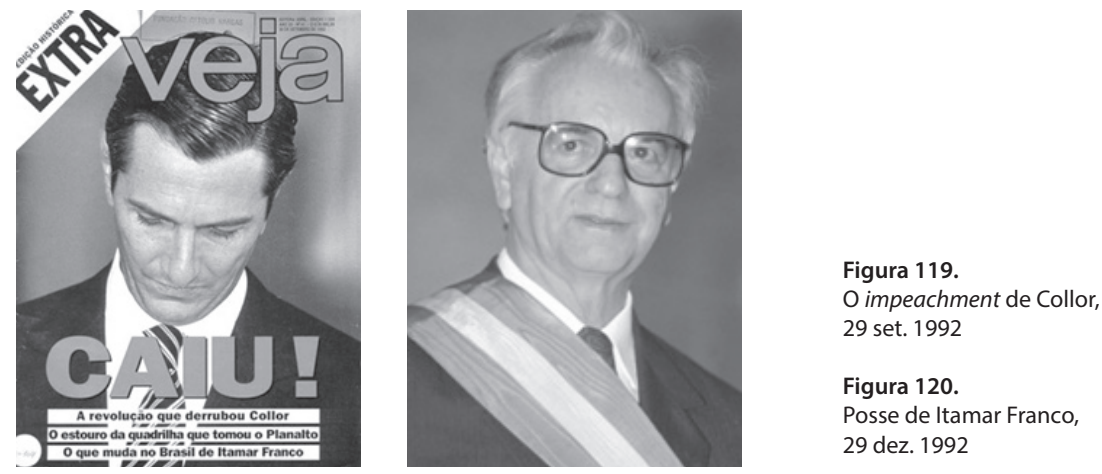

Impulsionado pela maciça presença do povo nas ruas, em um movimento conhecido como caras-pintadas, em 29 de setembro de 1992 foi aprovado, na Câmara dos Deputados, o processo de impeachment do presidente. Com a renúncia de Collor, assumiu o vice Itamar Franco.

Atendendo a uma demanda da própria comunidade acadêmica, o secretário da Educação Superior do MEC, do governo Itamar, criou a Comissão Nacional de Avaliação 5 e o Programa de Avaliação Institucional da Universidade Brasileira (Paiub), com o objetivo de estabelecer diretrizes e viabilizar a implementação do processo de avaliação institucional nas universidades brasileiras (Portaria n. 130, de 14 de julho de 1993).

Na UnB, entre novembro de 1989 e novembro de 1993, durante a gestão do professor Antônio lbañez Ruiz, foram dados alguns passos adicionais na direção da institucionalização do planejamento com a criação, em 1990, da Comissão Permanente do Espaço Físico, presidida pela Prefeitura do Campus, então sob a direção da arquiteta e professora Suely Franco Netto Gonzales. Nesse período foram realizados no Ceplan os projetos do Centro de Vivência, de autoria de Eurico João Salviatti e Nícia Paes Bormann; do Bloco K, na Colina, de Paulo Marcos de Paiva Oliveira e Silvano da Silva Pereira; e do Observatório Sismológico (SIS), de William Ramos Abdala e Alberto Alves de Faria.

Depois de um curto mandato, em que prevaleceu transparência na gestão e uma atitude mais conciliadora, em 15 de março de 1995 Itamar transmitiu o governo para o seu ministro da Fazenda, Fernando Henrique Cardoso, coordenador da equipe responsável pela implantação do bem-sucedido Plano Real, que teve como efeitos a queda da inflação e a estabilidade econômica do país ${ }^{6}$.

Durante o primeiro mandato de FHC, a Reforma Gerencial do Estado causou mudanças significativas nos padrões de intervenção estatal, redirecionando mecanismos, formas de gestão e também políticas públicas. No bojo dessa reforma, Luiz Carlos Bresser Pereira, então titular do Ministério Diferentemente das comissões anteriores, compostas por "notáveis", essa comissão, coordenada pela SESu, reuniu entidades representativas do ensino superior. da Administração e Reforma do Estado (Mare), pretendia transformar as universidades federais em organizações sociais a serem regidas por um contrato de gestão nos moldes das quasi non-governamental organizations (Quangos), difundidas na década de 1980 pelo governo de Margaret Thatcher, na Grã-Bretanha.

Data dessa época a homologação da Lei de Diretrizes e Bases da Educação Nacional (LDBEN-1996, Lei n. 9.394, de 20 dez. 1996) que, segundo Isaura Belloni (2002), ao contrário daquela que a precedeu, não contemplou devidamente o princípio da interação ensino-pesquisa-extensão. De acordo com a autora, ao definir as finalidades e objetivos da educação superior, a referida lei fez constar

Diferentemente das comissões anteriores, compostas por "notáveis", essa comissão, coordenada pela SESu, reuniu entidades representativas do ensino superio ${ }^{6}$ A equipe foi composta pelos economistas Pérsio Arida, André Lara Resende, Gustavo Franco, Pedro Malan, Edmar Bacha, Clóvis Carvalho e Winston Fritsch. 


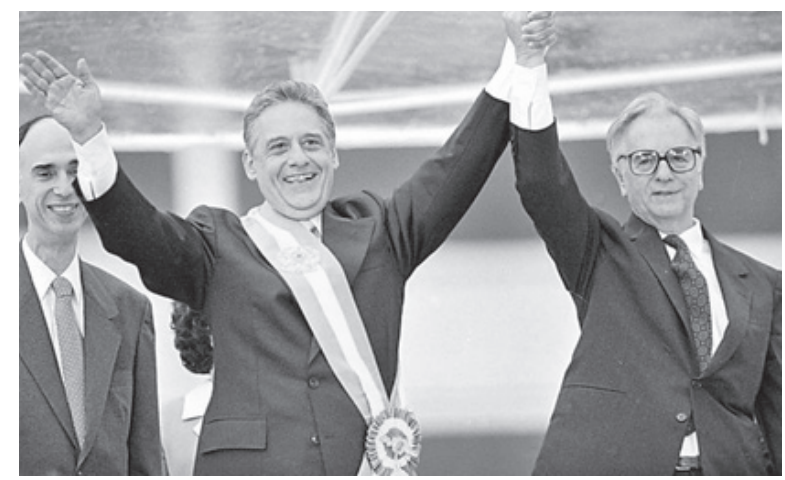

apenas o incentivo ao trabalho de pesquisa, não tendo mencionado, de forma explícita, a função e a obrigação de a universidade realizar ou desenvolver pesquisa e colaborar para o avanço do conhecimento. Além disso, presumiu a possibilidade de universidade especializada por área do saber, subestimando o valor da interdisciplinaridade e das convergências e divergências entre diferentes áreas do conhecimento.

Aproveitando a flexibilidade da LDBEN-1996, o governo sancionou novas regras para a escolha de dirigentes nas universidades federais e instituiu o Exame Nacional de Cursos (ENC), o chamado Provão, com a finalidade de avaliar a qualidade de ensino das instituições de nível superior por meio do desempenho do aluno. Um novo instrumento de avaliação seria criado, dois anos depois: o Exame Nacional do Ensino Médio (Enem), utilizado como ferramenta para avaliar a qualidade do ensino médio do país (Lei n. 9.192, de 23 nov. 1995).

A mais inovadora das propostas do MEC no período, pelo sentido de transformação na configuração do sistema de ensino superior no Brasil, foi consubstanciada no Decreto n. 2.207, de abril de 1997, que reconheceu e estimulou a diversificação das instituições de ensino superior no país. A consolidação desse processo só se daria a partir do Decreto n. 3.860, de 9 de julho de 2001, que alterou as regras de organização do ensino superior e da avaliação de cursos e instituições, definindo novas mudanças na diversificação das Instituições de Ensino Superior (IES). Esse processo, em que se seguiram as diretrizes do Banco Mundial para a educação superior na América Latina, foi sistematizado no documento La enseñanza superior: las lecciones derivadas de la experiencia, em que se recomenda:

A introdução de uma maior diferenciação no ensino superior, ou seja, a criação de instituições não universitárias e o aumento de instituições privadas podem contribuir para satisfazer a demanda cada vez maior de educação superior e fazer com que os sistemas de ensino melhor se adequem às necessidades do mercado de trabalho (BIRD/BANCO MUNDIAL, 1995, p. 31).

Além de continuar as privatizações de empresas estatais iniciadas por Collor, o governo de FHC ampliou ainda o investimento privado em educação superior - graduação e pós-graduação -, especialmente por meio da criação de linhas de crédito para as IES, como o Fundo de Financiamento ao Estudante do Ensino Superior (Fies), destinado à concessão de financiamento a estudantes regularmente matriculados em cursos superiores não gratuitos e com avaliação positiva. No geral, esse período foi caracterizado por uma política de estímulo à expansão do ensino superior no país. Embora tal política estivesse ancorada, sobretudo, no aumento do número de vagas nas instituições privadas, pôde-se observar também um crescimento nas universidades federais.

Essa expansão do ensino superior repercutiu na UnB, reforçando uma tendência de crescimento tanto do corpo discente como das instalações físicas que já vinha se manifestando. De novembro de 1993 a novembro de 2000, o número de alunos de graduação aumentou cerca de 50\% e houve um incremento de 50 mil metros quadrados de área construída, sem contar com os blocos para abrigar professores e alunos de pós-graduação. A par desse crescimento quantitativo, houve uma diversificação funcional dos edifícios e também das fontes dos recursos destinados às construções. 
A gestão do reitor João Cláudio Todorov ${ }^{7}$ foi marcada pelo início das parcerias entre a UnB e organizações públicas e privadas. Esse novo momento viria a sugerir uma estratégia institucional capaz de garantir mais eficiência e agilidade dos mecanismos de planejamento e consolidação física do campus, conforme explicitado no depoimento do professor Érico Weidle:

\begin{abstract}
Quando nós falávamos de planejamento do campus era uma coisa que envolvia especificamente as faculdades, os institutos, alguns edifícios administrativos, certos laboratórios etc. [...] Mas esse universo mudou muito, muito, por ' $n$ ' razões. Primeiro, os programas da universidade em desenvolvimento são programas que hoje têm financiamento de grandes empresas, como a Petrobras, por exemplo [...] naquele tempo em que nós trabalhávamos, as verbas eram exclusivamente do Ministério de Educação. Hoje as fontes são outras, sem contar o crescimento de atividades outras - por exemplo, o Cespe, que realiza concursos, vestibulares etc. [...] O planejamento também mudou, não tem mais aquela roupagem da verba ministerial, federal. Hoje a UnB é assediada! Existe um série de outros eventos e outras instituições instalando-se lá. Eu me lembro de ter participado de reuniões do Conselho Diretor em que grandes empresas, sejam elas empresas de pesquisa como a Fiocruz, pretendiam utilizar a UnB (Entrevista em 7 dez. 2011).
\end{abstract}

A necessidade de ocupar áreas disponíveis no campus para a implantação desses novos empreendimentos motivou a elaboração do Plano Diretor Físico do Campus, em 1998. Apesar de o plano ter ficado inconcluso, as parcerias foram concretizadas com a implantação da Autotrac, empresa privada de monitoramento de transporte de cargas por satélite, em 1994, com projeto de Cláudio José Pinheiro Villar de Queiroz, Paulo Castilho e Marcílio Mendes Ferreira; da Fundação de Empreendimentos Científicos e Tecnológicos (Finatec), entidade privada de fomento à pesquisa, em 1997, com projeto de Elizabeth Machado; e do Centro de Formação de Recursos Humanos em Transportes Urbanos (Ceftru), em 1998, com projeto de Maria do Carmo Thormann, sendo que os dois últimos empreendimentos não foram desenvolvidos no Ceplan.

Além dos já citados, foram realizadas ainda nessa época os projetos para os seguintes edifícios: Pavilhão de Oficinas Especiais do Instituto de Artes, de Cláudio José Pinheiro Villar de Queiroz; Posto Ecológico, de Matheus Gorovitz e Adilson Macedo; o Empório Ambiental, de Matheus Gorovitz; e Almoxarifado Central. Este último resultou do emprego de peças pré-moldadas de argamassa armada, desenvolvidas anteriormente por João da Gama Filgueiras Lima para escolas de $1^{\circ} \mathrm{grau}$, montadas de acordo com o leiaute de Maria do Carmo Thormann.

Foi ainda durante a gestão de Todorov que o campus da UnB recebeu a denominação de Campus Universitário Darcy Ribeiro, em homenagem a um de seus idealizadores e primeiro reitor. Durante esse período, mais precisamente em 20 de março de 1997, também o Ceplan passou a se chamar Centro de Planejamento Oscar Niemeyer.

Na década de 1990, passaram a integrar o quadro docente da FAU os professores Benny Schvarsberg, Cláudia da Conceição Garcia Santos, Eliel Américo Santana da Silva, Frederico Flósculo Pinheiro Barreto, Gabriel Dorfman, Gabriela de Souza Tenório, Ivan Manoel Rezende do Valle, Kristian Schiel, Marcílio Mendes Ferreira, Maria Assunção Pereira Rodrigues, Maria do Carmo de Lima Bezerra, Márcio Albuquerque Buson, Márcio Augusto Roma Buzar, Neander Furtado Silva, Oscar Luís Ferreira, Paulo Castilho Lima, Raquel Naves Blumenschein, Rosana Stockler Campos Clímaco, Reinaldo Guedes Machado e Vicente de Paulo Quintella Barcellos. 


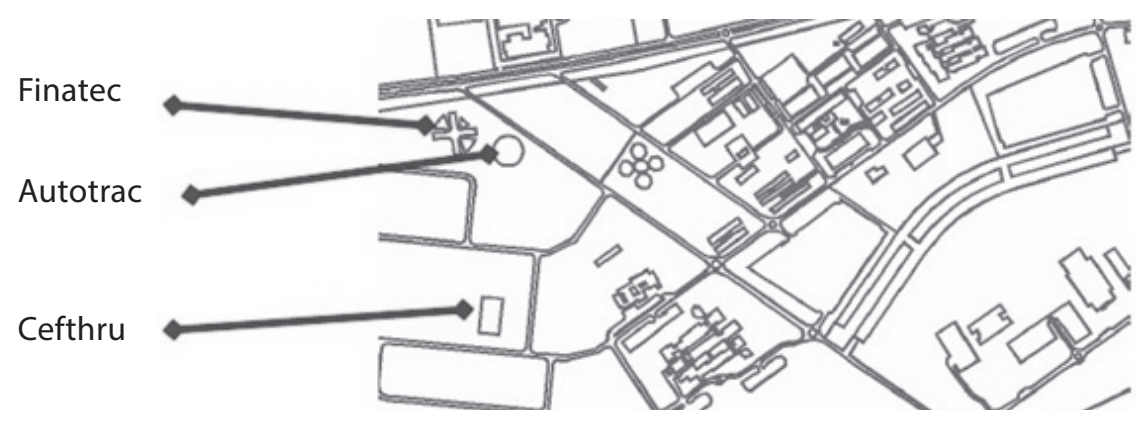

Tendo em vista as discussões, em andamento na FAU, sobre a situação institucional do Ceplan, em novembro de 1998 a Direção da FAU nomeou uma comissão ${ }^{8}$ que, composta por Luiz Henrique Pessina, Marcílio Mendes Ferreira e Márcio Albuquerque Buson, deveria elaborar um novo estatuto para o órgão. No estatuto elaborado por esse grupo propunha que o Ceplan voltasse a ser um centro de custo, vinculado diretamente à Reitoria. Entre as suas 12 atribuições estatutárias então previstas, constavam: elaborar o planejamento físico do campus e demais áreas de propriedade da FUB; realizar os projetos de edificações a serem construídas nessas áreas; propiciar aos professores da FAU condições para o exercício profissional.

Durante esse período, foram realizadas na UnB as seguintes obras: Centro Comunitário Athos Bulcão, cujo projeto foi desenvolvido por Frederico Luiz Aguiar de Carvalho, Silvano Pereira, Leandro Drumond Marques, Mona Lisa Lobo de Souza Choas e Joyce Mendonça; Centro de Apoio ao Desenvolvimento Tecnológico (CDT), com projeto de Leandro Drumond Marques e Alberto Alves de Faria; e os pavilhões Anísio Teixeira e João Calmon, de autoria de Cláudio José Pinheiro Villar de Queiroz, com a colaboração de Cláudio Sasse, Suzana Souza e Rosmery Hokino.

Durante o primeiro mandato de Fernando Henrique Cardoso, foi aprovada uma emenda constitucional que permitiu a reeleição para os cargos executivos em todos os níveis, o que fez com que FHC se tornasse o primeiro presidente brasileiro a ser reeleito. A principal bandeira da campanha para reeleição de FHC foi a política de estabilidade e continuidade do Plano Real.

Embora não tenha havido grandes investimentos nas reformas estruturais (privatizações), ocorreram algumas reformas no setor da Educação, principalmente em decorrência da aprovação, em 1996, da nova Lei de Diretrizes e Bases para a Educação (LDB). Criticada por prever um controle muito concentrado nas mãos do governo, a LDBEN-1996 estabeleceu, em seu artigo 69, que a União devia "[...] gastar no mínimo 18\% e os estados e municípios no mínimo $25 \%$ de seus orçamentos na manutenção e desenvolvimento do ensino público". Além disso, segundo Eunice Durham (2010), promoveu profundas mudanças no ensino superior:

\footnotetext{
Em primeiro lugar, a Lei regulamentou e ampliou a autonomia das universidades, inclusive no que diz respeito à possibilidade de reorganização de sua estrutura interna, até então obrigatoriamente organizada em departamentos e institutos. Além disso, liberou os cursos da obrigatoriedade do currículo mínimo, que definia as disciplinas a serem ministradas obrigatoriamente em cada curso, sistema que foi substituído por diretrizes curriculares mais gerais, as quais contemplam prioritariamente os objetivos do curso e o perfil profissional dos formandos. A LDB tentou também diversificar a oferta de cursos superiores, até então totalmente amarrada às licenciaturas e aos bacharelados, criando os cursos sequenciais.
}

No entanto, a autora reconhece que "[...] a grande liberdade na organização dos cursos e na estrutura do ensino superior propiciada pela LDB, em grande parte foi ignorada pelas universidades públicas. O ensino privado tirou maiores proveitos das inovações" (Durham, 2010). 
Na verdade, seguindo as diretrizes dos organismos internacionais, as reformas, implementadas entre a década de 1990 e início dos anos 2000, incorporaram a tese de que o ensino superior deveria se tornar mais diversificado e flexível, objetivando uma expansão com contenção dos gastos públicos. Embora reconhecendo que não houve nenhuma medida durante o governo FHC que pudesse justificar a acusação de favorecimento ao setor privado. Duhan (2010) registra que

Em 1965, no início do governo militar, o setor privado começa a crescer mais vigorosamente do que o público, ultrapassando-o em número de matrículas em 1970. A partir desta data, o predomínio do setor privado cresce continuamente até 1980 e cai (embora muito pouco) entre 1985 e 1995. O período do governo Fernando Henrique é marcado por uma nova expansão do setor privado, que continua a crescer até 2008 , durante o governo Lula, embora em ritmo menor.

Durante a primeira gestão de Lauro Morhy ${ }^{9}$ à frente da Reitoria, as atividades do Ceplan se tornaram bastante rarefeitas devido, por um lado, à falta de recursos disponíveis para novas construções e, por outro, à sobreposição de atribuições com a Prefeitura do Campus, que, com seu quadro efetivo de profissionais arquitetos e engenheiros, podia dar respostas mais rápidas às demandas da universidade. Em razão disso, o espaço físico do Ceplan acabou ficando subutilizado e, portanto, vítima de maus-tratos.

Talvez tenha contribuído para essa situação de esvaziamento a rotatividade na direção do Ceplan: Matheus Gorovitz, de setembro de 1988 a agosto de 1989; Otto Toledo Ribas, de setembro de 1989 a dezembro de 1990; Frank Algot Svenson, de abril de 1991 a outubro de 1992; Paulo Marcos de Paiva Oliveira, de dezembro de 1992 a agosto de 1993; Paulo Castilho Lima, de agosto de 1994 a setembro de 1995; e Marcílio Mendes Ferreira, de 1998 a 1999. Entre 1990 e 1996, foram coordenadores interinos do Ceplan: Elvin Mackay Dubugras (abril de 1990), Fernando Lopes Burmeister (fevereiro e março de 1991), Luis Henrique Gomes Pessina (abril de 1992) e Oscar Kneipp (junho de 1996).

No final da década de 1990, já se fazia sentir na UnB a necessidade de um plano de expansão. Embora a Prefeitura tenha tentado realizar a tarefa de elaborar um plano, não logrou êxito devido ao aumento das demandas de manutenção.

Nesse período, os projetos passaram a adotar tipologias arquitetônicas e construtivas diferenciadas entre si, o que contribuiu para quebrar a unidade do conjunto universitário. Talvez isso se deva em parte à contratação de profissionais de fora, contrariando o princípio original do Ceplan o qual previa que os arquitetos responsáveis pelos projetos das edificações do campus fossem professores da FAU.

Sobre a questão da integração entre os edifícios, assim se pronunciou Zimbres:

Não se procurou a integração do novo com o existente, nem mesmo do novo com o novo. Por exemplo, até hoje não se pensou em ligar os novos prédios às extremidades abertas ao Sul e Norte do Minhocão; talvez uma praça bem construída aglutinando as novas intervenções. Ficou tudo meio afastado, meio desarticulado, não se pensa em caminhos, passeios, pátios e praças ligando as entradas dos edifícios. Há um hábito arraigado de fazer prédios autorais isolados. $\mathrm{O}$ único setor do campus que apresenta certa ideia de conjunto integrado são os quarteirões onde foram construídos os prédios para os serviços gerais que acabaram sendo lindamente ocupados pelo ICA-FAU: Auditório da Música, Instituto de Artes, ateliês do curso de Arquitetura, o Ceplan [...] me preocupa o fato de que as intervenções dos últimos tempos tenham linguagem tão diversa; ou seria esse um bom sinal? Liberdade de expressão? Qual é o sentido da ideia de unidade arquitetônica? (Entrevista em 26 out. 2011). 
4.2. As novas demandas e a quebra da unidade arquitetônica

PAVILHÃO MULTIUSO I (PMU I)

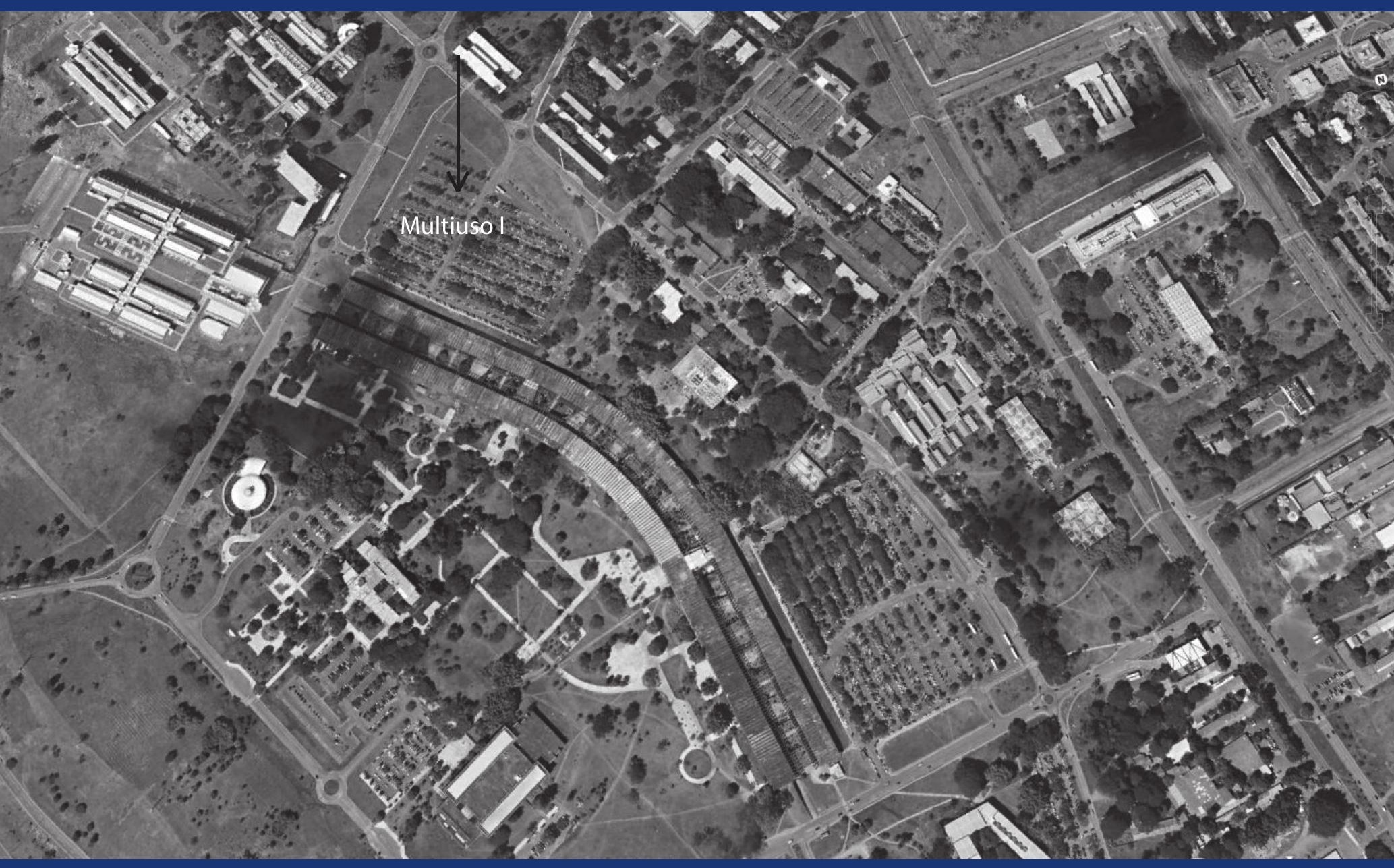

Autoria

Figura 123a.

Érico Paulo Siegmar Weidle, Rogério Carvalho de Melo Franco

Multiuso

Data

1986

Área Construída

$5.458 \mathrm{~m}^{2}$ 
O pavilhão foi construído com o intuito de abrigar órgãos já sedimentados na UnB que precisavam expandir suas atividades, e também o recém-criado Centro de Estudos Avançados Multidisciplinares (Ceam)1, que passou a coordenar os núcleos temáticos, conforme previsto no plano original da UnB.

O PMU I é composto por três blocos lineares com dois pavimentos, dispostos lado a lado e interligados por passarelas e escadas. A escolha da estrutura metálica deveu-se à rapidez da construção e à facilidade de adaptação do edifício a diversos tipos de atividades.
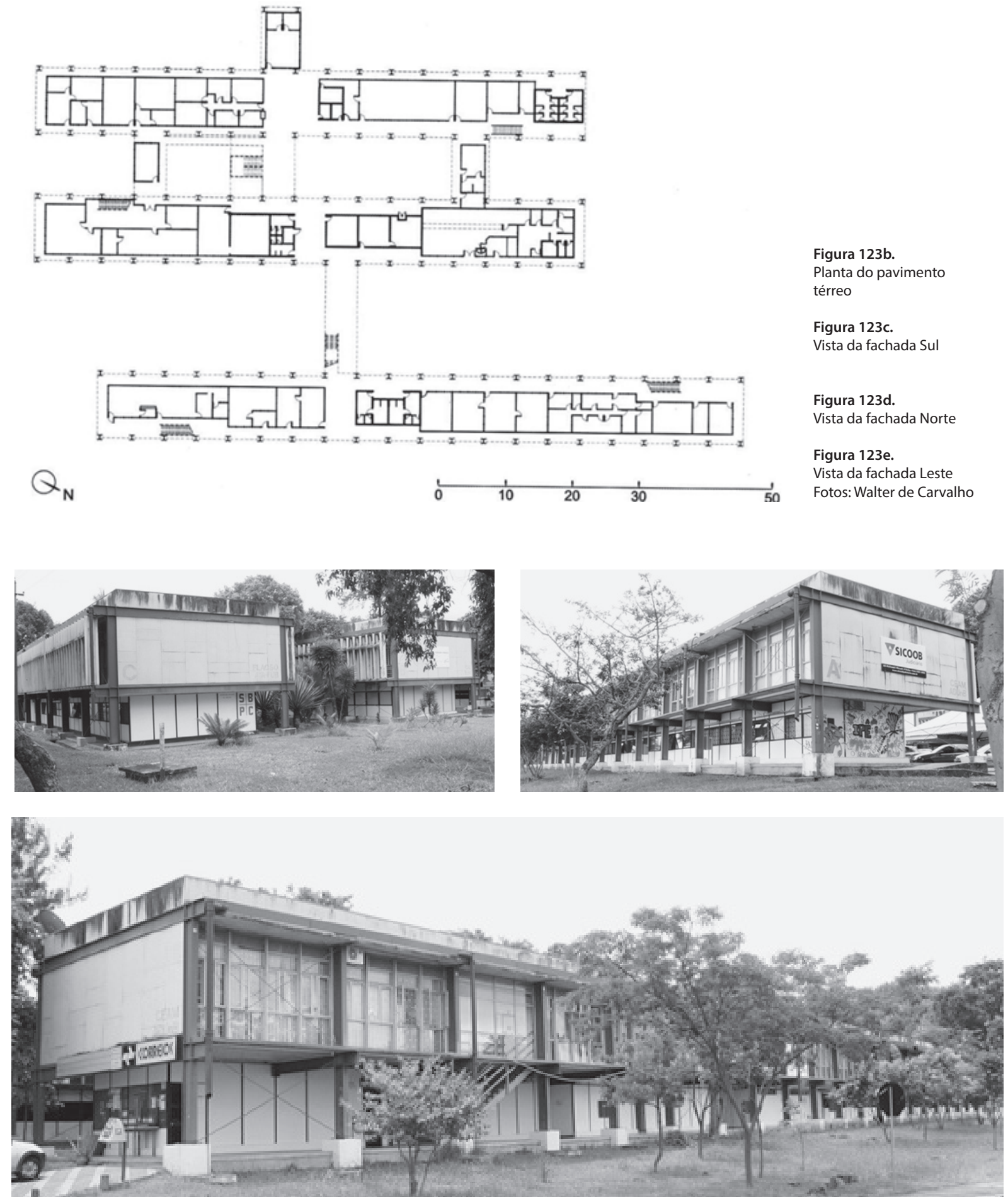

10 Ceam e seu Regimento foram aprovados na 295a reunião do Conselho Diretor da FUB, em 10 de abril de 1986, e efetivados pelo Ato da Reitoria n. 105/86, de 29 de abril de 1986. Atualmente o Ceam possui 36 núcleos temáticos. 
PAVILHÃO MULTIUSO II (PMU II)

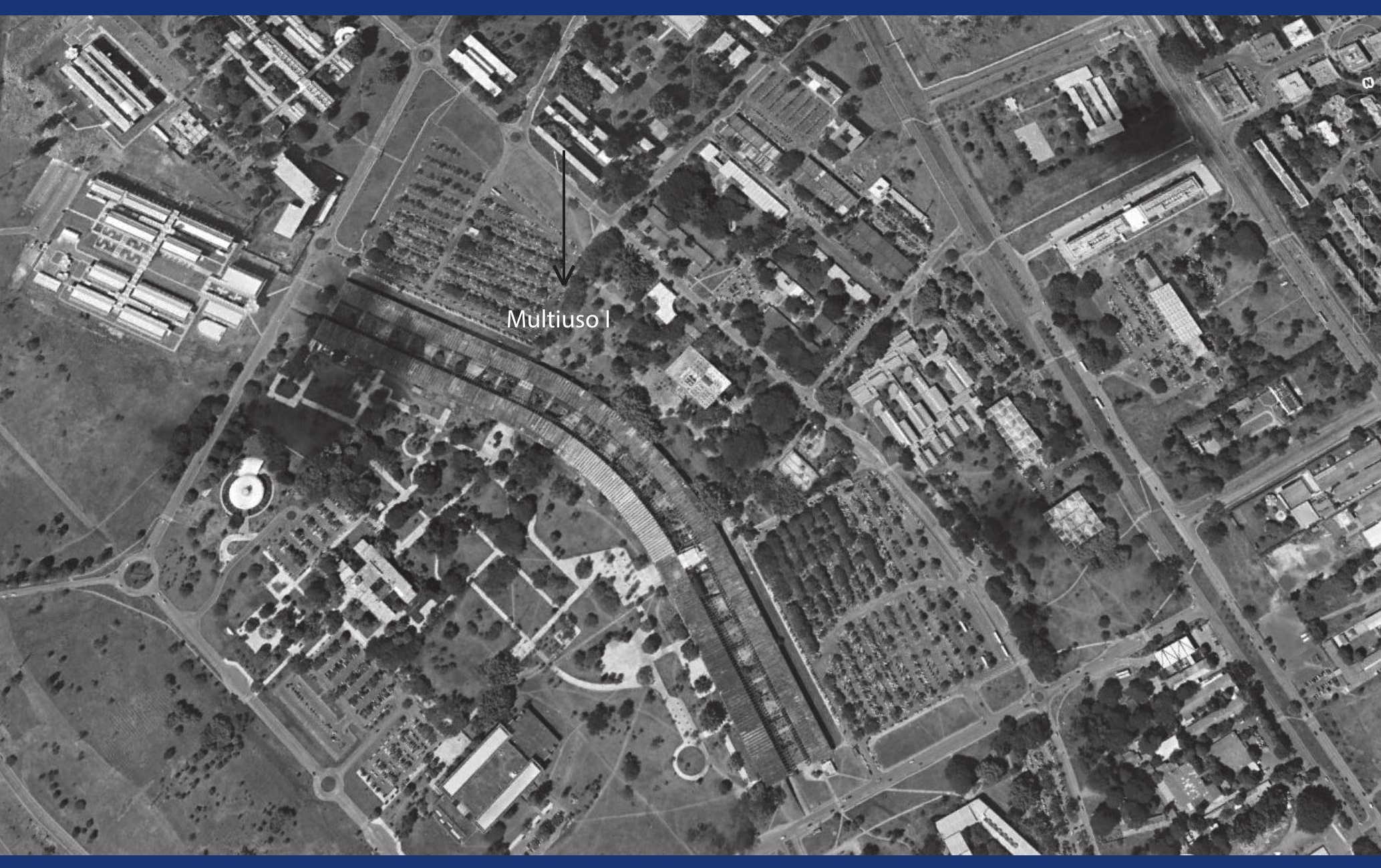

Autoria

Paulo Bica, Alberto Alves de Faria e Luís Otávio Alves Rodrigues
Figura 124a.

Implantação

do Pavilhão

Multiuso

Data

1986

Área Construída

$3.840 \mathrm{~m}^{2}$ 
O pavilhão foi construído com o intuito de abrigar órgãos já sedimentados na UnB, que desejavam expandir suas atividades, além dos núcleos e centros oriundos da nova filosofia de expansão universitária, entre os quais o Centro Internacional de Física da Matéria Condensada (CIFMC), que acabou ocupando definitivamente o edifício.

O PMU II é composto por dois blocos lineares com dois pavimentos, dispostos lado a lado e interligados por passarelas e escadas. O pavimento térreo apresenta uma planta modulada, que contrasta com fechamentos em planos curvos que se desenvolvem por entre os pilotis.

A escolha da estrutura metálica deveu-se à rapidez da construção, à facilidade de adaptação do edifício a diversos tipos de atividades, e provavelmente também à queda do preço do aço no mercado nacional à época.
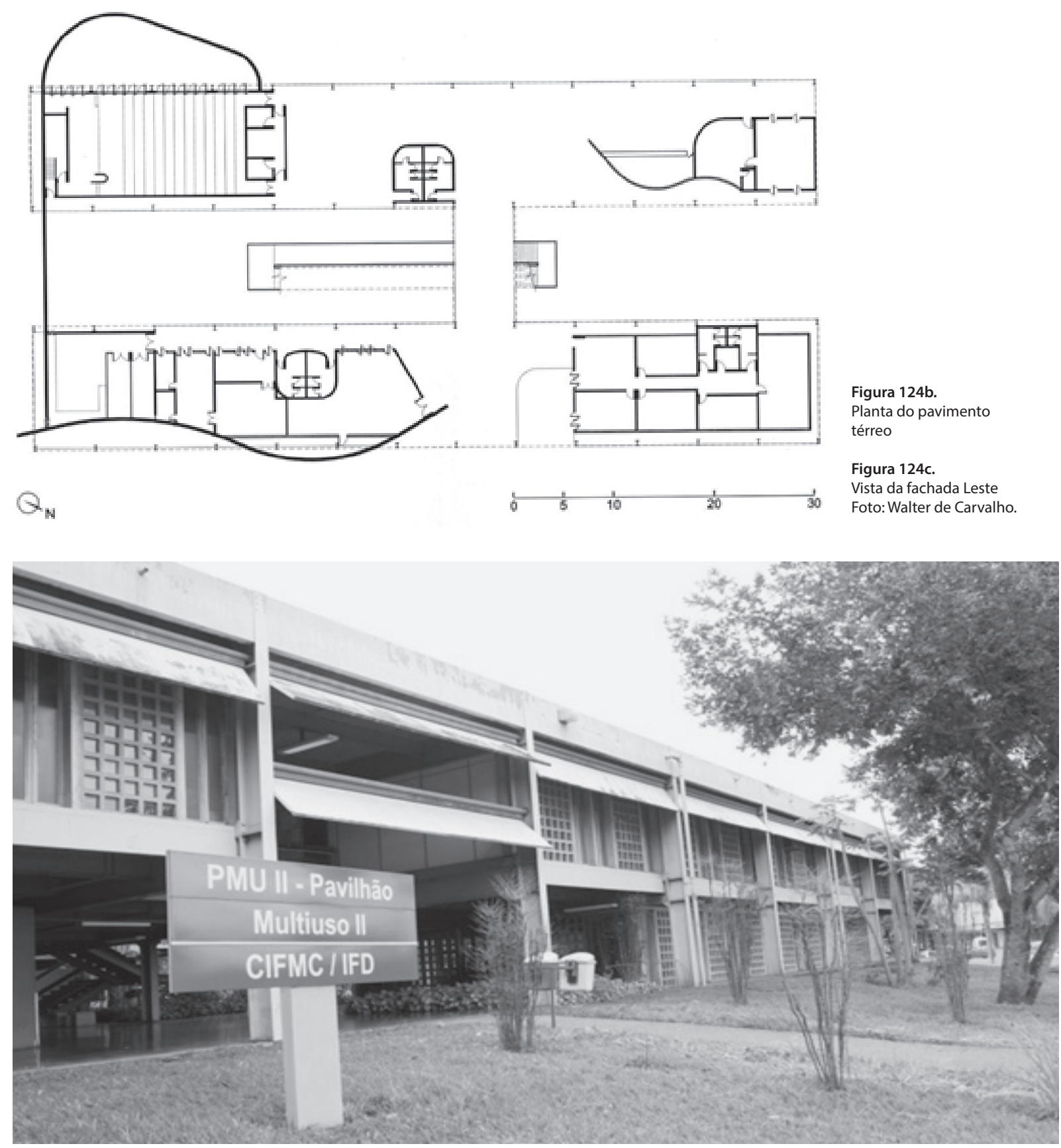
CENTRO DE EXCELÊNCIA EM TURISMO (CET)

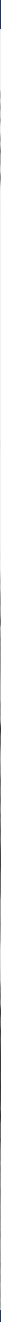

Autoria

José Zanine Caldas.

O paisagismo é de Zaida Machado

Data

1986 (projeto)

1998-2005 (obra)

Área Construída

$5.460 \mathrm{~m}^{2}$
Figura 125a.

Fachada Sudeste

ao fundo 
Concebido para abrigar o Instituto Nacional de Ensino e Pesquisa ligado ao Ministério da Educação (Inep/MEC), o conjunto foi desocupado, pouco tempo depois de construído, devido a problemas na estrutura. Posteriormente foi reformado para comportar as instalações do Centro de Excelência em Turismo (CET), criado em 1998, como parte do compromisso da UnB com um Plano de Desenvolvimento do Turismo Sustentável. O CET tinha como objetivo capacitar e formar profissionais para a indústria do turismo, nas áreas de hospedaria e gastronomia.

O edifício possui um módulo central e quatro periféricos, todos na forma de octógono, com estrutura em madeira da Amazônia, a carapanaúba, também conhecida como sapupema.
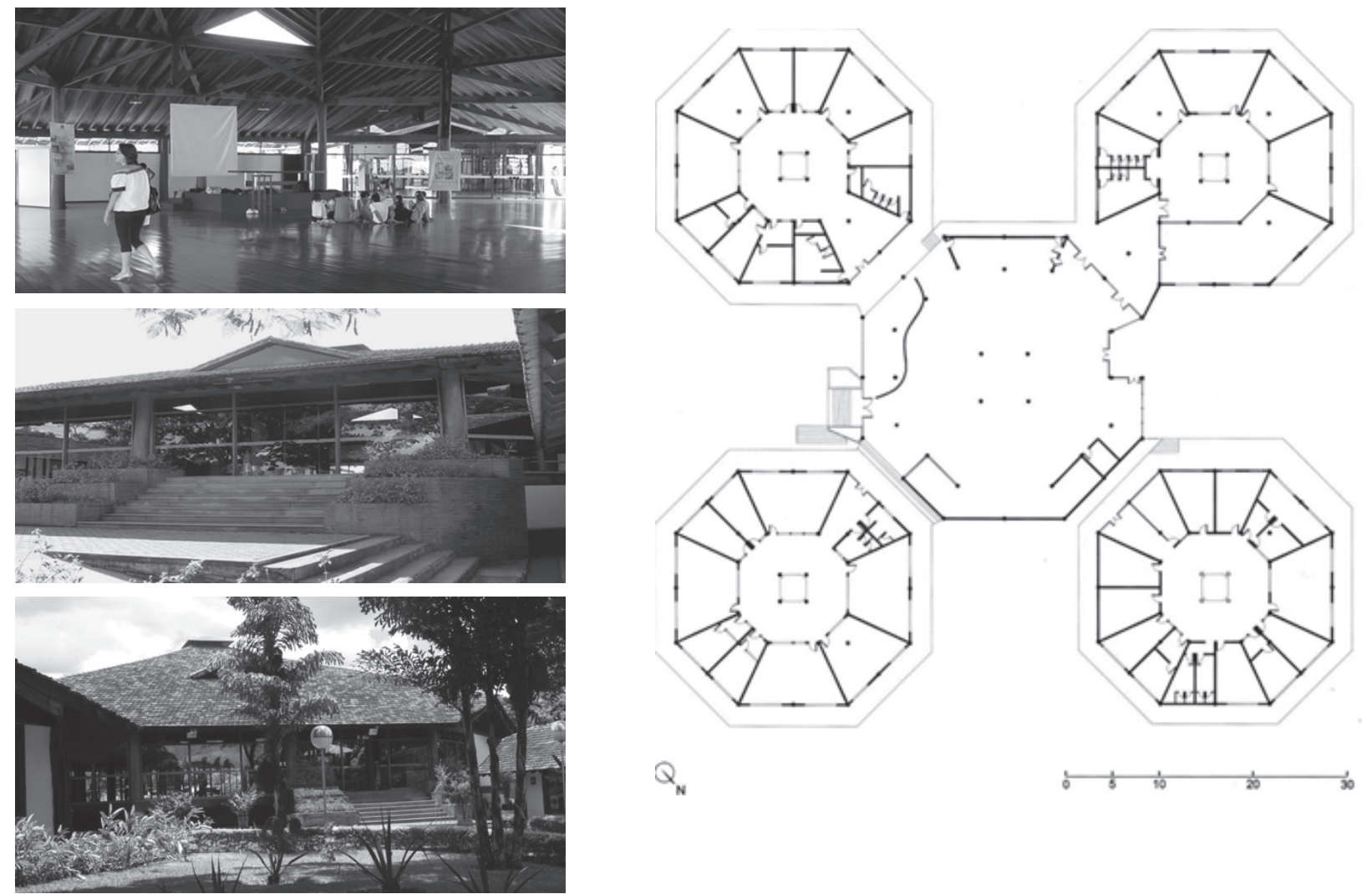

Vista interna do Módulo Central

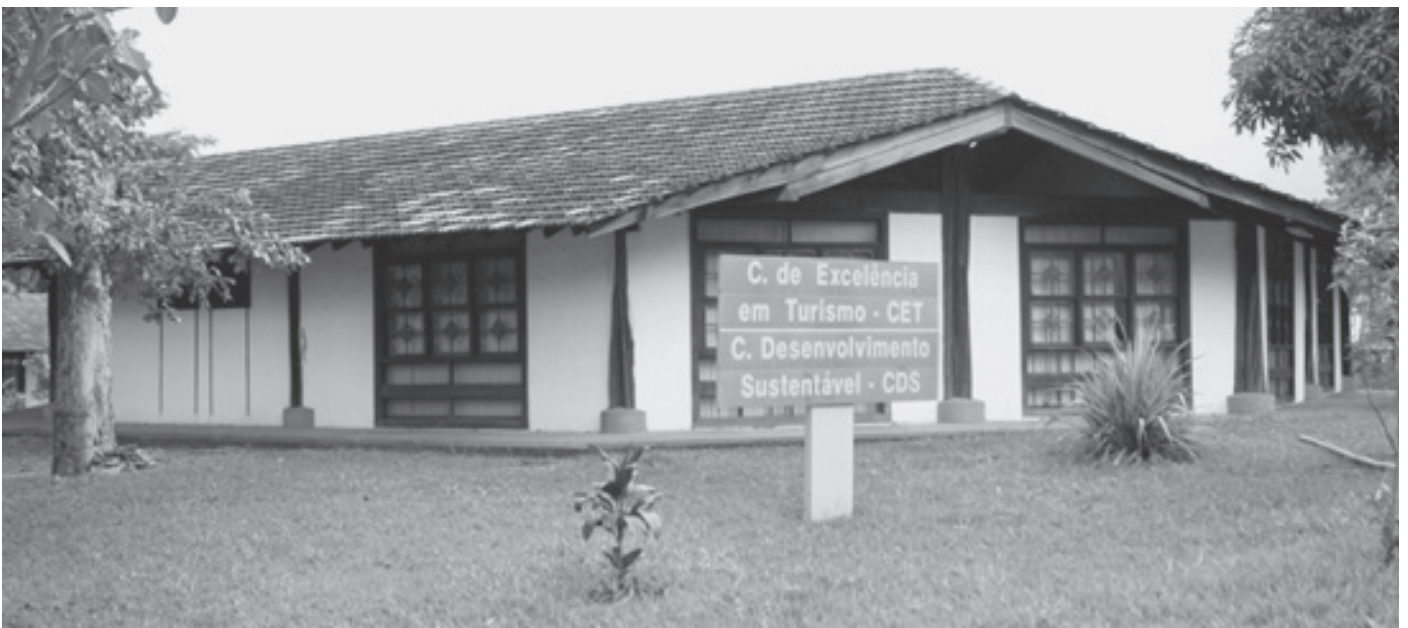

Figura $125 c$. Fachada Sudeste

Figura 125d.

Vista do pátio

interno

Figura 125e.

Planta esquemática

Figura 125f.

Vista interna do

Módulo Central

Figura $125 g$

Vista da fachada Nordeste 


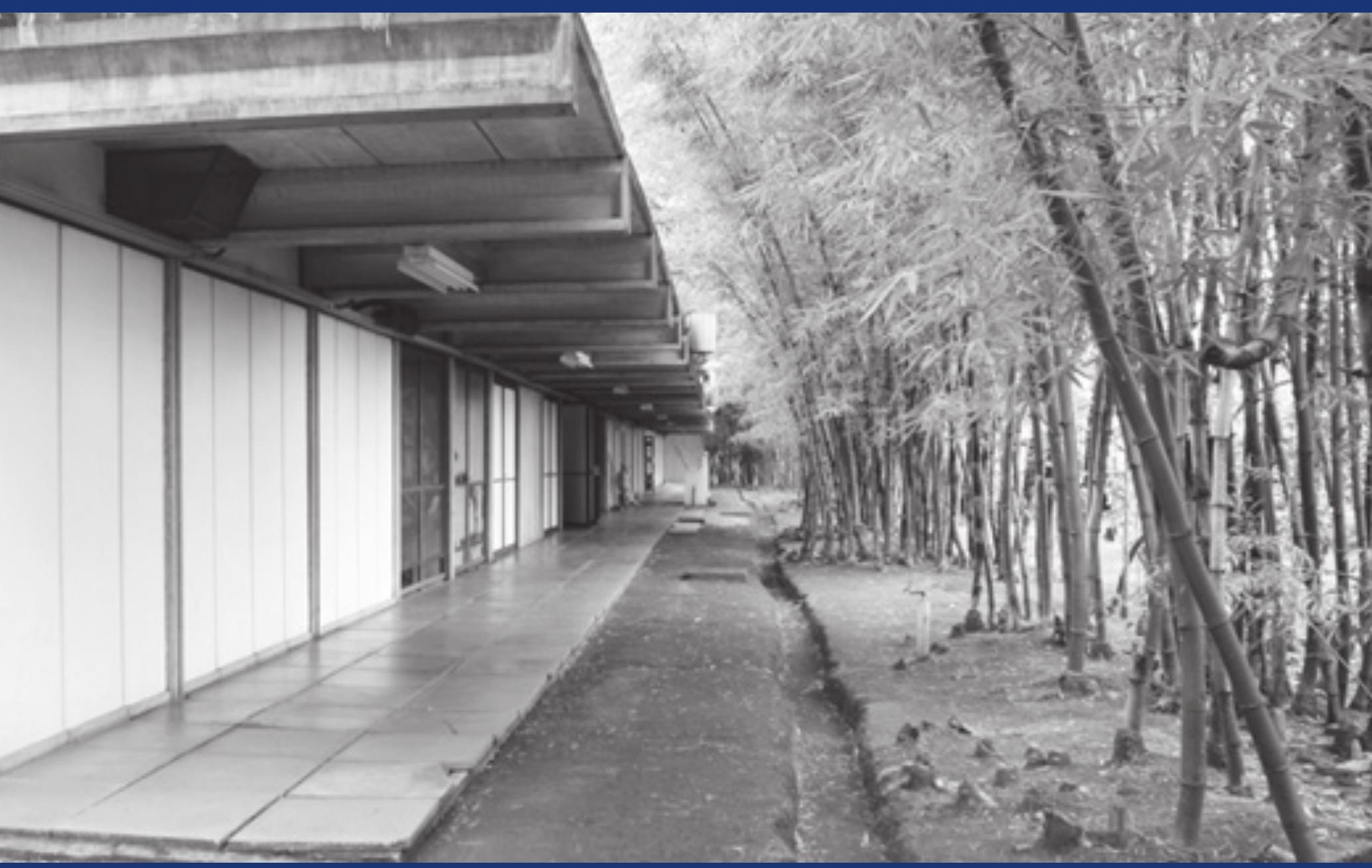

Autoria

João Filgueiras Lima

Data

1987

Área construída

$648 \mathrm{~m}^{2}$
Figura 126a.

Vista da circulação

externa 
O Laboratório de Termobiologia, criado após a reintegração do professor Luiz Fernando Gouveia Laboriau, passou a desenvolver pesquisas voltadas para os efeitos da temperatura em processos biológicos, com destaque para a germinação de sementes.

Vinculado ao Departamento de Botânica desde 2001, o laboratório tem acolhido estudantes de iniciação científica e de pós-graduação, tanto da Universidade de Brasília como de outras instituições. Professores de outros laboratórios, de outros departamentos da UnB, como os de Engenharia Florestal, Ecologia e Biologia Celular, e de outras instituições de ensino superior e de pesquisa também desenvolvem pesquisas no laboratório.

A construção do laboratório coincide com o retorno de João Filgueiras Lima à UnB, depois de anistiado.

Em decorrência do sistema de pré-fabricação leve, em argamassa armada, o edifício foi erguido em apenas 80 dias, com componentes produzidos pela Fábrica de Equipamentos Urbanos de Brasília, seguindo o mesmo princípio adotado para a construção da Escola Transitória, em Abadiânia, Goiás.

Trata-se de um partido linear composto de dois módulos: no primeiro foram instalados os laboratórios e as câmaras escuras e, no segundo, as salas dos pesquisadores, uma pequena biblioteca e o auditório.
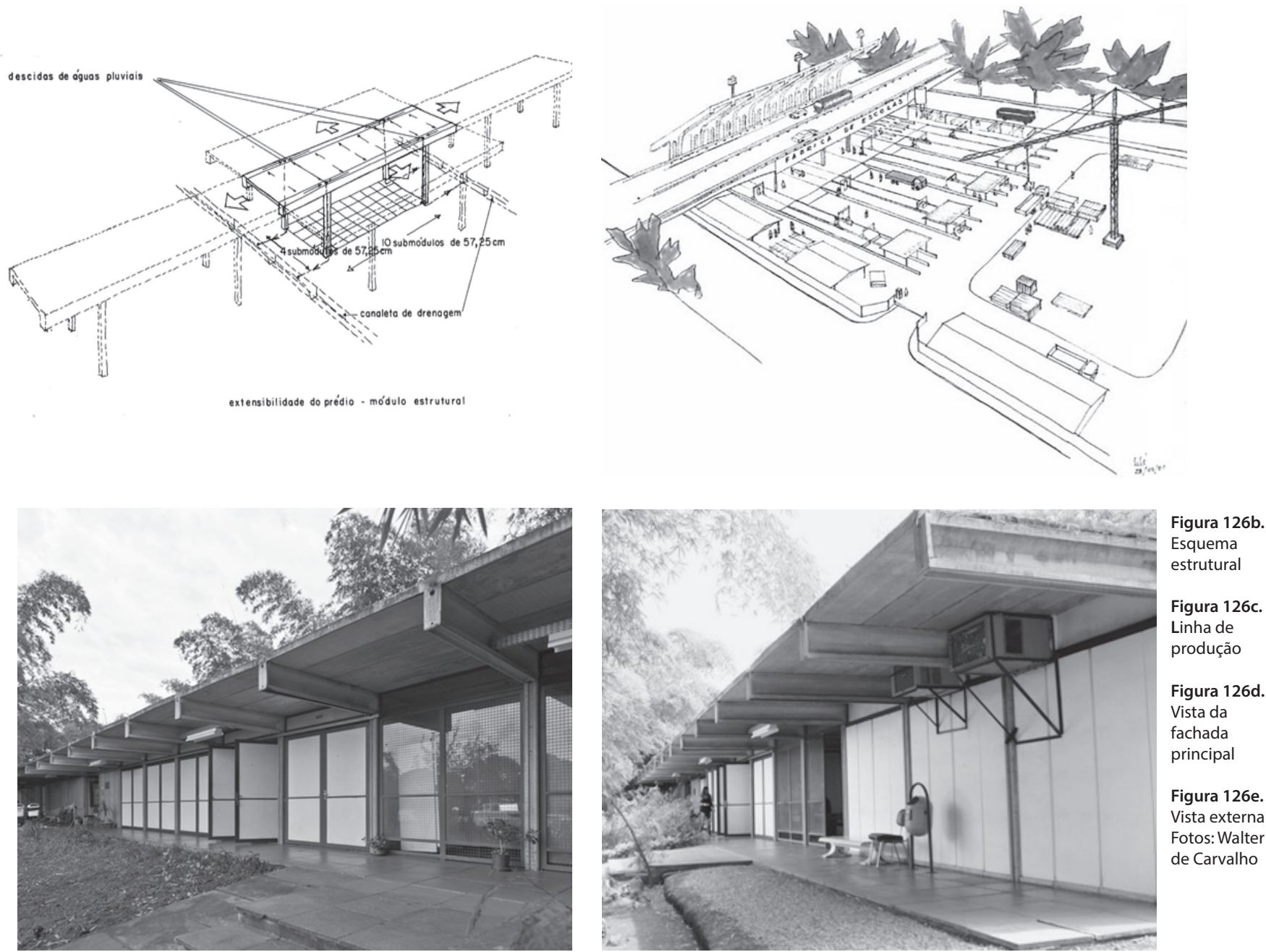
COLINA - BLOCOS E, F, G, H, I e J

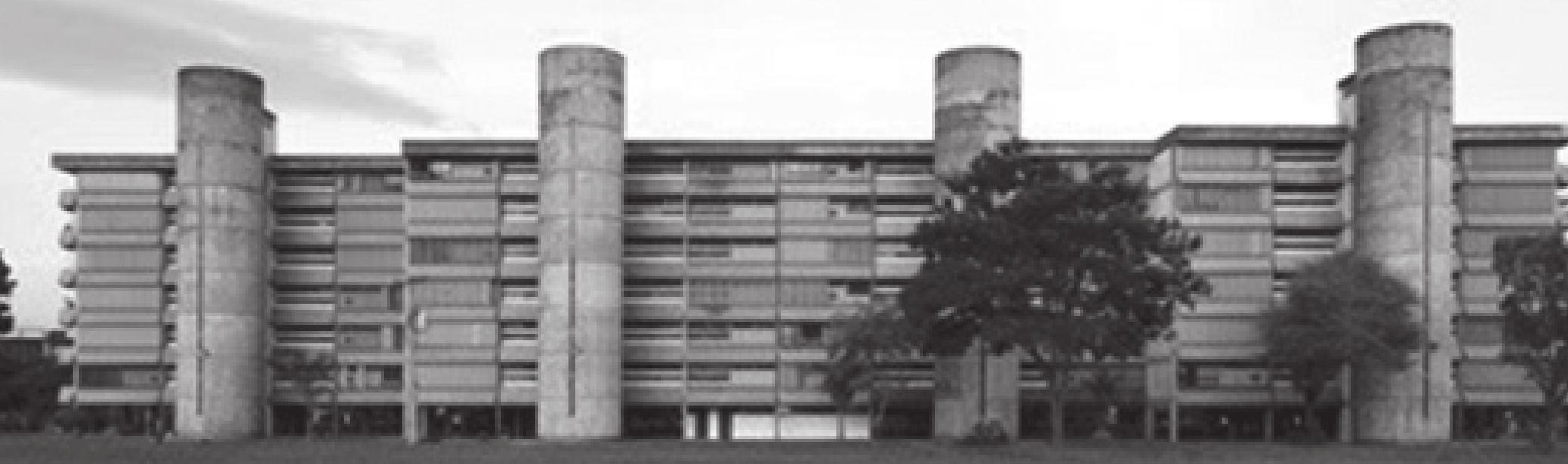

Autoria

Paulo Marcos de Paiva Oliveira

\section{Data}

1987 (projeto)

1988 (obra)

\section{Área Construída}

$11.621 \mathrm{~m}^{2}(\mathrm{E}), 8.756 \mathrm{~m}^{2}(\mathrm{~F}), 11.668 \mathrm{~m}^{2}(\mathrm{G}), 11.063 \mathrm{~m}^{2}(\mathrm{H}), 9383 \mathrm{~m}^{2}$ (I), $11.668 \mathrm{~m}^{2}(\mathrm{~J})$. Total $=64.159 \mathrm{~m}^{2}$
Figura 127a.

Fachada oeste

do Bloco $\mathrm{E}$ 
Em 1988, o crescimento da universidade e o aumento do seu quadro funcional levaram a uma ampliação da área residencial do campus, por meio da construção de um conjunto de edificações, que ficou conhecido como Colina Nova.

Os 264 apartamentos, que integram o conjunto destinado aos professores e funcionários, estão assim distribuídos: 54 de dois quartos; 156 de três quartos; e 54 de quatro quartos.

Embora tenham sido mantidos os pilotis, os edifícios construídos na segunda fase da Colina alteraram o gabarito de três para seis pavimentos, o que modificou a escala do conjunto.

Trata-se de edifícios com estrutura em concreto aparente, vedações em alvenaria e varandas. As aberturas são protegidas por grandes brises compostos de lâminas verticais coloridas.
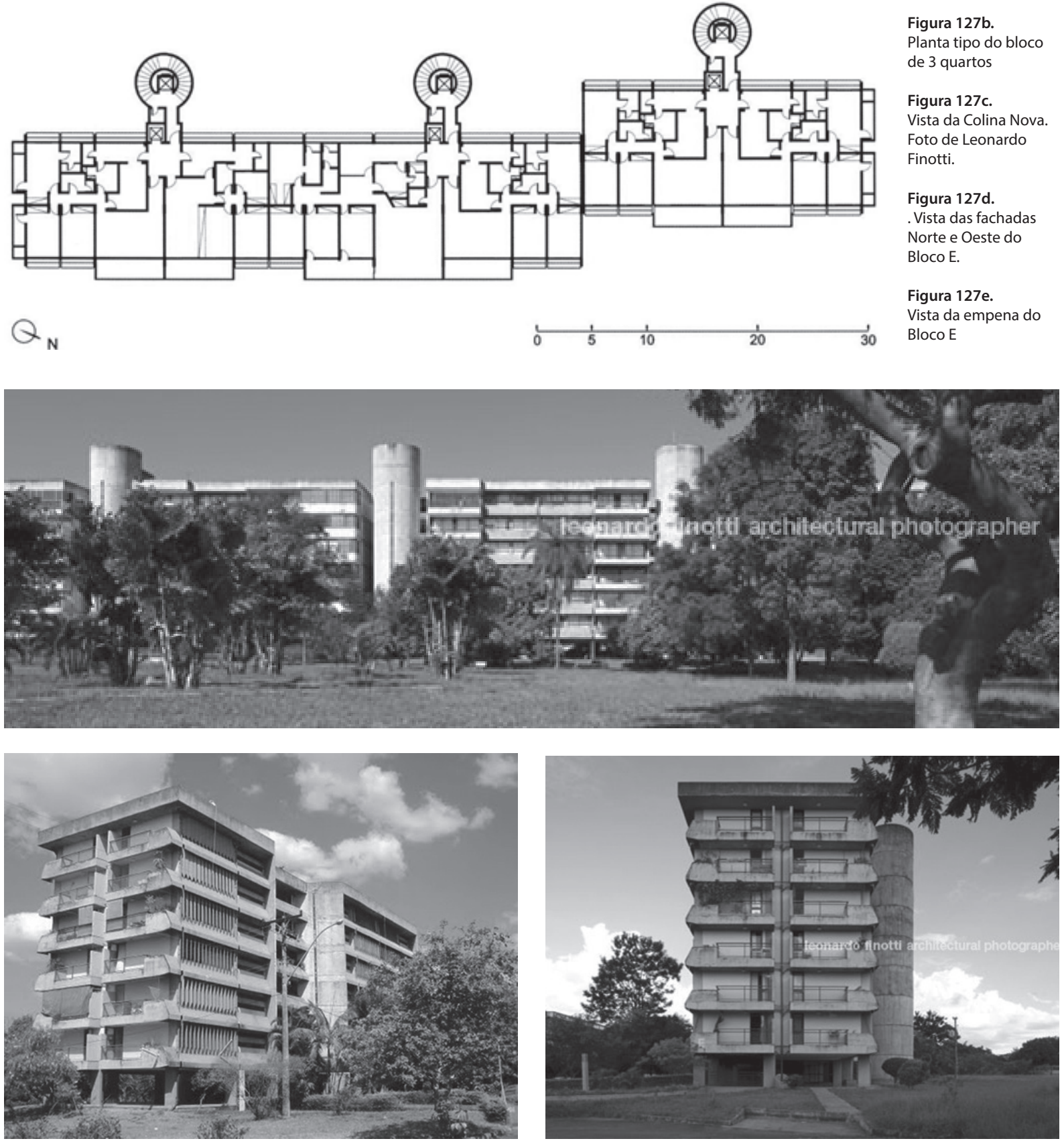


\section{CASA DO ESTUDANTE UNIVERSITÁRIO - PÓS- GRADUAÇÂO}

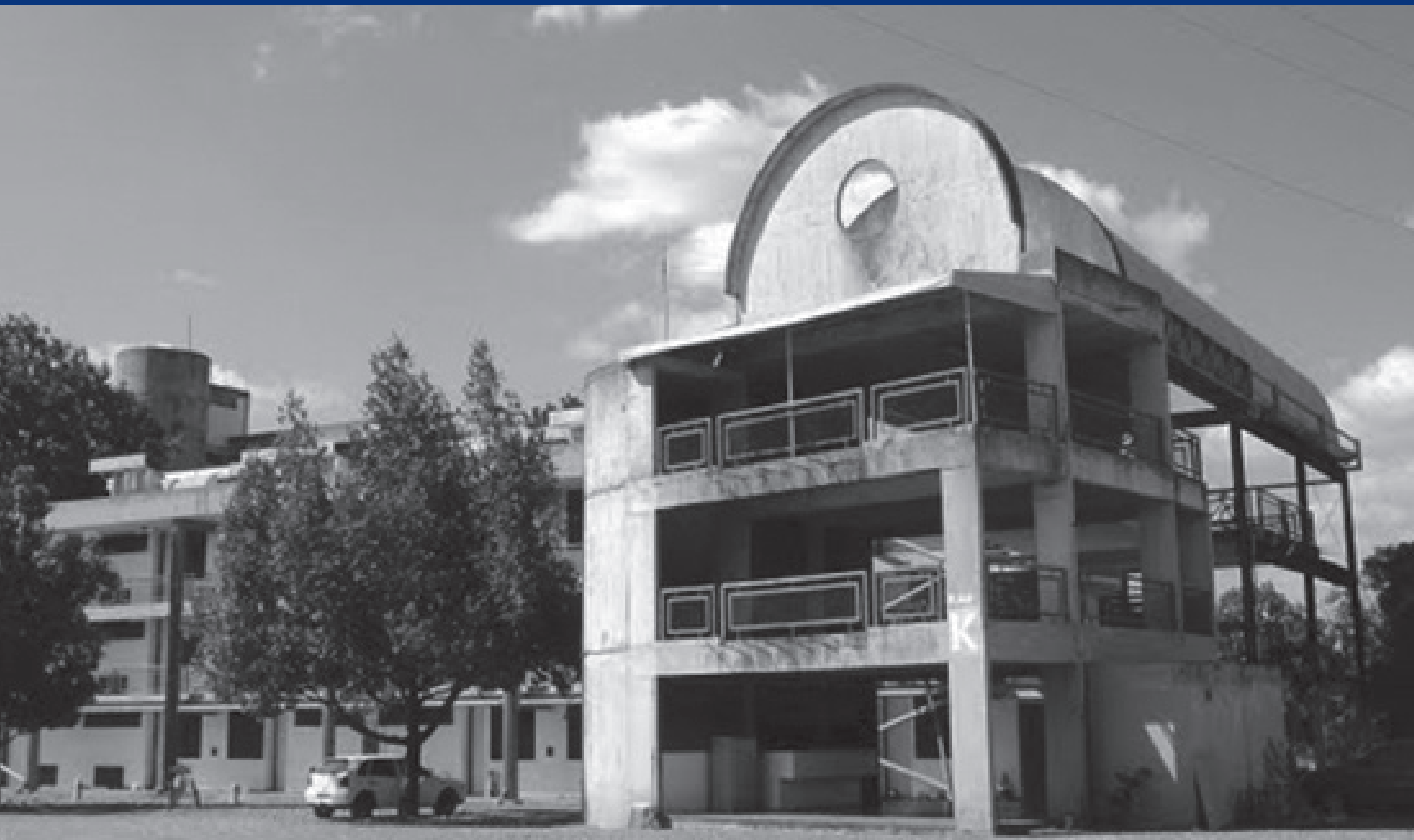

Autoria

Paulo Marcos de Paiva Oliveira, com a colaboração de Silvano da Silva Pereira

Data

1992.

Área Construída

$1.969 \mathrm{~m}^{2}$
Figura 128a.

Vista da fachada

Oeste do Bloco K 


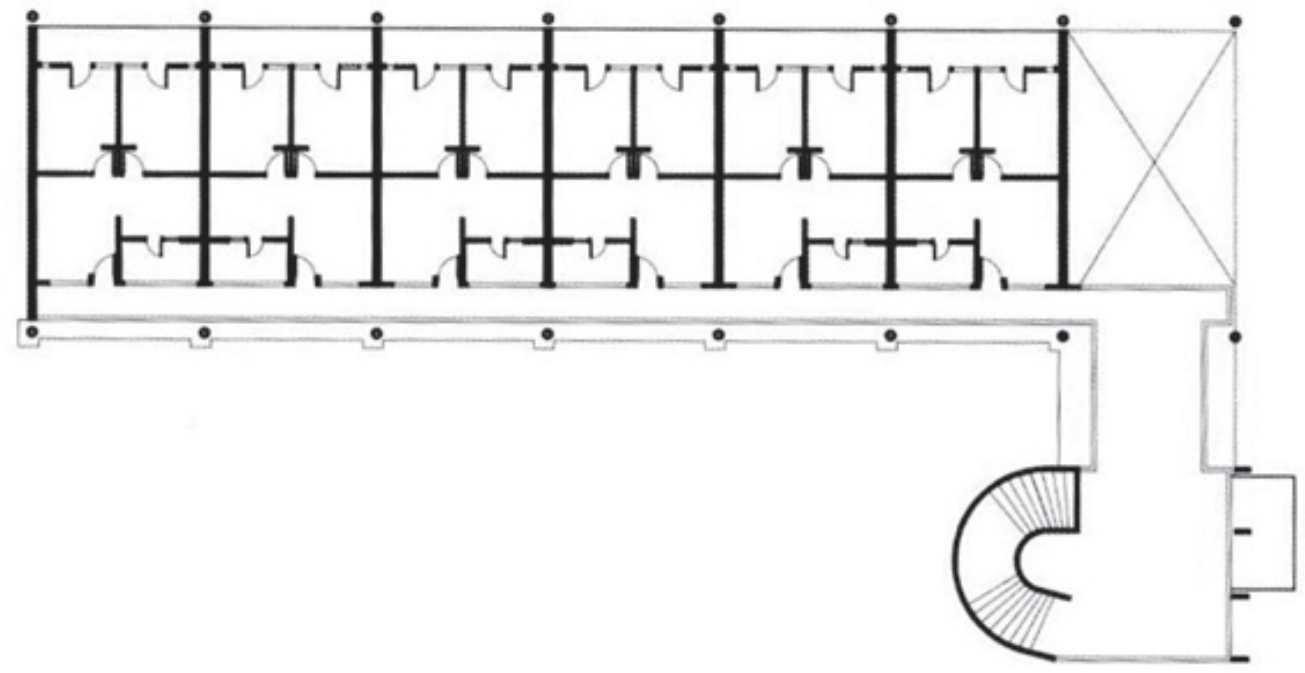

$Q_{N}$
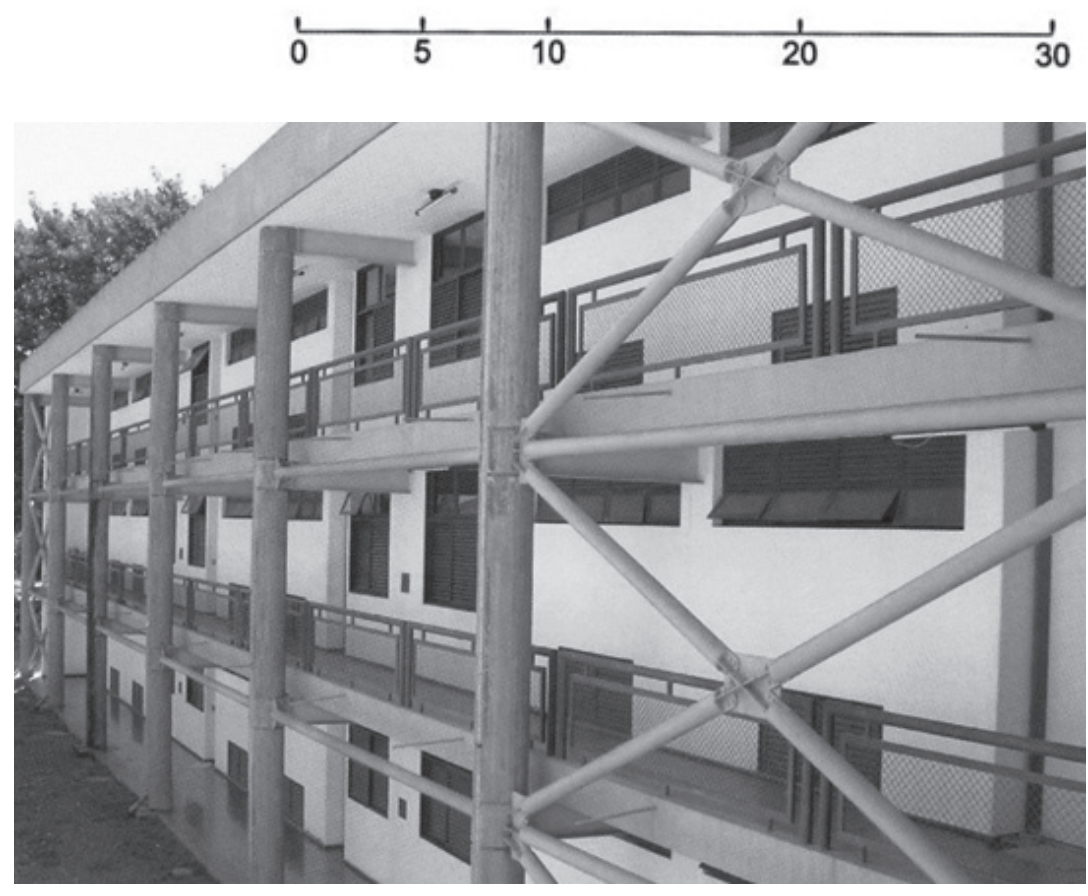

Figura 128b.

Figura 128c.

Vista da fachada

Oeste

Figura 128d.

Vista da fachada

Leste. Foto Silvio

Cavalcante

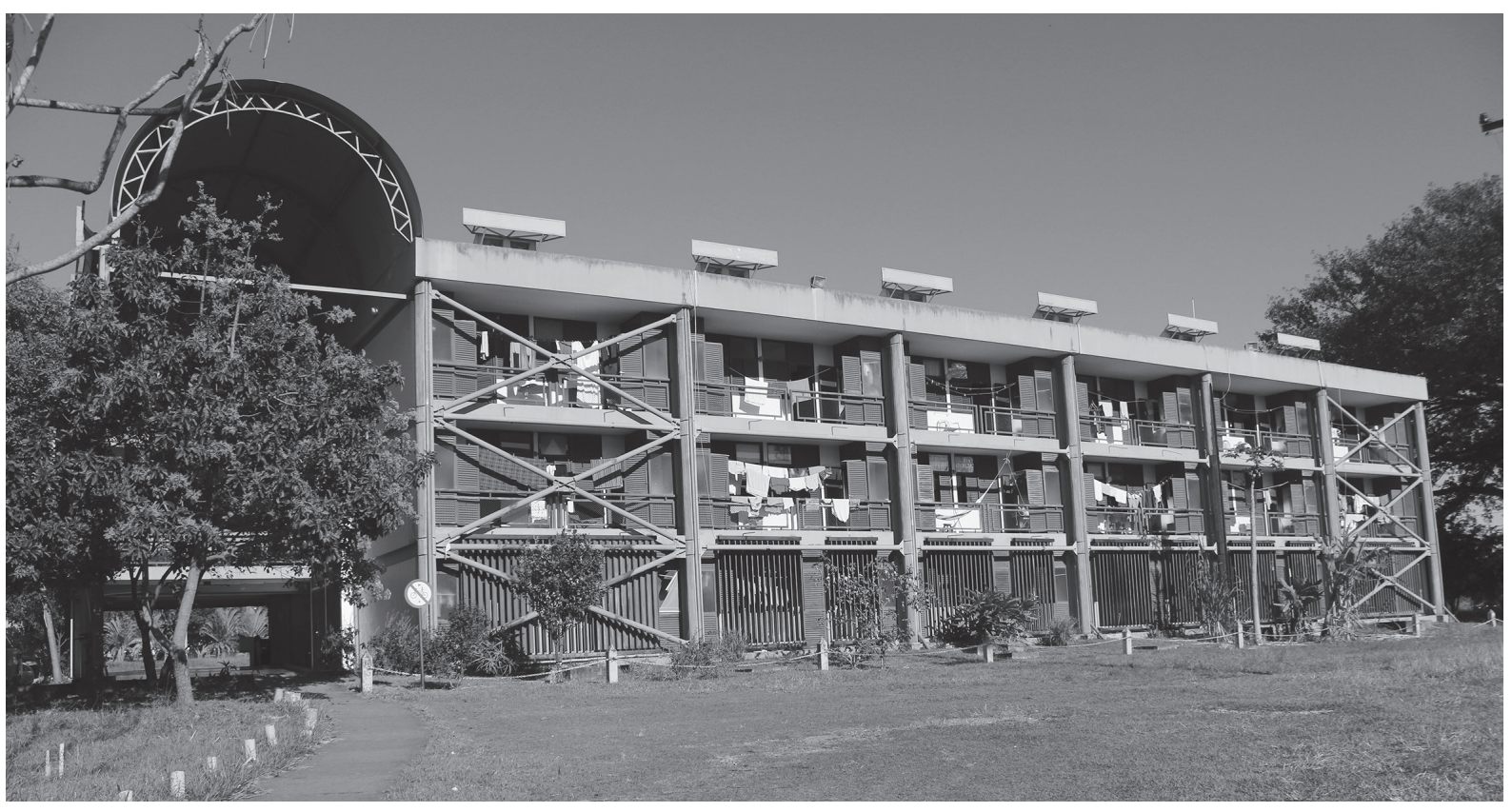


O abandono do projeto da Praça Maior fez com que o ICC (Minhocão), sobretudo nas entradas Sul e Norte, passasse a concentrar as atividades de convivência. Em 1974, com a construção do Restaurante Universitário, seu entorno passou a funcionar como ponto de atração, propício ao encontro da comunidade universitária, o que determinou a localização de um Centro de Vivência, que abriga uma agência bancária, um pequeno café e uma livraria.

O edifício foi projetado em módulos como forma de permitir um futuro crescimento de acordo com as necessidades.

O sistema construtivo apresenta uma estrutura independente de concreto armado que sustenta uma grelha reticulada em concreto aparente.

Na face Nordeste, voltada para o Restaurante Universitário, está o mural de azulejos "Maré", de Jayme Golubov.

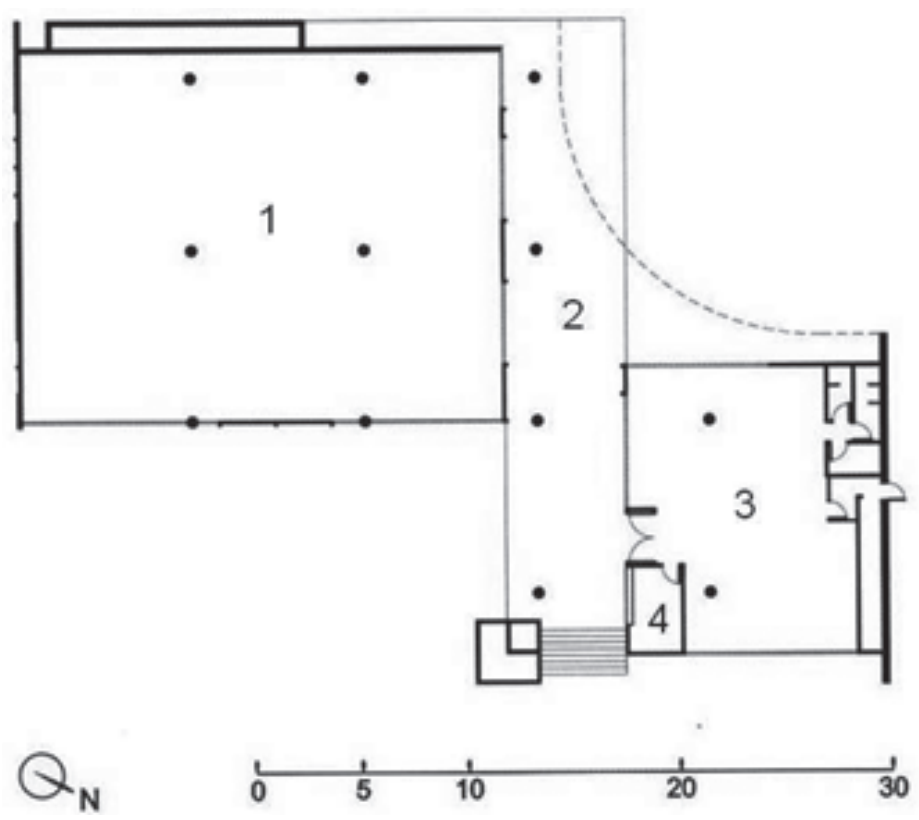

Figura 129b.

Planta esquemática

Figura 129c.

Vistas da circulação

coberta

Figura 129d.

Vista da fachada Leste
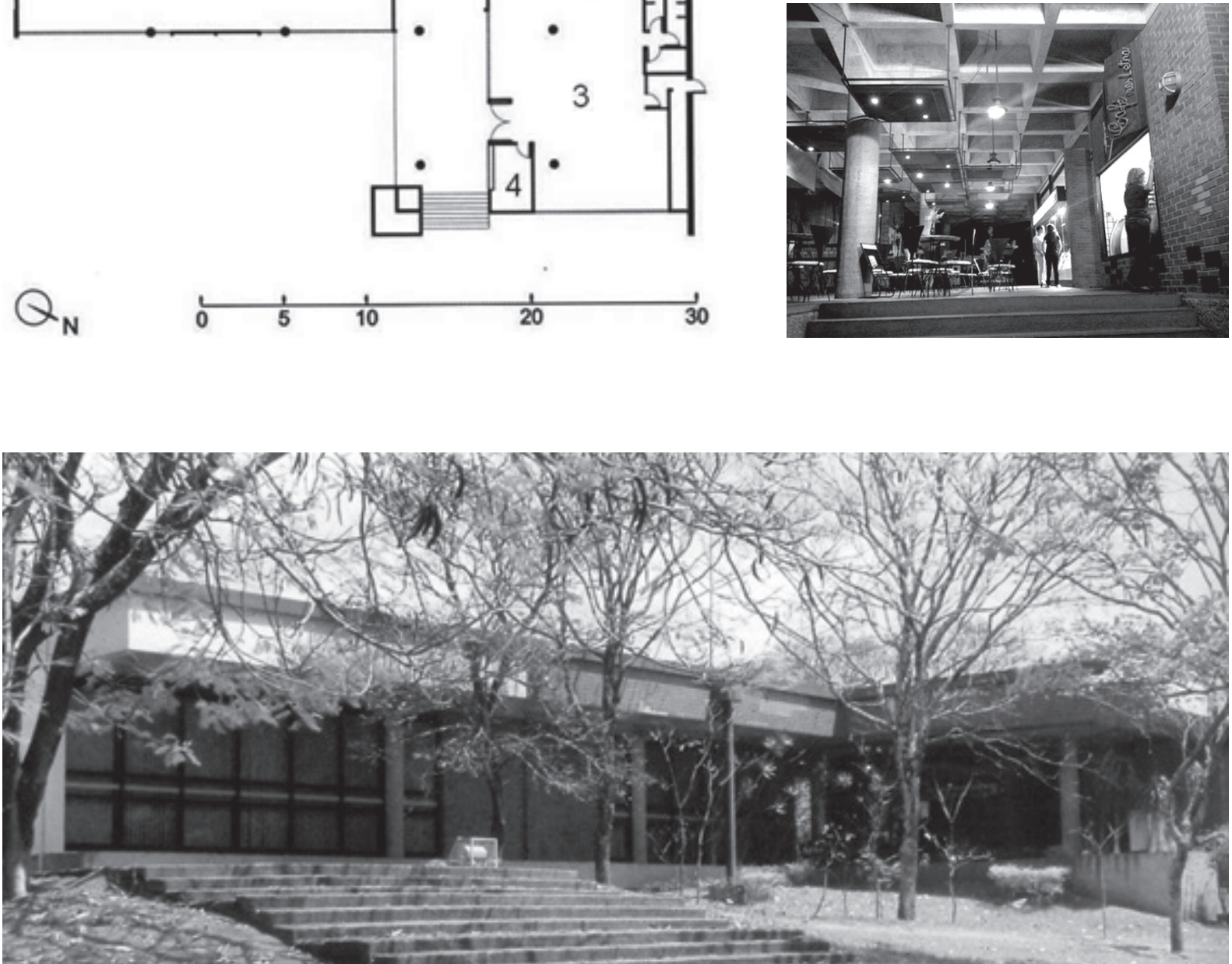
AUTOTRAC

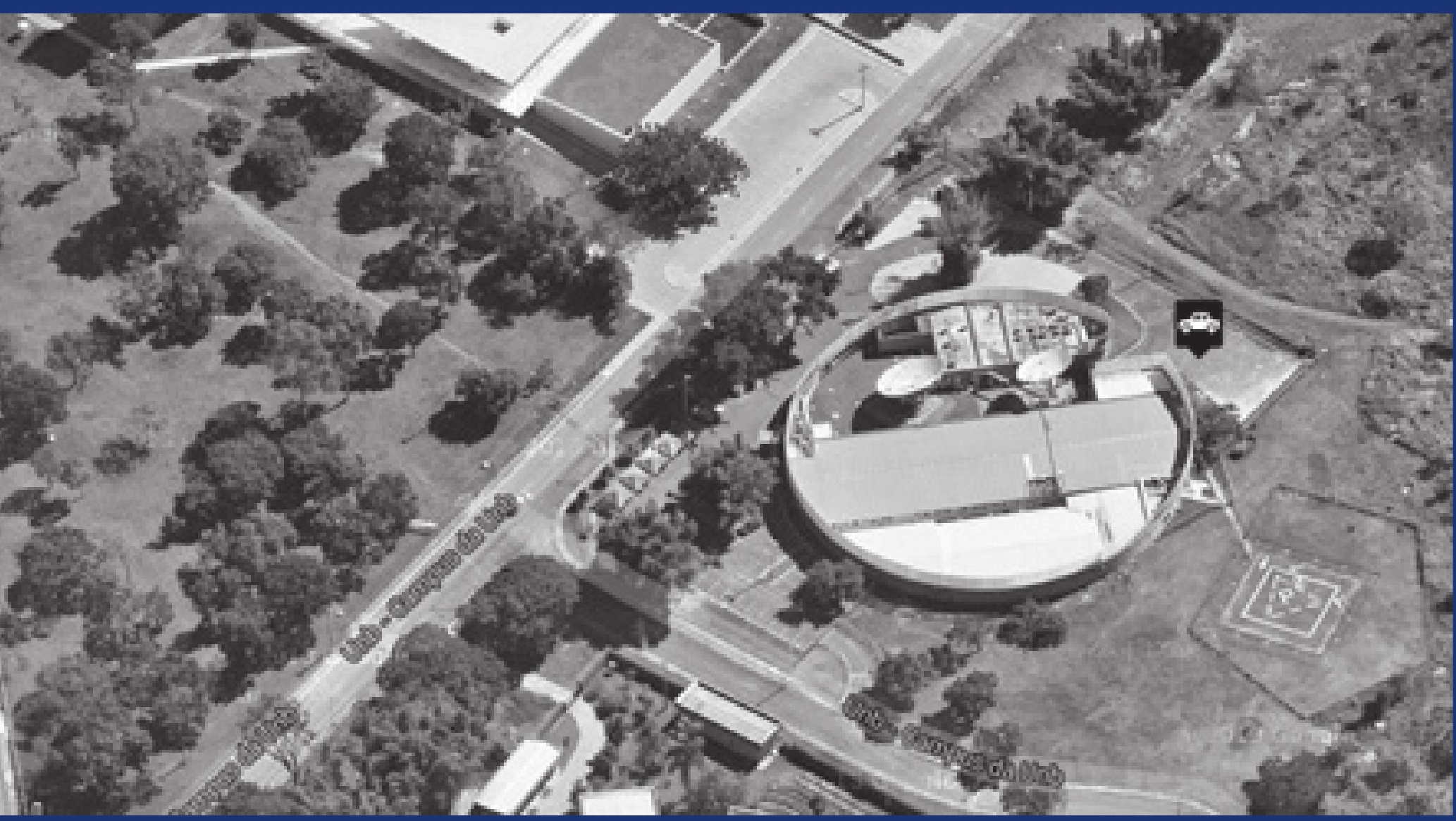

Autoria

Cláudio José Pinheiro Villar de Queiroz, Marcílio Mendes Ferreira e Paulo Castilho.

Data

1993-1994. 
Fundado pelo tricampeão de automobilismo Nelson Piquet, o equipamento permite a transmissão de dados entre os veículos e empresa, o rastreamento de veículos em mapas digitais e o monitoramento de veículos e de sua carga.

Um muro circular em alvenaria de tijolos aparentes, que marca o edifício, serve para esconder as atividades internas e proteger as várias antenas e equipamentos de rastreamento e comunicação. No interior do círculo, um pavilhão de base retangular abriga as funções.

O projeto não foi executado na íntegra e já sofreu alterações descaracterizadoras.
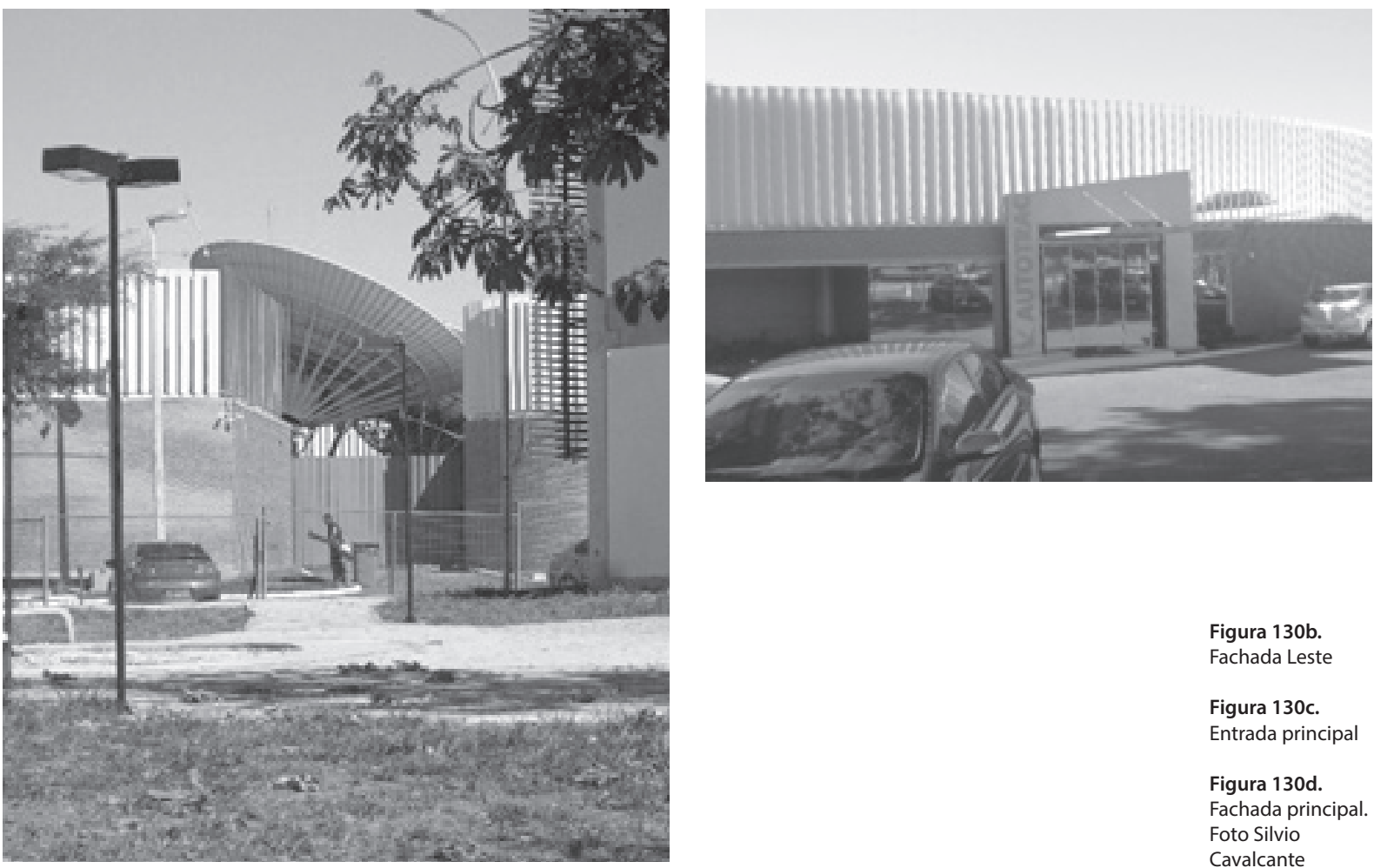

Figura 130b.

Fachada Leste

Figura 130c.

Entrada principa

Figura 130d.

Fachada principal.

Foto Silvio

Cavalcante

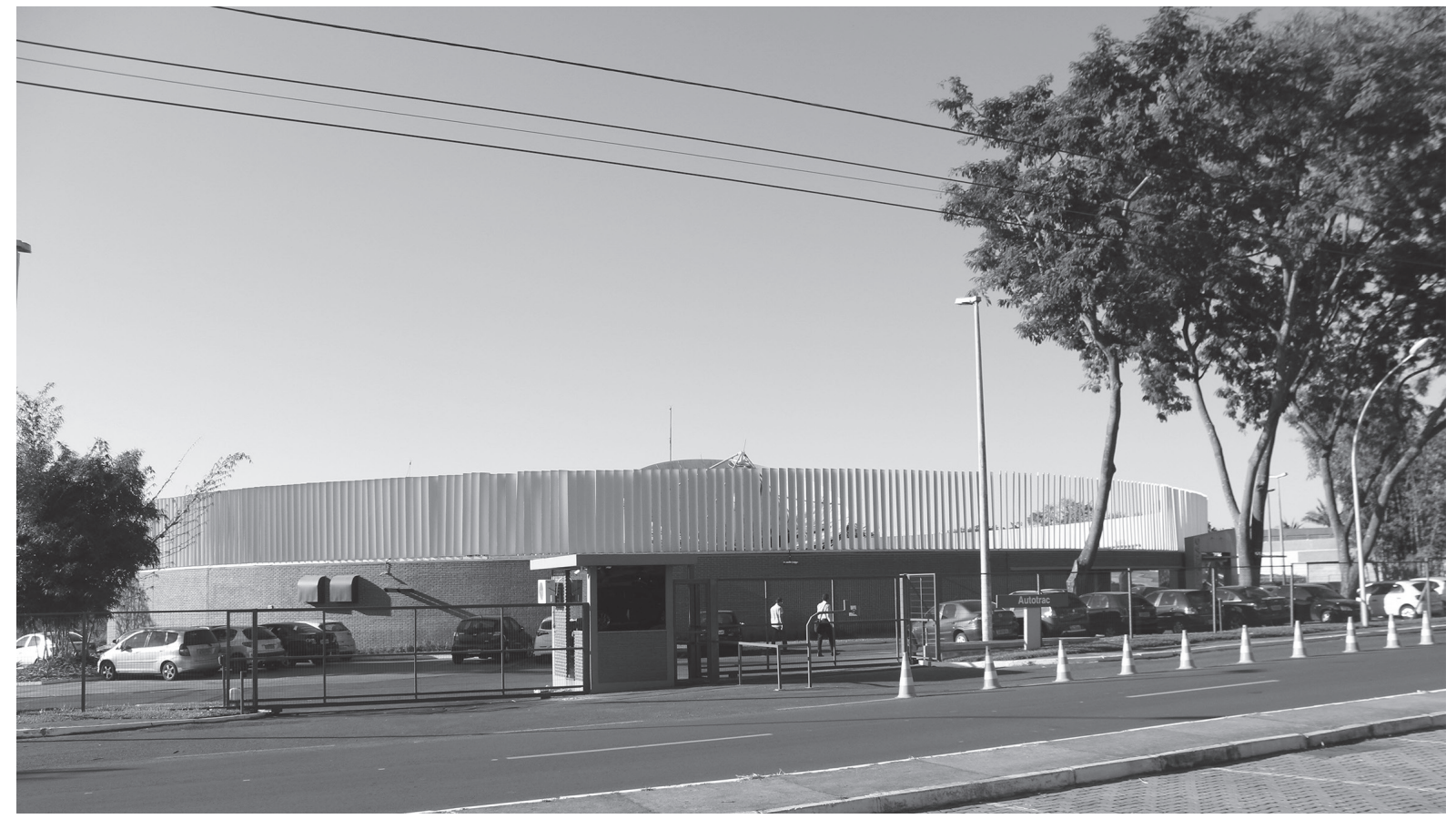




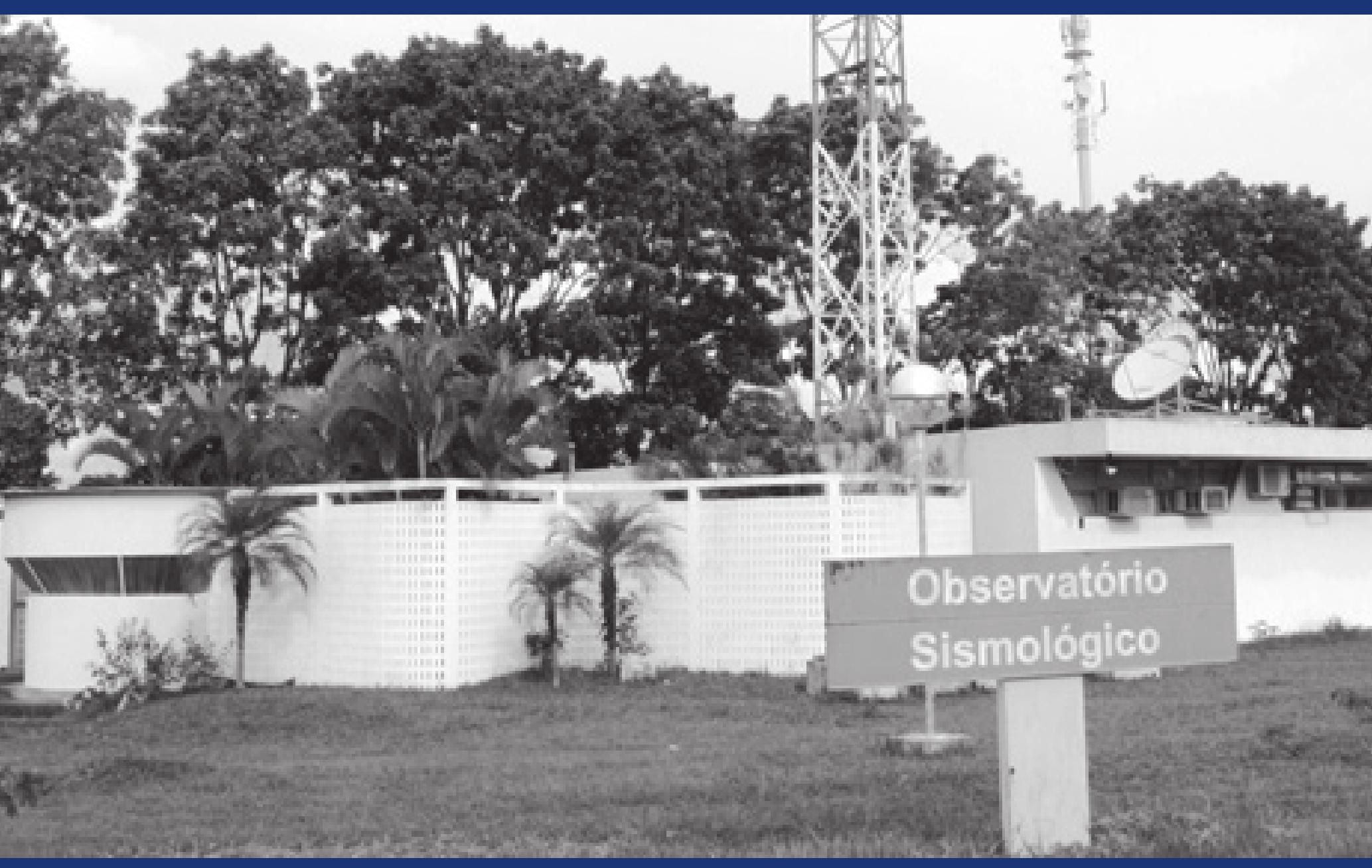

Autoria

William Ramos Abdala, Alberto Alves de Faria e Maria do Carmo Thormann. O projeto de ampliação foi executado por Alberto Alves de Faria, Taciana Vaz e Vanessa Bhering.

\section{Data}

1993 (projeto)

2007-2008 (obra do anexo)

Área Construída 
A Estação Sismológica foi criada em 1966, por recomendação da Organização das Nações Unidas para a Educação, a Ciência e a Cultura, como parte de um sistema, composto de 15 estações telemétricas, capaz de detectar sismos na Cordilheira dos Andes.

Em 1972 foi instalada a Estação Sismográfica BDF, como parte de uma rede mundial (World Wide Seismograph System Network), que contribuiu para o avanço da sismologia e para a ampliação da rede do SIS/UnB.

Em 1988 foi criado o Observatório Sismológico da UnB, que, ligado ao Instituto de Geociências, funcionou no ICC até 1993, quando foi transferido para sua sede própria.
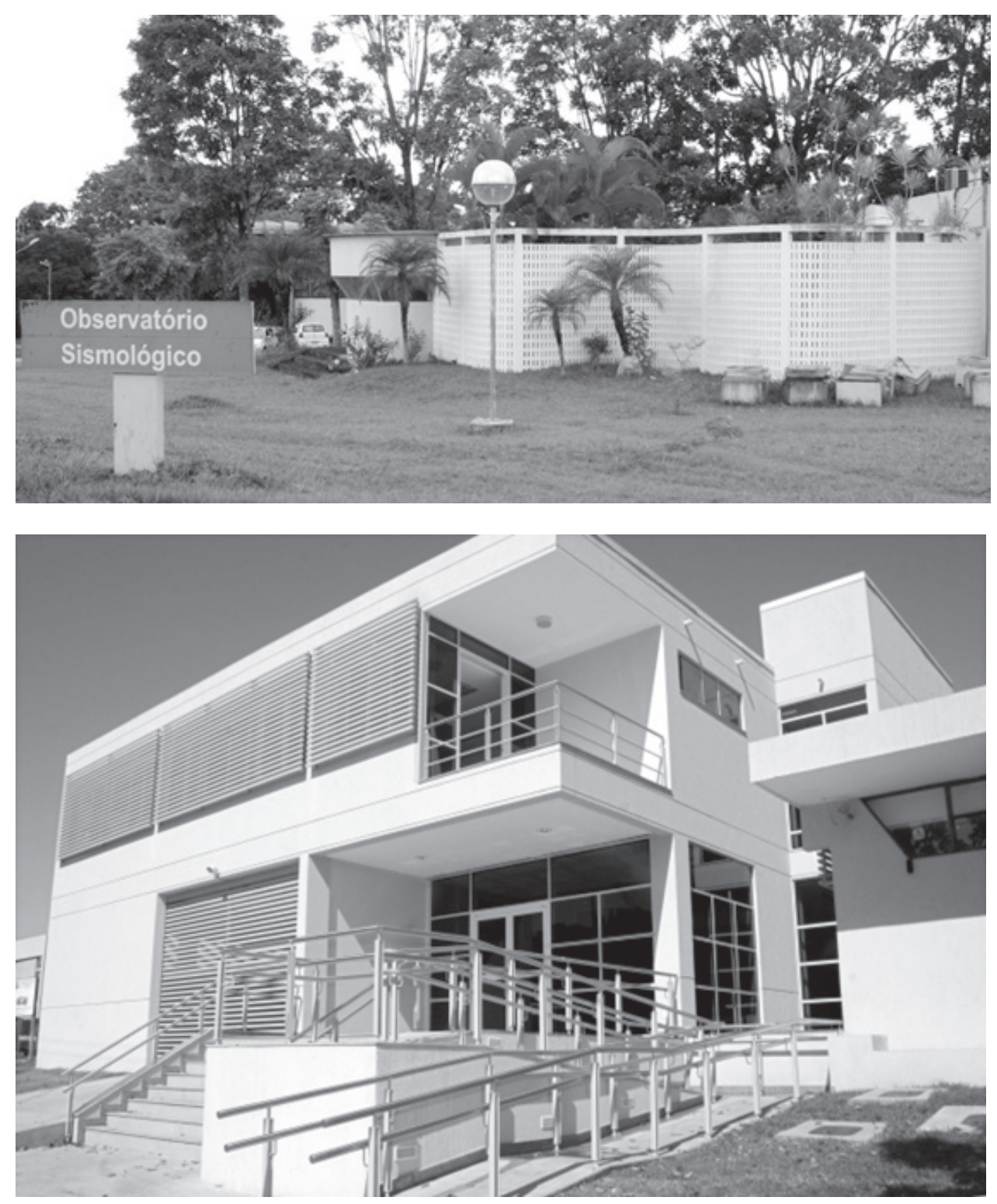

Figura 131b.

Vista da Fachada Oeste 


\section{CENTRO DE FORMAÇÃO DE RECURSOS HUMANOS EM TRANSPORTES}

URBANOS (CEFTRU)

\section{Autoria}

Maria do Carmo Thormann

\section{Data}

1996-1997

Área Construída

$2,170 \mathrm{~m}^{2}$
Figura 132a.

Vista da fachada

Sul 
O centro', que resultou de uma parceria entre a UnB e o Ministério dos Transportes, desenvolve pesquisas no setor de transporte, na formação e qualificação de profissionais voltados para as questões do meio ambiente, trânsito e pavimentação de vias.

Em 1994 foi realizado um concurso, tendo sido vencedor o projeto assinado pelos arquitetos Cláudio Quieroz, Marcílio Ferreira, Suzana Souza e Jônio Cintra. Mas a proposta não foi executada. Dois anos depois iniciaram-se as obras para construção do novo projeto elaborado pela arquiteta Maria do Carmo Thormann.

Com estrutura independente de concreto e vedações em alvenaria de tijolos, o edifício é composto de dois blocos paralelos de um pavimento, nos quais foram distribuídas as áreas de trabaIho e formação.

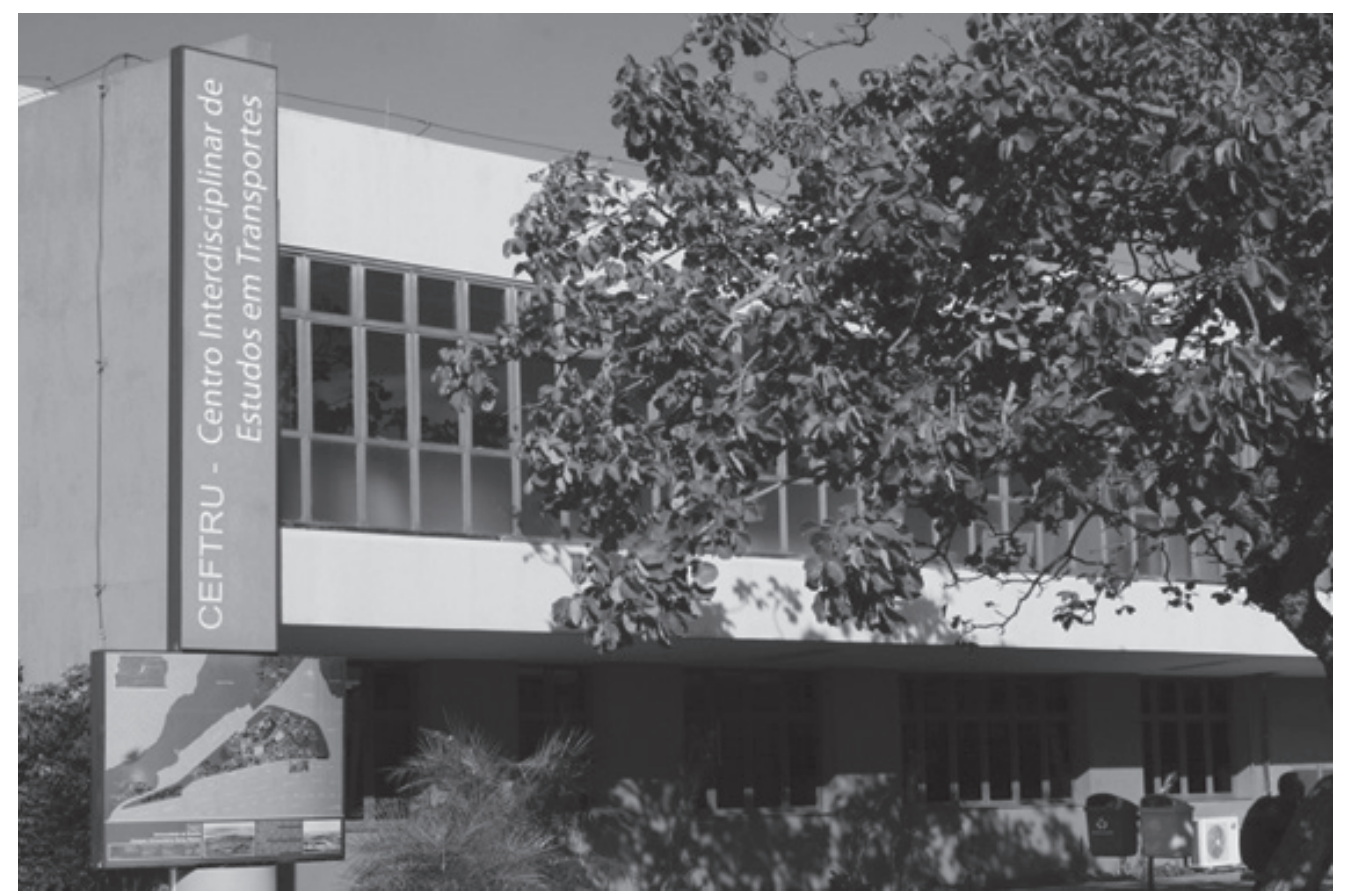

Figura 132b.

Vista das

fachadas Oeste

e Sul

Figura 132c.

Vista da

fachada Leste

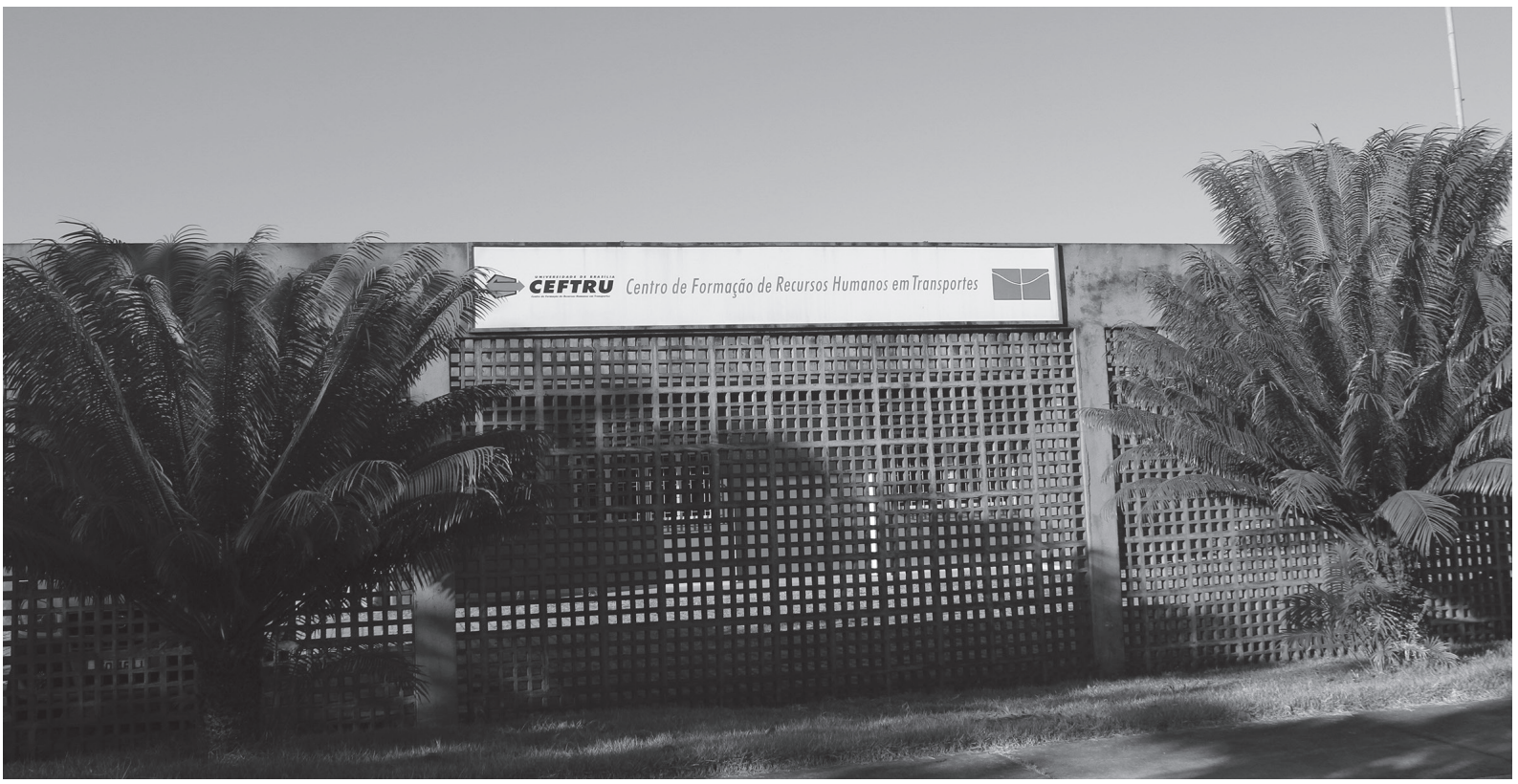

10 projeto não foi desenvolvido no âmbito de Ceplan, e sim na Prefeitura do Campus, na qual a arquiteta foi lotada 
PAVILHÃO DE OFICINAS ESPECIAIS - INSTITUTO DE ARTES (IDA)

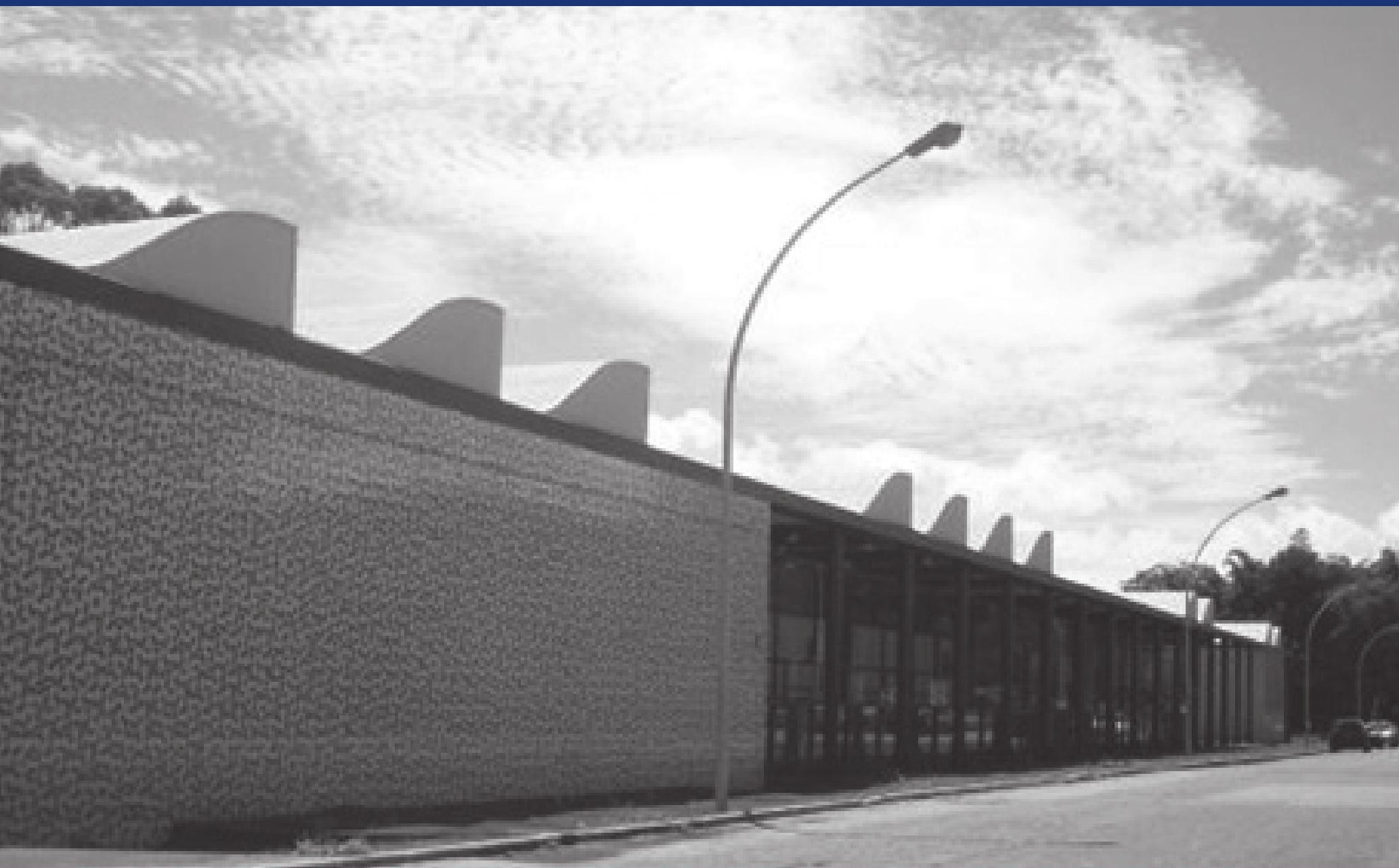

Autoria

Cláudio José Pinheiro Villar de Queiroz, com a colaboração da professora Tânia Regina Fraga

Data

1997 (projeto) 2002 (obra)

Área Construída

$4.270 \mathrm{~m}^{2}$ 
O pavilhão, elaborado com intuito de garantir aos professores e alunos do curso de Artes Cênicas do IdA um ambiente adaptado a suas atividades, é parte de um conjunto maior de edificações, novas e antigas, que deverão integrar o chamado Complexo das Artes da UnB. Constuída a primeira parte do projeto, o espaço foi ocupado pelo Departamento de Artes Cênicas e pela galeria de arte do Departamento de Artes Visuais (Espaço Piloto).

O edifício está dividido em dois blocos: o bloco A, onde desde 2006 se localiza o Espaço Piloto, constituído de três galerias de exposições, que incluem o subsolo, o térreo e o mezanino. $O$ bloco B é dotado de salas para o ensino das artes cênicas, com tablado de madeira, laboratório de sonoplastia, sala de figurino, laboratório de informática, sala de cenografia, sala de iluminação e um teatro com capacidade para 400 pessoas.

O pavilhão corresponde a uma caixa de vidro retangular, com $110 \mathrm{~m} \times 17,50 \mathrm{~m}$, contida entre dois sólidos e coberta por uma estrutura metálica independente.
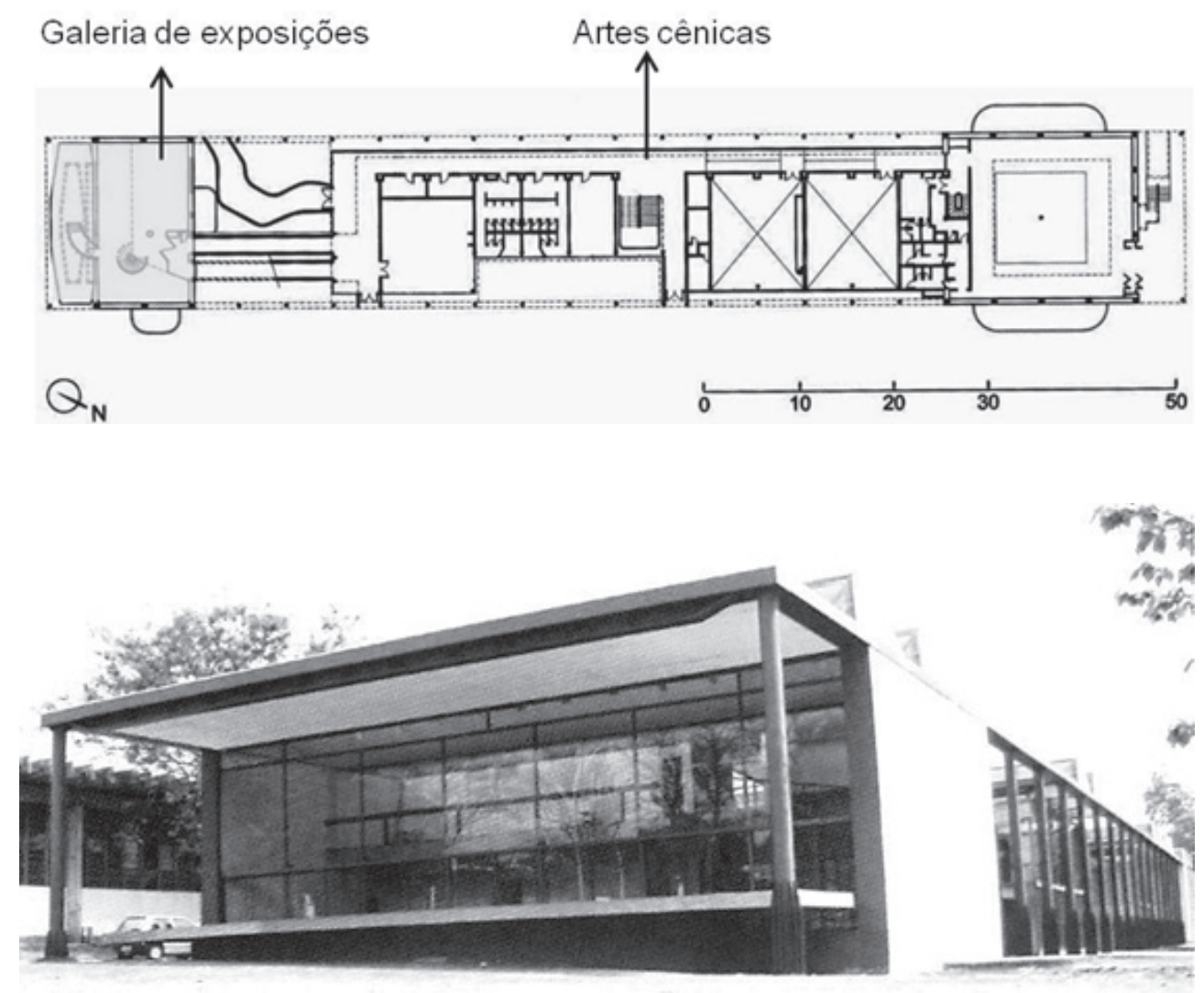

Figura 133b.

Planta esquemática

Figura 133c.

Vista da fachada

Sudeste

Para a proteção da caixa de vidro foi desenvolvido um sistema sequencial de pórticos metálicos que estruturam a cobertura em sheds. 

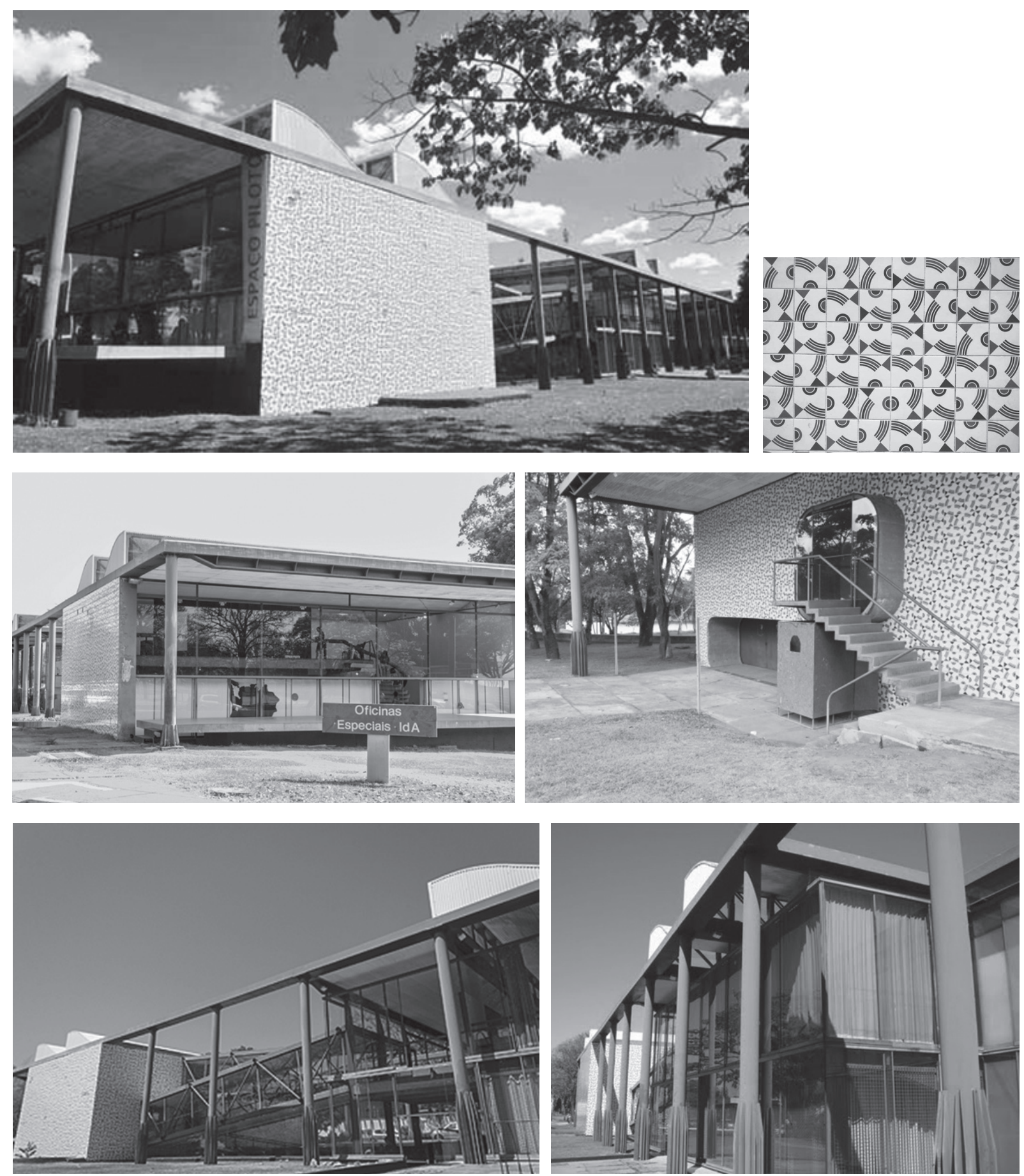

Figura 133d.

Vista da fachada Oeste

Figura 133e.

Detalhe do painel de azulejos de Athos Bulcão

Figura 133f.

Vista da fachada Sul

Figura 133g.

Vista da fachada Noroeste

Figura $133 \mathrm{~h}$.

Detalhes da estrutura

Figura 133i.

Vista da fachada Oeste.

Fotos: Walter de Carvalho 
POSTO ECOLÓGICO E EMPÓRIO AMBIENTAL

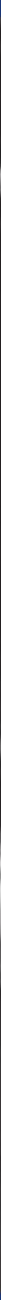

Autoria

Matheus Gorovitz e Adilson Macedo.

Data

1997 (projeto)

1998 (obra)

Área Construída

$1.842 \mathrm{~m}^{2}$ (posto) $141 \mathrm{~m}^{2}$ (empório). 
Em 1973 Matheus Gorovitz havia desenvolvido um projeto para a construção de um posto de gasolina na UnB, que seria implantado onde atualmente se localiza o bloco K da Colina. Posteriormente, foi redefinida a localização e o mesmo arquiteto fez um segundo projeto, construído com o patrocínio da Petrobras.

O posto apresenta uma grande cobertura em aço Corten apoiada em cinco pilares, que abriga as bombas de gasolina, e um pequeno bloco independente, onde estão localizados uma lanchonete e os demais serviços.

Por possuir, sob o concreto do piso, uma manta que impede a passagem dos combustíveis capazes de poluir o solo, o posto foi chamado de ecológico.

O empório corresponde ao espaço, anexo ao posto de gasolina, destinado a um café e ponto de encontro da comunidade universitária.
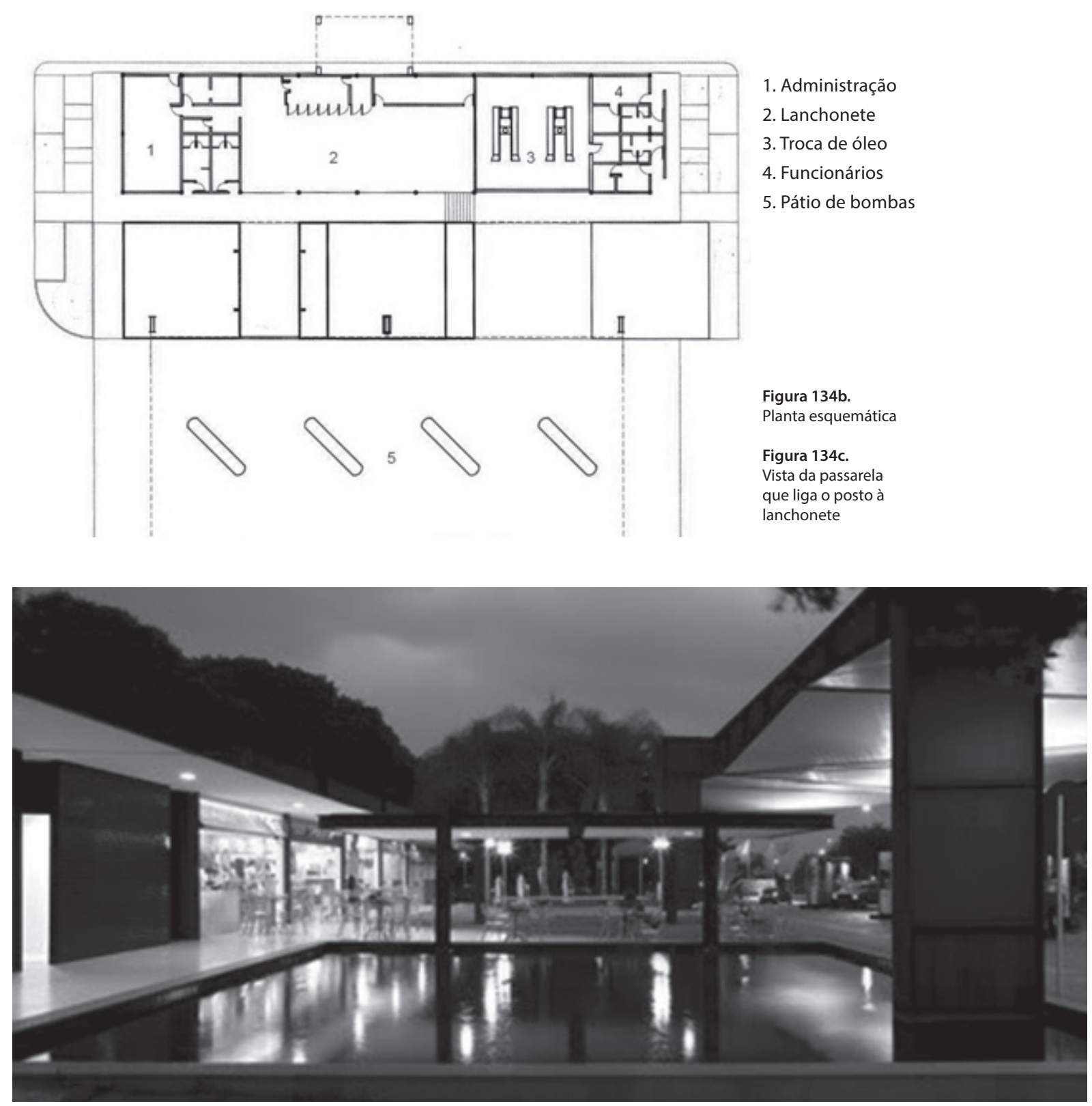

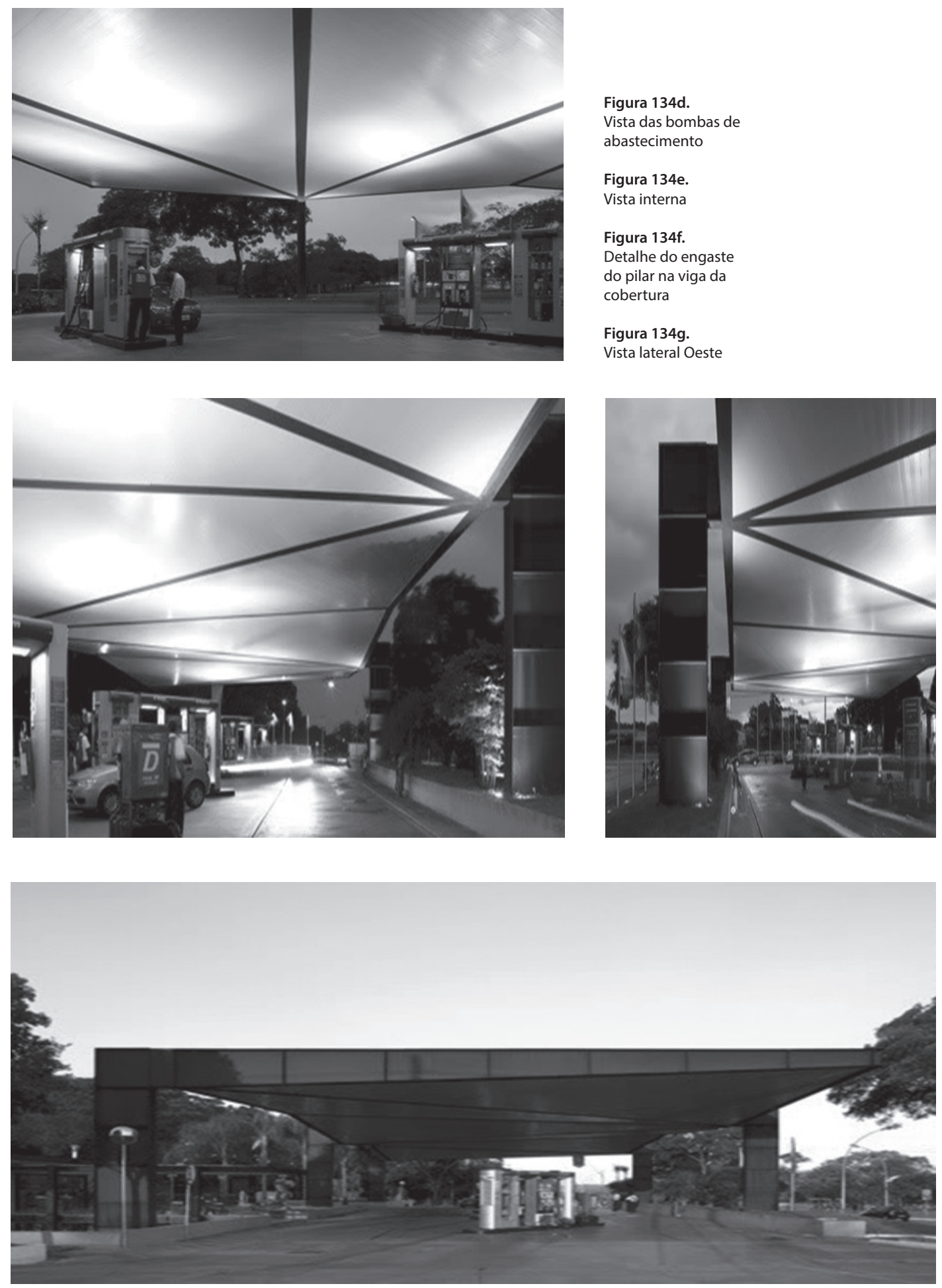

Figura 134d.

Vista das bombas de

abastecimento

Figura 134e.

Vista interna

Figura 134f.

Detalhe do engaste

do pilar na viga da

cobertura

Figura 134g.

Vista lateral Oeste

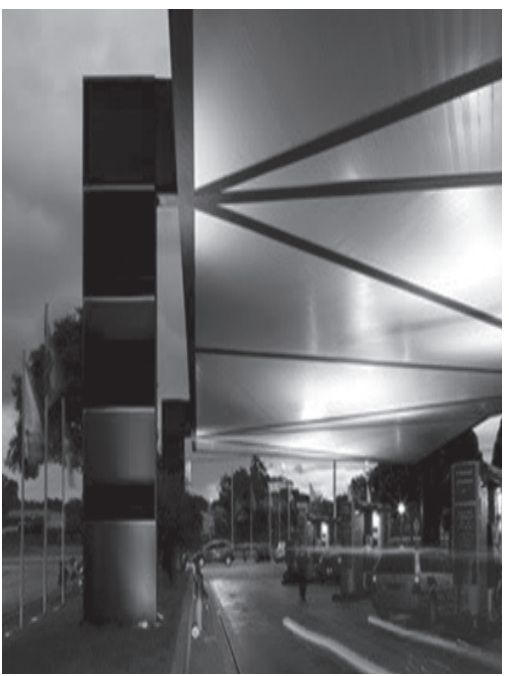




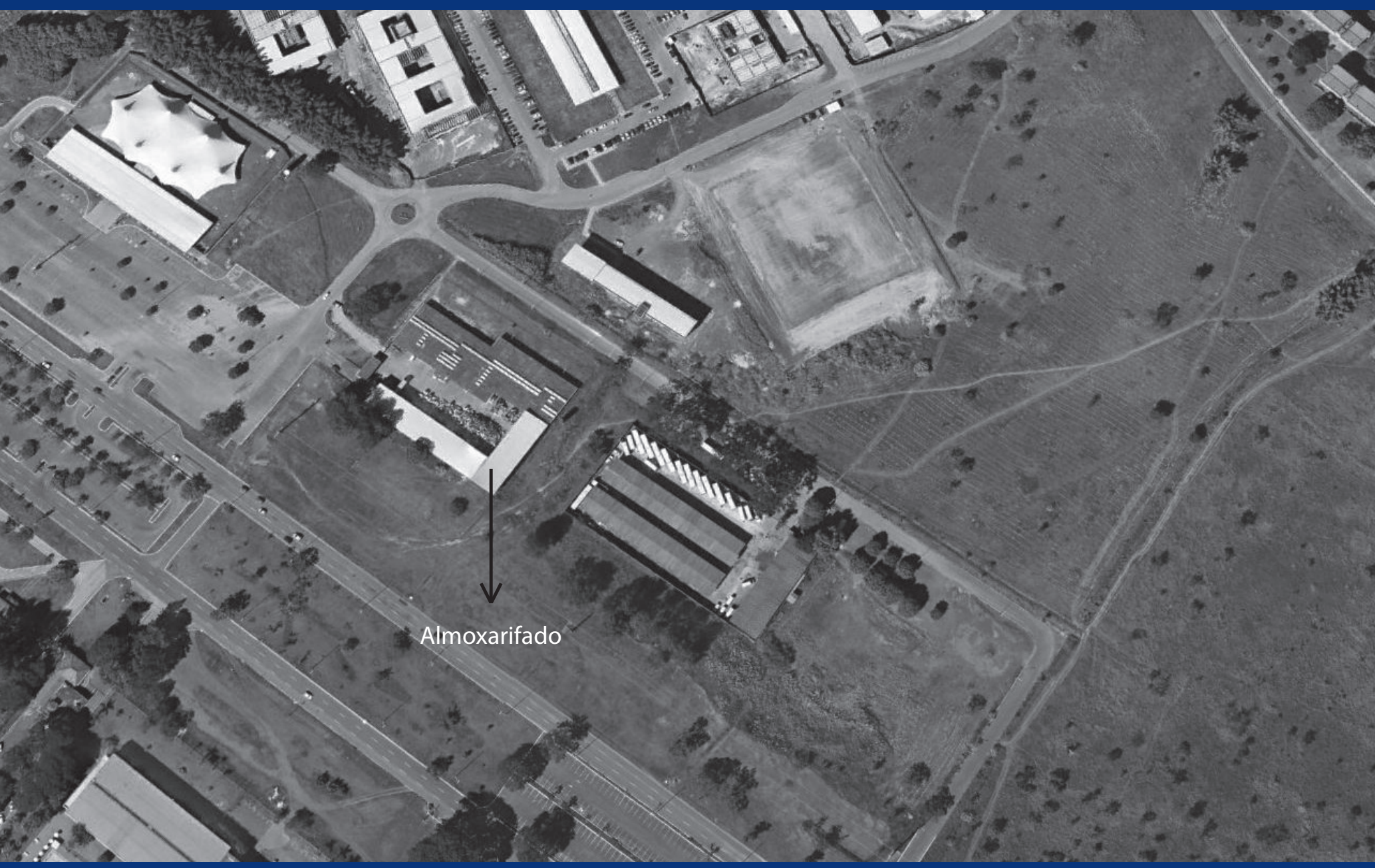

Autoria

Maria do Carmo Thormann

\section{Data}

1998, 2011 (novo galpão)

Área Construída

$6.375 \mathrm{~m}^{2} ; 700 \mathrm{~m}^{2}$ (novo galpão) 
O almoxarifado' é responsável pelo planejamento, coordenação e controle das atividades inerentes ao recebimento, armazenamento e distribuição dos materiais de consumo usados na UnB. Edifício composto de peças de argamassa armada, projetadas por João Filgueiras Lima na Fábrica de Equipamentos Urbanos de Brasília.

Em 2011, o Almoxarifado ganhou um novo galpão, de $770 \mathrm{~m}^{2}$, que contribui para melhorar o fluxo de entrega de suprimentos básicos para o funcionamento da UnB.
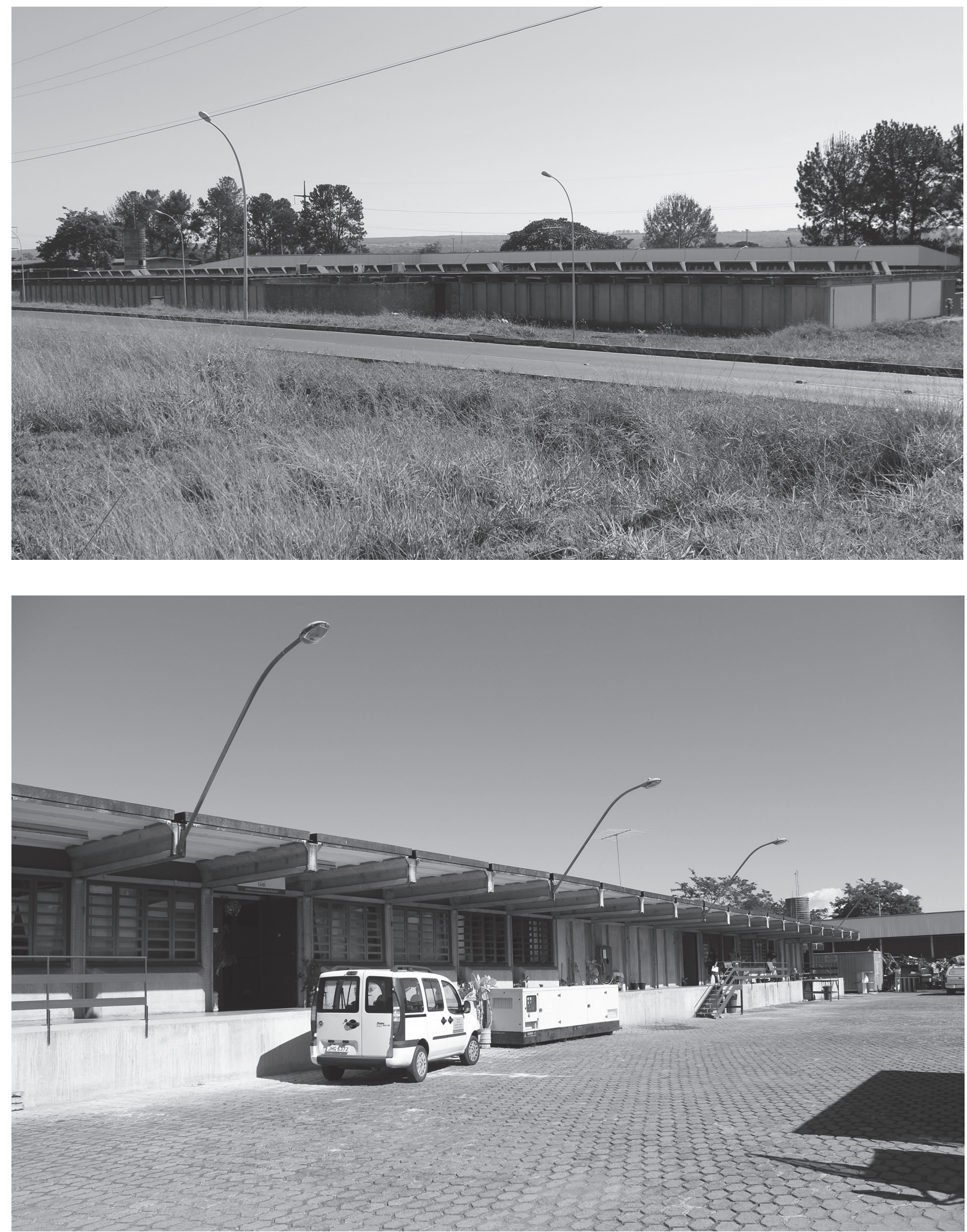
CENTRO COMUNITÁRIO ATHOS BULCÃO

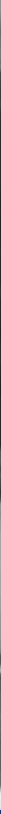

Autoria

Frederico Luiz Aguiar de Carvalho, Silvano Pereira, Leandro

Drumond Marques, Mona Lisa Lobo de Souza Choas e Joyce

Mendonça

\section{Data}

1999 (projeto)

2001 (obra)

Área Construída

$6.727 \mathrm{~m}^{2}$ 
O Centro ${ }^{1}$ foi construído para abrigar eventos variados, resolvendo os problemas gerados pelo uso indevido dos edifícios acadêmicos para festas, shows etc. Seu nome é uma homenagem ao artista plástico e professor que veio para a UnB na década de 1960 trazido por Darcy Ribeiro.

O conjunto é composto por duas edificações distintas e complementares: um edifício de planta retangular (com 120 m de extensão), construído em estrutura metálica, que serve para abrigar as funções administrativas e de apoio; e uma grande tenda, com vão livre de 70 m e capacidade para 2.000 pessoas, coberta por uma estrutura tensionada recoberta por uma membrana de poliéster importada da Itália. A estrutura da tenda, desenvolvida em parceria com o Departamento de Engenharia Civil da UnB, conta com seis mastros cônicos em chapa galvanizada a fogo.

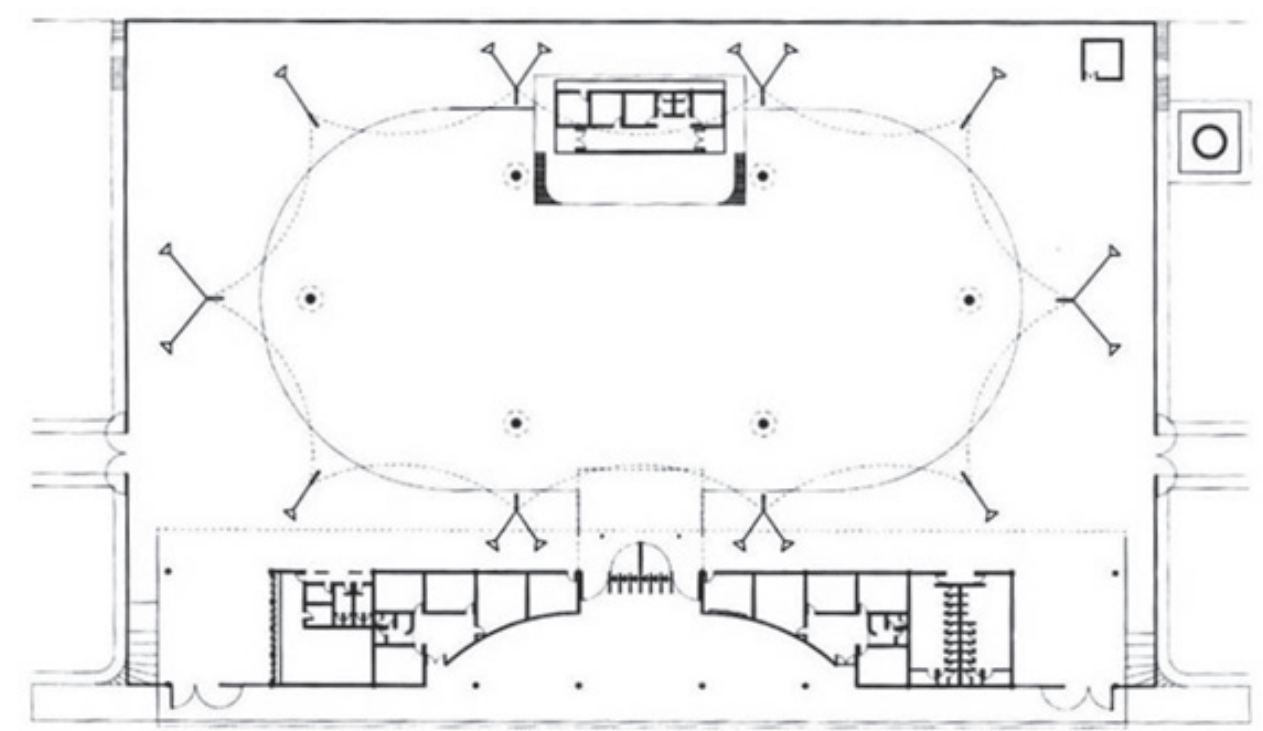

$Q_{N}$

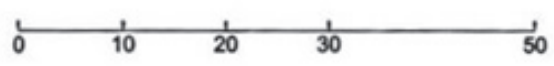

Figura 136b.

Planta esquemática do

conjunto

Figura 136c.

Vista do interior da tenda

Figura 136d

Vista das fachadas Leste

Figura 136e.

Vista da fachada principal
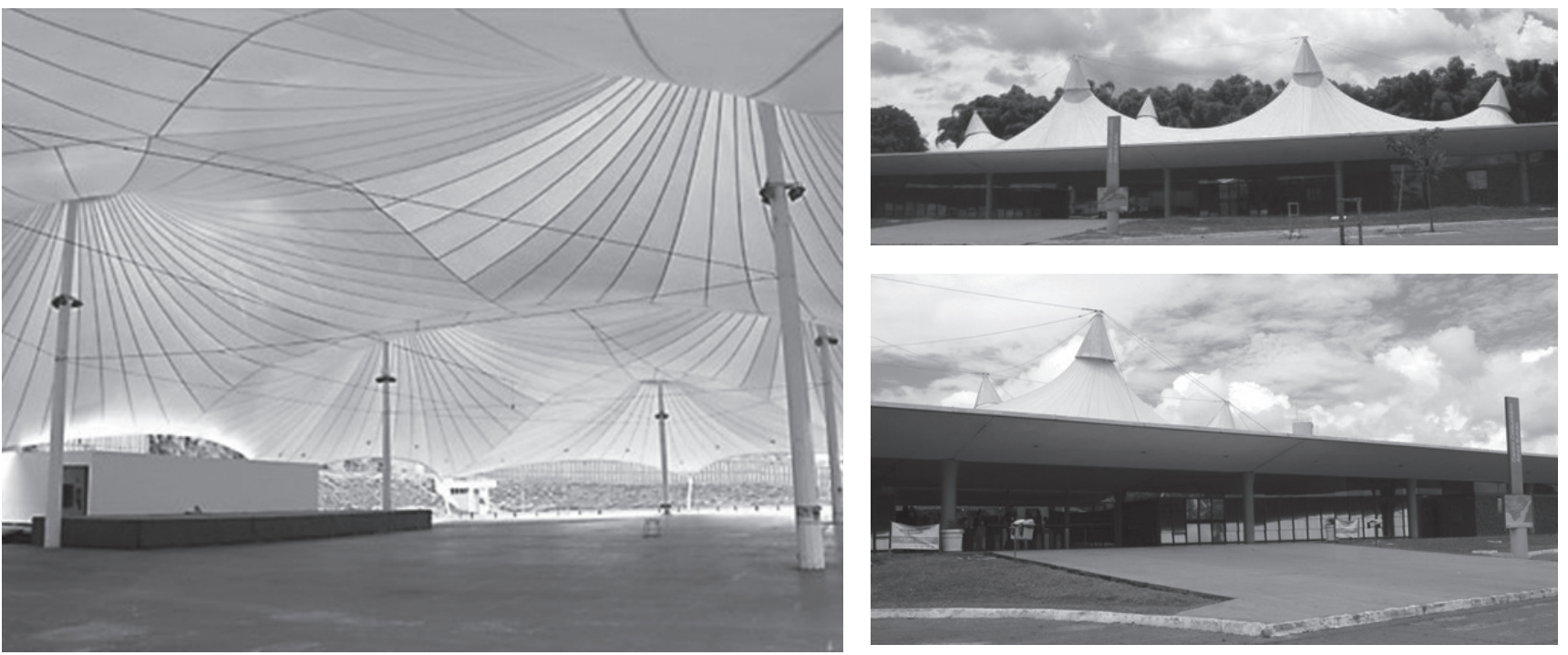
CENTRO DE APOIO AO DESENVOLVIMENTO TECNOLÓGICO (CDT)
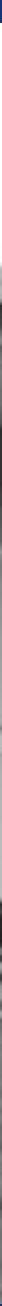

Autoria

Alberto Alves de Faria e Leandro Drumond Marques

\section{Data}

1999 (projeto)

2006 (obra)

Área Construída

$3.314 \mathrm{~m}^{2}$
Figura 137a. 
O Centro de Apoio ao Desenvolvimento Tecnológico foi criado em 1986 como um órgão de apoio à criação de novas empresas, incentivando a prática do empreendedorismo em escolas técnicas e na própria universidade.

Trata-se de um único volume, em forma de "U", contido em uma área de aproximadamente 45 x 42 $\mathrm{m}$. Nas duas alas principais foram localizados os espaços específicos e/ou restritos, como as empresas incubadas ou os núcleos tecnológicos. Entre as alas foram dispostos o hall de acesso e distribuição, o auditório, os sanitários e a lanchonete. O edifício abre-se para um grande pátio central. Externamente o edifício é marcado por um jogo de panos cegos em alvenaria de tijolo aparente intercalados por panos de vidro, e também pela cobertura metálica e seus longos beirais.
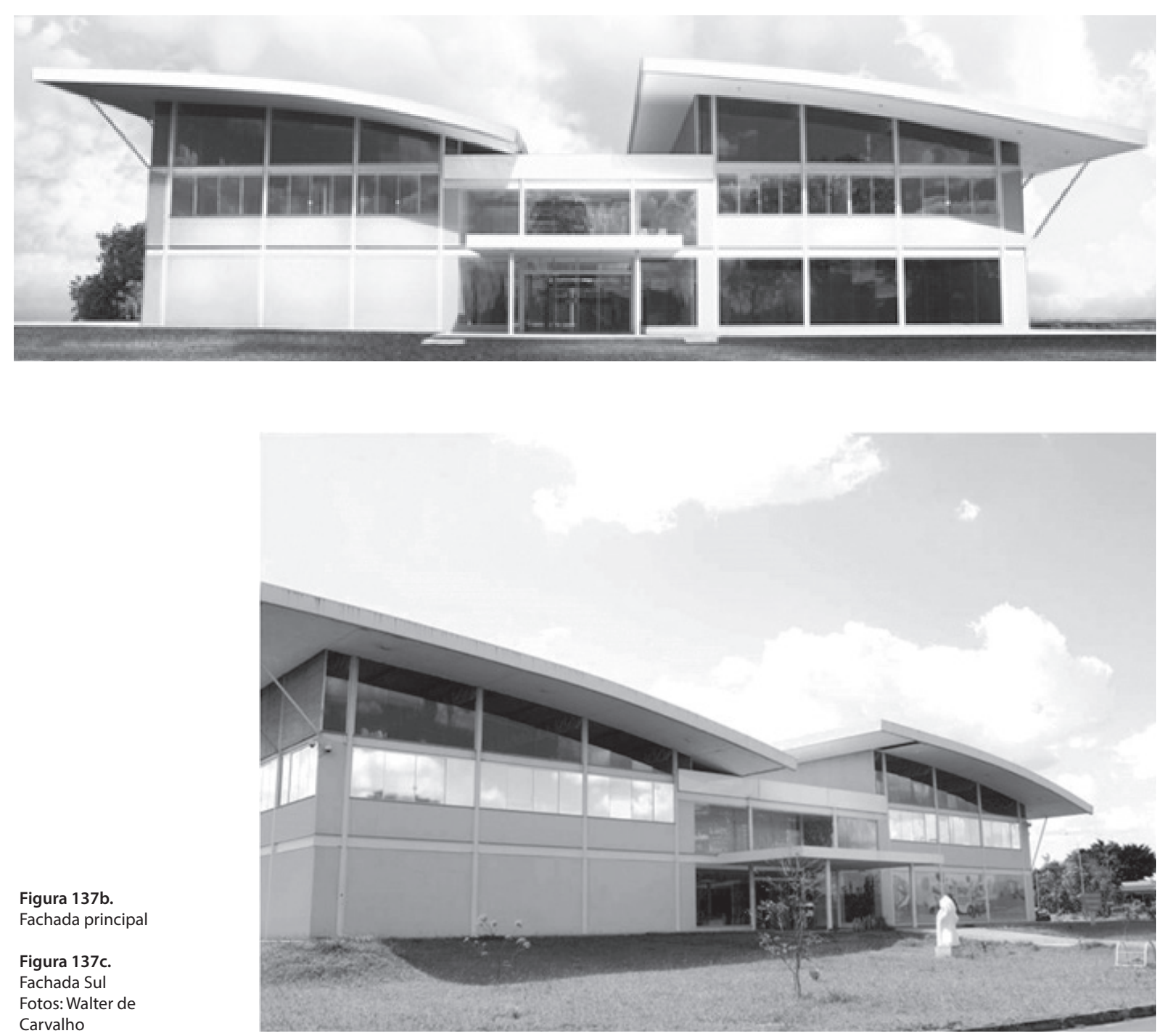
PAVILHÃO ANÍSIO TEIXEIRA (PTA) E PAVILHÃO JOÃO CALMON (PJC)

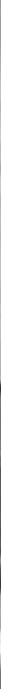

Autoria

Cláudio José Pinheiro Villar de Queiroz, com a colaboração de Cláudio Sasse, Suzana Souza e Rosmery Hokino

Data

1999 (projeto)

1999 (obra do Anísio Teixeira)

2000 (obra do João Calmon)

Área Construída

$2.880 \mathrm{~m}^{2}$ por pavilhão. Total $=5.760 \mathrm{~m}^{2}$
Calmon 
Os pavilhões foram construídos com o objetivo de minimizar a carência de espaços pedagógicos de diversas unidades, sobretudo aquelas ligadas às Ciências Humanas, sediadas no ICC Norte e na Faculdade de Estudos Sociais Aplicados.

Na verdade os dois pavilhões foram feitos numa circunstância emergencial porque faltavam salas de aula no ICC. [...] Eles foram projetados em um mês. Foi pedido, e um mês depois o projeto tava pronto. Os dois pavilhões foram construídos em seis meses. Três meses, três meses. O primeiro foi o Anísio Teixeira. No semestre seguinte do ano 2000, eles já foram usados (QUEIROZ, s.d.).

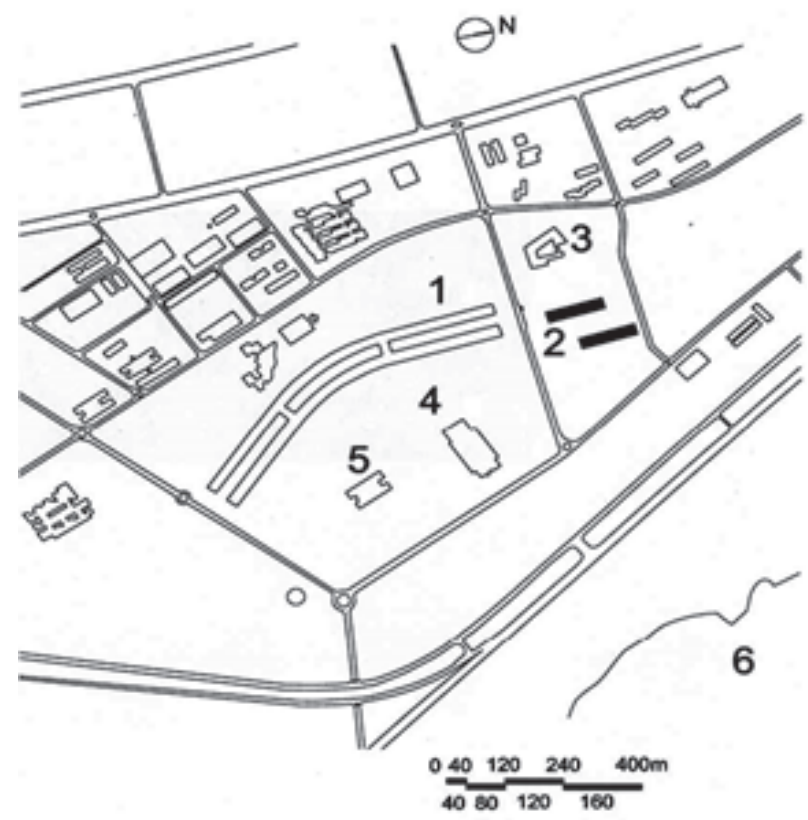

1. ICC - Instituto Central de Ciências

2. Pavilhões

3. Faculdade de Estudos Sociais Aplicados

4. Biblioteca Central

5. Reitoria

6. Lago Paranoá
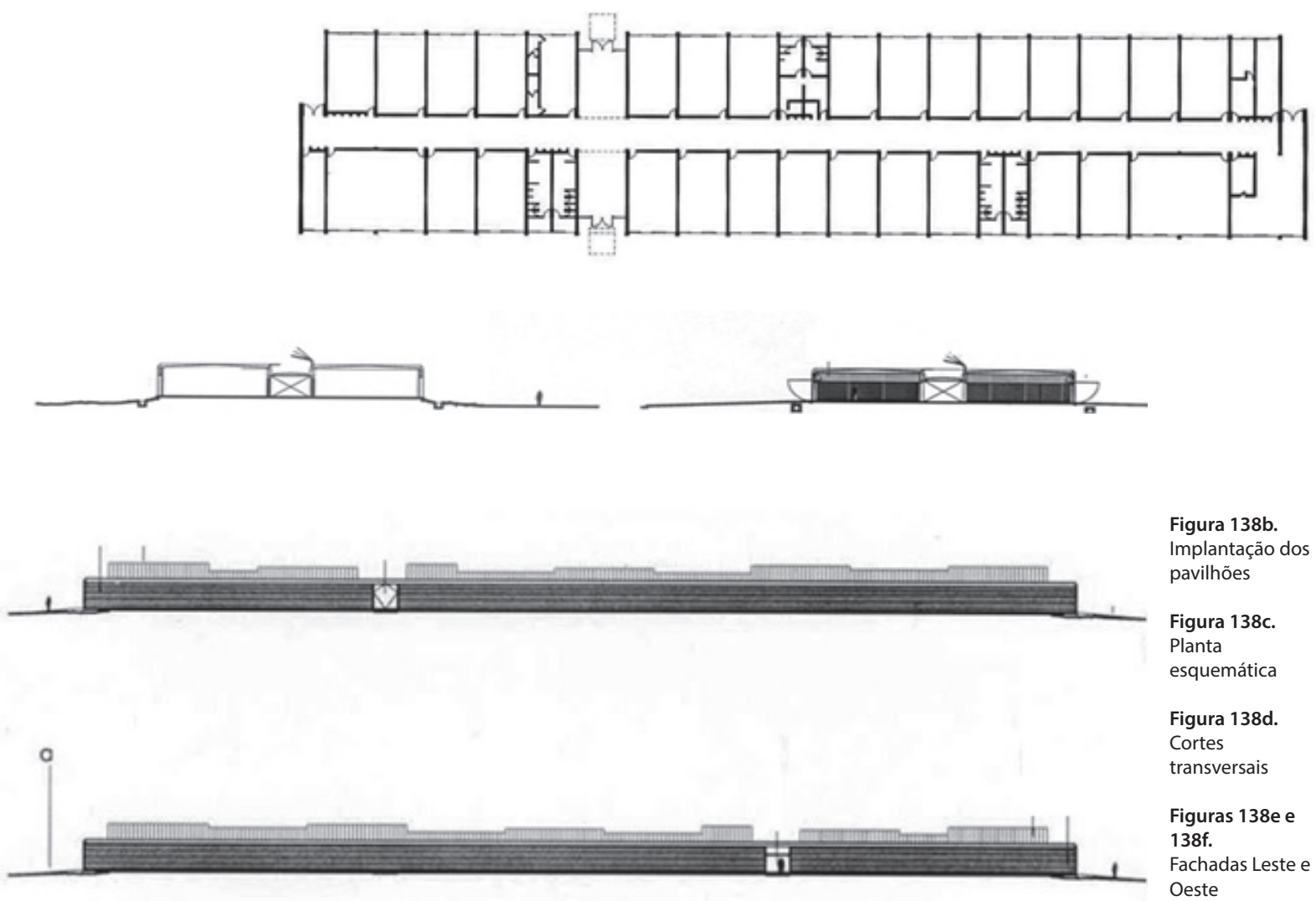
Cada bloco, que mede $120 \mathrm{~m} \times 24 \mathrm{~m}$, consiste na justaposição de duas sequências paralelas de 15 salas, de $10 \mathrm{~m} \times 6 \mathrm{~m}$, separadas por uma circulação de 4 metros, iluminada e ventilada por sheds pintados de amarelo.

Eu queria fazer um edifício que fosse radicalmente simples, a universidade não dispunha de dinheiro, de recursos [...] Então, eu estudei uma estrutura metálica, um esqueleto metálico, um chão de granitina, como é esse chão do ICC, muito resistente, como é o chão daqueles prédios todos do início (QUEIROZ, s.d.).

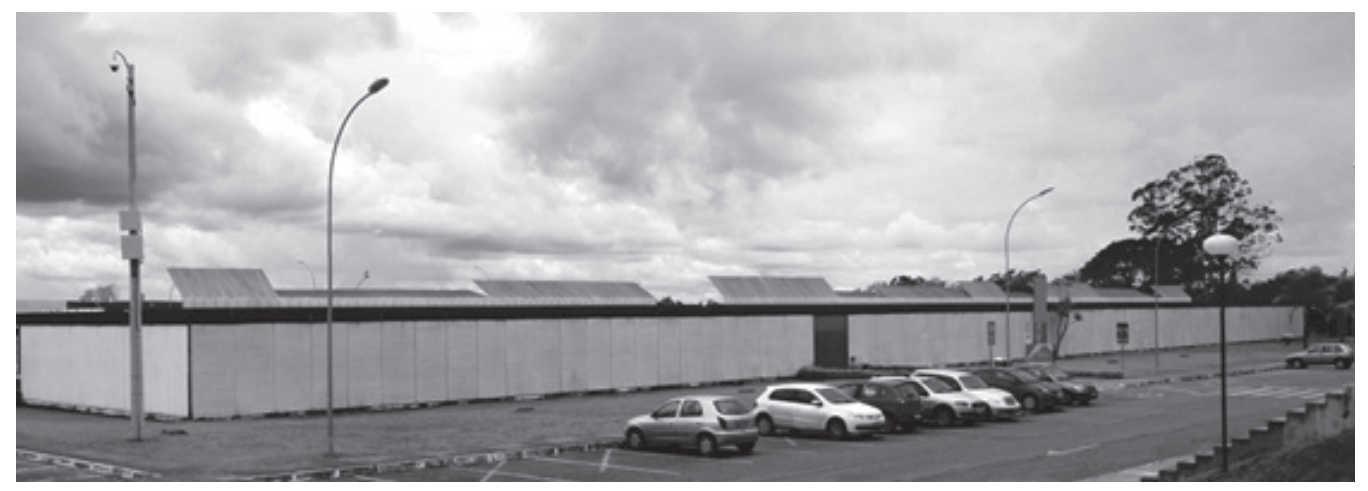

Erguidos em estrutura independente de aço patinável, tipo Corten, os edifícios foram revestidos, em suas fachadas transversais, por chapas corrugadas de aço pintadas de branco. Nas demais fachadas, as esquadrias metálicas de piso a teto foram protegidas por grelhas de aço galvanizado, pintadas também de branco.

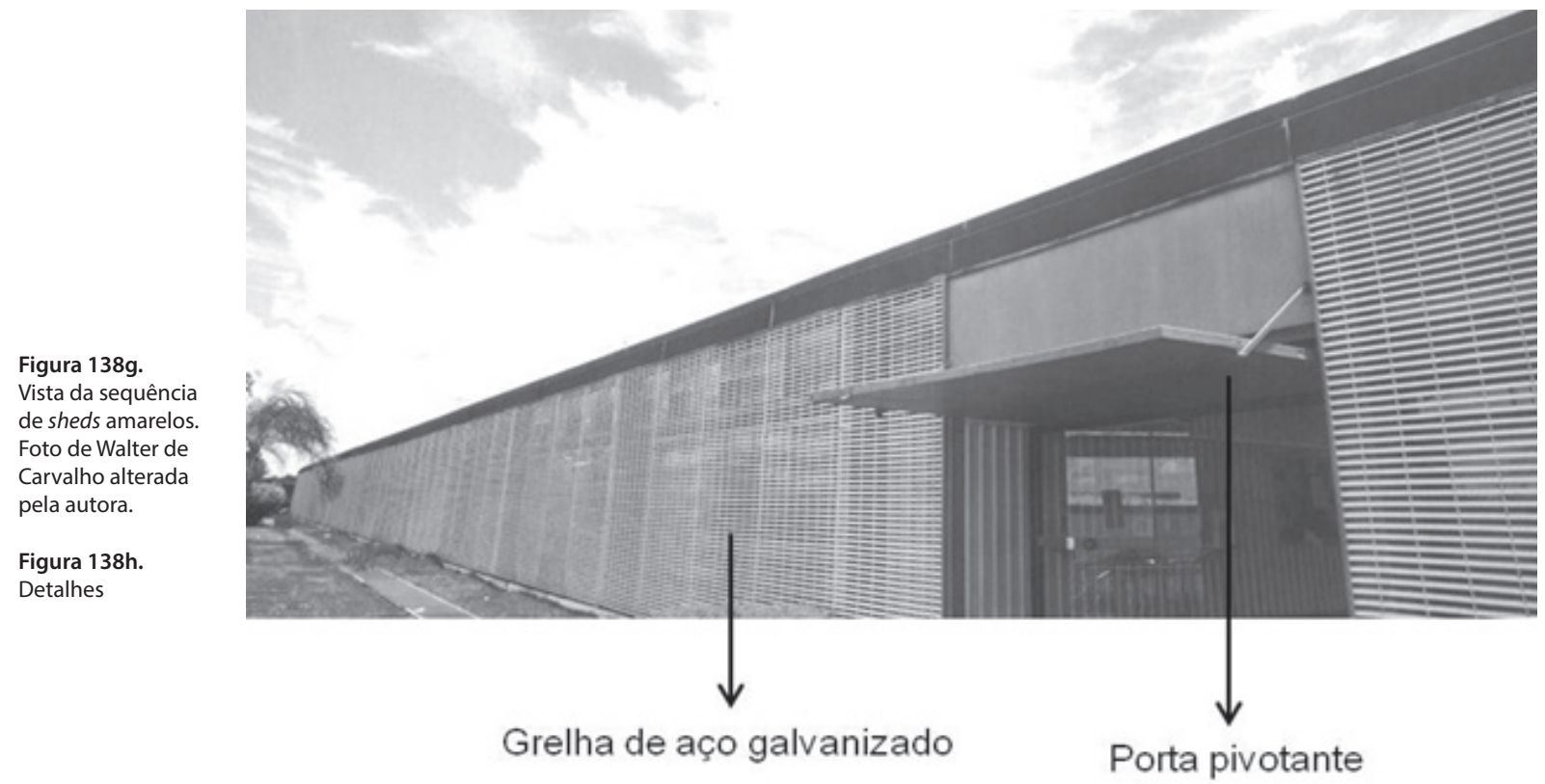

Os prédios são galpões. São edifícios de simplicidade material, no entanto são prédios cuja concepção tem uma certa ambição tecnológica [...] Eu queria um prédio que tivesse claridade intensa interiormente, que não fosse preciso usar luz durante o dia, que tivesse uma ventilação boa que não exigisse ar condicionado (QUEIROZ, s.d.). 

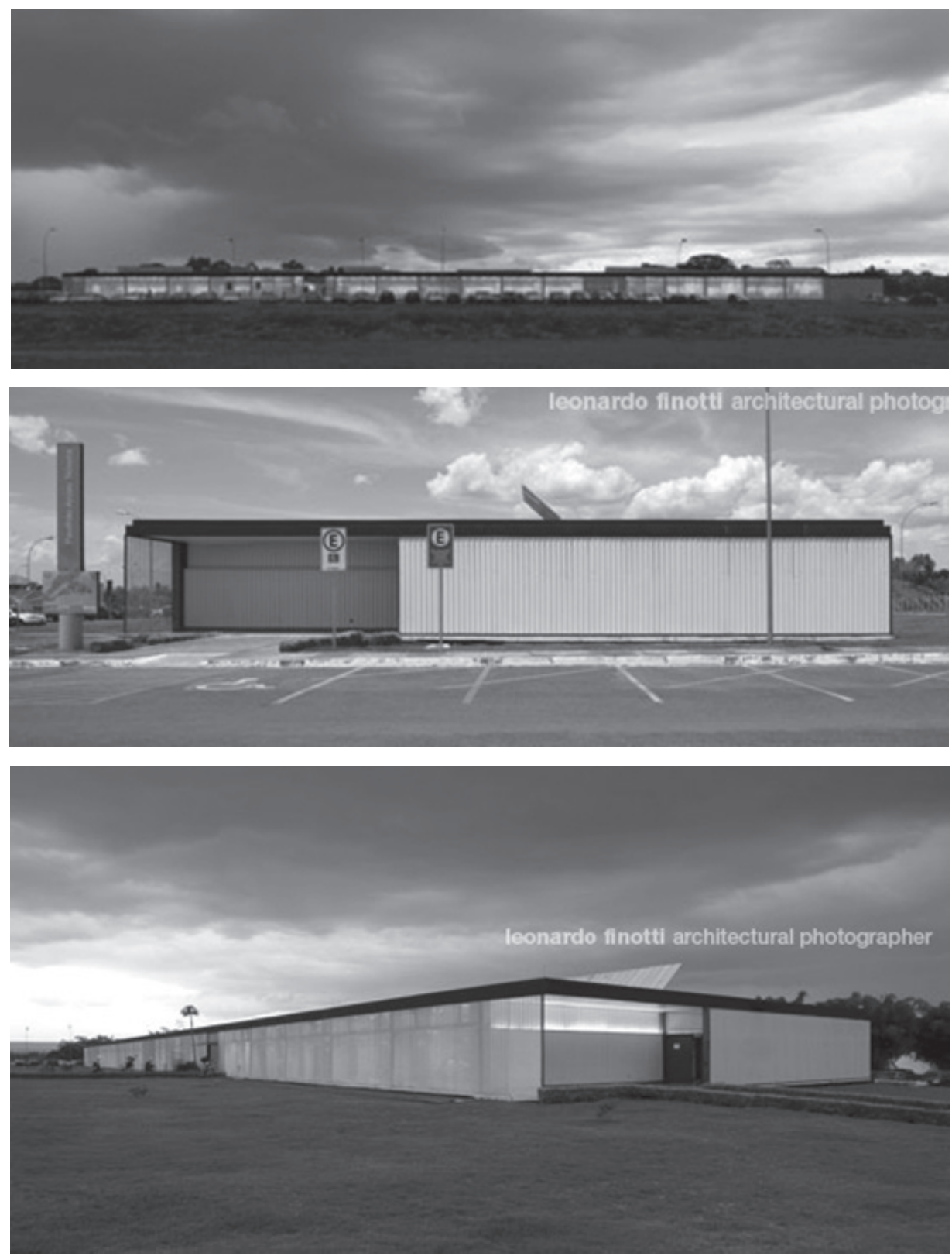

Figura 138i.

Fachada Oeste do

Pavilhão Anísio Teixeira

Figura 138j.

Fachada Sul do Pavilhão Anísio Teixeira

Figura 138k.

Fachadas Oeste e Sul do Pavilhão Anísio Teixeira

Figura 1381.

Vista interna do hall de

acesso

Figura 138m

Vista da circulação
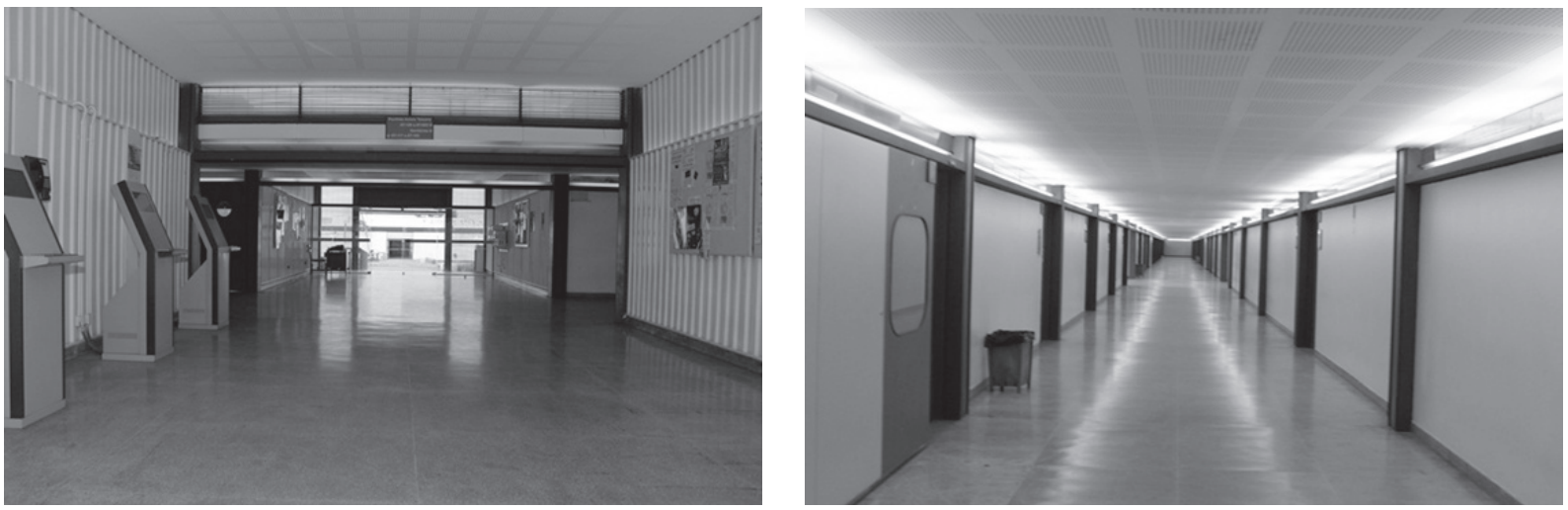



\section{O TEMPO DA EXPANSÃO}

[...] o universo mudou, o planejamento mudou, não tem mais aquela roupagem que era a da verba federal. Hoje a UnB é assediada! [...] grandes empresas, sejam elas empresas de pesquisa, etc., como é o caso da Fiocruz, querem utilizar a UnB, e a universidade, na medida em que pode ter uma convivência salutar, quer uma parceria.

Érico Weidle, 2011 



\subsection{Correndo contra o tempo}

No segundo mandato de FHC, o que houve foi um aprofundamento da parceria público-privada, tanto pela disseminação de cursos pagos de extensão como pelo estreitamento das relações entre instituições privadas e universidades públicas.

A promessa de definir e implementar a autonomia universitária plena, englobando os aspectos administrativos e financeiros, não avançou muito nesse período. No entanto, a meta de investir na melhoria dos laboratórios, equipamentos e espaços físicos foi parcialmente cumprida, devido ao Programa de Modernização e Consolidação da Infraestrutura Acadêmica das Instituições Federais de Ensino Superior e Hospitais Universitários (Ifes/HUs), integrante dos Programas de Apoio às Instituições Federais de Ensino Superior, lançados pela Secretaria de Ensino Superior do Ministério da Educação e Desporto (SESu/MEC) em 2001. Esses recursos passaram a atender a várias demandas de espaço físico, exigindo dos escritórios técnicos das universidades federais formas de gestão mais eficientes.

$\mathrm{Na}$ UnB, se os entraves burocráticos haviam até aqui dificultado as modificações na estrutura do Ceplan, as novas perspectivas de ampliação dos espaços físicos passaram a demandar urgentes modificações institucionais, já pleiteadas por membros da comunidade acadêmica da FAU. Assim, conforme decisão da comissão nomeada anteriormente para tal, o Ceplan retomaria sua condição de unidade vinculada à Reitoria, de onde provinham as demandas e os recursos para o seu atendimento.

[...] Quando o reitor Lauro me chamou para a direção do Ceplan, nos finais dos anos 90, eu já tinha vivido esta experiência difícil. Portanto, eu disse: 'Não sei trabalhar sob o comando de dois senhores!" Havia uma situação muito complicada entre a Faculdade e a questão de fazer projetos para a Universidade: um senhor para solicitar dinheiro, e outro para conceituar, criticar e discutir [...] Era preciso ter um senhor que financiasse esse Centro, com os professores projetando, e também um quadro de arquitetos contratados para executar aqueles projetos que os professores não estavam interessados em fazer [...] Então quero que isto fique bem claro, pois isto talvez seja o cerne do meu depoimento: um escritório de arquitetura numa escola precisa ser eficiente, precisa ter respostas profissionais e não amadorísticas. O que não quer dizer que esse escritório não possa ter um grande veio experimental (WEIDLE, entrevista em 7 dez. 2011). 
Assim é que, cumprindo a Resolução do Conselho Diretor da FUB n. 04/2000, na gestão do reitor Lauro Mohry, o Ceplan tornou-se um órgão da Administração Superior da FUB, com subordinação direta ao gabinete do reitor, garantindo-se, no entanto, um espaço para a prática profissional dos professores da FAU, conforme explicou Érico Weidle, que foi diretor do Ceplan de setembro de 1999 a novembro de 2001 1: “[...] foi feito um protocolo definindo essa divisão, os professores continuariam tendo o Ceplan como sua base para a prática, como laboratório para professores e alunos". No entanto, a subordinação do Ceplan à Reitoria não agradou a todos os professores da FAU:

\begin{abstract}
O Centro de Planejamento, ao recuperar institucionalmente sua denominação original Ceplan, anexou à sigla conhecida a referência histórica ao professor da FAU, seu primeiro diretor e autor da arquitetura do edifício. O significado do fato não poderia ser outro senão recuperar sua premissa acadêmica: a prática dos professores, o estágio de graduando e o treinamento dos arquitetos mestrandos e doutorandos [...] Contrariamente, a FAU se desfez de sua premissa diferencial, a de gerir o centro de planejamento que, por decisão unilateral e inquestionável, devolveu o Ceplan à Reitoria [...] A Reitoria assumiu o Ceplan sem ponderar a decisão da FAU, assumindo também o edifício SG-10, espaço historicamente do âmbito da faculdade. O novo Ceplan Oscar Niemeyer, como denominamos, foi então estruturado e equipado devidamente, para funcionar - como jamais se conseguiu fazer no âmbito da FAU, depois do AI 5 - tornando-se o Centro de Planejamento, indispensável, da Reitoria. Mas agora, fora da FAU... (Cláudio Villar Pinheiro de Queiroz, entrevista em 15 abr. 2012).
\end{abstract}

Entre as principais atribuições técnicas do Ceplan então definidas, estavam: I. Desenvolver diretrizes de uso do solo do território dos campi da UnB; II. Promover o desenvolvimento de estudos, planos e projetos nas áreas de arquitetura e urbanismo; III. Promover a construção de obras novas nos campi da UnB.

Em setembro de 1999, ao assumir o cargo de diretor, Érico Weidle viu que a situação do Ceplan não era das melhores, como relatou:

[...] encontrei um quadro muito triste: mobiliário quebrado, salas com coisas amontoadas sem destinação, máquinas de escrever ultrapassadas, salas totalmente atulhadas de velharias. $\mathrm{Ne}$ nhuma estrutura que pudesse receber alguém, pois a nossa ideia era atender no Ceplan não só a universidade, mas todos os órgãos de governo, um local onde pudéssemos atender alguém de fora. Começamos a fazer a limpeza e a reordenação física, pois naquele ambiente não podíamos receber ninguém. O edifício ainda se sustentava, mas os forros estavam caindo, havia goteiras, enfim, estava muito abandonado [...] Finalmente conseguimos, devagarzinho, em mais ou menos meio ano, resgatar as salas, pois o pessoal não tirava suas coisas, ou detinha as chaves para guardar seus pertences (WEIDLE, entrevista em 7 dez. 2011).

Além dos trabalhos para requalificar o espaço físico do Ceplan, durante essa gestão foi feito um Plano de Expansão da UnB. Nessa época, foi convidado a integrar o centro como assessor técnico o arquiteto Alberto Alves de Faria, que já tinha uma experiência de trabalho na Prefeitura do Campus. Tratava-se, então, de fazer a revisão do referido Plano de Expansão, uma ambiciosa iniciativa que, conhecida como Plano UnB 21, destinava-se à solução de diversos gargalos, entre os quais os relacionados ao Instituto de Ciências Biológicas (IB), o qual havia crescido muito e não cabia mais nas áreas que Ihe foram reservadas no ICC.

1 Nomeado pelo Ato da Reitoria n. 928, de 17 de setembro de 1999. 
Esse Plano UnB 21, que prepararia a UnB para a expansão, foi o primeiro trabalho que começamos a fazer na gestão do Érico, articulando as dimensões arquitetônica, financeira e política. Começamos por uma avaliação para confirmar os programas já existentes e acabamos vendo que alguns programas eram mais necessários que outros [...] No final de 2002, depois de muita conta, partimos para analisar os projetos que haviam sido desenvolvidos pelo Cláudio Queiroz. Eles tinham uma característica que não permitia uma modulação, uma expansão por etapas. Isso sempre fica meio comprometido, ou se faz igual ao ICC ou não se faz nada! Ou seja, ou você arrumava 100 milhões, ou... se eu dispusesse somente de 20 milhões não podia fazer nada. Isso nos fez reavaliar e descartar esses projetos [...] Em dezembro de 2002 esse plano foi aprovado (FARIA, entrevista em 8 mar. 2012).

Quando perguntado sobre a possibilidade de adaptação do ICC para abrigar as atividades do IB e de outros institutos de pesquisa, assim se manifestou Weidle:

Acontece que os espaços do ICC destinados a esses departamentos são subsolos inadequados para utilização acadêmica. Mesmo considerada a flexibilidade espacial e construtiva depois de ocupado, o remanejamento é dificultado pela necessidade de se dispor de espaços para utilização provisória durante as reformas. Sem essa estratégia, o espaço fica praticamente "imexível", parodiando o ex-ministro [...] O ICC, com aquele pé direito imenso, os grandes laboratórios como se fossem instalações industriais, isso nunca aconteceu! Então, o que foi feito no ICC? Em vários lugares, para conseguir aumentar a sua área, foi criado o mezanino e esse espaço foi recolonizado, como é o caso da Psicologia, da Agronomia, da Matemática (Entrevista em 7 dez. 2011).

A proposta previa grandes investimentos em novos espaços para ensino e pesquisa, sendo que os novos prédios seriam construídos com os recursos provenientes da venda de imóveis de propriedade da UnB no Plano Piloto. Além do IB, saíram do papel, em razão do Plano 21, o Instituto de Química (IQ) e a nova sede do Centro de Seleção e Promoção de Eventos (Cespe).

Sobre os projetos dos institutos de Biologia e de Química, segundo Weidle, "[...] a opção foi levar para fora as atividades que têm caráter mais específico, transformando o ICC na grande sala de aula da universidade, porque lá de fato se concentram todos os estudantes" (Entrevista em 7 dez. 2011).

Data dessa época a aprovação, pelo Conselho Diretor da FUB, do Plano de Setorização do Campus Universitário Darcy Ribeiro², que instituiu a setorização e as diretrizes de uso do solo do território do campus. Nesse plano foram determinadas sete categorias de uso e ocupação: estritamente acadêmica; apoio e convívio comunitário; manutenção e apoio técnico; habitação coletiva; recreação e lazer; natural de estrita preservação; e de instituições públicas ou privadas de interesse acadêmico.

Em decorrência de uma crise financeira na administração superior da UnB à época, motivada por um descompasso entre a quantidade de recursos da UnB e a atuação do Decano de Administração e Finanças, o reitor, professor Lauro Mourhy, chamou o arquiteto Érico Weidle para assumir essa função de confiança.

2 Nesse plano, aprovado em 6 de abril de 2000, um capítulo é dedicado às competências técnicas do Ceplan, entre as quais constavam: elaboração dos planos de uso do solo do campus; emissão de pareceres técnicos sobre o uso do solo, sobre os impactos ambientais dos projetos físicos; coordenação dos trabalhos de elaboração de normas e código de posturas relacionadas ao uso do solo; coordenação dos levantamento e preservação do patrimônio arquitetônico e urbanístico; e, principalmente, elaboração dos projetos de arquitetura, urbanismo e outros projetos de interesse da Universidade de Brasília. 
Figura 139.

Posse de Lula,

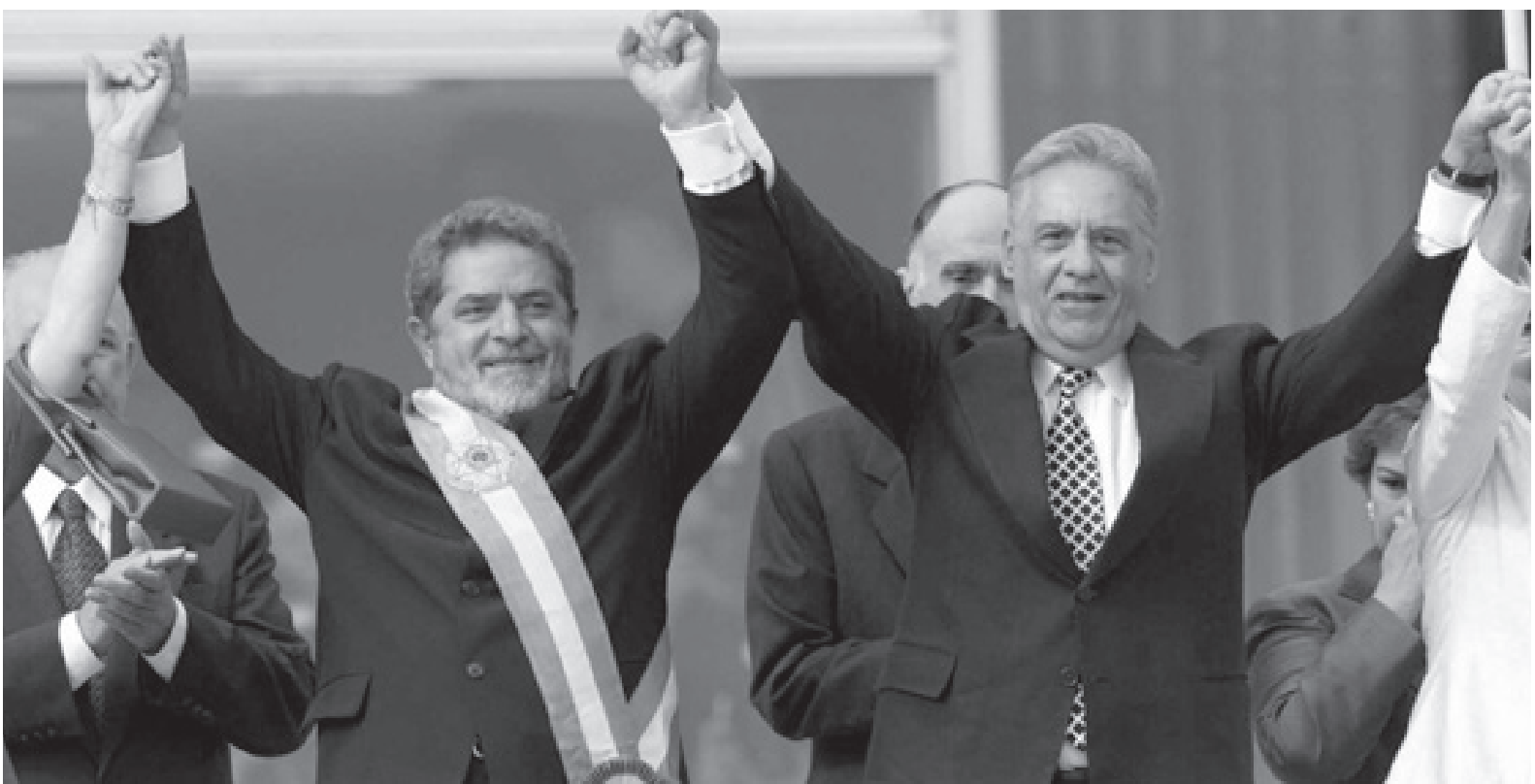

Ao deixar o Ceplan, o próprio Érico indicou Alberto Faria para o seu lugar. Segundo Érico, o diretor da FAU na época, Geraldo Nogueira Batista: "[...] achava melhor que não fosse um professor, pelas discussões todas que iriam envolver o Ceplan" (Entrevista em 7 dez. 2011).

Nomeado diretor do Ceplan pelo Ato da Reitoria n. 70/2002, Alberto Faria fez uma reunião com os professores da FAU onde teria afirmado que

[...] o Ceplan não poderia nunca perder as características que tem, ou seja, um local de prática profissional dos docentes e de treinamento para os alunos da UnB [...] temos que refazer todos os projetos e, para refazer, vamos lançar um edital com as regras, os professores se candidatam aos temas, e montamos as equipes. Se tiver mais de um professor querendo fazer mais de um tema, faremos um concurso (FARIA, entrevista em 8 mar. 2012).

Com o objetivo de proceder à revisão de áreas e projetos feitos anteriormente, foi lançado um edital que, segundo o próprio Alberto,

[...] foi uma novidade, porque antes ninguém sabia quem escolhia quem para fazer projetos [...] Os professores que compareceram ao Ceplan ali mesmo se dividiram em grupos. Não tinha sentido fazer concurso porque eram muito mais projetos do que professores disponíveis (Entrevista em 8 mar. 2012).

Em janeiro de 2003, Luiz Inácio Lula da Silva tomou posse como presidente do Brasil, cargo em que permaneceria até dezembro de 2010. O seu governo foi marcado, desde o início, pela estabilidade econômica, pela minimização dos riscos e pelo controle das metas de inflação.

A Reforma da Educação Superior do governo Lula foi iniciada com o decreto de 20 de outubro de 2003 que instituiu o Grupo de Trabalho Interministerial (GTI) encarregado de analisar a situação da educação superior brasileira e apresentar um plano de ação visando à reestruturação, ao desenvolvimento e à democratização das Instituições Federais de Ensino Superior (Ifes). Em seu relatório final, divulgado em dezembro de 2003, o GTI reconheceu a situação de crise da educação superior brasileira tanto nas universidades públicas quanto nas instituições privadas, que estariam ameaçadas pelo risco de inadimplência do alunado e da crescente desconfiança em relação ao efetivo valor de 
seus diplomas. Como solução para tais problemas, previu-se um programa emergencial de apoio ao ensino superior, especialmente às universidades federais, e uma reforma universitária mais profunda.

Em relação à ampliação do quadro docente e do número de vagas para estudantes, o GTI constatou a necessidade da realização de concursos para preencher as vagas de professores e servidores. Por outro lado, propôs a criação de novas bolsas da Coordenação de Aperfeiçoamento de Pessoal de Nível Superior (Capes), para aproveitar aposentados e recém-doutorados nas atividades de ensino de graduação; o aumento da carga horária dos professores em sala de aula; o aumento no número de alunos e a educação à distância.

Segundo o relatório, como a universidade pública brasileira não tinha condições de aumentar o número de vagas do ensino presencial, de forma maciça e em curto e médio prazos, a educação à distância apresentou-se como um caminho viável e importante. No documento também se indicou a garantia de autonomia das universidades como um passo necessário para minimizar "[...] as amarras que têm impedido cada instituição de captar e administrar recursos, definir prioridades e estruturas de gastos e planejamento" (BRASIL, 2003: 9) E se deixou evidente a existência de universidades federais que não contavam com um programa específico para recuperação predial e aquisição de equipamentos e livros para o ensino de graduação, o que levava ao fechamento de laboratórios e à degradação de espaços e instalações.

As alternativas de financiamento anexadas ao documento iam desde as contribuições voluntárias de alunos e ex-alunos até a distribuição da CPMF (Contribuição Provisória sobre a Movimentação ou Transmissão de Valores e de Créditos e Direitos de Natureza Financeira), passando pela retirada dos servidores e professores inativos do orçamento das universidades federais. Foram propostos ainda uma Lei de Incentivo Fiscal para o ensino superior, a criação de fundos empresariais para financiar essas universidades e a troca da dívida externa por investimentos em educação. Todas as proposições objetivavam reduzir os gastos da União com a educação superior substituindo-os por outras fontes de financiamento. De acordo com esse mesmo documento, o MEC se propunha a assegurar um fluxo regular adicional de recursos para as instituições que aceitassem aderir a um Pacto de Educação para o Desenvolvimento Inclusivo (OTRANTO, 2003).

Em 2004, o governo federal enviou ao Congresso Nacional o projeto de lei do Programa Universidade para Todos (Prouni), e em 10 de setembro desse mesmo ano o presidente Lula editou a Medida Provisória n. 213, instituindo o referido programa ${ }^{3}$, que seria transformada na Lei n. 11.096 em 13 de setembro de 2005. Em linhas gerais, o Prouni deveria estender a todas as instituições privadas que a ele aderissem a isenção de Imposto de Renda de Pessoa Jurídica; Contribuição Social sobre o Lucro Líquido; Contribuição Social para Financiamento da Seguridade Social e Contribuição para o Programa de Integração Social.

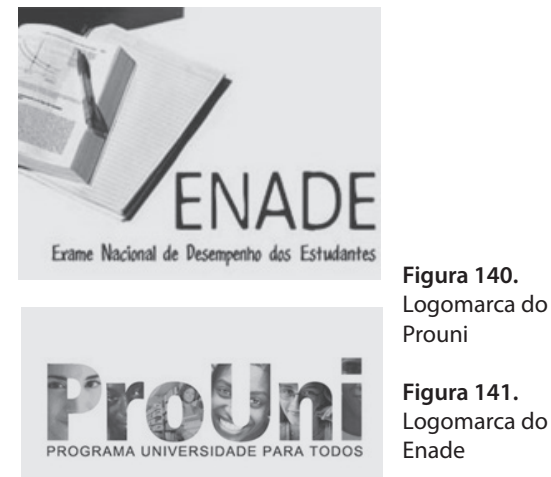

Com o objetivo de conduzir o processo de avaliação da educação, foi instituído, pela Lei n. 10.861, de 14 de abril de 2004, o Sistema Nacional de Avaliação da Educação Superior (Sinaes), assentado na avaliação das instituições de ensino superior (IES), dos cursos de graduação e do desempenho dos estudantes.

3 Logo em seguida, o Decreto n. 5.245, de 18 de outubro de 2004, regulamentou a MP, e a Portaria n. 3.268, de 19 de outubro de 2004, estabeleceram os procedimentos para adesão das instituições privadas de educação superior ao Prouni. 
E, dando continuidade à Reforma do Ensino Superior, foi aprovada a Lei n. 10.973, de 2 de dezembro de 2004, que dispôs sobre incentivos à inovação e à pesquisa científica e tecnológica no ambiente produtivo. Com isso, tanto os professores passaram a ser mais empreendedores como as instalações da universidade começaram a ser cedidas para uso das empresas, com ônus para o Estado. Essa chamada Lei de Inovação Tecnológica pode ser compreendida no bojo das parcerias público-privadas que, regulamentadas pela Lei n. 11.079 de 30 de dezembro de 2004, previam a aplicação de fundos federais em projetos de interesse comum para acelerar a incorporação de tecnologias pelas empresas.

A esses mecanismos legais foram acrescidos o Decreto Presidencial n. 5.205, de 20 de dezembro de 2004, que regulamentou as fundações de apoio privadas no interior das Ifes; o Decreto Presidencial n. 5.622, de 19 de dezembro de 2005, que regulamentou a educação à distância no Brasil e consolidou a abertura do mercado educacional brasileiro ao capital estrangeiro; e o Decreto $\mathrm{n}$. 5.773, de 9 de maio de 2006, que estabeleceu normas para as funções de regulação, supervisão e avaliação das IES no país.

$\mathrm{Na}$ UnB, em resposta explícita às determinações do Programa de Expansão Fase I das universidades federais, cujo objetivo principal era promover a interiorização da educação superior pública, foram iniciadas, em 2005, as obras da Unidade de Ensino, Administração e Serviços do Campus de Planaltina, seguindo projeto de Alberto Alves de Faria e Érico Paulo Seigmar Weidle.

Entre 2003 e 2008, período correspondente ao final do segundo mandato de Lauro Morhy e à gestão do reitor Timothy Mulholland, foram projetadas e construídas as seguintes unidades: Clínica Odontológica de Ensino e Farmácia Universitária; Associação dos Servidores da Universidade de Brasília (Asfub); Centro de Seleção e Promoção de Eventos (Cespe); Laboratório de Estudos Geodinâmicos e Ambientais (Lega); Associação dos Aposentados da FUB (Aposfub) e Associação dos Ex-Alunos da UnB (Ex-UnB); Casa do Professor, sede da Associação dos Docentes da Universidade de Brasília (Adunb); Instituto de Ciências Biológicas (IB) e Instituto de Química (IQ).

Em meio a uma grande demanda por projetos, vários professores se interessaram pelo do Museu de Ciência e Tecnologia, o que motivou a abertura de um concurso interno na FAU. Das cinco equipes que participaram, saiu vencedora a de número 3, do professor Raimundo Nonato Veloso 4 .

Projeto vencedor no concurso para o Museu de Ciência e Tecnologia da UnB, de autoria de Raimundo Nonato Veloso, com a colaboração de Camila Xavier e Rodrigo Xavier.

Projeto que obteve Menção Destaque no concurso para o Museu de Ciência e Tecnologia da UnB, de autoria de Eliel Américo Santana da Silva, Kristian Schiel, Márcia Urbano Troncoso e Neusa Cavalcante Imagens cedidas pela equipe.

Por volta dessa época, além de um edital para escolher quem iria desenvolver os vários projetos, havia um grupo de professores encarregado de estabelecer as diretrizes urbanísticas para determinadas áreas do campus, conforme explicou Alberto Faria: 


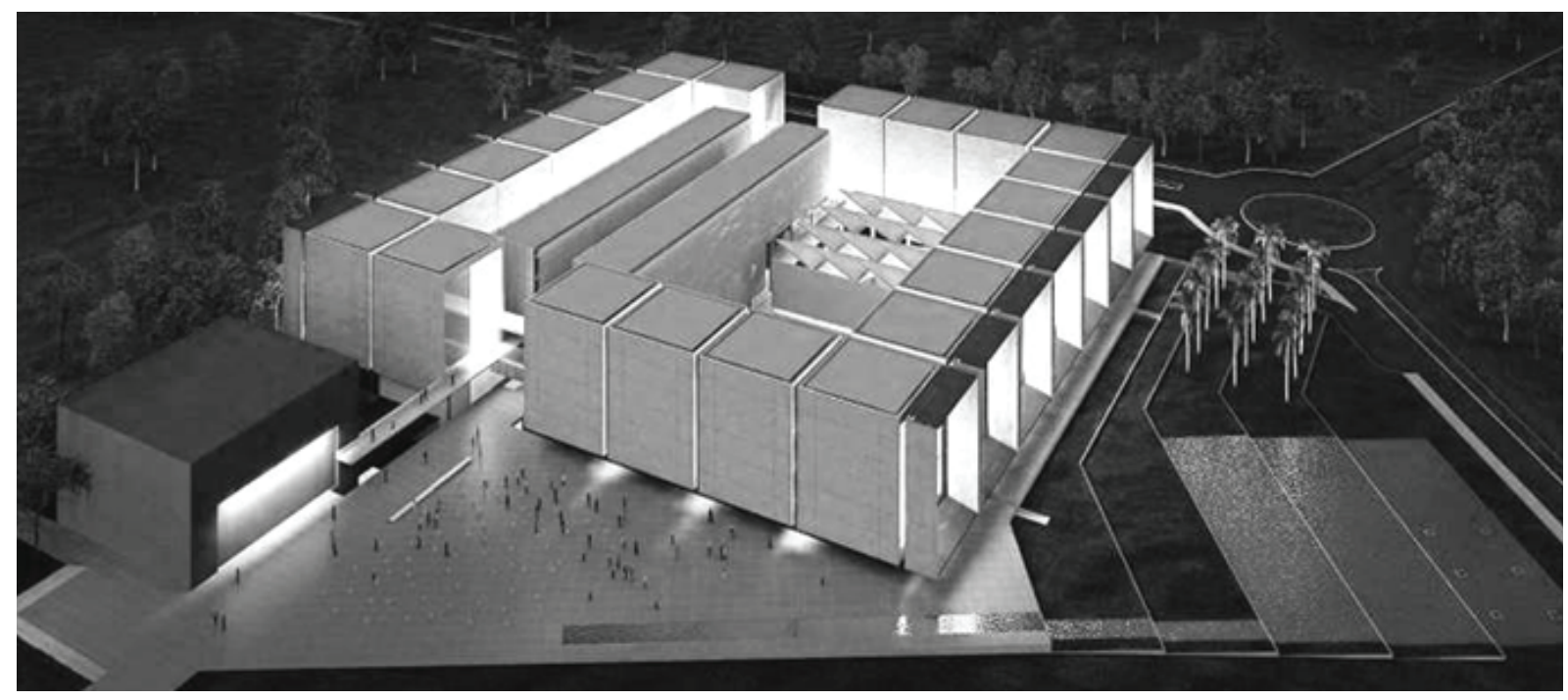

Figura 142a.

Vista aérea.

Maquete

eletrônica

Figura 142b.

Vista geral.

Maquete

eletrônica

Figura 142c.

Vista dos

brises da

fachada.

Maquete

eletrônica
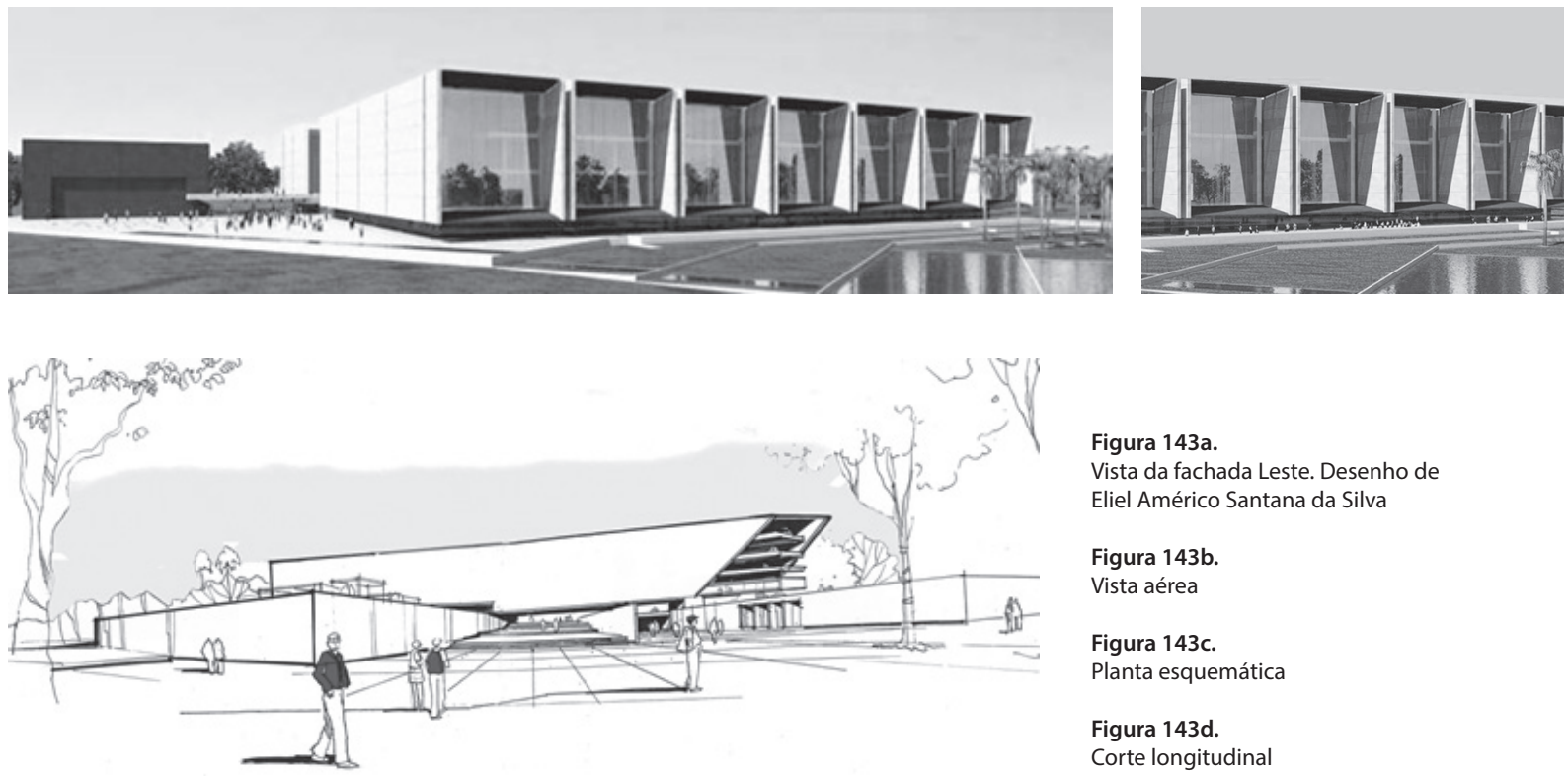

Figura 143a.

Vista da fachada Leste. Desenho de

Eliel Américo Santana da Silva

Figura 143b.

Vista aérea

Figura 143c.

Planta esquemática

Figura 143d.

Corte longitudinal
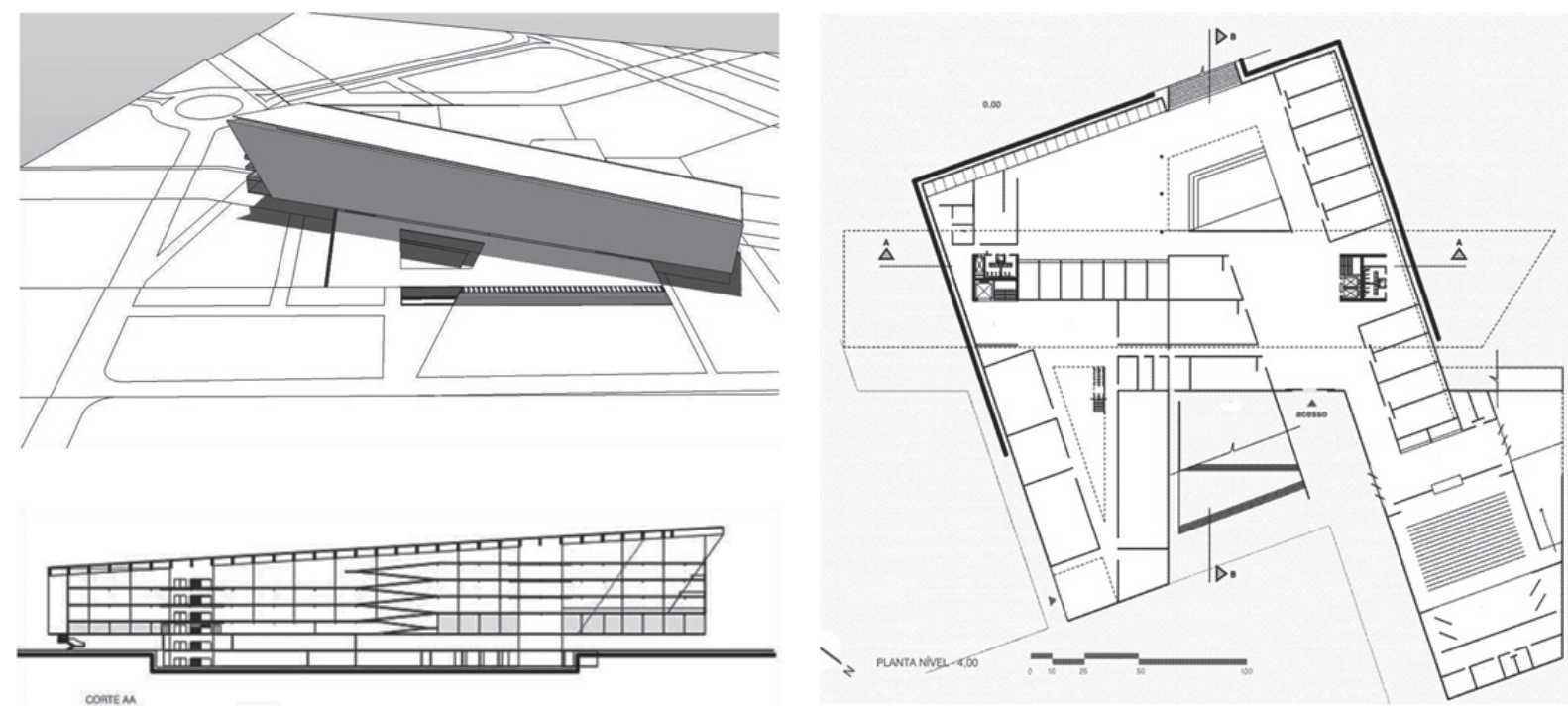


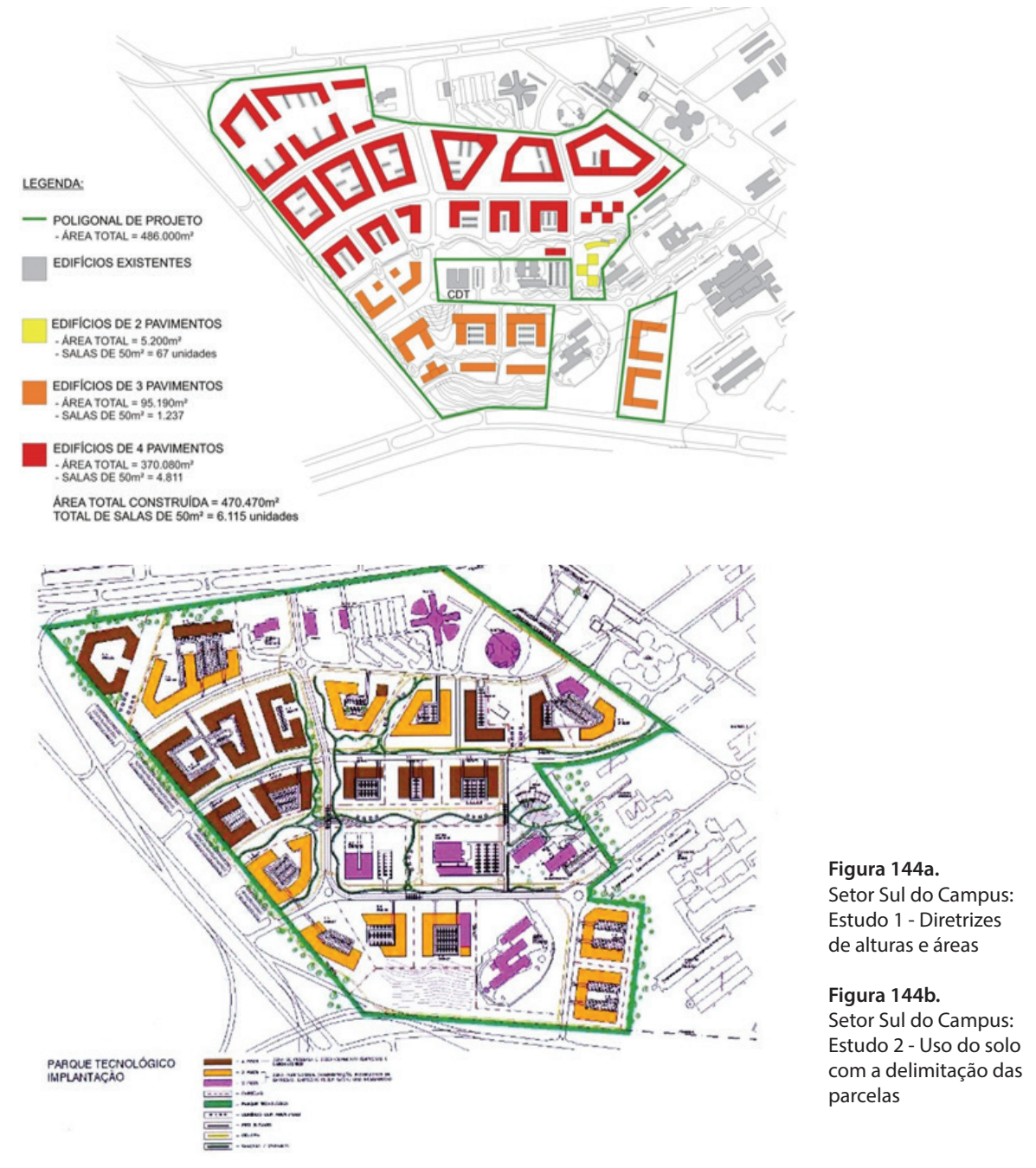

foi bom, porque se você deixa cada arquiteto colocar o seu projeto onde ele quer dentro do campus, cada um vai querer colocar no topo de uma colina. Hoje tem uma lógica urbana, temse hoje uma percepção mais harmônica principalmente de cotas (Entrevista em 8 mar. 2012).

Do trabalho da equipe de urbanismo, coordenada pela arquiteta e professora da FAU Marta Adriana Bustos Romero, resultou o estudo para a urbanização da área do extremo sul do campus, a ser ocupada pelo Parque Científico e Tecnológico (PCTec) da Universidade de Brasília. Além de diretrizes de altura e áreas para as novas edificações, foi proposto um estudo de parcelamento da área, conforme explicou Romero: "O projeto de urbanização foi realizado a partir de parcelas de tamanho médio para aumentar a acessibilidade, priorizando formas regulares e semelhantes e evitando deixar áreas residuais, contribuindo para a identidade gregária e auxiliando a orientação espacial" (2011, p. 34).

A partir desses estudos, o campus foi dividido em setores: Central, destinado a atividades acadêmicas, culturais, de pesquisa e extensão em geral; Sul, correspondente ao Parque Tecnológico (PTec); Norte, que incluiu a Estação Experimental de Biologia (EEB), destinado às ciências médicas; o da Península, voltado às atividades esportivas e à preservação da paisagem natural; e o Hospital Universitário.

Entre outras iniciativas, marcaram o segundo mandato do presidente Lula o lançamento, em 28 de janeiro de 2007, do Programa de Aceleração do Crescimento (PAC) - um conjunto de medidas com vistas à aceleração do ritmo de crescimento da economia brasileira - e o Plano de Desenvolvimento da Educação (PDE), que, instituído pelo Decreto n. 6.096, de 24 de abril de 2007, tinha

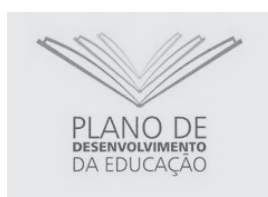


como objetivo nivelar a educação brasileira com a dos países desenvolvidos até 2021, prevendo-sea criação, até 2010, de um índice para medir a qualidade do ensino e de um piso salarial para os professores de escolas públicas. No âmbito do PDE, foi instituído o Programa de Apoio a Planos de Reestruturação e Expan-

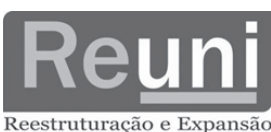
Reestruturação e Expansão das Univer são das Universidades Federais (Reuni), que resultou em um impacto direto nas instituições públicas de ensino superior, no que diz respeito tanto ao número de professores contratados quanto à ampliação de suas instalações físicas.

Em 2007, o governo federal decidiu investir no crescimento e na reestruturação das universidades, por meio do Plano Reuni I, o que motivou uma revisão do planejamento que o Ceplan havia feito anteriormente. Outro dado importante foi que o reitor Timothy Mullholland havia transferido para o Ceplan, no final de 2006, pelo Ato da Reitoria n. 1661, as atribuições de contratar obra com urgência. Por esse instrumento legal, o Ceplan estava autorizado a realizar licitações para a contratação de serviços e obras novas, bem como a fiscalizá-las e fazer o seu acompanhamento físico-financeiro. À Prefeitura do Campus, por sua vez, ficavam reservados as licitações e os contratos relativos à execução de serviços e obras de reforma ${ }^{5}$.

\begin{abstract}
O Ceplan faz o planejamento, o projeto, a licitação, a fiscalização e todo o controle das obras. Ou seja, hoje para ser diretor do Ceplan é exigida muita coragem e competência. Não é coisa para amador. Não é o domínio estritamente voltado para questões técnicas. Há questões de natureza política, de visão estratégica mais ampla e de uma responsabilidade muito grande. Criam certas amarrações, tudo que é bom para um lado é ruim para outro. Mas acho que é interessante que quem projete esteja também comprometido com a viabilidade. Isso vem acontecendo, porque o Ceplan agora conta com uma equipe técnica multidisciplinar. Hoje projeto tem orçamento! Isso antes não era um procedimento usual (WEIDLE, entrevista em 7 dez. 2011).
\end{abstract}

Os recursos do Reuni contribuíram para transformar o Campus Darcy Ribeiro da UnB em um grande canteiro de obras. Muitos projetos, alguns dos quais realizados anos antes, começaram a sair do papel. Assim foi com os seguintes edifícios: Faculdade Administração, Contabilidade e Economia (Face); Fundação Oswaldo Cruz (Fiocruz); Bloco de Salas de Aula Norte Eudoro de Sousa (Baes); Centro de Alta Complexidade em Oncologia no Hospital Universitário (Cacon/HUB); Centro de Apoio ao Desenvolvimento Tecnológico (CDT); Centro de Manutenção de Equipamentos Científicos (CME); sede do Programa de Educação Infanto-Juvenil (PIJ); Bloco de Salas de Aula Sul (BSA SUL); Módulo de Serviços e Apoio Comunitário (Masc); Instituto de Ciências Exatas (IE); Centro de Informática (CPD); Instituto de Ciência Política e de Relações Internacionais (Ipol/Irel); Instituto de Ciências Sociais (ICS); Centro de Atendimento e Estudos Psicológicos (Caep); Centro de Referência em Conservação da Natureza e Recuperação de Áreas Degradadas (Crad) e Centro de Desenvolvimento Sustentável (CDS).

Os referidos recursos levaram ainda à elaboração de uma nova proposta referente ao Plano UnB 21, para atualização dos dados e identificação de cursos e órgãos com premência de espaço físico, como, por exemplo, o Desenho Industrial, a Medicina e a Editora Universidade de Brasília (EDU), cuja localização atual, no Setor Comercial Sul, tem dificultado a realização de seus objetivos. A partir daí foram feitos os projetos para a Nova Casa do Estudante de pós-graduação a para a Editora da UnB.

Em janeiro de 2008, uma crise na administração de Timothy (que foi reitor de novembro de 2005 a abril de 2008), deixou parte do planejamento paralisada. Em abril do mesmo ano foi nomeado um reitor interino, o professor Roberto Ramos Aguiar ${ }^{6}$, que promoveu uma revisão completa dos 5 Ato da Reitoria n. 2.145 , de 19 de dezembro de 2006.

6 Depois dessa breve gestão, foi eleito o professor José Geraldo de Souza Junior, que permaneceu no cargo de reitor de novembro de 2008 a novembro de 
planos dependentes do Reuni I. Foram alterados inclusive os princípios, a própria filosofia de ensino da UnB: abandonou-se a ideia dos bacharelados, foram aumentadas as vagas e criados os cursos noturnos.

Do ponto de vista técnico, produzimos muitos estudos nessa época, e quando a administração interventora assumiu, nós tínhamos muita informação, o que ajudou a desenhar o Reuni II [...] nessa época eu me envolvi mais com projetos, os quais passaram a ser urgentes, pois tínhamos perdido o ano de 2008 (FARIA, entrevista em 8 mar. 2012).

Como havia urgência para realização de projetos e obras, chegou a ser cogitada a possibilidade de se adotar a pré-fabricação, modelo que fazia muito sentido em alguns dos programas:

\begin{abstract}
Cheguei a conversar com o Lelé, numa das vindas dele aqui. Ele alertou sobre a necessidade de se ter uma estrutura, o controle da máquina, pois, segundo ele, as empresas são difíceis de trabaIhar [...] Discutimos se seria viável montar uma estrutura aqui dentro para fazer a pré-fabricação e ele falou da experiência em Salvador, e que já tinha desmanchado a fábrica que havia sido montada [...] Resultado: optamos por fazer uns projetos usando a pré-fabricação disponível no mercado, consultamos os fabricantes, procuramos no mercado da construção sistemas industrializados [...] não tínhamos tempo para a inovação (FARIA, entrevista em 8 mar. 2012).
\end{abstract}

Em 2010, um novo concurso foi promovido pelo Ceplan, dessa vez para escolha do projeto do Centro de Convenções e Hotel da UnB, integrado à Praça Maior. O evento contou com a participação de quatro equipes, tendo saído vencedor o projeto desenvolvido pelos professores Matheus Gorovitz e Cláudia Garcia e os arquitetos Éder Alencar e Ana Carolina Vaz. Segundo o diretor do Ceplan,

[...] não houve problema, todos os membros do júri compareceram, felicíssimos por terem sido chamados para participar. Roberto Martins Castelo, Pedro Paulo de Melo Saraiva e Glauco Campello discutiram os trabalhos e julgaram. O concurso é um momento muito bom. Embora haja disputa, integra os alunos e incentiva a discussão (FARIA, entrevista em 8 mar. 2012).

Projeto vencedor do concurso para a Praça Maior e o Centro de Convenções da UnB, de autoria de Mateus Gorovitz.

Segundo dados fornecidos pelo diretor do Ceplan, de 2002 até 2011 a área física do campus cresceu $47 \%$, sendo que só no ICC foram mais de 12 mil metros quadrados de reforma, inclusive com a criação de novas áreas. Por outro lado, segundo dados da própria UnB, o número de alunos dobrou entre 2006 e 2011 , tendo passado de 19.823 para 39.940 .

Embora tenha sido alvo de críticas por membros da comunidade acadêmica, o Ceplan fez muitas obras no ICC durante esse período, algumas das quais são apenas complementações do projeto inicial, como, por exemplo, a colocação de forro. Outras modificações, como a mudança de esquadrias na fachada Leste, seguiram as orientações de um estudo feito pelas professoras Marta Bustos Romero e Rosana Stockler Campos Clímaco, que identificaram os condicionantes que interferem no conforto térmico do ICC.

Atualmente, além de contar com a participação eventual de professores e estudantes da FAU, o Ceplan possui um quadro de profissionais arquitetos, engenheiros e orçamentistas, o que, segundo o atual diretor, Alberto Faria, 

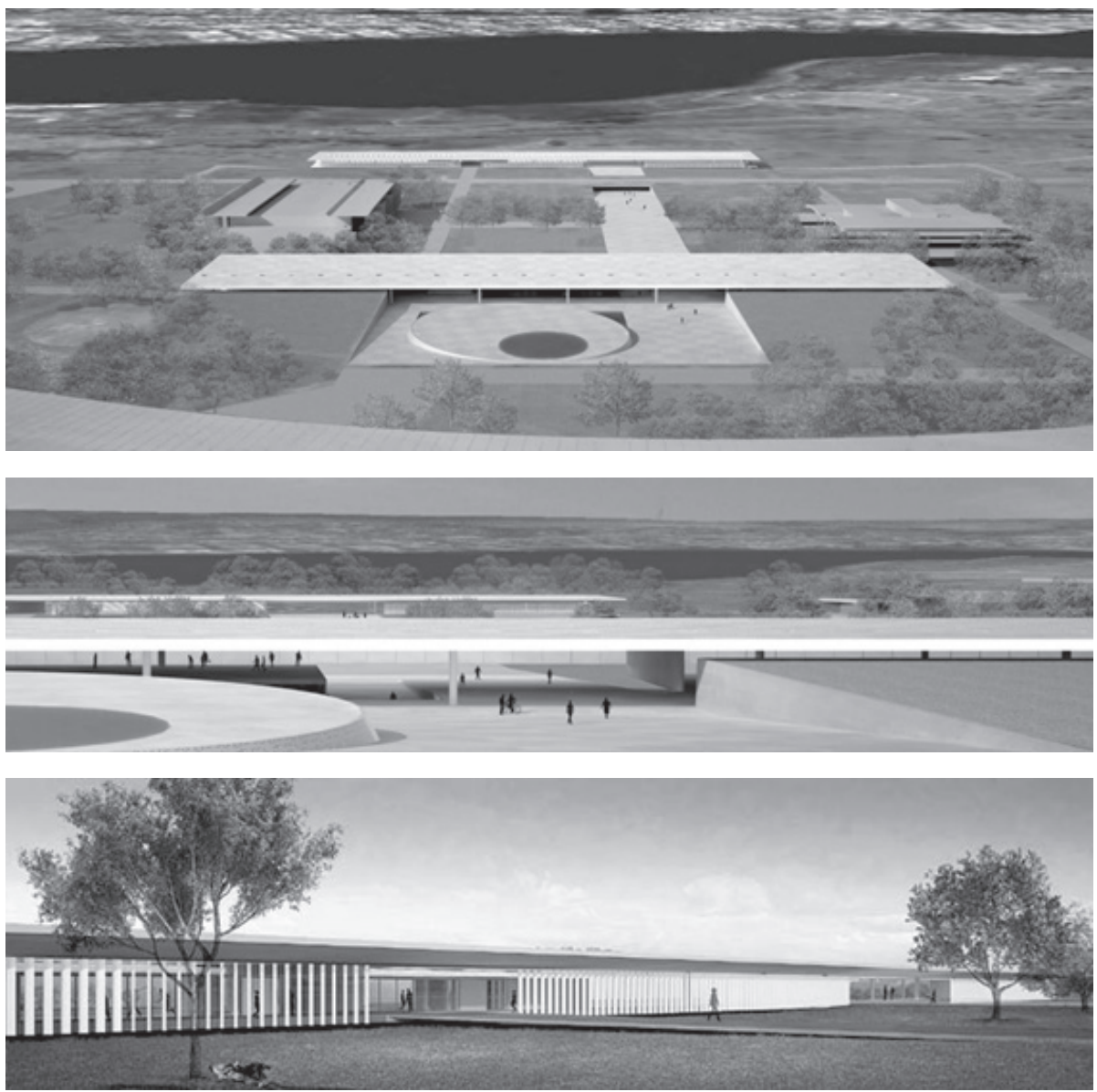

Figura 147a.

Vista aérea.

Maquete

eletrônica

Figura 147b.

Vista da

fachada Oeste

Figura 147c.

Vista da

fachada Leste

[...] é um ponto positivo, pois permite a existência de um ponto de integração do processo construtivo [...] Tem também um lado ruim, quando se tem uma coisa muito pesada como as obras, a área de planejamento fica meio a reboque. Hoje cuidamos mais de obra do que de planejamento, e já estamos vendo a necessidade de tirar a atribuição de obras do Ceplan (Entrevista em 8 mar. 2012).

Como os mestrandos e doutorandos não têm tempo para participar do Ceplan, por ficarem muito envolvidos com suas pesquisas individuais, a colaboração discente nos projetos do $\mathrm{Ce}$ plan vem dos alunos da graduação, principalmente aqueles matriculados na disciplina Estágio de Projeto. Por sua vez, atualmente a participação de professores da FAU tem sido eventual, não se constituindo em uma atividade regular de prática de projeto. Algumas vezes essas contribuições são remuneradas e outras não, sendo que sempre há uma cota para cobrir as despesas com a realização do trabalho.

O que parece ter sido perdido no Ceplan, ao longo de sua existência, foi o compromisso sistemático com a inovação. Sobre o assunto, assim se manifestou Faria:

O que temos procurado, aqui é trabalhar com a FAU, onde há muita experiência com as diretrizes de planejamento; com o bambu, trabalho do Jaime Almeida; e com a questão da sustentabilidade. Mas acho incomparável com o período inicial... eram os melhores do Brasil que estavam aqui! Hoje as nossas condições não são mais aquelas, pelas dimensões e circunstâncias. Agora se trata de trabalhar com o que se tem à mão. Aqui no Ceplan, o esforço atualmente é de tentar trabalhar com a questão urbana, já vimos que não dá mais para fazer prédio térreo; com a questão do transporte interno, temos que repensar esse modelo viário, introduzir a bicicleta... (FARIA, entrevista em 8 mar. 2012). 
Das trinta obras realizadas nos campi da UnB no período, em 17 delas foi adotado o sistema de pré-fabricação de ciclo aberto, em que os componentes, produzidos por empresas, são adquiridos no mercado e montados no canteiro. Sobre esse assunto, chamou atenção, em 2012, a matéria publicada no site de uma indústria de cimento, que exibia a seguinte manchete: “UnB resgata tradição de 'universidade do pré-fabricado'"' (SANTOS, 2012).

O fato de o Ceplan ter optado pelo uso de componentes produzidos no mercado para construção de seus novos edifícios de fato não representa um resgate da pré-fabricação desenvolvida nos tempos pioneiros, em que havia um compromisso com o desenvolvimento de novas tecnologias. Se o modelo adotado atualmente representou economia de tempo e qualidade de execução, trouxe também problemas.

Em primeiro lugar, cabe considerar o custo dessa opção, conforme declarou o próprio diretor do Ceplan, Alberto Faria: "[...] se permitiu construir em um tempo menor, por outro lado a escoIha do pré-fabricado também encareceu o projeto" (Entrevista em 8 mar. 2012).

Como mencionado anteriormente, todo o esforço feito na década de 1960 foi para que se produzisse com qualidade, rapidez e baixo custo. Por isso a produção das peças era feita junto ao canteiro de obras e sob o controle direto dos integrantes do Ceplan. Essa experiência não visava produzir tão somente prédios, mas, sobretudo, tecnologia, ou seja, conhecimento, cujo valor estava no que isso poderia significar em termos de real independência do país nesse saber específico. Mesmo que os edifícios pré-fabricados da época implicassem um custo mais alto do que se tivessem sido executados por métodos convencionais, estava embutido nesse custo um montante, não calculado, representado pelo investimento em pesquisa, muito raramente contemplado nos orçamentos de obras.

Um segundo problema diz respeito ao valor arquitetônico das obras construídas com base nesse modelo de pré-fabricação de ciclo aberto, com componentes disponíveis no mercado. A estrutura, por exemplo, que é parte indissociável do projeto, já comparece tão definida que limita a atividade de projeto. Reduzida a exercícios de leiaute para a adequação dos espaços, resta a essa atividade pouco espaço para a criatividade, a invenção e, consequentemente, para a inovação.

Um terceiro problema, que parece digno de reflexão, é o fato de que ao fazerem as obras pré-fabricadas na década de 1960, os arquitetos tiveram preocupação com a verdade estrutural e com o caráter didático de tais empreendimentos. Dessa forma, os SGs de um pavimento resultaram semelhantes entre si, assim como ficaram iguais entre si os de dois pavimentos e, pelo mesmo raciocínio, os edifícios da Colina Velha. Tratava-se então de divulgar, e de ensinar sobre, as novas descobertas no campo construtivo.

Na verdade, desde o final da primeira guerra na Europa, que coincide aproximadamente com a Revolução Bolchevique na URSS, a pré-fabricação colocava-se como a solução dos problemas da falta de habitações e equipamentos urbanos. O papel da industrialização na arquitetura fez parte das especulações de vários arquitetos da época, entre os quais Le Corbusier, que, com sua proposta da maison Dom-ino, antecipou soluções adotadas quando da reconstrução das cidades europeias após a Primeira Guerra. $\mathrm{O}$ sistema, concebido em 1914, constituiu um primeiro ensaio de racionalização e sistematização de um processo construtivo, posteriormente desenvolvido no projeto da casa Citrohan, de 1922.

As iniciativas pioneiras da UnB no campo da industrialização da construção, inspiradas nos ideais europeus, estavam no bojo das discussões acadêmicas levadas a cabo também no Brasil, país cuja 
carência de várias ordens sugeria a produção em massa. Tratava-se então de viabilizar a materialização das ideias em pauta, em resposta às demandas de seu tempo.

O que vem ocorrendo na UnB hoje é bastante diferente: não existe a preocupação de criar novos sistemas voltados para a inovação no campo da industrialização da construção. O que há é a incorporação de sistemas produzidos comercialmente, que nada trazem de novo como proposta de arquitetura e que, portanto, não despertam interesse. Como esses sistemas deixam, em geral, uma margem muito pequena para especulações formais, os edifícios, além de desprovidos de plasticidade, resultam similares em sua essência. Como forma de diferenciá-los, a solução tem recaído, via de regra, sobre os revestimentos, os dispositivos externos de proteção e outros elementos apostos à construção. Uma espécie de maquiagem recobre volumes construtivamente similares, tornando-se a principal responsável pela identidade funcional que cada um dos edifícios passa a adquirir. Sobre a presença da decoração na arquitetura, o construtivista russo Moisei Ginzburg, em sua obra Style and epoch (1924), afirma que os diferentes estilos, ou as progressivas transformações arquitetônicas, acontecem por meio da continuidade, pela assimilação dos princípios de base da experiência passada, e da independência, que corresponde à introdução de novidade em termos de conceitos e técnicas, com a presença de aspectos característicos da época em causa. Em um processo que chamou de "genético", o autor concluiu que cada estilo passa por três fases de evolução: a juventude, de caráter construtivo, em que há o aparecimento de novas técnicas e novos tipos de construção e total ausência de elementos decorativos ou apostos à edificação; a maturidade, em que há um aperfeiçoamento dos tipos de construção e da forma, com um equilíbrio entre preocupações construtivas e decorativas; e a velhice, em que o peso dos elementos decorativos ou apostos sufoca os aspectos construtivos, gerando o desaparecimento do estilo.

Do estudo dos estilos arquitetônicos históricos, o autor extraiu a seguinte lei:

\footnotetext{
[...] através da história, as novas formas arquitetônicas têm sido o produto das demandas funcionais e construtivas, não havendo necessidade de diluí-las em nada mais. Mais tarde, aparecem os detalhes decorativos, sem romperem, no entanto, a unidade orgânica da forma. Até que chega um momento em que os elementos decorativos extrapolam as fronteiras orgânicas, sufocando o estilo [...] a juventude de um novo estilo é, principalmente uma questão construtiva, sua maturidade é orgânica, e sua decadência é a decoração (GINZBURG, 1982, p. 60).
}

Dessa lei se depreende que a pré-fabricação experimentada na fase pioneira trazia concepções arquitetônicas novas, formas originais de fazer arquitetura, e que hoje a adoção desses sistemas comerciais atesta uma fase de envelhecimento da tecnologia, a qual, não despertando nenhum interesse em si mesma, acabou escondida pelos elementos que lhe foram sobrepostos.

Também o fato de os edifícios projetados a partir de componentes pré-fabricados terem sido desenvolvidos pela mesma equipe de arquitetos, sem vínculo com a FAU, contribuiu ainda mais para descaracterizar a função original do Ceplan como órgão dedicado à pesquisa e democratização do conhecimento produzido. Embora alguns estudantes tivessem participado, no Ceplan, do desenvolvimento de projetos, institucionalmente a FAU ficou alheia às discussões referentes tanto à implantação dos edifícios como à escolha das linguagens de projeto e dos sistemas construtivos. Assim, pode-se afirmar que esse último período, de 2000 a 2012, se caracterizou mais pela produção maciça de construções e menos pelo desenvolvimento de uma arquitetura formal e construtivamente coerente com as novas linguagens e com as atuais possibilidades da tecnologia no campo da construção civil. 

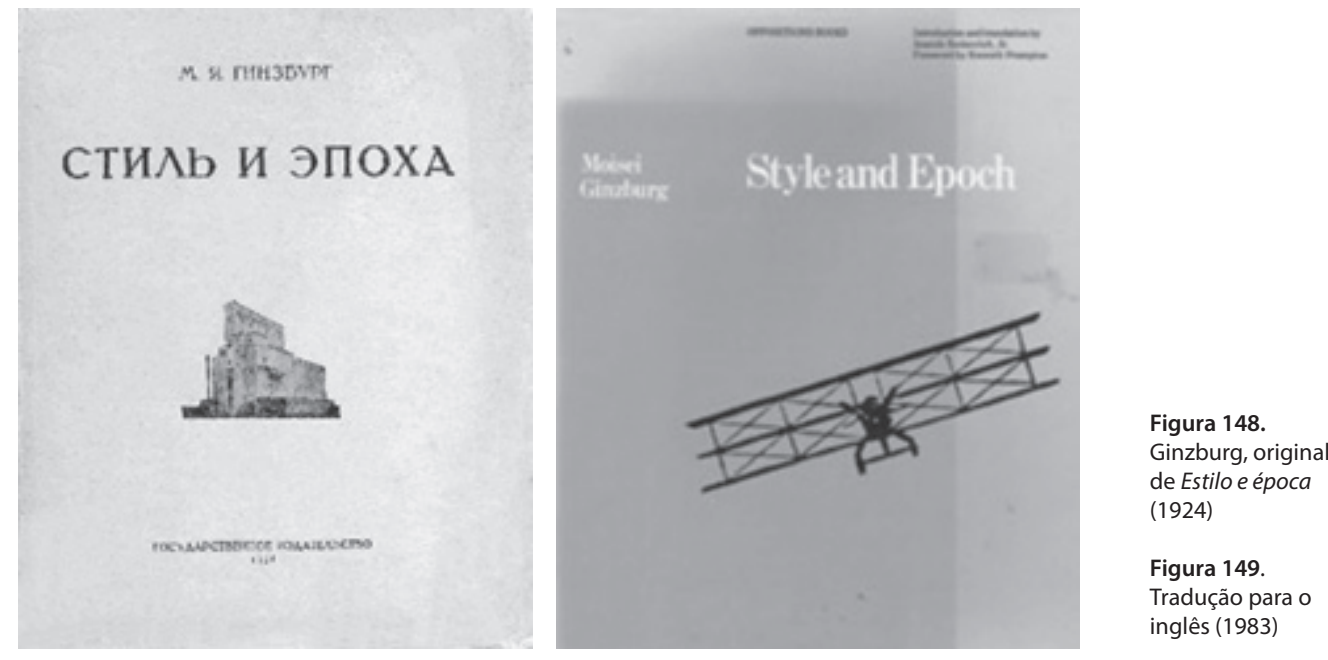

Um contraponto a essa situação surgiu com o Memorial Darcy Ribeiro, que, projetado pelo Lelé, resultou de um longo trabalho de pesquisa com pré-fabricados de aço, desenvolvido pelo arquiteto para a construção dos hospitais da Rede Sarah, na Fábrica de Salvador. O edifício, construído para abrigar o acervo do professor, antropólogo e ex-reitor da UnB, e que significou novamente a presença da arquitetura do Lelé no campus, representa, de certa forma, um avanço em relação às construções da década de 1960, quanto ao tempo de execução, à racionalização do sistema construtivo e, sobretudo, à liberdade plástico-formal.

Existe uma polêmica em torno da localização do beijódromo. O próprio Darcy teria escolhido o local para a edificação do memorial, segundo Cláudia Estrela Porto (2010b, p. 14). Alberto Faria, por sua vez, afirmou que o Ceplan "[...] escolheu aquele lugar, porque ali é a Praça Maior. O prédio da Reitoria vai crescer para trás, na direção do ICC [...] O prédio do Darcy é emblemático demais para colocar em outro lugar" (Entrevista em 8 mar. 2012).

Sobre um possível crescimento da Reitoria, assim se manifestou Zimbres:

Na verdade abandonou-se a ideia de expansão da área edificada a partir da Reitoria [...] Várias intervenções feitas ao longo do tempo sem considerar essa hipótese acabaram por criar barreiras à implantação dessa ideia. Um grande conjunto de belíssimos espécimes de pau-ferro foi plantado em direção à biblioteca. Esse bosqueto poderia representar uma expansão do espaço habitável do campus, um compartimento de paisagem a ser apropriado. Recentemente o colega João Filgueiras Lima, o Lelé, projetou o Memorial Darcy Ribeiro num canto da Praça Maior, como sempre um belo projeto. Creio que essa intervenção vem de encontro a essa ideia de crescimento linear a partir da Reitoria (Entrevista em 26 out. 2011). 


\subsection{O campus como canteiro de obras}

\section{CLÍNICA ODONTOLÓGICA DE ENSINO E FARMÁCIA ESCOLA}

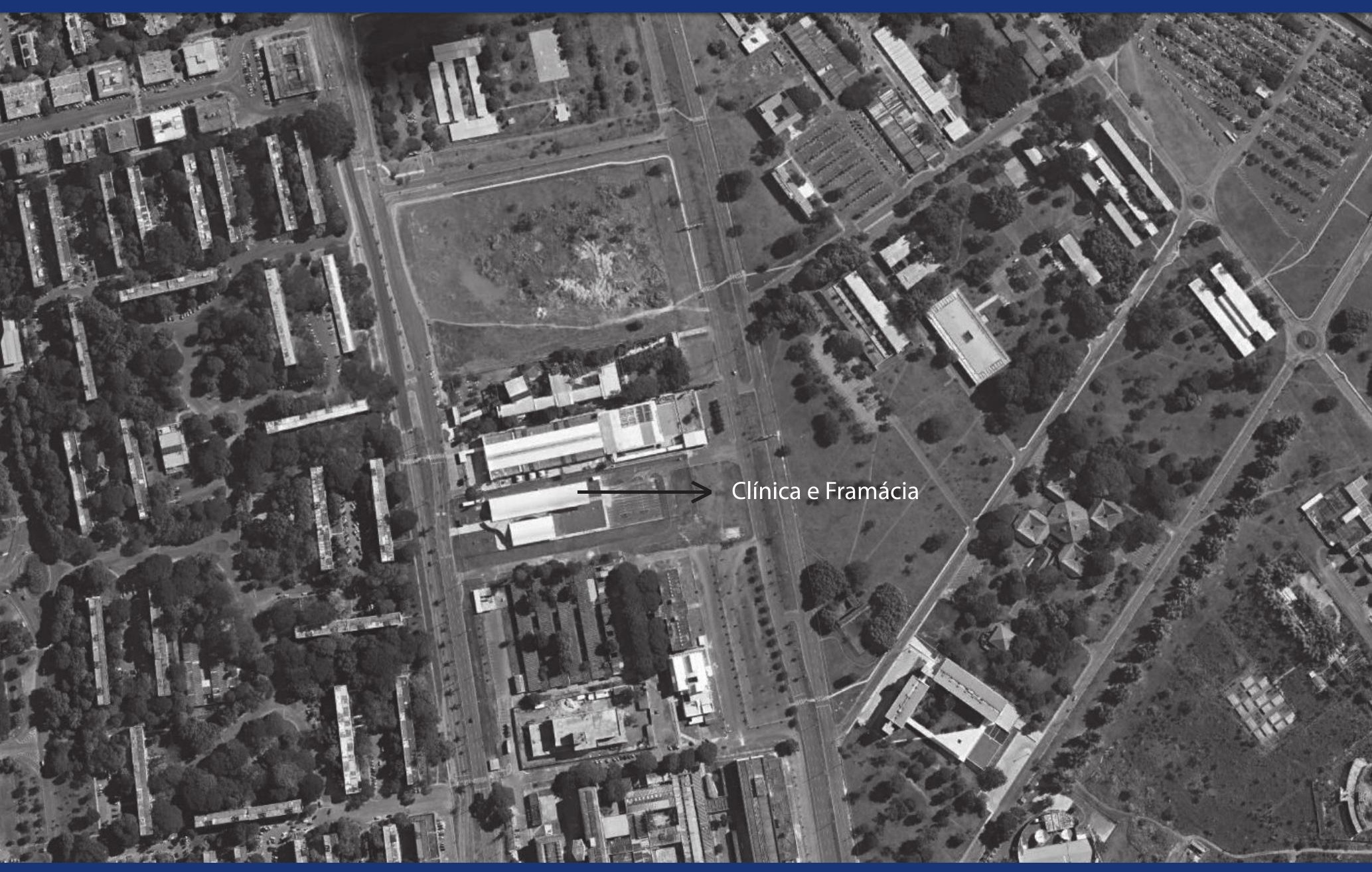

Autoria

Frederico Luiz Aguiar de Carvalho, com a colaboração de Kristian Schiel

Data

2003 (projeto)

2006 (obra)

Área Construída

$2.226 \mathrm{~m}^{2}$
Figura 150a.

Implantação 
O edifício foi criado para permitir o aprendizado prático dos estudantes de odontologia que, até então, vinha sendo feito de maneira precária nas dependências do Hospital Universitário de Brasília (HUB). Além disso, é dotado de espaços para o desenvolvimento de atividades práticas relacionadas ao curso de Farmácia, e para a comercialização de medicamentos. $O$ edifício foi localizado em uma área contígua ao HUB.

Trata-se de um conjunto resultante da articulação de dois blocos de planta retangular, independentes e que apresentam características tipológicas próprias: o da Clínica Odontológica, mais alongado, possui dois pavimentos, ao passo que o da Farmácia, além de menor em extensão, desenvolve-se em um único pavimento.

O sistema construtivo e de cobertura - estrutura metálica e telhas calandradas de aço zincado - é comum a ambos.
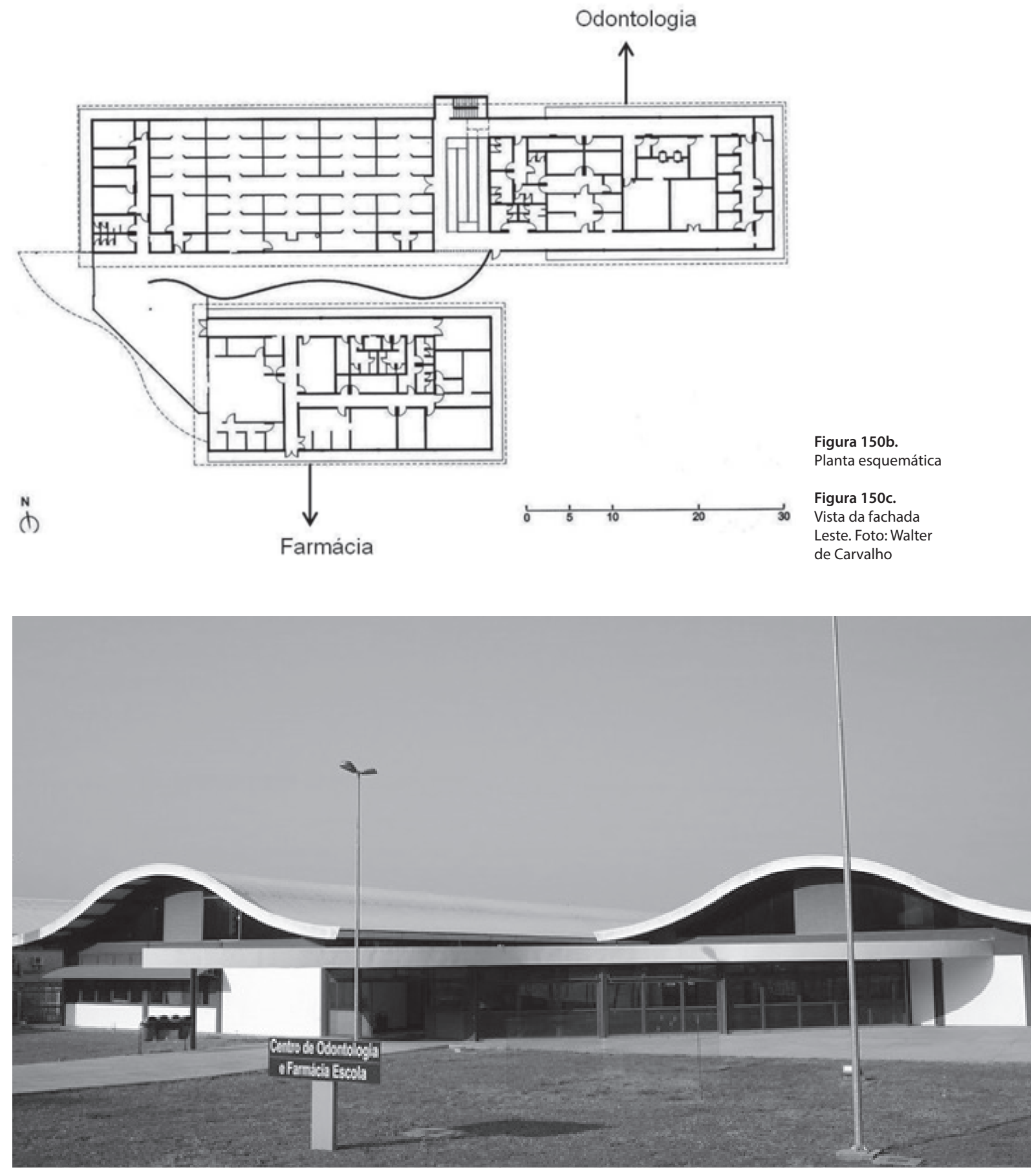


\section{CENTRO DE SELEÇÃO E PROMOÇÃO DE EVENTOS (CESPE)}

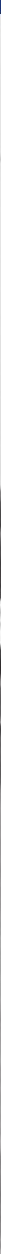

Autoria

Kristian Schiel, com a colaboração de Ivan Manoel Rezende do Valle, Frederico Carvalho e Fabiana Couto Garcia

Data

2003 (projeto)

2004 (obra)

Área Construída

$4.314 \mathrm{~m}^{2}$
Figura 151a.

Vista da fachada

principal. Foto de

Walter de Carvalho. 
Criado em 1993, o Cespe substituiu a Diretoria de Acesso ao Ensino Superior (DAE), que, por sua vez, havia ficado no lugar da Comissão Permanente de Concurso Vestibular (Copeve) criada em 1970. O Cespe foi criado com o objetivo de ampliar, mediante maior autonomia administrativa, financeira e orçamentária, as atividades da Diretoria de Acesso ao Ensino Superior (DAE), fundada em 1986.

O conjunto é formado por três pavilhões paralelos, separados por jardins e interligados por meio de passarelas cobertas.
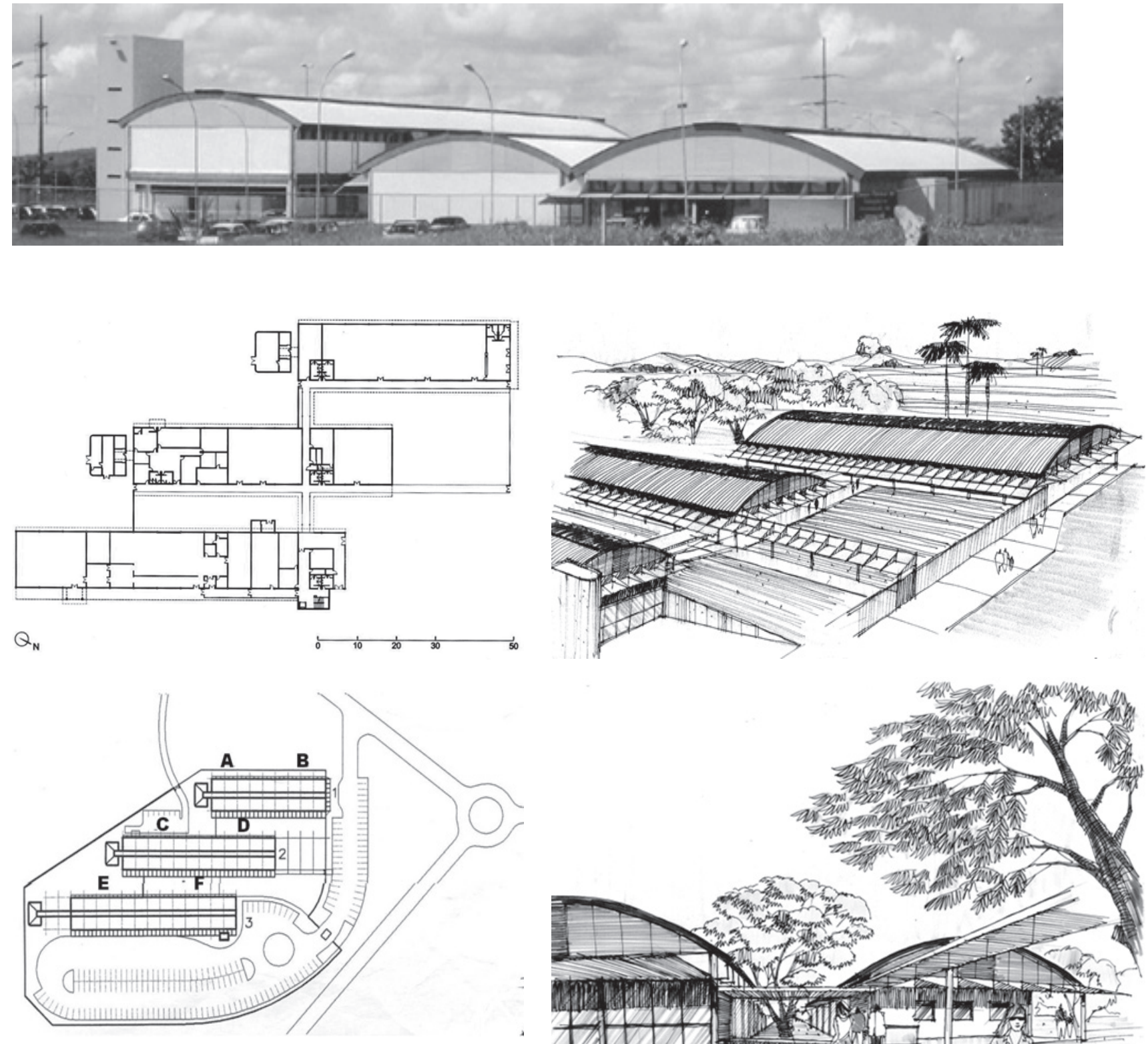

\footnotetext{
A - Atendimento a candidatos

B - Planejamento e logística

C-Informtica

D - Diretores

E - Diretoria Acadêmica

F - Almoxarifado e gráfica.
}

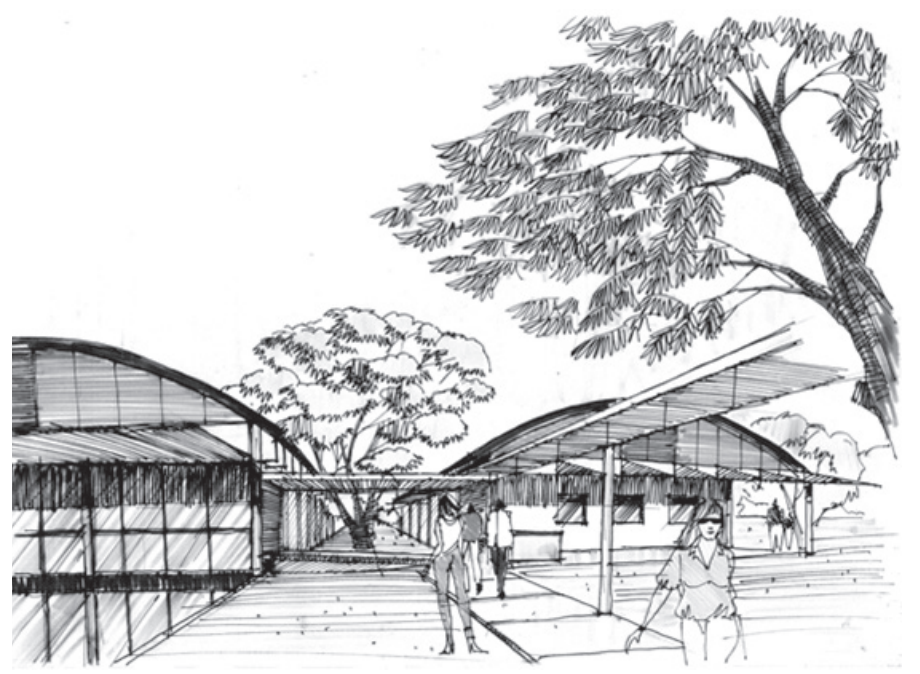

Figura $151 \mathrm{~b}$.

Vista da fachada Nordeste.

Figura 151c.

Planta esquemática

Figura 151d.

Vista geral do conjunto. Desenho de Frederico Carvalho

Figura 151e.

Implantação e distribuição dossetores pelos Blocos 1, 2 e 3

Figura $151 \mathrm{f}$.

Vistados jardins entre os blocos.. Desenho de Frederico Carvalho 

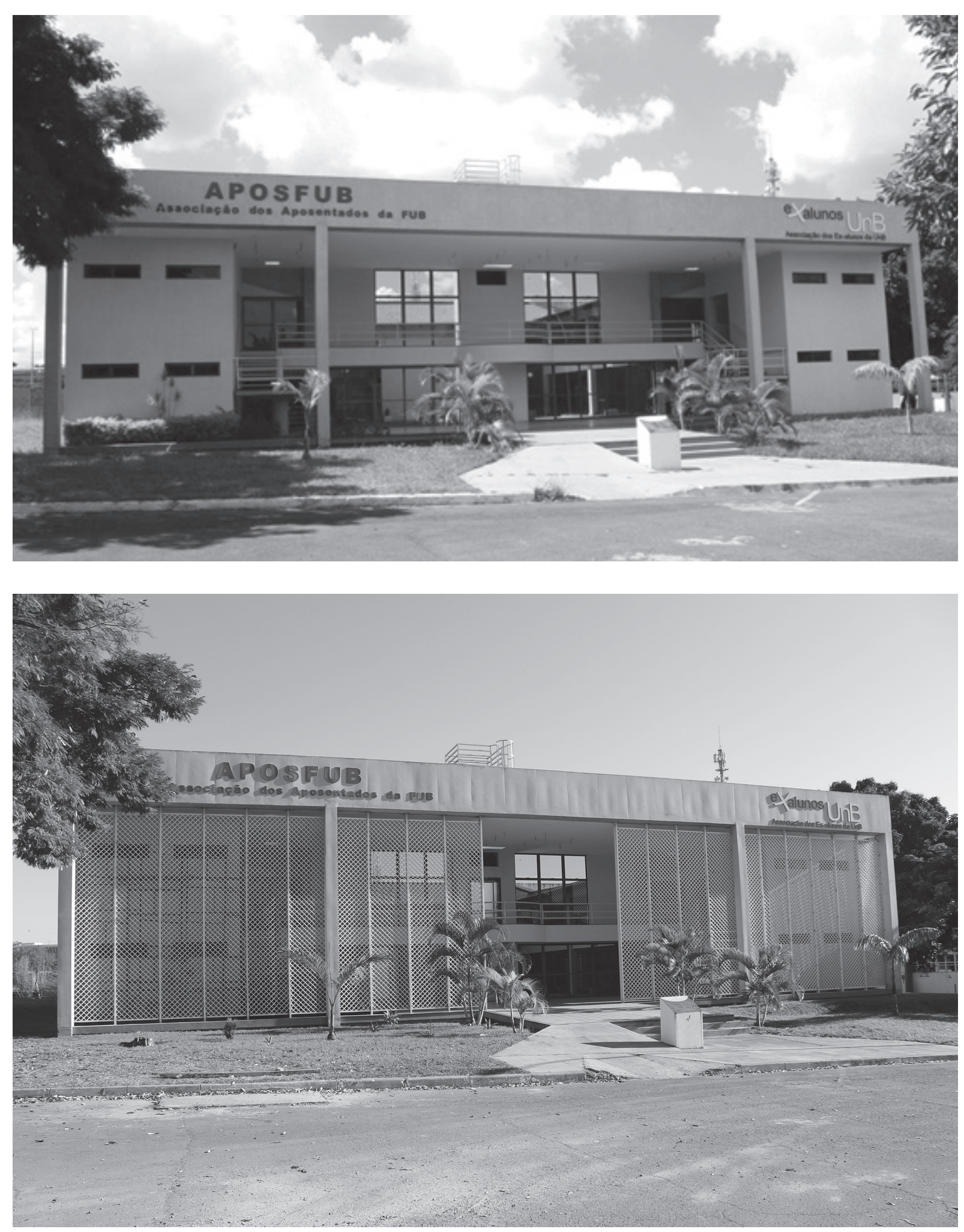

Figura 152b.

Vista da

fachada Sul

Figura 152c.

Vista da

fachada Sul.

Foto Silvio

Cavalcante 
CASA DO PROFESSOR - SEDE DA ASSOCIAÇÃO DOS DOCENTES DA UNIVERSIDADE DE BRASÍLIA (ADUnB)

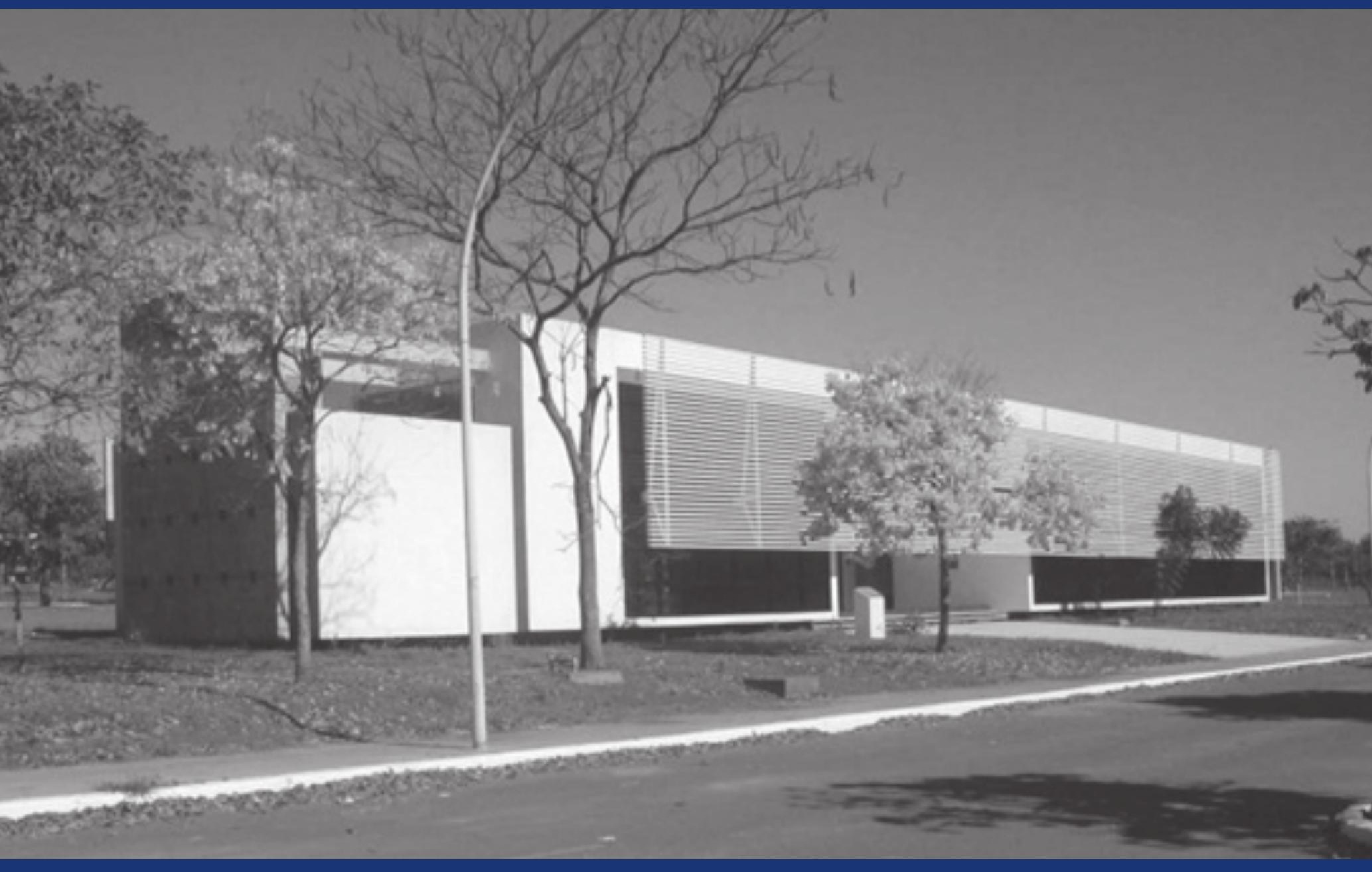

Autoria

Raimundo Nonato Veloso

\section{Data}

2004 (projeto)

2005 (obra)

Área Construída $878 \mathrm{~m}^{2}$
Figura 153a.

Vista Leste 
Criada em 1978, a ADUnB, que desempenhou importante papel no processo de redemocratização da UnB, funcionou provisoriamente no Pavilhão Multiuso I. O edifício-sede, projetado para abrigar as funções relacionadas à promoção, valorização e defesa das atividades docentes da UnB, foi entregue em maio de 2005.

O edifício foi implantado em um dos acessos de maior visibilidade dentro do campus, ao lado da Avenida L3 Norte. O sítio tem uma importância histórica que vem da implantação da própria UnB. Os ambientes principais são voltados para o estacionamento, a leste, e as áreas de apoio como sanitários e circulação vertical para oeste, contidas em bloco único, o que protege o edifício da pior insolação.

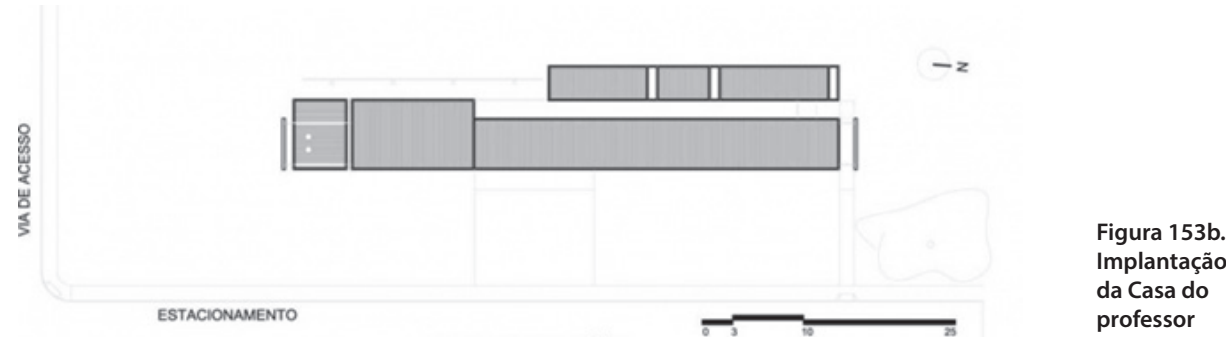

[...] (o projeto) foi fruto de um concurso aberto a professores da FAU/UnB e demais arquitetos que trabalhavam no campus, no final de 1999. O programa era bem maior e havia a exigência da possibilidade de sua execução por partes. Em 2003 houve o interesse da construção da frente do edifício contendo a parte administrativa da associação, deixando de lado restaurante, auditório e outras dependências. Resolvemos então redesenhar esta parte, incluindo um café e ajustando alguns pontos para deixá-la com aparência de "coisa acabada" (VELOSO, 2007).

Trata-se de um edifício de dois pavimentos, composto de um bloco principal, com $48 \times 10 \mathrm{~m}$, aberto e envidraçado; e um secundário, com $5 \times 10 \mathrm{~m}$, de concreto aparente. O menor abriga uma cozinha e um pequeno restaurante, e o maior salas de reuniões e a diretoria da Adunb. Ligando os dois, uma espécie de átrio aberto e com pé-direito duplo permite cruzar a edificação e, ao mesmo tempo, convida à participação de todos.

Tivemos que respeitar a horizontalidade, a escala e a calma do lugar. O edifício resultou de filiação definida. A ideia das empenas soltas emoldurando o edifício já é encontrada tanto na casa Celso Silveira de Mello, em Piracicaba, SP, 1962, dos arquitetos Paulo Mendes da Rocha e João de Gennaro, como recentemente na Clínica de Odontologia em Orlândia, SP, 1998, do grupo de arquitetura MMBB (VELOSO, 2007).

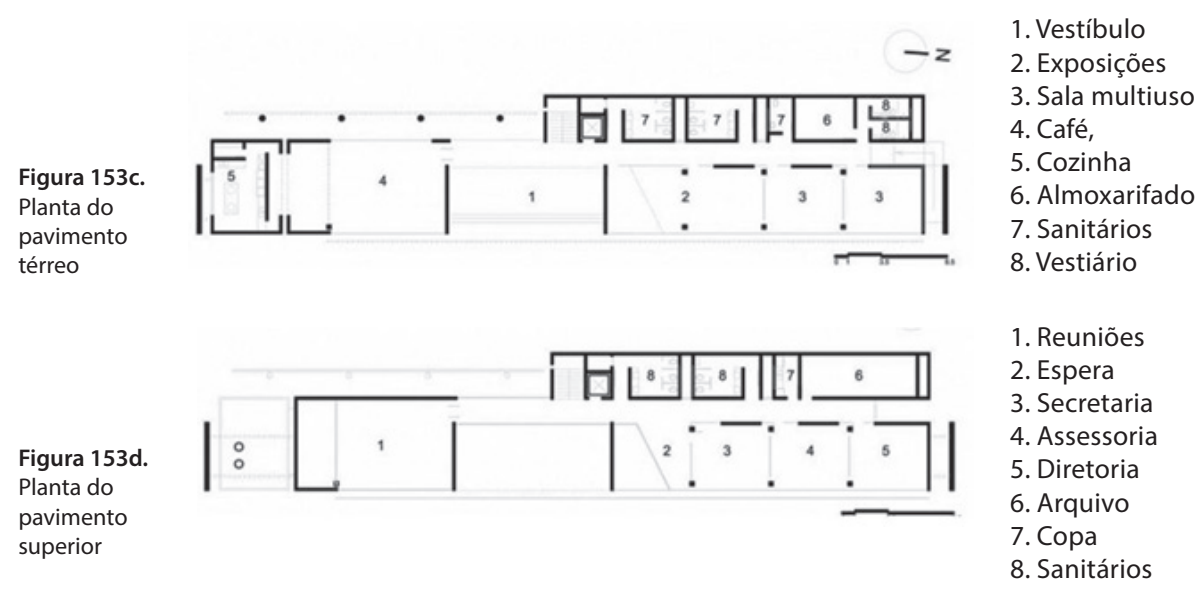



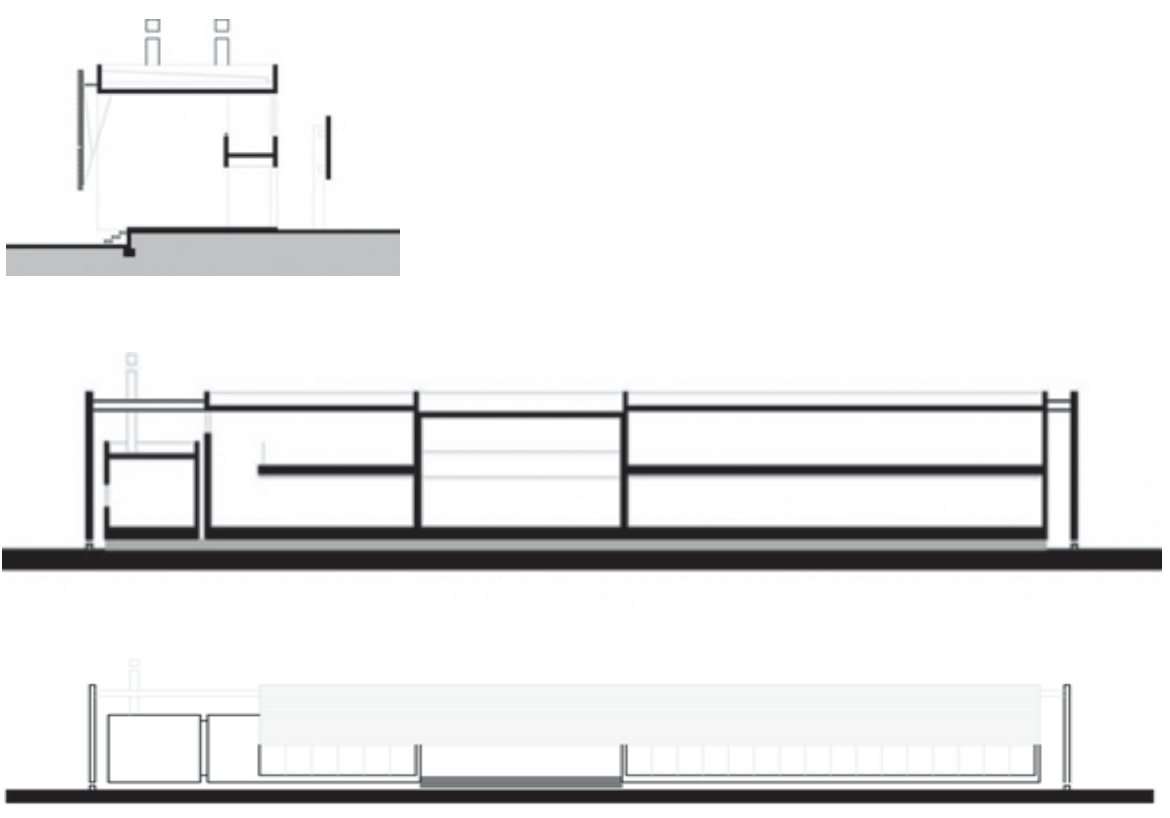

Corte transversa

Figura 153f.

Corte longitudinal

Figura 153g.

Fachada Leste

Figura $153 \mathrm{~h}$.

Fachada Oeste

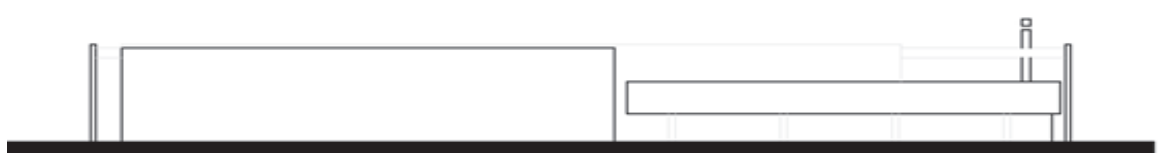

Figura 153i.

Vista da fachada Leste

Figura 153j.

Detalhes do brise

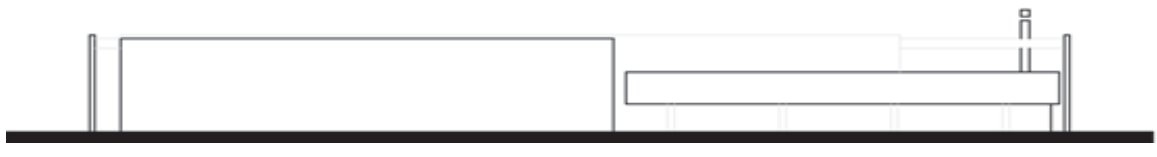

Figura 153k.

Vista Oeste

Figura 153I.

Detalhe da escada
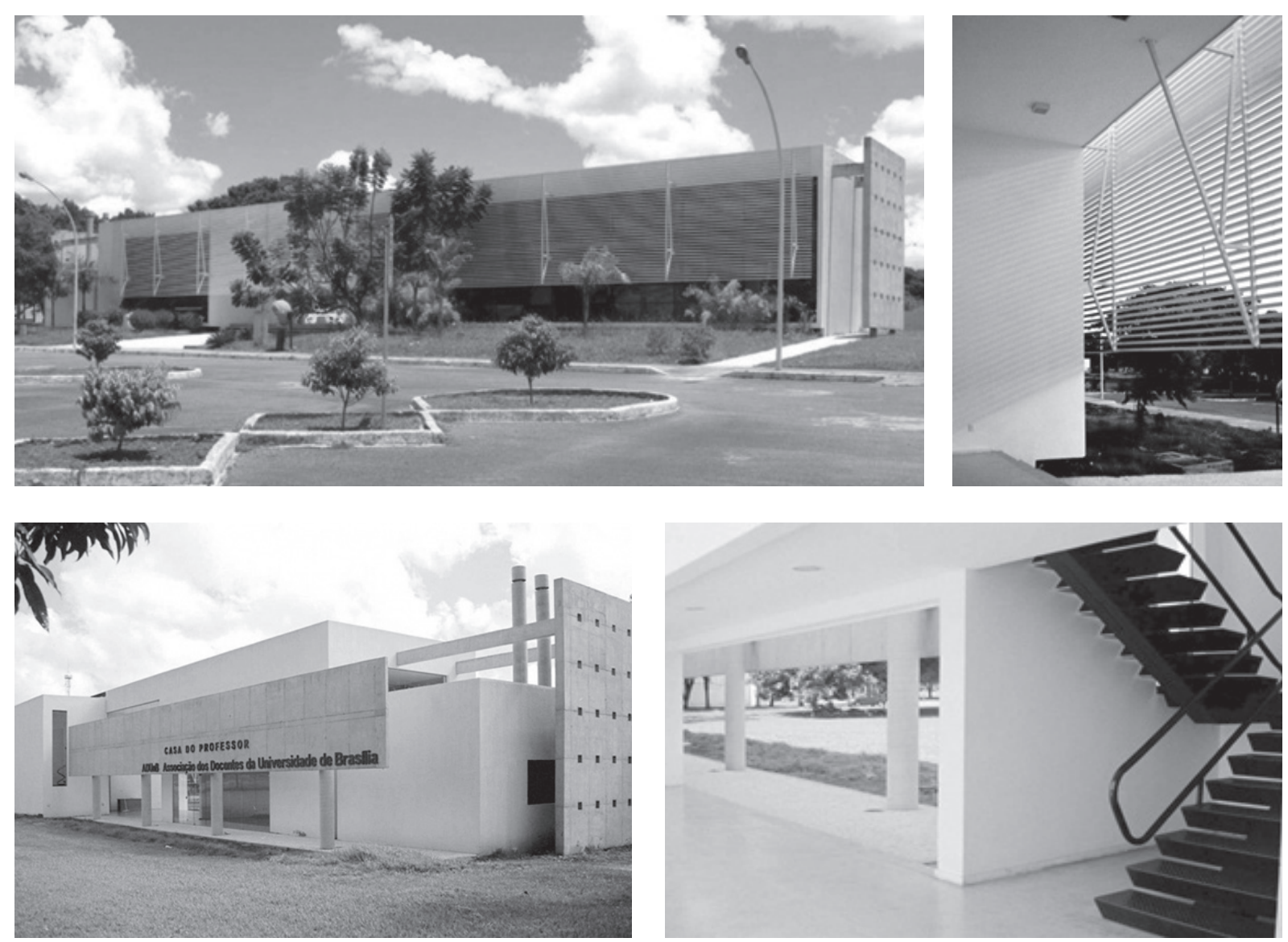


\section{INSTITUTO DE CIÊNCIAS BIOLÓGICAS (IB)}

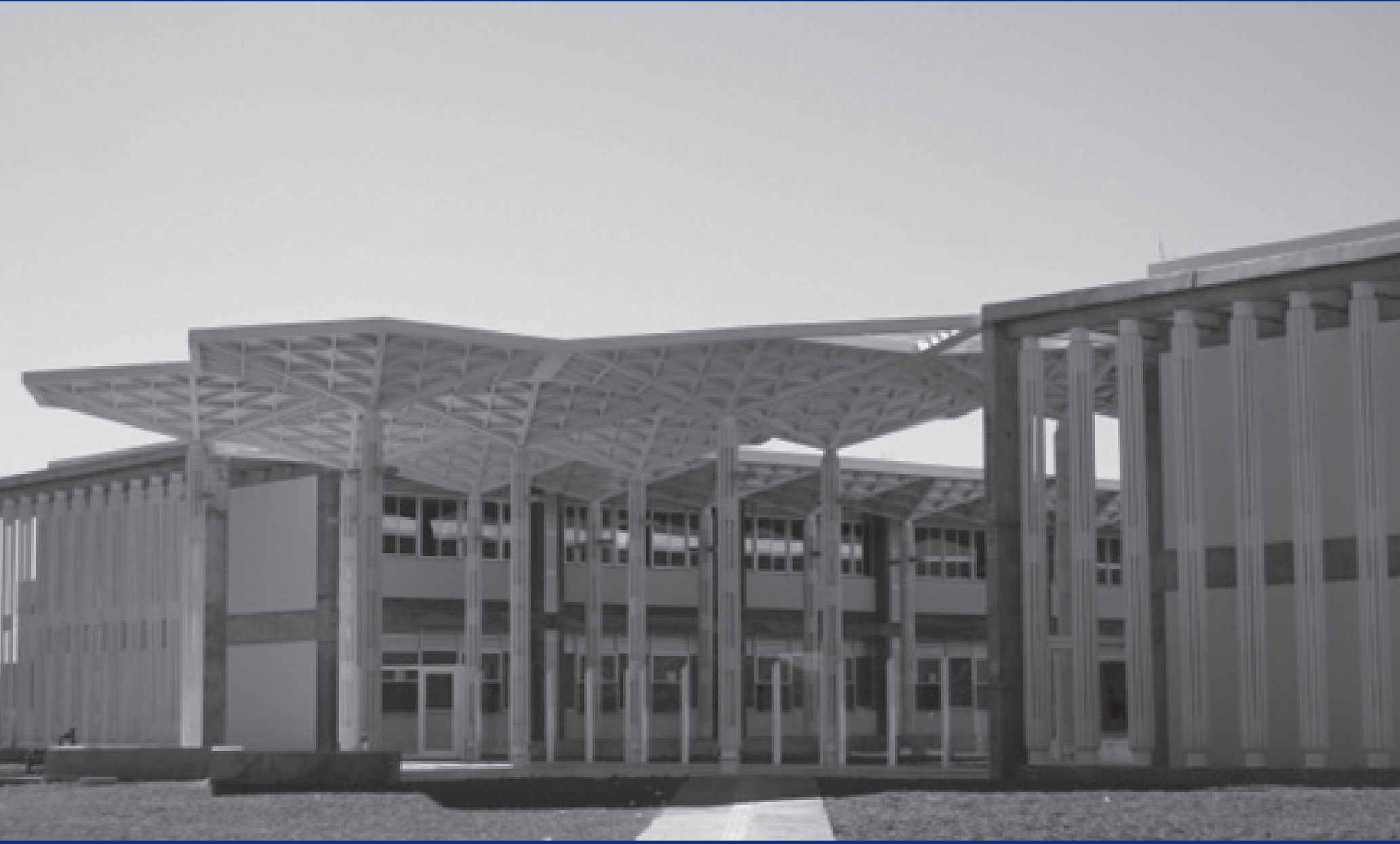

\section{Autoria}

Frederico Flósculo, Ivan Manoel Rezende do Valle, Oscar Luís Ferreira, Cristine da Silva Autran, Nelton Keti Borges, Vanessa Novais Bhering

\section{Data}

2004 (projeto)

2010 (conclusão da obra)

Área Construída26.250 $\mathrm{m}^{2}$
Figura 154a.

Vista da fachada

principal 
O ensino de Biologia na UnB foi implantado, em 1963, pelo professor Antônio Rodrigues Cordeiro, um dos primeiros geneticistas brasileiros. O primeiro laboratório foi montado no prédio da FE 3 . Em 1964, o então Instituto Central de Biociências passou a ocupar o SG 11. Com o Estatuto de 1970, o IB passou a ser constituído por quatro departamentos: Biologia Celular, Biologia Animal, Biologia Vegetal e Psicologia. Em 1987, o Departamento de Psicologia desligou-se do IB, vindo a constituir o Instituto de Psicologia. E, aos poucos, o IB foi sendo transferido para o ICC, onde passou a ocupar $12 \mathrm{mil} \mathrm{m}^{2}$, situação que perdurou até a conclusão das obras de sua sede definitiva.

O complexo arquitetônico do IB é constituído por 11 blocos, que configuram dois conjuntos em forma de " $\mathrm{H}$ " - o micro e o macro. Os blocos do conjunto micro, a Oeste, têm dois pavimentos e estão situados em uma cota de nível 3,50 m acima em relação ao térreo do conjunto macro. Essa diferença de nível, vencida por meio de um talude ajardinado que cruza todo o conjunto do IB, tornou possível criar, no conjunto macro, dois blocos de três pavimentos cada. Esse conjunto é complementado por mais dois blocos de dois pavimentos.

O projeto baseia-se em uma malha modular de $60 \times 60 \mathrm{~cm}$. As circulações ocorrem por entre os jardins, configurando-se 12 conjuntos de jardins com tratamentos paisagísticos diversificados.

Os pavimentos dos blocos de pesquisa apresentam uma larga faixa ao longo da qual estão dispostos os laboratórios, uma faixa de circulação e uma faixa para as salas de apoio, salas de professores, banheiros etc.

Foram garantidas ao conjunto e a cada parte componente facilidade de manutenção e flexibilidade. No espaço aberto pela longa faixa longitudinal entre os blocos, foi prevista uma galeria técnica aflorada de edículas destinadas à segura guarda dos torpedos de gases que alimentam os fornos, as capelas e demais equipamentos de pesquisa.

Figura 154b.

Planta do

pavimento

térreo
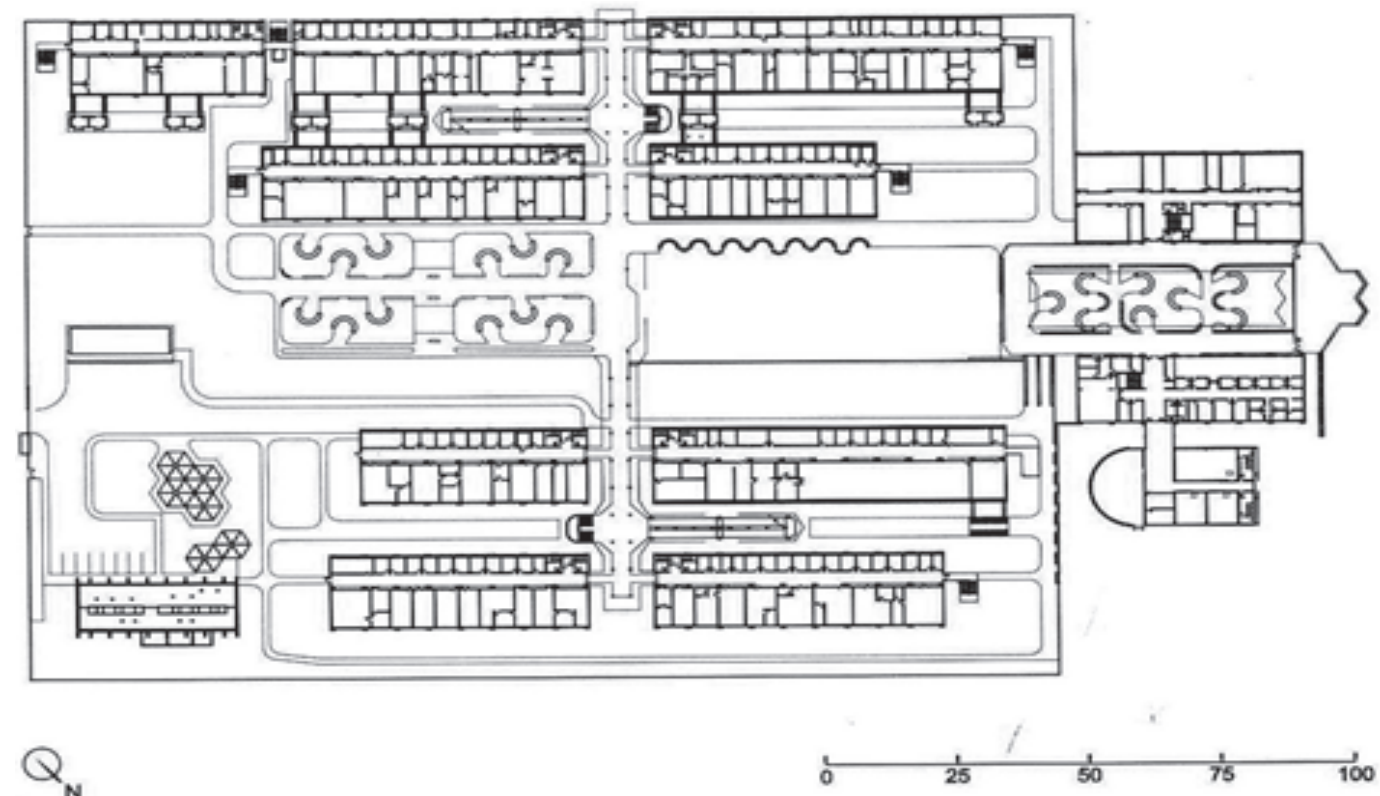


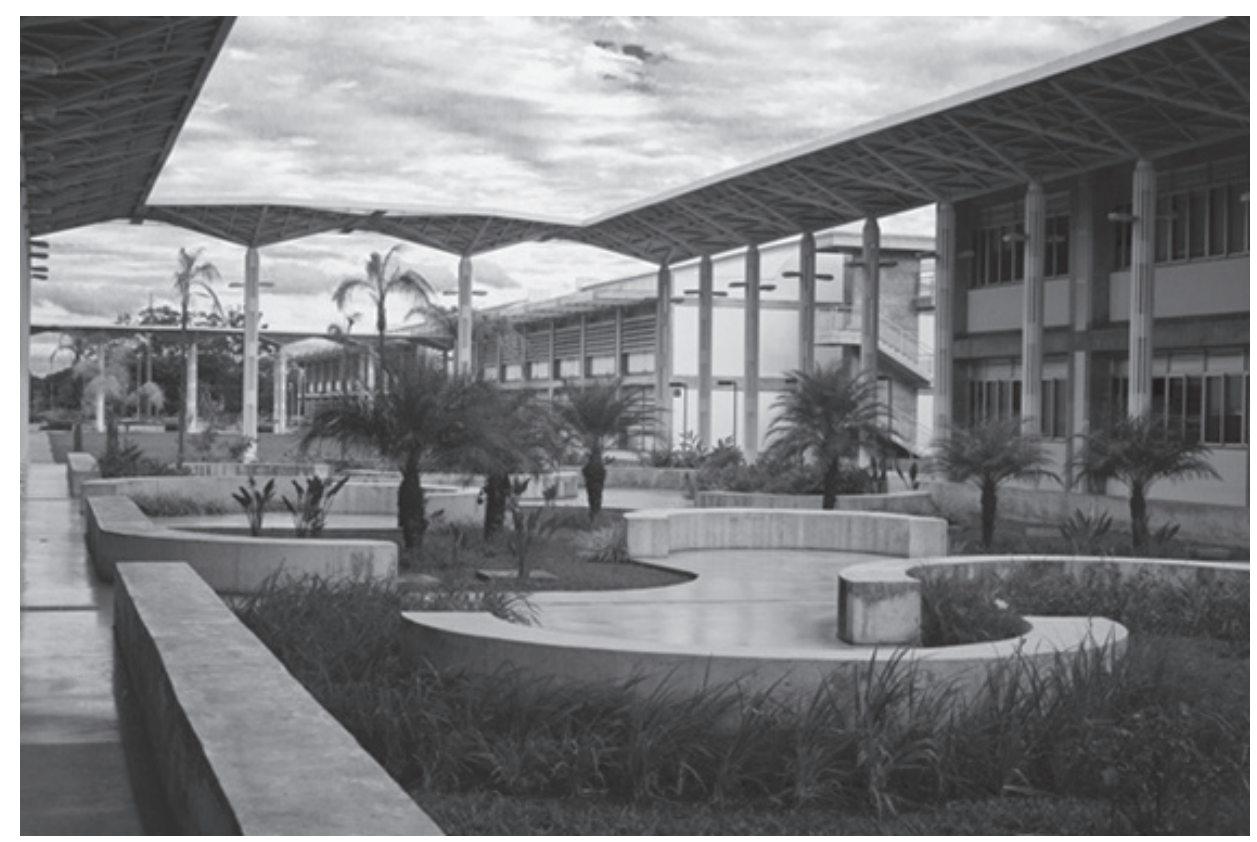

Figura 154c.

Vista dos jardins

Figura 154d.

Vista do pátio interno

Figura 154e.

Vista dos eixos de circulação

Figura $154 f$.

Vista da fachada Leste com

os elementos horizontais e

verticais de proteção solar

Figura 154g.

Vista das circulações

horizontal e vertical
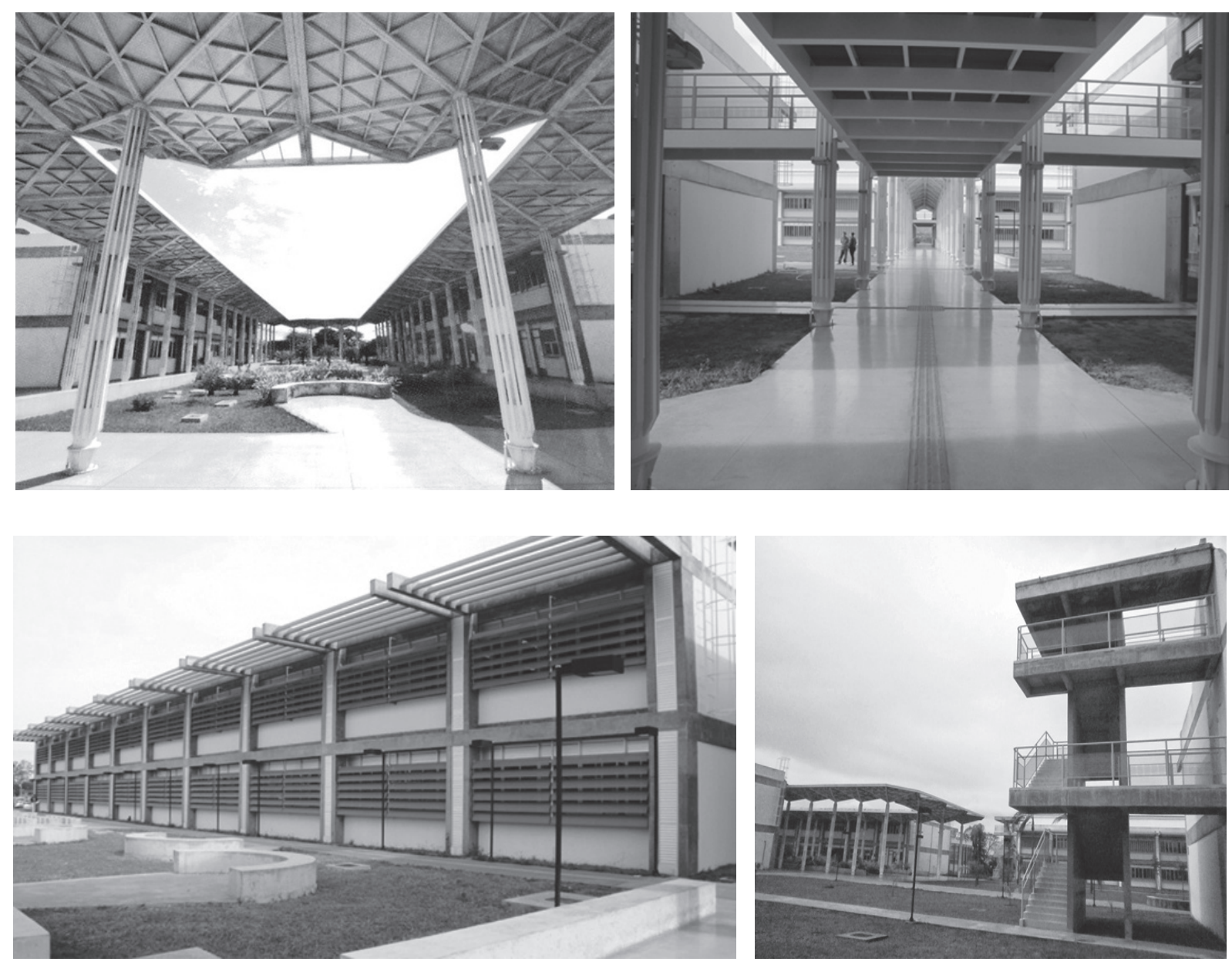
nas para os cursos básicos da área de ciências. Em 1970, o IQ, assim como o Instituto de Matemática e o de Física, foram transformados em departamentos e reunidos no Instituto Central de Ciências Exatas. Em 1999, o IQ recuperou sua autonomia, voltando a funcionar como instituto, sendo o novo prédio a culminação desse esforço.

O conjunto é formado por dois blocos longitudinais e paralelos de concreto armado, com 118,00 m x 14,00 m cada, ligados por uma praça central. A estrutura dos blocos obedece a uma modulação de $14 \mathrm{~m} \times 3 \mathrm{~m}$. Cada bloco possui dois pavimentos: no térreo fica a graduação e no superior, a pósgraduação. As fachadas estruturadas por elementos vazados e o vão entre os prédios favorecem a circulação do ar e o conforto térmico do ambiente.

Os trinta laboratórios são fechados por esquadrias de alumínio anodizado e protegidos por paredes vazadas. Entre eles, passarelas metálicas funcionam como circulação alternativa e rota de fuga, conduzindo às escadas de emergência. Ligadas diretamente às salas de professores, essas salas possuem duas saídas e duas entradas, criando escapes na diagonal e induzindo a ventilação cruzada. A transparência do vidro e dos elementos propicia vistas para o lago e para as áreas ajardinadas.

O pátio central, com cobertura de placas de vidro laminado, sustentadas por arcos metálicos e entremeadas por amplos vazios, possibilita a ventilação constante e a visualização do céu. Essa mesma estrutura suporta a passarela suspensa de ligação entre os blocos, por meio de tirantes de aço.

Por entre os jardins, as circulações também servem de escape e acesso para os laboratórios e salas de eventos. Para agregar a graduação e a pós, o projeto inclui copas comuns, próximas à circulação vertical no térreo, que atuam como salas de estar.

As instalações situam-se externamente e correm por shafts horizontais e verticais, conduzindo a exaustão das capelas dos laboratórios para o exterior e facilitando a manutenção.

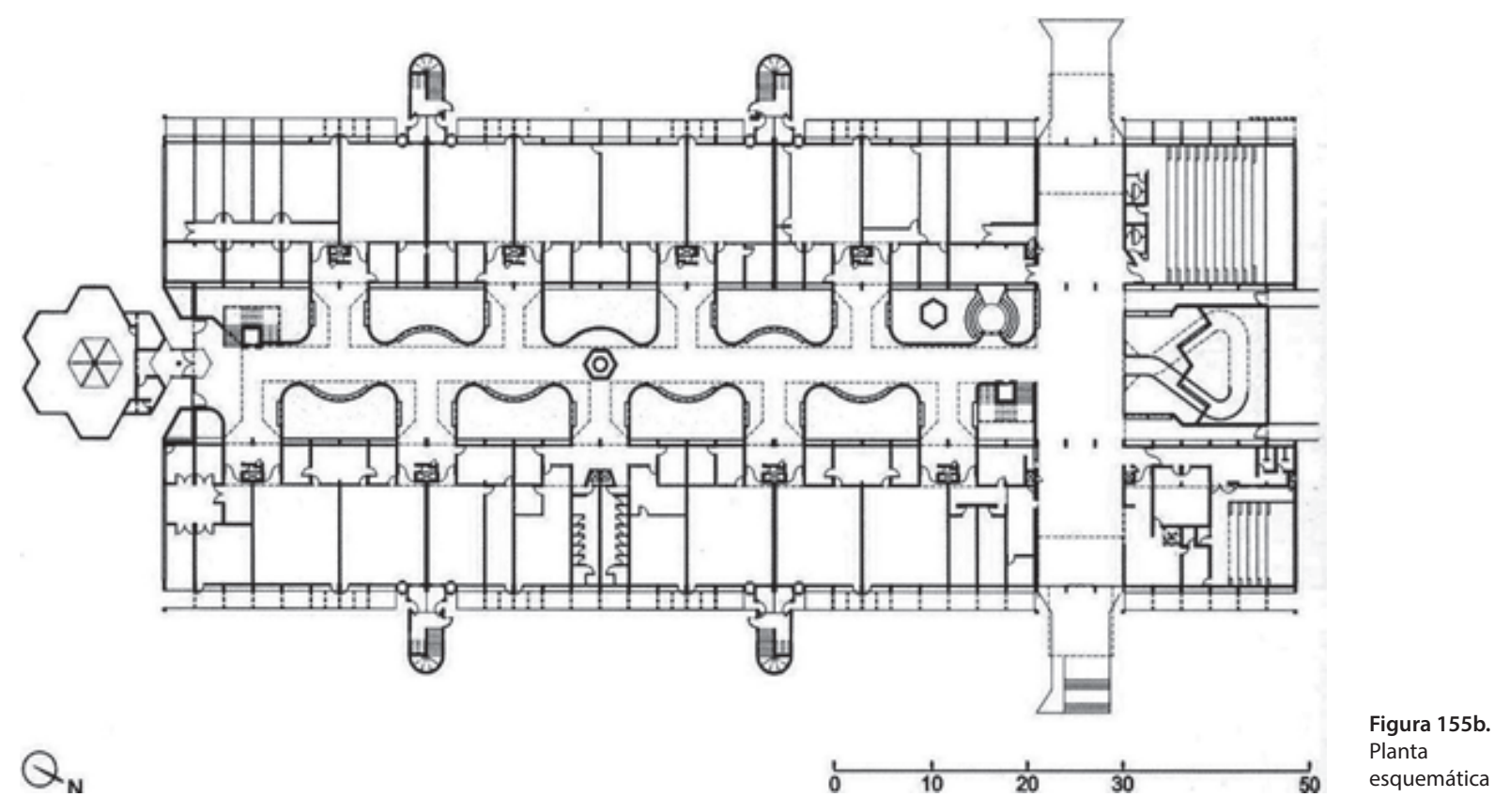


Entre os dois blocos, com estrutura de concreto armado, foi projetada uma grande praça, coberta por arcos metálicos de seção circular, que sustentam placas translúcidas de policarbonato, entremeadas de vazios para possibilitar a ventilação constante.

As circulações acontecem por entre os jardins que compõem a praça central.

A diversidade do tratamento paisagístico contribui para evidenciar cada um dos 12 conjuntos de jardins que conformam essas circulações.
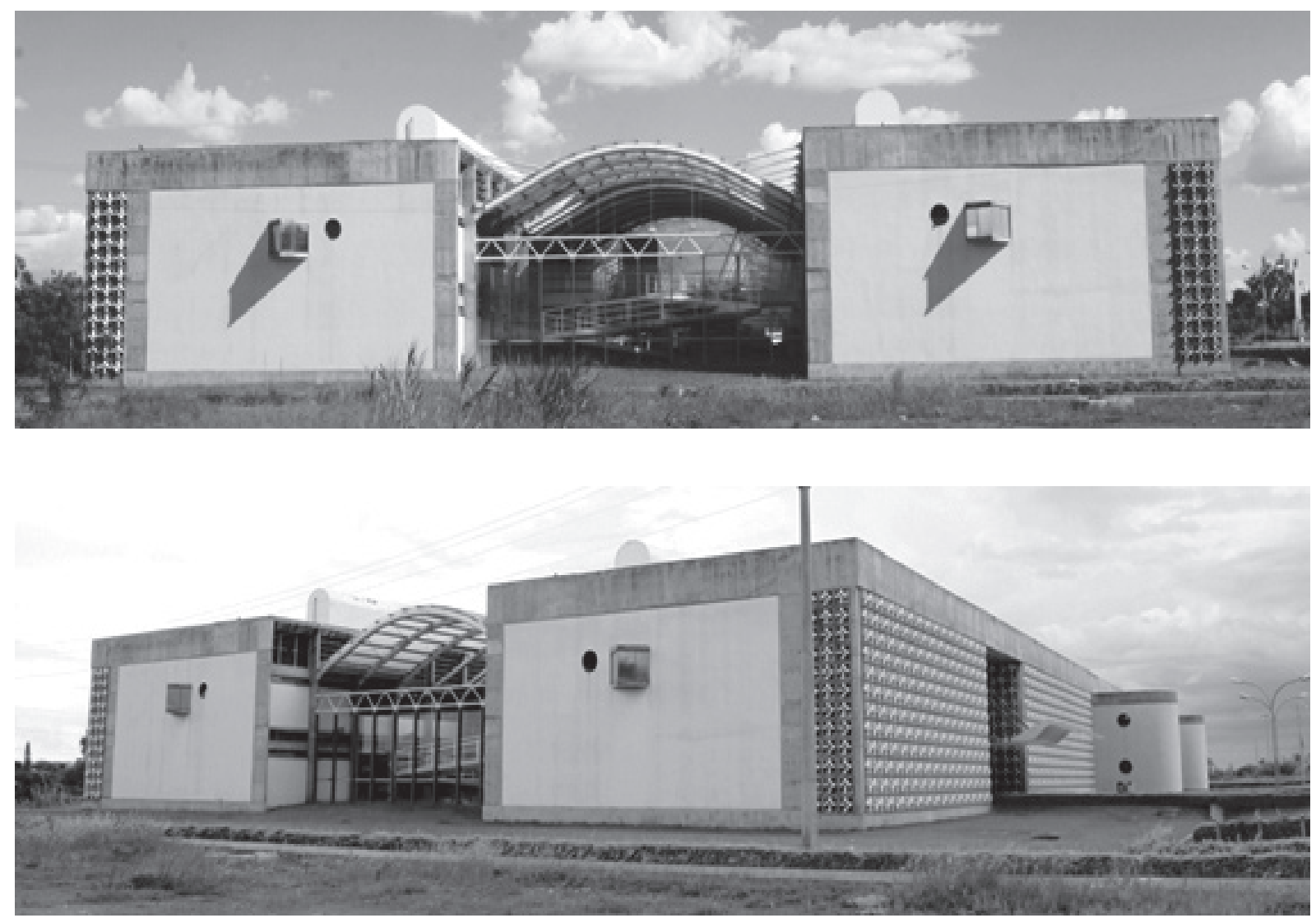

Figura 155c.

Vista da fachada Sudeste

Figura 155d.

Vista das fachadas

Sudeste e Nordeste

Figura 155e.

Vista da fachada

Nordeste

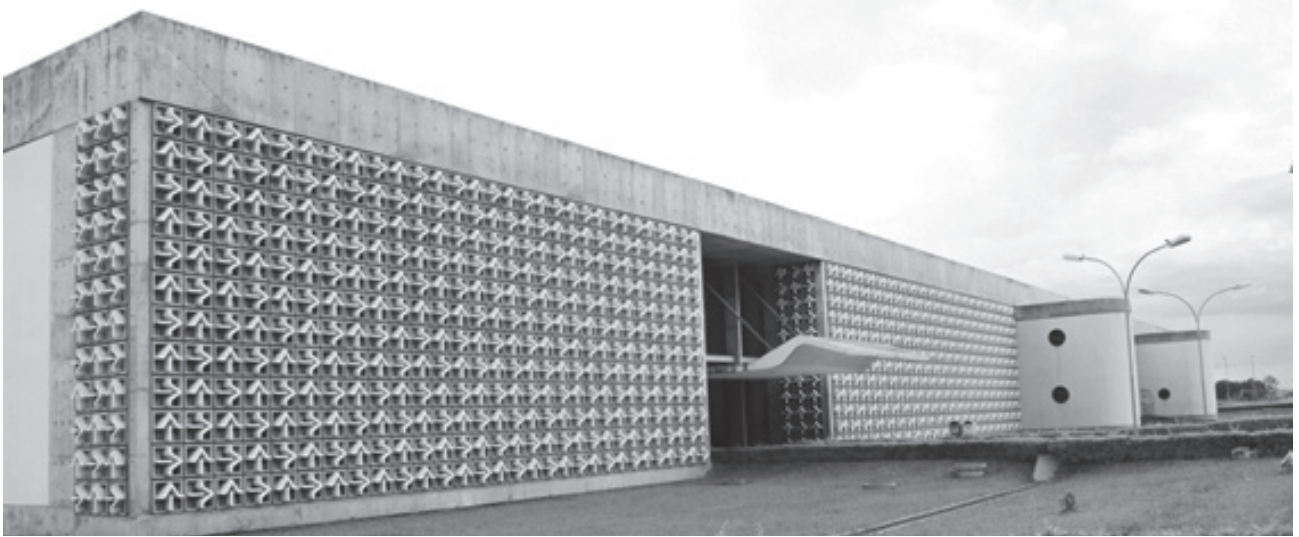

Figuras $155 \mathrm{f}$ e $155 \mathrm{~g}$.

Detalhes dos brises

Figuras $155 \mathrm{~h}$ e $155 \mathrm{i}$.

Detalhes dos painéis de azulejos
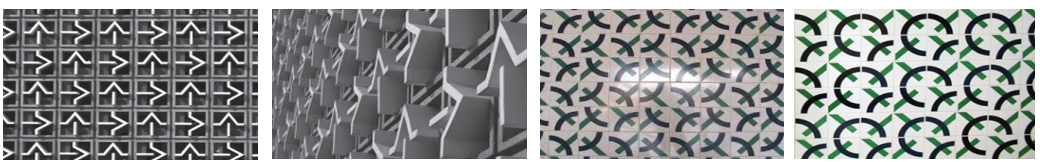

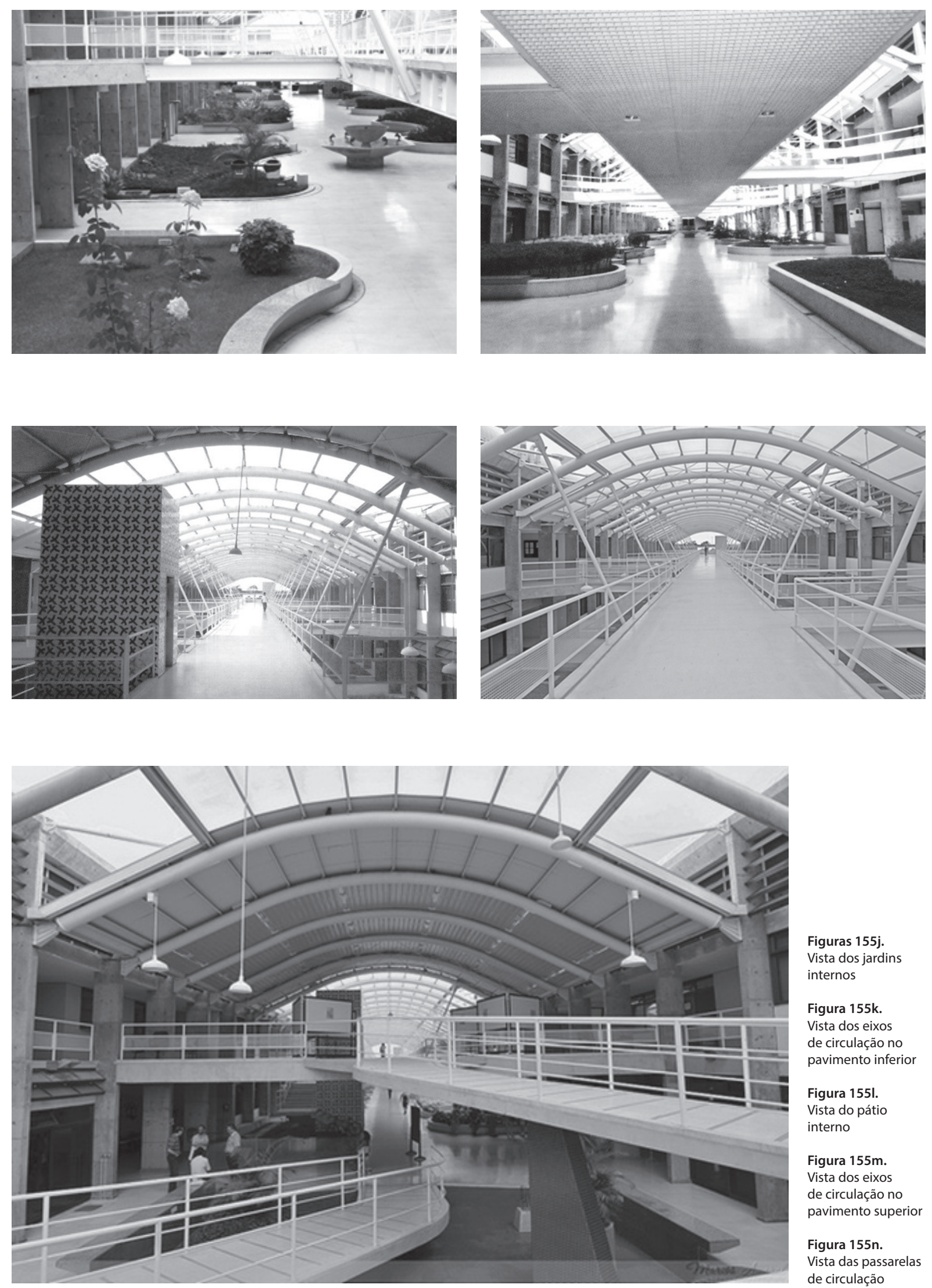

Figuras $155 \mathrm{j}$.

Vista dos jardins

internos

Figura 155k.

Vista dos eixos

de circulação no

pavimento inferior

Figura 1551.

Vista do pátio

interno

Figura $155 \mathrm{~m}$.

Vista dos eixos

de circulação no

pavimento superior

Figura 155n.

Vista das passarelas

de circulação 


\section{LABORATÓRIO DE ESTUDOS GEODINÂMICOS E AMBIENTAIS (LEGA) / LABORATÓRIO DE GEOCRONOLOGIA}

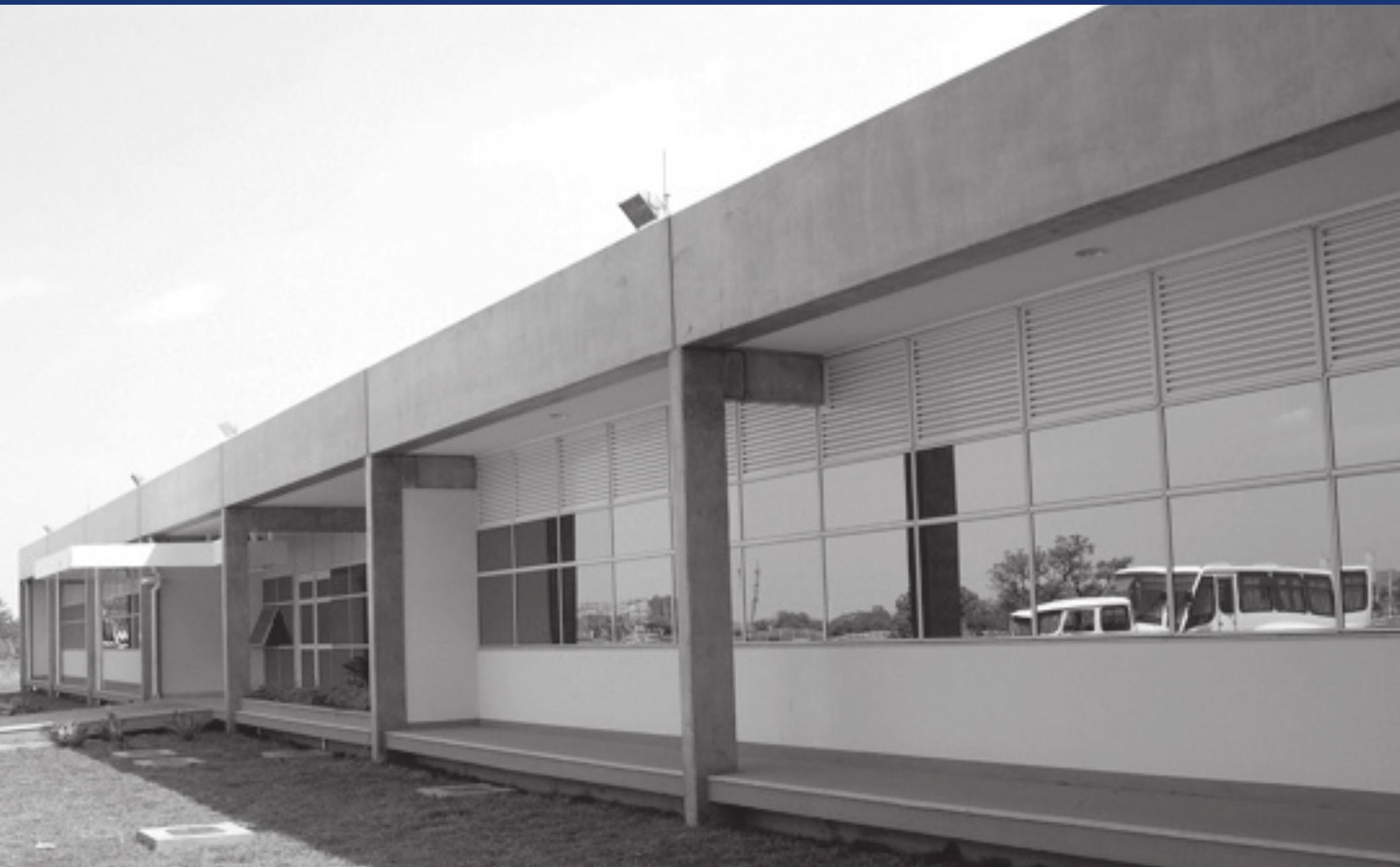

Autoria

Alberto Alves de Faria, Fabiana Couto Garcia e Vanessa Novais Bhering

\section{Data}

2005 (projeto)

2011 (conclusão da obra)

Área Construída

$1.380 \mathrm{~m}^{2}$ 
Vinculado ao Instituto de Geociências (IG), o Lega dedica-se a pesquisas geológicas na área de análises isotópicas para determinar a geração de fontes magmáticas e quantificar possíveis problemas ambientais, além de pesquisas de geocronologia na datação de rochas.

A modernização da infraestrutura e a construção do prédio definitivo foram possíveis graças aos recursos provenientes da Petrobras - Rede Geochronos - e da Finep.

O edifício, a primeira experiência de estrutura pré-fabricada de concreto armado da atual direção do Ceplan, é modulado (7,5 m x $10 \mathrm{~m}$ ) e articulado em torno de um hall central, que distribui as funções de laboratórios, auditório/sala de professores e área de preparo de amostras. Trata-se de uma construção pré-fabricada de ciclo aberto, ou seja, que usa elementos pré-fabricados de concreto disponíveis no mercado.

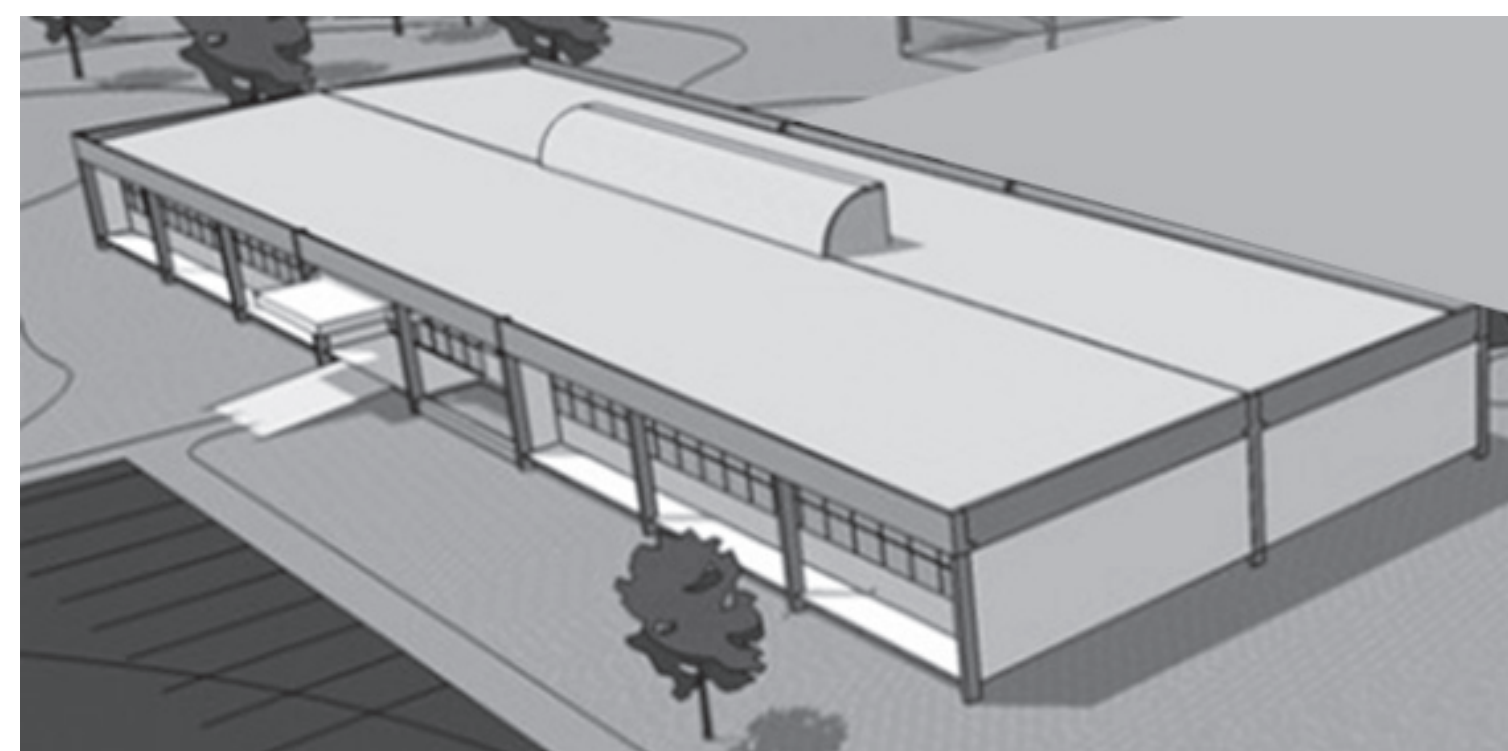

Figura 156b. Vista áerea.

aquete

eletrônica

Figura 156c.

Vista da fachada

Leste

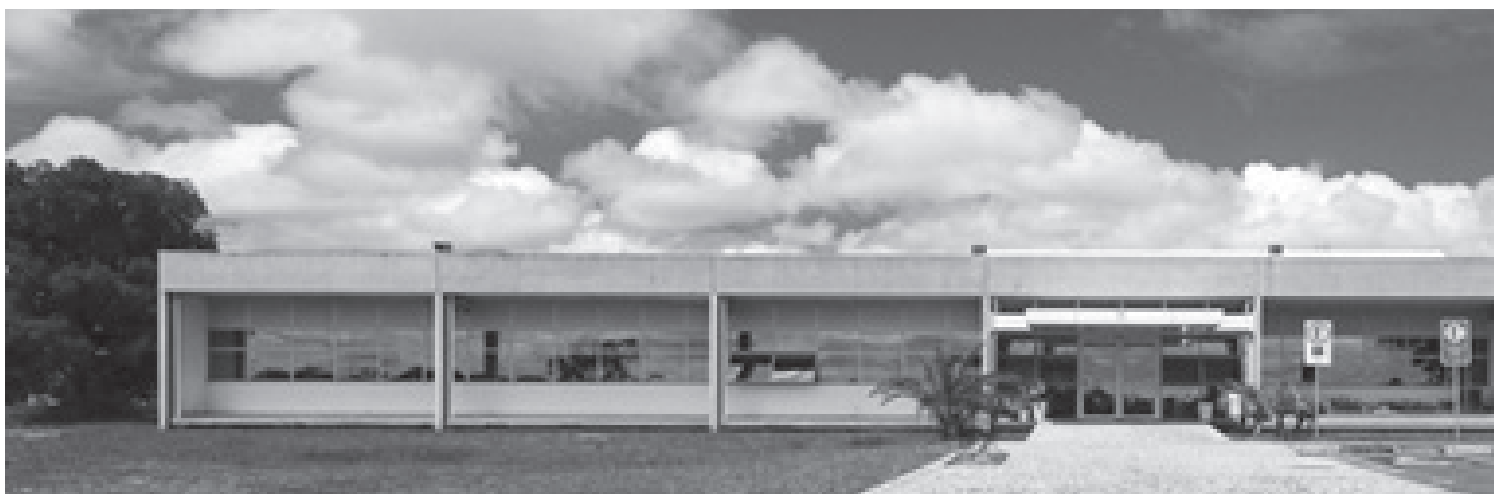


FACULDADE DE ECONOMIA, ADMINISTRAÇÃO E CONTABILIDADE (FACE)

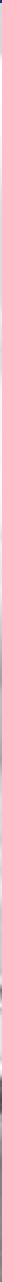

Autoria

Márcio Buson, Andrey Schlee, Claudia da Conceição Garcia, Fabiano Gonçalves de Castro e Adalberto José Vilela Junior

Data

2005 (projeto)

2010-2012 (obra)

Área Construída

$8.482 \mathrm{~m}^{2}$
Figura 157a.

Vista da

fachada Leste 
O edifício resultou da intenção de promover a integração física e acadêmica entre os departamentos de Economia, Administração, Contabilidade e Ciências da Informação e Documentação, tendo em vista que essas áreas apresentam muitos pontos de intercessão.

Trata-se de uma edificação polinuclear, caracterizada pela disposição dos volumes principais em torno de um pátio central. O setor acadêmico, que congrega as salas de professores e os espaços de estudo da pós-graduação, desenvolve-se em dois blocos dispostos paralelamente às curvas de nível, opção que gerou prédios de dois pavimentos (respectivamente junto às cotas 02 e 04), acessíveis por rampas. O setor administrativo foi desenvolvido em um edifício linear de um pavimento, localizado na cota 06 . O setor pedagógico, linear e perpendicular às curvas de nível, funciona como eixo de conexão entre os demais, fechando o pátio central.

Além das salas de aula, o conjunto edificado conta com salas para as direções, reuniões, secretarias, centro de documentação, além de dois auditórios, dez sanitários, três copas, 18 depósitos e espaços para lanchonete, centros acadêmicos, empresas juniores.
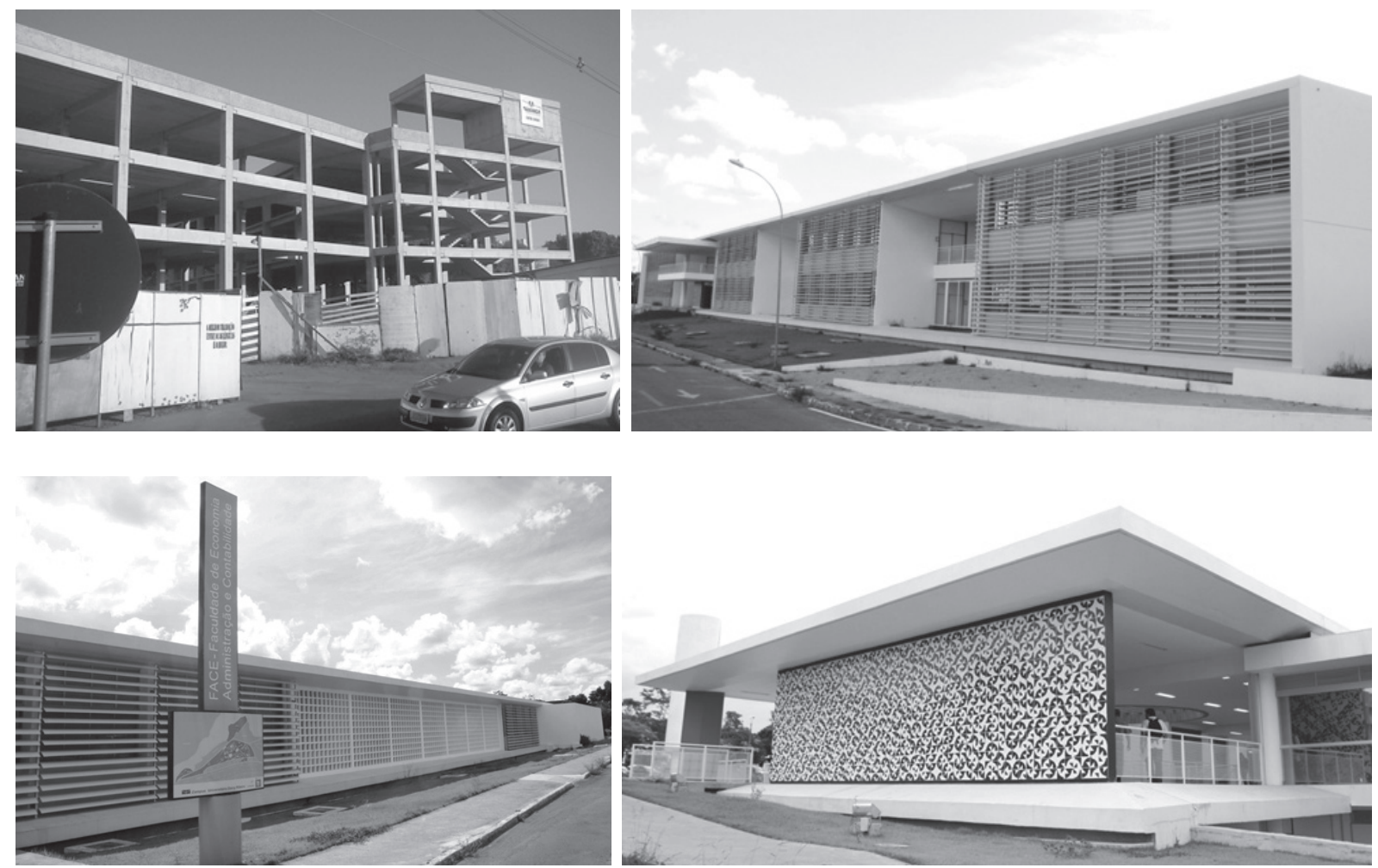
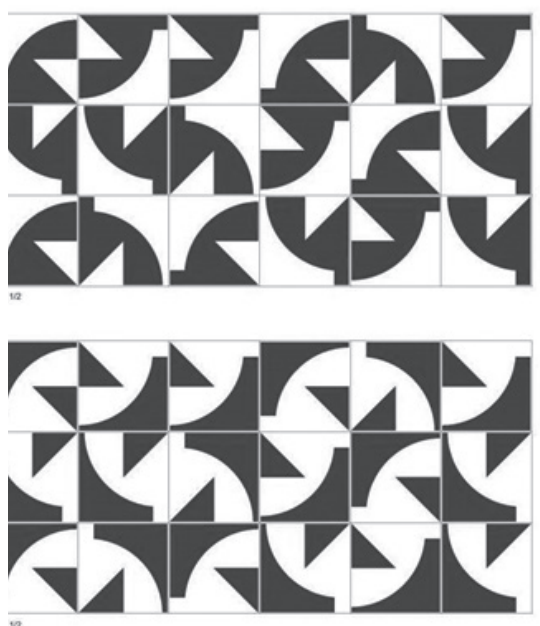

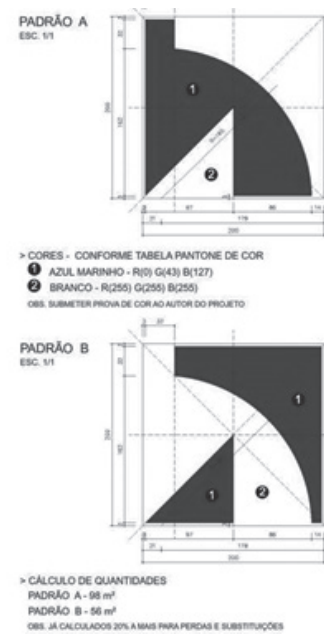

Figura 157b.

Face em construção

Figura 157c.

Vista da Fachada Oeste

Figura 157e.

Vista da fachada Oeste

Figura $157 d$

Painel de azulejos de autoria de

Adalberto Jose Vilela Junior

Figura 157e.

Detalhamento do painel de

azulejos, de autoria de Adalberto Jose Vilela Junior 
CENTRO DE ALTA COMPLEXIDADE EM ONCOLOGIA DO HOSPITAL UNIVERSITÁRIO DE BRASÍLIA (CACON-HUB)

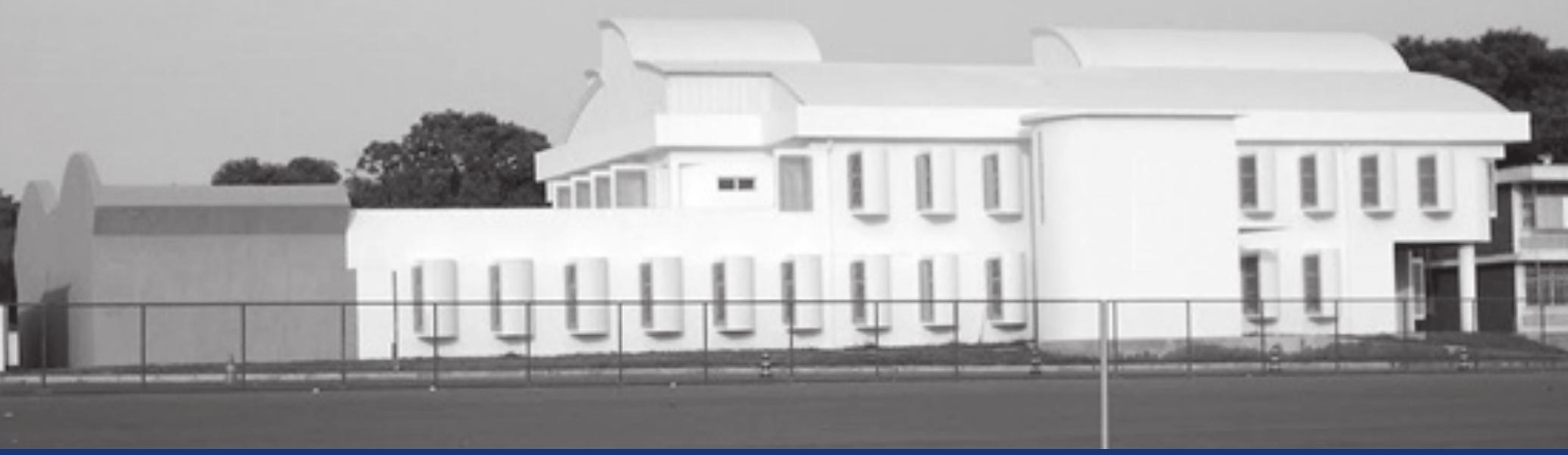

Autoria

Frederico Flósculo Pinheiro Barreto

\section{Data}

2004 (projeto)

2004-2009 (obra)

Área Construída

$1.945 \mathrm{~m}^{2}$ 
O edifício contém, entre outros mecanismos um sistema de ventilação eficiente, que torna desnecessário o uso de ar-condicionado. Ele possibilita que portadores de necessidades especiais tenham acesso fácil e cômodo, inclusive por meio de elevadores para leitos e cadeiras de roda, facilitando a circulação.
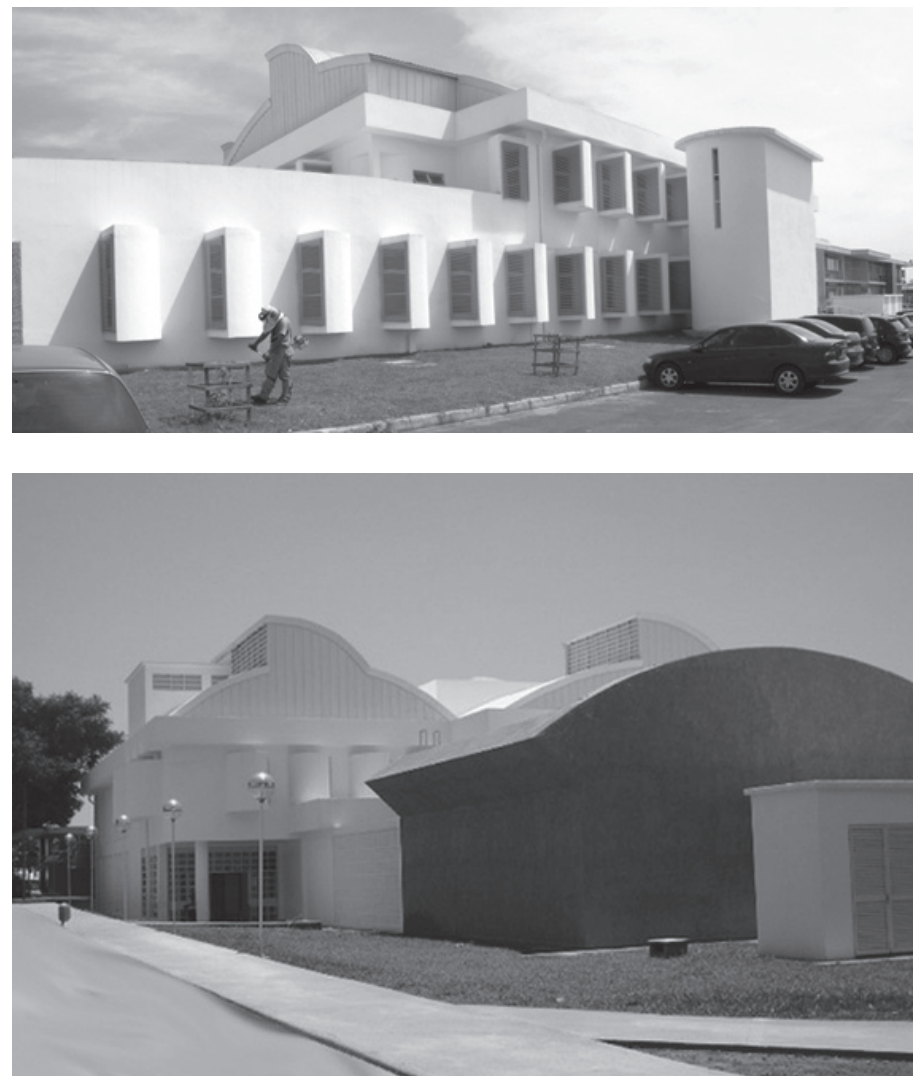

Figura 158b.

Vista da fachada

Leste

Figura 158c. Vista da fachada

Figura 158d.

Vista dos

elementos de

proteção solar e da

torre de circulação

vertical

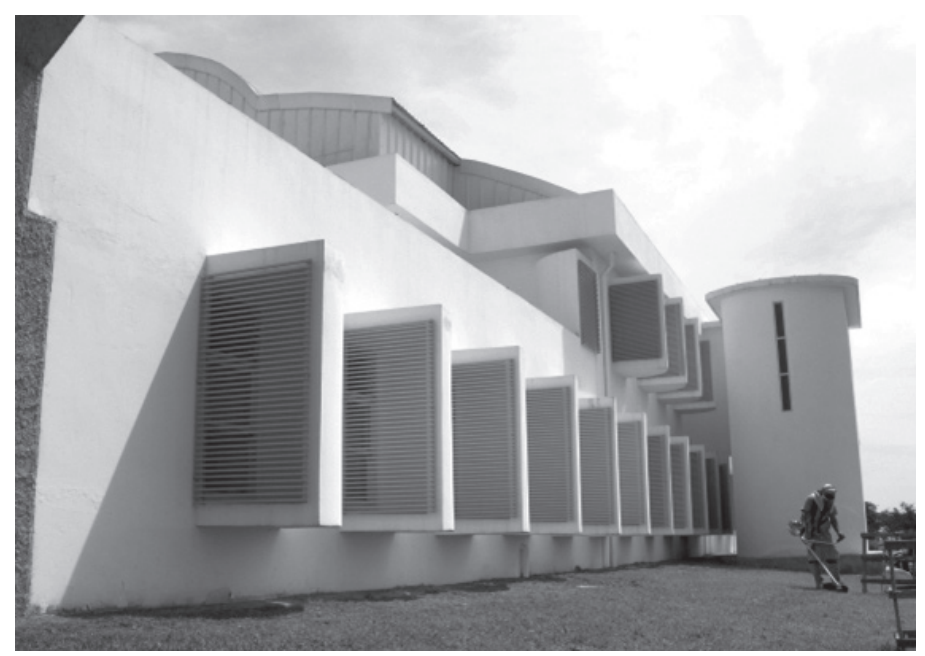




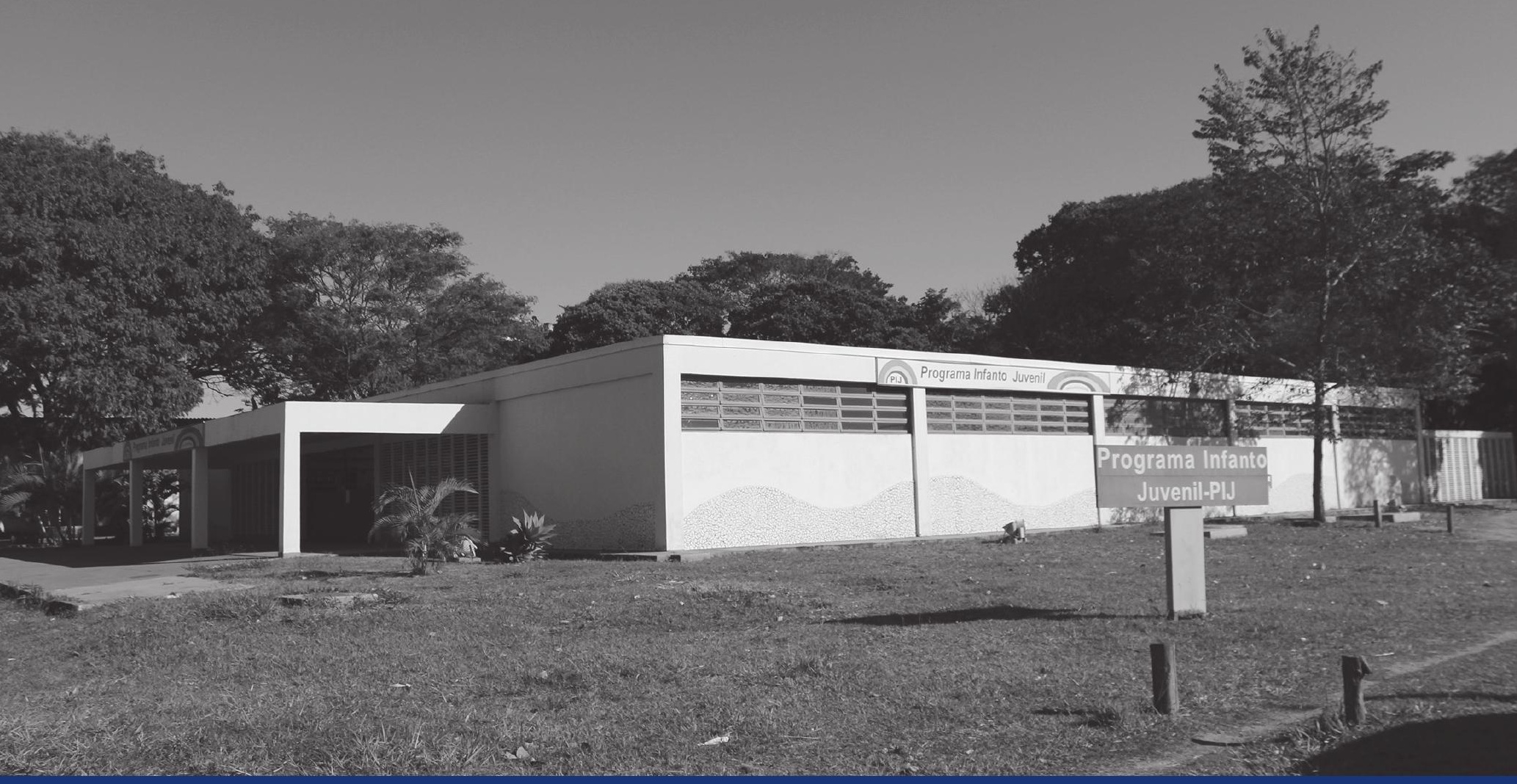

Autoria

Alberto Alves de Faria, Vanessa Bhering

\section{Data}

2006 (projeto)

2008 (obra)

Área Construída

$712 \mathrm{~m}^{2}$
Figura 159a. Vista

das fachadas

Sul e Leste. Foto

Silvio Cavalcante 
Coordenado pela Associação dos Servidores da Fundação Universidade de Brasília (Asfub) desde 1983, o PIJ atende crianças entre 2 e 10 anos, filhos de servidores, professores e alunos. As crianças recebem apoio pedagógico e participam de atividades lúdicas enquanto seus pais trabalham na universidade. O programa já funcionou na sede da segurança da UnB (OCA II) e no Centro Olímpico.

O edifício se desenvolve em torno de um grande pátio central, onde acontecem as atividades de recreação. Em torno desse pátio, dispõem-se as salas pedagógicas, os ambientes administrativos e as instalações sanitárias.

Parte superior do formulário
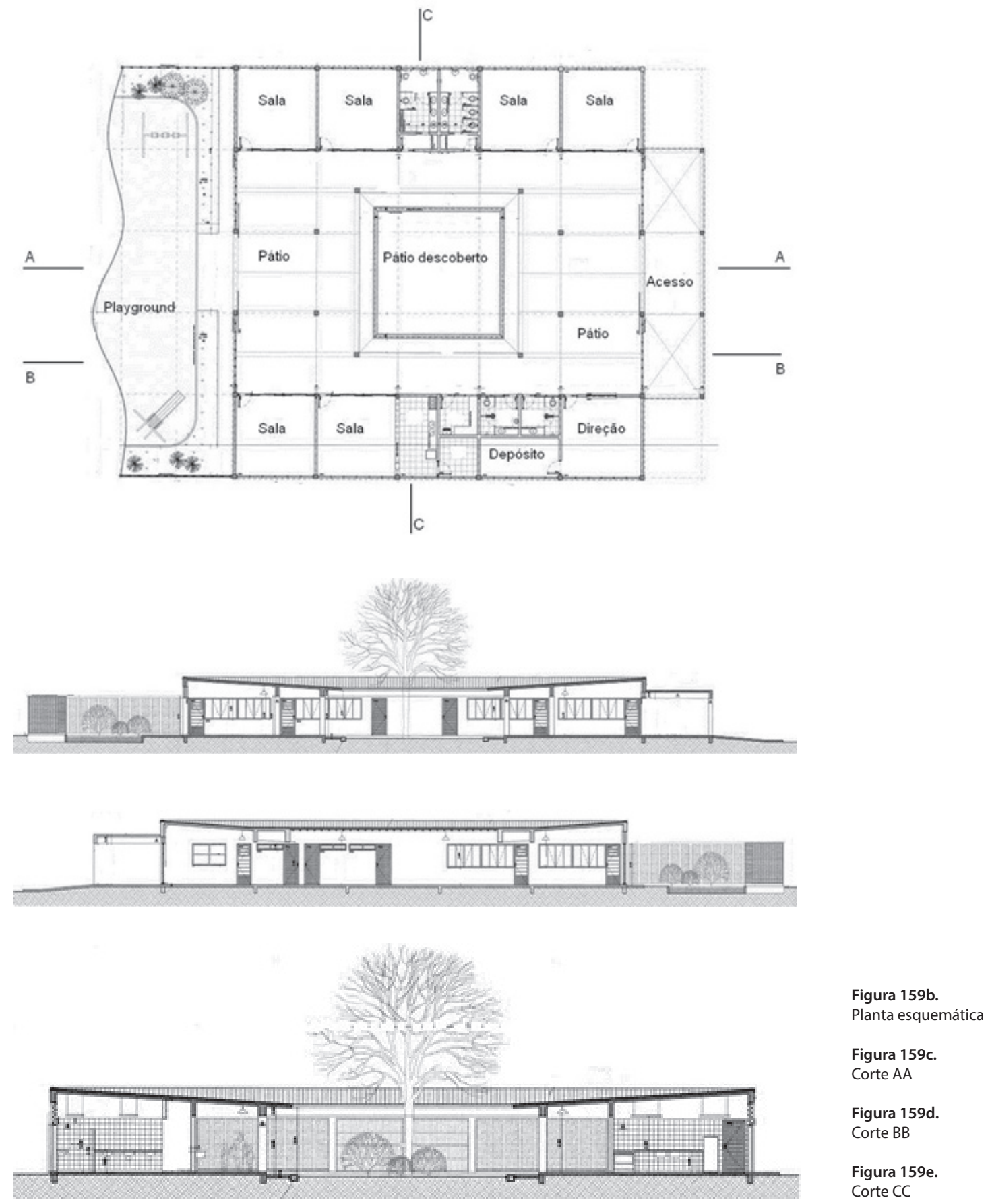

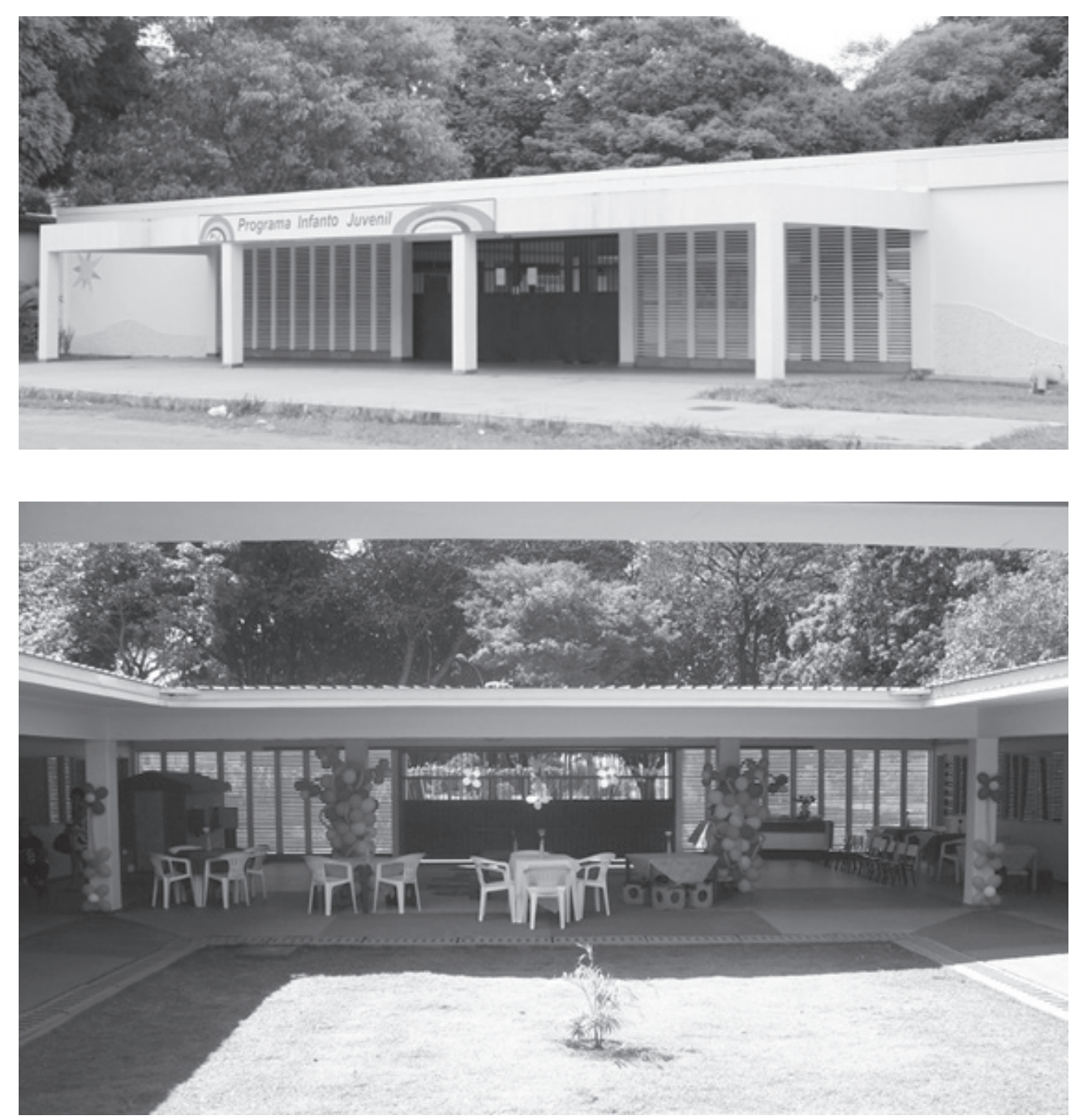

Figura $159 f$.

Vista do acesso

Figura 159g.

Vista do pátio central 
FUNDAÇÃO OSWALDO CRUZ (FIOCRUZ)

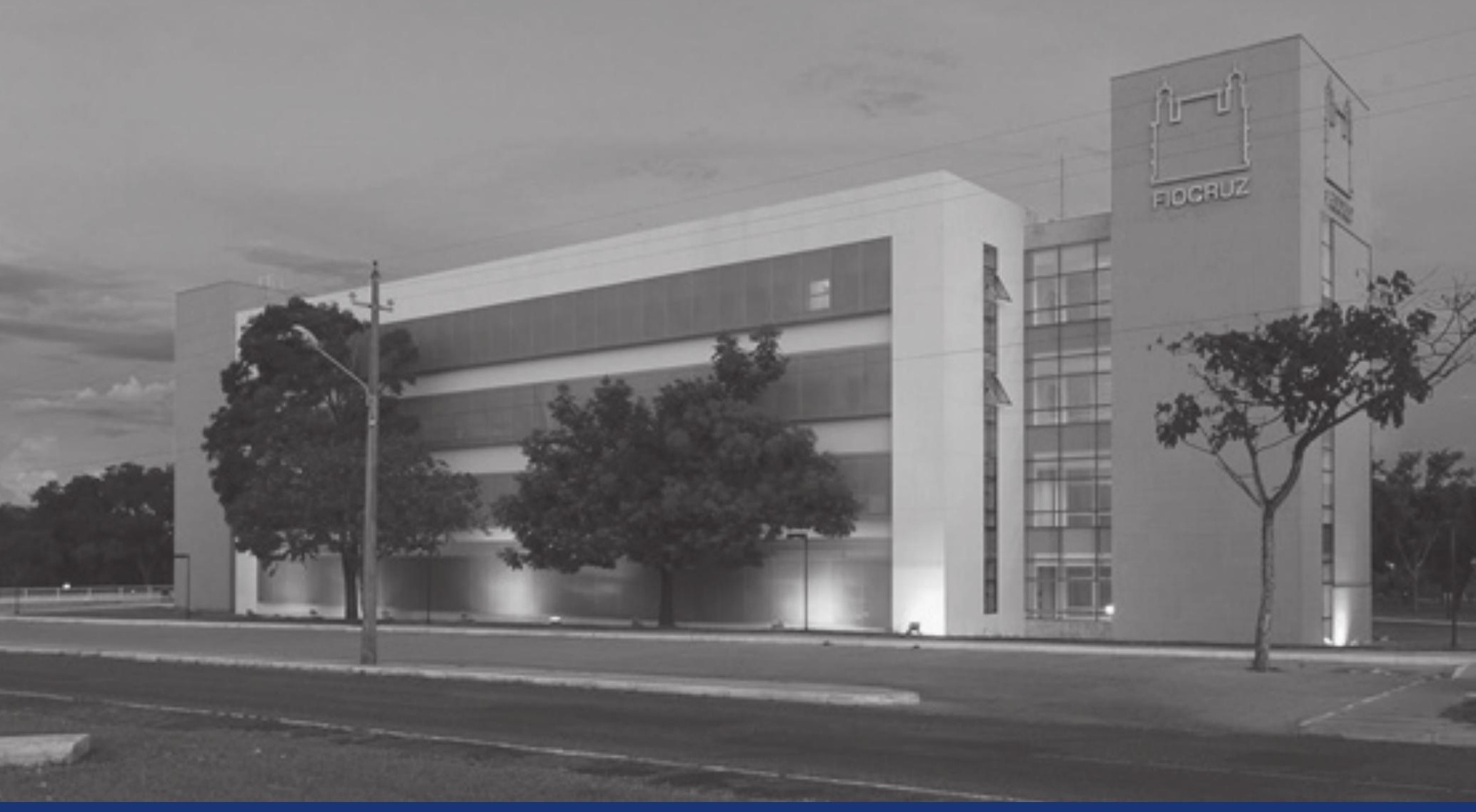

Autoria

Alberto Alves de Faria, Fabiana Couto Garcia, Fátima Lauria Pires

(integrantes do Ceplan/UnB), Beatriz Naomi Onishi, Márcio

administrativo

Magalhães das Neves e Eduardo Koatz (da Fiocruz)

\section{Data}

2007 (projeto)

2010 (obra)

Área Construída

$8.800 \mathrm{~m}^{2}$ 
A edificação consolida o estreitamento da cooperação entre a Fiocruz ${ }^{1}$ e a UnB, cujo objetivo central é a formação de qualidade dos quadros de saúde e a prestação de serviço de melhor qualidade à população.

A inauguração do conjunto deu início às atividades da Escola de Governo em Saúde (EGS). Além da representação institucional, que compete à unidade de Brasília, caberá à escola formar e capacitar os servidores públicos federais da área da saúde e também de áreas correlatas, como planejamento, educação, meio ambiente, entre outras.

O complexo é formado por quatro blocos localizados em torno de uma praça e interligados por caminhos e passarelas cobertas. O primeiro, de quatro andares, é destinado às atividades administrativas; o segundo, com dois pavimentos mais a garagem, correspondente à Escola de Governo em Saúde (EGS), abriga as salas de aula, os laboratórios e a biblioteca; o terceiro constitui um espaço para exposições, editora e um café; o quarto é um auditório com capacidade para 110 pessoas.

A implantação do conjunto levou em conta a preservação de um maciço das árvores nativas do Cerrado existentes no local e os caminhos e as calçadas trilhados pelos pedestres.

O bloco que abriga a escola tem uma fachada transparente voltada para o Lago Paranoá e a fachada do auditório exibe um painel de azulejos concebido por Athos Bulcão².

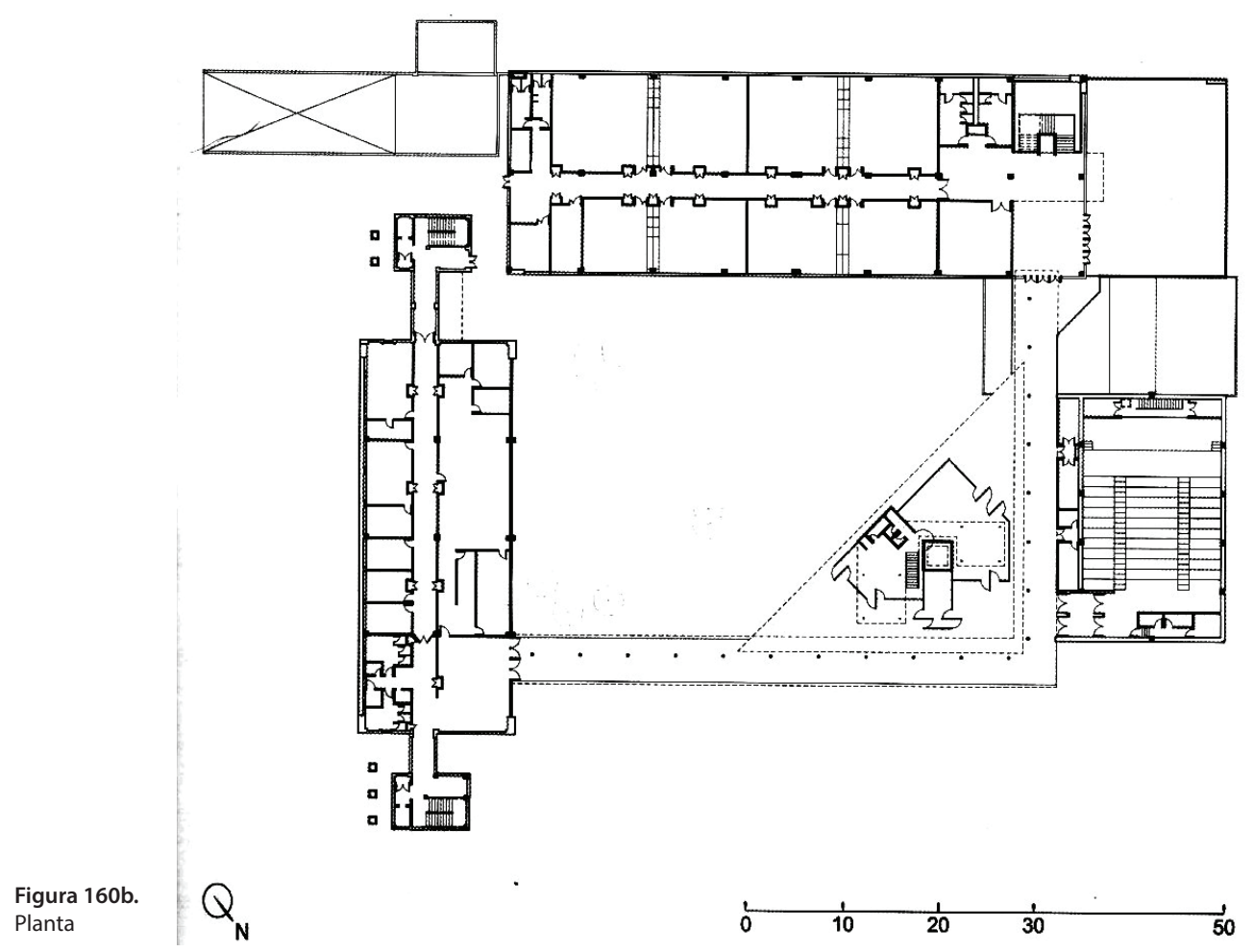

$\overline{{ }^{1} O}$ projeto foi vencedor na categoria institucional de obras construídas da XIII Premiação de Arquitetura IAB/MG. 

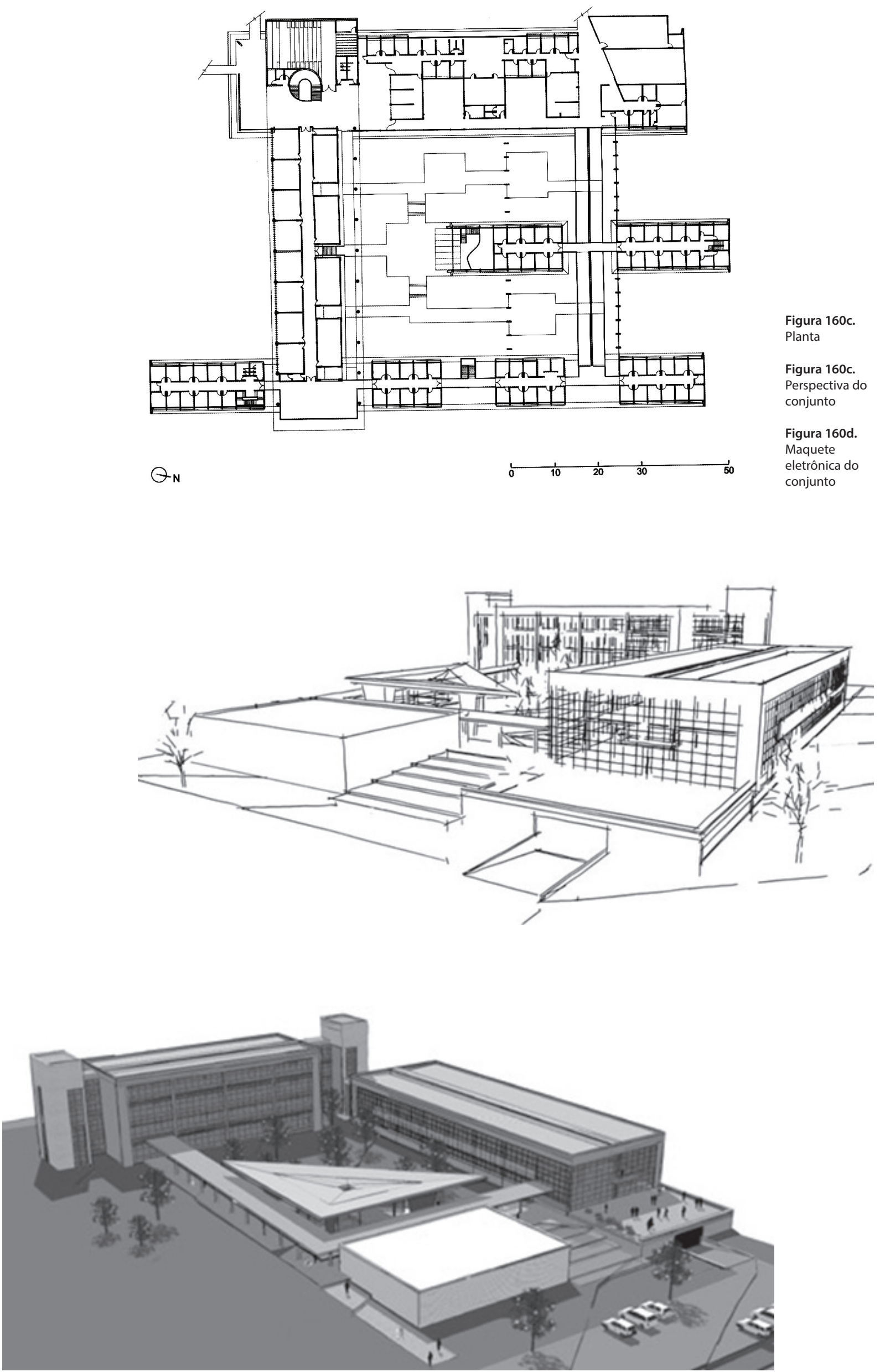
Figuras 160 e e $160 f$ Vistas do bloco de exposições

Figura 160g.

Vista das passarelas

Figura $160 \mathrm{~h}$.

Vista da passarela,

com o bloco da escola ao fundo
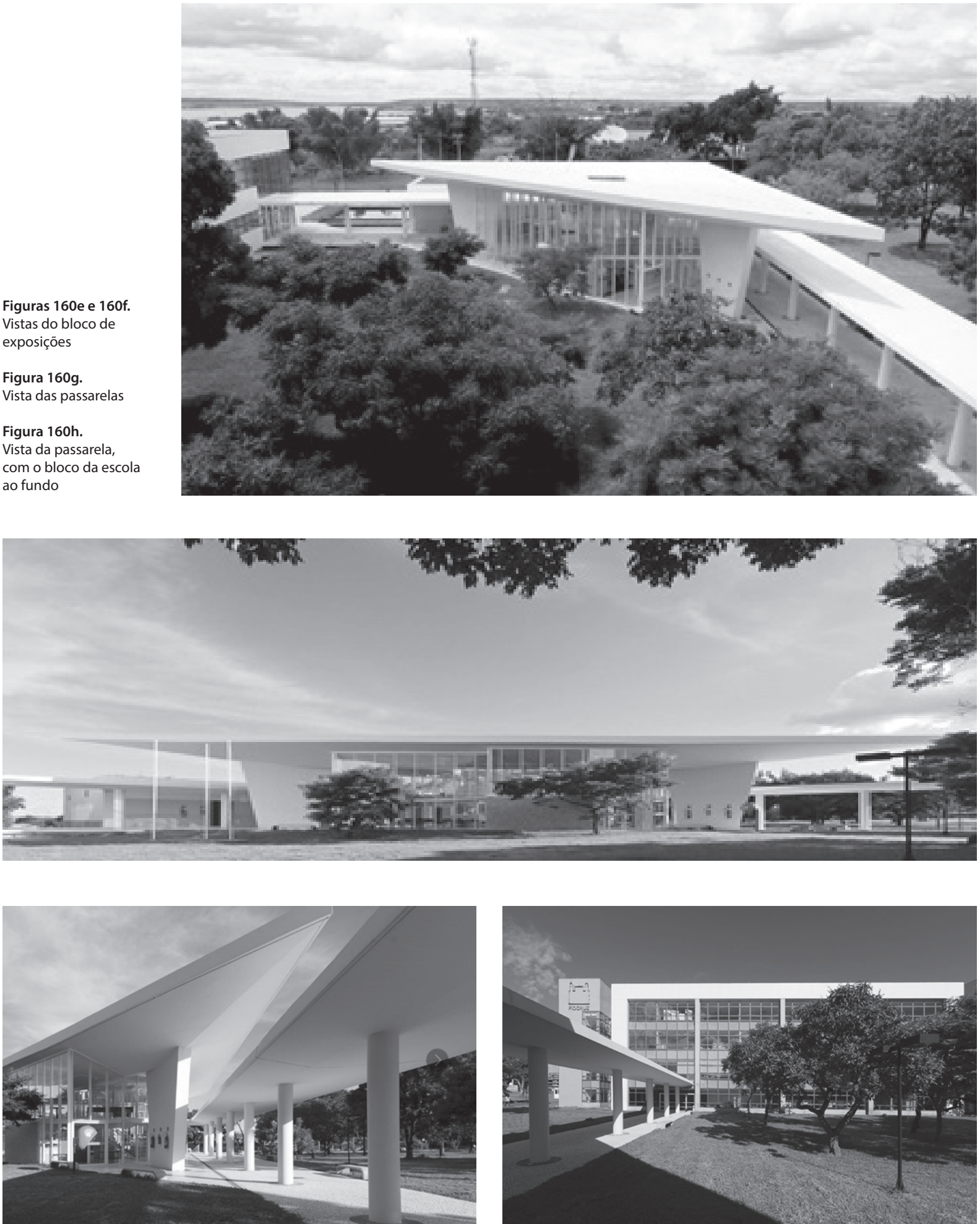

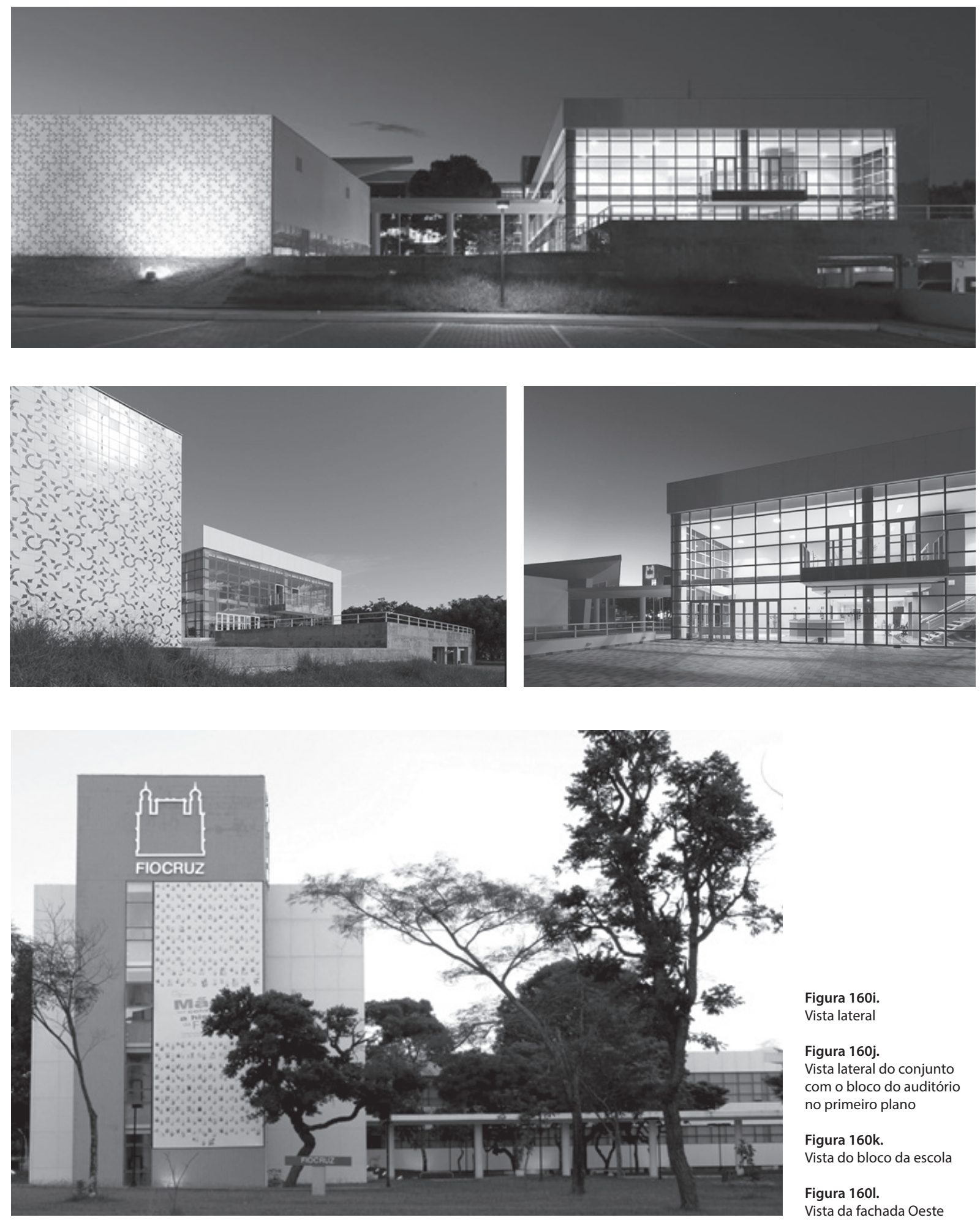

Figura 160i. Vista lateral

Figura 160 j.

Vista lateral do conjunto com o bloco do auditório no primeiro plano

Figura $160 k$

Vista do bloco da escola

Figura 1601 .

Vista da fachada Oeste 
CENTRO DE MANUTENÇÃO DE EQUIPAMENTOS CIENTÍFICOS (CME)

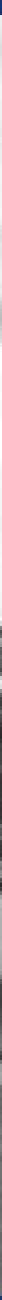

Autoria

Fabiana Couto Garcia, Alberto Alves de Faria e Fátima Lauria Pires.

Data

2007 (projeto)

2008 (obra)

Área Construída

$1.842 \mathrm{~m}^{2}$
Figura 161a. Vista

das fachadas

Leste e Sul. 
O CME foi criado em 1986 para promover a manutenção e o reparo nas máquinas utilizadas na universidade. A proposta é introduzir novos conceitos, metodologias e técnicas que reduzam as paradas de funcionamento desses equipamentos, visando a diminuir custos e a viabilizar as atividades de ensino e de pesquisa.

A edificação é composta por dois pavimentos com uso diferenciado: um social e outro de serviço. $E$ dois acessos: o primeiro destinado ao público externo e aos funcionários administrativos; o segundo para os funcionários que trabalham nas oficinas e nas atividades de carga e descarga.

No pavimento térreo estão as áreas de apoio e logística, os depósitos e vestiários, o almoxarifado e as seções de trabalho. As seções de trabalho, que possuem pé-direito duplo, dividem-se em: eletromecânica, eletrotécnica, microinformática, mecânica geral, refrigeração e eletrônica analógica. As demais -ótica, limpeza de equipamentos, serralheria e fundição - têm pé-direito de 3,60 m. No pavimento superior estão o refeitório, com capacidade para 90 pessoas, e a cozinha.
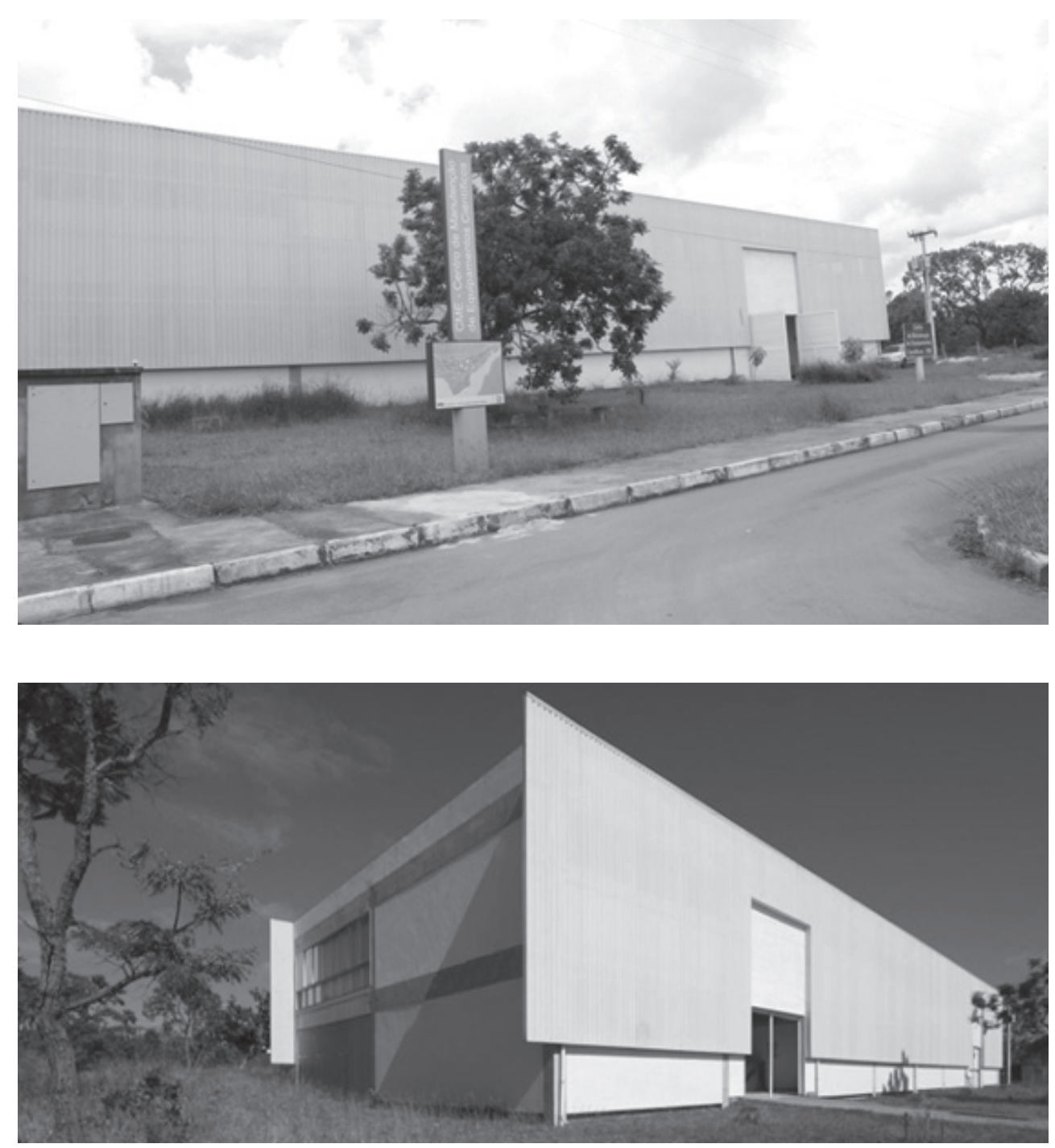

Figura 161b.

Vista da fachada

principal.

Figura 161c.

Vista das fachadas Leste e Sul 
BLOCO DE SALAS DE AULA NORTE EUDORO DE SOUSA (BAES)

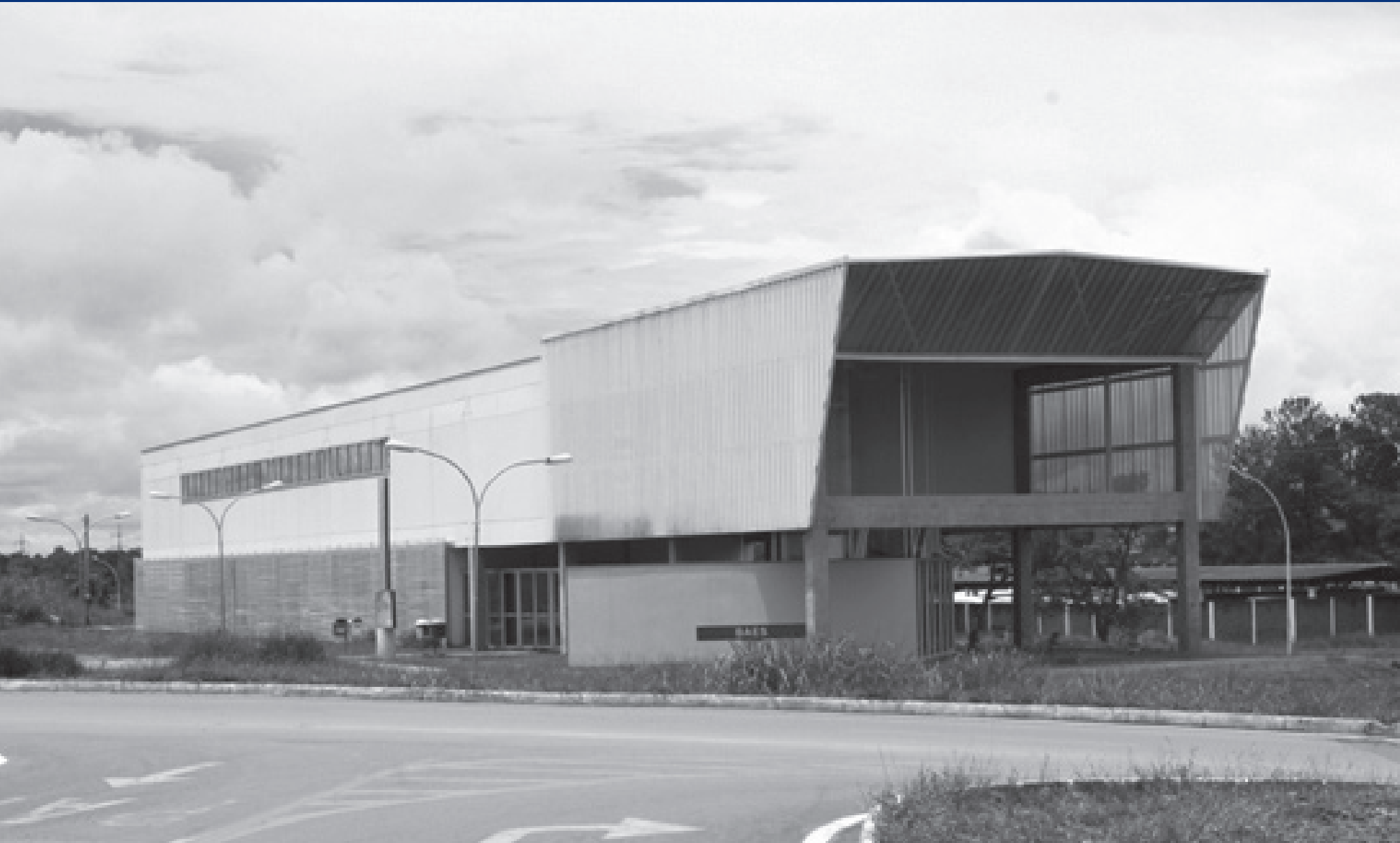

Autoria

Alberto Alves de Faria, Fabiana Couto Garcia, Fátima Lauria Pires e Paulo Silva Junior

Figura 162a.

Vista das

fachadas Oeste

e Sul. Foto:

Walter de

Carvalho

\section{Data}

2009 (projeto)

2011 (obra)

\section{Área Construída}

$1.265 \mathrm{~m}^{2}$ 
O edifício ${ }^{1}$, projetado a partir de componentes estruturais pré-fabricados de concreto, é composto de ambientes de estudo e de um grande hall de acesso, setorização evidenciada pelo tratamento diferenciado das fachadas.

A cobertura e os fechamentos laterais são em telha perfurada. A ligação entre os pavimentos inferior e superior é feita por uma escada principal contígua a uma plataforma para PNE e por outro acesso central, onde estão localizados também os sanitários.

A edificação é composta por dois pavimentos. No térreo, estão: secretaria e salas de aula para 36, 45 e 63 alunos. No pavimento superior localizam-se sala de estudo, de informática, e salas de aula para 12,18 e 63 alunos.

As maiores fachadas estão voltadas para Nordeste e Sudoeste, sendo que a Sudoeste tem vista para o lago Paranoá. O acesso principal se dá pela face Sudoeste, que possui poucas aberturas.
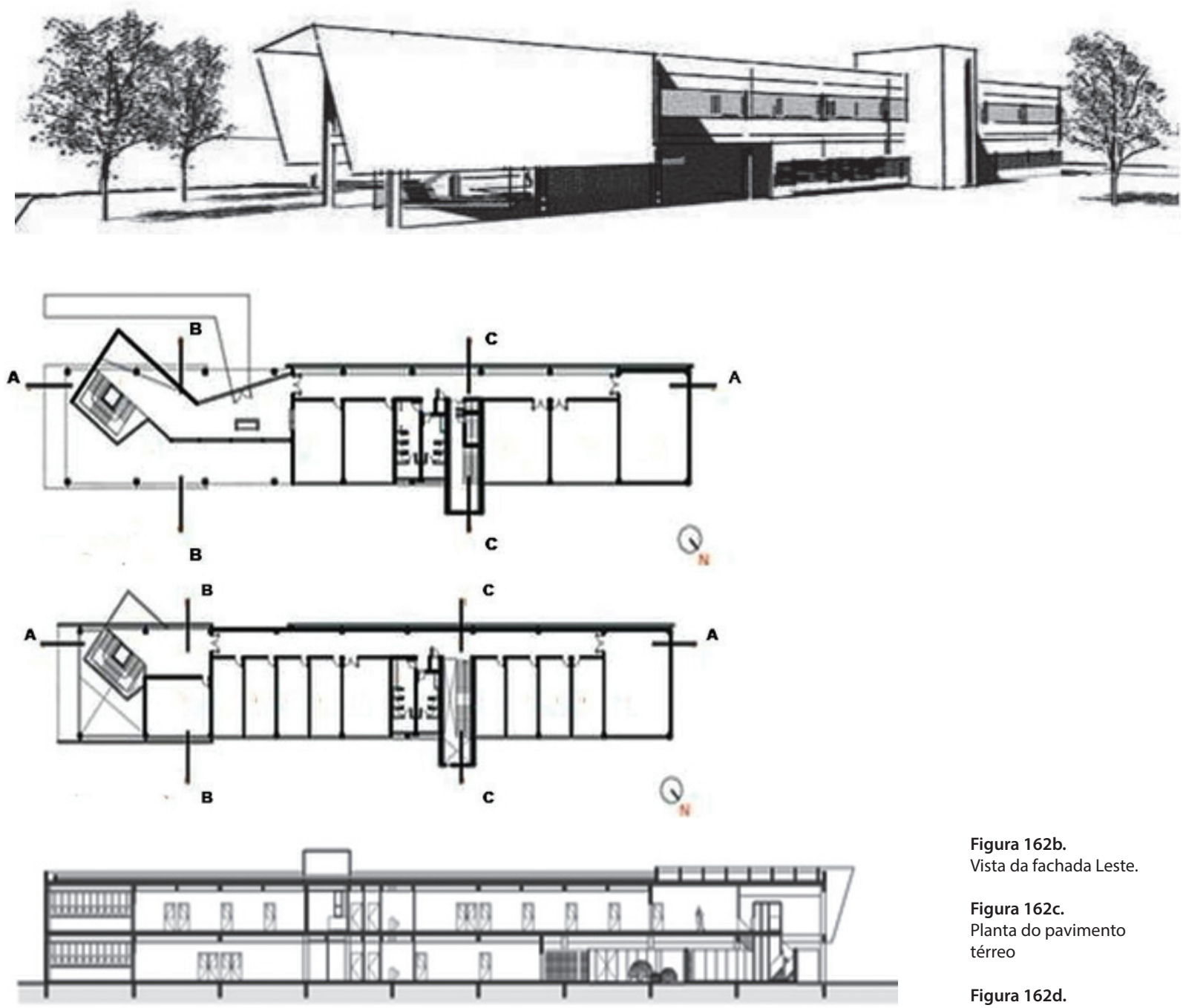

Figura 162b.

Vista da fachada Leste.

Figura 162c.

Planta do pavimento

térreo

Figura 162d.

Planta do primeiro

pavimento
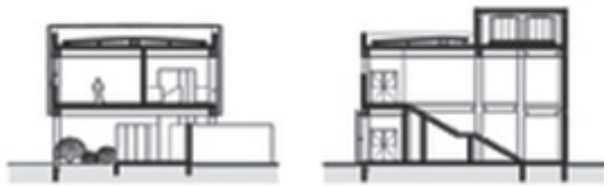

Figura 162e.

Corte AA

Figuras $162 \mathrm{f}$ e $162 \mathrm{~g}$. Cortes BB e CC

${ }^{1}$ Nome dado em homenagem a Eudoro de Sousa, filósofo luso-brasileiro e um dos fundadores, em 1962, do Instituto de Letras da UnB. 

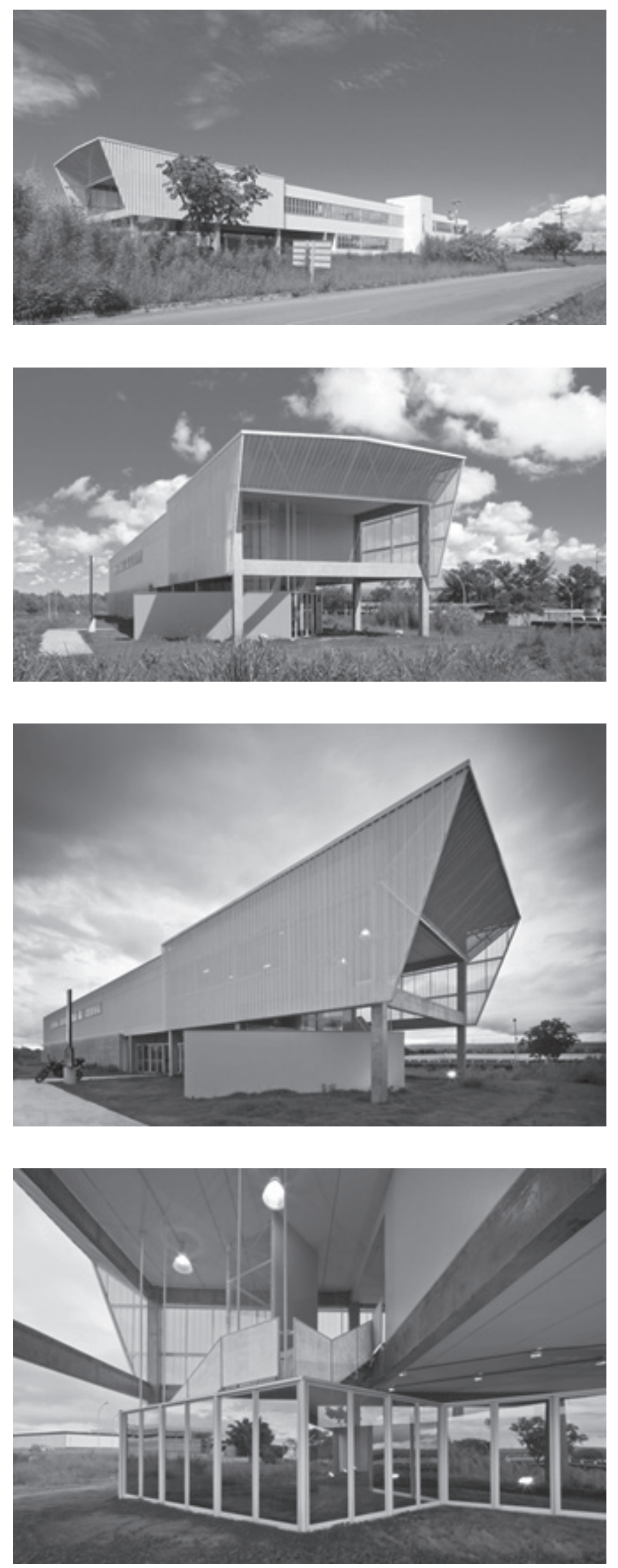

Figuras $162 \mathrm{~h}, 162 \mathrm{i}$

$162 \mathrm{j}, 162 \mathrm{k}$.

Vistas gerais. Fotos: 


\section{BLOCO DE SALAS DE AULA SUL LUIZ FERNANDO GOUVÊA LABOURIAU}

$(\text { BSA SUL) })^{1}$

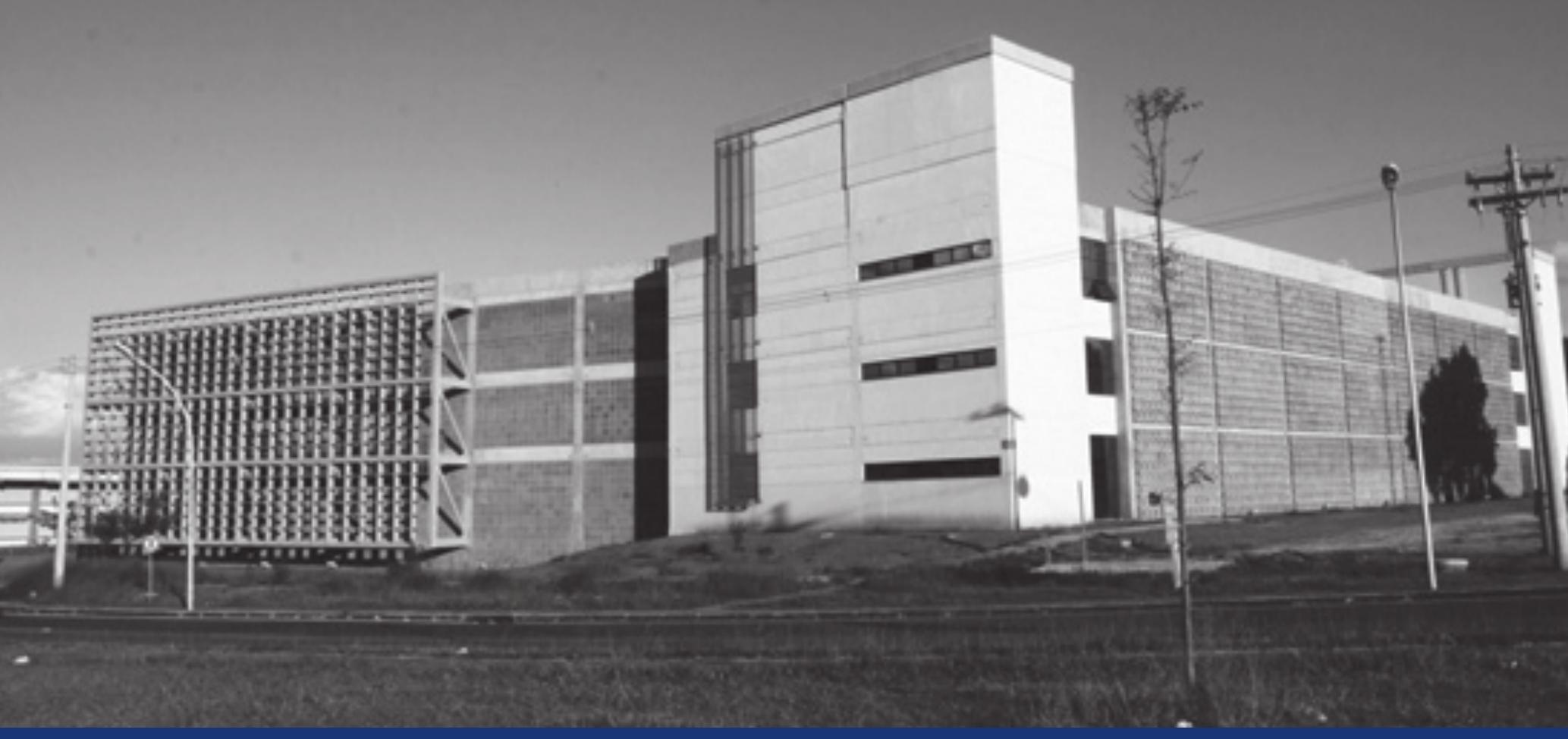

Autoria

Alberto Alves de Faria, Nelton Keti Borges, Cristine Autran, Vanessa Behring e Alexandre Rocha.

\section{Figura 163a.}

Vista das

fachadas Oeste

e Norte

\section{Data}

2009 (obra)

Área Construída

$7.418 \mathrm{~m}^{2}$ 

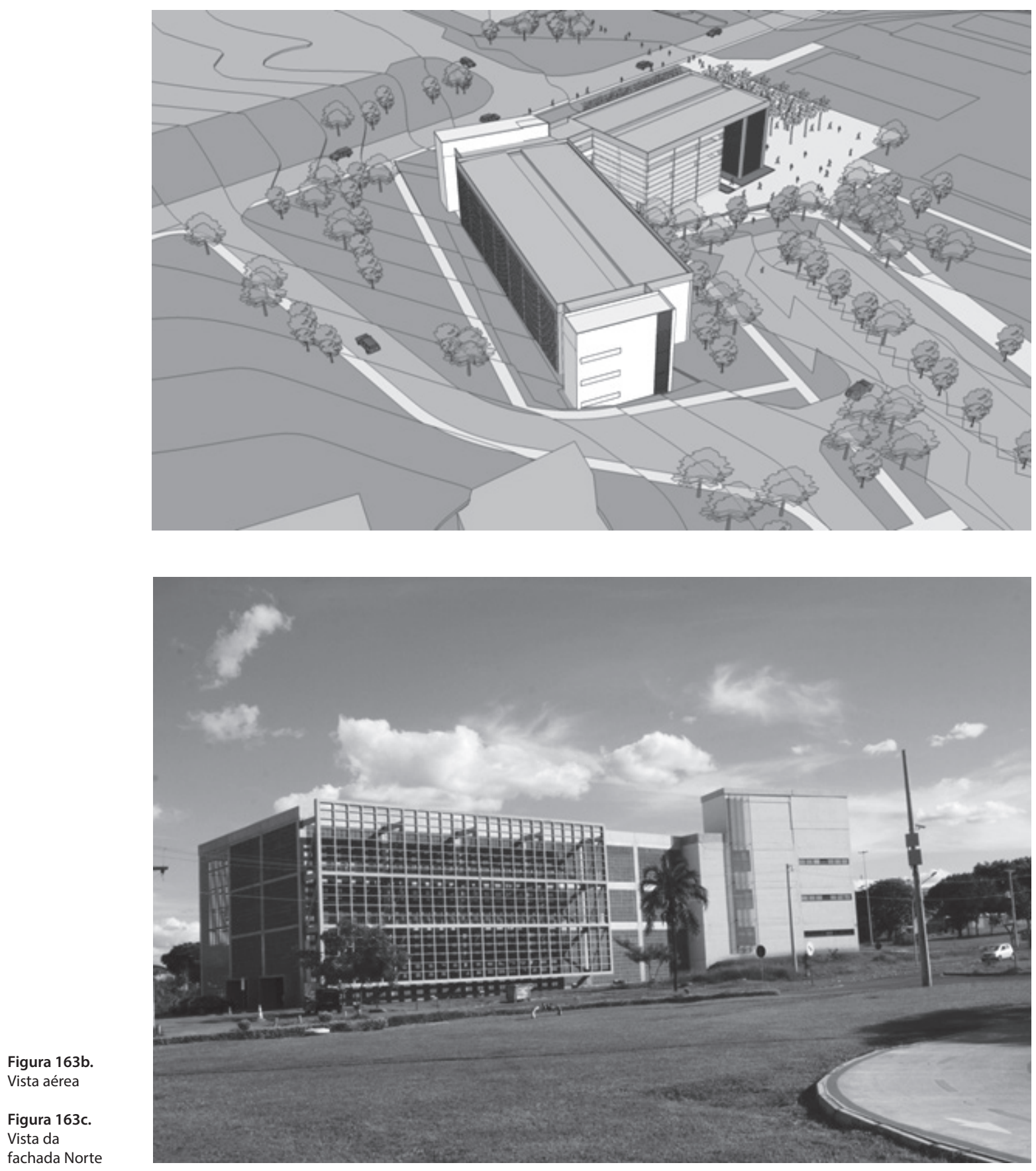


\section{MÓDULO DE ATIVIDADES E SERVIÇOS COMUNITÁRIOS (MASC)}

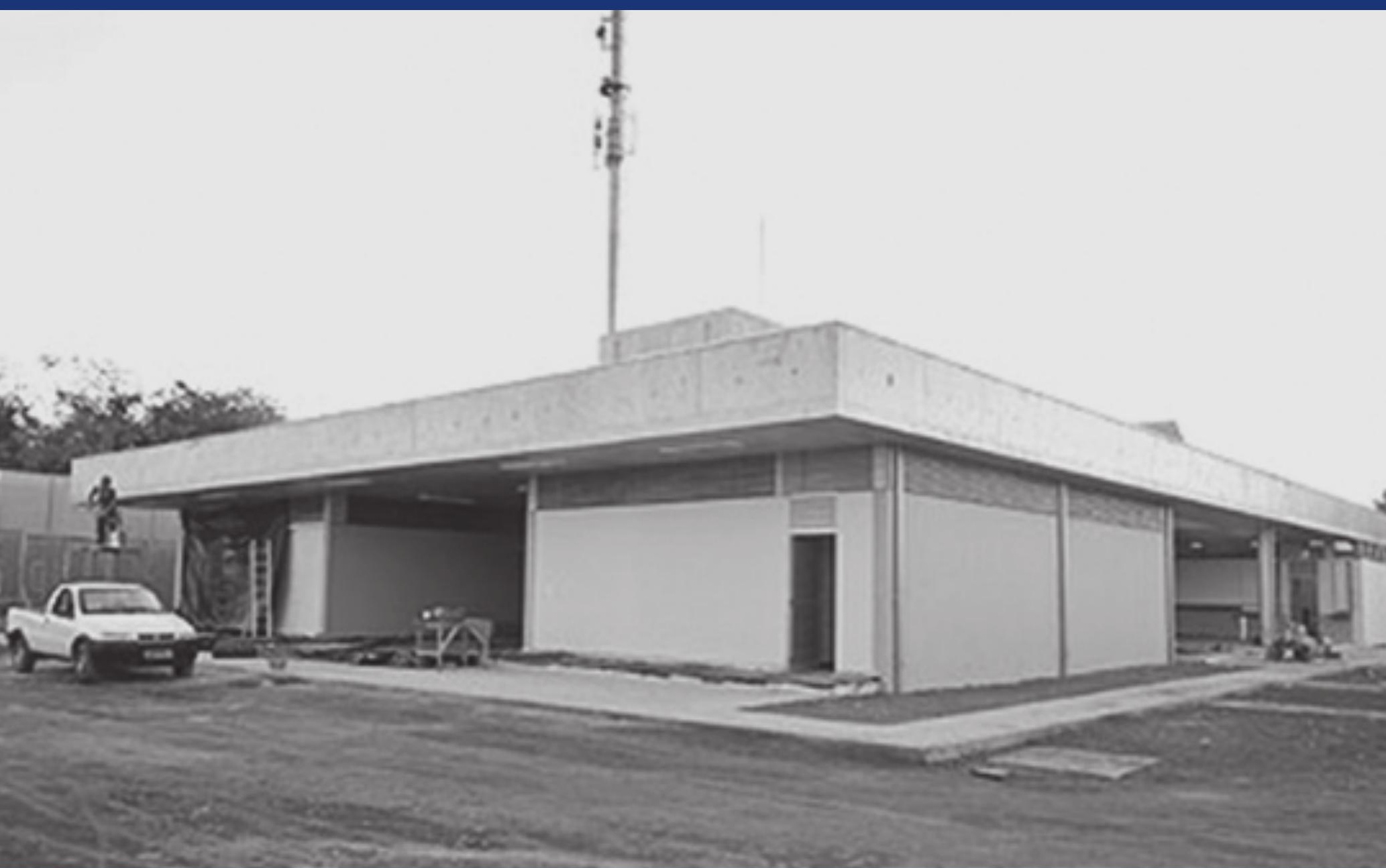

Autoria

Alberto Alves de Faria, Fabiana Couto Garcia, Fátima Lauria Pires

Data

2009(projeto)

2011 (obra)

Área Construída

$967 \mathrm{~m}^{2}$ 
O Módulo de Atividades e Serviços Comunitários foi desenvolvido para atender a demanda de espaços para comércio, alimentação e convívio nos Campus Darcy Ribeiro, Ceilândia, Gama e Planaltina da Fundação Universidade de Brasília. O projeto foi padronizado para racionalizar a construção e reduzir o prazo de execução.

O edifício foi desenvolvido em pavimento térreo para garantir a mobilidade dos usuários. O espaço coberto abriga três volumes dispostos alternadamente, onde estão localizadas as funções distintas.: o primeiro concentra os espaços multiuso; o segundo abriga os vestiários; e o terceiro, maior, é destinado à alimentação.

No espaço remanescente fica localizada a área de estar e convívio para instalação de mesas e bancos. O partido arquitetônico adotado buscou separar as diferentes funções do edifício conformando uma praça interna coberta como espaço de permanência.
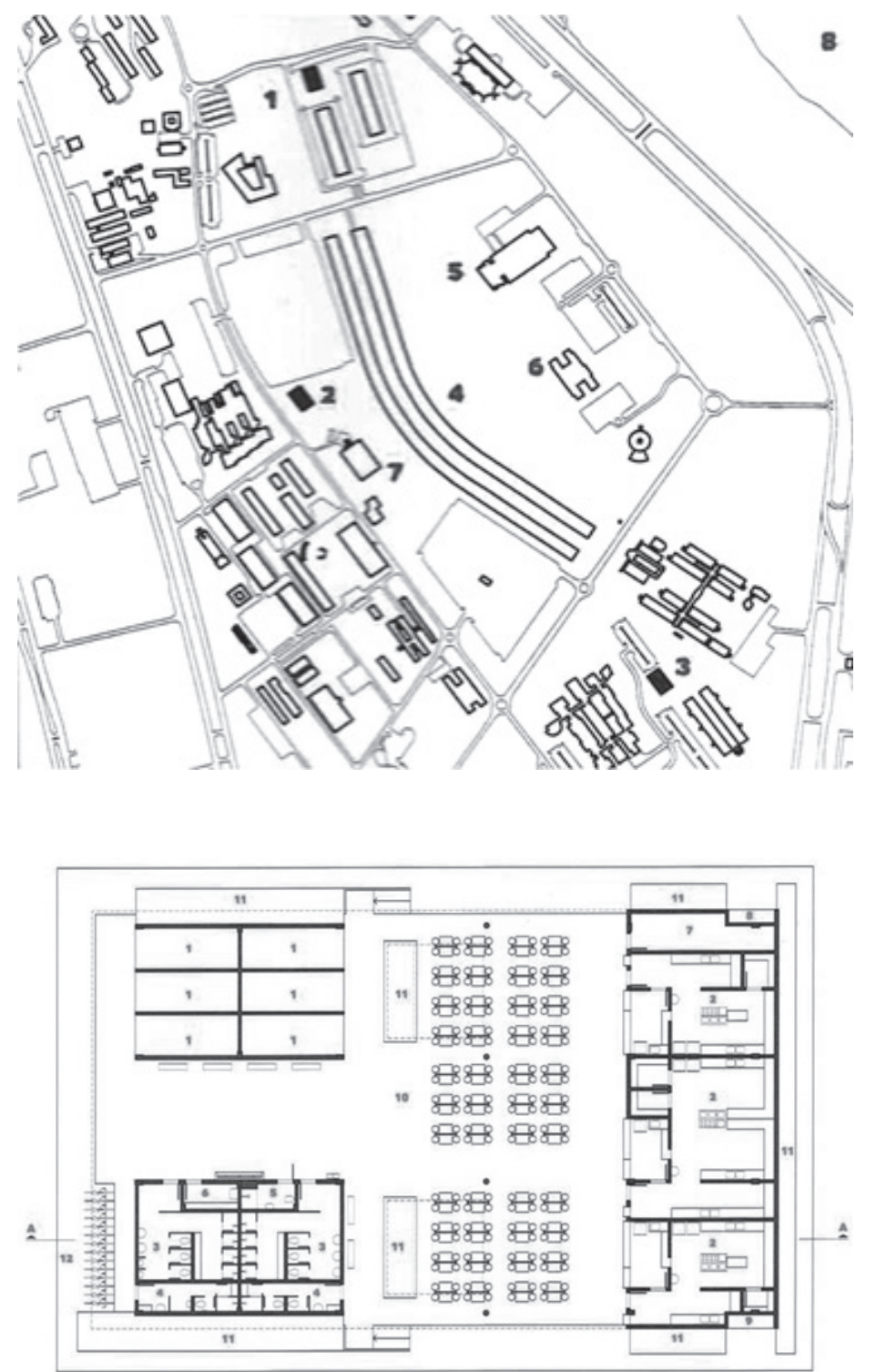

Figura 164b.

Implantação

1. Módulo Norte

2. Módulo Centro

3. Módulo Sul

4. ICC

5. Biblioteca

6. Reitoria

7. Restaurante

8. Lago Paranoá

Figura 164c.

Planta 

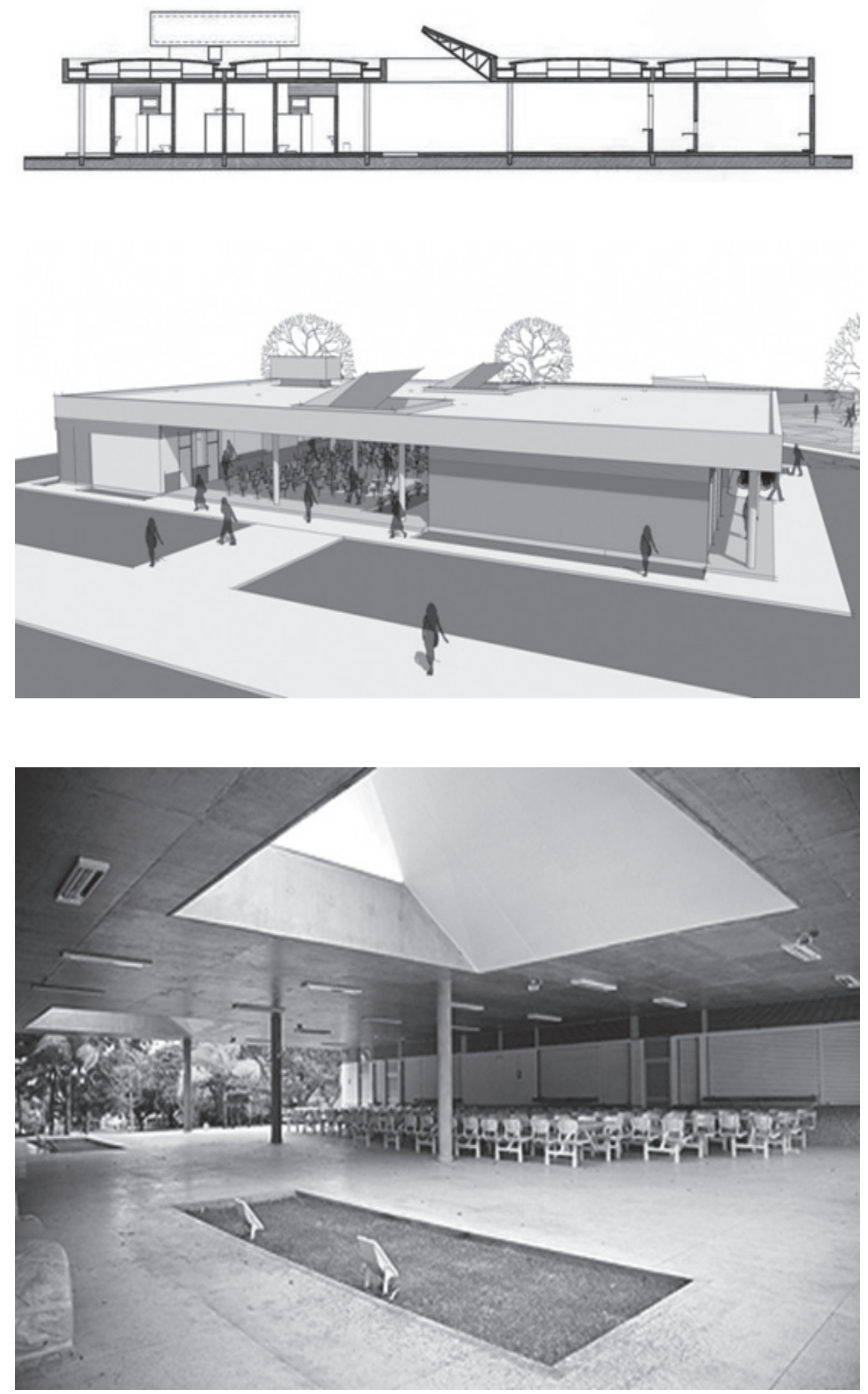

Figura 164d.

Corte AA

Figura 164e.

Vista da fachada

Leste do Módulo

Central

Figura $164 f$.

Vista do pátio central 
CENTRO DE INFORMÁTICA (CPD)

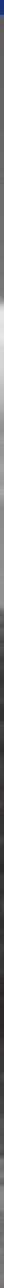

Autoria

Fabiana Couto Garcia e Alberto Alves de Faria

\section{Data}

2005 (projeto) 2012

(conclusão da obra)

Área Construída

$2.057 \mathrm{~m}^{2}$
Figura 165a.

Vista da fachada

Oeste 
O Centro de Informática foi criado em 1991, com a sigla Cl, para suceder ao então Centro de Processamento de Dados (CPD), órgão complementar criado na época da instalação da Universidade de Brasília com o intuito de desenvolver as atividades de caráter permanente de apoio, necessárias ao desenvolvimento do ensino, da pesquisa e da extensão no que se refere ao processamento de dados. Em 1993, o Centro de Informática (CIn) retomou o uso da sigla CPD.

O edifício foi dividido em quatro áreas articuladas pelo hall central, onde se concentram os sanitários e a circulação vertical com plataforma para deslocamento de portadores de necessidades especiais. A cantina localizada no pavimento superior promove a integração dos funcionários. A especificidade da edificação é uma sala-cofre que preserva os equipamentos e dados da universidade.

O telhado do hall possui grelha em concreto aparente com cobertura de vidro. Um brise de madeira permite a ventilação cruzada, evitando o aquecimento do ambiente. A escada social é atirantada nessa grelha, e abaixo dela um jardim de interno compõe a ambientação. A composição da fachada reflete as funções internas. A fachada Sul, com grande área envidraçada, abriga as estações de trabalho; na fachada Norte, totalmente cega, estão localizados os equipamentos e salas que não necessitam de abertura para a entrada de luz natural.
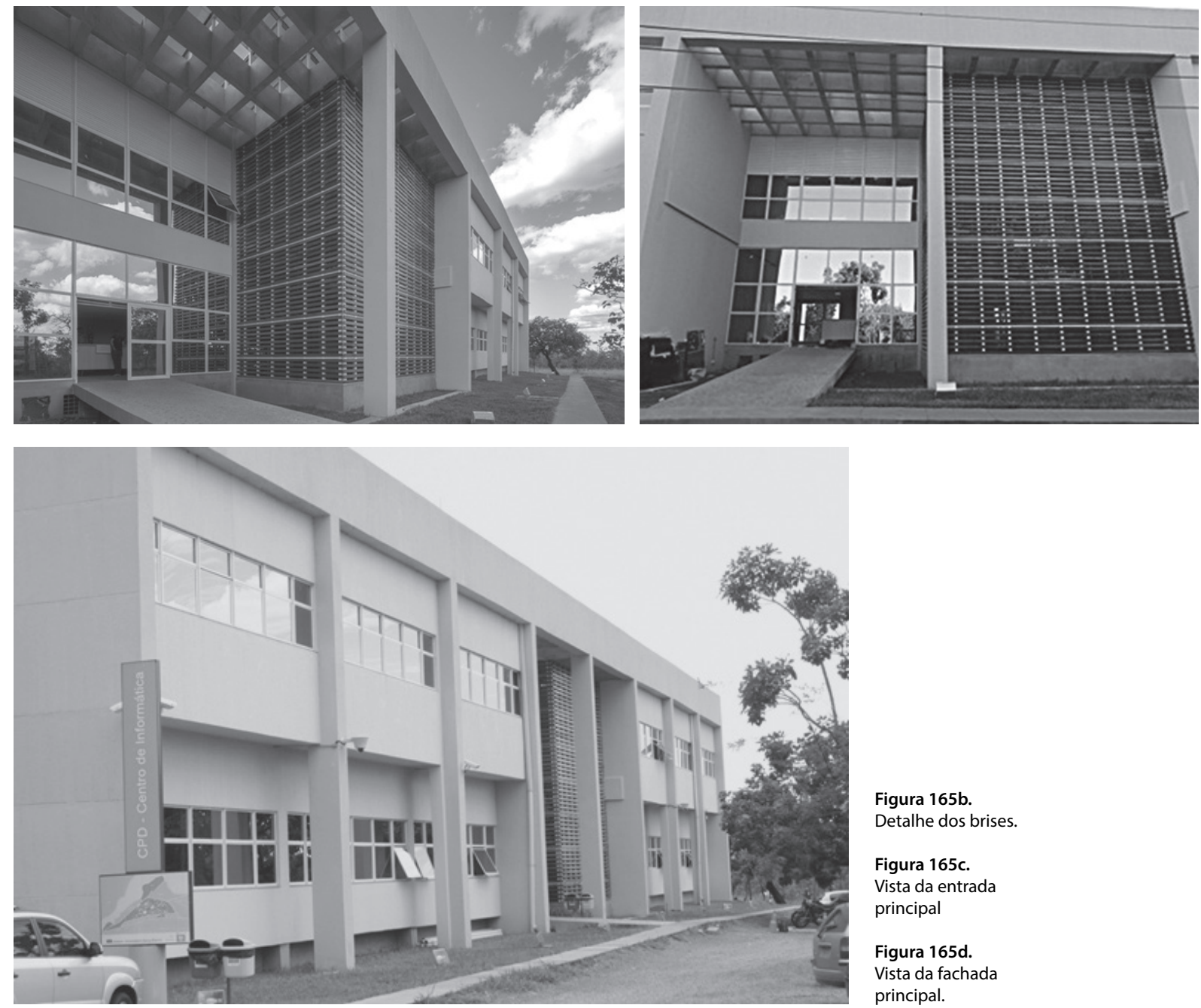

Figura 165b.

Detalhe dos brises.

Figura 165c.

Vista da entrada

principal

Figura 165d.

Vista da fachada

principal. 


\section{INSTITUTO DE CIÊNCIAS EXATAS (IE) - DEPARTAMENTOS DE CIÊNCIA DA COMPUTAÇÃO E ESTATÍSTICA (CIC/EST)}

\section{Autoria}

Alberto Alves de Faria, Fabiana Couto Garcia, Fátima Lauria Pires

Data

2010-2012 (conclusão da obra)

Área Construída

$4.485 \mathrm{~m}^{2}$
Figura 166a.

Vista das

fachadas 
O prédio abriga as secretarias de Graduação e Pós-Graduação, salas de professores, salas de estudos e projetos, centros acadêmicos, laboratórios, espaço multimídia e auditório.
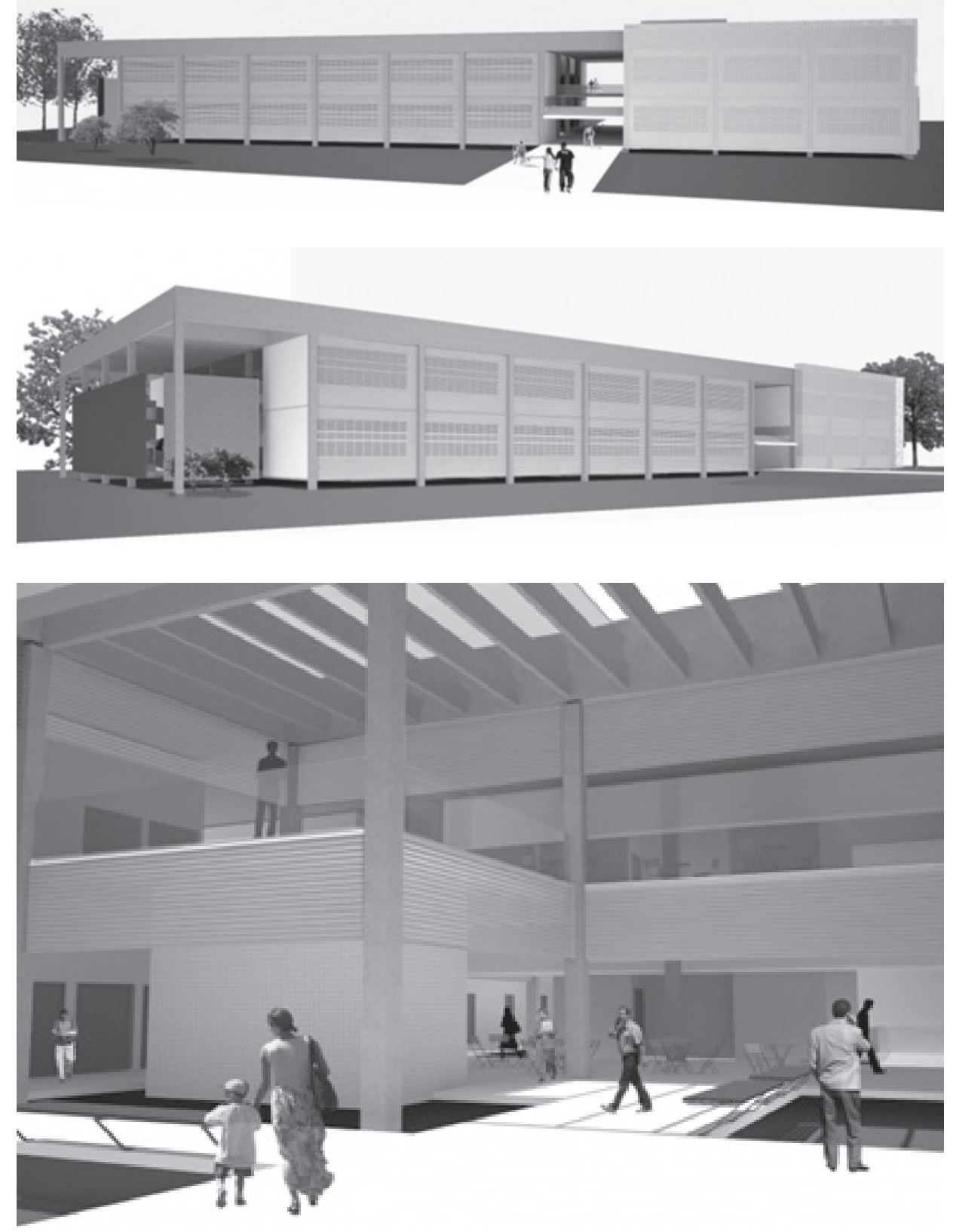

Figura $166 \mathrm{~b}$ e $166 c$

Vistas gerais.

Figura 166d.

Vista do pátio

interno.

Figuras 166e, $166 f$

Registro da

construção.
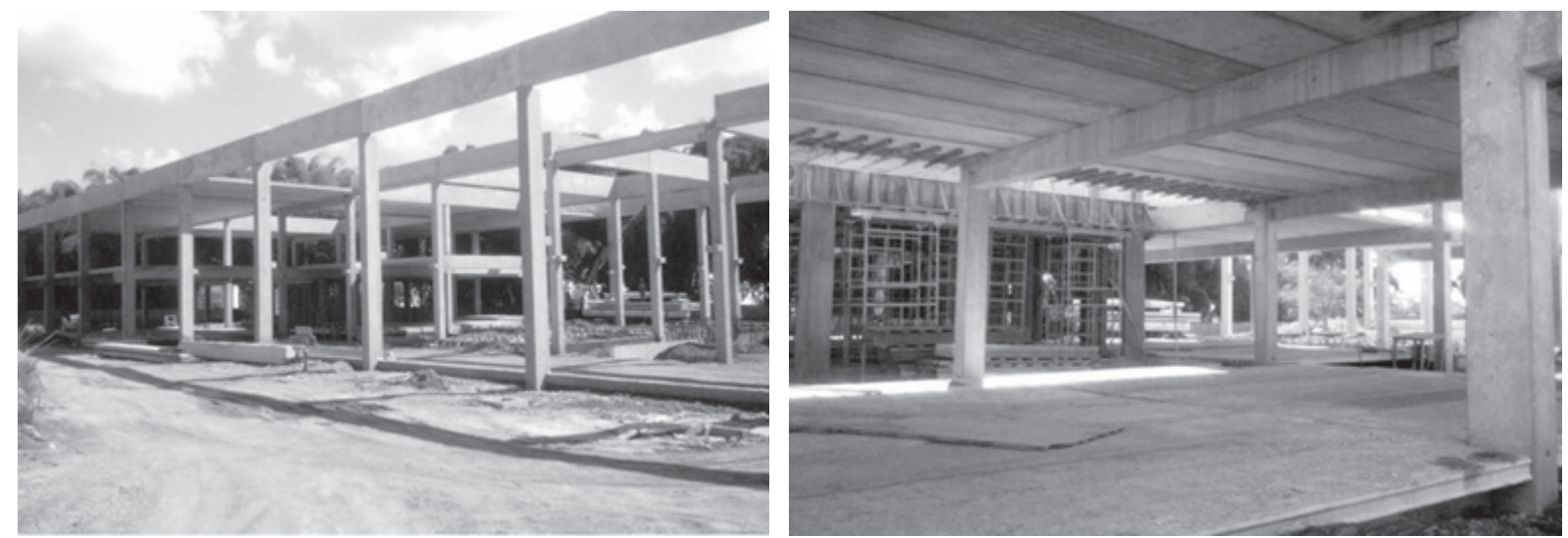

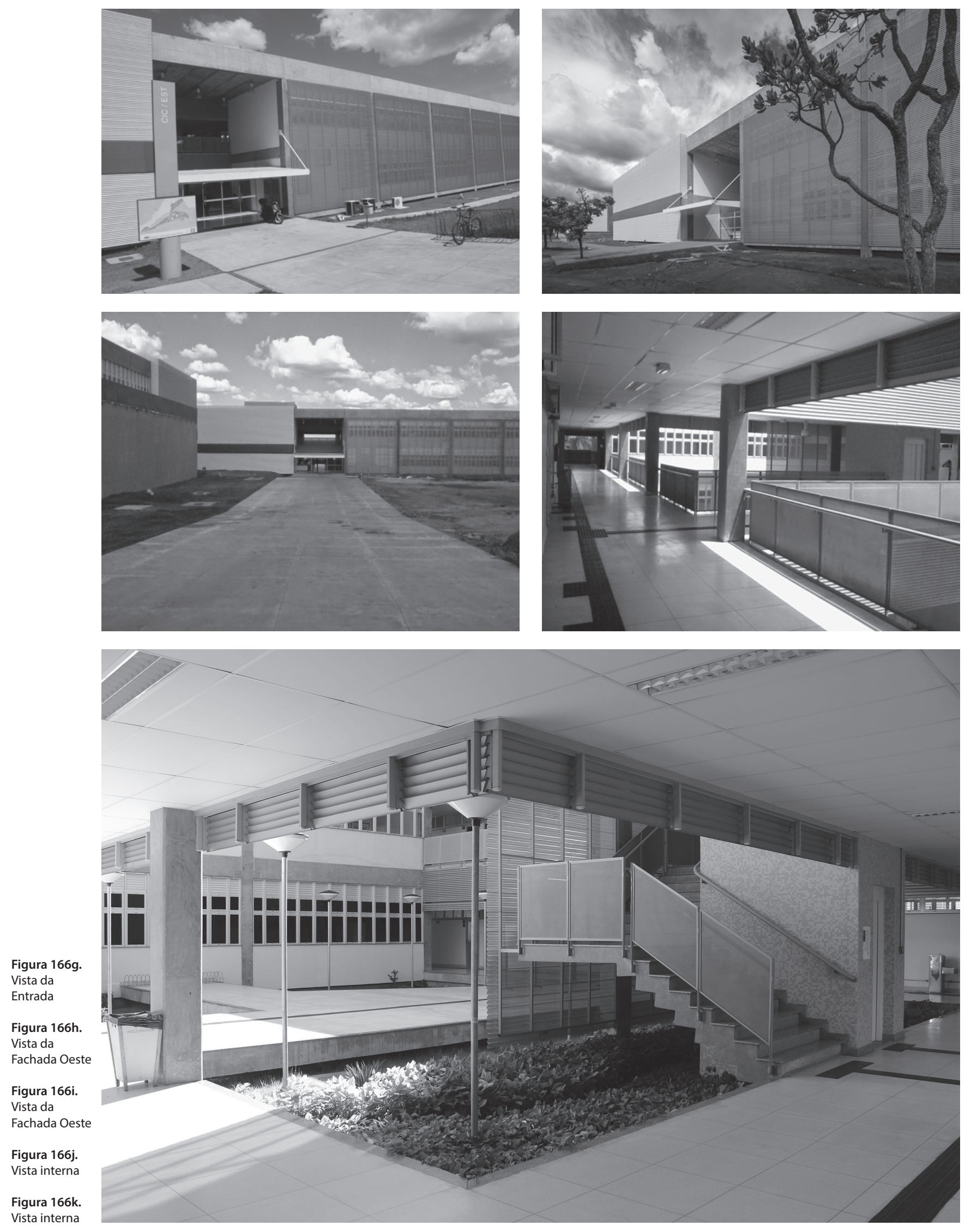


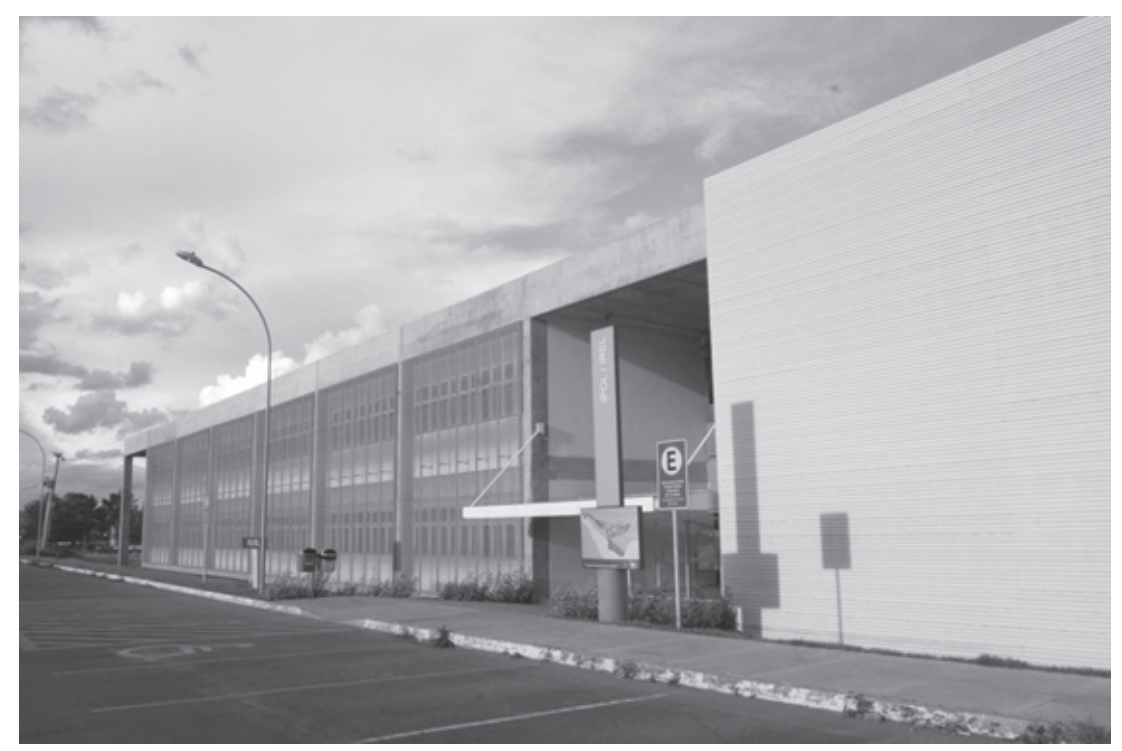

Figura 167c

Vista da entrada

Figura 167d.

Vista da facahda Norte.

Foto Silvio Cavalcante

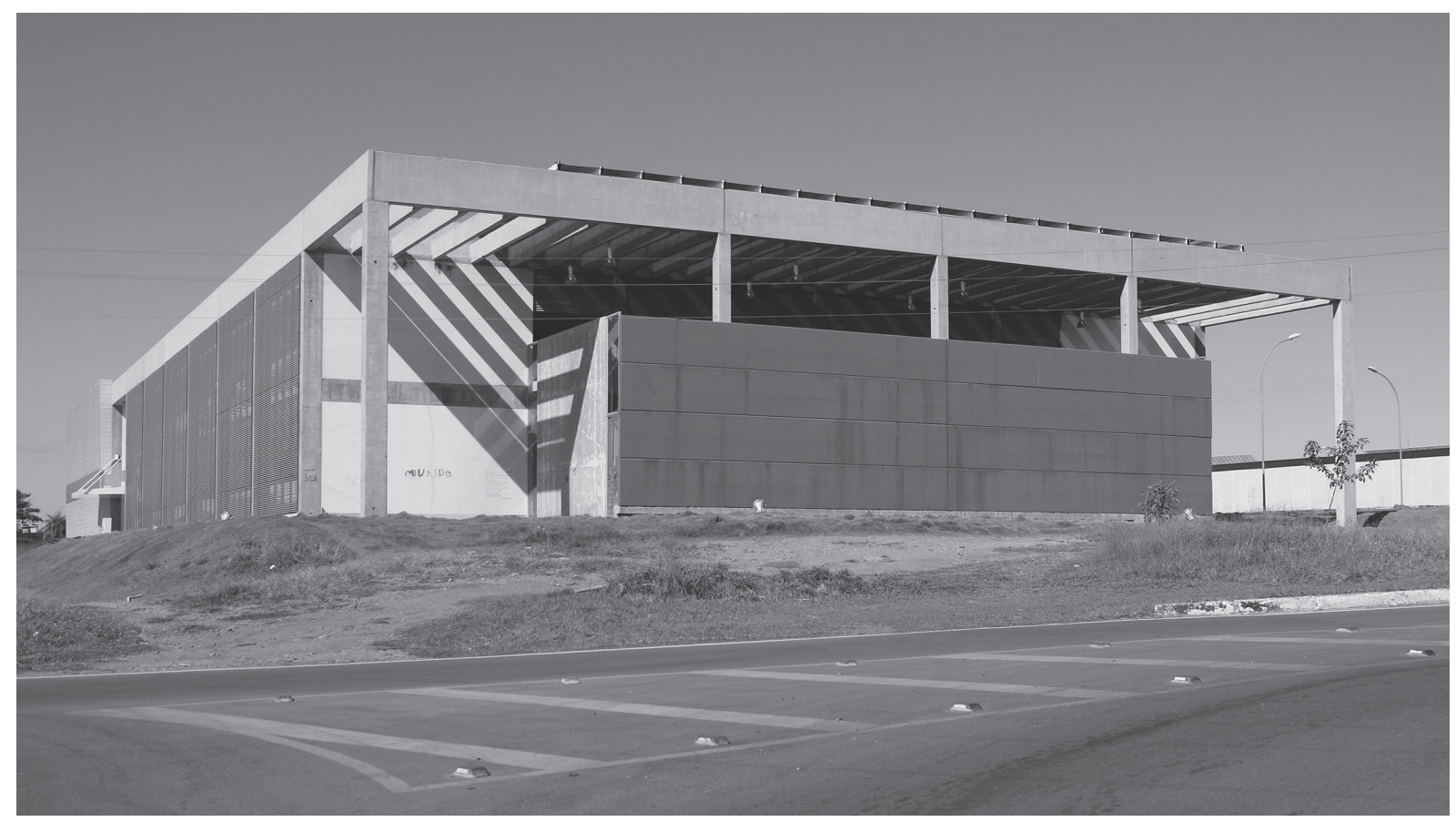


INSTITUTO DE CIÊNCIAS SOCIAIS (ICS)

Autoria

Alberto Alves de Faria, Fabiana Couto Garcia, Fátima Lauria Pires

Data

Obra em andamento

Área Construída

$4.485 \mathrm{~m}^{2}$ 
O ICS foi criado, em abril de 1996, com o objetivo de conferir maior visibilidade e acelerar a consolidação desse campo do conhecimento na Universidade de Brasília. O ICS foi desmembrado do Instituto Central de Ciências Humanas, ao qual pertenceu desde a criação do antigo Departamento de Ciências Sociais (CIS), em 1969.

O prédio conta com um auditório para 92 pessoas, 54 salas de professores, duas salas coletivas para a pós-gradução, uma biblioteca setorial e três centros acadêmicos. Há também espaços para laboratórios, secretaria, direção e dez salas de reuniões. Três salas multiuso poderão ser usadas para aulas, defesas de tese e palestras.

O edifício é iluminado, arejado, e possui as condições de segurança contra incêndio, pânico e segue as normas de acessibilidade.

As aulas de graduação ocorrerão no prédio chamado Unidade Acadêmica. Os dois prédios ficarão na área entre o bloco de salas de aula Eudoro de Sousa, o Bloquinho e a Colina.
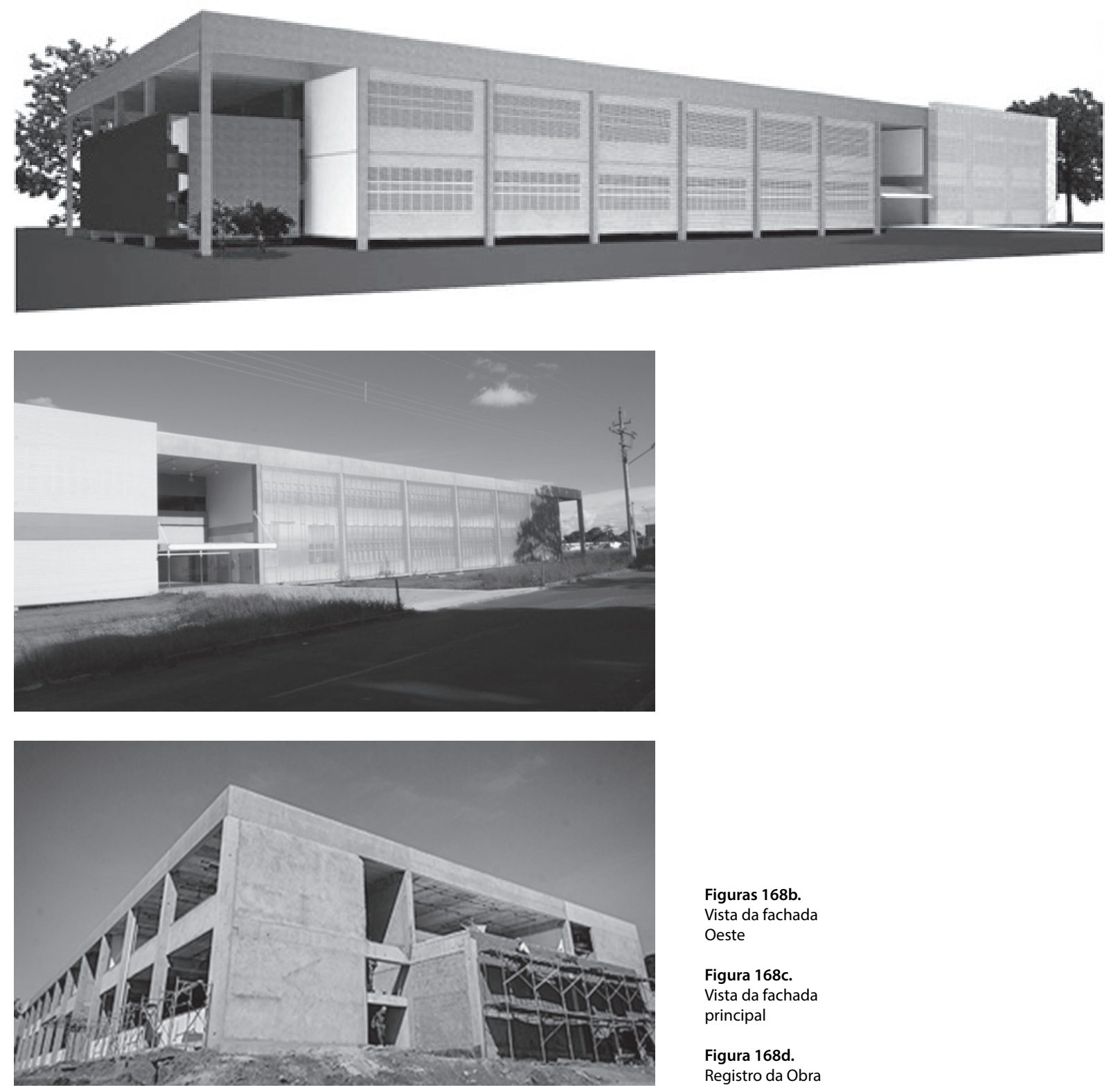

Figuras $168 \mathrm{~b}$.

Vista da fachada

Oeste

Figura $168 c$.

Vista da fachada

principal

Figura 168d.

Registro da Obra 
CENTRO DE ATENDIMENTO E ESTUDOS PSICOLÓGICOS (CAEP)

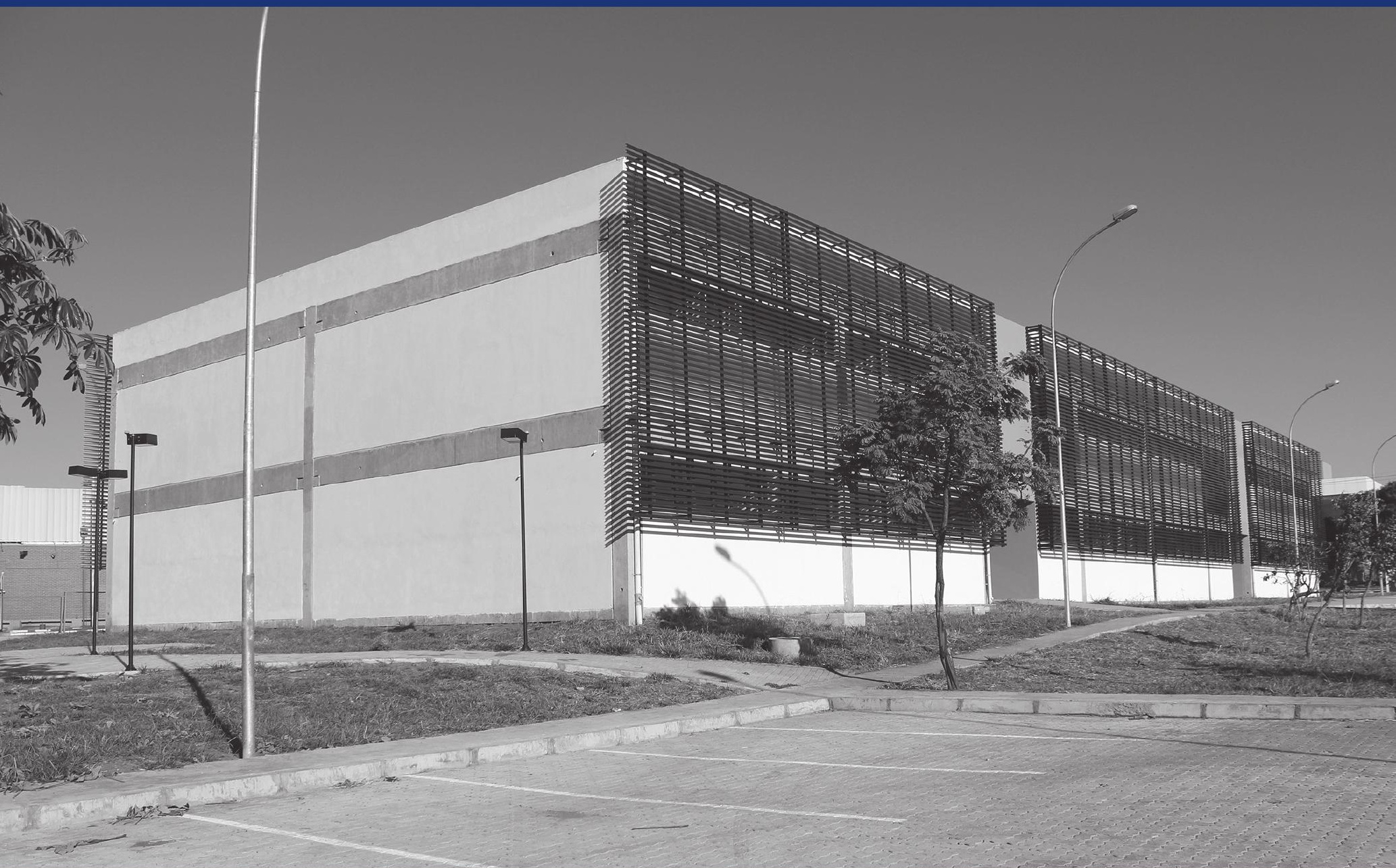

Autoria

Fabiana Couto Garcia, Alberto Alves de Faria e Fátima Lauria Pires

Figura 169a.

Data

2010 (projeto). Obra em andamento

Área Construída

$2.227 \mathrm{~m}^{2}$ 
O Centro de Atendimento e Estudos Psicológicos (Caep) da UnB tem como finalidade principal a prestação de serviços psicológicos desenvolvidos pelo Instituto de Psicologia (IP) da universidade. A prática clínica atende tanto a comunidade interna como a externa. Além disso, a unidade oferece suporte para as atividades de ensino, pesquisa e extensão.

O edifício é composto por dois pavimentos com quatro usos, para atendimento de públicos diferenciados. São quatro acessos para quatro núcleos distintos. O primeiro acesso destina-se ao atendimento dos pacientes de saúde mental. No segundo, uma recepção direciona o público para o pavimento superior, onde se localiza o atendimento de adultos e adolescentes. $O$ terceiro destinase aos ambientes de administração, avaliação e intervenção. No quarto, outra recepção direciona o público para o para atendimento de bebês e crianças, também localizado no pavimento superior.

Tanto na estrutura como nos fechamentos das fachadas foram utilizados componentes pré-fabricados, com o objetivo de garantir mais rapidez na execução. As fachadas longitudinais possuem fechamentos laterais em brises metálicos que, além de proteger a edificação contra a insolação, permitem a constante ventilação e iluminação dos postos de atendimento.

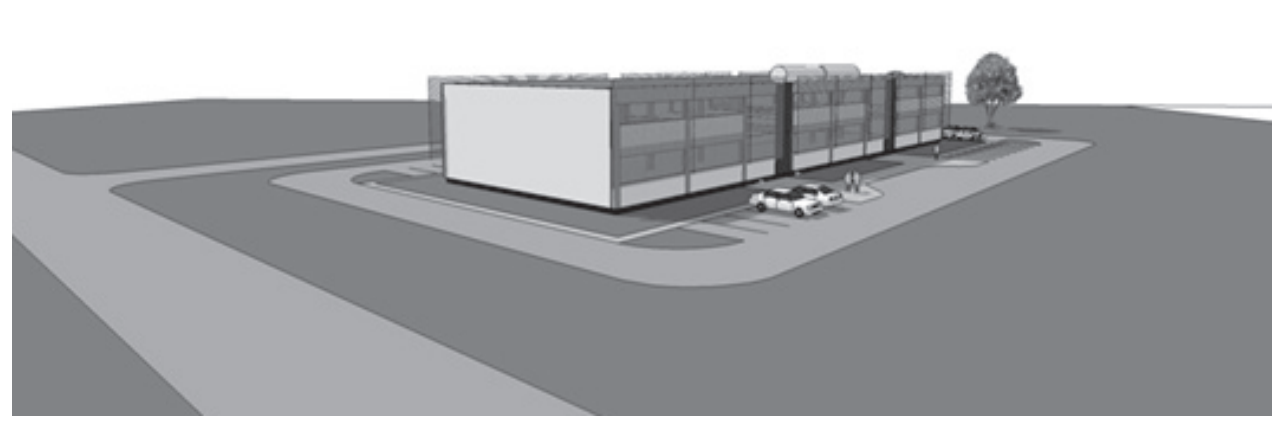

Figuras $169 b$, c e d.

Vistas gerais
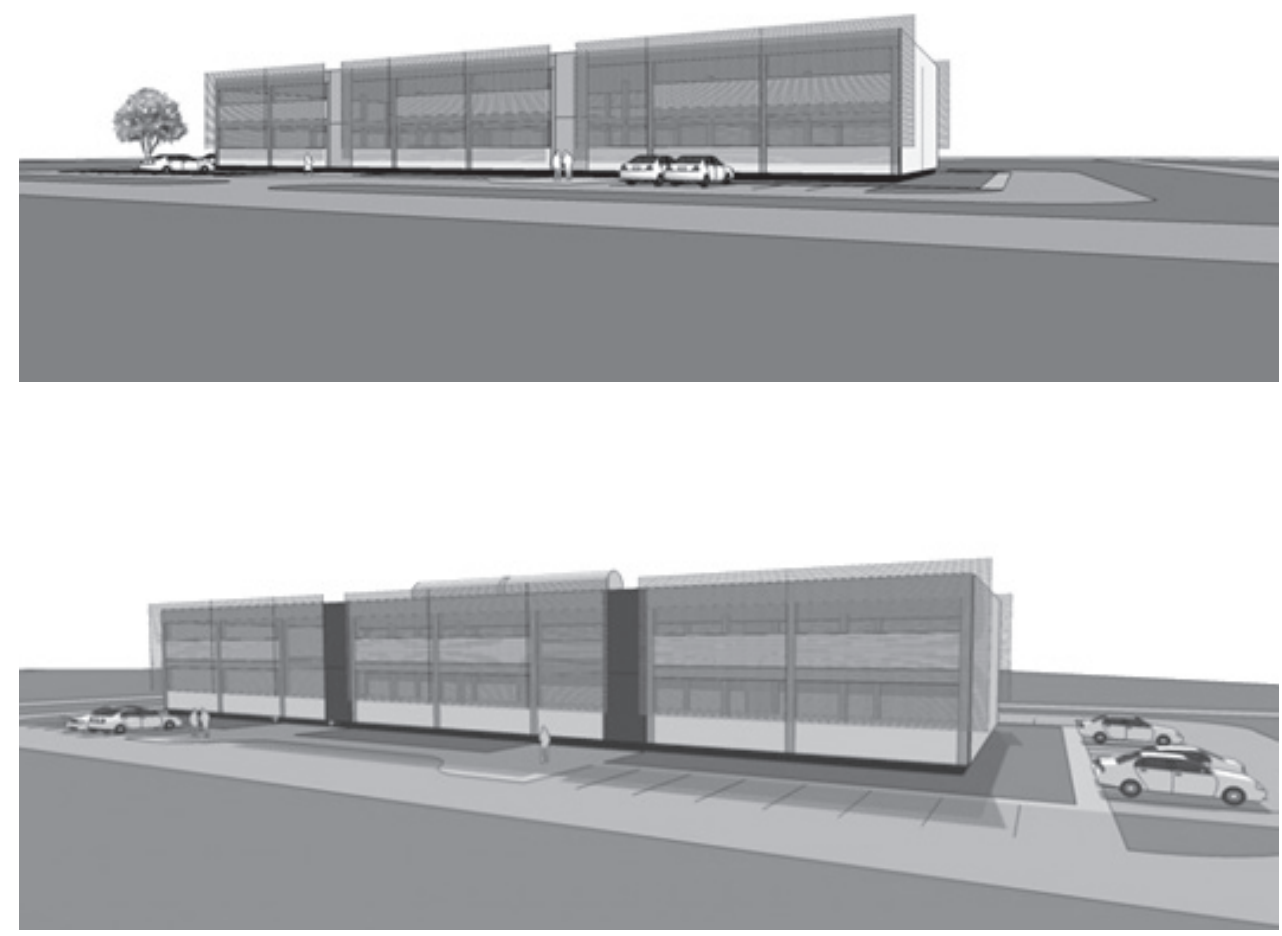


\section{CENTRO DE REFERÊNCIA EM CONSERVAÇÃO DA NATUREZA E RECUPERAÇÃO}

DE ÁREAS DEGRADADAS (CRAD)

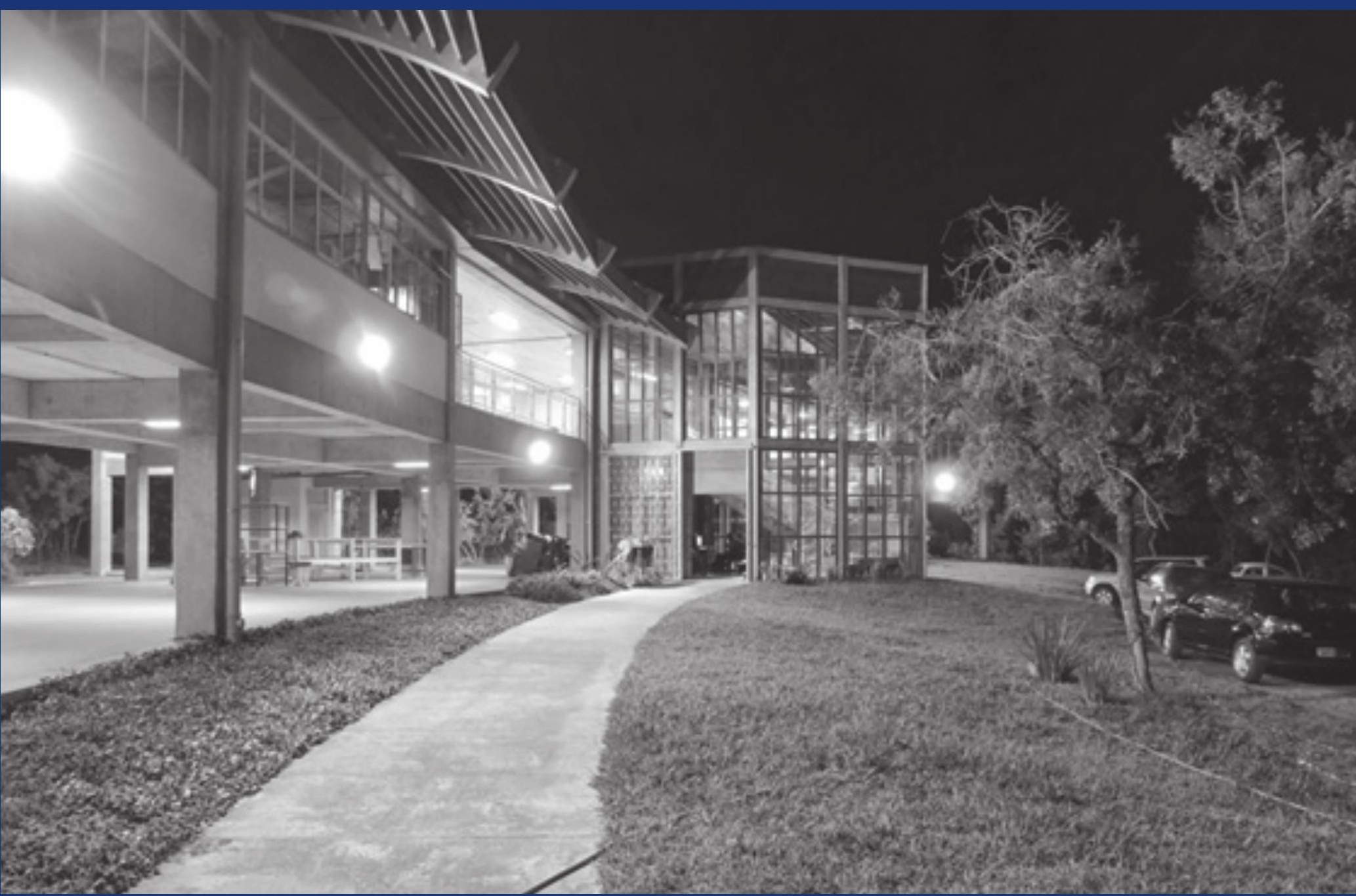

Autoria

Alberto de Faria, Marta Bustos Romero, Lisa de Andrade
Figura 170a.

Vista do pátio

central

Data

2010 (projeto)

Obra em andamento

Área Construída

$1.326 \mathrm{~m}^{2}$ 
O CRAD/UnB ${ }^{1}$ é parte de um grupo de quatro outros centros implementados na Bacia do São Francisco, com o objetivo de realizar atividades de: conservação de sementes e produção de mudas; desenvolvimento e implantação de modelos de recuperação de área degradada; treinamento e capacitação; mobilização e sensibilização da comunidade sobre a recuperação da vegetação e conservação da biodiversidade; de estruturação de banco de dados; monitoramento de áreas demonstrativas e articulação com redes de sementes que atuam em sua área de abrangência.
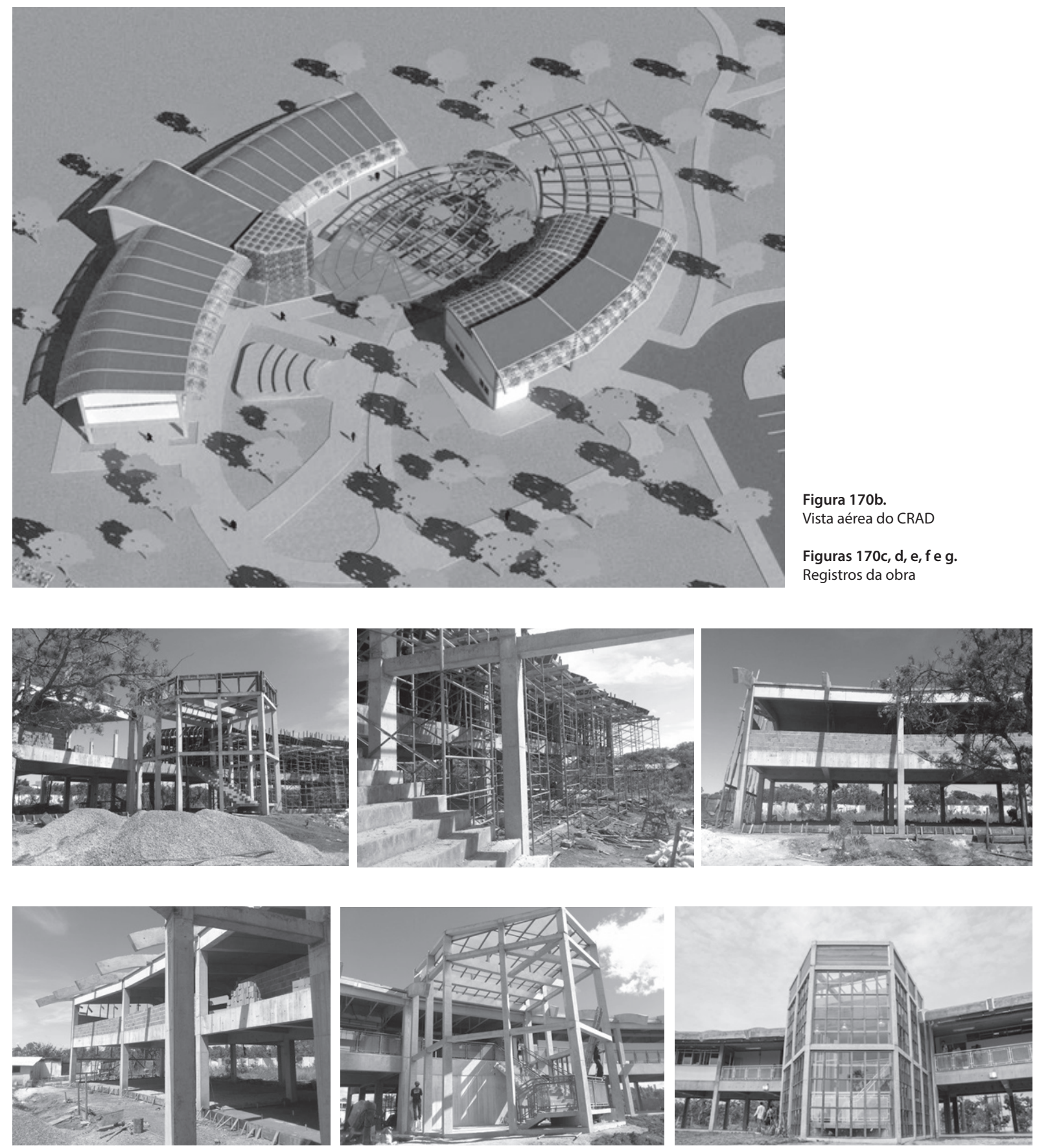

O conjunto edificado é uma homenagem à professora do Curso de Engenharia Florestal Jeanine Fagg, falecida em 2009. 


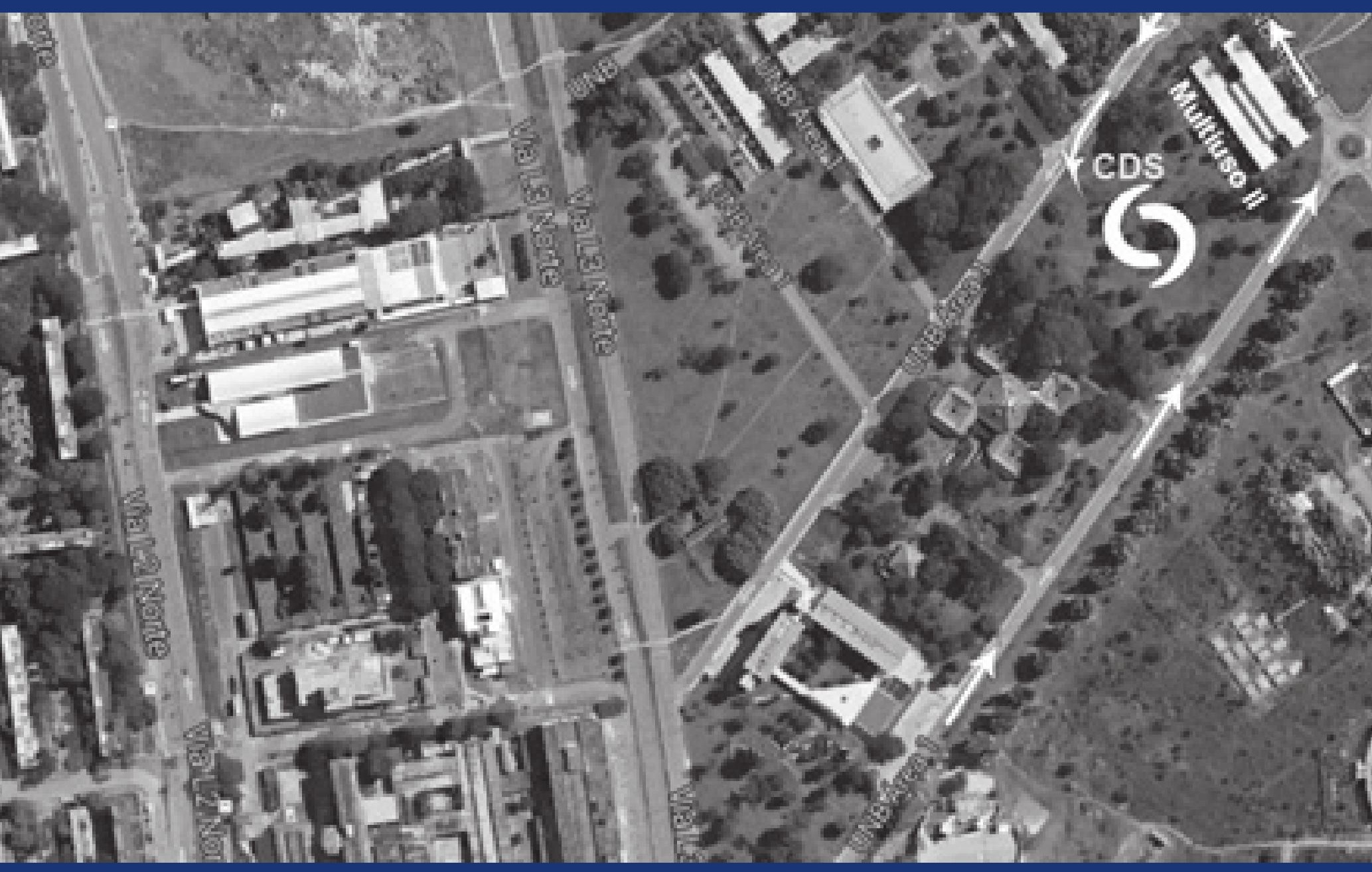

Autoria

Cláudio Villar Pinheiro de Queiroz, Raquel Naves Blumenschein, com a colaboração de Roberto Guedes

Data

2010 (projeto)

obra em andamento

Área Construída

$2.830 \mathrm{~m}^{2}$
Figura 171a.

Implantação

do CDS 
O Centro de Desenvolvimento Sustentável (CDS), criado em 1995, é uma unidade permanente da UnB, dedicada ao ensino, à pesquisa e à extensão.

Figura 171b. Vista geral

Figura 171c.

Vista aérea do CDS

Figuras 171d,

e, fe g.

Registros da

obra
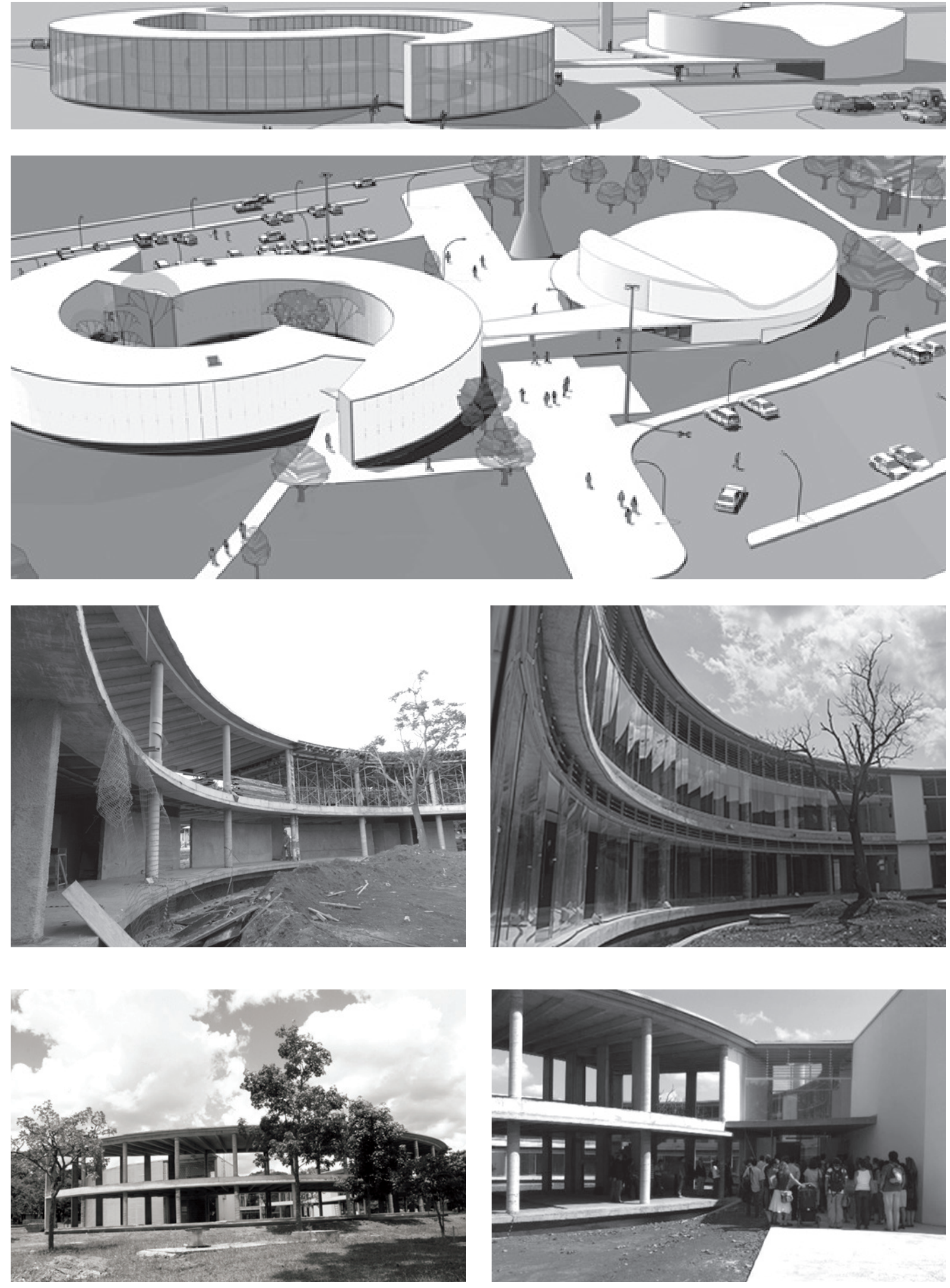
MEMORIAL DARCY RIBEIRO - BEIJÓDROMO

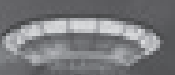

2)

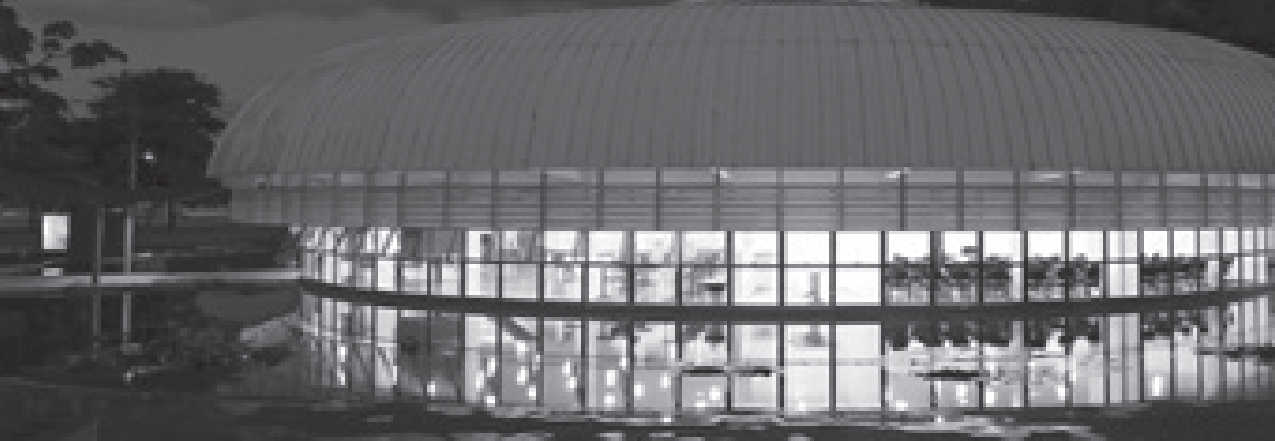

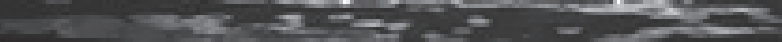

Autoria

João da Gama Filgueiras Lima; cálculo estrutural de Paulo Roberto de Almeida Freitas.

Data

1996 (projeto)

2009-2010 (obra)

Área Construída

$1.989,50 \mathrm{~m}^{2}$ 
Internado no Hospital Sarah Kubitschek de Brasília para tratamento de um câncer, em 1996 Darcy Ribeiro reafirimou ao Lelé, por meio de teleconferência, o desejo, já expresso anteriormente, de que o arquiteto projetasse uma local para o acervo do antropólogo, bem como o de sua primeira companheira, Berta Ribeiro. Sobre o assunto, assim se manifestou Lelé:

Darcy, pouco antes de morrer, ele já estava bem doente [...] estava no Sarah fazendo quimioterapia e me surpreendeu... De lá entrou naquele sistema de comunicação do Sarah, pela TV. E o Aloysio (Campos da Paz) falou: “O Darcy está querendo falar com você". Ele deu o programa do prédio pelo canal de televisão: “Vou te dar aqui o programa, quero fazer o prédio com você". O Darcy gostava muito de participar dos projetos, mas ele não tinha mais condições de saúde, na última reunião nossa ele disse: "Faz o que você quiser" (Entrevista em 29 fev. 2012).

Darcy desejava que o edifício combinasse arrojo e beleza, inovação e simplicidade. Uma semana depois, em uma videoconferência, Lelé mostrou-lhe o primeiro esboço do edifício.
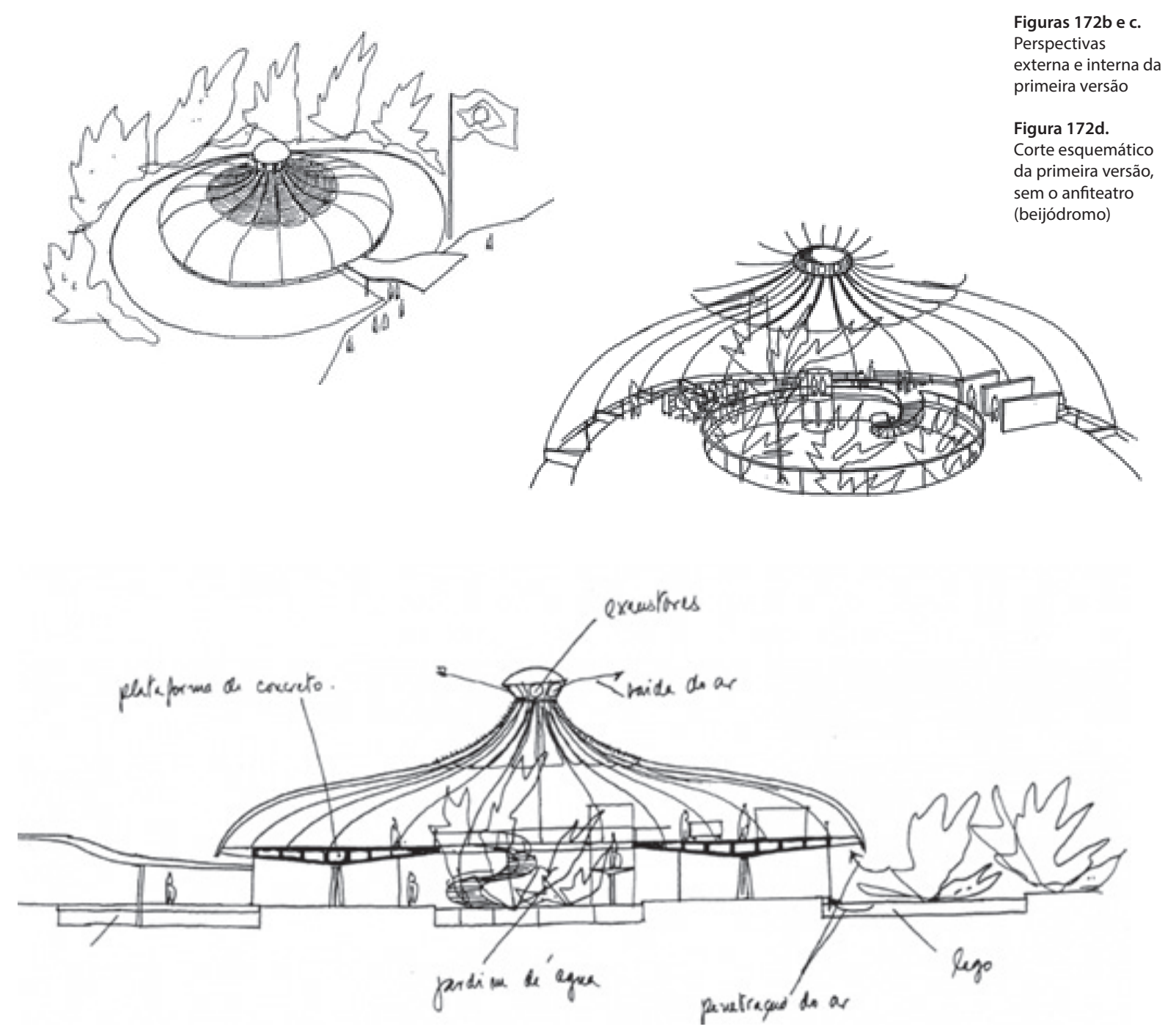

Fiz o projeto, ele gostou muito, a única coisa que ele reclamou foi: "mas eu quero um beijódromo". Ele não tinha posto isso no programa inicial. Eu perguntei: "Mas como é esse beijódromo?". Ele explicou que seria uma arquibancada que tivesse uns seresteiros para cantar e os casais poderiam ficar se beijando nas arquibancadas (LELÉ, Entrevista em 29 fev. 2012). 


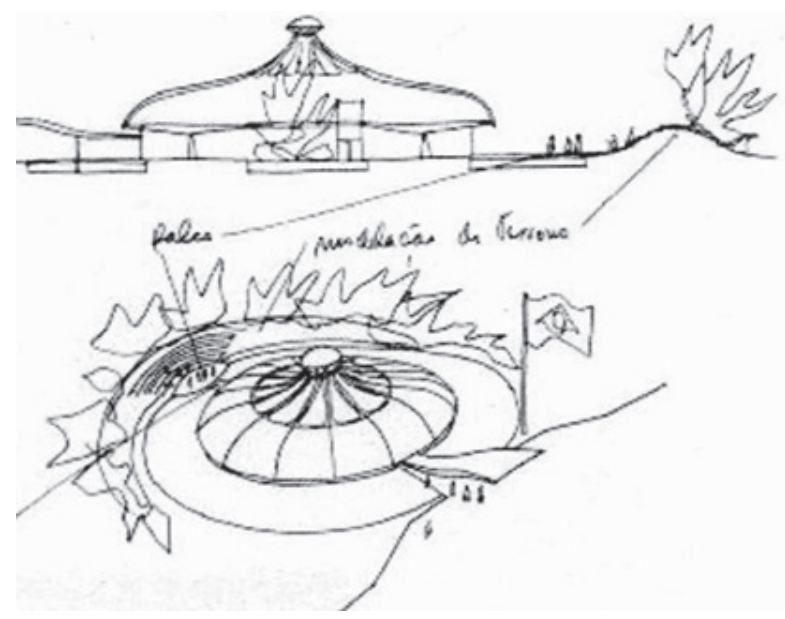

Figura 172e.

Croquis da segunda

versão, com o anfiteatro

(beijódromo) descoberto

Figura $172 \mathrm{f}$.

Croquis da terceira

versão, com a marquise

de cobertura do

anfiteatro (beijódromo)

Figuras $172 \mathrm{f} \mathrm{e} \mathrm{g}$.

Planta e cortes

esquemáticos da terceira

versão

Figura 172h.

Maquete

Finalmente veio a terceira e última versão, em que o beijódromo aparece devidamente protegido por uma marquise curva.
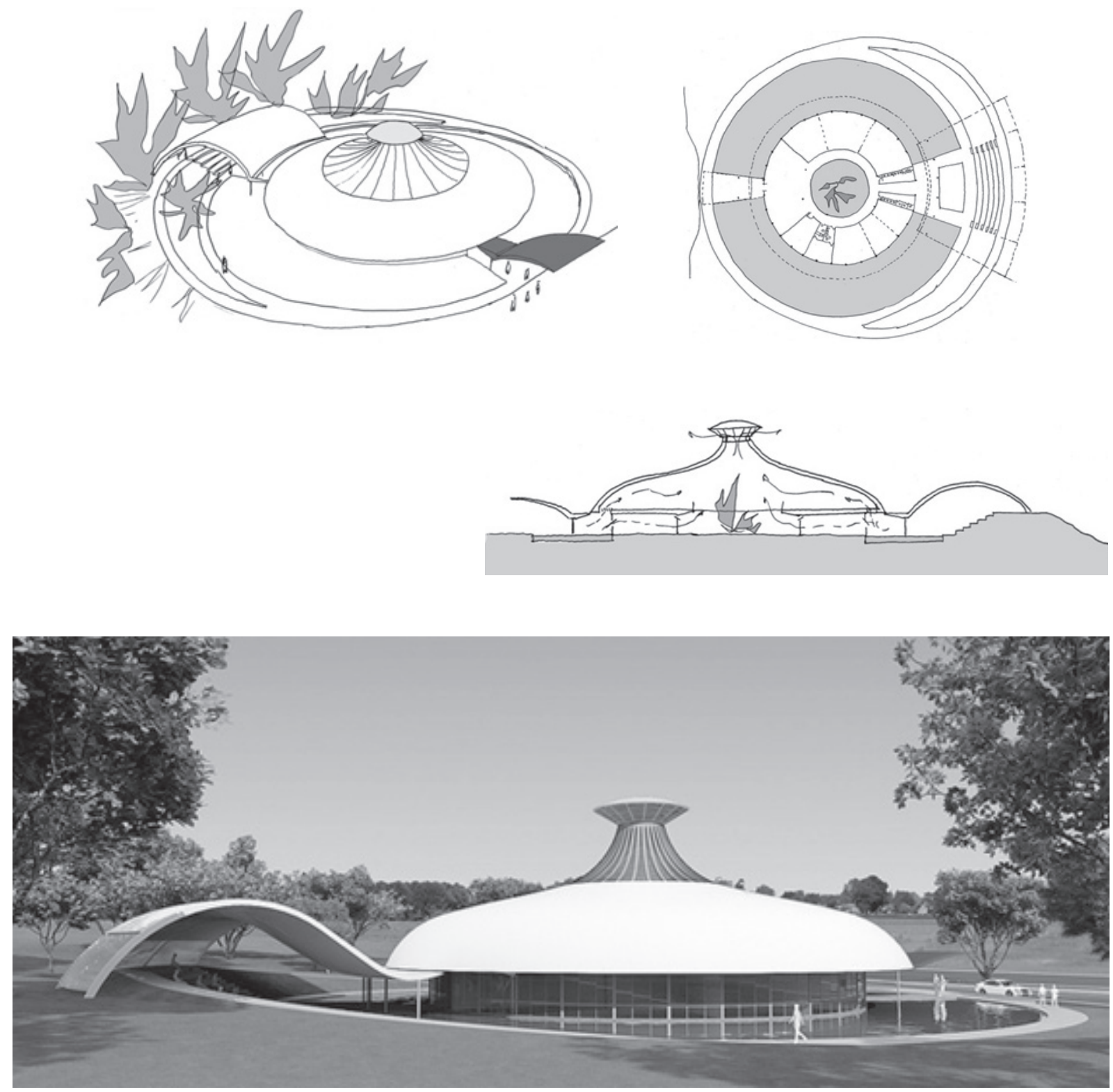
Nos desenhos e na maquete, o programa proposto consolidouse em uma composição inusitada que lembra um disco voador ou uma mistura de maloca dos Xavantes com a dos Kamayurás, conforme explicou o próprio Lelé:

Bilhete do Lelé para o Darcy Ribeiro

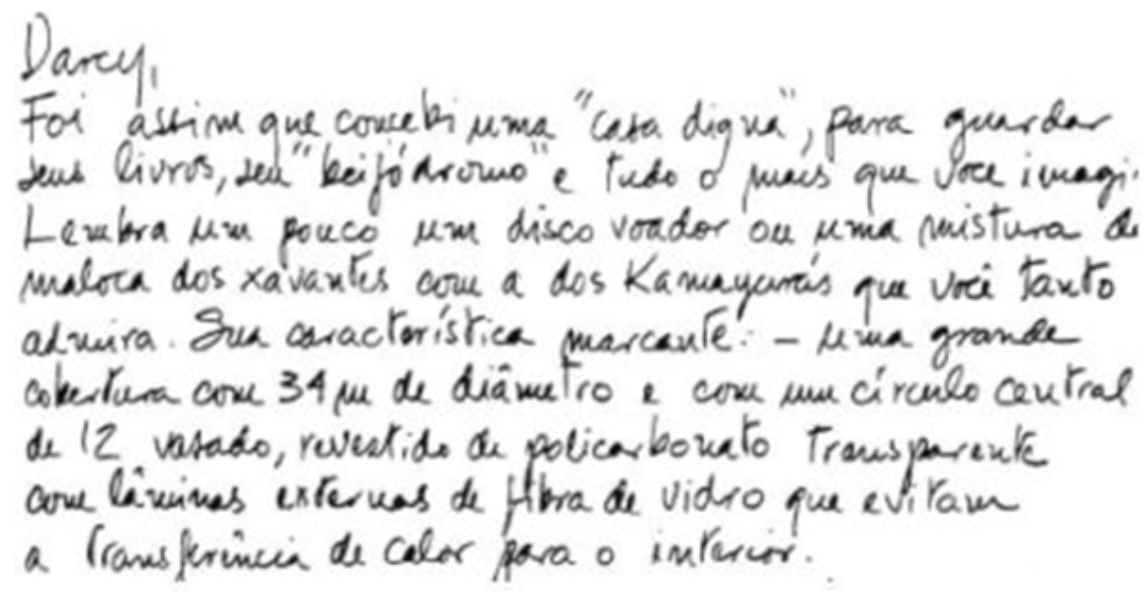

A justificativa para a adoção da forma está ainda em outro depoimento do próprio Lelé:

A cabana dos índios é uma coisa linda. Possui ventilação, até um shed como esses que utilizo em meus trabalhos... tem uma cumeeira por onde sai o ar quente. [...] É possível identificar ainda o contraventamento, contra efeitos de vento. [...] No projeto da Fundação Darcy Ribeiro, a grande cobertura tem um sentido um pouco disso, pode-se interpretar tanto como uma nave espacial quanto como uma cabana indígena. Depende da sensibilidade de quem vê. Tem dois apelos: pode ser uma nave espacial pousada, porque é uma coisa leve, muito delicada, e pode ser uma cabana, pela forma. Não que eu tenha pensado em fazer isso. O que queria resolver realmente era a questão de um espaço que todo mundo dominasse, exatamente como Darcy sempre foi: ele interagia com todo mundo. Nada como um círculo, uma forma circular, para criar essa unidade espacial (LIMA, 2004, p. 98).
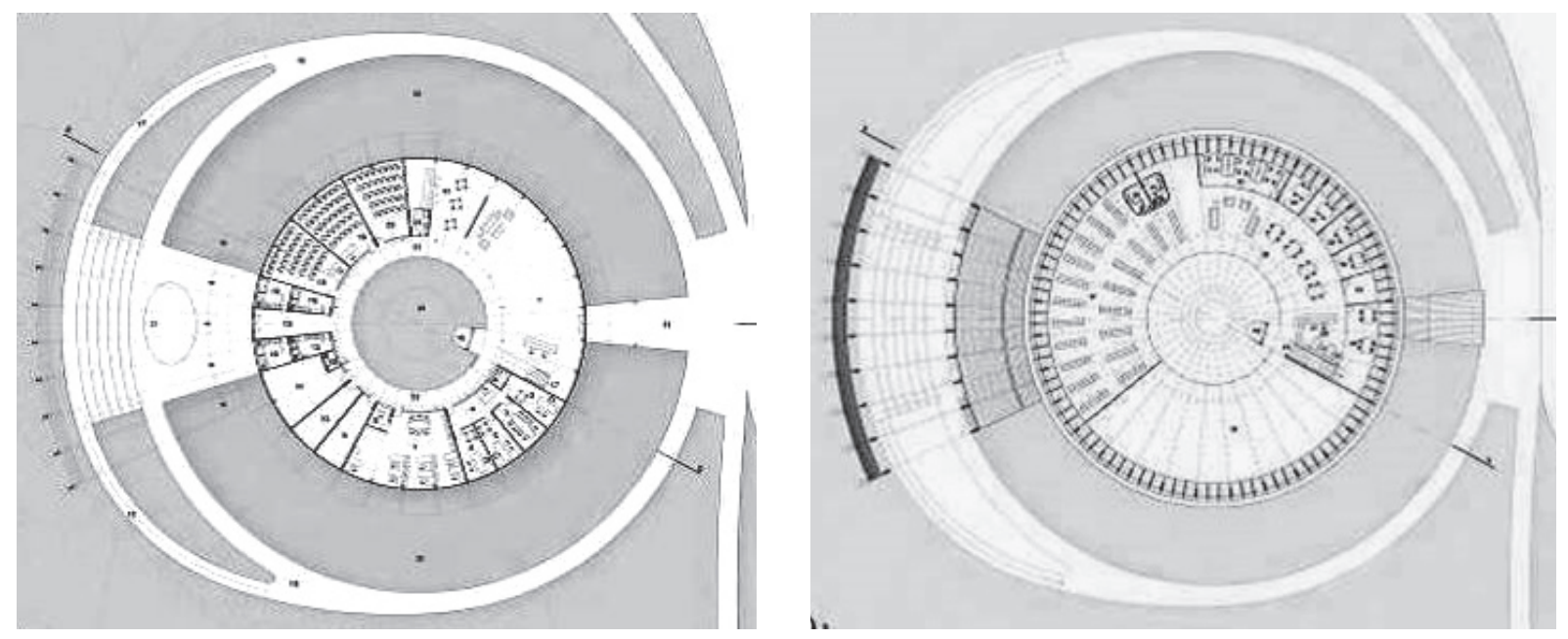

Figura $172 i$.

Planta do pavimento térreo

Figura 172j.

Planta do pavimento superior 


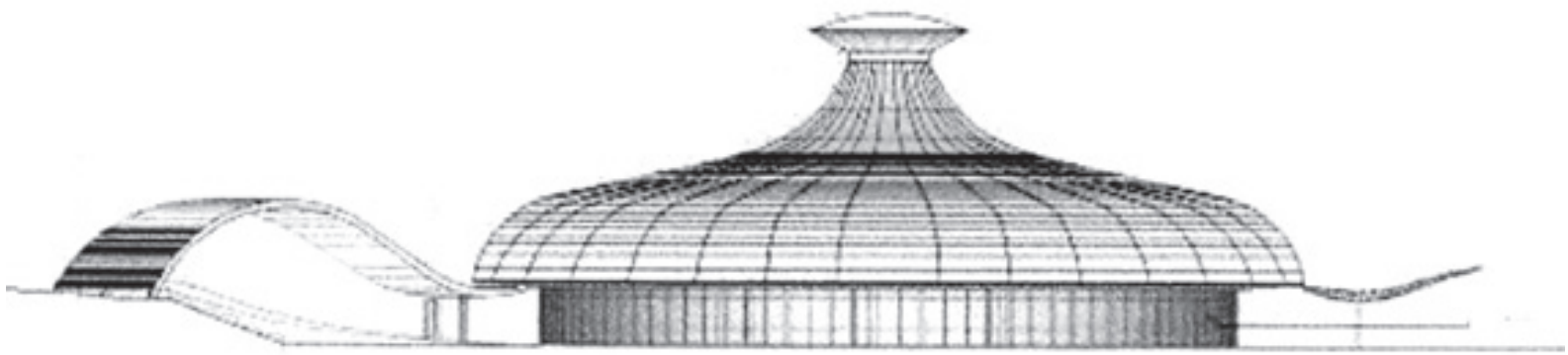

Trata-se de um edifício circular de dois pavimentos com 34 m de diâmetro e cobertura de 37 m, em cujo centro existe um espaço circular ajardinado com $12 \mathrm{~m}$ de diâmetro e pé-direito duplo.

Para a estrutura da cobertura, o arquiteto empregou 32 vigas radiais: apoiadas, de um lado, no anel de compressão da cúpula de 2,60 m; de outro, engastadas na ponta do balanço externo do pórtico do piso superior, composto também de 32 vigas radiais de alma cheia, em perfil I. "Estas vigas, por sua vez, são engastadas em 32 pilaretes metálicos, dispostos na periferia da construção, e nas vigas transversinas que formam o anel circular interno, distribuindo sua carga para 16 pilares metálicos tubulares, situados entre duas linhas de forças principais" (PORTO, 2010b, p. 21).
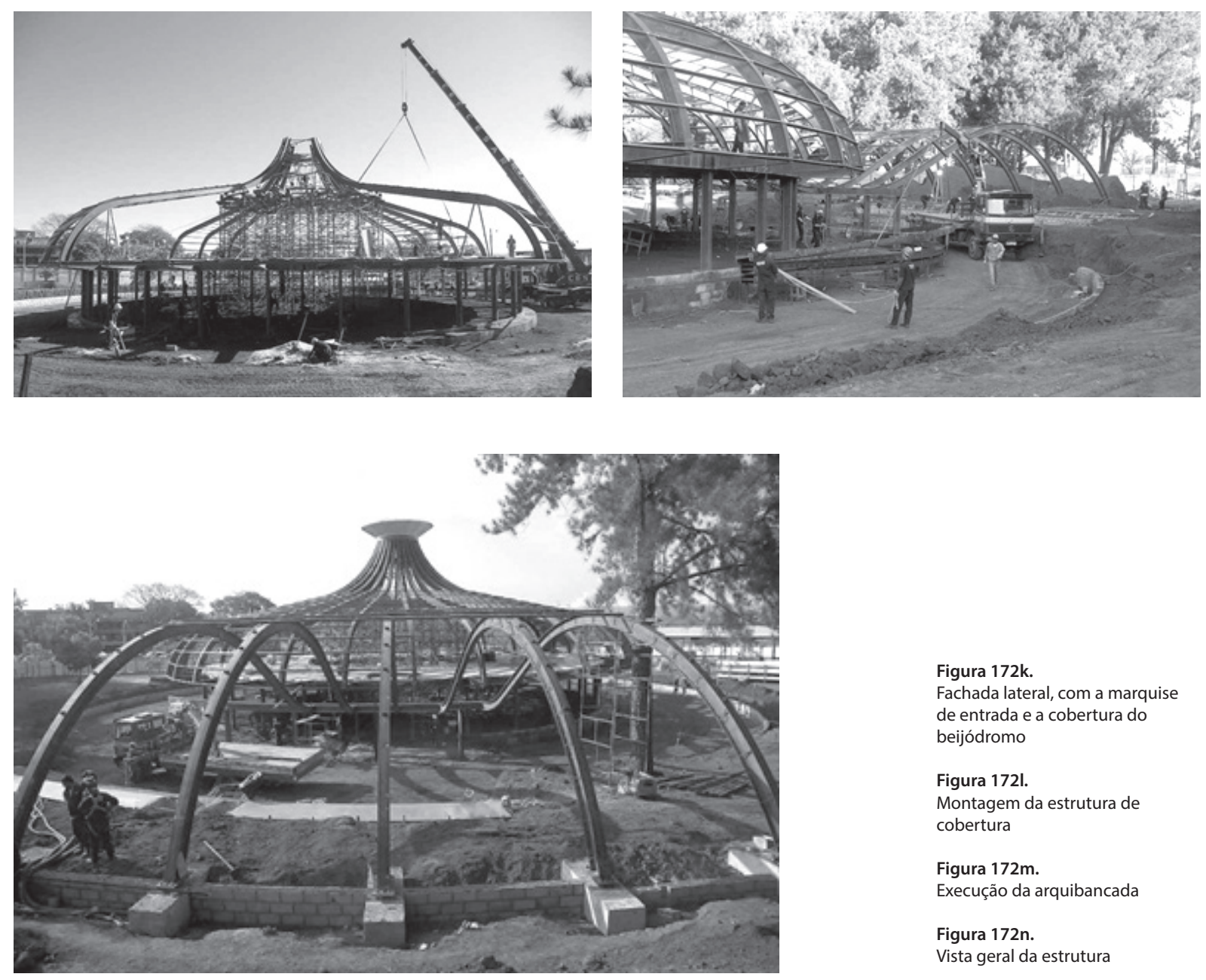

Figura $172 k$.

Fachada lateral, com a marquise de entrada e a cobertura do beijódromo

Figura 172l.

Montagem da estrutura de

cobertura

Figura 172m.

Execução da arquibancada

Figura 172n.

Vista geral da estrutura 

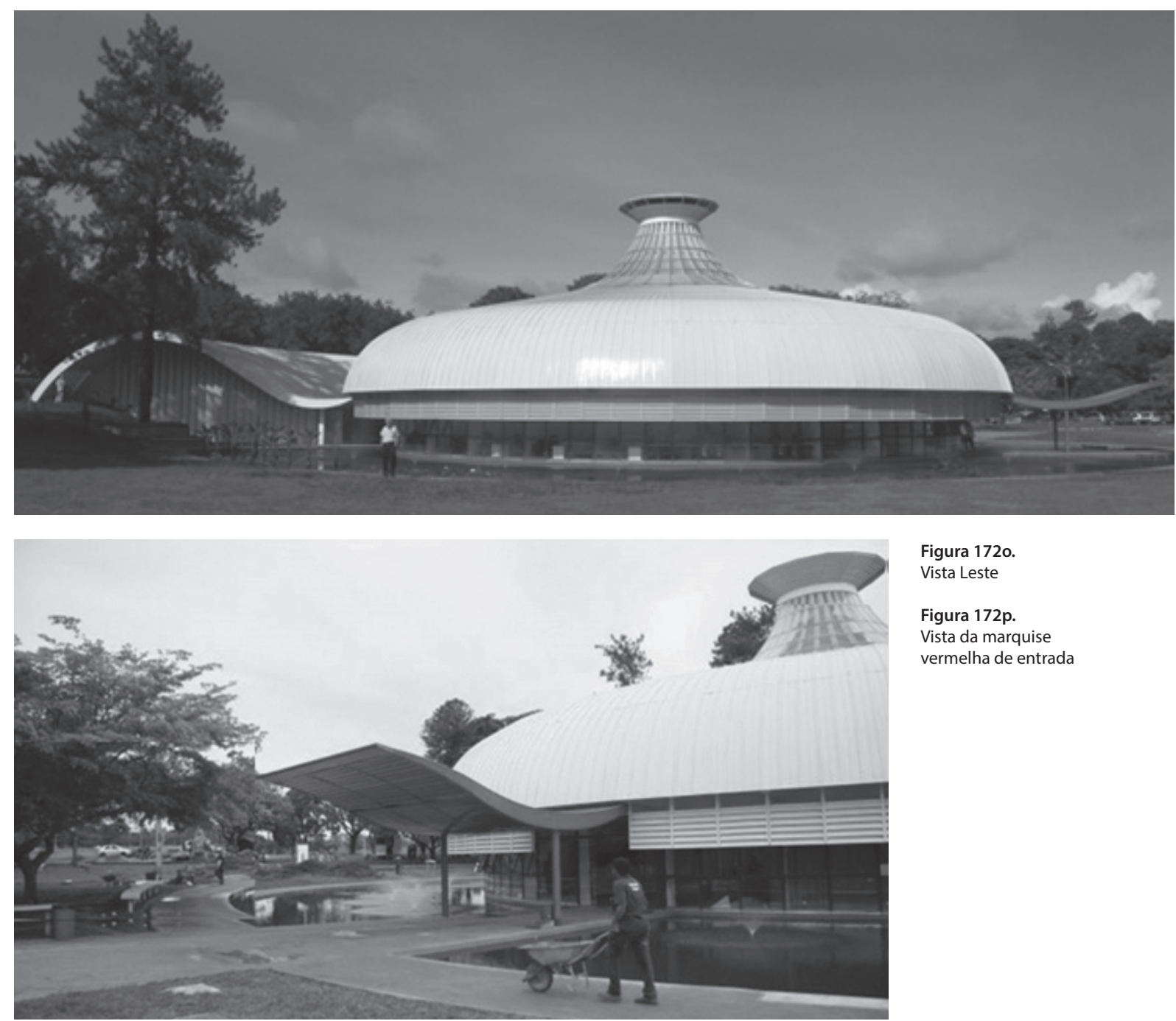

Figura 172o. Vista Leste

\section{Figura 172p.}

Vista da marquise vermelha de entrada

Rodeado por um espelho d'água, o memorial é acessado por meio de uma ponte coberta por marquise metálica. Na parte posterior da construção circular fica o auditório, que aproveita a formação em talude constituída pela terra retirada na escavação para o círculo de água.

O edifício abriga salas de aulas, galeria para exposição, cineclube, gabinetes de pesquisa, centro de documentação, café, livraria e um pequeno auditório, além do acervo de Darcy e Berta, a biblioteca do antropólogo, com cerca de 30 mil volumes. O espaço pode acolher apresentações artísticas, lançamento de livros e exposições. "[...] não estavam no programa as salas de aula, o projeto sofreu modificações, inclusive, agora estão fazendo uma lanchonete enorme, na entrada, à minha revelia. O projeto sempre vai se descaracterizando..." (LELÉ, entrevista em 29 fev. 2012).

Quando o projeto foi construído, eu tive que adaptar a uma situação nova, inclusive a biblioteca, que era toda integrada ao espaço. Naquela época não havia essa questão de segurança, de roubo de livros, então, acho que isso descaracterizou um pouco o prédio. Depois, por uma questão de ruído, aquele espaço central teve que ser fechado com vidro, acho que perdeu muito (Entrevista em 29 fev. 2012).

Um sistema de vaporização resultante da passagem do ar introduzido no prédio por meio de nebulização mecânica da água do lago proporciona conforto ambiental em todo o conjunto. 

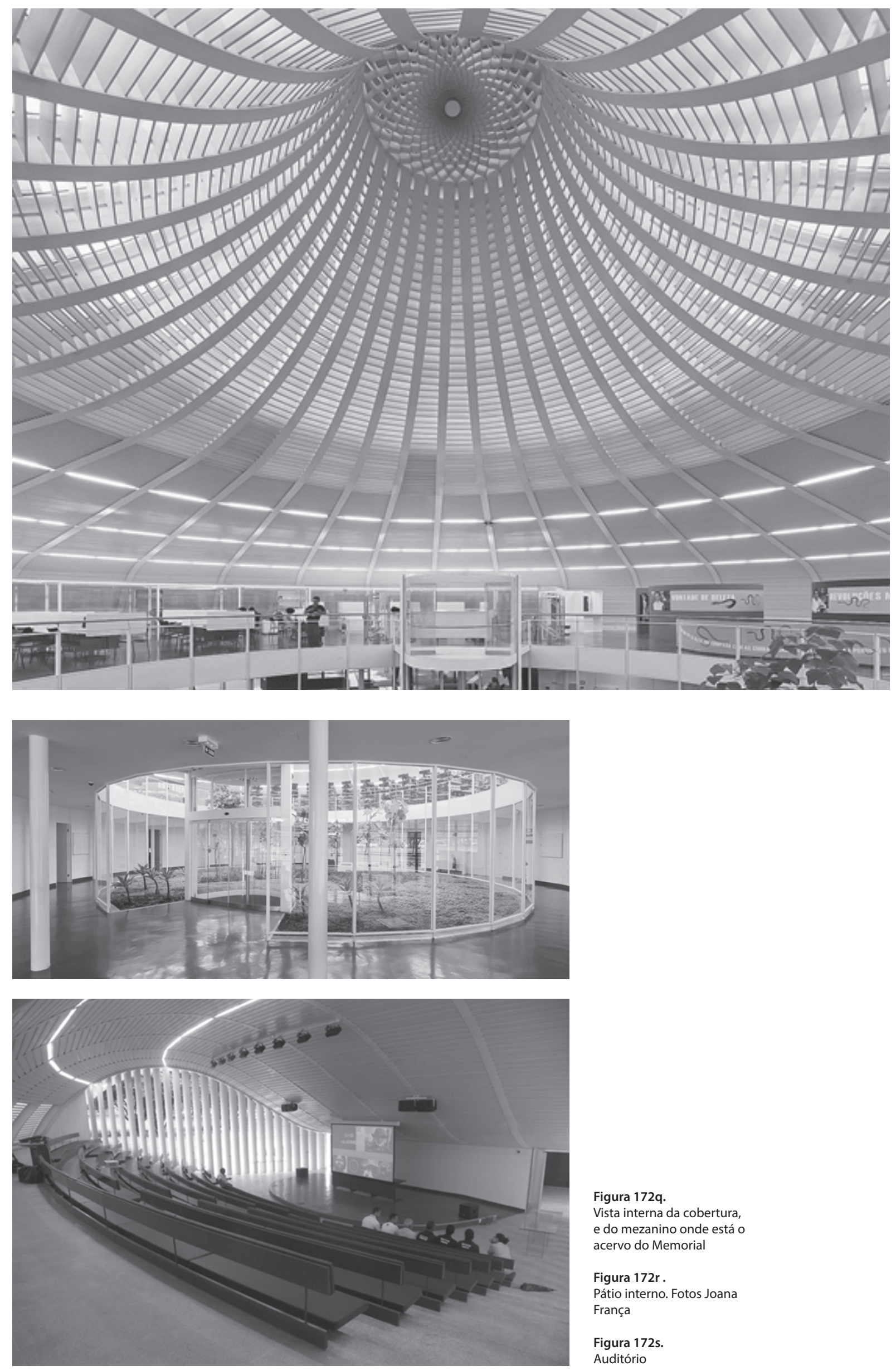

Figura 172q.

Vista interna da cobertura

e do mezanino onde está o acervo do Memorial

Figura 172r .

Pátio interno. Fotos Joana

França

Figura 172s.

Auditório 


\subsection{A ocupação de novos territórios}

O Conselho Universitário (Consuni) aprovou, em 19 de outubro de 2007, o documento "A UnB rumo aos 50 anos: autonomia, qualidade e compromisso social" como carta de intenções para o ingresso da Universidade de Brasília no Programa de Apoio a Planos de Reestruturação Expansão das Universidades Federais (Reuni). Instituído pelo Decreto n. 6.096, de 24 de abril de 2007, do Ministério da Educação, o Reuni teve como objetivos criar condições para a ampliação do acesso e permanência na educação superior, em nível de graduação; aumentar a qualidade dos cursos e melhorar o aproveitamento da estrutura física e de recursos humanos existentes nas universidades federais, respeitadas as características particulares de cada instituição e estimulada a diversidade do sistema de ensino superior.

Em consonância com tais objetivos, a UnB tem procurado estimular a participação dos diversos atores e movimentos sociais em suas atividades e priorizar a aproximação entre a comunidade universitária e a sociedade. Para tanto, a Universidade incluiu em seu Programa de Desenvolvimento Institucional (PDI) a criação de três novos campi: Planaltina, Gama e Ceilândia. 
FACULDADE UNB PLANALTINA (FUP)

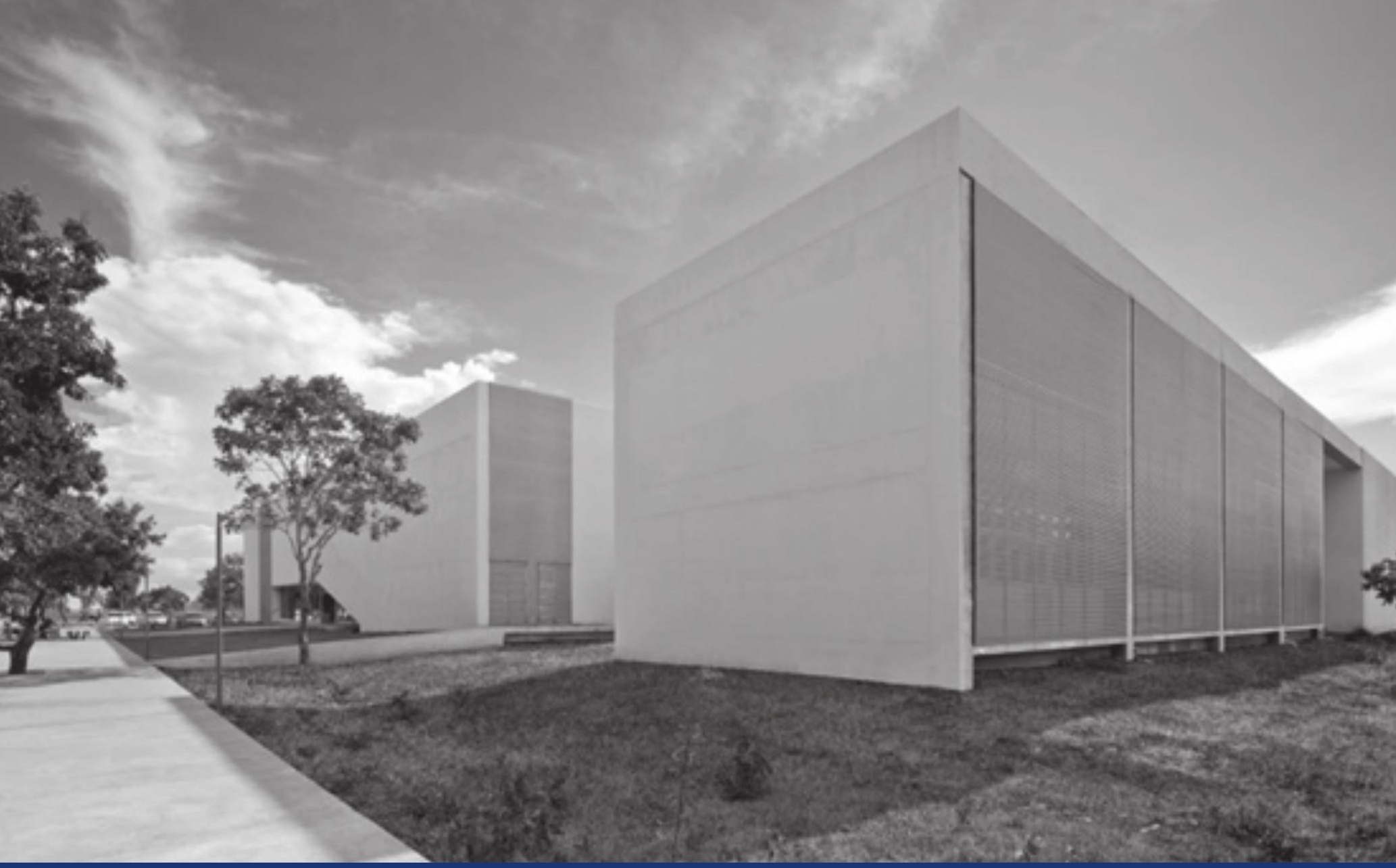

Autoria

Alberto Alves de Faria e Érico Paulo Seigmar Weidle

Data

2006 (projeto)

2011 (obra)

Área Total do Campus

$301.847 \mathrm{~m}^{2}$

Área Construída

$2.640 \mathrm{~m}^{2}$ (UEA); $1.684 \mathrm{~m}^{2}$ (UEP); $4.795 \mathrm{~m}^{2}$ (UAC) 
O campus de Planaltina ${ }^{1}$, inaugurado oficialmente em 2006, conta atualmente com três prédios: Unidade Acadêmica (UAC), Unidade de Ensino e Pesquisa (UEP) e o prédio original Unidade de Ensino e Administração (UEA).

Inicialmente, a UEA compreendia 12 salas de aula, um auditório para 150 pessoas, uma biblioteca e um laboratório de informática para trinta alunos; a área administrativa - salas para coordenação acadêmica, secretaria, apoio didático, professores, almoxarifado, coordenação administrativa e sanitários - e a área de serviço - posto de segurança, depósitos de material e de limpeza e lanchonete.

A UEP, um espaço para o ensino e a pesquisa, apresenta um amplo pátio central, três salas de aula, laboratórios de pesquisa e salas para acomodar todos os professores.

A UAC ${ }^{2}$, voltada para o ensino de graduação, possui, distribuídos nos seus dois pavimentos, dez salas de aula, dois laboratórios de informática, três laboratórios de ensino, auditório com capacidade para duzentas pessoas e biblioteca; no nível térreo situam-se a biblioteca, algumas atividades de ensino e áreas de vivência.

A planta é retangular, o pé-direito é de 3,00 m e, graças aos jardins internos, há ventilação cruzada em todos os ambientes. A circulação vertical é feita por meio uma grande rampa e dois núcleos contendo escadas e elevadores para portadores de necessidades especiais. Dois conjuntos sanitários no térreo e no primeiro pavimento foram projetados em cada lado da edificação.

A estrutura dos edifícios é constituída de componentes pré-fabricados de concreto, exceto no auditório, para o qual, devido aos grandes vãos, foi previsto um sistema misto de concreto armado nos pilares e nas lajes, e vigas metálicas. A organização dos espaços foi lançada sobre uma malha modular de 1,25 x 1,25 m, que condiciona a implantação dos espaços. O objetivo principal, além de promover ordem e clareza, é garantir a flexibilidade dos espaços internos.

A cobertura é feita com telhas metálicas tratadas com material de proteção termoacústica apoiadas em terças metálicas. As fachadas são protegidas com brise.

Segundo Alberto Faria, foi elaborado pela equipe do Ceplan um projeto básico da estrutura e as empresas contratadas elaboraram o projeto executivo. Como a edificação foi projetada para ser repetida, cada UAC foi estudada de acordo com o programa de necessidades dos respectivos institutos e faculdades, sempre seguindo a lógica de localização das atividades, das instalações, circulações verticais e vazios indicados no projeto inicial.

'O Governo do Distrito Federal, por meio da Lei Complementar n. 202, de 11 fev. 1999, regulamentada pelo Decreto n. 21.368 , de 20 jul. 2000, doou à UnB uma área de aproximadamente trinta hectares para a construção de um campus universitário em Planaltina. 

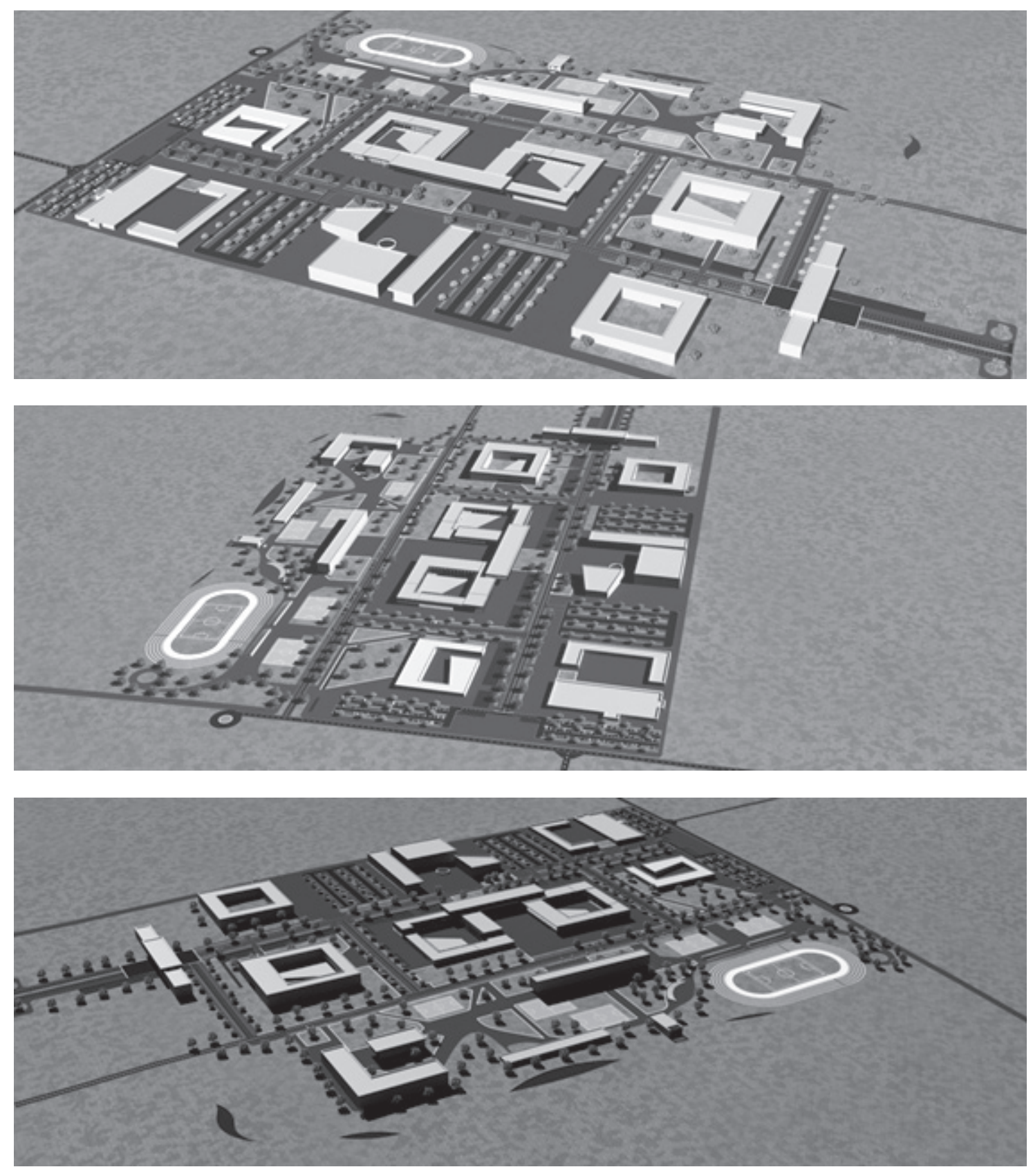

Figuras $173 \mathrm{~b}$, c e d. Plano Urbanístico do Campus da Fub desenvolvido por

Frederico Holanda

Gabriela Tenório e Viridiana Gomes. 


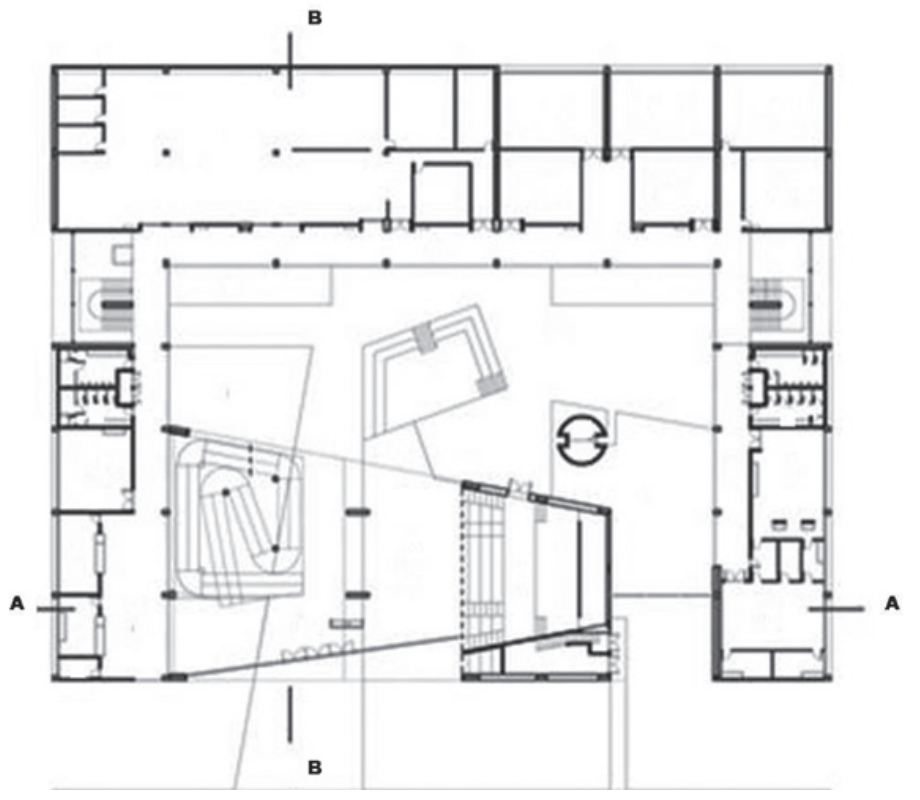

Figura 173 e.

Planta do térreo da

Figura $173 f$

Corte AA

Figura $173 \mathrm{~g}$

Corte BB

Figuras $173 \mathrm{~h} \mathrm{e} \mathrm{i.}$

Vistas gerais da UEA
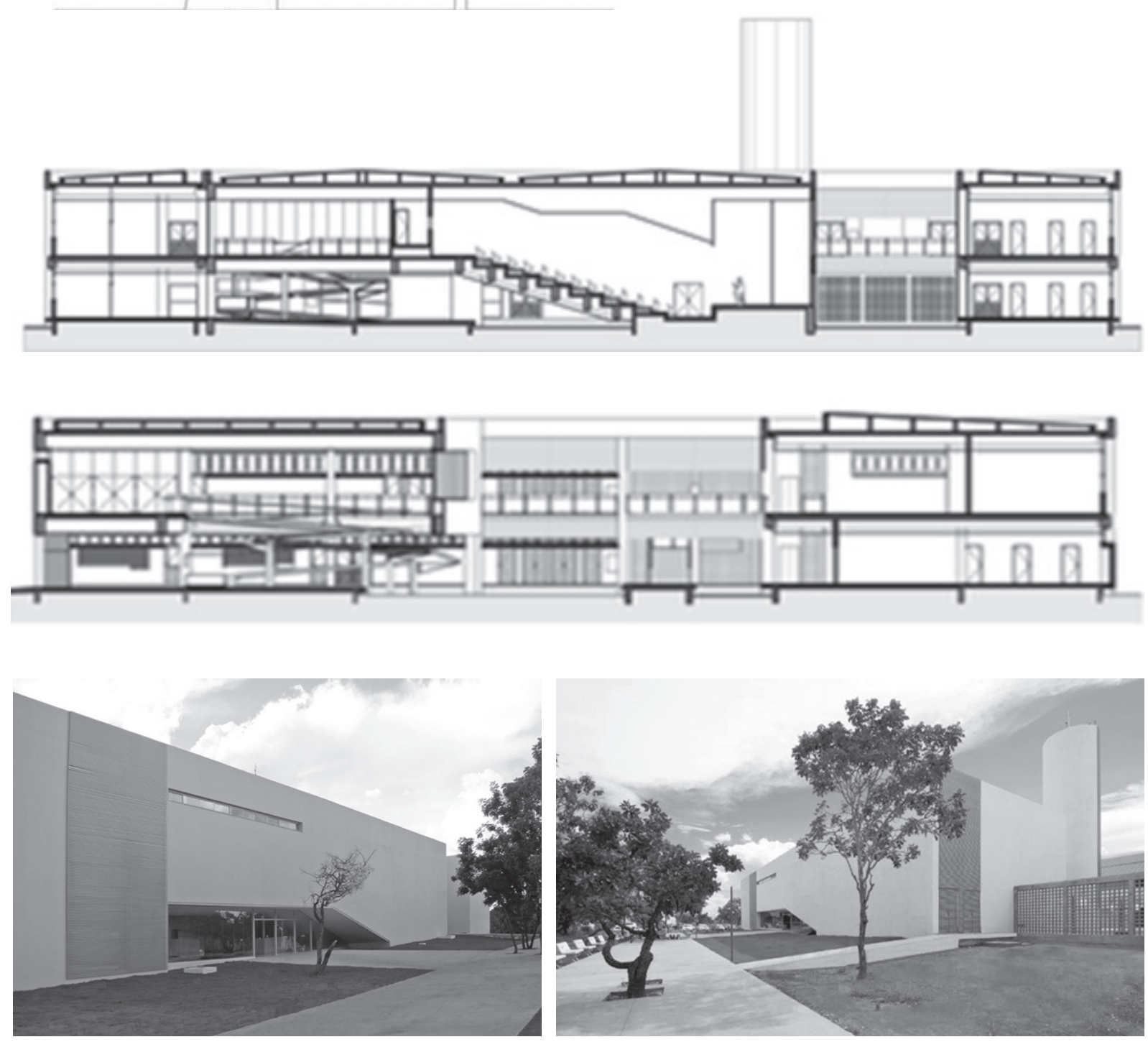
FACULDADE UnB CEILÂNDIA (FCE)

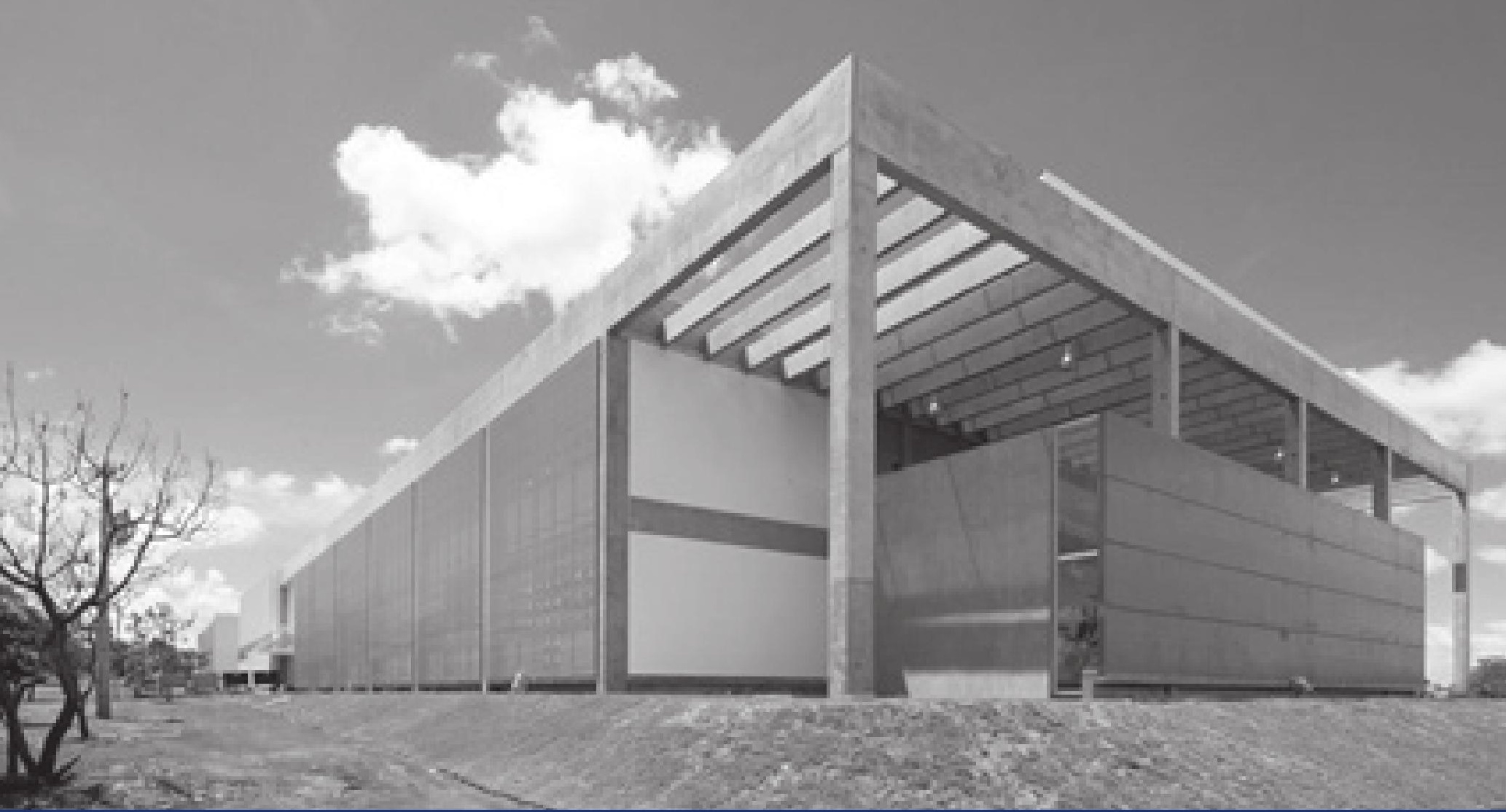

Autoria

Alberto Alves de Faria, Fabiana Couto e Fátima Pires Lauria

Data

2007 (projeto)

2008 (obra)

Área Total do Campus

$199.499 \mathrm{~m}^{2}$

Área Construída

$4.485 \mathrm{~m}^{2}$ (UED); $4.795 \mathrm{~m}^{2}$ (UAC); $2.026 \mathrm{~m}^{2}$ (MESP) 
Na Unidade de Ensino e Docência (UED) ${ }^{1}$ estão localizadas as salas dos professores, coordenadores e a direção do campus. Também se encontram nessa unidade os principais laboratórios e a Enfermaria. A Unidade Acadêmica (UAC) abriga as salas de aula, bem como o auditório, a biblioteca e os espaços de convivência dos alunos. No Módulo de Serviços e Equipamentos Esportivos (Mesp) ficam o Restaurante Universitário (RU) e uma fotocopiadora. Esse módulo tem como anexo uma quadra poliesportiva aberta a todos².

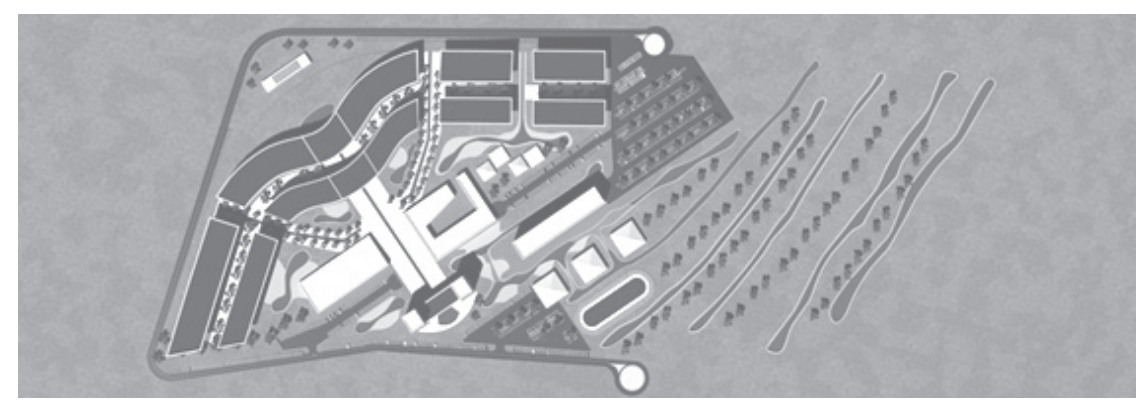

Figuras174b.

Plano Urbanístico

desenvolvido por

Marta Romero e Liza

Andrade.

Figuras174c, d, e e.

Vistas do Plano

Urbanístico
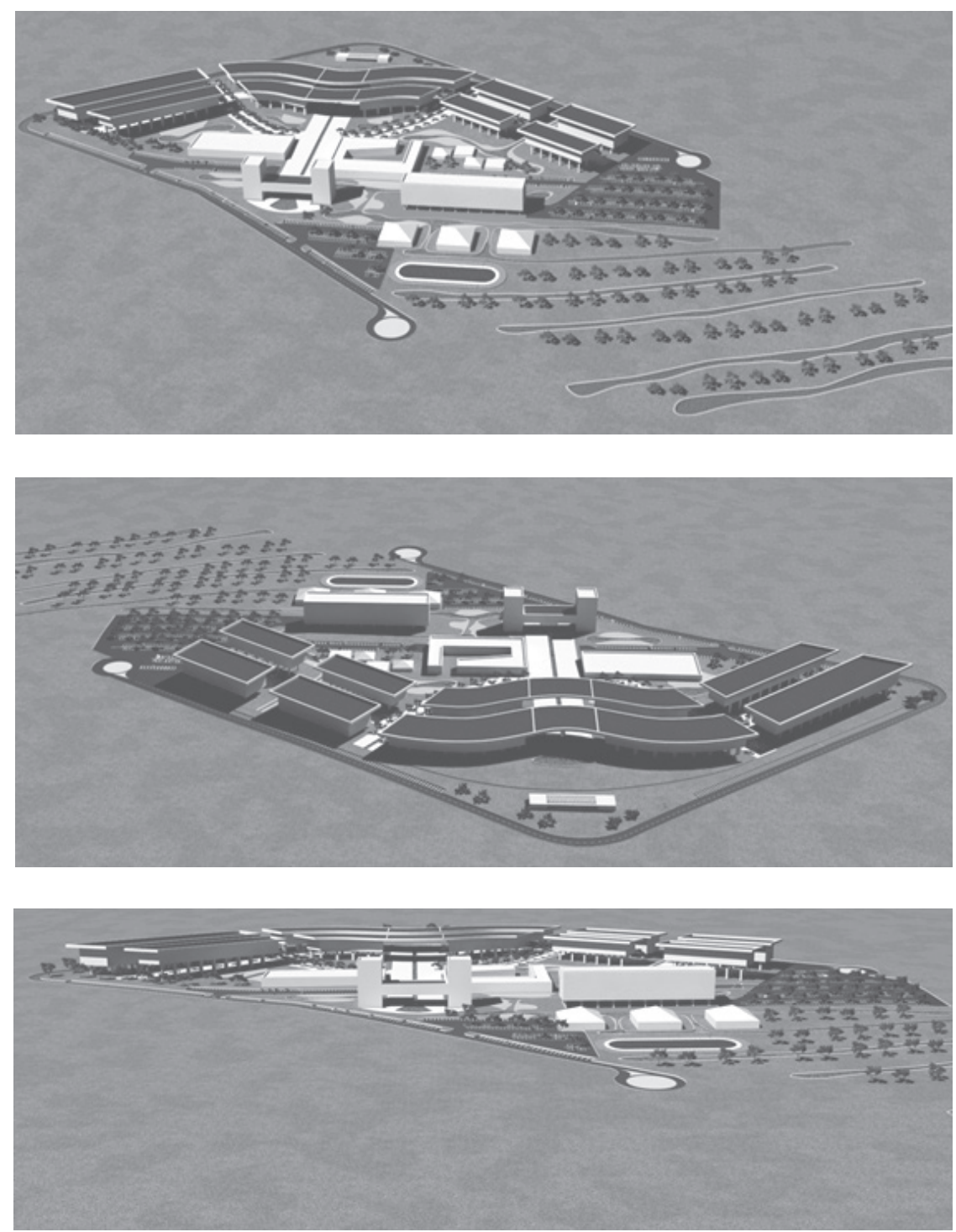

1 Pela Lei Complementar n. 649, de 16 set. 2002, o Governo do Distrito Federal cedeu um terreno de aproximadamente 20 hectares, na RA IX, para abrigar as instalações definitivas do campus da UnB na Ceilândia.

2 Além desses espaços, a FCE conta também com um prédio localizado ao lado do Centro de Ensino Médio 4, na QNN 14 da Ceilândia Sul, o qual também dispõe de salas de aula e laboratórios. 
O campus atenderá seis regiões administrativas do DF e oito municípios goianos. Essa unidade da UnB oferece cursos voltados para a área de saúde.

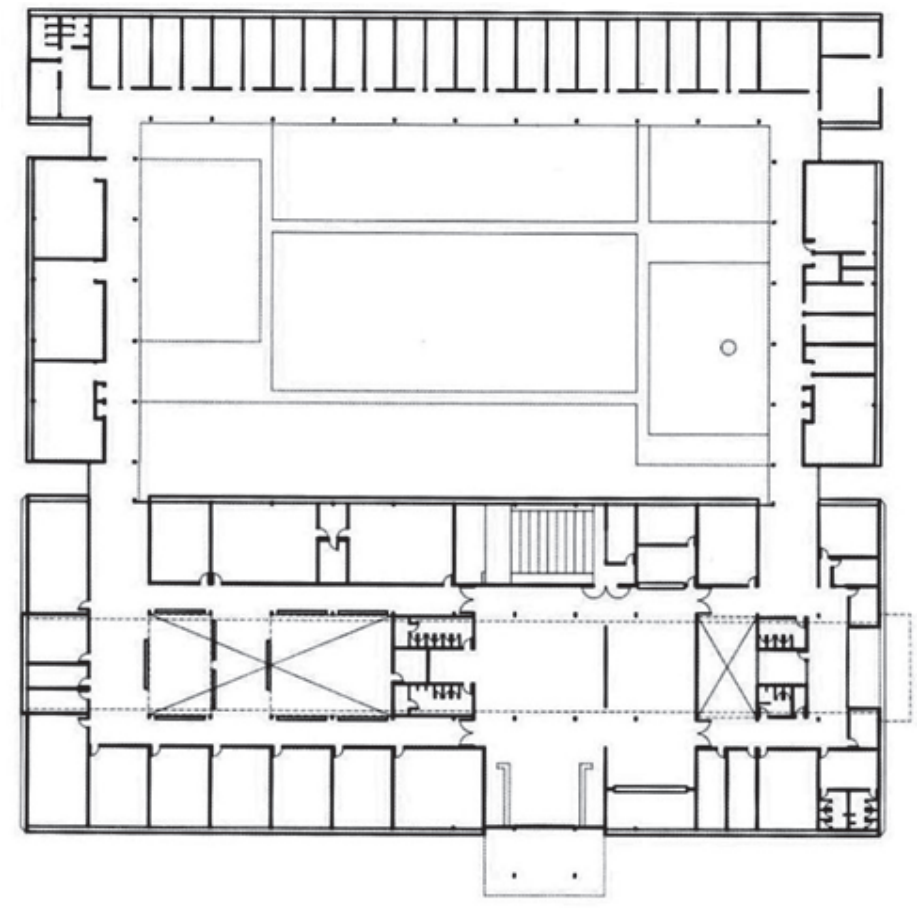

Figura 173f.

Planta do térreo

da UAC

Figuras $173 \mathrm{f} \mathrm{e}$

Vistas da UAC

A Unidade de Ensino e Docência (UED) possui, no nível térreo, secretarias de cursos, cantina, auditório e laboratórios; e, no pavimento superior, salas para grupos de professores. A integração visual entre os ambientes é garantida por três pátios internos.
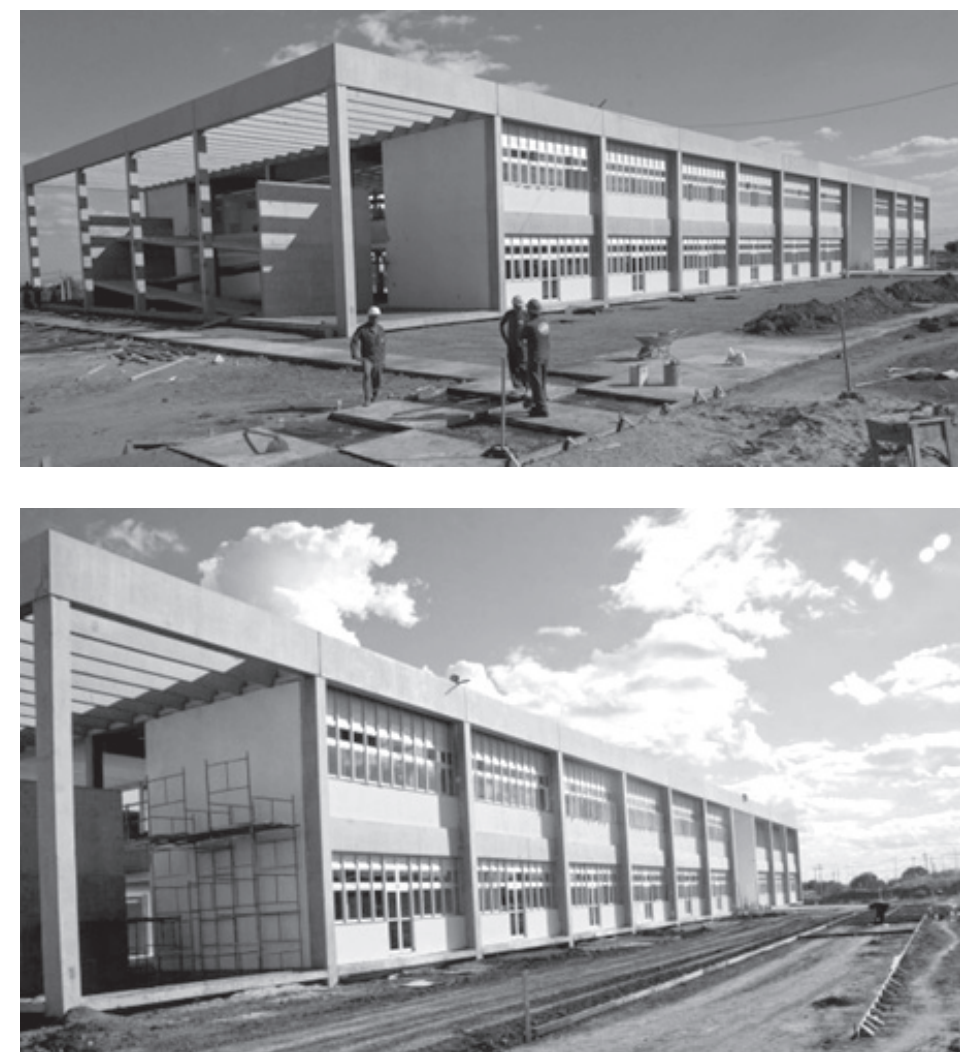

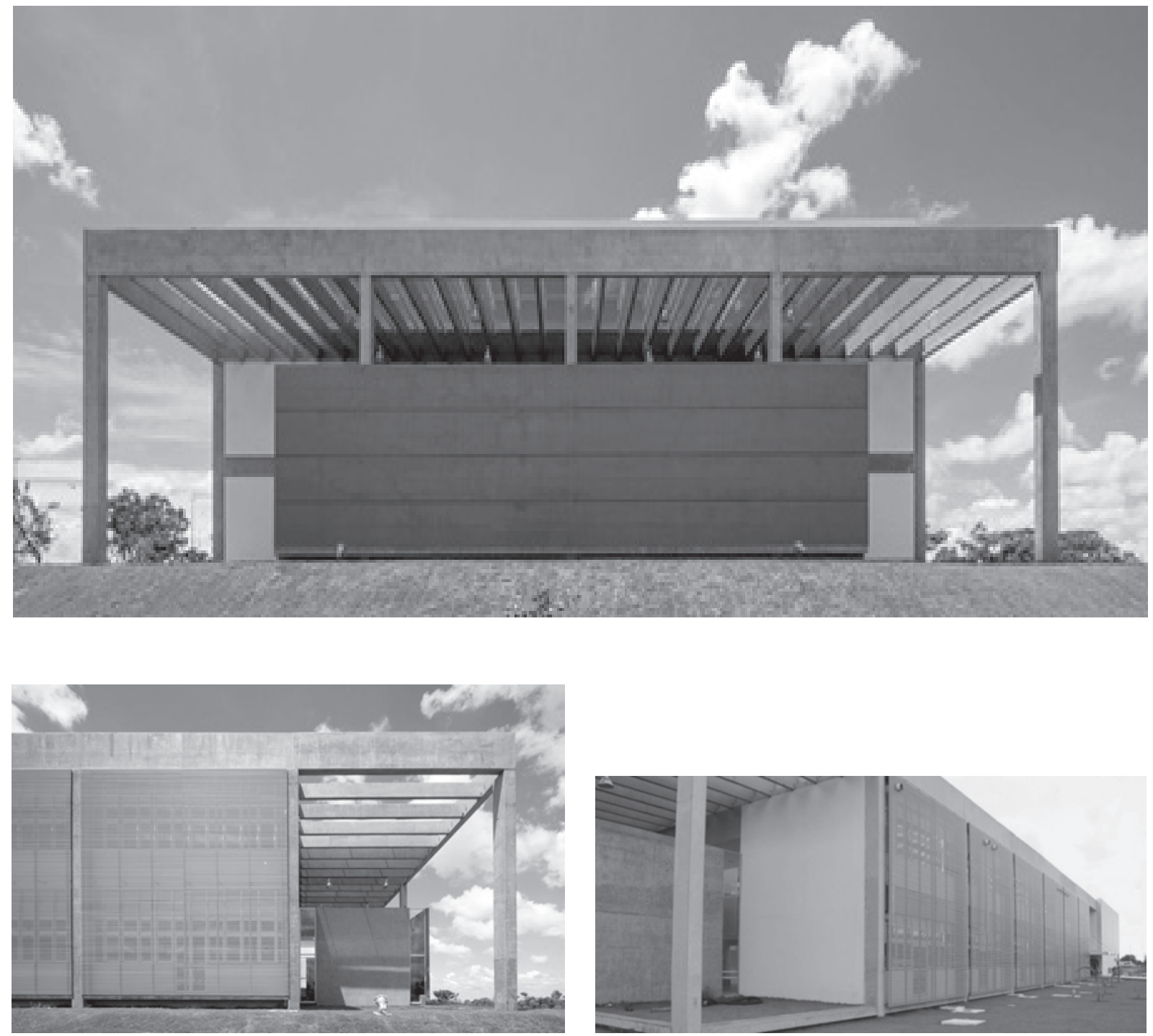

Para garantir segurança e controle, o acesso é feito por um único hall.

A circulação vertical se dá por meio de uma grande rampa e três núcleos dotados de escadas e elevadores para portadores de necessidades especiais. O conjunto de sanitários concentra-se na parte central da edificação, próximo à circulação vertical principal.

Figuras $174 \mathrm{~h}$. Vista da UAC

Figuras $174 \mathrm{i}$ e j.

Vistas da UED

Figuras $174 \mathrm{k}$ e l. Vista do pátio central da UED
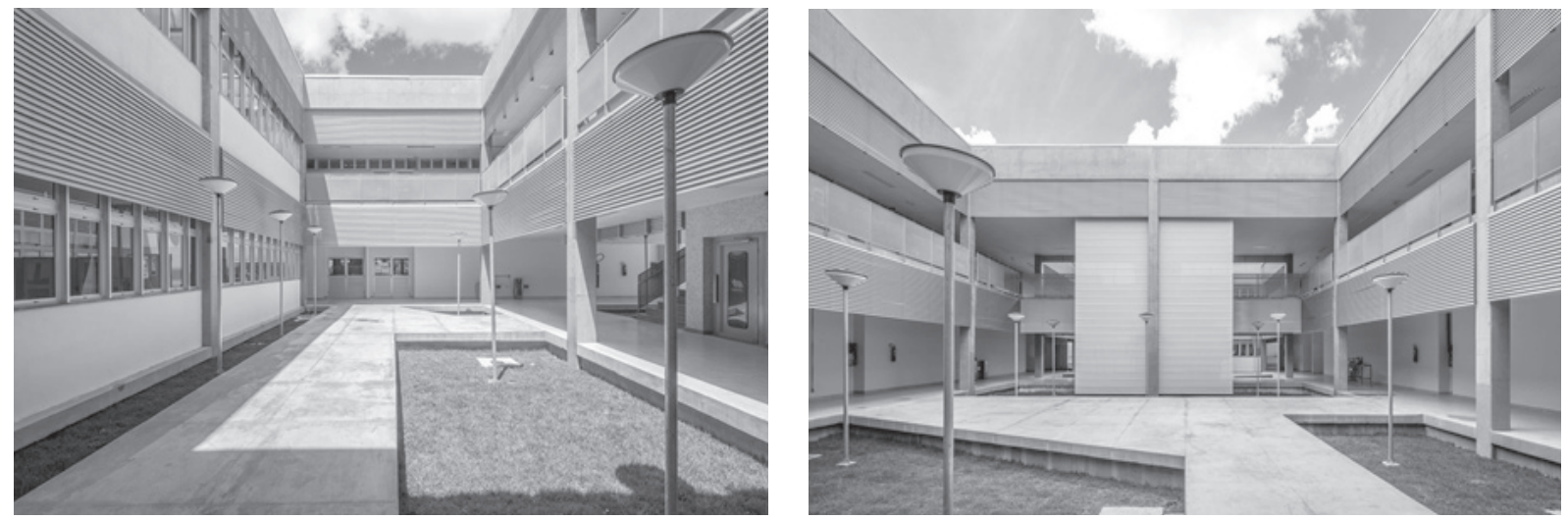
FACULDADE UnB GAMA (FGA)

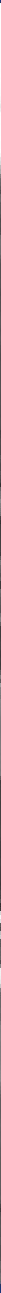

Autoria

Alberto Alves de Faria, Fabiana Couto Garcia, Fátima Lauria Pires

Data

2008 (projeto)

2011 (conclusão do primeiro edifício)

Área Total do Campus

$335.534 \mathrm{~m}^{2}$

Área Construída

$4.485 \mathrm{~m}^{2}$ (UED); $4.795 \mathrm{~m}^{2}$ (UEA); $967 \mathrm{~m}^{2}$ (Mesp). 
A Unidade de Ensino e Docência (UED) abriga as salas de aula, bem como o auditório, a biblioteca e os espaços de convivência dos alunos. Na Unidade de Ensino e Administração (UEA) estão localizadas as salas dos professores, coordenadores e a direção do campus. Também se encontram nessa unidade os principais laboratórios e a Enfermaria. No Módulo de Serviços e Equipamentos Esportivos (Mesp) ficam o Restaurante Universitário (RU) e uma fotocopiadora. Esse módulo tem como anexo uma quadra poliesportiva aberta a todos.
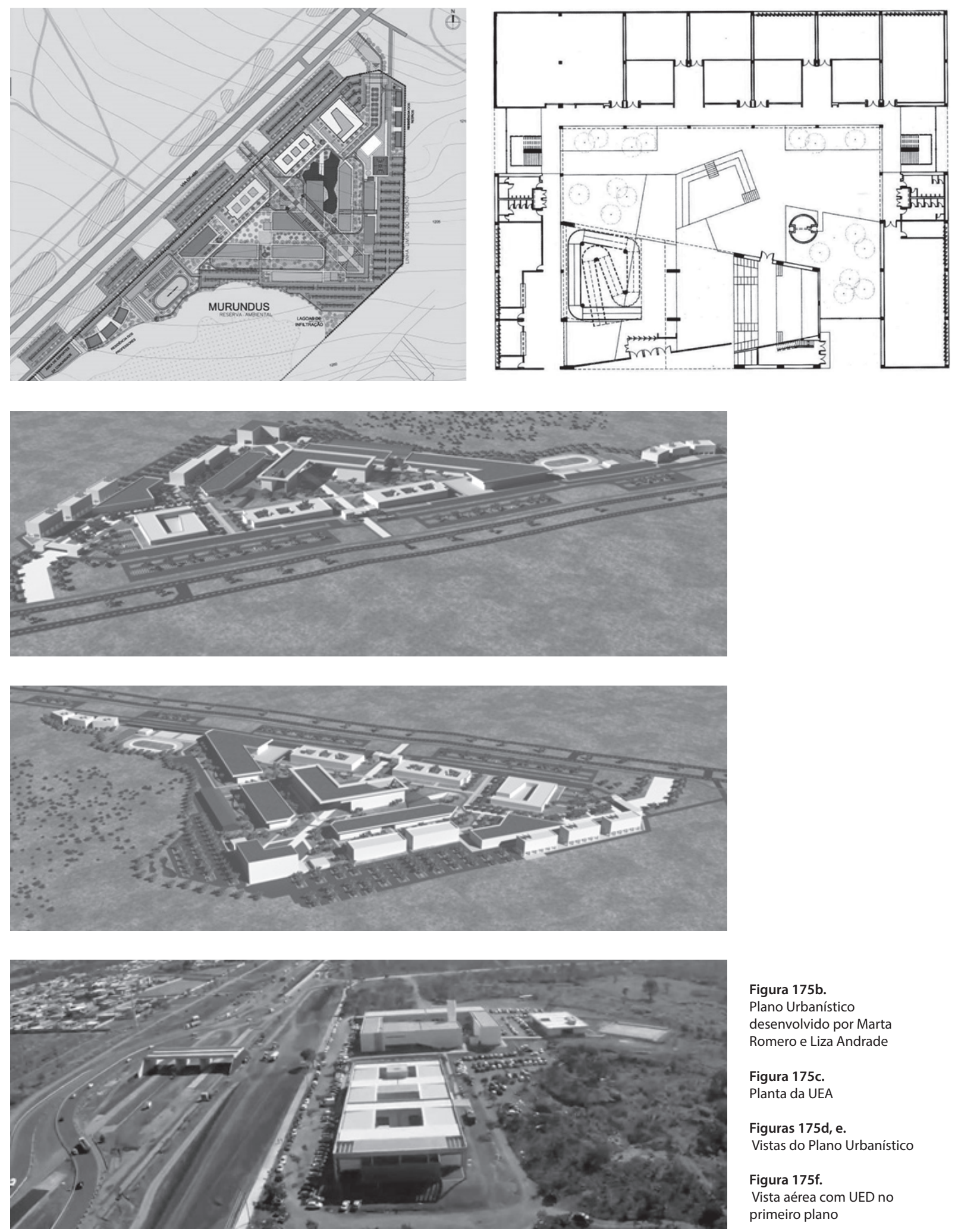

Figura 175b.

Plano Urbanístico

desenvolvido por Marta

Romero e Liza Andrade

Figura 175c.

Planta da UEA

Figuras 175d, e.

Vistas do Plano Urbanístico

Figura $175 f$.

Vista aérea com UED no

primeiro plano 

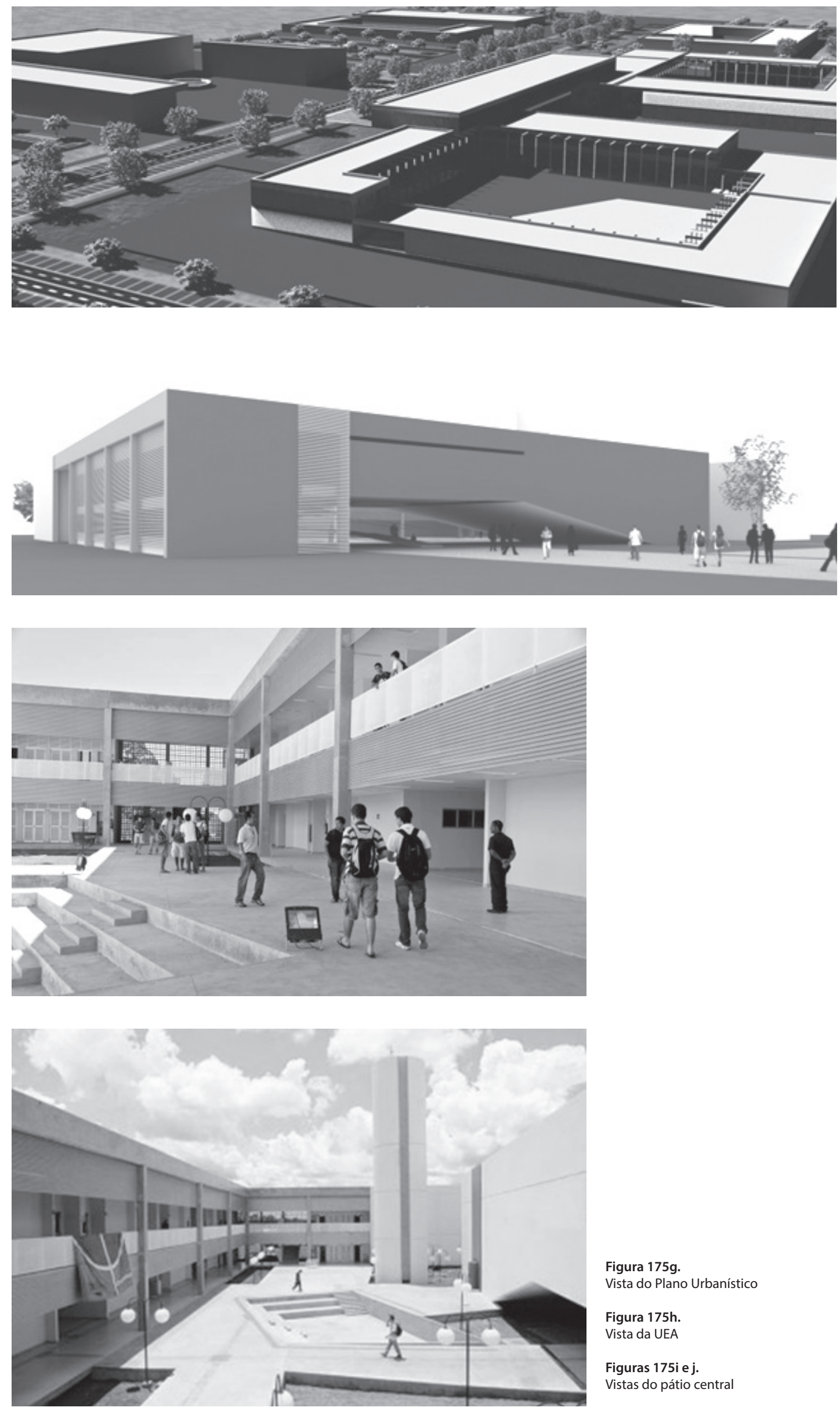

Figura $175 \mathrm{~g}$

Vista do Plano Urbanístico

Figura 175h.

Vista da UEA

Figuras $175 \mathrm{i} \mathbf{e}$.

Vistas do pátio central 

CONCLUSÃO 

Pretendeu-se, no presente trabalho, resgatar a história do Centro de Planejamento Oscar Niemeyer (Ceplan) da Universidade de Brasília, que, desde sua fundação, assumiu para si parte das responsabilidades do projeto de desenvolvimento do país.

Apesar do discurso de JK no dia da inauguração de Brasília - "Nosso parque industrial e nossos quadros técnicos apresentavam condições para traduzir no betume, no cimento e no aço as concepções arrojadas da arquitetura e do planejamento urbanístico modernos" (apud PINTO, 2010, p. 52) -, não foram poucas as dificuldades para garantir o cumprimento dos prazos das obras da nova capital. A necessidade inclusive de importar tecnologia estrangeira demonstrou que era preciso investir na modernização da construção civil, para que esta se tornasse capaz de produzir com qualidade e em quantidade suficiente para atender às demandas nacionais por habitação, educação, saúde etc.

Brasília, com seu plano urbanístico inovador e sua arquitetura arrojada, estimulou o sonho de um Brasil mais próspero e livre de suas históricas carências. Os planos de educação, saúde, segurança, alimentação, as unidades de vizinhança, a forma diferenciada de apropriação do solo urbano propostos para a nova capital constituíam os novos modelos a serem apropriados pela nação, conforme se pode deduzir da fala do presidente: "[...] a construção da nova Capital representou o estabelecimento de um núcleo, em torno do qual se vão processar inúmeras realizações outras, que ninguém negará fecundas em consequências benéficas para a unidade e a prosperidade do país" (apud PINTO, 2010, p. 52).

E foi sobre a utopia de um Brasil novo que se assentaram os alicerces da Universidade de Brasília. Reunindo em torno de seu projeto e sua implantação muitos dos maiores nomes das ciências humanas e exatas do país, a UnB constituía então uma oportunidade única para reorientar todo o sistema universitário brasileiro, preparando-o para formar quadros superiores capazes e mais aptos a enfrentar uma nova realidade política e social. A Universidade de Brasília não foi concebida para ser apenas mais uma, e sim aquela instituição devidamente preparada para, como afirmou Darcy Ribeiro, "[...] criar intencionalmente elites novas, orgulhosas do patrimônio que herdamos do passado - um território continental e um povo multitudinário, unificado em uma nação cheia de vontade de felicidade e de progresso [...] pronta para florescer como uma nova civilização" (1991, p. 17). 
Assim, o Ceplan, diferentemente do escritório técnico de arquitetura fundado, por exemplo, na Universidade de São Paulo na década de $1950^{1}$, já nasceu com uma tripla missão: primeiro, com foco no presente, ou seja, nas demandas da época, projetar e executar no ermo e longínquo Cerrado as edificações necessárias para abrigar as atividades do novo campus universitário; segundo, como parte do projeto político-pedagógico da nova universidade, funcionar como suporte para a prática profissional dos professores da Faculdade de Arquitetura e Urbanismo (FAU), e também para os instrutores e estudantes; e, terceiro, vislumbrando o futuro, buscar, por meio do desenvolvimento de tecnologia, soluções para os problemas da nação brasileira, carente de habitações e equipamentos de uso social.

Além das construções para abrigar as atividades da universidade emergente, o Centro de Planejamento deveria se impor como referência na pesquisa e produção da arquitetura. Isso fazia com que, indo além do desempenho de suas respectivas funções, os edifícios devessem significar contribuições expressivas no campo da geração de tecnologia construtiva.

No entanto, apesar de suas amplas e diferenciadas atribuições e do seu longo tempo de existência, até o momento o Ceplan não havia sido objeto de um estudo mais aprofundado, pois os trabalhos acadêmicos têm se concentrado, via de regra, em análises de exemplos pontuais resultantes da produção de profissionais que o povoaram. Além disso, em decorrência das várias crises por que passou a Universidade de Brasília, à falta de uma historiografia mais sistematizada sobre o tema somaram-se a perda e a destruição de boa parte dos documentos e registros acumulados no e sobre o Ceplan.

A precariedade de dados, em decorrência da falta de um acervo organizado e disponibilizado para consultas, não somente fez com que o tema se tornasse ainda mais instigante como foi responsável pela metodologia aqui utilizada, baseada, principalmente, no resgate e na costura dos recortes refugiados nas memórias de profissionais que, de uma forma ou de outra, mantiveram vínculos de trabalho com o Ceplan. Durante as entrevistas realizadas, além da coleta de informações, foi possível perceber as emoções dos arquitetos ao se referirem à sua contribuição pessoal para a produção da arquitetura que ali teve lugar.

Os diversos relatos desses profissionais não escondem o prazer do pertencimento ao grupo de projetistas/construtores, conduzindo ao que Nora (1993) chamou de "vontade de memória" ou "intenção de memória", a qual, somada à produção materializada em pedra e cal, dentro e fora do território do campus universitário, permitiu reafirmar o Ceplan como um "lugar de memória".

Em um mundo onde tem prevalecido a rápida obsolescência de coisas e valores, onde o descartável se impõe, parece importante promover a iluminação de lugares portadores de uma memória significativa capaz de preencher lacunas da história e de reconstruir identidades pessoais. Segundo Nora (1993), o mundo contemporâneo tem dificultado o sentido de pertencimento, fazendo com que o homem-memória seja substituído pelo lugar de memória. É o lugar onde um coletivo se reúne, trabalha, estuda, produz que permite que os seus participantes se reconheçam e readquiram sua identidade.

Alguns dos arquitetos-professores entrevistados não deixaram dúvidas sobre o compromisso e o envolvimento com a missão que a participação no Ceplan Ihes impôs, reconhecendo nesta o tão sonhado alcance social.

${ }^{1}$ Em 1944 foi criada uma comissão para a construção da Cidade Universitária da Universidade de São Paulo na capital do estado de São Paulo, que em 1956 recebeu o nome de Cidade Universitária Armando de Salles Oliveira (Cuaso). Essa comissão gerou a formação do Escritório Técnico 
O projeto mais ousado, entre muitos outros que não foram realizados, foi o da construção de uma fábrica de pré-moldados, que constituiria um laboratório de pesquisas no campo da construção civil... (LÉLÉ, entrevista em 22 fev. 2012).

[...] o Ceplan poderia ter colaborado com a cidade. Provavelmente, ter ajudado no planejamento das cidades-satélite, para que tivessem um desenvolvimento mais de acordo com o padrão urbanístico de Brasília. Isso não foi adiante, mas era uma ideia também, disso tudo ser desenvolvido na escola e no Ceplan (PESSINA, entrevista em 1 dez. 2011).

Aquela que poderia ter sido uma experiência rica, inspirada na Bauhaus, foi esvaziada. Ficou restrita a departamentos isolados, de Música, Artes Plásticas, Arquitetura e Urbanismo... (ZIMBRES, entrevista em 26 out. 2011).

[...] todos tinham o viés social e consciência disso. Pois se manifestava ali, de uma forma geral, que devíamos usar as obras como um experimento, uma pesquisa, de pré-moldagem, ou no mínimo de racionalização da construção, com vistas ao problema habitacional brasileiro, que era muito grave etc. E o exemplo estava na nossa frente, o ICC em construção; o Ceplan totalmente pré-moldado, montado, projeto muito bonito; a Colina; os SGS (GALBINSKY, entrevista em 20 fev. 2012).

Em muitos casos, a consciência sobre o caráter profissional, pedagógico e visionário do Ceplan misturou-se a um sentimento de orgulho, de honra, por se ver como parte integrante de um projeto transformador da universidade e do país.

Os depoimentos dos entrevistados diferenciam o Ceplan de um lugar que Nora (1993) chamou de"meramente digno de lembrança", ou seja, um lugar onde não seria possível detectar ou rastrear os investimentos humanos, um lugar onde não haveria "vontade" ou "intenção de memória". Pelo contrário, as manifestações dos arquitetos, muitas permeadas de forte carga emocional, trouxeram evidências de que o Ceplan é um verdadeiro "lugar de memória", isto é, uma unidade significativa, de ordem material ou ideal, que a vontade dos homens ou o trabalho do tempo converteu em elemento simbólico do patrimônio memorial de uma determinada comunidade, no caso a da Universidade de Brasília.

Nesse sentido, os estudos sobre o Ceplan remetem ao conceito de memória institucional, um marco referencial, cujo resgate permite que as pessoas, como elos da instituição da qual fazem ou fizeram parte, redescubram vivências e valores do passado, estreitem seus vínculos e, inclusive, passem a rever ou fazer planos para o futuro.

Cada vez mais, o sentimento do desaparecimento rápido conjuga-se a uma preocupação com o significado do presente e a incerteza do futuro, o que confere aos testemunhos em geral a dignidade do memorável. Para Nora, "São hoje as empresas privadas e as administrações públicas que engajam arquivistas com a recomendação de guardar tudo [...] e, com isso, a materialização da memória dilatou-se, descentralizou-se, democratizou-se" (1993, p. 15).

Acredita-se atualmente que a memória institucional, ao reforçar o sentimento de pertencimento e de identidade e ao permitir que as pessoas se vejam como parte de uma construção coletiva, concorre para manter a vitalidade e a preservação das instituições públicas ou privadas, garantindo a transparência de suas ações e conquistas. Nesse sentido, o Ceplan constitui um patrimônio cultural que merece ser preservado e permanecer vivo e atuante tanto para as futuras gerações de arquitetos-professores da Faculdade de Arquitetura da Universidade de Brasília, hoje carentes de 
uma prática profissional sistemática e continuada, como para os estudantes que são os maiores beneficiários dessa prática.

Ao longo do desenvolvimento deste trabalho, produzido por meio de uma exaustiva revisão bibliográfica, pelo mergulho nos discursos pessoais e pela análise de cada um dos edifícios que compõem o patrimônio materializado da Universidade de Brasília, persistiu a sensação de que o Ceplan foi, aos poucos, se distanciando de seus objetivos iniciais, de tal forma que só foi possível contemplar a totalidade de sua trajetória mediante sua subdivisão em períodos diferenciados.

No primeiro momento, de 1962 a outubro de 1965, a racionalização e a industrialização da construção se impuseram como o desafio maior a ser vencido pela equipe responsável pelos projetos. Em que pese sua qualidade plástica e funcional, os edifícios construídos nos tempos pioneiros não deixam dúvida sobre o caráter experimental da arquitetura então produzida. Embora a unidade do território universitário tenha sido garantida por uma correta implantação, pela manutenção da escala, pela singeleza dos partidos arquitetônicos e pelo uso comedido dos materiais, a diversificação dos sistemas construtivos demonstra o caráter experimental de um trabalho sistemático em busca de novas conquistas.

Nas mãos daqueles arquitetos visionários, a pré-fabricação transformou-se na possibilidade da construção de peças de montar que, em um experimento quase lúdico, iam abrigando isto e aquilo que se fizesse mais necessário e urgente para o funcionamento do cotidiano universitário. Era preciso dar abrigo aos professores que chegavam a todo momento; alojamento e restaurante para os estudantes que deixaram suas cidades de origem em busca de uma formação diferenciada; e salas e laboratórios para que as aulas não fossem mais adiadas. À medida que esses equipamentos iam sendo implantados no território universitário, as pesquisas que os originaram se desdobravam, nas pranchetas dos arquitetos, em soluções para habitações, escolas etc. fora dos limites do campus.

Ao mesmo tempo, os desenhos com uma maior carga simbólica, destinados aos edifícios emblemáticos da universidade, como a Reitoria, a Praça Maior, a Biblioteca e o Museu, aguardavam à espera do momento certo para se tornarem realidade.

Mas o golpe de 1964 veio antes que isso tivesse acontecido. E com ele, foi-se o sonho da pré-fabricação. O governo militar deixava claro o seu desinteresse em modernizar o setor da construção civil; tratava-se, ao contrário, de mantê-lo arcaico para que pudesse absorver a mão de obra da grande massa de trabalhadores sem qualquer qualificação e historicamente mal pagos.

Nem a endêmica falta de moradias, denunciada na famosa carta de Sandra Cavalcanti ${ }^{2}$ endereçada ao presidente general Humberto Castelo Branco em 1964, serviu para que a construção tomasse um novo rumo no país.

[...] nós achamos que a Revolução vai necessitar agir vigorosamente junto às massas. Elas estão órfãs e magoadas, de modo que vamos ter de nos esforçar para devolver a elas uma certa alegria. Penso que a resolução dos problemas de moradia, pelo menos nos grandes centros, atuará de forma amenizadora e balsâmica sobre as suas feridas cívicas (apud TRINDADE, 1971, p. 12).

Embora a industrialização fosse a solução adequada para enfrentar tão larga escala de produção, a manutenção e ampliação dos postos de trabalho, capaz também de funcionar como um bálsamo

${ }^{2}$ Sandra Cavalcanti foi deputada estadual da UDN na Assembleia Legislativa da Guanabara, politicamente vinculada a Carlos Lacerda, em cujo governo se tornaria secretária de Serviços Sociais e realizaria um trabalho na Companhia de Habitacional da Guanabara. 
para as "feridas cívicas", fez com que o Banco Nacional da Habitação optasse pela construção convencional na produção de moradias populares. No rastro dessa lógica às avessas, no Ceplan desfazia-se o compromisso pioneiro com a inovação e a industrialização da construção civil, e caía por terra talvez a mais importante de suas três missões.

Após o período das permanentes crises políticas, que se estendeu de outubro de 1965 a dezembro de1968, quando praticamente nada foi projetado e construído, o Ceplan tentou se reerguer para continuar atendendo às demandas da Universidade de Brasília, que, agredida em sua integridade, privada de autonomia institucional e de liberdade decisória, era abonada com recursos financeiros para investimento na sua consolidação física. Sem a possibilidade de investir na produção de conhecimentos no campo da modernização da construção, os novos integrantes do Ceplan se debruçaram sobre o brutalismo, que, tendo despertando o interesse dos arquitetos nas duas décadas precedentes, era identificado com uma linguagem arquitetônica afinada com produção em massa.

Ao contrário do período anterior, nesse momento a Administração Central da Universidade tornava prioritária a construção dos edifícios mais representativos e, portanto, mais visíveis, como, por exemplo, a Biblioteca e a Reitoria. Ficava adiada, no entanto, a construção dos grandes espaços de convivência e dos auditórios da Praça Maior, para evitar as concentrações de estudantes, na época bastante mobilizados contra a ditadura. Por essa mesma razão, os alojamentos de estudantes foram transferidos para áreas mais distantes do coração da universidade.

Na produção desse período, que durou de 1969 a 1984, apesar das batalhas travadas com a Administração Central, que interferia diretamente na produção dos arquitetos, buscou-se, por meio da adaptação à topografia e à manutenção de áreas livres no entorno dos edifícios, seguir as diretrizes de implantação preexistentes. A discrição na escolha dos materiais e o respeito às cotas de coroamento e aos alinhamentos fizeram com que a unidade arquitetônica do campus se mantivesse preservada. Com sua feição brutalista, os edifícios da Reitoria e da Biblioteca não destoam do Minhocão (ICC), também caracterizado pela verdade do sistema estrutural e pelo uso aparente dos materiais, sobretudo do concreto armado.

Com a aprovação do novo Estatuto, em 13 de março de 1970, o Ceplan, renomeado Laboratório Experimental de Arquitetura e Urbanismo (Leau), passou a ser vinculado institucionalmente à FAU. A despeito dessas mudanças, as duas outras missões do Ceplan - projeto e construção dos edifícios do campus e oferta de oportunidades para a prática profissional de professores e alunos da Faculdade de Arquitetura e Urbanismo -, foram mantidas. E a importância dessas duas frentes de atuação é destacada nos depoimentos dos arquitetos entrevistados:

[...] era uma condição imposta para a nossa vinda: atuar em dedicação exclusiva e a prática assegurada no Ceplan. Só aceitei o convite para integrar o corpo docente da UnB com essa condição (ZIMBRES, entrevista em 26 out. 2011).

[...] era considerada por nós uma questão de honra que todos os projetos do campus fossem elaborados pelos professores da Arquitetura. Isso permitia unir a prática com a proposta pedagógica do curso, que inclusive previa isso (GALBINSKY, entrevista em 20 fev. 2012). 
No entanto, com a desvalorização dos ciclos básicos e dos institutos centrais, o campus passou a ser paulatinamente ocupado pelos edifícios das diversas faculdades profissionalizantes, como as de Tecnologia, Ciências Médicas, Direito e Administração.

No período seguinte, que se estendeu de 1984 ao final de 1999, apesar da eleição para reitor, da reintegração dos professores que participaram da demissão coletiva em 1965 e de uma maior abertura democrática, as sucessivas crises que o país atravessou, com a inflação em alta, os escândalos e o consequente impeachment de Collor contribuíram para refrear o ritmo das obras no campus, mesmo com um aumento real do número de vagas nas universidades públicas e particulares.

$\mathrm{Na}$ UnB, o início das parcerias público-privadas repercutiu nas atividades do Ceplan, que, batizado de Centro de Planejamento Oscar Niemeyer em homenagem ao seu primeiro coordenador, passou a projetar também edifícios e instalações para empreendimentos privados a serem implantados no campus. As novas demandas e os apertados prazos para conclusão das obras levaram à contratação de arquitetos e engenheiros de fora da universidade, o que de certa forma constituiu uma primeira ameaça à missão pedagógica do Ceplan.

Além disso, a efetiva implantação da Prefeitura do Campus, criada em 1986, implicou uma sobreposição de funções, com prejuízo para o funcionamento do Centro. Dotada de um quadro efetivo de profissionais arquitetos e engenheiros, a Prefeitura podia dar respostas mais rápidas às demandas da universidade. Subutilizado e exposto a maus-tratos, o Ceplan teve sua situação agravada ainda pela rotatividade na sua direção - durante esse período, ocuparam a Direção do Ceplan nove arquitetos.

No que diz respeito ao patrimônio edificado no período, as novas demandas, a contratação de profissionais externos e as obras realizadas pela Prefeitura conduziram paulatinamente a uma quebra da unidade do conjunto universitário, expressa fisicamente por novas tipologias arquitetônicas e pelo uso de diferentes materiais e técnicas construtivas. Rompia-se ainda o espírito de equipe que, a despeito das vaidades autorais, ainda havia prevalecido no Ceplan.

Durante o último período considerado neste trabalho, entre 2000 e 2012, ano em que o Ceplan completou o seu cinquentenário, este, novamente vinculado à Administração Superior da Universidade, foi chamado a participar da implementação física do Plano UnB 21, que tratava da expansão da instituição como um todo e da solução dos problemas dos cursos que haviam ampliado suas atividades e não cabiam mais nos espaços que lhes foram destinados no ICC. O que poderia ter resultado em uma firme determinação de concluir e revitalizar o Minhocão, edifício mais emblemático do campus e inacabado desde 1965 devido à demissão coletiva dos professores da FAU, perdeu para a opção de construir edifícios novos, inicialmente com recursos provenientes da venda de imóveis da UnB, e, a partir de 2007, com recursos do Programa de Apoio a Planos de Reestruturação e Expansão das Universidades Federais (Reuni).

Devido ao grande volume de área a ser edificada, chegou a se aventar a possibilidade de retomar as pesquisas de pré-fabricação com a construção de uma unidade de produção no campus, ideia logo deixada de lado e substituída pela adoção da industrialização de ciclo aberto, baseada na compra de elementos pré-moldados já prontos no mercado. Com isso, a universidade perdeu a oportunidade de retomar seu compromisso original com a inovação. 
Deixando pouca margem para a criatividade e as especulações plástico-formais, esse sistema acaba produzindo edifícios similares entre si, carentes de identidade própria e desprovidos de plasticidade e de compromisso com o seu tempo. Ao que tudo indica, a vantagem significativa do sistema industrializado de ciclo aberto para as construções do campus foi a economia de tempo, pois, segundo Farias, diretor do Ceplan à época, "[...] a escolha do pré-fabricado encareceu o projeto", o que é justificado pela compra de tecnologia desenvolvida fora da universidade.

No afã de construir mais em menos tempo e em que pese a incansável atividade desenvolvida pelos técnicos do Ceplan, o campus da UnB foi se tornando paulatinamente um extenso agrupamento de prédios que, embora possam cumprir satisfatoriamente as funções para os quais foram projetados, estão longe de se constituírem em exemplares arquitetonicamente expressivos.

Entre esses edifícios cabe destacar, sobretudo, os blocos de salas de aula que, resultantes de uma política implantada entre 1999 e 2000, são atualmente presenças marcantes no campus. Sem identidade própria, os grandes volumes configuram o que Augé chamou de "não lugar", ou seja, um espaço transitório, de passagem, de permanência provisória, que tanto professores como alunos não são capazes de chamar de seu. Não estão próximos de nada, secretarias, departamentos, salas de professores... Não sendo parte de nada, instituto, faculdade, centro..., não despertam tampouco a sensação de pertencimento.

Com a democratização cada vez maior da Universidade de Brasília, representada pelo aumento do número de vagas e pela política de cotas, fica evidente a necessidade de espaços de permanência e de acolhimento sobretudo para os muitos e muitos alunos que moram distante da universidade e têm que enfrentar diariamente longos percursos.

Torna-se ainda mais difícil compreender o sentido desses blocos de aula quando eles, contrariando os princípios originais de UnB, coincidiram com o esvaziamento dos cursos básicos e com a construção sistemática de faculdades e institutos isolados, dotados, portanto, de seus espaços especializados.

A quebra da unidade arquitetônica, herdada do período anterior, somada aos conflitos referentes aos alinhamentos entre as edificações, ao aumento das cotas de coroamento e ao rápido adensamento, concorreu para transformar a feição do Campus Darcy Ribeiro, anteriormente mais rarefeito como convém à escala bucólica onde está inserido. Não se pode esquecer que a preservação dessa escala está diretamente relacionada à relação entre as áreas construídas e as áreas verdes.

Quanto ao Ceplan, se por um lado conquistou, em 2007, autonomia para realizar licitações, fiscalizar e fazer o acompanhamento físico-financeiro das obras, por outro não foi capaz de impor seu compromisso original com a inovação e de garantir seu papel de produtor e multiplicador de conhecimentos. Dos edifícios novos construídos no período, menos da metade foram projetados por professores da FAU. Os projetos dos prédios baseados no sistema de ciclo aberto foram executados por arquitetos contratados, sendo que, em muitos casos, o desenvolvimento foi feito pelas próprias empresas fornecedoras dos componentes pré-moldados, o que fez com que houvesse uma queda relativa da participação discente no processo de projeto.

Talvez esta reflexão sobre a trajetória do Ceplan seja importante para iluminar esse lugar de memória, atraindo para si novos olhares e novos agentes que, solidarizando-se com sua cinquentenária existência, possam lutar por sua transformação em patrimônio cultural da Universidade de Brasília e, ao mesmo tempo, contribuir para a preservação de seus espaços físicos e para a retomada de sua missão pedagógica e de pesquisa. 



\section{REFERÊNCIAS}

ABRAMO, Perseu. Depoimento sobre as ocorrências na Universidade de Brasília. São Paulo: Fundação Perseu Abramo, 2006. http://novo.fpabramo.org.br/content/depoimento-de-perseuabramo-sobre-ocorrencias-na-universidade-de-brasilia

ABREU, Regina. A emergência do patrimônio genético e a nova configuração do campo do patrimônio. In: ABREU, Regina; CHAGAS, Mário (Orgs.). Memória e patrimônio: ensaios contemporâneos. Rio de Janeiro: DP\&A, 2003, p. 30-45.

ACAYABA, Marlene Milan. Brutalismo caboclo e as residências paulistas. Projeto, São Paulo, n. 73, mar.1985.

ACRÓPOLE. Revista Acrópole. São Paulo, ano 31, n. 369/370, jan.-fev. 1970.

ALBERTO, Klaus Chaves. A pré-fabricação e outros temas projetuais para campi universitários na década de 1960: o caso da UnB. Revista de Pesquisa em Arquitetura e Urbanismo. Programa de PósGraduação do Departamento de Arquitetura e Urbanismo da USP, 2007. http://arquitetura.eesc.usp.br/revista_risco/Risco10-pdf/02_art07_risco10.pdf

Inconstantes cidades universitárias: um estudo da Universidade de Brasília. Anais do $7^{\circ}$ Seminário Docomomo Brasil. Porto Alegre, 22 a 24 out. 2009. www.docomomo.org.br/seminario\%207\%20pdfs/058.pdf

ALMEIDA, Jaime Gonçalves de. A formação do arquiteto e a universidade. Revista Brasileira de Estudos Pedagógicos, Brasília, vol. 78, n. 188-189-190, p. 57-85, jan.-dez. 1997._http://rbep.inep.gov.br/ index.php/RBEP/article/viewFile/251/251

ALVES, Renato; RODRIGUES, Gizella. Anísio Teixeira, morte sob suspeita. UnB Agência, 18 ago. 2012. http://unb.br/noticias/unbagencia/cpmod.php?id=92037

ANDES. Proposta das associações docentes e da Andes para a Universidade Brasileira. Olinda: Andes, 1986.

ARTIGAS, João Batista Vilanova. A função social do arquiteto. São Paulo: Nobel, 1989.

ASSIS, Machado. Dom Casmurro. 33. ed. Rio de Janeiro: Ediouro, 1996. (Coleção Prestígio).

AUGÉ, Marc. Não-lugares: introdução a uma antropologia da modernidade. Campinas: Papirus, 1994.

BANHAM, Reyner. El brutalismo en arquitectura: etica o estética? Barcelona: Gustavo Gili, 1966.

BARBOSA, Andréia Arruda. O lugar da memória institucional nas organizações complexas. TrabaIho apresentado no GT Processos, Políticas e Estratégias de Comunicação Organizacional do IV Congresso Brasileiro Científico de Comunicação Organizacional e de Relações Públicas. São Paulo, 2010. www.abrapcorp.org.br/anais2010/GT2/GT2_Andreia.pdf

BARONE, Ana Cláudia Castilho. Team 10: arquitetura como crítica. São Paulo: Annablume, 2002. 
BASTOS, Maria Alice Junqueira. Paulo Mendes da Rocha: breve relato de uma mudança. Arquitextos, São Paulo, ano 11, n. 122.01, Vitruvius, jul. 2010 www.vitruvius.com.br/revistas/read/arquitextos $/ 11.122 / 3472$

BERGSON, Henri. Matéria e memória: ensaio sobre a relação do corpo com o espírito. 2. ed. São Paulo: Martins Fontes, 1999.

BIRD/BANCO MUNDIAL. La enseñanza superior: las lecciones derivadas de la experiencia. Washington, D.C: Bird/Banco Mundial, 1995. (El desarrollo en la práctica).

BOMENY, Helena. A reforma universitária de 1968: 25 anos depois. Revista Brasileira de Ciências Sociais, out. 1993, p. 51-65.

www.anpocs.org.br/portal/publicacoes/rbcs_00_26/rbcs26_04.htm

BOSI, Éclea. Memória e sociedade: lembrança de velhos. São Paulo: Cia das Letras, 1994.

O tempo vivo da memória: ensaios de psicologia social. São Paulo: Ateliê Editorial, 2003.

BRASIL. Constituição Federal do Brasil, 1988. www.planalto.gov.br/ccivil_03/constituicao/ConstituicaoCompilado.htm

Presidência da República - Grupo de Trabalho Interministerial. Bases para o enfrentamento da crise emergencial das universidades brasileiras e roteiro para a reforma da universidade brasileira. Brasília, 2003.

BRUAND, Yves. Arquitetura contemporânea no Brasil. 3. ed. São Paulo: Perspectiva, 1997.

BRUNA, Paulo. Arquitetura, industrialização e desenvolvimento. São Paulo: Perspectiva, 1976.

BUARQUE, Cristovam. Discurso em homenagem aos 45 anos da UnB. Senado Federal, 25 abr. 2007. www12.senado.gov.br/noticias/materias/2007/04/25/na-homenagem-do-senado-a-unb-cristovam-diz-que-brasil-precisa-resgatar-sonhos-de-darcy-ribeiro

BURKE, Peter. Variedades de história cultural. Rio de Janeiro: Civilização Brasileira, 2000.

CALDEIRA, Jorge et al. Viagem pela história do Brasil. São Paulo: Cia das Letras, 1997.

CAMPOS, João. Da ideia ao traço do professor Niemeyer. Darcy, n. 3, nov.-dez. 2009.

CASTELLS, Manuel. A sociedade em rede: a era da informação: economia, sociedade e cultura. 4. ed. Rio de Janeiro: Paz e Terra, 2000.

CASTELO, Roberto. A Universidade de Brasília: as lições do passado. Palestra proferida na Faculdade de Arquitetura e Urbanismo da UnB. Brasília, 12 abr. 2010.

Entrevista concedida a Andrey Rosenthal Schlee em 12 de abril de 2010, e comentada em SCHLEE, Andrey Rosenthal. Registro arquitetônico da Universidade de Brasília. Brasília: Editora UnB, 2014 , p. 24. 
CEPLAN. Plano diretor físico 1974. Brasília: UnB, 1974.

Plano diretor físico 1998. Brasília: UnB, 1998.

CHAGAS, Mário. O pai de Macunaíma e o patrimônio espiritual. In: ABREU, Regina; CHAGAS, Mário (Orgs.). Memória e patrimônio: ensaios contemporâneos. Rio de Janeiro: DP\&A, 2003, p. 95-108.

CHAUÍ, Marilena. Convite à filosofia. 13. ed. São Paulo: Ática, 2005.

CHOAY, Françoise. A alegoria do patrimônio. 3. ed. São Paulo: Estação Liberdade; Editora Unesp, 2006.

CONCEIÇÃO, Maria José da. Entrevista. Campus Impresso: arquivos da UnB na ditadura, 2013. http://shalders.wordpress.com/2013/03/31/campus-impresso-arquivos-da-unb-na-ditadura/

CORBUSIER. Le Corbusier: 1910-1965. 7. ed. Barcelona: Gustavo Gili, 2001.

COSTA, Icléia Thiesen Magalhães. Memória institucional: um conceito em definição. Informare. Cadernos do Programa de Pós-Graduação em Ciência da Informação. Rio de Janeiro, vol. I, n. 2, p. 45-51, jul.-dez. 1995.

www.brapci.inf.br/_repositorio/2011/06/pdf_d21fddc817_0017382.pdf

. Memória institucional: a construção conceitual numa abordagem metodológica. 1997. Tese (Doutorado em Ciência da Informação) - CNPq/ lbict, ECO/UFRJ, Rio de Janeiro.

http://tede-dep.ibict.br/bitstream/tde/39/1/icleiacosta1997.pdf

COSTA, Lucio. Relatório do Plano Piloto de Brasília (1957). Brasília: Codeplan/Depha, 1991.

Sobre arquitetura. Porto Alegre : Centro dos Estudantes Universitários de Arquitetura, 1962.

Registro de uma vivência. São Paulo: Empresa das Artes, 1995.

COSTA, Rubens Vaz. O Sistema Nacional de Habitação e os corretores de imóveis. Rio de Janeiro: BNH, 1972.

COUTINHO, José Carlos Córdoba. Herança arquitetônica. Entrevista para UnB Agência, 19 abr. 2012. www.unb.br/noticias/unbagencia/unbagencia.php?id=6468

CRUZ, Teresinha Rosa. Uma experiência interrompida no Centro Integrado de Ensino Médio da UnB: 1964 a 1971. Brasília: Plano, 2001.

CUNHA, Luiz Antônio Constant Rodrigues. A universidade reformanda: o golpe de 1964 e a modernização do ensino superior. São Paulo: Editora Unesp, 2007.

DRUCKER, Peter. Administração em tempos de grandes mudanças. São Paulo: Pioneira; Publifolha, 1999. 
DURHAM, Eunice Ribeiro. A política educacional do governo Fernando Henrique Cardoso: uma visão comparada. Novos Estudos Cebrap, São Paulo, n. 88, dez. 2010.

http://dx.doi.org/10.1590/S0101-33002010000300009

FARIA, Alberto Alves de; ARANTES, Cláudio Oliveira; BARRETO, Frederico Flósculo B. Histórico do planejamento físico do Campus Universitário Darcy Ribeiro. Paranoá: Cadernos de Arquitetura e Urbanismo, Brasília, n. 1, jan. 2003, p. 7. Programa de Pesquisa e Pós-Graduação da FAU-UnB.

FERREIRA, Marieta de Moraes; MESQUITA, Cláudia. Os anos JK no acervo da Biblioteca Nacional. In: PEREIRA, Paulo Roberto (Org.). Guia de fontes sobre o Brasil. Rio de Janeiro: Fundação Biblioteca Nacional; Nova Fronteira, 2001, p. 329-368. http://cpdoc.fgv.br/producao_intelectual/arq/1283.pdf

FERRO, Sérgio; ARANTES, Pedro Fiori (Orgs.). Sérgio Ferro: arquitetura e trabalho livre. São Paulo: Cosac Naify, 2006.

FONSECA, Maria Cecília Londres. Para além da pedra e cal: por uma concepção ampla de patrimônio cultural. In: ABREU, Regina; CHAGAS, Mário (Orgs.). Memória e patrimônio. Rio de Janeiro: Lamparina, 2009, p. 56-76.

FREITAS, Maria Ester de. Cultura organizacional: identidade, sedução e carisma?. 2. ed. Rio de Janeiro: Editora FGV, 2000.

FROTA, Leila. Alcides da Rocha Miranda: caminho de um arquiteto. Rio de janeiro: UFRJ, 1993.

GALBINSKI, José. Planejamento físico de bibliotecas universitárias. Brasília: Probib, 1993.

GATTÁS, R.A. A indústria automobilística e a segunda Revolução Industrial no Brasil: origens e perspectivas. São Paulo: Prelo, 1981.

www3.babson.edu/ESHIP/research-publications/unload/GEM_2008_Executive_Report.pdf

GINZBURG, Moisei I. Style and epoch. New York: Graham Foundation/The Institute for Architecture and Urban Studies; London: Mit Press, 1982.

www.yumpu.com/en/document/view/4493880/moisei-ginzburg-style-and-epoch

GONÇALVES, Janice. Pierre Nora e o tempo presente: entre a memória e o patrimônio cultural. Historiæ, Rio Grande, vol. 3, n. 3, p. 27-46, 2012. www.seer.furg.br/hist/article/view/3260

GOROVITZ, Matheus; FERREIRA, Marcílio Mendes. A invenção da superquadra: o conceito de Unidade de Vizinhança em Brasilia. Brasília: Iphan, 2009.

GROPPO, Luís Antonio. A revolta mundial da juventude e o Brasil. Teoria e Debate Especial 1968, maio 2008, p. 35-41.

www.fpabramo.org.br/uploads/Especial68-Revolta_e_juventude.pdf

GUIMARÃES, Manoel Luiz Salgado. História, memória e patrimônio. In: OLIVEIRA, Antônio José Barbosa de (Org.). Universidade e lugares de memória. Rio de Janeiro: UFRJ, Fórum de Ciência e Cultura, Sistema de Bibliotecas e Informação, 2008, p. 17- 40.

HALBAWCHS, Maurice. A memória coletiva. São Paulo: Centauro, 2006. 
HUYSSEN, Andréas. Seduzidos pela memória: arquitetura, monumentos, mídia. Rio de Janeiro: Aeroplano, 2000.

IAB/RJ. Arquitetura brasileira após Brasília: depoimentos. Rio de Janeiro: IAB/RJ, 1978.

IANNI, Octavio. A ideia de Brasil moderno. São Paulo: Brasiliense, 1996.

IPÊS. A educação que nos convém. Fórum organizado pelo Instituto de Pesquisas e Estudos Sociais (Ipês), out.-nov. 1968. Rio de Janeiro: Apec, 1969.

IPHAN. Declaração do México, 1985. http://portal.iphan.gov.br/portal/baixaFcdAnexo.do?id=255

KIM, Lina; WESELY, Michael. Arquivo Brasília. São Paulo: Cosac Naify, 2010.

KOPP, Anatole. Quando o moderno não era um estilo e sim uma causa. São Paulo: Nobel; Edusp, 1990.

KOSSOY, Boris. Fotografia \& história. São Paulo: Ateliê Editorial, 2001.

KUNSCH, Margarida Maria Krohling. Gestão das relações públicas na contemporaneidade e a sua institucionalização profissional e acadêmica no Brasil. Organicom. Revista Brasileira de Comunicação Organizacional e Relações Públicas, São Paulo, ano 3, n. 5, p. 31-61, 2006.

LATORRACA, Giancarlo (Org.) João da Gama Filgueiras Lima, Lelé. São Paulo: Instituto Lina Bo e P. M. Bardi; Lisboa: Editorial Blau, 1999.

LE GOFF, Jacques. História e memória. Trad. Bernardo Leitão. Campinas: Editora da Unicamp, 1990. http://memorial.trt11.jus.br/wp-content/uploads/Hist\%C3\%B3ria-e-Mem\%C3\%B3ria.pdf

LIMA, João Filgueiras. Escola transitória. Brasília: MEC/Cedate, 1984.

O que é ser arquiteto: memórias profissionais de Lelé (João Filgueiras Lima), em depoimento a Cynara Menezes. Rio de Janeiro: Record, 2004.

Crônicas de Brasília: 1957-1961. Revista AU, São Paulo,

n. 192, p. 68-71, mar. 2010.

Sonho. In: SCHLEE, Andrey Rosenthal et al. Registro arquitetônico da Universidade de Brasília. Brasília: Editora UnB, 2014.

LOWENTHAL, David. El pasado es un país extraño. Madrid: Akal, 1998.

MALDONADO, Tomás. Opiniões dos críticos de arte. In: Anais do Congresso Internacional de Críticos de Arte. Brasília, ano 3, set. 1959.

MARCELINO, Gileno Fernandes (org.). Gestão estratégica de universidade. Brasília: Editora UnB, 2004. MARI, Marcelo. Depoimento in SAMORANO, C. Nas pegadas do mestre. Correio Braziliense, Brasília, 14 set. 2014. www.correiobraziliense.com.br/app/noticia/revista/2014/09/14/interna_revista_correio,446652/nas-pegadas-do-mestre.shtml 
MARICATO, Adriano. História e memória. In: MARCHIORI, Marlene (Org.). Faces da cultura e da comunicação organizacional. São Caetano do Sul Difusão, 2006, p. 123-134.

MÁRQUEZ, Gabriel Garcia. Viver para contar. Rio de Janeiro: Record, 2003.

MARTINS, Carlos Benedito. A Reforma universitária de 1968 e a abertura para o ensino superior privado no Brasil. Educação e Sociedade, Campinas, vol. 30, n. 106, p. 15-35, jan.-abr. 2009. www. cedes.unicamp.br

MAUAD, Ana Maria. Através da imagem: fotografia e história - intefaces. Tempo, Rio de Janeiro, vol. 1, n. 2, p. 73-98, 1996.

MEIHY, José Carlos Sebe B. Memória, história oral e história. Revista do Núcleo de Estudos em História Oral da USP, São Paulo, n. 8, p.179-191, jul.-dez. 2010.

MENDES, Manuel P. O cerrado de casaca. São Paulo: Thesaurus Editora,1995.

MÉNDEZ, Patrícia. A fotografia na arquitetura moderna. Arquitextos, São Paulo, ano 08, n. 086.02, Vitruvius, jul. 2007. www.vitruvius.com.br/revistas/read/arquitextos/08.086/229

MENESES, Ulpiano T. Bezerra de. Fontes visuais, cultura visual, história visual. Balanço provisório, propostas cautelares. Revista Brasileira de História, São Paulo, vol. 23, n. 45, p. 11-36, 2003.

MINISTÉRIO DE EDUCAÇÃO E CULTURA. Universidade de Brasília: projeto de organização, pronunciamento de educadores e cientistas e Lei n. 3.998, de 15 de dezembro de 1961. Brasília: MEC/S.E., 1962.

MIRANDA, Luiz Áquila da Rocha. Entrevista concedida a Helena Bomeny, Bernardo Buarque de Hollanda e Vanuza Braga, para o Projeto Dossiê Brasília 50 Anos, do Centro de Pesquisa e Documentação de História Contemporânea do Brasil (CPDOC/FGV). Rio de Janeiro, 16 mar. 2010.

MÓDULO. Revista Módulo, Rio de Janeiro, ano VIII, n. 32, mar. 1963.

NASSAR, Paulo (Org.). Memória de empresa: história e comunicação de mãos dadas. São Paulo: Aberje, 2004.

Relações públicas na construção da responsabilidade histórica e no resgate da memória institucional das organizações. São Caetano do Sul: Difusão Editora, 2007.

NIEMEYER, Oscar. Depoimento. Módulo, Rio de Janeiro, n. 9, fev. 1958.

. Minha experiência em Brasília. Rio de Janeiro: Vitória, 1961.

. Universidade de Brasília - Instituto de Teologia, 1960. Fundação Oscar Niemeyer. Coleção

Oscar Niemeyer, 1963. www.niemeyer.org.br/obra/pro099

Depoimento. Módulo, Rio de Janeiro, n. 40, p. 3-6, set. 1975. 
. Como se faz arquitetura. Petrópolis: Vozes, 1986.

Conversa de arquiteto. Rio de Janeiro: Revan; Editora da UFRJ, 1993.

. Entrevista para o Memória Roda Viva. São Paulo: Fundação Padre Anchieta; Fapesp, 12 jul. 1997. www.rodaviva.fapesp.br/materia/8/entrevistados/oscar_niemeyer_1997.htm

. Minha arquitetura. Rio de Janeiro: Revan, 2000.

NOBRE, Ana Luiza de Souza. O projetista de móveis. Entrevista com Sérgio Rodrigues. Editado por Soraia Cals, 2000.

www.revistaau.com.br/arquitetura-urbanismo/97/o-projetista-de-moveis-23743-1.asp (2 of 9) [8/9/2008 15:23:19]

. Fios cortantes: projeto e produto, arquitetura e design no Rio de Janeiro (1950-70). 2008. Tese (Doutorado em História) - Programa de Pós-Graduação em História Social da Cultura, PUC-Rio, Rio de Janeiro: PUC-Rio.

NORA, Pierre. Entre memória e história: a problemática dos lugares. Projeto História, São Paulo, n. 10, dez. 1993. http://revistas.pucsp.br/index.php/revph/article/viewFile/12101/8763

Realms of memory: the construction of the French past. New York: Columbia University Press, 1996.

. Les lieux de mémoire. Selección de José Rilla. Montevideo: Trilce, 2008.

OLIVEIRA, Antônio José Barbosa de. História, memória e instituições: algumas reflexões teóricometodológicas para os trabalhos do Projeto Memória. In:

OLIVEIRA, Antônio José Barbosa de (Org.). Universidade e lugares de memória. Rio de Janeiro: UFRJ, Fórum de Ciência e Cultura, Sistema de Bibliotecas e Informação, 2008, p. 41-62.

https://pt.scribd.com/doc/106806042/67608105-Livro-Memoria-Institucional-UFRJ-2

OTRANTO, Célia Regina. A reforma da educação superior do governo Lula: da inspiração à implantação. In: SILVA JR, João Reis; OLIVEIRA, João Ferreira de; MANCEBO, Denise (Orgs.). Reforma Universitária: dimensões e perspectivas. Campinas: Alínea, 2006, p. 43-58.

PEREIRA, Luis Humberto Martins. Entrevista concedida a Simonetta Persichetti. Discursos Fotográficos, Londrina, vol. 4, n. 4, p. 215-222, 2008.

www.uel.br/revistas/uel/index.php/discursosfotograficos/article/viewFile/1514/1260

PINTO, Lucia Helena Nunes (Org.). Discursos selecionados do Presidente Juscelino Kubitschek. Brasília: Fundação Alexandre de Gusmão, 2010.

POLLAK, Michael. Memória, esquecimento, silêncio. Estudos Históricos, Rio de Janeiro (CPDOC), vol. 2, n. 3, 1989.

PORTO, Cláudia Estrela (Org.). Olhares: visões sobre a obra de João Filgueiras Lima. Brasília: Editora da UnB, 2010a. 
O beijódromo de Darcy e Lelé: um presente para Brasília. I Encontro Nacional da Associação Nacional de Pesquisa e Pós-Graduação em Arquitetura e Urbanismo. Rio de Janeiro, 29 nov. a 3 dez. 2010. www.anparq.org.br/dvd-enanparq/simposios/158/158-726-1-SP.pdf

PORTO JÚNIOR, Gilson. Anísio Teixeira e a UnB: um breve olhar. Revista de Pedagogia, Rio de Janeiro, ano 2, n. 3.

PROJETO. Revista Projeto Design. Brasília 50 anos. Edição comemorativa www.arcoweb.com.br/especiais/brasilia-50-anos-parte-2-de-5-serie-especial-30-06-2010.html.

QUEIROZ, Cláudio José Pinheiro Villar de. Entrevista. Campus Online. http://campus.fac.unb.br/arquivo/literatura-brasiliense/item/2215-arquiteto-explica-como-projetou-os-pavilh\%C3\%B5es

RAMOS, Murilo Cesar (Coord.). Sonho e realidade: o movimento docente na Universidade de Brasília. Brasília: Editora Universidade de Brasília, 1994.

REIS, F. A. Arquitetura brasileira após Brasília: depoimentos. Rio de Janeiro: $I A B, 1978$.

RIBEIRO, Darcy. A Universidade de Brasília. Educação e Ciências Sociais, Rio de Janeiro, vol. VIII, n. 15, p. 33-99, 1960.

Universidade de Brasília. Revista Brasileira de Estudos Pedagógicos, Rio de Janeiro, vol. 36, n. 83, p. 161-230, jul.-set. 1961.

UnB: invenção e descaminho. Rio de Janeiro: Avenir, 1978.

A universidade necessária. Rio de Janeiro: Paz e Terra, 1978.

. A invenção da Universidade de Brasília: 1961-1965. Carta: falas, reflexões, memórias: informe de distribuição restrita do senador Darcy Ribeiro. Brasília: Gabinete do Senador Darcy Ribeiro, 1991.

RICKEY, George. Construtivismo: origens e evolução. São Paulo: Cosac \& Naify, 2002.

RICOEUR, Paul. A memória, a história, o esquecimento. Campinas: Editora da Unicamp, 2007.

RISSELADA, Max; LATORRACA, Giancarlo (Orgs.). A arquitetura de Lelé: fábrica e invenção. São Paulo: Imprensa Oficial do Estado de São Paulo; Museu da Casa Brasileira, 2010.

RODRIGUES, Sérgio. O projetista de móveis. Entevista concedida a Ana Luiza Nobre. Revista AU, São Paulo, ano 16, n. 97, p. 84-87, ago.-set. 2001.

Ninguém cria sozinho. Entrevista concedida Fernando Serapião. Projeto Design, n. 284, 30 out. 2003. http://arcoweb.com.br/projetodesign/entrevista/sergio-rodrigues-ninguem-cria-30-10-2003

Entrevista. Projeto Design. Edição comemorativa Brasília 50 anos. Parte 2 de 5. Publicada originalmente em Projeto Design, n. 362. www.arcoweb.com.br/especiais/brasilia-50-anos-parte2-de-5-serie-especial-30-06-2010.html

ROMANELLI, Otaíza de Oliveira. História da educação no Brasil. Petrópolis: Vozes, 1988. 
ROMERO, Marta Adriana Bustos. O desafio da construção de cidades sustentáveis. Brasília: UnB-Lasus, 2011.

SALMERON, Roberto A. Universidade interrompida: Brasília 1964-1965. Brasília: Editora Universidade de Brasília, 2007.

SANTOS, Altair. UnB resgata tradição de "universidade do pré-fabricado". Massa Cinzenta, $1^{\circ}$ nov. 2012. www.cimentoitambe.com.br/unb-resgata-tradicao-de-universidade-do-pre-fabricado/

SANTOS, Myrian Sepúlveda dos. Memória coletiva e teoria social. São Paulo: Annablume, 2003.

SANVITTO, Maria Luiza Adams. As questões compositivas e o ideário do brutalismo paulista. Arqtexto 2, Porto Alegre, 2002/1. www.ufrgs.br/propar/publicacoes/ARQtextos/PDFs_revista_2/2_ Maria\%20Sanvitto.pdf

Brutalismo paulista: uma estética justificada por uma ética? Comunicação apresentada no X Seminário Docomomo Brasil. Arquitetura Moderna e Internacional: conexões brutalistas, 195575. Curitiba: PUC-PR, 15-18 out. 2013.

SCHLEE, Andrey Rosenthal. A Praça Maior da UnB. Comunicação apresentada no 9o Seminário Docomomo Brasil. Brasília, abr. 2011. www.docomomobsb.org

Herança arquitetônica. Brasília: UnB/Secom, 2012.

www.unb.br/noticias/unbagencia/unbagencia.php?id=6468

et al. Registro arquitetônico da Universidade de Brasília. Brasília: Editora UnB, 2014.

SMITHSON, Peter; SMITHSON, ALLISON. New brutalism. Architectural Design, 1957.

SONTAG, Susan. Ensaios sobre fotografia. Rio de Janeiro: Arbor, 1981.

SOUZA LIMA, Mayumi Watanabe de. Aspectos da habitação urbana: projeto da habitação coletiva para a Unidade de Vizinhança São Miguel. 1965. Dissertação (Mestrado) - Universidade de Brasília, Brasília.

SOUZA, Willian Eduardo Righini de; CRIPPA, Giulia. O patrimônio como processo: uma ideia que supera a oposição material-imaterial. Em Questão, Porto Alegre, vol. 17, n. 2, p. 241-255, jul.-dez. 2011.

SUCUPIRA, N. Parecer n. 848. Brasília: Conselho Federal de Educação, 1968.

SVENSSON, Frank. Nem tudo está perdido! Contribuição ao congresso estatuinte UNB 2008. http://unblivre.blogspot.com/2008/05/histria-da-unb-sob-o-ponto-de-vista-de.html

TEDESCO, João Carlos. Nas cercanias da memória: temporalidade, experiência e narração. Passo Fundo: UPF; Caxias do Sul: Educs, 2004.

TEIXEIRA, Anísio. A educação e a crise brasileira. São Paulo: Cia. Editora Nacional, 1956

Ensino superior no Brasil: análise e interpretação de sua evolução até 1969. Rio de Janeiro: Editora da Fundação Getúlio Vargas, 1989. 
THOMPSON, Paul. A voz do passado: história oral. 3. ed. Trad. Lólio Lorenço de Oliveira. Rio de Janeiro: Paz e Terra, 1992.

TODOROV, João Cláudio. UnB: um depoimento. In: RIBEIRO, D. Cartas: falas, reflexões, memórias, n. 1, p. 55-59. Brasília: Gabinete do Senador Darcy Ribeiro, 1991, p. 55-59.

TRIGUEIRO, Michelangelo Giotto Santoro. Universidades públicas: desafios e possibilidades no Brasil contemporâneo. Brasília: Editora UnB, 1999.

TRINDADE, Mário. Habitação e desenvolvimento. Petrópolis: Vozes, 1971.

VARELA, Sebastião. Passados que não se apagam: histórias da UnB. Brasília: Editora UnB, 1989.

VEYNE, Paul. Como se escreve a história. Brasília: Editora UnB, 1992.

UNESCO. Convenção para a Salvaguarda do Patrimônio Cultural Imaterial. Paris, 17 out. 2003. http://portal.iphan.gov.br/portal/baixaFcdAnexo.do?id=271

UNIVERSIDADE DE BRASÍLIA. Plano orientador da Universidade de Brasília. Brasília: UnB, 1962.

Plano de desenvolvimento físico. Brasília: UnB, 1974.

Plano diretor físico do Campus Universitário Darcy Ribeiro. Brasília: FUB, 1998. https://pt.scribd.com/doc/98327211/UNB-PlanoDiretorFisico-1998-1

VELOSO, Raimundo Nonato. PORTAL VITRUVIUS. Casa do Professor da UnB. Projetos, São Paulo, ano 10, n. 111.01, Vitruvius, mar. 2010_www.vitruvius.com.br/revistas/read/projetos/10.111/3588

VERSIANI, Flávio Rabelo; BARROS, José Mendonça de. Formação econômica do Brasil: a experiência da industrialização. São Paulo: Saraiva, 1977.

WORCMAN, Karen. Memória do futuro: um desafio. In: NASSAR, Paulo. Memória de empresa: história e comunicação de mãos dadas, a construir o futuro das organizações. São Paulo: Aberje, 2004.

- PEREIRA, Jesus Vasquez (Orgs.). História falada:memória, rede e mudança social. São Paulo: Sesc, 2006.

XAVIER, Alberto (Org.). Depoimento de uma geração. São Paulo: Pini; Abea; Fundação Vilanova Artigas, 1987.

ZAINKO, Maria Amelia Sabbag. Avaliação da educação superior no Brasil: processo de construção histórica. Avaliação, Campinas/Sorocaba , vol. 13, n. 3, p. 827-831, nov. 2008. www.scielo.br/pdf/ aval/v13n3/12.pdf

ZAPPA, R.; SOTTO, E. 1968: eles só queriam mudar o mundo. Rio de Janeiro: Zahar, 2008.

ZEIN, Ruth Verde. A arquitetura da Escola Paulista Brutalista: 1953-1973. 2005 Tese (Doutorado em Arquitetura) - Faculdade de Arquitetura. Programa de Pesquisa e Pós-Graduação em Arquitetura. Universidade Federal do Rio Grande do Sul, Porto Alegre.

Brutalismo, sobre sua definição (ou, de como um rótulo superficial é, por isso mesmo, adequado). Arquitextos, São Paulo, ano 07, n. 084.00, Vitruvius, maio 2007. www.vitruvius.com.br/ revistas/read/arquitextos/07.084/243 
ENTREVISTADOS

\begin{tabular}{|c|c|c|c|c|c|}
\hline Entrevistado & Data & Local & Duração & Mídia & Revisão \\
\hline CAMPELLO, Glauco & - & - & - & Telefone & - \\
\hline $\begin{array}{l}\text { CASTRO, Antônio } \\
\text { Moraes de }\end{array}$ & 26 jan. 2012 & $\begin{array}{l}\text { Residência do } \\
\text { entrevistado }\end{array}$ & 1h32min & $\begin{array}{l}\text { Gravação } \\
\text { em áudio }\end{array}$ & - \\
\hline $\begin{array}{l}\text { FARIA, Alberto Alves } \\
\text { de }\end{array}$ & 8 mar. 2012 & Ceplan & 1h9min24seg & $\begin{array}{l}\text { Gravação } \\
\text { em áudio }\end{array}$ & - \\
\hline GALBINSKI, José & 4 nov. 2011 & $\begin{array}{l}\text { Residência do } \\
\text { entrevistado }\end{array}$ & $29 \min 44 \mathrm{seg}$ & $\begin{array}{l}\text { Gravação } \\
\text { em áudio }\end{array}$ & $20 / 02 / 2012$ \\
\hline GOROWITZ, Mateus & 20 dez. 2012 & - & - & E-mail & - \\
\hline $\begin{array}{l}\text { LELÉ - João da Gama } \\
\text { Filgueiras Lima }\end{array}$ & 22 fev. 2012 & $\begin{array}{l}\text { Residência de } \\
\text { Sônia Filgueiras }\end{array}$ & $49 \min 31 \mathrm{seg}$ & $\begin{array}{l}\text { Gravação } \\
\text { em áudio }\end{array}$ & \\
\hline LIMA, Paulo Castilho & 9 fev. 2012 & - & - & Telefone & - \\
\hline $\begin{array}{l}\text { PEREIRA, Luiz } \\
\text { Humberto Miranda } \\
\text { Martins }\end{array}$ & 26 jan. 2012 & $\begin{array}{l}\text { Residência do } \\
\text { entrevistado }\end{array}$ & $57 \mathrm{~min} 36 \mathrm{seg}$ & $\begin{array}{l}\text { Gravação } \\
\text { em áudio }\end{array}$ & - \\
\hline $\begin{array}{l}\text { PESSINA, Luiz } \\
\text { Henrique Gomes }\end{array}$ & 1 dez. 2011 & $\begin{array}{l}\text { Residência do } \\
\text { entrevistado }\end{array}$ & $47 \mathrm{~min} 06 \mathrm{seg}$ & $\begin{array}{l}\text { Gravação } \\
\text { em áudio }\end{array}$ & $20 / 02 / 2012$ \\
\hline $\begin{array}{l}\text { PESSINA, Luiz } \\
\text { Henrique Gomes }\end{array}$ & 9 dez. 2014 & - & - & Telefone & - \\
\hline $\begin{array}{l}\text { QUEIROZ, Cláudio } \\
\text { José Villar Pinheiro de }\end{array}$ & 15 abr. 2012 & - & - & E-mail & - \\
\hline $\begin{array}{l}\text { SVENSSON, Frank } \\
\text { Algot }\end{array}$ & 16 fev. 2012 & $\begin{array}{l}\text { Residência do } \\
\text { entrevistado }\end{array}$ & $1 \mathrm{~h} 52 \mathrm{~min} 52 \mathrm{seg}$ & $\begin{array}{l}\text { Gravação } \\
\text { em áudio }\end{array}$ & $01 / 03 / 2012$ \\
\hline $\begin{array}{l}\text { WEIDLE, Érico Paulo } \\
\text { Seigmar }\end{array}$ & 7 dez. 2011 & $\begin{array}{l}\text { Escritório do } \\
\text { entrevistado }\end{array}$ & 1h18min48seg & $\begin{array}{l}\text { Gravação } \\
\text { em áudio }\end{array}$ & 04/04/2012 \\
\hline ZETTEL Jayme & 9 dez. 2014 & - & - & Telefone & - \\
\hline $\begin{array}{l}\text { ZIMBRES, Paulo de } \\
\text { Mello }\end{array}$ & 26 out. 2011 & $\begin{array}{l}\text { Residência do } \\
\text { entrevistado }\end{array}$ & $28 \min 54 \mathrm{seg}$ & $\begin{array}{l}\text { Gravação } \\
\text { em áudio }\end{array}$ & $13 / 04 / 2012$ \\
\hline
\end{tabular}




\section{Capítulo 1}

Figura 1. http://historiasdosdias.blogspot.com.br/2014/01/31-de-janeiro-de-1956-juscelino.html. Figura 2. http://g1.globo.com/politica/fotos/2010/04/aniversario-de-50-anos-de-brasilia.html. Figura 3. http://50anosdetextos.com.br/1981/o-disco-que-lancou-a-bossa-nova-nao-nao-e-de-joao-gilberto/.

Figura 4 www.producaocultural.org.br/videos/andre-midani/.

Figura 5. www.telabr.com.br/noticias/2009/09/22/classicos-rio-40-graus/.

Figura 6. http://pt.wikipedia.org/wiki/Orfeu_Negro.

Figura 7. www.concretosparalelos.com.br/?p=19.

Figura 8. www.jblog.com.br/hojenahistoria.php?itemid=31128.

Figura 9. http://falandodob.blogspot.com.br/2009/05/50-anos-do-manifesto-neocroncreto.html. Figuras 10a. http://veja.abril.com.br/blog/ricardo-setti/tag/copa-do-mundo-de-1958/.

Figura 11. www.guiageo-esporte.com/tenis/maria-esther.html.

Figura 12 www.cyberboxingzone.com/boxing/jofre.html.

Figura 13. http://basquete.ig.com.br/index.php/tag/1959/.

Figuras 14, 15. https://lavidaenfotografia.wordpress.com/2010/11/13/a-construcao-de-brasilia -por-marcel-gautherot/.

Figura 16. http://ciep122.blogspot.com.br/2010/04/50-anos-de-brasilia.html.

Figura 17. http://acervo.oglobo.globo.com/fotogalerias/jk-inaugura-brasilia-9385770.

Figura 18. http://acervo.oglobo.globo.com/fotogalerias/jk-inaugura-brasilia-9385770.

Figura 19. http://segredodaescuridao.blogspot.com.br/2010/04/segredo-da-escuridao-historias -perdidas_21.html.

Figura 20. www.jornalopcao.com.br/posts/opcao-cultural/o-diario-intimista-e-melancolico-decyro-dos-anjos.

Figura 21. Cedoc/UnB.

Figura 22. http://veja.abril.com.br/blog/caca-ao-voto/tag/janio-quadros/.

Figura 23. http://fernandorodrigues.blogosfera.uol.com.br/2014/09/02/dilma-compara-marina-ajanio-quadros-e-a-fernando-collor/.

Figura 24. www.robertorequiao.com.br/revista-carta-capital-requiao-incorpora-joao-goulart/. Figuras 25, 26, 27, 28, 29. Cedoc/UnB.

Figuras 30a, 30b. Correio Braziliense, 8 e 10 abr. 1962.

Figura 31. www.traca.com.br/livro/368635/plano-orientador-da-universidade-de-brasilia.

Figura 32. www.pinterest.com/pin/188306828142710336/.

Figura 33. www.revistapessoa.com/2014/07/estudo-assombro/.

Figura 34.www.rbma.org.br/mab/unesco_03_rb_cerrado.asp.

Figuras 35a, 35b. Cedoc/UnB.

Figura 36. http://oglobo.globo.com/rio/tesouros-do-bau-do-designer-sergio-rodri-

gues-14438789.

Figuras 37a, 37b. www.iateclubedebrasilia.com.br/estrutura_praca.aspx.

Figura 38. Correio Braziliense, 19 abr. 1962.

Figura 39. Foto de Ana de Oliveira. http://diplomaciapublica.itamaraty.gov.br/45-diplomacia-cultural/94-o-itamaraty-e-o-design-i-sergio-rodrigues.

Figura 40. Correio Braziliense, 21 set. 2013. Disponível em: www.correiobraziliense.com.br/app/ noticia/cidades/2013/09/21/interna_cidadesdf,389338/mobiliario-ajuda-a-contar-parte-da-historia-da-unb-nos-anos-1960.html. 
Figuras 41a. http://unb.br/noticias/unbagencia/unbagencia.php?id=8115; http://institutozuzuangel.blogspot.com.br/2013/08/athos-bulcao-um-museu-ao-alcance-de.html; http:// erablogart.blogspot.com.br/2010/07/cronologia-amelia-toledohtml; www.antoniomiranda. com.br/iberoamerica/brasil/hugo_mund_junior.html; http://wp.clicrbs.com.br/almanaquegaucho/2014/05/29/o-teatro-de-fantoches-que-comecou-em-casa-e-conquistou-porto-alegre/.

Figuras 41 b. http://urbanascidadespoa.blogspot.com.br/2010/04/arquiteto-edgar-graeff.html; www.galeriacolecionador.com/acervo.php; www2.portoalegre.rs.gov.br/cs/default.php?re$\mathrm{g}=77215 \& \mathrm{p} \_$secao=3\&di=2007-07-31; http://elvindubugras.blogspot.com.br/; Foto colhida durante entrevista.

Figura 42a. www.archileb.com/article.php?id=695.

Figura 42b. http://marxismo21.org/oscar-niemeyer-uma-arquitetura-engajada/.

Figura 42c. http://memaranekashan.blogfa.com/post/155.

Figura 42d. http://jetsetmodernist.tumblr.com/post/903748776/strick-house-santa-monica-ca.

Figuras 43. http://angelaoskar.blogspot.com.br/2010_12_01_archive.html;

https://www.youtube.com/watch?v=Oi3jVz7REhM

http://servicos.iabdf.org.br/2012/imgs/index.html;

http://caumg.gov.br/plus/modulos/noticias/ler.php?cdnoticia=220

FROTA, 1993, 76.

Figura 44. www.youtube.com/watch?v=Z8DDjs418g4; www.youtube.com/watch?v=zF677UOO-

Zlc; www.facebook.com/geraldo.nogueirabatista?fref=ts; http://revistasim.ne10.uol.com.

br/2013/02/parceria-de-grandes-arquitetos/ www.facebook.com/marcia.nogueirabatista?fref=ts; foto colhida durante entrevista.

Figura 45a. Desenho do Lelé.

Figura 45b. Acervo particular do Lelé.

Figuras 46a, 46b, 46c, 46d, 46e. www.niemeyer.org.br/obra/pro099.

Figura 46f. Módulo, ano VIII, n. 32, mar. 1963, p. 55-57.

Figura 47. www.niemeyer.org.br/obra/pro497.

Figuras 48a, 48b, 48c, 48d. Módulo, n. 32, ano VIII, março de 1963, p. 42-43.

Figura 49. Módulo, n. 32, ano VIII, março de 1963, p. 46.

Figuras 50a, 50b. Cedoc/UnB.

Figura 50c, 50d. Acrópole, ano 31, n. 369-370, janeiro e fevereiro de 1970, p. 9.

Figura 50e, 50f. Módulo, n. 32, ano VIII, março de 1963, p. 50-55.

Figura 50g. Acrópole, ano 31, n. 369-370, janeiro e fevereiro de 1970, p. 9.

Figura 50h. Módulo, n. 32, ano VIII, março de 1963, p. 50-55.

Figura 51a, 51b. Módulo, n. 32, ano VIII, n. 32, março de 1963, p. 49-50.

Figuras 52a. Foto cedida por Luiz Henrique Pessina.

Figuras 52b, 52c. Desenhos de Eliel Américo da Silva.

Figuras 52d, 52e, 52f, 52g, 52h. Cedoc/UnB.

Figura 53a. Foto cedida por Luiz Henrique Pessina e modificada pela autora.

Figura 53b. Foto cedida por Luiz Henrique Pessina.

Figura 53c. http://www.fe.unb.br/.

Figuras 53d, 53e. FROTA, 1993, 148-149.

Figura 53f, 53h, 53i. Desenho de Eliel Américo da Silva.

Figuras 53g, 53j. http://www.fe.unb.br/.

Figura 53k. http://pesquisa-educao-a-distancia.blogspot.com.br/2011/06/fe-unb-mais-fotos.html.

Figura 53l. http://www.mubevirtual.com.br/pt_br?Dados\&area=ver\&id=211.

Figura 53m. Foto de Walter de Carvalho.

Figura 53n. www.panoramio.com/photo/54383889. 
Figuras 54a, 54b, 54c, 54d. Módulo, n. 27, v. VIII, mar. 1962, p. 29-35.

Figura 54e. Cedoc/UnB.

Figura 54f. Acrópole, ano 31, n. 369-370, jan.-fev. 1970, p. 19.

Figura 54g. Foto de Walter de Carvalho.

Figura 54h. http://sites.correioweb.com.br/app/noticia/encontro/revista/2013/06/21/interna_revista,718/niemeyer-para-estudantes.shtml.

Figura 55a. Foto cedida por Luiz Henrique Pessina.

Figura 55c. Acrópole, ano 31, n. 369-370, jan.-fev. 1970.

Figuras 55b, 55d, 55e, 55f, 55g. Fotos das peças e da montagem do SG 1 cedidas por Luiz Henrique Pessina.

Figura 55h. www.panoramio.com/user/2474947/tags/\%E2\%86\%92Educational\%20Institu-

tions?photo_page $=2$.

Figura 55i. UNIVERSIDADE DE BRASÍLIA, 1974, p. 64.

Figuras 55j, 55k. Fotos cedidas por Luiz Henrique Pessina.

Figura 55I. Imagem cedida por Luiz Henrique Pessina.

Figuras 55I, 55m, 55n. www.panoramio.com/user/2474947/tags/\%E2\%86\%92Educational\%20lnstitutions?photo_page $=2$.

Figuras 55, 55p, 55q. Desenho de Eliel Américo da Silva.

Figura 55r. Cedoc/UnB.

Figura 55u. Cedoc/UnB

Figuras 55t, 55v, 55x. Desenho de Eliel Américo da Silva.

Figuras 55w, 55y. Fotos de Walter de Carvalho.

Figuras 55z. www.Flickr.Com/Photos/Unb_Agencia/8250103005/.

Figuras 56a, 56b. Fotos cedidas por Luiz Henrique Pessina.

Figura 56c. Desenho de Eliel Américo da Silva.

Figura 56d, 56e. Acrópole, ano 31, n. 369-370, jan.-fev. 1970, p. 30.

Figura 56f. Cedoc/UnB.

Figura 56g. LATORRACA, 1999, p. 34.

Figuras 56g, 56i, 56j. Fotos cedida por Luiz Henrique Pessina.

Figuras 56k, 56l. Foto de Walter de Carvalho.

Figura 57a. Foto cedida por Luiz Henrique Pessina.

Figuras 57b, 57c. LATORRACA, 1999, p. 36.

Figuras 57d, 57e. UNIVERSIDADE DE BRASÍLIA, 1974, p. 73.

Figura 57f. Acrópole, ano 31, n. 369-370, jan.-fev. 1970, p. 24.

Figuras 57g, 57h. Fotos cedidas por Luiz Henrique Pessina.

Figura 57i. Acrópole, ano 31, n. 369-370, jan.-fev. 1970, p. 24.

Figura 57j. Fotos cedidas por Luiz Henrique Pessina.

Figura 57k. www.flickr.com/photos/mvitor/5325662484/.

Figuras 57l, 57m. LATORRACA, 1999, p. 36.

Figuras 58a. Desenho de Eliel Américo da Silva.

Figura 58b. SCHLEE, 2014, p. 48. (com alterações feitas pela autora deste trabalho).

Figura 58c, 58e. Foto de Walter de Carvalho.

Figura 58d. Fotos de Patrick Grosner. CAVALCANTE \& AZAMBUJA, 2009.

Figura 58e. Foto de Walter de Carvalho.

Figura 58g. Fotos de Patrick Grosner. CAVALCANTE \& AZAMBUJA, 2009.

Figura 59a. Foto cedida por Luiz Henrique Pessina.

Figura 59b. SCHLEE, 2014, p. 49. (com alterações feitas pela autora deste trabalho).

Figuras 59c, 59d. Fotos cedidas por Luiz Henrique Pessina. 
Figura 60a. Foto cedida por Luiz Henrique Pessina.

Figuras 60b, 60c. Ceplan/UnB.

Figuras 60d, 60e, 60f, 60g, 60h, 60i, 60j, 60k, 60l, 60m. Cedoc/UnB.

Figuras 60n, 60o. Fotos cedidas por Luiz Henrique Pessina.

Figura 60p. Desenho de Eliel Américo Santana da Silva.

Figura 60q. Acrópole, n. 369-370, 1970, p. 11 (com alterações feitas pela autora deste trabalho).

Figura 60r. Desenho de Oscar Kneipp. Cedoc/UnB.

Figuras 60r, 60t. Fotos cedida por Luiz Henrique Pessina.

Figura 60u. Foto Silvio Cavalcante.

\section{Capítulo 2}

Figura 61. www.cartamaior.com.br/?/Editoria/Politica/Golpe-de-1964-os-jornais-e-a-opiniao-publica-/4/16782.

Figura 62a, 62b. Detalhe. www.une.org.br/descomemoracaodogolpe/\#/step-4.

Figuras 62c, 62d. Cedoc/UnB.

Figura 63. www.infoescola.com/historia/marcha-da-familia-com-deus-pela-liberdade/.

Figuras 64a, 64b. Documentos cedidos por Luiz Henrique Pessina.

Figura 65. Correio Braziliense, 19 out. 1965, capa.

Figura 66. Correio Braziliense, 20 out. 1965, p. 2.

Figura 67. Correio Braziliense, 23 out. 1965, capa.

Figura 68. http://jestudante.blogspot.com.br/2011/03/edson-luiz-heroi-nacional.html.

Figura 69. www.vladimirpalmeira.com.br/ano1968_1.html.

Figura 70. Foto de Evandro Teixeira. Jornal do Brasil, 24 jun. 1968.

Figura 71. Correio Braziliense, 23 jun. 1968, capa.

Figura 72. Correio Braziliense, 23 jun. 1968, p. 5.

Figura 73. Correio Braziliense, 25 jun. 1968, p. 12.

Figura 74. Correio Braziliense, 27 jun. 1968, p. 12.

Figura 75. Correio Braziliense, 29 jun. 1968, capa.

Figura 76. www.redebrasilatual.com.br/cidadania/2013/09/ex-presidente-da-une-recebe-anistia-politica-post-mortem-em-cerimonia-na-unb-2913.html; http://jornaldiariodesalinas.blogspot. com.br/.

Figuras 77a, 77b, 77c, 77d, 77e, 77f, 77g, 77h. Cedoc/UnB.

Figura 78. www1.folha.uol.com.br/folha/treinamento/hotsites/ai5/extras/jornais.html.

Figura 79a. https://anos60.wordpress.com/2008/05/26/maio-de-68-40-anos/.

Figura 79b. http://blogdogutemberg.blogspot.com.br/2013/05/1968-uma-revolucao-do-desejo-2.html.

Figura 80a. www.discorsivo.it/magazine/2013/03/26/il-68-in-cecoslovacchia-linverno-sovietico-e -la-primavera-di-praga/.

Figura 80b. https://arazaoinadequada.wordpress.com/2013/09/06/primavera-de-praga/.

Figura 81a. www.juvenile-in-justice.com/wp-content/uploads/2013/04/MLK-Speech.jpg.

Figura 81 b. www.corbisimages.com/stock-photo/rights-managed/42-24013618/mourners-at -martin-luther-kings-funeral.

Figura 82. https://pibillwarner.files.wordpress.com/2010/06/black-panthers-led8oct06a1.jpg.

Figura 83. www.saraivaconteudo.com.br/Materias/Post/45950.

Figura 84. www.pelasruasecabides.com.br/moda/a-tropicalia-e-a-moda/.

Figura 85. www.redebrasilatual.com.br/revistas/88/uma-noite-em-1968-808.html.

Figura 86. www.redebrasilatual.com.br/revistas/88/uma-noite-em-1968-808.html. 


\section{Capítulo 3}

Figura 87. http://oglobo.globo.com/blogs/javoto/posts/2010/09/04/os-novos-tempos-da-une-321868.asp.

Figuras 88a, 88b, 88c. www.herancacultural.com.br/blog/2013/07/vilanova-artigas-e-a-escola -paulista-de-arquitetura/.

Figura 89. Cedoc/UnB

Figuras 90a, 90b, 90c. Acrópole, ano 32, ns. 369/70, jan.-fev. 1970.

Figuras 91a, 91b, 91c. UNIVERSIDADE DE BRASÍLIA. Plano de Desenvolvimento Físico, 1974, p. 147-148. Figuras 92a, 92b, 92c. Acrópole, ano 32, ns. 369/70, jan.-fev. 1970.

Figura 93. UNIVERSIDADE DE BRASÍLIA, 1998, p. 16.

Figuras 94a, 94b, 94c, 94d, 94e. UNIVERSIDADE DE BRASÍLIA, 1974, p. 144, 145 e 146.

Figura 95. Foto cedida por Luiz Henrique Pessina.

Figuras 96a, 96b. Fotos de Adonai Rocha, ex-aluno do curso de Comunicação. www.unb.br/noticias/unbagencia/unbagencia.php?id=4962.

Figuras 96c, 96d, 96e, 96f. http://independenciasulamericana.com.br/2010/04/.

Figura 97a. http://zonacurva.com.br/o-brasil-desperta-movimento-das-diretas-ja/.

Figura 97b. http://prof-guilherme.capesp.org/arquivos/tag/diretas-ja.

Figura 97c. www.ebc.com.br/noticias/politica/2014/03/insatisfacao-com-a-ditadura-eclode-nas -manifestacoes-das-diretas-ja.

Figura 97d. http://ultimosegundo.ig.com.br/politica/diretas+ja+e+eleicao+de+tancredo+foram+alvo+de+espionagem/n1597098849109.html.

Figura 98. http://minilua.com/o-arquivo-negro-presidente-morto-5/.

Figuras 99a, 99b, 99c. Fotos cedidas por Luiz Henrique Pessina.

Figuras 99d, 99e, 99f, 99g. UNIVERSIDADE DE BRASÍLIA, 1974, p. 87-89.

Figuras 99h, 99i, 99j, 99k. Cedoc/UnB.

Figura 99k. Desenho de Eliel Américo Santana da Silva.

Figura 99l. http://blog.pjvarquitetura.com.br/2011/06/biblioteca-unb-universidade-de-brasilia. html e www.thomaskellner.com/info/buildings/brazil/brasilian-architecture/brasilia-universidade-de-brasilia Figuras 99m, 99o, 99p. Cedoc/UnB.

Figura 99n. Foto de Walter de Carvalho.

Figuras 100a, 100b. Fotos cedidas por Luiz Henrique Pessina.

Figuras 100c, 100d. Acrópole, ano 31, n. 369-370, jan.-fev. 1970.

Figuras 100e, 100f, 100g. UNIVERSIDADE DE BRASÍLIA, 1974.

Figuras 100h, 100i, 100j, 100k, 100l, 100n. Cedoc/Unb.

Figura 100m. Acrópole, ano 31, n. 369-370, jan.-fev. 1970; Cedoc/UnB.

Figuras 101a, 101b. Fotos cedidas por Luiz Henrique Pessina.

Figura 101c, 101d, 101e, 101f, 101g. Acrópole, ano 31, n. 369-370, jan.-fev. 1970.

Figuras 101h, 103i, 103j, 103k. UNIVERSIDADE DE BRASÍLIA, 1974.

Figura 101l. Foto de Walter de Carvalho.

Figura 102a. Foto cedida por Luiz Henrique Pessina.

Figuras 102b, 102c, 102d, 102e, 102f. UNIVERSIDADE DE BRASíLIA, 1974, p. 92-95.

Figuras 102g, 102h, 102i. Fotos cedidas por Luiz Henrique Pessina.

Figuras 102j, 102k, 102l, 102m, 102n, 102o. Fotos de Leonardo Finotti. http://leonardofinotti.blogspot.com.br/2009/12/jose-galbinski-student-restaurant.html

Figuras 102p, 102q. Desenhos de Eliel Américo da Silva.

Figura 103a. Foto cedida por Luiz Henrique Pessina.

Figura 103b, 103c, 103d, 103e,103f. UNIVERSIDADE DE BRASÍLIA, 1974, p. 98-100. 
Figuras 103g. Cedoc/UnB.

Figura 103h. Foto cedida por Luiz Henrique Pessina.

Figura 103i. Foto de Walter de Carvalho.

Figura 103j. http://pt.wikipedia.org/wiki/Universidade_de_Bras\%C3\%ADlia\#mediaviewer/File:Reitoria_UnB.JPG.

Figura 103l. Cedoc/UnB.

Figuras 103m, 103n. www.vitruvius.com.br/revistas/read/arquitextos/04.048/583

Figura 103o. www.leonardofinotti.com/projects/rectory-unb/image/33201-091123-072d

Figura 103p. http://campus.fac.unb.br/arquivo/universidade/item/2213-especial-arquitetura-na -universidade-de-bras\%C3\%ADlia

Figura 103q. Cedoc/UnB.

Figura 103r. www.vitruvius.com.br/revistas/read/arquitextos/04.048/583

Figura 103s, 103t, 103u. Desenho de Eliel Américo da Silva.

Figura 104a. Cedoc/UnB.

Figura 104b. UNIVERSIDADE DE BRASÍLIA, 1974, p. 102.

Figuras 106b, 106c. Cedoc/UnB.

Figura 105a. Google Earth

Figuras 105b, 105c, 105d, 105e. UNIVERSIDADE DE BRASíLIA, 1974.

Figuras 105f, 105g, 105h. Cedoc/UnB.

Figuras 105i. Foto cedida por Luiz Herique Pessina.

Figura 106a. Foto cedida por Luiz Henrique Pessina.

Figuras 106b, 106c, 106d. UNIVERSIDADE DE BRASÍLIA, 1974.

Figura 106e. Cedoc/UnB.

Figura 107a. Desenho de Eliel Américo Santana da Silva.

Figuras 107b, 107c, 107d, 107e, 107 f, 107g. GOROVITZ \& FERREIRA, 2009.

Figura 107h. http://flickrhivemind.net/Tags/206,superquadra/Interesting.

Figuras 107i. www.Flickr.Com/Photos/Pianca/3775595315/.

Figura 107j. Fonte: GOROVITZ \& FERREIRA, 2009.

Figura 108a. Desenho de Eliel Américo Santana da Silva.

Figuras 108b, 108c, 108d, 108e. GOROVITZ \& FERREIRA, 2009.

Figuras 108f, 108g, http://lugaresquefazer.com/s?as=foto\&fp=77359535.

Figura 108h. http://zamorim.com/arquivo/2002_12_01_zarq.php.

Figura 109a. Google Earth.

Figura 109b. SCHLEE, 2014.

Figuras 109c. Cedoc/UnB.

Figuras 109d, 109e. Acervo da Biblioteca da FAUUSP. www.arquigrafia.org.br/photo/820;jsessioni$\mathrm{d}=$ D07ADBFD9A35101D9D9B2C75D0F6111A

Figuras 109f, 109g. Fotos de Walter de Carvalho.

Figura 109h. Acervo da Biblioteca da FAUUSP. www.arquigrafia.org.br/photo/820;jsessionid=D07ADBFD9A35101D9D9B2C75D0F6111A 


\section{Capítulo 4}

Figura 110. http://acervo.oglobo.globo.com/fatos-historicos/sarney-se-torna-presidente -em-1985-9916197.

Figura 111. www.schwartzman.org.br/sitesimon/?page_id=574\&lang=pt-br.

Figura 112. Acervo O Globo.

Figura 113. http://www.revistadehistoria.com.br/secao/artigos/a-forca-das-circunstancias

Figura 114. http://pt.wikipedia.org/wiki/Governo_Sarney\#mediaviewer/File:Ulyssesguimaraesconstituicao.jpg.

Figura 115. http://g1.globo.com/politica/noticia/2012/09/cientistas-politicos-e-historiadores-analisam-o-legado-da-era-collor.html.

Figura 116. www.jblog.com.br/hojenahistoria.php?itemid=29536.

Figuras 117, 118. http://cienciahoje.uol.com.br/noticias/2011/03/mais-educacao-menos-politizacao/; http://ediensino.com/tag/movimento-dos-caras-pintadas/.

Figura 119. www.estudopratico.com.br/governo-de-fernando-collor-de-melo/.

Figura 120. http://direitasja.com.br/2012/08/11/profissao-ex-presidente/.

Figura 121. http://superreforco.blogspot.com.br/2014/10/governo-fernando-henrique-cardoso-1995.html.

Figura 122. UNIVERSIDADE DE BRASÍLIA, 1998, p. 18.

Figuras 123a. http://www.leonardofinotti.com/projects/icc-central-institute-for-sciences-unb/ image/05555-090305-098d

Figura 123b. SCHLEE et al., 2014.

Figuras 123c, 123d, 123e. Fotos de Walter de Carvalho.

Figuras 124a. http://www.leonardofinotti.com/projects/icc-central-institute-for-sciences-unb/ image/05555-090305-098d

Figura 124b. SCHLEE et al., 2014.

Figuras 124c. Foto de Walter de Carvalho.

Figura 125a. Secom/UnB.

Figura 125b.

Figuras 125c, 125d. Fotos de Walter de Carvalho.

Figura 125e. SCHLEE et al., 2014.

Figuras 125f. Foto de Walter de Carvalho.

Foto 126a, 126b. Foto de Walter de Carvalho.

Figura 126c. Foto de Joana França. www.archdaily.com.br/br/603479/obras-do-lele-por-joanafranca.

Figuras 126d, 126e. LIMA, 1984.

Figura 127a. www.leonardofinotti.com/projects/colina-nova-at-unb.

Figura 127b. SCHLEE et al., 2014.

Figuras 127c, 127d, 127e. www.leonardofinotti.com/projects/colina-nova-at-unb.

Figura 128a. http://lugaresquefazer.com/s?as=foto \&fp $=60590445$

Figura 128b, 128c. SCHLEE et al., 2014.

Figura 128d, Foto Silvio Cavalcante.

Figura 129a. http://www.yelp.com.br/biz_photos/caf\%C3\%A9-

das-letras-lago-parano\%C3\%A1?select=4jVi8kLvOxD2618rRnUH4w

Figuras 129b. SCHLEE et al., 2014.

Figura 129c. http://www.yelp.com.br/biz_photos/caf\%C3\%A9-

das-letras-lago-parano\%C3\%A1?select=ShdAkbaN1F4mjRkh1IMzeg

Figura 129d. Foto de Walter de Carvalho.

Figura 130a. https://plus.google.com/116153205908821730164/about

Figuras $130 \mathrm{~b}$ e 130c. Fotos Kristian Schiel 
Figura 130d, Foto Silvio Cavalcante.

Figuras 131a, 131b. Fotos de Walter de Carvalho.

Figura 131c. http://www.unb.br/noticias/unbagencia/unbagencia.php?id=511.

Figuras 132a, 132b. Fotos de Walter de Carvalho.

Figura 132c, Foto Silvio Cavalcante.

Figura 133a. Foto de Walter de Carvalho.

Figura 133b. SCHLEE et al., 2014.

Figura 133c. Cedoc/UnB

Figura 133d. http://www.correiobraziliense.com.br/app/noticia/cidades/2013/07/08/interna_cidadesdf,375622/curso-de-artes-da-unb-vai-ganhar-4-predios-novos-proximos-da-14-norte.shtml Figura 133e. http://www.welcometobrasilia.com.br/2013/10/01/conhecendo-os-azulejos-de-athos-bulcao/

Figura 133f, 133g. Fotos de Walter Carvalho.

Figura 133h. http://www.unb.br/noticias/unbagencia/unbagencia.php?id=8867

Figura 133i. http://www.cpcestruturas.com.br/Entidade/12/DadosPortifolio/?sIP=32

Figura 134a. http://leonardofinotti.blogspot.com.br/2009/12/matheus-gorovitz-unb-gas-station.html Figura 134b. SCHLEE et al., 2014.

Figura 134c, 134d, 134e, 134f, 134g. http://leonardofinotti.blogspot.com.br/2009/12/matheus-gorovitz-unb-gas-station.html

Figura 135a. Google Earth

Figura 135b. Foto de Kristian Schiel

Figura 135c. Foto Silvio Cavalcante

Figura 136a. http://www.unb.br/unb/historia/linha_do_tempo/00/2002_centro_comunitario.php Figura 136b. SCHLEE et al., 2014.

Figura 136c. www.estruturas.arq.br/projetos/UnB\%E2\%80\%93Brasilia.html

Figura 136d. http://wikimapia.org/1242883/pt/Centro-Comunit\%C3\%A1 rio-UnB-Tenda-da-UnB Figura 136e. http://festaseshows.com.br/locais/tenda-da-unb-em-brasilia-distrito-federal/ Figuras 134d, 134e, 134f. Fotos de Walter de Carvalho.

Figura 134g, 134h. www.unb.br/noticias/unbagencia/unbagencia.php?id=8867.

Figura 134i. www.correiobraziliense.com.br/app/noticia/cidades/2013/07/08/interna_cidadesdf,375622/curso-de-artes-da-unb-vai-ganhar-4-predios-novos-proximos-da-14-norte.shtml..

Figura 134 j. www.brasiliaemdestaque.com.br/oficina-ensina-a-fazer-origamis-inspirados-nas-obras-de-athos-bulcao/.

Figura 135b. www.correiobraziliense.com.br/app/noticia/cidades/2013/07/08/interna_cidadesdf,375622/curso-de-artes-da-unb-vai-ganhar-4-predios-novos-proximos-da-l4-norte.shtml.

Figuras 135c, 135d, 135e, 135f, 135g, 135h. http://leonardofinotti.blogspot.com.br/2009/12/matheus-gorovitz-unb-gas-station.html.

Figura 136b. http://unb.br/noticias/unbagencia/unbagencia.php?id=3656.

Figuras 137a, 137b, 137c. Fotos de Walter de Carvalho.

Figura 138a. http://www.leonardofinotti.com/projects/anisio-teixeira-pavilion-at-unb-campus/ image/31201-091123-084d

Figura 138b, 138c, 138d, 138e, 138f. http://periodicos.unb.br/index.php/paranoa/article/ view/12270/8558

Figura 138g. Foto de Walter de Carvalho alterada pela autora.

Figura 138h. http://campus.fac.unb.br/arquivo/literatura-brasiliense/item/2215-arquiteto-explicacomo-projetou-os-pavilh\%C3\%B5es.

Figura 138i, 138j, 138k. http://www.leonardofinotti.com/projects/anisio-teixeira-pavilion-at-unbcampus/image/31201-091123-084d

Figuras 138l, 138m. http://campus.fac.unb.br/arquivo/campus12014/literatura-brasiliense/item/ 2215-arquiteto-explica-como-projetou-os-pavilh\%C3\%B5es 


\section{Capítulo 5}

Figura 139. http://fotografia.folha.uol.com.br/galerias/1585-era-lula-posse

Figura 140. www.youtube.com/watch?v=GqhUI-Icq7w

Figura 141. www.rondoniadinamica.com/arquivo/faculdades-particulares-de-porto-velho-tempior-desempenho-da-regiao-no-enade,7960.shtml

Figuras 142a, 142b, 142c. www.secom.unb.br/unbagencia/ag1006-46.htm.

Figuras 143a, 143b, 143c, 143d. Imagens cedidas pela equipe.

Figuras 144a, 144b. Ceplan, outubro, 2012.

Figura 145. www.educacao.rs.gov.br/pse/html/noticias_det.jsp?PAG=932\&ID=3476.

Figura 146. www.unb.br/administracao/decanatos/deg/expansao.php.

Figura 147a, 147b, 147c. www.skyscrapercity.com/showthread.php?t=1195437.

Figura 148. http://www.russianartandbooks.com/cgi-bin/russianart/00988R.html

Figura 149. www.stoutbooks.com/cgi-bin/stoutbooks.cgi/index.html.

Figura 150a. Foto de Walter de Carvalho.

Figura 150b. SCHLEE, et al., 2014.

Figura 151 a. Foto de Walter de Carvalho.

Figura 151b. Ceplan, outubro, 2012.

Figura 151c. SCHLEE, et al., 2014.

Figura 151d, 151e, 151f. Imagens cedidas por Kristian Schiel.

Figuras 152a, 152b. Fotos de Walter de Carvalho.

Figura 152c, Foto Silvio Cavalcante.

Figuras 153a, 153b, 153c, 153d, 153e, 153f, 153g, 153h, 153i, 153j, 153k, 153l. www.Vitruvius.Com. Br/Revistas/Read/Projetos/10.111/3588

Figura 154a.http://www.redelondres.com.br/cursos-gratuitos/unb-universidade-de-brasilia Figura 154b. SCHLEE et al., 2014.

Figura 154c. http://campus.fac.unb.br/arquivo/campus12014/universidade/item/2213-especial -arquitetura-na-universidade-de-bras\%C3\%ADlia

Figura 154d, 154e. http://www.panoramio.com/user/2072921

Figura $154 \mathrm{f}$. http://www.pgbiomol.com.br/?page_id=212

Figura 154g. http://rodrigovieiraeartes.blogspot.com.br/2014/04/instituto-de-biologia-ib-unb.html Figura 155a. Secom/UnB.

Figura 155b. SCHLEE et al., 2014.

Figuras 155c, 155d, 155e. Fotos de Walter de Carvalho.

Figuras 155f, 155g. www.flickr.com/photos/brenosilva/2896666820

Figuras 155h, 155i. www.flickr.com/photos/rbpdesigner/sets/72157601161230246/

Figura 155j. http://campus.fac.unb.br/arquivo/campus12014/universidade/item/2213-especial -arquitetura-na-universidade-de-bras\%C3\%ADlia

Figura 155k. https://www.flickr.com/photos/26601214@N07/2895819477

Figura 1551 .

http://www.panoramio.com/user/1548036/tags/Instituto\%20de\%20Qu\%C3\%ADmica\%20-\%20

UnB\%20-\%20Brasil

Figura 155m. https://www.flickr.com/photos/rbpdesigner/sets/72157601753898479/

Figura 155n.

Fontes: www.flickr.com/photos/marcossamaral/5083038606/;

Figura 155o. http://campus.fac.unb.br/arquivo/universidade/item/2213-especial-arquitetura-na -universidade-de-bras\%C3\%ADlia

Figura 156a. http://cogaarquitetura.com.br/website/outro-nome-de-projeto/ 
Figura 156b. http://www.cogaarquitetura.com.br/

Figura 156c. Foto de Walter de Carvalho.

Figura 157a. Secom/UnB

Figura 157b. SCHLEE et al., 2014.

Figura 157c. www.flickr.com/photos/51515752@N05/4963142663/

Figura 157d, 157e, 157f. Fotos de Walter de Carvalho.

Figura 157g. Imagem cedida por Adalberto Jose Vilela Junior.

Figuras 158a, 158b, 158c, 158d. www.panoramio.com/photo/32769668.

Figura 159a. Foto de Walter de Carvalho.

Figuras 159b, 159c, 159d, 159e. Ceplan/UnB.

Figuras 159f, 159g. http://pijasfub.xpg.uol.com.br/fotospij.htm

Figura 160a. http://cogaarquitetura.com.br/website/fiocruz/

Figura 160b. SCHLEE et al., 2014.

Figura 160c. www.ensp.fiocruz.br/portal-ensp/informe/site/materia/detalhe/7181

Figuras 160d. http://cogaarquitetura.com.br/website/fiocruz/

Figuras 160e, 160f. www.agencia.fiocruz.br/unidade-da-fiocruz-em-bras\%C3\%ADlia-ser\%C3\%A-

1-inaugurada-na-segunda-feira-com-a-presen\%C3\%A7a-de-lula

Figuras 160g, 160h, 160i, 160j, 160k, 160l. http://cogaarquitetura.com.br/website/fiocruz/

Figuras 161a, 161b, 161c. Fotos de Walter de Carvalho.

Figura 162a, 162b, 162c,162d, 162e, 162f, 162g. http://fgrurbanismo.blogspot.com.br/2012/05/

centro-de-planejamento-oscar-niemeyer.html

Figuras 162h, 162i, 162j, 162k. http://cogaarquitetura.com.br/website/chamada-home5/

Figura 163a. http://cogaarquitetura.com.br/website/masc/

Figuras 163b, 163c, 163d. Ceplan/ UnB, 2012.

Figuras 163e, 163f. http://cogaarquitetura.com.br/website/fiocruz/

Figuras 164a, 164b, 164c, 164d. http://cogaarquitetura.com.br/website/cpd/

Figuras 165a, 165b, 165c, 165d. http://cogaarquitetura.com.br/website/cic-est

Figuras 165e, 165f. Fotos de Walter de Carvalho.

Figuras 165g, 165h, 165i, 165j. http://cogaarquitetura.com.br/website/cic-est

Figuras 166a, 166b, 166c, 166d, 166e, 166f, 166g. Fotos de Walter de Carvalho

Figuras 166k, Foto Silvio Cavalcante

Figuras 167a, 167b. http://cogaarquitetura.com.br/website/ics

Figura167c. : www.unb.br/noticias/unbagencia/unbagencia.php?id=5061

Figuras 168a, 168b, 168c, 168d. http://cogaarquitetura.com.br/website/caep/

Figura 169a. Foto Silvio Cavalcante

Figura 169b. http://www.crad.unb.br/

Figuras 169b, 169c, 169d, 169e, 169f, 169g. http://www.crad.unb.br/index.php?option=com_phocagallery\&view $=$ category\&id=3:fotoscrad\&Itemid $=62$

Figura 170a.

Figuras 170b, 170c. www.cds.unb.br/cds/portal2/index.php/pt/noticia/475-confraternizacao-nocentro-de-desenvolvimento-sustentave

Figuras 170d, 170e, 170f e, 170g. http://aliancaempreendimentos.com.br/detalhaobra.php?-

cod=59; www.robertoguedes.com/projetos/

Figura 171a.: http://arcoweb.com.br/projetodesign/arquitetura/joao-filgueiras-lima-centro-cultural-20-07-2011

Figuras 171b, 171c, 171d. www.achabrasilia.com/unb-inaugura-beijodromo/

Figuras 171e, 171f, 171 g, 171h http://piniweb.pini.com.br/construcao/arquitetura/lele-apresenta -projeto-para-o-memorial-darcy-ribeiro-139521-1.aspx 
Figuras 171i, 171j, 171k. www.vitruvius.com.br/revistas/read/projetos/12.133/4186

Figuras 171l, 171m, 171n. www.gravia.net.br/grupo/obras-parcerias/especial-o-arquiteto-construtor Figuras 171o, 171p, 171q, 171r www.archdaily.com.br/br/603479/obras-do-lele-por-joana-franca Figura 171s. www.gravia.net.br/grupo/obras-parcerias/especial-o-arquiteto-construtor Figura 172a. http://cogaarquitetura.com.br/website/uac/ Figuras 172b, 172c, 172d. http://forum.skyscraperpage.com/showthread.php?t=207516 Figuras 172e, 172f, figura 172g. SCHLEE, 2014.

Figuras 172h, 172i. http://cogaarquitetura.com.br/website/uac/ Figura 173a. http://cogaarquitetura.com.br/website/ued/

Figuras 173b, 173c, 173d, 173e. http://forum.skyscraperpage.com/showthread.php?t=207516 Figura 173f. SCHLEE, 2014.

Figuras 173h, 173i, 173j, 173k. http://www.unb.br/noticias/unbagencia/unbagencia.php?id=4445 Figuras 173l, 173m. http://www.unb.br/noticias/unbagencia/unbagencia.php?id=7892

Figura 174a. https://www.youtube.com/watch?v=9kBjomJBBxQ

Figura 174b. http://forum.skyscraperpage.com/showthread.php?t=207516

Figura 174c. SCHLEE, 2014.

Figuras 174d, 174e, 174f, 174g. http://skyscraperpage.com/forum/showthread.php?p=6284797

Figuras 174h, 174i. https://www.youtube.com/watch?v=9kBjomJBBxQ

Figuras 174j, 174k. http://www.unb.br/noticias/unbagencia/unbagencia.php?id=4975

http://coletivo.maiscomunidade.com/conteudo/2013-07-03/educacao/8328/CAMPUS+DO+GAMA+MELHOR+EQUIPADO+.pnhtml 
ANEXO I 



\section{LINHA DO TEMPO}

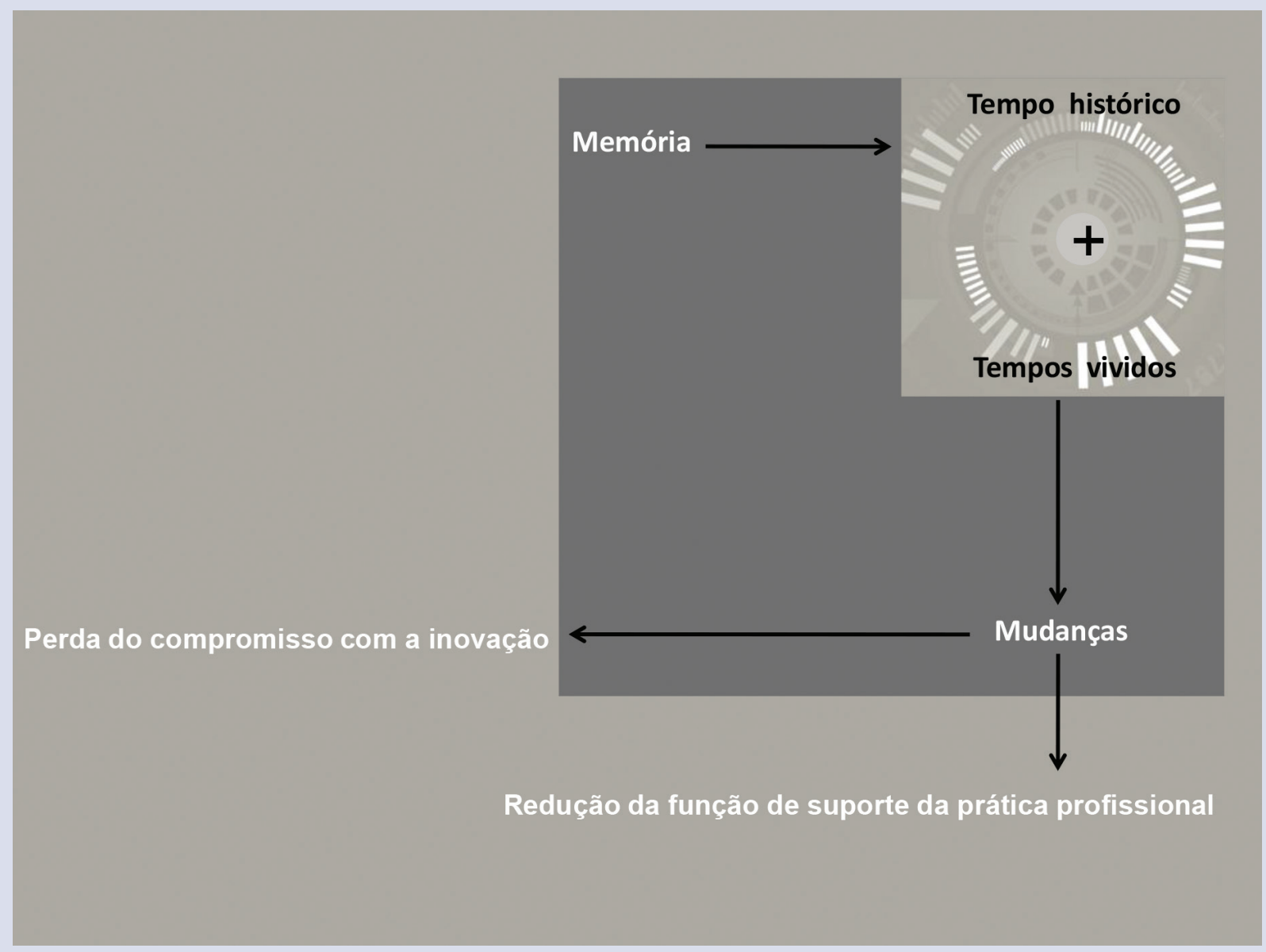




\section{Missões do Ceplan}

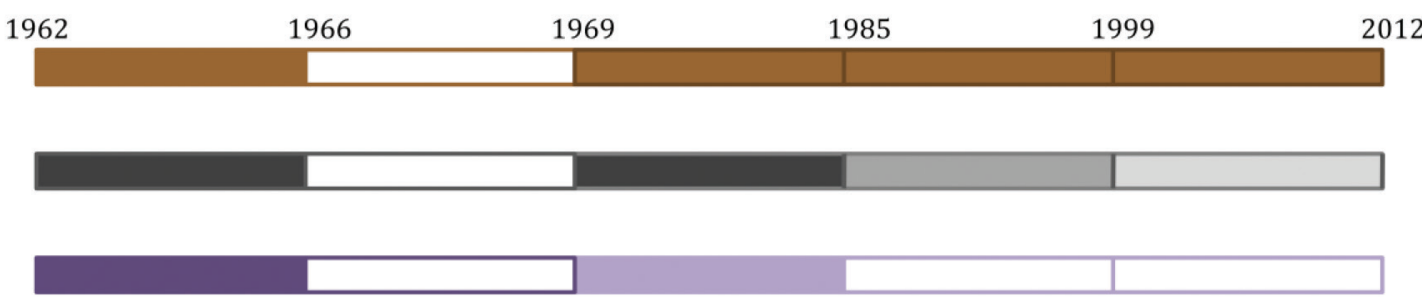

Planejamento e edificação do Campus

Suporte à prática profissional

Pesquisa e produção de tecnologia

\section{Missão 1. Edificações do Campus}

\section{Linguagem}

\begin{tabular}{|c|c|c|c|c|c|}
1962 & 1966 & 1969 & & 1985 & 1999 \\
\hline Minimalismo & & Brutalismo & Multiplicidade & Multiplicidade \\
formal & formal
\end{tabular}

\section{Função}

\begin{tabular}{|c|c|c|c|c|}
\hline Multifuncionalidade & Unifuncionalidade & Unifuncionalidade & $\begin{array}{c}\text { Indefinição } \\
\text { funcional }\end{array}$ \\
\cline { 1 - 4 } & & &
\end{tabular}


Missão 2. Suporte de prática profissional

\begin{tabular}{|c|c|c|c|c|}
\hline \multicolumn{2}{|c|}{1966} & \multicolumn{2}{|c|}{1985} & 1999 \\
\hline Professores da FAU & 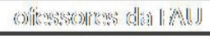 & Professores do IA & Professores da FAU & Professores da FAU \\
\hline Instrutores da FAU & & Giraduandos & Griaciuandos: & Griaduarios \\
\hline & & & & Comitratiandes: \\
\hline
\end{tabular}

Autoria dos projetos (\%)

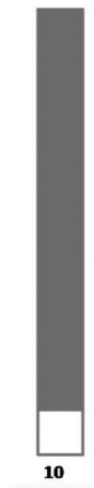

$1962-1966$

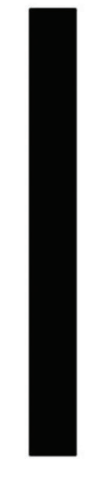

1966-1969

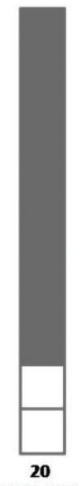

$\stackrel{20}{1969-1985}$

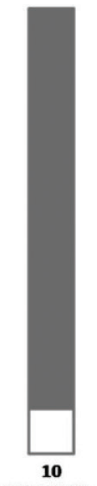

$\stackrel{10}{1985-1999}$

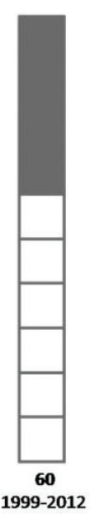

60
$1999-2012$
Professores

Arquitetos convidados

Era preciso ter um quadro de arquitetos contratados para executar aqueles projetos que os professores não estavam interessados em fazer (Weidle).

\section{Missão 3. Pesquisa e produção de tecnologia}

\section{Tecnologia}

\begin{tabular}{|c|c|c|c|c|}
\hline \multicolumn{2}{|c|}{1966} & \multicolumn{2}{|c|}{1985} & 1999 \\
\hline Pré-fabricação & 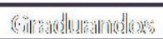 & Construção & Construção & Construção \\
\hline de ciclo fechado & & Convencional & Convencional & Convencional \\
\hline & & & & $\begin{array}{l}\text { Pré-fabricação de } \\
\text { ciclo aberto }\end{array}$ \\
\hline
\end{tabular}

Inovação

[...] optamos por fazer uns projetos usando a pré-fabricação disponível no mercado, consultamos os fabricantes, procuramos sistemas industrializados no mercado da construção [...] não tínhamos tempo para a inovação (FARIA). 




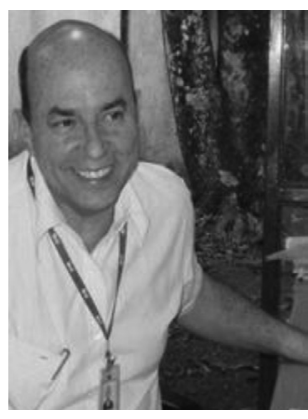

ENTREVISTA COM O ARQUITETO ALBERTO FARIA

Realizada em 8/3/12, em Brasília/DF

Vera - Queremos indagar que circunstâncias determinaram sua vinda para ser o primeiro diretor do Ceplan não sendo professor da FAU. ${ }^{1}$

Alberto - Ah, então nunca antes neste país? Olha, vou usar esse título! Não foram circunstâncias muito elaboradas não. Até onde eu acompanhei, tem uma discussão muito grande na FAU em 1997, a respeito de onde seria o vínculo mais adequado para o Ceplan, considerando que tem essa característica de ser uma unidade para a prática da arquitetura. Essa discussão foi muito debatida na FAU, não acompanhei, pois estava fora fazendo mestrado, mas culminou com a edição de ato que foi resultado dessa discussão. Obviamente que não foi unânime, mas existe um documento que vinculou o Ceplan ao Gabinete do Reitor. A UnB, de 1998 a 1999, já tinha a necessidade de fazer um plano de expansão. A estrutura da Prefeitura já não comportava esse tipo de trabalho, as demandas de manutenção eram maiores e a estrutura da Prefeitura trabalhou esse plano de expansão, mas não conseguiu viabilizar.

\section{Vera - Você estava na Prefeitura nessa época?}

Alberto - Não, até 1997 eu fui prefeito do campus. Quando o Lauro Morhy assumiu a Reitoria, eu saí para o mestrado. Quando volto, já em 2000, lembro, já havia esse Plano de Expansão com a instituição desse vínculo do Ceplan à Reitoria. O reitor tinha decidido chamar o professor Érico Weidle para ser o primeiro diretor com essa nova configuração. Ele deve ter contado para vocês na entrevista que encontrou o Ceplan meio abandonado. Nesse período o Ceplan fez alguns trabalhos isolados, projetos institucionais, mas sem um atendimento maior para a universidade. Ele me chamou para trabalhar com ele, como assessor técnico do Ceplan. Vem trabalhar conosco o Sergio, depois o Cláudio Arantes, que retorna do MEC. Então, esse núcleo inicial recebe do reitor a incumbência de fazer a revisão desse plano de expansão. Era um plano muito ambicioso e o Érico começa a montar esse trabalho, eu entro no Ceplan em janeiro de 2000 e ao longo do ano de 2000 e 2001 trabalhamos na montagem, na elaboração desse plano, chamado UnB 21. Era um plano que preparava a UnB para essa expansão. Esta expansão da UnB 21 era ainda decorrente dos gargalos todos existentes aqui. Quais eram esses gargalos? O IB (Instituto de Biologia) cresceu, a parte de infraestrutura do ICC estava toda comprometida, vários picos de energia, problemas de gases, acidentes com alunos por conta de situações de segurança, pois a ocupação desordenada do ICC nunca permitiu que ele tivesse algumas condições. Então, esse plano inicial contemplava isso. Era mais do que um planejamento físico, porque já existia um projeto que o Claudio Queiroz tinha elaborado em 1998 dessa expansão, mas não conseguiu ir além do projeto. Tinha somente o projeto, mas não estava pronto para virar obra, quanto e como... Então, esse Plano UnB 21 é o primeiro trabalho que na gestão do Érico começamos a fazer e a articular nestas dimensões: a arquitetônica, a financeira e a política. Porque começamos a fazer uma avaliação para confirmar esses programas ou não. E acabamos vendo que alguns programas que existiam não eram tão necessários e outros eram mais necessários. Por exemplo, nós vamos tirar desse programa de expansão o Instituto de Fí- 
sica. Porque foi feita uma análise que mostrava que a Física, basicamente, presta serviço. Então, ela não é uma unidade que pode ficar longe das outras, ela tem que estar no miolo, tem que continuar no ICC. O IB não presta serviços, mas é muito mais uma unidade de pesquisa. A Química também é muito mais pesquisa. Então, fizemos uma revisão deste plano e no final de 2002, depois de muita conta sobre quanto custa cada obra, quantos metros quadrados dá para fazer, partimos para analisar os projetos do Claudio. Eles tinham uma característica que não permitiam uma modulação, não permitiam uma expansão por etapas. Isso sempre fica meio comprometido, ou você faz igual ao ICC ou você não faz nada! Ou seja, ou você arruma 100 milhões, mas se eu dispunha somente de 20 milhões não posso fazer nada. Isso nos fez reavaliar os projetos e descartar esses projetos. Foi um processo que trabalhou todas essas questões e foi muito por conta disso. O financeiro, como isso se casaria com o processo de venda de projeção para financiar essas obras, dentro do que a lei permite, determina. Em dezembro de 2002 esse plano é aprovado. Ao longo desse tempo o Ceplan também fez análise dos permissionários, acompanhou projeto, acompanhou obra, tinha outras coisas acontecendo nesse período. Mas, principalmente, o Lauro Morhy queria viabilizar esse plano, já era o último ano da gestão dele, não queria sair sem estar implantando esse plano.

Então acontece uma crise na administração superior, motivado por uma crise financeira, decorrente da atuação incompatível com a quantidade de recursos que a UnB tinha por parte do Decanato de Finanças na época. E o Lauro Morhy não tinha senão o Érico para chamar para uma função dessas, porque era uma relação de muita confiança. O Érico sai da direção do Ceplan e disse: "Olha Alberto, dentro da continuidade dos trabalhos que você está acompanhando, eu vou te indicar para a direção do Ceplan". Argumentei que esse era cargo da FAU, ele disse que já tinha o entendimento da FAU. Na época, o diretor era o Geraldo Nogueira e a FAU achava melhor que não fosse um professor pelas discussões todas que iriam envolver o Ceplan. Então, as circunstâncias foram nesse contexto, a saída inesperada do Érico e a minha participação e conhecimento desse plano UnB Século 21.

Já tinha essa questão da expansão, o campus de Planaltina já era uma realidade e os outros campi virão depois. Como eu vim parar aqui, foi assim, não teve eleição, votação, nada disso.

\section{Vera - Em que projetos você se envolveu nesse período no Ceplan? Anteriormente, enquanto na Prefeitura, você não teve participação em projetos?}

Alberto - Na prefeitura eu trabalhava principalmente com a manutenção do campus. No período anterior à minha entrada no Ceplan estava trabalhando pouco com projeto. Na época do LEAU, a partir da década de 80, a produção do Ceplan cai muito. Por quê? Pelas discussões internas, dentro desse modelo do Ceplan, se é um laboratório ou coisa e tal, e também pela demanda. É o momento em que o país inteiro não investe nas áreas públicas. Então, em 95, quando o Cristóvão assume, o Ceplan volta a ter um período de discussão maior, se o Ceplan é vinculado à da FAU ou à Reitoria. É um debate que o Cristóvão faz também em relação aos hospitais, ele fala: "Temos que tomar muito cuidado com os hospitais universitários, por que o medico quer manter o paciente no hospital. Pois ele quer estudar, pesquisar determinada doença". Ele falou isso para os médicos, porque eles achavam que o diretor do hospital devia ser de dentro da estrutura orgânica da faculdade. Eram uns debates que havia nessa época. Eu estava na Prefeitura, onde se cuidava da manutenção, da contratação, de planejamento físico, fazia as articulações com os diversos órgãos. Mas os grandes projetos dessa época eram feitos no Ceplan. Teve o projeto da Nova Colina, do Paulo Marcos.

\section{Vera - Que projetos você desenvolve?}

Alberto - Vários projetos. Quando o Érico sai, como eu já não tinha nenhum vínculo profissional com a FAU, após ter passado por um período desgastante com o Cláudio por ter descartado o pro- 
jeto dos institutos. Tudo foi discutido às claras, mas não havia como viabilizar aquele projeto. Ele se mostrou inflexível quanto a modificar o projeto, portanto não havia como modificá-lo. Para refazer o projeto, eu fiz uma reunião com a FAU, onde coloquei o seguinte: "O Ceplan não poderia nunca perder as características que ele tem, ou seja, um local de prática profissional dos docentes e um local de treinamento profissional para os alunos da UnB, os estágios têm que ser aqui, ao máximo, e os professores têm que praticar aqui" (até hoje nos só aceitamos estagiários da UnB, porque tem hoje mais alunos, inclusive das particulares, querendo fazer estágio, mais do que nós podemos aceitar). E coloquei ainda nessa reunião: "Nós vamos ter que refazer todos os projetos, e para refazer vamos fazer um edital com as regras, os professores se candidatam aos temas, vamos montar as equipes e vamos fazer. Se tiver mais de um professor querendo fazer projeto, nós faremos um concurso".

\section{Vera - Eu trouxe esse edital para a nossa entrevista, está aqui. Achei-o na internet.}

Alberto - Isso mesmo, vários professores discutiram esse edital. Está dito no edital com toda a clareza que se tratava de revisão de áreas, revisão de projeto. Para não ter dúvidas. Esse edital é uma novidade, porque antes ninguém sabia quem escolhia quem para fazer projetos. Todos os professores que vieram ali mesmo se dividiram em grupos, porque não tinha sentido fazer concurso, porque havia muito mais projetos do que arquitetos professores disponíveis. Aleixo, Marcílio, Kristian resolveram fazer o projeto do Instituto de Química; Frederico Flósculo, Oscar e não sei mais quem foram fazer o IB; Claudia Garcia e Marcio Bujones vão fazer a FASC.; o Kristian depois vai fazer o CESPE. Esse é o procedimento até hoje para definir equipes para fazer os projetos aqui no Ceplan. Abrimos também uma linha de participação de professores da Faculdade de Tecnologia. Parte desses projetos de estrutura, cálculo fundações, instalações foi projetada por engenheiros da Faculdade de Tecnologia. Procuramos também trabalhar com a perspectiva de retomar o plano e dar sequência. Fizemos primeiro o estudo urbanístico para implantar esses edifícios, enquanto as equipes estavam trabalhando no programa de cada uma dessas áreas. A equipe de urbanismo, que era coordenada pela Marta Romero, Assunção, Vicente Barcelos e outros, trabalhou na diretriz urbana para a área que tínhamos escolhido. Deu alguns atritos, mas afinal foi bom, porque se você deixa cada arquiteto colocar o seu projeto onde ele quer dentro do campus, cada um vai querer colocar no topo de uma colina. Hoje tem uma lógica urbana, tem hoje uma percepção mais harmônica principalmente de cotas de nível.

\section{Vera - E as inter-relações entre as vias, os prédios?}

Alberto - Sim, inter-relações de saídas, acessos, percursos, então esse trabalho vai consumir a primeira fase desse plano no Ceplan, vai de 2002 a 2006. Então, não tinha como eu ter muito envolvimento em projeto específico, faltava tempo, eu participava das discussões, opinava.

\section{Vera - Teve participação dos alunos nessa fase?}

Alberto - Sim, vários alunos, alguns alunos interagiam desde o início, os estagiários que estavam concluindo o curso. Alguns arquitetos professores, inclusive, atribuíram autoria para alunos que participaram. Nesse período, essas obras começam a ser licitadas aqui no Ceplan, e não na Prefeitura. Porque eram muitas obras. Anteriormente a Prefeitura recebia um pacote de obras para licitar e as análises, revisão e questionamentos de projeto da Prefeitura para licitar atrasavam as licitações e a coisa não andava. Em 2006, o Lauro Morhy já tinha saído e já tínhamos licitado duas obras grandes, o CDT e o CESPE; faltava licitar as outras duas maiores, o IB e o IQ. Aí tem outro dado importante: o reitor Timothy no transfere para o Ceplan as atribuições de contratar obra com urgência. Toda a equipe da Prefeitura passou para o Ceplan e a partir de 2006 passamos também a contratar obras. 
Em 2007, é feito novo plano referente ao Plano UnB 21. Ele atualiza os dados de crescimento, já identifica outras áreas que estavam precisando de crescimento, Desenho Industrial, Medicina, Editora (o ideal era trazer a Editora para o campus, não fazia sentido ficar no SCS, alem do que essa distância afastava a Editora dos objetivos dela). Em maio 2007, com essa configuração, nós estabelecemos novo plano de obras e fizemos novos projetos, a Nova Casa do Estudante de pós-graduação, do Marcílio e o Aleixo, a Faculdade de Medicina, do Marcio Buzon, o prédio da Editora, do Jônio e a Claudia Estrela, e outros. Em novembro já estávamos com os projetos prontos.

Em janeiro de 2008 começa a crise da administração do Timothy, vai durar de fevereiro de 2008 até julho de 2008. Quando ele sai da Reitoria, isso ocasiona uma interrupção grande. Institucionalmente, também 2007 é o ano em que o governo federal decide aplicar no crescimento e na reestruturação das universidades, é o Plano Reuni I. Nós tínhamos trabalhado com a expansão e o Reuni traz outros números para essa expansão, então fizemos aqui no Ceplan uma revisão do planejamento inteiro e projetamos novas metas. Tinha muita discussão interna, pois o Reuni tinha muito recurso para obra e equipamento, mas não teve uma discussão ampla nas faculdades. 0 pessoal não sabia bem como era, estava muito em voga uma transição para um modelo de cursos baseados em bacharelados, não seriam mais áreas afins. Voltava um pouco ao que foi a UnB no seu começo, do Anísio Teixeira. Você entrava para um grande ICA, e dentro desse ICA você iria depois para a Faculdade de Comunicação, Arquitetura, Desenho Industrial etc. Essa era a ideia que estava por trás disso, mas isso acontece exatamente nesse período da crise do Timothy. No desenrolar da crise essa parte de planejamento vai ficando meio parada; quando ele sai, depois o vice, é nomeado um interventor, o professor Alberto Aguiar, em junho, promovendo toda uma revisão do Reuni I, inclusive aqui no Ceplan. Mudam os princípios, a filosofia. Abandona-se essa ideia dos bacharelados, a ideia passa a ser aumentar vagas no cursos, ampliar cursos noturnos. A FAU vai ter um curso noturno, como várias outras unidades, a Nutrição, a FIES. Do ponto de vista técnico, produzimos muitos estudos nessa época, quando a administração interventora assumiu nós tínhamos muita informação,isso ajudou a redesenhar esse novo REUNI.

\section{Vera - Isso traz mudanças na estrutura física do campus, então?}

Alberto - Do campus, ela traz sim, porque esse modelo inicial não trabalhava muito com a ideia de reforma dos espaços existentes. Mas no outro isso já era possível, então nós vamos aproveitar para reformar muito o ICC, muito mesmo. Foi a primeira chance que tivemos de dar uma nova cara para o ICC. Vamos criar alguns edifícios exclusivos para salas de aulas, porque isso não era pensado no outro modelo. Os bacharelados trabalhavam com aquele conceito, que está ate ali no ICC, com aqueles grandes auditórios, com turmas imensas. Essa mudança cria outro programa. E aqueles projetos de 2007, alguns ficaram, como o Desenho Industrial, a Casa do Estudante, mas a Faculdade de Medicina, não mais. Essa gestão do prof. Aguiar tem um prazo para a eleição do novo reitor, o José Geraldo, que vai assumir em novembro de 2009. Essa crise paralisou tudo, trocou prefeito, muita gente.

A discussão do Reuni ll vai fazer com que eu me envolva mais com projeto. Porque o tema passou a ser mais urgente, pois perdemos o ano de 2008. Não havia mais tempo, então tinha muito sentido fazer alguns programas com o modelo da pré-fabricação. Cheguei a conversar com o Lelé, numa das vindas dele aqui. Ele alertou sobre a necessidade de ter uma estrutura, o controle da máquina, pois, segundo ele, as empresas são difíceis de trabalhar, pois discutimos se seria viável montar uma estrutura aqui dentro para fazer a pré-fabricação. Ele acentuou a experiência dele em Salvador, que já tinha desmanchado a fábrica que havia sido montada. Em Brasília, também teve o desmonte da fábrica de pré-moldados da Novacap (...). Resultado: optamos por fazer uns projetos usando a pré-fabricação disponível no mercado, consultamos os fabricantes, procuramos no mercado da 
construção sistemas industrializados. Porque já tínhamos perdido um ano, não dava tempo, para tentar saber como vai ser. Analisamos esses prédios, os SGs e o ICC. (...) Percebemos que era uma maneira de apressar as obras e desenvolvemos alguns projetos que utilizam certos sistemas préfabricados com vãos de $7,5 \mathrm{~m}$ por $10 \mathrm{~m}$, mistura $7,5 \mathrm{~m}$ mais $7,5 \mathrm{~m}$ dá $15 \mathrm{~m}$. Enfim, dava para licitar, contratar e entregar.

Não tínhamos tempo para a inovação, olhamos para o passado e vimos que quando a UnB precisou rapidamente de espaços, optou por esta solução, prédios que não são monumentais mas têm uma variedade de espaços internos, têm segurança, por ter uma entrada só, os ambientes internos são tranquilos, como esse prédio do Ceplan (com duas peças repetidas se fez um prédio). Tal como os prédios dos SGs do Lelé, são prédios que já abrigaram todas as funções. Não era pretensão de ninguém comparar com esses prédios. Dava para ver que foram problemas semelhantes. (...) e com uma arquitetura que não comprometesse o gesto de cada arquiteto, porque isso também tem o seu risco. Nesse período, então, eu acabo me envolvendo mais com os projetos, pois os professores estavam ocupados com aquela pauta grande e ainda surge o interesse com projeto do concurso do Museu de Ciências.

Vera - Então, esse projeto vira concurso porque era um tema que muitos professores queriam projetar? E entram os alunos também? Eram cinco equipes de professores trabalhando.

Alberto - Sim, imagine, eram cinco equipes de professores trabalhando. Acabou ganhando a equipe do Nonato Veloso. E foi um concurso diferente, não aconteceu de cada equipe trabalhar escondida e não saber o que a outra equipe estava fazendo. Foi aberto, todas as cinco equipes toparam trabalhar porque era um concurso interno. Contratamos estagiários, fornecemos material, maquete, fizemos uma exposição pública dos projetos concorrentes na Semana de Ciência e Tecnologia, na Esplanada. Cada equipe recebeu uma poligonal que encaixava na maquete urbana e tinha que encaixar para fotografar, então foi uma coisa aberta. Foi um momento muito bacana, se discutiu muito arquitetura. Aleixo, Marcílio, Holanda, Neusa, Gabriela, Paulo Marcos... muitos participaram.

\section{Vera - Essa experiência deveria constar do livro, não, Neusa? E o júri?}

Alberto - O júri foi um problema, pois o Sindicato de Arquitetos e o IAB defenderam que o concurso deveria ser aberto para o mundo. Defendemos que a FAU era o campo certo para o concurso. Então, chamamos um júri do IAB Nacional, mas só veio o

Albano Volker e dois museólogos, e os dois arquitetos do IAB não vieram, tivemos que trazer dois professores da FAU; não tenho certeza, mas acho que vieram a Cláudia e o Andrey. Já para o outro concurso da Praça Maior, não houve problema. Todo o júri compareceu, felicíssimos de terem sido chamados para participar, discutiram os trabalhos, julgaram. Eram o Roberto Castelo, o Pedro Paulo de Melo Saraiva e o Glauco Campello. O concurso é um momento muito bom: embora tenha um momento de disputa, integra os alunos, incentiva a discussão.

Neusa - Defendo sempre os concursos, é uma oportunidade muito boa para os alunos, isso foi muito importante para os alunos verem os professores projetando, ver como eles trabalham.

Alberto - A apresentação foi no auditório da Reitoria, lotou. É um concurso, mas o processo é muito bacana, aberto, não teve isso de portas fechadas. A proposta do Aleixo era juntar todas as equipes e fazer coletivamente um projeto só. Não foi aceita, é um discurso interessante, mas sem viabilidade.

Neusa - Quem deu este título Centro de Planejamento Oscar Niemeyer? 
Alberto - Isso foi na gestão do reitor Todorov. Ele quis fazer homenagem ao Oscar e ao Darcy Ribeiro, na época senador. Havia sido recém-aprovada a Lei de Diretrizes e Bases, pela qual ele tinha trabalhado muito. E o Todorov resolve homenageá-lo dando o nome ao campus da UnB de Campus Darcy Ribeiro e denomina esse prédio de Centro de Planejamento Oscar Niemeyer.

Neusa - Na placa na entrada do Ceplan, está a data de 1997.

Alberto - É por aí.

Neusa - Gostaria de ter os documentos desse ato e do Plano UnB 21.

Alberto - Sim, vou localizar, dar uma revirada, e acho os atos.

Então, nesse período de 2007 a 2009, voltando à pergunta os projetos em que atuei. Foram esses prédios pré-fabricados, o projeto da Fiocruz. Algumas construções fora, nos outros campi da UnB. É sempre uma participação onde a gente esgota a capacidade interna. Uma coisa que está acontecendo na FAU é que, na minha visão, temos tido uma renovação muito baixa de pessoas com experiência em projeto, a experiência maior são pessoas com qualificação de doutorado. Ora, obter um doutorado força a pessoa a ficar muito tempo fora do mercado de projeto, por 5 a 6 anos. Hoje, se quiséssemos fazer o que fizemos em 2002, chamar uma turma grande para projetar, viria pouca gente. Já não tem mais, muitos já aposentaram, outros estão para aposentar.

Vera - Vi hoje, ao entrar no campus, uma placa de obra: "Bloco de Salas de Aula - ALA SUL". É destinado a uso de todos os institutos?

Alberto - Sim, são destinados a uso geral de todos os institutos, são salas de 40, 60, 80 lugares, auditórios de 200 lugares, salas de estudo. Passamos o período do Fernando Henrique todo sem investimento na área pública de ensino; quando chega, o programa Reuni traz esta perspectiva nova. Tivemos recurso público para construir e reformar, colocamos o ICC como foco das reformas e as construções dos prédios mais básicos para blocos de sala de aula. É para complementar essa demanda por sala de aula, e conseguimos naquela época ainda recursos para retomar a construção de alguns prédios, tipo a Faculdade de Comunicação, de 2002, que foi construída com recurso próprio. Então, o bacana foi o Reuni permitir fazer novas obras, reformar, retomar obras, resgatar uma infraestrutura que estava muito quebrada e crescer o número de alunos.

Porque os nossos números são vergonhosos: o Brasil, quando começa o Reuni, tinha 8\% da população entre 18 e 24 anos dentro das universidades, o Chile tinha 16\%, a Argentina 24\%, o Canadá $36 \%$. Hoje, depois do Reuni, tem 13\%; ainda está baixo, mas cresceu $5 \%$. Mais do que simplesmente um projeto de governo, nós vimos que era uma grande chance, enquanto que várias universidades contrataram projeto em escritório fora, alguns professores de outras unidades de ensino chegaram a pegar projeto, sugerindo que usássemos aqui no Ceplan, não aceitamos e nos propusemos a fazer aqui, enfrentar o desafio em prazo, em pessoal.

\section{Vera - O quadro técnico do Ceplan: hoje você tem engenheiros, orçamentistas?}

Alberto - Este é o lado bom, positivo: passou a haver um ponto da integração do processo construtivo, o arquiteto, o engenheiro e o orçamentista estão aqui. $O$ arquiteto vê como o cálculo e o orçamento interferem; a maioria participa da licitação; vê como uma falta de revisão no projeto interfere. Vê que o custo interfere. Tem também um lado que é meio ruim, quando você tem uma coisa muito pesada como as obras, a área de planejamento fica meio a reboque. Hoje estamos cuidando mais de obra do que de planejamento. Já estamos vendo a necessidade de tirar a atribuição de obras do Ceplan. Fiscalização, atestar fatura é muita guerra. 
Vera - Todos os entrevistados que responderam à pergunta sobre o ICC abordaram a necessidade de complementação do forro do ICC? A demora na solução é em função do custo altíssimo?

Alberto - Estamos fazendo o forro do ICC, por etapas, cada trecho de obra, trabalhamos esta parte. Não tem uma linha assim, vamos forrar todo o ICC. Fizemos um trabalho que está exposto aqui no Ceplan, do laboratório da Marta Romero e Rosana Clímaco, elas identificaram todos os condicionantes ambientais que interferem hoje no ICC. Só para ter uma ideia das mudanças que nós fizemos: as mudanças que fizemos sobre o forro, logo recebemos críticas gerais do Claudio e da Neusa. Acham que as vigas têm que aparecer, o forro não pode cobrir.

Neusa - Não é exato, foi a introdução da laje no espaço da FAU dentro do ICC que nós não aceitamos.

Alberto - Em relação ao fechamento do mezanino, as esquadrias eram até o chão, nós cortamos em certa altura e colocamos paredes, porque esse estudo mostrou que essa insolação precisava ser contida.

\section{Vera - Mas não tinha os brises?}

Alberto - Os brises não funcionavam porque eram todos verticais, todos iguais em toda a fachada, teria que mudar os brises ou colocar as paredes.

Neusa - Mas os brises não mexem?

Alberto - Mexem, mas quando fecha eles não ventilam. Cria outro problema, falta conforto, isso tudo foi colocado nesses estudos. Então, foram decisões feitas baseadas nesses estudos. Passamos a adotar ar-condicionado nos auditórios porque tecnicamente se mostrou viável. Tem um projeto de acústica feito pela Rosana que deu um desenho para aquele forro, então passamos realmente a fazer uma série de trabalhos nesse sentido.

Alberto - O que eu acho é que, como eu não sou da FAU, não tenho notícia dos assuntos que são discutidos na FAU, as idiossincrasias que a Neusa tem e as que as pessoas possam ter contra a Neusa, só para dar um exemplo. Alguns só gostam de criticar.

\section{Vera - Dessa forma, você tem certa isenção...}

Alberto - Alguns professores me falam que, por eu estar aqui, mais gente passou a fazer projeto, a se interessar, a saber que existem regras Estes números eu tenho que dar para vocês: neste período que estou aqui já foram mais de 200 estagiários, mais de 80 professores que fizeram projetos aqui.

Neusa - Na escola ficam falando em canteiro experimental. Ora, com esse volume de obras no campus era para estar toda a escola dentro da do canteiro de obra...

Alberto - Isso eu vivo falando! É chocante, pois a maioria dos estagiários aqui é de arquitetura e não da engenharia, e nas obras também tem mais estagiários da arquitetura.

Neusa - Eles sonham com canteiro experimental, e ninguém sabe bem o que é. Quando eu era aluna, o Ernesto Walter nos levava para a obra do ICC, eu aprendi muito. Esta era e deve ser uma das funções do Ceplan: proporcionar uma aula viva de obra.

Alberto - Aqui está um resumo, detalhamento com área dos prédios necessários, o Plano de Obras de 2010; a data é de 16/10/2006, do ato em que o reitor delega competência ao diretor do Ceplan. O resultado, na prática, é que de 2002 para cá crescemos a área física do campus em 47\%. Só dentro do ICC são mais de $12.000 \mathrm{~m}^{2}$ de reforma, de áreas novas criadas dentro do ICC, menos a FAU, que brigou internamente; não brigou com o Ceplan, mas brigou com o projeto e não deixou terminar a obra. É um volume muito grande, mas foi assim, aproveitando as circunstâncias: juntou um plano 
que foi o Reuni, no qual desenvolvemos projetos que davam certa velocidade (não mais o projeto cada arquiteto fazendo o seu projeto) e as reformas.

Neusa - Teve algum pedido para fazer o projeto da Escola de Arquitetura?

Alberto - Não, mas falei isso numa reunião, que a FAU deveria sair do ICC, não cabe mais.

Vera - Em relação ao planejamento do campus?

Alberto - Temos uma publicação do Plano Diretor do Campus que fizemos, no qual aprovamos uma resolução que usamos dentro do campus: tem uma setorização, e dentro desta setorização tem um detalhamento, um arruamento. Temos uma preocupação com esse planejamento, essas regras existem. É projeto do Zimbres feito em 1988.

Vera - E sobre a expansão prevista da Reitoria, hoje tem o Memorial Darcy Ribeiro, bem próximo. Quando aquele espaço foi designado para o Memorial?

Alberto - Foi designado em 2010. Foi o Ceplan que escolheu aquele lugar, porque ali é a Praça Maior, o prédio da Reitoria vai crescer para trás, na direção do ICC. O Zimbres tinha uma proposta de o prédio crescer no sentido longitudinal, mas depois ele vê que não era viável, pois virava outro ICC. O prédio do Darcy Ribeiro é emblemático demais para colocar noutro lugar. O Lelé veio aqui e disse: "Vamos colocar o Memorial onde vocês escolherem"; ele foi supergentil e respeitoso, teve a preocupação em manter no projeto dele a mesma altura do ICC, não ultrapassando a cota máxima do ICC. Então, ficou numa posição meio lateral, onde não tem muita expansão. Tanto que o projeto do Matheus que ganhou o concurso preserva a Praça Maior, ficou nesse miolo entre a Reitoria e a Biblioteca.

Voltando àquela questão sobre a participação dos alunos, quero colocar que temos uma questão sobre os mestrandos e doutorandos, em geral eles estão muito envolvidos com as pesquisas que estão fazendo, não têm uma participação muito grande no Ceplan, também porque as linhas de pesquisas raramente são para fazer projeto. Mas entre os alunos de graduação a participação é grande. Sabemos que no início do Ceplan essa participação dos mestrandos era intensa, teve o Pessina, a Mayumi e muitos outros.

Neusa - Agora está para ser aprovado o mestrado profissional.

Vera - Sobre o grau de interferência da Reitoria no Ceplan, no planejamento do campus, você tem alguma colocação?

Alberto - No meu período nunca teve, todos os reitores e a comunidade enxergam o Ceplan como órgão técnico.

\section{Vera - Os projetos feitos pelos professores no Ceplan têm alguma remuneração?}

Alberto - Não. Há nesse período, agora, compensação de carga horário por conta da atividade de projeto. Há um entendimento que não é por que não estão dando aulas que essa atividade tenha que ser remunerada, pois em alguns momentos essa remuneração foi questionada pelo Tribunal de Contas, noutros não. Então, às vezes conseguimos remunerar, outras vezes não. Entendemos que deve ter algum tipo de remuneração. Se não há, pelo menos entendemos que o Ceplan deve oferecer as condições de trabalho. Por exemplo, no concurso do Museu de Ciência e Tecnologia, o professor não ganhou remuneração, mas teve uma equipe de estagiários contratada para desenhar, pagamos as maquetes, material, todas as cópias.

Neusa - Tínhamos um cartão corporativo para comprar os materiais na papelaria. 
Alberto - É uma forma de não onerar o professor, que, além do tempo trabalhando, ainda teria os gastos com o projeto para um concurso. Pelo menos tinha uma compensação.

Vera - O Zimbres e o Galbinski falam que na época inicial os salários eram tão bons que compensavam a dedicação exclusiva e a dedicação aos projetos no Ceplan.

Neusa - Hoje está impraticável, e na aquela época as aulas eram todas pela manhã e permitiam a prática no período da tarde.

\section{Vera - E sobre a questão da inovação?}

Alberto - Sobre a questão da inovação na arquitetura, não dá para comparar com o período inicial. O período atual, na questão da inovação da arquitetura tem trabalhado, aqui no Brasil, mais com o resgate do modernismo, como o Isay Weinfeld, Marcio Kogan. O que temos procurado aqui é trabalhar com a FAU, onde há muita experiência em trabalhar com as diretrizes de planejamento, discutir as experiências alternativas, as experiências com o bambu (trabalho do Jaime Almeida), tem algumas experiências com a questão da sustentabilidade.

Mas acho incomparável com aquele período inicial, não dá para comparar com aqueles caras; eram os melhores do Brasil que estavam aqui. Hoje as condições nossas não são mais aquelas, pelas dimensões e pelas circunstâncias. Agora é trabalhar mais com o que temos à mão. Realmente, aqui no Ceplan o esforço atualmente é o de tentar trabalhar a questão urbana - já vimos que não dá mais para fazer prédio térreo -, a questão do transporte interno - temos que repensar esse modelo viário, introduzir a bicicleta.

Vera - Numa entrevista foi sugerida pelo Moraes a introdução de uma linha de pequeno transporte interno elétrico, incluindo a rua interna no subsolo do ICC.

Alberto - Diria, assim, que não é possível estabelecer essa comparação, não só pela dimensão dos caras do período inicial, mas pelas circunstâncias atuais.

Neusa - Se você pensar aparecem outras coisas, ninguém falava em reaproveitamento de material, apareceram muitos campos novos.

Vera - E ainda sobre o ICC, você teria alguma observação?

Alberto - O ICC continua sendo para nós um grande espaço, mais para ensino do que para pesquisa. Achamos que o ICC irá virar um dia um grande local cultural e um grande centro de salas de aula, vejo uma tendência das faculdades saírem do ICC. Já os institutos básicos devem ficar no ICC. Para voltar a ser o que era: o Instituto Central de Ciências, Exatas, Física e Letras.

Sobre a última questão, o material que estiver aqui, está tudo disponível; pessoalmente não tenho nenhum documento para fornecer.

Vera - Alberto, então muito obrigada pela entrevista e pela atenção.

Vera - Arquiteto Cláudio Arantes, você vai nos contar um caso, ocorrido aqui no Ceplan, na ocasião da visita do dr. Lúcio Costa, quando você era estudante, não?

Cláudio Arantes - O prof. Coutinho, toda vez que me encontra, pede para contar este caso. Foi naquela vez que o Lúcio Costa veio a Brasília para o seminário da Brasília Revisitada- nessa época, não sei a data. 
Vera - O Érico era diretor do ICAFAU e trouxe o dr. Lúcio para visitar a UnB, em 1988.

Cláudio Arantes - Eu já tinha lido em um texto sobre a Bauhaus que os críticos de arquitetura só conseguiram discutir a Bauhaus depois que o Walter Gropius morreu, e fiz esta referência para o Dr. Lúcio. Ele era muito defensivo. Aquele livro, Sobre Arquitetura, feito pelo Alberto Xavier, foi feito à revelia dele. $O$ Xavier juntou todos os artigos e um dia acertou um encontro para dizer que iria publicar. O Lúcio, disse para ele: "Você sabe que o senhor pode ser preso por apropriação indébita?". Então, naquele dia no auditório do Ceplan, depois que ele falou sobre Brasília, por achar que ele era pouco dado a discutir Brasília, ele raramente falava e todos ficavam constrangidos, ele não abria a discussão. Então, eu coloquei ao final da palestra: "Dr. Lúcio, o pessoal só conseguiu discutir a Bauhaus depois que o Gropius morreu". Ele falou assim: "Não preocupa não, porque eu não vou durar muito mais tempo, não. Então vocês poderão discutir mais". (...) 


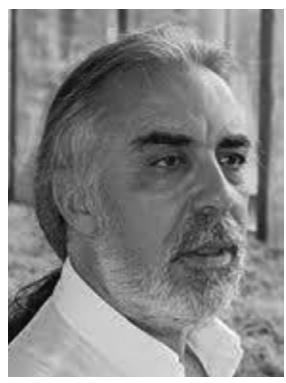

ENTREVISTA COM O PROF. CLÁUDIO QUEIROZ

Realizada via email, enviada em 15/04/2012, Brasília/DF

1 - O Centro de Planejamento Oscar Niemeyer (Ceplan), criado em 1962, é um órgão de assessoria técnica da Reitoria da Universidade de Brasília, cuja finalidade é promover o desenvolvimento de estudos, planos e projetos nas áreas de arquitetura e urbanismo. Tanto dentro do campus da UnB quanto atuando no DF e na região de influência, tem permanentemente em vista a integração da prática profissional e didática $\mathrm{O}$ que mudou em relação ao período de sua atuação?

Cláudio - Ingressei em 1983, como professor colaborador da FAU-UnB, à época Instituto de Arquitetura, tornando-me professor assistente em 1984.

Visitei o Ceplan com alunos no mesmo ano de 1983. Dei-me conta de sua denominação, no campus: SG 10, entre os SG(s). Trata-se de um dos edifícios de Niemeyer paralelos aos mais altos, os de João Filgueiras Lima, o Lelé, todos construídos para abrigar os serviços gerais, daí a sigla SG.

Como obra significante, em celebrações acadêmicas pós-Al-5, o Ceplan era mostrado como "o escritório do Oscar no começo da UnB". Mas sem valorizar muito, a despeito de sua simplicidade arquitetônica e de seu pioneirismo em pré-moldagem. Nem sobre a sua função precípua e possibilidades de reativação. Mas, enfim, ficava o entendimento de que se pensava em alternativas de uso, apesar do edifício não oferecer conforto climático em função das inversões térmicas; mosquitos etc., sem dar ao edifício o valor devido. Basta visitá-lo hoje e se constatará a compreensão e a consideração tida com o edifício - entre outros, o prof. Coutinho se referiu a seu merecido tombamento.

A sigla Ceplan, denominação de origem do início da década de 1960, parece ter sido substituída pela do Laboratório Experimental de Arquitetura e Urbanismo (LEAU), pretendendo suprir funções análogas.

Funcionou em algum momento, após o Al-5 até 1983/84, período das Diretas Já. Depois desse tempo testemunhei sua existência. Enquanto LEAU, parece ter ocupado intermitentemente o emblemático edifício, o SG-10, durante parte daqueles 15 anos entre o Al-5 e as Diretas Já. No entanto, sem a aparente intensidade dos tempos do Ceplan e sem a animação concorrente refletida pelo ICA-FAU.

Professores ilustres como Farret, Galbinski, Geraldo, Villas Boas e Zimbres, entre outros, falarão melhor sobre o LEAU e o período inconstitucional: se funcionou no SG 10; quanto à produção arquitetônica e acadêmica, se era tal como foi no período do Ceplan; se ocorria lá o treinamento de estagiários da graduação junto aos pós-graduandos, junto aos professores do Instituto de Arquitetura e Urbanismo, pós ICA-FAU.

Isso porque a partir de 1968 houve chance de extensão e continuidade análoga à do Ceplan, dada a intensidade construtiva nos anos 1970. Foi a época dos projetos e obras, como a Biblioteca, a Reitoria, a Tecnologia e a Medicina, estendendo-se ao Restaurante Universitário (RU), ao Centro Olímpico e ao Direito, as principais ao longo daquele tempo. 
Ao que parece o LEAU veio a funcionar no SG-10, onde funcionava anteriormente o Ceplan. Infelizmente, talvez pela inconstitucionalidade do período não se promoveu a atmosfera do período de Niemeyer/Lelé e outros, momento primaz desta história.

Vários entre os colegas se referem àquele tempo, como de resistência, na expressão altiva do prof. Coutinho, referindo-se ao engajamento dos quantos colegas que, sem deixarem o país, militaram, nas universidades federais e nas unidades da UnB. Dessa militância acadêmica, por exemplo, resultou a fundação da Associação dos Docentes da UnB, ADUnB, fundada pelos que viveram duramente a resistência contra os reitores e reitorias da ditadura, pela autonomia universitária. Épocas particularmente intensas a partir do Instituto de Arquitetura, inclusive, pela tradição herdada, e honrada.

Nos tempos do Centro de Planejamento, o Ceplan, lá, de fato funcionava o escritório de Niemeyer, mas o espaço era utilizado - com o caráter pioneiro da construção de Brasília - por estudantes, estagiários, desenhistas, arquitetos em pós-graduação e mestres orientadores - como Lelé, entre outros.

Era propriamente um centro de planejamento de uma universidade, frequentado por acadêmicos de diferentes níveis, por engenheiros, técnicos e mestres de obras. Além de personalidades estruturantes menos cotidianas: como um Darcy, frei Mateus, ou dr. Alcides, entre outros. Esses acentuavam uma espécie de tempo épico da nova capital, e o do canteiro da sonhada universidade brasileira por excelência e para a excelência.

Mas desde período, no que concerne ao Ceplan, talvez tenha restado uma visão onírica de algo anterior, superado pelos fatos reais ulteriores, sem nunca mais dar vez à formação do diferencial pretendido, para ensinar o planejar, o projetar e construir, intensificando no ensino de massa a práxis inerente à arquitetura. Nesse sentido, as décadas de 1980 e de 1990 foram as dos Seminários de Desenho Urbano, resultante produtiva e expressiva do Instituto/FAU UnB.

"Desenho urbano" foi o termo "pós-modernista" para urbanismo. A Escola, com os Seminários, destacou-se em meio à crítica acadêmica predominante. As perspectivas dessa tendência tiveram relevância de meados dos anos 1970 até os primórdios dos anos 1990.

Entre outras generalizações, foi injusto, senão desonesto, desqualificar Brasília como o "exemplo acabado do modernismo". Porque esta expressão ismo/ista, compreensível, mesmo que irreal, para outras artes, como a literatura, e saberes, como a história, é espaço temporalmente equivocada em relação à arquitetura, notadamente para pressupor o movimento moderno como mal \& mau, em si. Com base no pressuposto de superação espaço-temporal, elabora-se a inversão ideológica neoliberal, sublimando-se a superestrutura histórica, pelo 'incrementalismo' especulativo e pragmático de mercado. Enfim, perdoando o sistema e culpando arquitetos e arquitetura.

Nesse tempo, a crítica na academia foi parcial em relação a Oscar Niemeyer; em relação a Lúcio Costa foi velada; ou oportunista em relação a ambos e, na prática, foi ideológica. Por exemplo: a concessão do título de doutor honoris causa a dr. Lucio e a Oscar resultou favorável após dois meses em quase toda a UnB; "em quase toda" porque na FAU passaram-se mais de três anos até que fosse aprovada. A concessão dos títulos se tornou viável graças à presença dos professores anistiados, sem os quais os professores favoráveis teriam sido derrotados em assembleia.

A retomada da sigla Ceplan foi objeto de discussões acirradas em meados da década de 1990. Metade dos colegas a considerava superada, ao passo que LEAU seria uma evolução apropriada e realista daquela. A vantagem numérica dos que propugnavam o retorno da denominação das origens da UnB dispunha somente da diferença favorável resultante de uma minoria de anistiados que ainda não se aposentara, gerando certo apoio moral à retomada dos aspectos históricos da escola da qual eles foram cassados. 
A Prefeitura do Campus, também dirigida por professores da FAU, participa ativamente em projetos do campus, entre 1990 e 2000, enquanto o Ceplan busca a desconstrução da ideia original, para encontrar uma existência extensiva às realizações. Tais disputas, em verdade, denotavam as tensões internas incubadas desde o Al-5, fermentadas com as Diretas Já e com a retomada da autonomia universitária.

Contudo, o Ceplan não se resolvia na FAU, diante de questões conceituais no ensino de arquitetura e notadamente dos reflexos de visões diversas sobre a concepção e a preservação de Brasília. Sobretudo a predominante defesa da Escola, empregando as fórmulas trazidas das cidades ditas tradicionais, ou comuns. Em verdade, nunca foi outra coisa, senão a especulação nos centros urbanos, através do avanço, igualmente especulativo, de terras urbanas sobre as rurais, mais próximas, com as ferramentas do crescimento incremental especulativo.

Desde então, desvelaram-se novas contradições, diferenças e interesses, impossibilitando a perspectiva acadêmica de instalação do centro de planejamento nos moldes do Ceplan, ou mesmo do LEAU.

O Centro de Planejamento, ao recuperar institucionalmente sua denominação original, Ceplan, anexou à sigla conhecida a referência histórica ao professor da FAU, seu primeiro diretor e autor da arquitetura do edifício. $O$ significado do fato não poderia ser outro senão recuperar sua premissa acadêmica: a prática dos professores, o estágio de graduando e o treinamento dos arquitetos mestrandos e doutorandos.

Ao lembrar as décadas de 1970, 1980 e mesmo 1990, é de admirar a placa de mármore com os escritos: "Ceplan, Centro de Planejamento Oscar Niemeyer. FAU-UnB, 20-03-1997". Com a nova sigla para o SG-10, Ceplan ON, pretendeu-se reiterar sua principia ethica e essência original: existindo no âmbito da FAU e, através da práxis de projeto face ao real, complementando o ensino conceitual "acerca de" arquitetura.

Contrariamente, a FAU se desfez de sua premissa diferencial, a de gerir o centro de planejamento que, por decisão unilateral e inquestionável, devolveu o Ceplan à Reitoria. A Reitoria assumiu o Ceplan ON sem ponderar a decisão da FAU, assumindo também o edifício SG-10, espaço historicamente do âmbito da faculdade.

O novo Ceplan ON, foi, então, estruturado e equipado devidamente, para funcionar -como jamais se conseguiu fazer no âmbito da FAU, depois do Al-5 - se tornando o centro de planejamento, indispensável, da Reitoria. Mas agora, fora da FAU! Todavia, tal como agora, já funcionava na Prefeitura do Campus, estruturado pelos próprios ex-prefeitos/professores-arquitetos da FAU que reduziam mais, e expressamente, a possibilidade de o Ceplan FAU ter sua perspectiva diferencial, como lugar da práxis arquitetônica na academia e confronto com o real, o centro de planejamento.

A ação não envolveu sequer a direção da FAU.

A Reitoria dispunha, portanto, do pessoal técnico experiente, recursos humanos da Prefeitura do Campus. Conta, eventualmente, com a gama de professores da universidade: consultores especializados, arquitetos-professores de diversas unidades, inclusive os da FAU-UnB, entre eles vários que se preocupam com o campus há décadas.

Não parece ponderável, em princípio. Mas o Ceplan foi perdido pela FAU-UnB, e com ele perde-se a própria identidade diferencial que a Escola buscou na origem. Talvez a perspectiva do Mestrado Profissionalizante de par com o Canteiro Experimental possa resgatar o espírito inicial do Ceplan na FAU. 


\section{2 - Qual o período de sua atuação no Ceplan e em quais projetos você atuou diretamente?}

Cláudio - Em 1985 iniciei o uso do ateliê que era do Ceplan, o SG 10, para desenhar. Nesse tempo o edifício era utilizado por poucos colegas; preferiam-se as salas opostas.

O SG 12 era afeto à FAU-UnB, que o utilizava em turnos intermitentes, à época iniciando as especializações em Desenho Urbano e Planejamento, que raramente se acomodavam no ateliê.

A profa. Suely Gonzalez se dedicava a projetos, fazendo estudos experimentais de sistemas construtivos no Campus Avançado da UnB em Barra do Garças, Mato Grosso, sob direção da profa. Leda Del Caro. Fui para lá com estudantes da FAU - verificando trabalho da profa. Suely, cujo processo foi extensivo a outras aplicações nas administrações do DF e em áreas em risco. Estive no local, percebendo a possibilidade de projetar para instituições do gênero.

Assim, desenvolvi como voluntário estudos para a Prefeitura de Abadiânia, em Goiás, com apoio para combustível e eventual hospedagem. Isso ocorreu à época em que o Lelé foi para o Rio. A seu pedido o prof. Edgar Graeff me apresentou ao prefeito Vander Almada, envolvido com as Comunidades Eclesiais de Base, sob orientação pastoral de frei Mateus Rocha.

Executei projetos e construí casa comunitária para atividades produtivas diversas. A construção foi levantada em três dias, com sistema leve e econômico, a exemplo de experiências do Lelé na região. O sistema simples, mas rigoroso e de fácil absorção por pedreiros, carpinteiros e construtores amadores das comunidades partícipes -nordestinas, sulistas e do centro-oeste. Concluímos o mercado em argamassa armada, implantado pela comunidade com o Lelé.

Cuidamos da igreja matriz de Posse da Abadia, também chamada de Abadiânia Velha, com o respeito de quem restaura o vernacular; com a mesma simplicidade, e por extensão, demos acabamentos ao entorno da praça, para a qual concebi o coreto, entre outros trabalhos do gênero.

Nas cidades do âmbito da prelazia, projetei, desenhando e detalhando no local, e orientei a construção da Prefeitura de Santa Terezinha, e a reforma da Prefeitura de Canarana; em ambas projetei praças e pequenas escolas: postos médicos e casas, utilizando pessoal das comunidades, apurando recursos construtivos locais e materiais da região.

Durante esse período desenvolvi estudos sobre o ICC, compreendendo-o sob as lembranças, então recentes, dos desenvolvimentos de estudos e acompanhamento da construção dos edifícios de tecnologia e dos bâtiments de classes et amphis para a Universidade de Ciências e de Tecnologia de Alger e a Université de Constantine, ao lado Niemeyer.

Esse período de três anos, de 1985 a 1988, foi essencial para animar uma pequena equipe, de três a seis estudantes e de até três recém-formados em permanência, no SG 10. Desses, ficaram, de 1985 até depois do ano 2000, Sasse, Rosemeri Hokino e Suzana Souza, que viveram a mudança de tecnologia: da habilidade rigorosa do grafite em vegetal ao CAD.

Ocupávamos o ateliê aberto, onde vários colegas, alternadamente, utilizavam duas ou três das 16 pranchetas. Usávamos quatro delas, sobravam 12. Mas a maior parte dos meses o ateliê tinha pouca ocupação e nas férias não era ocupado.

Da permanência ali, surgiram oportunidades de colaboração em diversos projetos. Como a de estudar uma casa de tipo palafita pré-fabricada, para reconhecido pesquisador da Agronomia que trabalhava com comunidades coletoras na Amazônia; o projeto foi o desenho em perspectiva das sucessivas fases construtivas, em papel ofício, para reprodução e divulgação local. E como a Casa Comunitária do Paranoá, a pedido de professor conhecido da Assistência Social: um projeto de extensão, cumprindo compromisso do então reitor Cristóvão. 
Como esses, surgiram diversas temáticas no contexto do DF. Do gênero, o mais significante foi o conjunto do Mosteiro Franciscano de Valparaíso II, composto também da Escola Comunitária da Paróquia e da Igreja de São José Operário.

As condições da paróquia para realizá-lo eram mínimas e a circunstância do projeto parecia pequena. Foi solicitado pela arquiteta Luciana Finageive (que estagiara conosco no SG 10), acompanhada do chefe do projeto, o franciscano polonês frei Wenceslau. Arquiteto de vocação, com portfólio, o frei apresentou o partido arquitetônico pronto, desenhado em estilo polonês, segundo sua referência, para a Igreja de São Judas Tadeu na 911 Sul.

Visualizei a possibilidade da tecnologia de abóbadas de tijolos maciços que o Lelé vinha utilizando, e que o prof. Oscar Kneipp já experimentara em sua casa, estudando-a cuidadosamente. Refletimos sobre a tecnologia face às possibilidades construtivas e os recursos, aplicando-a ao projeto, com equipe de três alunos e três ex-alunas da FAU orientados pelo prof. Kneipp e por mim.

Até hoje acompanho sua construção, ao sabor da pastoral e da paróquia, realizada com poucos paroquianos ao longo dos últimos 15 anos. A técnica referida para as possibilidades locais - abóbadas de tijolos, sobre vigamentos de concreto -foi experimentada a partir de realizações primorosas de Lelé no DF e de seus estudos e realizações em Salvador.

A solução, comprometida com a intenção arquitetônica de frei Wenceslau, interlocutor inicial, foi desenhada e paginada, desde o partido até o detalhamento construtivo, em gratificação final de próprio punho, em uma centena de pranchas de arquitetura. Em formato duplo ofício, em escalas até 1:2, facilita as conveniências de reprodução e os recursos paroquiais.

O projeto do Instituto de Artes, o IdA, antes, ICA, começou em 1988.

A profa. Grace, antes de se tornar diretora, conduziu cerca de quatro reuniões. Os colegiados do Instituto foram convidados a definir e formular o programa de necessidades. Entre os colegas alternadamente presentes, foram fundamentais João Antônio, Mund, Athos, Maravalhas, Marília, Helena Barcellos, Tânia Fraga e outros nomes referenciais.

Com a arquiteta Tânia, professora do IdA, trabalhamos o projeto arquitetônico. Ultimamos a interpretação do programa, através do Estudo Preliminar apresentado aos colegiados do Instituto. $\mathrm{O}$ anteprojeto foi apresentado à Reitoria e à FAU, depois do IdA. Os estudos técnicos foram concluídos em 1991, e três anos depois ficou pronta a estrutura de concreto e aço do Galpão de Oficinas Especiais, que esperou - ao sol e à chuva - até o ano 2000. A cobertura permitiu iniciar os demais corpos técnicos, e a obra foi inaugurada em 2003.

A Finatec construiu essa parte da obra com recursos da Lei Rouanet, que foi inaugurada incompleta, conforme relatório, considerando as numerosas irregularidades face às normas da arte. Faz referência a "com problemas", "sem funcionar", "não realizados", ou simplesmente "esquecido" e "mal feito", "a refazer". Entre outros, o elevador do palco do teatro-oficina algumas vezes testado, mas entregue sem funcionar e com problemas de segurança na área operacional; o elevador do PNE para público e atores, no teatro-oficina, não existe; as esquadrias concebidas visando a custos baixos de material, desenhadas para serem facilmente fabricadas no canteiro, ficaram inconclusas.

Talvez se deva aos relatórios a ausência, na inauguração, de operários, encarregados de obras ou mestres, de engenheiros calculistas ou dos engenheiros que se substituíram na condução dos trabalhos. Os arquitetos não foram convidados pela Finatec para a inauguração desta parte do projeto, o Galpão de Oficinas Especiais do IdA. Presente, sem convite, não fui citado sequer pro forma, apesar da disponibilidade cotidiana, como consultor/fiscal voluntário, durante toda a construção dessa parte do IdA, por mais de dez anos. 
Pelo menos duas serralherias abandonaram as esquadrias sem acabamentos e metade dos painéis corrediços sem deslizar, fora de prumo e com irregularidades gerais; faltou aperfeiçoamento para entrega e testes para recebimento definitivo da obra. As razões conhecidas no canteiro foram os atrasos nos pagamentos, pela "construtora". O processo da construção passou distante das normas da arte.

Em meados de 1996 o reitor Todorov consultou a FAU em razão do projeto da Autotrac. Era um período em que o Ceplan ressurgia, depois de recuperar a velha sigla. A Faculdade começava a eleger chefias para o órgão. Os professores interessados compareceram ao Salão de Atos da Reitoria duas semanas antes do Natal. Todorov sugeriu o Ceplan a Nelson Piquet, que teria o anteprojeto arquitetônico que contratara até 31 de dezembro.

Diante da expectativa de retomada do Ceplan, os professores presentes entenderam o tema, apresentado como de interesse relevante para a UnB e outras unidades acadêmicas envolvidas, e aceitamos o prazo desafiador.

O partido - definido com os profs. Marcílio Ferreira, Paulo Castilho, Jônio Cintra, José Sanchez e eu - foi consensual. Decorreu da necessidade fundamental de privacidade e segurança dentro de área $\left(\mathrm{em} \mathrm{m}^{2}\right)$ atribuída contratualmente à Autotrac. Piquet a exigia com muro, e alto, para preservação fiável dos equipamentos ultrassensíveis, notadamente a grande antena em um dos dois pátios, o de serviço.

Daí decorreu o círculo, sugerido anteriormente por Lúcio Costa para várias parcelas no campus, segundo seu projeto-piloto: o muro alto e os dois pátios, um de serviço, outro de contemplação, diametralmente separados pelo edifício implantado no sentido norte-sul, e seus acessos extremos, o frontal e o posterior.

A Autotrac, ao que parece, em poucos anos foi vendida por Piquet. Bem antes, durante a obra, o edifício dentro da murada foi realizado à revelia do projeto arquitetônico. A estrutura da murada de tijolos aparentes, além de modificada nos "bolsos" dos acessos, não impediu outro limite alambrado ostensivo, incorporando área maior do que foi acordado no contrato original com a UnB. As reclamações foram inúteis.

Entre 1996 e 2000 ocorreram vários projetos represados nas unidades da UnB, que chegavam ao Ceplan por intermédio dos dirigentes de unidades, centros e apoios dos grupos interessados. Muitos foram repassados pela Prefeitura do Campus ou pelo próprio Decanato de Administração e Finanças. A maioria sem perspectivas de viabilidade imediata.

Entre tais projetos, estão:

A Casa de Cultura do Japão, que envolveu concurso interno na FAU, caracterizou-se pelo projeto incomum, do acesso ao conjunto constituído em volta de um pátio até à casa de chá, na cobertura. Projeto desenvolvido em coautoria pelo prof. Marcílio M. Ferreira e por mim. Até hoje não foi realizado.

O CEFTRU, também objeto de concurso interno na FAU. Centro de pesquisas em transportes públicos, projetado pelo prof. Marcílio Ferreira e por mim, em coautoria. Pouco tempo depois foi realizado a partir de projeto de arquiteta da Prefeitura do Campus, sem nossa concorrência.

O Cespe, a ser implantado próximo ao Direito, foi realizado posteriormente em outro setor do campus, segundo projeto arquitetônico competente do prof. Kristian Schiel, com programa menor.

A Finatec. Sua construção posterior evidenciou a negação à proposta feita por mim. 
A Estação da Telebrasília e a grande antena, ambos projetados, buscavam atender com simplicidade e rigor à concessionária do GDF no campus. Tempos depois foi realizado outramente, sem minha participação e sem notícias a respeito, com base em negociações entre a Prefeitura do Campus e a CEB.

O Galpão de Salas de Aulas: como denominava a encomenda, foi desenhado no mês de fevereiro de 2000, para execução. O edifício, pronto em três meses foi inaugurado como Pavilhão Anísio Teixeira, tendo custado à época U\$ 250,00 , ou $R \$ 250,00 / \mathrm{m}^{2}$, o mesmo custo do $\mathrm{m}^{2}$ dos CIACs, usinados e em série. no mês de fevereiro de 2000. Em razão do custo foi realizado o segundo edifício, com características do primeiro. Com menos de dois anos, sem manutenção, as janelas superiores foram soldadas ,impedindo a ventilação cruzada entre as fachadas e o rebaixo do corredor, o que atingiu gravemente a concepção.

Edifícios de Tecnologia - Física, Química, Biologia e Geologia. Abertas as inscrições na FAU, os professores iniciaram juntos as pesquisas dos programas de necessidades, com as quatro unidades. Ao fim de um ano os colegas arquitetos paulatinamente desistiram do longo período analítico, das reuniões semanais com os quatro institutos e da formulação da programação, concluída duramente no último mês do ano.

O Decanato de Finanças, pagando aos colaboradores, fiscalizava o andamento dos trabalhos por intermédio dos professores das unidades, e o dos trabalhos que se desenvolviam abertamente no SG 10, nessa altura já reconhecido como Ceplan, sob a direção do prof. Marcílio. O prof. Marcílio, arquiteto de grande experiência, não suportando a pressão, notadamente dos professores, conforme relato seu, devolveu o Ceplan à Reitoria.

A nova direção do Ceplan/Reitoria recebeu o projeto dos quatro institutos, cujo programa de conjunto fora definido com a Reitoria. Eles foram projetados, portanto, em conjunto, religados ao ICC por passagem sob a via, e entre eles por passagem coberta, passando por quatro anfiteatros entre os institutos, chegando ao grande auditório na extremidade da área, a mais próxima do lago. Todos os edifícios pré-fabricados em aço visavam à praticidade de realização, a bons custos e à relação com o Minhocão.

O projeto arquitetônico pago e desenvolvido foi intensamente disponibilizado pelos novos projetistas, colegas, aos quais foram atribuídos. Recebi pelos estudos o mesmo pró-labore dos demais colaboradores que mantive nos anos em que me exercitei com eles no SG10.

Foi boa a ocasião de trabalhar a escala do conjunto articulado internamente e em relação ao entorno próximo. Permitiu reviver a experiência com Oscar Niemeyer nas duas universidades de tecnologia, em Argel e Constantina.

Acredito que o projeto desenvolvido e pago teria sido melhor e mais sustentável como estratégia construtiva do que o projeto executado. Neste, em que cada prédio tem sua arquitetura diferenciada, com sistemas estruturais e de instalações diferentes, despreza-se, em consequência, a economia de escala, por gerar sistemas táticos de manutenção próprios a cada um e, assim, reduzir a possibilidade prática da manutenção comum a todos, a qual implicaria estoques de reposição de corpos técnicos e custos logicamente menores. Além dessas questões fundamentais, restaria a arquitetura do conjunto em relação à universidade e ao ICC.

Apesar da qualidade arquitetônica dos novos edifícios, particularmente do edifício do Instituto de Química, creio na expressão da unidade, do caráter, da proporção do conjunto e da sua lógica econômica intrínseca, a economia de escala. 
Nosso projeto foi abandonado, sem satisfações, com quase três anos de trabalho dedicado, aberto e pago.

A diferença determinante foi a que levou à estruturação da equipe de arquitetos da PRC, criada por ex-prefeitos professores da Faculdade, para reduzir a possibilidade de renascimento do Ceplan. Finalmente não está mais no âmbito da FAU e seu corpo de arquitetos e engenheiros seniores veio da PRC. Isso não era o que esperava um grupo de professores DE que lutaram por sua recuperação, desejosos da prática em projetos arquitetônicos na Universidade.

A disputa entre os colegas é parte de luta política dentro de instituições e das escolas de arquitetura desde sempre, relevando oposições entre uns e outros, entre práticos e teóricos, entre arquitetos e urbanistas. Particularmente na FAU-UnB, desvelam-se outras diferenças marcando os grupos, como a referente a Brasília, sua concepção e preservação.

O diretor do Ceplan distribuiu os institutos de tecnologia entre grupos de professores, aproveitando os novos fluxos de recursos advindos das políticas para a educação e pesquisa em curso. $\mathrm{O}$ ato afirmou sua habilidade política no direcionamento dos projetos. Tal habilidade, reconhecida, desimpediu-o de tomar para si boas oportunidades de projetos, desenvolvidos com a equipe constituída no Ceplan com eventuais professores e eventuais alunos da FAU. Com poucas exceções, a quase totalidade dos projetos em curso de construção é de autoria do diretor do Ceplan \& equipe.

O Centro de Desenvolvimento Sustentável, em construção, foi estudado em diferentes tecnologias, incluindo dois projetos diferentes em madeira apreendida, para finalmente ser realizado em concreto.

O edifício do CDS, em coautoria com a profa. Raquel Blumenschein, é constituído de duas partes semicirculares, confrontadas em torno do pátio interno, ligado por passagem coberta ao auditório, e entre ambas está o castelo d'água. O auditório foi inserido no programa por incentivo da Reitoria; o castelo d'água, por demanda da PRC. São, portanto, três volumes que compõem o conjunto.

Uma vez concluída a arquitetura, não nos foi facultada a indicação de projetistas dos corpos técnicos complementares. Estes foram desenvolvidos por professores da tecnologia, com os quais mantivemos reuniões suficientes. Apesar da competência técnica, a coordenação da equipe, movida por suas interpretações tecnológicas, não guardou a fidelidade indispensável ao projeto arquitetônico.

Em fase de construção, só metade do edifício do CDS será terminada; a outra terá apenas a estrutura concluída nesta fase; tampouco o auditório, o castelo d'água e a passagem coberta serão construídos, causando risco à composição do conjunto encomendado.

Nossa participação oficial na fiscalização da obra foi dispensada.

3 - No período inicial da UnB qual era a importância do Ceplan para Brasília, para a UnB e para a comunidade?

Cláudio - O Ceplan funcionou para a realização da Universidade de Brasília. No Plano Orientador da Universidade de Brasília de 1962 (EdUnB), o Centro de Planejamento Regional integra o âmbito da FAU. Como, aliás, outros equivalentes, integrados às demais faculdades. Por exemplo: o Centro de Pesquisa Tecnológica está na Engenharia, o Hospital Escola nas Ciências Médicas e assim, em todas. Ocorrendo da mesma forma com os Institutos Centrais, Órgãos Complementares e seus respectivos centros.

As personalidades, as perspectivas políticas e as forças que construíam a UnB coexistiam na realização da nova capital. No desenho do plano-piloto da capital, Lucio Costa situou o campus o simé- 
trico às principais embaixadas e equidistante em proximidade do centro cívico federal. Quer dizer, a concepção do plano-piloto da Universidade de Brasília também é de Lucio Costa e os primeiros edifícios foram concebidos por Alcides da Rocha Miranda e Oscar Niemeyer, respectivos diretores do ICA-FAU.

O referido Plano Orientador de 1962 refere-se às faculdades e institutos com seus respectivos dirigentes, e menciona os coordenadores de curso da FAU, Lúcio Costa e Oscar Niemeyer. No mesmo ano, sob o título "O ritmo de trabalho na Universidade de Brasília", Antônio de Oliveira Britto, ministro da Educação e da Cultura no último parágrafo, informa que "grupo de arquitetos, tendo à frente Oscar Niemeyer e Alcides da Rocha Miranda, já iniciou estudos e começou a projetar os edifícios que se encontram na Praça Maior da Universidade de Brasília (...)", passando a enumerá-los.

A última frase da $1^{\text {a }}$ pergunta é precedida pelos aspectos gerais da questão, incluindo o período de atuação própria no Ceplan. No entanto, o período inicial, no qual existiu como Ceplan, de 1962 a 1968, foi o de sua formulação conceitual, cujo aspecto fundamental, é ser integrado à FAU e - primordialmente - à UnB, para concepção e construção do seu campus e de Brasília. Tal se realizaria com a participação de professores e alunos da FAU: iniciando estagiários da graduação, treinando alunos do programa de pós-graduação, reciclando professores e permitindo extensões acadêmicas profícuas.

\section{4 - Qual era o grau de importância entre o Ceplan e a Faculdade de Arquitetura? Persiste hoje a participação dos alunos, mestrandos e doutorandos?}

Cláudio - O idealizado Ceplan seria, portanto, o órgão capaz de concorrer para atenuar a contradição entre o ensino acadêmico - de massa - e a práxis inerente à concepção da obra a construir, desvelando a arquitetura. De 1984 para 1995 lutamos para reavê-lo; de 1995 até 2000 ele passou a existir sem estrutura prática nem institucional junto à Reitoria, que apenas o afagava de tempos em, apesar da PRC. De 2000 para cá, após a "devolução" do Ceplan à Reitoria, no primeiro momento os professores se encantaram com a distribuição de projetos, com contratações e barganhas favorecendo aspectos anacrônicos do corpo acadêmico da FAU, até que a maioria dos projetos deixou de contar conosco.

Presentemente o Ceplan se relaciona fundamentalmente com a Reitoria e conta com arquitetos recém-formados, tanto da FAU como do CEUB. Eventualmente os professores da FAU se relacionam com o centro de planejamento em um concurso de projeto, que não ocorre com os edifícios dos campi e do Campus Darcy Ribeiro levados a obra, predominantemente projetados pelo diretor do Ceplan. Este, ex-aluno de graduação e da pós-graduação da FAU, atualmente presidente do CAU/ DF e professor de uma disciplina na faculdade, foi prefeito e constituiu o órgão com os profissionais, predominantemente trazidos da PRC: um arquiteto, espécie de chefe de gabinete, mais um ou outro arquiteto sênior, e alguns engenheiros, todos da PRC - e mais os jovens arquitetos projetistas contratados, contando até mesmo com eventuais formados da FAU, mas não necessariamente.

Para mim o atual Ceplan é como seria se, antes de ser "devolvido" pela FAU à Reitoria, a PRC tivesse vencido a queda de braço conosco - nós que desejávamos fazer os projetos do campus e disputávamos, entre nós da FAU, o pouco que caía da mesa, com eles, os colegas da PRC que aludiam a seus direitos profissionais injustamente monopolizados por nós, professores da FAU, que brandíamos uma suposta tradição. Em verdade esta cessou com o Al-5 e nunca mais fizemos jus. O Ceplan, instituição e edifício, foram perdidos, inclusive com a nova sigla do nome que idealizamos - Ceplan ON - antes de resolvê-lo entre nós e obtermos as condições de fazê-lo cumprir sua perspectiva onírica. Finalmente, mais do que queda de braço, perdemos, além do Ceplan, o próprio edifício, extensão física de nosso espaço no ICC. 
Agora vemos o SG 10 transtornado em seu caráter histórico, tornando-se mero galpão de serviços gerais que abriga um centro de planejamento da Reitoria.

5 - Quando o Ceplan se desvincula do Instituto Central de Artes/Faculdade de Arquitetura e Urbanismo e fica subordinado, como órgão de assessoria técnica, à Reitoria da Universidade de Brasília?

Cláudio - Ele se desvincula do ICA-FAU com o Al-5; vira Laboratório Experimental de Arquitetura e Urbanismo entre 1968 e 1983 - época em que cheguei, e posso assegurar que não existia mais como LEAU. Desde então forcei a existência do Ceplan, conseguindo uma espécie de salvo-conduto do Todorov - período da anistia, em que passou a ser considerado oficiosamente em face da PRC, com seus prefeitos - professores da FAU que não acreditavam ou não entendiam mais um Ceplan feito de arquitetos/professores/projetistas em face dos prefeitos/professores/planejadores apetrechados na PRC, inclusive de uma nova turma de arquitetos convertidos em funcionários fiéis, o que não ocorria com os colegas da FAU.

6 - Qual o grau de interferência da Reitoria no planejamento do campus em várias épocas? Em que períodos essa interferência foi mais forte em relação à localização dos vetores de expansão, partido, custos, dimensionamento? A coordenação do Ceplan chegou a ter em alguma época a sua autonomia ameaçada?

Cláudio - A primeira pergunta permite duas visões: houve o tempo do Ceplan/ICA-FAU/Darcy, cuja reitoria e centro de planejamento caminhavam na mesma direção, tal como no período LEAU/ IAU/"Azevedismo"; e o período depois de 1983, aproximadamente, em que os Ceplan(s) se relacionaram com a Reitoria de formas oficiosas - caminhando como podiam - e oficiais, como agora, período Ceplan ON, caminhando "vamo que vamo", democrática e pragmaticamente, sobre vetores estabelecidos.

Quanto à segunda interrogação, a meu ver o Ceplan só existiu até o Al-5. Até então, o Ceplan desenvolvia uma dialética natural; depois disso, buscou existir e se afirmar, mudando até de nome. Atualmente, sua conceituação precípua não é a original, da fundação da UnB, não tem mais o vínculo acadêmico que o caracterizava.

7 - Como eram selecionados os arquitetos para projetar determinada obra? Era determinante serem professores de dedicação exclusiva? E como se estabeleciam os compromissos desse arquiteto com a obra projetada, em termos de prazos, detalhamento, fiscalização arquitetônica da obra etc.? Havia alguma compensação na carga horária da atividade docente, alguma remuneração?

Cláudio - À época do Ceplan, a da criação da UnB, os projetos construídos foram de Oscar Niemeyer, Alcides da Rocha Miranda e Lelé.

No período entre 1968 e 1983 teria vigorado o LEAU. Desse tempo não restaram, ou não são conhecidos, os procedimentos que regeram a construção das obras do campus, deixando práxis normativas duradouras.

Depois de 1983 foram retomadas as perspectivas das normas, envolvendo inscrições, prazos, formação de equipes e concursos. Embora, até a presente data, não existam edificações que tenham sido objeto de concurso. No entanto, dois concursos de projetos foram vencidos pelos profs. Nonato Veloso e Matheus Gorowitz, com fortes possibilidades de serem construídos.

Atualmente, julgando pelo exemplo do edifício do Centro de Desenvolvimento Sustentável (CDS), de autoria da profa. R. Blumenschein e minha, o que motivou os convites do diretor do Ceplan para a reunião na qual conhecemos os engenheiros da construtora e outros relacionados com a obra. 
No entanto, não houve nenhuma formalização, estabelecendo condições de acompanharmos ou fiscalizarmos a obra, pelo Ceplan, em visitas periódicas.

Por iniciativa pessoal e curiosidade visitei o canteiro. Identificando-me como arquiteto-autor do projeto, fui acompanhado pela engenheira encarregada da obra, que não estava presente na citada reunião de apresentações. Apontei grave equívoco em elementos estruturais em desacordo com o projeto arquitetônico, mas não fui convidado a registrar a visita no diário de obras, tampouco o fato específico.

Quer dizer, esta forma do professor conceber e desenvolver um projeto - de vez em quando, sem acompanhar a obra devidamente, no seu papel que também é o de construtor - não parece responder ao fim precípuo do Ceplan. Não é o espírito para o qual foi criado, no sentido da proposta original, tal como o prof. Niemeyer registrou no livro da Editora Mondadori (1975), por ocasião da realização da Escola Politécnica de Arquitetura (1972), antecedendo a Universidade de Ciências e Tecnologia de Argel. Portanto, não responde à integração da práxis acadêmica devida, entre o Centro de Planejamento e a FAU.

8 - Poderia estabelecer uma comparação entre o compromisso do Ceplan com a inovação, com as novas tecnologias, entre as duas primeiras décadas do Ceplan e o período atual?

Cláudio - Eu só atribuiria a referência Ceplan, com sua natureza, à primeira década da UnB. O Centro de Planejamento, em sua plenitude, encerrou trabalhos em 1970, com a partida dos seus titulares.

Caso tenha havido vida institucional protagonizada pela FAU, Ceplan e a própria UnB na década de 1970, já não mantinha o mesmo espírito da pesquisa em arquitetura, como era conduzida a da pré-moldagem monástica, como as dos SGs, da Colina e do ICC.

A segunda década, a de 1970, que também permitiu a realização de projetos importantes, não manteve o espírito dos primeiros tempos. Como de resto, as décadas seguintes, até presentemente.

9 - Quais são as perspectivas para a ocupação total do Campus Darcy Ribeiro?

Cláudio - Os novos campi da UnB nas demais cidades talvez arrefeçam a tendência ao crescimento caótico do Campus Darcy Ribeiro, promovendo, com isso a espaço-temporalidade conveniente à conclusão, ao restauro e ao desenvolvimento do ICC.

10 - O ICC continuou sendo, nestes anos, o grande espaço para ensino e pesquisa, destacandose também como centro de vivência, de efervescência cultural da UnB, o grande ponto de encontro. Como será a apropriação do ICC, visto que alguns institutos já estão sendo transferidos para novos prédios isolados e novos prédios estão sendo projetados para os demais institutos?

Cláudio - Em meados da década de 1990, na ala leste do ICC, no Instituto de Psicologia, era fechada a área do I.P. com o pé-direito duplo, previsto em toda a longitudinalidade desse lado do edifício de laboratório.

À mesma época, do outro lado, o Instituto de Física providenciava os meios para retirar as lajes pré-moldadas, criando novos espaços de pés-direitos duplos na ala oeste, concebida para abrigar secretarias pedagógicas, salas de aulas e anfiteatros.

Por premissa da arquitetura moderna, os edifícios são constituídos com a ossatura independente; as paredes perderam o papel de sustentação, guardando apenas o de vedação. Por isso, os edifícios modernos com seus espaços ditos flexíveis, permitem ocupações d mais variadas. Isto aumenta o 
tempo de uso dos edifícios pela condição de flexibilização das funções sociais dos espaços arquitetônicos.

O ICC tem espaços horizontais modulados e amplos; sua flexibilidade é, por assim dizer, absoluta; os três diferentes níveis são separados por lajes nervuradas pré-moldadas, passivas de serem removidas para formar pés-direitos triplos, assim como os espaços de pés-direitos duplos podem ser fechados. O ICC poderia se tornar-se até - nos limites do inimaginável- um condomínio de habitações coletivas, com tipicidade de espaços surpreendentemente mais variados e dinâmicos do que os das unités d'habitation.

Mas não acontecerá assim, e a longo prazo ao Minhocão continuará reservado o papel de espinha dorsal da universidade e de todos os seus campi, podendo tornar-se um equipamento fundamental na perspectiva das C\&T. Como, por exemplo, um condomínio de espaços flexíveis para sucessivos encontros científicos e tecnológicos, abrigando áreas apropriadas a congressos, colóquios, exposições, galerias, comunicações midiáticas variegadas, e toda sorte de celebrações acadêmicas. A curto prazo as áreas liberadas dos institutos atenderão às necessidades de contenciosos de institutos, órgãos e centros; a médio prazo será planejado seu restauro, para implantação em longo prazo.

11 - A determinação de localização de novas edificações dentro do campus seguiu, durante as primeiras décadas, o planejamento urbanístico determinado pelo Ceplan? Atualmente, como vem ocorrendo essa ocupação de áreas dentro do campus?

Cláudio - Na década de 1990 começa, no âmbito da cultura neoliberal predominante. O Instituto de Tecnologia parece estar entre as primeiras instituições a fechar com grades que impedem o acesso, a passagem ou travessia pelas áreas de influência do conjunto edificado. Além da Tecnologia, a Autotrac e a Finatec parecem ter sido os primeiros conjuntos a adotar a cerca por meio de alambrados.

12 - Narração do histórico da construção do ICC, da Colina e dos processos construtivos.

Cláudio - A concepção do ICC construído nem sempre é compreendida como a de um edifício: inconcluso, incompleto, inacabado e invadido, além de deixado, em extensos e renovados períodos, sem manutenção predial. Para agravar, tem sido objeto de experiências funcionais esdrúxulas e modificadoras de sua inteireza desfigurada, em suas partes e fachadas. Contudo, é um marco na pré-moldagem, cujo sistema não parece ter sido assimilado hoje. Notadamente quando os campi, e sobretudo o Campus Darcy Ribeiro, são invadidos por um picadinho de construções pré-fabricadas, com escalas e proporções aparentemente inflexíveis.

Niemeyer, antes da definição tecnológica, optou pelo partido de um único conjunto, uma construção com duas alas longitudinais paralelas, estendidas no sentido das curvas de nível, de norte a sul. Como é sabido, ao invés de realizar os diferentes institutos em cada uma das projeções previstas no plano de Lúcio Costa para a UnB, Niemeyer os reuniu em um edifício com duas alas separadas: uma para laboratórios e outra para classes e anfiteatros.

As duas alas com dois pavimentos e um subsolo são separadas pelo surpreendente pátio longitudinal entre elas, parcialmente descoberto. Aparentemente, uma área aberta e paisagística, uma terceira ala entre as duas construídas, e que aparece longitudinalmente separando as outras duas, mas na verdade religa todo o conjunto, pelo subsolo. O térreo e o subsolo são extensivos aos limites transversais de todo o edifício sob as três alas, quer dizer, a toda a largura do Minhocão. 
Todavia, parece uma fenda inteira, em toda a longitudinalidade do edifício, separando as duas alas de três pavimentos. É uma contínua sucessão de espaços abertos ao céu e pavimentados por jardins entre as calçadas largas de ponta a ponta. O verde de grama, arbustos e cortinas de trepadeiras são espaçados pelas praças e outras calçadas transversais estreitas ritmando, no térreo, o comprimento de $750 \mathrm{~m}$, parcialmente sombreado pela pérgula.

O formidável pátio interno - separando o bloco de laboratórios e o de classes -acentua a forma longilínea sobre o terreno, bem justificando o codinome Minhocão, por sua área de $120.000 \mathrm{~m}^{2}$ e a magnífica proporção do comprimento de aproximadamente 12 vezes a largura.

Assim, o partido longitudinal, reunindo linearidade e paralelismo, permitiu avançar o canteiro com a grua oportuna que, desempregada da rodoviária do plano-piloto de Brasília, foi oportunamente readmitida no canteiro do futuro ICC.

O partido visa à realização e à cultura dos bens do espírito harmoniosos e indissociáveis, obstinada resultante arquitetônica de latente classicismo vitruviano.

13 - Finalmente, indagamos se você tem algum documento ou imagem que considere significativo para a história do Ceplan. Caso positivo, gostaríamos de saber sobre a possibilidade de disponibilizá-lo para digitalização ou fotografia.

Cláudio - Gostaria que conhecessem os projetos feitos e pagos para os edifícios de Tecnologia, Biologia, Física, Química e Geologia, para os quais me inscrevi com colegas, continuando durante semestres e férias; cumpri prazos para a conclusão dos programas de necessidades com os professores dos respectivos institutos e departamentos para a execução dos projetos arquitetônicos. Como disse: prontos e pagos.

Com a mudança decorrente da "devolução do Ceplan à Reitoria", da nova direção do Ceplan - com a qual examinei os diversos projetos - não recebi esclarecimento ou informação a respeito. Mas soube, no entanto, que os projetos foram redistribuídos e desenvolvidos pelos colegas, entre eles os profs. Marcílio e Aleixo, que amigavelmente se referiram à disponibilização dos meus estudos para consulta.

\section{Post scriptum}

O SG 10, o edifício do Ceplan ON era, antes, parte do espaço da FAU.

Hoje é ocupado exclusivamente pelo órgão, o centro de planejamento da Reitoria, que é conduzido por profissional nomeado pelo reitor. Esse profissional pode, como é o caso, ser funcionário da UnB e, eventualmente, contratar arquitetos professores, embora disponha de corpo técnico e de arquitetos, podendo ele próprio ocupar-se dos projetos com seus funcionários.

Os espaços principais do SG 10 eram mantidos, respeitosamente, tal como se encontravam à época de Niemeyer e se mantiveram assim depois do começo da década de 1970, pós-Al-5, apesar do desprezo com os jardins da arquiteta Alda Rabelo, inexistentes já em 1983. E registre-se, sofreram duas agressões com precisão cirúrgica, impetradas displicentemente por docentes, como sabido à época, ainda na década de 1980.

A primeira foi a retirada da pequena maquete, fixada à parede branca dos afrescos de Niemeyer, ponto focal para quem entra no Ceplan, vista do foyer e do auditório, olhando na direção do ateliê, do qual é separado pelo bloco sanitário e pelo cômodo onde funcionou a copiadora heliográfica. Nesse lugar do painel de Niemeyer, a parede desenhada é a perpendicular, mas afastada do muro estrutural periférico, feito de pré-moldados, é o canto do foyer de exposições e de estar, onde fica bem conveniente a mesa de 12 lugares para reuniões. 
Mais baixa que a mesa, a maquetinha do ICC - fixada à esquerda da parede, no rés dos croquis da Praça Maior e da Aula Magna -, delimita virtualmente o remanso para a área de reuniões. O modelo reduzido do ICC estava encerrado, como que contido no estojo de acaju - com menos de $50 \times 30$ cm -, "tampado" com vidro sobre o terreno verde-musgo e as edificações brancas: o Minhocão, tal como concebido, com as coberturas sobre o pátio longitudinal; e, próximo, o RU redondo, a grande antena e a caixa d'água.

O canto mais profundo no espaço das reuniões é o encontro apontado pela parede dos afrescos, perpendicular ao pré-moldado, e o outro, virtual também, no limite do jardim da pérgula, claridade e ventilação principal do foyer de exposições; o terceiro vértice é o da maquetinha balanceada da parede, de onde foi subtraída.

Portanto, como lugar das reuniões, o outro limite do espaço, um quarto canto, era a demarcação feita pelo painel fotográfico dupla face e significativo, pelo que era aquele Ceplan. Significativo e fundamental, porque definia virtualmente o espaço retangular aberto, sendo o limite principal da área das reuniões, todavia, dentro da integridade do foyer, localizado em oposição ao lugar do pequeno auditório; a área se anuncia pelo objeto, que, além de significante, é materialmente relacionado com a maquete fixada à parede, mas separado por quatro metros, demarcação sutil da largura do espaço de reuniões.

Tratava-se uma estrutura também de acaju, como o estojo da maquete, dois montantes da mesma madeira, suspendendo uma foto ampliada de Le Corbusier, na face externa. Na interna, a foto dos cobogós dos apartamentos da Colina. As fotos, ambas em preto e branco, sobre os dois montantes em acaju foram arrancados por quem não suportava sutis demarcações de espaço e, pior, referências ideológicas da arquitetura moderna. Não só fundamental, mas significante.

Como a estátua da Justiça de Ceschiatti, a demarcar o ambiente do Poder Judiciário com seu avarandado acessível; análogo aos os montantes, em acaju, que além de fundamental para limitar sutilmente o lugar de reuniões, suspende do chão, com a mesma sutileza, a própria ideia do Ceplan do Oscar - portanto, significante, pelas duas fotos - acima de 1,80 m até 2,30 $(50 \mathrm{~cm})$, deixando livre em cima o mesmo tanto, até as duas nervuras onde se fixavam às vigas, distantes $1 \mathrm{~m}$.

A retirada da maquete teve como justificativa restaurá-la. Sumiu um tempo. Reclamada nos anos 1990, reapareceu no Cediarte (o centro de documentações que sublimou o prof. Graeff por essa sigla, apagando-o da memória da FAU). Hoje a maquete se encontra em meio a muitas que, empiIhadas, celebram o atual Ceplan, desfigurado o espaço de seu caráter.

A retirada desse signo do Ceplan genuíno, segundo justificativa, foi para dar lugar à divisória de montantes metálicos pretos, como os das esquadrias do vidro aramado do ICC, que acolheram painéis de vidro a meia altura colocados para proteção das reuniões, principalmente da chuva da pérgula.

O próprio professor - com seu desejo latente de desideologizar o curso de desenho urbano, exorcizando-o daquela celebração do pensamento modernista - ele mesmo, em sua primeira aula no lugar das reuniões, derrubou toda a divisória de 5 metros arquitetada e realizada por demanda sua. Hoje não existe a divisória, nem a memnona (no sentido de Hegel), retirada pelo professor, o que também é significante em si, porque ulteriormente ele - entre os que foram prefeitos do campus eram contra retomar a sigla primaz Ceplan, favoráveis à manutenção da LEAU.

Hoje o ateliê é subdividido por divisórias que obstruem a perspectiva para o jardim intramuros, características extensões do ateliê de sua natureza simples e dialética. 
As numerosas maquetes e a superocupação do edifício atentam contra a sua concepção inicial, cuja atmosfera em respeitosa harmonia com sua função denotava a adequada ambiência e a elegante simplicidade.

Escrevi ao diretor do Ceplan, respondendo a assunto análogo, pelo que fui consultado. Sugeri que o edifício em estrutura de madeira, projetado por Sergio Rodrigues - hoje entregue ao serviço de segurança - fosse atribuído ao centro de planejamento, abrigando o corpo técnico composto predominantemente por oriundos da prefeitura e por jovens arquitetos e estagiários contratados.

O esvaziamento do SG 10 de sua condição atual permitirá analisar a condição do edifício, na perspectiva conceitual do restauro de obras modernas, levando em conta o significado da obra e sua utilização de continuada riqueza acadêmica, reformando, com o cuidado do restauro tradicional, vários dos seus corpos técnicos:

- as instalações prediais;

-a rede elétrica sobre o forro entre vigas e sobre os dos banheiros, depósito e copa;

- a rede hidráulica, até os acabamentos de espelhos de interruptores e elementos metálicos de válvulas e de água servida;

- o piso de granitina e as paredes de alvenaria fissuradas;

- o teto sob as calhas metálicas de escoamento das APs;

- os elementos de concreto aparente da cobertura prejudicados pelos experimentos das sucessivas impermeabilizações;

- o mobiliário a ser estudado, segundo conceitos apurados, incluindo a renovação adequada e devida, no ateliê, no estar da espera, no auditório e nas salas;

- os painéis desenhados por Niemeyer, segundo metodologia adequada;

- as portas de vidro e as esquadrias e portas metálicas;

- os três jardins, segundo princípios da solução original e da autora do projeto.

O restauro do SG 10, a ser restituído à FAU, é fundamental para sua articulação com o Canteiro Experimental, para as celebrações periódicas, como defesas e exposições de trabalhos de final de curso, defesas de dissertações e de teses, além das exposições expressivas da Escola, como alternativa aos espaços no ICC. É fundamental também para a reconsideração do indispensável ambiente de práxis acadêmica, estágio de estudantes de graduação, treinamento de partícipes do programa de pós-graduação e prática dos professores em projeto, tal como sempre foi seu espírito original, na perspectiva da superação dos paradoxos do ensino de massa, em arquitetura. 


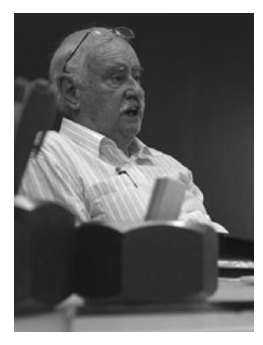

ENTREVISTA COM O PROF. ÉRICO WEIDLE

Realizada em 07/12/2011, Brasília/DF

\section{Vera - Queremos saber sobre a sua atuação dentro do Ceplan, o período em que você foi diretor e os projetos que você desenvolveu?'}

Érico - Trabalhei no Ceplan assim que cheguei à UnB em 1972. Já no final daquele ano estava participando de projetos de boa envergadura para o desenvolvimento da UnB. Primeiro, do projeto da Reitoria, junto contigo, quando o prof. Zimbres se afastou para cursar pós-graduação. Em 1973, juntamente com o prof. Adilson Macedo, começamos a desenvolver os projetos da Faculdade de Tecnologia e de Ciências da Saúde. Essa foi a minha participação mais efetiva como arquiteto diretamente nos projetos. Com o decorrer do tempo participei de outros trabalhos, numa condição diferente, ou como diretor, ou até como administrador da Universidade, onde tivemos a possibilidade de interagir com os arquitetos que desenvolviam trabalhos para a UnB. Participei do planejamento do campus, que teve uma série de propostas que se sucederam no tempo. Algumas se concretizaram e outras se somaram aos bons projetos no currículo de cada um.

\section{Vera - Então tivemos a primeira fase de 1973, um período de muita atuação.}

Érico - Exatamente. Passei o ano de 1973 a 1975 dentro do Ceplan, sem feriado nem fim de semana. A minha mulher, grávida do Carlos, praticamente gestou o filho lá dentro do Ceplan. Ficava sentada naquelas poltronas desajeitadas que ainda estão lá. Tricotava grande parte do tempo, pois eu quase não ia mais para casa, totalmente envolvido com os projetos das faculdades de Tecnologia e de Ciências da Saúde. Após três anos de dedicação árdua e concluídos os projetos da Reitoria e das faculdades me afasto desse tipo de atividade no Ceplan, permanecendo em ações pontuais no planejamento e no desenvolvimento do campus da UnB.

No final dos anos 90, o então reitor da UnB, o professor Lauro Mohry, convidou-me a assumir a direção do Ceplan. Respondi que não poderia aceitar, pois teria de me reportar a dois "senhores" e isso seria inaceitável para mim, que conhecia aquele modelo desde os primórdios: de um lado a Escola de Arquitetura, responsável conceitual pelos projetos do desenvolvimento físico do campus, e do outro o "cliente", a Reitoria, na época nominada Administração Central. Entre os fatores, além dos políticos da época, outro agente perturbador era o financiamento da execução dos trabalhos.

Peço licença para abrir parênteses, pois me lembrei de uma oportunidade em que, cansado das dificuldades para conseguir os meios para conduzir os trabalhos, pedi entrevista ao coronel Lister, o todo-poderoso superintendente da Universidade. Fui ter com ele vestido com um boné velho na cabeça. Tirei o roto chapéu da cabeça e, com ele na mão, estiquei-o em sua direção, como que pedindo uma esmola. Falei que a esmola não seria para mim, mas para a própria UnB, que não oferecia as condições para a realização dos trabalhos. Sem orçamento e

sem a mínima estruturação administrativa, os trabalhos realizados no Ceplan careciam das mínimas condições para realizar os projetos em si. Foi essa a forma que encontrei de sensibilizá-lo para dotar o Ceplan de desenhistas, material e equipamentos necessários ao desenvolvimento dos 
projetos. Funcionou. O modelo de contratação de pessoal e o custeio dos projetos inviabilizava o funcionamento do Ceplan. Os registros, a publicação, fotografia, maquetes e acompanhamentos de projetos em execução não entravam na composição dos custos da Administração Central. $O$ entendimento do trabalho de arquitetura era limitado e bisonho. Assim, qualquer alteração no projeto ou uma exposição, por exemplo, já não contava com o pessoal e o material necessários, pois o projeto, dado como concluído, não contava com mais verba. Os próprios autores cumpriam tarefas de desenho, montagem e produção de material ilustrativo às próprias custas. Essa experiência de realizar projetos em bases precárias me esgotou. No meu escritório particular trabalhei em condições muito superiores às encontradas naquele tempo no Ceplan.

Voltando à questão, quando o professor Lauro me chama para a direção do Ceplan, eu já tinha vivido essa experiência desgastante. Disse-lhe que não aceitaria na velha modalidade: um "senhor" para as questões conceituais e profissionais e outro para o suprimento dos recursos. Essa dicotomia é uma administração insustentável. O Ceplan ligado à Escola não dispunha de meios para se desenvolver. Finalmente o reitor ouviu nossas ponderações para uma existência profícua do Ceplan e deslanchou a discussão da vinculação administrativa do Ceplan à Reitoria. Tal como tinha sido originalmente na época de Oscar Niemeyer e de João Filgueiras Lima (Lelé). Tive o "desplante" de defender essa proposta. Para quem não sabe da história, parece que estou negando as condições de reabertura da Escola em 1968. O Instituto de Arquitetos do Brasil, que mediava a reabertura, exigiu que a Escola reabrisse tendo um laboratório profissional, o Ceplan como escritório de prática permanente dos professores de arquitetura que estavam em sua maioria na condição de dedicação exclusiva. Esse vínculo foi vital, como experiência e até como forma de atrair professores, na época oriundos exclusivamente da atividade profissional.

Estou me remetendo a esses antecedentes para que se entenda por que concordei e insisti em recuperar administrativamente o Ceplan da forma inicial quando da sua implantação por Oscar Niemeyer. E assim foi feito, com a concordância da Faculdade de Arquitetura. Era vital dotar o Ceplan de orçamento próprio que financiasse e promovesse as atividades desse centro de projetos. OS professores trabalhando juntamente com outros arquitetos contratados. Então, foi aprovado um protocolo definindo os papéis da Escola e da Reitoria, em que os professores e alunos teriam sua base para a prática profissional e atividades de pesquisa. Portanto, não foi corrompido o compromisso da reabertura. O vínculo conceitual da relação Escola-Ceplan foi preservado, com a vantagem de agora dispor de meios e financiamento de suas atividades com administração autônoma.

No modelo anterior, notadamente no período autoritário, esse balanceamento a duas mãos quase sempre tropeçou na bipolaridade amplificada pelo contexto político adverso. Explicitando: qualquer posicionamento ou exigência da administração era vivenciado pela Escola como truculenta interferência nos misteres arquitetônicos dos professores pela Administração Central. Estes por sua vez, utilizaram do exercício da arquitetura como argumento de contestação ao status quo. Esse embate não era explícito, era tácito, o que piorava as relações ao se confundir os conflitos políticos num campo pseudoconceitual do exercício da arquitetura. Confundindo ainda mais o meio de campo desse confronto infame, havia alguns poucos que acreditavam demiurgicamente achar que eles, exclusivamente eles, sabiam o que era bom para a comunidade acadêmica e o desenvolvimento do seu espaço físico.

Sei de embates conflituosos, como por exemplo sobre a localização do Restaurante Central. Houve interferência absoluta da Reitoria, que não aceitava a possibilidade de se concentrar os estudantes. Por eles a distribuição física dos edifícios seria como papel picado por toda a UnB para localizar os diferentes edifícios. Queriam um efeito difusor da concentração dos estudantes. Por isso áreas de vivência de estudantes nunca foram aceitas pela Reitoria. O ICC, neste particular, sempre foi para a administração um quebra-cabeças, um problema muito sério. Quando entrava nesse território da concentração discente, era conflito certo. 
Voltando à questão de quando assumi a direção do Ceplan, já com a nova versão: era agora uma casa financiada pela administração, mas um quadro de abandono. Mobiliário quebrado, salas com coisas amontoadas sem destinação, equipamentos sucateados, salas totalmente atulhadas de veIharias. Não havia nenhuma estrutura que permitisse levar clientes e outros profissionais lá - a ideia era atender no Ceplan não só a Universidade, mas também órgãos do governo que pudessem ser atendidos sem fissurar com o pessoal da casa nem com os colegas da cidade. Começamos pela recuperação e a reordenação física, pois naquele ambiente não se recebia ninguém. Não era uma tapera. Mas a imagem do abandono, o arquivo sem controle, um quadro triste. Finalmente, conseguiu-se, dentro de mais ou menos meio ano, resgatar as salas, pois havia pessoas que mantinham suas coisas lá, ou detinham as chaves para guardar pertences.

Encontrei, também, a situação seguinte: o prof. Lauro tinha pedido um projeto para o desenvolvimento dos Departamentos de Química e Biologia, para tirar do ICC essas unidades, pois estavam numa situação precária. Trabalhavam em subsolos, em condições insalubres e inseguras. Então a Administração da UnB cogitou deslocar essas estruturas para fora do ICC, talvez contrariando, exatamente...

\section{Vera - Mas não se pensou em adaptar o ICC?}

Érico - Acontece que os espaços do ICC destinados a esses departamentos eram subsolos inadequados para utilização acadêmica. Mesmo considerada a flexibilidade espacial e construtiva depois de ocupado, o remanejamento é dificultado pela necessidade de se dispor de espaços para utilização provisória durante as reformas. Sem essa estratégia o espaço fica praticamente "imexível", parodiando o ex-ministro. Ao se retirar departamentos inteiros de dentro do ICC, sobra espaço de manobra para recolonizar o 'Minhocão.

Quando a UnB passa a eleger seus dirigentes, o relacionamento referido anteriormente muda. Inicialmente diria que os erros passam a ser compartilhados. Ou, seja "o cliente" não é mais sua majestade, nem o autor dos projetos é o detentor das certezas sobre o que é bom ou não para a universidade. É fundamental essa responsabilidade compartilhada peculiar na atitude democrática.

Meu posicionamento pessoal a respeito de que um escritório de arquitetura, uma escola de arquitetura, experimental ou não, não sobrevive na conivência com o diletantismo acadêmico. Um escritório de arquitetura deverá sempre primar pela eficiência, comprometido com propostas do mais alto desempenho profissional, sem abrir mão da busca pela inovação e do exercício da pesquisa. O horizonte é amplo, mas este sempre nasce do chão, afastado da leviandade amadorística.

Ao assumir o Ceplan estavam em desenvolvimento pela Prefeitura do Campus os projetos daqueles departamentos que há muito aguardavam soluções para sua inadequação e exiguidade físicas. Mais adiante o reitor Lauro Mohry convidou-me a assumir o Decanato de Administração e Finanças. Foi nomeado para me substituir o arquiteto Alberto Faria.

\section{Vera - Em que ano entra o Alberto?}

Érico - Se bem me lembro, foi em 2001. O Alberto já tinha a experiência de Prefeitura do Campus. Conhecia bem a estrutura física da universidade. Tinha uma visão desenvolta das questões administrativas, não só das variáveis estritamente arquitetônicas. Sabia como manejar os orçamentos e conduzir o diálogo com a escola, com os professores.

\section{Vera - Ele veio ser o primeiro diretor do Ceplan que não era professor.}

Érico - É. E havia o receio de que ele não tivesse a sensibilidade necessária para entender o papel do Ceplan na Faculdade por não ser professor, mas a relação com a área acadêmica tornou-se logo muito positiva. Talvez, o fato de não ser professor (à época) ajudou. 


\section{Vera - Ele incentivou a questão dos concursos para projetos no campus?}

Érico - Sim, dos concursos e, melhor ainda, com os alunos participando das equipes. Isso está funcionando até hoje com bons resultados, promovendo a ampliação da universidade fora dos muros do campus inicial, com projetos em Planaltina, Ceilândia, Gama. Tudo isso está acontecendo, além de outros projetos dentro do próprio Campus Darcy Ribeiro.

\section{Vera - E tem contratado equipes para isso?}

Érico - Tem sim. E aí, entra uma coisa interessante que nós tínhamos discutido muito por conta dele e eu também termos sido prefeito: se seria o caso de a Prefeitura do Campus ou do Ceplan conduzir as obras. E nós chegamos à conclusão de que seria interessante que o planejamento e as obras tivessem um elo, que tudo andasse associado. Iniciou-se nova fase do Ceplan, que é a atual. Hoje o Ceplan conduz as obras da UnB! Sim, projeta e constrói, ou seja, hoje o diretor do Ceplan tem uma responsabilidade redobrada. A interação projeto-obra cobra muita responsabilidade dos participantes.

\section{Vera - Então o Ceplan também faz as licitações?}

Érico - Sim, é um ciclo completo! O Ceplan faz o planejamento, o projeto, a licitação, a fiscalização e todo o controle das obras. Ou seja, hoje para ser diretor do Ceplan é exigida muita coragem e competência. Não é coisa para amador. Não é o domínio estritamente voltado para questões técnicas. Há questões de natureza política, de visão estratégica mais ampla e de uma responsabilidade muito grande. Criam certas amarrações, tudo que é bom para um lado é ruim para outro. Mas acho que é interessante que quem projete esteja também comprometido com a viabilidade. Isso vem acontecendo, porque o Ceplan agora conta com uma equipe técnica multidisciplinar. Hoje projeto tem orçamento! Isso antes não era procedimento usual.

\section{Vera - Exato, isso sempre faltou; o orçamentista tem que acompanhar o projetista!}

Érico - Exatamente. Lá, agora há o orçamentista, o engenheiro fiscal, há um corpo de fiscais. O Ceplan, hoje, é uma estrutura complexa. O Ceplan tem não só os arquitetos professores que lá trabalham nos projetos, mas os arquitetos que desenvolvem projetos executivos acompanham as obras, aqueles que fazem a fiscalização do projeto e os engenheiros de fiscalização, cada um na sua especialidade. Há os fiscais na área de ar-condicionado, de instalações complexas, como foi o caso da Química, por ter instalações de todos os tipos. Então, traz para dentro do Ceplan um corpo técnico altamente diversificado e aparelhado, mais qualificado. Algumas vezes não se consegue as pessoas certas, mas tem hoje um aparelhamento muito grande.

Essa é a trajetória do que aconteceu, em poucas palavras, no Ceplan. Eu não me referi mais ao inicio do Ceplan, porque eu acho que é importante o depoimento, principalmente, do Zimbres, que teve uma atuação muito efetiva naquele momento. Eu não percebi aquele momento por que eu estava mergulhado em projetos. Sei que esse desenvolvimento era quase que fatal, o Ceplan não conseguiria viver numa estrutura puramente acadêmica. A arquitetura é uma atividade profissional, ela não pode se restringir ao exercício acadêmico. E quem pensou que pudesse fazer projetos só nessa base, acho que pode ter se equivocado.

\section{Vera - Você citou aí, só para ter como exemplo, o Instituto de Química, não?}

Érico - Foi trabalheira. Os projetos do Instituto de Química e o de Biologia saindo do ICC e os demais em remanejamento programado em andamento, pelo menos na gestão da qual eu participei. Hoje não estou a par de todo remanejamento do ICC para transformá-lo na grande sala de aula da universidade, porque lá de fato se concentram todos os estudantes. A opção foi levar para fora as 
atividades que têm caráter mais especifico. O ICC com aquele pé-direito imenso, os grandes laboratórios como se fossem instalações industriais, isso nunca aconteceu! Então, o que foi feito no ICC? Em vários lugares, para conseguir aumentar a sua área, foi criado o mezanino e recolonizado este espaço, como é o caso da Psicologia, da Agronomia, da Matemática.

\section{Vera - A Faculdade de Arquitetura...}

Érico - a Arquitetura, não muito. Na Arquitetura foi menos, muito menos. Eu digo usar parte desses espaços que eram de pés-direitos duplos, e isso deu significativo crescimento em área e deu a possibilidade de fazer uma revisão de usos, porque a UnB continua crescendo. Hoje há mais de 30 mil alunos. O ICC foi obrigado a crescer de dentro dele mesmo. É a reprodução do espaço, cada vez mais disputado na Universidade.

Vera - Você diria crescer de uma maneira sofisticada, com maior conforto acústico, ambiental, térmico?

Érico - Ah, sim! Todos os auditórios e espaços que nunca foram concluídos. Aliás, critica-se o Lelé injustamente, porque na verdade o ICC nunca foi terminado. Os grandes auditórios estavam no osso e colocaram-se as aulas ali dentro. Hoje muita coisa já foi feita dentro do Ceplan, na nova versão. Sou suspeito, mas acho que os resultados são muito positivos.

Vera - Para completar, dentro desta cronologia do Ceplan nós colhemos o depoimento do arquiteto Luís Henrique Pessina, e ele abordou a fase em que ele volta para a UnB, nos finais dos anos 80 , quando viveu um período, junto com o prof. Marcilio, diretor do Ceplan, defendendo também o retorno do Ceplan como órgão técnico da Reitoria.

Érico - É natural que tenha tido também esse tipo de ideia, porque ele sempre pensou e agiu como bom arquiteto... Ele que colocou em discussão este tipo de coisa que depois eu também encetei. Eu vi o que aconteceu com os meus colegas. Assumiam a direção do Ceplan e viravam bagaço. Não havia como trabalhar sem estrutura. Não havia a mínima condição de andar. Quando eu assumi, essa mudança já tinha sido debatida e aprovada, e coube a mim implantá-la.

Vera - Érico, vamos voltar para a primeira fase em que você entra na UnB e vai projetar a Faculdade de Tecnologia. Você viveu o deslumbramento na criação de estruturas arrojadas para a Faculdade. Li alguma coisa que você cria um novo método até, dentro da Faculdade de Arquitetura, para o aluno estudar a parte estrutural. Essa ênfase pode ser considerada uma integração entre o ensino da arquitetura e o Ceplan?

Érico - Isto eu posso esclarecer bem. De certa forma é, sim, uma integração entre Ceplan e o ensino. As inquietações estruturais, parte delas, eu consegui desenvolver dentro do Ceplan, desenvolvendo estruturas em paraboloide hiperbólico. Essa experiência foi efetivamente realizada no Ceplan, e na atividade como professor percebi que os nossos alunos estudavam as disciplinas de estrutura ministradas no currículo de Engenharia Civil e não absorviam, nem incorporavam esses conhecimentos aos seus trabalhos. Nem eram chamadas de disciplinas de estrutura, eram aquelas disciplinas clássicas: Mecânica, Resistência, Estabilidade e Análise Estrutural. Os alunos passavam por aí a duras penas, sendo motivo de chacota, porque cursavam essas disciplinas não entendendo para que nem por que poderia ser úteis, junto com os estudantes de Engenharia civil, com o foco voltado exclusivamente para a verificação estrutural. Os arquitetos deveriam ser preparados para a concepção estrutural, ali não se aprendia nada disso! Eu percebi isso como professor de projeto (Projeto de Edificações e Urbanismo Vl). Um belo dia, falei que tínhamos que pensar seriamente no ensino de estruturas e tecnologia de construção no novo currículo. Porque percebi que do modo praticado era inócuo, sem sentido. 
Naquele semestre aconteceu um grande encontro de professores de estrutura em São Paulo. A FAU resolveu me mandar para representar a escola. Ponderei que não sendo professor da área, iríamos passar vergonha. Nenhum professor de engenharia da UnB foi enviado. No encontro só havia sumidades como Mario Franco, Zigbert Zanetini. Gente da primeira linha do Brasil estava lá. Ali começaram a germinar muitas ideias. Apresentei-me não como professor de estrutura, e sim de arquitetura. Certamente falei alguma coisa que bateu, pois fui parar na comissão de redação dos anais do encontro. Eu, Zanetini, Mario Franco e mais um professor de FAU do RJ. Discutimos muito, produzimos um documento denso, sobre o pensamento desse ensino nas escolas de arquitetura. A bíblia das mudanças que depois ocorreram em vários lugares. Volto com esse texto dentro da mala, chego, falo o que aconteceu. Pronto, tem que implantar! Aí começa uma escalada muito tortuosa que não vou contar aqui. Deu greve, fui envolvido como sendo um dos mentores, porque os alunos não queriam mais cursar nenhuma disciplina dentro da Tecnologia. Eu havia ministrado um semestre experimental de ensino de estruturas, e eles queriam continuar. Isto virou um curso voltado para a concepção estrutural, e não necessariamente só a verificação. Não quer dizer, que não se estudasse a teoria. Tem que ser estudada sim. Mas não só. Além da teoria e do desenvolvimento estrutural, devem-se estudar também o espaço arquitetônico e a história das tipologias estruturais e sua construção. Então, história, o espaço e a teoria estrutural. São de fato três as pernas de um corpo desse tipo de conhecimento. E esse novo conceito começou a ser implantado. Uma desafiante experiência que deu muita alegria, e a razão da minha existência como professor.

\section{Vera - Daí você passou a ser responsável por essas disciplinas?}

Érico - Sim, junto com o professor Ernesto Walter. Convidamos o Ernesto porque, para argumentar com a universidade, era necessário um professor de prestígio na área de tecnologia para dar credibilidade e aval ao novo método. Ernesto era um diplomata da tecnologia. Eu brincava: "Tu és o tecnólogo migrando para a arte e eu sou o artista que está virando tecnólogo, e nós nos encontramos no meio do caminho". Foi muito boa e profícua essa convivência acadêmica de inquietações especulativas. Mas esta é uma longa história.

Vera - Érico, você poderia dar um apanhado sobre as perspectivas de ocupação total do campus? Hoje tem um planejamento, tem as suas diretrizes? E como vem ocorrendo essa ocupação? Durante as primeiras décadas o planejamento seguiu a orientação do Ceplan, não?

Érico - Isso deve ser colocado dentro de uma perspectiva de tempo. Quando nós falávamos de planejamento do campus, o âmbito envolvia especificamente as escolas, os laboratórios, a administração e os espaços comuns. As faculdades, os institutos e alguns edifícios administrativos e laboratórios. E isso tudo circunscrito a um polígono restrito ao que hoje é o cuore do campus. Isso era a área de planejamento grosso modo, com a Colina também. Mas esse universo mudou muito, por novos fatores. Primeiro, os programas que a universidade tem em desenvolvimento são programas com financiamentos de grandes empresas, como a Petrobras, por exemplo, a Geocronologia. Os programas de obra no tempo em que participei do planejamento eram financiados exclusivamente pelo Ministério de Educação. Hoje há outras fontes, é mais complexo. E também é um crescimento de atividades outras, por exemplo, o Cespe da UnB, que coordena os concursos, vestibulares, etc. Existe ainda uma série de outros programas e outras instituições se instalando. Então, toda aquela parte sul do campus, que é uma área enorme, está sendo ocupada por esses programas novos. Os programas da área de Saúde já estão definidos locacionalmente. Foi aprovado um plano diretor bastante pormenorizado. Há projetos sem vínculo específico com a Universidade, como a Fundação Oswaldo Cruz, próximo do hospital da UnB. O universo mudou. O planejamento mudou, ampliou seu raio de ação. Hoje a UnB é assediada! Eu me lembro de ter participado de reuniões do Conselho Diretor em que grandes empresas, sejam elas empresas de pesquisa ou não apresenta- 
vam propostas para construção de áreas novas. Estas empresas são admitidas na medida em que podem ter uma convivência salutar, uma parceria. O professor Zimbres tratou, em priscas eras, uma parceria com o CNPq. Toda aquela parte que liga com L-4 estão densamente construídas, com os institutos de Química, de Biologia, com o Cespe. Há ainda outro tipo de atividade, as incubadoras. Todos esses programas estão se expandindo. Todo o esquema viário que tinha sido projetado foi executado em ritmo acelerado, para implantar os novos programas nessa nova área.

Vera - A próxima questão do nosso roteiro é sobre o ICC, acho que você já nos deu a sua visão, com a perspectiva de ser um local de convivência, a grande sala de aula, não?

Érico - Basicamente, é o grande conjunto de salas de aula, porque lá estão os grandes auditórios. O ICC é o lugar onde todos os alunos têm suas aulas. A universidade optou por retirar do ICC as principais áreas laboratoriais e disponibilizar espaços com especificidade técnica e segurança adequada àqueles fins. Lembro-me do laboratório de Fisiologia Vegetal, do prof. Laboriau.

\section{Vera - Teve projeto do Vasco Mello e do Galbinsky.}

Érico - O projeto do Oscar para o ICC tinha uma inteligência intrínseca muito grande para apoiar e dar suporte para essas unidades. Mas, de fato, o edifício não reflete o que o pesquisador imagina. Na minha experiência com os pesquisadores, percebi que querem saber se está chovendo, querem ver a luz do dia e sentir a ventilação natural. Quando essas características não estão presentes com um caso de edifício muito denso, ou muito largo e compacto, onde há necessidade da ventilação forçada e o uso do ar-condicionado etc., o pesquisador reage. E principalmente a questão acústica do ICC, este tipo de coisa fez com que o pessoal, principalmente da área de ciências, não quisesse mais ficar no ICC. E as áreas de salas de aula comportavam melhor as atividades, mediante pequenos ajustes, o prédio funcionaria por azar, a Biologia chegou depois do pessoal da Medicina. Foi alojada no subsolo, e este, que eu saiba, nunca foi pensado como local para atividades de uso permanente. Nunca! Era, sim, para depósitos, lugar para atividades onde não havia necessidade de instalações realmente especiais de ar-condicionado, etc. Porque ele é muito fechado. Na verdade, a ânsia e a pressão por instalar a universidade são as causadoras de uma ocupação infeliz.

\section{Vera - Érico, fale sobre esta foto do Lúcio Costa no Ceplan, que você vai nos ceder para escane- ar, como aconteceu essa visita?}

Érico - Em 1974 acontece no Senado Federal o I Seminário de Estudos dos Problemas Urbanos de Brasília. Estou no plenário do Congresso, o dr. Lúcio falando e eu consultando os meus colegas: "Vamos convidar o Lúcio Costa para visitar a UnB?" Seria natural que a reitoria convidasse o criador de Brasília. Confirmei, e não estava agendado nada. Confabulei com os colegas e decidimos levar o mestre para o Ceplan. Convidei-o e ele aceitou. Na hora articulei com o Ceplan, com a estudantada, para reunir todos, porque vem aí o Lúcio Costa! Chegando à UnB o Ceplan cheio, lotado! Eram 5 da tarde. Entramos no Ceplan, aquele alvoroço! Havia duas cadeiras vazias na entrada do auditório. E ele, incontinente, senta ali no meio da plateia, e diz: "Senta ai, Érico". Eu respondo: "Dr. Lúcio, o senhor poderia ir lá para frente do auditório, seria melhor?". Dr. Lúcio. "Não, estou muito bem aqui, este lugar está perfeito, estou vendo bem". Eu falo: "O senhor está vendo bem, mas o senhor, como homem muito educado que é, não vai querer que este pessoal da plateia vá ter torcicolo". Ele deu uma risadinha e disse: "Você vai querer que eu vá lá para frente mesmo, né?". "Sim, você é a estrela, você tem que estar lá na frente!" Lúcio Costa: "É, desse ponto de vista, então, não tenho outra opção". A contragosto, ele se levantou e fomos lá para frente.

Vera - Ah, entendo, no auditório do Ceplan, eram aquelas primeiras cadeiras soltas no mesmo nível do piso. 
Érico - Abri a reunião e provoquei-o a falar, dar sua mensagem aos alunos e professores da Escola. Ele falou alguma coisa tão baixa, tipo "não sei por que estou em Brasília". Coisas bem do Lúcio. Tive que entrar e dar uma redirecionada e a reunião correu bem, com muito debate bom e muita mancada também, pois houve colegas nossos que perderam a noção das coisas. A Reitoria ficou furiosa com a Faculdade de Arquitetura, por ter convidado o Lúcio Costa e não termos comunicado antes a eles. Tudo aconteceu de última hora. Eles não o tinham convidado, eu confirmei isso. Azar, o que podia eu fazer? Ganhamos um rolo e uma histórica visita. Então, ai está aqui a foto com o Lúcio Costa sentadinho no Ceplan.

Vera - Então, Érico, muito obrigada por esta grande entrevista. 


\title{
ENTREVISTA COM PROF. FRANK SVENSSON
}

\author{
Realizada em 16/02/12, Brasília/DF
}

\begin{abstract}
Vera - Hoje o Ceplan é um órgão técnico ligado diretamente à Reitoria, com todas aquelas atribuições que o senhor conheceu. $O$ que mudou em relação ao período em que o senhor foi diretor? ${ }^{1}$
\end{abstract}

Frank - Posso dizer alguma coisa do que mudou no Ceplan, mas antes eu gostaria de falar sobre o que originou o Ceplan. A ideia da Universidade de Brasília (UnB) se desenvolveu no Ministério da Educação (MEC) sobre a liderança de Anísio Teixeira. O projeto de lei que criava a UnB foi aprovado pelo Congresso Nacional.

Existe história e existem versões que atrapalham a memória a respeito, mas é a partir das versões e dos testemunhos que se chega aos fatos havidos. Darcy Ribeiro, não sei se por escolha ou por oferecimento (eu o conheci, era uma pessoa de grandes ideias, de muito valor político para este país, contribuiu com tudo que ele coscuvilhou e escreveu). Ele fazia parte desse grupo no MEC e seu nome surgiu para ser o primeiro reitor da universidade. Havia propósitos bastante definidos nessa lei de criação da UnB: entre outras coisas, ela devia ser uma universidade de excelência, que se dedicasse à produção de conhecimento para a solução dos problemas nacionais. Devia se equiparar às melhores universidades do mundo.

Então, surgiu a questão: onde vai ser a universidade? No início, ela não estava prevista para ser onde é hoje. Não sei exatamente, mas já ouvi que seria junto onde é a Fazenda Experimental da UnB. Por duas razões principais: porque não se queria estudantes intranquilos e inquietos perto da Esplanada dos Ministérios (estávamos nos primórdios dos anos 60; lembro que eu, como estudante, assisti à ocupação do Ministério da Educação pelos estudantes, pela UNE, era ministro o Armando Falcão) e porque se queria a UnB como uma espécie de MIT brasileiro que se dedicasse às ciências, as humanas e as ciências naturais. $O$ dr. Alcides é que se bateu para que houvesse também uma formação para a arte e a arquitetura. Foi o dr. Alcides quem nisso mais se empenhou. $E$ foi assim que se contrariou aquela ideia proposta para o local da Fazenda Experimental e veio a ideia da localização no plano-piloto.

A primeira vez que vim a Brasília foi de 1958 para 1959, mas como aluno. Vinha em todos os períodos de férias estagiar no escritório de Oscar Niemeyer, que ficava ali junto do Hotel Palace, um barracão enorme de tábuas, junto aos seus anexos. Me hospedei durante dois períodos de férias escolares, naqueles anexos.

Voltando, então ao Ceplan: surgiu o problema de concretizar a universidade em termos de construção. E não havia nenhum programa de como essa universidade seria arquitetonicamente. Aí surge um personagem importante, mas que, por ser comunista, a memória da UnB o tem esquecido. Anísio Teixeira trouxe com ele um médico chamado Heron de Alencar, que é uma pessoa muito importante para se entender o Ceplan. Ele tinha participado do projeto da Petrobras na Bahia. Era primo em primeiro grau de Miguel Arraes, era obstetra, mas muito interessado em cultura regional. Escreveu um livro sobre José de Alencar. Heron de Alencar proferiu na Universidade da Bahia uma aula magna, 
que foi transformada em livro de umas 30 a 40 páginas, sobre universidade, cultura e região. Ele se dedicou ao ensino da Medicina no início, mas era, dessa turma, quem mais tinha se aproximado de leituras e reflexões em torno do que seria uma universidade. Anísio Teixeira disse para o Darcy Ribeiro, sabendo que o Darcy era um homem de grandes ideias, grandes voos, aconselhou: "Leva o Heron de Alencar e ele irá ajudar". Então se fez com e Oscar Niemeyer um programa de construção que motivou a necessidade de um escritório de arquitetura e da equipe indispensável. Aquela primeira lei da UnB, com as diretrizes gerais em favor da produção de conhecimento e de solução de problemas nacionais etc., se transformou numa necessidade de construção. $\mathrm{E}$ isso não teve a participação decisiva dos que fizeram as primeiras propostas - "Ah, vamos chamar o Oscar" -, mas quem com ele chegou a um programa de concretização inicial da UnB foi Heron de Alencar.

Vera - No início teve a contribuição do prof. Alcides, com o projeto e construção do FE, Auditório e antiga Reitoria, não?

Frank - Antes disso conseguiu que o campus ficasse onde ele é hoje. Isso nós devemos ao Alcides.

\section{Marco - E também, o plano urbanístico do campus já constava do plano-piloto.}

Frank - Então, tomou forma de projeto a Universidade. Quando trabalhei com o Oscar na Argélia, ele me contava: "eu fui convidado, eu não sou professor, não sei ensinar, mas eu coloquei à disposição o meu escritório". De forma que ele se transferiu para a universidade, e aí vai germinar duas instituições: o Cediarte, a partir da biblioteca que o prof. Alcides colocou à disposição da Universidade para pesquisas e trabalhos (acho que foi a Neusa ou a Filomena Miller que me contou isso, que ele colocou a sua farta biblioteca à disposição), e o Ceplan. Então surgem estes dois centros, a parte mais pedagógica tem a presença dinâmica do Darcy Ribeiro, mas para discutir com os arquitetos como seria essa universidade, transformar isso em um programa, é o Heron de Alencar. E aí que surge que surge a força desse programa.

Haveria o ICC, dividido em cinco aéreas a serem atendidas por pesquisa e produção de conhecimento. O Oscar propõe cada uma em torno de uma praça no Minhocão. Essas áreas eram Ciências e Matemáticas, Ciências Naturais, Ciências Sociais e História, Engenharias, e o que seria o instituto das artes e da arquitetura (ICA-FAU). Cada uma dessas áreas teria uma praça no ICC como um centro de um instituto como entidade maior que permitiria todas as formas de ensino e de pesquisa daquela área. Resumindo, as faculdades seriam parte dos institutos para a formação das necessidades profissionais, da formação de mão de obra para essas aéreas. Então haveria faculdades de ciências; de nutrição, medicina, fisioterapia etc. na área de ciências da saúde.

E cada uma dessas unidades, desses institutos, teria um centro de pesquisa interdisciplinar. Desses só sobreviveu o Ceplan e um da área de Psicologia. Não sei como está hoje, mas durante muito tempo havia um trabalho bastante interessante de psicopedagogia que atendia, entre outros, alunos problemáticos. (Eu mesmo mandei para lá um aluno problemático que não tinha nenhuma capacidade de síntese. Aí trataram dele e sei de outros casos também.). Com isso quero ilustrar que foi tomando forma, havendo uma relação bastante nítida e orgânica entre a intenção de ter a UnB e a necessidade de concretizá-la arquitetonicamente.

Mas aí vem um fato político importante a considerar. Eu era estudante em Minas Gerais quando, a partir da Juventude Universitária Católica (JUC), foi criada a Ação Popular (AP). A Igreja, de certa forma, se assustou com o crescimento do PCB, o chamado Partidão, principalmente na área dos estudantes e dos professores. Depois veio o golpe de 64, e a participação dos universitários foi muito marcante. Vim para cá a convite, principalmente, da célula do Partidão na FAUSP, para atuar numa espécie de conselho político oculto na UnB, e trazer para cá a experiência da interdisciplinaridade da Superintendência do Desenvolvimento do Nordeste (Sudene). De modo que eu fui um arquite- 
to meio diferente em relação aos outros vindos todos do Sul Maravilha, de Porto Alegre, São Paulo e Rio de Janeiro. Alguns com experiência no serviço público, gente que tinha trabalhado com o Reidy, com Lúcio Costa, tipo Milton Ramos e Glauco Campello, vieram do Rio de Janeiro. Os demais vinham de escritórios da profissão liberal. O currículo político pesava na nova UnB na escolha dos setores que exerciam resistência à ditadura.

Havia cinco escolas de arquitetura no país, em cada uma delas havia uma célula do PCB. Os nomes de liderança eram Demétrio Ribeiro, Edgar Graeff, Paiva, no Rio Grande do Sul, Artigas e Paisani em São Paulo, e assim por diante. Os conselhos mais políticos tinham forma de frente ampla nos quais se buscava consenso para as medidas em questão. Da resistência da ditadura, tinha gente desde a juventude PSD do Juscelino e a juventude do PTB, que em Belo Horizonte era dirigida pelo Paulo Pertence, até a $\mathrm{AP}$ e o $\mathrm{PCB}$, havendo ainda um pequeno grupo trotskista. Entre esses grupos desenvolveu-se um comportamento de frente ampla. Discutíamos as decisões formais e institucionais na UnB após havermos discutido entre nós. Só levávamos à instituição da universidade o que tivesse sido de consenso.

Porque a UnB ainda tinha uma série de mecanismos propostos por Heron de Alencar, de interação e de síntese. Não sei se você lembra que na direção do ICA-FAU, havia um conselho de professores de outros institutos. A proposta inicial era de que você fosse estudar matemática no Instituto de Matemática e sofresse o problema de transpor para o seu problema específico de arquitetura, fosse de física ou de história. Isso se deve muito ao esforço de Darcy Ribeiro. Ele captou isto e se empenhou muito nestes mecanismos, a relação entre teoria e pratica, por exemplo. O Ceplan tem a ver com isso, porque para a formação de graduação de profissões se instituiu também o primeiro mestrado de arquitetura deste país. Antes, no Brasil, havia pós-graduação em planejamento urbano. Eram dois anos feitos depois da graduação em arquitetura, era de planejamento urbano, ou urbanismo, todas as faculdades tinham. Já com a participação de Edgar Graeff o ensino da arquitetura resultou em dois turnos. $\mathrm{O}$ turno da manhã era para a formação de arquitetos já formados como mestrandos em arquitetura.

Aglutinou-se um grupo em torno do Alcides e outro em torno do Oscar. O Oscar me disse na Argélia: "Eu não sou professor, não sei ensinar, eu coloquei o meu trabalho à disposição como possibilidade de prática". Daí decorreram várias coisas extremamente interessantes. O pessoal que ficou em torno do Rocha Miranda e do Cediarte era o Luiz Humberto, o Eduardo Maia Mendonça, Filomena Muller, que fez o primeiro mestrado sobre conforto térmico, orientada pelo alagoano Eustáquio Toledo. Com o Oscar, ficam o Lelé, o Pessina, o Burmeister e outros. Então vem o golpe, com a resistência, a articulação política, a militância da qual não se fala muito. Mas à Igreja foi permitido manter o seu púlpito e ela estimulou as suas formas de luta e organização. No princípio a gente convivia muito bem. O humanismo católico que é a base da cultura brasileira é altamente flexível e mutável desde que não se dê um salto para a visão materialista que era a do Partidão.

Então, houve a primeira prisão na UnB. Eram seis professores comunistas, entre os quais o Las Casas, do Direito, tinha um da Saúde, não lembro o nome dele (na época o hospital escola da UnB era em Sobradinho, e lá havia uma célula do partido; havia outra no Minhocão).

Nós do PCB em Belo Horizonte éramos cinco ou seis estudantes, procuramos o Oscar no Hotel Amazonas, perguntamos se podíamos conhecer a experiência de Brasília, e ele disse: "Claro!". E se aventou possibilidade de virmos para o escritório dele em Brasília. Aqui ele designou o Gladson da Rocha, que estava trabalhando com ele, para nos orientar.

Dessa tensão se desmilinguiu a integridade da proposta de Heron de Alencar. O governo militar adotou certas coisas do projeto inicial da UnB, querendo transformar a UnB numa universidade de excelência, e até certo ponto permitindo a interdisciplinaridade. Incentivou o doutoramento no 
exterior, mas estes novos doutores voltaram do Primeiro Mundo com uma nova experiência, um novo registro de comparações, dos Estados Unidos e da Europa. E quando voltaram para cá não encontraram campo na universidade para desenvolver o que os seus doutorados tinham experimentado no Primeiro Mundo. Então, surgiu toda uma situação de voltarem para a universidade sem poderem considerar os problemas candentes do país. Tiveram que botar um pé na iniciativa privada para exercer suas práticas, virar chefe de escritório, chefiar empresas e clínicas particulares.

Da experiência da Sudene resultaram muitos com experiência de consultoria, que surgiram nessa época, como a Cerete, a Hidroservice e outras que vieram para os programas da Usaid no nordeste. Em função disso houve um esvaziamento da Sudene, e tive que pedir demissão.

\section{Vera - A partir daí, você ingressa na FAU/UnB?}

Frank - Sim, o partido disse: "Você vai para Brasília levar a experiência da Sudene". O ICA-FAU havia sido fechado e tentaram várias formas para reativá-lo, inclusive trouxeram o Silvio Vasconcelos para reativar, os arquitetos do Paraná (Jaime Lerner, os Gandolfi). Houve nova greve dos alunos que não aceitavam o modelo da profissão liberal, que já tinham bebido na experiência do Oscar e do Alcides e de alguns outros que vieram do Nordeste. Em 1969, estava aquela efervescência. O Azevedo era vice-reitor, ele tinha dito: "Eu sei que vocês são de esquerda, desde que vocês não desenvolvam militância e façam o instituto funcionar...." Porque eles tinham convidado o Oscar para reabrir o ICAFAU e ele disse "Não, só vou se os duzentos forem readmitidos". O Partidão foi contra a demissão dos duzentos, achava que não era a hora de fazer isso, era entregar o ouro para o bandido. Mas a Igreja e o pessoal do PTB foram a favor. Os estudantes queriam o Paulo Magalhães como chefe da reabertura. Entretanto, Miguel Pereira é indicado pelo Graeff como chefe da reabertura e veio também o Neudson Braga, do Ceará, Pasqualini Magnavita, da Bahia; o Mauricio Nogueira, o Paulo Bastos, de São Paulo. Ele é que se bateu em São Paulo para me convidarem. Miguel trouxe consigo a equipe do seu escritório de Porto Alegre: o Farret, o Coutinho, o Galbinski, o Xavier e, finalmente, o Bicca. E o Miguel teve abertura para receber a minha experiência da Sudene, e se dividiu o ateliê de projeto da graduação entre projetos abordando Brasília e projetos da região Centro-Oeste. A minha relação com o Ceplan vai por aí. Eu não sou um arquiteto vindo da profissão liberal, feito o Zimbres, o Galbinski, mas da área de projetos da área de desenvolvimento, da arquitetura em projetos de desenvolvimento. (...) Chego aqui em março de 1970. Houve essa experiência e conseguimos criar, a partir do Ceplan, núcleos de planejamento na região Centro-Oeste, em convênio com o Ministério do Interior e a Superintendência do Desenvolvimento do Nordeste (Sudeco). Nós tínhamos trabalhos de diplomação de equipes pluridisciplinares, o que unia essas equipes era um objeto urbano, rural escolhido para ser trabalhado. Trabalhamos, por exemplo, em Ceres. Lembro que chegamos a Ceres, estava surgindo Rialma, que era uma espécie de Núcleo Bandeirante de cada uma dessas cidades planejadas no governo Vargas. A ampliação de Porangatu, Aragacarças gerou Barra do Garça, e assim por diante. (...) Nós usávamos um livro do Francisco Withaker, ligado à PUC do Rio de Janeiro, sobre desenvolvimento urbano. Então, isso gerava projetos e nos tínhamos que diplomar na FAU projetos de Arquitetura, e os alunos de História se diplomavam em projetos de História. Tinha um professor de Economia, Raimundo Nonato, que dava aula de desenvolvimento. Foi isso que me fez ser enquadrado no ato Al-5. Eu sou o único professor da UnB enquadrado neste ato, na lei de exceção 477, assinado pelo Jarbas Passarinho, ministro de Educação. Fui proibido de lecionar em todo território nacional. Isso só foi desativado na gestão do Cristóvão, nem com a Anistia. Houve uma anistia ampla e geral e outra das profissões subtraídas das pessoas. O Demetrio foi anistiado logo no primeiro ato. Nós que tínhamos sido enquadrados no ato Al-5 tínhamos que ser reintegrados nos nossos empregos anteriores, e eu só fui reintegrado no início de 1989,quando retornei para o Brasil. A cassação foi no fim de 1972, mas o Azevedo permitiu que eu tirasse o passaporte, fui para a Suécia. Lutei 15 anos para ter uma indenização. A Sudene me reintegraria, 
mas não financiava a minha volta. Então, houve essa experiência de três anos. Tem muitos alunos que se lembram disso. O Marco, o Jaime de Almeida, o Chico, o Isaac, o Inaldo, o Tancredo e outros.

\section{Vera - Esses trabalhos resultaram em aplicações diretas nas prefeituras?}

Frank - Não sei, mas resultou que vários alunos diplomados na UnB foram trabalhar nesses distritos de planejamento - Tancredo foi para o Acre, alguns foram para a Sudeco - e gerou vários convênios.

\section{Vera - Quando você retorna para a UnB em 1990, você ocupa a direção do LEAU? Pois temos alguns documentos que apontam isso.}

Frank - Não lembro. Só sei que fui nomeado chefe do Departamento de Arquitetura. Trabalhei com o Frederico Holanda, que tinha trabalhado comigo na Sudene e o recomendei para trabalhar aqui. $O$ instituto virou faculdade, fui eleito diretor e o Pessina, vice. Fiquei um período de dois a quatro anos. O Claudio foi eleito para o urbanismo e o Sanchez é hoje diretor. Mas, não vou dizer tudo o que sei.

Quando o Itamar Franco sucedeu o Collor, ele era engenheiro meio maluco, mas não era burro. Ele colocou no SNI, que virou Secretaria de Assuntos Especiais, o embaixador Sardenberg para criar uma ponte entre a Presidência da República e a universidade. São Paulo lutou para que a base fosse da USP, mas o Todorov conseguiu trazer isso para a UnB. Teresa Carvalho, arquiteta com doutoramento em planejamento regional em Glasgow, foi convidada para ser a diretora do recém-criado Centro Integrado de Ordenamento Regional (Ciordi). Fui vice-diretor do Ciordi durante uns dois, três anos, fizemos uma série de convênios de planejamento ambiental e ordenamento territorial que trouxeram uma possibilidade financeira para este Centro, que depois, na época do Cristóvão, foi absorvido por outro centro, e depois fui aposentado.

\section{Vera - Então esse centro estava ligado ao LEAU-Ceplan ou à FAU?}

Frank - Não, o Ciordi era ligado à Reitoria. Lembro que a Teresa levou o Claudio, então, chefe do Departamento de Urbanismo da FAU, para conversar com o chefe do setor de Inteligência na Presidência da República. Cláudio disse que tinha o maior interesse em receber o Ciordi na FAU, mas não conseguiu convencer, e o Ciordi não ficou ligado a FAU, e sim à Reitoria. O LEAU era integrado à FAU, a separação do Ceplan da FAU e sua vinculação à Reitoria foram depois. O Ceplan a partir daí virou escritório para resolver os projetos encomendados pela Reitoria. Aquela vinculação orgânica a partir do Heron de Alencar, e os mecanismos de interação de trabalho em equipe, conselho disto, daquilo, tudo isso foi desvirtuado. O Érico virou professor de estrutura; primeiro veio o Ernesto Walter, talvez a pessoa mais culta que passou pela FAU, morreu precocemente. Desgosto também mata! Lauro Campos, idem. Acho que é isso que posso dizer.

\section{Vera - Você não se lembra de nenhum projeto ligado ao LEAU na sua época.}

Frank - Lembro que foi feita a Nova Colina, em 1989. O Ibañez, na sua campanha para reitor, tinha prometido o alojamento para os pós-graduandos; ele me chamou, mais a decana para Assuntos Comunitários, me indagaram se eu não podia assumir o projeto. Disse que iria orientar uma equipe de diplomação sobre habitação no campus e a partir daí daríamos indicações. Nessa equipe participou o Júnior, a Rose, eram cinco ou seis, com mais duas professoras de outros setores. Esse estudo gerou uma série de constatações que encaminhamos para o lbañez. Isso deu uma briga, porque o Paulo Marcos não admitia que ninguém abordasse esse tema além dele. (...) Nessa época passou a haver um frenesi na UnB para a captação de recursos. (...) Durante o tempo que estava no Ciordi, também dava aula na FAU. (...) Eu não estava aqui na época da determinação da equipe para fazer o projeto da Nova Colina. Foi na época do Cristovão. Fizeram alguns projetos para o Hospital da UnB 
no LEAU, nessa época, o Kristian, também fez algum projeto.

\section{Vera - Gostaria de falar alguma coisa sobre o ICC?}

Frank - Durante o início da construção trouxeram um engenheiro para ser prefeito do campus, e o reitor, não sei se foi frei Matheus, ficou chateado com aquele buracão no meio do ICC. O Oscar trabalhou aqui, como ninguém, com o imprevisível. Aquela coisa no meio estava vazia, ocorre que estava previsto que haveria necessidade de novas construções que não caberiam no pé-direito do ICC, ali no meio subiriam torres de decantação e, se não me engano, estava previsto ter alguma espécie de auditório, tanto que nos desenhos do Oscar para o ICC tem algumas insinuações coroando o ICC. E esse reitor, com esse engenheiro prefeito, eles decidiram ocupar este vazio com os quadrados ajardinados por cima, como os terraços do Le Corbusier. Então, surgiram aqueles cheios vazios. (...) Outra modificação: no projeto do Oscar desenvolvido pelo Lelé e outros era para ter, nos laboratórios, grandes vitrines, para as pessoas passarem e verem o pessoal trabalhando e criar um ambiente de ciência. Estavam previstos também museus, saindo do ICC para a Praça Maior, saídas subterrâneas que afloravam nos museus de ciência. Sugeri ao reitor, no meu tempo de diretor da FAU, que convidasse o Oscar para fazer a proposta desses anexos. Pois havia a possibilidade de uma contribuição. O Japão fez muito esforço para evitar a IBM na UnB, era a JVC. Era o início da época da informática e programação, eles enviaram um arquiteto de museus que fez umas conferências, no sentido de equipar esses museus desde que a UnB fizesse a construção, mas não deu em nada, pois a IBM assumiu a liderança. Esse convite, acho que foi na época em que o Oscar foi nomeado doutor honoris causa pela UnB. (...) Isso morreu na praia, como muitas coisas - entre outras, algumas pessoas se empenharam para que o Lelé fosse contratado para dirigir o LEAU, eu participei da reunião na Reitoria, ele estava até aceitando a ideia, mas alguns arquitetos da FAU não aprovaram. (...) Desculpe a minha forma descontraída, o que eu queria salientar em relação ao Ceplan é a necessidade de formular um programa de arquitetura participando organicamente do projeto da UnB. Darcy Ribeiro, Anísio Teixeira e outros discutiram princípios e desejos desenvolvimentistas para a universidade. Mas isso sempre acontece, quando é a hora de definir espacialmente e construtivamente um programa de intenções, há um feedback importante que modifica muita coisa ou pelo menos reconfigura o que antes eram mais ideias e teorias. A pessoa-chave aí é Heron de Alencar.

\section{Vera - Tem alguma coisa escrita, algum livro dele?}

Frank - Tem um livro que estou procurando em sebos, Universidade, Cultura e Região, editado pela Universidade da Bahia. Recentemente fizeram um mestrado sobre ele na Universidade Federal da Bahia. Acesse no Google o nome dele, vai aparecer o nome do filho também Heron de Alencar, cineasta. O Pessina mantém contatos com a Virginia, que era esposa do Heron. Ela vive em Paris. Além do Heron, temos várias pessoas que foram substituídas na memória deste país por outros nomes, o Anísio Teixeira foi substituído pelo Paulo Freire, ele foi o fundador do Inep no MEC, ele esteve nos USA, estudou com o Whitney, e lembro que o Inep criou agências nos estados e facultava testes vocacionais.

\section{Vera - Você teria algum documento ou foto para o Projeto Memória?}

Frank - Sobre o Ceplan, não, mas tenho uma palestra feita sobre o Heron de Alencar. Acho que tenho no computador, também tenho uma entrevista feita para o Museu da Imagem e do Som do Rio de Janeiro, dois DVS sobre as minhas relações com Brasília.

Ainda quero acrescentar com relação ao Ceplan que, devido a minha origem sudeneana, sempre houve a preocupação de trazer para dentro da Universidade a preocupação do desenvolvimento da região do Centro-Oeste. Aconteceu que alunos meus, formados em Arquitetura, foram convidados pelo governo de Mato Grosso para desenvolver o projeto do Centro Político-Administrativo 
de Mato Grosso, em Cuiabá: o Julio de Lamonica, o Sergio Moraes e mais dois ou três arquitetos. Nessa época estava sendo desenvolvido um projeto de universidade, muito interessante, em Belo Horizonte, na Pampulha, sobre a orientação de Alípio Castelo Branco. (...) Em minha opinião, foi o primeiro projeto de arquitetura no Brasil com apoio da informática. Tinha lá um matemático, superdotado, que junto com o Alípio conseguiram fazer uma enquete das necessidades e desejos dos professores em matéria de espaço. (...) Depois, o matemático criou um jeito de transformar isso em unidades, múltiplos dessa modulação, e colocaram no computador. (...) Criaram um solução estrutural, pois o Alípio colocou dois escritórios de estrutura a brigarem entre si para permitir um megaprojeto que pudesse compatibilizar em altura e em superfície esses módulos e espaços derivados, como sala de aula, auditórios, laboratório. Tinha também um lado de psicologia. Tinha ideias, assim: uma reunião de conselho não precisava de muitas janelas, mas um pesquisador solo deveria ter uma grande janela para ter contato com natureza, lá fora. Tinha uma série de novidades e cientificidades nesse projeto. Trouxemos esse pessoal para o Ceplan, eles deram algumas palestras, ficamos entusiasmados. Então, o Centro Político-Administrativo de Cuiabá foi projetado sob esses princípios. Foi muito bem construído pela Rabello, na época era diretor o Marcelo Fragelli. Mas como eu fui cassado e tive que sair do Brasil, o Zimbres, diretor do Ceplan, passou a assumir a direção desse projeto. Sei que na inauguração do centro chegou o embaixador da Suécia e disse: "Mas isto aqui é uma arquitetura socialista, como é que vocês fazem isso em pleno regime militar?". Fizemos também um projeto habitacional que foi construído. Então, este Centro Político- Administrativo de Cuiabá, ele congrega, num projeto derivado da influência da Pampulha, dum lado da rua principal que dá acesso, o palácio do governo e as secretarias. Isto foi entre 1970 e 72 , o Sergio e o de Lamonica vinham a Brasília, de vez em quando, para nós discutirmos e eu também fui algumas vezes até Cuiabá, prestar consultoria pelo Ceplan.

Vera - Então, Frank, muito obrigada por esta entrevista, foi um grande prazer este nosso reencontro. 


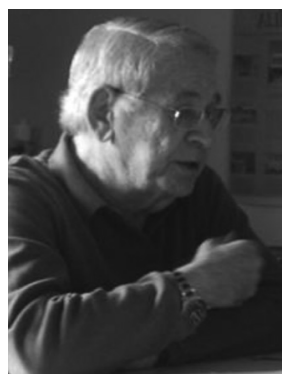

ENTREVISTA COM O PROF. JOSÉ GALBINSKI

Realizada em 04 de nov. de 2011, em Brasília/DF

Vera - O Centro de Planejamento Oscar Niemeyer (Ceplan), criado em 1962, hoje é um órgão de assessoria técnica da Reitoria da Universidade de Brasília, responsável pelos estudos, planos e projetos nas áreas de arquitetura e urbanismo tanto dentro do campus da UnB quanto no DF e na região de influência. $O$ que mudou em relação ao período de sua atuação? ${ }^{1}$

Galbinski - Minha participação no Ceplan foi a partir da reabertura da Faculdade de Arquitetura, no fim de 1968. Naquela época, e mesmo vários anos depois, era considerado por nós uma questão de honra que todos os projetos do campus fossem elaborados pelos professores da Arquitetura. Isso permitiria unir a prática com a proposta pedagógica do curso, que inclusive previa isso. Essa questão era fundamental. Exemplo disso foi quando fui fazer o projeto do Restaurante Universitário, o Bandejão. Naquele momento estavam sendo desenvolvidos, simultaneamente, os projetos da Reitoria, em que tu trabalhaste, e o do Museu, pelo Vasco de Mello. A pressão por tempo era tanta que a Reitoria nos propôs a liberação das atividades didáticas: "que vocês se dediquem 100\% aos projetos para ganhar tempo", que parássemos de ministrar aulas. Isso foi rejeitado por nós porque abriria um flanco capaz de separar o Ceplan da parte didática. Não aceitamos e continuamos com as aulas. As aulas concentravam-se no turno da manhã e tínhamos o período das tardes para trabalhar nos projetos. A carga didática, comparada com a de hoje, era menor. Então, isso era fundamental. Os professores que projetavam tinham que ser do curso de Arquitetura. Hoje mudou um pouquinho. Já houve casos, alguns anos atrás, de projetos serem contratados fora. O Ceplan tem funcionários, sempre teve, mas não tinha funcionários arquitetos, somente no final de 1970, foram contratados os arquitetos Moraes, você e o Josué. O Moraes trabalhou comigo no projeto do Restaurante. Foi a primeira vez, era um reforço para o trabalho dos professores.

Hoje o Ceplan não é mais vinculado umbilicalmente à faculdade, mas a maioria dos projetos continua a ser feita pelos professores, inclusive professores aposentados, como o Matheus, que participou de um concurso. Eles podem integrar, participar, não vejo problema, só me preocupa um pouco que os jovens professores da área de projeto tenham menos oportunidades de projetar. Agora, por outro lado, compensando isso, fartamente, a UnB hoje tem uma posição mais flexível com relação ao tempo integral. Naquela época, tempo integral era com dedicação exclusiva. Obsessiva, como a gente dizia. Trabalha-se sábado inclusive. Hoje isso está mais flexibilizado. Primeiro teve uma flexibilização interna. E outra coisa, hoje tem as fundações, que antes não existiam, e através das fundações você pode fazer uma série de trabalhos e não terá problemas. Vou te dar um exemplo: eu e o Matheus fomos convidados a fazer o projeto da parte central do campus da Universidade Federal de Feira de Santana, Bahia. Para elaborar esse projeto, foi preciso que a UnB estabelecesse um convênio com a Universidade de Feira de Santana. Isso demandou muito tempo, o que é superado hoje rapidamente através dessas fundações. Simplesmente faz-se um contrato de trabalho, e não um convênio envolvendo reitores, advogados etc. Em outra ocasião recebi convite para participar de concurso privado para elaboração do projeto para a Casa Thomas Jefferson, filial Lago Sul. Para entrar nesse concurso tive de pedir autorização não só ao meu departamento,

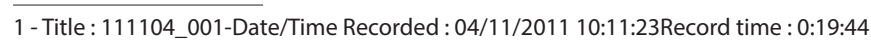


mas, inclusive, ao reitor. Depois que ganhei o concurso, tinha que desenvolver o projeto, mas então já havia o precedente da autorização inicial, mas assim mesmo, tive que pedir nova autorização. Eu acho que a flexibilidade de hoje, para os professores de projeto, é muito importante.

O campus continua tendo obras, mas não é mais naquele volume dos anos 70 , quando aqui chegamos (68) havia muitos projetos para serem feitos. Por isso, o canal aberto pelas fundações possibilita aos professores a prática profissional. No conceito original da universidade os professores teriam tempo integral e dedicação exclusiva, mas não seria por tempo indeterminado, seria de acordo com os projetos. Dentro de um determinado projeto o professor tinha tempo integral, ao final deixaria de ser tempo integral. Nos Estados Unidos é um pouco diferente, quando eu estava no MIT e em Cornell, onde estudei, os professores ganhavam 10 salários por ano. Como funcionava? Durante o ano os professores faziam suas pesquisas, financiadas por agências e instituições, mas recebiam os pagamentos oriundos das pesquisas durante os dois meses de férias da faculdade, sem retenção alguma da universidade e, veja, dessa maneira auferiam o dobro dos salários. $\mathrm{O}$ fato é que nos EUA existem muitas entidades de financiamento à pesquisa, não é como aqui, que tem o CNPq, Finep, Capes... Lá tem essa válvula para eles se conectarem com a sociedade.

Vera - Você poderia listar os projetos que você elaborou dentro do campus? Qual foi o período de sua atuação no Ceplan como diretor?

Galbinski - Primeiro foi a Biblioteca Central, depois o Restaurante, o Bandejão, depois um trabalho que não foi construído, muito rápido, o Laboratório de Fisiologia Vegetal, para o prof. Laboriau, com você e o Xavier na equipe, lembras? E fiz um trabalho grande, que também não foi construído, o CPD - Centro de Processamento de Dados. Na última hora mudaram o nome para Centro de Informática. Isso já está em 1982, nessa época era tudo ainda feito à mão. Você não chegou a conhecer esse projeto?

\section{Vera - Não, eu saí do Ceplan em 1973.}

Galbinski - Tenho os croquis até hoje, eu fotografei tudo, esse projeto está arquivado no Ceplan. Eu gosto muito desse projeto. Foi um dos últimos projetos antes de fazer uma experiência com o pós-modernismo. É um projeto modernista, mas tem alguns elementos de busca, como por exemplo as questões de simetria da composição. No modernismo não existe essa questão. Simetria "é uma coisa do passado", o modernismo trabalhava com modulação, mas não com a simetria, mas eu estava resgatando esses conceitos e algumas outras coisas. Na Europa e Japão já se trabalhava intensamente com esses conceitos.

\section{Vera - Então foi construída a Biblioteca, o Restaurante e, em algum período você chegou a co- ordenar o Ceplan?}

Galbinski - Sim, teve um período em que fui coordenador do Ceplan, não lembro o ano, mas posso verificar. Eu lá fui de tudo, eu era o secretário executivo, chefe do departamento, chefe do programa de pós-graduação... Ah! Chegou o cafezinho.

\section{Vera - No período inicial da UnB qual era a importância do Ceplan para Brasília, para a UnB e para a comunidade? ${ }^{2}$}

Galbinski - Vou te dizer o seguinte: como os professores eram de dedicação exclusiva, o contato com a cidade era mínimo. A influência era através dos alunos, mas a interação dos professores com a cidade era mínima. Até os cinco primeiros anos da reabertura da faculdade, de 1968 em diante, os professores nas férias corriam para as suas origens, iam para São Paulo, Fortaleza, Rio, Porto

2-Title : 111104_002-Date/Time Recorded : 04/11/2011 10:41:50Record time : 0:26:29 
Alegre, não tinham raízes aqui. O trabalho era tanto e tão absorvente que nos vivíamos muito o campus e não vivíamos a cidade. Era uma falha muito grande, por muitos motivos, mas Brasília não oferecia condições de interação. Hoje tem de tudo, os professores hoje convivem na cidade, em clubes, instituições, tudo que a cidade oferece. Mas naquela época oferecia muito pouco, e os professores não tinham vínculo. Quando você pergunta qual a influência do Ceplan na cidade, direta eu não creio que tivesse. Eram unicamente indiretas, através dos alunos que viam o trabalho daqueles professores. Posteriormente, sim. Mas nos cinco primeiros anos de implantação, após a reabertura era mínima.

\section{Vera - Qual o grau de importância Ceplan para a Faculdade de Arquitetura? Persiste hoje a par- ticipação de alunos e mestrandos?}

Galbinski - Estou aposentado há muito tempo, não posso falar com conhecimento de causa. Mas o que percebo, sinto, é que a pós-graduação na UnB tem um cunho mais voltado para a teoria e menos para o projeto, portanto, com perspectiva teórica a relação do Ceplan com a pós-graduação é menor. Vou te dar um exemplo. Sou coordenador do curso de Arquitetura do UniCEUB, que fundei, sou o primeiro e único... E fiz o projeto pedagógico do mestrado, que está na Capes sendo analisado. O PP do Mestrado é voltado para o projeto de arquitetura. Isso até foi argumento de que nosso mestrado não seria concorrente ao mestrado da UnB, pois tem enfoque diferenciado, diria que são complementares.

Vera - Temos um exemplo nos primórdios, a tese de mestrado da Mayumi e Sérgio era o projeto de uma superquadra.

Galbinski - Exatamente, e não foram aceitos pelo MEC! Infelizmente, eles não chegaram a ter o titulo reconhecido. Se tu leres, até hoje, a definição de mestrado, você vai ver que tem um item que diz que o trabalho final é uma dissertação e por causa desse conceito foi considerado que eles não fizeram uma dissertação. Agora o MEC está aceitando, após implantar o mestrado profissional, cujas normas estabelecem que "o trabalho final" - já não usa a palavra dissertação - "será definido pela instituição". Por causa disso, nestes últimos anos estão aceitando projetos, antes disso não. Não sei se você conhece a Bea, formada na FAU, com o mestrado na AA - Architecture Associations, Londres, uma das lideranças internacionais da pesquisa em arquitetura. Ela apresentou sua documentação, e nada! Tenho um professor no UniCEUB que fez graduação e mestrado em Amsterdam, entregou a documentação, e nada! Um terceiro caso, com mestrado no Arizona, USA, eles disseram "nem perde o teu tempo". Não foi aceito porque a tese era um projeto, mas agora isso está mudando.

Vera - Qual o grau de interferência da Reitoria no planejamento do campus? Alguma vez, quando você foi diretor, a autonomia ameaçada?

Galbinski - Na minha época, quando fui coordenador, não. Mas a interferência existia para alguns aspectos, para outros não. "Vocês podem fazer o que bem entenderem", eles diziam. Mas para alguns aspectos existiu, e forte.

Vou te dar um exemplo da época em que foi formado o grupo para estudar o campus e os projetos do Centro de Vivência, do Restaurante Universitário, da Reitoria e do Museu. Naquela época, o chefe do Ceplan era o Pedro Paulo de Melo Saraiva. Ele disse: "Tá resolvido, está aqui o projeto". E era isto [croqui]: o ICC, a via L4, aqui o lago, isto aqui é a Praça Maior. A biblioteca já estava implantada. E o que o Pedro Paulo pensou? Entre essas duas vias laterais à Praça Maior ele fez um projeto belíssimo! Era o Centro de Vivência. Competia-me desenvolver o projeto do Restaurante naquele espaço generoso. O projeto foi rechaçado! Estávamos, nessa época nos anos 70, e em 68 os grandes movimentos estudantis na Europa começaram sempre nos restaurantes universitários. 
Nenhum começou numa faculdade, ou em outro local qualquer. A Reitoria tinha isso catalogado. Eles disseram o seguinte: "a Praça Maior, de Oscar Niemeyer, é o lugar da Biblioteca, da Reitoria e Aula Magna. Nós não queremos colocar o restaurante aqui. Aqui, não". O coração do Centro de Vivência (CV) seria o Restaurante, mas a verba que existia não era para o CV, e sim para o Restaurante. O CV era uma obra muito grande e iria ser construída somente uma parte com a verba disponível. O Pedro Paulo queria que fosse construído tudo, evidentemente, tinha aquela entrada muito bacana. A proposta do Pedro Paulo estava de acordo com a concepção dos grandes traços de Brasília. Então, a intervenção da Reitoria foi neste sentido: "aqui não!".

Depois, pensando nos ventos dominantes de Brasília notei que sopram do Leste. Quando chove inverte, vem do Oeste. Com o restaurante mais abaixo, ia ter fumaça e odores na Biblioteca. Então, intimamente, fui pensando, tinha uma boa área, com grande acessibilidade, entre os estacionamentos Norte e Sul do ICC, e fui pensando em localizar o Restaurante ali, onde está hoje. E enfim, ficou muito bem situado. O lugar atual foi discutido e aprovado no Ceplan, sem mais interferências.

Uma vez, o coronel Lister, quando estávamos vistoriando a obra da Biblioteca, me disse: "Olha, vou Ihe dizer uma coisa, se nós fossemos coerentes, faríamos este restaurante lá", apontando para a Península Norte! Teve interferência sim, mas não nos projetos, as interferências eram no planejamento, no projeto não havia nenhuma.

Vera - Como eram selecionados os arquitetos para projetar determinada obra? Era determinante serem professores de dedicação exclusiva? E como se estabeleciam os compromissos desse arquiteto com a obra projetada, em termos de prazos, detalhamento, fiscalização arquitetônica da obra etc.? Havia alguma compensação na carga horária da atividade docente, alguma remuneração?

Galbinski - Vim para a UnB no fim de 1968, e em janeiro de 1969 foi a primeira vez que fizemos distribuição de trabalhos: o Centro Olímpico, o Alojamento de Estudantes, a Biblioteca e alguns outros projetos que não foram construídos, não lembro agora, porque não tinham verba. As verbas, quando vinham, eram carimbados para tais e tais projetos. Então, no auditorinho do Ceplan estavam escritos, numa lista, os nomes dos projetos e os professores se manifestavam. Manifestavam-se livremente. Eu cheguei atrasado nessa reunião, tudo preenchido, sobrava só a Biblioteca. Eu já tinha certo conhecimento, porque tinha feito o concurso da Biblioteca Municipal, Bahia. Pensei: não vamos inflacionar uma equipe aqui, quando a outra não tem quase ninguém. Mais tarde, em 71, foi diferente essa destinação de projetos. Por ocasião da execução dos projetos do Restaurante, Reitoria e Museu, não foi mais assim, porque alguns daqueles projetos iniciais não se desenvolveram dentro do prazo, não andaram naquela primeira fase de janeiro de 69. Então foi determinação do grupo de professores do Ceplan que esses projetos deveriam ser feitos, respectivamente, pelo Galbinski, Zimbres e Vasco de Mello, porque havia verba carimbada para isso e prazo determinado para conclusão dos projetos. Tivemos que contratar uma equipe de desenhistas de São Paulo. Gozado, sabe como eu trabalhava? Eu ficava num boxe, era um boxinho de paredes removíveis. [Uma baia, exatamente! (Vera)] e os desenhistas no centro da sala. Eu ficava projetando ali e desenvolvendo os detalhes, o Moraes coordenava a equipe de desenhistas. Funcionou muito bem, por que o Moraes estava em cima o dia inteiro, ninguém o enganava, ele tirava de letra. Eu calculei que teria que fazer uns trinta detalhes, e eu só tinha trinta dias. Então, eu teria que fazer um ou dois detalhes por dia. E tinha que ser feito em papel-manteiga, porque o papel vegetal era muito caro. Ao final, fiquei com medo de que estes desenhos, que estou lhe mostrando agora, se estragassem no Ceplan. Então, guardei-os comigo. O Waldemar passou essa fita nas bordas, e isso é o que mantém este material. Agora, eu poderia colocar lá no Ceplan para serem fotografados e arquivados. Vamos ver: este detalhe é de uma esquadria no pilar, então eu usei aqui, e as dimensões. Usei para isso, para fazer essa modulação, a série numérica de Fibonacci. Aqui uma passagem sobre o espelho d'água, 
com as pontes metálicas. Estudo das bordas das rampas. Este é um croqui de um banco nas bordas, do Restaurante. Temos os desenhos dos detalhes também da Biblioteca. Detalhe de uma mesa para a fiscalização na entrada da Biblioteca. Isso aqui...

\section{Vera - Então, todos esses desenhos foram feitos todos por você, dentro daquela programação?}

Galbinski - Sim, fiquei com este material porque os desenhos em nanquim ficaram muito feios, então eu guardei os meus desenhos, faz quase quarenta anos, e este material está até bem conservado.

Vera - Poderia estabelecer uma comparação entre o compromisso do Ceplan com a inovação, com as novas tecnologias, entre as duas primeiras décadas do Ceplan e o período atual?

Galbinski - Essa questão da tecnologia era quase uma ideologia no Ceplan, tanto assim que nós vivíamos autopressionados, ninguém estava nos pressionando. Mas nós vivíamos autopressionados, preocupados em usar a melhor tecnologia. Vivíamos sob a influência de fazer obras de alto nível; todos nos tínhamos um viés social, alguns eram fortemente, até engajados em partidos políticos de esquerda, outros menos; mas todos tínhamos o viés social, e consciência disso. Pois se manifestava ali de uma forma geral, que nós devíamos usar as obras como um experimento, uma pesquisa, de prémoldagem, ou no mínimo de racionalização da construção com vistas ao problema da habitacional brasileiro, que era muito grave etc. E o exemplo estava na nossa frente, o ICC em construção; o Ceplan totalmente pré-moldado, montado, projeto muito bonito; a Colina; os SGS. E ai, diante disso, eu estava com a Biblioteca. O que vou fazer com a Biblioteca? Fiquei pensando, fiz o projeto, a concepção. E agora, onde entra a pré-moldagem? Cheguei à conclusão que em obras isoladas a pré-moldagem seria um encarecimento muito grande da obra. E nós tínhamos o orçamento de um milhão e meio de dólares. O que você faz hoje com esse valor? Não tinha condição. Mas tinha a possibilidade de fazer a racionalização da construção. Teve outro grupo que enfrentou essa situação no prédio dos alojamentos: como eram dois ou três blocos, que tem um módulo repetido, ele foi feito para ser pré-moldagem. Mas a firma que ganhou a licitação para construção apresentou um orçamento que barrou todas as outras. Então, não foi construído em pré-moldagem. No projeto do Restaurante, eu já desisti da pré-moldagem, pois como obra isolada... O ICC tem o módulo de 3 metros, esse módulo é repetido ad infinitum. Então, aqui, o conceito de pré-moldagem se encaixava direitinho. Você tem o mínimo de peças e essas pecas serão repetidas, mas no caso da Biblioteca, não. No caso do Restaurante, não estávamos mais falando em pré-moldagem, tanto o Restaurante quanto a Reitoria. A experiência com a obra dos alojamentos mostrou que a coisa não funcionava nas licitações. Mas tinha outro detalhe... mas isto nunca vinha muito claramente! O BNH, que foi fundado nesta época, estava a todo vapor. $\mathrm{O}$ BNH não queria a pré-moldagem, era programático, porque a construção civil tradicional era absorvedora de mão de obra, se colocássemos a pré-moldagem aqui no Brasil, se criaria um problema social. A pré-moldagem era malvista pelas instituições federais, era coisa de esquerdista, de comunista. Esse pensamento do $\mathrm{BNH}$, naquela época, não era totalmente errado, existia este problema, você tem que enfrentar esse tipo de coisa. Claro que a posição deles foi uma posição exarcebada, não só não fazia pré-moldado como faziam aquelas coisas horrorosas. Isso é o outro extremo. No Ceplan, o que se pensava era a racionalização, a modulação, o tipo de vão, tanto a Reitoria como o Restaurante. Naquela época o problema da ideologia era fortíssimo. Tínhamos que conviver com essas pressões.

Vera - O ICC continuou sendo, nestes anos, o grande espaço para ensino e pesquisa, destacando-se também como centro de vivência, de efervescência cultural da UnB, o grande ponto de encontro. Como será a apropriação do ICC, visto que alguns institutos já estão sendo transferidos para novos prédios isolados e novos prédios estão sendo projetados para os demais institutos? A grande altura do pé-direito projetado para abrigar grandes laboratórios no projeto inicial, que uso terá para o futuro? 
Galbinski - Bem, a futura e a presente. O ICC é uma grande concepção, um grande projeto. Enfim, o coração da UnB, até hoje. Isso, quando eu estava fazendo o Restaurante, foi fundamental, porque com o Restaurante situado aqui, frontal ao ICC, o que pensei? Estou diante da obra máxima da UnB. Tem o desnível de cinco metros, mas não posso colocar uma obra fechada aqui na frente, porque irei obstruir a visão do ICC, isso não pode. A cozinha, depósitos e a administração ocupam área muito grande. Eu tinha morado por três ou quatro meses, quando cheguei a Brasília, no Brasília Palace Hotel onde esses serviços estão semienterrados. Achava aquilo horrível, não tem boa ventilação... enfim, uma péssima solução. O hotel é belíssimo. Mas a parte de serviços, enterrada não vou fazer, no térreo também não, porque iria obstruir mais ainda. Onde farei? Acima! Então, o partido do Restaurante se deve ao conceito de preservar a visão do ICC! A relação com o ICC é que determinou o partido do Restaurante e de uma série de outras coisas.

O ICC já está ali tem mais de 50 anos, é um prédio simbólico, que nós temos que preservar, eu pensei em preservar sempre o caráter simbólico do ICCC, que é agregador, é o centro. Mas ele tem também lá seus problemas. Certa vez, o Adilson Costa Macedo, o Macedinho, fez um trabalho muito interessante. Foi uma enquete com todos os usuários do prédio, os professores e pesquisadores, em todos os setores do ICC, e uma estatística. O ICC tem um jardim central, e de vez em quando tem uma parte rebaixada, onde tem jardins e laboratórios na faixa central, no miolo. Pois esses laboratórios foram considerados pelos entrevistados o melhor lugar do ICC. Esse trecho é uma coisa muito interessante na história do projeto do ICC. Porque esse miolo não foi projetado pelo Oscar. Por que isso foi construído assim? Porque a Construtora Rabelo, para construir o projeto do Oscar, teve que escavar toda a largura do ICC em todo o comprimento, e teria de construir dois muros de arrimo e depois reaterrar o miolo. A Rabelo considerou um contrassenso financeiro e sugeriu não fazer o reaterro, sugeriu a solução que lá está. Então, essa parte não foi projetada pelo Oscar! O ICC tem problemas acústicos, até nos banheiros, isso é grave para uma escola. Penso que o ICC tem que ser preservado como o coração da UnB. Mas, gradativamente, na medida em que forem construindo outros institutos, que estão sendo construídos fora, vamos reajustando o ICC para outras funções, modernizando e eliminando problemas, como naquele subsolo onde, recentemente, teve aquela inundação. Tem que adaptar, como os prédios hoje em dia, no mundo inteiro. Por exemplo: o SESC Pompeia, aquilo era uma fábrica, mas hoje tem outra função. Como o ICC é muito grande, gradativamente podem ser introduzidas novas funções. Falam que querem alterar o Restaurante, até fui chamado pela decana de Assuntos Comunitários, pelo decano do Ensino de Graduação, o DCE, a administração do Restaurante, no início dos 2010. Eles disseram que queriam fazer do Restaurante um centro cultural. Eu disse que centro cultural, tranquilamente, eu posso fazer. Não tem problema transformá-lo num centro cultural. Aliás, o tema de mudar a função de prédios é um tema recorrente, hoje. Agora, por que fazer? Desfiei uma série de argumentos, dentre os quais descentralizar. Quando o Bandejão foi feito não tinha nada em torno, tanto no lado Sul quanto no lado Norte, hoje está cheio de prédios. Por que não criar outras opções? Restaurantes menores em outros pontos, diversificar, ao invés de ficar tudo no Bandejão. Essa ideia foi adotada. Foi decidido manter o Restaurante e criar outras opções. Uma dessas opções poderia ser no próprio ICC, mas não aqueles buracos mal feitos. Pega, por exemplo, onde está a pós-graduação da Arquitetura, voltada para a Praça Maior, tem uma iluminação, amplia a área para um belo jardim, ali no subsolo. Se você expandir aquele jardim dez metros não altera absolutamente, porque a Praça Maior é enorme. Ali você instala um excelente restaurante com ar-condicionado, com um espaço ao ar livre e com acesso por rampas, com jardins acima e abaixo. Quero dizer que o ICC pode ser usado muito tempo. Mas dentro de um conceito, adaptado, mantendo aquele prédio. Aquele prédio é fantástico.

Vera - A determinação de localização de novas edificações dentro do campus seguiu durante as primeiras décadas o planejamento urbanístico determinado pelo Ceplan? Atualmente, como vem ocorrendo essa ocupação de áreas dentro do campus? 
Galbinski - Sim. Não tenho visitado hoje aqueles prédios que estão sendo construídos. Mas dá para notar que alguns prédios são bem longitudinais.

Vera - Na época em que você viveu o planejamento do campus, tinha uma intenção de vetores de expansão, não?

Galbinski - Sim, eram vetores de expansão, hoje acho que falta diretriz. Hoje, no campus, falta uma estrutura básica. Continua o ICC estruturando, a Praça Maior inconclusa, continua com aquele caráter, mas não se tem uma leitura clara da estrutura do campus, não tem. Eu me surpreendo sempre quando vou lá, de certo desequilíbrio do lado Sul em relação ao lado Norte. Não me refiro aos projetos, mas ao planejamento. Tiveram certa interação, aqui tinha a Medicina, então bota a BIOLOGIA; ali, coloca outros prédios que é da família, expandindo.

Aqueles projetos iniciais que fizemos naquele período eram projetos que a gente tinha medo. Medo de que não atingissem o nível das edificações que já estavam lá. Isso era obsessivo, ameaçador... O que estava lá nós considerávamos o nível a ser atingido. Não quero dizer que o nível caiu, longe disso, mas o padrão de buscar a excelência não existe em muitos prédios. Hoje, por exemplo, se você vai ao campus da UFRJ, no Fundão, aquele campus tem uma estrutura até hoje, aqueles prédios que foram construídos têm presença. O prédio da Arquitetura é belíssimo na sua simplicidade, na sua implantação, na sua proporção. Estamos entrando numa universidade, tem um investimento cultural, não é um prédio funcional. Para prédio funcional eu vou na W3, e tem outros que são tão funcionais que cobram aluguel bem caro. Mas, não é isso, é algo mais. É aquela mensagem de conteúdo, de cultura, que uma universidade tem que apresentar.

Marco - Soube que implodiram o prédio da Medicina, aquele que estava inacabado, com a estrutura ameaçada.

Galbinski - Não sabia! Eu acompanhei essa construção. Eu era estudante do $5^{\circ}$ ano de Arquitetura, ganhei um prêmio de duas semanas de estágio no escritório do Fundão, do arquiteto Jorge Moreira, durante a construção do campus. Ele me impressionou. O prédio da Arquitetura era o único construído no campus, ainda estava vazio. Ele nos mostrou toda a sua obra construída. Grande arquiteto, figura extraordinária. Ele tinha até aspectos anedóticos da vida dele. Quando terminou a nossa visita, ele nos levou para visitar uma residência, o galpão de obras que ainda não tinha sido demolido, ele mostrou os projetos que estavam lá, tudo desenhado na escala de 1: 20. Ele falou sobre a vida de arquiteto, eu fiquei tão emocionado com as palavras dele que jamais esqueci. E o primeiro projeto que fiz de uma residência, desenhei todo o projeto em 1: 20.

\section{Vera - Nós convivemos com o Jorge Moreira no IAB.}

Galbinski - Ele era um cara respeitável como arquiteto, já no IAB ele fazia lá das suas...

Vera - Sobre algum documento significativo para história do Ceplan? Você já disse que fará a doação desses desenhos para o Ceplan?

Marco - Inclusive estão no site do Ceplan os desenhos do Oscar Kneip, os desenhos do ICC, ele também desenhava em $1: 20$.

Galbinski - Sim, farei a doação desses desenhos para o Ceplan. Deixa-me mostrar o trabalho do CPD, na UnB, que não foi construído, está todo fotografado e está aqui no meu laptop, pode virar um CD, e a cópia, se houver interesse, posso fornecer. Veja esses detalhes da simetria, muitos estudos com relação à simetria, todos são desenhos a lápis. Tem estudos para a expansão do prédio através de um tubo bem dimensionado. . 


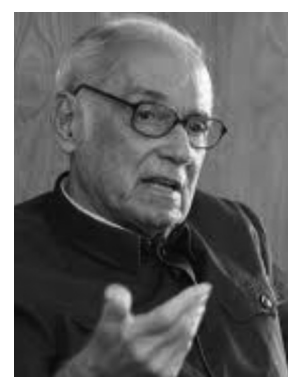

\section{ENTREVISTA COM JOÃO FILGUEIRAS LIMA - LELÉ}

Realizada em Brasília, em 29/02/2012

Neusa - Lelé, eu queria que você contasse sobre aquele período em que você esteve no Ceplan. ${ }^{1}$

Lelé - Eu fiz até um exercício de memória, depois que eu soube que você gostaria de ter estas informações, porque você sabe, aos 80 anos a gente começa a esquecer tudo. Eu imagino que seria importante saber, desde aquele tempo, a história da criação do Ceplan. Vou tentar lembrar. Porque naquele período, depois você edita da forma que você achar melhor, vou tentar, da minha maneira, falar sobre o início. Na verdade, em 1961, quando começou o governo do Jânio, teve toda uma perspectiva terrível de que o Jânio, por ter falado muito mal de Brasília, iria fechar o DUA (Departamento de Arquitetura e Urbanismo), não haveria mais escritório. O Oscar tinha me convidado, naquela época, para assumir o DUA, porque o Nauro Esteves estaria indo para o Rio de Janeiro. Então, ficamos naquela expectativa de criar um novo DUA. Nisso surgiu o Darcy Ribeiro com aquela esfuziante necessidade de criar uma porção de coisas. Eu sei que ele tanto pressionou o Oscar, que em vez de remontar o DUA, conforme estava se pretendendo, ele montou o Ceplan. Foi uma coisa toda assim acidental o que aconteceu. Então, o Darcy falou para o Oscar: "O escritório que você está querendo montar no DUA da Prefeitura, você monta na universidade e faz lá todos os projetos de Brasília". O Oscar também estava empenhado nos projetos que ele estava fazendo para o exterior. Eu sei que nós sentamos na véspera do Oscar viajar e ele delineou aquele projetinho: o espaço do Ceplan como deveria ser. Viajou e disse: "Seja o que Deus quiser". Eu sei que neste ínterim o Darcy pressionou e Oscar já tinha estudado aquela questão, porque ele sempre me convidara para trabalhar na área de pré-moldados e nós não tínhamos tido ainda a oportunidade de desenvolver. Então, o Oscar disse: "Vamos fazer em pré-moldado". Aquelas primeiras peças do Ceplan foram desenhadas. Ele viajou e o Darcy, na mesma hora, disse: “Nós temos que fazer não é só o Ceplan, nós temos que fazer o prédio para a Música, o ICA e mais um auditório". E aí surgiu aquele conjunto. $\mathrm{O}$ Darcy começou a me pressionar para fazer outros projetos para os Serviços Gerais e a Colina para habitação dos professores. O Oscar voltou e organizou tudo. Aí se delineou a função do Ceplan. Pois quando o Oscar viajou, praticamente só tinha designado para o Ceplan: eu, como secretário executivo, o Glauco Campello, o Abel Carnaúba, o Ítalo, o Virgílio Ernesto Souza, arquiteto panamenho que já estava atuando conosco no DUA. E o Jaime Zettel, ligado ao dr. Lúcio Costa, que faria a parte de urbanismo. Então, houve um deslocamento do DUA, do Bloco 1 do Ministério da Educação. Mas nós só fomos para a universidade quando o Oscar voltou. Foi assim que começou o Ceplan. Mas nesse período já havia o Instituto de Artes, até o curso de Arquitetura já estava se iniciando com o Alcides da Rocha Miranda, o Luiz Humberto, o Mendonça; enfim, eram arquitetos do grupo do Alcides que já tinham iniciado aqueles prédios do FE 1. Então, convencionou-se que o curso de formação, o curso básico, continuava sendo ministrado pela equipe do Alcides, e nos montaríamos, então, o curso de formação de arquitetura já no Ceplan. Usando o Ceplan como um espaço de convívio também, para a formação profissional e para a pós- graduação. Foram integrados na pós-graduação o Pessina, o Fernando Burmeister, a Márcia, a Mayumi Watanabe, o Sergio Souza Lima. Então, esses arquitetos foram integrados ao Ceplan e passamos a atender a todos os 
projetos. O Graeff também já estava no instituto base com as disciplinas de Teoria da Arquitetura. O nosso curso no Ceplan foi dividido em três partes. A Teoria, em que o Ítalo ficava responsável, eu responsável pela Técnica da Construção e o Glauco Campelo e o Virgilio com o ateliê de Composição de Arquitetura. E aí juntaram-se ao nosso grupo o Oscarzinho, o Abel e outros.

\section{Neusa - O Glauco veio do Rio?}

Lelé - Não, ele já estava no DUA; ele foi um dos primeiros arquitetos do DUA, de uma leva de arquitetos vindos de Pernambuco. O DUA tinha muitos arquitetos. Esses que o Oscar escolheu eram arquitetos que estavam mais afinados com ele. O grupo foi aumentando com o Evandro e outros, são arquitetos já falecidos. Mas aconteceu o seguinte: nesse período, quando o Ceplan entrou efetivamente em ação, o Darcy já estava no Ministério da Educação e depois na Casa Civil, o reitor era frei Matheus Rocha. Ele sempre foi muito simpático, ia sempre ao Ceplan, até fizemos um projeto para a casa dele.

Neusa - Nós conseguimos umas imagens lindas dessa casa, esse projeto é seu, não?

Lelé - Sim, mas era engraçado. Todo mundo colaborava um pouco no projeto, inclusive frei Matheus. Era um cara excelente. Passamos a conviver muito com frei Matheus. Ele foi uma espécie de mentor da universidade; além de ser reitor, era uma pessoa com aquela vocação de formador de opinião. Mas eu estou falando demais.

Neusa - Havia algum desentendimento, entre o grupo do Oscar e o grupo do dr. Alcides?

Lelé - Não, de minha parte não. Havia uma coisa meio complicada. Porque um grupo que tinha sido já muito bem formado - o dr. Alcides (muito meu amigo, gostava muito dele, uma figura ótima), o Luiz Humberto e o Elvin -, já estava desenvolvendo aqueles dois projetos da Reitoria, e, lógico, foi depois criado outro grupo, ali do lado, para fazer as mesmas coisas! Eu pessoalmente nunca tive desentendimento. Pelo contrário, até depois, na época do projeto que frei Matheus quis fazer, a Teologia, o Luiz Humberto já estava começando o projeto, eu fui falar com o Luiz: "vamos trabalhar juntos", mas ele foi extremamente gentil, "não, o Oscar faz". Não havia ressentimentos. Agora, claro que a gente brincava muito, eu até fiz uma música para o Athos, brincando com essa situação. Porque o Athos em vez de trabalhar conosco, pois ele era do DUA, ele foi trabalhar no Instituto com o Alcides.

Neusa - Como era a música? Dá para colocar a letra da música no livro?

Lelé - Dá sim.

Professor Monsenhor chegou,

Professor Monsenhor chegou,

Ele agora é o dono do Lombrigão.

Mas deixa só, deixa só, o Oscar chegar

Para mostrar que ele não é de lá.

O prédio do ICA, o Darcy batizou de Lombrigão e o ICC era o Minhocão. A gente cantava a música na brincadeira e o Alcides também frequentava esse clima. Mas isso era um pouco provocado pela intriga que sempre existe num bando de professores vindo de toda parte, mas eu particularmente, não.

Neusa - Eu estou perguntando isso porque nós que continuamos em Brasília e vivendo isto na escola. Acho que perdemos muito depois daquele ato de 1965, e fico com vontade de escrever um livro: Brasília, uma questão de escola. Tem o livro do professor Matheus, Brasília, uma Ques- 
tão de Escala. Seria, então, Brasília, uma questão de escola: da construção ao desmanche. Porque acontece que, na hora que tem essa perda (da demissão), começa a se enfatizar umas brigas, 0 Oscar contra o Lúcio etc.

Lelé - Você não imagina o que eram as nossas reuniões. Acho que foi um pouco de falta de amadurecimento aquela demissão coletiva, mas era nossa, porque aquilo estava eminente. Podíamos ter resistido mais, mas nesse ambiente começam a surgir intrigas: é demitido um professor de um departamento, depois de outro... A gente fazia aquelas reuniões, o Oscar estava fora, eu e o Ítalo o representávamos. O Oscar soube e deixou um documento de demissão pronto, caso fosse preciso. Então, naquele contexto era impossível segurar. Uma reunião daquelas, principalmente com os professores da ala de Ciências, com as intrigas entremeando, foi um período muito difícil e complicado, eu sofri o diabo. Pois nós sentíamos que tínhamos uma responsabilidade enorme permitindo que duzentos e tantos professores se demitissem. Mas eu acho que havia duas posturas, uma de resistir e continuar brigando, mas também certos professores, principalmente na área de Ciências, eles não admitiam certa postura mais indisciplinar, como a greve. Então, por exemplo, o Salmeron (uma figura ótima, extremamente disciplinado), o Jayme Tiomno, também muito disciplinado. Era difícil chegar a um consenso, e uma solução daquelas só podia ser feita através de consenso.

Neusa - Você falou do início do Ceplan e da ligação com o DUA. O Ceplan tinha uma função inclusive para a cidade, não?

Lelé - Sim, inclusive aquela quadra do Itamaraty foi feita pelos arquitetos que estavam fazendo mestrado, foi feito em convênio com o Itamaraty. Mas o Darcy tinha ideias mirabolantes, infelizmente esse convênio só se realizou depois, mas havia uma infinidade de projetos que fizemos para a cidade. E o que o Darcy pensava? Ele promoveu uma viagem minha e do Sabino, incorporada a um grupo científico que foi ao Leste Europeu para pesquisar sistemas de pré-fabricação. A intenção era desenvolver aquele veio da pré-fabricação que nós tínhamos iniciado na UnB. Eu fui e passei três meses no Leste Europeu.

Neusa - Certa vez entrevistei o Graeff, ele tinha uns projetos todos modulados e eu perguntei por que não foram feitos como pré-fabricados, ele respondeu "porque não se tinha tecnologia". Exatamente! Daí é que iria se desenvolver essa tecnologia!

Lelé - Claro, e o Darcy era muito esperto. Porque o Brasil tinha fornecido à Polônia uma venda enorme de café, ele descobriu isso e queria readquirir em matéria-prima e equipamentos do Leste Europeu como um todo. Fomos principalmente à Checoslováquia, onde tinha um sistema de préfabricação com guindastes, e tudo já bem desenvolvido. A intenção era montar aqui, chegamos a projetar a nossa fábrica. Qual era a ideia? Era um espaço de convívio que seria dirigido pelo Ceplan e pela Faculdade de Engenharia, um espaço coletivo, até para desfazer essas diferenças entre engenheiro e arquiteto.

\section{Neusa - Você não tem esse projeto?}

Lelé - Eu cheguei a fazer uma perspectiva, mas esse projeto sumiu. Na verdade, havia uma pressão da Rabelo, que estava montando os pré-fabricados, para participar do projeto. O Oscar fez a proposta inicial do projeto e depois eu fiz a adaptação e desenvolvimento do projeto. A construtora Rabelo iria construir a obra, e isso aconteceu exatamente na época da demissão.

\section{Neusa - Como eram escolhidos os arquitetos para determinados projetos?}

Lelé - Nesse período o Oscar ficou muito ausente, por causa dos projetos no exterior. Ele dizia “Vamos arrumar um projeto para o Virgílio...". Tinha um pedido para fazer um projeto de uma hotelaria de professores, mas não foi construída. Glauco também fez um projeto, eu também fiz uma porção 
de projetos que não foram construídos. Só foram construídos os SGs e a Colina, logo na primeira leva, mas depois os outros projetos que nós fizemos não foram construídos.

O ICC foi um projeto muito trabalhoso que nós desenvolvemos no Ceplan. Tinha o prof. Ramiro (pai do lon, um saxofonista), ele foi incumbido de ajustar comigo os programas de todos os institutos. Foi uma trabalheira! Eu ia para o Rio, o Ramiro estava no Rio, até que conseguimos organizar o programa, em contato com todos os cientistas. Foi até engraçado como surgiu o projeto do ICC. Tinha o plano de urbanismo da UnB, do dr. Lúcio. No plano do Lúcio tinha aquelas bolinhas que até faziam uma curva, o Oscar disse: "Vamos fazer logo um prédio só, pegando todos esses institutos".. E O ICC surgiu assim.

Neusa - O Darcy fala uma frase muito engraçada: "O Oscar fez o ICC de preguiçoso", pois seriam não sei quantas edificações, e o Oscar resumiu em um único prédio.

Lelé - É, foi exatamente isso. Também porque nos conseguimos, através daquela unificação, reduzir muito o programa, porque cada cientista pedia um feudo, se fôssemos reproduzir cada feudo o ICC teria dez vezes o tamanho que tem. Cada um teria um auditório de 200 a 300 lugares. Essa integração tão procurada no próprio projeto, para haver aquele convívio entre todas as áreas. Agora, com essa fragmentação do conhecimento, tantas novas profissões diferentes vão surgindo, e tudo é feito fragmentado, ninguém conversa mais um com o outro. Horrível.

Neusa - Fizemos uma entrevista com o Frank Svensson e ele fala muito do Heron de Alencar, já pesquisamos eu e Vera e não achamos nada escrito por ele ou sobre ele. Qual a contribuição dele?

Lelé - Eu e Oscar fomos muito amigos do Heron de Alencar. Numa das vezes que eu tive que ir a Paris discutir com o Oscar, por ocasião do projeto de anexo e reforma do Congresso, foi o período que o Heron estava com câncer e o Oscar ia diariamente visitá-lo, eu também fui visitá-lo. Vou te dizer qual o papel do Heron. Ele era um professor extremamente conceituado dentro da UnB, muito ligado a um grupo pernambucano, do Arraes, que tinha um influência política muito grande naquele período. Então, o Heron, muito amigo do Darcy, ele participava muito dos programas da UnB. Eu me reuni várias vezes com o Heron, ele estava muito a par de todo o esquema da universidade. Ele era amigo de Anísio também. Era uma espécie de eminência parda, ele não tinha uma função muito precisa, que eu me lembre, pode ser até que tenha tido junto com Darcy, mas não me lembro. Ele atuava muito na universidade.

Neusa - Segundo o Frank, o Heron teria encaminhado essa necessidade de construção de espaço físico, então ele teria a ver com o Ceplan indiretamente.

Lelé - Não, isso ele não tinha. Mas tinha pelo fato de ser amigo do Oscar, muito amigo nosso. Havia essa discussão com ele, mas era uma discussão informal. Não era uma coisa formalizada. No caso, por exemplo, preciso, quando decidimos fazer aqueles prédios chamados de Serviços Gerais, é porque era um espaço mais simples de ser executado para a universidade começar a ser implantada. O Oscar fez também o projeto da Praça Maior com a Aula Magna e a Biblioteca e depois ele complementou com o prédio do ICC. Esse conjunto era o que nos almejávamos que fosse prioritário, com esses prédios. Agora, é claro que o Heron participava muito e depois participou muito junto com o Oscar, já na época do exílio, porque ele foi para a Argélia e Oscar fez aqueles projetos na Argélia. Ele se tornou uma pessoa extremamente ligada ao Oscar. Acho que por isso o Frank levanta essa questão.

Neusa - O dr. Alcides também teve um papel muito importante na criação da universidade, ele acompanhava o Darcy nessa tramitação inicial. 
Lelé - Muito. Ele teve um papel muito importante, ele foi uma espécie de auxiliar do Darcy, na reflexão justamente sobre a formação do curso de arquitetura. Ele antecedeu o Oscar neste trabalho, junto com o Darcy.

Neusa - Ele até fala que se pensava (acho que foi o Frank que lembrou) numa universidade como a Universidade de Massachusetts, assim científico, e no lado da arte o dr. Alcides teria contribuído muito com isso.

Lelé - Sim, ele era uma pessoa extremamente culta, eu gostava muito dele, sei que havia uma amizade muito grande dele por mim. (...) O que mais me emocionou foi quando fui fazer uma exposição no IAB/RJ, fiz uma palestra e vejo-o presente, bem velhinho, sentado na primeira cadeira.

O Alcides também foi muito ligado ao dr. Lúcio. Aquela forma de expressão do dr. Lúcio, de desenho, fazem parte de uma época.

\section{Neusa - O dr. Lúcio e o Oscar continuaram amigos?}

Lelé - Amigos sim! Mas, algumas pessoas estimulam os fuxicos. Naquela época, havia sim, pois o Ceplan tinha que produzir os prédios para a universidade. Certa vez tive uma briga com o prof. Cordeiro, geneticista, foi terrível. Estava se implantando o laboratório de genética que ele dirigia naquele prédio do SG, e no prédio não cabiam certos recursos técnicos, pois era uma implantação provisória, pois logo iria para o ICC. Ele começou a criar tantas dificuldades de um laboratório supercomplexo. Eu dizia "não dá para montar neste prédio, não é possível". Certo dia, tomei um susto. Chega o reitor prof. Anísio com o professor Cordeiro: "Vamos sentar aqui, desfazer essa briga". Eu expliquei para o prof. Anísio: "Não estou brigando, estou apenas dizendo que este tipo de laboratório é impossível de implantar, teria que quebrar o prédio, fazer outro prédio para isto, vai sair muito caro. E estamos fazendo tudo isso no ICC". Aí dr. Anísio, com aquele jeito dele, foi cortando as arestas.

Neusa - O Zimbres conta na entrevista que foi ao Rio de Janeiro perguntar ao dr. Oscar se ele não queria retomar os projetos da Praça Maior, e o Oscar teria dito que era uma ferida que não estava estancada e que eles fizessem os projetos que estaria bem feito.

Lelé - Sim, eles foram muito éticos, todos, mesmo na primeira leva, antes do Zimbres, pois ele ficou, mas o Paulo Mendes da Rocha, estas coisas todas foram realmente colocadas. Até lembro que Paulo falou que eu tinha que voltar para a UnB. Respondi: "Impossível! Como vou voltar para o Ceplan? Houve a demissão junto com duzentas pessoas". Pareceu até uma decisão equivocada, mas não havia amadurecimento maior.

Neusa - Parece que o Partidão teve uma atuação decisiva...

Lelé - Não sei, mas foi o seguinte: a decisão dos cientistas era não à greve, foi uma reunião de umas cinco horas. (...) Eu não era do Partidão, mas representava o Oscar. Na época da UnB havia umas cisões enormes, tinha a Polop, a linha chinesa, a AP, a linha católica. Aquelas reuniões que fazíamos na UnB eram uma briga de todos os lados. (...) Não sei por que surge sempre essa disparidade. Aquela música que eu fiz era também brincando um pouco com isso, mas entre nós arquitetos havia um respeito pelas áreas. O Oscar sempre dizia: "Não! isto aqui é com o Lúcio, isto não é conosco". Para evitar disciplinarmente aquela confusão, porque daqui a pouco tinha gente da equipe fazendo projeto de urbanismo. E o dr. Lúcio ficava no Rio e depois o Oscar veio para Brasília. Então, quando o Oscar sugeria essa separação não é porque ele estivesse brigando com o dr. Lúcio; era, pelo contrário, para evitar, para garantir que não houvesse um fuxico. O pessoal, às vezes, fazia o contrário. 
Neusa - Vamos falar sobre o projeto do Laboratório do prof. Laboriau. A construção do laboratório foi posterior a essa fase, ele foi feito com peças das suas escolas pré-fabricadas, e o almoxarifado da UnB também, não?

Lelé - Não sei, eu não participei, não sei nada. Nessa época estava muito afastado com o trabalho da Fábrica de Escolas no Rio de Janeiro, depois fui para Salvador. Era difícil por causa da Novacap, que criava todas as dificuldades. O Kristian assumiu a fábrica da Novacap, ele deve saber.

\section{Neusa - E sobre o Beijódromo, conta essa história.}

Lelé - Foi uma coisa esquisita. O Darcy, pouco antes de morrer, ele já estava bem doente. Ele estava no Sarah fazendo quimioterapia e me surpreendeu, de lá entrou naquele sistema de comunicação do Sarah, pela TV. O Aloysio falou: "o Darcy esta querendo falar com você". Ele deu o programa para o prédio pelo canal de televisão: "Vou te dar aqui o programa, quero fazer o prédio com você". O Darcy gostava muito de participar dos projetos, mas ele não tinha mais condições de saúde, na última reunião nossa, ele disse "faz o que você quiser". Fiz o projeto, ele gostou muito, a única coisa que ele reclamou foi "mas eu quero um beijódromo". Ele não tinha posto no programa inicial o beijódromo. Eu perguntei "mas como é esse beijódromo?". Ele explicou que seria uma arquibancada que tivesse uns seresteiros para cantar e os casais poderiam ficar se beijando nas arquibancadas. Mas quando esse projeto foi construído, eu tive que adaptar à situação nova, inclusive a biblioteca, que era toda integrada ao espaço. Naquela época não havia essa questão de segurança, de roubo de livros, então acho que isso descaracterizou um pouco o prédio. Depois, por uma questão de ruído, aquele espaço central teve que ser fechado com vidro, acho que perdeu muito.

Neusa - Interessante. Também acho que a gente chega ali e pensa naquele espaço todo aberto.

Lelé - Também não estavam no programa aquelas salas de aula, o projeto sofreu modificações; inclusive, agora estão fazendo uma lanchonete enorme, na entrada, à minha revelia. O projeto sempre vai se descaracterizando, mas acho que temos que aceitar que há 15 anos era diferente.

Neusa - Você tem os riscos desses projetos? Acho muito importante publicar isso, pois marca uma volta sua para a universidade.

Lelé - Do inicial tenho, da época do Darcy, tenho até umas cartas que fiz para o Darcy. Eu acho que o prédio é importante, porque tem uma simbologia, ligada ao Darcy, que ele participou, que gostaria muito de fazer. Agora, sempre fica aquela vontade de ter sido feito 15 anos atrás... em que ele pudesse ver.

Neusa - Eu assisti à aula inaugural naquele anfiteatro, proferida pelo Darcy. Chorei feito criança, ele tinha uma força muito grande em tudo o que ele dizia, ele acreditava!

Lelé - Ele acreditava em tudo que ele dizia, era uma paixão! Uma coisa apaixonada. E na Fábrica de Escolas no Rio, você nem imagina! Darcy era uma figura. Maluco!

Neusa - Mas eu acho que a gente tem que ser um pouco maluco, não pode ser sempre muito certo.

Lelé - Ah é! Mas que mais eu posso falar, quer que eu lembre mais alguma coisa?

\section{Neusa - Você lembra alguns casos engraçados?}

Lelé - Sim! Causos engraçados! Acho que era justamente esse convívio com o grupo do Alcides, com o Elvin, que sempre foi um cara meio enrustido, e depois havia também o grupo mais, como é que se diz, mais maluco mesmo, que era o Alex Chacon, o José Paulo de Bem, mais três arquitetos e mais o filho do Alcides. Eles organizaram um espaço para fazer as maluquices deles. Existiam histó- 
rias engraçadíssimas. Numa ocasião foi montada no prédio do ICA uma exposição africana. O Alex ficou incumbido de fazer, no final todo mundo começou a interferir na exposição e o Alex ficou danado, porque mudaram o esquema da exposição. Essa exposição iria ser inaugurada pelo presidente Jango. Sabe o que o Alex fez? Chegou lá no quadro de luz, tirou todos os fusíveis e deixou tudo escuro. Foi uma confusão incrível. Foi uma correria, ninguém sabia o que estava acontecendo, a luz não acendia! Conseguiram acender a luz depois e foram ver o que tinha no quadro de luz. Ele, o Alex tinha roubado os fusíveis. São coisas que aconteciam na universidade.

Neusa - E você sabe como apareceu o Klaus Bergner? Eu gostava muito dele, apreendi muito com ele. Com quem ele vem? Porque quem trouxe o Alfredo Ceschiatti e muitos outros foi o dr. Alcides. Mas e o Klaus?

Lélé - Sei que o Ceschiatti já estava há bastante tempo aqui em Brasília, porque ele ficava fazendo aqueles trabalhos com o Oscar.

Kristian - A Neusa descobriu um depoimento seu que falava do Ceschiatti, bem no começo de Brasília, quando ele acordou depois de um porre e chegou a Brasília...

Neusa - É um depoimento seu a uma revista, em que você fala do hotel do Santos Dumont, a planta era do 14 Bis. Essa entrevista é ótima, muito boa.

Lelé - O que aconteceu nesse dia foi o seguinte: houve a inauguração da cumeeira dos prédios da superquadra do IAPB (Instituto de Aposentadoria e Pensão dos Bancários). Houve um churrasco e o Juscelino trouxe todos os amigos, aí vinha Dilermando Reis e todo aquele pessoal, Ceschiatti veio junto. Mas o Ceschiatti estava de porre quando foi apanhado no Hotel Plaza, e ele nem sabia para onde estava indo, puseram ele no avião. Ele chegou a Brasília dormindo e dormindo o jogaram na casa da Fazenda Gama, onde tinha a estação de rádio. De manhã, quando ele foi tomar o café da manhã no nosso acampamento, ele contou que quando acordou sozinho naquela casa, no meio do nada, olhou e pensou: jogaram uma bomba atômica! Não sabia o que estava acontecendo.

Neusa - Aconteceram muitas coisas engraçadas. Mas então foi o dr. Alcides que trouxe o Ceschiatti, a Amelinha...

Lelé - Sim. Muita coisa não foi só o Alcides, foi o próprio Darcy. O Scliar estava no ICA também.

Neusa - Olha! O Scliar também! Vão faltar nomes na minha lista...

Lelé - Mas ele não chegou a ficar muito tempo. Esse pessoal, essa leva do Rio Grande do Sul, vieram todos juntos. O Grassmann, o Bianchetti, o Fernando Burmeister, o Kneip, a turma que o Graeff trouxe. O Graeff veio meio a convite do Darcy e do Alcides. Foi essa turma que antecedeu...

Kristian, e o velho Schiel, teu pai? Quantos bons momentos, o velho Schiel era exigente, eu lembro que eu tocava flauta, ele colocava a partitura, eu tinha que acompanhar ele no violão e eu lia mal à beça...

Kristian - Boas lembranças...

Lelé - Eu cheguei a escrever um livro que nunca foi editado, sobre essas experiências todas, e tem um retrato do Schiel, que você me forneceu. Você sabe, eu sempre dizia que quando ele foi para Salvador, ele tinha quase 70 anos, não? Pois,ele sentava na prancheta e desenhava.

Neusa - Você continua a praticar música?

Lelé - Muito pouco, não tenho tempo. Depois, com o instituto que resolvemos fazer... 


\section{Neusa - Como está o instituto?}

Lelé - Está acabando, não tem espaço. Nós pensamos no instituto como uma organização sem fins lucrativos credenciada pelo Ministério da Justiça, para poder fazer convênios com instituições. $O$ projeto que a gente tinha mais vontade de fazer, logo no princípio quando Dilma entrou na Presidência e me convocou para discutir habitação. Eu fiz o projeto, ela ficou encantada: "Vamos fazer, vamos para a Caixa Econômica". Foi uma luta, o instituto gastou um dinheirão no desenvolvimento desse projeto, e não saiu. Não pode ser pela Caixa Econômica. Sempre tinha que ser através de uma empreiteira e não pelo instituto. Confusão desse tipo! É impossível, como a Presidência e o Ministério das Cidades não conseguiram viabilizar isso? Tínhamos um convênio com o governo do Estado, mas acontece que a centralização hoje é terrível, os recursos dos programas são liberados para os estados ou para as prefeituras, mas por conta da Caixa. É o órgão que repassa mediante um projeto que tem que ser de acordo com o que a Caixa quer. O projeto foi feito para o governo do estado e ele não consegue furar o bloqueio da Caixa. Esse presidente da Caixa, o Jorge Hereda, é arquiteto, ele sofreu pressão direta da Dilma. Ele chegou a falar comigo "eu não posso mudar as regras". Aí desistimos. O que adianta você criar um instituto que tem determinada finalidade? Nós já tínhamos convenio com a UFBA, com a Escola da Cidade em São Paulo, para servir de laboratório dos cursos de formação e pós-graduação, mas não se conseguiu fazer os convênios. A única obra que se conseguiu fazer foi a do Darcy, aqui, mas mal e mal, a duras penas, pois não tínhamos a fábrica, então vieram para cá os operários do instituto para fazer o prédio do memorial.

Neusa - Este país! Lelé, então muito obrigada por este encontro e por esta entrevista. 


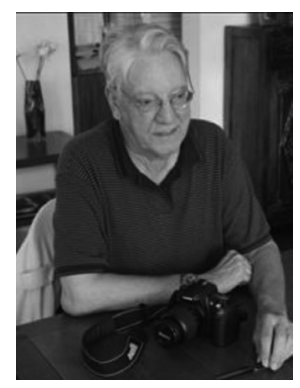

ENTREVISTA COM O PROF. LUIZ HUMBERTO PEREIRA

Realizada em 26/01/2012, em Brasília/DF

Vera - Você viveu a fase inicial da UnB e do Ceplan, conte para nós a sua experiência. ${ }^{1}$

Luiz Humberto - Não havia Ceplan, o Ceplan é uma invenção posterior. O Darcy Ribeiro queria que o Oscar Niemeyer fizesse o projeto. Ora, o Oscar não acreditava em universidade, ele falou qualquer coisa assim: “Universidade no cerrado...." Eu lembro que, certa vez, ele tinha um escritório ali num daqueles prédios dos ministérios, era uma sobreloja. Então, nós fomos lá, e o dr. Alcides era aquela pessoa que você conheceu que juntava as peças, que animava as pessoas. Ele foi tentar convencer o Oscar a fazer o projeto da primeira construção da universidade. E o Oscar não se interessou. Então, o Darcy disse: "Alcides, faz você!". Então, ele fez o projeto do que é hoje a Faculdade de Educação, que foi a Reitoria em tempos passados, o Auditório Dois Candangos, aquele conjunto de prédios.

Eu trabalhava na Divisão de Obras do MEC, lugar que não tinha nada para se fazer, mas como sabia que o Alcides estava no andar de baixo, eu descia para conversar com o Alcides. O Alcides deve ter me achado um jovem interessante, então me convidou para trabalhar com ele.

Marco - Imaginava que você já conhecia o Alcides desde o Rio de Janeiro?

Luiz Humberto - Não, o conheci aqui, só o conhecia de nome, na nossa geração era um nome conhecido. Em Brasília descobri que ele era uma pessoa fantástica, e ainda tinha a vantagem de que ele morava num prédio atrás do meu, aqui na SQS 107. Então, ia com ele para a universidade. No início nós projetávamos dentro do prédio do MEC. Lá não tinha nada mesmo para fazer nos núcleos, se chamavam Núcleo do Patrimônio, Núcleo de Divisão de Obras. Isso em 1961. Era engraçado, pois no oitavo andar do MEC tinha uma sala da Universidade de Brasília, e o pessoal comentava: "Picaretagem!". Ninguém acreditava, ninguém sabia quem era Darcy Ribeiro, somente os iniciados em Antropologia.

O dr. Alcides da Rocha Miranda foi fundamental para a Universidade de Brasília, ninguém fala nisso, eu fico impressionado como não se sabe da atuação de Alcides. Como a família Rocha Miranda era na época uma família importante, o Alcides ajudava muito o Darcy na conversa com os deputados para a promulgação da lei de criação da universidade, ocorrida em dezembro de 1961.

Então, nós começamos o projeto. O Alcides chamou outros arquitetos do ministério, mas ninguém se interessou. Agora, trabalhar com o Alcides era outro curso de Arquitetura. Era o cara que te dava praticamente uma aula na conversa.

Vera - Então, o dr. Alcides doou esse primeiro projeto para a UnB.

Luiz Humberto - Claro, o Alcides, como eu, tínhamos uma incompetência para ganhar dinheiro, horrorosa, tanto ele como eu, juntou uma equipe selecionada... Ele começou a trabalhar e Darcy o convidou para coordenar o curso-tronco de Arquitetura e Urbanismo, do qual você fez parte. A ideia era que aquele curso-tronco fosse, vamos dizer, uma espécie de rótula de onde saíssem várias

1 Title : 120126_001Date/Time Recorded : 26/01/2012 15:38:54Record time : 0:57:36 
atividades relacionadas com a área de artes; o Instituto de Artes seria formado a posteriori. Então, o que aconteceu? Quando chegou mais ou menos em 1963, o Darcy precisava de nomes para conseguir aporte financeiro da Fundação Rockfeller, da Fundação Ford e outras. Ele não teve conversa, chamou o Oscar para assumir a Faculdade de Arquitetura, daí entra aquela coisa partidária e vêm com ele o Graeff e outros. Foi de surpresa, pois o dr. Alcides tinha ido a Goiás Velho fazer uma vistoria pelo Patrimônio. Lá ele ficou mal da saúde. Inclusive, ele já tinha convidado o Elvin para a universidade, ele tinha sido sócio dele no Rio.

Mas vamos voltar ao projeto do prédio. Foi complicado porque não tínhamos quem desenhasse, então quando a construção se iniciou nós só tínhamos o projeto base, o projeto de instalação e a planta de concreto, do Waldemar, um engenheiro da Novacap.

\section{Vera - Mas o prédio foi muito bem construído, não?}

Luiz Humberto - Mais ou menos, você não conhece os incidentes anteriores. Aquela aba do FE 1 que sai para fora, ela tem uma viga de inércia variável, aquela viga em balanço, que sustenta a laje e a cobertura em calha Tekno, de aço dobrado. Então, não sei se o mestre estava bêbado, foi o que disseram, ele colocou a ferragem que devia ser em cima, colocou fora de posição, e quando desformou a coisa ficou cheia de beiço, porque trabalhou de maneira diferente. Aí foi uma loucura! Tivemos que demolir e contratar o engenheiro dr. Kanyó para pôr em ordem esse atropelo, e todo o resto da obra. Pois a gente desenhava, tenho ainda lapiseira 6B, porque eu desenhava os detalhes, durante a obra em construção. O FE 1 e o Auditório Dois Candangos foram feitos primeiro, depois que feito o outro prédio. A construção desses prédios foi cheia de aventuras. Muitos anos atrás, o Xavier, arquiteto gaúcho historiador, disse para mim: "Eu não estou encontrando nada desses projetos". "Não vai encontrar mesmo, porque não existe!", eu disse para ele. (...) Isso, enfim, foi o de menos dentro de uma loucura total.

\section{Vera - Em consequência dos prazos de construção, tinha muita pressão?}

Luiz Humberto - Sim, muita. Ah! Teve outra: o Ranieri Mazzilli, presidente da República na época (ele estava sempre sendo presidente nas ausências do Jango), veio visitar a obra e alguém disse assim: "Vamos desformar aqueles pilares". Quando tirou a forma, o concreto se desmanchou! O pedreiro idiota tinha posto um acelerador de pega, achando que se você aumentasse a dosagem teria um efeito mais rápido, só que era exatamente ao contrário. Ele alterava toda a química do concreto e acabava com a possibilidade de pega. Tivemos que fazer tudo de novo! Como aquilo era uma estrutura leve nós mantivemos as formas, e as formas ficaram funcionando por inércia como pilar e os ferrinhos ficaram lá dentro. Ora, era uma quantidade de problemas. (...)

\section{Vera - Então, o prédio levou quantos meses para ser construído?}

Luiz Humberto - Acho que, entre projeto e construção, de 4 a 5 meses; foi de dezembro de 1961 até abril de 1962. E ainda teve outra: aquela aba, o Alcides queria aquele pilar largo na quina, o calculista se enganou e calculou a coisa em balanço, aí aquele pilar não teria sentido. Então, se fez o pilar e colocou um rolete em cima, por isso que o pilar está lá glorioso e belo. Ele está apoiado numa viga em balanço, ele é que está em balanço, tem uma viga embaixo, ela está coberta, está na cinta de fundação. Então, foi assim, uma coisa atrás da outra de problemas. O velho Alcides era um cara que se aborrecia, mas ele conseguia superar os aborrecimentos, eu aprendi muito com ele.

Vera - E depois o prof. Alcides vai para a Escola de Arquitetura? 
Luiz Humberto - Não, nós ainda continuamos projetando, fizemos o Auditório Dois Candangos e uma ala ao longo com as salas de aula, como deveriam ser. E Darcy interviria muito, disse que precisavam ser umas salas maiores para caber mais alunos, pois ele não tinha onde colocar, só que a sala maior acabou indo para um quadrado, que não é a solução ideal para uma sala de aula. E fizemos aquela varanda com aquelas pérgulas com jardim interno. Nós pagamos muito alto o tributo por termos feito as primeiras construções da UnB. Falam que foi a OCA; ora, a OCA chegou lá e montou. A primeira obra definitiva foi a nossa! Aí veio o azulejo. O Alcides ficou pensando no azulejo. Athos não estava aqui, aí eu desenhei o azulejo. Originalmente ele era amarelo e branco, mas ficava muito apagado, o Alcides disse assim: "tenta em azul". Aquele azulejo é meu, e todo mundo pensa que é do Athos. Eu fico honrado e o Athos também fica, agora não, ele está no reino dos céus. No Auditório Dois Candangos, o Alex Chacon se juntou ao grupo e fez o desenho das cadeiras, mas o Darcy achou que ia ficar caro e comprou as cadeiras da OCA, muito mais caras, que balançavam e rangiam, lembra? Aquelas que estão lá não são do Alex, são do Sergio Rodrigues. Para resolver o forro, o Alcides colocou uns tecidos no teto. Hoje, já foi substituído. Estive lá outro dia, o que me incomoda muito, porque volta tudo na memória. A parede continua a mesma, porque era muito quente. Então foi assim, uma sucessão de loucuras, com falta de dinheiro. Apareceu aquela escultura do Brecheret, nós pusemos lá, mas eles puseram um poste junto. A sensibilidade do burocrata é algo de estarrecer, comove até as lágrimas!

Marco - Então, primeiro foi o FE 1, depois o Auditório com a ala de salas de aula e depois a Reitoria velha?

Luiz Humberto - Essas duas foram construídas praticamente ao mesmo tempo.

Marco - E o Ciem, não é do dr. Alcides?

Luiz Humberto - Não, é do Sabino Barroso, era projeto da Fundação Educacional. (...) Depois vem essa história de que o Darcy precisava do nome do Oscar, ele aproveitou o momento que o Alcides não estava aí, porque o Darcy gostava muito do Alcides. Ele fez uma reunião, quem estava na direção do curso-tronco era o Elvin, então veio o Henrique, um loirinho, mineiro, da administração, chegou à janela daquele prédio que hoje é da Música, disse: "Olha, amanhã tem uma reunião sobre a dupla coordenação do curso de Arquitetura". Dissemos: "Que dupla coordenação é essa?". Nos reunimos, e o Darcy, sempre gentil, disse: "Olha, a partir de agora, vai se fazer a Faculdade de Arquitetura (não sei se era este o nome dado na época). O Oscar vai se responsabilizar por esta área, vai ficar na mão dele". Aí, todos nós acoelhados diante da decisão. Eu acho que aí já existia o Ceplan, que era o órgão destinado a projetar a universidade, já tinha a Colina e o SG 9 - antiga Biblioteca. O Oscar fala mais ou menos assim, (50 anos depois não tenho a menor condição de jurar o que ele disse; memória, quando falha, a gente inventa os heroísmos), ele diz: "Eu só quero o Graeff aqui". Eu ainda falei: "mas, professor Darcy (porque a Universidade tinha aquela história: você, para ser professor, tinha que ter o exercício na tua profissão, para ter o que ensinar, senão você ficava falando dos livros dos outros, não?), como é que ficam os arquitetos que não estariam, então, na escola?". Esta, eu me lembro bem, ele falou: "Eu não reconheço a existência de arquitetos fora da Escola de Arquitetura". Aí eu me senti órfão! Como se ele tivesse dito: "Te vira!".

Então o Alcides quis se demitir. Andava com a carta de demissão dentro do bolso, e eu segurava ele. Pois até aí, ele era o responsável pelo curso-tronco, a ideia era o curso-tronco se desdobrar depois em outras coisas. O curso-tronco passaria a ser o Instituto de Artes, e o Instituto de Artes iria gerar outras coisas: Teatro, Cinema, Arquitetura. Era a flor que abria para essas coisas todas. $\mathrm{O}$ curso-tronco na verdade era uma espécie de primeira triagem, os primeiro anos da Universidade de Brasília. 
Vera - Conforme o Pessina falou, os arquitetos jovens vieram para fazer o mestrado e depois seguir a carreira de professor, entre estes o Pessina, o Fernando, o José Leal.

Luiz Humberto - O José Leal não. Ele como eu já estávamos como professores assistentes. O Leiva, sim. Eu adorava o Graeff, era o único teórico de arquitetura que eu lia. Uma vez foi publicado no Jornal do Brasil, em 1959, um inquérito nacional sobre arquitetura, com o depoimento de vários arquitetos. $O$ texto dele era o mais lindo, o mais lúcido. Mas não concordo com o que fizeram com o Alcides. O problema era a fidelidade partidária. Uma tolice trabalhar na questão de juntar argumentos que justifiquem a decisão tomada.

O Elvin era um cara muito persuasivo e foi uma figura fundamental na formação da UnB, ele convenceu o Alcides a antecipar a criação do ICA. Não era para aquele ano, então foi em 1963. Montamos o ICA, e foi uma experiência magnífica. Os do Partidão contestavam: a Bauhaus foi numa outra época. Mas argumentávamos que ninguém estava falando em Bauhaus, era diferente, era somente inspirador. A ligação das artes com a arquitetura, com a construção. A gente montava as turmas nas trincheiras do ICC.

O Alcides ganhou entusiasmo de novo. O Instituto de Artes era uma coisa aberta, ele dizia "para você criar um curso de Artes, você não pode criar nos moldes da escola de Belas-Artes, onde você forma artista; artista não se forma!". Então, ele trouxe Bianchetti, Leo Dexane, Hugo Mund, Ceschiatti, Athos Bulcão, Amélia Toledo, Marília Rodrigues. Com essas pessoas, nós formamos um grupo. A causa era tão importante, tão boa que você conseguia suportar os insuportáveis - por exemplo, a Amélia Toledo, mas ao mesmo tempo era uma artista extraordinária! Uma capacidade de criar extraordinária! Ela fez o primeiro mestrado, não foi um mestrado formal, o tema eram os paramentos litúrgicos da capela do frei Mateus, projetada pelo Lelé. Aquela capelinha ali atrás do que é hoje a Secretaria de Educação, que deveria ser o mosteiro dominicano. Para o primeiro projeto, eu e o Oscar Kneipp fomos convidados pelo frei Mateus, mas demoramos muito e ele passou para o Oscar Niemeyer. Mas como aguentar eu e o Kneipp na época? Conhece a história do Kneipp estudando francês? Ele disse para a Geneviève, que era uma mulher bonita de cabelos grisalhos, e ele, todo meio que entusiasmado quando ela perguntou "Vous êtes marié?", o Oscar, com aquele sotaque gaúcho dele, respondeu: "Non, parce que je suis un celibataire..." Então, frei Matheus nos chamou para fazer o projeto, mas eu estava na obra do FE, dava aula, meio complicado.

Voltando à obra, peguei um mestre de obras, tive sorte. Tem aquela pérgula, no prédio da antiga Reitoria, que são dois pavimentos, porque nós não tínhamos levantamento topográfico, foi tudo na raça. Na obra, vimos que o desnível era enorme e deu um segundo andar.

Vera - E ficou bonito, bem integrado ao terreno, quem vê pensa que foi muito bem estudado.

Luiz Humberto - Nada! Para evitar aquele pé-direito duplo no pátio central da Reitoria, nós fizemos umas vigas Gerber ali. O cara fez mal feito, quando chegou de manhã a viga estava lá no pátio, tombada, caiu com forma e tudo. O mestre de obras, seu Zé, para não aborrecer, era uma figura ótima, mandou fundir rapidamente outra viga. Quando eu cheguei, todas as outras vigas desformadas e aquela toda engessadinha: "O que é isso, seu Zé?"; “Eu não queria que o sr. se chateasse, mas aconteceu o seguinte, ela caiu!".

Teve coisas assim. Foi tudo feito com o coração, a certeza que você está fazendo alguma coisa que vale a pena, esta que é a verdade da Universidade de Brasília, uma coisa que valia a pena! Assim foi: instala-se o Instituto de Artes, o Elvin se dedica ao desenho dos móveis da UnB. O Elvin desenhava uma cadeira, então tinha os vários biotipos - o Klaus, que era gordo, o Leo, que era pequeno e gordinho, eu, que era grande -, a gente ia sentando para ele fazer os ajustes das cadeiras, e ele 
ficava medindo. Fez o barracão da maquete. O melhor lugar da universidade eram os barracões. Lá trabalhava também o Zanine, que foi atropelado na primeira leva de cassados.

O Zanine estava fazendo o mestrado casado com o meu doutorado. Nós éramos obrigados a fazer, mas eu cuidava da obra, de dar aula, então os prazos foram aumentados. O tema era o seguinte: eu cheguei aqui em 1961 e me assustou um pouco a política paisagística. No eixo central, o Eixão, era política de terra arrasada, passavam o trator, arrancavam tudo e mandavam vir umas espatódeas campanulatas africanas que não resistiam com esse ciclo de muita luz em Brasília, elas morreram todas, poucas sobreviveram. Eu pensei o seguinte: eu tenho que mostrar que o cerrado é uma coisa que vale a pena do ponto de vista formal e do ponto de vista econômico também. Porque é uma vegetação que já está ambientada, o cerrado é $2 / 3$ da vegetação brasileira. Então, como fazer isso? Tem que provar... Comecei a fotografar e achar as espécies. Melhorei o equipamento, a minha fotografia, chamei uns caras da Botânica, para classificar, uns mestrandos, junto um panamenho.

\section{Vera - Então a dedicação à fotografia começa aí?}

Luiz Humberto - Não, começa quando o meu filho que vai fazer 50 anos nasceu. Isso está no livro. Fui descobrindo que a Fotografia era muito mais interessante, me divorciei da Arquitetura, ainda levei uns 12 anos. Mas quando eu fiz contrato profissional com a Veja, ficou um negócio muito esquisito eu entrar no Ministério de Educação para fotografar o ministro, sendo arquiteto do Ministério! Eu mesmo não tava entendo direito, imagina os caras!

Eu entrei na Fotografia numa época em que o preconceito contra o fotógrafo era muito grande, por força do fotógrafo ser uma figura emergente de uma categoria de classe média baixa, semianalfabeto. Tenho dois exemplos muito engraçados que cito sempre. O deputado Leão Sampaio, constituinte de 1934, cearense, quando minha primeira mulher, Eloá, trabalhava na Câmara, ele foi procurá-la e disse assim "Eloá, vocês estão passando necessidades?". "Não, por quê?". "Porque eu vi o Luiz fotografando no plenário". Você vai introjetando certo sentimento de inferioridade. Eu carregava no bolso uma Leica, pequenininha, quando era uma matéria que não precisava trabalhar mais lentamente, eu trabalhava com essa máquina. Pronto, estava vestido como repórter.

Como o ICA era uma coisa muito aberta e eu já estava na Fotografia, eu cheguei e pedi para ao Alcides, para abrir um centro experimental de fotografia. Experimental porque eu ainda não sabia nada. O Alcides submeteu ao colegiado, foi aprovado, e nós ocupamos aquele espaço no SG, e trabalhamos com o Eliseu, o Teobaldo e o Barra, posteriormente. O ICA então era efervescente, não pretendia formar artistas, as matérias eram para serem como integração, complementação. Tinha um escultor do nível do Ceschiatti, um artista plástico do nível do Athos que dava aulas de Desenho, de Plástica, a Amélia Toledo, a Marília que dava Gravura. $O$ aluno, então tinha muitas opções e oportunidades que não tinham a ver com uma formação formal, onde você iria ganhar um diploma e sair um doutor pintor, essa não era a ideia. Poderia se desdobrar numa escola de Cinema, de Arquitetura etc. O Pompeu de Souza, posteriormente, pegou o nosso pessoal de cinema para formar o departamento dele na Comunicação, o Paulo Emilio Sales Gomes, o Nelson Pereira dos Santos, o Jean-Claude Bernardet, que eram do ICA. Foi assim.

Depois veio o golpe de 1964 com a demissão de 15 ou 14 pessoas, nós aguentamos. O Zanine Caldas entra na primeira lista, ele estava fazendo o mestrado, ele não tinha graduação, na UnB tinha várias pessoas que não tinham graduação - como nas universidades de fora, você aproveita quem é um talento comprovado. O Zanine provou isso, encheu a Barra da Tijuca de belas casas. Então, o seu trabalho de mestrado era um trabalho concreto de valorização do cerrado, a proposta era limpar, tirar o que não interessava e deixava as espécies mais interessantes (ele era meio multimídia, fazia tudo, pois era um cara muito inteligente). $\mathrm{O}$ dr. Alcides o conhecia desde o tempo em que ele fazia maquetes no Rio. Algumas pessoas tentavam desmerecê-lo chamando o de maqueteiro. 
Lembro de um caso engraçado. O Zanine estava trabalhando conosco nos desenhos de plantas do cerrado e tinha que motivar, pois ficar desenhando árvore do cerrado depois de uma semana cansa. Um dia nós estávamos desenhando, ele chegou na Kombi dele, era uma Kombi velhíssima, antes de inventarem a Kombi ele já tinha aquela. Ele chegou, abriu a porta e saltou com um carneiro, um carneiro vivo, era para desenhar o carneiro! Ele era fantástico, ele se dava muito bem comigo. No Rio de Janeiro ele fez um projeto, mas não tinha quem assinasse, era um projeto para o Banco da Guanabara, o BEG, e ninguém queria assinar, sabe quem assinou por ele? O dr. Lúcio Costa.

\section{Vera - Então, veio a demissão coletiva?}

Luiz Humberto - Nós sobrevivemos um ano ainda, foi o que deu fôlego ao ICA, ainda conseguimos fazer muita coisa. Na primeira fornada, o Eustáquio Toledo, marido da Amélia. Ele foi atropelado porque o Zeferino Vaz não gostava dele, já tinham tido uma encrenca em São Carlos. A Amélia foi embora, antes me passou um bolsista: "Tenho um bolsista aqui, você fica com ele". Era bolsista da Amélia, o Bodanski.

Em 1964, tem um episódio que contam que o Zeferino Vaz, numa recepção no Palácio do Planalto, é cercado pelo Castelo Branco, que vira para ele e diz assim: "Professor, na Universidade de Brasília a questão lá não acabou ainda não". O Zeferino, na verdade não era um bandido, apesar de ser da turma do Ademar, ele fundou a Escola de Medicina de Ribeirão Preto, fez a Unicamp, era um cara que conversava. Naquela reunião no Auditório Dois Candangos, éramos todos nós, uns duzentos e pouco, e o Zeferino começa a descascar a Universidade de Brasília, fala sobre a ignorância dos professores, e aí o Pompeu de Souza, o Eduardo Galvão, o Hélio Pontes, e não quem sei quem mais, foram lá na frente e devolveram as ofensas. Passa um tempo, corre o boato na Rádio Candango de que vão demitir mais gente, o professor Eudoro de Souza vai à Reitoria e diz "Reitor, corre no campus a notícia de que o senhor vai demitir mais professores". "Não quero nem saber". "Não faça isso, o senhor vai acabar com a universidade".

Os que tinham desafiado o Zeferino iam ser cassados e os que os que estavam cedidos iam ser devolvidos para os órgãos de origem, a universidade ia ficar vazia. Então, começam as reuniões, as discussões. Um grupo foi ao Palácio do Planalto falar da importância da UnB, ao que o Castelo teria dito "Ora, para mim isso não é novidade, esse formato nos já tínhamos na Academia Militar de Agulhas Negras". E aí foi o que deu. Correu no nível dos departamentos uma lista para avaliar como seria considerada a demissão coletiva, como último recurso para mobilizar a opinião pública e repercutir no exterior. Quando a lista chegou ao ICA, eu estava como secretário executivo e chefe do Departamento de Artes Visuais. Eu assinei junto com o dr. Alcides, pois o Elvin estava no exterior por conta do mestrado. (...) Um dia, estou numa exposição comemorativa da UnB, numa vitrine estava a carta assinada por mim, foi emocionante, eu me vi 30 anos depois. Quando estava na Fundação Cultural fui procurado pelo IDA para voltar a dar aulas, na época do lbañez fui decano de Extensão (...).

Vera - Nós estamos confiando na sua boa memória para indagar sobre um nome. O Pessina nos cedeu parte do acervo dele, lindas fotos do campus, algumas fotos ele não tem certeza da autoria, citou o nome de Pinheiros, você conheceu? Vamos resgatar a história dele?

Luiz Humberto - Sim, João Pinheiro, ele era fotógrafo não sei de quem exatamente, ele fotografou muita coisa no período em que esteve na UnB, era uma pessoa de bom relacionamento. Depois ele estava na Presidência da República, no tempo do Médici, o irmão dele era da assessoria de imprensa, lembro que eu estava fotografando para a Veja e ficávamos numa arquibancada, para ficar longe do presidente. Chegou o Pinheiro e disse: "O Presidente, no último Natal dele, vai cumprimentar os jornalistas e fotógrafos". Eu pensei: eu não vou cumprimentar esse canalha, como vou fazer? 
Então, fui fotografando o presidente dando a mão para os jornalistas e fotógrafos e fazendo a volta, documentando. O Pinheiro chegou para mim e disse "O que você tem contra o presidente?". "Ô, Pinheiro, eu não tenho nada a favor". "Você foi o único jornalista que ele não cumprimentou”. "Ora, nem reparei, eu vim aqui para trabalhar".

Vera - Muito bom! Então, você não documentou, não acompanhou esse crescimento da UnB?

Luiz Humberto - Não, o que eu fiz muito foram as exposições com o Alex Chacon, e eu fotografei tudo. O IDA sumiu com esse material, tinha tudo lá, em preto e branco, eu fotografei todas as exposições. Teve uma época em que o Pinheiro não estava mais e não tinha quem fizesse isso. Houve isto, as pessoas não se importavam com isso. O diretor do CPDOC, o José Carlos, professor da Faculdade de Educação, ele que implantou, sistematizou isso. Tanto que, uma vez, eles iam fazer um calendário e tinha uma foto do começo da UnB, acho que era do Pinheiro, o pessoal jogando futebol no campo que tinha lá atrás do Ciem, tinha o Domir. Eu identifiquei todo mundo, pois os nomes estavam todos errados. É impressionante, eu tenho o maior rigor nessas coisas, tenho muita pena. Brasília mesmo tem uma documentação muito fragmentada. Na época tinha o Fontenelle, que não era nem fotógrafo, ganhou a câmera do presidente. Tem fotos do Thomaz Farkas, do Peter Scheier, do Marcel Gautherot, mas tudo muito pouco. O cara vinha aqui, fotografava e ia embora, não tinha uma coisa cotidiana de uma cidade. O Marcel era fotografo do Oscar, ele era uma bela pessoa. Talvez se vocês precisarem deve ter alguma coisa no Instituto Moreira Sales no Rio de Janeiro. Mas o Marcel tem um problema, não tem gente nas fotos dele.

Vera - Então, muito obrigada por esta entrevista e pelo belo livro de fotografias com que você está nos presenteando.

Luiz Humberto - Espera aí que vai sair um cafezinho. 


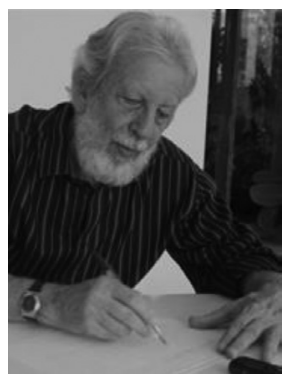

ENTREVISTA COM O ARQUITETO MORAES DE CASTRO

Realizada em Brasília, em 26/01/12

Vera - Você que viveu o Ceplan como estudante e depois como arquiteto contratado, como vê o Ceplan hoje ligado à Reitoria?'

Moraes - Não estou a par disso, não. O que eu sei, não estou muito lembrado, você até me corrige, pois não tenho boa memória, tenho uma vaga lembrança. Lembro o seguinte: cheguei a Brasília em março de 1960, só fui tomar contato com a UnB em 1963, como aluno especial, fiz o vestibular em 1964. (...) Então estava muito ligado ao ICA, mas já tinha o ICC e os SGs em obras, e ficava entusiasmado com o pré-moldado. Sabia que era projeto do Oscar e do Lelé, mas nunca os via por lá. Lembro que em 1965 fui com o Castelo e outros alunos visitar a obra do ICC, vimos aquelas vigas e pilares no chão. A gente atravessava um matagal de 4 metros de altura, para nós era uma distância enorme do ICA até lá. Não sei exatamente quando fiquei sabendo o que era o Ceplan. Talvez lá pelo $3^{\circ}$ ou $4^{\circ}$ ano da escola, pois metia a cara no curso. Quando veio a crise a gente começou a entender mais, pois veio o Fórum ICA-FAU. Em 1969, o Ceplan estava precisando de arquiteto para coordenar os desenhistas. Como eu havia me destacado na liderança da minha equipe de diplomação, os professores me convidaram para um contrato precário de oito meses. Em dezembro de 1970 foi feito o concurso para três vagas de arquiteto do Ceplan. Participaram 16 pessoas, incluindo a gente, lembro do Holanda, Paulo Brasil, Ruth Py e Dalva concorrendo conosco. E entramos nós três: você, eu e o Josué Macedo. Aquelas vagas foram criadas a fórceps, na marra. A direção do Ceplan pressionou o Azevedo para criar essas vagas com a justificativa da necessidade de ter alguém permanente no Ceplan, porque os professores com dedicação exclusiva davam aula pela manhã e não tinha ninguém para atender o ateliê de desenho nesse período.

\section{Vera - De que projetos você participou?}

Moraes - Participei do planejamento do campus em 1969 e 1970 e nas equipes formadas para vários estudos preliminares, com a equipe básica do Ceplan, onde trabalhou o Vasco de Mello, Zimbres, Miguel, Pedro Paulo e outros. Trabalhei com o Pedro Paulo Saraiva no Centro de Vivência. Eram quatro estudos preliminares: Aula Magna, Museu, Reitoria e Centro de Vivência. O projeto da Biblioteca deslanchou antes, era projeto do Galbinski, Miguel, Jodete e Walmir. O Leo Bonfim e o Sólon Leão e José Paulo de Bem faziam o projeto do Alojamento.

Marco - Nós trabalhamos como desenhistas contratados nesse projeto.

Moraes - Cheguei a desenhar os móveis para o Alojamento de Estudantes. O Farret, o Marcio e o Zimbres fazendo o Centro Olímpico. A obra da Biblioteca, quando começou, eu já estava coordenando o ateliê de desenho. O Zimbres me encomendou o projeto do Ateliê, fizemos aquelas baias, tinha vinte tantos arquitetos e uns cinco desenhistas. Depois veio a obra do Restaurante, inaugurou no final de 1971. Foi uma obra de um ano e tanto, essas datas são difíceis de precisar, mas tenho uns papéis que localizam isso bem. O Nelson Saraiva foi trabalhar no paisagismo do ICC, colaborei no projeto, tinha uns bares com estrutura pênsil que nunca construíram. Depois veio o projeto e a 
execução do paisagismo da Praça Maior, do Fernando Chacel, também colaborei não no projeto, mas na adaptação de alguns desenhos. Sólon tinha feito aquele projeto dos estacionamentos do ICC, com aquela caixinha de concreto (projeto do Niemeyer). Fiz o projeto de estacionamento em frente à antiga Reitoria. Na época acharam que estava superdimensionado. Então, fazendo projeto mesmo, eu participei o tempo todo dos projetos do Restaurante com o Galbinski, os móveis do Alojamento, no paisagismo do ICC com o Saraiva, no Planejamento do Campus, foram o I e II, nos detivemos em buscar as diretrizes e os caminhos. Depois me soltaram uns projetinhos: o Ambulatório do Funrural que não construíram; o projeto de instalação da Faculdade de Comunicação no ICC, com estúdio de TV etc.; a instalação da Arquitetura no ICC, com o Tomio e a Marta, e convênios com outras universidades. Enfim, fiquei quatro anos, fui demitido em abril de 1973.

\section{Vera - Você poderia falar sobre a pressão política da Reitoria sobre o Ceplan?}

Moraes - A pressão política que se fazia sobre o Ceplan era uma paranoia terrível. A Arquitetura sempre foi o foco, onde tinha o pessoal mais politizado. A UnB era um local de resistência. Não recebia a pressão direta, pois nas federais cortavam a verba, mas na UnB a estrutura era diferente. O objetivo do Ceplan era duplo, ter o campus como cliente, construir o campus e ao mesmo tempo poder utilizar todo o potencial que você tinha ali, a dedicação exclusiva e outros contratos. Então, tinha crise lá em que você não tinha uma folha de papel-manteiga, não tinha borracha, grafite. Os caras não davam. Para quê? Para sacanear. Davam o prazo, mas não davam material, não davam desenhistas. Para caracterizar o quê? Uma incapacidade de fazer: "O Ceplan não cumpriu o prazo". Ao que respondíamos: "Mas não temos condições". O Zimbres, como diretor nessa época, sofreu muito. A Administração justificava nos seus relatórios que o Ceplan era inoperante, perigando fechar. Daí contrataria grandes escritórios, fora da UnB, o dinheiro rolaria e o campus sairia com uma proposta ideológica diferente. Na época do Pedro Paulo, com o Restaurante no Centro de Vivência, fechou o tempo: "Aqui não fica!". Tinha crises lá em que se ficava entre a cruz e a cadeia: se eu não faço os caras vão fazer a pressão, se faz você mesmo tem arranjar os meios. Quantas vezes peguei o carro e ia à papelaria comprar umas duas dúzias de papel-manteiga e grafite! Então, ficava o burburinho entre os professores da FAU: "este cara é de direita, reacionário, puxa-saco, tá fazendo projeto para agradar os caras". "Vocês preferem ficar à toa? Eu não!", eu argumentava. Algumas vezes fiz isso e outras pessoas também fizeram. Quando fizemos aquela virada violenta lá, de entregar tudo, eu estava casado havia pouco tempo, o Josué também. Nós chegamos a levar aquelas camas de abrir, de campanha. Quantas noites dormi ali? Das 4 da manhã ate às 8 horas, lavava o rosto e continuava, para entregar no prazo. No detalhamento do Restaurante não tinha desenhista suficiente, mas já tinha desenhistas permanentes sim, mas os prazos eram apertados e tinha outros projetos sendo desenhados. Tivemos que contratar desenhistas de fora.

\section{Vera - Pois eu lembro que no projeto da Reitoria nos já tínhamos uma equipe de uns cinco ou seis.}

Moraes - Sim, depois tivemos o Osvaldo, o José Luiz, o Edson, Tinoco, e outro que não lembro o nome. Não sei situar onde fica a virada, só lembro que, pra entregar o projeto do Restaurante, de duas coisas tenho certeza:, que o processo veio do MEC com seis meses de prazo e o cel. Lister de Figueiredo, que eu chamava last but not leaster, puxou o prazo para cinco meses, era a sacanagem armada, para deixar a gente no sufoco. Como é que tratavam os escravos? No chicote, sem comida! Aí que nós demos também uma grande virada para entregar o projeto do Restaurante. O Zimbres falou para mim: "Eu vou compensar você pela virada". O Lister veio para a reunião e disse que iria pagar com horas extras. Iria dar o dobro do salário. A Vera, a secretária, anotou tudo (tinha outro secretário que se chamava Aguinobaldo, então eu chamava a Vera de Aguinobalda, tinha outra datilógrafa, que se chamava Inele). Passou uns dias e o processo voltou, indeferido. Não ganhei as tais das horas extras, mas o Zimbres tentou compensar nos recessos de Natal e Ano Novo. Então, a Vera 
veio me falar que o substituto do Zimbres não aceitou e quem se ferrou fui eu. Mas o Zimbres tinha um relacionamento muito bom dentro do Ceplan, organizou e coordenou bem a realização desses projetos e deixou todos os relatórios explicativos. Depois que você saiu, extinguiram a sua vaga e correu o boato que a minha vaga também seria extinta, porque a Reitoria queria matar o Ceplan. Então, o pessoal da FAU se movimentou para eu dar aula, e no período da tarde e em qualquer folga, continuar no Ceplan. Seria como colaborador IV, apresentei currículo. (Cheguei a fazer palestras apresentando os projetos completos do Ceplan, os alunos tinham uma vontade enorme de entender os desenhos, detalhes, porque eles não faziam isso no ateliê da FAU, eles tinham uma loucura para ver os detalhamentos). Na outra semana voltou o processo de contratação, indeferido, pela segunda vez. Parece que alguém ligado ao Pedro Paulo Saraiva teria dito que o argumento lá dentro da Reitoria era que eu era ex-aluno e ex-funcionário. Mas o Aleixo e o Silviano eram ex-alunos e foram contratados logo depois, então, ficou evidente que a marcação era contra o Ceplan.

Vera - Sobre a participação de alunos no Ceplan,você disse que os alunos vibravam ao ver o detalhamento de projetos. Explique por que não tinha a participação de alunos no Ceplan: era devido aos prazos apertados, ao grande volume de trabalho?

Moraes - Não dava tempo de ter estagiário para aprender a desenhar. Mas tivemos muitos alunos contratados para desenhar projetos.

Vera - Certo, nós mesmo tivemos que fazer teste para ser contratados. Como alunos, eu, Arnaldo, Marco e outros fomos contratados para desenhar o Alojamento de Estudantes, o Genari para desenhar o Laboratório de Fitologia, que eu lembro.

Moraes - Sim, teve mais gente lá, lembro que o Zimbres deu a ideia de pegar uma turma de fora de Brasília, pois era época de férias, contrataram seis rapazes de São Carlos. E fizemos mais de quarenta pranchas com viradas, e eu coordenando na marra, o Galbinski trazia os detalhes em papel-manteiga. Pagaram bem pela taxa de urgência.

Eu tenho um fato pitoresco sobre um professor chegou para mim e disse: “Esse aluno está na FAU há nove anos e não sabe pensar como arquiteto. Gostaria que esse rapaz ficasse algum tempo no Ceplan para você ensiná-lo a desenhar". Ele ficou seis meses, eu o mandando copiar desenhos, após esse tempo eu disse "Não dá, manda ele fazer vestibular de odontologia em Anápolis, ele não consegue ver, nem pensar arquitetura". Certo dia, eu estou lá no CREA, na Comissão de Ética, e aparece o caso para analisar, um anúncio no Correio, nos classificados: "Planta de projeto, preços módicos" com telefone e o nome do cara que foi mandado para o Ceplan, portanto recebeu o diploma. Infelizmente. Culpa do Ceplan? Da UnB?

A estrutura do Ceplan eu achava que podia ter continuado bem, mas ela sempre viveu em crises. Tinha também o pessoal novo que se formou em 62 e 63 que passou logo a ser professor, mas tinha que passar pelo Ceplan, como o Sólon, o Walmir, a Jodete. Tinha outro grupinho que não tinha coragem de entrar nos projetos para trabalhar com afinco, talvez inibidos. Ao contrário, você, eu e o Josué, logo vestimos a camisa. Assim como os recém-formados que vinham de fora, o Nelson Saraiva, o Fausto Nilo, o Hotz, a Marta Tanaka, o Marcio, com capacidade de fazer projetos. E muita coisa foi feita.

\section{Moraes - Você tem algum material, documentos, fotos sobre a história do Ceplan?}

Moraes - Tenho fotos, desenhos, a foto do Candilis no Ceplan, do Nuno Portas não tem. Tenho fotos do Galbinski e Zimbres explicando os projetos no Ceplan para o reitor. Lembro o dia em que o Oscar foi ao Ceplan, eu não fiz nenhuma foto, também não sei quem tenha, em 1973. O Fisberg pegou muitos desenhos que o Oscar fez na palestra, eram umas quinhentas pessoas. Lembro que 
ele pichou o Restaurante. Teve uma coisa engraçada, ele começou a contar sobre os projetos na Argélia e logo perguntaram por que o trabalho não foi concluído, ele falou: "Chegou um tal de um japonesinho, não lembro o nome dele, vocês conhecem". A plateia falou "O Kakasu? O Hanashiro?"; "Não, o Kengo, é esse tal de Kengo, vocês conhecem...." O Oscar ficava em Paris e a equipe dele ralando na Argélia, trabalhando, uma equipe de 16 pessoas. O Kenzo Tange baixou lá de avião particular com toda a tecnologia de ponta e abraçou todos os projetos. Quando o Kenzo Tange esteve em Brasília, em 1986, o Oscar falou para o Graeff "Mostra só o teatro, a catedral e o Congresso". O Graeff me convidou, como conselheiro do IAB, para acompanhá-los na visita a Brasília. O Kenzo premiou vinte arquitetos do escritório dele com uma viagem para conhecer Brasília. Entrevistei o Kenzo e publiquei na Módulo: "Fiquei impressionado com a vista aérea da cidade, se vê o desenho original do Lúcio, leitura muito clara, e sugiro que seja feito um Congresso Mundial de Arquitetos em Brasília". O governador Aparecido encampou a ideia do Kenzo na hora e disse "vamos fazer!". O maluco do Aparecido ignorou que a antecedência mínima é de seis anos!

Vera - Então, voltando ao Ceplan...

Moraes - Sim! Ceplando! Lembro da Prefeitura ao lado, era o braço executivo, fazia as licitações, lembro dos engenheiros, o Caulino, estava ali desde o início, fez os primeiros barracões. E os engenheiros militares, eram o Fernando, o Decio, o Machado, o Turbay, o Murilo era o prefeito do campus. A Prefeitura era o braço político da Reitoria, os executivos militares: "Onde tem dinheiro, não bota os artistas para tomar conta não", eles eram os tesoureiros, as licitações eram feitas ali.

\section{Vera - E sobre o compromisso do Ceplan com a inovação, a introdução dos pré-moldados?}

Moraes - O campus foi precursor dessa experimentação, dessa tecnologia. Enfim, toda a universidade começa com essa tecnologia. Os SGs com a proposta do Oscar (ICA e Ceplan), depois a Colina e os SGs, projeto do Lelé. Os únicos prédios feitos, naquela época, com a tecnologia tradicional foram o FE 1, a Reitoria, mas o próprio Auditório Dois Candangos já tem algumas placas pré-moldadas. Mais tarde, outra experiência foi a do Érico com as coberturas em paraboloide hiperbólica. Uma coisa que observei é que o sistema estrutural da Colina é muito semelhante ainda aos conceitos estruturais com madeira. É o pré-fabricado muito ligado ainda à madeira. O que me lembra dos prédios do Bica no campus, de estrutura de ferro superdimensionadas. Excetuando o Zanettini, que sabe o que está fazendo, a maioria não tem a linguagem da estrutura do aço. O Lelé faz depois com os prédios do Sarah, aí tem uma lógica. (...) Tenho o filme com a narração do Coutinho sobre a construção do Ceplan. Teve o projeto do Paulo Magalhães para a casa transitória. O princípio é o mesmo da parede e da telha laje em U. Tem o detalhe tecnológico do concreto que substitui o ferro pela taquara e o agregado com a fibra mascada, bagaço de cana, areia de rio, algum seixo, traço 12/1. Ainda como estudante trabalhei com o Paulo, acompanhei a construção, na beira de um rio. Quero ressuscitar esse projeto da casa transitória. Seu Oswaldo foi ser morador da casa. Ela é atual ate hoje. Escrevi um artigo incluindo a fantástica teoria comportamental dos moradores elaborada pelo Paulo. A casa, bastante linear, tem o cômodo maior, que é a sala cozinha, no quintal da frente tem a plantação, atrás tem os animais, pois tem uma lógica, o cara vem do meio rural, então ele pode ter um porco, um cabrito, umas galinhas, depois tem os quartos, com uma mesa contínua, onde pode ter a mesa para os filhos estudarem, a sala em volta do fogão. Atrás é o banheiro; nos anos 60, o cara tinha vergonha de ir ao banheiro, o Paulo coloca a casinha no fundo. Não se pode trazer as pessoas e jogar no meio urbano com todo o meio de viver burguês, pois somente na outra geração os caras vão chegar nisso. Transitória entre o rural e o urbano (...) Tenho certeza que deve ter no Brasil uns cinco mil projetos de habitação popular. Que mundo é este que consegue fazer um automóvel industrializado que serve para todos e não consegue fazer uma casa popular indus- 
trializada? Projetos de habitação popular com a experiência com pré-moldado? Nas universidades, nos escritórios, acho que se deveriam fomentar todas essas experiências e achar um meio político para realizar essas experiências. Porque, afinal, tudo que está construído em habitação popular foi feito pelo usuário, pega o número de habitações que tem no Brasil, todo mundo sabe fazer. Os programas são sempre massivos, a SHIS chegou a fazer a casa zero quartos, ou então um poste com luz e água. Até hoje o programa é o mesmo, as mesmas casinhas. Tem o projeto de um inglês para a favela nos morros (...)

\section{Vera - Quando você volta para a UnB?}

Moraes - Em 1993, o Pessina me sugeriu a reintegração, pois todos os que foram considerados vítimas da perseguição da ditadura teriam o seu direito. Fiz um documento, levei para a FAU e consideraram que a minha demissão foi uma pressão política, demos entrada no MEC e em 1993, 21 anos depois, fui reintegrado, pois havia a intenção de fechar o Ceplan. Fui realocado no Ceplan, encontrei um Ceplan todo dividido, e cada grupo queria me conquistar para o seu lado. Tinha pessoas boas, mas também um bando de neófitos e recém-formados, brigando por projeto. Estava no meio de uma crise. Entraria no meio de dois fogos, num lugar onde era para se fazer projeto. Havia dois grupos, um acusava o outro de estar trabalhando de forma contraditória ou de estar fazendo convênios, via Reitoria, de projetos remunerados com os alunos trabalhando e furando o mercado de trabalho lá fora, criando um meio de produção interno. Como eu já tinha tempo de serviço, no fim da primeira semana entrei com o meu pedido de aposentadoria.

\section{Vera - Como você vê hoje o planejamento do campus? Você, que trabalhou numa fase de gran- de definição?}

Moraes - Mudou muito. Acho brilhante a ideia básica da universidade. A ideia do Ceplan de ter um centro de planejamento e pesquisa. Toda a pesquisa, a investigação daqueles prédios foi feita lá dentro. Agora, nestes últimos dez anos tem uma quantidade enorme de prédios novos, de tipologias diferentes, não que eu pretendesse chegar lá e achar uma leitura da arquitetura da UnB. Mas você não percebe nada, por exemplo, você poderia ter um centro de investigação. Tem alguns projetos lá que tentam chegar atrás do Lelé, do Oscar, do Eladio Dieste. (...) Um dos caras que não procura repetir o Oscar é o Lelé, o Decio Tozzi e alguns outros. São arquitetos únicos. (...) Sobre o plano urbanístico do campus, é mais ou menos igual à questão de Brasília: eu chamo o casco histórico de Brasília, você consegue ainda ler o avião do Lucio Costa, você vê as diretrizes gerais, a cidade resistiu, o que tem de barbaridades é uma loucura. A UnB é aquele tramo ali de cima, com o Faculdade de Educação, os SGS, o Ceplan, o Restaurante, puxa aquela diretriz que vai lá para o Faculdade de Tecnologia e a Colina, vai para o ICC, desce até lá embaixo, a Biblioteca. Nesses espaços ainda tem uma identidade, mas hoje, não sei, não posso falar porque não estudei se houve planejamento ou não. Só sei que olho para os lados e vejo prédios com todos os tipos de orientação, com dois, três ou um pavimento, com ideias arquiteturistas, algumas estruturas interessantes, outras não (cheguei até a fazer estudo de acessibilidade para alguns desses prédios). Sabe, sou cicerone de arquiteto há uns cinquenta anos, todos os arquitetos estrangeiros que chegam aqui tenho que mostrar Brasília. Um dos prédios que mais surpreendem as pessoas em Brasília, seja arquiteto da Finlândia, do Japão, da México, dos Estados Unidos, é a Reitoria, principalmente quando tinha o espelho d'água. Porque a diferença de clima é de 6 a 8 graus, é evidente, o prédio é lindo. Tem uma leitura fácil da arquitetura, você sabe onde as coisas funcionam, está na cara onde você deve circular. Tem muito a ver com o trabalho de diplomação que nós fizemos, eu, Castelo e outros, aquela malha candiliana, com os pés-direitos duplos, que podia se expandir, ampliar, é muito agradável. 


\section{Vera - E a grande rua de integração do ICC?}

Moraes - A alameda central do ICC? Outro dia cheguei a fazer a conta de quanto custaria colocar todas aquelas vigas pré-moldadas para completar o desenho do ICC. Talvez acabar com os laboratórios e voltar a abrir aquilo e colocar os bares que o Nelson Saraiva projetou. Aquele footing é sensacional, aquele jardim. A rua de serviço, no subsolo, tinha que ter vida mesmo, talvez passar um ônibus, um elétrico circulando por ali para o transporte dos alunos. O que o Zimbres fazia naquele tempo, sentar e discutir o planejamento do campus, vai se encaminhar para cá ou pra lá, e como. Não é só fisicamente não, mas com intenção de crescimento. Essa unidade que se falava, acho que não existe mais no campus. Devia ter crescido um centro de pesquisa bom, estudos sobre habitação popular, pavimentação de blocos, reaproveitamento de material da construção. Tem o Jaime Almeida investigando o bambu, a sua resistência. Mas sobre a reciclagem poderia ter mais experimentos sobre a aplicação de materiais na construção.

\section{Vera - Você, que trabalhou com o Galbinski no projeto do Restaurante, poderia falar um pouco sobre a execução do projeto?}

Moraes - O Restaurante do Galbinski, com aquela caixa em cima, não foi aleatório, foi proposital, se botasse embaixo os caras iam fazer puxadinhos. Ou uma série de coisas, invasão, roubo, e ainda deterioração por conta de insetos e umidade. Ele é finito para 13.000 refeições, e quando a demanda ultrapassar isso? Faz outro! Então, é a mesma coisa, você faz um prédio de apartamentos e vai entulhando de gente? Não dá mais, tem que fazer outro! Esta era ideia do projeto do restaurante, a política de restaurante. Para ter controle e não ter vulnerabilidade. A arquitetura ficou preservada, embora os brises tenham brochado, alguns caíram, não consertam. Ora, isso altera a fachada, a função de proteção, secaram os lagos, a função plástica e ambiental da arquitetura. Outra grande qualidade do projeto foi a previsão de todos os problemas de circulação, circula toda a mercadoria, tem a copa do dia que separa toda a mercadoria, a câmara frigorífica para o lixo. De madrugada vem o cara e pega o tambor de lixo gelado, desenhei o tambor. O projeto foi todo muito bem estudado, com assessorias mais modernas na época. Você chega, já tem as balanças, a parte de contabilidade, o frigoríficos diversos separados, de carne, de peixe, de laticínios, isto é um projeto. Você tira a quantidade por dia, prepara a cozinha. O piso onde tem as panelas de autoclave a vapor, sete ou oito panelas de 350 litros, duas de 500 litros, é um piso falso, de placas de grade de aço inox, suspenso $50 \mathrm{~cm}$ do piso de concreto. Porque quando transborda a espuma gordurosa das panelas, já está prevista para onde vai escorrer, senão alguém iria escorregar ali. Isso é projeto! Elas são removíveis, no final do turno se tira e lava. Isso foi uma das sacadas de projeto do Galbinski. Outra: o piso mais alto da caixa é solto, a junta de dilatação é horizontal. As placas de $20 \times 20 \mathrm{~cm}$, com $35 \mathrm{~mm}$ de neoprene, esta caixa inteira dança lá em cima, isso era a maior novidade na época. Isso faz parte da inovação! (...) A estrutura foi o Figueiredo Ferraz, o desenho das vigas estava tão bem dimensionado já no projeto de arquitetura, as peças tão bem desenhadas que o escritório do Figueiredo chegou a mandar um bilhete - "está muito bem dimensionado, só falta colocar a ferragem, então vou dar uma elaborada nas formas". O Galbinski foi feliz nesse projeto. A rampa em viga Gerber. A estrutura com a junta de dilatação horizontal. $O$ arquiteto é que lançou as ideias estruturais, o restaurante é uma inovação, do ponto de vista do funcionamento, com a precisão da circulação, da produção, a fábrica de alimentação, e do ponto de vista da solução estrutural e arquitetônica. A única coisa que me chateia muito são os pilares em saia e superdimensionados.

\section{Vera - Você lembra algum caso pitoresco ocorrido no Ceplan na sua época?}

Moraes - Uma história engraçada. Estávamos dando uma virada maluca para entregar um projeto a nanquim, uma pressão violentíssima, tinha uma reunião prevista para a manhã seguinte com o reitor Caio Benjamim Dias. Quando chegou lá pelas $11 \mathrm{~h} 30$ da noite, tínhamos que fazer um lanche, 
fechamos o Ceplan, devia ter umas trinta pessoas. Durante o trajeto baixou aquele temporal tropical de arrasar. Inundou a Asa Norte, faltou luz, mas conseguimos chegar ao Ceplan à meia-noite para terminar de desenhar o projeto. Zimbres, eu, Josué, Farret, Hotz, Álvaro e outros. Quando abrimos o Ceplan, terra arrasada. Tinha um cachorro vagabundo, peludo, bege, que chamávamos de reitor, nós não vimos que ele ficou lá dentro, preso. Preso ele ficaria lá quietinho. Mas acontece que faltou luz, ele no escuro, com a trovoada, desesperado, ele pisoteava o jardim e pulava em cima das pranchetas para tentar escapulir. Rasgou e inutilizou todas as pranchas, quarenta pranchas inutilizadas, com lama e rasgadas. Queriam matar o cão. Quando abriu a porta, o bichinho saiu correndo desesperado. Deu aquele caos total. Ferrou! Aquele desespero, e alguém disse "Não, pera aí, a prancha de locação dá pra aproveitar, limpar e secar, e a prancha de corte dá para cortar um pedaço e montar outra". Já era $1 \mathrm{~h}$ da madrugada. O Zimbres disse "Não adianta , vamos todos embora, se começasse tudo agora, limpar, redesenhar, não ia dar ficar pronto a tempo da reunião. Vamos todos embora. Amanha venham todos aqui às 9 horas, não vamos desmarcar a reunião". Às 9 horas chegaram ao Ceplan o reitor, o Azevedo, a turma toda. "Cadê o projeto?"; "Está aqui"; "Mas o que é isso?". O Zimbres responde: "Isso é o resultado das condições precárias em que nos trabaIhamos aqui, sob pressão, de madrugada, sem pessoal, não podemos nem ir comer um sanduíche". Aí contou a historia, por conta da trovoada, cachorro preso, prédio sem vigia: "Olha só, meses de trabalho jogado fora. Papel que demorou um mês pra vir, nanquim que faltou, desenhista que trabalha aqui e não dá para ganhar hora extra. Taí, pode mandar construir". "Não professor, vamos ver se a gente consegue mais uns dias". Aí o Zimbres impõe: "Não, agora só trabalho dentro dos prazos técnicos normais, vocês coloquem material aqui, preciso de um mês". O Zimbres foi inteligente, escancarou as nossas condições precárias e impôs prazos, não tentou disfarçar, expôs a situação. Outro caso fantástico foi num momento de crise braba do Ceplan. Você sabe que o Ernesto Walter era um gozador incrível, ele tinha sido mandado embora da UnB, em 1965, quando era o diretor executivo da UnB, e o professor Andre Czajka, também. Nós estávamos querendo contratar os dois para fazer os projetos de cálculo e de instalações dos projetos da Reitoria e da Fitologia. Eles eram ótimos profissionais, mas tinha esse ranço com eles. Houve essa reunião no Ceplan, naquela mesa do Ceplan, o Zimbres na cabeceira, o Josué, o Vasco, o Leo, o Ernesto, o André, eu, você lembra? Umas 12 pessoas, quatro lá de cima, o Azevedo, o Lister e não sei mais quem. Um desgaste maluco nessa reunião, muito rígido, ninguém podia abrir o jogo, o flanco, negociando a situação do $\mathrm{Ce}$ plan , prazos e planejamento no campus. Em dado momento, chega o garçom com a bandeja do cafezinho e a água, é o intervalo. Seria o momento do relax, ele serve todos e ninguém fala com ninguém. Ninguém fala "você sabe quanto foi o jogo do Flamengo?", nada disso. Porque era um negócio de inimigo, ninguém fala nada, todo mundo olhava para a cara do Zimbres, e silêncio. De repente o Andre Czajka, outro gozador, fala: "Ô, Zimbres", com aquele jeitão e sotaque só dele. Aí quebrou o gelo, todo mundo olha para ele: "Ô, Zimbres, você sabe o que eu está observando aqui? Você é a carra de uma namorada que eu tive". Ninguém sabia o que dizer, e o Azevedo com cara de espanto. O André e o Ernesto Walter fizeram o que você fez agora, uma tremenda gargalhada. Os dois rindo, e o André repetindo "é a carra dela, é a carra dela". Como se o André estivesse pensando "e vocês com medo desses caras...". E o melhor é que se conseguiu colocar os dois para fazer os projetos de cálculo e de instalações da Reitoria.

\section{Vera - Esta é ótima, não lembrava. Então, Moraes, esse é o último, ou tem mais algum caso?}

Moraes - Você quer ficar aqui até a semana que vem? Eu conto. Ainda tem os projetos que quero realizar, um deles é reconstruir a casa igrejinha do frei Mateus no campus. Os desenhos nós já conseguimos, e já falei com umas três madeireiras para cederem o material. Pois aquele projeto é lindo! (...) 
Vera - Então, muito obrigada pela entrevista e por este material que você está apresentando, as fotos do interior do CEPLAN que você esta cedendo para serem escaneadas (fotos do ato de entrega de projetos no Ceplan para o reitor Caio Benjamin e arquitetos do Ceplan) e os CDs (o CD Goluboviedros e o CD do Seminário de Estudos Urbanos do Distrito Federal). 


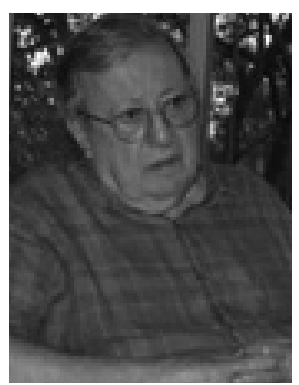

ENTREVISTA COM O PROF. L. H. PESSINA

Realizada em 1/12/2011, em Brasília/DF.

Vera - Estamos aqui no apartamento do arquiteto e professor Luiz Henrique Pessina, ele vai nos falar como foi a experiência dele nos primórdios da UnB, praticamente da construção do campus. Quando você chegou a Brasília e como desenvolveu esse trabalho?'

Pessina - Eu cheguei dois meses e meio depois da fundação da Universidade, que foi em 21 de abril. Cheguei em 1 de julho de 1962. Nessa época, na universidade, no campus, o que existia mesmo eram os barracos, os alojamentos para professores, instrutores, alunos de pós-graduação, a Faculdade de Educação em obras e o prédio que abrigava o Auditório Dois Candangos. Os alojamentos foram produzidos pela OCA, uma firma do Rio de Janeiro que fez construções muito boas em madeira, e era ali que nos morávamos. Havia também o restaurante. $O$ resto eram os barracos. O Ceplan chega talvez no início de 1963, com a construção do seu prédio. Chegou-se à conclusão de que era mais barato fazer o Ceplan em pré-fabricados de concreto. Seria uma construção definitiva, embora com um uso que poderia ser provisório. No futuro, o Ceplan poderia se mudar para um prédio projetado somente para ele. Dava-se o nome a esse tipo de prédio de Serviços Gerais. O Ceplan foi um deles. E essa construção em concreto armado seria definitiva, enquanto que o barraco, bem caro; aliás, a construção do barraco se perderia. Começa aí, então, a história dos préfabricados da UnB. O Ceplan funcionou antes num dos prédios dos ministérios na Esplanada, até se mudar para a sua sede, onde está até hoje.

Bem, eu vim como instrutor, aluno de pós-graduação, para fazer o mestrado aqui. Iniciar uma carreira de professor, que era como se iniciava a carreira de professor na UnB: mestrado, doutorado. E vim trabalhar com o prof. Edgar Graeff, juntamente com Fernando Lopes Burmeister e José de Anchieta Leal. Eu vim substituir o Oscar Kneip, que deu aulas de Teoria de Arquitetura, por uns tempos, mas depois foi trabalhar no Ceplan. Bom, no ano seguinte eu fiz o estágio no Ceplan. Então, foi o momento em que eu pude trabalhar como arquiteto de prancheta, e trabalhei no desenvolvimento de projetos em andamento.

Vera - De que prédios, exatamente?

Pessina - Um deles, o prédio onde funcionou a Biblioteca da UnB. Era um projeto do Lelé, préfabricado, em dois pavimentos e subsolo. Então, é o térreo e uma sobreloja. Esta, pendurada nas vigas da cobertura. Detalhei uma escada pré-fabricada, que ia do térreo para a sobreloja. O prédio era concebido de tal maneira que ele podia ser modificado amanhã. A sobreloja podia diminuir ou aumentar. Então, a escada tinha que sair de um lugar e ir para outro, era mais ou menos assim. Era muito versátil a coisa toda.

Vera - Exato. Os prédios tiveram usos diversos, Tecnologia, Astronomia.

Pessina - No prédio ao lado deste o Lelé estudou outra escada pré-fabricada, muito bem bolada, com uma estrutura totalmente metálica. Aquelas coisas que ele sabe fazer muito bem, muito bem desenhada, e uma coisa leve. Outro projeto em que trabalhei no Ceplan, também, foi na adaptação

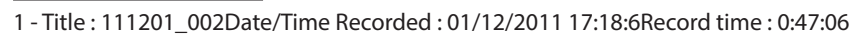


dos apartamentos da Colina. O terceiro andar de um prédio que tinha apartamentos de três quartos. Os apartamentos do último andar, em um dos prédios, foram transformados em alojamento para os instrutores. Eram oito quartos e um banheiro coletivo. Houve essa adaptação dos apartamentos, havia evidentemente uma sala de convívio. O projeto do Ceplan era muito simples. Ele tinha basicamente um desenho de cálculo estrutural e os detalhes de marco de portas, mapa de esquadrias metálicas, detalhe da cobertura. Não era muito mais do que isso, não! Ainda, banheiros, copa e auditório. Mas o projeto era muito simples.

Vera - Vocês faziam o acompanhamento da obra?

Pessina - Não, eu não fazia, quem fazia era a divisão de obras que era ao lado do Ceplan, quando este foi ampliado, era quem acompanhava a fiscalização dos prédios. Ali havia muito contato, qualquer problema que acontecesse estávamos por ali mesmo, saíamos, íamos até a obra e verificávamos o que era e voltávamos a trabalhar. Agora, Vera, o interessante disso era o seguinte: foi uma coisa importante em termos de Brasil, esse avanço construtivo na época. Tempos depois, quando saímos da universidade em outubro de 1965, talvez dois anos depois, foi feita a licitação para construção de mais dois prédios iguais ao projeto do Lelé. Só que ele foi construído de forma tradicional, eu nunca examinei, nunca visitei esse prédio, mas sei que não ficou bom. Entrou um concorrente que deu um preço mais barato e deve ter ficado ruim.

Vera - Lembro que estudávamos na UnB naquela época e vimos essa construção como um retrocesso. Se a licitação tivesse sido técnica e preço, talvez...

Pessina - É, mas naquela época quem é que estava se importando com isso?

Vera - Pessina, no período inicial da UnB, como você vê a importância do Ceplan para Brasília, para a UnB e para a comunidade?

Pessina - O Ceplan, naquele tempo, estava muito ocupado com a construção da universidade. Mesmo assim, num certo momento, já em 64, talvez, foi feito o projeto da Unidade de Vizinhança São Miguel. Eram quatro superquadras na Asa Norte, o projeto era para ser desenvolvido no Ceplan. $O$ embaixador Wladimir Murtinho foi encarregado de preparar a transferência do Ministério das Relações Exteriores para Brasília. Nesse sentido, a UnB e o Itamaraty fizeram um acordo em que as SQN 107, 108, 307 e 308 seriam edificadas com prédios destinados à moradia de servidores daquele órgão, a professores da UnB e, creio, a diplomatas estrangeiros. Essas superquadras constituiriam a Unidade de Vizinhança São Miguel, que deveria ser completada com escolas, comércio etc. O projeto foi confiado pelo Ceplan aos instrutores por meio de um concurso vencido por Fernando Burmeister, Mayumi e

Sergio Souza Lima. Sei que foram construídos só três prédios na SQN 107. São três prédios quadradinhos.

\section{Vera - E o longitudinal?}

Pessina - O longitudinal foi projetado depois, e tinha uma garagem comum interligada com os quadradinhos.

\section{Vera - Foi projetado no Ceplan?}

Pessina - Foi, mas foi alterado por outro arquiteto de fora, que tinha bom trânsito no governo militar. Ele ganhou os seus honorários, mas o projeto ali não é mais do grupo que ganhou, foi alterado, embora a gente olhando para o prédio perceba que houve cópia de alguns detalhes, sobretudo do pilotis; era para serem todos construídos como pré-fabricados, moldados no local. Enfim, veja 
bem, isso seria o que o Ceplan poderia ter colaborado com a cidade. Provavelmente, ter ajudado no planejamento das cidades-satélites, para que tivessem um desenvolvimento mais de acordo com o padrão urbanístico de Brasília. Isso não foi adiante, mas era uma ideia também, disso tudo ser desenvolvido na escola e no Ceplan. Enfim, em 64 e 65 houve essa ruptura realmente.

Vera - Agora eu gostaria que você falasse da relação coesa entre a Faculdade de Arquitetura e o Ceplan, essa efervescência que você viveu naquela época.

Pessina - Todos os arquitetos do Ceplan eram professores na Faculdade de Arquitetura. Existiam os projetos em andamento desde 1962. As primeiras construções são decorrentes do projeto do professor Alcides da Rocha Miranda e são os prédios destinados à Faculdade de Educação, com construção feita tradicionalmente, in loco. E o Ceplan vem depois e começa com as construções pré-fabricadas para substituir aquelas construções provisórias de madeira, barracões, enfim, caros, de difícil manutenção e enfim, meio favela. Mas existia o grupo de arquitetos que estava desde o início do Ceplan, por exemplo: Glauco Campello, Lelé, que era o nome principal do Ceplan depois do Oscar Niemeyer, o Evandro Pinto e outros.

\section{Vera - O Ítalo?}

Pessina - Não, o Ítalo era do urbanismo, da cidade de Brasília, ele e o Jaime Zettel. Mas eles é que desenvolveram o projeto do urbanismo da universidade, seguindo o risco de Lucio Costa. Eles estavam trabalhando na área de urbanismo de Brasília. Mas vejam bem, esses arquitetos que estavam no Ceplan foram trabalhar para a universidade, mas já trabalhavam na construção de Brasília. Então, isso aconteceu com o Lelé, o Glauco, enfim, com os demais, e eles foram todos arregimentados para projetar a UnB. Então, esses arquitetos tornaram-se professores da UnB. Eu mesmo fui auxiliar do Lelé, eu fui auxiliar primeiro do Glauco, estagiei com Glauco, que era o professor responsável pela disciplina Projeto de Arquitetura. Quando eu me tornei professor mesmo, entreguei a tese e fui aprovado no mestrado, fui trabalhar com o Lelé. Ele era o professor responsável pela disciplina Técnicas de Construção, que abrangia a parte de eletricidade, hidráulica, concreto armado, técnicas e métodos construtivos.Eu fui dar a parte de Hidráulica da disciplina e a Mayumi foi dar a parte de Eletricidade. Era necessário saber o que ensinar aos alunos e não sobrecarregá-los com cálculos disto e daquilo, porque acabavam não sabendo fazer a aplicação direito. O Lelé ensinava os métodos construtivos. O cálculo estrutural era ministrado por um engenheiro, Lúcio Pontual, que não estou sabendo se era engenheiro ou arquiteto, mas, enfim, ele era calculista, mas este era mais sensível e deu certo. Quando não estávamos dando aula, voltávamos para trabalhar no Ceplan, mas não eram todos - não cabia, inclusive, o número de instrutores que existiam na escola. Daí a ideia do concurso para o projeto da superquadra. Não sei como se desenvolveu dali em diante. $O$ Ceplan poderia ter tido um corpo certo de arquitetos. Os instrutores nem todos permaneceram, alguns desistiram do mestrado, antes da nossa demissão coletiva, e foram embora.

\section{Vera - Já que você falou na demissão coletiva, qual era o grau de interferência da Reitoria no Ceplan?}

Pessina - O que aconteceu foi que os projetos todos pararam em 1965, sobretudo com o novo reitor. O Zeferino Vaz tentou não mexer demais na UnB, tentou manter. Mas o segundo reitor, Laerte Ramos de Carvalho, veio para acabar com a UnB. Praticamente todas as coisas pararam, os projetos pararam, e você não tinha o que fazer lá. Você tinha só que aguardar. Chato pra chuchu! Sem saber o que iria acontecer no dia seguinte. Por incrível que pareça, no momento em que a gente pediu demissão, foi um alívio. Pelo menos a coisa estava resolvida, antes a gente estava somente segurando a barra. 
Vera - O que acontece quando o Laerte toma posse? Ele manda parar os projetos e obras?

Pessina - Era uma coisa esquisita, não sei se as obras pararam. A grande obra que estava em construção era o ICC. Não me lembro de mais nada.

Vera - Acho que a obra do ICC paralisou um bom tempo.

Pessina - Lembro uma coisa que talvez valha a pena registrar. O subsolo da parte central do ICC não fez parte do seu projeto e não deveria existir. Ele surgiu em função do tipo de fundação adotada, ou seja, um radier. Essa solução foi proposta pela construtora do prédio e executada em toda a sua extensão e largura. Resultou daí o espaço vazio entre os dois lados no nível do subsolo, onde deveria haver o terreno natural. Optou-se então por cobri-lo, em vez de aterrá-lo. Não sei se deveria ter feito o radier, de um lado a outro. Poderia ter sido feita uma ala e a outra e deixado o terreno original no meio. Aí se deu origem àquela ala embaixo no ICC. O pessoal reclama: "Nós estamos enterrados, e não sei o que mais...."

Vera - No depoimento do Galbinski, ele fala de uma pesquisa que foi feita: não lembro que professor entrevistou todos os usuários do ICC e apurou que, pelo fato terem a laje coberta com terra, grama e jardim em algumas laterais, esses laboratórios do centro têm um conforto ambiental maior, são mais agradáveis do que os outros laboratórios do subsolo.

Pessina - Claro, mas o ICC até hoje não teve um forro, como projetado. A laje lá em cima tinha que ter um forro. Agora, naqueles com jardim em cima o conforto térmico é muito melhor.

Vera - Todos os professores tinham dedicação exclusiva. Como se estabeleciam os compromissos do arquiteto com a obra projetada, em termos de prazos, detalhamento, fiscalização arquitetônica? Havia alguma compensação na carga horária da atividade docente, alguma remuneração? Ou era só em função da dedicação exclusiva?

Pessina - Não tinha não, era dedicação exclusiva mesmo.

Vera - Só para complementar, queremos uma comparação entre o compromisso do Ceplan com a inovação, com as novas tecnologias, entre as duas primeiras décadas do Ceplan e o período atual. Você já abordou isso na primeira fase.

Pessina - Esta foi a orientação do Oscar Niemeyer: "Nós vamos ter que desenvolver aqui a melhor tecnologia; avançar na tecnologia brasileira da construção". Daí essa coisa dos pré-fabricados, que encontrou no Lelé um executor maravilhoso, um craque nesta área. Em todas as áreas da arquitetura o Lelé é bom, na realidade.

Vera - Continuando sobre o ICC, como você vê a adaptação que está sendo feita? Os institutos que estão querendo sair de lá? Muito pelo desconforto, não pelo projeto, mas pelas más soluções de conforto ambiental.

Pessina - O principal é o forro, que deveria ter sido feito logo que se habitou. Nunca fizeram, ali passa um calor danado. Eu tive uma sala,quando eu retornei nos anos 90 para a FAU, lá no mezanino. Era muito quente o lugar. Passava direto o calor da laje, tinha que ter um forro que não foi feito. Principalmente isso.

Vera - Então, você viveu esse outro momento, ao retornar nos anos 90 para dar aulas. Você teve alguma participação no Ceplan?

Pessina - Não, não tive mais não. Chamaram-me até para participar de um projeto que foi proposto para uma entidade japonesa que queria fazer alguma coisa na UnB. O Marcílio Mendes Ferreira e 
- Claudio Queiroz me convidaram para fazer parte do grupo, mas por uma circunstância qualquer não deu para eu participar. Mas o Marcilio era muito meu amigo, nós trabalhamos juntos na Caixa Econômica, projetamos a SQN 311, projeto mais dele do que meu. Num certo momento ele foi diretor do Ceplan. E ele veio conversar comigo sobre o Ceplan. Porque o Ceplan era vinculado à Escola de Arquitetura. Acho que ele analisou a coisa muito bem. Achávamos que o Ceplan deveria ser vinculado à Reitoria para que pudesse se desenvolver como uma unidade capaz de projetar para a UnB. Houve críticas. Mas isso daí, você precisa confirmar as datas e tudo. Houve críticas sobre o Ceplan deixar a Escola de Arquitetura. Mas o Ceplan na Reitoria, do ponto de vista funcional, é muito mais certo. Porque a escola ou um instituto que queira fazer alguma coisa, vai procurar a Reitoria, e a Reitoria determina para o Ceplan fazer o projeto. E antes não estava desse jeito, tanto é que a Finatec, e não sei mais o quê, fizeram aqueles projetos horrorosos. Acabaram fazendo coisas de qualquer maneira. Aqueles são os piores projetos. Foram feitos diretamente. Veja bem, no início da UnB o Ceplan estava vinculado à Reitoria, não era um órgão da Escola de Arquitetura. A Escola de Arquitetura é que se servia do Ceplan. O Oscar respondia ao reitor, primeiro o Darcy Ribeiro, depois frei Mateus Rocha e Anísio Teixeira. Enquanto as coisas andaram por aí, andaram bem, não? Ah, sim! Teve o Instituto dos Dominicanos, o de Teologia, estava em andamento. Era o Ernesto Walter que tocava aquele projeto. Aquilo garantia a unidade da arquitetura do campus, o fato de você ter um nome principal. O Ceplan começou a fazer esses projetos todos depois que foi para a Reitoria. São feitos por professores de arquitetura.

Vera - Queremos situar a atuação do Marcílio. Pela experiência dele e pela análise dos projetos construídos no campus, ele sugere essa vinculação do Ceplan à Reitoria?

Pessina - Sim, ele sugere, pois do outro jeito ele achava que não se conseguia fazer projetos direito lá. É bom você conferir esses dados. Eu me aposentei em 93 e depois fui contratado como professor substituto, pois eles precisavam de professores com experiência de projeto, mas com o salário que pagavam, era só para quem não precisasse de salário. Era o meu caso. Na época do Cristóvão, ele chama os demissionários, eu levei um ano para aceitar, quase todos os meus amigos tinham aceitado: Fernando Burmeister, Sergio Souza Lima, Mayumi, Glauco, Jaime Zettel aceitaram, não via razão para não aceitar. Enfim, acabei voltando.

\section{Vera - Sobre o planejamento do campus, vamos detalhar mais?}

Pessina - O risco era do dr. Lúcio, era o sistema viário criado pelo dr. Lúcio e a disposição dos prédios. O ICC, por exemplo, foi construído sobre um conjunto de círculos, se você for olhar a planta do Lúcio, os institutos estão dispostos lado a lado. O Oscar junta todos no ICC. É uma coisa engraçada, o ICC. Porque é realmente um local de convívio, muito rico. Muito bom realmente. Então, tem que se olhar com cuidado essa transferência das unidades para fora dali.

Marco - Merecia ter maior investimento em acabamento, em melhorias na conservação.

Vera - E sobre o material importante que você está apresentando, mais de cinquenta fotografias lindíssimas sobre a construção do campus, e ainda os documentos. Fale sobre isso.

Pessina - As fotografias, eu acho que seria bom, depois, elas serem enviadas para a UnB, para algum arquivo da UnB, um centro de documentação.

Marco - Você saberia identificar a autoria dessas fotos? São suas e do Fernando?

Pessina - As minhas e do Fernando são fáceis de identificar, são aquelas ali sobre pré-moldados, faziam parte da nossa tese de mestrado. Eram fotos mais sobe detalhes da construção do prédio da Biblioteca, sobre como a coisa estava evoluindo, detalhes dos pilares. As outras são talvez de um 
fotógrafo chamado Pinheiro. Aquela da Colina, na fase de obra, é do Pinheiro, se não me engano. Agora, parece que ele trabalhava para a UnB. É possível que o Luiz Humberto saiba alguma coisa.

Vera - Então essas fotos e documentos, depois de escaneadas pelo Projeto Memória Ceplan, serão encaminhadas para o acervo da UnB, onde possam estar mais bem conservados.

Pessina - Esses documentos são sobre o momento crítico da nossa demissão. Pode ser que esses negativos tenham sumido quando houve a invasão da UnB, porque eles andaram levando muita coisa, boa parte do que eu tinha, do que eu consultava. Eu tinha os anais da União Internacional dos Arquitetos, do congresso em Havana. Esse congresso era sobre pré-fabricação, então interessava diretamente para a minha tese, que foi sobre pré-fabricados. Esses anais foram confiscados porque eram de Havana, e também as fichas do Congresso da UIA foram embora. Os caras também levaram fotografias!

Vera - Antes de o Ceplan ficar pronto, onde o Oscar Niemeyer trabalhava?

Pessina - O Oscar trabalhava em um dos ministérios, ele tinha uma sala lá, onde todos os projetos foram feitos. O projeto do prédio do Ceplan foi feito lá. Se não me engano era o primeiro ministério próximo da Catedral. A sala do Oscar era ali numa sobreloja, dali foi transferido para o prédio do Ceplan. Quem trabalhou em barracão de madeira foi o dr. Alcides, onde depois teve a oficina de maquetes, a oficina em que o Alex Peirano trabalhou e em que o Elvin Dubugras era o responsável. Algumas pessoas também moravam no campus, em barracões. Por exemplo, o Zanini morava num barracão de madeira por ali, onde hoje é o Instituto de Artes. O ICA foi construído onde havia um campo de futebol, onde nos jogávamos umas peladas.

Vera - Então, muito obrigada, Pessina, pela sua entrevista e pela doação deste riquíssimo material.

Pessina - Sim, se vocês precisarem de mais alguma informação, podem me consultar.

Vera - Sim, gostaria de saber se já existe na Biblioteca Central ou no Cediarte uma cópia da tese de mestrado que você fez naquela época, sobre os projetos e a construção de pré-fabricados na UnB? Pois, caso contrário, considero indispensável que o Projeto Memória Ceplan providencie essa cópia.

Pessina - Deve existir, mas posso disponibilizar se vocês quiserem. 


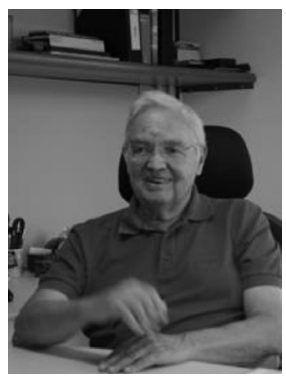

ENTREVISTA COM O PROF. PAULO ZIMBRES

Realizada em 26/10/11, Brasília/DF

Vera - O Ceplan hoje é um órgão de assessoria técnica da Reitoria da Universidade de Brasília, cuja finalidade é promover o desenvolvimento de estudos, planos e projetos nas áreas de arquitetura e urbanismo, tanto dentro do campus da UnB quanto no DF e na região de influência. Tem permanentemente em vista a integração da prática profissional e didática, o planejamento do campus e de outras áreas pertencentes à FUB e a captação de recursos, através da prestação de serviços, junto às entidades públicas ou privadas. $O$ que mudou em relação ao período de sua atuação? ${ }^{1}$

Zimbres - Quando aqui chegamos em 1968 para reorganizar o Instituto Central de Artes e Arquitetura (ICA-FAU), encontramos um legado importante da equipe que o criou. A ideia do Ceplan sempre foi essa. Nossa equipe em 1968 pautou seu trabalho pelos mesmos princípios. Encontramos projetos construídos e em andamento que refletiam um claro compromisso com a pesquisa, a inovação. Os prédios onde funcionava o ICA-FAU eram exemplares em termos de arquitetura - integração entre áreas de trabalho e jardins, a escala e a dignidade dos espaços interiores, os auditórios construídos através do simples rebaixamento escalonado dos pisos, minimalismo, acabamentos espartanos, tudo isso exibindo pedagogicamente as soluções estruturais e construtivas inovadoras. Nos grandes arquivos e mapotecas encontramos o testemunho de numerosos trabalhos de pesquisa desenvolvidos pelos professores de então, associando sempre pesquisa e inovação às atividades de projetar. Após inúmeras reuniões de trabalho e de formulação de um projeto cultural para o Ceplan, resolvemos formalmente conduzir nossos trabalhos de acordo com os mesmos princípios: o campus, Brasília e sua região de influência eram a temática básica do instituto, tanto para as atividades didáticas como para as de pesquisa e extensão. Naquele tempo não se enfatizava a atividade de captação de recursos.

\section{Vera - Como eram conduzidos os projetos no Ceplan?}

Zimbres - O conjunto das equipes responsáveis pelos projetos individualizados constituía a grande equipe do Ceplan, liderada pelo colega Pedro Paulo de Melo Saraiva. Todos os projetos eram discutidos por todos em nosso aconchegante auditório que às vezes se transformava em um efervescente espaço de debates. Isto é a pura verdade, a gente discutia, ficava vermelho, mas fazia parte do debate. Naqueles primórdios, não raramente as equipes colaboravam entre si, mais interessadas no sucesso do Ceplan do que na alimentação de um clima de competição. As equipes se ajudavam mutuamente. Eu auxiliei uma equipe liderada pelo Vasco Mello que participava de um concurso de anteprojetos de uma feira de exposições em Canoas, RS, montando uma perspectiva panorâmica do complexo.

Vera - Eu me lembro.

Zimbres - Eduardo Hotz preparou lindas perspectivas do interior dos alojamentos do Centro Olímpico, para a equipe do colega Leo Bonfim. Era um jeito bom de a gente trabalhar, como membros

1 - Title : 111026_002-Date/Time Recorded : 26/10/2011 16:49:46-Record time : 0:08:54 
ativos de uma equipe coesa. Havia algumas dúvidas quanto às questões de autoria - autores, colaboradores etc.? Alguns questionavam o papel de coordenador do Ceplan. Pedro Paulo defendia que, como coordenador do Ceplan, seria naturalmente autor também dos projetos ali elaborados. Eu mesmo não entendia bem esse critério. Com um acervo técnico ainda em construção, entendia que a autoria deveria se atribuída a cada membro das equipes responsáveis. Hoje vejo que estava equivocado. Autoria não é apenas reconhecimento de mérito, mas envolve responsabilidade técnica sobre as soluções arquitetônicas, que compulsoriamente vão afetar a vida dos usuários e o bolso dos contribuintes. Penso que certa dose de vaidade toldava o entendimento dessa questão. Se soubéssemos trabalhar em conjunto, se todos ouvíssemos os colegas e o coordenador Pedro Paulo, poderíamos produzir mais e melhor, a instituição ganharia muito e ele seria reconhecido naturalmente como coautor de todos os projetos, por estar presente, trabalhando ativamente em todas as equipes. $O$ fato é que a questão de autorias nunca foi bem definida e resolvida, disputas entre colegas têm se revelado por todos estes 40 anos, incluindo algumas demandas junto ao CREA e na Justiça. A própria autoria dos projetos de que participei no Centro Olímpico ficou um tanto nebulosa por essa dificuldade de definir quem são autores ou colaboradores, no passado, no presente e no futuro. Tempos atrás eu apresentava alguns projetos aos colegas da Federação Pan -Americana de Associações de Arquitetos, em Tegucigalpa, mencionando sempre todos os colegas que participaram dos trabalhos. A arquiteta Perla Copola, presidente da Sociedad de Arquitectos de Uruguay, me cumprimentou pelo fato, segundo ela raro, de eu haver mencionado todos os colegas que participaram das diversas equipes.

Vera - Exatamente: na nossa equipe do projeto da Reitoria, você sempre citou Josué, Vera e o Érico, enquanto eu imaginava que o crédito seria como colaborador ou no desenvolvimento de projeto; muito me honra essa citação.

Zimbres - Considero muito tênue a distinção entre autoria e colaboração: está na equipe, está fazendo, contribuiu efetivamente, é coautor. A experiência, a liderança e a responsabilidade técnica facilmente são reconhecidas. Não posso evitar responder pelos projetos que coordenei. É comum associarem o projeto da Reitoria a meu nome, mesmo que em toda a divulgação eu tenha sempre nomeado todos os coautores. Enquanto a questão de autoria era assunto recorrente no âmbito das equipes do Ceplan, sempre nos preocupou o fato de lidarmos com os projetos para o campus. Quando aqui chegamos encontramos inúmeros projetos em andamento, propostas interessantes interrompidas. Nos primeiros passos do IAB com vistas à revitalização do ICA-FAU, seu presidente, arquiteto Fábio Penteado, e a comissão de reestruturação, que contava com os colegas Miguel Pereira, Paulo Bastos, Neudson Braga e Liberal de Castro, já havia estabelecido um entendimento com a equipe pioneira no sentido de assegurar liberdade de ação aos colegas que comporiam a equipe de reabertura. Mesmo assim, no caso do projeto da Reitoria a questão de autoria me preocupava. O grande mestre Oscar Niemeyer já havia apresentado uma proposta para a Praça Maior da UnB, da qual constavam Biblioteca, Reitoria e Aula Magna. O Ceplan de nossa época apresentou um plano de atualização dessa proposta, introduzindo na praça, que fora pensada como lócus dos grandes eventos, um centro dinâmico de convivência, incluindo o restaurante universitário, enriquecendo o dia a dia no campus. O prédio da Reitoria seria substituído por um grande edifício para a Administração Central da Universidade. Diante dessa mudança de enfoque programei uma visita a Oscar Niemeyer, para convidá-lo a assumir esse novo projeto, oferecendo-lhe todas as condições de suporte para o desenvolvimento dos trabalhos. Cheguei lá no Rio, às vésperas da Copa do Mundo de 1970. Ele me atendeu com muita atenção e simpatia. Conversamos sobre vários assuntos; um elogio ao Paulo Mendes da Rocha pelo pavilhão de Osaka, fazendo-me portador de um bilhete cumprimentando-o pelo feito; chegamos a falar sobre a escalação do time do Brasil - palpitou pela escalação do Jairzinho, jogador que admirava muito. Abordei então o tema que 
me levou à sua presença: "No Ceplan fomos incumbidos de projetar o edifício da Reitoria, porém com um novo programa, atualizado pela equipe de planejamento institucional do reitor doutor Caio Benjamin Dias". Otimista quanto à possibilidade de criar as condições para recebê-lo, ofereci várias possibilidades de apoio técnico contando com a equipe do Ceplan e com os profissionais que nos auxiliariam com os projetos complementares. Delicadamente declinando do convite, lembrou-me que não se sentiria confortável em voltar dessa maneira à universidade, pois ainda não fora adequadamente superada a crise que culminou com a demissão coletiva dos professores em 1965. Reafirmou seu apoio à equipe que naquele momento trabalhava para revitalizar o ICA-FAU, reconhecendo que o Ceplan era o laboratório necessário para unir atividade docente, de pesquisa e prática do ofício, sugerindo que fizéssemos com liberdade as intervenções que julgássemos necessárias no campus.

Vera - Continuando, quando você assume a direção do Ceplan, e em que projetos atuou diretamente? ${ }^{2}$

Zimbres - Em 1968, logo no início de nossas atividades na UnB, em equipe com os colegas Ricardo Farret e Márcio Villas Boas, tocamos alguns projetos do Centro Olímpico da Juventude de Brasília, cujo plano de ocupação e arcabouço básico já haviam sido lançados pela equipe pioneira, incluindo um projeto de vestiário semienterrado em início de implantação: concluímos e atualizamos essa obra; projetamos então o conjunto de piscinas com plataforma de saltos ornamentais, trampolins, quadras de tênis, bola ao cesto e vôlei e elaboramos um anteprojeto de quadra coberta multiuso, finalizamos o projeto executivo da pista de atletismo. [Com licença, preciso atender a essa ligação.] No final de 1969 ou início de 1970 assumi a coordenação do Ceplan, em substituição ao colega Pedro Paulo Saraiva, que se desligou da UnB, voltando para São Paulo. Em sintonia com o diretor do ICA FAU, arquiteto Miguel Alves Pereira, procuramos reforçar o espírito de equipe no Ceplan, integrando os esforços de nossas equipes técnicas. Para melhor contextualizar a atuação das equipes responsáveis por intervenções pontuais, revisitamos o plano diretor do campus para criar uma moldura para essas intervenções. Na época foram realizados projetos de diversos edifícios: Biblioteca Central, Restaurante, Reitoria e Laboratório de Fitologia. Nesse período, em equipe com os arquitetos Vera Braun Galvão, Josué de Carvalho Macedo, nos responsabilizamos pelo projeto da Reitoria. Mais tarde, essa equipe seria acrescida com a integração do arquiteto Érico Weidle, que se ocupou do detalhamento e acompanhamento das obras. Em setembro de 1972, me desliguei do Ceplan para cumprir programa de pós-graduação de dois anos de duração, na Universidade de Edimburgo, Escócia. Quando voltei assumi a coordenação do Programa de Pós-graduação da FAU. Não participei mais das equipes do Ceplan, embora estivesse sempre presente nos seminários internos de debate sobre os projetos em andamento. Em 1991, me aposentei.

\section{Vera - Então, de 74 a 91 ?}

Zimbres - De 1974 em diante, como disse, não fui um ativo participante, não fiz mais projetos no Ceplan. Minha última contribuição foi ainda em 1972, um plano para a estruturação de novas intervenções: fazendo uma releitura da estrutura do campus, sugeriu-se concentrar as intervenções na região de Praça Maior, na procura de maior integração com o Minhocão. Como professor e administrador das atividades acadêmicas minha participação como fazedor de projetos se retraiu, porém sempre opinei sobre os projetos em curso. Quando voltei, em 1974, o campus contava com novos prédios de autoria dos colegas Adilson e Érico: eles projetaram a Faculdade de Tecnologia e a o Instituto de Ciências da Saúde. Obras de grande expressão consolidaram, juntamente com o Prédio do Restaurante Universitário, um novo eixo de estruturação do campus, ao qual atribuí- 
ram grande importância. Sem me alongar muito, creio que ao se prestigiar essa nova orientação negligenciou-se o papel aglutinador do Minhocão, não enfatizando o potencial de sua rua interna ajardinada como principal ponto de encontro do campus; creio que essa vocação possa ainda ser incentivada. Hoje vejo que persiste um vício na condução dos projetos no campus: as intervenções autorais foram povoando o campus no decorrer do tempo, não se procura a integração do novo com o existente, nem mesmo do novo com o novo. Por exemplo, até hoje não se pensou em ligar os novos prédios às extremidades abertas ao Sul e Norte do Minhocão; talvez uma praça bem construída aglutinando as novas intervenções. Ficou tudo meio afastado, meio desarticulado, não se pensa em caminhos, passeios, pátios e praças ligando as entradas dos edifícios. Há um hábito arraigado de fazer prédios autorais isolados. O único setor do campus que apresenta certa ideia de conjunto integrado são os quarteirões onde foram construídos os prédios para os serviços gerais que acabaram sendo lindamente ocupados pelo ICA-FAU: Auditório da Música, Instituto de Artes, ateliês do curso de Arquitetura, o Ceplan. Mais recentemente quarteirões adjacentes receberam a Faculdade de Tecnologia. Constitui-se ali uma estrutura quase urbana tradicional na qual o pedestre é quase bem tratado.

Vera - Sim, sobre isto queria Ihe perguntar. Sobre o Memorial Darcy Ribeiro, com a expansão da Reitoria, o prédio não vai ficar muito próximo do eixo de expansão da Reitoria?

Zimbres - Na verdade abandonou-se a ideia de expansão da área edificada a partir da Reitoria! Não esperava mesmo que essa expansão obrigatoriamente devesse guardar semelhança com a Reitoria.

\section{Vera - Não vai ser construída? Mas há um projeto de expansão!}

Zimbres - Várias intervenções feitas ao longo do tempo sem considerar essa hipótese acabaram por criar barreiras à implantação dessa ideia. Um grande conjunto de belíssimos espécimes de pau-ferro foi plantado em direção à Biblioteca. Esse bosqueto poderia representar uma expansão do espaço habitável do campus, um compartimento de paisagem a ser apropriado. Recentemente o colega João Filgueiras Lima, o Lelé, projetou o Memorial Darcy Ribeiro num canto da Praça Maior, como sempre um belo projeto. Creio que essa intervenção vem ao encontro dessa ideia de crescimento linear a partir da Reitoria. Porém será necessário que os espaços públicos venham sendo configurados na medida em que os edifícios sejam implantados. Apenas me preocupa o fato de que as intervenções dos últimos tempos tenham linguagem tão diversa; ou seria esse um bom sinal? Liberdade de expressão? Qual é o sentido da ideia de unidade arquitetônica?

Vera - Pelo que eu li, ele atendeu a um anseio de um projeto que ele discutiu com o Darcy que teria aquela forma lembrando uma oca...

Zimbres - Correto! Mas veja, existe outro projeto naquele sítio, do colega Mateus Gorowitz tradicionalmente denominado como Aula Magna. Na versão recente desse projeto, selecionada através de um concurso interno da UnB, nota-se a retomada muito interessante de conceitos e linguagem arquitetônica que revelam parentesco com as soluções brilhantes do passado, regatando os grandes gestos que marcaram as primeiras intervenções no campus. Lembro-me de uma linda proposta para aquele espaço entre o Minhocão e a Reitoria apresentada por alunos do curso de Arquitetura e Urbanismo. Uma grande estrutura de três pavimentos, cujas lajes acompanhavam as curvas de nível daquela encosta, num desenho caprichoso e adaptado à topografia. Ali seriam acomodados espaços para atividades acadêmicas e de convívio.

Vera - Ah, foi o projeto da nossa equipe: Arnaldo Braga, Ceça Guimaraens, Luciano Lopes e eu, para um concurso sobre planejamento de campus universitário, entre os alunos de PEU, em 1969. 
Zimbres - É mesmo, a sua equipe! Isto era um projeto superinteressante para ser feito. No início o projeto da Reitoria não foi bem recebido por alguns colegas. Algumas críticas nossa equipe acoIheu, ainda durante os debates no Ceplan. Depois da obra construída, ocupada e ajardinada seus atributos ficaram mais evidentes e sua presença "brutalista" foi amenizada pelo arvoredo que a envolveu. Aracy Amaral, professora titular de História da Arte pela Faculdade de Arquitetura e Urbanismo da USP, escreveu sobre a reitoria uma resenha elogiosa. Dizendo ter encontrado no campus um projeto interessante, ela comenta: "trata-se de um prédio que exibe certa horizontalidade presente na arquitetura brasileira, que tem também um jeito paulista de ser... mas que se abriu no cerrado encontrando uma feliz relação interior/exterior. Apresenta-se como um oásis no cerrado a acolher a quem vem vindo do campus ensolarado e encontra ali um lago e áreas ajardinadas, que criam um clima ameno em seu interior". Você conhece esse texto?

Vera - Não, mas eu li um artigo maravilhoso sobre a Reitoria na Vitruvio.

Zimbres - O colega José Carlos Coutinho tem sempre manifestado admiração por aquele projeto, o que muito me honra. O prédio tem sido muito elogiado.

Vera - Sim, estivemos lá há pouco tempo, passam os anos e o valorizo cada vez mais.

Zimbres - Ah, mas ele está envelhecendo demais!

Marco - É uma pena, pois parece sem manutenção.

Zimbres - Tenho aqui um livro do arquiteto holandês Dick van Gameren, que, visitando o prédio há alguns anos, se interessou principalmente pela maneira como ele acolhe as pessoas, oferecendo sua sombra no pilotis e "orientando seu percurso pelas rampas, oferecendo diversos ângulos de percepção de seu interior e seus destinos"; no livro faz comentários sobre o modo de fruição do espaço oferecido ao visitante pelos edifícios.

Vera - Qual era a importância do Ceplan para Brasília e para a comunidade?³

Zimbres - Quando aqui cheguei em 1968 a população do plano-piloto era pequena, de 120 a 140 mil habitantes. A visão do ICA-FAU e a opinião dos professores era muito valorizada pelo Correio Braziliense, desde sempre o principal jornal da região. Além disso, o projeto cultural do ICA-FAU apontara Brasília e o Distrito Federal com sua área de influência, como a temática de base para as suas atividades de ensino, pesquisa e extensão.

\section{Vera - Era a única universidade.}

Zimbres - Então, a gente era muito presente na cidade, discutia sobre arquitetura, urbanismo, planejamento urbano e regional, Assim fomos nos integrando à sociedade brasilense, à comunidade técnica de arquitetos, urbanistas, geógrafos, engenheiros. Fizemos muitos trabalhos para o GDF, vários convênios ligaram os professores às instâncias de planejamento urbano, territorial e de pesquisa no Distrito Federal. Em 1977, por iniciativa do colega Jorge G. Francisconi, através de um convênio da Secretaria de Planejamento da Presidência da República com o GDF, foi elaborado o Plano Estrutural de Ordenamento da Ocupação do Distrito Federal (Peot). Sob a coordenação do colega Luiz Alberto Cordeiro, esse trabalho contou com a participação efetiva dos professores, Gunther Kohlsdorf, Geraldo Nogueira Baptista e minha. Fizemos um trabalho interessante, primeiro identificando as áreas com aptidão para o desenvolvimento urbano no Distrito Federal e por fim delineando uma estrutura para orientar o crescimento da capital. Havia intensa relação profissional da UnB com a sociedade; o Ceplan sempre presente. Quando falo de professores arquitetos não 
posso deixar de lembrar cineastas, músicos, pintores escultores, atores. Departamentos como os de Cinema, Artes Cênicas, Desenho Industrial e outros contribuíam para que se estabelecesse um momento muito rico de convivência acadêmica que facilitava a constituição de excelentes equipes interdisciplinares. Contávamos também com quadros dos departamentos de Geografia, Geologia, Tecnologia, Economia e outros para compor nossas equipes.

Vera - Qual o grau de interferência da Reitoria no planejamento do campus? Em que período esta interferência foi mais forte em relação à localização dos vetores de expansão, partido, custos, dimensionamento? O Ceplan chegou a ter a sua autonomia ameaçada?

Zimbres - Muito frequentemente entrávamos em conflito com a administração. Alguns colegas reclamavam da maneira um tanto radical com que, como coordenador, eu defendia nossos pontos de vista. Mas nossos clientes eram os nossos comandantes. Havia colegas que achavam que a relação tinha que ser mais amena. Eu tinha uma visão de que, como professores e arquitetos, éramos também clientes de nosso trabalho. Nossa missão era a de pensar a estrutura do campus, propor estruturas espaciais compatíveis com certo projeto de universidade com a qual sonhávamos. Era difícil, na verdade, conciliar o papel de profissional contratado obediente às diretrizes da alta administração, com a fidelidade à nossa consciência de professores e dirigentes das unidades de ensino e pesquisa. Nos colegiados a gente brigava por algumas ideias e na hora de projetar a gente encontrava resistências.

Um bom exemplo foi a condução da questão da localização do Restaurante Universitário. Segundo pensava a Reitoria, os restaurantes universitários sempre foram um espaço de origem de movimentos estudantis. Esse assunto foi o projeto do restaurante novo, a gente tinha um projeto do Pedro Paulo Saraiva que colocava o restaurante na Praça Maior. A Praça Maior não seria só um espaço de grandes eventos, de grandes momentos da universidade, excelência, das aulas magnas, mas seria também um espaço do cotidiano, e o restaurante foi proposto na Praça Maior para enfatizar esse destino. Isso causou uma grande dificuldade de entendimento dos quadros dirigentes, a maioria militares, que viam naquela posição um foco muito complicado de rebeldia, de geração de protestos e tudo mais. Sua preferência seria deslocar o restaurante para o Centro Olímpico, perto do Alojamento de Estudantes. Iniciou-se um debate acalorado que resultou em um acordo: "Tudo bem, não sendo na Praça Maior, propomos localizá-lo em um local equidistante de todas as unidades de ensino então existentes, no eixo do Minhocão". Foi então decidida a questão. O Restaurante foi localizado naquele lugar em que está hoje. Foi uma discussão que, sem algum calor, a gente perderia. Alguns colegas estavam quase dispostos a ceder. A teimosia deu certo, acabou ficando junto ao centro histórico do campus. Era uma solução de compromisso, que tinha seu lado bom porque aquela era uma área de grande presença de estudantes e professores. Quando aparece a ideia de um novo eixo, que liga a escola de Medicina à Colina, onde seriam postos os novos edifícios acadêmicos, essa posição do Restaurante vem confirmar um ponto de encontro com forte centralidade. Hoje se juntaram ao restaurante o banco, o correio, um bar e café, uma livraria. Isso tudo aconteceu como fruto daquele debate. Acho que isso, de certo modo era um prenúncio da abertura democrática pela qual se lutava.

A administração central interferia muito; percebia claramente a relação entre o arranjo físico do campus e o grau de interação social que se poderia proporcionar. O próprio projeto cultural do ICA-FAU foi afetado muito pelo governo autoritário. Nós recebemos ordens expressas da Presidência da República, na época, dizendo para cortar os cursos de Teatro, Cinema etc. Eram notórios os conflitos entre teatro e poder constituído. O curso de cinema podia, mas não contaria com apoio oficial, não haveria mais contratações. Projetos foram sendo cortados. Aquela que poderia ter sido uma experiência rica, inspirada na Bauhaus, foi esvaziada. Ficou restrita a departamentos 
isolados, de Música, Artes Plásticas, Arquitetura e Urbanismo, que se transformou em um Instituto de Arquitetura e Urbanismo hoje com 50 anos de vida, com certa história para ser contada. Tem uma tradição, mas foi originada de um processo de cisalhamento de uma ideia estimulante. Mas a FAU inspira respeito, tem a sua história. Teve momentos brilhantes na inovação; teve rupturas importantes em 65 com o fechamento; foi reaberta; depois se lutou muito diante de uma situação de autoritarismo pleno; depois a reabertura, até os dias de hoje. Muitos contarão essa história de modo diverso, sei que vocês ouvirão outros colegas.

Vera - Voltando ao campus da UnB, você falou "a reitoria limitava a criação de teatros, de teatro de arena", mas você conseguiu colocar dentro do projeto de paisagismo da Praça Maior, do arquiteto Fernando Chacel, uma arena, não é mesmo?

Zimbres - Nós colocamos mesmo, coisa de contrabando, de mansinho, como quem não quer nada; cumpriu durante muito tempo seu papel como o espaço da resistência democrática.

Vera - Lembro-me que o coronel Lister, ou foi o Azevedo que teria dito? Ele chegou a perceber, e teria dito: “Mas, como, Zimbres? Você colocou uma arena!", ao ver o projeto da arena, "Vamos ter que colocar um aspersor aí no centro!".

Zimbres - ah! Foi? Eu não me lembro disso, então foi bom, essa história é boa! Então, você vê o projeto da Reitoria que nos fizemos, ele tem um pouco desse diálogo com o poder, aquele auditório pendurado em tirantes e transparente era para abrigar o Conselho. O que nós pensávamos? Era para pôr um auditório vulnerável porque lá é que iria funcionar o Conselho Universitário. Eu queria que os conselheiros fossem vistos de fora tomando as grandes decisões, e que eles percebessem a sociedade ao lado, no momento de certo aquecimento das relações. E eu fui muito gratificado quando uma vez, naquela invasão de 1977, o Conselho se reuniu urgentemente e o reitor Azevedo, comandando uma reunião pesada, vendo ao redor o campus todo tomado por estudantes e policiais. Quase que um vulcão preparando uma erupção ao redor, e o Conselho tomando suas decisões naquele auditório, francamente aberto. Isso não foi por acaso, era intenção de projeto fazer com que a reunião dos dirigentes sempre fosse vista pela comunidade. Acho que isso se confirmou como uma característica boa do projeto. A gente aprendeu muito com todos lá do Ceplan. O auditório de Música abre todas as portas, do teto ao chão, os outros auditórios também, todos abertos. Eu não sou inventor da roda, as ideias estavam lá, só fizemos foi pendurar o auditório aberto acima do lago da Reitoria.

Vera - Como eram selecionados os arquitetos para projetar determinada obra? Era determinante serem professores de dedicação exclusiva? E como se estabeleciam os compromissos desse arquiteto com a obra projetada, em termos de prazos, detalhamento, fiscalização arquitetônica da obra etc.? Havia alguma compensação na carga horária da atividade docente, alguma remuneração?

Zimbres - A gente se organizava em equipes por interesse no tema e afinidades quanto à forma de ver e fazer arquitetura. Todos em dedicação exclusiva, pois essa era uma condição imposta para a nossa vinda: atuar em dedicação exclusiva, e a prática era assegurada no Ceplan. Só aceitei o convite para integrar o corpo docente da UnB com essa condição. A gente constituía equipes quando abertas as inscrições para os projetos. Quando o tema era muito atraente montavam-se concursos internos. Há pouco tempo foi organizado um concurso de anteprojeto para o Museu de Ciências e Tecnologia. Cinco ou seis propostas foram apresentadas. Foi designado um júri, com dois arquitetos e um museólogo, recrutados fora da UnB. O resultado foi muito bom!

Os trabalhos no Ceplan nunca tiveram remuneração, mas tínhamos uma remuneração decente naquela época, compatível com o mercado, para se tornar atrativo para os profissionais experientes 
que para cá vieram. Com o tempo os salários foram perdendo o valor. Surgiram algumas transgressões ao princípio de dedicação exclusiva, surgindo algumas oportunidades de serviços profissionais para o governo federal e para o GDF.

Vera - Quais são as perspectivas para a ocupação total do campus? Embora você já tenha abordado os vetores, poderia detalhar um pouco mais?

Zimbres - O que eu vejo como necessário é, por assim dizer, o artesanato do espaço público; é o trabalho meticuloso de articulação de todos os compartimentos do campus, a constituição de um repertório rico de espaços de uso coletivo: passeios, praças, pátios, parques, interligando todos os edifícios. Hoje vemos ainda muitos prédios isolados por áreas verdes residuais, perdidos no cerrado. Através de estudos de morfologia urbana, poder-se-ia trabalhar em busca de certo nível de urbanidade dentro do campus.

Vera - Você deu consultoria neste trabalho aqui que eu imprimi do site da UnB, o Conjunto Cultural da UnB?

Zimbres - Ajudei um pouco. Esse é um trabalho da Maria Elaine, ela buscava introduzir uma tessitura mais urbana no campus. Trabalhei um pouco no projeto do museu de que falei antes. Ainda busquei certa horizontalidade na massa construída. Porém, acredito que, com um pouco de coragem, poderíamos pensar em prédios verticais no campus. O limite de 12 metros de altura para os prédios da orla bucólica na verdade não garante a vista do lago. Prédios contíguos com essa altura criam barreiras.

Vera - Ainda sobre o ICC, o grande espaço para ensino e pesquisa. Como você vê a apropriação futura do ICC? Você gostaria de abordar ainda este assunto?

Zimbres - Sim, mas quero acrescentar que o ICC tem que ser muito bem tratado, acho difícil dar uma opinião rapidinha. Há que se debruçar sobre o problema de revitalizá-lo. Como preservar e valorizar uma infraestrutura tão bacana? Ninguém faz uma rua principal de uma cidade de 700 metros de comprimento, coberta e ajardinada de ponta a ponta, como é a rua interna do Minhocão. Quando finalmente conseguimos localizar o Restaurante Universitário no core comunitário do campus ouvi uma crítica apressada: "O que puseram na frente do ICC? Puxa!" Não há como colocar um edifício próximo ao Minhocão sem, de algum modo, tê-lo como pano de fundo. Arrisco uma opinião: para melhor utilizar a grande "rua principal" do campus, melhor seria construir mais laboratórios, salas de aula, anfiteatros e espaços comunitários a distâncias convenientes de suas fachadas Leste e Oeste, ligando-os à rua central através de passarelas. Esses novos edifícios estariam, por assim dizer, mamando no Minhocão. Essas passarelas poderiam tocar o "mall" central através das praças existentes, em dois níveis, ou nas extremidades Norte e Sul, como já disse.

Vera - Isso mesmo, muito bom, mamando no Minhocão!

Zimbres - E assim potencializar a livre apropriação coletiva daquele eixo, daquele monumental ambiente de convívio. Tem que aproveitar isso. A provocação que eu faço: organize-se um concurso nacional para revisitar o projeto. As releituras mais competentes seriam entregues aos autores do projeto como contribuição para a elaboração de uma plataforma conceitual para a condução de um projeto de revitalização do edifício.

Vera - Agora, você falando, está me ocorrendo que o ICC é como uma esfinge, ainda não foi decifrado.

Zimbres - É. Tem que decifrar, reconhecer e valorizar. Se quiserem, me convidem para participar da organização desse trabalho. 


\section{Vera - Como você vê o loteamento dos espaços do campus?}

Zimbres - Não sabia que o campus está sendo loteado; para falar em parcelamento, há que se definir como são as ruas, calçadas, praças e parques. É necessário definir regras edilícias. Precisa de um plano, que nunca foi feito. Não sei se foi inaugurado um loteamento de forma competente com estruturação semelhante à de uma cidade. Só que não deve ser cópia de qualquer cidade, mas seria uma proposta deste milênio; não deveria repetir o modelo das superquadras, porque eu não acredito na superquadra como panaceia universal. Acho que temos que pensar em estruturas novas para o campus. Nossos mestres nos ensinaram a pensar com liberdade. Ser contemporâneo é saber ler as oportunidades que foram criadas e que estão à disposição.

Vera - Rever o ICC, com uma boa tecnologia de conforto térmico- acústico.

Zimbres - E também, ao pensar e construir um prédio, pautar os serviços técnicos de projeto e construção com antena ligada em sustentabilidade, em manutenção e permanência. Utilizar boas técnicas e bons materiais. Os prédios do campus estão envelhecendo muito.

Marco - Talvez a pressa em concluir e o grande problema da falta de manutenção.

Zimbres - Exato, se construíssemos mais cuidadosamente evitaríamos os custos de reconstrução e reformas, os prédios seriam mais duráveis. As obras públicas focalizam prioritariamente o custo da obra e sua inauguração, não compreendendo que durante a vida útil do prédio os custos de utilização e manutenção atingem aproximadamente três vezes os custos de implantação.

Vera - Chegamos à última questão. Você teve tempo de localizar alguma fotografia da época ou documento? Ou gostaria de citar ainda alguma lembrança marcante?

Zimbres - Lembro-me das emoções de frequentar os prédios que já estavam construídos no campus, produtos da dedicação e competência de nossos precursores. Lembro-me da emoção dos primeiros trabalhos no ICA-FAU, do frio na barriga ao dar a primeira aula. Do início dos trabalhos no Ceplan. Do espírito de companheirismo que reinava nos primeiros momentos da vida do novo ICA-FAU. Dos colegas e dos alunos mais brilhantes. Lembro-me também dos momentos críticos: no início de nossos trabalhos no ICA-FAU foi decretado o AI-5, recrudescendo atribulações que afetaram estudantes e professores por muito tempo; duas invasões do campus ocorreram até 1977. Muitos dos colegas que aderiram entusiasmados ao projeto de revitalização da instituição retornaram decepcionados às suas origens, em virtude das restrições ao desenvolvimento do ICA-FAU. Quanto ao material, eu tenho umas boas fotos da Reitoria, do fotógrafo e colega Rubens Mano, que com prazer coloco à sua disposição. Preciso de um tempo para verificar o que mais eu tenho que possa interessar. Se vocês quiserem aprofundar mais algum assunto, contem sempre comigo.

Vera - Certo. Então, muito obrigada pela sua grande contribuição para o Projeto Memória Ceplan. 


\begin{tabular}{|c|c|c|c|c|c|}
\hline Entrevistado & Data & Local & Duração & Mídia & Revisão \\
\hline CAMPELLO, Glauco & - & - & - & Telefone & - \\
\hline $\begin{array}{l}\text { CASTRO, Antônio } \\
\text { Moraes de }\end{array}$ & 26 jan. 2012 & $\begin{array}{l}\text { Residência do } \\
\text { entrevistado }\end{array}$ & 1h32min & $\begin{array}{l}\text { Gravação } \\
\text { em áudio }\end{array}$ & - \\
\hline $\begin{array}{l}\text { FARIA, Alberto Alves } \\
\text { de }\end{array}$ & 8 mar. 2012 & Ceplan & 1h9min24seg & $\begin{array}{l}\text { Gravação } \\
\text { em áudio }\end{array}$ & - \\
\hline GALBINSKI, José & 4 nov. 2011 & $\begin{array}{l}\text { Residência do } \\
\text { entrevistado }\end{array}$ & $29 \mathrm{~min} 44 \mathrm{seg}$ & $\begin{array}{l}\text { Gravação } \\
\text { em áudio }\end{array}$ & $20 / 02 / 2012$ \\
\hline GOROWITZ, Mateus & 20 dez. 2012 & - & - & E-mail & - \\
\hline $\begin{array}{l}\text { LELÉ - João da Gama } \\
\text { Filgueiras Lima }\end{array}$ & 22 fev. 2012 & $\begin{array}{l}\text { Residência de } \\
\text { Sônia Filgueiras }\end{array}$ & $49 \min 31 \mathrm{seg}$ & $\begin{array}{l}\text { Gravação } \\
\text { em áudio }\end{array}$ & \\
\hline LIMA, Paulo Castilho & 9 fev. 2012 & - & - & Telefone & - \\
\hline $\begin{array}{l}\text { PEREIRA, Luiz } \\
\text { Humberto Miranda } \\
\text { Martins }\end{array}$ & 26 jan. 2012 & $\begin{array}{l}\text { Residência do } \\
\text { entrevistado }\end{array}$ & $57 \mathrm{~min} 36 \mathrm{seg}$ & $\begin{array}{l}\text { Gravação } \\
\text { em áudio }\end{array}$ & - \\
\hline $\begin{array}{l}\text { PESSINA, Luiz } \\
\text { Henrique Gomes }\end{array}$ & 1 dez. 2011 & $\begin{array}{l}\text { Residência do } \\
\text { entrevistado }\end{array}$ & 47min06seg & $\begin{array}{l}\text { Gravação } \\
\text { em áudio }\end{array}$ & $20 / 02 / 2012$ \\
\hline $\begin{array}{l}\text { PESSINA, Luiz } \\
\text { Henrique Gomes }\end{array}$ & 9 dez. 2014 & - & - & Telefone & - \\
\hline $\begin{array}{l}\text { QUEIROZ, Cláudio } \\
\text { José Villar Pinheiro de }\end{array}$ & 15 abr. 2012 & - & - & E-mail & - \\
\hline $\begin{array}{l}\text { SVENSSON, Frank } \\
\text { Algot }\end{array}$ & 16 fev. 2012 & $\begin{array}{l}\text { Residência do } \\
\text { entrevistado }\end{array}$ & $1 \mathrm{~h} 52 \mathrm{~min} 52 \mathrm{seg}$ & $\begin{array}{l}\text { Gravação } \\
\text { em áudio }\end{array}$ & $01 / 03 / 2012$ \\
\hline $\begin{array}{l}\text { WEIDLE, Érico Paulo } \\
\text { Seigmar }\end{array}$ & 7 dez. 2011 & $\begin{array}{l}\text { Escritório do } \\
\text { entrevistado }\end{array}$ & 1h18min48seg & $\begin{array}{l}\text { Gravação } \\
\text { em áudio }\end{array}$ & $04 / 04 / 2012$ \\
\hline ZETTEL Jayme & 9 dez. 2014 & - & - & Telefone & - \\
\hline $\begin{array}{l}\text { ZIMBRES, Paulo de } \\
\text { Mello }\end{array}$ & 26 out. 2011 & $\begin{array}{l}\text { Residência do } \\
\text { entrevistado }\end{array}$ & $28 \min 54 \mathrm{seg}$ & $\begin{array}{l}\text { Gravação } \\
\text { em áudio }\end{array}$ & $13 / 04 / 2012$ \\
\hline
\end{tabular}

